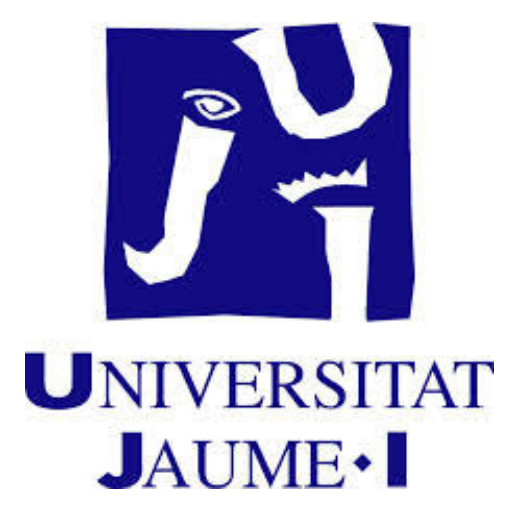

Universitat Jaume I

Facultat de Ciències Humanes i Socials

\title{
APROXIMACIÓN A LA OBRA CERÁMICA DE MANOLO SAFONT
}

Cristina Benaches Mifsud

Tesis doctoral dirigida por:

Dr. D. Joan Feliu Franch

Dr. D. Víctor Mínguez Cornelles

Castellón, 2015. 

Cuando un trabajo de investigación se dilata tanto como esta Tesis Doctoral, el número de personas y entidades a quienes agradecer su ayuda y colaboración es directamente proporcional al tiempo empleado.

Aunque pudiera hacerlo, creo que me resultaría imposible citar a todas aquellas personas con las que durante este tiempo he hablado, comentado y me han proporcionado datos y documentación sobre Manolo Safont y sus obras. Vaya por adelantado mi agradecimiento a todas ellas.

Aún así, debo reseñar algunas de ellas, como el propio Manolo Safont, a quien le debo no sólo el tema de esta Tesis Doctoral y toda la documentación que me proporcionó, sino el haberme ofrecido su amistad y enseñarme a entender y disfrutar sus pinturas cerámicas.

Al Doctor Víctor Mínguez Cornelles, por ofrecerme su apoyo y su experiencia académica en la codirección de esta Tesis.

Al Doctor Joan Feliu Franch, codirector de esta investigación, debo agradecerle su inestimable ayuda académica en la realización de este trabajo, y por partida doble, su apoyo y compañía en el día a día.

A Adrián, por quien paré este proyecto para poder atenderlo y verlo crecer, y que ahora, tras el paso de los años, se ha convertido en un hombre con un futuro lleno de ilusiones y proyectos.

A Carmen, mi madre, siempre presente, ejemplo de lucha, trabajo y constancia.

A los Doctores Kosme de Barañano, Felipe Jerez y Juan Chiva, quienes han tenido la amabilidad de evaluar este trabajo y aceptaron ser miembros de este tribunal. Me siento honrada por ello.

A tantas personas que sería imposible nombrar a todas, Begoña, Toni, Nadal, Chelo, Lola y Manolo, a todos esos amigos, amigas, conocidos, que me han parado por la calle o han venido a casa a decirme: "Tengo una obra de Manolo" o "Se quien tiene obras de Manolo". Todos ellos han hecho posible lo que en un principio parecía imposible, que me abrieran la puerta de más de 30 hogares que tienen obras de Safont y que me han permitido ver todas esas obras de colecciones privadas para fotografiarlas y medirlas así poder incluirlas en el catálogo.

A todos ellos/as mi más sincero agradecimiento. 



\section{ÍNDICE}

1.- Manolo Safont, artista cerámico. Introducción.

2.- Aproximación biográfica a la figura de Manolo Safont.

3.- Técnica y estilo en la obra de Manolo Safont. 73

3.1.- El arte cerámico: estado de la cuestión.

3.2.- La etapa de figuración en la obra de Manolo Safont. 102

3.3.- La etapa de transición en la obra de Manolo Safont. 106

3.4.- La etapa de abstracción en la obra de Manolo Safont. 115

4.- Manolo Safont, personaje social. 129

4.1.- La casa de Manolo Safont, centro cultural de reuniones. 131

4.2.- Manolo Safont, un artista comprometido: del Museo

Histórico Municipal de Onda al Museo del Azulejo Manolo Safont. 135

4.3.- Los movimientos artísticos de vanguardia alrededor de Manolo Safont: La Saleta Municipal de Onda.

4.4.- Reconocimiento social: Premios y Homenajes. 146

4.4.1.- En el 70 aniversario del nacimiento de Manolo Safont.

4.4.2.- El Museo del Azulejo de Onda también llevará el nombre de Manolo Safont.

4.4.3.- El calendario de Caixa Rural d'Onda de 2003.

4.4.4.- Seny Onder 2002.

150

4.4.5.- Premio Protagonistas de Castellón 2003.

4.4.6.- XI Exfilnucol en octubre de 2004.

4.4.7.- VI Premio Vicent Ventura en abril de 2005.

4.4.8.- Fallecimiento de Manolo Safont.

4.4.9.- Celebración del Día Internacional de los Museos, en mayo 2006, en el Museo del Azulejo Manolo Safont.

4.4.10.- Ampliación del Parque de la Cerámica de Onda en marzo 2007.

4.4.11.- Homenaje a Safont en el Cau de l'Art, Lucena, en julio de 2007.

4.4.12.- El Ayuntamiento de Castellón dedica una calle al ceramista Manolo Safont en octubre 2008.

5.- La presencia de Manolo Safont.

5.1.- Manolo Safont: Las exposiciones.

5.1.1.- Exposiciones individuales. 162

5.1.2.- Exposiciones colectivas. 165

5.2.- Manolo Safont: Los concursos. 168

5.3.- Manolo Safont: Su obra en museos. 169

5.4.- Manolo Safont: Su obra pública e institucional. 171

5.5.- Manolo Safont: Su obra en colecciones privadas. 173

5.6.- Manolo Safont: Su obra perdida e inacabada. 174 
5.7.- Manolo Safont: Su obra pendiente de localizar.

5.8.- Manolo Safont: Cine documental y documentación audiovisual.

6.- Fichas catalográficas de la obra de Manolo Safont.

6.1.- Fichas catalográficas: Obra gráfica impresa en los programas de Fira d'Onda.

6.2.- Fichas catalográficas: Bocetos, dibujos y carteles. 239

6.3.- Fichas catalográficas: Obras de la etapa de figuración. 318

6.4.- Fichas catalográficas: Obras de la etapa de transición

de la figuración a la abstracción.

344

6.5.- Fichas catalográficas: Obras de la etapa de abstracción. $\quad 387$

6.6.- Fichas catalográficas: Obras de aplicación arquitectónica. $\quad 509$

6.7.- Fichas catalográficas: Obras murales. 516

7.- Conclusiones sobre la figura y obra de Manolo Safont. 589

8.- Apéndice documental. 597

8.1.- Índice de figuras. 597

8.2.- Bibliografía. 602

8.2.1.- Bibliografía general. 602

8.2.2.- Bibliografía específica. 606

8.2.3.- Artículos de prensa. 611

8.2.4.- Bibliografía cronológica. 619

8.2.5.- URLs. 633

8.3.- Fuentes. 636

8.4.- Anexo. 638 


\section{CAPITULO 1 \\ MANOLO SAFONT, ARTISTA CERÁMICO. INTRODUCCIÓN}

Si vives o resides en Onda, es imposible no saber quien fue Manolo Safont. Manolo Safont era una persona conocida y reconocida en esta población. En 1992 comencé a ir a menudo a esta localidad por motivos laborales, y al poco tiempo tuve la suerte de que me presentaran a Manolo.

Con sus largos cabellos y bigotes, ya canosos, siempre vestido con su camiseta, camisa o jersey rojo, según la época del año, pero siempre de color rojo, y su collar metálico con una pieza de silex engastada. Era todo un personaje. Amable y sociable, casi nuca llegaba a tiempo a donde tenía previsto... por el camino siempre encontraba con quien detenerse a hablar. Tuve la gran fortuna de establecer desde muy pronto una relación de amistad con él, y ya que yo era nueva en el pueblo... él encontró en mi a quién contar historias, aventuras y desventuras, sin temor a que yo le dijera que eso ya lo sabía o que eso ya me lo había contado.

Confieso que hasta que no llegué a Onda, nada sabía sobre Manolo y muy, muy poco, sobre su trabajo. El hecho de conocerlo hizo que me interesara por su obra artística y por su labor como gestor cultural. Así fue como poco a poco, sin orden cronológico alguno, Manolo me fue relatando diferentes episodios de su vida, de su trabajo en las fábricas, sobre cómo montó su taller, su labor como director del Museo Histórico Municipal de Onda, o cómo recorría obras y derribos rescatando azulejos de las casas que se demolían y se reformaban, y los iba guardando en el almacén municipal que se había creado en el antic llavador de Onda (lugar hoy ocupado por la Casa de Cultura) y como no; hablaba de su salud, o mejor dicho, de sus problemas de salud, ocasionados según él, por todo lo que respiró los años que estuvo trabajando en las fábricas azulejeras. Manolo decía que la salud no le acompañaba, pero que él había alcanzado a un acuerdo con su cuerpo, y que cuando le llegaba un nuevo encargo o proyecto, él le explicaba lo importante que era y que necesitaba que aguantara hasta que lo acabara. Y así fue encadenando trabajo tras trabajo y proyecto tras proyecto: "tinc un acord amb el meu cos". 
El afán por saber y aprender de Manolo fue una constante en su vida. Creo que no conozco a nadie que comprara tanta prensa como él. Cada día, o cada dos días, se acercaba hasta el quiosco y recogía toda la prensa que encargaba. Estaba al corriente de todas las noticias y hechos que ocurrían, y no cesaba en su afán de aprender. Era locuaz pero también tenía el don de saber escuchar, y así, poco a poco fue aprendiendo y entendiendo todo aquello que por falta de formación académica y cultural desconocía.

Tan hablador era que más de una vez se despistaba y no podía hacer todo lo que tenía previsto. Cuando Manolo venía a mi casa, no sabías a que hora se marcharía. Era capaz de hablar durante horas, y yo escuchaba encandilada sus historias. Pero estos encuentros también se producían a la inversa. La casa de Manolo era la casa de todos, no tenía puertas. Manolo y Anita siempre te recibían con una sonrisa.

Con todos estos antecedentes que acabo de describir es lógico pensar que cuando finalicé mis estudios de doctorado en Historia del Arte y decidí comenzar a realizar la Tesis Doctoral, hacerla sobre la obra y la figura de Manolo Safont fue una decisión relativamente sencilla.

El primer paso fue preguntarle a Manolo si estaba de acuerdo, y debo reconocer que aceptó encantado. La mañana siguiente a nuestra conversación, Manolo acudió a mi casa con una carpeta llena de recortes de prensa y catálogos de sus exposiciones "per a que pugues començar a treballar", me dijo. El paso siguiente fue exponer el tema y la idea de Tesis a mis directores, ambos vieron viable el proyecto y me alentaron en mi proyecto. Una vez matriculado en la UJI, tan sólo quedaba comenzar a trabajar.

Un trabajo que se ha demorado en el tiempo mucho más de lo que yo hubiera querido, dado que por circunstancias personales y profesionales, la Tesis fue quedando en un segundo plano, aunque siempre estuvo presente.

Manolo seguía proporcionándome documentación, que yo seguía leyendo, analizando y archivando, esperando el momento en que pudiera dedicarle todo el tiempo y la dedicación que un proyecto de tal envergadura requiere.

Recuerdo que cuando inscribí en la UJI el proyecto de esta Tesis Doctoral, fotocopié el impreso oficial y se lo llevé a Manolo. Fue el día en que le concedieron el premio Vicent Ventura. El miró el documento y me preguntó: 
"m'el dones?", y cuidadosamente dobló el folio y lo guardo en su bolsillo. A lo largo de la noche lo sacó varias veces para enseñarlo a todos los amigos que habían acudido a la cena homenaje que en su honor organizó el Ayuntamiento de Onda.

La labor investigadora se ha centrado en ordenar, estructurar y analizar todos los recortes de prensa que Manolo fue proporcionándome y los que, tras un arduo trabajo de hemeroteca, he logrado localizar para poderlos fechar y ordenar cronológicamente. Apenas he logrado encontrar bibliografía específica sobre la persona y la obra de Safont, no hay libros escritos sobre su arte y su técnica cerámica, pero hay innumerables artículos publicados en prensa, además de las diversas publicaciones escritas en los diferentes catálogos de sus numerosas exposiciones.

Una vez realizada esta tarea, comenzó el trabajo de campo, localizando, fotografiando y midiendo las obras de Manolo en diferentes instituciones y museos, así como su obra pública y arquitectónica, para posteriormente comenzar el rastreo y localización de parte de esa producción artística que actualmente se encuentra en colecciones privadas.

La muerte de Manolo truncó sus proyectos artísticos y yo dejé de tener ese acceso privilegiado a sus comentarios, historias y documentos. Dejé de recibir sus carpetas llenas de fotocopias de artículos de prensa, sus invitaciones manuscritas a las inauguraciones de sus exposiciones y sus felicitaciones navideñas, escritas a mano con una cuidada caligrafía que identificabas como suya con sólo mirar el sobre, que denotaba su carácter de artista, y que guardo con gran afecto.

Desearía que este trabajo, sirva y ayude a que perdure por mucho tiempo la imagen de Manolo, pero no sólo de Safont como artista plástico, sino de un Safont que se rebeló contra las ataduras y las normas intelectuales atávicas de su época, que con una amplitud de miras y una gran visión de futuro, rescató y defendió el patrimonio histórico y artístico de su pueblo, que hizo de la Saleta de Onda estandarte del arte contemporáneo castellonense, luchador incansable y defensor de libertades, porque al final el arte no es nada más ni nada menos que un vehículo que nos permite expresar nuestras ideas, emociones y pensamientos de una forma libre. 


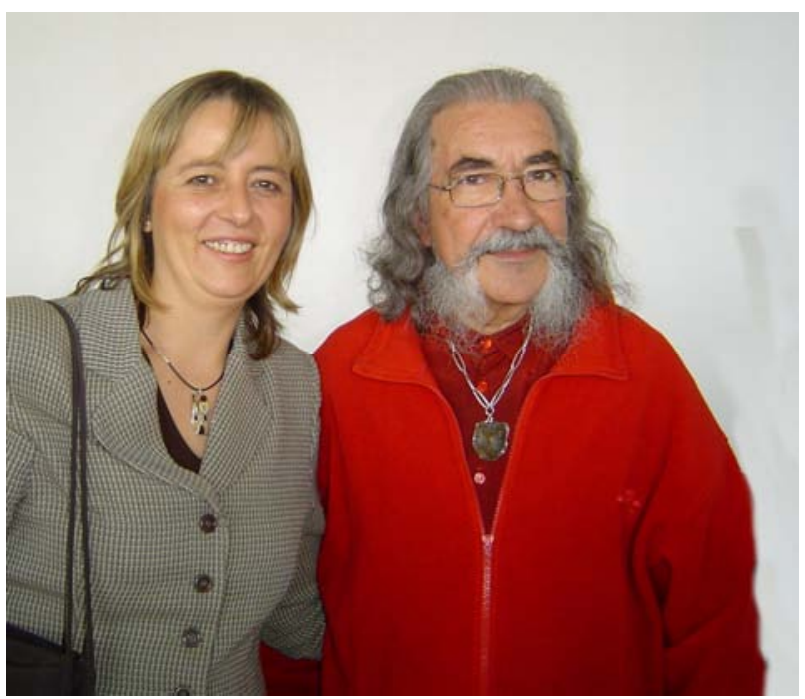

Figura 1: Manolo Safont y Cristina Benaches 


\section{CAPÍTULO 2 \\ APROXIMACIÓN BIOGRÁFICA A LA FIGURA DE MANOLO SAFONT}

1928

Hijo de Manuel Safont y María Castelló, ${ }^{1}$ Manuel Safont Castelló nació en Onda el 28 de marzo de 1928, una población de Castellón en la que la producción cerámica no era tan sólo un referente económico sino la base de todo movimiento mercantil, industrial y social.

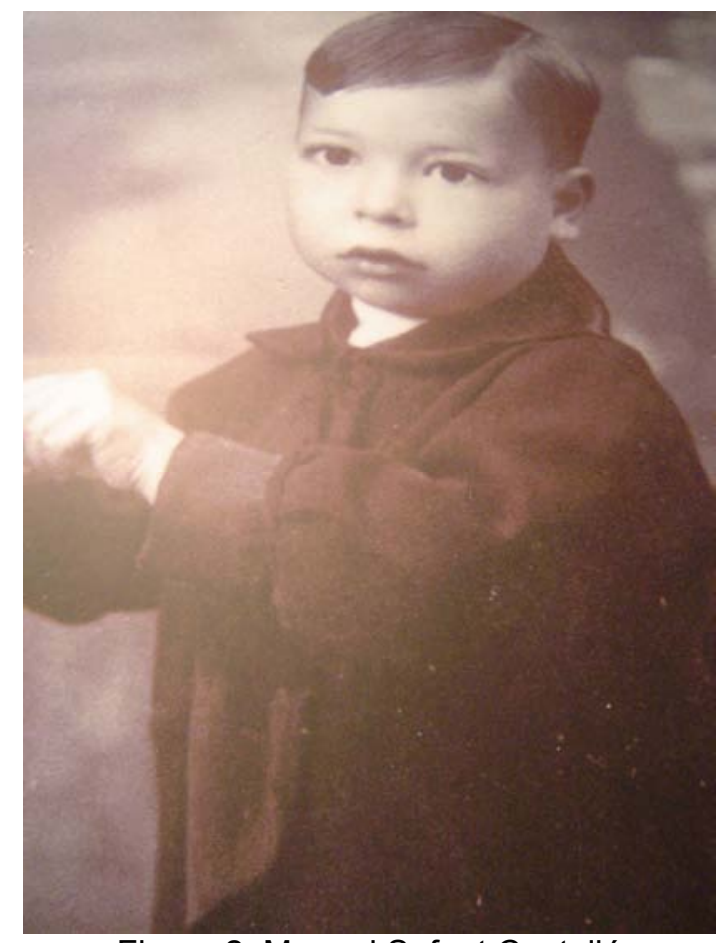

Figura 2: Manuel Safont Castelló

La relación de Safont con la cerámica empezó desde niño, nadie que haya nacido o viva en Onda es ajeno a este mundo. La vida de los trabajadores de Onda se rige por los horarios y los turnos de trabajo en las fábricas azulejeras. La abuela de Safont vivía en un piso junto a la antigua fábrica de cerámica artística Sajironda, y desde muy pequeño, Safont creció rodeado de arcillas, barbotinas y engobes.

\footnotetext{
1 BeLLÉs, Salvador. "Seres humanos de Castellón. Manolo Safont: Pasión por la cerámica y el arte universal".

http://www.elperiodicomediterraneo.com/noticias/castellon/seres-humanos-castellonsalvador-belles-pasion-ceramica-arte-universal_199460.html
} 


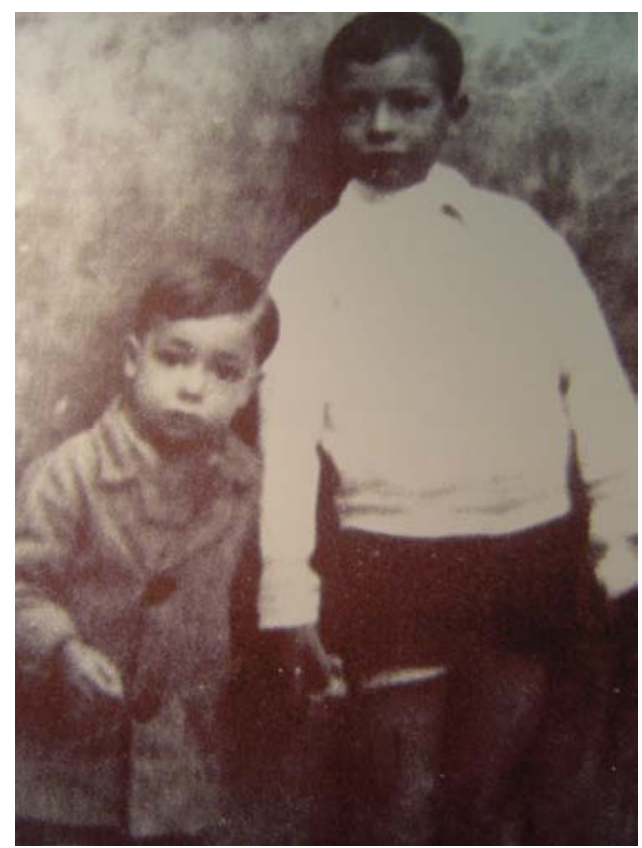

Figura 3: Manuel Safont (el menor).

En su infancia, Safont estudió en las escuelas regentadas por los Padres Carmelitas, que se encontraban ubicadas en las salas del castillo de Onda, ${ }^{2}$ y hasta 1937 asistió como alumno a la Escuela Provincial de Cerámica de Onda. ${ }^{3}$

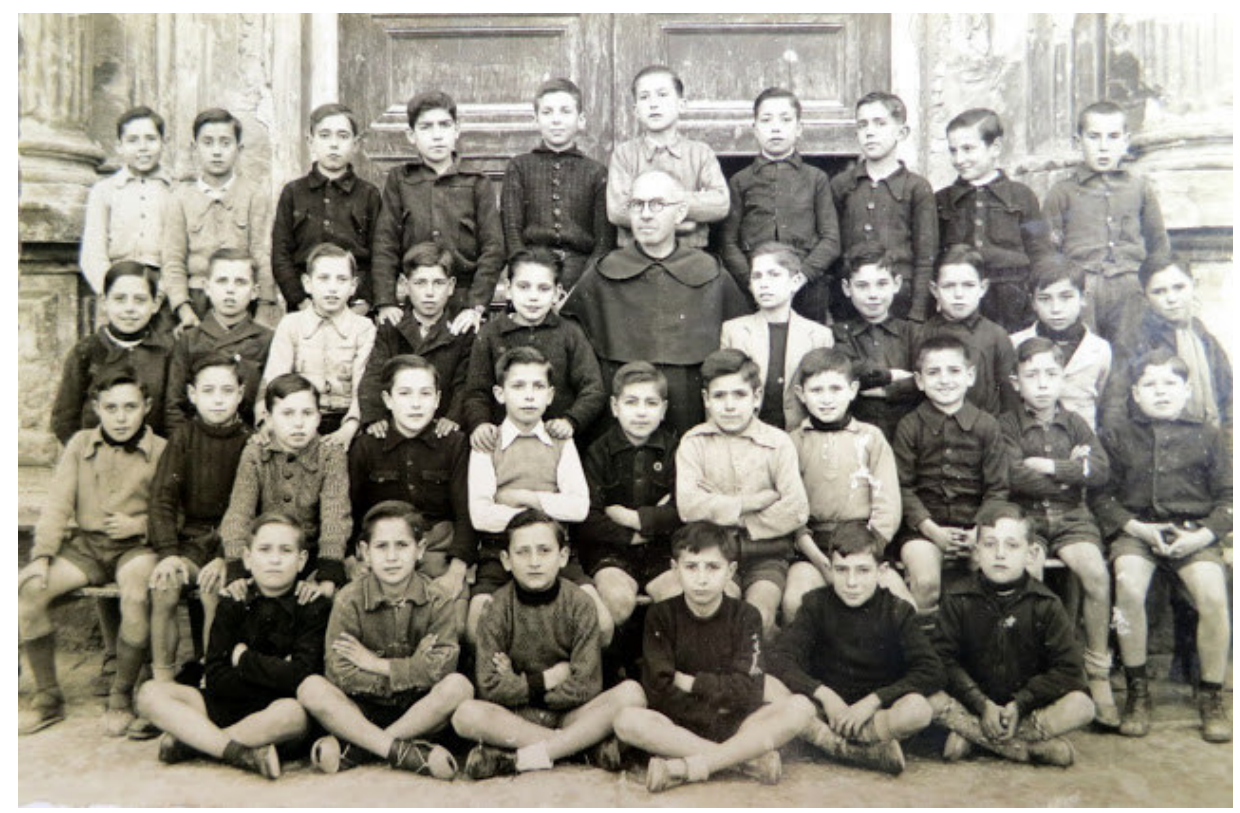

Figura 4: Manolo Safont, situado el cuarto por la derecha de la fila superior, posando con sus compañeros de escuela en la puerta de la Iglesia de Nuestra Señora de la Asunción de Onda.

${ }^{2}$ FerRé PÉREZ, Juan Bautista. Lista de fácil acceso a las fotografías de alumnos. Colonia Escolar Virgen del Carmen. S.e., Onda, S.d.

3 Datos obtenidos del cortometraje realizado en 1968 por Rafael Menezo Fang $i$ Pinzells: El mon i l'obra de Manolo Safon. 
1942

Con catorce años de edad, en 1942, comenzó a trabajar en la fábrica de azulejos de Vicente Martí, pasando piezas cerámicas por el horno. ${ }^{4}$

1947

Tras cinco años de trabajo, en 1947, abandona la fábrica de azulejos y comienza a trabajar en el taller de cerámica artística de formas populares de Eusebio Ferrer Momplet. ${ }^{5}$ Es en esta etapa de su vida cuando Safont adquiere los conocimientos técnicos imprescindibles que le posibilitaron poder generar toda su producción artística posterior.

Una de sus primeras obras fue un Sant Joan que realizó por encargo de uno de los hermanos Sansano, de Onda. Lo hizo en la fábrica de la Balsa de la Vila y lo llevó a cocer a Sajironda, conocida en Onda como La Fabriqueta.

1951

Tras varios años trabajando y aprendiendo en el mundo cerámico, al regresar a Onda después de realizar el servicio militar en sanidad, ${ }^{6}$ en 1951 monta su propio taller, en la buhardilla de una casa situada en el Raval de San José, actual calle Historiador Bernardo Mundina de Onda (Castellón). ${ }^{7}$

\footnotetext{
${ }^{4}$ Notas manuscritas tomadas por Manuel Galver, presidente del Ateneo Cultural y Mercantil de Onda, en una conversación que mantuvo con Manolo Safont para preparar el discurso que debía pronunciar con motivo del homenaje que se realizó en Onda por la concesión del premio Seny Onder de 2003. Vicente Martí Castelló fue el propietario de la fábrica de azulejos "El León" ubicada en la población de Onda (Castellón).

${ }^{5}$ Dato proporcionado por Juan Salvia Manuel, sobrino de Eusebio Ferrer Momplet.

${ }^{6}$ Notas manuscritas tomadas por Manuel Galver, presidente del Ateneo Cultural y Mercantil de Onda, en una conversación que mantuvo con Manolo Safont para preparar el discurso que debía pronunciar con motivo del homenaje que se realizó en Onda por la concesión del premio Seny Onder de 2003.

${ }^{7}$ Albalat, Antoni. "La intifada del fang", en Levante EL MERCANTIL VALENCIANO. 27 de noviembre de 2005, pág. 7.
} 


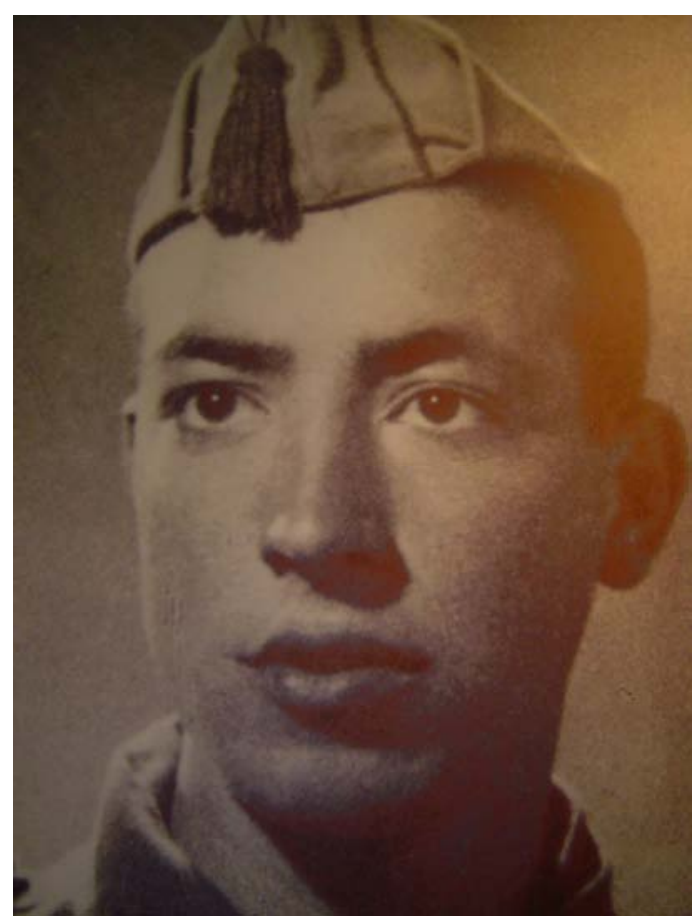

Figura 5: Manolo Safont durante el servicio militar.

En el bajo de este edificio, en el cual Safont instala su taller, estaba el bar de Acción Católica, del cual Safont realizó el diseño y los azulejos para decorar la barra del bar.

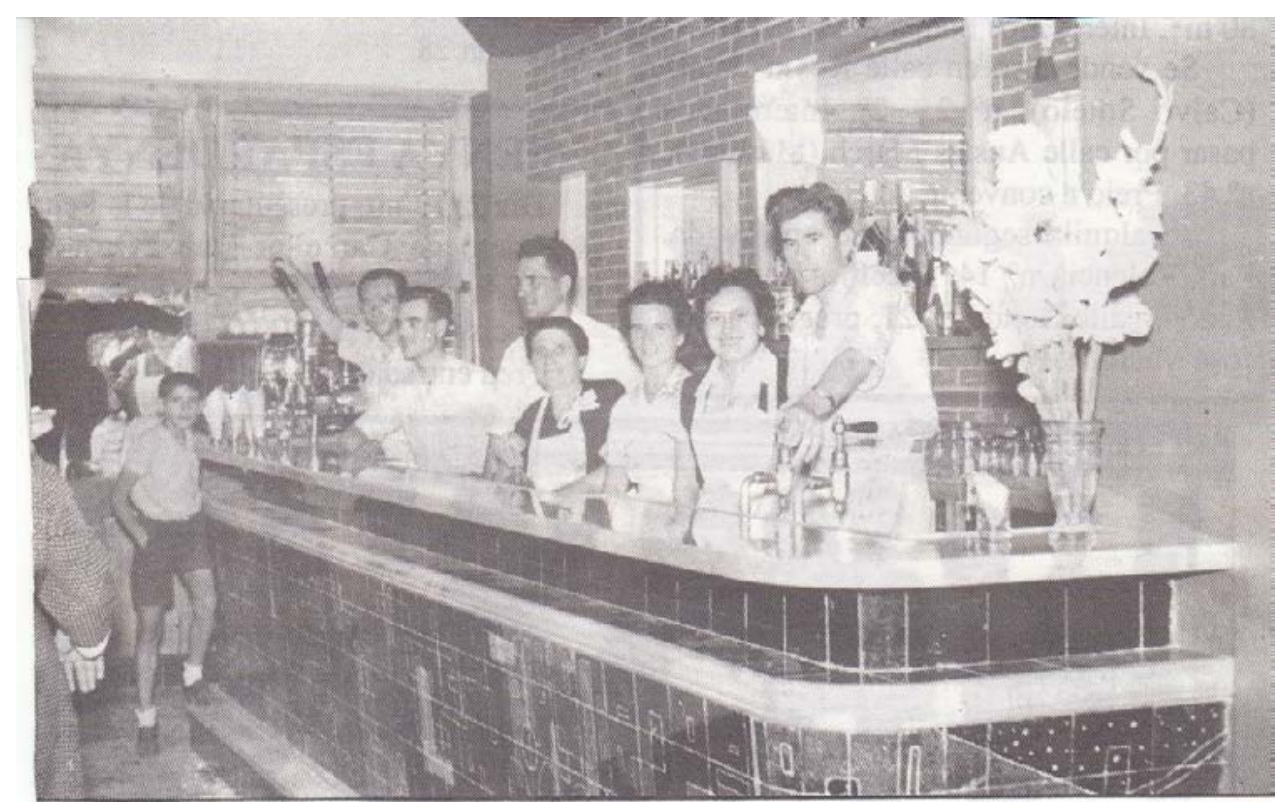

Figura 6: La barra del bar de Acción Católica con los azulejos realizados por Safont. 
1952

Durante el año 1952, Safont realiza un importante encargo para la Iglesia Parroquial de Nuestra Señora de la Asunción de Onda, la elaboración de cinco paneles murales de azulejos, de estilo clásico, compuestos por más de 300 azulejos, que se colocarán en la capilla de la comunión de la iglesia. ${ }^{8}$

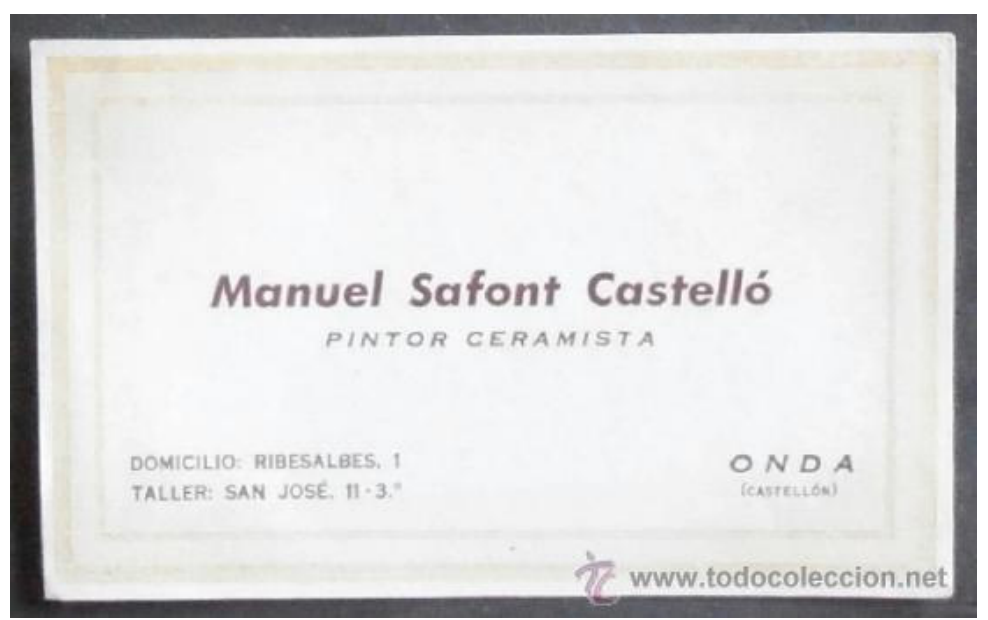

Figura 7: Tarjeta de visita profesional de Safont.

1953

El 1 de octubre de 1953, se casa con Ana del Moral Fabregat ${ }^{9}$ a la que había conocido en casa de Marita Canelles, una amiga común, que vivía en el mismo edificio en el que Manolo tenía su taller. La ceremonia del enlace fue oficiada en la Iglesia Parroquial de Tales por ocho capellanes $y$, posteriormente, el matrimonio se fue de viaje de novios a Palma de Mallorca, destino en el cual Safont había realizado el servicio militar. ${ }^{10}$

\footnotetext{
${ }^{8}$ Notas manuscritas tomadas por Manuel Galver, presidente del Ateneo Cultural y Mercantil de Onda, en una conversación que mantuvo con Manolo Safont para preparar el discurso que debía pronunciar con motivo del homenaje que se realizó en Onda por la concesión del premio Seny Onder de 2003.

${ }^{9}$ Ibidem.

${ }^{10}$ Ana del Moral Fabregat (24-10-1926), nacida en Tales (Castellón) se traslada a Onda (Castellón) recién terminados sus estudios de matrona, comenzando a trabajar como ayudante de la comadrona Dña. Elisa Messeguer, ejerciendo en Onda hasta su jubilación (1992). Acta de elección y nombramiento del Seny Onder 2002. Ateneo Cultural y Mercantil de Onda (Castellón).
} 
En este año realiza un panel de azulejos, una reproducción de la obra $\mathrm{La}$ Última Cena de Leonardo da Vinci, destinada al comedor del Seminario de Tortosa, con una paleta cromática basada en diferentes tonalidades de azules. $^{11}$

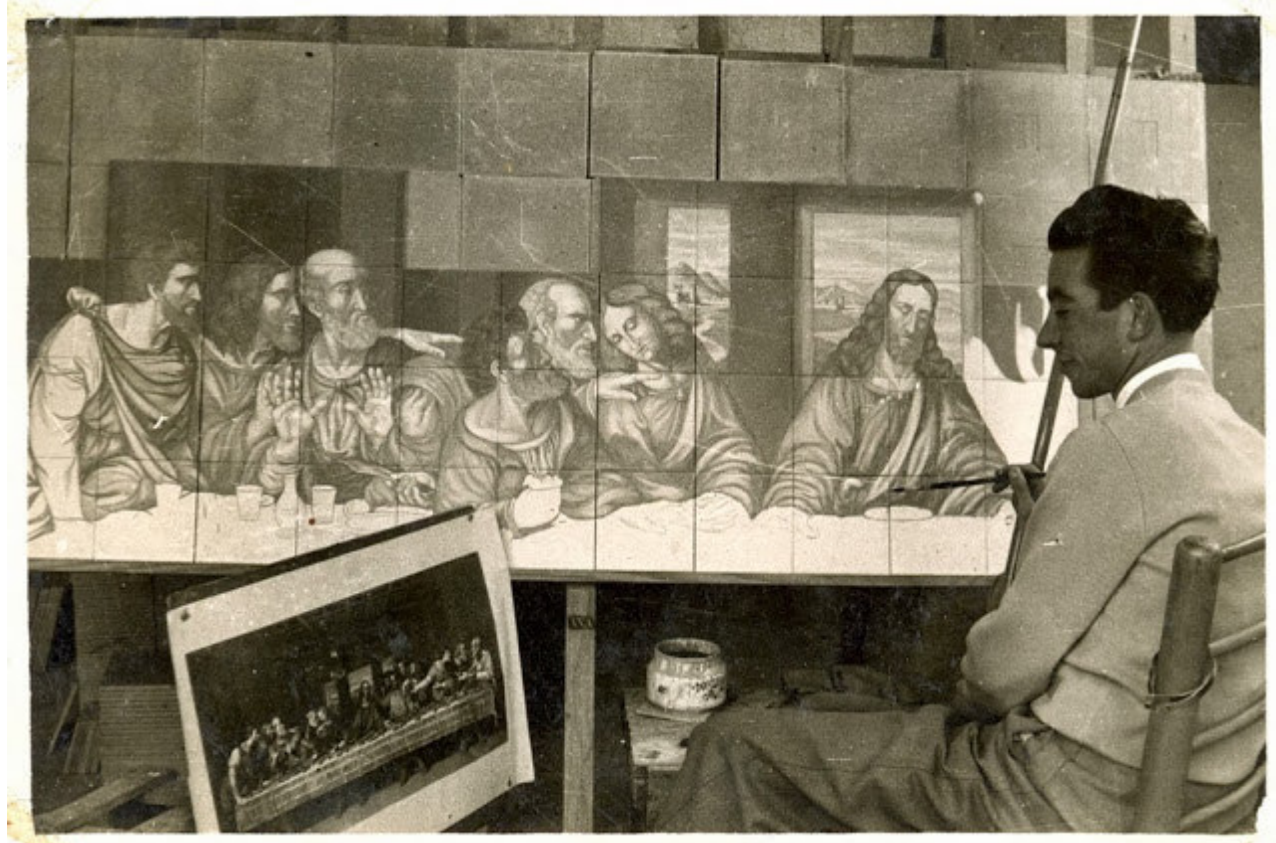

Figura 8: Safont realizando el panel para el Seminario de Tortosa.

1954

En 1954 realiza el gran panel de azulejos del tímpano de la portada de la Iglesia Parroquial de la Asunción de Nuestra Señora de Sueras (Castellón).

\footnotetext{
${ }^{11}$ Notas manuscritas tomadas por Manuel Galver, presidente del Ateneo Cultural y Mercantil de Onda, en una entrevista con Manolo Safont para preparar el discurso homenaje de la concesión del premio Seny Onder de 2003.
} 


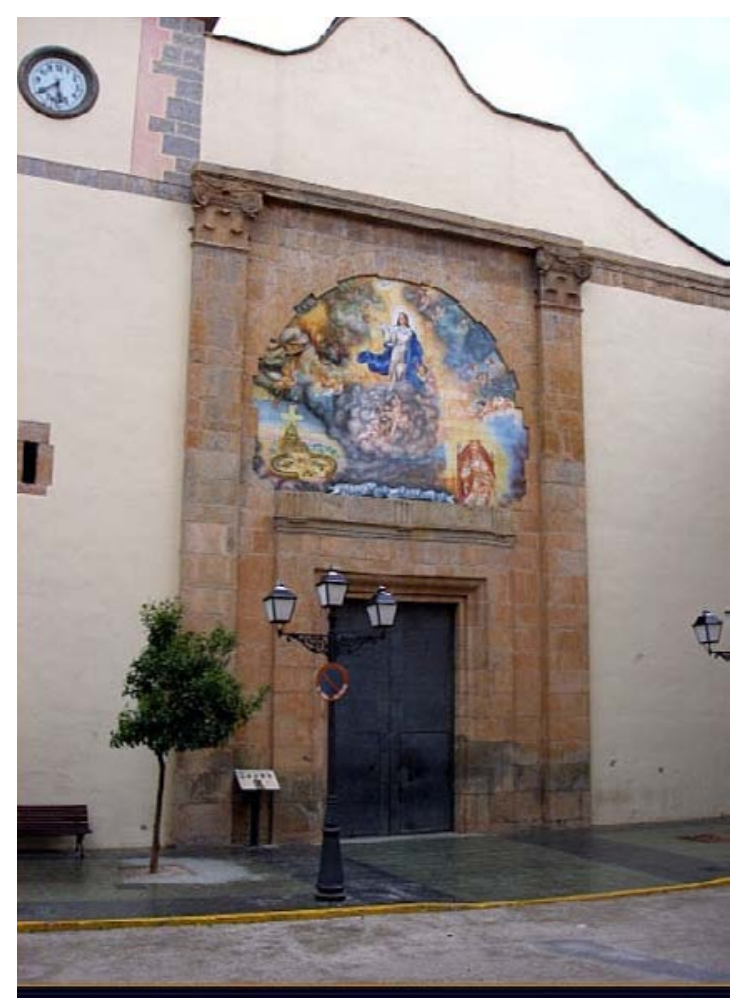

Figura 9: Iglesia Parroquial de la Asunción de Nuestra Señora, Sueras.

1957

Recibió un Diploma de Honor, en la Exposición Nacional de Artesanía en Granada, organizada por la Delegación Provincial de Sindicatos, en la sección Obra Social "Artesanía”, celebrada del 14 al 22 de mayo de 1957, coincidiendo con el IV Congreso Eucarístico Nacional, concedido al trabajo: pieza de cerámica $\mathrm{n}^{\circ} 12$, con el $\mathrm{n}^{\circ}$ de catálogo 105.

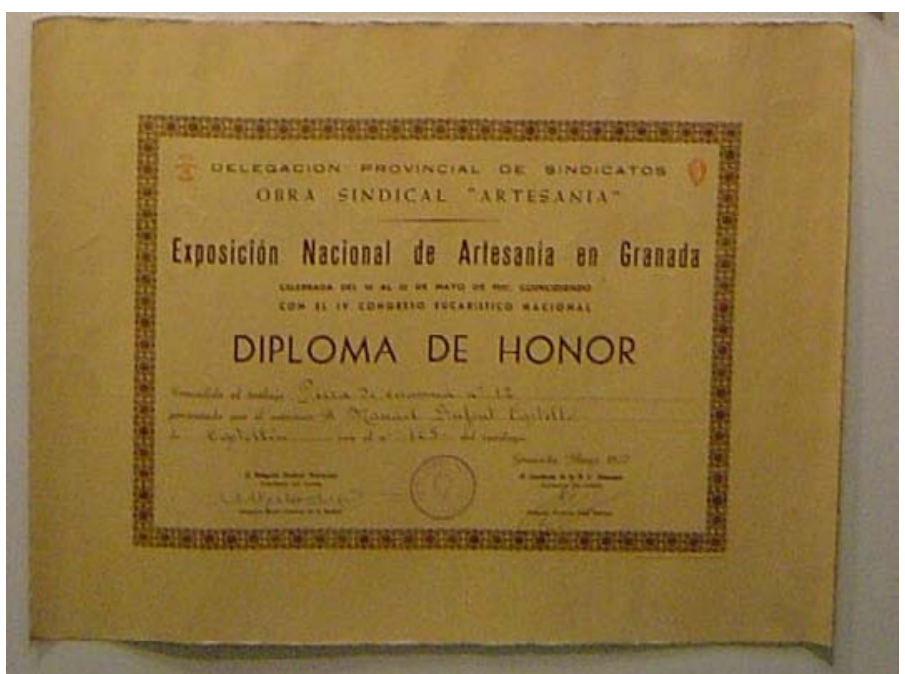

Figura 10: Diploma Exposición Nacional de Artesanía de Granada. 
1958

Durante este año, obtuvo tres premios en un concurso en Valencia, uno de ellos concedido por una representación de una imagen de San José. ${ }^{12}$

En 1958 realiza un panel devocional con la imagen de San Jorge, para ser colocado en la calle con dicho nombre en Onda.

La empresa Ciclón construcciones comienza las obras para la edificación de un cine en Onda, el cine Mónaco, y Safont realiza algunos azulejos para decorar el vestíbulo y colabora también en el diseño del resto de los azulejos empleados en la obra.

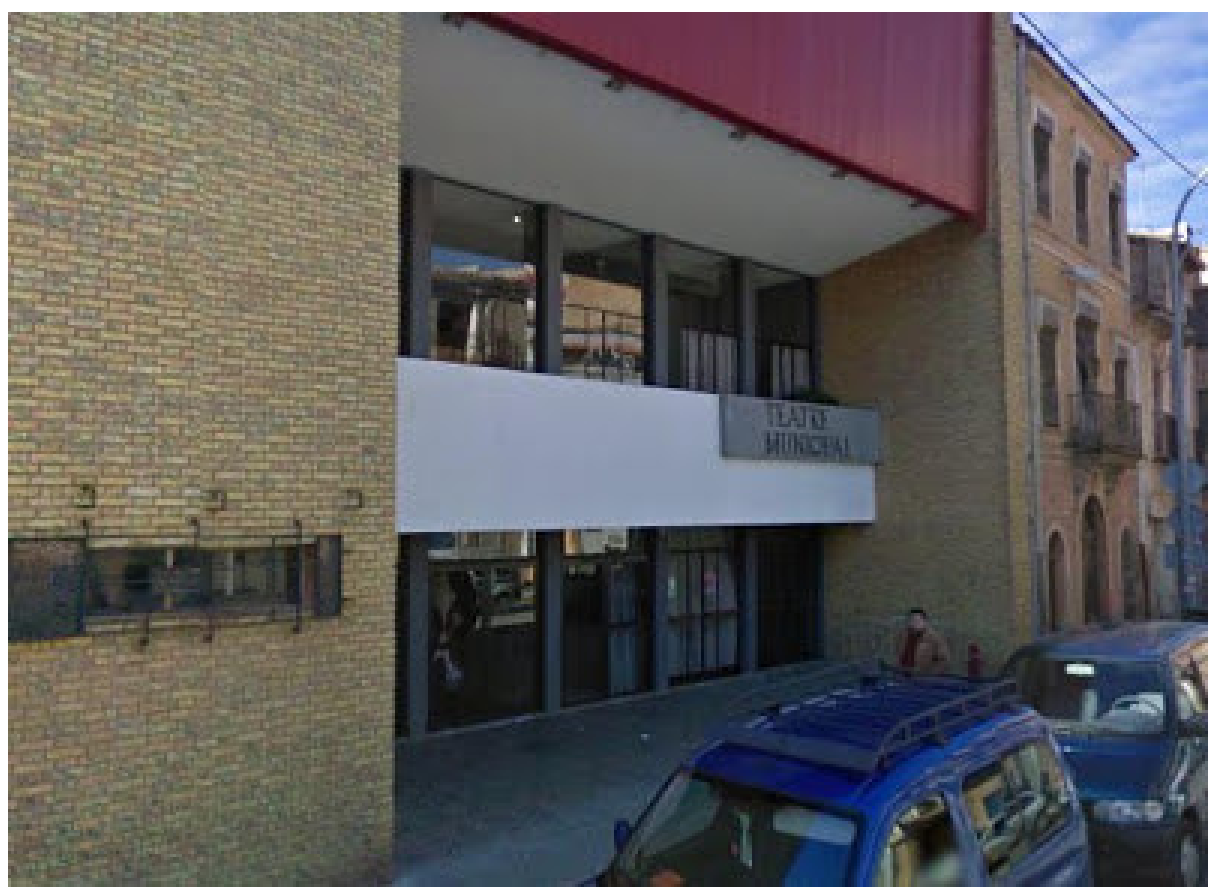

Figura 11: Cine Teatro Mónaco de Onda.

Es en este momento, cuando inicia su investigación en colores y texturas cerámicas, "Vaig aguantar cinc anys de casat pintant encàrrecs i ensenyant allò que volia fer i no m'ho demanaven. Vaig haber de tallar"13

${ }^{12}$ Datos obtenidos en "Manolo Safont. Unas notas" www.gva.es/museo/safon.htm, en el que se hace referencia a los textos escritos por Jaime Jiménez de Haro, en 1987, en el Catálogo de la obra expuesta por Manolo Safont con motivo de la inauguración de la Casa de la Cultura de la Pobla Tornesa (Castellón).

13 "Aguanté cinco años de casado pintando encargos y enseñando aquello que quería hacer y no me pedían. Tuve que cortar" Albalat, Antoni. Op. Cit. 27 de noviembre de 2005. 
Durante este período, finales de la década de 1950 e inicio de la década de 1960, Safont comienza a incorporar la materia en sus obras cerámicas, realiza obras con imágenes egipcias y reproducciones de arte rupestre sobre superficies rugosas y texturizadas.

1959

En 1959 recibe el primer premio de la Asociación El Micalet de Valencia, por una composición sobre la Virgen María y el Niño, de corte moderno.

En esta etapa aún figurativa Manolo Safont trabaja el efecto de cinco calidades, que consigue mediante cinco temperaturas diferentes en una única cocción.

Entre los años 1958 y 1961 realizó diversos trabajos de cerámica arquitectónica. Pero esta vertiente de aplicación cerámica no le permitía expresar todo lo que Safont quería, ni experimentar tanto con los materiales, por lo que pronto abandonó para centrarse el su obra definitiva y característica, sus cuadros cerámicos, que durante esta etapa muestran aún una evolución oscilante entre la figuración y la abstracción, una lucha constante en busca de la materia y el color, cuyo resultado final ha estado siempre condicionado por el fuego y por el color rojo. ${ }^{14}$

Durante la década de 1960, abandonará progresivamente el estilo figurativo, al que tan sólo regresa para realizar alguna obra de crítica a la dictadura franquista, ${ }^{15}$ obras con carácter social y de denuncia, como en las que se representan a trabajadores de las fábricas de azulejos, las obras que vemos en el documental que Paco Marco y Rafael Menezo hicieron en Onda: ${ }^{16}$ trabajadores en las prensas hidráulicas, un mural con una gran mano blanca, cortada con fondo negro, o un mural con el rostro de Ernesto Che Guevara. Utiliza la abstracción como una liberación, en la cual prima la materia y desaparece la figura.

\footnotetext{
${ }^{14}$ Ibidem.

${ }^{15}$ Ibidem.

${ }^{16}$ Menezo, Rafael. Fang i Pinzells: El món i l'obra de Manolo Safont. 1968.
} 
Se impone la abstracción, con una exaltación de la materia pura, que resalta con formas y una paleta escasa de colores.

1960

Safont realiza los azulejos tanto de la fachada como del zaguán e interior del edificio de Caja Rural de Onda, ubicado en la calle San Miguel de la población. ${ }^{17}$

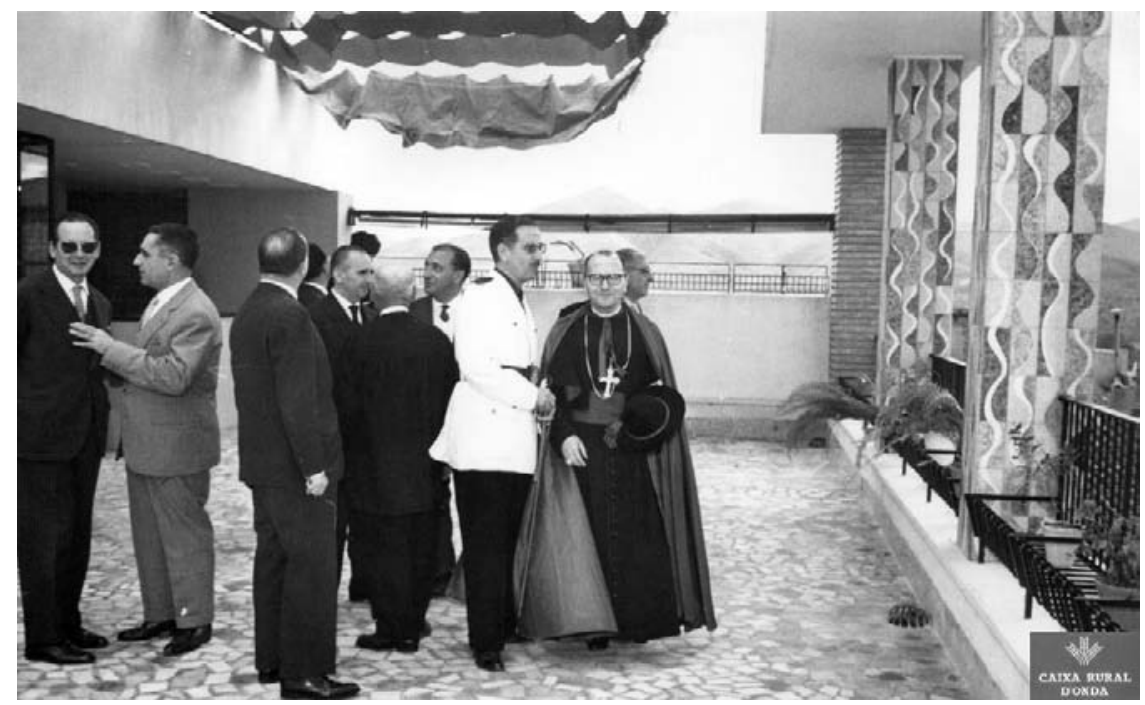

Figura 12: Inauguración edificio Caja Rural Nuestra Señora de la Esperanza de Onda.

Safont comienza a colaborar con el Ayuntamiento de Onda, creando obra gráfica, destinada a ilustrar el programa de las fiestas patronales de Onda.

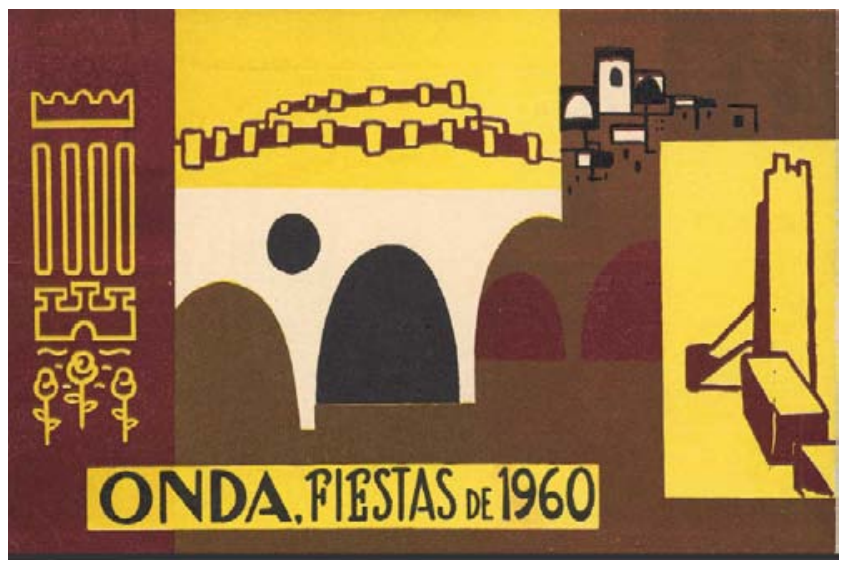

Figura 13: Portada programa fiestas Onda 1960

${ }^{17}$ La Cámara. Butlletí Informatiu de la Caixa Rural d’Onda. n8, septiembre 2005. Onda. 
En 1961 inaugura su primera exposición individual de sus obras en la Sala Estilo de Castellón, galería actualmente desaparecida que estaba situada en la Plaza del Sol. Al ver las obras de Safont expuestas, el pintor castellonense Batiste Porcar lo apodará "El pintor del foc". 18

En marzo de este mismo año, recibe un Diploma por los trabajos presentados a la VI Exposición de Cerámica de Arte, organizada por la Sociedad Coral El Micalet, Instituto Musical Giner, de Valencia, y también participó invitado en el V Salón de Mayo de Barcelona. ${ }^{19}$

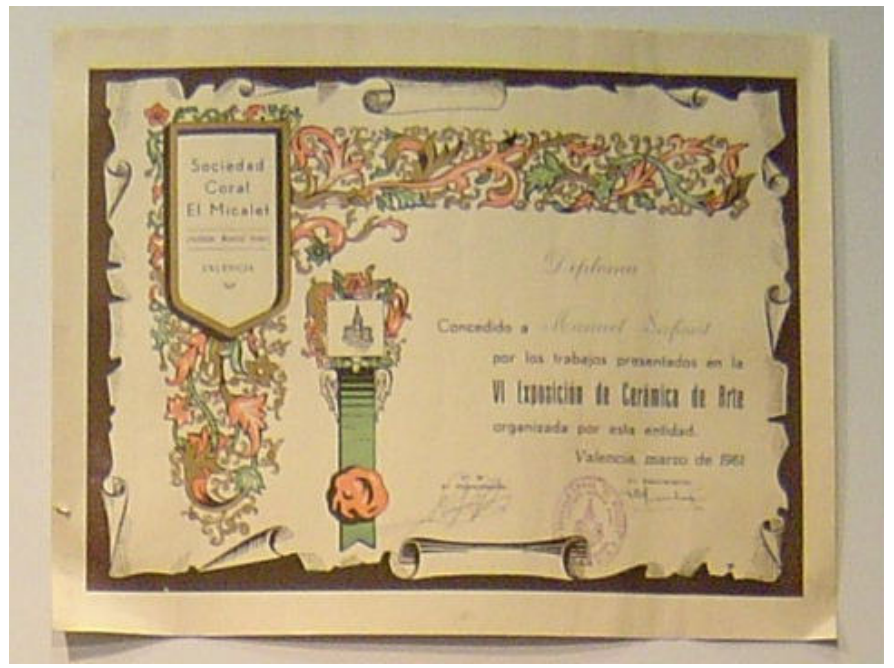

Figura 14: Diploma Sociedad Coral El Micalet.

En los inicios de los años 60 fracasa una exposición que Manolo había preparado para exponer en Bélgica. Aunque no hemos podido contrastar la información que sobre este hecho nos han relatado, parece ser que su esposa, Ana, fue vendiendo sin que Safont se diera cuenta, o más bien sin que quisiera darse cuenta, las piezas que tenía previstas exponer, para así poder saldar las deudas económicas y conseguir ingresos.

\footnotetext{
${ }^{18}$ Datos obtenidos en "Manolo Safont. Unas notas" www.gva.es/museo/safon.htm, en el que se hace referencia a los textos escritos por Jaime Jiménez de Haro, en 1987, en el Catálogo de la obra expuesta por Manolo Safont con motivo de la inauguración de la Casa de la Cultura de la Pobla Tornesa (Castellón).

${ }^{19}$ Datos obtenidos del catálogo de la exposición: OLUCHA MONTINS, Ferran; GIRALTMIRACLE, Daniel, Wences Rambla: olis i tècniques mixtes; Manuel Safont: Pintura ceràmica. Alcoi, Centre Cultural d'Alcoi, marzo de 1995.
} 
Entre 1961-1962, Safont se adentra en el mundo de la cerámica arquitectónica, diseñando la estructura y realizando los azulejos cerámicos del nuevo quiosco de prensa de La Safona, que era propiedad de la asociación de Acción Católica de Onda, ya que por las obras de ensanche de la calle se había derribado el quiosco que había anteriormente.

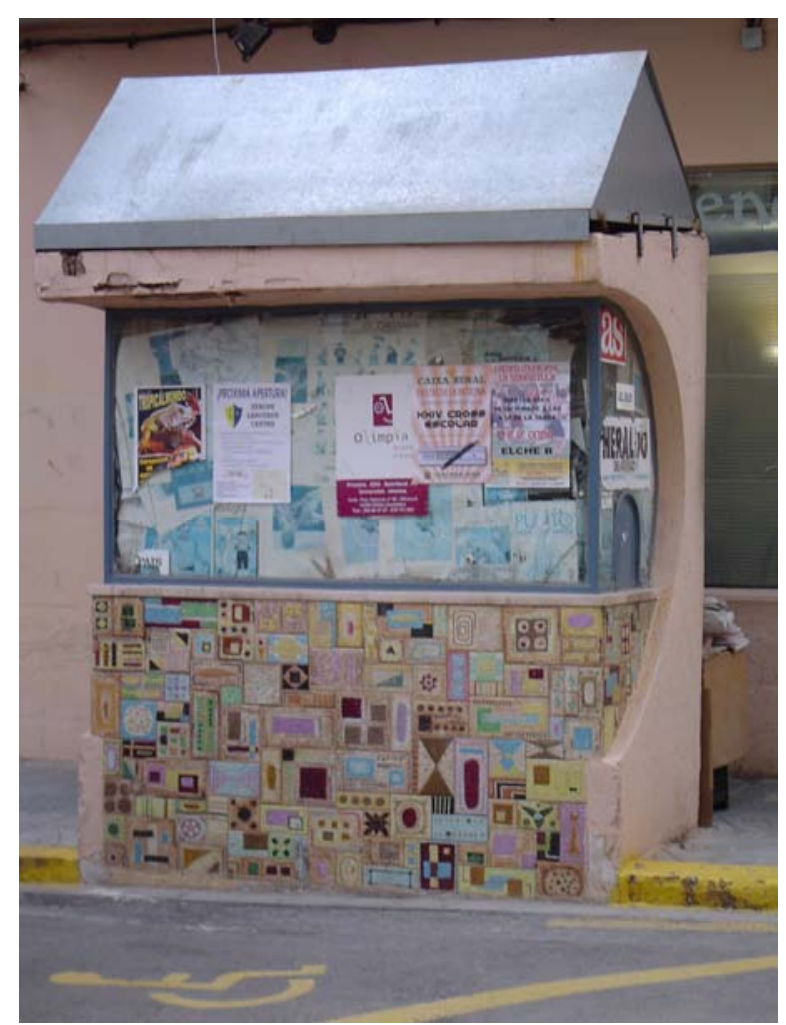

Figura 15: Quiosco de prensa de La Safona.

1962

Con el dinero que obtuvo por la obra del quiosco de La Safona, en 1962 Safont fue a Madrid junto con su esposa Ana, para realizar su primera exposición en esta ciudad, invitado por la Dirección General de Bellas Artes, en la Sala de Exposiciones de esta institución, situada en la calle Marqués de Cubas, 15, de la cual se realizó un catálogo escrito por José Luis Castillo Puche. En Madrid conoció a José Hierro, a quien le impresionó su trabajo y el resultado obtenido con sus texturas, lo animó a que sus manos buscasen sin miedo mayores espacios, incitándole hacia la abstracción, dedicándole la frase "no se hicieron las tres carabelas para navegar por el Manzanares", 
refiriéndose a que el arte que ya se apreciaba en esas obras primeras de Safont debía explorar nuevos campos de expresión. ${ }^{20}$

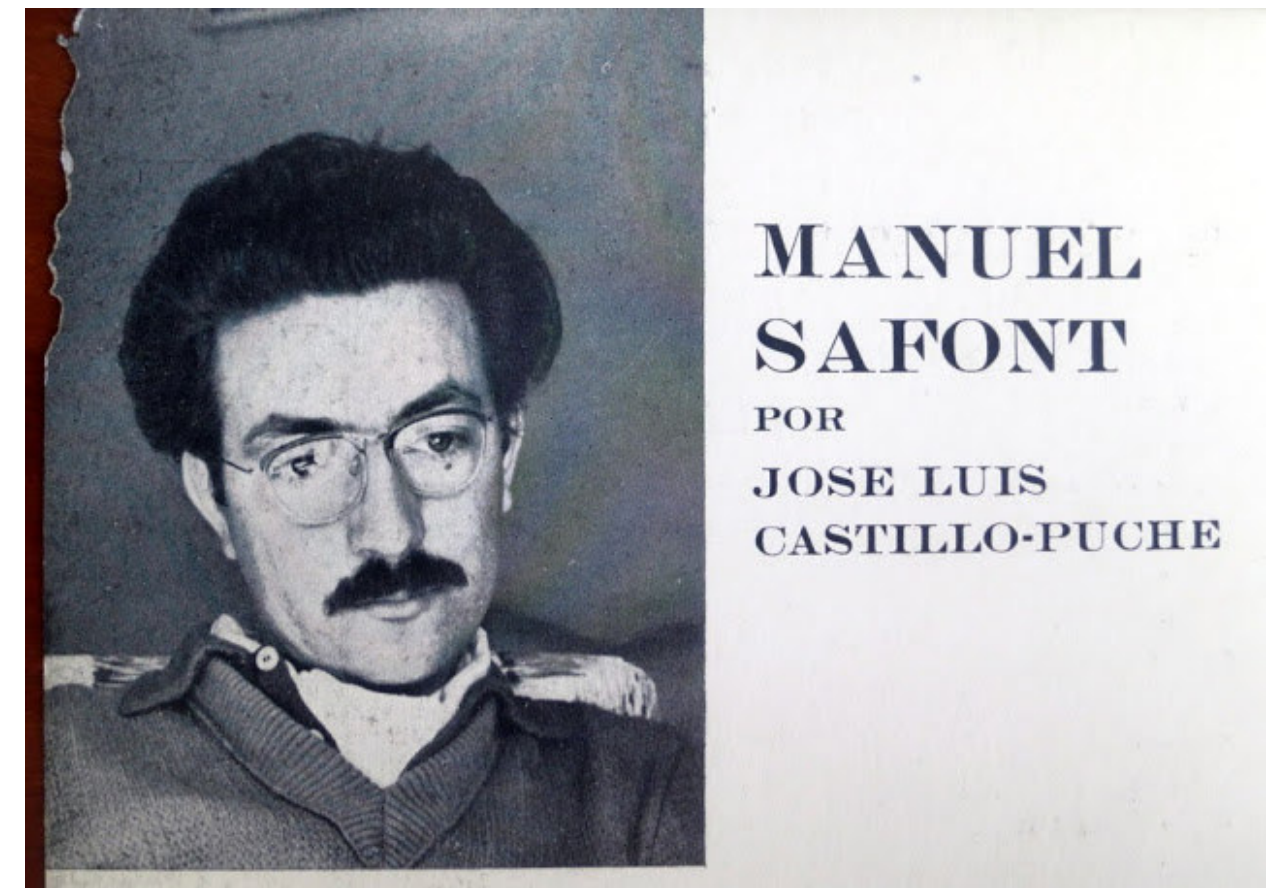

Figura 16: Catálogo exposición Sala Exposiciones Dirección General de Bellas Artes de Madrid, 1961.

También en este mismo año, participó en el VI Salón de Mayo en Barcelona. ${ }^{21}$

En esta etapa, aún combina su pasión por la abstracción y la materia, con algunos encargos de piezas figurativas, como la realización de las estaciones del calvario de Espadilla (Castellón).

\section{3}

Participó en el VII Salón de Mayo de Barcelona ${ }^{22}$, y comenzó la realización de un mural cerámico de gran formato, que finalizó en 1964, para la oficina principal de la Caja de Ahorros y Monte de Piedad de Castellón, en la

${ }^{20}$ Datos obtenidos en "Manolo Safont. Unas notas" www.gva.es/museo/safon.htm, en el que se hace referencia a los textos escritos por Jaime Jiménez de Haro, en 1987, en el Catálogo de la obra expuesta por Manolo Safont con motivo de la inauguración de la Casa de la Cultura de la Pobla Tornesa (Castellón).

${ }^{21}$ OluCha Montins, Ferran; GIRALT-MIRACle, Daniel, Op. Cit, marzo de 1995.

22 Ibidem. 
calle San Miguel de Onda. Es una obra de gran tamaño $3 \times 2,5 \mathrm{~m}^{2}$, titulada La Sagrada Familia. Al remodelarse el edificio, la obra fue desmontada y donada al Museo del Azulejo de Onda, donde está expuesta actualmente.

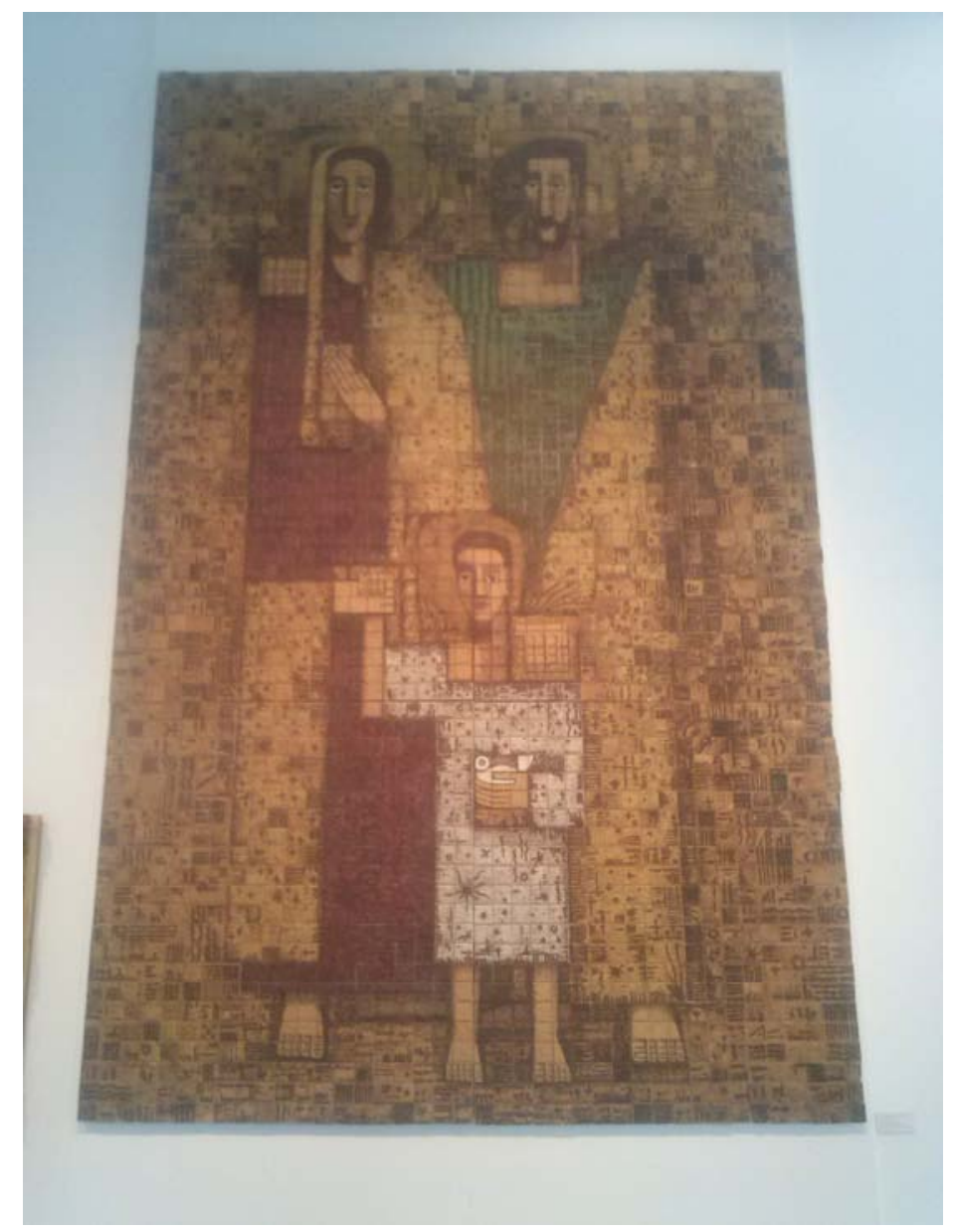

Figura 17: Mural La Sagrada Familia. MAMS.

1964

Participa en el VIII Salón de Mayo de Barcelona. ${ }^{23}$

1965

Participa de nuevo en el IX Salón de Mayo de Barcelona. ${ }^{24}$

\footnotetext{
${ }^{23}$ Ibidem.

${ }^{24}$ Ibidem.
} 
1966

Volvió a participar en el X Salón de Mayo de Barcelona. ${ }^{25}$ También expuso en el Ateneo Cultural de Castellón y participó en la Exposición Nacional de Cerámica de Madrid, y en la Exposición del Premio Ciudad de Barcelona realizada en la capital catalana. ${ }^{26}$

En el Programa de las fiestas patronales de Onda, Luís Padres Perona, presidente del Ateneo de Castellón, publicó un artículo titulado "Safont. Ceramista de Onda". Es el primer artículo del que tenemos constancia que se publica sobre la obra de Safont. ${ }^{27}$

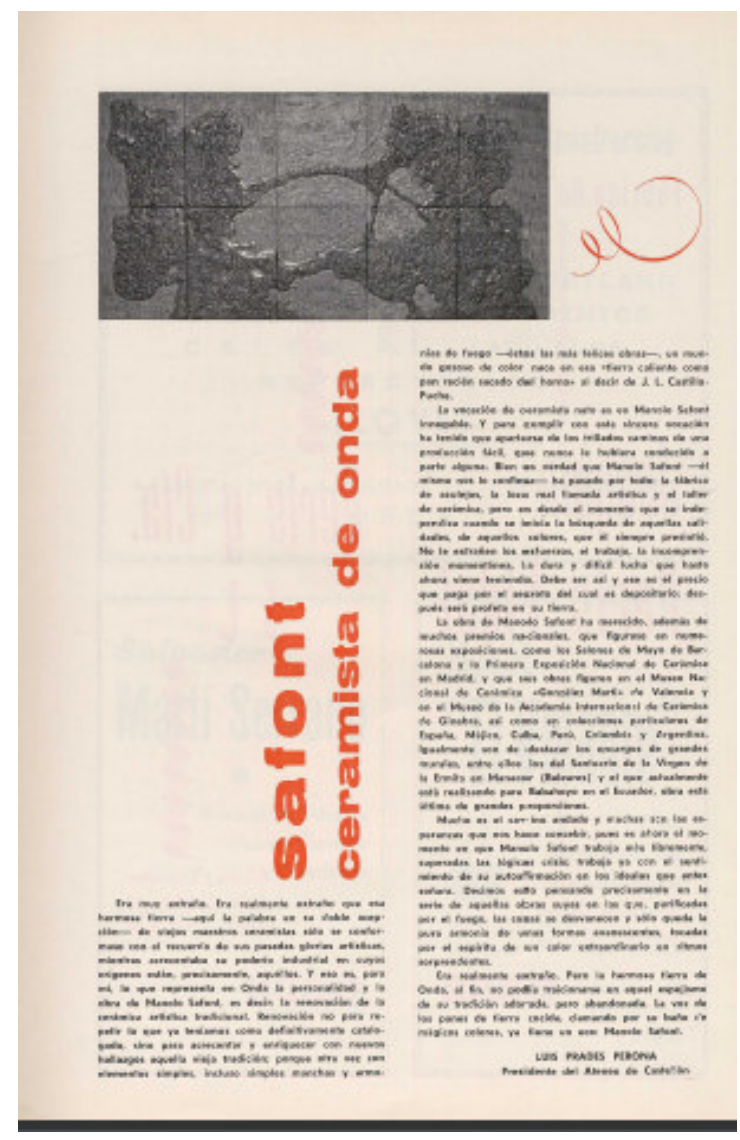

Figura 18: Artículo de Luís Padres Perona.

\footnotetext{
${ }^{25}$ Ibidem.

${ }^{26}$ Ibidem.

${ }^{27}$ Prades Perona, Luís. "Safont ceramista de Onda" en Programa de Fiestas de Onda, Ayuntamiento de Onda, 1966.
} 
1967

En 1967 volvió a concurrir al XI Salón de Mayo de Barcelona, y expuso también en Sant Miquel de Cuixá y en el Cercle Artístic de Sant Lluc de Barcelona. $^{28}$

En este año, crea una obra, un retrato de Ernesto Che Guevara, que supuso una ruptura con su estilo artístico anterior, de pintura cerámica al uso, iniciando una nueva etapa en la que predominan la materia y el color sobre el dibujo.

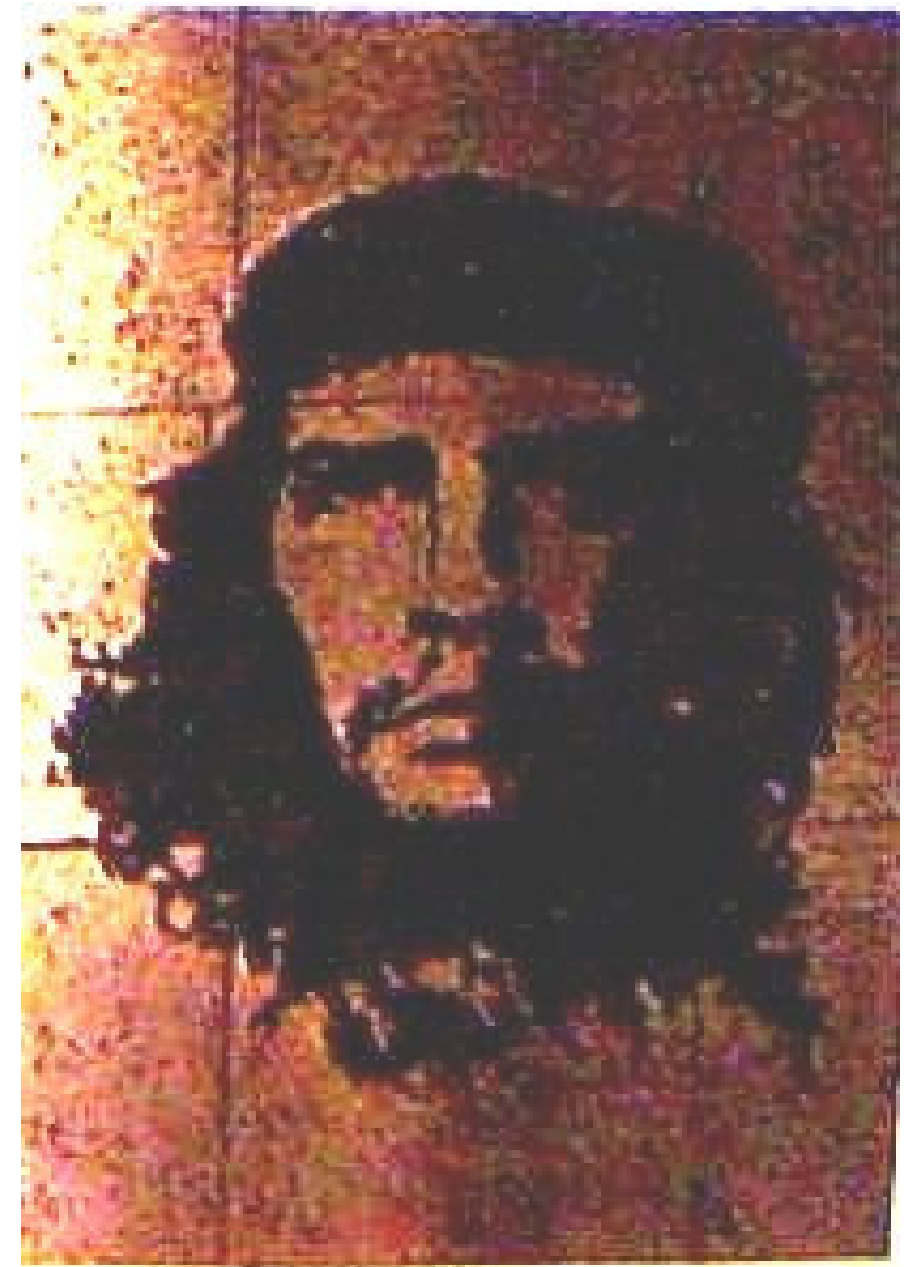

Figura 19: Ernesto Che Guevara de Manolo Safont.

A partir de 1967, Manolo Safont, solo recurre a la figuración en sus obras, como medio de denuncia, plasmando la situación social y política española del momento. Sus obras figurativas de este período reflejan el miedo, la violencia y la opresión social de la sociedad española.

${ }^{28}$ OluCha Montins, Ferran; GIRALT-MIRACLE, Daniel, Op. Cit, marzo de 1995. 
1968

En 1968 volvió a participar en el XII Salón de Mayo de Barcelona, ${ }^{29}$ y realizó otro mural cerámico de gran formato, de $110 \mathrm{~m}^{2}$, encargado por la Catedral de Babahoyo en Ecuador, un edificio de nueva construcción. ${ }^{30}$

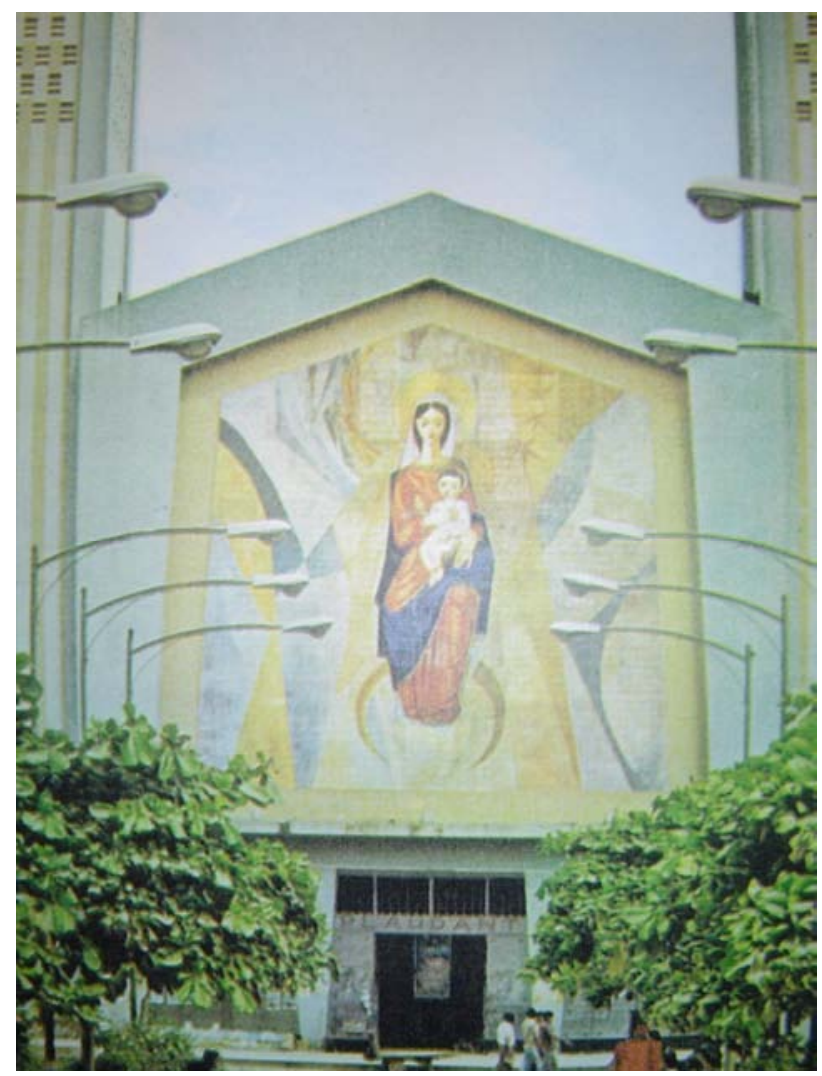

Figura 20: Mural Catedral de Babahoyo, Ecuador.

En la reunión celebrada por la Corporación Municipal del Ayuntamiento de Onda, el 17 de junio de 1968, se acordó solicitar el nombramiento de Manuel Safont Castelló para el cargo de Director del Museo Histórico Municipal, y el 24 de enero de 1969, el Director General de Bellas Artes del Ministerio de Educación y Ciencia, Sección de Museos y Exposiciones, aprueba la designación de Manolo Safont como Director del Museo Histórico Municipal de Onda, por estimarla justa, en atención a los méritos y

\section{${ }^{29}$ Ibidem.}

${ }^{30}$ Notas manuscritas tomadas por Manuel Galver, presidente del Ateneo Cultural y Mercantil de Onda, en una entrevista con Manolo Safont para preparar el discurso homenaje de la concesión del premio Seny Onder de 2003. 
circunstancias que concurren en el mismo. ${ }^{31}$ Siendo ya en esta etapa de su vida, un referente en el mundo de la cerámica artística.

En este mismo año, Rafael Menezo, rueda un cortometraje de carácter documental sobre Safont titulado Fang i Pinzells: El món i l'obra de Manolo Safont, con guión de Tomás Ribera. ${ }^{32}$

Safont continúa colaborando con el Ayuntamiento de Onda, realizando la portada del programa de fiestas, así como el diseño gráfico del interior del programa.

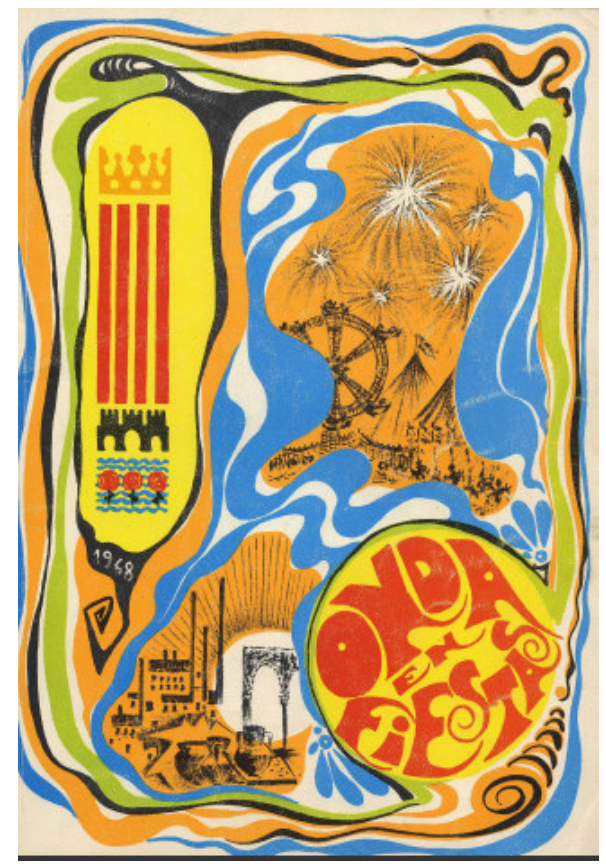

Figura 21: Portada programa de fiestas de Onda de 1968.

1969

Expuso en Trilce, Barcelona. ${ }^{33}$

El 24 de enero, la Dirección General de Bellas Artes, del Ministerio de Educación y Ciencia, Sección de Museos y Exposiciones, aprobó la designación de Safont como Director del Museo Histórico Municipal de Onda.

\footnotetext{
${ }^{31}$ Documento enviado por el Ministerio de Educación y Ciencia, Sección de Museos y Exposiciones, con fecha del 24 enero de 1969, al Alcalde-Presidente del Magnífico Ayuntamiento de Onda, y con registro de entrada del Ayuntamiento de Onda del 31 de enero de 1969.

${ }^{32}$ Cortometraje documental Fang i pinzells: El món i l’obra de Manolo Safont.

${ }^{33}$ Olucha Montins, Ferran; Giralt-MiRacle, Daniel, Op. Cit, marzo de 1995.
} 


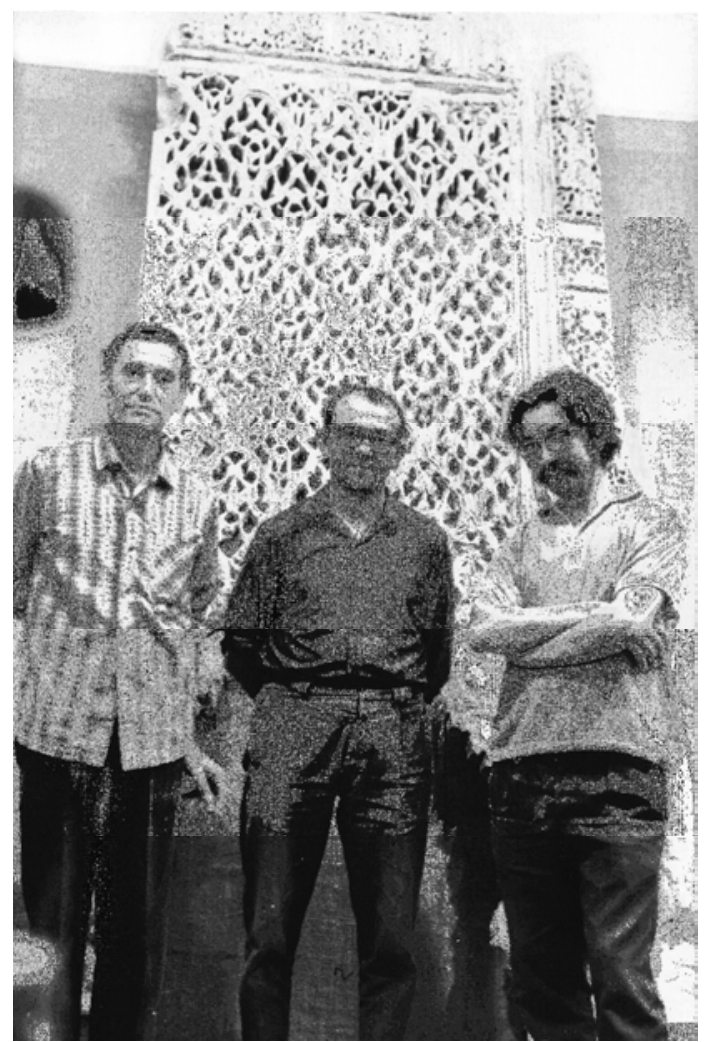

Figura 22: Safont en los inicios de su etapa como director del Museo de Onda.

Continúa su colaboración con el Ayuntamiento de Onda, para la elaboración del programa de fiestas local.

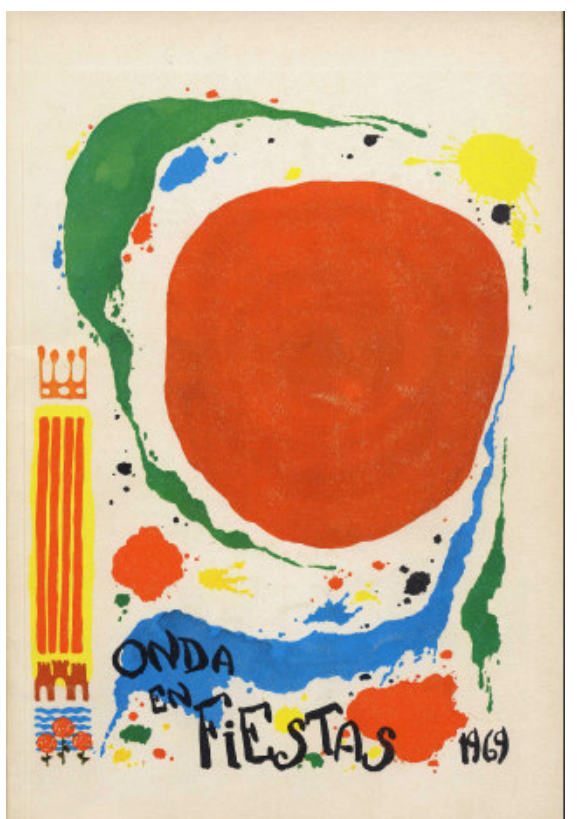

Figura 23: Portada programa fiestas 1969. 
1970

En 1970, del 28 de febrero al 15 de marzo, inaugura en el Círculo Mercantil e Industrial de Castellón, la exposición "Manolo Safont", de la cual se edita un catálogo, cuyo texto de presentación escribió Joan Fuster. ${ }^{34}$

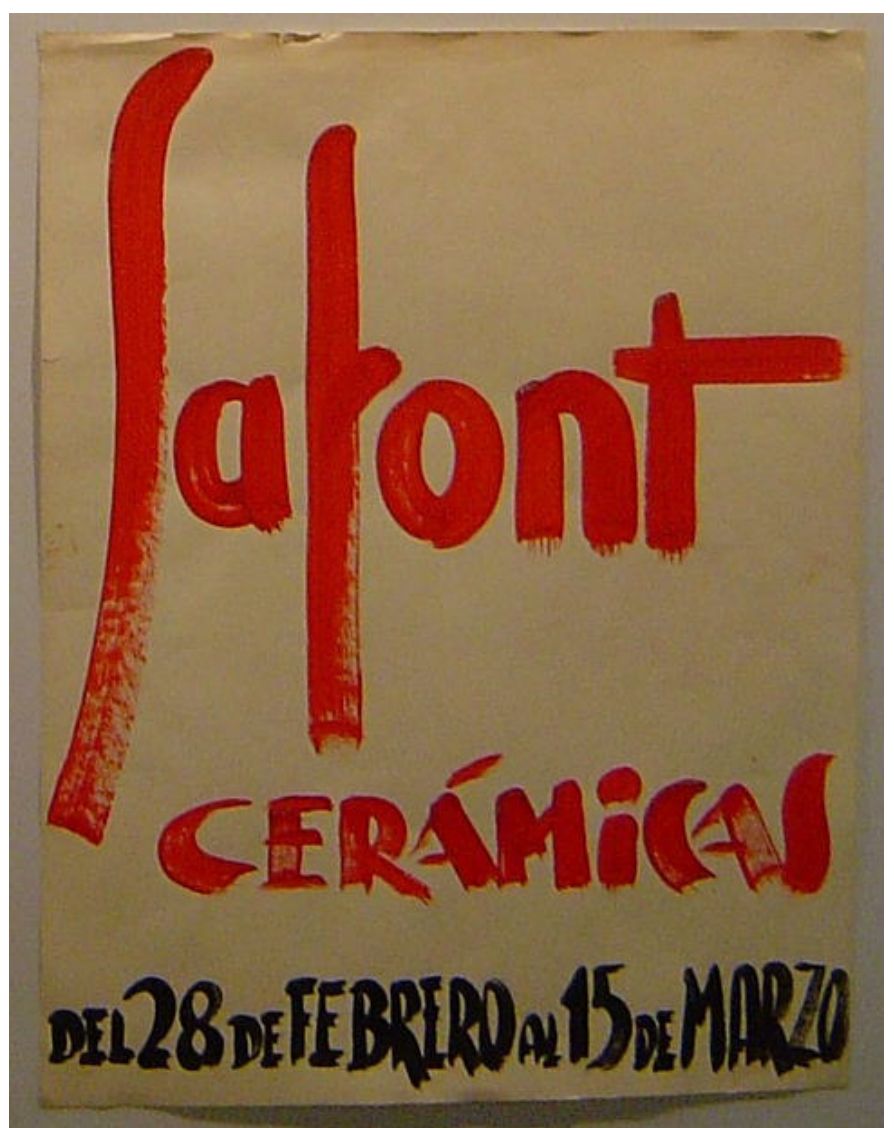

Figura 24: Cartel anunciador de la exposición del Círculo Mercantil e Industrial de Castellón, realizado por el propio Safont.

También participó en la Exposició d'Art Contemporani, en Valencia, y expuso en Viver (Castellón). ${ }^{35}$

Safont continúa colaborando en la elaboración del programa de las fiestas patronales de Onda de este año, realizando la portada así como diferentes dibujos para ilustrar su interior.

${ }^{34}$ De la Calle, Romà; Pérez Mondragón, F. Sobre el descrèdit de la modernitat. PUV, Universitat de València, 2010, pág. 58

${ }^{35}$ Datos obtenidos del catálogo de la exposición OLUCHA MONTINS, Ferran; GIRALTMIRACLE, Daniel, Op. Cit, marzo de 1995. 


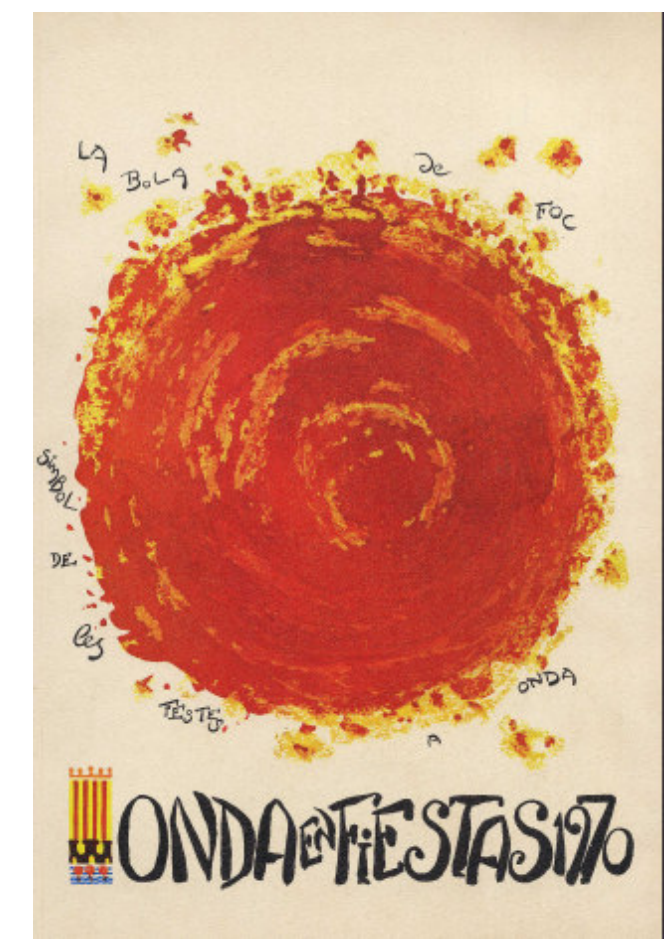

Figura 25: Portada programa fiestas de Onda 1970.

1971

En 1971 Manolo Safont logra hacer realidad uno de sus grandes sueños, crear en Onda una sala de exposiciones en la cual poder mostrar el arte vanguardista y actual que se estaba realizando en la Comunidad Valenciana, un proyecto expositivo que podía tener una ubicación fija y permanente, la Sala Municipal d'Onda, ubicada en una pequeña sala anexa a la edificación del Ayuntamiento de Onda.

Una sala de exposiciones a la cual por su tamaño se denominó cariñosamente "La Saleta", y en la cual desde 1971 hasta 2005 se expuso la mejor propuesta expositiva y divulgativa del arte contemporáneo valenciano, en la cual se inauguraban exposiciones de forma periódica, cada quince días o cada mes, convirtiéndose en cita ineludible no sólo para artistas y estudiosos del arte, sino para gran parte de la población ondense que acudía expectante a ver las nuevas propuestas expositivas. 


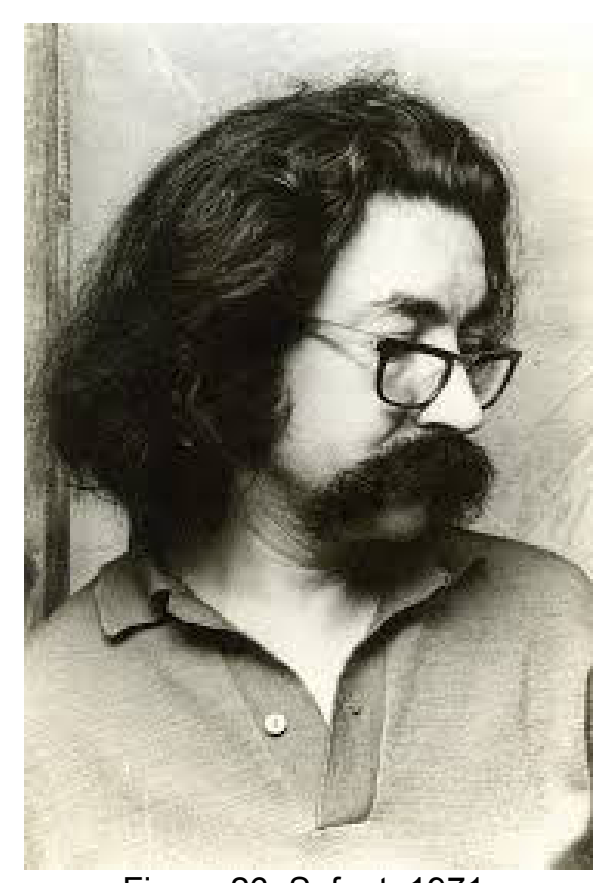

Figura 26: Safont 1971.

Safont luchó por crear esta Saleta y mostrar el arte actual a los ciudadanos de Onda, y por ayudar y propiciar que los jóvenes y nuevos artistas emergentes, muchos de los cuales son hoy en día son consagradas figuras de la plástica contemporánea, tuvieran un lugar donde exponer y mostrar sus obras, dándoles una oportunidad que los circuitos artísticos más comerciales o las galerías de arte no les concedían. Safont, junto con su esposa Ana, se encargaba de seleccionar las exposiciones, los artistas, las obras, colgar los cuadros, preparar los catálogos, repartirlos y enviarlos por correo, vigilar las exposiciones y encargarse de abrir y cerrar La Saleta. Safont fue el artífice que propició que la gente de Onda tuviera, a través de La Saleta, en una época sin internet, la posibilidad de ver obras artísticas de las corrientes plásticas más contemporáneas. ${ }^{36}$

Esta Sala Municipal de exposiciones, se inauguró en octubre, con una exposición cerámica colectiva de Manolo Safont y Angelina Alós: Exposición Manolo Safont y Angelina Alós. Sala Municipal d'Exposicions d'Onda,

En 1971 vuelve a exponer en el Círculo Mercantil e Industrial de Castellón, del 13 al 27 de marzo. ${ }^{37}$

\footnotetext{
${ }^{36}$ Homenatge a La Saleta. Sala Municipal d'Exposicions d'Onda. Octubre 2005, Onda.

${ }^{37}$ Olucha Montins, Ferran; GIRALT-MiRacle, Daniel, Op. Cit, marzo de 1995.
} 


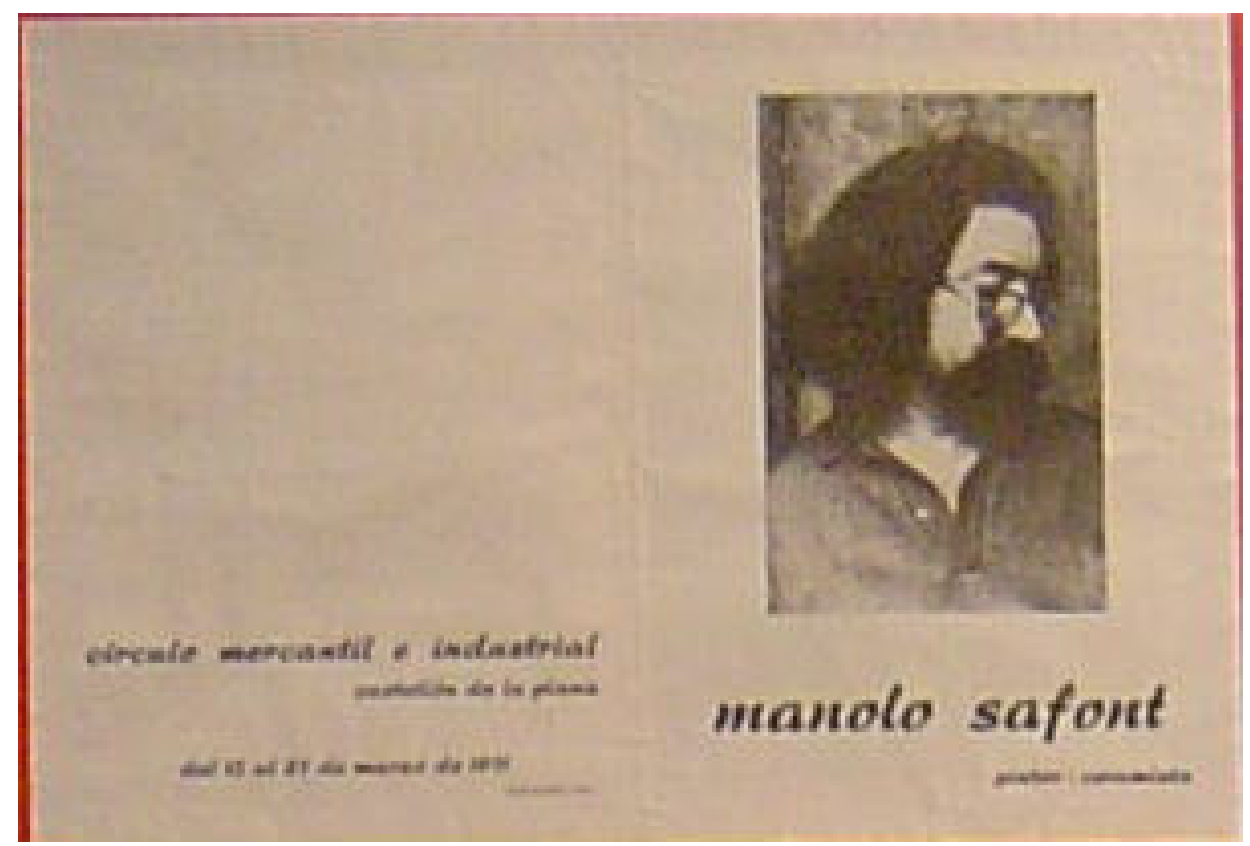

Figura 27: Catálogo exposición Círculo Mercantil e Industrial de Castellón, 1971.

En esta ocasión no realizó la portada del programa de fiestas de Onda, aunque sí los diferentes dibujos para ilustrar su interior.

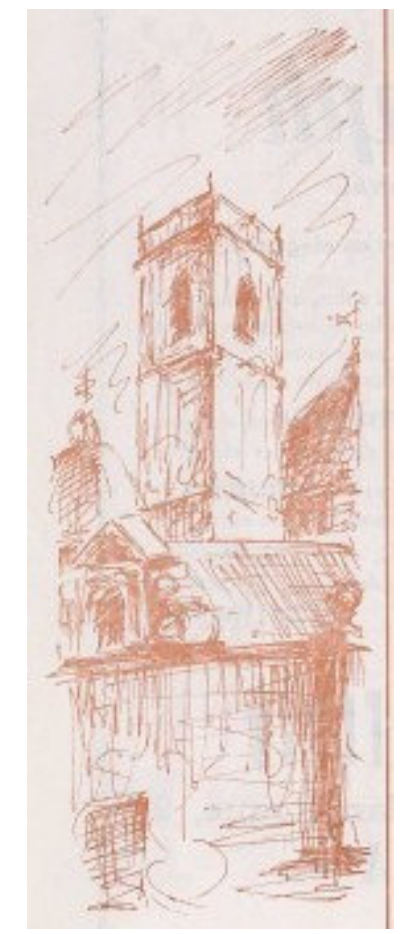

Figura 28: Dibujo de la Iglesia de la Asunción de Onda.

A partir de 1971, se impone absolutamente la abstracción sobre la figuración, y sus obras adquieren mayor libertad de expresión y creación. 
En 1972 participó como invitado en la Feria Monográfica Nacional de Vidrio y Cerámica que se realizó en Valencia, así como en el XXX Concurso Internacional de Cerámica de Faenza (Italia) y expuso en el Ayuntamiento de Viver (Castellón) y en la Sala Municipal de Onda (Castellón) en la exposición colectiva Art Castellonenc d'Avui. ${ }^{38}$

1973

En febrero-marzo de 1973 expuso la muestra "Manolo Safont" en la Sala Ramón Durán (Madrid), de la cual se realizó un catálogo con textos de Víctor Nieto Alcaide, ${ }^{39}$ y participó de nuevo en el Concurso Internacional de Cerámica de Faenza (Italia) en su XXXI edición, así como en el II Concurso Internacional de Cerámica de Gdañsk en Polonia, en el que obtuvo un diploma, en la Setmana d'Art de Burriana (Castellón) y también expuso de nuevo en el Ayuntamiento de Viver. ${ }^{40}$

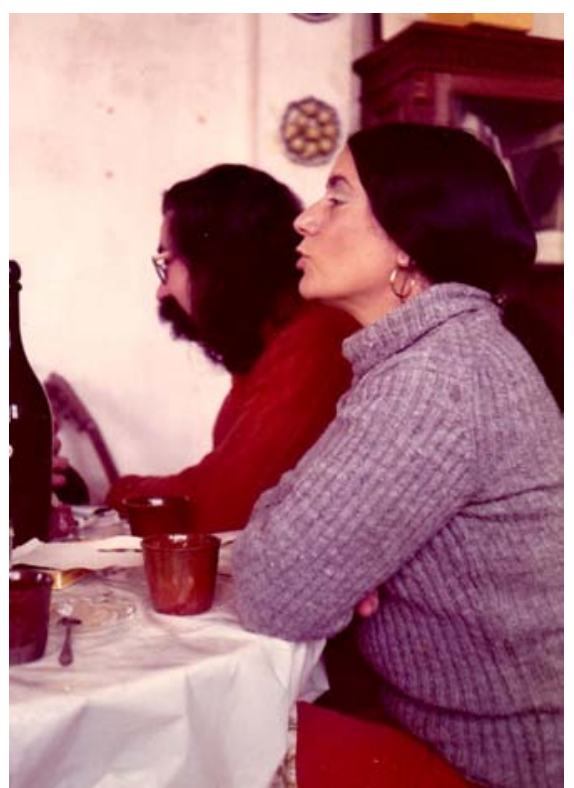

Figura 29: Manolo y Ana, 1973.

\footnotetext{
${ }^{38}$ Ibidem.

${ }^{39}$ http://www.racba.org/es/mostrarcurriculum.php?id=554

${ }^{40}$ Olucha Montins, Ferran; Giralt-MiRacle, Daniel, Op. Cit, marzo de 1995.
} 
Este año expuso dos veces en la Sala Municipal de Onda, en la II edición de la muestra colectiva Art Castellonenc d'Avui, ${ }^{41}$ y con una exposición individual realizada desde diciembre de 1973 a enero de 1974.

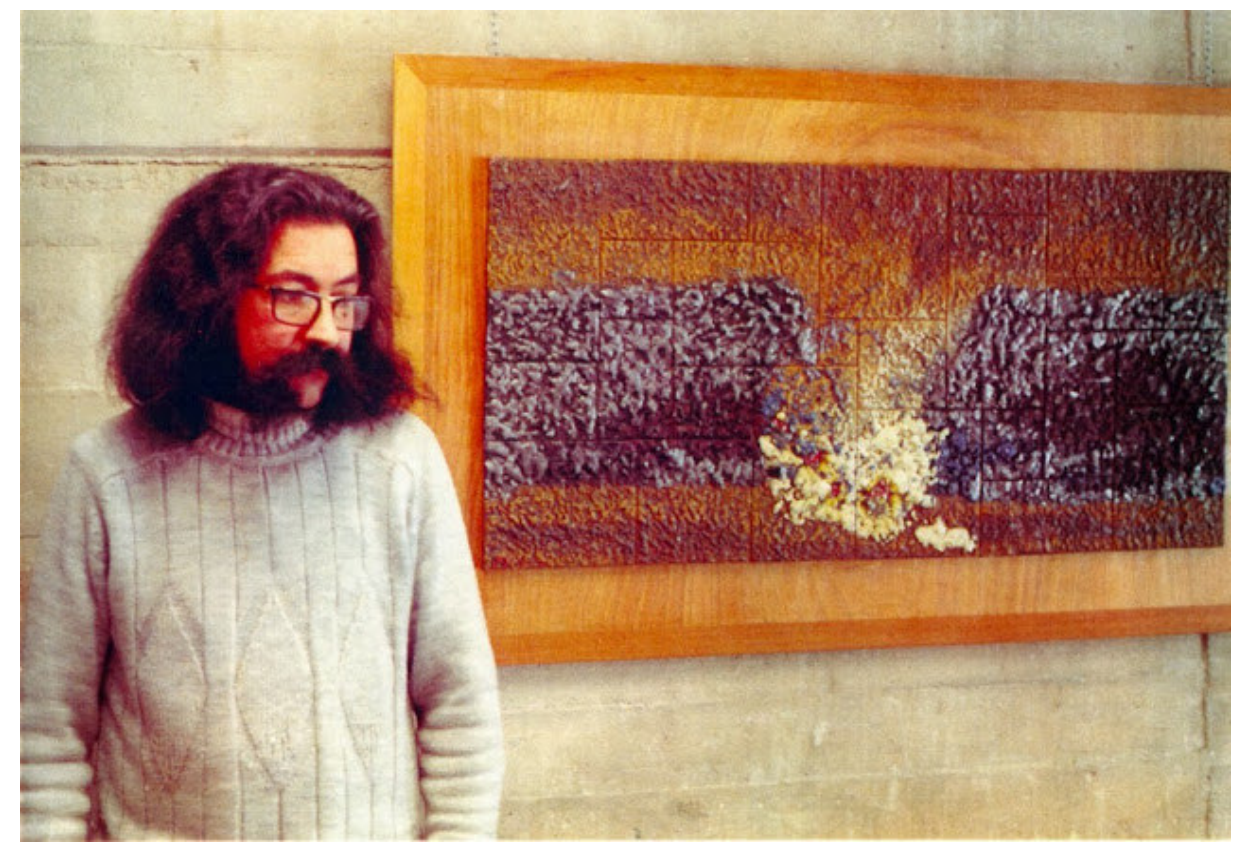

Figura 30: Safont en la Saleta Municipal d'Onda, 1973.

Miguel Manuel Arrando, amigo personal de Safont, le encargó el diseño de un zócalo de azulejos y del logotipo de la nueva farmacia que iba a abrir en la localidad de Onda, situada en la actual avenida del País Valencià.

1974

En 1974 expuso en Subex (Barcelona) y en Burriana (Castellón) y volvió a participar en la III edición de Art Castellonenc d'Avui celebrada en la Sala Municipal de Onda. ${ }^{42}$

\footnotetext{
${ }^{41}$ Ibidem.

${ }^{42}$ Ibidem.
} 


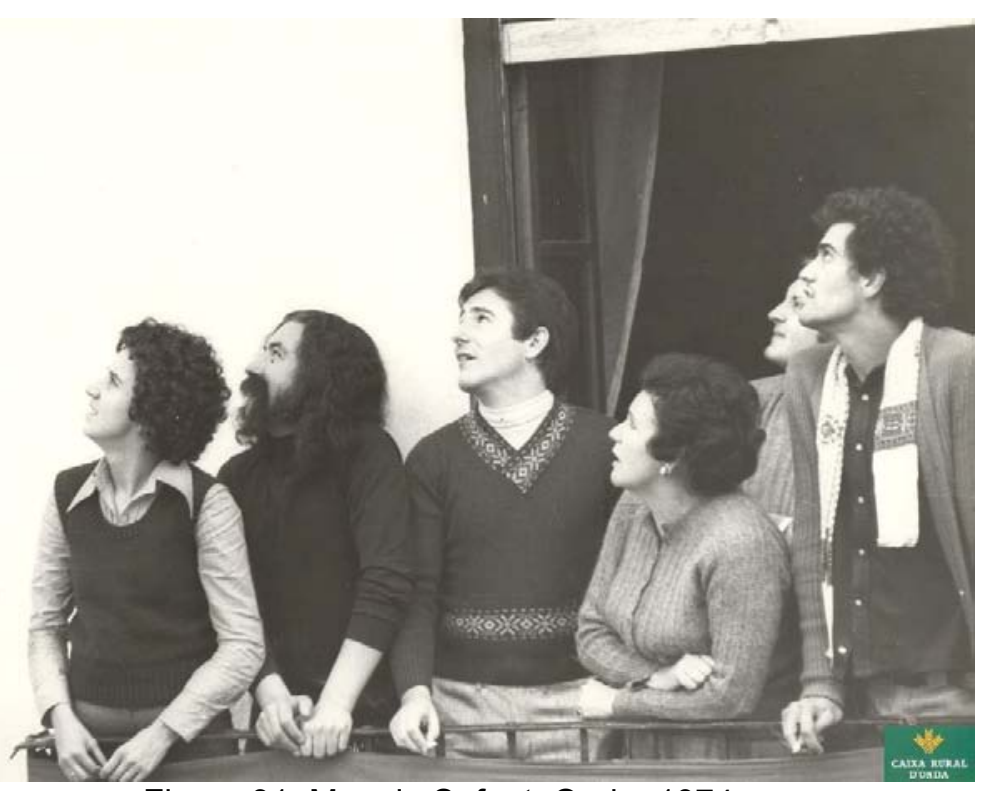

Figura 31: Manolo Safont, Onda, 1974.

De nuevo colaboró con el Ayuntamiento de Onda y realizó la portada del programa de fiestas de este año.

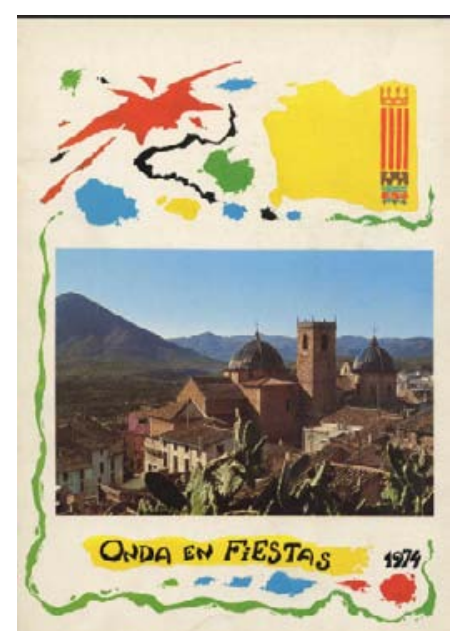

Figura 32: Portada programa de fiestas de Onda de 1974.

1975

En 1975 expuso dos veces en la Sala Municipal de Onda, una de forma individual y otra participando en la colectiva IV edición de la muestra "Art Castellonenc d'Avuí".

Este mismo año, también expone entre el 28 de febrero y el 26 de marzo en la Galería Cànem de Castellón con la exposición titulada "Safont. Pintures ceràmiques". 


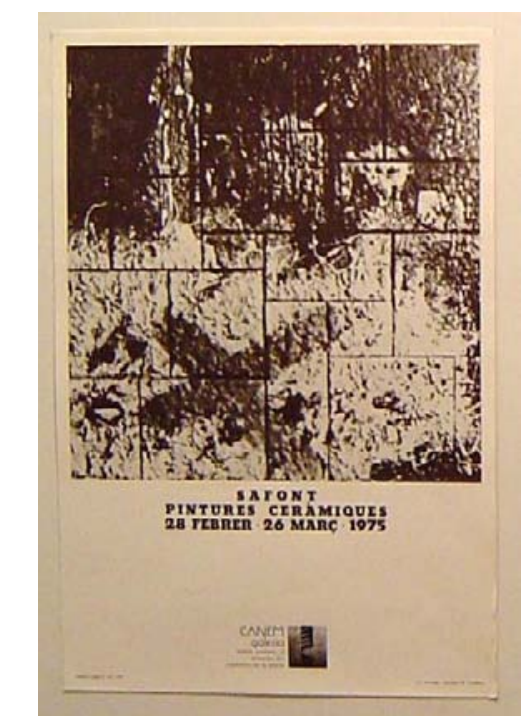

Figura 33: Cartel exposición Galería Cànem, 1995.

Expuso en la galería Ramón Durán de Madrid y también participó en la Muestra de Pintura Castellonenca realizada en Nules (Castellón). ${ }^{43}$

En el programa de fiestas de Onda de este año, vuelven a utilizarse dibujos de Safont para ilustrar el interior.

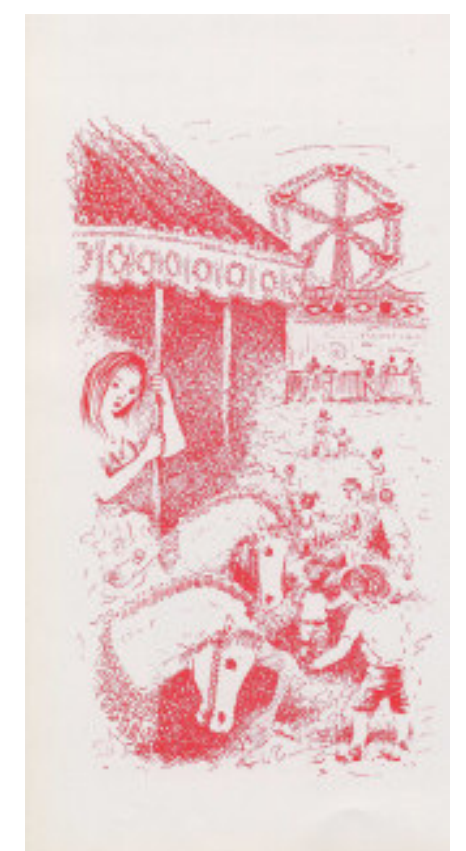

Figura 34: Dibujo de Safont para el programa de fiestas de 1975.

\footnotetext{
${ }^{43}$ Ibidem.
} 
1976

En 1976 Safont presenta un proyecto, que resulta seleccionado junto con otros once, para un concurso convocado por la Fundación General Mediterránea para la creación de doce murales cerámicos para las áreas de servicio de la autopista del Ebro Zaragoza-Barcelona.

Participó en la $V$ edición de la muestra Art Castellonenc d'Avui realizada en la Sala Municipal de Onda, y de nuevo sus dibujos sirvieron para ilustrar el interior del programa de fiestas de Onda de este año.

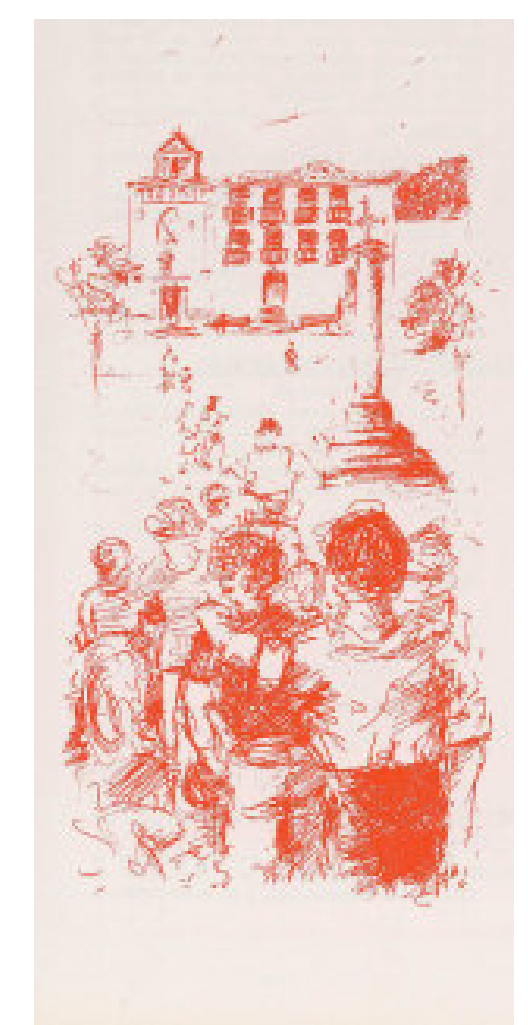

Figura 35: Dibujo de Safont para el programa de fiestas de Onda de 1976.

1977

Participó en la VI edición de la muestra Art Castellonenc d'Avui realizada en la Sala Municipal de Onda, que desde esta edición pasa a denominarse Art d'Avui al País Valencià. ${ }^{44}$ Los dibujos de Safont ilustran de nuevo el programa de fiestas de este año.

\footnotetext{
${ }^{44}$ Ibidem.
} 
En 1978, Manolo Safont traslada su taller a una alquería situada en las afueras de la localidad de Onda, situada en la actual calle Escultor Foliá nº 22.

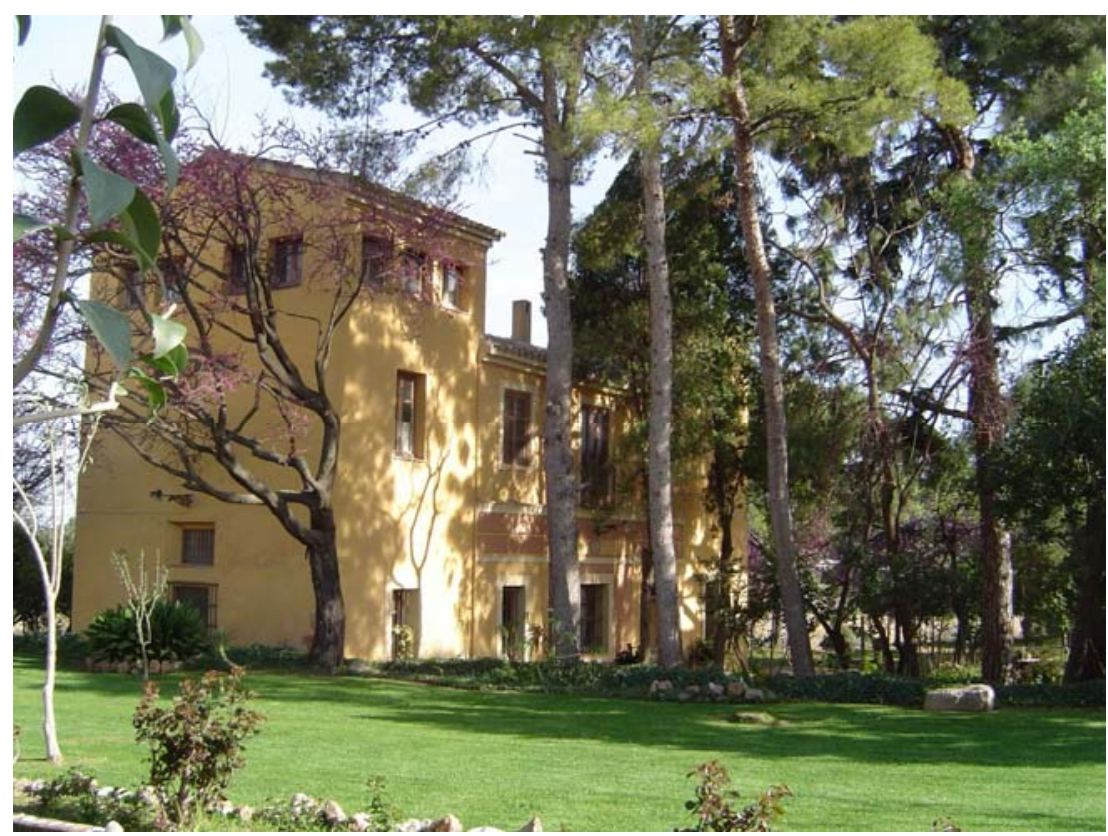

Figura 36: Casa-alquería de Manolo Safont.

La casa de Manolo y Ana, tanto la primera vivienda-taller situada en la calle Historiador Bernardo Mundina, como la alquería del barrio de la Morería, fue el punto de irradiación cultural más importante de la provincia de Castellón durante la década de 1960 y 1970. Allí se crearon asociaciones culturales como "Amics d'Onda" o "Amics del Museu" y revistas como Panderola.

La transición de la década de los años 1960 y 1970 no fue fácil. Los intelectuales de la Comunidad Valenciana, los que luego ocuparían cátedras, los que mostraban inquietudes y trabajaban en pro de la cultura, sobre todo de la valenciana, contaban con el apoyo de algunas personas que ofrecían todo, aunque fuera poco, y que hicieron más llevadera su lucha. Se dice que en ese periodo existían dos santuarios laicos en la actual Comunidad Valenciana. Uno, estaba ubicado en la calle de San José en Sueca (Valencia): la casa de Joan Fuster. El otro, en la plaza de San José, en la plaza del Raval de Onda (Castellón): la casa de Manolo Safont. Por allí pasó mucha gente, entre los que se encontraban Arcadi García, Manuel Ardit, Josep Renau, Joan Fuster, Alberto García Esteve, Vicent Pitarch, Jesus Huguet, Antoni Seva, etc, cuyas 
ideas y proyectos, fueron y son, protagonistas y referentes de la vida cultural y social valenciana y española, convirtiéndose en un destacado foco cultural. ${ }^{45}$

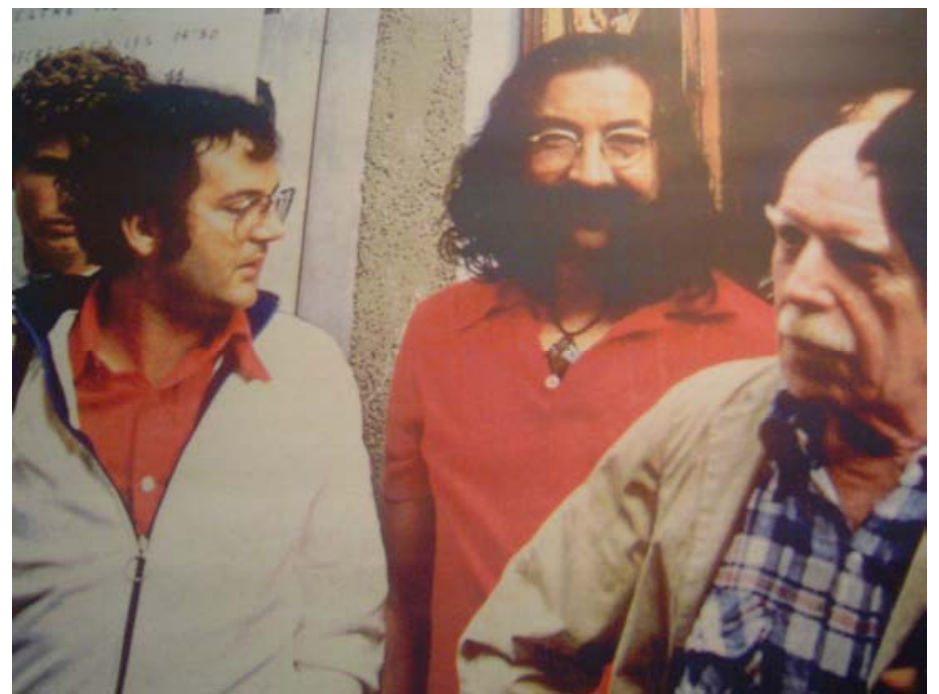

Figura 37: Manolo Safont.

Tampoco en este nuevo taller pudo disponer Safont de un horno propio en el que cocer sus obras, pues no tenía instalación eléctrica, ${ }^{46}$ por lo que siguió cociendo sus obras en diferentes hornos cerámicos de diversas fábricas de Onda.

En 1978 expuso de forma individual, "Safont" del 23 al 30 de septiembre, en la Sala Municipal de Onda, y de forma colectiva, participando en la VII edición de la muestra Art d'Avui al País Valencià que se realizó en esta misma Sala Municipal de Onda.

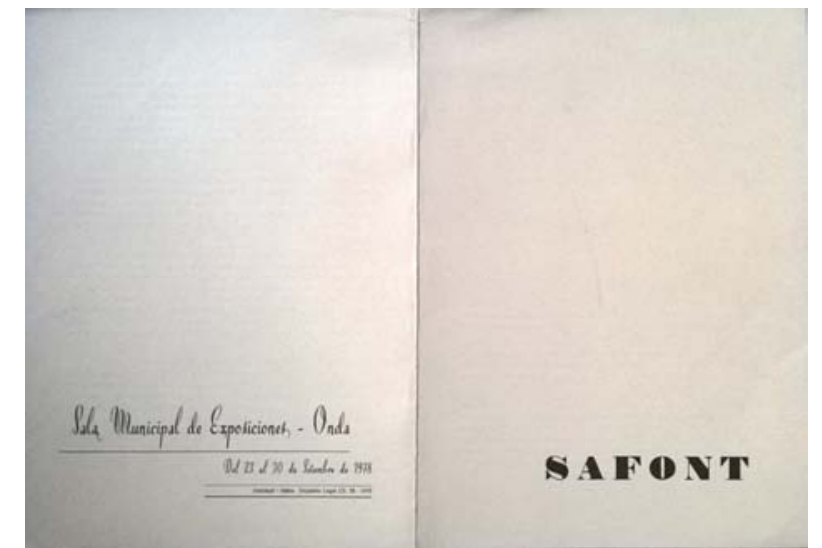

Figura 38: Catálogo exposición Safont en Sala Municipal de Onda, 1978.

\footnotetext{
45 FABRA, María. "El señor del santuario laico", en EL PAíS, 15 abril 2005, http://elpais.com/diario/2005/04/15/cvalenciana/1113592712_850215.html

${ }^{46}$ La vivienda no se conectó a la red eléctrica municipal de Onda hasta 1984.
} 
También expuso en la Sala Goya de la Casa de España en París, entre el 5 y el 15 de octubre, así como en Bree (Bélgica) y en la Galería Cànem de Castellón con la exposición "Grans obres de petit format". ${ }^{47}$

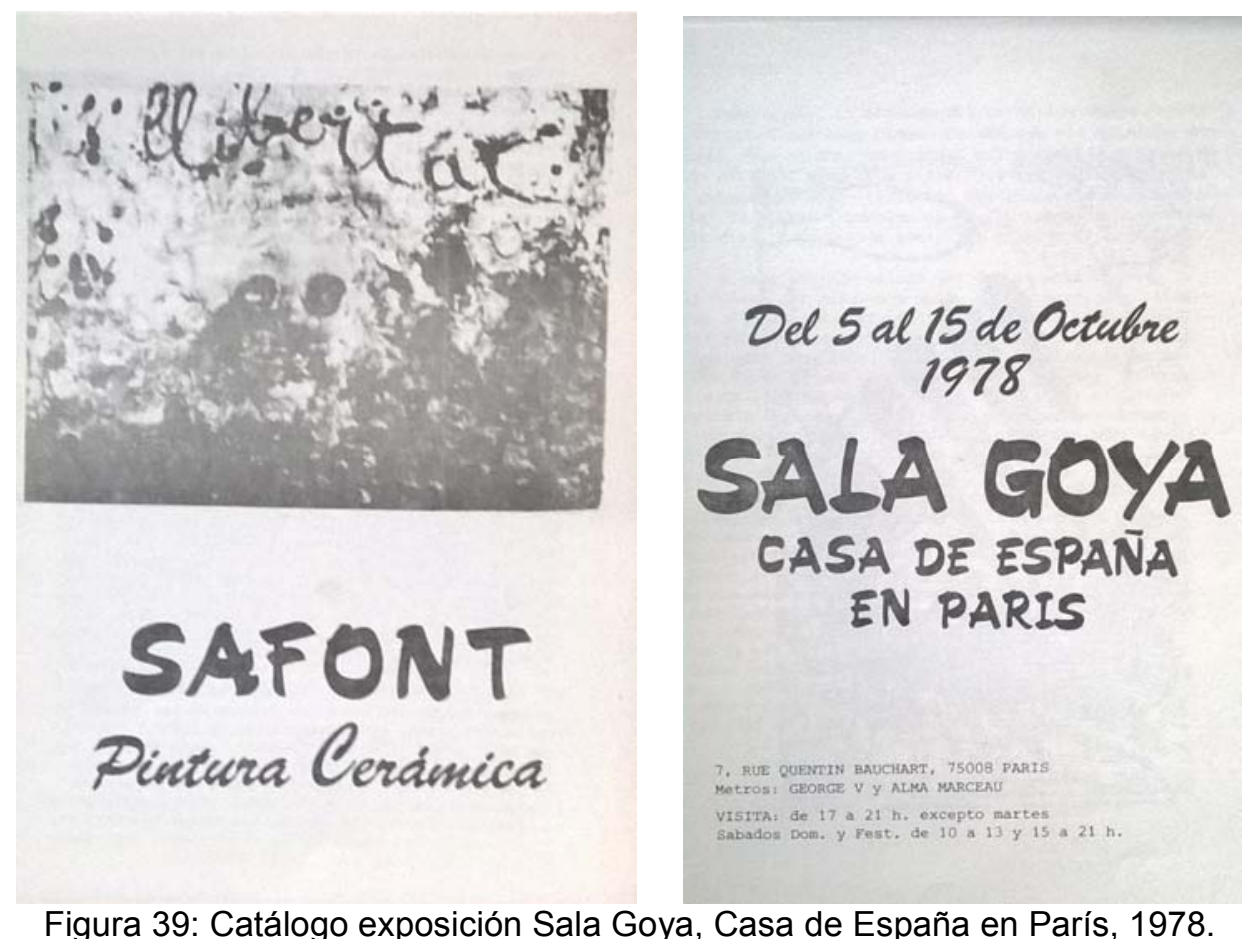

1979

En 1979 expuso en Opheylissem en Helecine (Bélgica), en la colectiva Cinco artistas españoles y cuatro polacos realizada en Aix-en-Provence (Francia) y en Ceràmica actual dels Països Catalans organizada por FAD en Barcelona. ${ }^{48}$

A finales de la década de 1970, una vez acabada la etapa histórica del franquismo, Safont abandona definitivamente la figuración para centrarse y trabajar exclusivamente la abstracción.

\footnotetext{
${ }^{47}$ OLUCHA MONTINS, Ferran; GIRALT-MIRACLE, Daniel, Op. Cit, marzo de 1995. 48 Ibidem.
} 
1980

Entre el 3 y el 30 de marzo de 1980 expone en el Museo Nacional de Cerámica de Valencia y en la Biblioteca Municipal de Vila-Real (Castellón) entre el 17 y el 31 de mayo. ${ }^{49}$

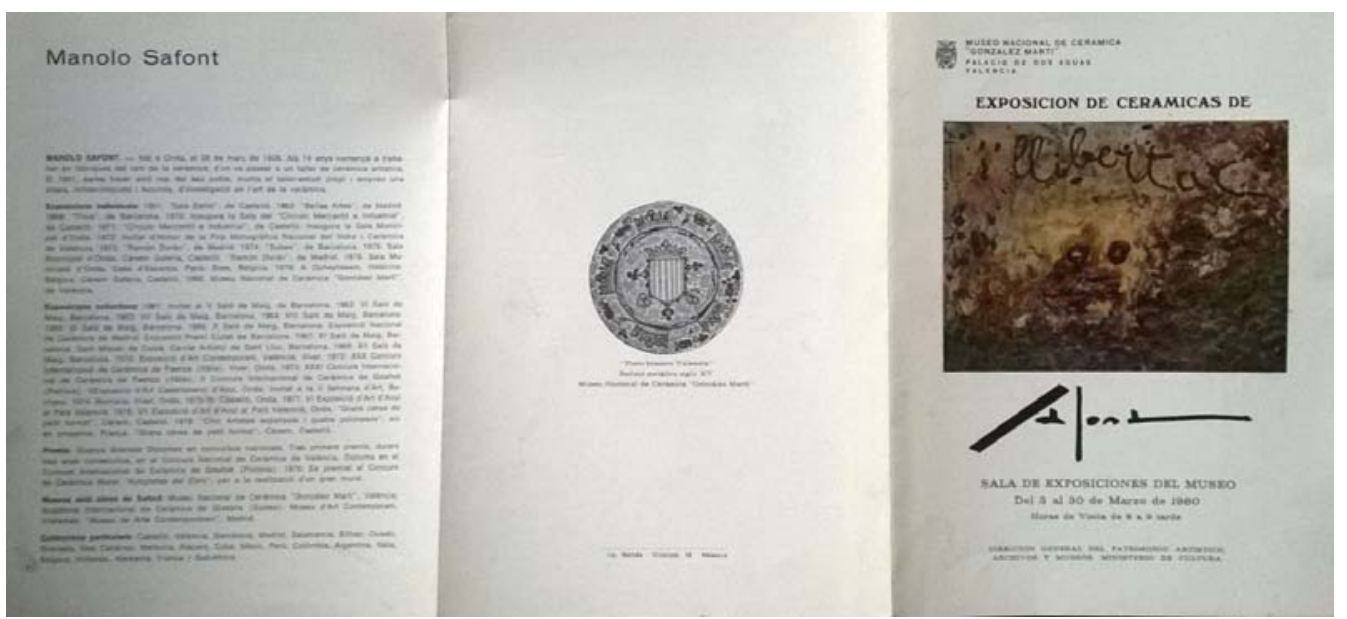

Figura 40: Catálogo exposición Museo Nacional de Cerámica González Martí, 1980.

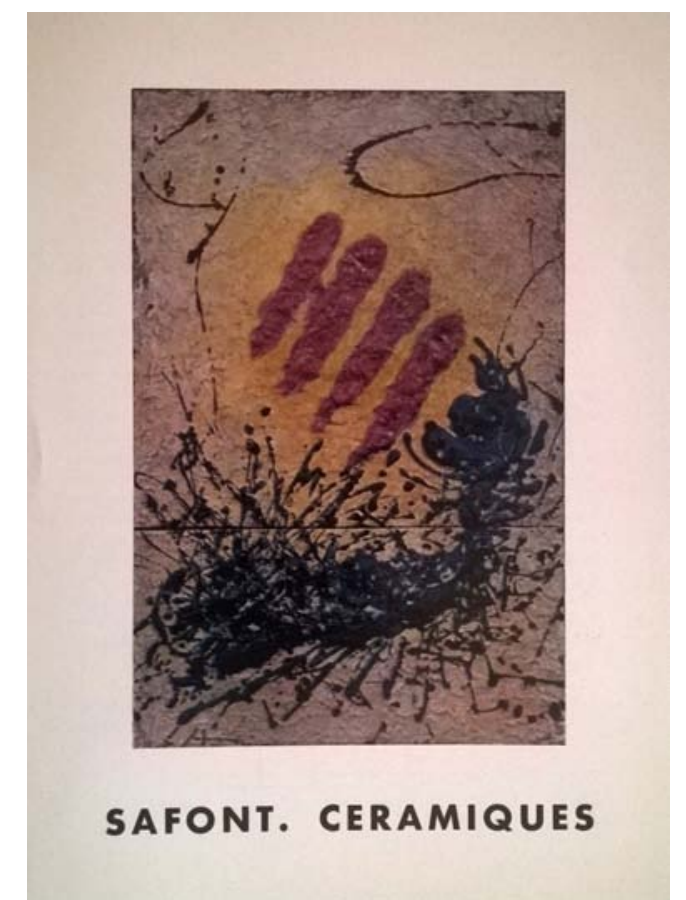

Figura 41: Catálogo exposición Biblioteca Municipal Vila-Real.

En octubre de este año, se publica el programa de fiestas de Onda, en el que de nuevo colabora Safont, realizando los dibujos del interior.

${ }^{49}$ Ibidem. 
Del 2 al 21 de noviembre expuso "Manolo Safont" en la Sala Municipal d'Exposicions del Ayuntamiento de Torrent (Valencia), publicándose un catálogo con prólogo de Joan Fuster. ${ }^{50}$

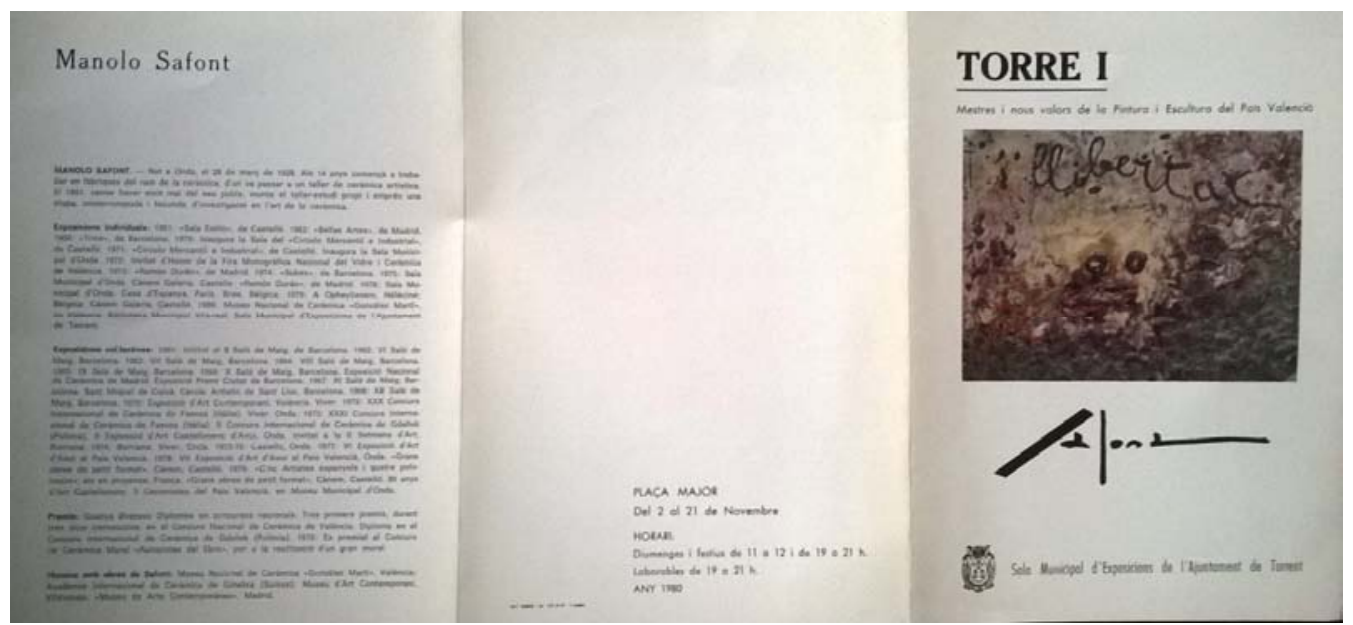

Figura 42: Catálogo exposición Ayuntamiento de Torrent.

Del 24 de noviembre al 6 de diciembre, realizó la exposición "Manolo Safont" en la Caja de Ahorros de Alicante y Murcia en Elche (Alicante).

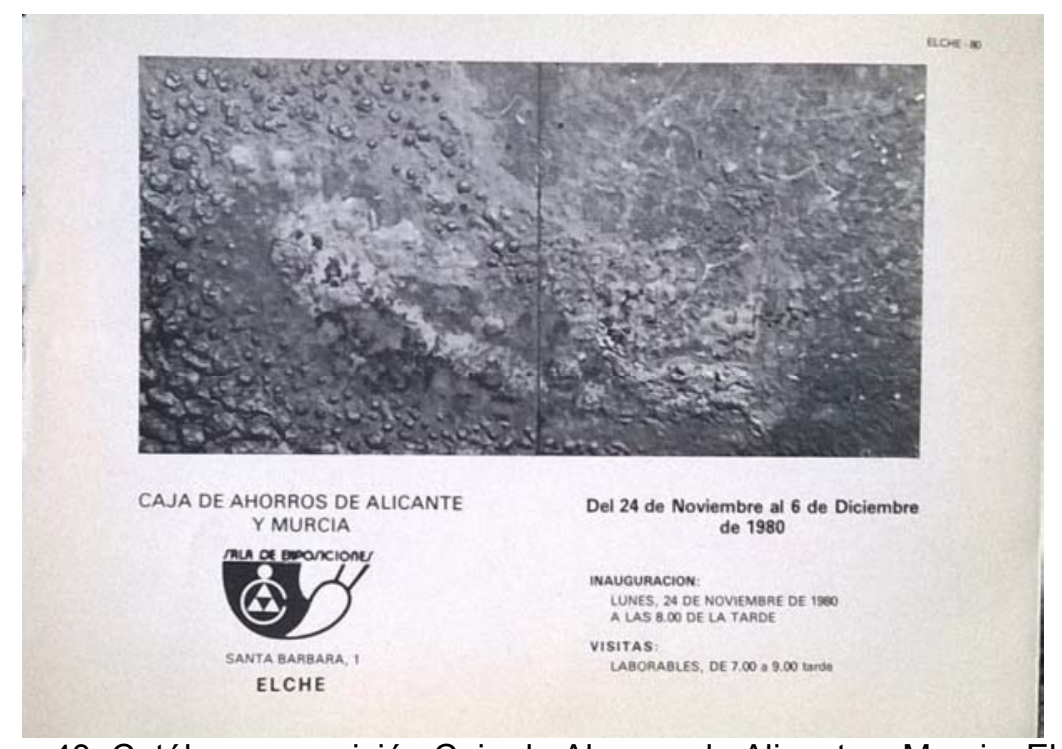

Figura 43: Catálogo exposición Caja de Ahorros de Alicante y Murcia, Elche.

En 1980 también participó en varias exposiciones colectivas: 80 anys d'art castellonenc que organizó el Museo Provincial de Castellón, y 3

${ }^{50}$ De la Calle, Romà / Pérez Moragón, F. Op. Cit, 2010, pág. 58. 
ceramistes del País Valencià, junto con Angelina Alós y Enric Mestre, que se realizó del 19 al 30 de octubre, organizada por el Museo Municipal de Onda. ${ }^{51}$

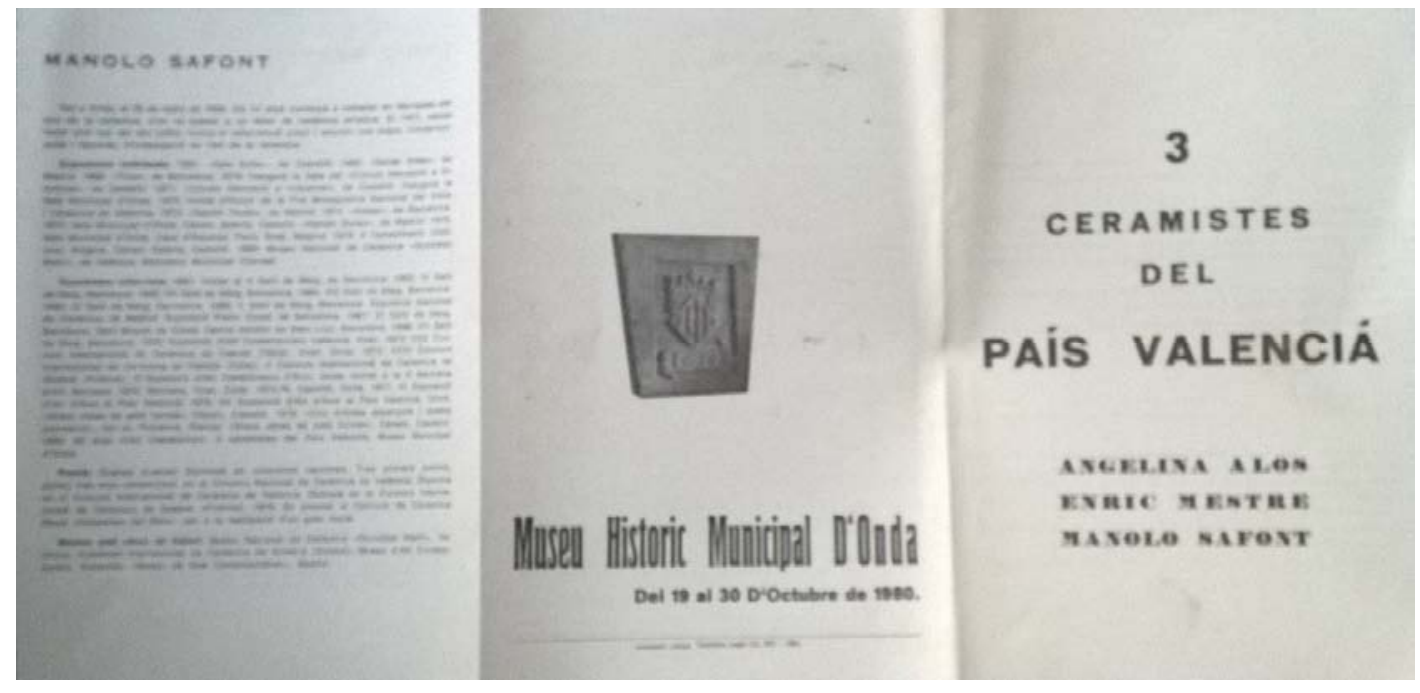

Figura 44: Catálogo exposición Museu Historic Municipal d’Onda.

En diciembre expuso en el Museu d'Art Contemporani d'Alacant. Con motivo de esta exposición en Alicante, se publica un interesante artículo en que se entrevista a Manolo Safont, y en el cual, sin tapujos, habla de su formación, estilo, ideas políticas y el reconocimiento de sus obras, así como de la crisis que atraviesa el sector cerámico industrial y artesanal. ${ }^{52}$

1981

En 1981 expuso en el Ayuntamiento de Riba-Roja (Valencia), en el Ayuntamiento de Manises (Valencia) y en el Ayuntamiento de Puerto de Sagunto (Valencia). ${ }^{53}$

\footnotetext{
${ }^{51}$ Olucha Montins, Ferran / GIRALT-MiraCle, Daniel, Op. Cit, marzo de 1995.

52 M.V. "Manolo Safont. La lluita contra el foc", Generalitat, segona quinzena, desembre 1980, pág. 29.

${ }^{53}$ Olucha Montins, Ferran/ GiRalt-MiRacle, Daniel, Op. Cit, marzo de 1995.
} 
1982

En 1982 expuso en la Galería Expo d'Art de la Vall d’Uixó (Castellón) y del 20 de octubre al 20 de noviembre, en el Museu de Ceràmica del Palau de Montjuïc de Barcelona. ${ }^{54}$

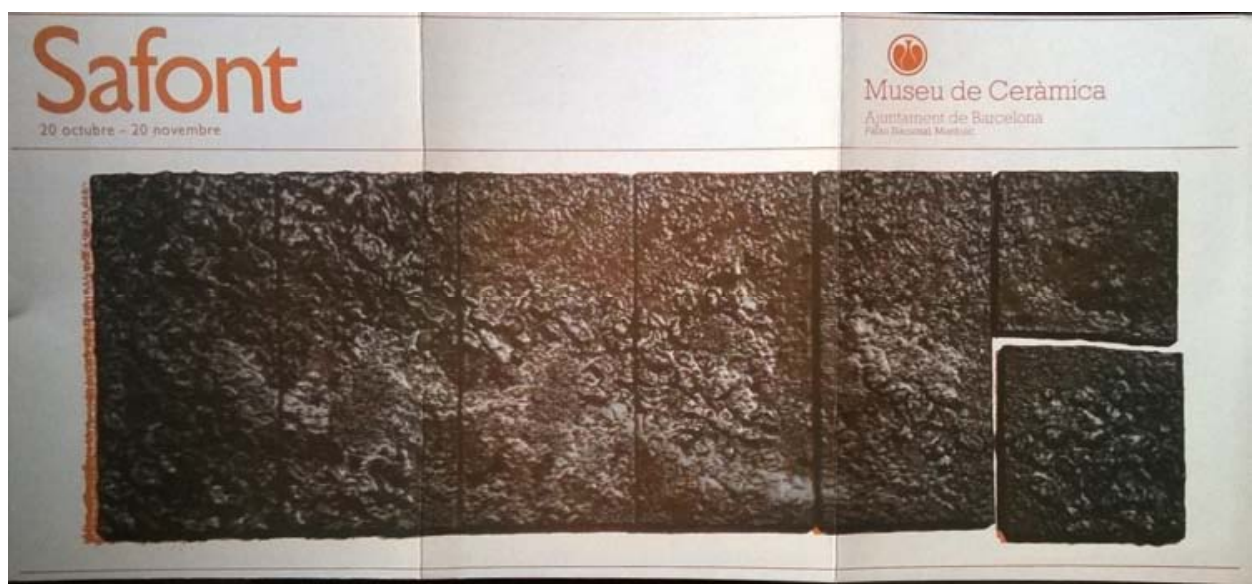

Figura 45: Catálogo exposición Museu de Ceràmica, Barcelona.

1983

Entre el 28 de marzo y el 16 de abril expuso "Manolo Safont" en Fontana d'Or en Girona.

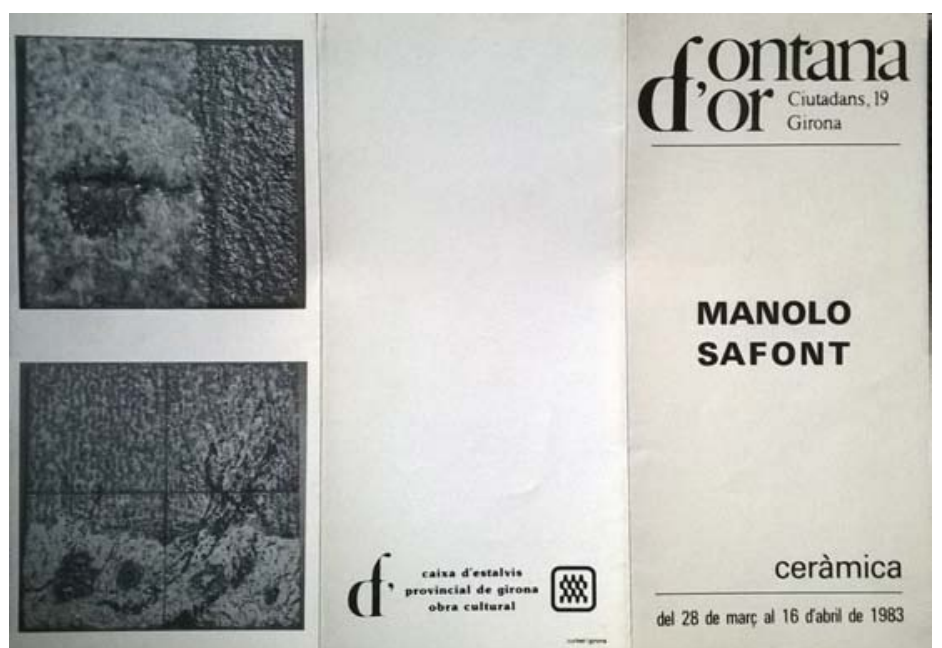

Figura 46: Catálogo exposición Fontana d’Or, Girona.

${ }^{54}$ Ibidem. 
Del 9 al 16 de mayo de 1983 expuso Safont. Ceràmica en el Palau Oliver de Boteller de Tortosa (Tarragona) de la cual se realizó un catálogo con textos prologados por Joan Fuster. ${ }^{55}$

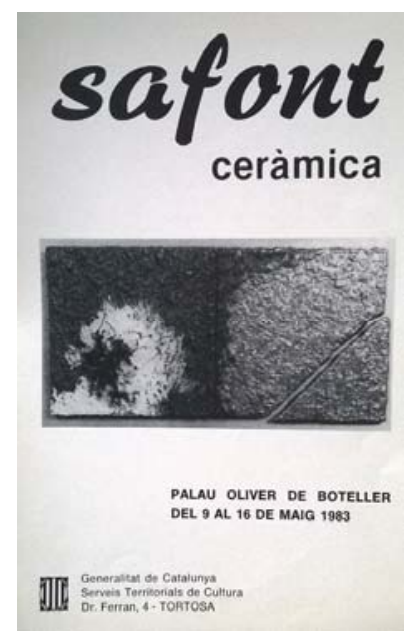

Figura 47: Catálogo exposición Palau Oliver de Boteller, Tortosa.

También participó en la muestra colectiva organizada por la Sala Municipal de Onda (Castellón) Art Valencià d'Avuí. ${ }^{56}$

La portada del programa de Fira d'Onda, se ilustró con una obra de Safont.

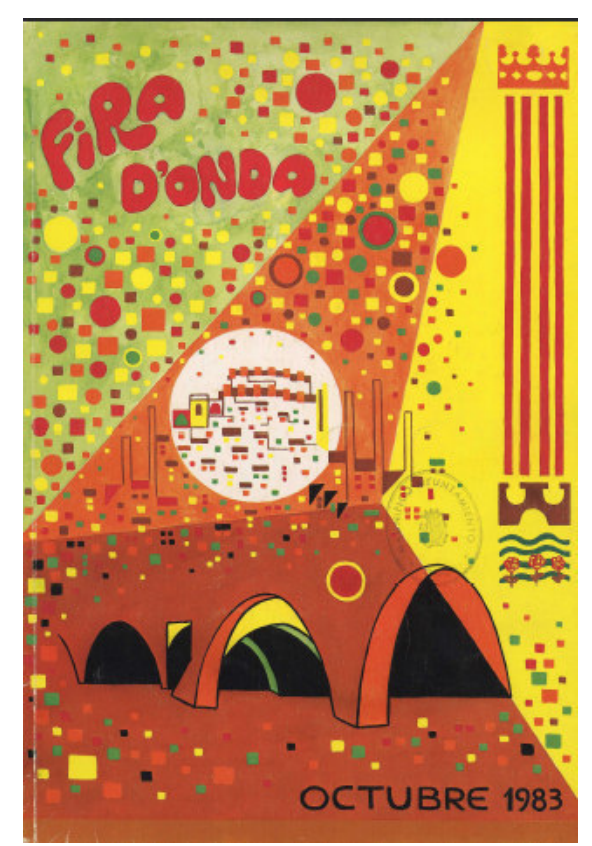

Figura 48: Portada Programa Fiestas de Onda, 1983.

\footnotetext{
${ }^{55}$ De la Calle, Romà / Pérez Moragón, F. Op. Cit. 2010, pág. 58.

${ }^{56}$ Olucha Montins, Ferran / GiRAlt-Miracle, Daniel, Op. Cit, marzo de 1995.
} 
Hasta este año, Safont realizaba sus piezas en su taller y las cocía en hornos cerámicos de diferentes empresas locales de Onda, pero en 1984, instaló un horno cerámico en su casa. ${ }^{57}$ Con este nuevo horno, Safont era mucho más libre a la hora de investigar y experimentar con la materia, creando nuevas fórmulas de texturas y acabados para temperaturas de cocción que iban desde los $980^{\circ}$ hasta los $1000^{\circ}$, pudiendo llegar incluso a alcanzar los $1260^{\circ}$ en la cocción de algunas piezas de pequeño formato.

En 1984 expuso desde el 28 de julio hasta el 19 de agosto, en el Castell del Papa Luna de Peñíscola (Castellón), en una muestra colectiva junto con los artistas Marcelo Díaz y Amat Bellés, organizada por la Diputación Provincial, ${ }^{58}$ y en la Caja Rural de Vila-Real (Castellón). ${ }^{59}$

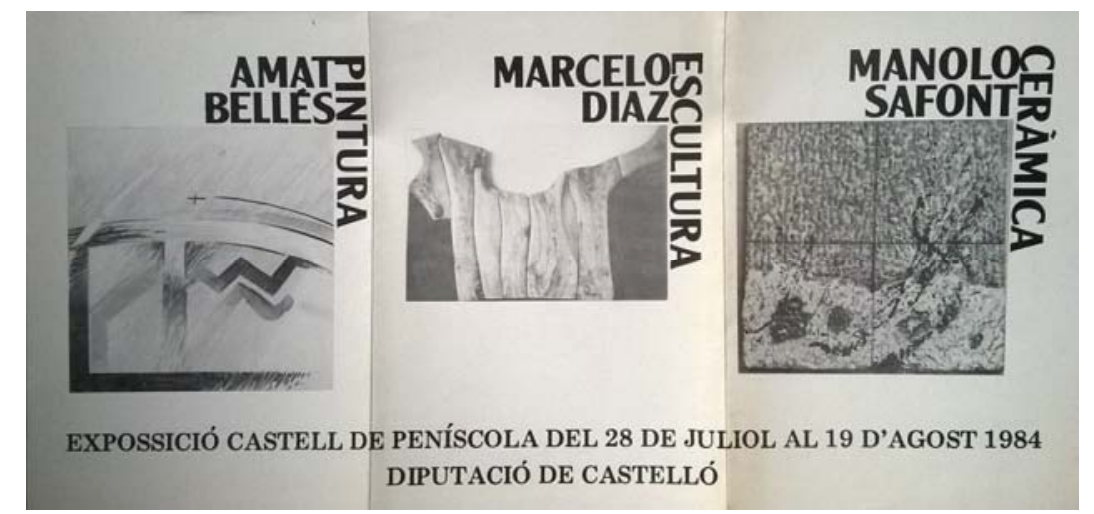

Figura 49: Catálogo exposición Castell del Papa Luna, Peñíscola.

1985

En el año 1985 participó en una exposición colectiva junto con los artistas Marcelo Díaz y Amat Bellés, realizada del 9 al 24 de marzo, en la Biblioteca Municipal de Segorbe (Castellón), y en otra colectiva Homenaje de artistas contemporáneos a la Cartuja de Vall de Christ con motivo del VI centenario de su fundación, con motivo del VI Centenario de la Fundación de la

\footnotetext{
${ }^{57}$ Albalat, Antoni. Op. Cit. 27 de noviembre de 2005, pág. 7.

58 “Exposición de Díaz, Bellés y Safont”, Castellón Diario, 27 de julio de 1984, pág. 9.

${ }^{59}$ Olucha Montins, Ferran / GiRAlt-MiRACle, Daniel, Op. Cit, marzo de 1995.
} 
Cartuja de Val de Christ y en la Casa de Cultura de Soneja (Castellón) ${ }^{60}$ y realizó por encargo un mural cerámico de $20 \mathrm{~m}^{2}$ para el Instituto $\mathrm{n}^{0} 5$ de Castellón (actual IES Vicent Castell i Domènech).

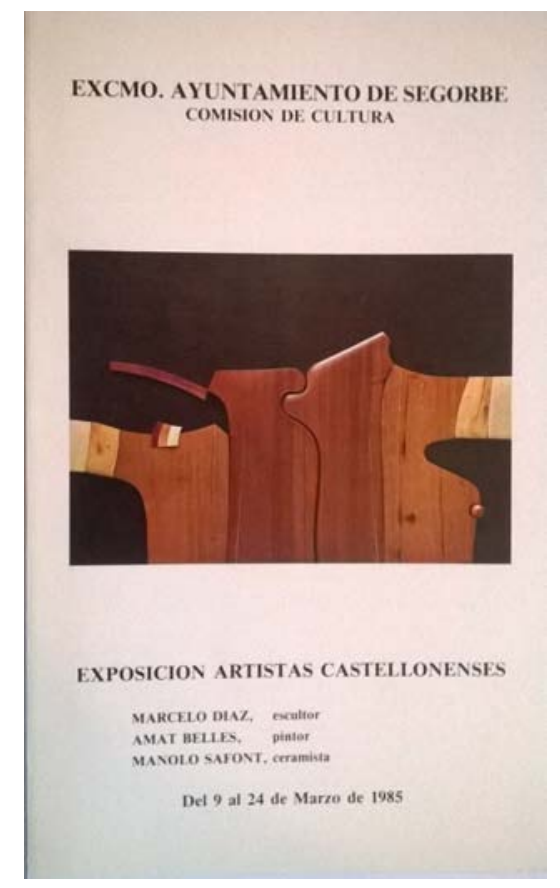

Figura 50: Catálogo exposición colectiva Segorbe.

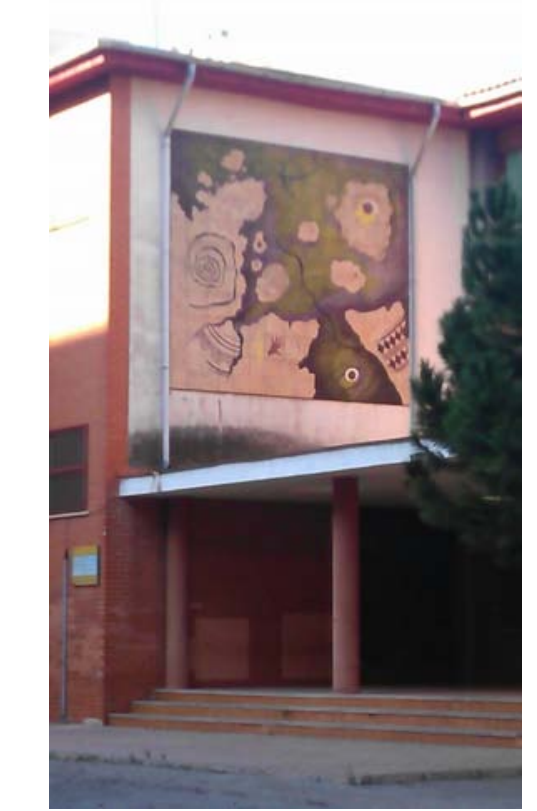

Figura 51: Mural IES Vicent Castell i Doménech.

\section{${ }^{60}$ Ibidem.}


1986

En 1986 participó en Trovades de Ceràmica, Arts Aplicades de Castellón, ${ }^{61}$ y en las "Jornades de ceràmica" que organizó la delegación de Castellón del Colegio Oficial de Arquitectos de la Comunidad Valenciana, entre el 8 y el 18 de enero, junto con Arcadi Blasco y Enric Mestre.

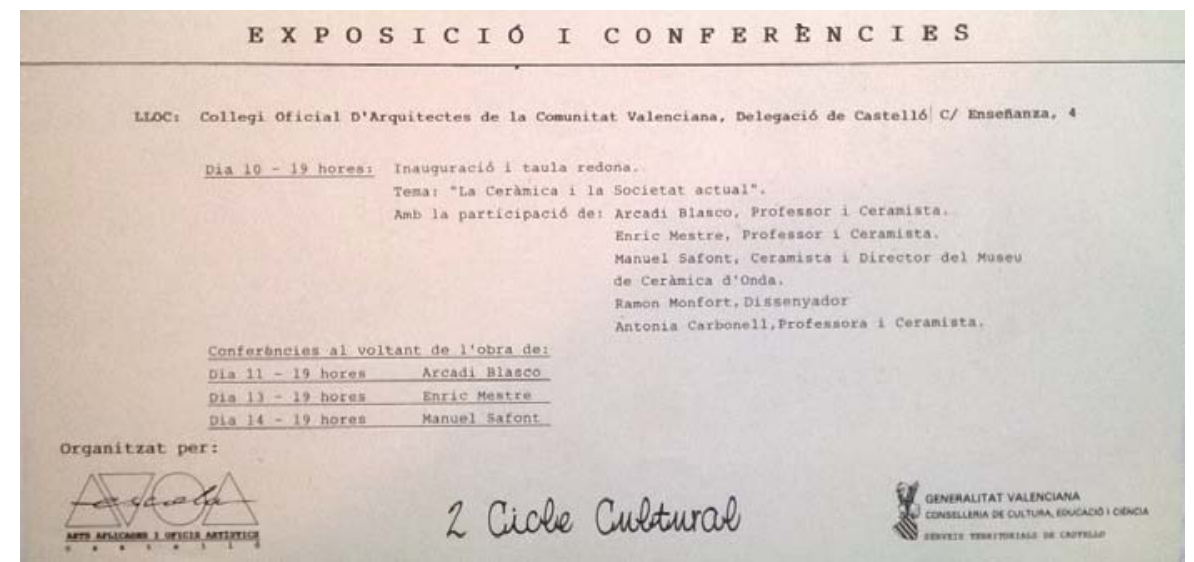

Figura 52: Jornades de ceràmica, Colegio Oficial de Arquitectos de la Comunidad Valenciana.

Realizó dos nuevos murales cerámicos uno de ellos un mural cerámico de $9 \mathrm{~m}^{2}$ para el colegio Mestre Caballero de Onda (Castellón).

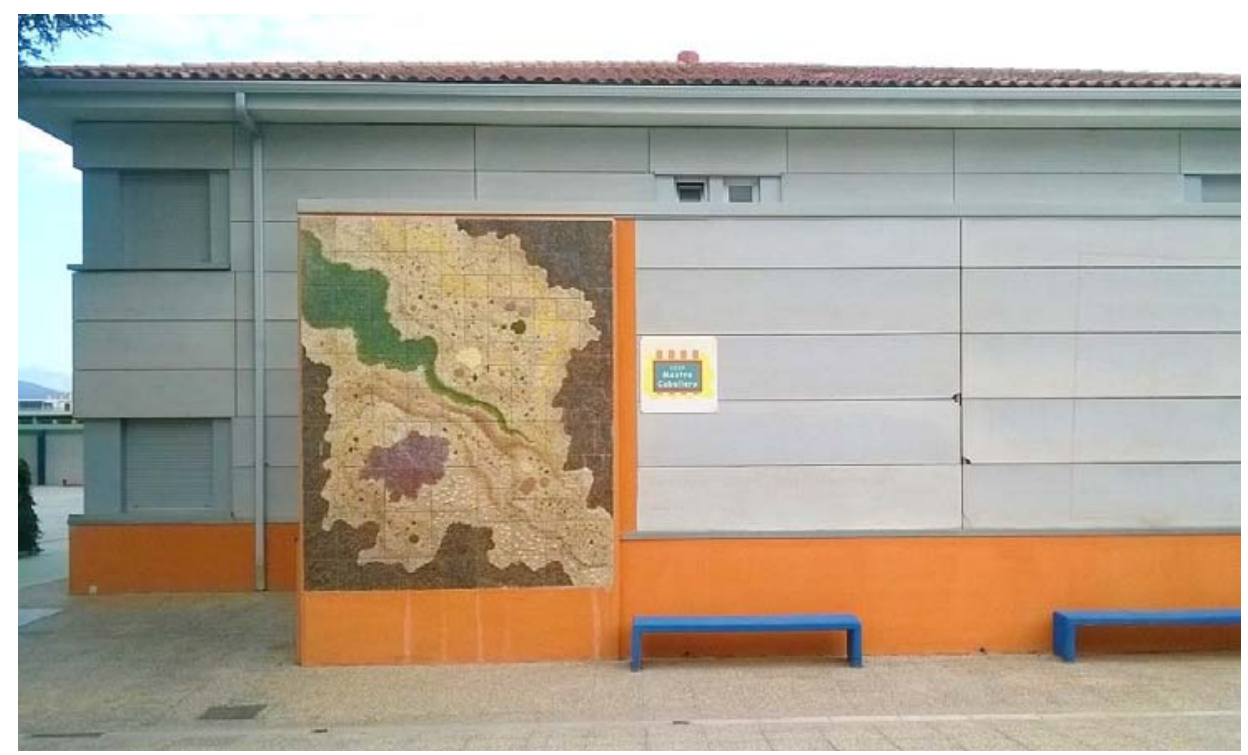

Figura 53: Mural cerámico del CEIP Mestre Caballero de Onda.

El otro, un mural para el salón del edificio del IMPIVA de Valencia, situado en la esquina de la calle San Vicente con la Plaza del Ayuntamiento.

${ }^{61}$ Ibidem. 
1987

Durante el verano de 1987 participó con una exposición de sus obras en la inauguración de la Casa de la Cultura de la Pobla Tornesa (Castellón), de la cual se editó un catálogo con textos de Jaime Jiménez de Haro, "Safont a la Pobla Tornesa: Inauguració de la Casa de la Cultura, estiu, 1987". ${ }^{62}$

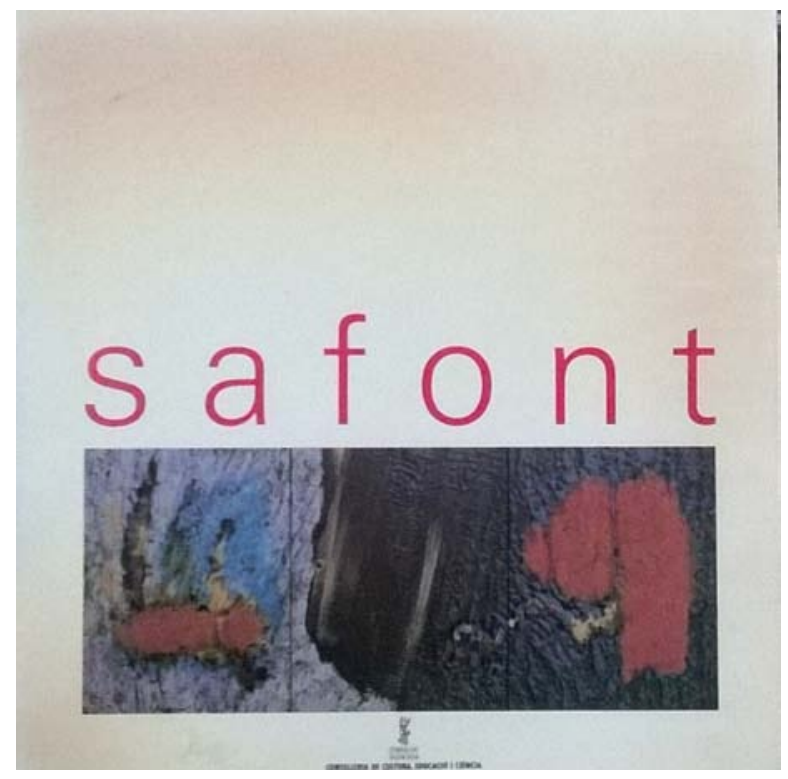

Figura 54: Catálogo exposición La Pobla Tornesa.

Consolidada su labor como muralista, en 1987 realizó un mural de $12 \mathrm{~m}^{2}$ para el interior del edificio de Gobierno Civil de Castellón, encargado por Pilar Bravo, gobernadora civil de Castellón. ${ }^{63}$

\footnotetext{
${ }^{62}$ LÓPEZ, María José. "El ceramista Manolo Safont crea con sus manos universos de luz y color", Castellón Diario,_19 de agosto de 1991.

OluChA Montins, Ferran / GIRALT-MiRACle, Daniel, Op. Cit, marzo de 1995.

${ }^{63}$ Albalat, Antoni. Op. Cit. 27 de noviembre de 2005, pág. 7.
} 


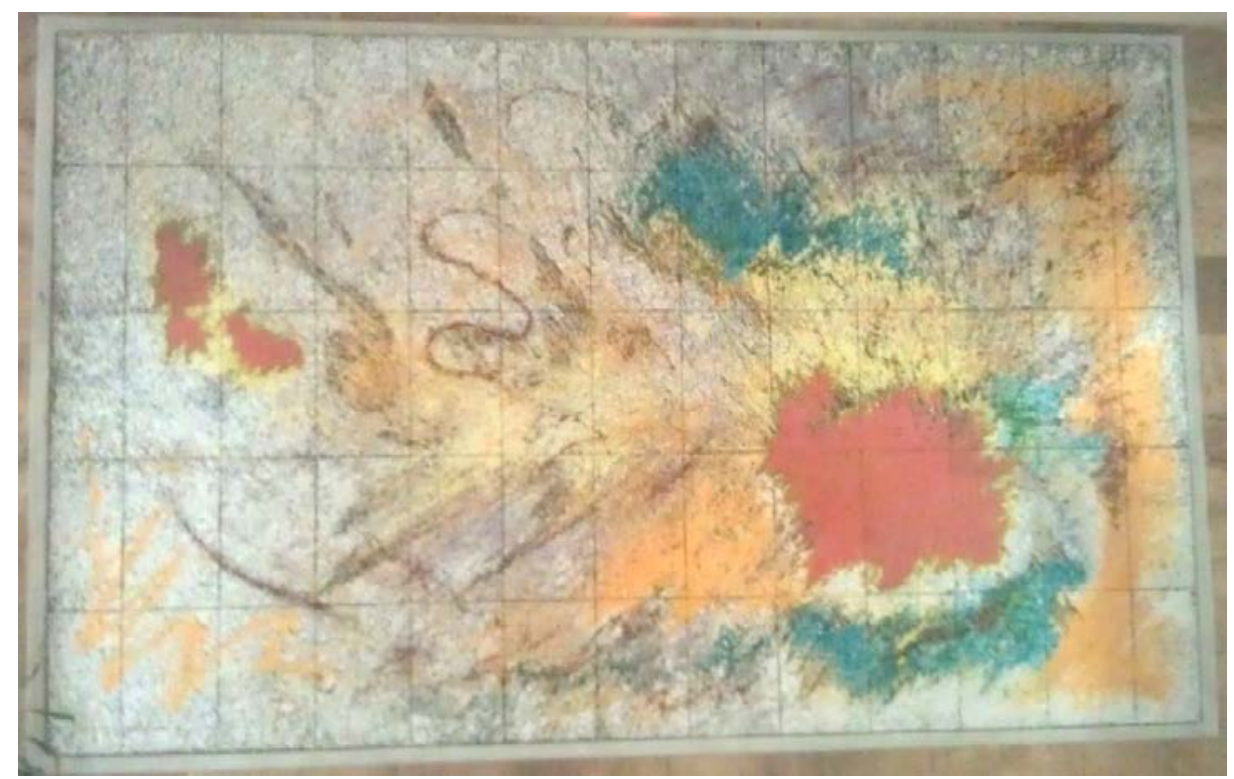

Figura 55: Mural Gobierno Civil Castellón.

1988

En 1988 expuso en la muestra 30 ceramistas-40 alfareros organizada por la Diputación de Salamanca y en el Pabellón Nacional de Miami Beach en Miami. ${ }^{64}$

Desde el 22 de diciembre al 12 de enero de 1989, expuso Safont en el Ayuntamiento de Castellón.

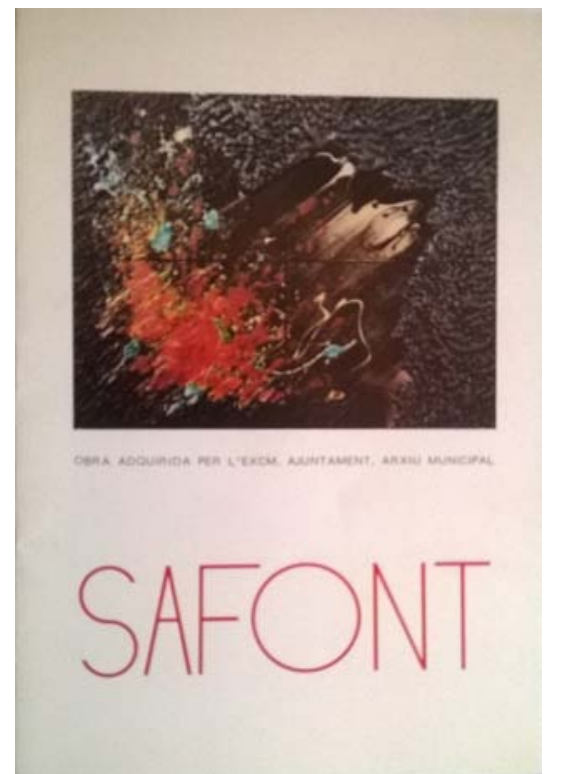

Figura 56: Catálogo exposición Ayuntamiento de Castellón.

${ }^{64}$ Olucha Montins, Ferran / GIRALT-MiRACle, Daniel, Op. Cit, marzo de 1995. 
1989

Expuso en el Hotel Carlemagne de Bruselas Safont in Brussel del 9 de marzo al 23 de abril y en Hasselt Safont-Koninklij-Atheneum I. ${ }^{65}$

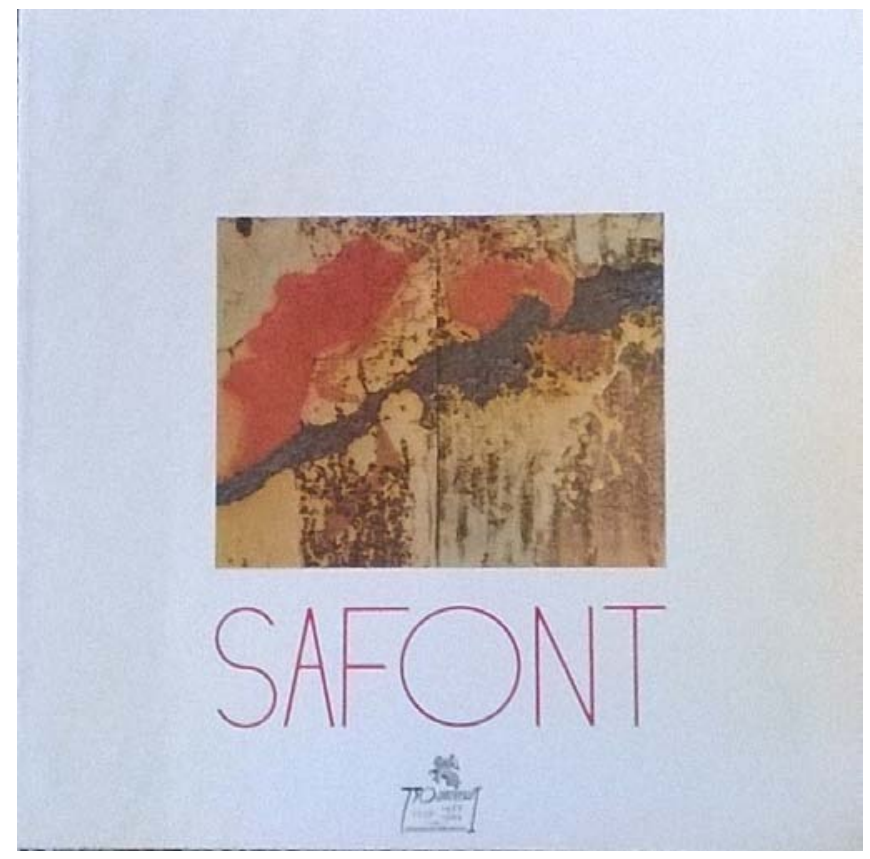

Figura 57: Catálogo exposición Safont in Brussel.

Entre diciembre de 1989 y el 12 de enero de 1990, expuso su obra en La Saleta de Onda. ${ }^{66}$

1991

Su labor como muralista cerámico continúa, realizando en 1991 un gran mural, compuesto por placas de $60 \times 38 \mathrm{cms}$, dispuestas en cuadrícula de $4 \times 25$, creando un panel de 240x950 cms, para el interior de la Escuela de Artes y Oficios de Castellón, situada en el edificio de la antigua Beneficencia. ${ }^{67}$

\footnotetext{
${ }^{65}$ Ibidem.

${ }^{66}$ GAscó, Antonio. "Importante muestra de Manolo Safont de pintura cerámica", Castellón Diario, 31 de diciembre de 1989, pág.6.

OluCha MONTINS, Ferran / GIRALT-MiRACLE, Daniel, Op. Cit, marzo de 1995.

${ }^{67}$ Albalat, Antoni. Op. Cit. 27 de noviembre de 2005, pág. 7.
} 


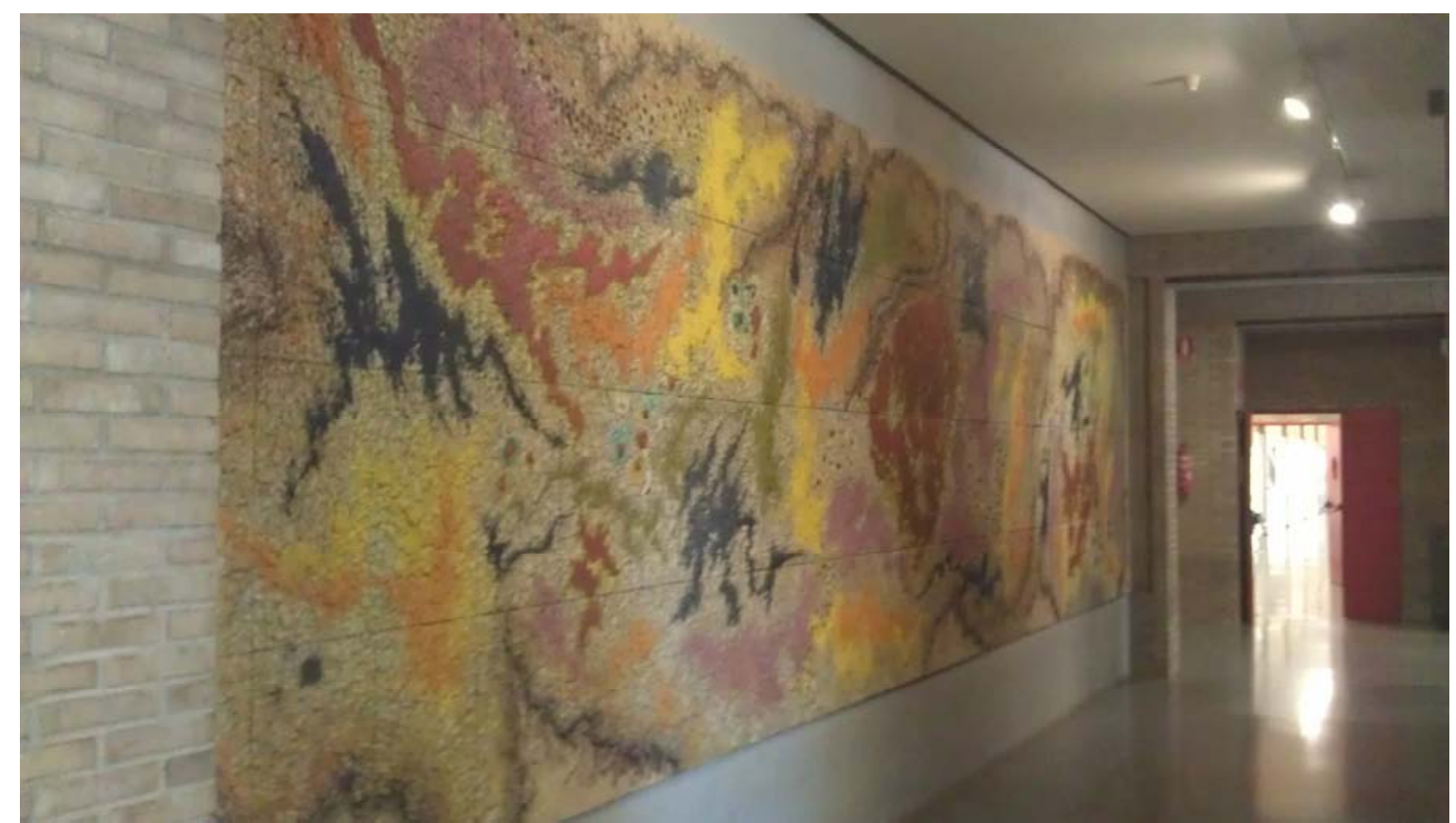

Figura 58: Mural Escuela de Artes y Oficios, Castellón.

También expuso en Octubre Galeria d'Art, la sala de exposiciones de la Universitat Jaume I de Castellón, del 13 de marzo al 12 de abril. ${ }^{68}$

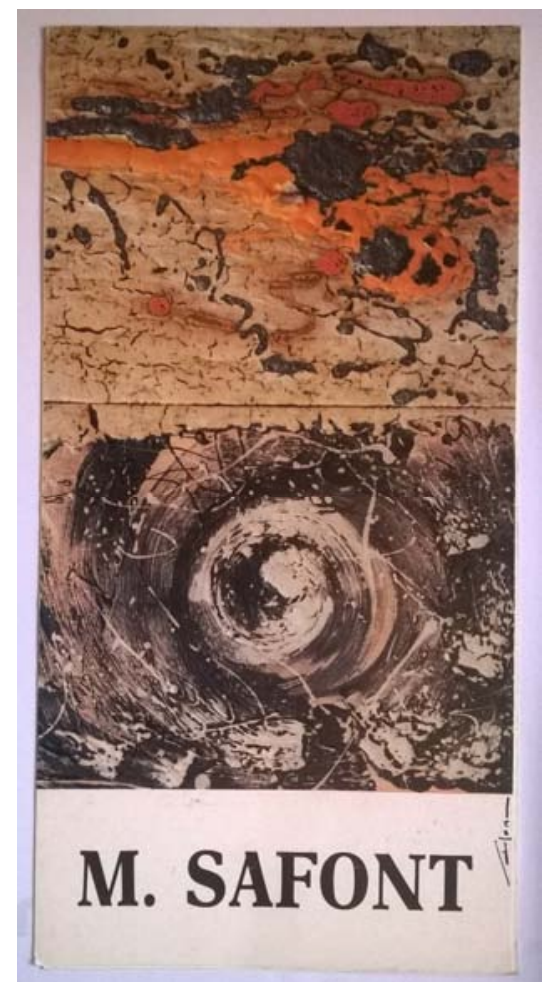

Figura 59: Catálogo exposición Galería Octubre, Universitat Jaume I.

${ }^{68}$ M. Safont, Catálogo exposición Galería Octubre, Universitat Jaume I, Castellón. 
Este año, Safont abandona la dirección del Museo Histórico Municipal de Onda.

1992

En 1992 participó en la Feria Hàbitat, tanto en la realizada en Castellón, como en la de Alicante, con presencia en Vuit ceramistas holandesos, vuit ceramistas espanyols en Alicante y en Ceràmica a l'equipament urbà = Cerámica en el equipamiento urbano realizada del 26 de mayo al 30 de junio en la Sala Municipal d'Exposicions Lonja del Pescado de Alicante. ${ }^{69}$

1993

Continuando su labor de muralista, en 1993 comenzó la realización de un mural, que finalizó en 1994, de 3x4,5 metros, compuesto por 60 piezas de $60 \times 38 \mathrm{cms}$, realizadas sobre soporte liso refractario, para el Centro Ocupacional de Vila-Real (Castellón), en la calle Onda, situado en la fachada exterior y encargado por la Consellería de Trabajo de Valencia. ${ }^{70}$

\footnotetext{
${ }^{69}$ Ceràmica hàbitat: ceràmica a l'equipament urbà=ceramics as part of urban amenities = cerámica en el equipamiento urbano: del 26 de maig al 30 de juny de 1992, Sala Municipal d'Exposicions Lonja del Pescado, Alacant. Exposición colectiva. Porcar, Josep Lluís. Alicante: Centro Eusebio Sempere de Arte y Comunicación Audiovisual, 1992.

VV.AA. Cerámica Hábitat. Ayuntamiento de Alicante, 1992

OluChA MONTINS, Ferran / GIRALT-MiRACLE, Daniel, Op. Cit, marzo de 1995.

70 "Safont concluye su mosaico cerámico en Vila-Real", Mediterráneo, 1 de febrero de 1994, pág. 7.
} 


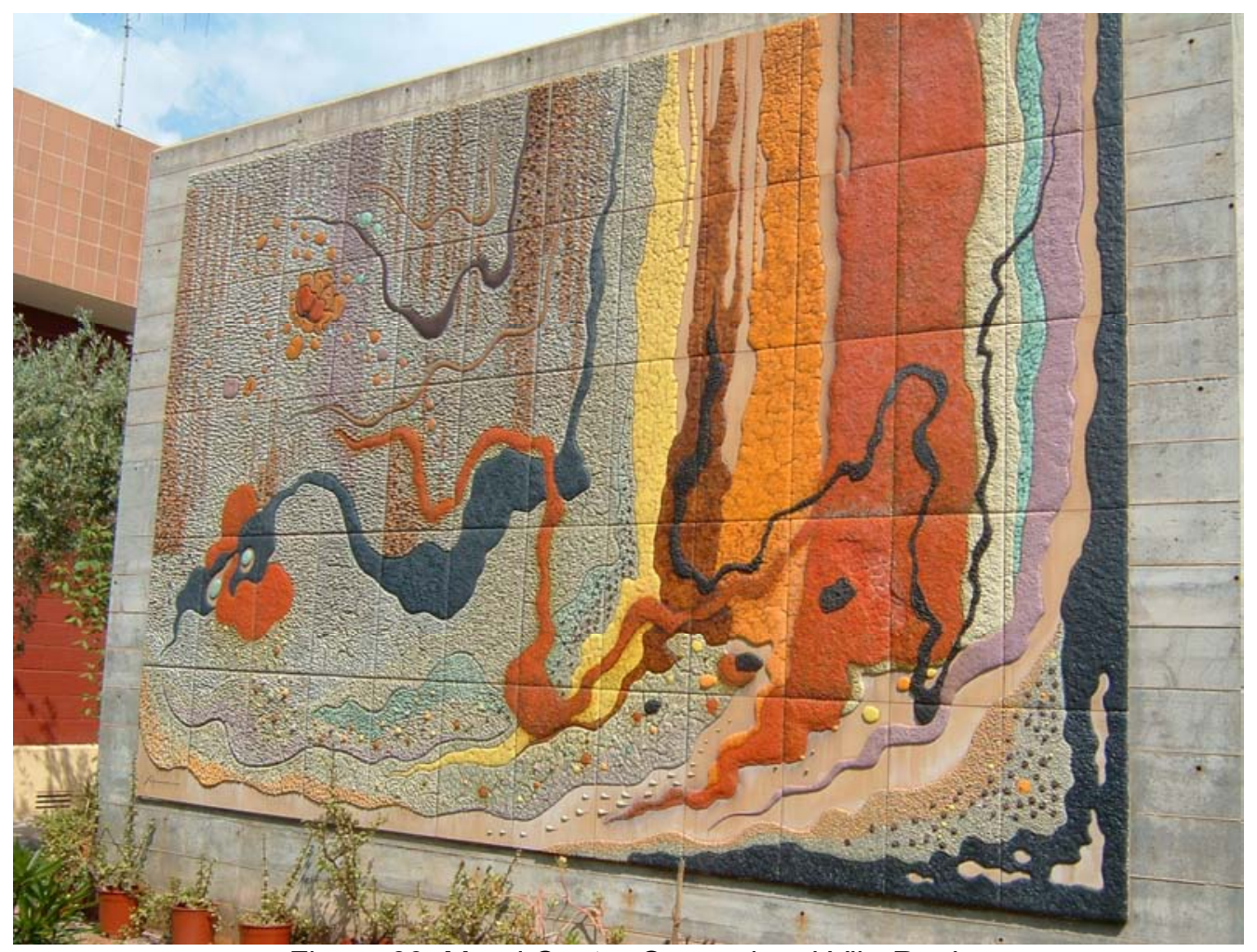

Figura 60: Mural Centro Ocupacional Vila-Real.

1994

Entre los actos culturales organizados con motivo de la celebración del 50 Sexenni de Morella (1673-1994) en Castellón, se realizó en agosto de 1994 una exposición en la Escola-Llar de Morella con el título Safont-Multi-Art $94 .^{71}$

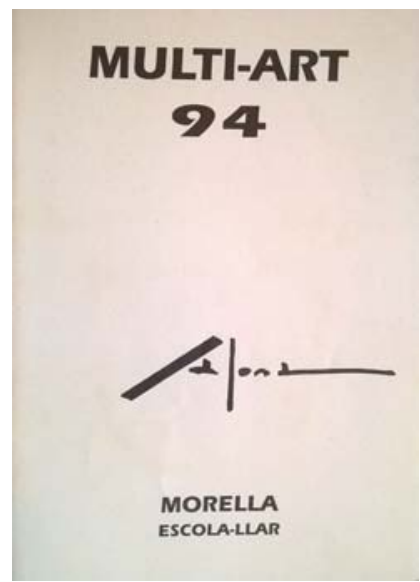

Figura 61: Catálogo exposición Morella.

${ }^{71}$ Olucha Montins, Ferran / GIRALT-MiRACle, Daniel, Op. Cit, marzo de 1995. 
Sus encargos como muralista continúan, y con motivo del hermanamiento entre la Comunidad Valenciana y la prefectura de Mies, en Japón, Safont recibe el encargo para realizar un mural de más de $6 \mathrm{~m}^{2}$, $216 \times 320 \mathrm{~cm}$., que se instaló en Mies. ${ }^{72}$

1995

En marzo de 1995 participó en una exposición colectiva junto con el pintor Wences Rambla en el Centre Cultural d'Alcoi (Alicante) titulada Wences Rambla, olis i tècniques mixtes; Manuel Safont, pintura ceràmica ${ }^{73}$ y en una muestra individual "Manolo Safont" realizada entre el 11 de mayo y el 16 de junio en la Galería Cànem de Castellón. ${ }^{74}$

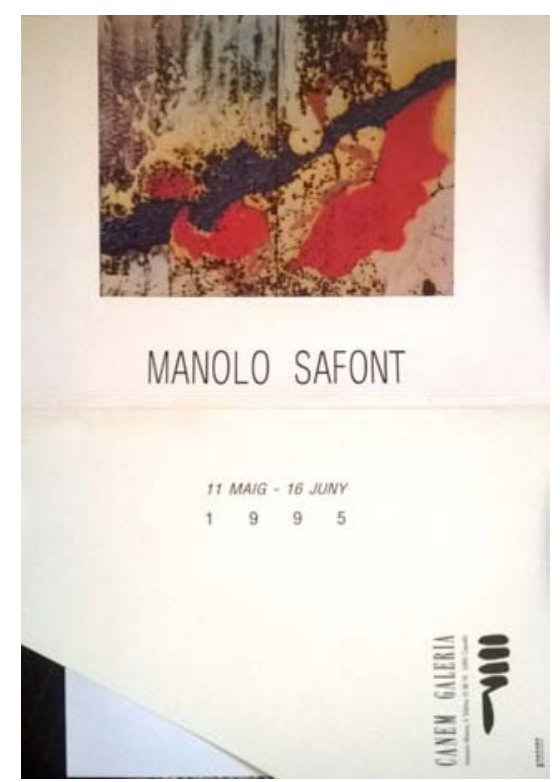

Figura 62: Catálogo exposición Galería Cànem.

\footnotetext{
${ }^{72}$ Ibidem.

${ }^{73}$ Olucha Montins, Ferran / GIRALT-Miracle, Daniel, Op. Cit, marzo de 1995.

PATUel Chust, Pascual. "W. Rambla- M. Safont dos poéticas abstractas". Tendencias en las artes y el diseño, 1995, n¹6, abril, pág. 37.

${ }^{74}$ Olucha Montins, Ferran / GiRALt-MiRACle, Daniel, Op. Cit, marzo de 1995.
} 
En 1997 podemos ver una vertiente diferente en la utilización de las obras de Manolo Safont, ya que una de sus obras ilustra el cartel del Symposium Internacional de Estrés Profesional, que se celebró entre el 13 y 15 de noviembre en Castellón y Benicassim (Castellón).

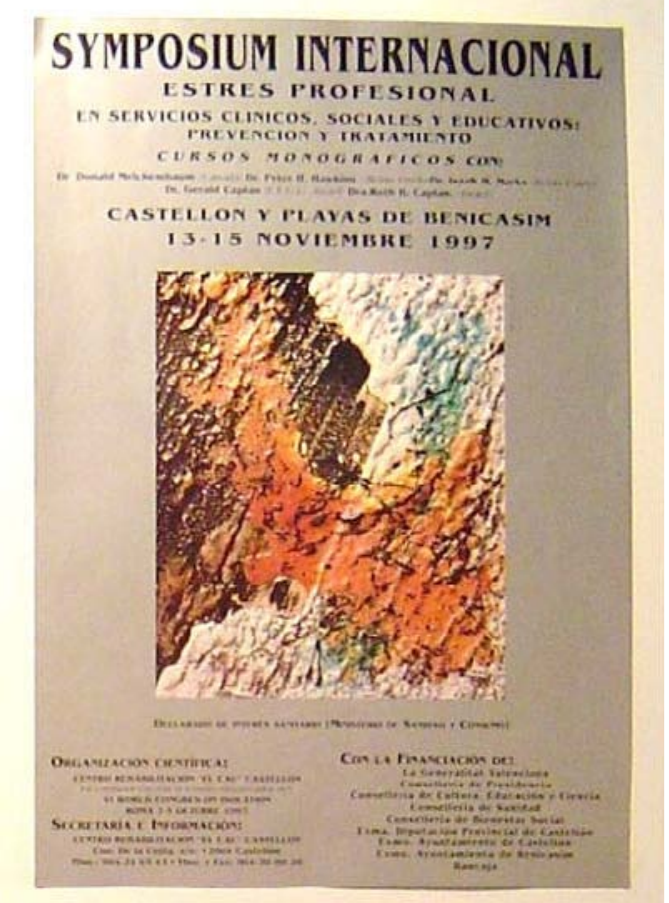

Figura 63: Cartel Symposium Internacional de Estrés Profesional.

1998

El 28 de marzo de 1998, con motivo del 70 aniversario de nacimiento de Manolo Safont, se realizó un acto homenaje en los locales de la Unión Musical Santa Cecilia de Onda (Castellón), con mas de 200 asistentes, en el cual se leyeron discursos y diferentes cartas enviadas por amigos y representantes del arte y el mundo de la sociedad y la cultura local, provincial y nacional como Josep Palomero, Joan Francesc Mira (Castellón), Antonio Miró (Alcoi), Manuel Ardit (Valencia), Pilar Estepona (Presidenta de Amics dels Museus de la Cominitat Valenciana \& CyberMuseu Interactiu), Joan Romero (Secretario General del Partido Socialista del País Valencià), Jesús Huguet, Vicent Pitarch, Antoni Seva (Barcelona), Nadal Escrig (Alcalde de Borriol), Lola Navarro y Enrique Navarro (Alcalde de Onda). 
El 9 de octubre de 1998 inauguró una exposición individual titulada Safont en el Ayuntamiento de Morella.

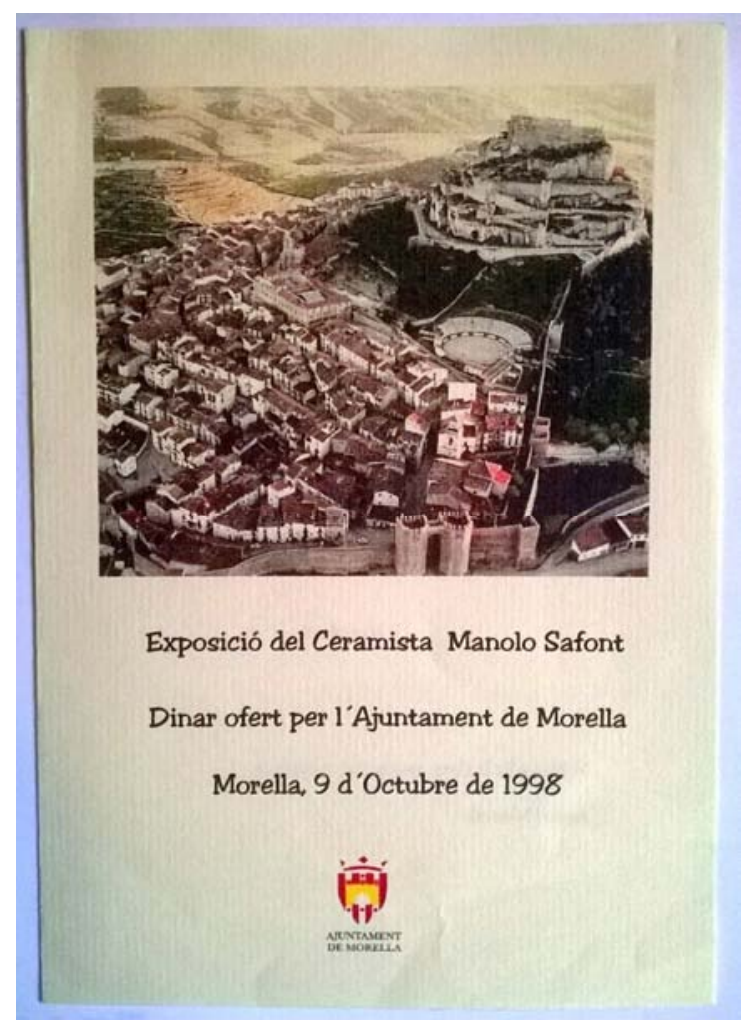

Figura 64: Catálogo exposición Morella 1998.

1999

En 1999 volvió a exponer de forma individual durante el mes de octubre en la Saleta Municipal de Onda.

2000

Desde el año 2000, Manolo Safont trabajó en el proyecto para un mural cerámico de 3×10 metros, destinado al vestíbulo principal o sala de grados de la Facultad de Ciencias Humanas y Sociales de la Universidad Jaume I de Castellón. 
El 29 de enero de 2001, el Ayuntamiento de Onda, propuso, de forma consensuada con la Dirección General de Patrimonio Artístico de la Generalitat Valenciana, dar al Museo de Onda, el nombre de Museo del Azulejo de Onda "Manolo Safont", lo cual le fue comunicado a Manolo de modo oficial el 14 de febrero. En marzo, el equipo de gobierno y Fernando Romero, como rector de la Universitat Jaume I de Castellón, felicitaron por escrito a Manolo por la nueva denominación del museo. ${ }^{75}$

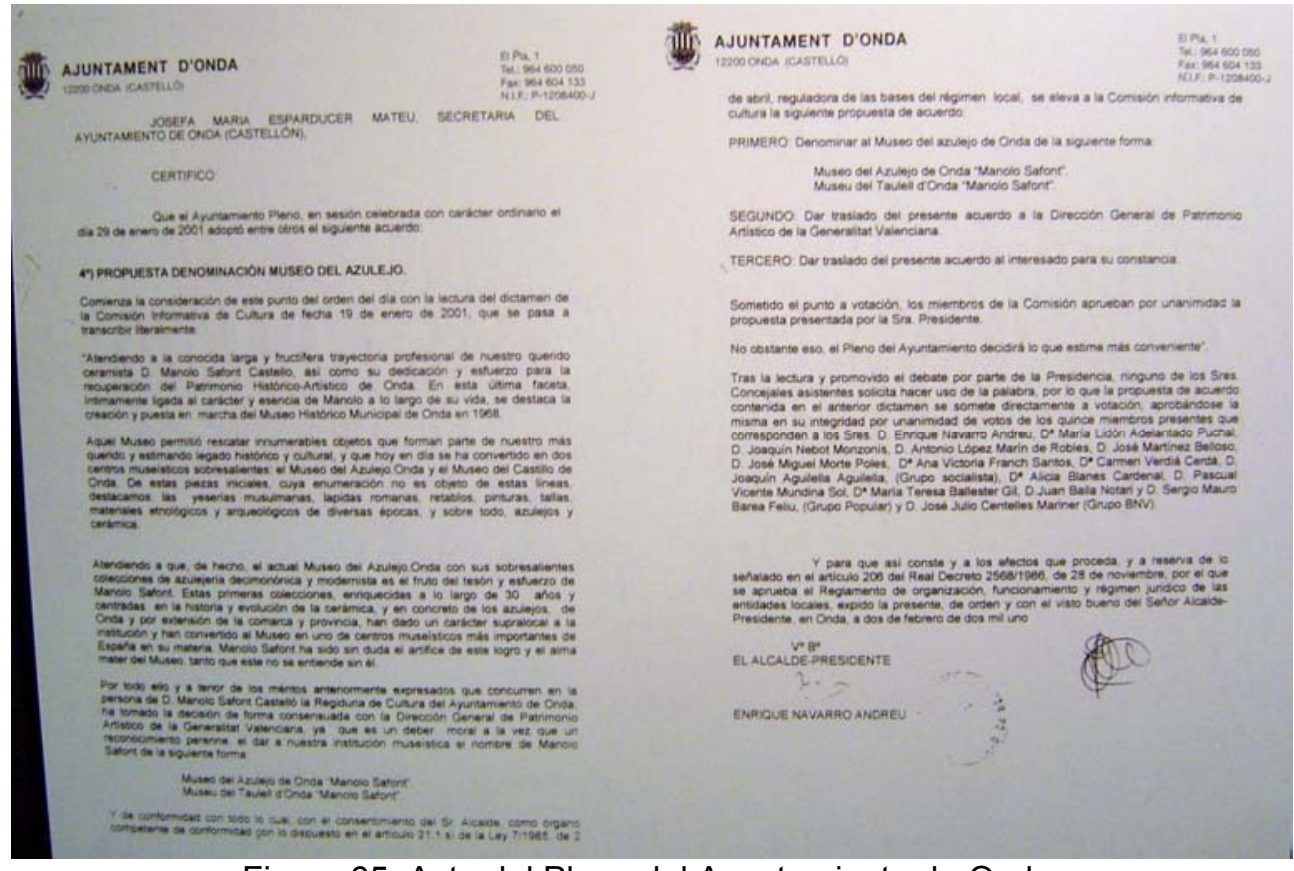

Figura 65: Acta del Pleno del Ayuntamiento de Onda.

El 22 de noviembre de 2001, Jesús Huguet, presentó en la Casa de la Cultura de Onda (Castellón) el libro II Butletí d'Estudis Municipals editado por el Ayuntamiento de Onda, en el cual figura un artículo sobre Manolo Safont, escrito por Carmela Falomir. ${ }^{76}$

Del 23 de diciembre de 2001 al 6 de enero de 2002 en la sala de exposiciones de la Caja Rural Nuestra Señora de la Esperanza de Onda, realizó una exposición con motivo de la Inauguración del Nuevo Edificio Social de la entidad.

\footnotetext{
${ }^{75}$ Documentos inéditos facilitados por Manolo Safont pertenecientes a su archivo personal.

${ }^{76}$ FALOMIR, Carmela. "La pintura cerámica de Manolo Safont", en Butletí d'Estudis Municipals, $2^{a}$ etapa, n², Ayuntamiento de Onda, 2001.
} 
El 29 de enero, Jesús Huguet presenta de nuevo el libro II Butletí d'Estudis Municipals de Ayuntamiento de Onda, con un artículo sobre Manolo Safont, escrito por Carmela Falomir, en la librería Forum Babel de Castellón.

Tras un tiempo pensando en ello, es en 2002 cuando Manolo Safont y Ana del Moral, al no tener descendientes directos de primer grado, deciden hacer donación de sus propiedades y obras al pueblo de Onda, y así, el 24 de junio de 2002, el Ayuntamiento de Onda acepta la donación de los bienes de Manolo y Ana, consistente en una finca urbana (la vivienda y el terreno que la rodea ubicada en la calle Escultor Oliet de Onda) incluyendo las obras del pintor que se encuentran dentro del domicilio, lo que origina la necesidad de cuantificar el valor económico de las propiedades por parte del Ayuntamiento de Onda.

Con su trabajo y su arte, tanto Safont como Ana, hicieron de su casa un museo y de su huerto un jardín, y quisieron que el conjunto de esta obra pasara a futuras generaciones como muestra de su historia, haciendo donación al pueblo de Onda de tan preciado patrimonio, conscientes del beneficio comunitario y del enriquecimiento que esto significará en un futuro para la población de Onda.

Desde el Ayuntamiento de Onda, se aceptó la donación, de forma unánime, conscientes del beneficio que supone para la población, pero la aceptación de esta donación conllevaba el compromiso de aceptar y hacer posible el objetivo con el cual se realiza la cesión, que el espacio formado por la vivienda y el jardín se conviertan en un futuro es un centro cultural y artístico que sirva para mejorar la oferta cultural y social en Onda, contribuyendo al enriquecimiento de su población. 


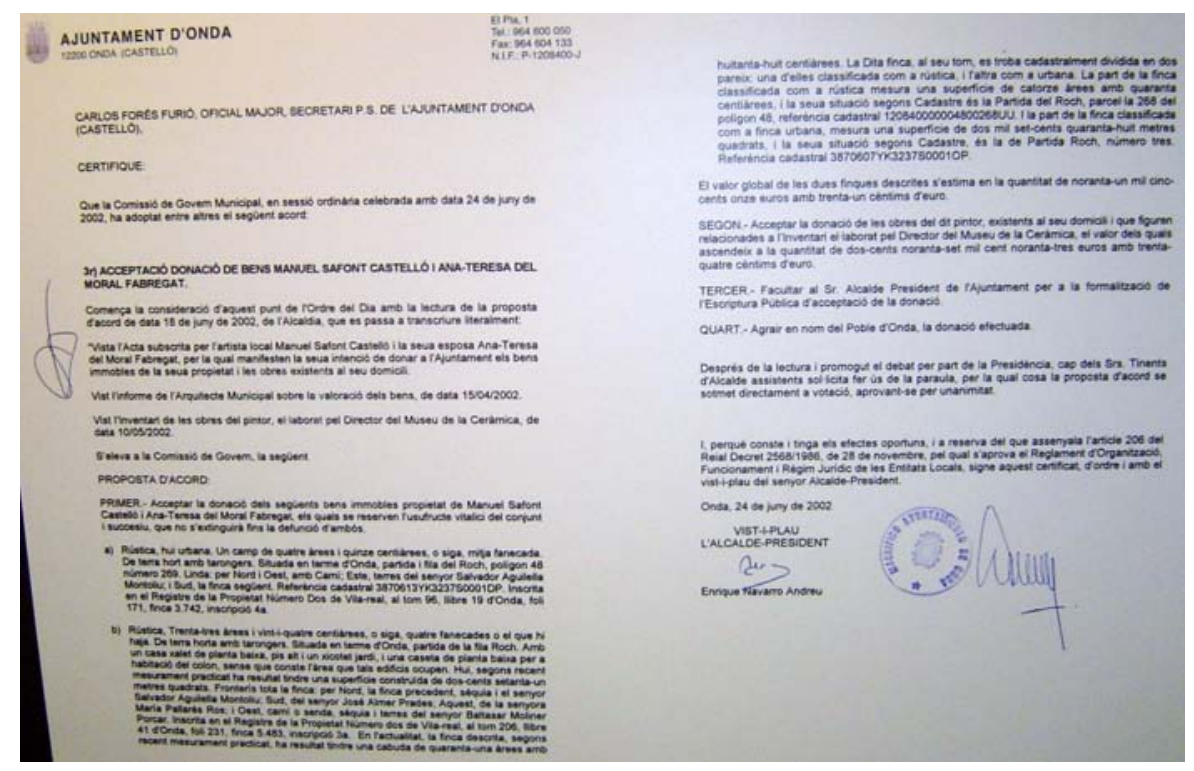

Figura 66: Acta de aceptación de los bienes de Manolo Safont donados al pueblo de Onda.

Entre el 26 de marzo y el 28 de abril de 2002, se celebró la exposición Pintura castellonenca dels 70-80. S XX. Museu de Bellas Arts de Castelló. Coleccions Artístiques de la Diputació de Castelló, una colectiva en la que se expusieron obras de Manolo Safont, junto a otros artistas plásticos castellonenses del período, como Amat Bellés, José Córdova, Juan GonzálezCampos, Marcelo Díaz, Beatriz Guttman, Joël Mestre, Pepe Nebot, Luis Prades, Wences Rambla, María José Rico, Juan G. Ripollés, Ximo Roures, Manuel Sáez, Manolo Safont, Fernando S. Sesé y Vicente Traver Calzada. De Safont se expuso la obra titulada Blanco, negro y rojo. ${ }^{77}$

2003

En enero de 2003 la Caja Rural Nuestra Señora de la Esperanza de Onda (Castellón) utiliza imágenes de diversas obras de Safont para ilustrar el calendario anual con el que habitualmente obsequia a sus socios. En esta ocasión, debido al hecho de ser obras de Manolo Safont las que ilustran este calendario, provoca que se agoten rápidamente los calendarios, y que un suceso cotidiano y en cierto modo vanal, como es la edición de un calendario

77 Pintura castellonenca dels 70-80. S XX. Museu de Bellas Arts de Castelló. Coleccions Artístiques de la Diputació de Castelló. Castellón, 2002. Con textos de Wences Rambla. 
promocional por parte de una empresa local, tenga repercusión en la prensa provincial. $^{78}$

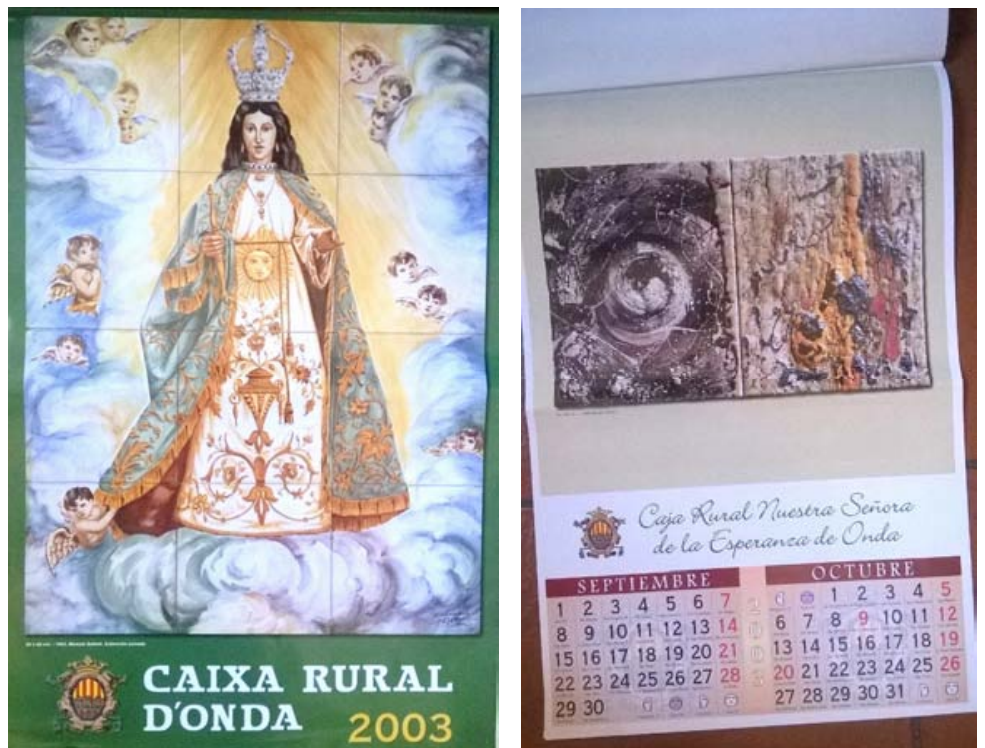

Figura 67: Calendario 2003 Caja Rural Nuestra Señora de la Esperanza. Onda.

A lo largo de este año, Safont continúa trabajando en el mural encargado por la Universidad Jaume I de Castellón.

El 28 de febrero de 2003, Manolo Safont recibe junto a su esposa Ana del Moral el galardón "Seny Onder 2002" que de forma anual concede el Ateneo Cultural y Mercantil de Onda (Castellón), por su onderismo compartido y su labor pública y privada desarrollada en Onda, así como por su altruismo y amor a Onda, demostrado con la donación de su casa y jardines, así como el patrimonio cultural y artístico que alberga la casa, como futuro Museo para la población de Onda. ${ }^{79}$

Basta comprobar toda la repercusión que tiene en prensa la concesión de este premio, para entender el calado personal, social y artístico de Manolo Safont. Numerosos artículos, viñetas, etc, se hicieron eco de la entrega de este

\footnotetext{
${ }^{78}$ PanAdero, Amparo. "Arte”, en El Periódico Mediterráneo, 5 de enero de 2003.

${ }^{79}$ Acta Seny Onder 2002. Ateneo Cultural y Mercantil de Onda. 29 de enero de 2003. Con motivo del nombramiento para el premio Seny Onder 2002, Manolo y Ana reciben numerosas cartas de felicitación de amigos y conocidos, muchos de ellos personajes relevantes en la esfera social y cultural, como: D. Enrique Arenós Cortés (Vila-Real), Ferran Olucha (director del Museo de Bellas artes de Castellón), Matilde Salvador (compositora).
} 
galardón, no tanto por la importancia del premio concedido, sino más bien por la importancia y relevancia de quien lo recibía. ${ }^{80}$ La entrega del galardón se realizó en un acto al que asistieron más de 300 personas entre familiares, amigos, representantes de entidades locales y miembros de la Corporación Municipal de Onda. ${ }^{81}$

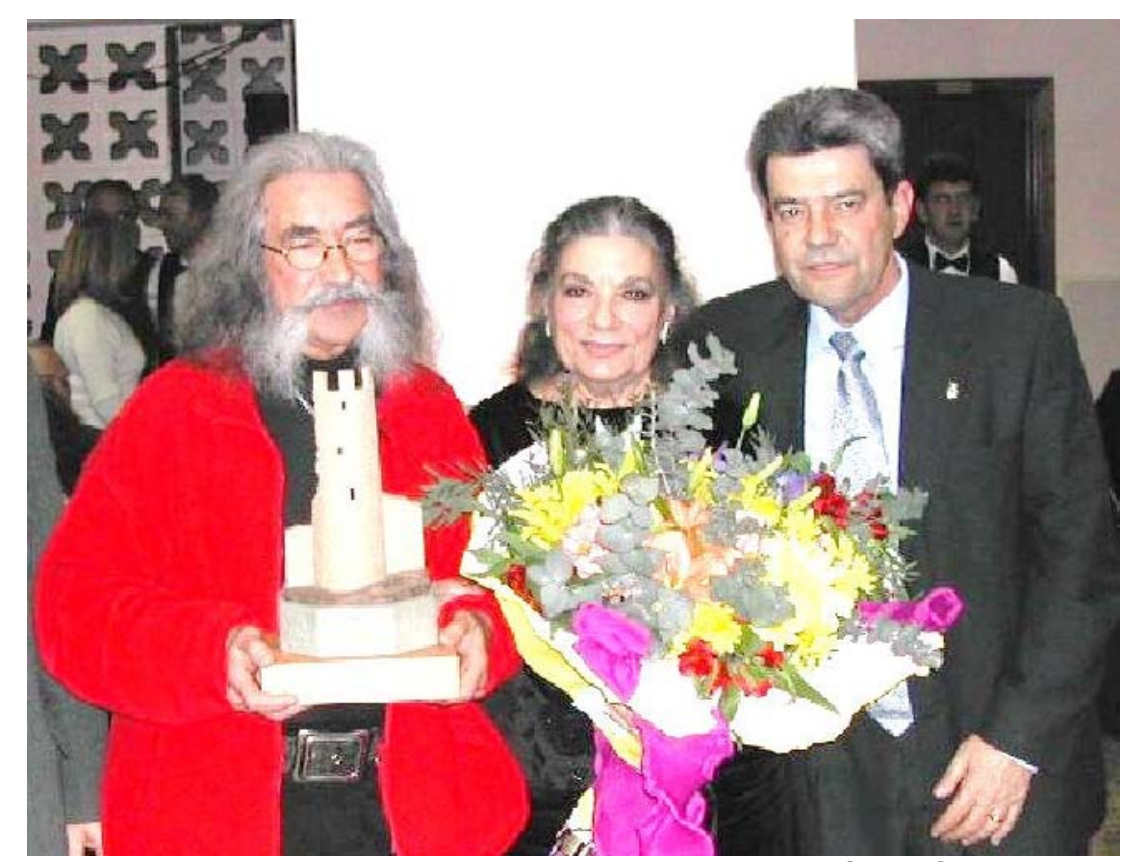

Figura 68: Manolo y Anita recibiendo el galardón del Seny Onder 2002.

En junio de 2003, recibe el premio Protagonistas de Castellón, como protagonista de las Artes Plásticas $2003 .^{82}$

${ }^{80}$ QUIQUE. Viñeta Humor Gráfico. El Periódico Mediterráneo, 1 de marzo de 2003.

MARTínEZ, Ángel. "El Seny Onder es para Ana del Moral y Manolo Safont", en El Periódico Mediterráneo. 7 de febrero de 2003, pág. 21.

ALÓs, Víctor. "El Ateneo de Onda reconoce a Safont con el Seny Onder 2002", en El Mundo/ Castellón al día, 2 de marzo de 2003.

PANADERo, Amparo. "Seny Onder", en El Periódico Mediterráneo. 2 de marzo de 2003.

${ }^{81}$ MARTíneZ, Ángel, "Tributo para Ana y Manolo", en El Periódico Mediterráneo. 2 de marzo de 2003. pág. 26.

"Ana del Moral y Manolo Safont recibieron el Seny Onder en un emotivo acto"., en Anuario El Full. Febrero 2003, Onda.

82 Diploma: Premios Protagonistas de Castellón 2003. Onda Cero Radio. Patrocinado por Ceracasa Cerámica, el jurado de los Premios Protagonistas de Castellón en su segunda edición decide por mayoría otorgar el galardón Protagonista de las Artes Plásticas 2003 a Manuel Safont. Castellón, 12 de junio de 2003. 


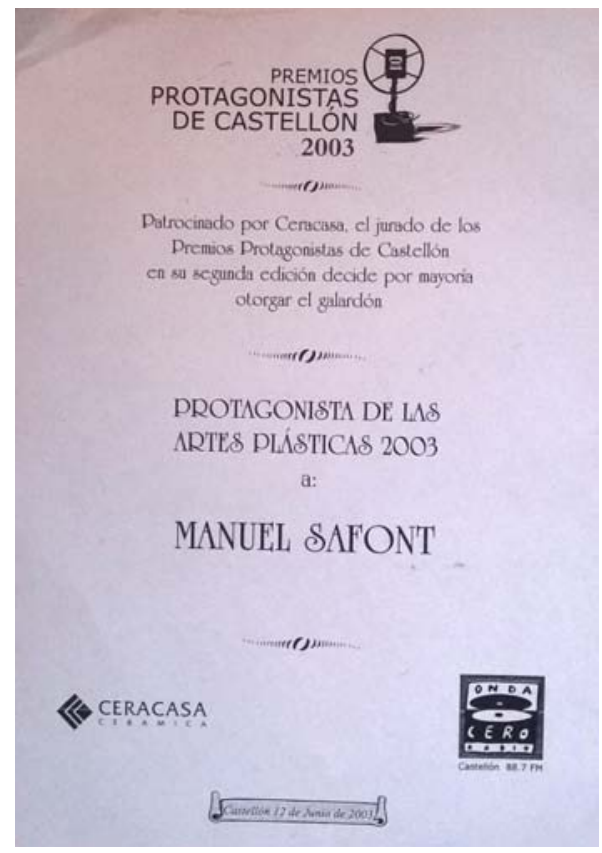

Figura 69: Premio Protagonistas de Castellón, Artes Plásticas 2003.

\section{4}

En octubre del año 2004 finalizaron las obras del nuevo museo en Onda, ubicado en las afueras del núcleo urbano, creado para solucionar los problemas de antigüedad y falta de espacio que planteaba el antiguo museo. Este nuevo edificio se denominó Museu del Taulell Manolo Safont, y el 24 de octubre de 2004, en la XI Exfilnucol 2004, se habilita una Oficina Temporal de Correos creándose un matasellos especial conmemorativo de la inauguración del "Museo del Azulejo Manolo Safont".

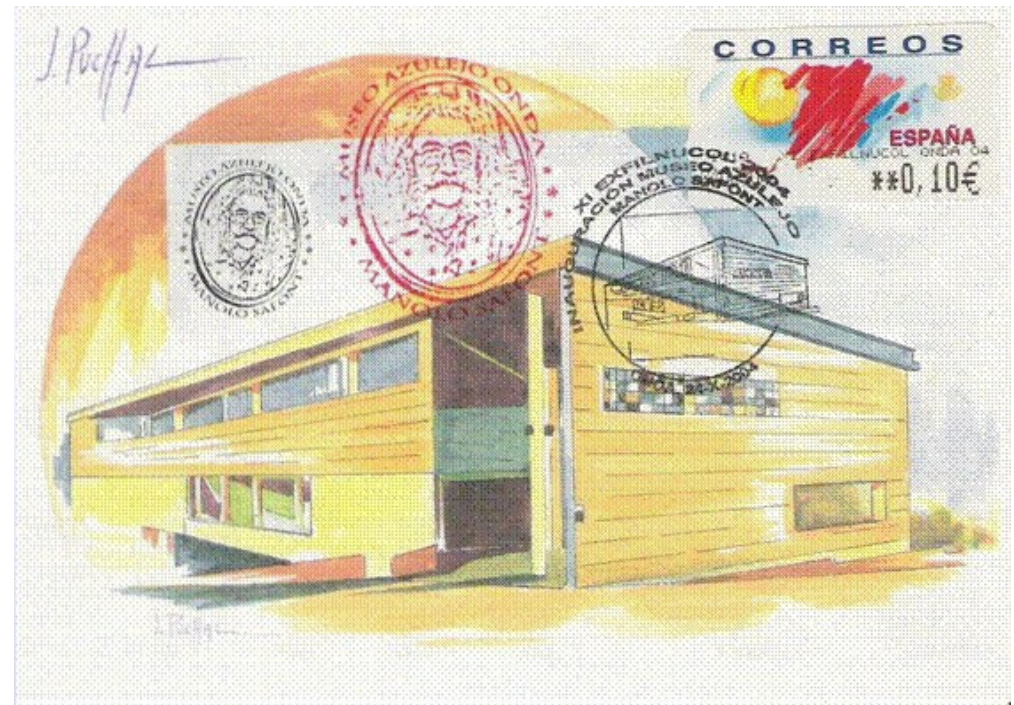

Figura 70: Matasellos conmemorativo inauguración Museo Azulejo Manolo Safont. 
En octubre, el Ayuntamiento de Onda anuncia que durante próximo mes de noviembre se inaugurará la primera fase del Museo del Azulejo Manolo de Safont de Onda. Para dicha inauguración se estaba preparando una exposición sobre la vida y la obra de Manolo Safont, con el título Un museu, un llegat, un compromís.

Ese mismo mes, octubre, el Consell Valencià de Cultura, presidido por Santiago Grisolía, se reúne en el Ayuntamiento de Onda, para celebrar un pleno extraordinario y conocer la realidad cultural de la población. A este acto al que asistieron todos los grupos políticos municipales, fue invitado Manolo Safont, como personalidad relevante de la cultura en Onda. ${ }^{83}$

El 27 de noviembre de 2004, se realizó en Onda el acto de inauguración de la primera fase del Museu del Taulell "Manolo Safont" y para ello la primera exposición que se programó e inauguró en este nuevo edificio, estuvo dedicada, tal y como había anunciado anteriormente el ayuntamiento de Onda, a la obra de Manolo Safont. La exposición titulada Manolo Safont, un Museu, un llegat, un compromís, mostró alrededor de cincuenta de las obras más representativas del ceramista. De dicha exposición se editó un tríptico sobre su vida y legado. ${ }^{84}$

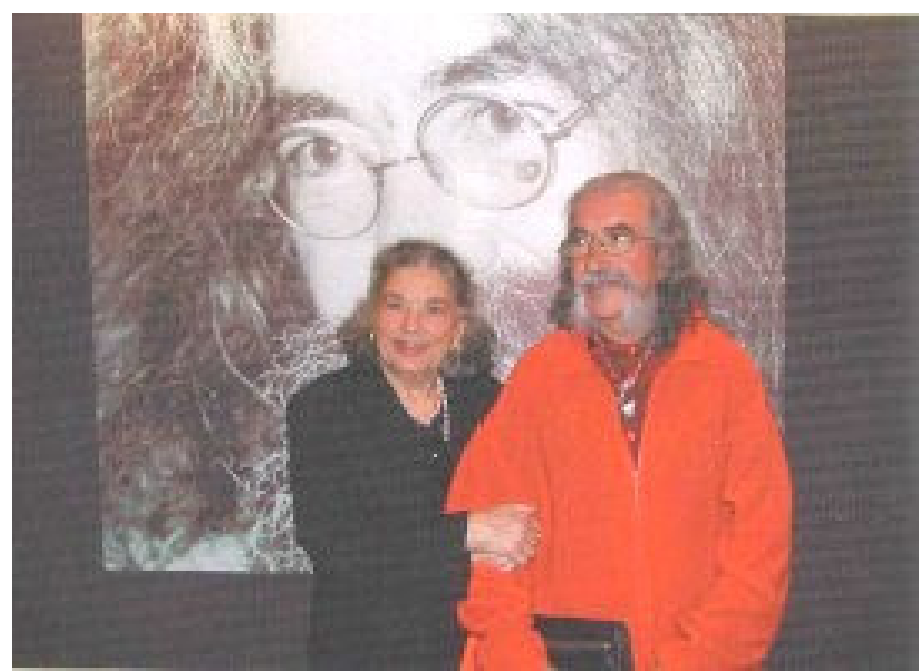

Figura 71: Manolo Safont y Ana del Moral. Inauguración Museo del Azulejo Manolo Safont.

\footnotetext{
83 "El Consell Valencià de Cultura visitó la localidad", en Crónica d'Onda. Octubre y noviembre de 2004, pág. 7.

84 "Onda conocerá la obra completa de Manolo Safont en una exposición", en Crónica d'Onda. Octubre y noviembre de 2004, pág. 12.

"El Museo del Azulejo será inaugurado oficialmente el próximo 27 de noviembre", en El Full. 19 de noviembre de 2004, Onda.
} 
El 14 de abril de 2005, Manolo Safont recibió en un acto académico realizado en el Aula Magna de la sede de La Nau, de la Universitat de Valencia, el VI premio Vicent Ventura, en un acto con intervención de Francisco Tomás (rector de la Universitat de València), Francisco Toledo (rector de la Universitat Jaume I de Castellón) y Antoni Seva (Universitat Pompeu Fabra de Barcelona). ${ }^{85}$ El premio Vicent Ventura está patrocinado por la Universitat de València, la Unió de Periodistes Valencians, CC O०, Sindicat de Treballadors de l'Ensenyament, UGT, Unió de Llauradors i Ramaders y la Universitat Jaume I, creado en memoria y homenaje al periodista valenciano Vicent Ventura y que distingue la trayectoria cívica, democrática y de compromiso social de una persona o colectivo que haya trabajado a favor de la Comunidad Valenciana, tanto en el mundo de la cultura y la sociedad civil, como por la trayectoria vital en campos de investigación creativa y por su implicación en la sociedad civil. ${ }^{86}$

Al día siguiente, el 15 de abril de 2005, el Ayuntamiento de Onda organiza en los Salones Campus de Onda una cena homenaje a Manolo Safont, con motivo del premio recibido a la cual acuden tanto la corporación municipal de Onda, personalidades del mundo del arte y cultura valenciano como Jesús Huguet (miembro del Consell Valencià de Cultura), Margarita Porcar (Vicerrectora de la Universitat Jaume I), Manuel Ardit (Universitat de Valencia), Vicent Pitarch (Universidad Jaume I) y Antoni Seva (Universitat Pompeu i Fabra) y numerosos amigos personales de Safont. ${ }^{87}$

85 "Manolo Safont rep el premi Vicent Ventura" nota de prensa del Ayuntamiento de Onda, El Full, n 1029, 15 de abril de 2005.

"El ceramista Manolo Safont gana el premio Vicent Ventura", en Levante El Mercantíl Valenciano, 14 de abril de 2005, pág. 63.

86 "El ceramista Manolo Safont gana el Premio Vicent Ventura", en Heraldo de Castellón, 14 de abril de 2005.

${ }^{87}$ SILVESTRE, Jacobo "Onda rinde tributos al ceramista Manolo Safont", en El Mundo. Castellón al día, 18 de abril de 2005.

"El ceramista Manolo Safont, homenajeado en Onda tras la concesión del VI Premio Vicent Ventura", en El Full, no 1030, 22 de abril de 2005, Onda.

"El ceramista Manolo Safont recibió un homenaje", en La Rodalía, n²0, mayo 2005, pág 21.

"Onda se rinde al genial arte de Manolo Safont", en Crónica d'Onda, mayo y junio de 2005, pág. 13. 
En verano de 2005 participó en una exposición realizada en el Cau de l'Art en Lucena (Castellón).

En Octubre 2005, con motivo de la demolición del edificio del Ayuntamiento de Onda, se realiza una exposición homenaje a La Saleta, la Sala d'Exposicions Municipals d'Onda, que se encuentra situada en una dependencia anexa al edificio del Ayuntamiento, y que también será demolida. En esta exposición colectiva, se expone también obra de Manolo Safont, ya que al margen de su vertiente como dinamizador cultural y creador y gestor de este espacio, también expuso en ella como artista en numerosas ocasiones. ${ }^{88}$

El 24 de noviembre de 2005, Manolo Safont falleció a la edad de 77 años, en su domicilio de Onda (Castellón). La capilla ardiente se instaló en el Museo del Azulejo "Manolo Safont" y el funeral se realizó esa misma tarde en la Iglesia Parroquial de Nuestra Señora de la Asunción de Onda, con un funeral repleto de familiares y amigos. ${ }^{89}$

${ }^{88}$ Homenatge a La Saleta. Sala Municipal d'Exposicions d'Onda. Octubre 2005. Onda.

${ }^{89}$ ORTEGA, L. "Fallece el célebre artista de Onda Manolo Safont", en Las Provincias, 25 de noviembre de 2005, pág. 12.

RODRÍGUEZ, Carlos "Enrique Navarro destaca que Safont ha sido el mejor artista que hemos tenido", en Levante EL MERCANTIL VALENCIANO, 25 de noviembre de 2005, pág. 72.

RODRíGUEZ, Carlos "Onda despide emocionada a Safont", en Levante EL MECANTIL VALENCIANO 26 de noviembre de 2005, pág. 55.

RODRÍGUEZ, Carlos "Manolo Safont. Onda despide al reconocido artista", en Levante EL MERCANTIL VALENCIANO, 26 de noviembre de 2005, pág. 57.

MARTíneZ, Ángel "Hasta siempre, maestro", en El Periódico Mediterráneo, 26 de noviembre de 2005, pág. 27.

PUIG, Ximo "A Manolo Safont, un ànima lliure”, en El Periódico Mediterráneo, 26 de noviembre de 2005, pág. 27.

FABRA, María. "Manolo Safont el alquimista de la cerámica", en El País. 25 de noviembre de 2005, pág. 57.

"Onda dice adiós a Manolo Safont", en El País, 26 de noviembre de 2005.

"Mor Manolo Safont, reconegut artista ceràmic i soci d'ACPV", en http:// www. acpv, 30 de noviembre de 2005.

"Onda dio el último adiós al genial Manolo Safont", en Crónica d'Onda, diciembre del 2005 y enero del 2006, pág 9. 


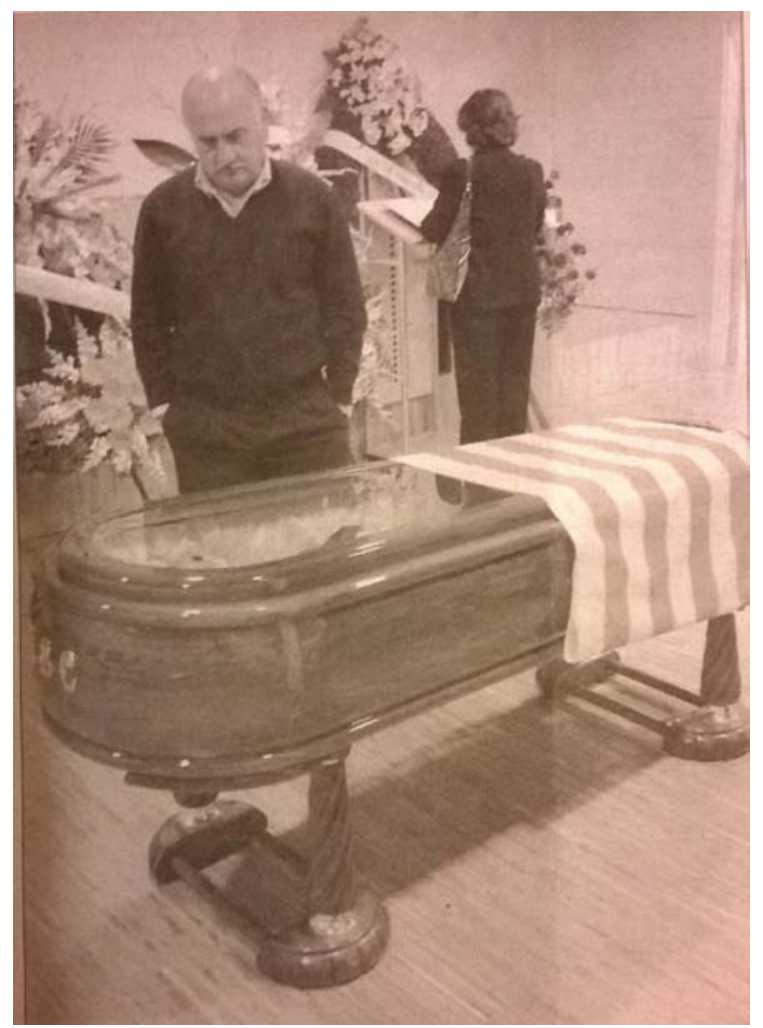

Figura 72: Capilla ardiente en el Museo del Azulejo de Onda.

En los numerosos artículos publicados en diferentes medios de prensa escrita, no sólo se cita su muerte como la pérdida de un ceramista o artista, sino como la pérdida de una personalidad relevante en el mundo del arte y la cultura. Así se refieren diferentes periodistas a Manolo Safont como "el célebre artista de Onda", ${ }^{90}$ "pérdida para el mundo de la cultura", ${ }^{91}$ "Con él se cierra un gran capítulo de la historia del arte del País Valencià", "un ondense que no sólo ha trabajado por el arte sino que también ha contribuido junto a personas aglutinadas en torno a su figura a mejorar nuestra sociedad", ${ }^{93}$ "Manolo ha compartit amb molts de nosaltres un projecte col.lectiu de pau, llibertat i tambè

${ }^{90}$ ORTEGA, L. "Fallece el célebre artista de Onda Manolo Safont", en Las Provincias, 25 de noviembre de 2005, pág. 12.

${ }^{91}$ GARcía, Cristina. "Fallece el ceramista Manolo Safont", en Heraldo de Castellón, 25 de noviembre de 2005, pág. 36.

${ }^{92}$ GASCÓ, Antonio. "Fallece el ceramista Manolo Safont", en Levante EL MERCANTIL VALENCIANO, 25 de noviembre de 2005, pág. 71.

${ }^{93}$ RODRíGUEZ, Carlos "Enrique Navarro destaca que Safont ha sido el mejor artista que hemos tenido", en Levante EL MERCANTIL VALENCIANO, 25 de noviembre de 2005, pág. 72. 
de solidaritat", 94 "su calidad artística y humana le llevó a ser un personaje emblemático y apreciado, comprometido con el arte y la cultura, durante toda una vida abanderada por el amor a su tierra y a la libertad"95 o personalidades y amigos como el entonces alcalde de Onda, Enrique Navarro "Una de las personas más emblemáticas de la población, tanto en la vertiente social, ya que fue el impulsor y creador del Museo de la Cerámica y por aglutinar políticas progresistas; como en la artístico, por que fue el mejor ceramista europeo", Jesús Huguet, miembro del Consell Valencià de Cultura "Con la muerte de Manuel Safont se pierde al artista plástico más importante del siglo XX. Supo unir la pintura en el arte de la cerámica y rompió con el esquema tradicional, creando una obra moderna y comprometida con la realidad", Manolo Sales, ceramista, "era una de las referencias más importantes y prestigiosas del panorama cerámico actual", ${ }^{96}$ el entonces conseller de Cultura, Alejandro Font de Mora "estem parlant d'un artista amb majúscules, no només pel seu vessant com a ceramista, sino també per la seua faceta com a pintor". ${ }^{97}$

\section{6}

Tras el fallecimiento de Safont, han continuado realizándose diferentes actividades artísticas sobre su persona y su producción artística, así como exposiciones con sus obras, como la muestra homenaje que se presentó en el stand que el Museo del Azulejo Manolo Safont tuvo en la XXIV edición de la Feria Cevisama, celebrada del 7 al 11 de febrero de 2006, en Valencia. ${ }^{98}$

94 D.G./L.S. "In memoriam: Manolo Safont", en El Periódico Mediterráneo, 25 de noviembre de 2005, pag 28.

95 "Adios a un gran artista y ondense", en El Full, n¹057, 2 de diciembre de 2005, Onda.

${ }^{96}$ MARtínez, Ángel "Adiós a un gran artista", en El Periódico Mediterráneo. 25 de noviembre de 2005, pág. 27.

${ }^{97}$ Europa Press. "Font de Mora lamenta la pèrdua del ceramista d'Onda Manolo Safont i destaca la seua generositat i qualitat artística", 25 de noviembre de 2005, http://es.news.yahoo.com/051125/4/4fa6K.html

98 "El Museu Manolo Safont volverá a ocupar un lugar de privilegio en CEVISAMA 2006", en El Full, n¹065, 3 de febrero de 2006, Onda. 
El 21 de julio, en el centro expositivo Cau de l'Art, en Llucena, Eloisa Tarazona y Jesús Broch, gestores culturales, organizan una exposición homenaje a Manolo Safont, en la que participan gran número de artistas castellonenses, pintores, escultores y músicos. Al homenaje acudió Ana del Moral, la viuda de Safont.

\section{1}

El 23 de febrero, Pilar Gregorio, ex directora de la emisora de radio COPE de Vila-Real, dona una obra abstracta de Safont, realizada en 1978 al Museo del Azulejo Manolo Safont.

2013

El 24 de marzo, dentro de un secretismo casi absoluto, se comunica el fallecimiento de Ana del Moral, viuda de Safont. El 11 de abril se oficia en la Iglesia Parroquial de Nuestra Señora de la Asunción de Onda, una misa en su recuerdo.

Con motivo de la celebración del Día Internacional de los Museos, el 18 de mayo, el Museo del Azulejo Manolo Safont, inaugura la víspera, el 17 de mayo, una nueva muestra de la obra de Safont, titulada "Manolo Safont, un museu, un llegat". Tras varios años en que las obras de Safont habían estado guardadas en los depósitos del Museo del Azulejo Manolo Safont, a partir de esta fecha forman parte de la exposición permanente del Museo. 


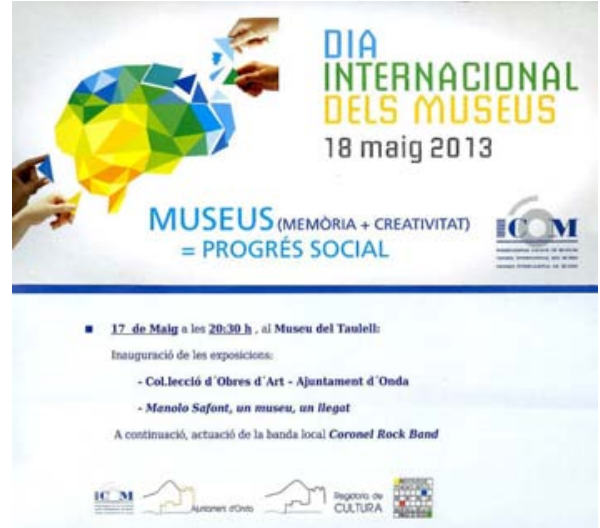

Figura 73: Tarjeta invitación Día Internacional de los Museos, MAMS.

2014

La Diputación de Castellón restauró el mural cerámico La Sagrada Familia, obra de Safont, que se exhibió en la exposición Magnificat. Nuevas metáforas de lo sagrado, junto con otras creaciones culturales religiosas destacadas del último siglo en la provincia de Castellón, como parte de las actividades programadas por el II Año Mariano por la Fundación Caja Castellón en la Sala San Miguel de la capital de La Plana. Una vez finalizada la exposición, la obra fue depositada de forma permanente en el Museo del Azulejo de Onda, donde se exhibe actualmente.

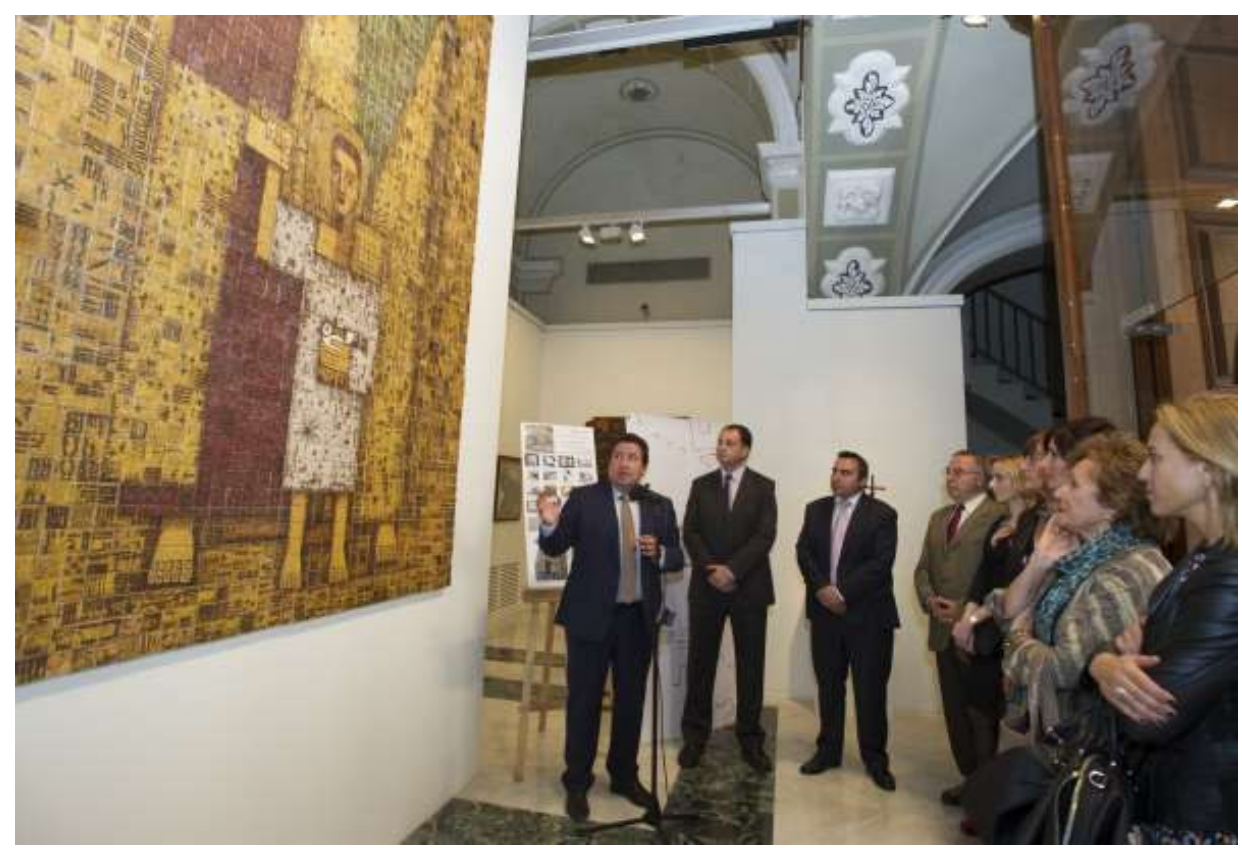

Figura 74: Inauguración exposición Magnificat. 


\section{CAPITULO 3 \\ TÉCNICA Y ESTILO EN LA OBRA DE MANOLO SAFONT}

La expresión de Bellas Artes fue acuñada en el siglo XVIII para distinguir las artes cuya única finalidad era la belleza, el arte por el arte, en oposición a la artesanía, considerada como un oficio, y a otras artes llamadas aplicadas, industriales o decorativas, que debían anteponer su función práctica a la estética.

El arte es entendido generalmente como cualquier actividad o producto realizado por el ser humano con una finalidad estética o comunicativa, mediante la cual se expresan ideas, emociones o, en general, una visión del mundo, mediante diversos recursos, que pueden ser plásticos, lingüísticos, sonoros, etc. El arte es un componente de la cultura, que refleja en su concepción los sustratos económicos y sociales, y la transmisión de ideas y valores, inherentes a cualquier cultura humana a lo largo del espacio y el tiempo.

Se suele considerar que con la aparición del Homo Sapiens el arte tuvo en principio una función ritual, mágica o religiosa, pero esa función cambió con la evolución del ser humano, adquiriendo un componente estético y una función social, pedagógica, mercantil o simplemente ornamental. 


\section{1.- EL ARTE CERÁMICO: ESTADO DE LA CUESTIÓN}

La cerámica y el arte siempre han estado relacionados, las primeras esculturas realizadas por el ser humano fueron hechas de barro y la obra más famosa y controvertida del Arte Contemporáneo del siglo pasado La Fuente de Marcel Duchamp está realizada en cerámica. Carmen González indica que cuando Marcel Duchamp presentó en Nueva York en 1917 La Fontaine como una de las obras de arte más relevantes, realizada con material cerámico, se tambalearon las clasificaciones entre las distintas disciplinas del arte. ${ }^{1}$

No obstante, los estudios realizados sobre el tema de la cerámica suelen centrarse en dos categorías: los biográficos o monográficos y los técnicos, pero difícilmente encontramos textos de investigación, ensayos o crítica.

Explorar las posibilidades de la cerámica en el mundo del Arte Contemporáneo exige contextualizar su significado, su lenguaje y los diferentes roles históricos de su práctica formal.

Durante el auge de la teorización y la crítica sobre las artes visuales en la década de 1980, los trabajos realizados con materiales pertenecientes a las Artes Aplicadas quedaron fuera del debate cultural, y al mismo tiempo, el acercamiento de la crítica a la escultura excluyó los trabajos realizados en cerámica por considerarla menos relevante que otros materiales como el mármol, la piedra y los metales, considerados como materiales nobles.

Los artesanos están comprometidos con el mundo de los objetos cotidianos, se comunican con los materiales a través de la técnica y adquieren el oficio a base de la repetición de procesos preestablecidos. Sus productos reflejan dominio técnico, identidad e individualidad, y su característica principal reside en que sus obras se ubican entre el arte y la vida cotidiana.

Con la Revolución Industrial, la automatización y la mecanización de los procesos de producción en el mundo occidental provocó el declive de la artesanía. Los alfareros se enfrentaron al dilema de tener que elegir entre dos opciones: trabajar en una fábrica o continuar produciendo de manera independiente objetos que pasaron de la categoría de indispensable a la de superfluos o decorativos.

\footnotetext{
${ }^{1}$ http://elpais.com/diario/2002/06/07/cvalenciana/1023477505_850215.html
} 
Históricamente, el movimiento británico de Artes y Oficios, que se desarrolló desde mediados del siglo XIX hasta la segunda década del siglo XX, surgió como una reacción a la enajenación de la Revolución Industrial, buscando el regreso a la sensibilidad y el placer estético desde una práctica moderna. Al mismo tiempo, los ejemplos de cerámica provenientes de Corea y Japón mostrados en la Exposición Mundial de París en 1878 y 1889 impresionaron a los ceramistas de la época y su influencia fue determinante. Conseguir una vasija torneada de líneas simples y con esmaltes extraordinarios se convirtió en el punto focal de la cerámica moderna, la cual, impulsada por una creciente autonomía artística evolucionó hacia nuevas posibilidades y propuestas, surgiendo así las nuevas categorías adjetivales de "pieza única", "cerámica de estudio" o "cerámica artística", aplicada a las nuevas creaciones artísticas cerámicas.

Glenn Adamson, jefe de investigación del Victoria and Albert Museum de Londres, plantea en su obra La invención de la artesanía dos elementos poco considerados como determinantes en la percepción de la cerámica como un material menor: las figuritas coleccionables y el modelo o la maqueta. Las figuritas de cerámica o porcelana, populares desde el siglo XVIII, representan la trivialización del arte figurativo y todo aquello que el arte desdeña: preciosas, sentimentales y $\sin$ consecuencias. Por su parte las maquetas tienen la misma función que los bocetos para un pintor, lo que significa su utilidad para representar una idea en proceso de formación, pero este hecho conlleva su apreciación como un material sin la suficiente presencia para ser el material final de una escultura. En resumen, dos percepciones contaminantes: piezas

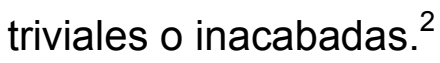

A pesar de estos obstáculos, corrientes como el Arte Abstracto, el Brutalismo y el Arte Povera con sus características informales y transgresoras facilitaron el camino. Durante la década de 1960 y gran parte de la década de 1970 se introdujo un nuevo y decisivo impulso: el descubrimiento y la apreciación de las potencialidades de la cerámica como medio para el arte.

El mundo de la cerámica reaccionó con incertidumbre y desconfianza al rompimiento del principio que dicta "la forma sigue a la función", aspecto que

\footnotetext{
${ }^{2}$ AdAmson, Glenn. The invention of arts. Ed. Bloomsbury, 2013.
} 
permitió la ampliación del término "cerámica artística" para usarse más allá de las vasijas, rompiéndose así las barreras tradicionales que existían entre el arte y la artesanía, y aunque el Post-minimalismo teóricamente pregonaba la flexibilidad, aún encontramos en este periodo prejuicios relacionados con las obras realizadas en cerámica, que siguen siendo clasificadas como "artesanía artística".

La ausencia de límites en el arte actual y el abandono de las estereotipadas definiciones clásicas de las diferentes disciplinas artísticas, así como el hecho de que los artistas, a través de sus obras, fusionen constantemente las clasificación tradicionalista de Bellas Artes y Artes Aplicadas, dificulta describir las obras cerámicas que no son funcionales, debido a que no entran en lo que reconocemos como "cerámica artística" o escultura.

Los artistas contemporáneos que trabajan con materiales como cerámica, vidrio, textil, etc, tradicionalmente identificados con las Artes Aplicadas evitan referirse a su trabajo como un oficio y a su obra como artesanal. Formados en estudios sobre las artes visuales, diseño, arquitectura, etc, dominan la técnica pero ésta no los limita, trabajan con ideas y el material es tan sólo su medio de expresión. Su obra se exhibe en galerías de arte y museos que definen su trabajo como obras de Arte Contemporáneo realizadas en determinado material, es decir, que el éxito de una obra es un asunto de intención y sobre todo de comunicación, su valoración ya no depende del material o del virtuosismo con que está realizada sino de su relevancia visual y de su carga simbólica o conceptual.

La definición y la práctica de la escultura fueron modificadas a partir de la década de 1970 convirtiéndose en una categoría mucho más amplia y flexible que se alejó del territorio de las formas para explorar la relación e interacción entre lo físico, lo visual, las propiedades de los materiales y los procesos de creación.

Esta tendencia fue descrita por Jackson Pollock como "pensar a través del arte, el arte como pensamiento y la apreciación en y a través del encuentro con el proceso del trabajo artístico". Este proceso no se refiere simplemente al aspecto técnico de la realización de una obra sino a un sistema de 
percepciones sobre la relación entre el artista, el material, el proceso de realización, su contenido conceptual y el espacio en el que se realiza.

Entre los años 1967 y 1968, el escultor americano, Richard Serra elaboró un listado de 63 acciones generadoras de formas que se pueden realizar en la materia: Verb List Compilation: Actions to Relate to Oneself. El listado de acciones está redactado en forma de infinitivos verbales, indicando que los materiales son únicamente los elementos vehiculares y son convertidos en formas a través de la intencionalidad de los artistas. ${ }^{3}$

Los artistas han cambiado su visión del arte, ampliando horizontes y dirigiéndose hacia el pluralismo, buscando con nuevos y diferentes materiales una nueva forma de comunicación, modificando la percepción del arte, que ya no se concentra únicamente en la obra creada, sino en la relación de ésta con su entorno.

Una obra debe comenzar con una idea, cuando un artista consigue convertir una idea en una forma visible, todos los pasos del proceso de creación son importantes, incluso en ocasiones más importantes que el propio resultado final.

Los trabajos realizados en cerámica se van posicionando en el mundo del arte contemporáneo: Grayson Perry ganador del prestigioso premio Turner 2003 marcó un cambio en la percepción de la cerámica en el mundo de las Bellas Artes. Transgresor de límites, su técnica derivada del hobby del siglo XVIII de cortar y pegar para generar objetos decorativos, explora temas perturbadores a través de imágenes y textos aplicados a objetos de cerámica

\footnotetext{
${ }^{3}$ Las acciones propuestas por Richard Serra son: "rodar, plegar, doblar, almacenar, curvar, acortar, torcer, motear, arrugar, rasurar, rasgar, hacer virutas, hender, cortar, cercenar, caer, quitar, simplificar, diferenciar, desordenar, abrir, mezclar, esparcir, anudar, derramar, inclinar, fluir, retorcer, levantar, incrustar, impresionar, encender, desbordar, untar, girar, arremolinar, apoyar, enganchar, suspender, extender, colgar, reunir, de tensión, de gravedad, de entropía, de naturaleza, de agrupación, de capas, de fieltro, agarrar, apretar, atar, amontonar, juntar, dispersar, arreglar, reparar, desechar, emparejar, distribuir, exceder, elogiar, incluir, rodear, cercar, agujerear, cubrir, abrigar, cavar, atar, ligar, tejer, juntar, equiparar, laminar, vincular, unir, marcar , ampliar, diluir, alumbrar, modular, destilar, de ondas, de electromagnetismo, de inercia, de ionización, de polarización, de refracción, de mareas, de reflexión, de equilibrio, de simetría, de fricción, estirar, saltar, borrar, rociar, sistematizar, referir, forzar, de mapa, de posición, de contexto, de tiempo, de carbonización, continuar". LAYUNO ROSAS, María Ángeles. Richard Serra. Editorial Nerea, San Sebastián, 2001.
} 
convencionales como platos o jarrones a los que la crudeza de los temas despoja de cualquier refinamiento. ${ }^{4}$

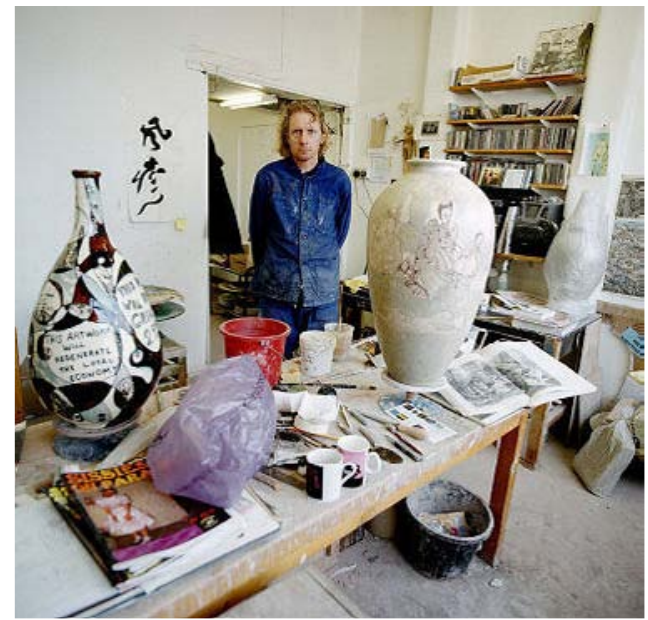

Figura 75: Grayson Perry.

Rebeca Warren, escultora, finalista del mismo premio Turner en 2006 presentó una obra que fue descrita por los jueces como "proyectando un sentido de incontrolable creatividad, pareciendo explotar y vuelto a fusionar en las amorfas propiedades de la materia". ${ }^{5}$

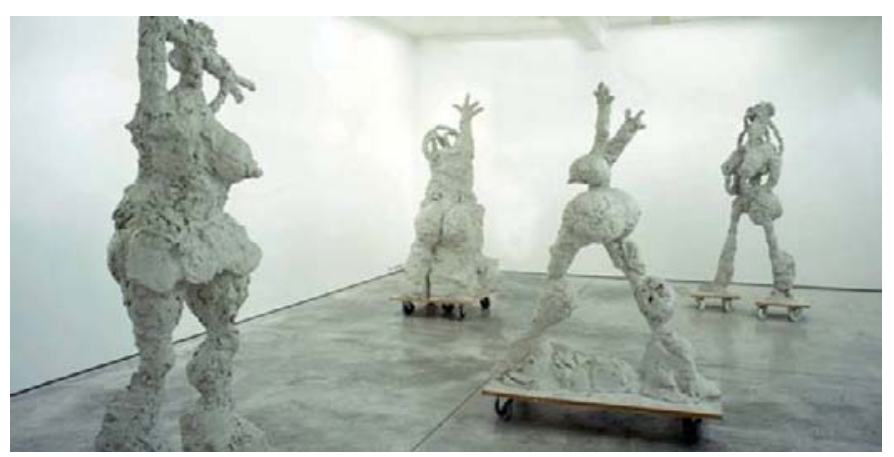

Figura 76: Rebecca Warren.

La obra de Richard Deacon es definida como un acercamiento en cerámica a la escultura experimental que investiga las propiedades y el comportamiento del material. Su exploración parte de pequeñas esculturas en cerámica que traslada posteriormente a grandes formatos, sobre los que Deacon aplica sus marcas personales en un dramático acto de performance,

\footnotetext{
${ }^{4}$ http://masdearte.com/opinion/arte-sin-trabas/grayson-perry-who-are-you-exhibition/

${ }^{5} \mathrm{http}: / /$ www.saatchigallery.com/artists/rebecca_warren.htm
} 
sin un plan preconcebido, la clave de sus obras radica más en el proceso que en el objeto final, aprovechando además la oportunidad y el accidente, manteniendo abierta la posibilidad de nuevas opciones. ${ }^{6}$

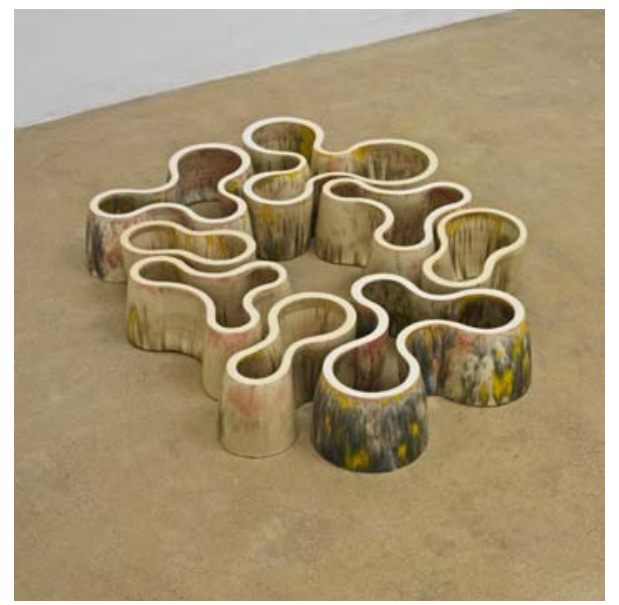

Figura 77: Richard Deacon.

Kosho Ito, reconocido internacionalmente, trabaja sólo con cerámica, es catalogado como desafiante y describe su trabajo como experimentos para exponer las características del material, busca probar los límites de lo que es considerado arte cerámico. En su instalación Virus en la Tate Gallery en St Ives, Ito tritura 1500 láminas delgadas de porcelana, individualmente con la mano. Sus elementos son la interacción entre el cuerpo y el material, las leyes de la física y la temporalidad. ${ }^{7}$

Para muchas personas, el término "arte de la cerámica" evoca la imagen de elementos de cerámica funcional: tazas, tazones y platos llenos de comida y bebida, o tal vez puede significar figurillas de terracota o simplemente una escultura realizada utilizando la arcilla como material principal. Pero para Kosho Ito, el "arte de la cerámica" es a la vez algo a lo cual ha dedicado toda su vida y una etiqueta restrictiva que se niega a aceptar.

Kosho Ito lucha por derribar esta clasificación del mundo del arte, trabajando en el ámbito cerámico, una clasificación rígida y conservadora en Japón, derribando las fronteras de la artesanía tradicional, creando obras que desafían la categorización. Independientemente de si se puede o no clasificar

\footnotetext{
${ }^{6} \mathrm{http}: / / \mathrm{www}$.lissongallery.com/artists/richard-deacon

${ }^{7}$ Kosho Ito. Tate St. Ives, 2002
} 
su producción artística, lo que es evidente es que sus obras están hechas de y sobre arcilla.

La constante experimentación sobre el material de Kosho Ito, le condujo a someter a la arcilla a temperaturas extremas, primero congelándola y posteriormente cociéndola a alta temperatura, lo que provocó grietas y fisuras en el material, creando superficies texturizadas de gran vistosidad orgánica. ${ }^{8}$

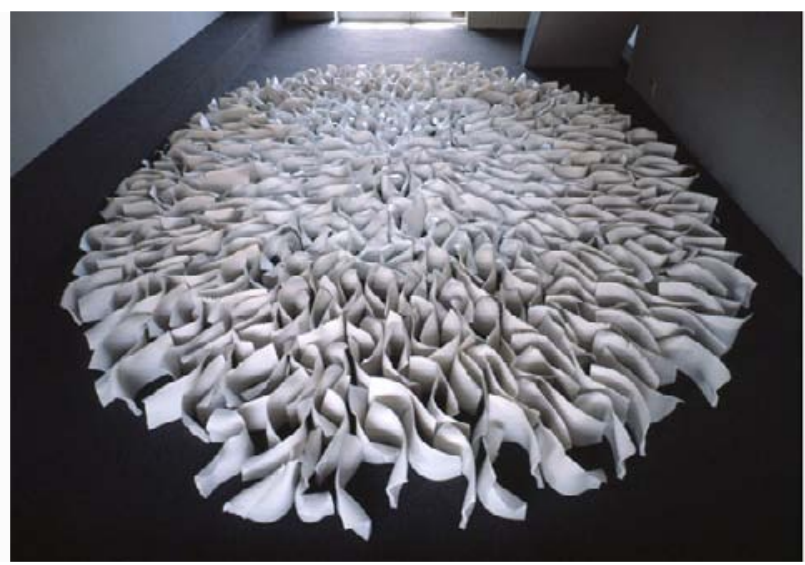

Figura 78: Kosho Ito.

Los artistas que trabajan con cerámica son generalmente definidos por su medio a diferencia de los demás artistas plásticos, pintores, escultores, grabadores, etc. que lo son por su actividad, su concepto y su proceso creativo. Los ejemplos anteriores demuestran las potencialidades de la cerámica para ser reconceptualizada, desde una perspectiva diferente, artistas contemporáneos que trabajan con diferentes materiales están optando por trabajar con cerámica por sus posibilidades materiales y su extraordinaria capacidad de registrar cada evidencia en el proceso de transformar ideas y conceptos en acciones.

Esto significa que debemos cuestionar el planteamiento tradicional de crear a través de materiales para explorar la libertad de convertirse en vehículo de creación al permitir que el barro se exprese a través del artista, sorprender y ser sorprendido. ${ }^{9}$

\footnotetext{
${ }^{8}$ http://www.japantimes.co.jp/culture/2009/08/14/arts/breaking-all-the-rules-inceramics/\#.VYMTLPntmkp

${ }^{9}$ http://www.taringa.net/posts/arte/13574520/La-Ceramica-en-el-ArteContemporaneo.html
} 
La cerámica es un material que nació con el hombre y en la actualidad artistas, alfareros y ceramistas la esculpen, modelan, pintan y cuecen hasta generar la obra. La creación del ceramista es un proceso largo y dedicado dentro del cual las aptitudes personales del autor definen la creación como única a través de un lenguaje artístico personal. Valor añadido para una obra que cotiza con el paso de los años. Pintores, escultores, diseñadores o arquitectos encontraron y encuentran en la cerámica una misteriosa inquietud artística, descubriendo en el proceso creativo de la cerámica artística el fascinante mundo de la alquimia y sus elementos (agua, tierra, fuego y aire). Es un excelente material que debido a sus características como la resistencia fisico-química, variedades tonales y de textura, lo convierten en una apuesta segura de futuro como material constructivo y decorativo, en un material dinámico que evoluciona con el hombre y con sus conocimientos.

El mercado artístico actual, algo cerrado a nuevos materiales, va dejando atrás prejuicios obsoletos y valorando a ceramistas junto a sus obras, reafirmando la cerámica artística como un medio mas de expresión formando parte indiscutible del arte contemporáneo y vanguardista de nuestros tiempos. El arte al igual que el lenguaje sigue siendo y será un medio de expresión y comunicación.

La evolución de la historia de la cerámica ha sido constante a lo largo de los siglos, desde las primitivas cerámicas con decoraciones geométricas, con líneas y círculos concéntricos, al desarrollo del realismo con la incorporación de figuración humana, animal y vegetación, hasta llegar al arte cerámico actual.

Alfareros, pintores o escultores con espíritu de artista, enriquecen el material cerámico haciéndolo llegar al público, en forma de piezas escultóricas, murales modelados y obra abstracta. Son muchos los ceramistas destacados, y a ellos recurren también artistas de otras disciplinas, para poder trasladar a este complejo material sus obras artísticas. En el panorama del arte contemporáneo español, cabe destacar la asociación del ceramista Josep Llorens i Artigas y Joan Miró, ${ }^{10}$ la alfarería de Pedro Mercedes, los murales exquisitos de Arcadio Blasco o la cerámica arquitectónica de Enric Mestre.

10 LUBAR, Robert S. La Mediterrània de Miró: concepción d'una identitat cultural. Fundació Joan Miró. Leonardo Arte, 1993.

http://www.ceramista.biz/ceramica_artistica.htm 


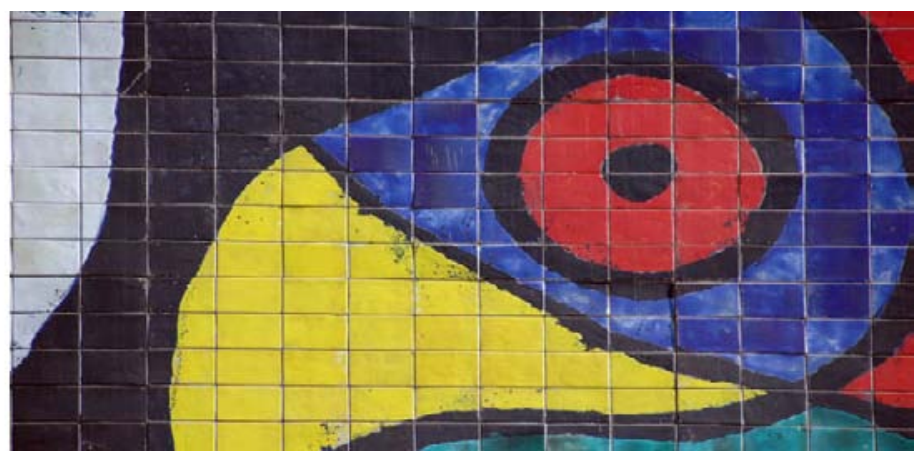

Figura 79: Detalle mural cerámico de Joan Miró. Palacio de Congresos de Madrid.

En la actualidad, la elaboración de piezas cerámicas tiene un cierto componente alquímico, fusionando la tradición ancestral de un arte y un proceso antiguo, en el cual el fuego nos desvela el misterio de una creación, con los últimos avances tecnológicos y científicos en cuanto a materiales y técnicas de cocción.

En 1999, la Direcció General de Promoció Cultural i Patrimoni Artístic de la Consellería de Cultura, Educació i Ciència de la Generalitat Valenciana, organizó una exposición titulada "Cerámica Fin de Siglo"11 que se realizó en las Atarazanas del puerto de Valencia. Con esta exposición se ofreció una revisión, tanto en su vertiente estética como histórica, de la evolución de este arte mediante las aportaciones creativas de las diferentes franjas generacionales de artistas valencianos desde los años del franquismo hasta la época actual. Cerámica Fin de Siglo llamó la atención sobre la versatilidad existente en el mundo de la cerámica, realizando un repaso de las obras más representativas de autores de reconocido prestigio como el propio Manolo Safont, Arcadio Blasco o Enrique Mestre, artistas ya consolidados durante las postrimerías de la dictadura franquista, y también de las generaciones emergentes durante la transición, en las que destacan nombres como Miquel Navarro, Carmen Calvo, Mercedes Sebastián, Marisa Herrón, Carmen Ballester, Evaristo Navarro, Anna Pastor, Carmen Sánchez o Presentación Rico, hasta llegar a promociones recientes donde despuntan brillantemente las iniciativas expresivas de artistas como Xavier Montsalvatje, Vicente Roda, Pablo Ruíz o Joan Esquerdo.

\footnotetext{
${ }^{11}$ Cerámica Fin de Siglo. Catálogo Exposición. Atarazanas del 25/11 de 1999 al 2/1 del 2000. Arte. Generalitat Valenciana. Valencia 1999.
} 


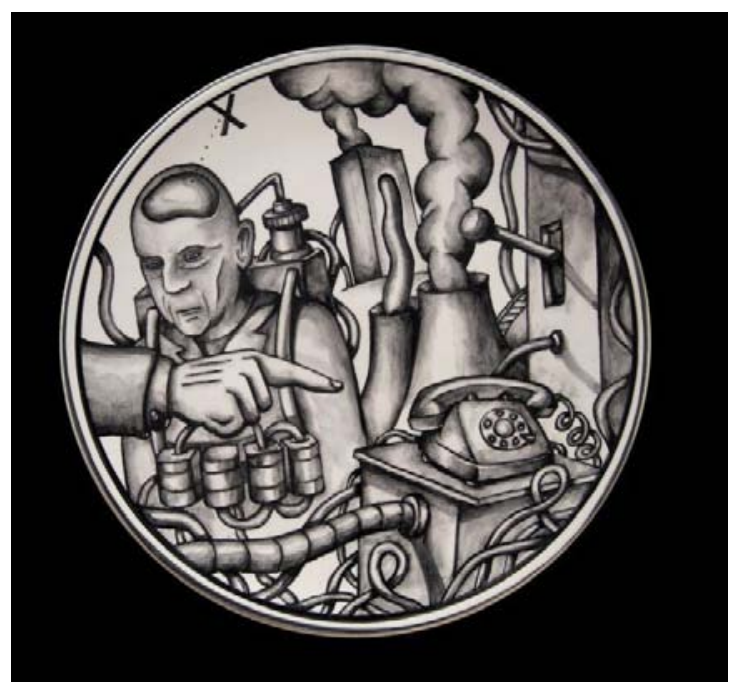

Figura 80: Xavier Montsalvatje.

Desde 2002, La Comisión Organizadora de CERCO, formada por: el Departamento de Industria, Comercio y Turismo del Gobierno de Aragón, el Ayuntamiento de Zaragoza, el Área de Cultura y Patrimonio, de la Diputación de Zaragoza, la Asociación Profesional de Artesanos de Aragón, convocan CERCO, Feria Internacional de Cerámica Contemporánea Aragón, que se celebra en Zaragoza, con objeto de contribuir a la promoción y difusión de la cerámica contemporánea. El eje principal de CERCO es la Feria Internacional de Cerámica Contemporánea y el Premio Internacional de Cerámica Contemporánea. En torno a ellos y coincidiendo en las fechas, tienen lugar diversas exposiciones que muestran tanto los valores emergentes como los ya consolidados, convirtiéndose así en una cita imprescindible para los amantes de la cerámica y del arte. CERCO inició en 2013 un nuevo formato, convocando Feria y Premio cada dos años en ediciones alternas. ${ }^{12}$

Entre septiembre de 2013 y marzo de 2014, el Museo de Arte y Diseño de Nueva York (MAD) recopiló en la muestra Body \& Soul (Cuerpo y alma) las "dramáticas cerámicas figurativas" de 24 escultores actuales para explorar el modo en que creadores de varios países del mundo afrontan con su obra la figura humana y abordan con ella diferentes cuestiones sociales y políticas. Los organizadores apuntaban a la versatilidad de la arcilla y destacaban cómo el

\footnotetext{
${ }^{12} \mathrm{http}: / / w w w . c e r c o . e s / c e r c o \_i n d e x . a s p ? i d=57$
} 
material ha participado del renacimiento que en los últimos años ha experimentado la representación del ser humano en el arte contemporáneo. ${ }^{13}$

En abril de 2015 se realizó la exposición 17 Visiones Contemporáneas en el Museo Nacional de Cerámica González Martí de Valencia, dando así por inaugurada la primera edición de la que quiere ser la Feria Internacional de Arte y Cultura Cerámica Contemporánea de referencia, que se celebró en esta ocasión entre los meses de Marzo y Abril de 2015. La exposición seleccionó la obra de diecisiete autores: Ángel Garraza, Antonio González, Bibiana Martínez, Elena Colmeiro, Gregorio Peño, Jesús Castañón, Juan Gómez, Lorenzo Pérez Vinagre, Madola, María Ramis, Miguel Vázquez, Monona Álvarez, Nicolás de Maya, Rafa Pérez, Ricardo Bonnet, Sara Biassu y Txaro Marañón, procedentes de cada una de las diecisiete comunidades autónomas del territorio español. Partiendo de la premisa de mostrar distintas líneas de la cerámica contemporánea, reflejo de la esencia de esta primera FACC, se realizó una selección de obras que mostraban lenguajes que albergaban desde la figuración, la escultura, el objeto, lo conceptual o lo encontrado entre otros. Esta selección no respondía a la idea de mostrar lo más representativo de cada comunidad autónoma, sino a través de las obras que componían la exposición dar una idea amplia de los distintos lenguajes utilizados dentro de la cerámica contemporánea, con propuestas conceptuales, escultóricas y pictóricas que conviven con aquellas que enraízan en la tradición japonesa o enfatizan los propios materiales a través del objeto cerámico. Esta exposición tuvo carácter itinerante y se expuso también en Alicante y en Vila-Real. ${ }^{14}$

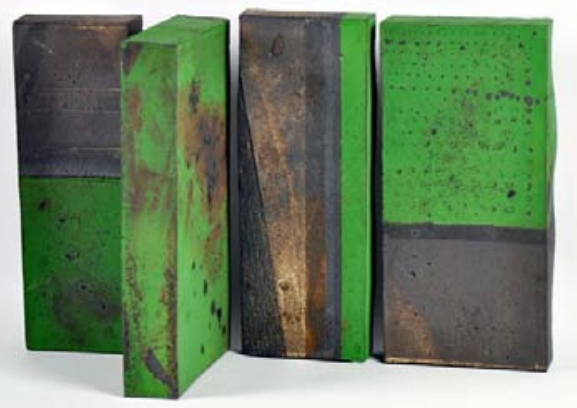

Figura 81: Sin palabras de Antonio González.

\footnotetext{
${ }^{13} \mathrm{http}: / /$ madmuseum.org/exhibition/body-soul

${ }^{14}$ http://www.mecd.gob.es/prensa-mecd/dms/mecd/prensamecd/actualidad/2015/03/20150311-ceramica/dossierprensa.pdf
} 
El Concurso Internacional de Cerámica de l'Alcora (CICA) ha seguido a lo largo de más de 3 décadas una trayectoria ciertamente notable. Desde sus inicios en 1981 (convocado entonces con carácter nacional) ha sabido adaptarse a los tiempos, evolucionar a la par que lo hacía el sector cerámico artístico, e instalarse en una privilegiada situación, pues no en vano está considerado como uno de los más prestigiosos de Europa en su género. La colección de cerámica contemporánea se ha formado a partir de la convocatoria de este certamen. Desde entonces, ha crecido en prestigio y en participación, siendo en la actualidad uno de los más importantes del continente europeo. Superadas ya las tres primeras décadas de historia, cada verano la exposición de las obras finalistas ofrece al visitante una amplia visión de algunas de las tendencias creativas más actuales en el campo de la cerámica de autor. De esta aceptación y brillante evolución, son buena muestra las cifras de participación de las últimas ediciones.

El Museo acoge el fruto del Concurso, en forma de premios y donaciones. Ceramistas de la talla de los españoles Claudi Casanovas, Rafael Pérez, Alberto Hernández, Barbaformosa, Rafaela Pareja, Juan Ortí, y también Ken Eastman (Reino Unido), Pekka Paikkari (Finlandia), Graciela Olio (Argentina), Roland Summer (Austria), Luigi Gismondo (Italia) o Lu Bin (China) forman parte de la colección, ofreciendo un contrapunto y a la vez un complemento al resto de las exposiciones permanentes del Museo. ${ }^{15}$

Desde 2015, la Cátedra de Innovación Cerámica Ciutat de Vila-real celebra la Feria de Arte y Cultura Cerámica Contemporánea (FACC), una iniciativa en la que participan todos los museos y escuelas superiores de cerámica de la Comunidad Valenciana, que pretende poner en valor la cerámica como elemento de expresión y creatividad, desde sus orígenes hasta la actualidad. Para ello, esta cátedra, con la colaboración del Ayuntamiento de Vila-real y la Universidad Jaume I de Castellón, programa actividades tales como conferencias, exposiciones, talleres y performances abiertas a todo el público, con la participación de algunos de los ceramistas internacionales más reconocidos, como el ceramista japonés Masakazu Kusakabe, el maestro

\footnotetext{
${ }^{15}$ http://www.museulalcora.es/
} 
ceramista Xohan Viqueira y muestras colectivas como FANGtàstic, con más de 30 autores de la Asociación Nacional de Profesionales de la Cerámica (ANPEC). ${ }^{16}$

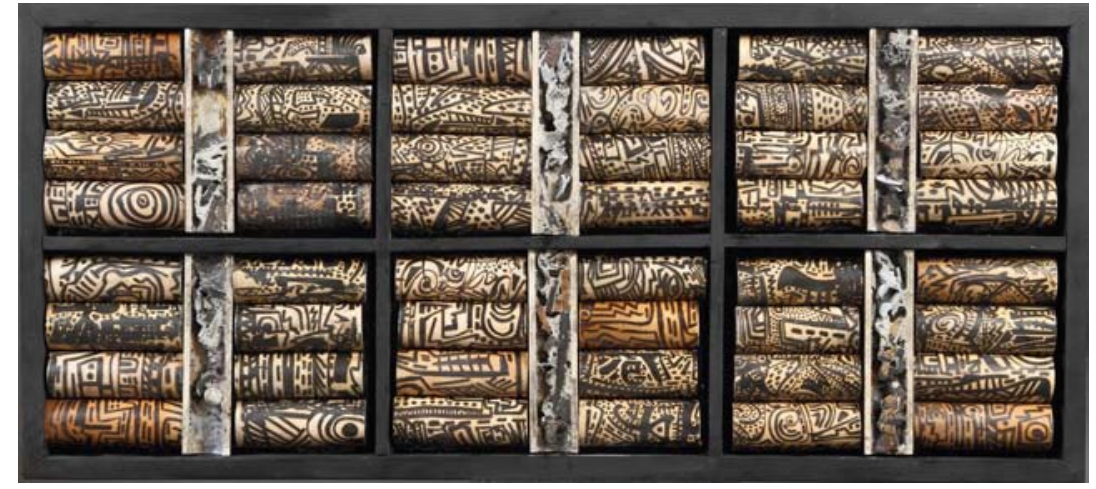

Figura 82: Bambú 25 de Xohan Viqueira.

No pretende ser este el espacio ni el lugar idóneo para detallar las innumerables muestras, exposiciones, premios y ferias sobre el arte cerámico contemporáneo que se han realizado en los últimos años en el territorio español, pero quizás una breve reseña sobre algunas de ellas nos ayude a comprender y entender la importancia y el auge actual de esta disciplina artística.

En octubre de 2008, María Bofill inauguró exposición en el Espai Foc, Can Ventura de Sabadell (Barcelona), organizada por la Asociación de Ceramistas del Vallés ${ }^{17}$ y Cristina Guzmán Traver, expuso Dones Atrapades en la Galería Espai Assaig de Vila Real (Castellón). ${ }^{18}$

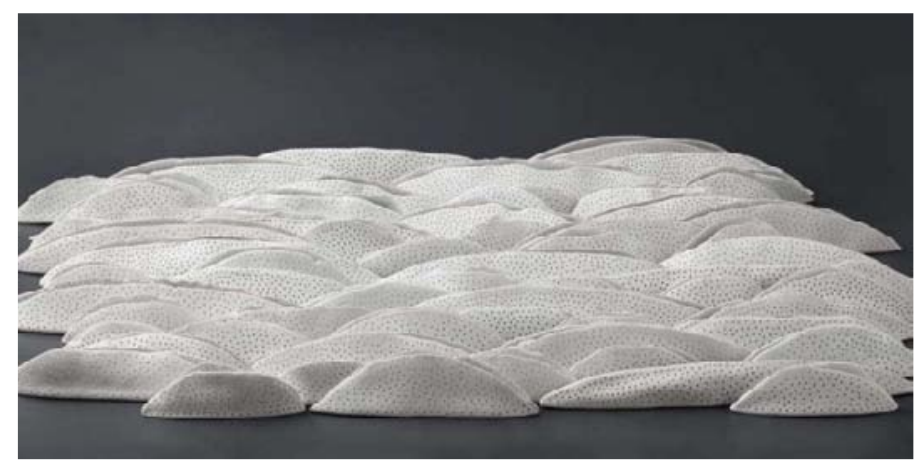

Figura 83: Mar de Gel de María Bofill.

\footnotetext{
${ }^{16}$ http://www.ifacc.es

17 http://mariabofill.com

${ }^{18}$ http://www.cristinaguzman.com/index.htm
} 
May Criado realizó la exposición Manuscrita en Ponferrada, en noviembre de 2008, en la que expuso sus obras, en las cuales combina cerámica con impresión digital y otros materiales como madera, estopa y acero. $^{19}$

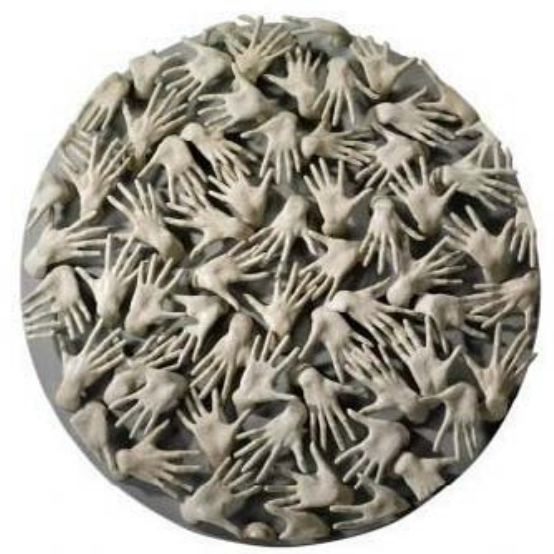

Figura 84: Manuscrita, $123 \mathrm{~cm}$ diámetro de May Criado.

Relacionados fue el título de la exposición que presentó Agustín Ruiz de Almodóvar, en octubre de 2008, en la Galería Camil.la Pérez en El Vendrell (Tarragona). Esta exposición se encuadró dentro de las diferentes actividades en torno a la IV Bienal Internacional de Cerámica de EI Vendrell.

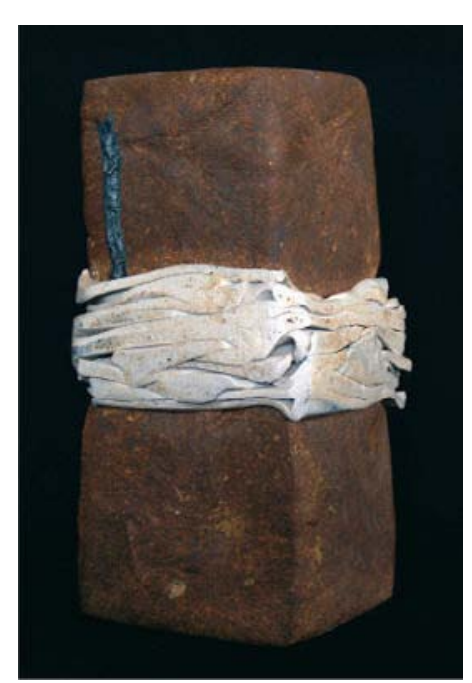

Figura 85: Obra de Agustín Ruíz de Almodóvar.

\footnotetext{
${ }^{19}$ www.maycriado.com
} 
En noviembre de 2008, Rafa Pérez expuso en una colectiva en la Galería Puls Contemporary Ceramics de Bruselas. ${ }^{20}$

Entre finales de 2008 y principios de 2009, Jordi Marcet y Rosa VilaAbadal presentaron su exposición Origens en el Museo de Lérida, y Hisae Yanase presentó una colectiva itinerante en el Instituto Cervantes de Bruselas que posteriormente se expuso en Córdoba, en los meses de febrero y marzo.

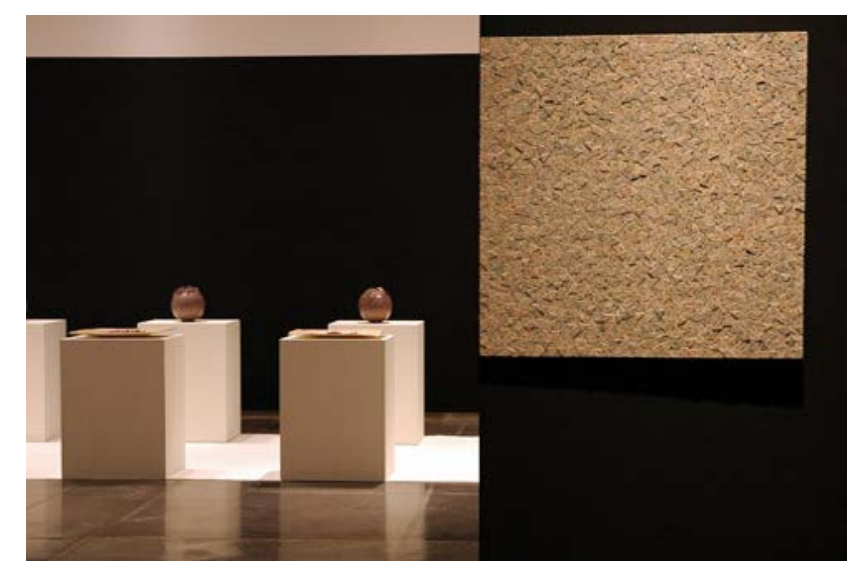

Figura 86: Orígens de Jordi Marcet y Rosa Vila-Abadal.

Desde noviembre de 2008 a enero de 2009 Elena Canencia realiza la exposición colectiva "Triálogos" junto a Alfonso Vidal y Isabel Micaela en el Centro de Innovación Turística Sierra Norte "Villa de San Roque" de La Cabrera (Madrid). ${ }^{21}$

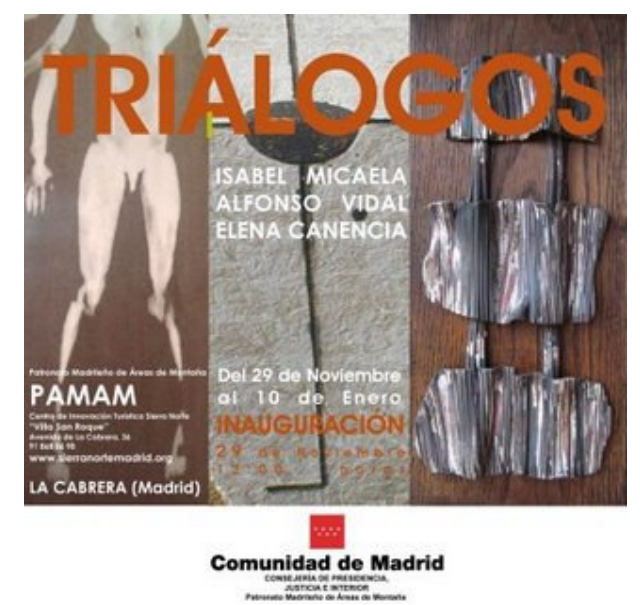

Figura 87: Exposición Triálogo.

\footnotetext{
${ }^{20} \mathrm{http}: / /$ www.pulsceramics.com

${ }^{21}$ http://"recortesdeforolandia.blogspot.com"
} 
Rosa Cortiella, inauguró en enero de 2009 Allà, on el món s'acaba... (Allá, donde el mundo se acaba...) en el Museo de Cerámica de Barcelona una muestra con cinco instalaciones cerámicas. ${ }^{22}$

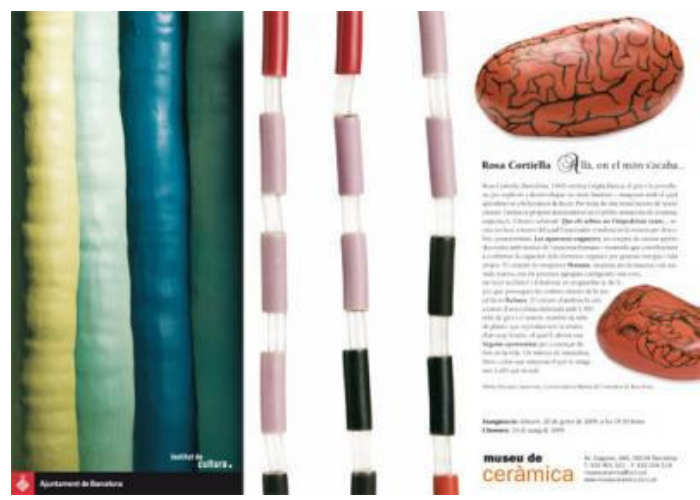

Figura 88: Exposición Allà, on el món s'acaba.

De enero a abril de 2009, Rafa Pérez expuso en la Galería 100 Kubik, en Colonia (Alemania). ${ }^{23}$

También en enero de 2009 se convoca la V Bienal de Cerámica de El Vendrell.

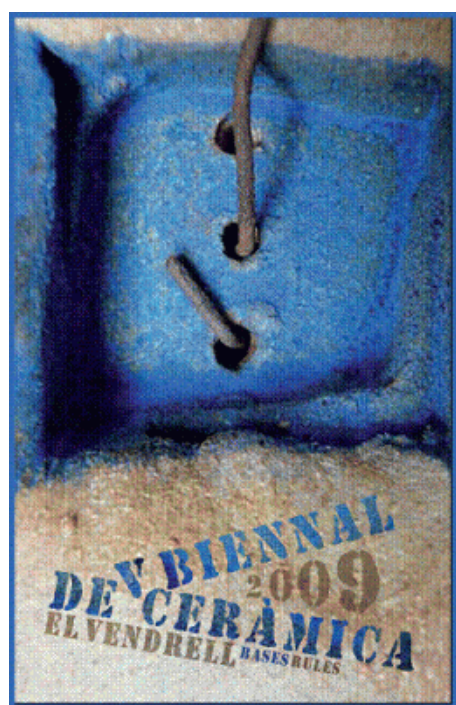

Figura 89: V Bienal de Cerámica. El Vendrell.

Cristina Guzmán participó en febrero de 2009 en una exposición colectiva Objectes, junto a Veena Seshadri y Ana Devis, realizada en el Centre Cultural de Massamagrell (Valencia). ${ }^{24}$

\footnotetext{
${ }^{22}$ museuceramica@bcn.cat http://www.museuceramica.bcn.cat

${ }^{23}$ http://www.100kubik.de

${ }^{24} \mathrm{http}: / /$ www.cristinaguzman.com
} 
En marzo de 2009, la Escuela Superior de Cerámica de Alcora, organizó las jornadas Cerámica en la Red. Difusión de la cerámica artística a través de Internet, en la que se presentaron diferentes páginas web de artistas cerámicos y se realizaron ponencias y mesas redondas sobre la importancia del uso de las nuevas tecnologías en la difusión artística, con el fin de crear un espacio de encuentro e intercambio entre los interesados en el campo de la cerámica artística.

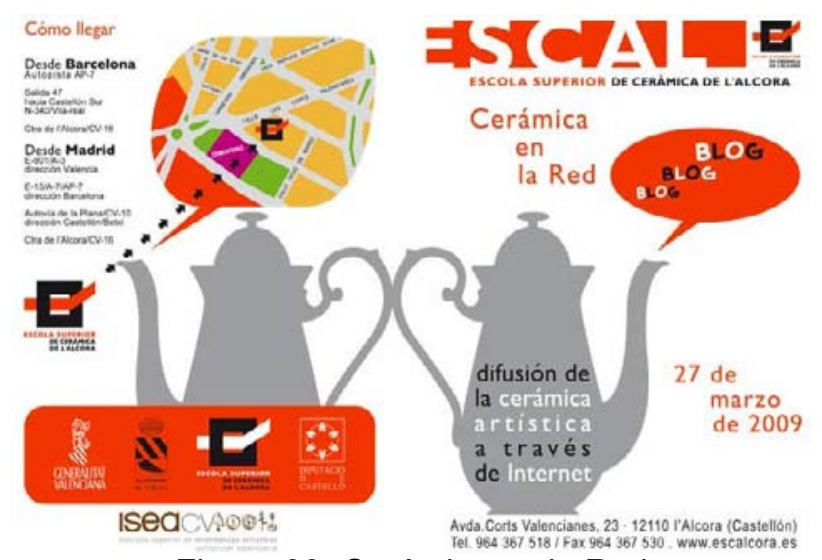

Figura 90: Cerámica en la Red.

Organizado por los ceramistas de Girona y el Ayuntamiento de Celrá (Gerona), se realizó en abril de 2009 Enfanga't, unas jornadas donde participaron ceramistas reconocidos que mostraron sus técnicas y experiencias cerámicas, así como la exposición de 35 autores que participaron en la Feria Internacional de Cerámica, un encuentro con la cerámica contemporánea que en su cuarta edición se consolidaba como una actividad destacada del panorama nacional. En ella participaron artistas cerámicos nacionales como Rafa Pérez (La Rioja) e internacionales como Peter Beard (Reino Unido), Hisae Yanase (Japón- Córdoba), Françoise Dufayard (Francia), Eve Ariza (FranciaAndorra), Wali Hawes (India- Japón). ${ }^{25}$

Carmen Vila expuso en abril de 2009, en la Galería Ruiz de Linares de Granada, Un jardín urbano, instalaciones cerámicas en las que la porcelana fue la materia dominante acompañada de cristalizaciones.

\footnotetext{
${ }^{25}$ http://www.enfangat.net
} 
En abril de 2009, Miguel Ángel Gil presentó en la Escuela de Arte Francisco Alcántara de Madrid, la exposición, conferencia y acción "¿Esto es cerámica contemporánea?". ${ }^{26}$

Madola, inauguró El cos 2003-2007 en mayo de 2009 en el Museo de Cerámica González Martí de Valencia.

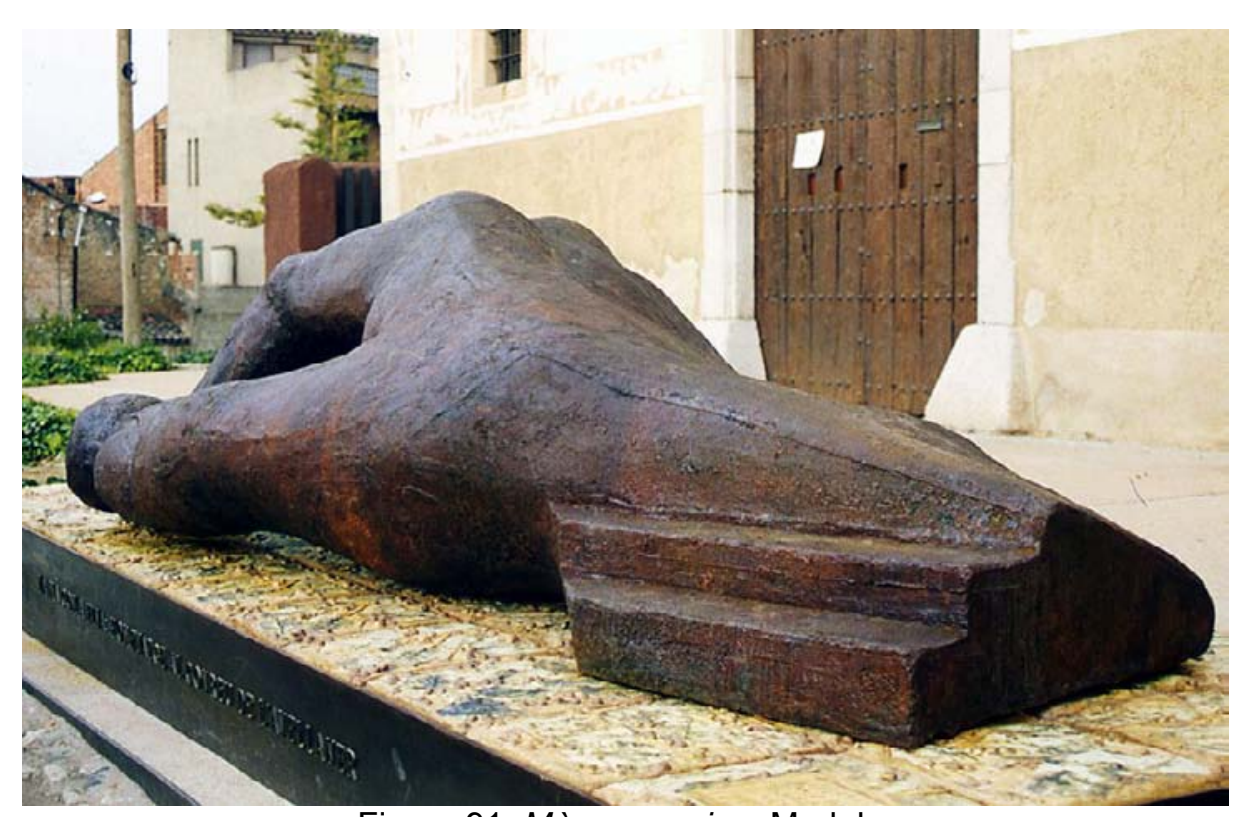

Figura 91: Mà com a eina, Madola.

También en mayo de 2009, Ángel Garraza expuso su trabajo más reciente en la Feria ART AMSTERDAM de la mano de la Galería De Witte Voet, bajo el título Cosas y Causas.

Dentro del marco de la Feria CERCO 2009, Carles Vives expuso Ombres/Sombras/Shadows, invitado por la ACC (Associació Ceramistes de Catalunya) y con el apoyo de Artesania Catalunya.

Elena Canencia expuso en mayo de 2009 Todo lo que nos puede suceder dentro del espacio Arte Intruso, en el Centro de Humanidades de La Cabrera (Madrid), Alberto Hernández expuso Señales de humo, en la Escuela de Arte de Talavera ${ }^{27}$ y Joaquín Espuny expuso en la Galería Camil.la Pérez Salvà de El Vendrell (Tarragona).

\footnotetext{
${ }^{26} \mathrm{http}: / /$ www.eafac.com

${ }^{27} \mathrm{http}: / /$ ceramico.blogspot.com
} 


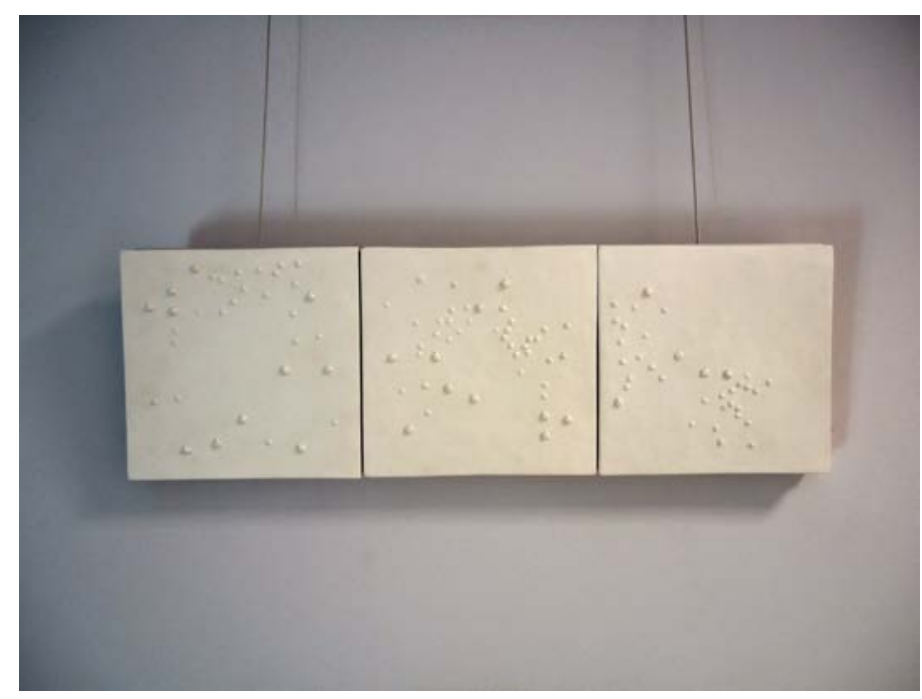

Figura 92: Estrella de Elena Canencia.

En junio de 2009 se inauguró la exposición de tres relevantes ceramistas contemporáneos Daniel Caxigueiro, Alberto Hernández y Rafael Pérez bajo el título Terra Libris, enmarcada en el proyecto Páginas de Barro, en la sala de exposiciones Galatea de la Casa Góngora en Córdoba, con carácter itinerante fue expuesta también en el Taller-Escuela de Cerámica de Muel (Zaragoza).

El grupo de artistas ceramistas gallegos Trasosmontes expuso en junio de 2009 una colectiva en la cual participaron Verónica Pérez, Emilia Guimeráns, Toño Pérez, Miguel Vázquez, Marta Amada, Javier Aguilera y Suso Dobao, en la Galería Artebronce de A Guarda (Pontevedra).

De la amplia programación dedicada a la cerámica en la 59 Feria del Càntir celebrada en agosto de 2009 en Argentona (Barcelona), con talleres, exposiciones, concursos, etc., destaca la realización de un ciclo sobre cine cerámico.

En agosto de 2009, Jesús Sanz expuso en Aínsa (Huesca); Miguel Ángel Gil y Victoria Luengo, ganadores de la edición 2008 del concurso de cerámica Ciudad de Valladolid, expusieron septiembre en las salas de exposiciones de Caja Duero Valladolid.

De septiembre a noviembre de 2009, el Colectivo Base f, integrado por Alejandro González, Alicia Mancheño, Ana Tejerina, Armando Díaz, Blanca Torrego, Carmen Puerto, Isabel Companys, Jacinto Morales, Raquel Mendiola y Ricardo Martín, expuso en el Centro Comarcal de Humanidades Cardenal Gonzaga de La Cabrera (Madrid). 
Fanny Galera presentó en septiembre de 2009 Otros Rumbos, su obra más reciente, en su tercera individual en la madrileña sala de CAPA. ${ }^{28}$

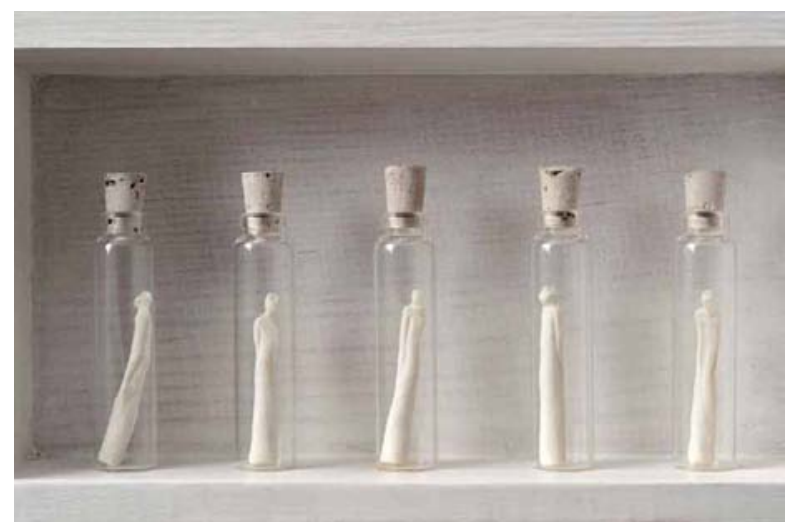

Figura 93: Detalle de En esencia de Fanny Galera.

La artista catalana Madola inauguró en octubre de 2009 su exposición Livres en la Galeria SMA Société Mutuelle Artistique de Carouge-Geneve en Ginebra (Suiza). Profesora de la Escuela Massana y discípula de Llorens Artigas, es una de las ceramistas referentes de nuestro país.

Samuel Bayarri con una de sus series AHUMA2, y Rafaela Pareja con Anatomías de una Ide", expusieron en octubre de 2009, en Dols ceramistas, Carretera Ibiza-Santa Eulalia Km. 5, ca na negreta, una nueva galería que apuesta por la cerámica contemporánea de creación. ${ }^{29}$

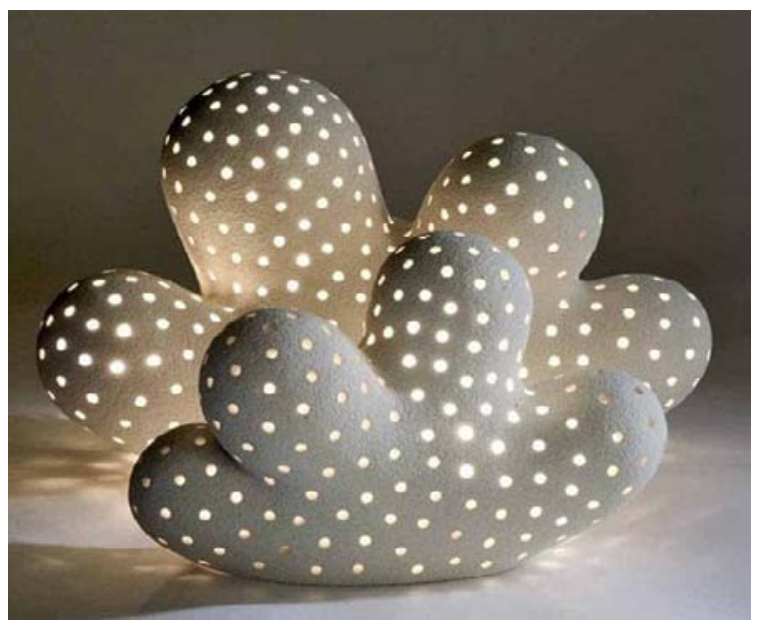

Figura 94: Obra de Samuel Bayarri.

\footnotetext{
${ }^{28} \mathrm{http}: / /$ www.capaesculturas.com

${ }^{29} \mathrm{http}: / /$ www.dolsceramistes.com
} 
Miguel Angel Gil, inauguró en noviembre de 2009 su exposición Algunas impresiones sobre barro, o las virtudes de la inconsistencia en la sala del Centro Mesonada de Utebo.

En enero de 2010, Cristina Guzmán, inauguró la exposición de sus últimos trabajos con la muestra Ulls de fang en el MUCBE (Museo Ciudad de Benicarló).

En febrero de 2010 el Museu de Belles Arts de Castellón ofreció en su sala de exposiciones temporales una muestra dedicada a Enric Mestre, que está considerado como el artista valenciano, junto a Arcadi Blasco y Manolo Safont, que "ha elevado la cerámica a las más altas cotas de la escultura contemporánea". La muestra, comisariada por el presidente de la Real Academia de Bellas Artes de San Carlos de Valencia, Román de la Calle, fue una selección de 38 esculturas realizadas por Mestre entre los años 1979 y 2005 , ofreciendo una primera parte donde se muestran las 20 piezas más representativas de un periodo y otra parte con 18 esculturas de menor tamaño. Esta muestra reivindicaba el papel de la cerámica como arte de primera categoría. $^{30}$

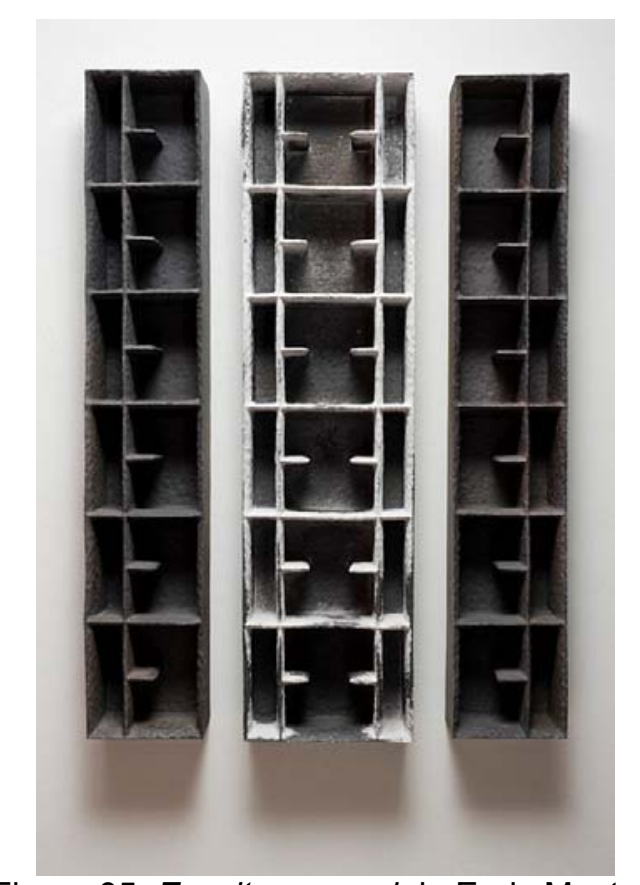

Figura 95: Escultura mural de Enric Mestre.

\footnotetext{
${ }^{30} \mathrm{http}: / /$ www.lasprovincias.es/v/20100219/culturas/ceramica-enric-mestre20100219.html
} 
María Bofill expuso desde julio a octubre de 2010 una retrospectiva compuesta por medio centenar de piezas realizadas entre 1980 y 2010, en el Museo de Cerámica Palau Reial de Pedralbes de Barcelona.

En la sala Hucha del edificio Bancaja de Castellón, Cristina Guzmán presentó en septiembre de 2010, su obra Astres acompañada con las obras de sus colegas del grupo Beni-Art.

De noviembre a diciembre de 2010, Jordi Marcet y Rosa Vila-Abadal expusieron en Espai d'art de Tarrasa.

Con motivo de la conmemoración de los 10 años del premio CERCO, se realizó en el Taller Escuela de Muel (Zaragoza) desde abril a junio de 2011 la exposición Diez años de cerámica contemporánea, que reunió veintiocho piezas premiadas en la feria internacional de CERCO, en la que se pone de manifiesto la evolución del trabajo de los ceramistas en la última década.

Además de mostrar de manera cronológica las diez obras premiadas y las dieciocho que consiguieron accésit en las sucesivas ediciones de la Feria Internacional de Cerámica Contemporánea (CERCO), la exposición se apoyó en imágenes de todas las piezas seleccionadas, un total de 344. Unas obras procedentes, además de España, de Alemania, Francia, Reino Unido, Bélgica, Estados Unidos, México, Argentina, Brasil e incluso de China, Japón o Corea, diferentes culturalmente pero en los que la cerámica forma parte de su esencia cultural. Propuestas que van desde trabajos escultóricos hasta instalaciones, líneas conceptuales o se apoyan en la aportación estética que aportan las técnicas ceramistas. Esta muestra itinerante fue expuesta posteriormente en el Museo Nacional de Cerámica González Martí de Valencia y en el Museo de Bellas Artes de Badajoz. El comisario de la muestra, Alberto Andrés, pretendió de este modo, dar a conocer, de manera cronológica, la evolución que han experimentado los ceramistas desde el año 2001, cuando comenzó a celebrarse en Muel, Teruel y Zaragoza un certamen entorno a la cerámica contemporánea que se ha convertido en el más importante a nivel español, y una de las referencias en su entorno cultural europeo, en la que han sido premiadas obras de Javier Fanlo, Bodil Manz, María Oriza o Ursula Comandeur. ${ }^{31}$

\footnotetext{
${ }^{31} \mathrm{http}: / /$ www.abc.es/agencias/noticia.asp?noticia $=759124$
} 
En abril de 2011 se realizó la muestra colectiva La pasta, con ceramistas españoles y portugueses: Sonia Abollo, Marisa Alves, Xela Area, Marc Brocal, Juana Fernández, Andreina Franceschi, Ainara Garay, Cristina Guzmán, Joáo Lourenço, Arístides Martín, Ángela Ortega, Salvador Pardo, Luis Plaza, Joaquim Pomba, Lourdes Rodríguez, Magdalena Rodríguez, Estefanía Sánchez, Lourdes Zapata. De carácter itinerante, se inauguró en la Asociación de Ceramistas de Cataluña de Barcelona y posteriormente viajó a Pontevedra, Málaga, Barcelona, Onda (Castellón), Dos Hermanas (Sevilla) y Aveiro (Portugal). ${ }^{32}$

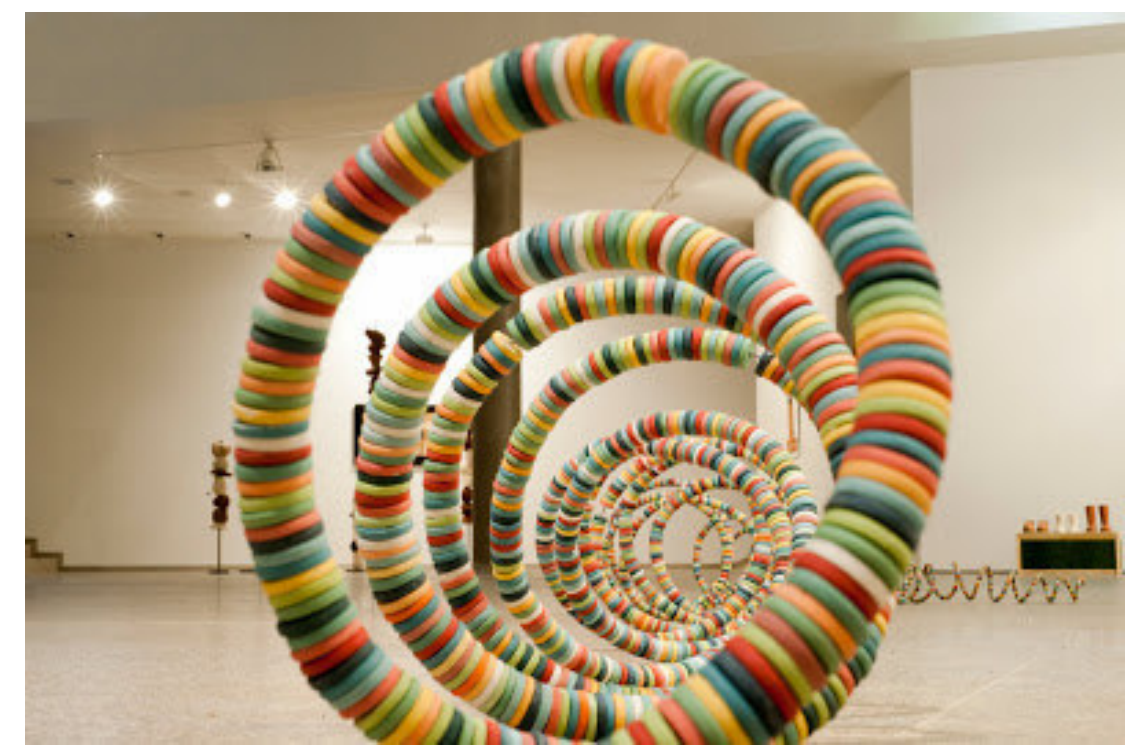

Figura 96: Obra de Juana Fernández.

Mención especial merece MICICE, Muestra Internacional de Cine Cerámico que se celebró del 23 al 26 de junio de 2011 en el Auditorio-Palacio de Congresos de Castellón. El festival contó con la participación de 30 películas de 13 nacionalidades diferentes, que repasaron el uso de la cerámica desde distintos ámbitos: culturales, artísticos, creativos, industriales, arquitectónicos, investigación, etc. Además de las proyecciones de películas hubo otras actividades paralelas: máster class, mesas redondas, actuaciones musicales de percusión con elementos cerámicos, etc. Esta iniciativa contó con el patrocinio de la Consellería de Cultura, Castelló Cultural, el Ayuntamiento de

\footnotetext{
${ }^{32} \mathrm{http} / / /$ albertoandres.blogspot.com.es/2010/10/la-pasta-pontevedra-espana.html
} 
Castellón, el Instituto de Promoción Cerámica (IPC), Ciudad de la Luz y del Instituto Valenciano Audiovisual (IVAC) y estuvo organizada por la productora TV ON Producciones. ${ }^{33}$

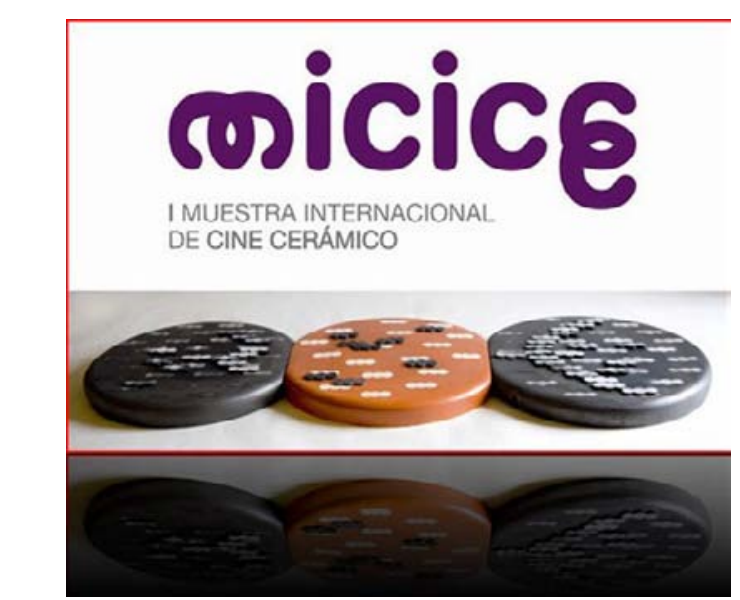

Figura 97: I Muestra Internacional de Cine Cerámico.

"En España hay más libertad para crear que en China", son las declaraciones del artista y profesor, miembro de la Academia Internacional de Cerámica (UNESCO), Lu Bin que con su película Pottery from the ethnic Minorities in Southwest China (China) fue el ganador de la I Edición de la Muestra Internacional de Cine Cerámico. Es la primera película documental que muestra la técnica de alfarería de los ocho grupos étnicos y comunidades que viven en el suroeste de China: Li, Tibetanos, Yi, Dai, Bai, Miao, Shui y Chuanging. No sólo es un documental que estudia, preserva promueve la diversidad y colorido de las culturas étnicas de China, al mismo tiempo ayuda también a la comunidad internacional de cerámica y a los educadores a que comprendan la importancia de la alfarería como tradición milenaria en China. El segundo premio fue para el documental Mar de Fang (España) del mallorquín Luis Ortas. La película relata el proceso creativo del mural cerámico que Miquel Barceló creó para la catedral de Mallorca. La Mención Especial del jurado recayó en Artigas (España), la película realiza un análisis de la vida y obra del ceramista Josep Llorens Artigas, bajo la dirección de su nieto, el artista Isao Llorens Ishikawa. ${ }^{34}$

\footnotetext{
${ }^{33} \mathrm{http}: / /$ www.micice.es

${ }^{34}$ http://www.elmundo.es/elmundo/2011/06/27/castellon/1309171104.html
} 
Antonio González inauguró en Septiembre de 2011, en la Sala Alfajar, de Málaga, su nueva exposición Preta luz. ${ }^{35}$

Durante el otoño-invierno de 2011, en el Celler Mas Foraster de Montblanc, se pudo visitar la exposición L'oli, el pa i el vi de Camil.la Pérez Salvà, presentada por el Taller Cinta Dalmau de Montblanc. ${ }^{36}$

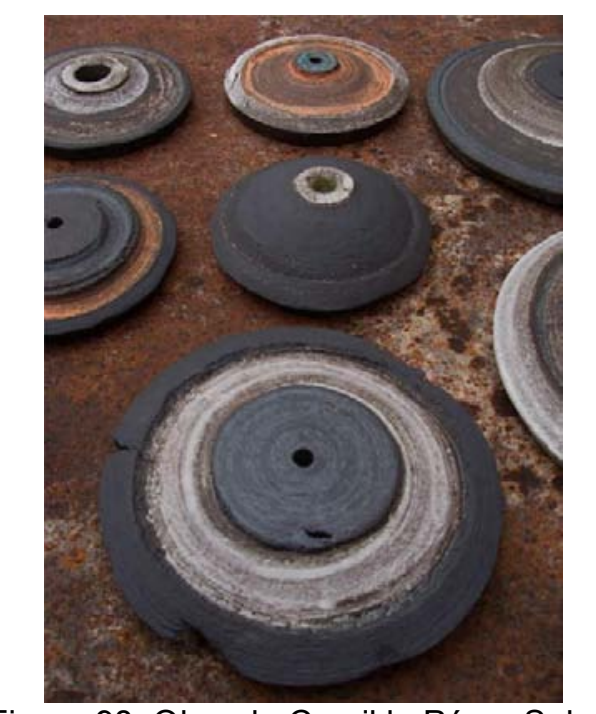

Figura 98: Obra de Camil.la Pérez Salvà.

En octubre de 2011, se celebró en Madrid, en el marco del Centenario de la Escuela de Cerámica, una jornada de cerámica multimedia con Antonio Vivas, durante la cual además de abordar un repaso a la cerámica histórica y contemporánea de España, Japón, China, Estados Unidos, India y Corea, entre otros países, y realizar una inmersión en la cerámica mas emblemática: rakú, hornos noborigama, reducciones, reflejo metálico, decoración y cerámica negra, entre otras y de grandes artistas que han hecho cerámica como Chillida, Barceló o Miró, y grandes ceramistas contemporáneos como Paul Soldner, Artigas, Raku Kichizaemon, Alberto Hernández, Alan Caiger Smith, Takuo Kato, Jim Romberg o Robert Piepenburg, se proyectaron películas de temas cerámicos.

Este mismo mes, la exposición Maestros con Escuela. Enric Mestre, promovida por el Taller-Escuela de Cerámica de Muel mostró en un breve

\footnotetext{
${ }^{35}$ alfajarsala@alfajar.es

${ }^{36}$ http://www.josepforaster.com
} 
recorrido alrededor de cincuenta obras, la influencia de Enric Mestre en lo artístico y/o personal sobre diez autores, discípulos suyos. Esta exposición fue la primera de la serie "Maestros con Escuela", exposiciones en las cuales se refleja la influencia del maestro sobre sus alumnos, los cuales, además son seleccionados por él. La obra del propio Enric Mestre fue uno de los atractivos de la exposición y los alumnos seleccionados por él fueron: Carmen Sanchez, $\mathrm{Su} \mathrm{Pi}$, Xavier Monsalvage, Bibiana Martínez, Concha Regné, Juan Luis Tortosa, Pablo Ruiz, Carmen Ballester, Esperanza Fontecha, Xohan Viqueira, Ana Pastor, Fanny Galera, Carmen Marcos, Antonia Carbonell, Hisae Yanase, Marisa Herrón y Ana Felipe. La exposición fue una nueva forma de mostrar los universos creativos comunes que a menudo comparten alumnos y maestros.

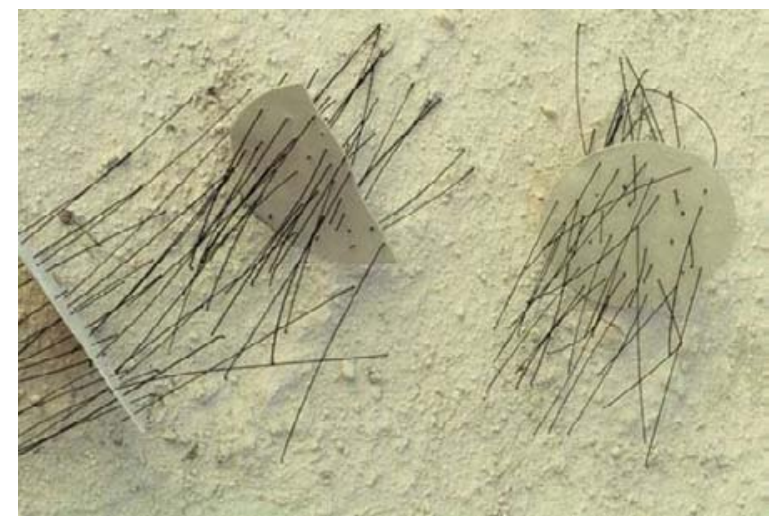

Figura 99: El Carmen de Carmen, instalación de Carmen Ballester.

De noviembre a 2011 a enero de 2012, María Bofill expuso en el Espacio Pepa Jordana de Madrid, una de las pocas galerías que siguen apostando por la cerámica.

Biarritzkitsch es una galería de arte cerámico online, fundada en 2014, que trabaja con artistas cerámicos tanto emergentes como consolidados, acudiendo a ferias de arte, con el propósito de situar la cerámica en el lugar que merece dentro de las artes plásticas ${ }^{37}$.

La Galería Octubre de la Universitat Jaume I de Castellón, acogió durante el mes de marzo de 2015, la exposición colectiva Essencial con obras de los artistas Myriam Jiménez, Mariano Poyatos, Juan Ortiz y Manolo Sales. La exposición, articulada alrededor de la idea de la esencialidad, potencia la

\footnotetext{
${ }^{37}$ http://www.biarritzkitsch.com/sobre-biarritzkitsch/
} 
realidad del objeto cerámico, la íntima relación entre material, técnica y sensibilidad. ${ }^{38}$

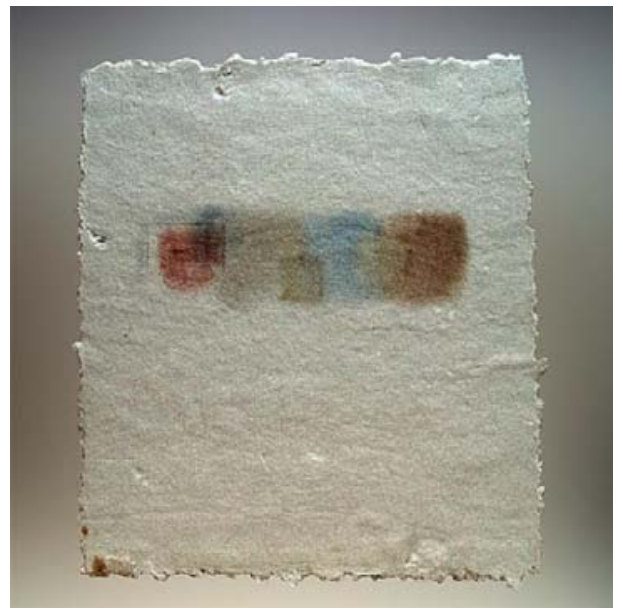

Figura 100: Obra de Manolo Sales.

Sirvan estas breves reseñas expositivas, de certámenes y ferias para reflexionar sobre el estado del arte cerámico contemporáneo. En el discurso pronunciado al recoger el premio MACICE 2011, el ganador Lu Bin aseguró que los ceramistas chinos y los españoles tienen un punto en común y es que ninguno de los dos colectivos puede vivir de sus creaciones cerámicas, salvo excepciones. "Ni los ceramistas de España ni los de China, pueden vivir de su arte" aunque, según apuntó el artista, existe una importante diferencia y es que en España hay más libertad para crear que en el continente asiático" "Creo que lo importante son las sensaciones, la cerámica es un medio que sirve para transmitir mi visión del mundo. Es un elemento de comunicación más". ${ }^{39}$

En la actualidad existe gran número de artistas con multitud de lenguajes artísticos que utilizan la cerámica como medio de expresión. La intención de las obras ha ido cambiando y evolucionando con el paso de los años, incorporando nuevos conceptos al alejarse del concepto inicial de la alfarería. La cerámica contemporánea evoluciona con la humanidad, con las nuevas tecnologías e inquietudes artísticas de quien la trabaja, una nueva era en la historia de la cerámica, un recuerdo constante y agradecimiento a todas las civilizaciones y edades del hombre que hicieron de la cerámica aquello que es hoy en día.

\footnotetext{
${ }^{38} \mathrm{http} / / /$ ujiapps.uji.es/com/noticies/2015/03/1q/exposicio-essencial

${ }^{39} \mathrm{http}: / /$ www.elmundo.es/elmundo/2011/06/27/castellon/1309171104.htm
} 
Además de la rica tradición ceramista de la Comunidad Valenciana, hay que empezar a tener en cuenta las contribuciones específicas de una serie de ceramistas contemporáneos que, desde perspectivas y facturas bien diferenciadas, han planteado nuevas formas expresivas y temas variados a la cerámica artística. Nos estamos refiriendo a artistas como Arcadio Blasco, Enrique Mestre y Manolol Safont. ${ }^{40}$

Excepcional análisis sobre la realidad actual del mundo cerámico, es la que realiza Arcadio Blasco, en el texto que escribió para el catálogo de la exposición La Pasta de $2011^{41}$.

"POSIBLEMENTE, en los últimos tiempos, se está hablando de cerámica más que nunca. Aparecen revistas, exposiciones, catálogos, ángulos insólitos, visiones originales en torno a la nueva aportación de los ceramistas. Todo esto esta muy bien, dado que significa que algo está vivo y no es tan sólo una referencia al objeto utilitario, en la ornamentación, la arqueología ... Que ya son muchos los que a la cerámica le dedican sus cavilaciones; felizmente y de manera afortunada con vocación apasionada que a la larga serán buenos los resultados.

Desde siempre ha sido reconocido el hecho de que el nivel de los pintores y escultores españoles es elevado. Y lo sigue siendo.

Nos ha tocado asistir a los inicios de este nuevo concepto de la cerámica. La cerámica como técnica $\mathrm{AL}$ SERVICIO DEL CREADOR PLÁSTICO, más allá del recipiente utilitario uno ornamental, de la vasija exquisito, de la textura matérica insólita, la cerámica como la transformación de los materiales por medio del fuego en el exclusivo servicio de la creación plástica.

Se va tejiendo el tejido y se acerca el día en que la cerámica sea una expresión plástica capaz como ninguna otra, de todas las posibilidades que puede dar esta transformación de los materiales la forma y el color en el espacio, con la espontaneidad de la pintura, sin su ficción, la rotundidad de la escultura más el concepto espacial de la arquitectura, el vacío. Y con la magia añadida del fuego dominante.

Os deseo lo mejor para un futuro brillante."

Arcadi Blasco.

\footnotetext{
${ }^{40}$ http://elpais.com/diario/1979/04/19/cultura/293320808_850215.html

${ }^{41}$ Catálogo exposición itinerante La Pasta 2011.
} 


\section{2.- LA ETAPA DE FIGURACIÓN EN LA OBRA DE MANOLO SAFONT}

Hay artistas que utilizan el material cerámico para crear objetos cuya finalidad no es el utilitarismo, sino su carácter artístico. Dentro de esta vertiente creativa destaca la obra de Safont. En sus inicios como trabajador cerámico, al igual que otros muchos artesanos, realizó obras sobre soportes tradicionales relacionados con la cerámica artística de forma, sobre jarrones y platos, de las cuales se conservan pocos ejemplares en la actualidad. Tan sólo hemos podido localizar unos platos cerámicos con unas escenas de caza de estilo británico. Estos platos formaban parte de una serie de 7 u 8 obras, de la cual Safont regaló dos, en 1952, a una pareja de recién casados de Onda. ${ }^{42}$

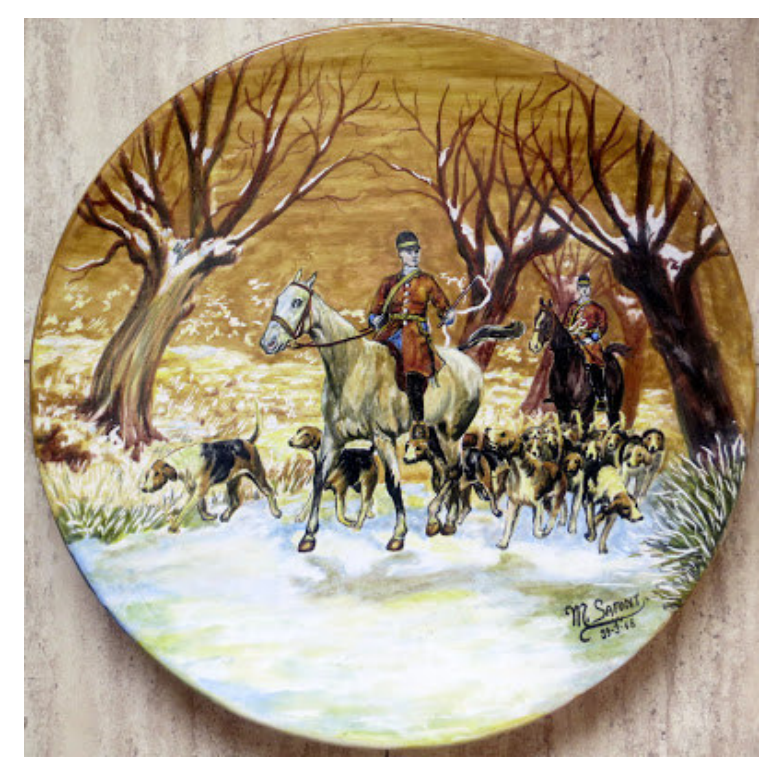

Figura 101: Sin Título. Safont. Obra cat. n³.1

También realizó diversas obras sobre soporte plano, azulejos, material abundante y fácil de conseguir para Safont, ya que la localidad de Onda es uno de los centros más importantes españoles de producción azulejera.

A pesar de su formación autodidacta su conocimiento cerámico fue amplísimo, debido a su continuo estudio teórico y a su práctica durante sus años como trabajador en diversas fábricas de azulejos y talleres de cerámica artística.

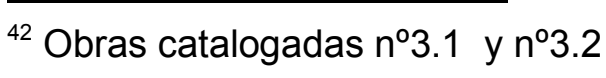


"Treballava en una fàbrica i per afició pintava en tornar a casa. No tinc vergonya de dir-ho: pintaba estampetes. Les coses que un aficionat pinta perquè en la seua desinformació creu que eixe és el camí o que pot ser el camí....Pero no me conformava amb el que feia. En realitat tractava de pintar d'una manera més bèstia, més lliure, presentant unes superficies més violentes, amb relleu, amb arrugues. Tot eixe camí el feia sol, sense guies ni mestres. No tenía cap títol. M'havia format tot sol. Aixó si, comprava molts llibres i procurava llegir molt. Jo he anat seguint mitjançant els llibres i les revistes el que ha estat la línia de l'art modern". ${ }^{43}$

Al no tener un horno propio en el cual poder cocer sus obras, Safont lo hacía en diferentes empresas azulejeras de Onda, adaptándose al tipo de cocción estandarizado utilizado por la industria. ${ }^{44}$ Lo habitual era que hablara con los encargados de las fábricas que, aprovechando huecos libres en los carros de azulejos, le permitían cocer sus piezas, sin cobrarle nada. Safont, agradecido por ello, les regalaba de vez en cuando alguna pieza a los encargados de las fábricas o a los responsables de los hornos. Así es como recibió esta pareja de recién casados un par de platos de Safont, ya que el padre de la novia era el encargado de la fábrica cerámica de Nebot, a la que Safont llevaba para cocer algunas de sus obras.

43 Declaraciones de Safont en M. V. "Manolo Safont. La lluita contra el foc", Generalitat, segona quinzena, desembre 1980, pág. 29. "Trabajaba en una fábrica y por afición pintaba al volver a casa. No me avergüenzo de decirlo: pintaba estampitas. Las cosas que un aficionado pina porque en su desinformación cree que ese es el camino, o que puede ser el camino...Pero no me conformaba con lo que hacía. En realidad trataba de pintar de una forma más bestial, más libre, presentando unas superficies más violentas, con relieve y arrugas. Todo ese camino lo hacía a solas, sin guías ni maestros. No tenía ninguna titulación. Me había formado solo. Eso sí, compraba muchos libros y procuraba leer mucho. Yo he ido siguiendo mediante los libros y las revistas lo que ha sido la línea del arte moderno".

44 Soler Ferrer, María Paz / Pérez CAmps, Josep. Historia de la cerámica valenciana, tomo IV, Vicent García Editores. Valencia, 1992, págs. 273-275. 


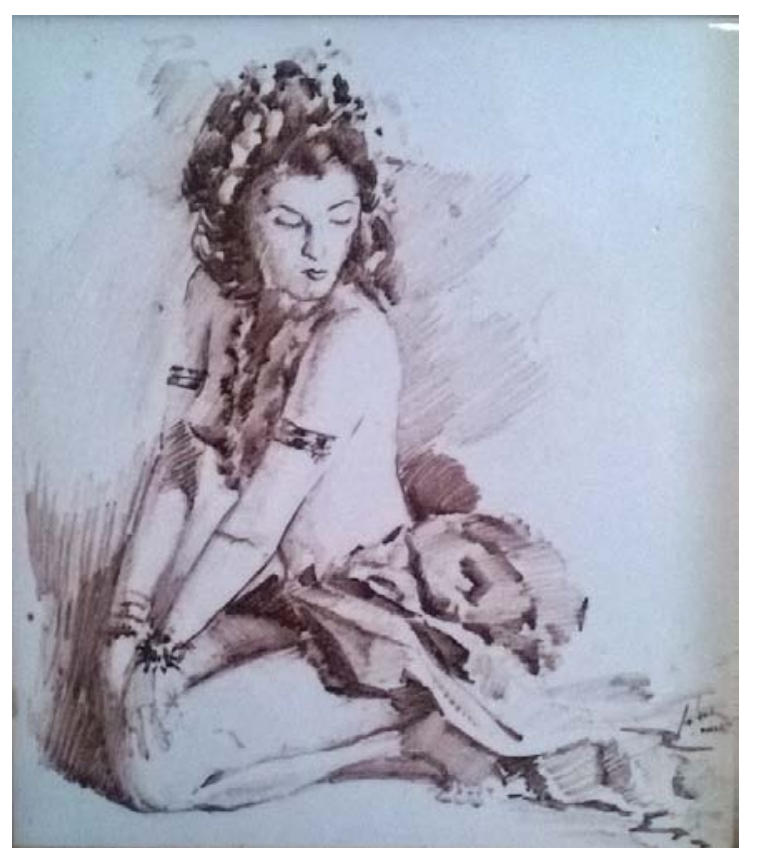

Figura 102: Sin Título. Safont. Obra cat. n³3.9

La depurada técnica de Safont como pintor sobre azulejos, hace que sus obras de esta etapa parezcan pintadas con técnicas tradicionales de la pintura, como el óleo o la acuarela. Utilizaba la pintura cerámica imitando los estilos pictóricos de otras artes.

En esta etapa, desde finales de la década de 1940 hasta mediados de la década de 1950, realiza obras de corte clásico, con motivos tradicionales de paisajes y escenas de género, estampas decorativas, bailarinas, pájaros, santos y todas aquellas piezas que le encargaban los clientes, como el panel de azulejos de la fachada de la Iglesia de Nuestra Señora de la Asunción de Sueras (Castellón), los paneles de azulejos de a capilla de la Comunión de la Iglesia Parroquial de Nuestra Sra. de la Asunción de Onda (Castellón), el panel exterior de la Iglesia de San Juan Bautista de Tales (Castellón) y se presenta a diferentes certámenes y concursos a nivel nacional, pero sus inquietudes artísticas van más allá de este mero trabajo artesanal.

La amistad y buena relación de Safont con diferentes encargados y dueños de fábricas de Onda hizo que no tan sólo pudiera cocer sus obras, sino que como ocurría con Vicente Olucha Marco, propietario de la fábrica "El Cerámic", dedicada a la fabricación de colores y esmaltes cerámicos, estos encargados y dueños, le regalaran a menudo a Safont los colores cerámicos e incluso actuaran como marchantes o representantes de su producción. Safont 
les ofrecía sus obras y, bien adquirían algunas de ellas o bien le ponían en contacto con algún cliente que podía estar interesado en ellas. Así fue como Elías Olucha, hijo de Vicente Olucha Marco, puso en contacto a Safont con un cliente de su fábrica, que acabó adquiriendo una obra suya, un retrato de Ernesto Ché Guevara, que actualmente forma parte de una colección privada en Sudáfrica. ${ }^{45}$

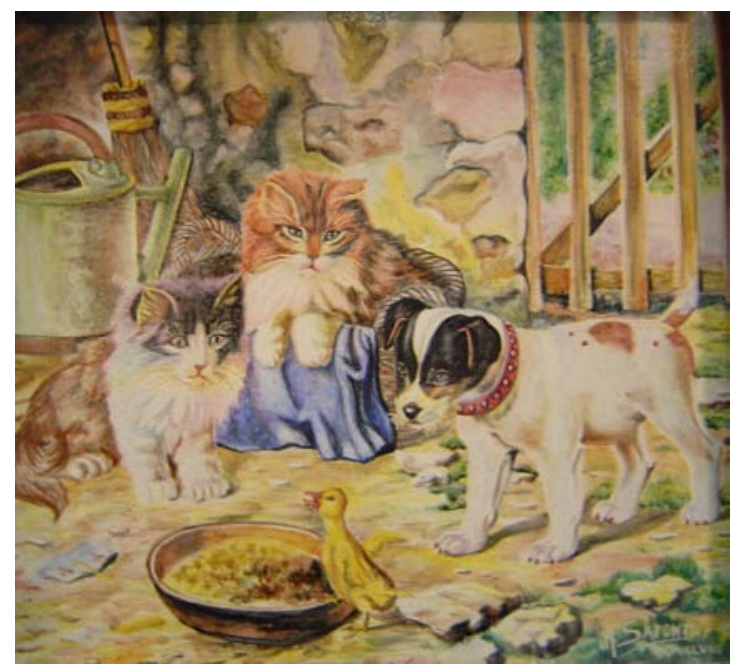

Figura 103: Sin Título. Safont. Obra cat. $n^{\circ} 3.3$

Al abandonar el trabajo en las fábricas cerámicas de Onda, tanto de azulejos como de formas artísticas, Safont inicia un camino sin retorno, un camino en el cual dejará tras de si al ceramista artesano para convertirse en ceramista artista. Al oficio adquirido tras tantos años de trabajo se le añade el afán de experimentación.

Al final de los años de su etapa artística realista, y como fruto de su constante investigación, en las obras de Safont predomina una técnica basada en las cinco calidades, conseguidas mediante la utilización de cinco temperaturas diferentes en una sola cocción. La utilización de esta técnica marca su progresivo abandono de la figuración para adentrarse en el universo de la abstracción plástica.

${ }^{45}$ Obra catalogada $n^{\circ} 3.22$ 


\section{3.- LA ETAPA DE TRANSICIÓN EN LA OBRA DE MANOLO SAFONT}

A finales de la década de 1950, a Safont cada vez le interesa menos reproducir imágenes religiosas o de género, pero debe seguir haciéndolo: "seguir una vocació i, alhora, haver-se de guanyar el menjar requereix molts sacrificis". ${ }^{46}$ Safont quería y necesitaba dedicarse a crear obras diferentes, pero las necesidades económicas le obligaban a seguir pintando escenas costumbristas, así que derivaba a un pintor ceramista que contrató como ayudante los encargos que no encajaban con su línea de trabajo artístico.

El aprendiz copiaba los modelos de Safont e incluso bromeaba sobre el nuevo estilo de Safont, que le rentaba económicamente menos que el dinero que conseguía él con las copias. ${ }^{47}$

"Me vaig adaptar a les condicions de treball que tenia al meu abast. Amb el temps he creat una línia de ceràmica no comercial enmig d'una comarca on tot el que es fa és comercial. La meua lluita ha consistit en no deixar-me assimilar, en no integrar-me. De vegades he tingut ganes d'anar-me'n, perquè no he tingut mai prou mitjans per treballar bé. La meua es la vella lluita contra el foc. Bo, i contra les institucions". ${ }^{48}$

Pero ni se fue, ni abandonó, Safont hizo de esa precariedad de medios su principal instrumento de trabajo, consiguiendo llevar a un primer plano la rústica simplicidad de la arcilla, del barro cocido y refractado.

En 1961, en la inauguración de su primera exposición en Madrid, al ver José Hierro sus obras figurativas trabajadas sobre superficies ricas en textura y

\footnotetext{
46 "Seguir una vocación y, a la vez, tener que ganarse la comida requiere muchos sacrificios"

${ }^{47}$ SeVA I Llinares, Antoni. Fang i pinzells, inédito, 1966.

48 M., V. "Manolo Safont. La lluita contra el foc", Generalitat, segona quinzena, desembre 1980, pág. 29. "Me adapté a las condiciones de trabajo que tenía a mi alcance. Con el tiempo he creado una línea de cerámica no comercial en medio de una comarca donde todo lo que se hace es comercial. Mi lucha ha consistido en no dejarme asimilar, en no integrarme. A veces he tenido ganas de irme, porque no he tenido nunca suficientes medios para trabajar bien. La mía es la vieja lucha contra el fuego. Bueno, y contra las instituciones"
} 
color, le dijo "no se hicieron las tres carabelas para navegar por el Jarama" refiriéndose a que debía ampliar horizontes y buscar nuevas vías de expresión, por la gran fuerza que ya se advertía en el poder expresivo de las superficies de Safont, incitándole hacia la abstracción, pero en esta época, Safont aún se debate entre la abstracción y la figuración, utilizando los dos estilos artísticos para expresar todo aquello que le inquieta. ${ }^{49}$

En esta etapa de transición, durante la década de 1960 y 1970, utiliza el recurso de la figuración para adentrarse en la pintura social, en un principio con temas referidos al entorno laboral que conoce y rodea a Safont, los trabajadores de las fábricas de azulejos, obras de gran valor expresionista en las que representa a los trabajadores trabajando en las fábricas, con las prensas hidráulicas. La mayor parte de esta producción fue vendida y exportada fuera de España.

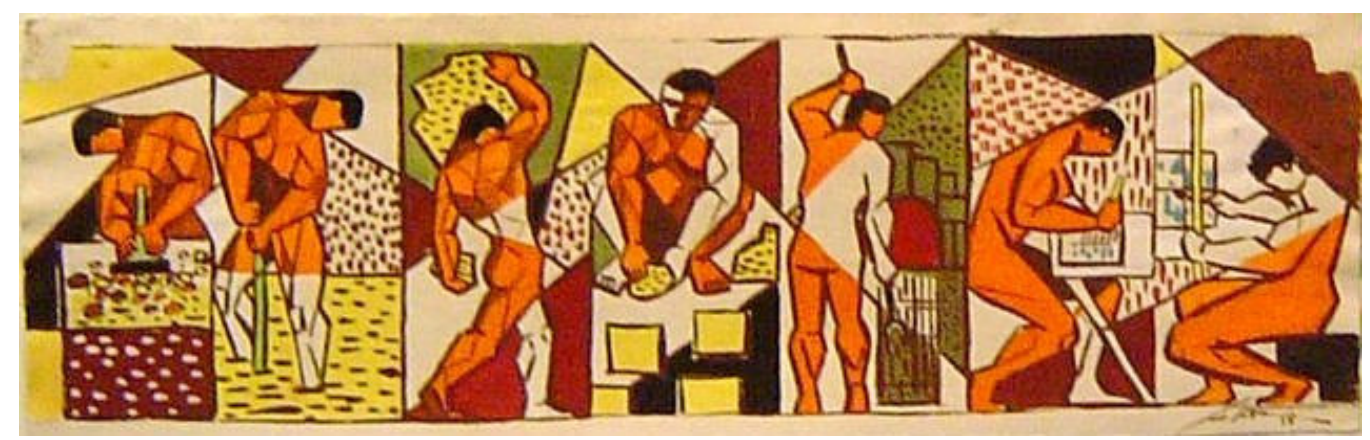

Figura 104: Sin Título. Safont. Obra cat. $n^{\circ} 2.5$

Safont es un artista comprometido con su tiempo y con su historia, con una conciencia de obrero proletario adquirida en su etapa como trabajador de las fábricas de azulejos de Onda "Desde un principio me he sentido obrero, he estado junto al obrero". ${ }^{50}$

Entre los años 1958 y 1960, Safont recibe diversos encargos de dueños de las fábricas azulejeras de Onda para realizar obras con las que decorar sus despachos. Predominan las obras del género de naturaleza muerta y paisajes, realizadas con un estilo que recuerda el estilo cubista, con predominio de

\footnotetext{
49 JIMÉNEZ DE HARO, Jaime. Catálogo de la obra expuesta en la inauguración de la Casa de Cultura de La Pobla Tornesa, Castellón, 1987.

${ }^{50}$ LÓPEZ, María José. "El ceramista Manolo Safont crea con sus manos universos de color y luz". Castellón Diario, 19 agosto 1991
} 
líneas geométricas, cuyas formas recuerdan el estilo pictórico de algunas obras de Georges Braque y Henry Matisse.

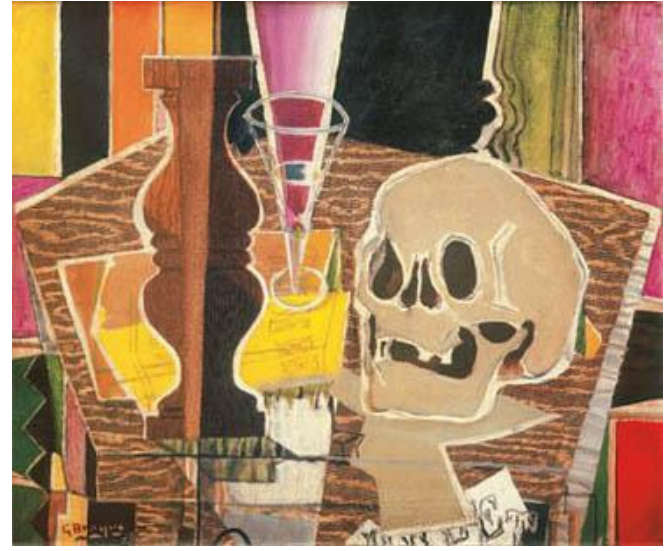

Figura 105

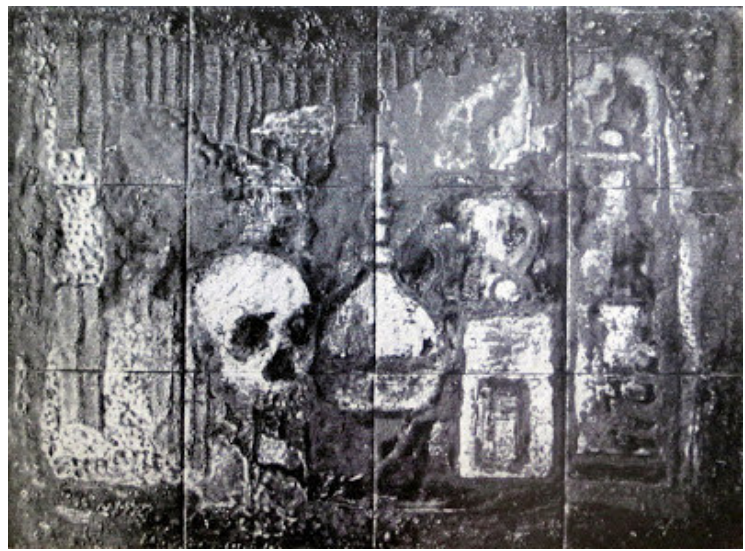

Figura 106

Figura 105: Balaustres y cráneo, Georges Braque, 1938.

Figura 106: Sin Título, Manolo Safont, anterior a 1962. Obra cat. n4.8

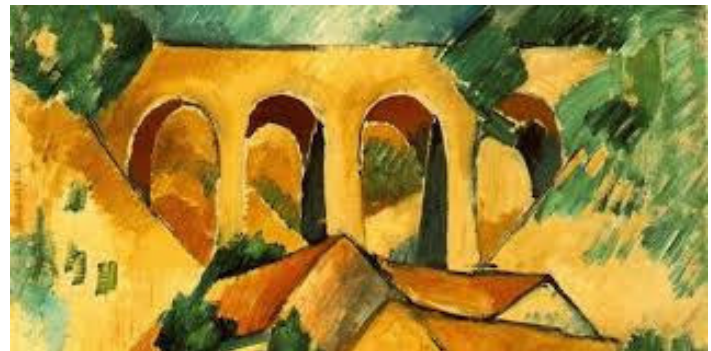

Figura 107

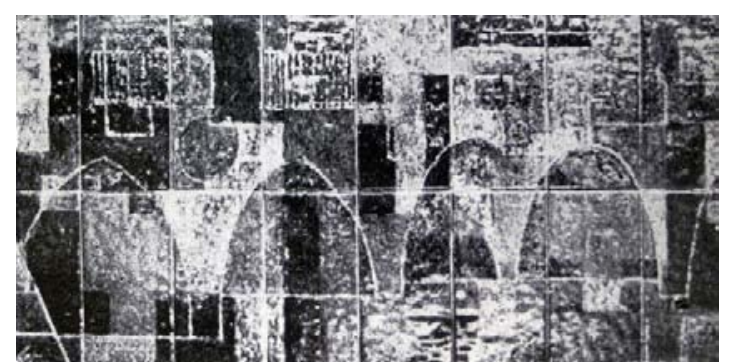

Figura 108

Figura 107: Viaducto en L'Estaque, Georges Braque, 1908.

Figura 108: Sin Título, Manolo Safont, anterior a 1962. Obra cat. $n^{\circ} 4.10$

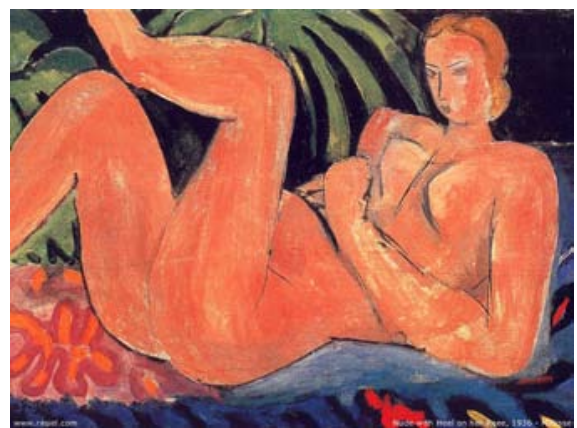

Figura 109

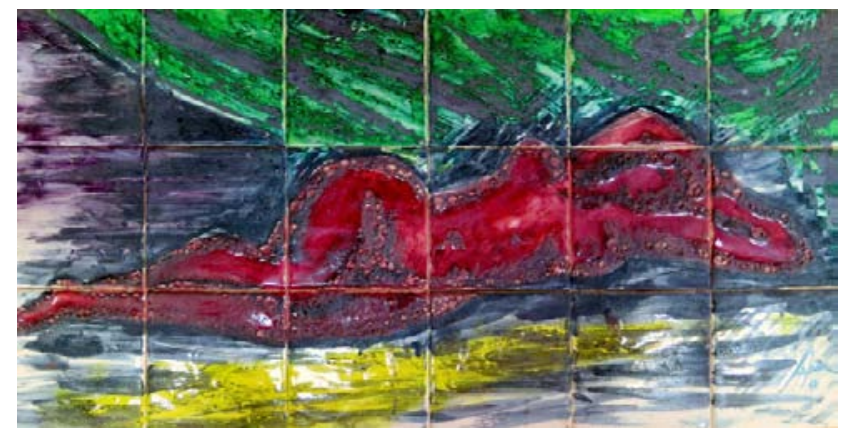

Figura 110

Figura 109: Desnudo yaciente, Henry Matisse, 1936.

Figura 110: Sin Título, Manolo Safont 1959. Obra cat. $n^{\circ} 4.3$

Durante la etapa de transición, Safont también utiliza la figuración como medio de denuncia social. Pese a primar la materia como componente principal en sus obras, recurre a la utilización de la figuración para crear composiciones que denuncian la comprometida situación social y política que se vive en la 
España de las décadas de 1960 y la primera mitad de la década de 1970. Las obras de Safont parece que se resisten a abandonar los referentes tradicionales de las obras cerámicas. Sin abandonar la materia, será esta figuración la que ayude a percibir los sentimientos de opresión, violencia, miedo y rebeldía, que Safont nos muestra en sus obras, y que trasmiten gran fuerza y dramatismo.

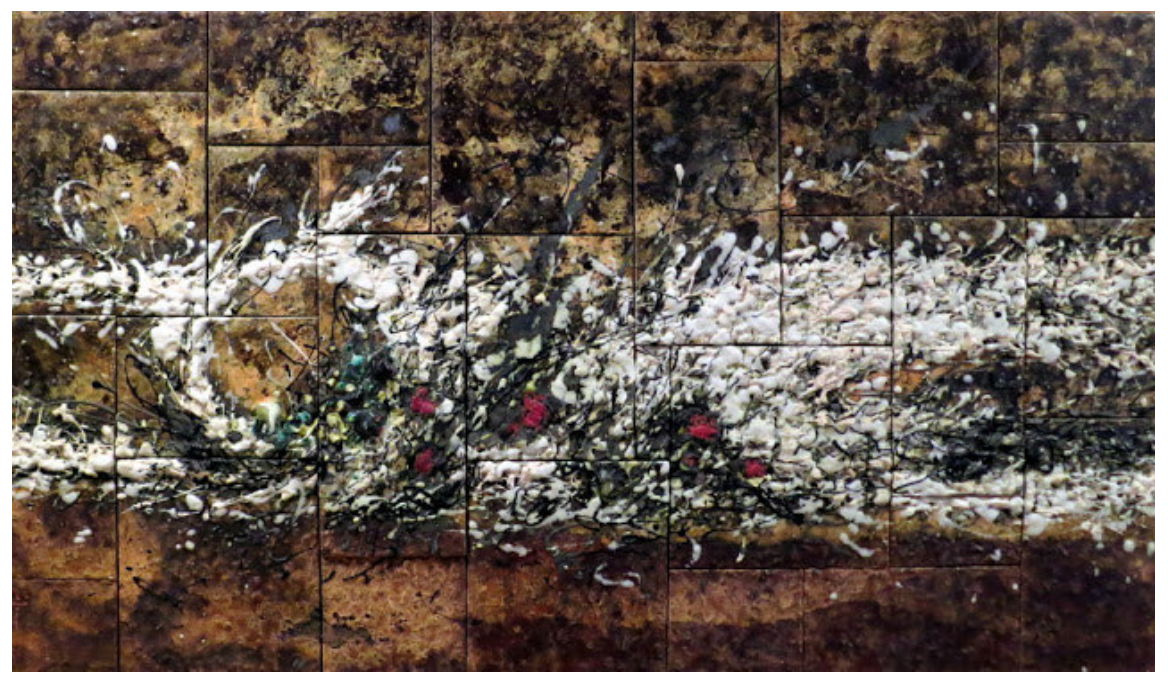

Figura 111: Sin Título. Safont. Obra cat. $n^{\circ} 4.23$

Las últimas ejecuciones de la dictadura franquista, en octubre de 1975, provocan un estremecimiento en Safont que inmediatamente toma forma a través de sus obras, empieza a plasmar figuras de fusilados, alambradas, sangre, manos cortadas... a través de figuras desgarradas, sombras, claroscuros y materia rota. Fondos oscuros y colores que estallan como un grito de denuncia, fruto de un fuerte compromiso social, para mostrar las cárceles y el exilio a través de una pintura violenta. Safont utilizó su arte, al igual que otros muchos artistas españoles, para denunciar a través de los medios que tenía a su alcance y que era su vehículo de expresión, la opresión del poder estatal.

"Manolo Safont, tot fent seu el missatge de Celaya, va maleir l'art concebut com a luxe cultural i va aportar una dura figuración al despertar de la conciencia artística" ${ }^{51}$

\footnotetext{
51 TORRENT, Rosalía. "Manolo Safont". Catálogo Exposición Saleta Municipal d'Onda, Regiduria de Cultura, Ajuntament d'Onda, del 24 al 31 octubre, 1999. "Manolo hace suyo el mensaje de Celaya, maldice el arte concebido como un lujo cultural y aporta una dura figuración al despertar de la conciencia artística".
} 


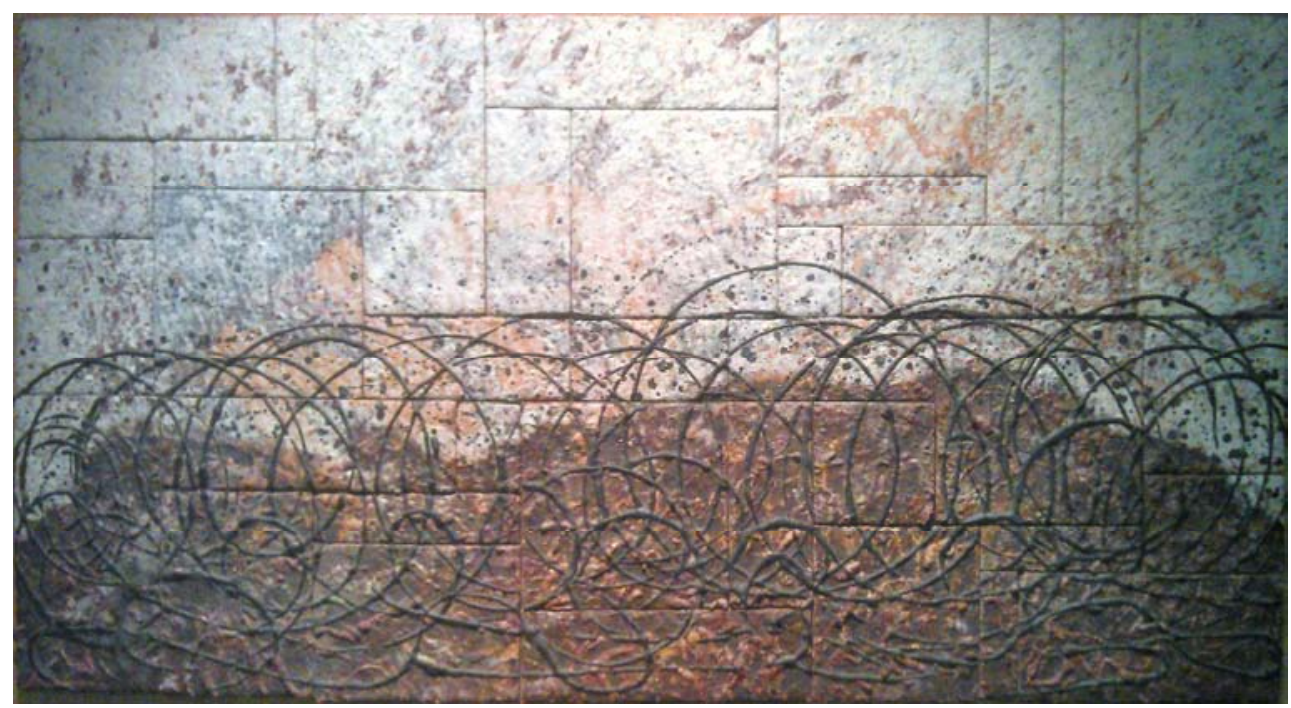

Figura 112: Sin Título. Safont. Obra cat. $\mathrm{n}^{\circ} 4.21$

Safont crea obras para ser expuestas y admiradas, no utilizadas. Las piezas de Safont, son cuadros o paneles, pensados para ser anclados a una pared, huyendo de las piezas escultóricas de bulto redondo, influido por el ambiente que le rodea en Onda, cuna productora de azulejos, y por sus inicios laborales y artísticos. Herederas del pasado de Safont, sus obras tienen dos dimensiones, aunque funcionan como picto-esculturas o como pinturas cerámicas, con un estilo artístico que está íntimamente relacionado con el informalismo, a partir de una propuesta a mitad de camino entre la figuración y la abstracción en la que, a través del tiempo, Safont ha ido plasmando no sólo su preocupación por el hombre, sino por el propio lenguaje de la cerámica. De esta manera, en la obra de esta etapa de Safont aparecen una serie de elementos simbólicos que denotan su preocupación por hechos sociales y culturales de su país. Asimismo aborda los aspectos formales de la obra desde una textura rugosa con colores muy compactos y variados. Son cerámicas cocidas en horno industrial a más de mil grados de temperatura y realizadas sobre lozas individualizadas de medio formato, dípticos y trípticos que, en ocasiones, trocea, rompiendo la simetría tradicional de la cerámica artística plana. ${ }^{52}$

En este período de experimentación continuada con la materia, Safont se transforma en un auténtico alquimista, empleando diferentes materiales,

${ }^{52}$ http://elpais.com/diario/1979/04/19/cultura/293320808_850215.html 
arcillas, tierras y pigmentos, creando él mismo los colores compuestos que utiliza, buscando nuevos matices cromáticos en una dura y constante labor artesanal, hasta lograr en sus obras la magia de poder realizar una pieza con una única cocción. Quizás no resulte relevante este dato si no comprendemos bien la complejidad de la técnica cerámica. Cada color cerámico funde a una temperatura diferente, y cuantos más colores tiene una obra, más difícil es controlar el proceso de cocción para lograr que todos fundan y que ninguno se queme. Safont logró este perfecto equilibrio entre los colores, y el dominio de esta técnica sobre la materia fue lo que le permitió ampliar la paleta cromática de sus obras, pese a realizar una única cocción de las piezas, en hornos industriales, con temperaturas de $1000^{\circ}$ centígrados.

Pero no fue tan sólo el dominio del color, Safont domina la materia, logra crear volumen a través de los pigmentos cerámicos. Si trabajamos aplicando colores sobre una pieza con volumen o texturizada, es lógico que presente dichos volúmenes tras el proceso de cocción. El arte de Safont respecto a este proceso, radica en que pese a trabajar sobre superficies planas, logra conferir con los colores, pigmentos y óxidos, un volumen a sus obras que las hace únicas, logra fundir el color sin perder el volumen, creando cada vez obras más texturizadas, más matéricas. Un relieve conseguido aplicando con el pincel diferentes capas colores y óxidos, a través de una técnica aplicada con gran maestría. $^{53}$

Cuando las piezas salen de sus manos, no parecen más que barro sucio, pero hay tres, cuatro o cinco capas de color, que tras pasar por el horno de cocción, cobran vida transformándose.

La experiencia de manipular la arcilla, cocerla y crear cerámica le cautivó, por sus posibilidades de tratar el material cerámico como medio de expresión artístico. La cerámica artística comparte características con la pintura y la escultura; todas las disciplinas requieren de una fase preliminar en la cual se realizan bocetos, ya sean sobre un papel, un pedazo de barro o simplemente un boceto mental, que darán forma y vida a la materia inerte. El proceso comprende una investigación sobre el trabajo a desarrollar, bocetos

53 SÁNCHEZ PACHECO, Trinidad. "Safont". Catálogo exposición Museu de Ceràmica, Palau Nacional, Barcelona, 1982. 
previos, recopilación de información y estudio de la aplicación o uso de la obra cerámica, generando un diseño que en líneas y tonalidades capte la esencia de su función y un entorno en armonía. El diseño para Safont será único y original para cualquier encargo, cobrando así valor como pieza artística única cerámica de autor.

Es el dominio de la técnica, lo que le otorga seguridad a Safont, una convicción que se manifiesta de forma clara en sus obras, que progresivamente realiza con pinceladas más sueltas y más fluidas. Pero esa certeza y el haber logrado el objetivo perseguido, no son suficientes. Una vez ha conseguido aquello que buscaba, ese efecto, esa textura, ese nuevo color, etc, las piezas, pierden interés para él. No se recrea en los objetivos alcanzados, inmediatamente busca un nuevo objetivo, nuevos efectos: "la meua lluita com a pintor ceramista és aconseguir noves qualitats, tons i formes en cada cuadro, per arribar a un conjunt de forma, color i matèria". ${ }^{4}$

En sus obras de este período de transición hacia la abstracción, se observa una clara evolución desde los inicios. Al principio de la etapa, predomina el concepto clásico de figuración, evoluciona hacia el geometrismo y posteriormente utiliza la figuración para a través de formas de gran dramatismo denunciar la opresión y la violencia: comienza pintando fusilados que poco a poco irán perdiendo sus formas precisas y perfiles. Safont va abandonando progresivamente el equilibrio de líneas y formas, dando paso a figuras que, diluyéndose como sombras, se transforman en monstruos, son obras de mucha más fuerza y dinamismo, más complejas, creadas con una rica paleta cromática. $^{55}$

A partir de la exposición realizada en 1962 en Madrid, el nombre de Safont comenzó a ser conocido en el panorama artístico nacional, y aún lo hubiera sido más, si hubiera puesto en el aspecto económico y publicitario de su producción tan sólo una mínima parte del interés que ponía en el aspecto

\footnotetext{
${ }^{54}$ SeVA I LlinARES, Antoni. Op. Cit, 1966. "Mi lucha como pintor ceramista es conseguir nuevas calidades, tonos y formas en cada cuadro, para llegar a un conjunto de forma, color y materia"

${ }^{55}$ García Edo, Vicent. Safont Pintura cerámica. Catálogo exposición Sala Goya, Casa de España en París, del 5 al 15 de octubre de 1978.
} 
artístico. Siempre huyó de la publicidad, y cuando las cámaras de televisión fueron a grabar esta exposición de Safont en Madrid, él no se dejó filmar.

"preferesc fer exposicions sense guanyar diners perquè les galeries trenquen la llibertad creadora"56

En 1968, cuando le encargaron el mural cerámico para la Catedral de Babahoyo (Ecuador), sus honorarios fueron tan modestos que, por iniciativa propia, el cliente que le había realizado el encargo, añadió cien mil pesetas al presupuesto. ${ }^{57}$

Pero no tan sólo se pueden vincular o relacionar las influencias de las obras de este periodo de transición de Safont con referentes artísticos universales como George Braque o Henry Matisse, sino también con artistas vinculados al movimiento de arte urbano internacional, como Gérard Zlotykamion. $^{58}$

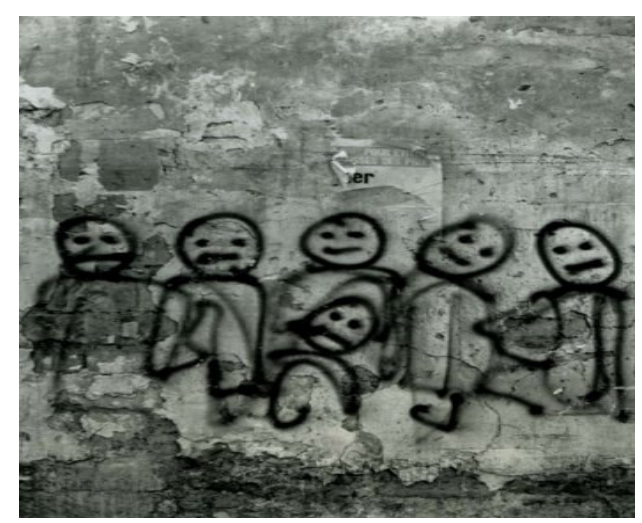

Figura 113

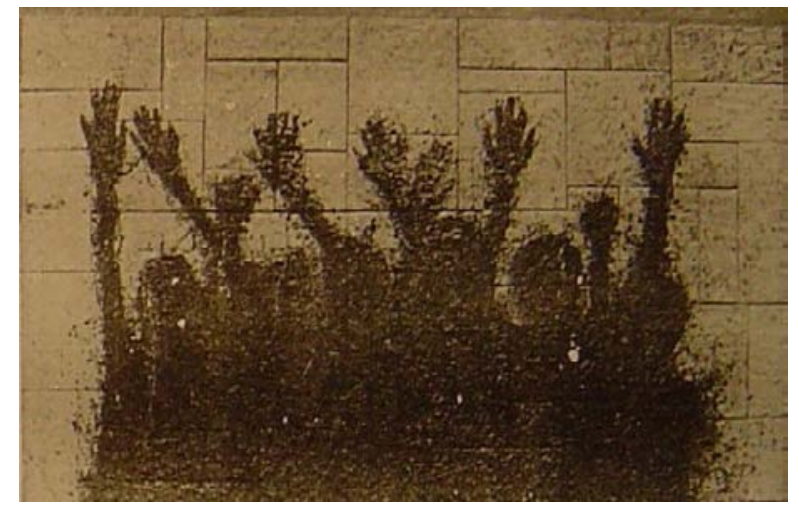

Figura 114

Figura 113: Sin Título, Gérard Zlotykamion, década de 1960.

Figura 114: Sin Título, Safont, anterior a 1972. Obra cat. $n^{\circ} 4.18$

\footnotetext{
${ }^{56}$ AlbalAT, Antoni. "Manolo Safont. La Intifada de fang". El Temps, 1991. "Prefiero hacer exposiciones sin ganar dinero porque las galerías rompen la libertad creadora".

${ }^{57}$ Seva I Llinares, Antoni. Op. Cit, 1966.

58 Gérard Zlotykamion, nacido en Francia en 1940, es considerado uno de los iniciadores del arte urbano en Francia durante la década de 1960 y 1970 . Entre sus intervenciones destacan las obras que representan siluetas fantasmagóricas que evocan las sombras humanas que quedaron impresas en los muros tras la explosión de Hiroshima.
} 


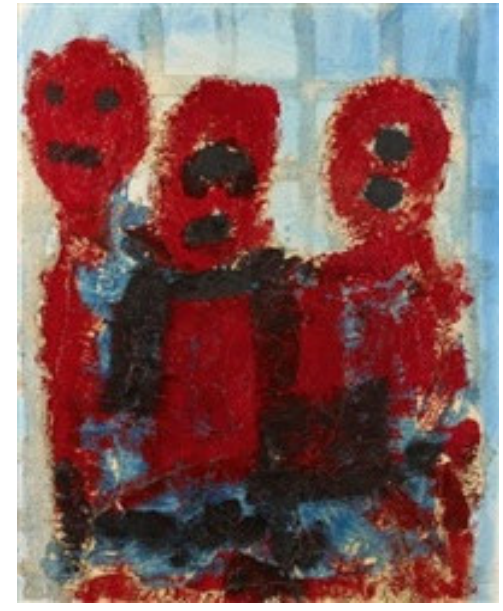

Figura 115

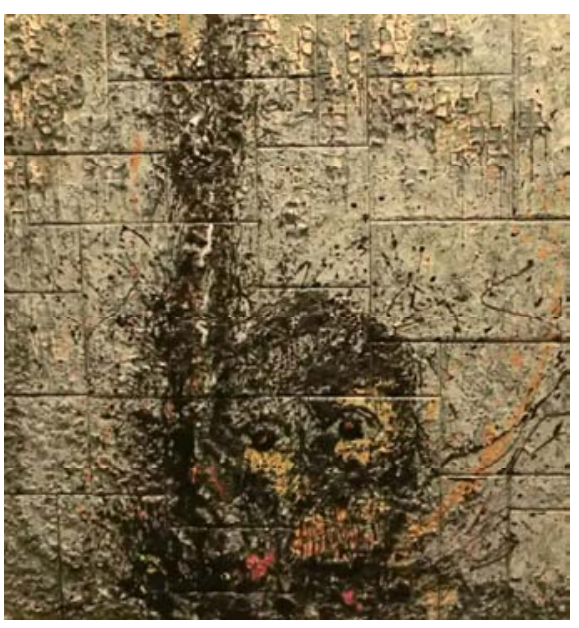

Figura 116

Figura 115: Sin Título, Gérard Zlotykamion, 1965-1970.

Figura 116: Sin Título, Safont, 1976. Obra cat. n4.30

En este momento de su trayectoria artística, Safont ya había abandonado definitivamente la cerámica de artesano para destacar en la cerámica de artista. Se encuentra en plena fase de madurez, donde el dominio de la tierra y el fuego se hacen patentes. En las obras de esta etapa amplía cada vez más la paleta cromática, incorporando verdes, blancos, azules, negros, amarillos y rojos, que utilizados junto a gran cantidad de materia, provocan superficies de diferentes niveles, que aplicados sobre soportes formados por una retícula compuesta por piezas de diferentes tamaños, contribuyen a transmitir una sensación de inestabilidad, acorde con el mensaje social que Safont nos quiere transmitir. ${ }^{59}$

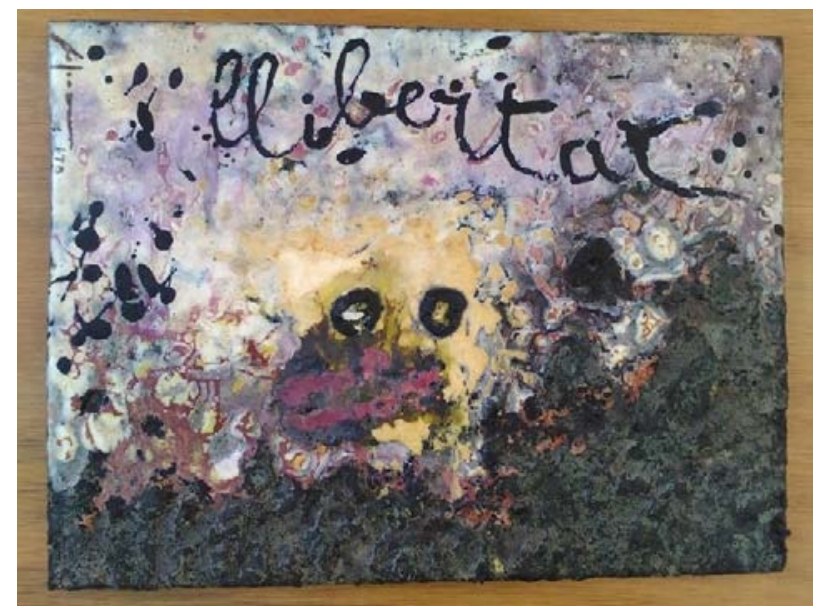

Figura 117: Llibertat, Safont, 1978. Obra cat. $n^{\circ} 4.34$

59 FALOMIR, Carmela. "La pintura cerámica de Manolo Safont". Butlletí d'Estudis Municipals, $2^{\mathrm{a}}$ etapa, n², Ajuntament d'Onda, 2001, pág. 24. 


\section{4.- LA ETAPA DE ABSTRACCIÓN EN LA OBRA DE MANOLO SAFONT}

El inicio de la década de 1980, marca un nuevo cambio evolutivo en la trayectoria artística de Safont. A partir de 1980, la abstracción será el estilo dominante, y casi exclusivo en sus creaciones artísticas de Safont, al desligarse de los condicionamientos de las figuración, sus composiciones reflejan una mayor libertad de expresión. Pese a no contar con el apoyo de las formas reconocibles, a través de la combinación de texturas, volúmenes y colores, las manchas tonales de sus obras siguen comunicándonos esa lucha por vencer la opresión y el sometimiento. Se impone la fuerza matérica en sus obras.

Abandonada definitivamente la figuración, al no necesitarla ya para expresarse, se centra exclusivamente en la materia, la forma y el color que manifiesta a través de nuevas composiciones. El inicio del periodo de abstracción estilística de Safont está predominado en sus orígenes por la exaltación y utilización máxima de la materia, experimentando con diferentes tipos de arcillas y, aún apoyada en algunas creaciones por la forma, con la utilización de una reducida paleta de colores en la que predominan los ocres, negros y tierras, gama cromática que se va ampliando conforme evoluciona su estilo y se sumerge por completo en la abstracción, creando composiciones que van adquiriendo progresivamente nuevos tonos con colores más vivos y luminosos que incorporará a la paleta inicial.

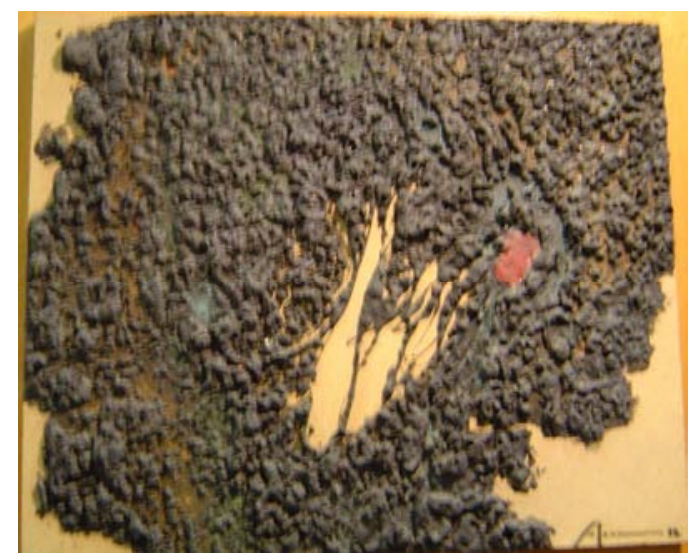

Figura 118: Sin Título, 1982. Safont. Obra cat. $n^{\circ} 5.29$ 
Safont siguió la corriente artística informalista con la continua experimentación tanto en los materiales empleados como en el control del fuego necesario para cocer y crear sus obras. ${ }^{60}$

"Les conseqüencies mes extremes de l'informalisme prenen cos a l'obra del curiós ceramista Manuel Safont, (...) La seua especialitat és la textura, amb una insòlita efervescència de la materia i dels colors". ${ }^{61}$

Las obras de esta etapa muestran una composición equilibrada, que se configura poco a poco, cada elemento, cada mancha de color, es analizada y estudiada para lograr el equilibrio en medio de un caos organizado, en el que cada color, cada línea y trazo, encuentran su lugar para contribuir a mostrar un conjunto armónico.

En las primeras obras de esta etapa, su pintura sigue siendo pintura de denuncia, que se manifiesta mediante una tensión interna tanto en el gesto como en la acción, con manchas oscuras pero al final de la década de 1980, entre los años 1987 y 1988, coincidiendo con la exposición realizada en La Pobla Tornesa (Castellón), las sombras se desvanecen y las masas oscuras dan paso a piezas con una nueva luz y color, obras más equilibradas que denotan también una paz interior en su autor, Safont busca el hacer arte por el arte, con ricas texturas y variada policromía.

"He estat dins dels corrents més diversos de l'art actual quasi sense adonar-me'n. He tingut una llarga evolució interna. Primer traballava per encarrec i feia cuadres. Després tenia altra clientela. Me demanaven coses per a decoració i feia moltes peces repetides. Els primers panels eren figuratius. Per a mi era més còmode. Me digueren que la part figurativa no acabava mai de quallar i vaig començar a expressar-me més lliurement. Sense cap dubte sota l'influencia de l'art abstracte" 62

${ }^{60}$ RAMBLA, Wenceslao / TORRENT, Rosalía. "El arte del siglo XX" en Historia de Castellón. Levante de Castellón. Editorial Prensa Valenciana, S.A., Castellón, 1992, pág. 668.

${ }^{61} \mathrm{CIRICl}$, Alexandre / MANENT, Ramón. Ceràmica catalana. Ed. Destino, Barcelona, 1977, pág. 462. "Las consecuencias mas extremas del informalismo toman forma en la obra del curioso ceramista Manuel Safont, (...) Su especialidad es la textura, con una insólita efervescencia de la materia y los colores".

${ }^{62}$ M., V. Op. Cit, 1980, pág. 29. "He estado dentro de las corrientes más diversas del arte actual casi sin darme cuenta. He tenido una larga evolución interna. Primero 
Por fin pinta libre. Sin someterse a las reglas consumistas del mercado ni de las galerías de arte. La imaginación y la fantasía son imprescindibles para entender su obra. Recupera con las obras abstractas la espontaneidad y sencillez de los antiguos talleres artesanales, los tiempos de cocción, la alquimia de las mezclas y proporciones, con el fin de seguir creando, experimenta con temperaturas, formas y materias en un constante proceso evolutivo. Cada obra parte de lo conseguido en la obra anterior, no se acomoda. No le interesa lo ya conseguido.

Safont, que es un artista con una dilatada experiencia en el campo de la figuración, escoge la abstracción de un modo consciente y consecuente, tanto por la posibilidad de establecer un lenguaje más universal, como por la necesidad de expresarse en unos términos nuevos, polémicos, internacionales, inusuales, incluso proscritos en una época de falta de libertades.

Abandonada la figuración y despojadas sus obras de ataduras socioculturales, Safont explota su faceta más creativa a través de su pasión por la materia, por las tierras, pigmentos, barnices que hace que sus trabajos resulten vistosos, de gran viveza en sus formas y combinaciones de texturas y colores, no dejando indiferentes a quienes contemplan su obra, provocando el interés mediante formas curiosas y activando así la imaginación personal de cada uno. La experimentación constante en los materiales y técnicas cerámicas como metodología de investigación resulta necesaria para la evolución del ceramista, arrojando nuevas vías de creación. Conociendo la ilusión con la que Safont realizaba y esperaba los resultados de las pruebas de nuevos colores, entendemos que este proceso no era un mero trámite, sino que era parte del proceso creador que le posibilitaba la creación de nuevas obras.

trabajaba por encargo y hacía cuadros. Después tenía otra clientela. Me pedían cosas para decoración y hacía muchas piezas repetidas. Los primeros paneles eran figurativos. Para mí era más cómodo. Me dijeron que la parte figurativa no acababa de cuajar nunca y comencé a expresarme más libremente. Sin lugar a dudas bajo la influencia del arte abstracto". 


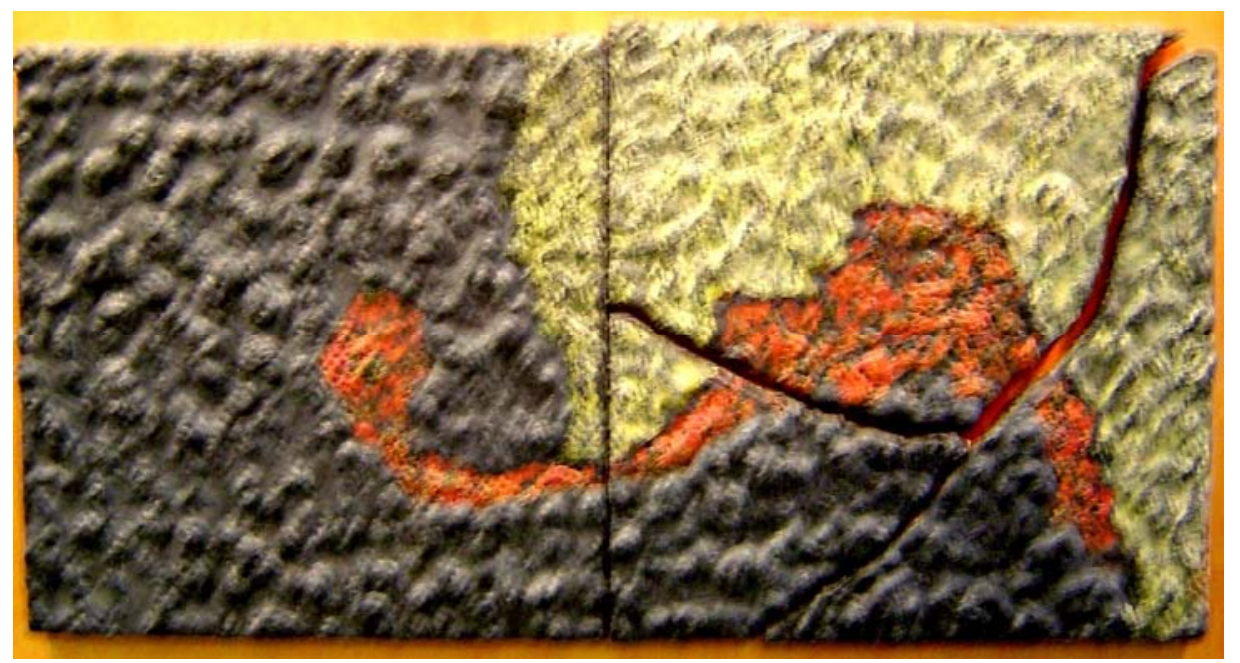

Figura 119: Sin Título, Safont. Obra cat. n5.20

El oficio cerámico queda patente en las obras de Safont. Pese a su manifestación abstracta, el casamiento de las diferentes placas que componen la obra mantienen una unidad completa, las imágenes no quedan rotas 0 fragmentadas por las aristas de las piezas, las pinceladas y materias se extienden sobre el puzzle de placas como si de una sola se tratara.

Como características generales de su producción cerámica de estos años podemos destacar las texturas, en las que se aprecian todo tipo de incisiones y huellas aparentemente anárquicas: círculos, ondulaciones, rectángulos, espirales, caminos sin destino, pero combinados con un rigor constructivo que ordena los elementos, y un rico colorido, con rojos y naranjas y las gamas de azules y verdes, con los que crea un mundo de fantasía con una poética totalmente personal. Unas obras que podemos clasificar dentro del expresionismo abstracto, con derivaciones de signo y gesto, visible en el fluir de la mano.

Tal y como analiza Rosalía Torrent en su artículo "Manolo Safont" de $1999,{ }^{63}$ Safont en esta etapa hace lo que realmente quiere hacer, es capaz de reflejar en su obra las composiciones y obras que crea en su mente, por fin su mano es capaz de reflejar todo esto sin perder nada en el proceso de transmisión. Las obras que crea, son las obras que piensa. Su dominio absoluto de la técnica hace que pueda reflejar fielmente con materia cerámica las obras pensadas e imaginadas, sin perder fuerza en este camino. Domina

${ }^{63}$ TORRENT, Rosalía. Op. Cit, 1999. 
pigmentos, colores, barnices y soportes de tal modo, que pese a que la acción del fuego es necesaria para realizar su obra, un proceso que implica tantos cambios en el resultado final, esto no es impedimento para el. Ha estudiado, experimentado y aprendido tanto, que al aplicar en crudo estos productos, que ve ya en ellos el resultado final que obtendrá tras el proceso de cocción. No hay sorpresas en sus obras tras pasar por el horno, consigue exactamente lo que pretendía, resultado de un trabajo constante y profundo y de la asimilación y años de oficio. Nada queda al azar, en las obras de Safont lo que vemos nosotros refleja fielmente lo que él veía en el interior de su mente. Nada más sencillo para corroborar esta afirmación que poder comparar y contrastar los bocetos de sus obras con el resultado final. ¿Cómo es posible que una obra cerámica refleje tan fielmente las formas, colores y texturas de un boceto realizado con lápices de colores cuando debe afectarle todavía el proceso de cocción de un horno? ¿Cómo puede Safont dominar el fuego?

El boceto a realizar sobre plancha cerámica precisa del estudio previo de su fragmentación. El despiece de una composición de placas de arcilla corresponde principalmente a las limitaciones impuestas por el tamaño del horno y el grosor de la propia plancha, ambas características han de integrarse en el diseño, generando así piezas murales cerámicas de cualquier dimensión en donde la forma, el diseño y el color se pueden compenetrar en armonía.

Pero todo este oficio, este dominio de la técnica y materiales, no resta frescura y fuerza a sus obras, más bien al contrario, lo que pudiera ser un condicionamiento se convierte en un recurso útil por su savoir faire. Al carecer de un horno propio en el que poder cocer sus obras, no lo tuvo hasta 1984, Safont tuvo que adaptar sus piezas a las temperaturas y sistemas de cocción de los hornos industriales de las fábricas de azulejos de Onda. Aprendió a crear adaptándose a las circunstancias, y así evolucionó también en sus obras conforme progresaba la tecnología cerámica de su entorno, adaptándose dese los antiguos hornos árabes, a los de pasaje, bicanal o de túnel.

Desde el momento en que pudo instalar y utilizar su propio horno, la experimentación artística de Safont avanzó aún de forma más rápida, ahora era mucho más libre para poder experimentar y crear todo aquello que deseaba. Su trabajo y experimentación constante le llevaron a crear nuevas formulas para lograr nuevas texturas y calidades. Así pasó a cocer sus piezas de $980^{\circ}$ a 
$1000^{\circ}$, llegando incluso a poder cocer a $1260^{\circ}$ algunas placas o cuadros de pequeño formato. ${ }^{64}$

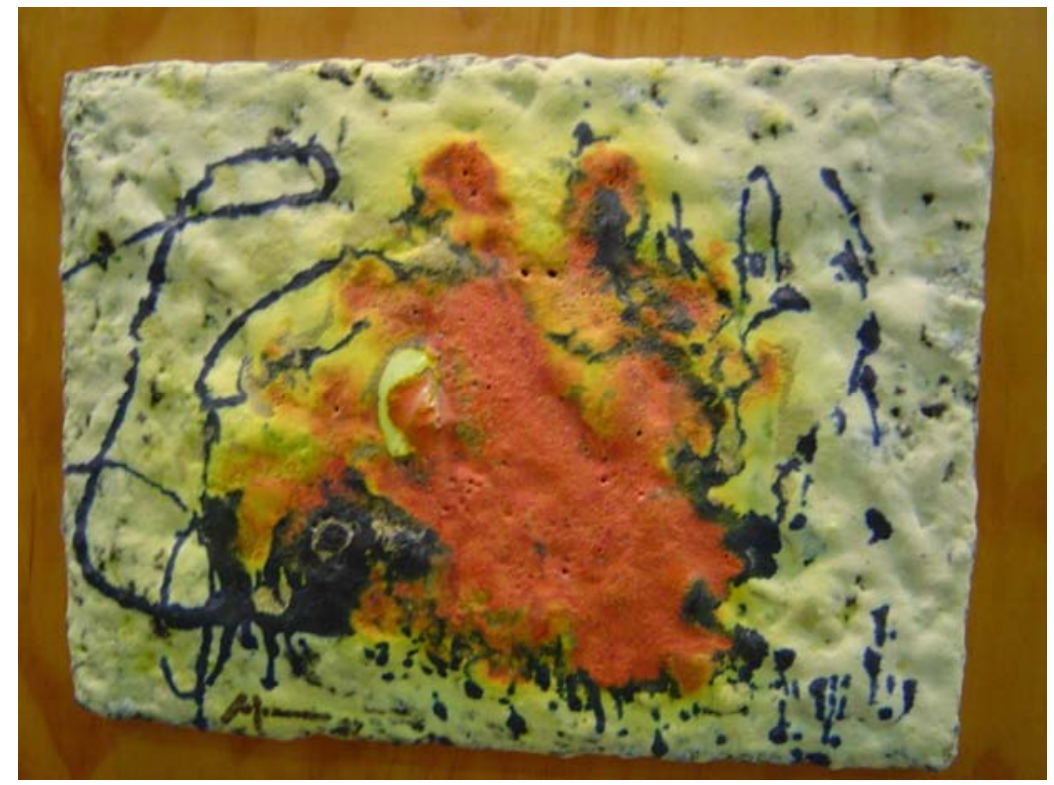

Figura 120: Sin Título, Safont. Obra cat. n5.57

Safont trabajó sobre placas planas bizcochadas, aplicando barnices, colores, óxidos y pigmentos que creaban rugosidades, texturas e incluso importantes volúmenes con grandes desniveles de espesor, superponiendo colores que conferían a sus obras una gran expresividad. No le interesaba experimentar sobre otros soportes o formas, se centró en el trabajo sobre piezas planas. Al no tener que pensar y crear nuevas formas originales, eliminó este condicionamiento e hizo que su fuerza creadora se centrara en la materia y los esmaltes.

No se trata de aplicar técnicas pictóricas a la cerámica, ni de utilizar la técnica cerámica para imitar efectos pictóricos, con su trabajo pretende crear una nueva expresión artística con nuevos elementos.

Si en la etapa de transición de la figuración a la abstracción, sus obras entroncan directamente con la corriente artística del informalismo, con la adquisición del nuevo horno, su arte evoluciona y se engloba en la corriente del abstraccionismo lírico, en el cual transmite sentimientos a través el dinamismo del color y la utilización premeditada de la materia en sus obras.

\footnotetext{
${ }^{64}$ Datos obtenidos de la exposición Manolo Safont, un Museu, un llegat, un compromís realizada en el Museo del Azulejo Manolo Safont de Onda en 2004.
} 
En esta etapa de abstraccionismo lírico, Safont desligado completamente de las limitaciones que para sus creaciones supone la forma y la figuración, se sumerge en una etapa alejada de cualquier atadura en la cual la libertad compositiva será su máximo exponente. Prescinde de la forma sin prescindir del mensaje, abandona la figuración porque le oprime, le coarta, no le deja expresar todo lo que siente, piensa y que necesita trasmitir. En sus obras domina el gesto, hasta el punto que podemos establecer cierta relación entre las obras cerámicas de Safont y las obras gestuales del action painting de Jackson Pollock.

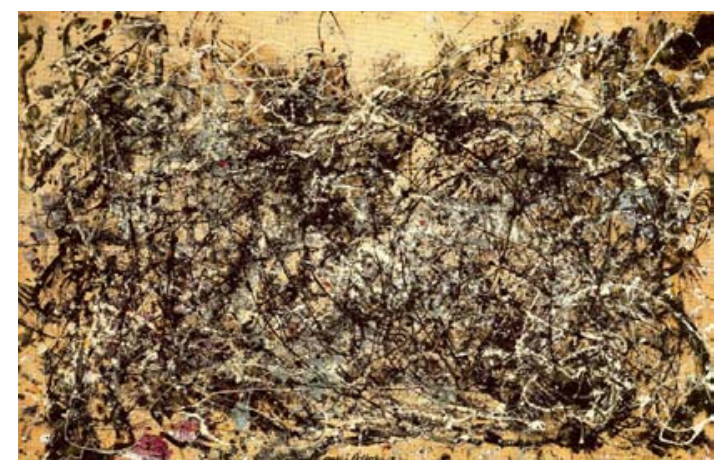

Figura 121

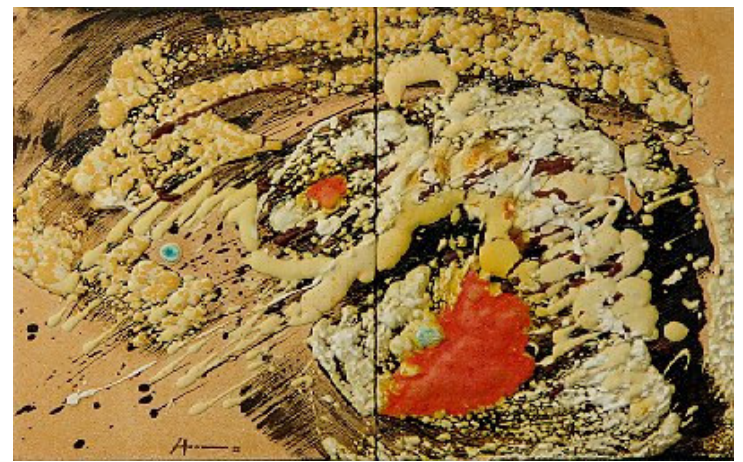

Figura 122

Figura 121: Número 1 A, Jackson Pollock, 1948. Figura 122: Sin Título, Safont. Obra cat. n5.61

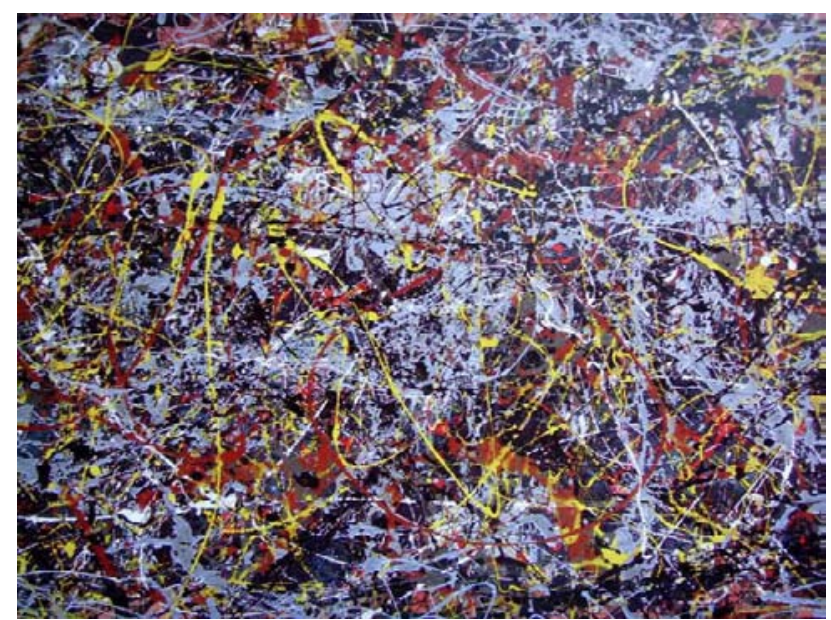

Figura 123

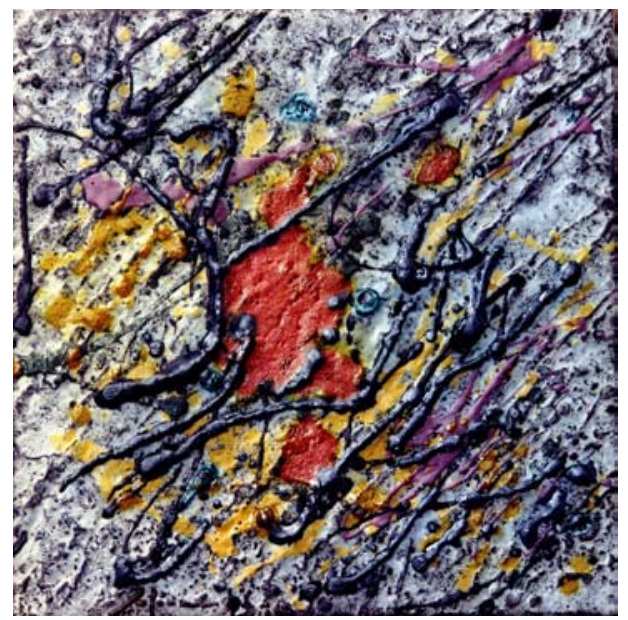

Figura 124

Figura 123: Número 5, Jackson Pollock.

Figura 124: Sin Título, Safont. Obra cat. n5.78

En esta etapa, Safont ha logrado encontrar lo que tanto tiempo ha buscado y por lo que tanto ha trabajado, no intenta trabajar la cerámica 
aplicando sobre ella técnicas de otras artes pictóricas como el óleo, no pretende copiar ni imitar en cerámica lo que otros artistas crean sobre lienzos o tablas, no le interesa crear obras que reproduzcan lo más fielmente posible la realidad ni tan siquiera que se aproximen a los resultados obtenidos con el óleo, la acuarela, etc, Safont busca y encuentra un lenguaje propio creado a partir de los materiales y técnicas ancestrales de la cerámica, un lenguaje que hacen reconocibles sus obras a simple vista, con un estilo propio y característico, coherente, sin caer en la manida repetición.

La cerámica es para Safont una prolongación de su persona, una opción y necesidad de renovación frente al trabajo y al arte tradicional, y con este leguaje propio, su estilo de artista, confiere a sus obras la categoría de arte. El arte debe dar cabida a las emociones humanas y a lo que estas determinan, se alimenta de raíces y oficio, cualidades que hoy en día parecen obsoletas, de identidad, sabiduría y singularidad.

"...no hay que olvidar que hay centenares de fórmulas, y cada fórmula lleva diez o doce materias. Lo más complicado es que en una sola cocida tiene que ir todo con una paleta tan amplia como arriesgada. Trabajas como si pintases sobre un lienzo, pero luego está el problema de la cocción, teniendo en cuenta que cada esmalte funde a una temperatura determinada. Ello se resolvería cociendo cada color a su temperatura pero no se podría tener la unidad pretendida, porque estallarían los colores ya cocidos....Es difícil, ya no sólo la combinación de colores sino la química y el dominio del fuego. Si falla algo falla todo el trabajo. Nunca cesas de empezar de nuevo; cada veladura, cada color que superpones es una aventura nueva. Es la aventura hermosa que lleva la cerámica que nunca acabas de conocer y que une la creatividad artística a la labor investigadora"65

Ferran Olucha resume en unas breves líneas la evolución estilística de la obra Safont, explicando cómo en sus inicios artísticos la técnica se apoya en la figura, posteriormente es la técnica la que se impone con la abstracción, más tarde la figuración se impone a la técnica para finalmente esa misma técnica

65 GAScÓ, Antonio. "Safont y Rambla, las dos caras de la abstracción". Levante EL MERCANTIL VALENCIANO, Posdata, marzo 1995, pág 5. 
acabar destruyendo la forma. ${ }^{66}$ Así es como el informalismo expresionista de intencionalidad socio-política evoluciona hacia un arte gestual expresado con grandes manchas de color creadas con pasta pictórica y aplicadas con soltura sobre fondo plano para consolidarse como un arte plenamente abstracto, donde el color gana en intensidad y las cristalizaciones y texturas adquieren un maravilloso resultado plástico, que estimulan la percepción y la sensibilidad, el sentimiento y la imaginación, a través de la libertad.

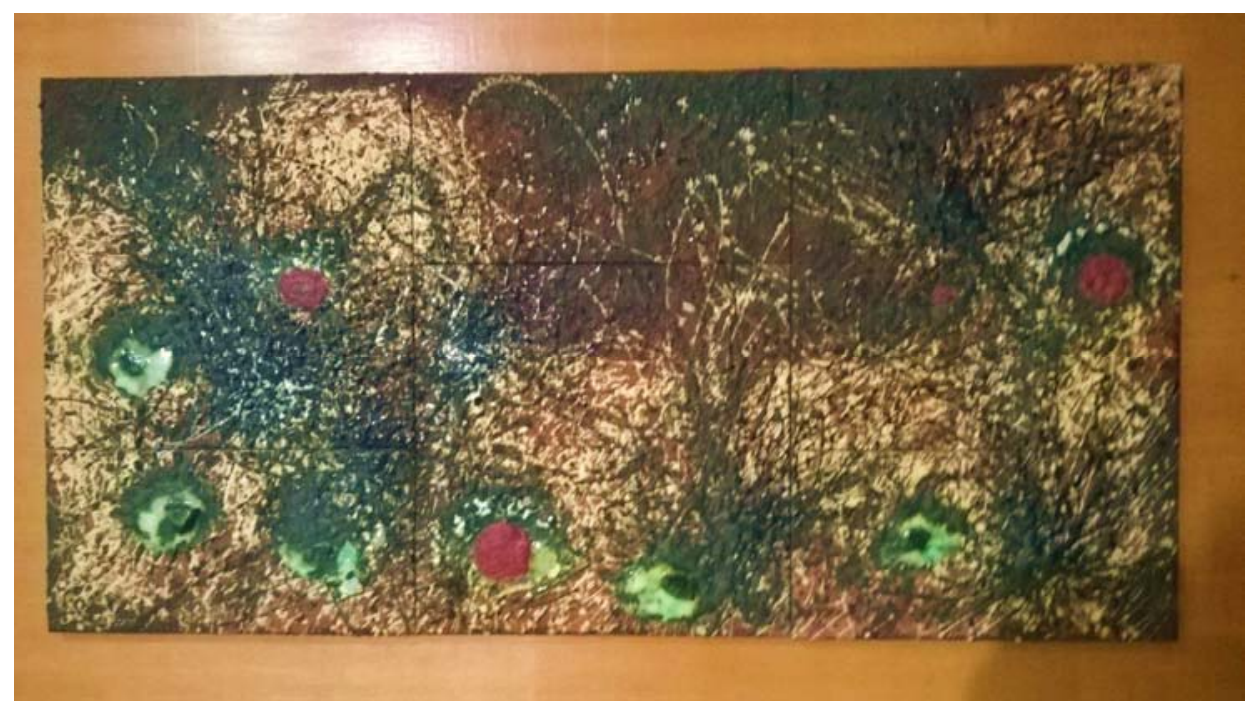

Figura 125: Sin Título, Safont. Obra cat. n5.14

Safont nos sumerge en un mundo en que la abstracción y la libertad en el trazo, el goteo, el chorreo, el relieve y la suma de aguadas de color, asumen el conocimiento de la plástica contemporánea en las manos de un ceramista que materializa con tierra, óxidos y fuego aquello que toca. Acción colorista, informalista, que impresiona al espectador con los colores vibrantes, contrastados, en donde los tonos cálidos llegan incluso a ser agresivos, llameantes, con vigorosas manchas que poco a poco van abandonando una anterior gama oscura en que la armonía va ganando la batalla al gesto.

Safont contaba cómo en una ocasión al principio de su etapa de abstracción le habían recomendado que debía cambiar la forma de hacer sus cuadros, que debía elegir entre el fondo y el cuadro en sí, pero es que en su

${ }^{66}$ OlUChA Montins, Ferran. "Manolo Safont". Catálogo exposición Fontana d'Or, del 28 marzo al 16 abril, Gerona, 1983. 
obra no hay barreras entre fondo y forma, ambos son necesarios $y$ complementarios, no hay obra sin ambos.

Con la plenitud del periodo de abstracción, Safont llega al punto cumbre de disfrute por y para el arte, ya no necesita reivindicar a través de su obra los derechos de los trabajadores, ni denunciar la opresión de la dictadura franquista.

El fundamento artístico de las obras de Safont está basado en un equilibrio entre calidades y tonalidades. Durante todo el proceso creativo, anotaba fórmulas y combinaciones de elementos en diferentes libretas, así como las etapas de cocción en el horno, para ver cómo reaccionaban las diversas materias. Arriesgaba con opciones complejas, como poner tonalidades pardas de las que emerge un rojo brillante o un azul celeste, combinaciones muy expresivas que resultan complejas de obtener en el horno. Evidentemente es mucho más sencilla la elaboración de un cuadro individual, que la elaboración de un mural, ya que estos al estar compuestos por decenas de piezas que no pueden cocerse en una única hornada, por las limitaciones de capacidad de un horno, y plantean graves problemas para lograr la sensación de unidad, de pieza única.

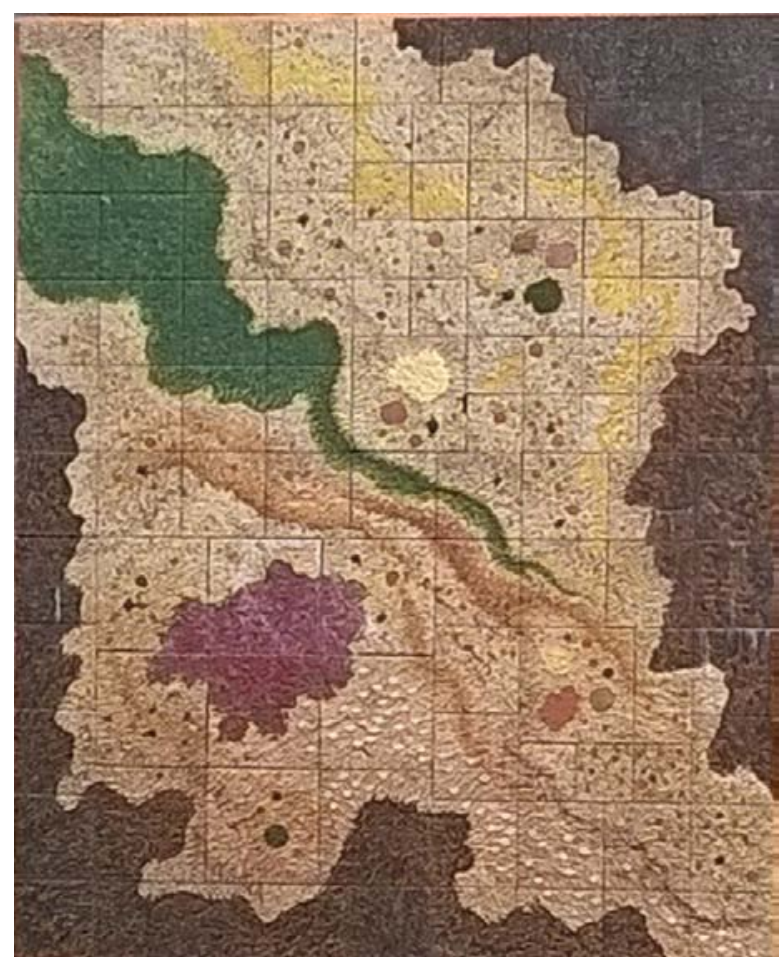

Figura 126: Mural CEIP Mestre Caballero, Safont. Obra cat. $n^{\circ} 7.29$ 
En el informalismo abstracto de Safont, materia y color definen el conjunto. La materia es muy rica en cuanto a formas, suaves, texturizadas, rugosas; el dibujo genera manchas y acciones; y el color transmite sensaciones. Tan importante es el relieve como el gesto y el color, no obstante, en toda obra intenta imperar la armonía.

Poder ver una exposición de Safont con el propio Safont era un lujo, un disfrute para los amantes del arte. Recorrer con él la sala de exposiciones mientras pasaba de una obra a otra explicándolas: "Mira, açi el roig fa referencia a la sang vessada, i destaca per damunt del negre, que amb la seua foscor simbolitza la ignorancia". ${ }^{67}$

"Safont ha entendido muy bien la lección del informalismo, ritmo, color, masa de acción móvil y evidenciarse de un mundo interior apasionado y sensitivo que se cuaja en el fuego haciéndose eterno y perenne, con ese brillo mágico rotundamente expresivo del esmalte que fortalece los colores y les confiere más personalidad y definición" ${ }^{\text {"68 }}$

"Safont es un artista que se ha propuesto resolver una serie de problemas plásticos por medio de la cerámica, sometiéndose a los imperativos materiales y técnicos que el horno impone y teniendo en cuenta los comportamientos y limitaciones de los colores. El estudio de estas cuestiones le ha llevado muchos años, que él ha ido resolviendo en su Onda natal al contacto con los hornos que pululan por nuestras tierras. Ha ido aportando diferentes soluciones a los problemas que se le planteaban hasta que ha conseguido, sin ir mas allá de los condicionamientos que le impone el nivel de industrialización cerámica, la obra tremendamente sugestiva que nos ofrece, sobre la compartimentación estandarizada de unos ladrillos corrientes y componiendo una superficie homogénea con ellos, los colores, en todas las gamas que el artista quiere imponer, se disponen en núcleos amorfos, zonas

\footnotetext{
67 "Mira, aquí el rojo hace referencia a la sangre derramada y destaca por encima del negro, que con su oscuridad simboliza la ignorancia". Conversación personal mantenida con Safont en la inauguración de la exposición Manolo Safont. Un museu, un llegat $i$ un compromís. MAMS. Del 27 de noviembre de 2004 al 8 de enero de 2005. Onda.
}

${ }^{68}$ GaScÓ, Antonio. "Importante muestra de Manolo Safont de pintura cerámica". Castellón Diario, 31 diciembre 1989, pág. 6. 
interpretadas o de precisa limitación, ritmos que saltan densificándose 0 enrareciéndose 0 emergiendo rugosos y accidentados. El conjunto es una sorprendente caligrafía visual y táctil al mismo tiempo". 69

Pese al paso de los años, y de los innumerables textos o artículos que sobre la persona y obra de Manolo Safont se han escrito, sigue siendo este entrañable texto de su amigo personal, Joan Fuster, tantas veces reproducido es los catálogos de sus exposiciones, uno de los que mejor define su arte:

"Hi ha unes formes d'art que conserven mes que les altres la passió i l'estructura del treball. Tot art es treball, sens dubte: però no de la mateixa manera, ni amb el mateix sentit. L'obra de Manolo Safont tè les seues arrels en la profunda energia del treball artesà, treball de tradición popular, d'experiència popular, de materia popular. La ceràmica pot semblar un joc amb la terra $\mathrm{i}$ amb el foc, i tanmateix és un resultat de lentes meditacions, de savieses contrastades, de provatures insistents. Com qualsevol treball eficaç. Només que Safont el transporta, del nivell maquinal i repetidor, al de creació estimulant. La seua mà -els seus colors, les sues qualitats, les formes que insinua- encara respon a impulsos ancestrals, d'estudi acumulat, en els quals vibra l'esperit anónim de moltes generacions. Peró la seua imaginació i la seua intenció hi posen l'accent d'una aventura inédita, que és alhora confianza i força. Safont sap traume dels vells procediments del poble -del seu poble d'Onda- un profit brillant i segur, i el multiplica en la investigació personal. Ell continua sent el treballador que sempre ha estat, i del seu sentit amorós del treball obté el secret d'una tènica i la dignitat d'un ofici. Per ser encara i sempre un treballador, les coses que fa reflecteixen una voluntat de lluita i d'afirmació solidària càlidament expressada. Les admiracions, les moltes admiracions que Manolo Safont es mereix, tenen aquí en aixó- la més plena i animosa justificació.

$$
\text { Joan Fuster" }
$$

69 GutTManN GoldBerger, Beatriz. El Museo de Vilafamés: Un hecho insólito. Diputació de Castelló, Castelló, 1995, pág. 295

${ }^{70}$ FUSTER, Joan: "Hay unas formas de arte que conservan más que las otras la pasión y la estructura del trabajo. Todo arte es trabajo, sin duda: pero no de la misma manera, ni con el mismo sentido. La obra de Manolo Safont tiene sus raíces en la profunda energía del trabajo artesano, trabajo de tradición popular, de experiencia popular, de materia popular. La cerámica puede parecer un juego con la tierra y el fuego, y a la vez es el resultado de lentas meditaciones y sabidurías contrastadas, de pruebas insistentes. Como cualquier trabajo eficaz. Solo que Safont lo transporta, del nivel 
Manolo Safont, trabajando la tierra y dominando el fuego, rescató la cerámica del estrato de artesanía para mostrárnosla transformada y renovada como símbolo de identidad de un pueblo y de su historia, "treballe com a pintor, pero dominant el foc, alliberant la materia"71

La obra de Safont supone una dignificación de la cerámica, en la que el arte se impone sobre la artesanía, consiguiendo elevarla, dignificándola, eliminando la manida etiqueta de pieza decorativa e integrándola como una disciplina más del arte.

maquinal y repetitivo, al de creación estimulante. Su mano, sus colores, sus cualidades, las formas que insinúa, aún responden a impulsos ancestrales, de estudio acumulado, en los cuales vibra el espíritu anónimo de muchas generaciones. Pero su imaginación y su intención, ponen el acento de una aventura inédita, que es a la vez confianza y fuerza. Safont sabe sacar de los viejos procedimientos del pueblo, de su pueblo de Onda, un provecho brillante y seguro y lo multiplica en la investigación personal. Él continúa siendo el trabajador que siempre ha sido, y de su sentido amoroso por el trabajo obtiene el secreto de una técnica y la dignidad de un oficio. Por ser aún y siempre un trabajador, las cosas que hace reflejan una voluntad de lucha y afirmación solidaria cálidamente expresada. Las admiraciones, las muchas admiraciones que Manolo Safont se merece, tiene aquí la más plena y animosa justificación"

${ }^{71}$ OluCha Montins, Ferran. Manuel Safont. Catálogo exposición Wences Rambla; Manuel Safont, Centre Cultural d'Alcoi, marzo 1995 "trabajo como pintor pero dominando el fuego, liberando la materia" 


\section{CAPÍTULO 4 MANOLO SAFONT, PERSONAJE SOCIAL}

Manolo Safont fue un artista con un gran compromiso social, que a través de su actitud personal y su obra artística realizó una crítica social a la dictadura franquista y ocupó un papel importantísimo para la cultura de Castellón y de la Comunidad Valenciana.

"Manolo Safont ha sigut sempre un veí d'Onda preocupat per tots els problemes del poble, sobretot, per tot allò que té a veure amb el patrimoni historicoartístic" (Enrique Navarro) ${ }^{1}$

"Difícilment trobariem en tota la plástica actual un autor que estiguera tan indisolublemente lligat al seu poble com Manolo Safont. I no solament per l'actitud personal de viure ininterrompudament a la seua ciutat sino també, i pot ser el més important, pel compromís amb la societat local i pel lligam entre la seua obra i la realitat productiva i mercantil d'Onda" (Jesús Huguet) ${ }^{2}$

"I en eixa simbiosis Onda-Safont hauríem d'incloure les seues tasques $\mathrm{i}$ preocupacions pel patrimoni $\mathrm{i}$ cultura de la vila: des de la creació del museu municipal (mai ningú no ha fet tant per a que Onda tinguera un museu de ceràmica digne de la seua tradició) a les ajudes i estímuls en la gestió de publicacions i actes culturals i socials diversos" (Jesús Huguet) ${ }^{3}$

\footnotetext{
1 Safont. Saleta Municipal d'Onda, Regiduria de Cultura, del 24 al 31 de octubre de 1999, Onda. "Manolo Safont ha sido siempre un vecino de Onda preocupado por todos los problemas del pueblo, sobretodo por todo aquello que tiene que ver con patrimonio historicoartístico"

${ }^{2}$ Ibidem. "Difícilmente encontraríamos en toda la plástica actual un autor que estuviera tan indisolublemente ligado a su pueblo como Manolo Safont. Y no sólo por la actitud personal de vivir ininterrumpidamente en su ciudad, sino también, y puede ser lo más importante, por el compromiso con la sociedad local y por la relación entre su obra y la realidad productiva y mercantil de Onda"

${ }^{3}$ Safont. Exposición conmemorativa de la inauguración del nuevo edificio social, Caja Rural Nuestra Sra. de la Esperanza. Onda, del 23 de diciembre de 2001 al 6 de enero de 2002. "Y en esa simbiosis Onda-Safont deberíamos incluir sus trabajos y preocupaciones por el patrimonio y la cultura de la villa: desde la creación del museo municipal (nunca nadie ha hecho tanto por que Onda tuviera un Museo de cerámica digno de su tradición) a las ayudas y estímulos en la gestión de publicaciones y actos culturales y sociales diversos.
} 
La ideología política de Safont provocó el rechazo de su arte por parte del estado y las instituciones oficiales, hasta que acabó la dictadura franquista.

"He estat un home obert. Des de fa molts anys he pertangut a l'esquerra $\mathrm{i}$ he tingut unes conviccions nacionalistes, amb idees, inquietuds, curiositat... M'han prohibit alguns quadres. Al Museu de Ceràmica González Martí m'en feren retirar un perqué en un cantó tenía les quatre barres, com quatre pinzellades. I sempre he tingut problemas d'aquests tipus. La por a la reacció dels mateixos de sempre"

${ }^{4}$ M., V. "Manolo Safont. La lluita contra el foc", Generalitat, segona quinzena, desembre 1980, pág. 29. "He sido un hombre abierto. Desde hace muchos años he pertenecido a la izquierda y he tenido unas convicciones nacionalistas, con ideas, inquietudes, curiosidad.....Me han prohibido algunos cuadros. En el Museo de Cerámica González Martí me hicieron retirar uno porque en una esquina tenía las cuatro barras, como cuatro pinceladas. Y siempre he tenido problemas de este tipo. El miedo a la reacción de los mismos de siempre". 


\section{1.- LA CASA DE MANOLO SAFONT, CENTRO CULTURAL DE REUNIONES}

Todo aquel que tenía un interés por la cultura y por las artes, tenía un sitio en Onda, la casa de Manolo y Anita. Desde el piso-estudio de Safont, en la esquina de la actual calle Historiador Bernardo Mundina con la plaza del Raval de San José, hasta su casa-alquería en la calle Escultor Foliá, en el barrio de la Morería de Onda, la casa de Manolo y Anita fue durante muchos años el espacio cultural de la localidad, y no tan sólo de Onda, sino también un importante foco cultural y de referencia tanto en la provincia de Castellón como en toda la Comunidad Valenciana, durante las décadas de 1960, 1970 y 1980.

"En Onda, la casa del ceramista Manolo Safont reunía a un buen número de inquietos. En el bar situado en los bajos del edificio "El Centro", los universitarios contaban sus hazañas en Valencia." (Lluís Doménech) $^{5}$

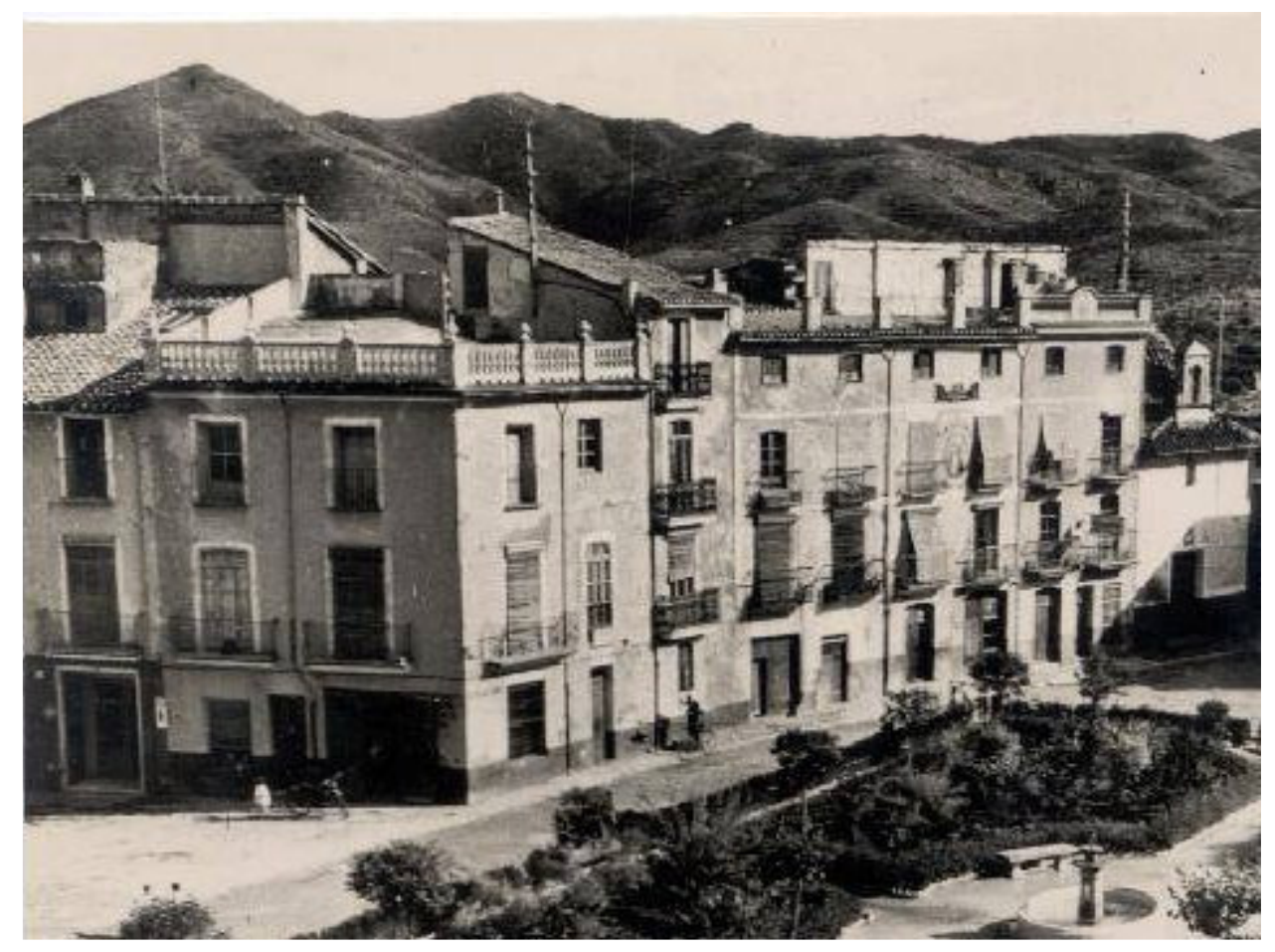

Figura 127: Piso-estudio de Safont en el Raval de San José de Onda, situado en el último piso de la casa situada a la izquierda en la imagen.

\footnotetext{
${ }^{5}$ DOMÉNECH, Lluis. "Radio Luxemburgo, desde Onda", Cuéntame Castellón, pág. 40.
} 
"En realitat, en l'únic ambient en què es sent al seu gust és en el de sa casa, amb la seua dona, amb les diverses amistats i un bon grapat de joves del poble que han pres sa casa i la seua biblioteca com a pròpies; al costat dels seus llibres i dels seus discos" (Antoni Seva) ${ }^{6}$

"Un ser humà bondadós i benigne, tan benigne i generós que no li ha importat fer de sa casa un espai de relax o un refugi en temps dificils, i només, a tall d'exemple, vull recordar un amic ja absent que va saber la importància d'eixe refugi: Alberto García Esteve" (Jesús Huguet) $^{7}$

"Tots sense discriminació vam trobar sempre recull en aquell raconet de la plaça de sant Josep: la casa havia envellit però es mantenia infinitament acollidora, negada de llibres i reblada de quadres de ceràmica i de peces d'antiquari. Alli mateix, entre el giradiscos que mai no s'aturava, els lladrucs del Koli i la mirada sorneguera i dolcíssima de l'auelet, s'obria de bat a bat una casa sense mur, sense fronteres, la més acollidora, sens dubte, que hi havia a Onda. És evident, Anna i Manolo, que només en vosaltres hem pensat molts cada vegada que hem escoltat la melodia d'aquells versos colpidors "A casa meva és casa vostra, si és que hi ha cases d'algú..." (Vicent Pitarch) ${ }^{8}$

\footnotetext{
${ }^{6}$ SeVA, Antoni. "Fang i pinzells", inédito, 1966. "En realidad, en el único ambiente en que se encuentra a gusto es el de su casa, con su mujer, con las diversas amistades y un buen grupo de jóvenes del pueblo que han tomado posesión de su casa y de su biblioteca como propias; al lado de sus libros y de sus discos"

${ }^{7}$ Huguet Jesús. Discurso en el homenaje del 70 aniversario de Safont, 28 marzo 1998, inédito. "Un ser bondadoso y benigno, tan benigno y generoso que no le ha importado hacer de su casa un espacio de relax o un refugio en tiempos difíciles, y tan solo, a modo de ejemplo, quiero recordar a un amigo ya ausente que supo la importancia de ese refugio: Alberto García Esteve". Albero García Esteve fue abogado laboralista con despacho en la ciudad de Valencia. De 1962 a 1975, fue asesor jurídico de la Agrupación Nacional de Industriales Azulejeros, por lo que acudía semanalmente a Onda por motivos laborales. Tras declararse el 25 de enero de 1969 el estado de excepción en España, Alberto García Esteve permaneció oculto una temporada, temeroso de las represalias del estado español.
}

${ }^{8}$ PITARCH, Vicent. Discurso en el homenaje del 70 aniversario de Safont, 28 marzo 1998, inédito. "Todos sin discriminación encontramos siempre refugio en aquel rincón de la plaza de san José: la casa había envejecido pero se mantenía infinitamente acogedora, llena de libros y repleta de cuadros de cerámica y de piezas de anticuario. Allí mismo, entre el giradiscos que nunca se paraba, los ladridos del Koli y la mirada dulce del abuelito, se abría de par en par una casa sin muros, sin fronteras, la más 
"La meua memòria d'Onda va també indissolublement lligada a dues persones, Manolo Safont i Anna del Moral, i a la seua casa, aquell espai públic pel qual desfilava tota la gent inquieta del poble, als seus cafés, als seus vins sabiament triats, a les xerrades interminables, al taller de Manolo on exercia de sum sacerdot de biscuits, fangs, terres, verníssos i foc." (Manuel Ardit) ${ }^{9}$

De las reuniones en esta casa, surgieron proyectos culturales y asociaciones como "Amics d'Onda" o "Amics del Museu" y revistas como Panderola. Ana y Manolo realizaban reuniones en su domicilio a las que acudían intelectuales de la talla de Josep Renau, Joan Fuster, Alberto García Esteve, Manuel Ardit, Antoni Seva, Vicent Pitarch, Jesus Huguet, Josep Palomero, etc, cuyas ideas y proyectos fueron, y son, protagonistas y referentes de la vida cultural y social valenciana y española, convirtiéndose en un destacado foco cultural. ${ }^{10}$

La opción política de Safont contra el absolutismo dictatorial, a favor de la pluralidad de ideas y de la libertad democrática como condición básica de las personas, le conllevó el rechazo de cierto sector tradicionalista de la sociedad, su ideología nacionalista y su defensa de la cultura y lengua valenciana, hizo que su obra fuera vetada o censurada en determinados círculos artísticos y sociales.

acogedora, sin duda, que había en Onda. Es evidente, Ana y Manolo, que solo en vosotros hemos pensado muchos cada vez que hemos oído la melodía de esos versos estremecedores "Mi casa es vuestra casa, si es que hay casas de alguien"

${ }^{9}$ ARDIT, Manuel. "Memoria d'Onda”, Programa Fira d'Onda 1998, Octubre 1998, Onda. "Mi memoria de Onda está indisolublemente ligada a dos personas; Manolo Safont y Ana del Moral, y a su casa, aquel espacio público por el que desfilaba toda la gente inquieta del pueblo, a sus cafés, a sus vinos sabiamente escogidos, a las tertulias interminables, al taller de Manolo donde ejercía de sumo sacerdote de bizcochados, barros, tierras, barnices y fuego"

${ }^{10}$ Seva, Antoni. Op. Cit. 


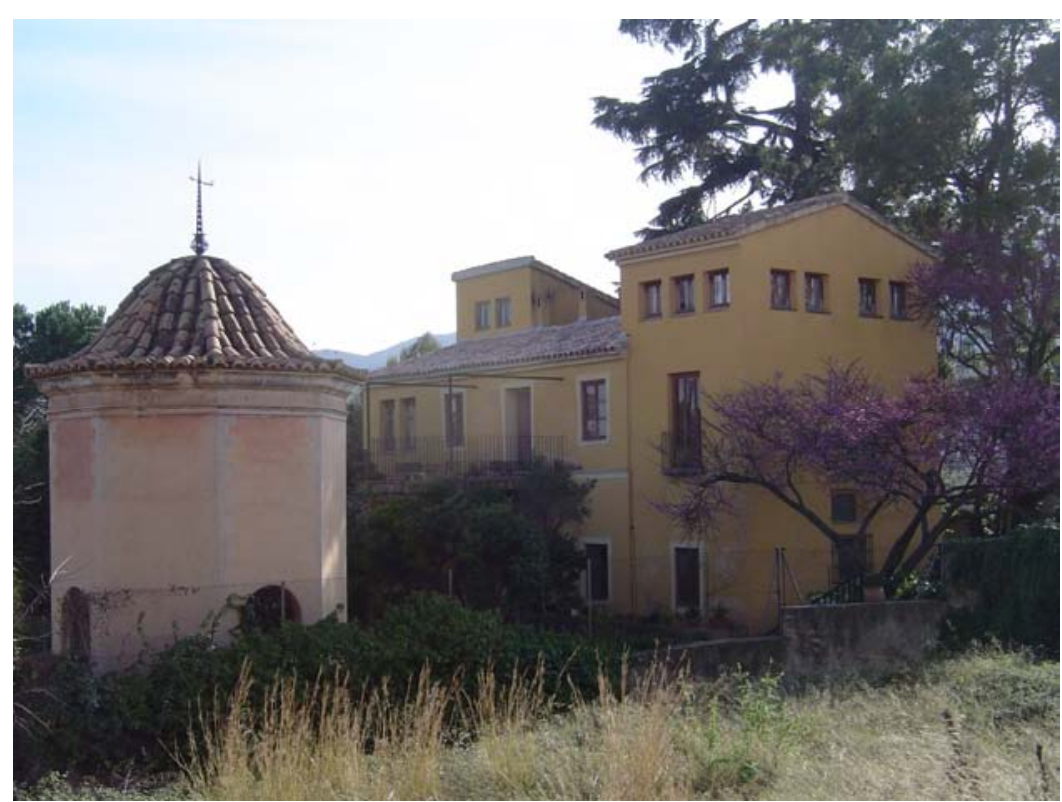

Figura 128: Casa-estudio de Safont en la calle Escultor Folià.

Fue decisión de Manolo Safont y de su esposa Ana, donar al pueblo de Onda su casa-alquería ubicada en el barrio de la Morería de la localidad, así como todo su contenido, tanto las obras creadas por Safont como la colección de obras de arte que de otros artistas fue comprando o le fueron regalando o intercambiando por obra suya. ${ }^{11}$ El 24 de junio de 2002, la Comisión de Gobierno Municipal del Ayuntamiento de Onda, acordó aceptar la donación de los bienes inmuebles de su propiedad, dos fincas rústicas valoradas en $91.511,31 €$, así como aceptar también la donación de las obras del artista, existentes en su domicilio y que fueron inventariadas por el Director del Museo de la Cerámica, cuyo valor ascendía a $297.193,34 €$, comprometiéndose al mantenimiento de sus propiedades y a revalorizar toda su obra. ${ }^{12}$

La noticia de la donación de este importante legado, tuvo gran repercusión en prensa, sobre todo, como es lógico en la prensa local de Onda. ${ }^{13}$

\footnotetext{
11 Regalado, Emilio. "Onda gestionará la amplia obra del ceramista Safont tras la cesión del patrimonio del artista”, el periódico Mediterráneo, 27 junio de 2002, pág. 16.

${ }^{12}$ Certificado de la Secretaría del Ayuntamiento de Onda, con las propuestas de acuerdo sobre la aceptación donación de bienes de Manolo Safont y Ana-Teresa del Moral, 24/06/2002, inédito.

13 Redacción. "Manolo Safont y su mujer, Ana del Moral, ceden su patrimonio inmobiliario y artístico al pueblo de Onda", El Full, Junio 2002.
} 


\section{2.- MANOLO SAFONT UN ARTISTA COMPROMETIDO: DEL MUSEO HISTÓRICO MUNICIPAL DE ONDA AL MUSEO DEL AZULEJO MANOLO SAFONT}

"Manolo, a més de ceramista, era -i és- un enamorat d'Onda i va dedicar un gran esforç per preservar el seu patrimoni, esforç certament contagiós. Tant que em va convéncer perquè col.laborara amb ell en la creació d'una de les seues grans il.lusions: el Museu. Aquesta potser ha sigut la meua contribució més permanent al poble d'Onda: els quatre papers que vaig escriure per tal que el Museu d'Onda fos una realitat. Pero no vaig ser més que el braç instrumental i aixó no pot amagar que l'autèntic creador del Museu va ser Manolo Safont" (Manuel Ardit) $^{14}$

Ciertamente, Safont estaba obsesionado por preservar el arte y la historia local de Onda, y para ello consideró que la mejor opción era impulsar la creación de un Museo Histórico Municipal, tal y como consta en la petición realizada ante el Ayuntamiento de Onda y firmada en 1967 por Manuel Ardit Lucas, catedrático entonces de la Sección Delegada del Instituto de Bachillerato "Francisco Ribalta" en Onda, actual IES Serra d'Espadà, Safont encabezó una manifiesta y creciente "ilusión y entusiasmo de jóvenes dispuestos a trabajar".

El 28 de mayo de 1968 se autorizó la creación del Museo Histórico Municipal de Onda por parte del Ministerio de Educación y Ciencia, según Orden Ministerial publicada en el BOE de 22 de junio de $1968 .^{15}$

En este Museo Histórico Municipal se recuperaron una significativa cantidad de objetos, un total de 112, según constan en los archivos,

\footnotetext{
${ }^{14}$ ARDIT, Manuel. Op Cit, Octubre 1998, Onda. "Manolo, además de ceramista, fue -y es- un enamorado de Onda y dedicó un gran esfuerzo para preservar su patrimonio, esfuerzo ciertamente contagioso. Tanto que me convenció para que colaborara con él en la creación de una de sus grandes ilusiones: el Museo. Esta ha sido mi contribución más permanente al pueblo de Onda: los cuatro papeles que escribí para que el Museo de Onda fuera una realidad. Pero no fui mas que el brazo instrumental y eso no puede ocultar que el auténtico creador del Museo fue Manolo Safont"

${ }^{15} \mathrm{https}: / / \mathrm{www}$. google.es/search?q=museo+historic+municipal+onda\&oq=museo+ historic+municipal+onda\&aqs=chrome..69i57.14751j0j9\&sourceid=chrome\&es_sm=12 $2 \& \mathrm{ie}=\mathrm{UTF}-8$
} 
relacionados con la historia de Onda. De esta colección inicial destacan las yeserías musulmanas, las lápidas romanas, relieves góticos, pinturas medievales, tallas barrocas, materiales etnológicos y arqueológicos de diversas épocas, cerámicas de diversas culturas y, sobre todo, azulejos de Onda de los siglos XIX y XX.

El 17 de junio de 1968, conociéndose ya la resolución del Ministerio de Educación y Ciencia, aprobando la creación de un Museo Histórico Municipal, la corporación municipal del Ayuntamiento de Onda acuerda designar como director del Museo Histórico Municipal a Manolo Safont, y así lo solicitan ante la Dirección de Museos y Exposiciones del Ministerio de Educación y Ciencia, quien aprueba la solicitud, con fecha 29 enero de 1969, por estimarla justa, en atención a los méritos y circunstancias que concurren en la misma. ${ }^{16}$

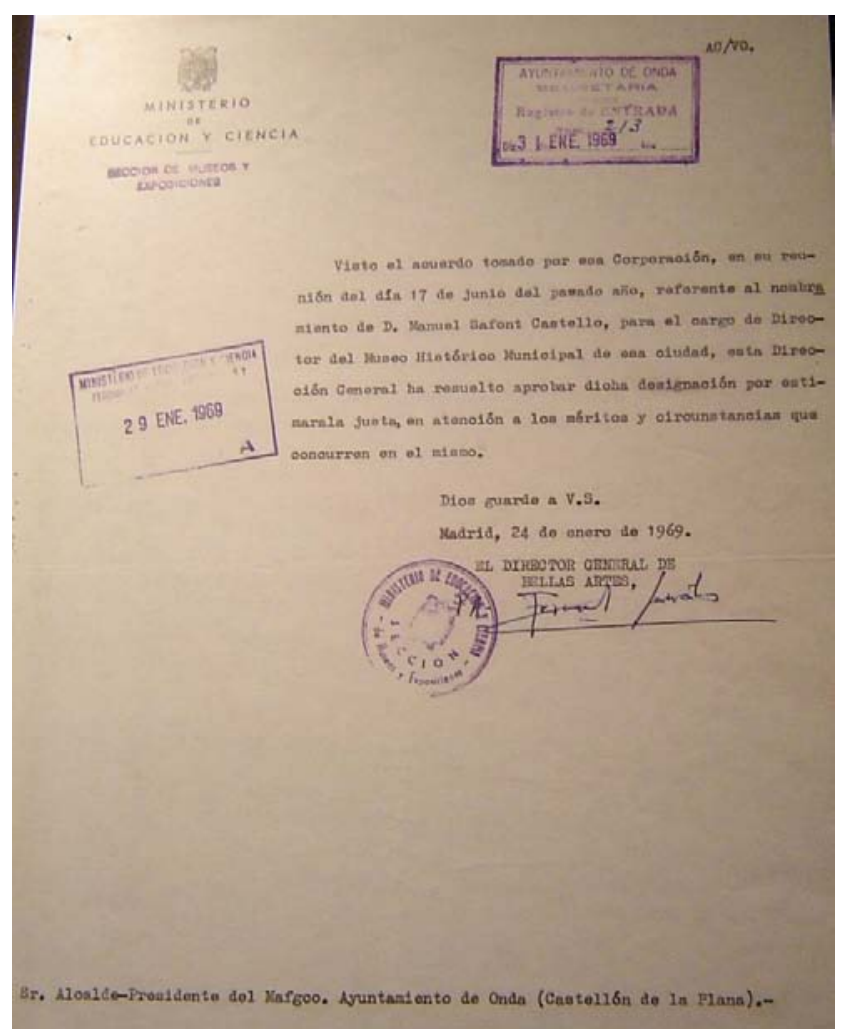

Figura 129: Carta de la Dirección de Museos y Exposiciones del Ministerio de Educación y Ciencia, con el nombramiento de Safont como director del Museo Histórico Municipal.

Eran años de renovación y cambios, se derribaban las viviendas unifamiliares que habían pertenecido a la misma familia durante varias

${ }^{16}$ Carta escrita por el Director General de Bellas Artes, dirigida al Alcalde del Ayuntamiento de Onda, inédita. 
generaciones, y se construían edificios de varios pisos. $Y$ toda Onda sabía que Manolo recogía los azulejos para el Museo, así que cuando derribaban una vivienda, era habitual que los propietarios de la misma le llevaran a Manolo algunos azulejos rescatados del sotobalcón, de la cenefa de la fachada, o del arrimadero del zaguán. Y ni siquiera hacía falta que los llevaran al Museo, si se encontraban con Safont en la calle, allí mismo le entregaban los azulejos, jamás dudaron de él, sabían que las piezas que le daban, pasaban a engrosar los fondos del Museo. También es cierto que muchas personas no eran conscientes de la importancia testimonial de poder reunir todo este repertorio de azulejos, y muchos de los azulejos que no se entregaban a Safont, fueron tirados junto a los escombros de los derribos de las viviendas. En cuanto Safont sabía que se iba a producir un derribo, se acercaba por la dirección de la obra, para ver si había algo que valiera la pena, algo importante o testimonial que pudiera rescatar y que pasara a engrosar los fondos del Museo de Onda.

"Molts veïns recordaran la imatge de Manolo regirant entre la runa, preocupant-se per les coses que es podien salvar en les reformes, visitant el castell per tal de recuperar tot allò que tinguera algun valor, i així, va nàixer, peça a peça, el Museu Històric Municipal d'Onda, a partir del seu esforç individual i de la seua preocupaciò social." (Enrique Navarro) $)^{17}$

Tal y como argumenta Jesús Huguet, hablando de Safont, "el Museu Municipal, que només per la seua dedicació i direcció va poder ser realitat" 18

En 1992, los fondos del Museo, enriquecidos y acrecentados enormemente, se separaron en dos grandes colecciones. Por un lado los objetos arqueológicos e históricos, y por otro, todas las piezas cerámicas y azulejos, con la pretensión de crear un gran museo de cerámica valenciana.

\footnotetext{
17 Safont. Saleta Municipal d'Onda, Regiduria de Cultura, del 24 al 31 de octubre de 1999, Onda. "Muchos vecinos recordaran la imagen de Manolo rebuscando entre los escombros, preocupándose por las cosas que se podían salvar de las reformas, visitando el castillo para recuperar todo aquello que tuviera algún valor, y así, nació, pieza a pieza, el Museo Histórico Municipal de Onda, a partir de su esfuerzo individual y de su preocupación social".

${ }^{18}$ Ibidem. "El Museo Municipal, que solo por dedicación y dirección, pudo ser una realidad".
} 


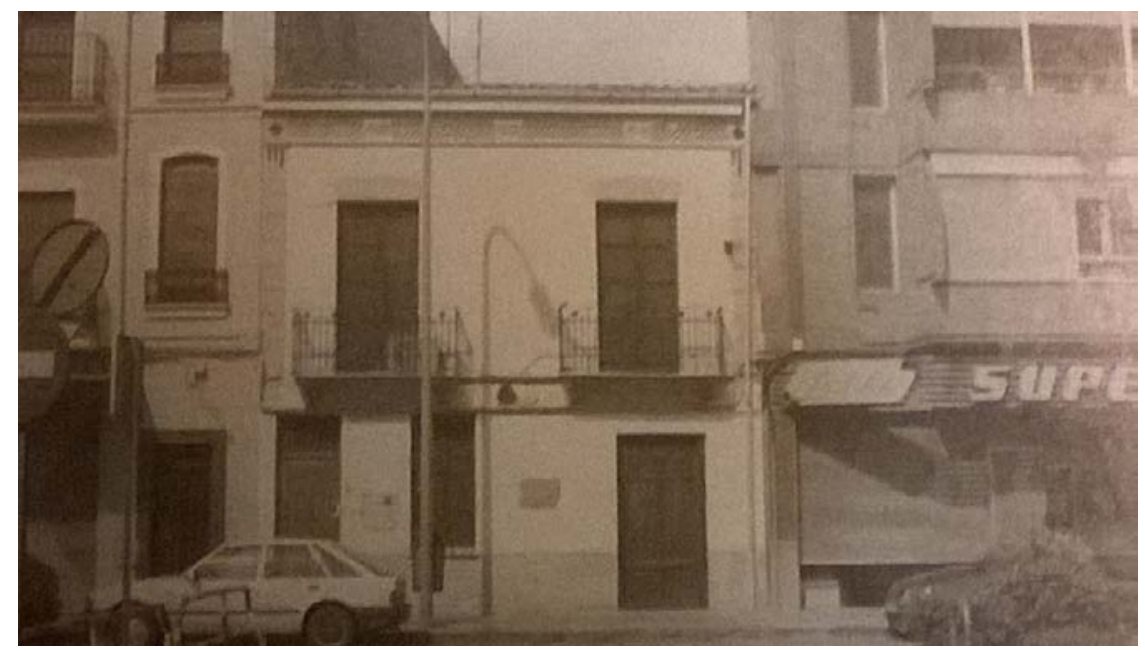

Figura 130: Museo Histórico Municipal de Onda.

En 1993, el Museo Histórico Municipal, desaparece de forma oficial, y la Generalitat Valenciana reconoce oficialmente el Museo de la Cerámica de Onda, con la adscripción al mismo de la Colección Museográfica de Historia Local de Onda. Esta última colección se ha constituido en el Museo de Arqueología e Historia de Onda, con sede en el Castillo de Onda.

El 29 de enero de 2001, reunida en Pleno la Corporación Municipal del Ayuntamiento de Onda, entre los puntos del orden del día se adoptó el acuerdo para la propuesta de denominación del Museo del Azulejo, de la siguiente forma: Museo del Azulejo de Onda "Manolo Safont" o Museu del Taulell d'Onda "Manolo Safont". Esta propuesta se basa, según el acta de dicho Pleno, en el dictamen presentado por la Comisión Informativa de Cultura:

"Atendiendo a la conocida larga y fructífera trayectoria profesional de nuestro querido ceramista D. Manolo Safont Castelló, así como su dedicación y esfuerzo para la recuperación del Patrimonio HistóricoArtístico de Onda. En esta última faceta, íntimamente ligada al carácter y esencia de Manolo a lo largo de su vida, se destaca la creación y puesta en marcha del Museo Histórico Municipal de Onda en 1968.

Aquel Museo permitió rescatar innumerables objetos que forman parte de nuestro más querido y estimado legado histórico y cultural, y que hoy en día se ha convertido en dos centros museísticos sobresalientes: el Museo del Azulejo.Onda y el Museo del Castillo de Onda. De estas piezas iniciales, cuya enumeración no es objeto de estas líneas, destacamos: las yeserías musulmanas, lápidas romanas, retablos, pinturas, 
tallas, materiales etnológicos y arqueológicos de diversas épocas, y sobre todo, azulejos y cerámica.

Atendiendo a que, de hecho, el actual Museo del Azulejo.Onda con sus sobresalientes colecciones de azulejería decimonónica y modernista es el fruto del tesón y esfuerzo de Manolo Safont. Estas primeras colecciones, enriquecidas a lo largo de 30 años y centradas en la historia y evolución de la cerámica, y en concreto de los azulejos, de Onda y por extensión de la comarca y provincia, han dado un carácter supralocal a la institución y han convertido al Museo en uno de los centros museísticos más importantes de España en su materia. Manolo Safont ha sido sin duda el artífice de este logro y el alma Mater del museo, tanto que este no se entiende sin él.

Por todo ello y a tenor de los méritos anteriormente expresados que concurren en la persona de D. Manolo Safont Castelló la Regiduría de Cultura del Ayuntamiento de Onda, ha tomado la decisión de forma consensuada con la Dirección General de Patrimonio Artístico de la Generalitat Valenciana, ya que es un deber moral a la vez que un reconocimiento perenne, el dar a nuestra institución museística el nombre de Manolo Safont de la siguiente forma:

Museo del Azulejo de Onda "Manolo Safont"

Museu del Taulell d'Onda "Manolo Safont"19

En 2002 se nombra a Safont asesor del Museo del Azulejo "Manolo Safont", como contrapartida a la cesión de su obra y patrimonio al Ayuntamiento de Onda. ${ }^{20}$

El 27 de noviembre de 2004 se inaugura la primera fase del nuevo Museo del Azulejo "Manolo Safont". La nueva sede ha permitido desarrollar las misiones fundamentales del Museo: conservar, investigar y difundir, y llevar a cabo múltiples actividades que permiten constatar el carácter supralocal y la proyección internacional del Museo.

Un año después, en 2005, se constituía la Fundación del Museo con el objetivo de valorizar y potenciar al máximo el patrimonio cultural, histórico y artístico, etnológico e industrial que conserva el mismo. En el Patronato de la

\footnotetext{
19 Acta del acuerdo adoptado en Pleno por el Ayuntamiento de Onda sobre la denominación del Museo del Azulejo, 2 de febrero de 2001, Onda, inédito.

${ }^{20}$ REDACCIÓN, El Full, junio 2002.
} 
Fundación hay representantes de la administraciones públicas (Generalitat, Diputación de Castellón y Ayuntamiento de Onda) y de todas las asociaciones e instituciones relacionadas con el sector azulejero, así como la propia Universitat Jaume I y numerosas industrias y empresas, que han sabido comprender la importancia real que tiene el Museo para el conjunto de la sociedad. ${ }^{21}$

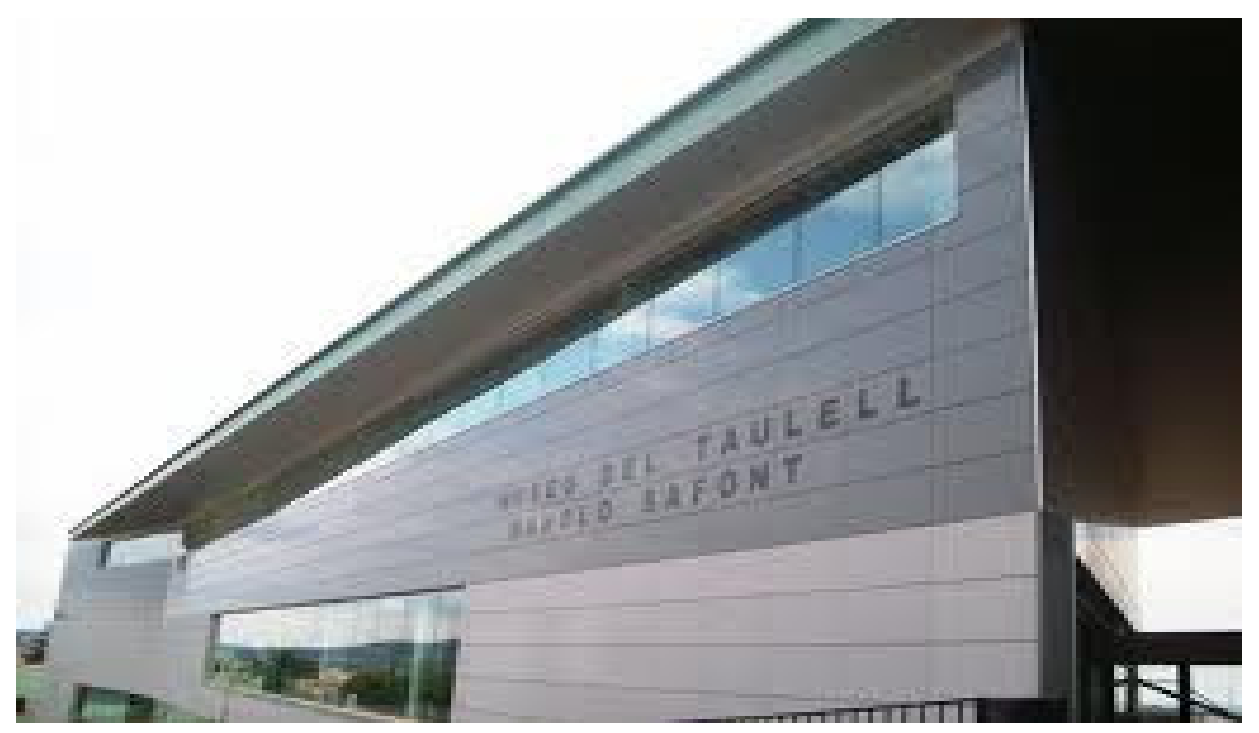

Figura 131: Museo del Azulejo Manolo Safont.

${ }^{21}$ http://ajuntament.onda.es/web/guest/home/journal_content/56/10124/43798? refererPlid $=10127$ 


\section{3.- LOS MOVIMIENTOS ARTÍSTICOS DE VANGUARDIA ALREDEDOR DE MANOLO SAFONT: LA SALETA MUNICIPAL DE ONDA}

El Castellón de la década de 1970 y 1980 no era un territorio muy proclive a la creación de grupos artísticos de vanguardia. Los artistas que abandonaron los cauces del arte tradicional, acabaron reuniéndose en un único grupo o colectivo que unía a creadores de diferentes disciplinas, con propuestas innovadoras, alejadas de los cánones sociales establecidos. Al no existir la posibilidad de encauzarse en diferentes corrientes, todos ellos acabaron creando un único grupo de vanguardia, compuesto por artistas que aunque separados por una diferencia de edad importante, se unieron a través de un arte que querían revolucionario e innovador.

La Saleta Municipal d'Exposicions d'Onda fue un espacio expositivo que estuvo unido a Safont tanto en su faceta de artista como en la de promotor cultural, ya que Safont, como director de La Saleta, consiguió en la década de 1970 que este espacio fuera todo un referente expositivo para los artistas de la época.

La Sala Municipal d'Onda, se encontraba ubicada en una pequeña sala anexa a la edificación del Ayuntamiento de Onda, en la plaza de El Plà. Una sala de exposiciones a la cual por su reducido tamaño se denominó cariñosamente "La Saleta", y en la cual desde 1971 hasta 2005 se expuso la mejor propuesta expositiva y divulgativa del arte contemporáneo valenciano. Se inauguraban exposiciones de forma periódica, cada quince días o cada mes, cita ineludible no sólo para artistas y estudiosos del arte, sino para gran parte de la población ondense que acudía expectante a ver las nuevas propuestas expositivas.

Manolo Safont luchó por crear esta Saleta y por mostrar el arte actual a los ciudadanos de Onda, y por ayudar y propiciar que los jóvenes y nuevos artistas emergentes, muchos de los cuales son hoy en día son consagradas figuras de la plástica contemporánea, tuvieran un lugar donde exponer y mostrar sus obras, dándoles una oportunidad de exponer que los circuitos artísticos más comerciales o las galerías de arte, no les concedían. Manolo, junto con su esposa Ana, se encargaba de seleccionar las exposiciones, los 
artistas, las obras, colgar los cuadros, preparar los catálogos, repartirlos y enviarlos por correo, vigilar las exposiciones así como abrir y cerrar La Saleta.

Manolo Safont fue el artífice que propició, gracias a su labor como gestor cultural, que la gente de Onda tuviera, a través de La Saleta, en una época sin Internet, la posibilidad de ver obras artísticas de las corrientes plásticas contemporáneas más vanguardistas. ${ }^{22}$

En ella se expusieron las obras de los mejores artistas del País Valencià. Era un espacio físico destinado a exposiciones temporales, de unos $80 \mathrm{~m}^{2}$, con paredes de hormigón y sin ningún tipo de revestimiento, cuya iluminación provenía de unas claraboyas situadas en el techo.

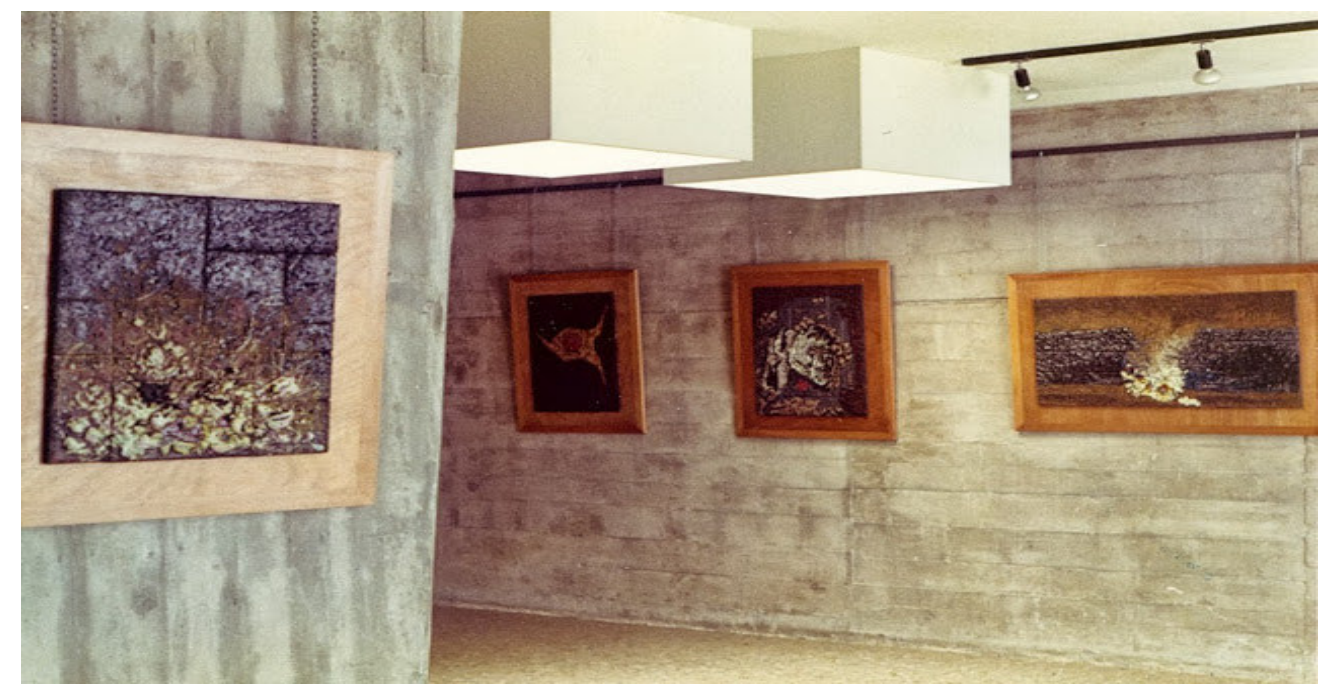

Figura 132: La Saleta de Onda.

En octubre de 1971, con motivo de las fiestas patronales de Fira d'Onda, se inauguró la Saleta con una exposición conjunta de la obra cerámica de los dos artistas ondenses que han tenido una mayor proyección, Angelina Alós y Manolo Safont.

En octubre de 1972, se presentó la muestra Arte castellonense de hoy, organizada por Safont, que a partir de ese momento, se repitió año tras año en el mes de octubre, y que en 1977, además de acoger la obra de artistas procedentes de las comarcas castellonenses, se amplió con artistas valencianos de otras comarcas, pasando a llamarse Art d'Avui al País Valencià, volviéndose a celebrar en 1978.

${ }^{22}$ Homenatge a La Saleta. Sala Municipal d'Exposicions d'Onda. Octubre 2005, Onda. 
En estas exposiciones colectivas participaron muchos de los artistas que habían expuesto también de forma individual en La Saleta. Esta década entre los últimos años del período franquista y la etapa de la transición fueron la época más activa y brillante de la sala.

Tras cinco años, en que no se realizaron exposiciones, por la política local y conflictos personales, en 1983 se retomó la actividad expositiva y volvió a realizarse la muestra colectiva, Art d'Avui al País Valencià con los mismos artistas que participaron en la edición de 1978. Safont era el "alma mater" de estas exposiciones colectivas que agrupaban a los pintores, ceramistas, grabadores y escultores más renovadores del panorama artístico castellonense. Incluso hubo una primera muestra, que tuvo lugar antes de que se inaugurara el nuevo edificio del ayuntamiento, en las paredes del ancho pasillo que daba entrada al bar "La Juventud", del Centro de Acción Católica, ubicado en la planta baja del edificio en que Safont tenía su vivienda-estudio. ${ }^{23}$

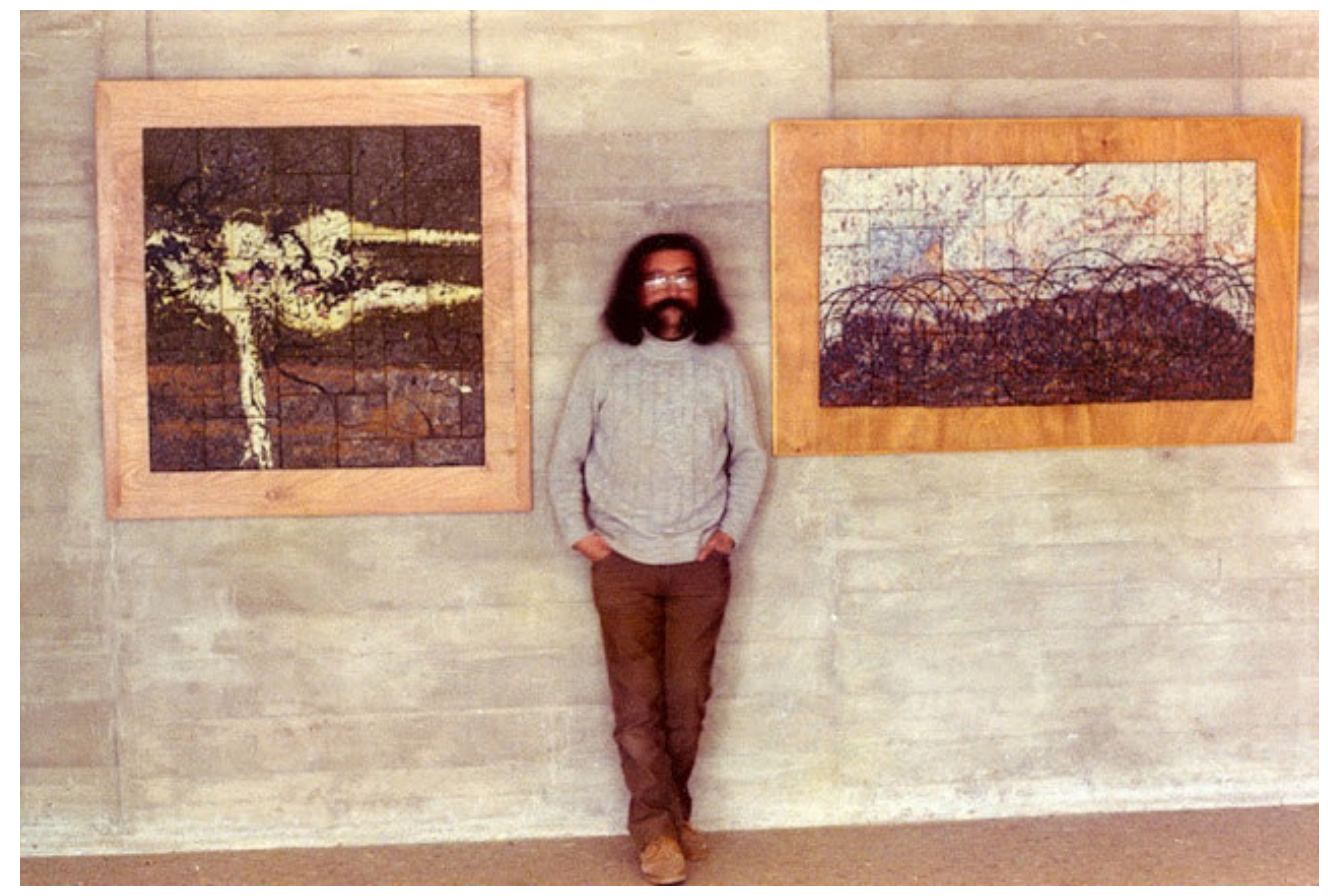

Figura 133: Safont exponiendo en La Saleta diciembre 1973 - enero 1974.

Pero la Saleta no era tan sólo una galería de arte en la que las obras estaban "decorando" paredes y peanas, esperando un comprador, la Saleta era un espacio vivo y dinámico, que mantenía la actividad expositiva durante todo

${ }^{23}$ PAtuel Chust, Pascual. Wences Rambla. Un itinerario plástico. Valencia, 1993. 
el invierno. Safont creó a los vecinos de Onda el hábito de acudir cada quince o treinta días a una nueva inauguración, y allí estaba Safont, que se había encargado de seleccionar al artista que exponía, las obras a mostrar, había colgado los cuadros, preparado el catalogo de la exposición, recogido y enviado las invitaciones a la inauguración, y no sólo eso, se encargaba de abrir, vigilar, cerrar, barrer y explicar a todo aquel que se acercara por la exposición la obra del artista que exponía. ${ }^{24}$

Los catálogos de estas exposiciones suponen una fuente de material indispensable para conocer y analizar el arte de vanguardia en Castellón y en la Comunidad Valenciana. Estos catálogos, además de reproducciones de las obras de los artistas participantes en la muestra, tienen también textos de presentación de intelectuales de la talla de Joan F. Mira, Vicent García Edo, Vicent Pitarch, Eduardo López-Chavarri, etc.

Safont le dio a la población de Onda, a través de La Saleta, una formación y conocimiento sobre el arte contemporáneo y de vanguardia que en pocos lugares podía encontrarse. Cada inauguración era un motivo de encuentro de todo aquel que tenía en Onda inquietudes artísticas y culturales o intelectuales, La Saleta se convirtió en un lugar de reunión y al que acudir cada fin de semana, muchos ondenses cuyos gustos artísticos no tenían por qué coincidir con la estética de las obras expuestas, acudían para elogiar o criticar tanto la obra expuesta, como al autor, o incluso a Safont, en calidad de director de la sala.

La Saleta se convirtió en un lugar de culto para los artistas consagrados, pero también los artistas emergentes tuvieron aquí su espacio y su tiempo, en La Saleta expusieron artistas de la talla de Manuel Boix, Angelina Alós, Pilar Dolz, Rosendo Esteller, Artur Heras, Antoni Miró, Marcelo Díaz, Traver Calzada, Pepe Agost, Rafael Armengol, Amat Bellés y, por supuesto, el propio Manolo Safont.

"La Saleta Municipal d'Onda és filla de Manolo però tambè la seua preocupació i el seu amor" (Jesús Huguet) ${ }^{25}$

\footnotetext{
${ }^{24}$ http://ca.wikipedia.org/wiki/Sala_Municipal_d\%27Exposicions_d\%27Onda

${ }^{25}$ Homenatge a La Saleta. Sala Municipal d'Exposicións d'Onda. La Saleta d'Onda, del 23 octubre al 20 noviembre 2005, Ajuntament d'Onda, Onda. "La Saleta Municipal de Onda es hija de Manolo, pero también su preocupación y su amor"
} 
En 2005, y tras más de 200 exposiciones y 35 años después de su creación, el derribo del edificio del Ayuntamiento y la construcción de una nueva edificación, conllevó también la desaparición de la Saleta, y como despedida, desde el Ayuntamiento de Onda se propuso repetir el esfuerzo que hizo Safont en tantas ocasiones y volver a reunir a los artistas participantes en la muestra de Art Valencià d'Avui de 1978 y 1983, con la exposición Homenatge a La Saleta. Sala Municipal d'Exposicions d'Onda. ${ }^{26}$

${ }^{26} \mathrm{Ibidem}$. http://www.elperiodicomediterraneo.com/noticias/comarcas/emotivorecuerdo-manolo-safont-saleta_188415.html 


\section{4.- RECONOCIMIENTO SOCIAL: PREMIOS Y HOMENAJES}

\subsection{1.- En el 70 aniversario del nacimiento de Manolo Safont}

A finales de febrero o inicios de marzo de 1998, Jesús Huguet, Carme Barceló y Daniel Gozalbo, amigos personales de Manolo, se reunieron para hablar y preparar algún pequeño acto-homenaje para celebrar el 70 aniversario de Manolo entre algunos amigos y amigas. $Y$ tal y como ha ocurrido siempre, cuando Safont es el tema o protagonista de algún evento, las previsiones se desbordaron, los amigos y conocidos de Manolo no quisieron perderse este evento. Quedaron a comer con Safont, en el local de la Unión Musical Santa Cecilia de Onda, y cuando Manolo esperaba comer con cuatro o cinco amigos, se encontró con una auténtica fiesta sorpresa, en la que se habían reunido más de 200 personas, y en la cual, además de hablar los asistentes al acto, como Vicent Pitarch, ${ }^{27}$ Jesús Huguet, ${ }^{28}$ Enrique Navarro, etc., también se leyeron telegramas y textos de muchos amigos que no pudieron asistir, pero no quisieron dejar pasar la ocasión para enviar textos referentes a su relación personal con Manolo, como Josep Palomero, ${ }^{29}$ cuyo texto fue leído por Lola Navarro, o el humorista gráfico Quique, con la viñeta publicada el 28 de marzo de 1998 en el Periódico Mediterráneo, o sencillamente cartas enviadas para excusar su ausencia y/o felicitar a Manolo, como el artista Antoni Miró; ${ }^{30}$ el escritor Joan F. Mira; ${ }^{31}$ el secretario general del Partit Socialista del País Valencià, Joan Romero; ${ }^{32}$ la presidenta de Amics dels Museus de la Comunitat

\footnotetext{
${ }^{27}$ PITARCH, Vicent. "Parlament en l'homenatge a Manolo Safont (Onda, 28.03.98)", 1998, inédito

${ }^{28}$ Huguet, Jesús. "Homenatge a Manolo Safont. Onda, 28 de març de 1998”, 1998, inédito.

${ }^{29}$ PALOMERo, Josep. "A Manolo Safont, en el seu setanté aniversari, i a Anna, per haver-los propiciat”, 1998, inédito.

${ }^{30}$ Carta enviada por Antoni Miró a Manolo Safont en marzo de 1998, inédita.

${ }^{31}$ Carta enviada por Joan F. Mira a Manolo Safont en marzo de 1998, inédita.

${ }^{32}$ Carta enviada por Joan Romero a Manolo Safont el 277/03/1998, inédita.
} 
Valenciana, Pilar Espona; ${ }^{33}$ el profesor Antoni Seva; ${ }^{34}$ el alcalde de Borriol, Nadal Escrig; ${ }^{35}$ el profesor Manuel Ardit; ${ }^{36}$ etc.

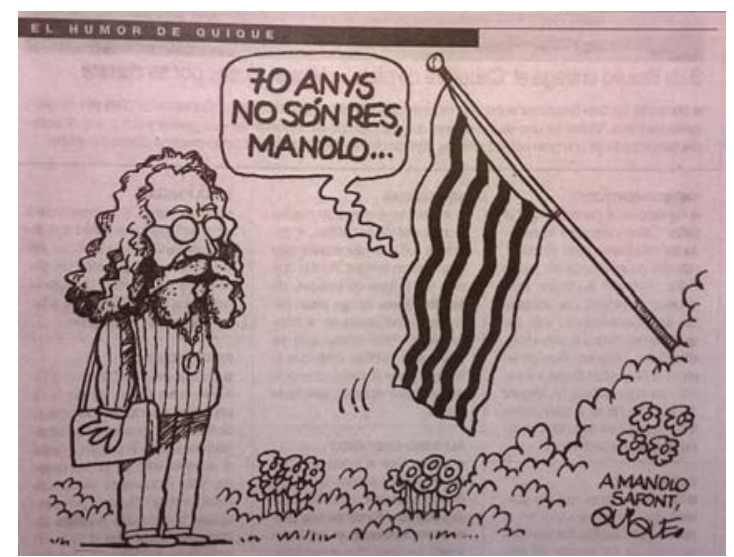

Figura 134: Viñeta de Quique.

Durante el acto, Enrique Navarro, alcalde de Onda, le comunicó a Safont, la decisión del Ayuntamiento de Onda de nombrar a la nueva calle que se acababa de urbanizar junto a su casa, Avinguda Manolo Safont.

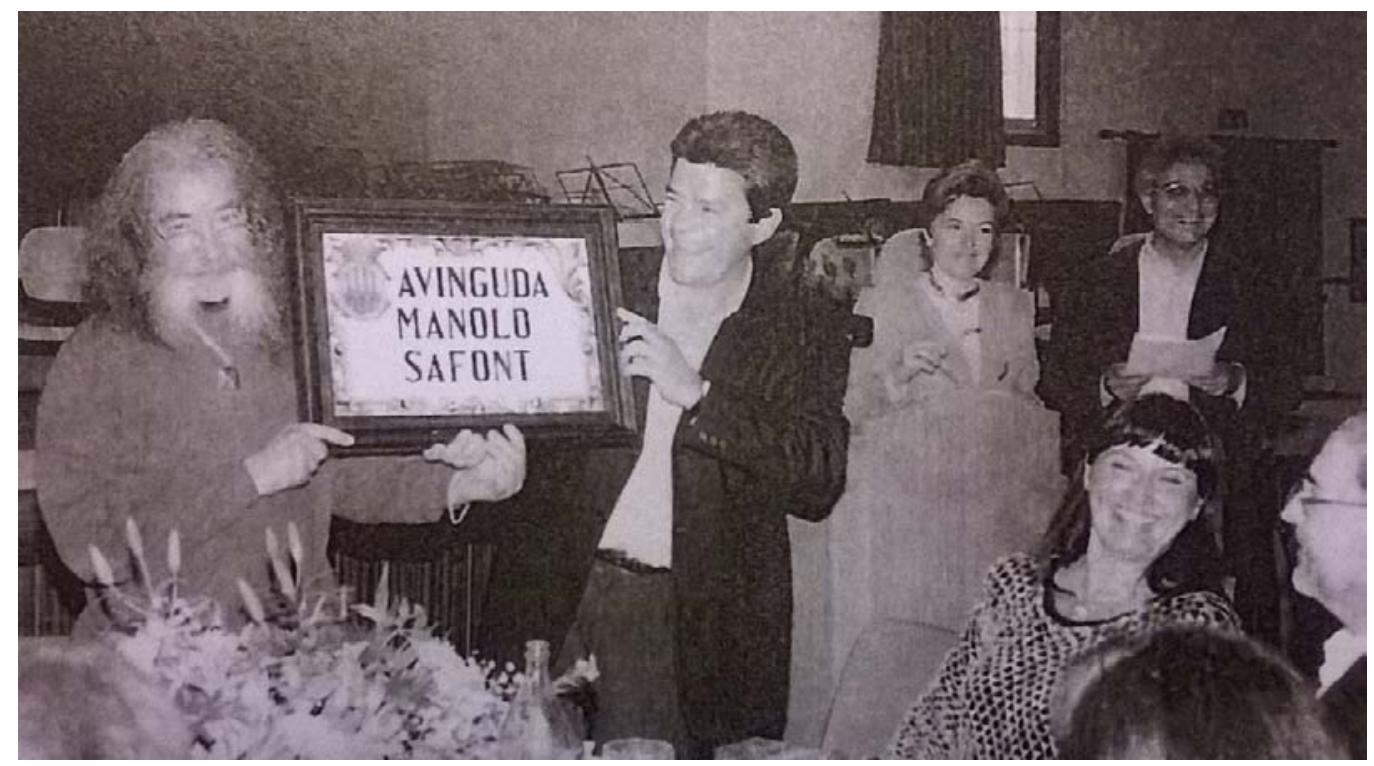

Figura 135: Manolo Safont y Enrique Navarro, alcalde de Onda.

${ }^{33}$ Carta enviada por Pilar Espona a Manolo Safont el 25/03/1998, inédita.

${ }^{34}$ Carta enviada por Antoni Seva a Manolo Safont el 25/03/1998, inédita.

${ }^{35}$ Carta enviada por Nadal Florenci Escrig González a Manolo Safont el 28/03/1998, inédita.

${ }^{36}$ Carta enviada por Manuel Ardit Lucas a Manolo Safont el 22/03/1998, inédita. 
También se redactó un manifiesto, que firmó la práctica totalidad de los asistentes al acto, solicitando al Ayuntamiento de Onda, que el Museo de Cerámica de Onda, lleve también el nombre de Manolo Safont, como reconocimiento hacia la persona que lo ideó, lo creó y lo dirigió.

\begin{abstract}
"Al Magnific Ajuntament d'Onda i Patronat del Museu de Ceràmica.

Manolo Safont no és solament un referent inqüestionable de l'art valencià modern sinò tambè una de les persones que amb major dedicació s'ha lliurat a la promoció cultural i l'extensió artística per tot arreu del País, especialment, del seu poble Onda. Pocs artistes han fet per la dignificació cultural i artística del seu lloc de naixement tant com ha fet Manolo. Revistes com "Panderola" o "Ibn al- Abbar", associacions o grups d'investigació i estudis, mestratge artístic o humà per a tots aquells que preteníen fer d'Onda objecte de les seues dedicacions intel.lectuals, etc... que han tingut la seua col.laboració desinteresada i el seu suport material.
\end{abstract}

Però d'entre totes les seues aportacions al patrimoni onder és el Museu de Ceràmica alló que ha comptat amb la seua més plena dedicación temporal, material i intel.lectual i la que s'ha estimat més fervorosament. Onda, estem segurs, no tindría un Museu de la qualitat i amb els fons actuals si no hagués existit un Manolo Safont que va fer d'eixa tasca una de les raons de la seua actuación i, encara, del seu viure. No solament va ser el primer Director del Museu, ell va ser qui amb l'esforç personal més autèntic i decidit va buscar i procurar bastir un fons i un projecte que avui considerem essentials per estudiar la ceràmica i el procés industrial i artístic d'Onda i de tot l'espai ceràmic valencià.

Per tot aixó, el signants d'aquest escrit ens dirigim al Magnífic Ajuntament d'Onda i al Patronat del Museu de Ceràmica per tal que designen l'esmentat Museu amb el nom de Manolo Safont, unint així aquell que ha fet possible l'existència del museu amb la seua obra més estimada"37

${ }^{37}$ Documento inédito. "Al Magnífico Ayuntamiento de Onda y Patronato del Museo de Cerámica. Manolo Safont no es solo un referente incuestionable del arte valenciano moderno sino también una de las personas que con mayor dedicación se ha dedicado a la promoción cultural y la extensión artística por todo el País, especialmente en su pueblo de Onda. Pocos artistas han hecho por la dignificación cultural y artística de su lugar de nacimiento tanto como ha hecho Manolo. Revistas como "Panderola" o "Ibn al-Abbar", asociaciones o grupos de investigación y estudios, enseñanzas artísticas o humanas para todos aquellos que pretendían hacer de Onda objeto de sus 
De este acto-homenaje se hicieron eco en prensa Antonio Gascó, con su artículo "D'un temps, d'un país"; Federico Canelles; ${ }^{38}$ el Periódico Mediterráneo ${ }^{39}$ y El País. ${ }^{40}$

\subsection{2.- El Museo del Azulejo de Onda también llevará el nombre de Manolo Safont}

El 25 de noviembre del año 2000, la prensa de Castellón, tanto en el Periódico Mediterráneo como en el Levante de Castellón, se hacen eco de que, en reconocimiento a su labor como impulsor de este proyecto durante más de 30 años, el Museo del Azulejo de Onda, pasará a llamarse Museo del Azulejo de Onda Manolo Safont. ${ }^{41}$

Esta propuesta parte desde la Corporación Municipal del Ayuntamiento de Onda, siendo aprobada en Pleno por unanimidad, y trasladada a la Dirección General de Patrimonio Artístico de la Generalitat Valenciana. También se le comunicó a Safont, ${ }^{42}$ y al hacerse pública esta decisión, Safont comenzó a recibir felicitaciones de particulares e instituciones, como Consuelo

dedicaciones intelectuales, etc... que han tenido su colaboración desinteresada y su soporte material. Pero de todas sus aportaciones al patrimonio ondense es el Museo de la Cerámica aquello que ha contado con su más plena dedicación temporal, material e intelectual y el que ha querido más fervorosamente. Onda, estamos seguros, no tendría un Museo de la calidad y con los fondos actuales si no hubiese existido un Manolo Safont que hizo de esa tarea una de las razones de sus actuaciones y, más, de su vida. No solo fue el primer Director del Museo, el fue quien con el esfuerzo personal más auténtico y decidido buscó y procuró abastecer unos fondos y un proyecto que hoy consideramos esenciales para estudiar la cerámica y el proceso industrial y artístico de Onda y de todo el espacio cerámico valenciano. Por todo ello los firmantes de este escrito nos dirigimos al magnífico Ayuntamiento de Onda y al Patronato del Museo de Cerámica para que designen el citado Museo con el nombre de Manolo Safont, uniendo así a aquel que ha hecho posible la existencia del museo con su obra más querida".

${ }^{38}$ CANELLES, Federico. "Per molts anys", El Full, marzo 1998.

39 MARTíneZ, Ángel. "70 años de homenaje al artista de la cerámica Manolo Safont", el Periódico Mediterráneo, 29 de marzo de 1998.

${ }^{40}$ MARISCAL, Paco. "Safont", El País, 2 de abril de 1998.

${ }^{41}$ ANDRÉS, Javier. "Nombres propios", el Periódico Mediterráneo, 30 noviembre 2000.

${ }^{42}$ Documento enviado por el Alcalde de Onda, Enrique Navarro a Manolo Safont el 14/02/1998, inédito. 
Císcar Casabán, Directora General de Promoció Cultural i Patrimoni Artístic de la Conselleria de Cultura, Educació i Ciència ${ }^{43}$; Fernando Romero Subirón, rector de la Universitat Jaume I, ${ }^{44}$ etc.

\subsection{3.- El calendario de Caixa Rural d'Onda de 2003}

En diciembre de 2002, la Caixa Rural d'Onda Nuestra Señora de la Esperanza, realizó su tradicional calendario mural, que todos los años y por estas fechas regala a todos sus socios y clientes. En esta ocasión, el calendario fue un homenaje a Manolo Safont y se ilustró enteramente con obras del artista. Fue tal el éxito de este calendario entre la población de Onda, que la tirada realizada se agotó en pocos días. ${ }^{45}$

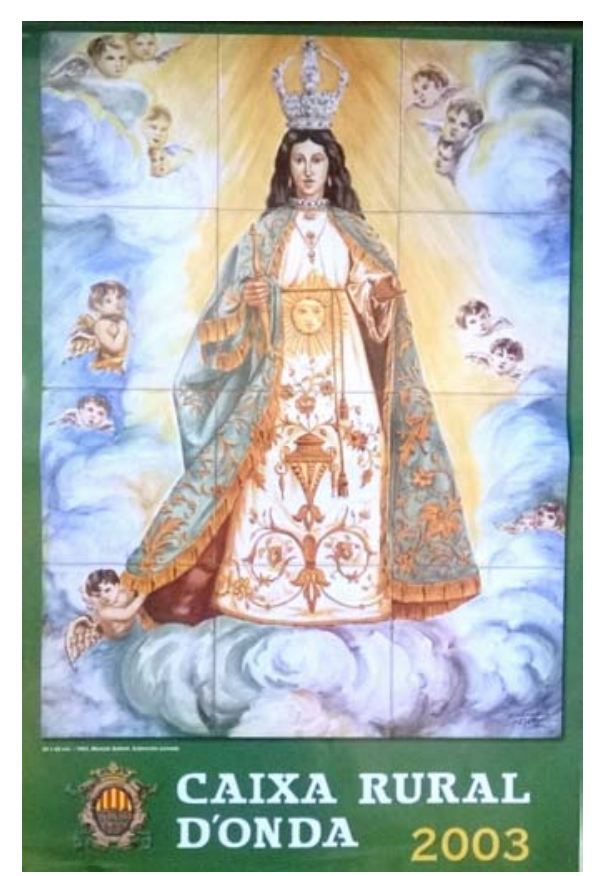

Figura 136: Calendario Caixa Rural d'Onda 2003.

\subsection{4.- Seny Onder 2002}

El Ateneo Cultural y Mercantil de Onda, concedió, reunidos en enero de 2003, el premio "Seny Onder 2002" al matrimonio formado por Manuel Safont

\footnotetext{
${ }^{43}$ Carta enviada por Consuelo Císcar a Manolo Safont el 23 /01/2001, inédita.

${ }^{44}$ Carta enviada por Fernando Romero Subirón a Manolo Safont el 12/03/2001, inédita.

${ }^{45}$ PANAdero, Amparo. "Arte”, el Periódico Mediterráneo, 5 enero 2003.
} 
Castelló y Ana-Teresa del Moral Fabregat, en atención a su onderismo compartido y al desarrollo de una labor privada y de alguna manera, también pública en cuanto a su trascendencia, por su trabajo, repercusión pública y considerando la gran importancia, altruismo y amor a Onda demostrado con la donación de su casa y jardines, con el patrimonio cultural y artístico común que en su casa se alberga, como futuro museo para la población de Onda. ${ }^{46}$

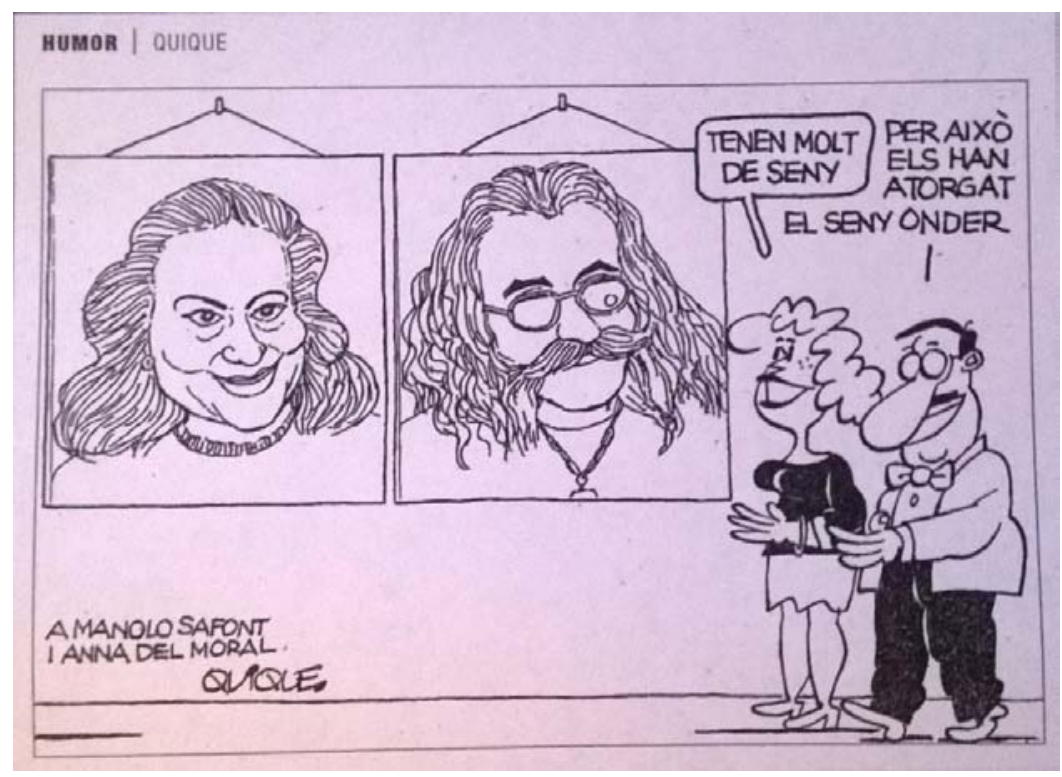

Figura 137: Viñeta de Quique.

El acto de entrega de este galardón se realizó tras una cena, a la que asistieron entre familiares, amigos, representantes de entidades locales y miembros de la corporación municipal, más de 200 personas, que quisieron compartir este emotivo acto con Manolo y Anita.

$Y$ al igual que ocurriera en anteriores ocasiones, el reconocimiento y premio hacia la figura de Safont con la entrega de este galardón, provocó la recepción de numerosas cartas de felicitación, de Enric Arenós Cortés ${ }^{47}$ del director del Museo de Bellas Artes de Castellón, Ferran Olucha; ${ }^{48}$ de la

\footnotetext{
${ }^{46}$ MARTíneZ, Ángel. "El 'seny onder' es para Ana del Moral y Manolo Safont", en el Periódico Mediterráneo, 7 febrero 2003, pág. 21.

${ }^{47}$ Carta enviada por Enric Arenós Cortés a Manolo Safont el 25/02/2003, inédita.

${ }^{48}$ Carta enviada por Ferran Olucha a Manolo Safont el 25/02/ 2003, inédita.
} 
compositora Matilde Salvador; ${ }^{49}$ etc. y de nuevo la prensa se hizo eco del evento, tanto el Periódico Mediterráneo, como El Mundo, El Full, etc. ${ }^{50}$

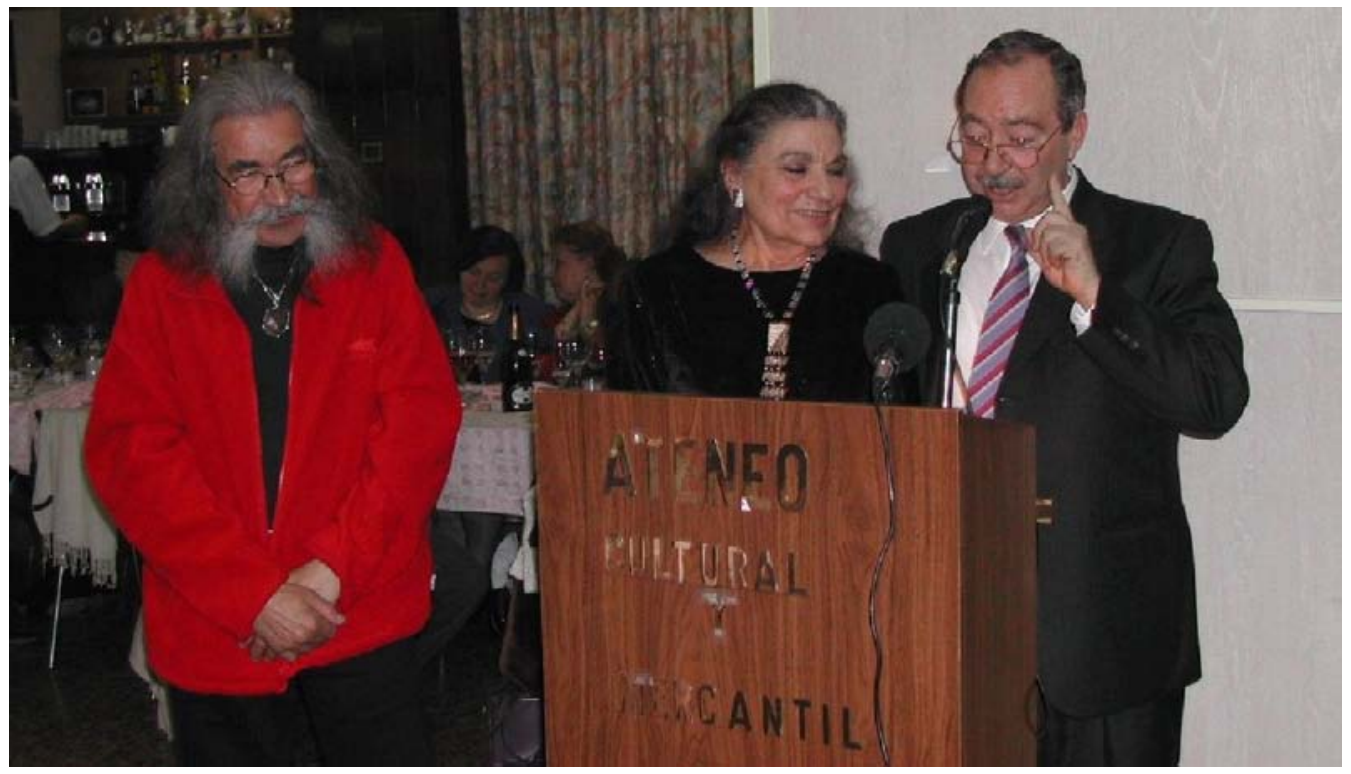

Figura 138: Manuel Galver, presidente del Ateneo Cultural y Mercantil de Onda, con Ana del Moral y Manolo Safont.

\subsection{5.- Premio Protagonistas de Castellón 2003}

En junio de 2003, Safont fue galardonado con el Premio Protagonistas de Castellón, en la modalidad de artes plásticas. Premio creado por Onda Cero Radio y patrocinado por Ceracasa Cerámica. ${ }^{51}$

\footnotetext{
${ }^{49}$ Carta enviada por Matilde Salvador a Manuel Galver, Presidente del Ateneo Cultural y Mercantil de Onda el 27/02/2003, inédito.

${ }^{50}$ QUIQUE, "Humor gráfico", en el Periódico Mediterráneo, 1 marzo 2003.

ALÓs, Víctor. "El Ateneo de Onda reconoce a Safont con el 'Seny Onder 2002'”, en El Mundo/Castellón al día, 2 marzo 2003, pág. 91.

PANADERO, Amparo. "Seny Onder", en El Periódico Mediterráneo, 2 marzo 2003.

MARTíneZ, Ángel. "Distinción del 'Seny Onder' de Onda. Tributo para Ana y Manolo", en El Periódico Mediterráneo, 2 marzo 2003, pág. 26.

REDACCIÓN. "Ana del Moral y Manolo Safont recibieron el 'Seny Onder' en un emotivo acto", en El Full, marzo 2003.

${ }^{51}$ Diploma del premio, inédito.
} 


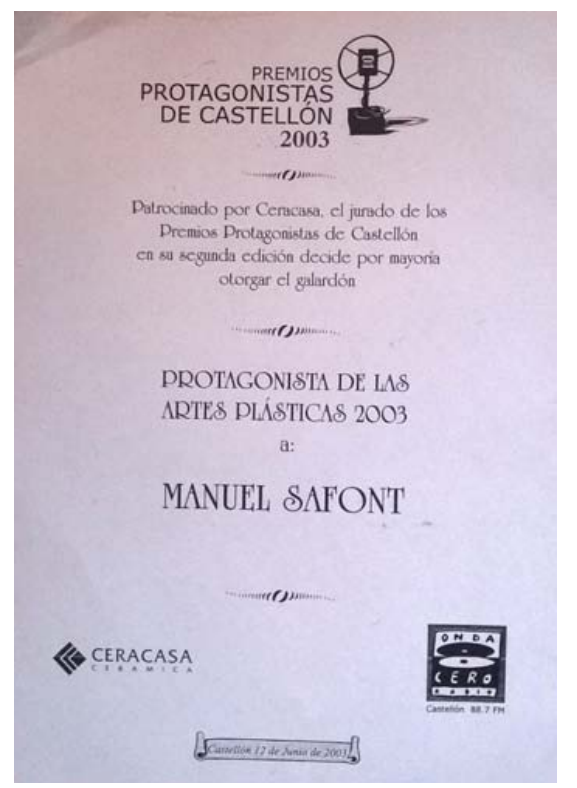

Figura 139: Diploma Premio Protagonistas 2003

\subsection{6.- XI Exfilnucol en octubre de 2004}

Con motivo de la inauguración del Museo del Azulejo Manolo Safont de Onda, en octubre de 2004, el "Círculo Filatélico Numismático y de Coleccionismo Ibn al-Abbar", creó un matasellos especial conmemorativo del acto, ${ }^{52}$ con una imagen del Museo del Azulejo Manolo Safont, así como una estampilla conmemorativa con el rostro de Safont. ${ }^{53}$
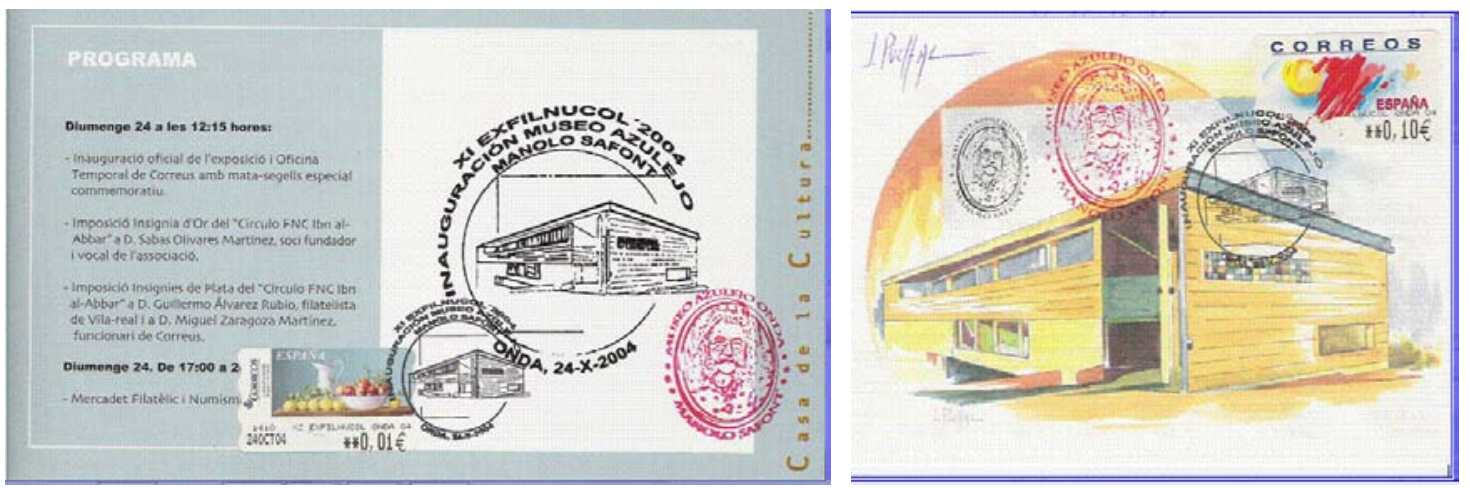

Figura 140: Matasellos conmemorativo Museo del Azulejo Manolo Safont.

\footnotetext{
${ }^{52}$ Exposicions Fira d'Onda 2004. Ajuntament d'Onda, Octubre 2004.

${ }^{53} \mathrm{http}: / / \mathrm{www}$. clubcece.es/pdf/exfilnuco2.htm.
} 


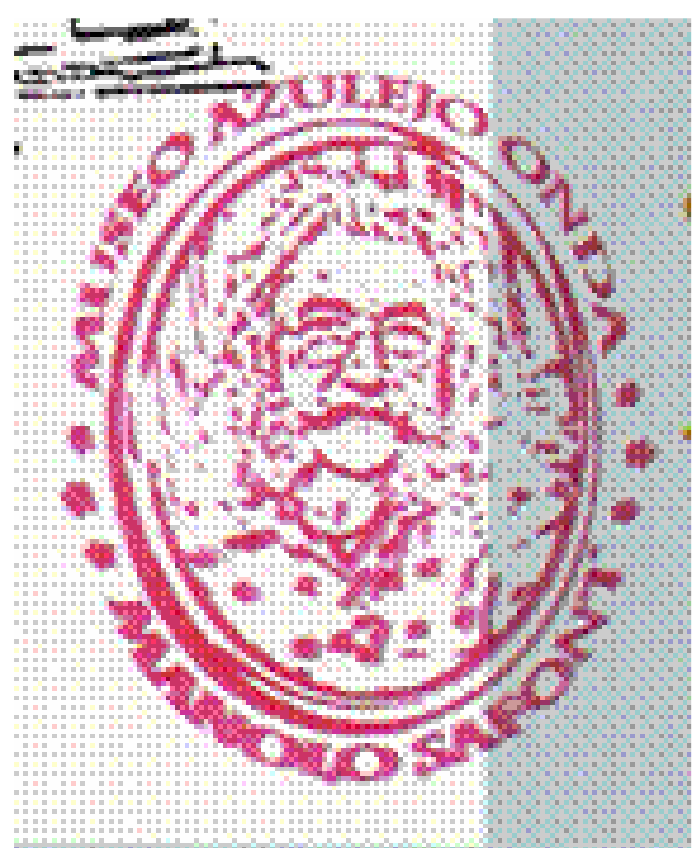

Figura 141: Matasellos conmemorativo Museo del Azulejo Manolo Safont

\subsection{7.- VI Premio Vicent Ventura en abril de 2005}

La Universitat de València y la Universitat Jaume I de Castelló, junto a la Unió de Periodistes Valencians, CCOO, STE-PV Sindicat de Treballadors de l'Ensenyament, UGT, Unió de Llauradors i Ramaders, organizadores del Premio Vicent Ventura, decidieron otorgarlo en su VI edición, en abril de 2005, al ceramista de Onda Manolo Safont. ${ }^{54}$ Este galardón fue creado en memoria y homenaje al periodista Vicent Ventura y distingue la trayectoria cívica, democrática y de compromiso de una persona o colectivo que haya trabajado a favor de la Comunidad. ${ }^{55}$

La entrega del premio se realizó en el Aula Magna del edificio histórico de La Nau, en un acto académico en el que intervinieron los rectores de la Universitat de València, Francisco Tomás, y de la Universitat Jaume I, Francisco Toledo, y el profesor de la Universitat Pompeu i Fabra, Antoni Seva.

De nuevo, los amigos y conocidos de Manolo, quisieron festejar con él este nuevo premio, y se organizó en Onda una cena, a la que además de Manolo y Anita, y amigos personales de ellos, acudió también la corporación

\footnotetext{
${ }^{54}$ REDACCIÓN, "Manolo Safont rep el premi Vicent Ventura", en El Full, n¹029, 15 abril 2005.

55 RedAcCión, "EL ceramista Manolo Safont gana el premio Vicent Ventura", en Levante EL MERCANTIL VALENCIANO, 14 abril 2005, pág. 63.
} 
municipal del Ayuntamiento de Onda; la vicerectora de promoción universitaria, sociocultural y lingüística de la UJI, Margarita Porcar; los profesores Manuel Ardit de la UV; Antoni Seva, de la Universitat Pompeu Fabra; así como los secretarios de CCOO y UGT País Valencià. ${ }^{56}$

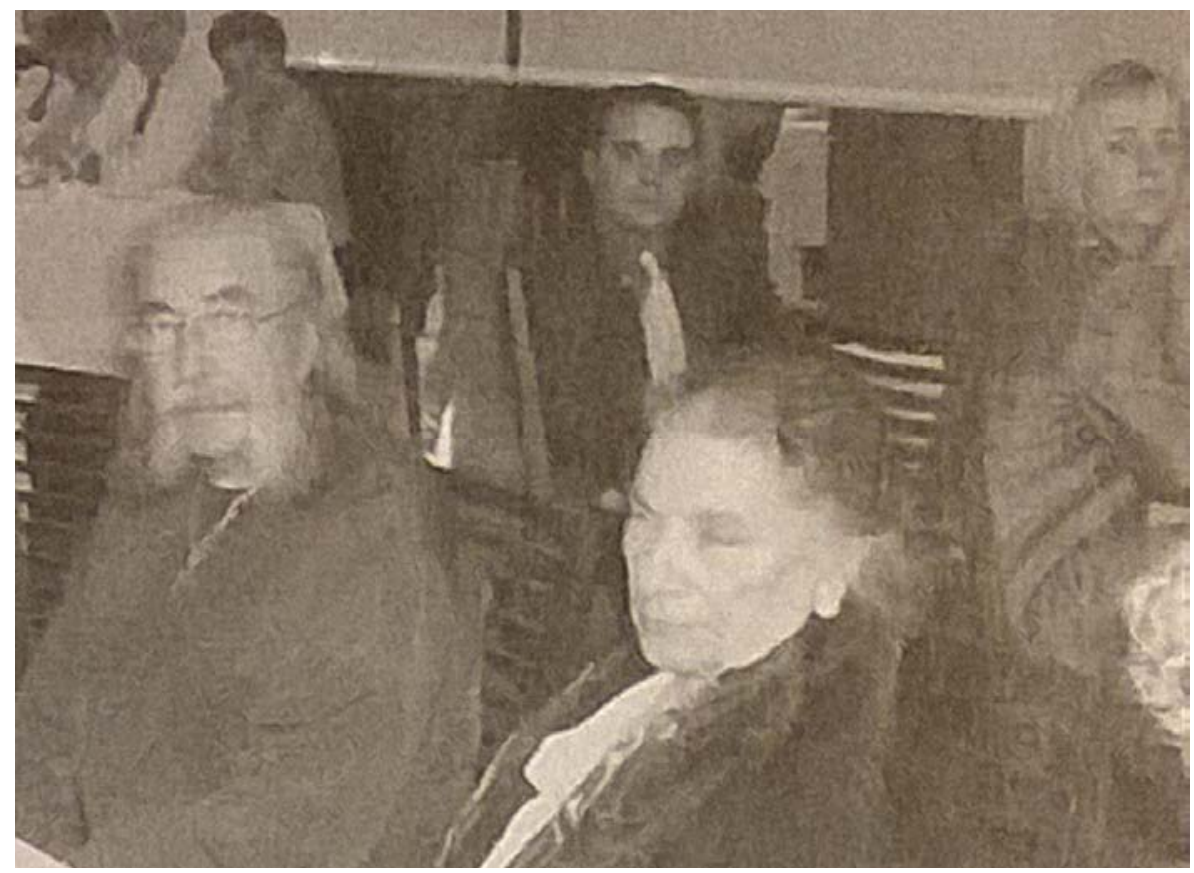

Figura 142: Cena homenaje a Manolo Safont.

\subsection{8.- Fallecimiento de Manolo Safont}

El 24 de noviembre de 2005, tras una convalecencia de varios meses, Safont falleció en su domicilio de Onda. Desde el Ayuntamiento de Onda se organizó un acto oficial, instalando el 25 de noviembre de 2005, la capilla ardiente en el Museo del Azulejo Manolo Safont. Posteriormente, se ofició un funeral en la Iglesia Parroquial de Nuestra Señora de la Asunción de Onda, al que acudieron numerosos amigos, familiares y personalidades destacadas del

\footnotetext{
${ }^{56}$ SILVESTRE, Jacobo. "Onda rinde tributos al ceramista Manolo Safont", en El MundoCastellón al Día, 18 abril 2005.

REDACCIÓN, "El ceramista Manolo Safont gana el premio Vicent Ventura", en Heraldo de Castellón, 14 de abril de 2005.

REDACCIÓN, "El ceramista Manolo Safont, homenajeado en Onda tras la concesión del VI Premio Vicent Ventura", en El Full, n¹030, 22 abril 2005.

REDACCIÓN, "El ceramista Manolo Safont recibió un homenaje", en La Rodalía, n²0, mayo 2005.

REDACCIÓN, "Onda se rinde al genial arte de Manolo Safont", en Crónica d'Onda, mayo y junio de 2005, pág. 13.
} 
mundo de la política y la cultura de la Comunidad Valenciana. La noticia del fallecimiento de Safont fue ampliamente difundida por la prensa escrita. ${ }^{57}$

${ }^{57}$ ORTEGA, L. "Fallece el célebre artista de Onda Manolo Safont", en Las Provincias, 25 noviembre 2005, pág. 12.

GARCíA, Cristina. "Fallece el ceramista Manolo Safont", en Heraldo de Castellón, 25 noviembre 2005, pág 36.

GASCÓ, Antonio. "Fallece el ceramista Manolo Safont", en Levante EL MERCANTIL VALENCIANO, 25 noviembre 2005, pág. 71.

RODRígueZ, Carlos. "Fallece Manolo Safont", en Levante EL MERCANTIL VALENCIANO, 25 noviembre 2005, pág. 72.

D.G./L.S. "In memoriam: Manolo Safont", en El Periódico Mediterráneo, 25 noviembre 2005.

MARTínez, A. "Adiós a un gran artista", en El Periódico Mediterráneo, 25 noviembre 2005, pág. 27.

FABRA, María. "Manolo Safont, el alquimista de la cerámica", en El País, 25 noviembre 2005, pág. 57.

EUROPA PRESS, "Font de Mora lamenta la pèrdua del ceramista d'Onda Manolo Safont i destaca la seua generositat i qualitat artistica", en http://es.news.yahoo,com /051125/4/4fa6k.html, 25 noviembre 2005.

REDACCIÓN. "Onda dice adiós a Manolo Safont", en El País, 26 noviembre 2005. RODRÍGUEZ, Carlos. "Onda despide emocionada a Safont", en Levante EL MERCANTIL VALENCIANO, 26 noviembre 2005. pág. 55.

$\mathrm{R}$, C. "Manolo Safont. Onda despide al reconocido artista", en Levante EL MERCANTIL VALENCIANO, 26 noviembre 2005, pág. 57.

MARTíneZ, Ángel. "Hasta siempre, maestro", en El Periódico Mediterráneo, 26 noviembre 2005, pág. 27.

PUIG, Ximo. "Tots els colors del roig. A Manolo Safont, una ànima lliure", el Periódico Mediterráneo, 26 noviembre 2005, pág. 27.

ALBALAT, Antoni. "La Intifada del fang", en Levante EL MERCANTIL VALENCIANO, 27 noviembre 2005, pág. 7.

RedAcción. "Mor Manolo Safont", Acció Cultural del País Valencià, 27 noviembre 2005.

CANelles I Roca, Federico. "Pels segles dels segles", en El Full, n¹057, 2 diciembre 2005.

REDACCIÓN. "Adiós a un gran artista y ondense", en El Full, n¹057, 2 diciembre 2005. NAVARRO ANDREU, Enrique. "Manolo Safont, un projecte, un poble", en El Full, n¹057, 2 diciembre 2005.

REDACCIÓN. "Onda dio el último adiós al genial Manolo Safont", en Crònica d'Onda, Diciembre del 2005 y enero del 2006, pág. 9.

ESTALL I POLES, Vicent. "Manolo Safont: Un museu, un llegat i un compromís", en Crònica d'Onda, Diciembre del 2005 y enero del 2006, pág. 10.

GozALBO, Daniel. "Manolo Safont, in memoriam", en El Temps, 6 decembre 2005, pág. 79. 


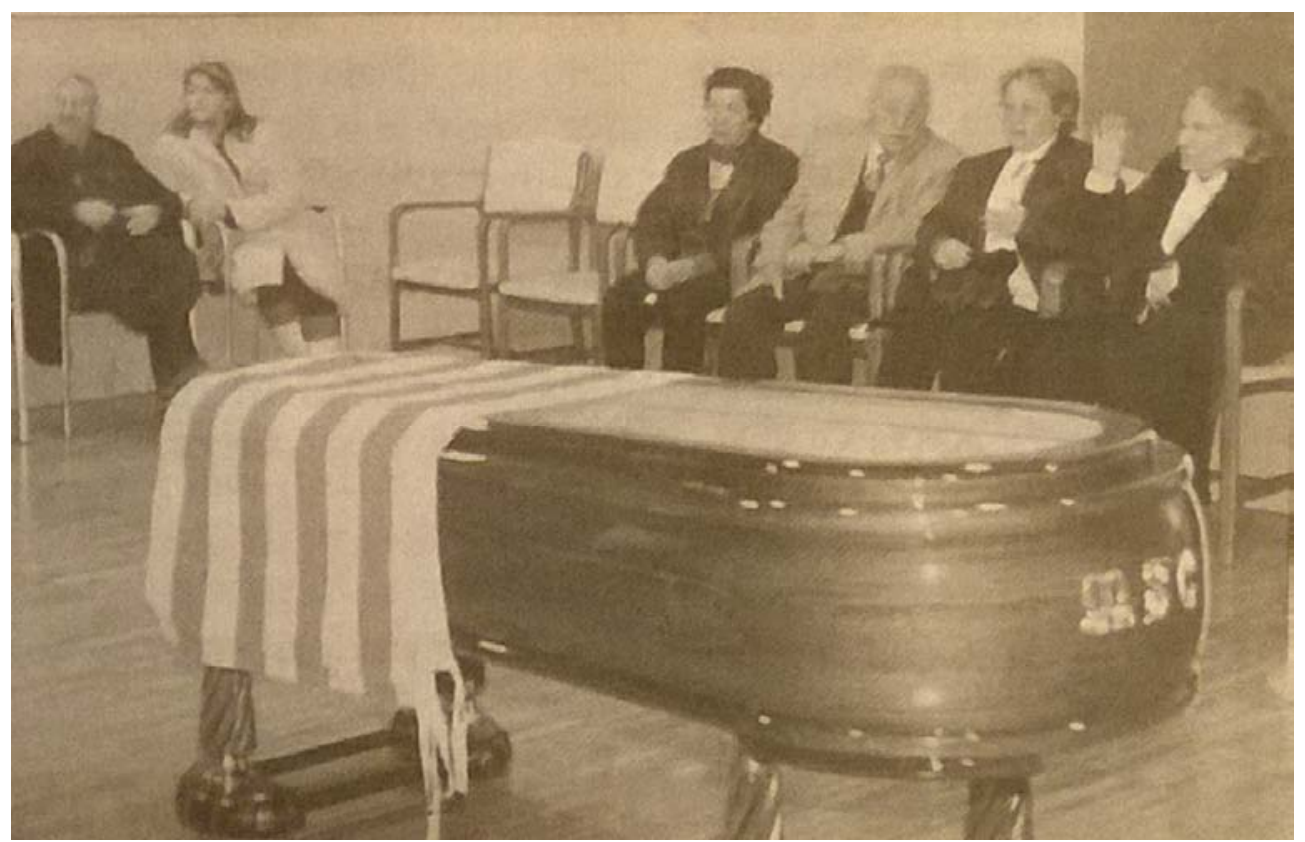

Figura 143: Capilla ardiente en el Museo del Azulejo Manolo Safont.

\subsection{9.- Celebración del Día Internacional de los Museos, en mayo 2006, en el Museo del Azulejo Manolo Safont}

En mayo de 2006, como conmemoración del Día Internacional de los Museos, en el Museo del Azulejo Manolo Safont, se inauguró una muestra artística "La obra de Manolo Safont vista por los niños y las niñas. Los artistas del colegio público Pío XII", en la que se expusieron los trabajos del alumnado de cuatro y cinco años de este centro escolar de Onda, realizados en torno a la obra artística de Safont. Los trabajos realizados también se expusieron en el CEIP Pío XII. ${ }^{58}$

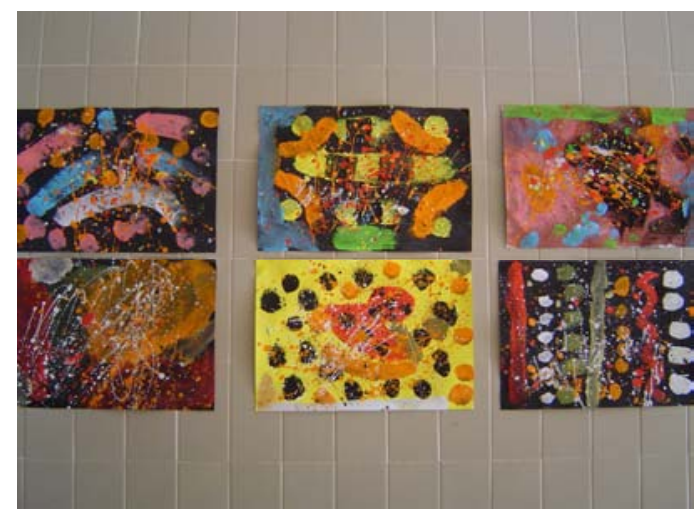

Figura 144: Trabajos del alumnado del CEIP PÍO XII.

\footnotetext{
${ }^{58}$ REDACCIÓN, "Onda celebra el Día de los Museos con una exposición infantil sobre la obra de Safont", en El Full, n¹080, 26 mayo 2006
} 


\subsubsection{0.- Ampliación del Parque de la Cerámica de Onda en marzo 2007}

En marzo de 2007, se acometió la segunda fase de construcción del Parque de la Cerámica de Onda, y se inició un proyecto según el cual, toda aquella persona que hubiera trabajado en el sector cerámico, podrá inscribir su nombre, o el de sus antepasados, en un pequeño azulejo, que se instalará en un muro del parque. Las piezas creadas para este homenaje a los trabajadores del mundo cerámico, son unos pequeños azulejos romboidales, y para la presentación de este proyecto y con carácter de homenaje, la primera placa que se creó y que sirvió al Ayuntamiento para la presentación y explicación del proyecto, fue la que se hizo con el nombre de Manolo Safont Castelló.

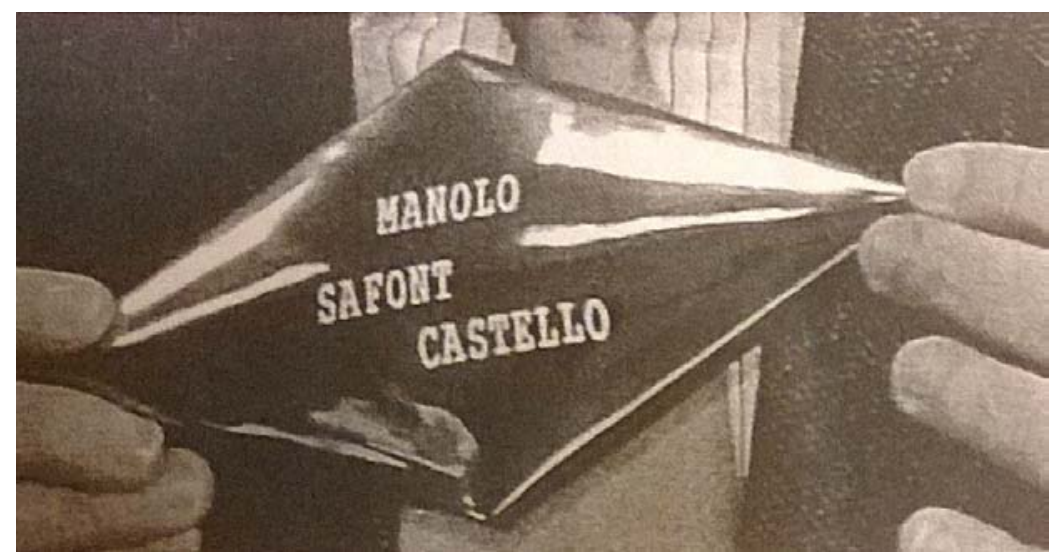

Figura 145: Pieza romboidal Parque de la cerámica de Onda.

\subsubsection{1.- Homenaje a Safont en el Cau de l'Art, Lucena, en julio de 2007}

En julio de 2007, el Cau de l'Art de Lucena, bajo la dirección de Jesús Broch y Eloisa Tarazona, organizó una exposición colectiva en memoria del ceramista ondense Manolo Safont. Más de 200 personas relacionadas con el mundo del arte, su viuda Ana del Moral, y amigos personales de Safont, se dieron cita en Lucena para rendirle homenaje. Antonio Gascó, crítico de arte, y Antoni Rollo, delegado de las comarcas de Castelló de Acció Cultural, ensalzaron la trayectoria artística e ideológica de Safont, como referente histórico de la cultura castellonense. 


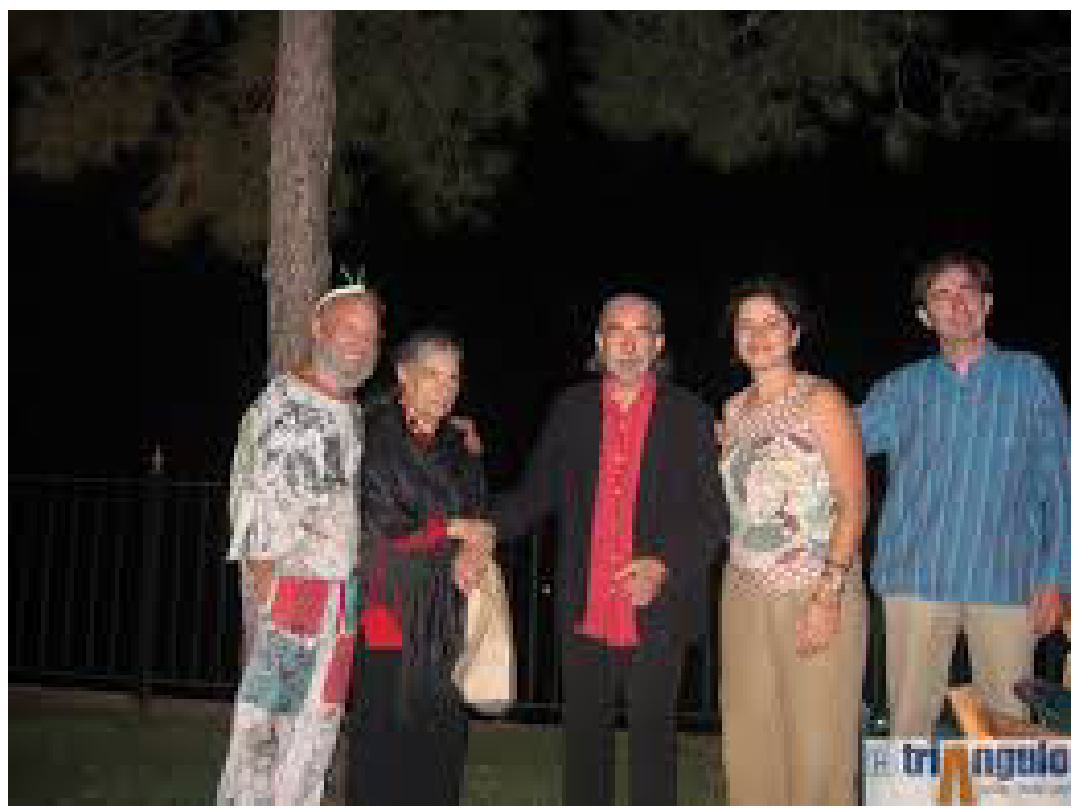

Figura 146: Safont con su esposa Ana, el artista Ripollés, y Eloisa Tarazona y Jesús Broch, gestores del Cau de l'Art. Verano 2005.

Los poetas Antoni Arbeloa y Román Bernad, realizaron un pequeño recital poético dedicado a Safont. La muestra artística estuvo compuesta por más de 50 obras de diversos artistas: Antoni Albalat, Mikel Bodajós, Luis Bolumar, Vicent Forés, Marja Maya Jankovic, Wences Rambla, Joan Ripollés, Manolo Sales, Taló, Eloisa Tarazona, Traver Calzada y Melchor Zapata. Asistieron en representación del mundo político los diputados Miguel Ángel Mulet y María Gràcia Molés; y $\mathrm{M}^{\mathrm{a}}$ Carmen Aguilella y Rosarín Fabra, como representantes del Ayuntamiento de Onda, también asistió Margarita Porcar, como vicerrectora de cultura de la UJI. ${ }^{59}$

\subsubsection{2.- El Ayuntamiento de Castellón dedica una calle al ceramista Manolo Safont en octubre de 2008}

El 6 de Octubre de 2008, la teniente de alcalde de Servicios a la Ciudadanía, Carmen Amorós, comunicó que el Ayuntamiento de Castellón, iba a dedicar una calle al ceramista Manolo Safont y otros tres viales al Agua, la Tierra y el Fuego, ubicados en la zona de la UJI, en el distrito Oeste de la capital de La Plana, dando luz verde a una propuesta del Vicerrectorado de Infraestructuras de la UJI. La elección de los nombres de los otros tres viales,

\footnotetext{
${ }^{59}$ MARINER, A. “Homenaje a Safont”, en Arrels, n40, 25 julio 2007, pág. 29.
} 
fue por su referencia a los tres elementos esenciales para la elaboración de la cerámica y por están muy ligados a la labor del artista Manolo Safont como son la tierra, el fuego y el agua. ${ }^{60}$

${ }^{60} \mathrm{http}: / / \mathrm{www}$.elperiodicomediterraneo.com/noticias/castellon/dedicaran-calle-alceramista-safont_412307.html http://castello.es/web30/pages/noticias_web10.php?cod=2701 


\section{CAPÍTULO 5 \\ LA PRESENCIA DE MANOLO SAFONT}

\section{1.- MANOLO SAFONT: LAS EXPOSICIONES}

Desde 1961, Safont realiza exposiciones individuales periódicamente, en salas de exposiciones, galerías de arte y museos, tanto nacionales como extranjeros. Es habitual que un artista exponga a lo largo de su vida artística en una misma galería en repetidas ocasiones, ya que suelen ejercer de marchantes de arte, así Safont expuso en diversas ocasiones en la Galería Cànem de Castellón, pero también realizó más de una exposición en otras galerías como las celebradas en 1973 y 1975 en la Sala Durán de Madrid y las exposiciones consecutivas realizadas en 1970 y 1971 en el Círculo Mercantil e Industrial de Castellón

No es extraño que el lugar en el que más exposiciones realice sea la Sala Municipal de Exposiciones de Onda "La Saleta", en la que expone de forma individual en 1973, 1975, 1978, 1989 y 1999, ya que Safont, además de residir en Onda, fue el promotor y creador de este espacio expositivo.

Destacados autores y artistas como José Luís Castillo Puche, Eduardo Codina, Alfonso Pérez Sánchez, Víctor Nieto Alcaide, Trinidad Pacheco, Ferran Olucha, Vicent García Edo, Miguel Signes, Jesús Huguet, Jaime Jiménez de Haro, Amat Bellés, Wences Rambla, Francesc Miralles, Felipe Vicente Garín Llombart, Vicent Andrés Estellés, Joan Fuster, etc. participaron con sus textos en los numerosos catálogos que se han editado de las exposiciones de Safont.

También participó junto a otros artistas en numerosas exposiciones colectivas y muestras de arte, siendo representativas de su carrera artística sus periódicas participaciones en la muestra colectiva Art Castellonenc d'Avui celebradas en La Saleta de Onda, así como en el Salón de Mayo de Barcelona y en la Setmana d'Art de Burriana. 


\subsection{1.- Exposiciones Individuales}

1961

- Sala Estilo de Castellón. Esta fue la primera exposición individual de la obra de Safont. Se editó un catálogo con texto de Eduardo 1962 Codina Armengot.

- Manuel Safont. Sala de Exposiciones, Dirección General de Bellas Artes, Madrid. Se editó un catálogo con textos del escritor y periodista Jose Luis Castillo-Puche.

1966

- Ateneo Cultural de Castellón.

1969

1970

- Trilce (Barcelona)

- Manolo Safont. Círculo Mercantil e Industrial de Castellón, del 28 de febrero al 15 de marzo. Exposición inaugural de la sala de exposiciones. Se editó un catálogo con texto de Joan Fuster.

1971

- Manolo Safont, pintor ceramista. Círculo Mercantil e Industrial de Castellón, del 13 al 27 de marzo. Se editó un catálogo con texto de Alfonso E. Pérez Sánchez, subdirector del Museo del Prado.

1973

- Manolo Safont, Sala Ramón Durán (Madrid), febrero-marzo. Se editó un catálogo con textos de Víctor Nieto Alcaide.

- Ayuntamiento de Viver.

- Manolo Safont, en la Sala d'Exposicions Municipals d'Onda, desde diciembre de 1973 a enero de 1974.

1974

- Galería Subex (Barcelona). Se editó un catálogo con texto de Francesc Miralles.

1975

- Safont. Sala Municipal de Onda

- Safont. Pintures ceràmiques, Galería Cànem de Castellón, del 28 de febrero al 26 de marzo.

- Galería Ramón Durán de Madrid. Se editó un catálogo con texto de Miguel Signes.

1978

- Galería Lame-Lierre, en Avignon (Francia)

- Safont. Sala Municipal de Onda, del 23 al 30 de septiembre. Se editó un catálogo con texto de Vicent García Edo.

- Safont. Sala Goya de la Casa de España en París, del 5 al 15 de octubre. Se editó un catálogo con textos de Vicente García Edo y Joan Fuster.

1979

- Bree (Bélgica)

- A Opheylissem en Hélécine (Bélgica) 
- Safont. Museo Nacional de Cerámica de Valencia, del 3 al 30 de marzo. Se editó un catálogo con textos de Felipe Vicente Garín Llombart y Joan Fuster.

- Safont. Ceràmiques. Biblioteca Municipal de Vila-Real (Castellón), del 17 al 31 de mayo. Se editó un catálogo con texto del poeta Vicent Andrés Estellés.

- Manolo Safont, en la Sala Municipal d'Exposicions del Ayuntamiento de Torrent (Valencia), del 2 al 21 de noviembre. Se editó un catálogo con textos de Vicent Andrés Estellés y Joan Fuster.

- Manolo Safont, en la Caja de Ahorros de Alicante y Murcia en Elche (Alicante), del 24 noviembre al 6 de diciembre. Se editó un breve catálogo de la exposición.

- Museu d'Art Contemporani d'Alacant, diciembre.

- Ayuntamiento de Riba-Roja (Valencia)

- Ayuntamiento de Manises (Valencia)

- Ayuntamiento de Puerto de Sagunto (Valencia)

- Galería Expo d'Art de la Vall d'Uixó (Castellón)

- Safont, Museu de Ceràmica del Palau de Montjuïc de Barcelona, del 20 de octubre al 20 de noviembre. Se editó un catálogo de esta exposición con texto de Trinidad Sánchez Pacheco.

1983

- Manolo Safont, Fontana d'Or en Girona, del 28 de marzo al 16 de abril. Se editó un catálogo de esta exposición con texto de Francesc Miralles.

- Safont. Ceràmica, en el Palau Oliver de Boteller de Tortosa (Tarragona), del 9 al 16 de mayo. Se editó un catálogo de esta exposición con textos de Vicent Andrés Estellés y Joan Fuster.

1984

1985

- Caja Rural de Vila-Real (Castellón)

Casa de Cultura de Soneja (Castellón)

- Safont, Casa de la Cultura de la Pobla Tornesa (Castellón), verano. Se editó un catálogo con textos de Ciprià Ciscar i Casaban, Conseller de Cultura, Educació i Ciència; Vicent Renau i Castellet, alcalde de la Pobla Tornesa; Francesc Miralles; Amat Bellés; Ximo Puig; Ramón Monfort Salvador; Ferran Olucha Montins; Jesús Huguet y Jaime Jiménez de Haro, director de la Escuela de Artes y Oficios de Castellón. 
- Safont, Ayuntamiento de Castellón, desde el 22 de diciembre al 12 de enero de 1989. Se editó un catálogo de esta exposición con textos de Daniel Gozalbo, alcalde de Castellón, y Francesc Miralles.

- Safont in Brussel, Hotel Carlemagne de Bruselas, del 9 de marzo al 23 de abril. Se editó un catálogo de esta exposición con textos de Ferran Olucha, Jesús Huguet.

- Safont-Koninklijk-Atheneum I, Hasselt.

- Safont, La Saleta de Onda, desde diciembre de 1989 al 12 de enero de 1990.

- Safont. Ajuntament de Castelló (Castelló)

- M. Safont, Octubre Galeria d'Art, Universitat Jaume I de Castellón, del 13 de marzo al 12 de abril. Se editó un breve catálogo de esta exposición con texto de Ferran Olucha.

1994

- Safont-Multi-Art 94, Escola-Llar de Morella, Castellón, agosto. Se editó un breve catálogo.

1995

- Manolo Safont, Galería Cànem de Castellón, del 11 de mayo al 16 de junio. Se editó una carpeta con láminas con reproducciones de las obras de Safont.

1998

- Safont, en el Ayuntamiento de Morella. 9 de octubre.

1999

- Safont. Saleta Municipal de Onda. Octubre.

2001

- Sala de exposiciones Edificio Social Caja Rural Nuestra Señora de la Esperanza de Onda, del 23 de diciembre de 2001 al 6 de enero de 2002.

2004

- Manolo Safont, un Museu, un llegat, un compromís, Museu del Azulejo "Manolo Safont", inaugurada el 27 de noviembre 2004, Onda. De esta inauguración el Ayuntamiento de Onda edita un tríptico.

2005

- En verano de 2005 participó en una exposición realizada en el Cau de l'Art en Lucena (Castellón).

2006

- Safont, stand que el Museo del Azulejo Manolo Safont tuvo en la XXIV edición de la Feria Cevisama, celebrada del 7 al 11 de febrero de 2006, en Valencia.

2013

- Manolo Safont, un museu, un llegat. Museo del Azulejo Manolo Safont, 17 de mayo. 


\subsection{2.- Exposiciones colectivas}

1961

- V Salón de Mayo de Barcelona. Invitado por la organización. 1962

- VI Salón de Mayo de Barcelona.

1963

- VII Salón de Mayo de Barcelona.

1964

- VIII Salón de Mayo de Barcelona.

1965

- IX Salón de Mayo de Barcelona.

1966

- X Salón de Mayo de Barcelona.

- Exposición Nacional de Cerámica de Madrid.

- Exposición Premio Ciudad de Barcelona.

1967

- XI Salón de Mayo de Barcelona.

- Sant Miquel de Cuixà.

- Cercle Artístic de Sant Lluc (Barcelona)

1968

- XII Salón de Mayo de Barcelona.

1970

- Exposició d'Art Contemporani, Cullera (Valencia)

- Viver (Castellón)

1971

- Exposición Manolo Safont y Angelina Alós. Sala Municipal d'Exposicions d'Onda, octubre. Exposición inaugural de la Sala Municipal de Exposiciones de Onda (Castellón).

1972

- Feria Monográfica Nacional de Vidrio y Cerámica, en Valencia, en la cual Safont fue invitado de honor.

- Ayuntamiento de Viver (Castellón)

- Il edición de la muestra Art Castellonenc d'Avui, Sala Municipal de Exposiciones de Onda (Castellón), celebrada en octubre.

1973

- II Setmana d'Art de Burriana (Castellón), acude invitado por la organización.

- Art Castellonenc d'Avui, Sala Municipal de Exposiciones de Onda (Castellón), octubre diciembre de 1973-enero de 1974.

1974

- III Setmana d'Art de Borriana (Castellón), febrero.

- III edición de la muestra Art Castelonenc d'Avui, Sala Municipal de Exposiciones de Onda (Castellón)

1975

- Viver (Castellón)

- IV edición de la muestra Art Castellonenc d'Avui, Sala Municipal de Exposiciones de Onda (Castellón)

- Muestra de Pintura Castellonenca, Nules (Castellón) 
- V edición de la muestra Art Castellonenc d'Avui, Sala Municipal

1977 de Exposiciones de Onda (Castellón)

- VI edición de la muestra Art Castellonenc d'Avui - Art d'Avui al País Valencià, Sala Municipal de Exposiciones de Onda (Castellón)

1978

- VIl edición de la muestra colectiva Art d'Avui al País Valencià, Sala Municipal de Exposiciones de Onda (Castellón)

- Grans obres de petit format, Galeria Cànem (Castellón)

- Cinco artistas españoles y cuatro polacos, Aix-en-Provence (Francia)

- Cerámica actual dels Països Catalans, FAD (Barcelona)

- Grans obres de petit format, Galeria Cànem (Castellón)

1980

- 80 anys d'art castellonenc, Museo Provincial de Castellón.

- 3 ceramistes del País Valencià: Angelina Alós, Enric Mestre y Manolo Safont, Museo Municipal de Onda (Castellón), del 19 al 30 de octubre. Se editó un breve catálogo.

- VIII muestra Art Valencià d'Avui, Sala Municipal de Exposiciones de Onda (Castellón). Tras cinco años sin celebrarse esta muestra, Safont la retoma, convocando para ello a los mismos artistas que la inauguraron en el año 1968.

- Marcelo Díaz, Amat Bellés y Manolo Safont, Castell del Papa Luna de Peñíscola (Castellón), Diputación Provincial, del 28 de julio al 19 de agosto. Se editó un catálogo de esta exposición con texto de Ferran Olucha.

- Exposición artistas castellonenses: Marcelo Díaz, Amat Bellés y Manolo Safont, Biblioteca Municipal de Segorbe (Castellón), del 9 al 24 de marzo. Se editó un catálogo con texto de Ferran Olucha.

- Homenaje de artistas contemporáneos a la Cartuja de Vall de Christ con motivo del VI centenario de su fundación, Segorbe (Castellón)

- "Trovades de Ceràmica, Arts Aplicades de Castellón, Arcadio Blasco, Enric Mestre y Manolo Safont", delegación de Castellón del Colegio Oficial de Arquitectos de la Comunidad Valenciana, del 8 al 18 de enero. Castellón de la Plana (Castellón) 
- 30 ceramistas-40 alfareros, Diputación de Salamanca, (Salamanca)

1992

- Feria Hàbitat de Castellón (Castellón)

- Vuit ceramistas holandesos, vuit ceramistas espanyols. Ceràmica a l'equipament urbà = Cerámica en el equipamiento urbano, Feria Hàbitat Alicante, Sala Municipal d'Exposicions, Lonja del Pescado 1995 de Alicante, del 26 de mayo al 30 de junio. (Alicante)

- Wences Rambla, olis i tècniques mixtes; Manuel Safont, pintura ceràmica, Centre Cultural d'Alcoi (Alicante). Se editó un catálogo de la exposición, con el texto Manuel Safont escrito por Ferran Olucha Montins.

2002

- Pintura castellonenca dels 70-80. S XX. Museu de Bellas Arts de Castelló. Coleccions Artístiques de la Diputació de Castelló del 26 de marzo al 28 de abril. Exposición colectiva con obras de Amat Bellés, José Córdova, Juan González-Campos, Marcelo Díaz, Beatriz Guttman, Joël Mestre, Pepe Nebot, Luis Prades, Wences Rambla, María José Rico, Juan G. Ripollés, Ximo Roures, Manuel Sáez, Manolo Safont, Fernando S. Sesé y Vicente Traver Calzada. De Safont se expone la obra Blanco, negro y rojo, propiedad de la Diputación Provincial de Castellón que forma parte de la colección permanente del Museo de Bellas Artes de 2005 Castellón. Castellón de la Plana (Castellón)

- Exposición Homenatge a La Saleta, la Sala d'Exposicions Municipals d'Onda (Castellón), del 23 de octubre al 20 de noviembre. Con ocasión del futuro derribo de La Saleta, se organiza una exposición homenaje en la que participan los mismos artistas que participaron en la última muestra de Art Valencià d'Avui, realizada en 1983: Rafael Armengol, Amat Bellés, Manuel Boix, Andreu Castellejos, Marcelo Díaz, Pilar Dolz, Rosendo Esteller, Ana García-Pan, Artur Heras, Martí Quinto, Joaquim Michavila, Antoni Miró, Eva Mus, Vicente Ortí, Traver Calzada y Manolo Safont. 


\section{2.- MANOLO SAFONT: LOS CONCURSOS}

Desde 1957, Safont se presenta a numerosos concursos y certámenes, tanto a nivel nacional como en el extranjero, ganando muchos de ellos. La dotación económica que conllevan estos premios le suponen un medio de subsistencia durante los primeros años de su trayectoria artística así como un escaparate de su obra, hasta que su trabajo será más conocido y los coleccionistas particulares e instituciones adquieran o le hagan encargos.

1957

- Diploma de honor por la pieza de cerámica n¹2, en la Exposición Nacional de Artesanía en Granada, celebrada en Mayo.

1959

- Primer premio de la Asociación "El Micalet" de Valencia.

1961

- Diploma por los trabajos presentados a la VI Exposición de Cerámica de Arte, organizada por la Sociedad Coral El Micalet, Instituto Musical Giner, de Valencia.

1972

- XXX Concurso Internacional de Cerámica de Faenza (Italia) 1973

- XXXI Concurso Internacional de Cerámica de Faenza (Italia)

- Diploma II Concurso Internacional de Cerámica de Gdañsk (Polonia)

1976

- Concurso Mural cerámico, Fundación General Mediterránea, autopista del Ebro Zaragoza-Barcelona. Safont realiza uno de los doce murales seleccionados tras el concurso.

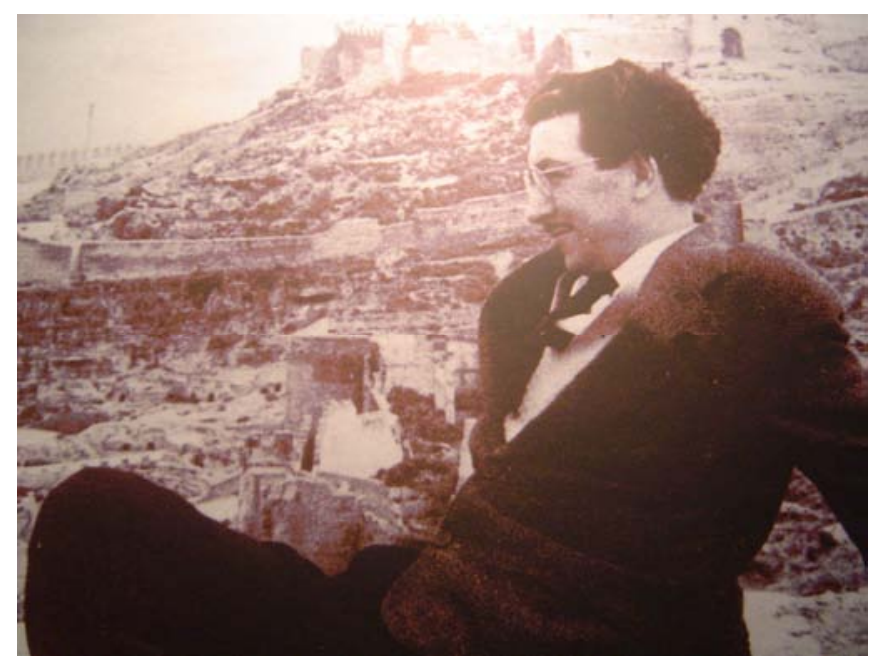

Figura 147: Manolo Safont. 


\section{3.- MANOLO SAFONT: SU OBRA EN MUSEOS}

Diferentes Museos tienen entre sus fondos obras de Safont. Como el museo de la Academia Internacional de la Cerámica de Ginebra, de la cual Safont era miembro, o el Museo de Bellas Artes de Castellón, que cuenta entre sus fondos varias obras de Safont que pertenecen a la Diputación de Castellón.

Es una práctica habitual que los artistas donen o cedan en depósito una obra suya en aquellos museos en los que exponen, así fue como Safont cedió obras a diferentes Museos que posteriormente le fueron devueltas.

Aunque en diferentes biografías de Safont se constata el dato de que tiene obra en el Museu d'Artistes dels Països Catalans y en el Museo de Arte Contemporáneo de Madrid, al contrastar estos datos hemos comprobado que actualmente no cuentan entre sus fondos con ninguna obra de Safont. En el Museu d'Artistes dels Països Catalans de Banyoles, Barcelona, estuvo la obra titulada Contra violencia, que fue devuelta a su autor en 1991, por petición expresa del mismo, según datos proporcionados por Josep Grabuleda Sitjà, archivero municipal de Banyoles.

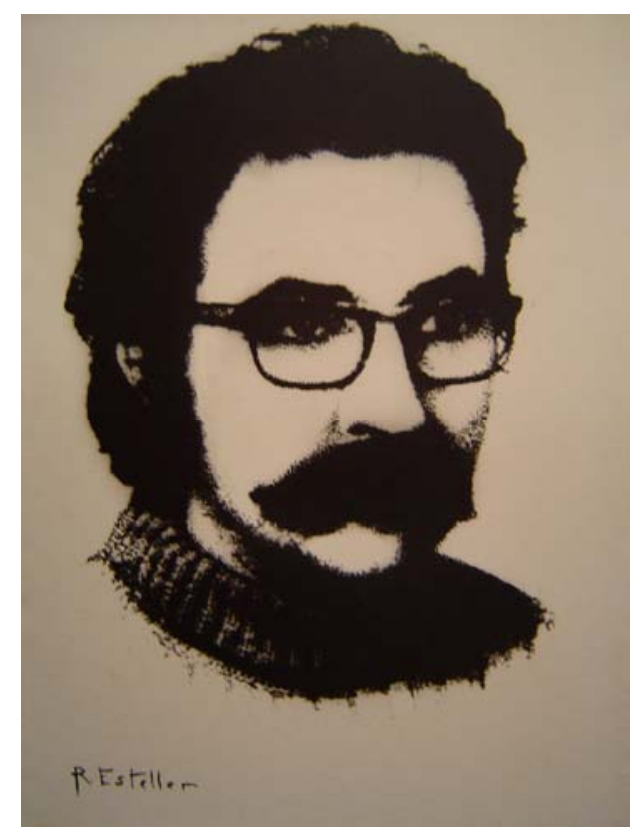

Figura 148: Manolo Safont, obra de Rosendo Esteller. 
Tampoco figura ninguna obra de Safont en los inventarios del Museo Nacional Centro de Arte Reina Sofía, al que se derivaron los fondos del antiguo Museo de Arte Contemporáneo de Madrid, según datos proporcionados por Lorena Canela Forero, encargada del departamento de colecciones del museo. No hay obra en el inventario de fondos, ni hay constancia alguna en el archivo documental de que Safont hubiera expuesto nunca en dicho Museo.

- Academia Internacional de la Cerámica, Ginebra (Suiza)

- A Ophelyssem, Helecine (Belgica)

- Museo Nacional de Cerámica González Martí (Valencia)

- Museu d'Art Contemporani de Elche (Alicante)

- Museu d'Art Contemporani Aguilera Cerní de Vilafamés (Castellón)

- Museo de Bellas Artes de Castellón (Castellón)

- Museo del Azulejo Manolo Safont de Onda (Castellon)

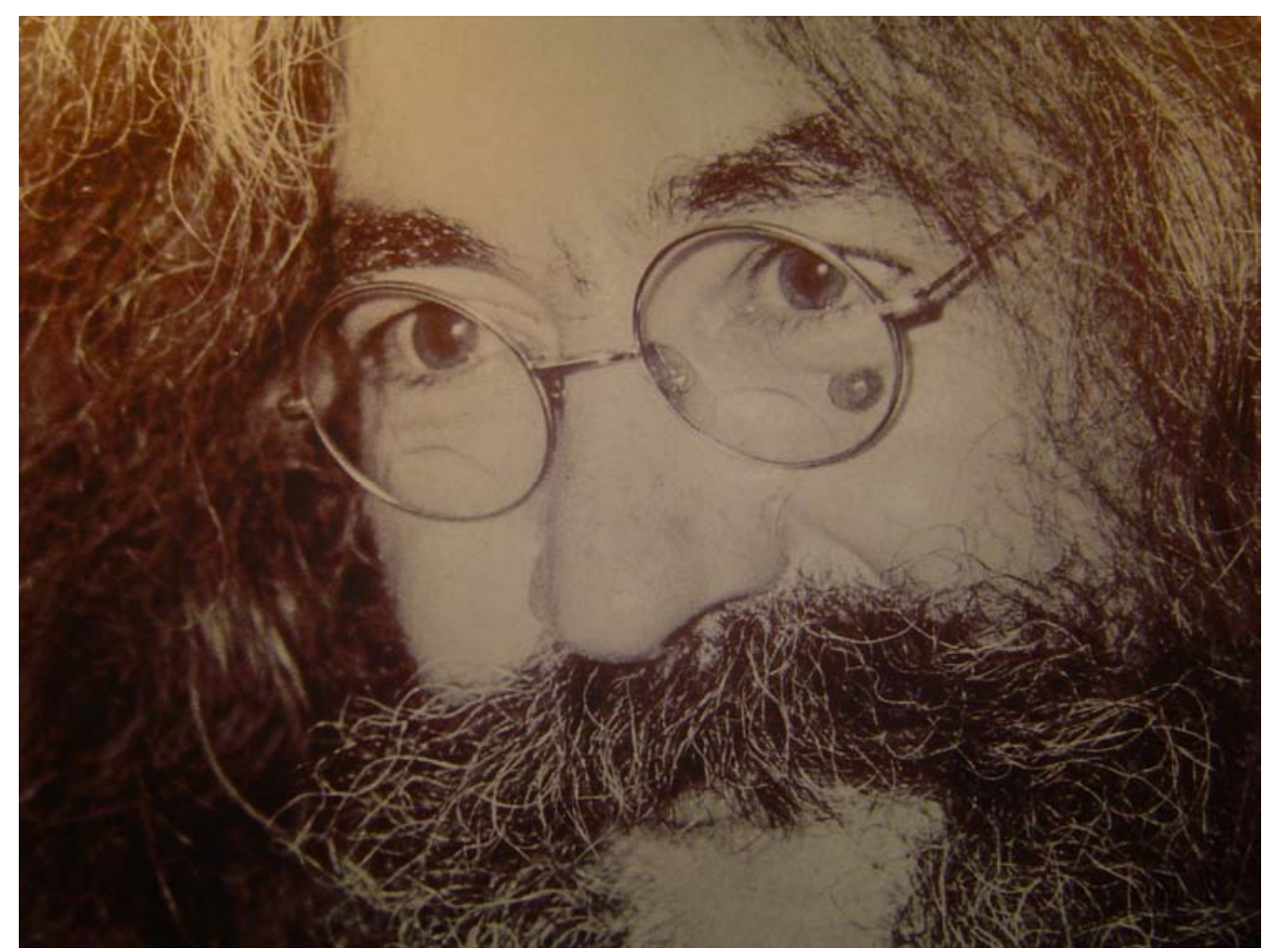

Figura 149: Manolo Safont 


\section{4.- MANOLO SAFONT: SU OBRA PÚBLICA E INSTITUCIONAL}

1952

- Cinco paneles de azulejos para la Capilla de la Comunión de la Iglesia Parroquial de Nuestra Señora de la Asunción de Onda (Castellón)

1953

- Panel de azulejos La Última Cena, comedor del Seminario de Tortosa (Tarragona). Obra monocromática realizada en color azul. 1954

- Panel de azulejos del tímpano de la portada de la Iglesia Parroquial de la Asunción de Nuestra Señora de Sueras (Castellón)

1958

- Panel devocional con la imagen de San Jorge, situado en la calle San Jorge de Onda (Castellón)

1960

- Azulejos de la fachada, zaguán e interior del edificio de Caja Rural Nuestra Señora de la Esperanza de Onda, calle San Miguel de Onda (Castellón)

1961-1962

- Estructura y azulejos del quiosco de prensa de la Safona en Onda (Castellón).

1962

- Paneles cerámicos estaciones del Vía Crucis, Calvario de Espadilla (Castellón)

1963-1964

- Mural cerámico La Sagrada Familia, oficina principal de la Caja de Ahorros y Monte de Piedad de Castellón, calle San Miguel de Onda (Castellón) ${ }^{1}$

1968

- Mural cerámico Virgen de la Merced, fachada de la Catedral de Babahoyo (Ecuador)

1976

- Mural cerámico para área de servicio de la Autopista del Ebro, Zaragoza-Barcelona, Fundación General Mediterránea.

1985

- Mural cerámico para el Instituto $\mathrm{n}^{\circ} 5$ de Castellón, actual IES Vicent Castell i Domènech. Situado en la fachada exterior.

1986

- Mural cerámico para el CEIP Mestre Caballero de Onda (Castellón). Situado en la fachada exterior.

- Mural cerámico para el salón del edificio del IMPIVA de Valencia.

${ }^{1}$ Esta obra fue creada originalmente como un mural para la oficina de la Caja de Ahorros, pero actualmente se exhibe adherida sobre paneles móviles en el Museo del Azulejo Manolo Safont de Onda. 
- Mural cerámico de $12 \mathrm{~m}^{2}$ para el interior del edificio de Gobierno 1991 Civil de Castellón, Castellón.

- Mural cerámico para el interior de la Escuela de Artes y Oficios de Castellón, situado en el antiguo edificio de la Beneficencia. 1993-1994

- Mural cerámico situado en la fachada exterior del Centro 1994 Ocupacional de Vila-Real (Castellón), en la calle Onda.

- Mural cerámico para la Prefectura de Mies, en Japón. 


\section{5.- MANOLO SAFONT: SU OBRA EN COLECCIONES PRIVADAS}

Además de la obra que forma parte de colecciones museísticas y de la obra pública e institucional, la mayor parte de la producción artística de Safont fue adquirida por particulares y forma parte hoy en día de diferentes colecciones privadas, tanto en España como en el extranjero.

Resulta imposible rastrear el actual paradero de todas las obras creadas por Safont, pero sí reseñamos alguna colección privada que, bien por la cantidad o bien por la calidad de las obras de Safont con que cuenta, nos parece relevante.

Por deseo de los propietarios, para preservar el anonimato, las colecciones se reseñan con un número y su ubicación geográfica. Este mismo sistema se utiliza en las fichas catalográficas del catálogo general de obras.

- Colección privada $n^{0} 1$ Onda.

- Colección privada n² Sudáfrica.

- Colección privada n³ Onda.

- Colección privada nº Onda.

- Colección privada n5 Castellón.

- Colección privada $n^{\circ} 6$ Onda.

- Colección privada ${ }^{0} 7$ Vila-Real.

- Colección privada n8 Tarragona.

- Colección privada n9 Onda.

- Colección privada n¹0 Borriol.

- Colección privada n¹1 Borriol.

- Colección privada n¹2 Onda.

- Colección privada n¹3 Onda.

- Colección privada ${ }^{\circ} 14$ Castellón.

- Colección privada n¹5 Castellón.

- Colección privada n¹6 Onda.

- Colección privada n¹7 Onda.

- Colección privada n¹8 Castellón.

- Colección privada n¹9 Castellón.

- Colección privada n²0 Onda.

- Colección privada n²1 Onda.

- Colección privada ${ }^{\circ} 22$ Onda. 


\section{6.- MANOLO SAFONT: SU OBRA PERDIDA E INACABADA}

A lo largo del tiempo, diferentes obras de Safont, sobre todo obras de aplicación arquitectónica, se han perdido $\mathrm{o}$ han desaparecido como consecuencia de las reformas o derribos realizados en los inmuebles en los que se encontraban.

Hoy en día, no se conservan los azulejos que Safont realizó para decorar tanto la barra como los pilares del bar del Centro de Acción Católica de Onda, situado en la actual calle Historiador Bernardo Mundina de Onda. Este local fue remodelado al ser adquirido para ubicar la Ferretería Salvia, que lo ocupa desde 1975 hasta la actualidad.

Tampoco se conservan los azulejos del zócalo de la Farmacia de Miguel Manuel Arrando, situada en la Avinguda País Valencià de Onda, que se eliminaron tras la reforma del establecimiento, ni los azulejos del zócalo del vestíbulo del Cine Mónaco de Onda, que también fue remodelado.

Desde el año 2000, Manolo Safont trabajó en el proyecto para un gran mural cerámico de $3 \times 10$ metros, destinado al vestíbulo principal o sala de grados de la Facultad de Ciencias Humanas y Sociales de la Universidad Jaume I de Castellón. Este proyecto se fue posponiendo debido a unas obras que Safont tuvo que realizar en su taller y a su delicado estado de salud. Actualmente las piezas inacabadas de este mural están depositadas en el Museo del Azulejo Manolo Safont de Onda. Nadie mejor que el propio Safont, para explicar cuales fueron los problemas que tuvo para no poder acabar su obra, en la carta manuscrita que envió en enero de 2004 a Francisco Toledo, rector de la Universitat Jaume I de Castellón.

"Onda 15 de gener de 2004

Estimado Rector de la Universidad Jaume I, Francisco Toledo Lobo.

El destrozo del techo de la casa, me ha retrasado mucho el trabajo. Después, cuando empezaron a rehacer el techo, con un trabajo muy costoso que los trabajadores también pasaron frío.

Al estudio pusieron unos montajes para cuidarlo.

Mi trabajo me es grato, me gusta la cerámica que es bastante difícil y no ves el resultado hasta que no ha pasado por el horno. 
Primero iba a cocer a las fábricas, en la casa que vivimos, tenemos una casita aparte que es donde tenemos el horno. El horno nos va muy bien.

El estudio está seguro y no hay problema de que pase agua desde el techo y caiga el piso de abajo.

Me gusta mucho mi trabajo y me gusta ir siempre adelante.

El retraso de las placas fue que yo no sabía que estas placas no tenían poros. Me enteré que eran para la cocción de $1260^{\circ}$.

Así que he tenido que trabajar haciendo pruebas y he conseguido un buen resultado.

Me gusta el relieve y también jugar a crear.

Ahora espero poder trabajar más a gusto. Espero que muy pronto están las placas en el horno.

Francisco, le escribo todo esto porque necesito seguir trabajando para adelantar el mural, y seguir adelante con mucha alegría.

Estos días ha sido de verdadero invierno y los he pasado con dolores por dentro de mi cuerpo, ahora me he animado mucho más.

Te estimo y espero seguir adelante

Safont"

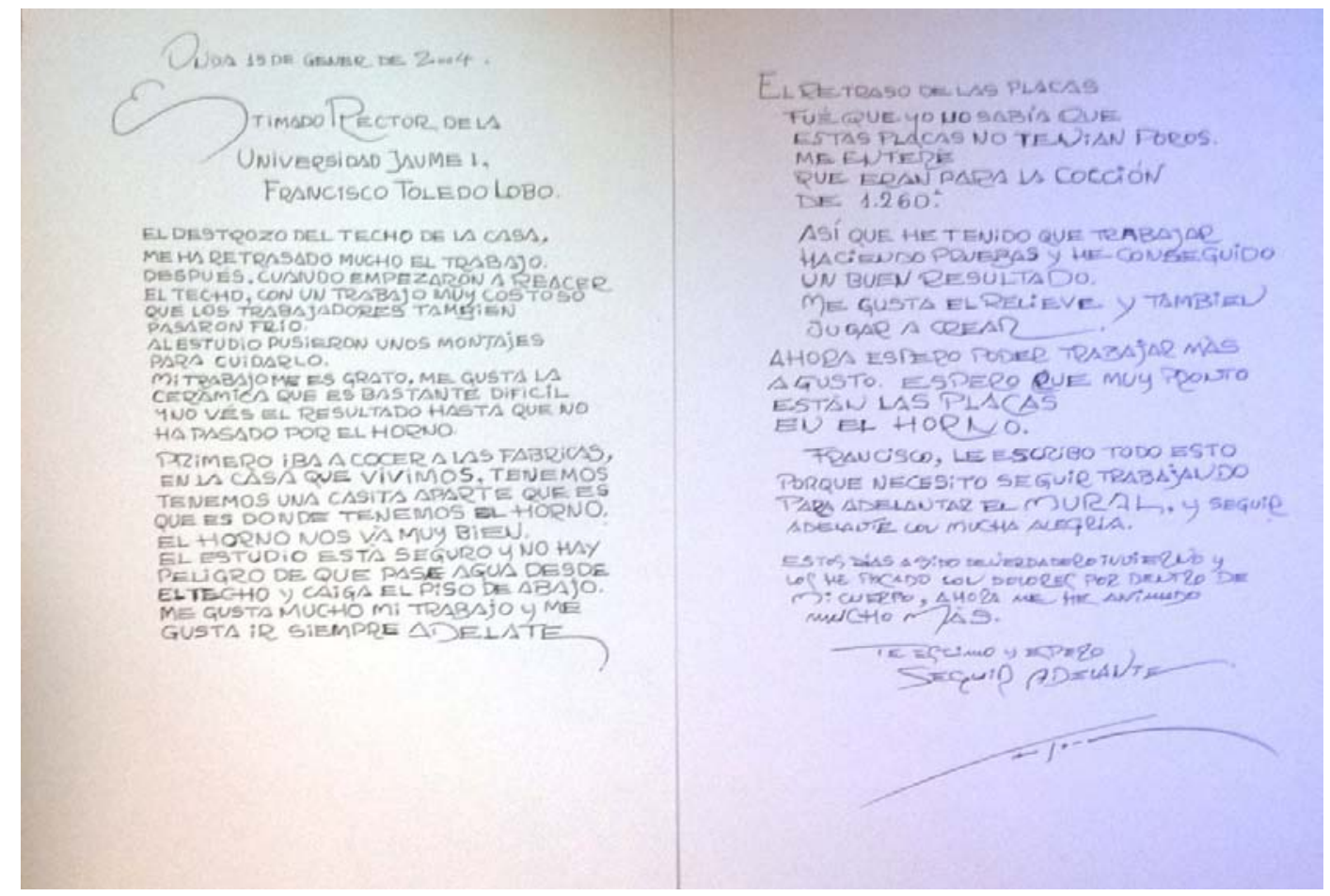

Figura 150: Carta manuscrita de Manolo Safont.

${ }^{2}$ Carta manuscrita enviada por Manolo Safont a Francisco Lobo Toledo, rector de la Universitat Jaume I de Castellón, en la cual explica el estado del proyecto del mural cerámico encargado por la UJI. Inédita. 


\section{7.- MANOLO SAFONT: SU OBRA PENDIENTE DE LOCALIZAR}

Pese al tiempo y esfuerzo dedicado a localizar la mayor cantidad posible de obras de Manolo Safont, hay referencias que no he podido contrastar adecuadamente y obra que no he podido comprobar si existe aún actualmente. Casi todos estos datos provienen de conversaciones mantenidas con amigos personales de Safont, que no han podido proporcionarme suficientes datos sobre ellas. De todos modos, considero interesante poder citar algunas, a espera de poder obtener más información en un futuro:

- Cuadro compuesto por dos placas con un motivo de una niña ataviada con un traje de labradora, propiedad de Miguel Signes.

- Mural de Safont, en una hornacina de una finca, en una valla de obra, en un huerto, cerca de la fuente de Quartell, en la población de Quartell, cercana a Sagunto (Valencia)

- Mural en una de las fachadas de un chalet, conocido como la Villa Berlanga, situado en la playa de Oropesa del Mar (Castellón)

- Vía Crucis, de estilo moderno, hecho por Safont, en el interior de la iglesia del Rosario de Mas d'en Verge, en Tortosa.

- Murales cerámicos en una iglesia de Mahón (Menorca)

- Lápidas cerámicas en el Cementerio Municipal de Onda (Castellón)

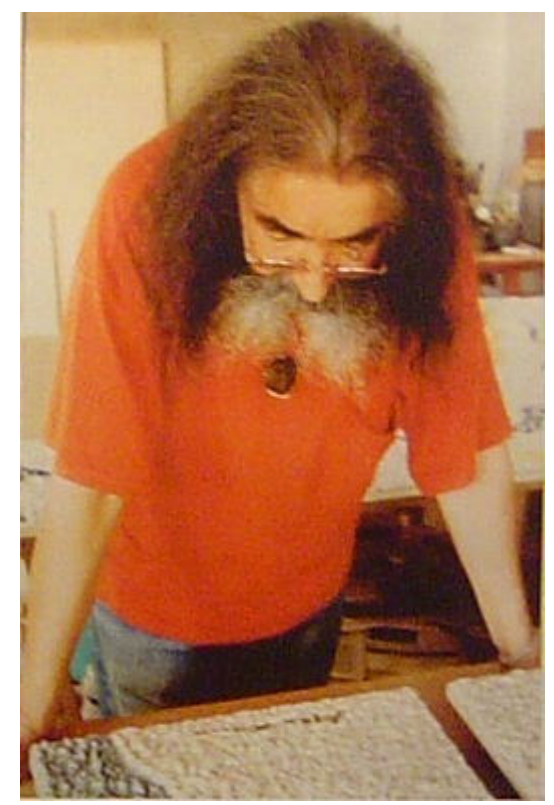

Figura 151: Manolo Safont. 


\section{8.- MANOLO SAFONT: CINE DOCUMENTAL Y DOCUMENTACIÓN AUDIOVISUAL}

Debido a su timidez, Safont era poco amigo de las cámaras, de hecho cuando se rodó para televisión un reportaje sobre su exposición de 1962 en la Sala de Exposiciones de la Dirección de Bellas Artes de Madtrid, se negó a que lo filmaran.

En 1968, cedió ante un grupo formado por amigos, y se prestó para filmar un cortometraje titulado Fang i pinzells: El mon i l'obra de Manolo Safont, que narra tanto la vida y obra de Manolo Safont, como la vida cotidiana en la localidad de Onda (Castellón), su pueblo. Dirigido por Rafael Menezo y con guión de Tomás Ribera, según el director "Tracta de l'obra d'un autor que s'encarna en una terra i com la seua pintura ceràmica té un valor artístic. Fugint d'un realisme socialista que temps desprès ens pareixerà desarrelat". ${ }^{3}$ En el que podemos ver y oir a Safont hablar sobre su vida y su obra.

Pocos registros documentales más hay sobre Safont, por lo que pese a no tener sonido, es interesante reseñar un pequeño video, de tan sólo 6 segundos de duración que existe colgado en youtube, y que parte de una grabación realizada en marzo de 1967 sobre soporte de $8 \mathrm{~mm}$. En el que vemos a Safont y a Ana. ${ }^{4}$

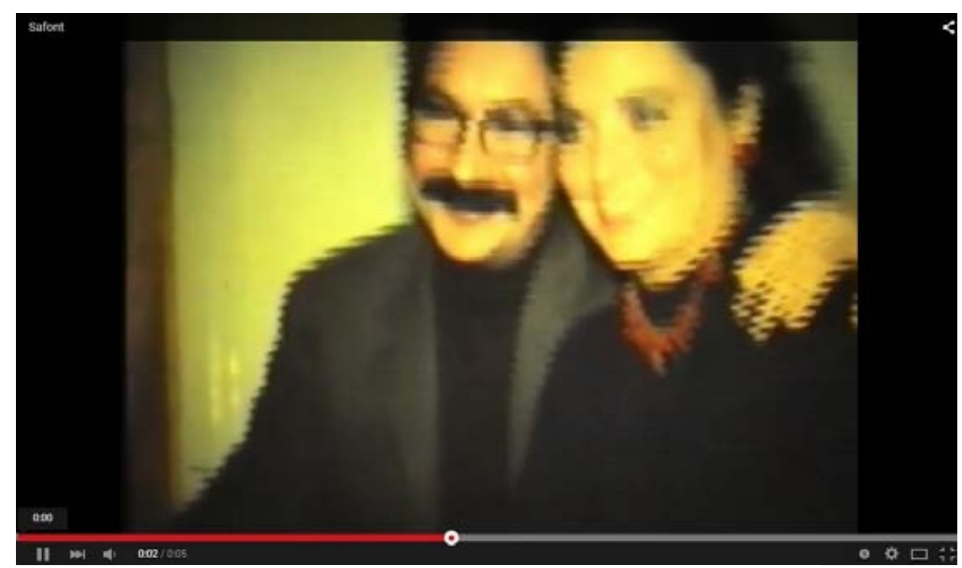

Figura 152: Manolo Safont y Ana del Moral.

\footnotetext{
${ }^{3}$ MENEZO, Rafael. "Miradas sobre una década. Un conte de pel.lícules", Cuéntame Castellón, pág. 232. "Trata de la obra de un autor que se encarna en una tierra y cómo su pintura cerámica tiene un valor artístico. Huyendo de un realismo socialista que tiempo después nos parecerá desarraigado".

${ }^{4}$ https://www.youtube.com/results?search_query=manolo+safont
} 
Referente a su obra, hay también en youtube, un video sobre la inauguración de la exposición Magnificat realizada en Castellón en 2014, en el cual se habla y se muestran imágenes sobre el mural de La Sagrada Familia restaurado por la Diputación de Castellón. ${ }^{5}$

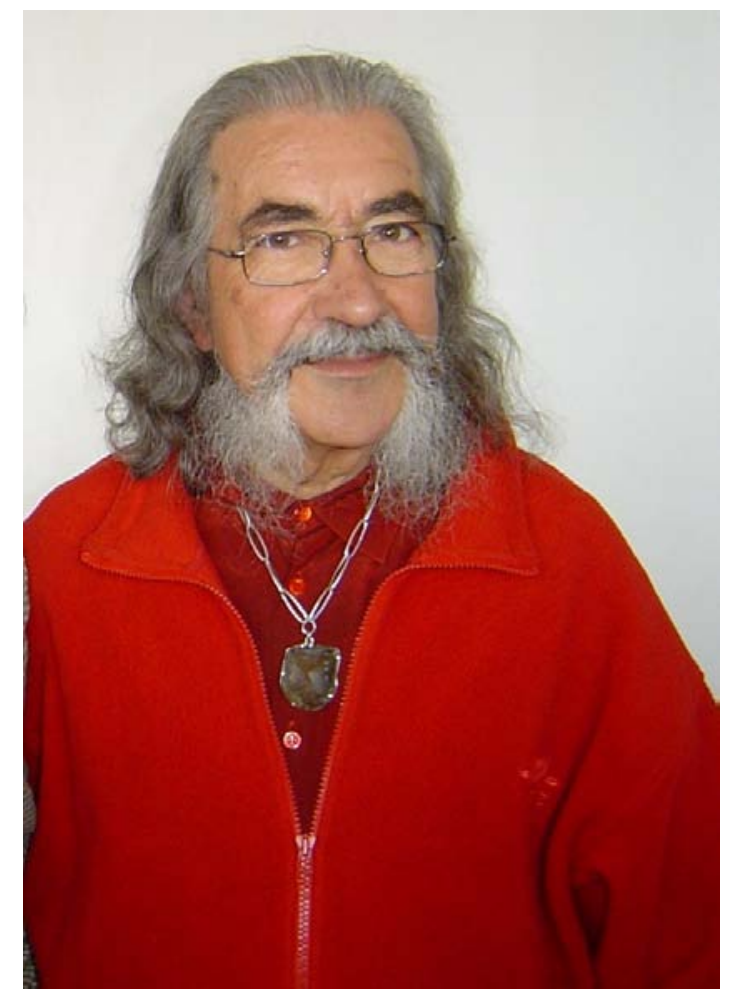

Figura 153: Manolo Safont

\footnotetext{
${ }^{5}$ La Diputación restaura un emblemático mural cerámico de Manolo Safont que se expondrá de forma permanente en el Museu de Onda https://www.youtube.com/watch?v=jrsG9S1d6FY (1:40 min)
} 


\section{CAPÍTULO 6}

\section{FICHAS CATALOGRÁFICAS DE LA OBRA DE MANOLO SAFONT}

El fichero catalográfico de la obra de Safont se ha estructurado en diversos capítulos para facilitar de este modo la comprensión y localización de las obras.

El criterio utilizado para establecer esta clasificación se ha basado en aspectos técnicos, de formato y estilísticos, valiéndonos en cada ocasión de aquellos que nos permitían agrupar las obras que comparten espacio, temática, estilo, etc

Se ha intentado mantener una unidad estructural, dotando a cada capítulo de una numeración independiente y correlativa, establecida según la datación de las obras.

Al inicio de cada capítulo se presenta una breve introducción sobre aspectos y características destacadas de las obras que se catalogan.

La abreviatura MAMS utilizada en el item de localización hace referencia al Museo Azulejo Manolo Safont.

6.1.- Fichas catalográficas: Obra gráfica impresa en los programas de Fira d'Onda.

6.2.- Fichas catalográficas: Bocetos, dibujos y carteles.

6.3.- Fichas catalográficas: Obras de la etapa de figuración.

6.4.- Fichas catalográficas: Obras de la etapa de transición de la figuración a la abstracción.

6.5.- Fichas catalográficas: Obras de la etapa de abstracción.

6.6.- Fichas catalográficas: Obras de aplicación arquitectónica.

6.7.- Fichas catalográficas: Obras murales. 


\section{1.- FICHAS CATALOGRÁFICAS: OBRA GRÁFICA IMPRESA EN LOS PROGRAMAS DE FIRA D'ONDA}

Desde 1960, Safont colabora de forma habitual en la realización del Programa de Fiestas, que con motivo de las fiestas patronales de Fira d'Onda, que se celebran en octubre, edita anualmente el Ayuntamiento de Onda.

Desde el Ayuntamiento de Onda, en algunas ocasiones se le encarga la realización del dibujo que servirá como portada, en otras ocasiones se le encarga la realización de dibujos alusivos al calendario de actividades que se programan para esa semana festiva, incluso en alguno de ellos, es Safont quien maqueta las páginas que muestran las fotografías de la reina de fiestas y sus damas de honor. A diferencia de las portadas que están realizadas con un amplia paleta cromática, las ilustraciones interiores están impresas a una sola tinta.

Posteriormente, el Ayuntamiento de Onda convoca un concurso de carteles de Fira d'Onda y será el dibujo ganador el que se utilice como portada del programa de fiestas.

En las obras creadas para ser utilizadas como portada del programa de fiestas, figura el lema "Onda en Fiestas" así como el año, y a partir de la década de 1980 figura el lema "Fira d'Onda", el año y las fechas de la semana festiva.

Las temáticas de las obras utilizadas para ilustrar estos programas siempre están relacionadas con la programación de actos de las fiestas de Fira d'Onda: el pregón de fiestas, procesiones religiosas, escenas taurinas de bous al carrer, castillos de fuegos artificiales, pasacalles de gigantes y cabezudos con dolçainers y tabaleters, romerías al ermitorio del Santísimo Salvador, celebraciones religiosas en la Iglesia Parroquial de Nuestra Sra. de la Asunción, actuaciones musicales y deportivas, o imágenes alusivas a diferentes edificios y enclaves de la localidad de Onda.

Muchas de estas ilustraciones se repiten en diferentes programas a lo largo de los años, por lo que para datarlos hemos utilizado la fecha del primer programa en el que aparecen. 
La faceta de Safont como ilustrador, ha sido poco referenciada y estudiada, de hecho tan sólo he podido encontrar un artículo de prensa publicado en el Periódico Mediterráneo, titulado "La fiesta en el tiempo", del 23 de octubre de 1988, en el que se muestran las diferentes portadas de los programas de fiestas y se cita a Safont como autor de algunas de ellas.

En 2006, el Ayuntamiento de Onda, editó una recopilación de todos los programas de fiestas que se conservan en la biblioteca municipal desde 1928 hasta 2006, en formato de cd, Fira d'Onda. Programes de Festes. Biblioteques d'Onda. Ajuntament d'Onda. Onda, 2006. Ha sido este documento, una base fundamental para buscar y localizar las diferentes obras que Safont realizó para ilustrar los programas de fiestas.

Analizando estas publicaciones se puede apreciar tanto la evolución estilística en diseños como en los formatos y tipografías, y por supuesto en las imágenes fotográficas y en las ilustraciones, tanto de Safont como de otros artistas ondenses: J. Adelantado, J. Puchal, Carmen Ballester, V. Adelantado, Begoña Molina, etc.

Constituyen también un excelente material documental para realizar un análisis de la evolución de la población y la sociedad ondense a través de los diferentes actos y actividades programadas, así como de los anuncios impresos de empresas, establecimientos y productos, y los distintos artículos que sobre temas variados pero siempre vinculados con la localidad de Onda contienen, destacando autores como: Baltasar Rull, Luís Prades Perona, Manuel Ardit, Joan Serrat, Ana Rebeca Mezquita Almer, Francisco Gusi, Ramón Rodríguez Culebras, Vicente García Edo, Bernardo Mundina, José Eugenio Varona, Jesús Huguet, Joan Feliu Franch e incluso el propio Manolo Safont.

Muestra de su constante interés y desinteresada colaboración, en cualquier faceta artística, fue el ofrecimiento de Safont para realizar el diseño y composición de la portada y contraportada del libro La arquitectura esmaltada. Cerámica arquitectónica de Onda en el siglo XIX, escrito por Joan Feliu Franch y publicado por el Ayuntamiento de Onda en 2001. 
Este capítulo 1 del catálogo general, está compuesto por 51 obras gráficas impresas, numeradas desde el 1.1 al 1.51, realizadas por Safont y utilizadas bien como portada o como ilustración interior en programas de fiestas editados por el Ayuntamiento de Onda entre 1960 y 1983. Aunque, como ya hemos citado, en algunas ocasiones se utilizan las mismas ilustraciones en diferentes programas de fiestas, se ha catalogado cada ilustración de modo independiente ya que difieren los colores de las tintas utilizadas para la impresión. 
No: 1.1

Título: Onda, fiestas de 1960

Autoría: Manolo Safont

Datación: 1960

Inscripciones: Onda, fiestas de 1960

Técnica: Impresión gráfica

Localización: Biblioteca Municipal de Onda

Descripción: Portada de la revista programa de las fiestas patronales de Onda, Fira d'Onda, que se celebran durante el mes de octubre. En la contraportada del programa se indica que Safont es el autor del dibujo de la portada. La escena representa elementos arquitectónicos característicos de Onda, como el castillo, la iglesia de Nuestra Señora de la Asunción, los arcos de la plaza porticada de la Font de Dins y el escudo de Onda. En el MAMS se conserva el dibujo original utilizado para esta impresión, obra catalogada $n^{0} 2.18$. Paleta cromática: blancos, amarillos, rojos, marrones y negros.

\section{Bibliografía:}

- Revista Programa Fiestas Patronales de Onda. Ayuntamiento de Onda, Onda, 1960

- Fira d'Onda. Programes de Festes. Biblioteques d'Onda. Ajuntament d'Onda. Onda, 2006

Imagen:

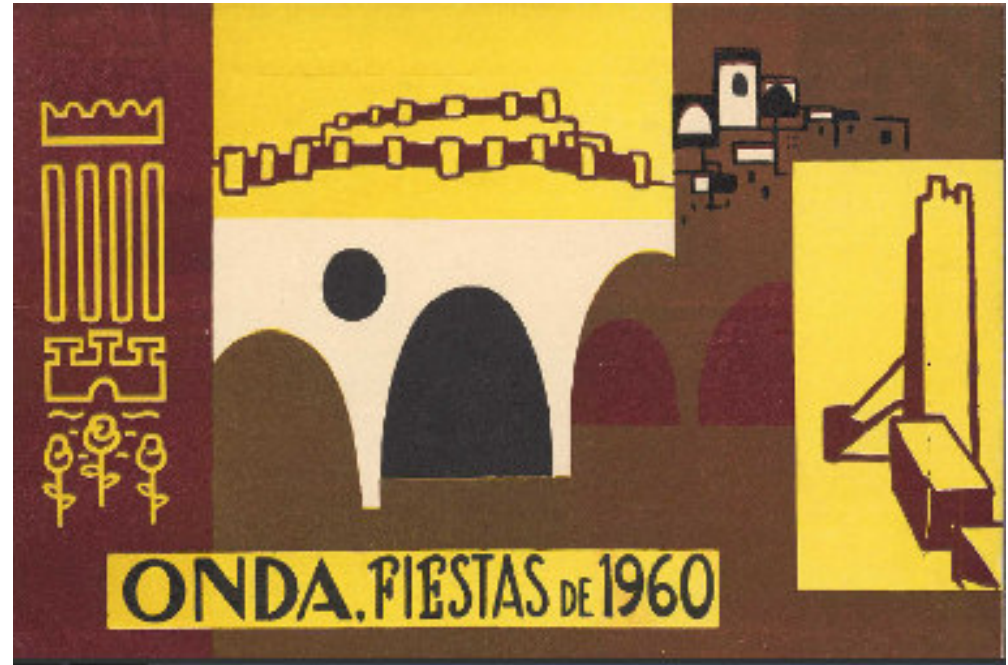

\section{Imágenes relacionadas:}

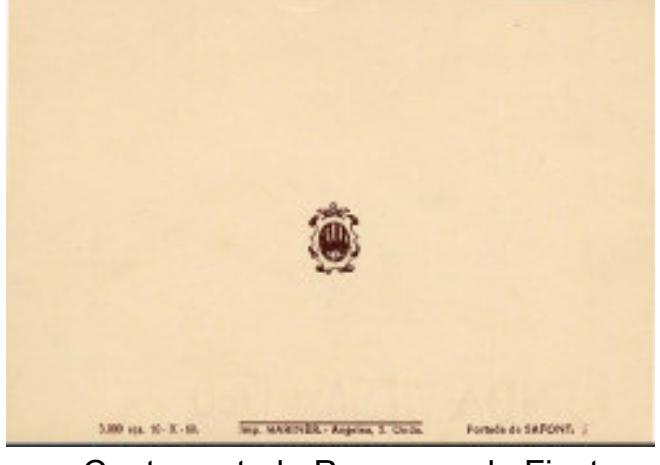

Contraportada Programa de Fiestas

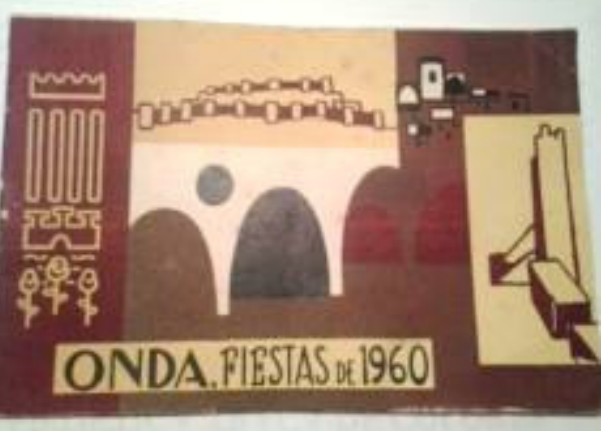

Obra cat. $n^{\circ} 2.18$ 
$N^{0}: 1.2$

Título: Onda, fiestas de 1967

Autoría: Manolo Safont

Datación: 1967

Inscripciones: Onda-fiestas 1967

Técnica: Impresión gráfica

Localización: Biblioteca Municipal de Onda

Descripción: Portada de la revista programa de las fiestas patronales de Onda, Fira d'Onda, que se celebran durante el mes de octubre. En el interior del programa se indica la autoría de Safont. El dibujo, realizado a lápiz, representa un rincón de la plaza porticada Font de Dins de Onda. Paleta cromática: blancos, marrones y negros.

Bibliografía:

- Revista Programa Fiestas Patronales de Onda. Ayuntamiento de Onda, Onda, 1967

- Fira d'Onda. Programes de Festes. Biblioteques d'Onda. Ajuntament d'Onda. Onda, 2006

Imagen:

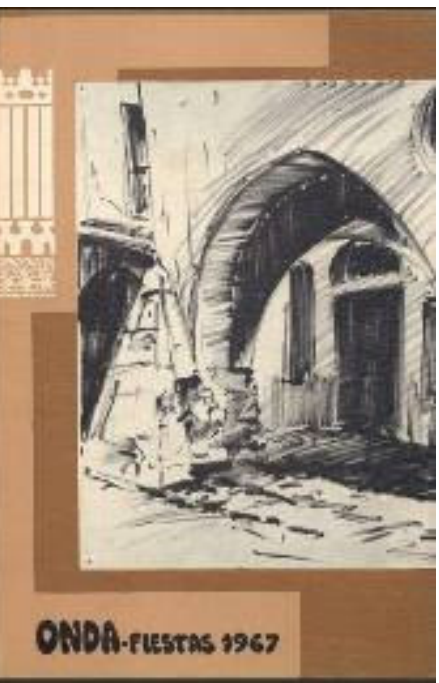

Imágenes relacionadas:

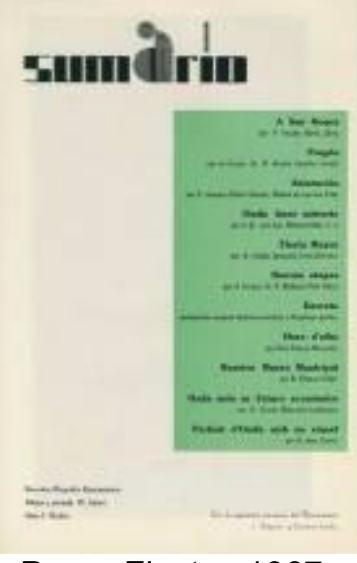

Progr. Fiestas 1967 
No: 1.3

Título: Pregón de fiestas

Autoría: Manolo Safont

Datación: 1967

Inscripciones: Pregón de fiestas

Técnica: Impresión gráfica

Localización: Biblioteca Municipal de Onda

Descripción: Dibujo interior del programa de fiestas, que representa la imagen de un pregonero, tocando la trompeta y que sirve de ilustración al pregón de fiestas realizado por el alcalde. Paleta cromática: blancos y violetas.

Bibliografía:

- Fira d'Onda. Programes de Festes. Biblioteques d'Onda. Ajuntament d'Onda. Onda, 2006

\section{Imagen:}

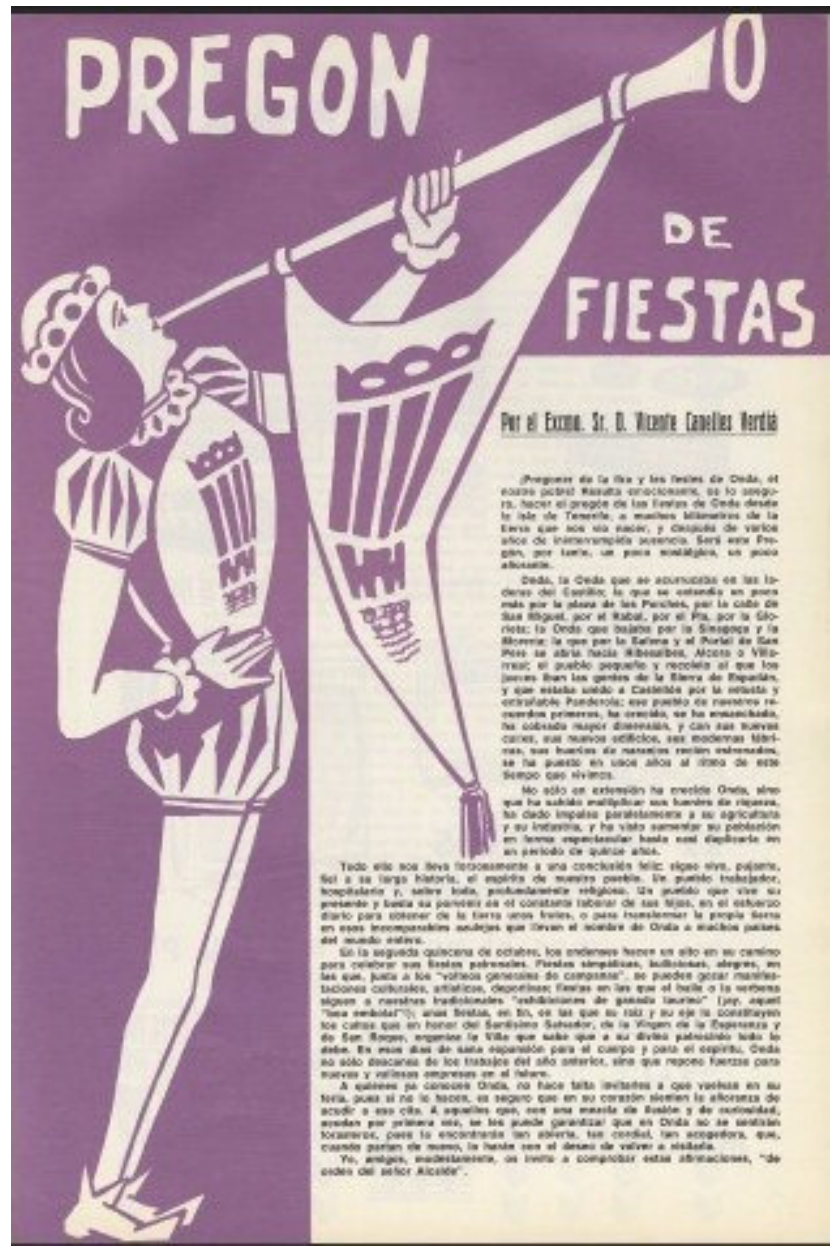


$\mathbf{N}^{0}: 1.4$

Título: Sin Título

Autoría: Manolo Safont

Datación: 1967

Técnica: Impresión gráfica

Localización: Biblioteca Municipal de Onda

Descripción: Safont realizó los dibujos para ilustrar el programa de Fiestas de 1967. La autoría se indica en el sumario del propio programa de fiestas. Esta imagen es un dibujo de la iglesia Nuestra Señora de la Asunción de Onda, y se utiliza también para ilustrar el programa de fiestas de 1968, 1971, 1974 y 1980. Paleta cromática: blancos y negros.

Bibliografía:

- Revista Programa Fiestas Patronales de Onda. Ayuntamiento de Onda, Onda, 1967

- Revista Programa Fiestas Patronales de Onda. Ayuntamiento de Onda, Onda, 1968

- Revista Programa Fiestas Patronales de Onda. Ayuntamiento de Onda, Onda, 1971

- Revista Programa Fiestas Patronales de Onda. Ayuntamiento de Onda, Onda, 1974

- Revista Programa Fiestas Patronales de Onda. Ayuntamiento de Onda, Onda, 1980

- Fira d'Onda. Programes de Festes. Biblioteques d'Onda. Ajuntament d'Onda. Onda, 2006

Imagen:

Imágenes relacionadas:
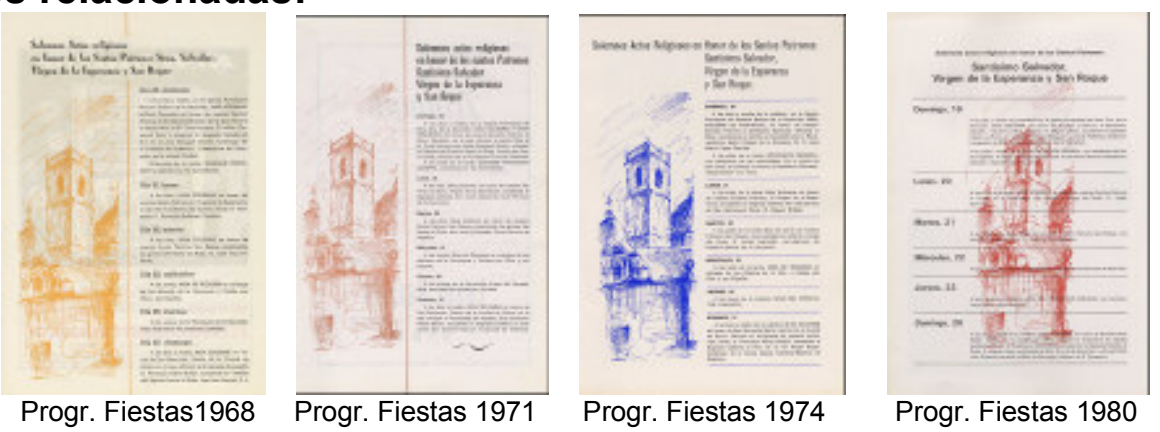
$\mathbf{N}^{0}: 1.5$

Título: Sin Título

Autoría: Manolo Safont

Datación: 1967

Técnica: Impresión gráfica

Localización: Biblioteca Municipal de Onda

Descripción: Safont realizó los dibujos para ilustrar el programa de Fiestas de 1967. La autoría se indica en el sumario del propio programa de fiestas. En esta ilustración se muestra una combinación de diferentes dibujos alusivos a alguna de las actividades programadas durante las fiestas patronales de Onda: gigantes y cabezudos y la feria de atracciones. Paleta cromática: blancos y verdes.

Bibliografía:

- Revista Programa Fiestas Patronales de Onda. Ayuntamiento de Onda, Onda, 1967

- Fira d'Onda. Programes de Festes. Biblioteques d'Onda. Ajuntament d'Onda. Onda, 2006

\section{Imagen:}


No: 1.6

Título: Sin Título

Autoría: Manolo Safont

Datación: 1967

Técnica: Impresión gráfica

Localización: Biblioteca Municipal de Onda

Descripción: Safont realizó los dibujos para ilustrar el programa de Fiestas de 1967. La autoría se indica en el sumario del propio programa de fiestas. Esta misma imagen se utilizó también para ilustrar los programas de fiestas de 1971, 1974 y 1980. La imagen representa una escena de un encierro taurino, tema relacionado con las fiestas ondenses. Paleta cromática: blancos y verdes.

Bibliografía:

- Revista Programa Fiestas Patronales de Onda. Ayuntamiento de Onda, Onda, 1967

- Revista Programa Fiestas Patronales de Onda. Ayuntamiento de Onda, Onda, 1971

- Revista Programa Fiestas Patronales de Onda. Ayuntamiento de Onda, Onda, 1974

- Revista Programa Fiestas Patronales de Onda. Ayuntamiento de Onda, Onda, 1980

- Fira d'Onda. Programes de Festes. Biblioteques d'Onda. Ajuntament d'Onda. Onda, 2006

\section{Imagen:}

Imágenes relacionadas:

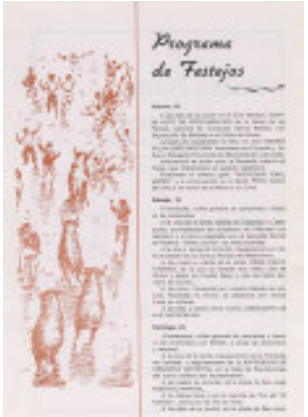

Progr. Fiestas 1971

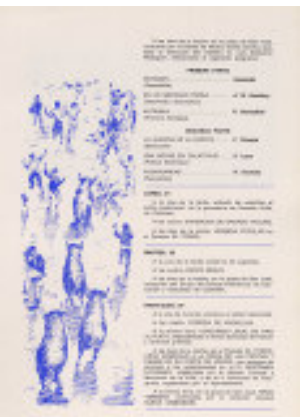

$\overline{\text { Progr. Fiestas } 1974}$

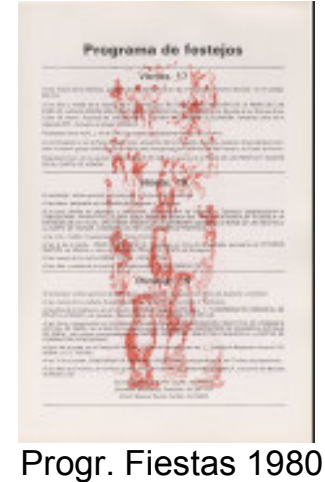

Progr. Fiestas 1980 
No: 1.7

Título: Sin Título

Autoría: Manolo Safont

Datación: 1967

Técnica: Impresión gráfica

Localización: Biblioteca Municipal de Onda

Descripción: Safont realizó los dibujos para ilustrar el programa de Fiestas de 1967. La autoría se indica en el sumario del propio programa de fiestas. La ilustración representa una escena de un espectáculo de un castillo de fuegos artificiales y el público asistente en primer plano. Paleta cromática: blancos y negros.

Bibliografía:

- Revista Programa Fiestas Patronales de Onda. Ayuntamiento de Onda, Onda, 1967

- Fira d'Onda. Programes de Festes. Biblioteques d'Onda. Ajuntament d'Onda. Onda, 2006

Imagen:

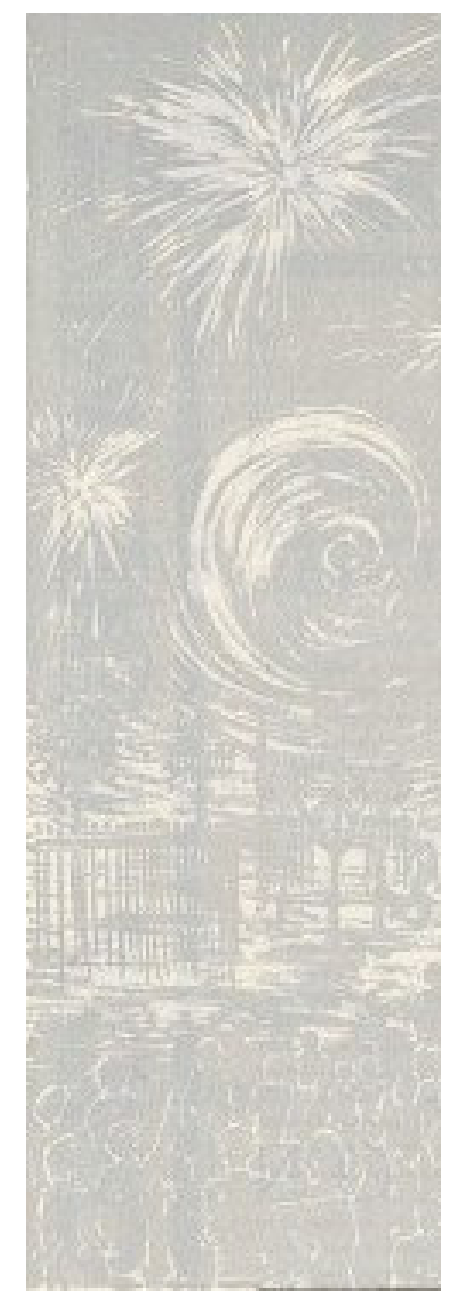


$N^{0}: 1.8$

Título: Sin Título

Autoría: Manolo Safont

Datación: 1967

Técnica: Impresión gráfica

Localización: Biblioteca Municipal de Onda

Descripción: Safont realizó los dibujos para ilustrar el programa de Fiestas de 1967. La autoría se indica en el sumario del propio programa de fiestas. La imagen representa una escena taurina, con un toro en posición de embestida en primer plano. Esta misma imagen se utilizó en el programa de fiestas de 1970. Paleta cromática: blancos y rojos.

Bibliografía:

- Revista Programa Fiestas Patronales de Onda. Ayuntamiento de Onda, Onda, 1967

- Revista Programa Fiestas Patronales de Onda. Ayuntamiento de Onda, Onda, 1970

- Fira d'Onda. Programes de Festes. Biblioteques d'Onda. Ajuntament d'Onda. Onda, 2006

\section{Imagen:}

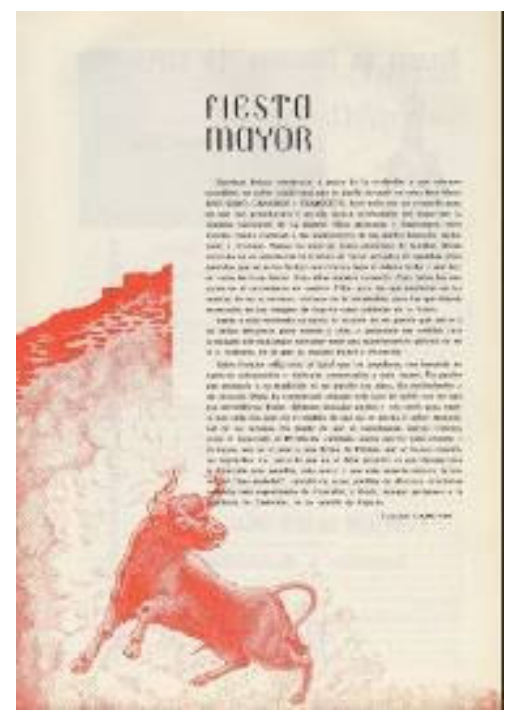

Imágenes relacionadas:

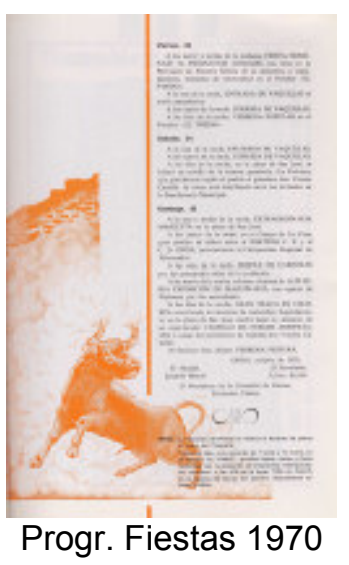




\begin{tabular}{|l|}
\hline No: 1.9 \\
\hline Título: Onda en Fiestas \\
\hline Autoría: Manolo Safont \\
\hline Datación: 1968 \\
\hline Inscripciones: Onda en Fiestas \\
\hline Técnica: Impresión gráfica \\
\hline Localización: Biblioteca Municipal de Onda \\
Descripción: Revista programa fiestas patronales de Onda, Fira d'Onda, nº4, \\
que se celebran durante el mes de octubre. En el sumario del programa se \\
indica la autoría del dibujo de portada y de los dibujos interiores: Safont. En la \\
portada se representan elementos arquitectónicos característicos de Onda, así \\
como unas imágenes alusivas al circo y a los fuegos artificiales, como \\
elementos festivos, y el escudo de Onda. Safont realizó también los diseños de \\
las páginas interiores correspondientes al saluda de la Alcaldía y a las \\
imágenes de la corte de honor. En el MAMS se conserva el dibujo original \\
utilizado para esta impresión, obra catalogada no2.24. Paleta cromática: \\
blancos, amarillos, naranjas, rojos, verdes, azules, marrones y negros. \\
\hline Bibliografía: \\
Revista Programa Fiestas Patronales de Onda. Ayuntamiento de Onda, \\
Onda, 1968 \\
Fira d'Onda. Programes de Festes. Biblioteques d'Onda. Ajuntament \\
d'Onda. Onda, 2006
\end{tabular}




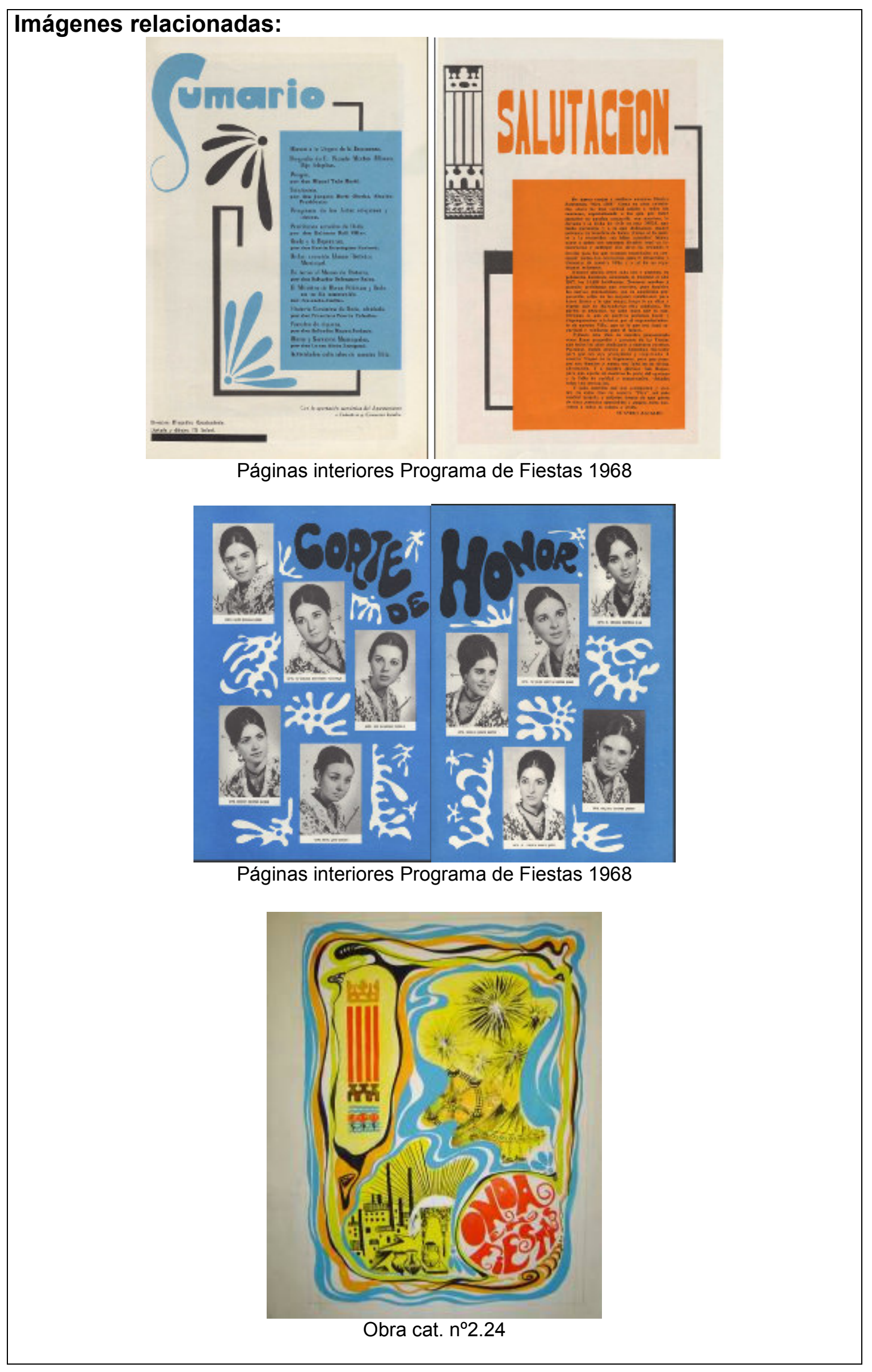


$\mathbf{N}^{0}: 1.10$

Título: Sin Título

Autoría: Manolo Safont

Datación: 1968

Técnica: Impresión gráfica

Localización: Biblioteca Municipal de Onda

Descripción: Safont realizó los dibujos para ilustrar el programa de Fiestas de 1968. La autoría se indica en el sumario del propio programa de fiestas. Esta imagen es un dibujo de la fachada de la iglesia Nuestra Señora de la Asunción de Onda, con la torre campanario, y se utiliza también para ilustrar el programa de fiestas de 1967, 1971, 1974 y 1980. Paleta cromática: blancos y naranjas.

Bibliografía:

- Revista Programa Fiestas Patronales de Onda. Ayuntamiento de Onda, Onda, 1967

- Revista Programa Fiestas Patronales de Onda. Ayuntamiento de Onda, Onda, 1968

- Revista Programa Fiestas Patronales de Onda. Ayuntamiento de Onda, Onda, 1971

- Revista Programa Fiestas Patronales de Onda. Ayuntamiento de Onda, Onda, 1974

- Revista Programa Fiestas Patronales de Onda. Ayuntamiento de Onda, Onda, 1980

- Fira d'Onda. Programes de Festes. Biblioteques d'Onda. Ajuntament d'Onda. Onda, 2006

Imagen: 


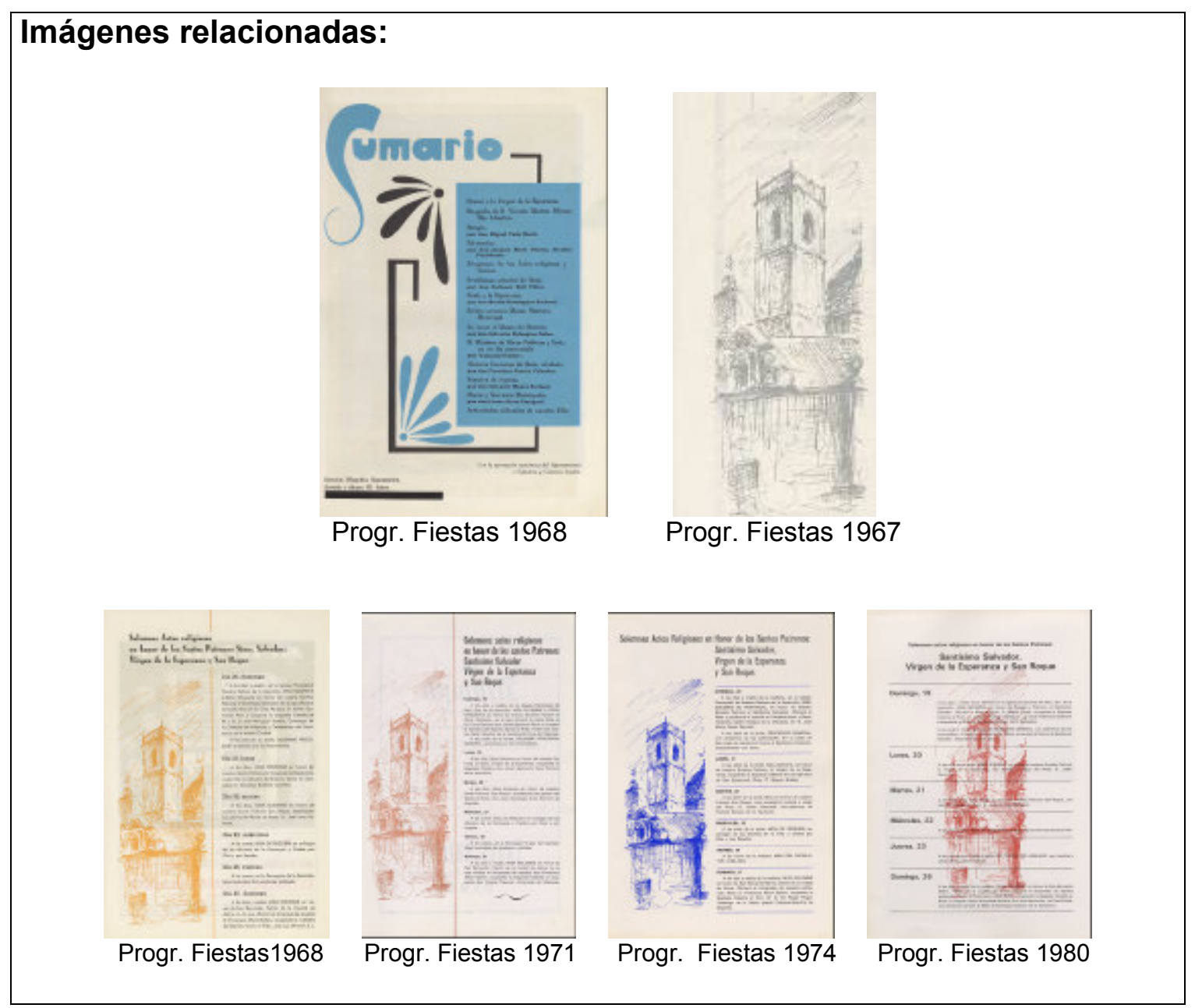


$\mathbf{N}^{0}: 1.11$

Título: Sin Título

Autoría: Manolo Safont

Datación: 1968

Técnica: Impresión gráfica

Localización: Biblioteca Municipal de Onda

Descripción: Safont realizó los dibujos para ilustrar el programa de Fiestas de 1968. La autoría se indica en el sumario del propio programa de fiestas. La imagen representa a dos niños tocando el tabal y la dolçaina, instrumentos característicos de la música tradicional valenciana. Paleta cromática: blancos y naranjas.

Bibliografía:

- Revista Programa Fiestas Patronales de Onda. Ayuntamiento de Onda, Onda, 1968

- Fira d'Onda. Programes de Festes. Biblioteques d'Onda. Ajuntament d'Onda. Onda, 2006

\section{Imagen:}

Imágenes relacionadas:

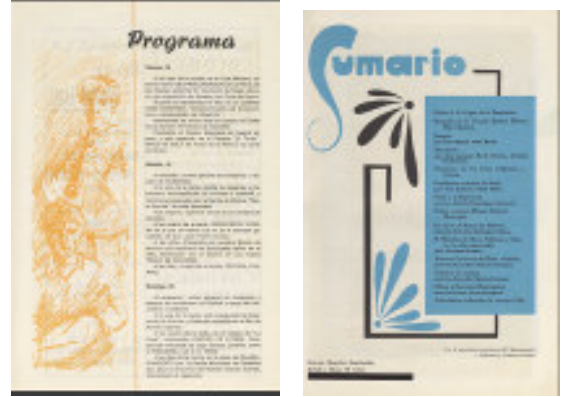

Progr. Fiestas 1968 
$\mathbf{N}^{0}: 1.12$

Título: Sin Título

Autoría: Manolo Safont

Datación: 1968

Técnica: Impresión gráfica

Localización: Biblioteca Municipal de Onda

Descripción: Safont realizó los dibujos para ilustrar el programa de Fiestas de 1968. La autoría se indica en el propio sumario del programa de fiestas. La imagen de una carrera ciclista se utilizó para ilustrar los actos deportivos. Paleta cromática: blancos y naranjas.

Bibliografía:

- Revista Programa Fiestas Patronales de Onda. Ayuntamiento de Onda, Onda, 1968

- Fira d'Onda. Programes de Festes. Biblioteques d'Onda. Ajuntament d'Onda. Onda, 2006

\section{Imagen:}

Imágenes relacionadas:

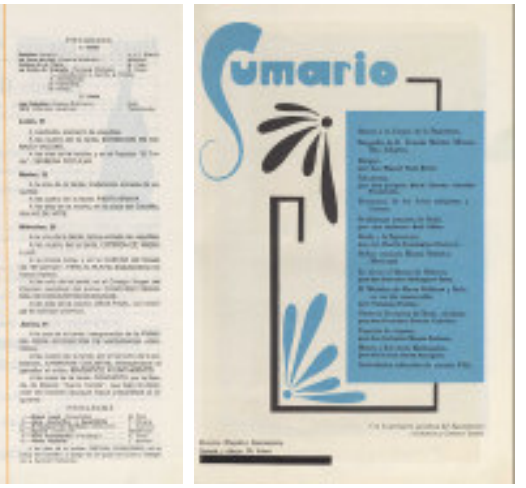

Progr. Fiestas 1968 
$\mathbf{N}^{0}: 1.13$

Título: Sin Título

Autoría: Manolo Safont

Datación: 1968

Técnica: Impresión gráfica

Localización: Biblioteca Municipal de Onda

Descripción: Safont realizó los dibujos para ilustrar el programa de Fiestas de 1968. La autoría se indica en el sumario del propio programa de fiestas. La imagen representa una mujer y un hombre, ataviados con ropajes tradicionales realizando un baile tradicional. Este dibujo vuelve a ser utilizado para ilustrar el programa de fiestas de 1971. Paleta cromática: blancos y naranjas.

Bibliografía:

- Revista Programa Fiestas Patronales de Onda. Ayuntamiento de Onda, Onda, 1968

- Revista Programa Fiestas Patronales de Onda. Ayuntamiento de Onda, Onda, 1971

- Fira d'Onda. Programes de Festes. Biblioteques d'Onda. Ajuntament d'Onda. Onda, 2006

Imagen:

Imágenes relacionadas:

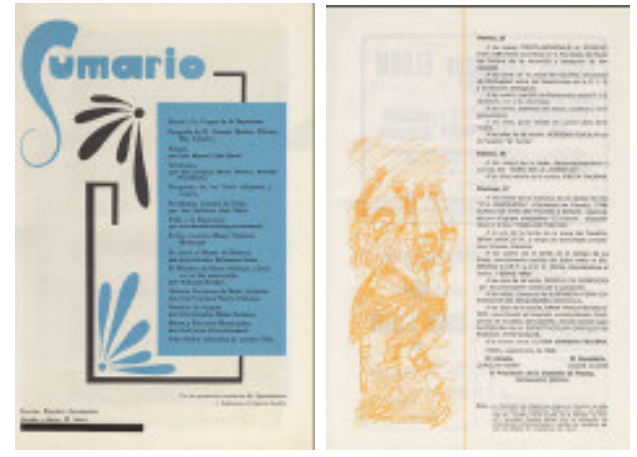

Progr. Fiestas 1968

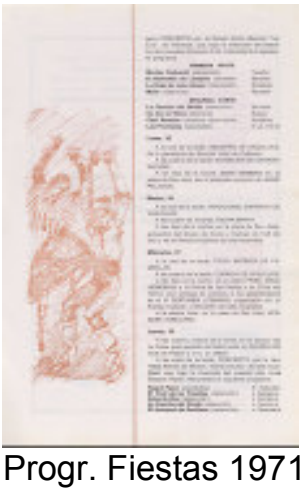


$\mathbf{N}^{\circ}: 1.14$

Título: Onda de Fiestas 1969

Autoría: Manolo Safont

Datación: 1969

Inscripciones: Onda en Fiestas 1969

Técnica: Impresión gráfica

Localización: Biblioteca Municipal de Onda

Descripción: Safont realizó tanto el dibujo de la portada como los dibujos interiores de la doble página con las fotografías de la corte de honor del Programa de Fiestas de 1969, se indica la autoría de Safont en el sumario del propio programa de fiestas. El dibujo de la portada de estilo abstracto, con un gran círculo central de color rojo, rodeado de manchas de colores, incluye también el escudo de Onda en el margen inferior izquierdo. Se conserva en el MAMS el dibujo original, obra cat. $n^{\circ} 2.26$. Paleta cromática: blancos, amarillos, rojos, verdes, azules y negros.

\section{Bibliografía:}

- Revista Programa Fiestas Patronales de Onda. Ayuntamiento de Onda, Onda, 1969

- Fira d'Onda. Programes de Festes. Biblioteques d'Onda. Ajuntament d'Onda. Onda, 2006

\section{Imagen:}

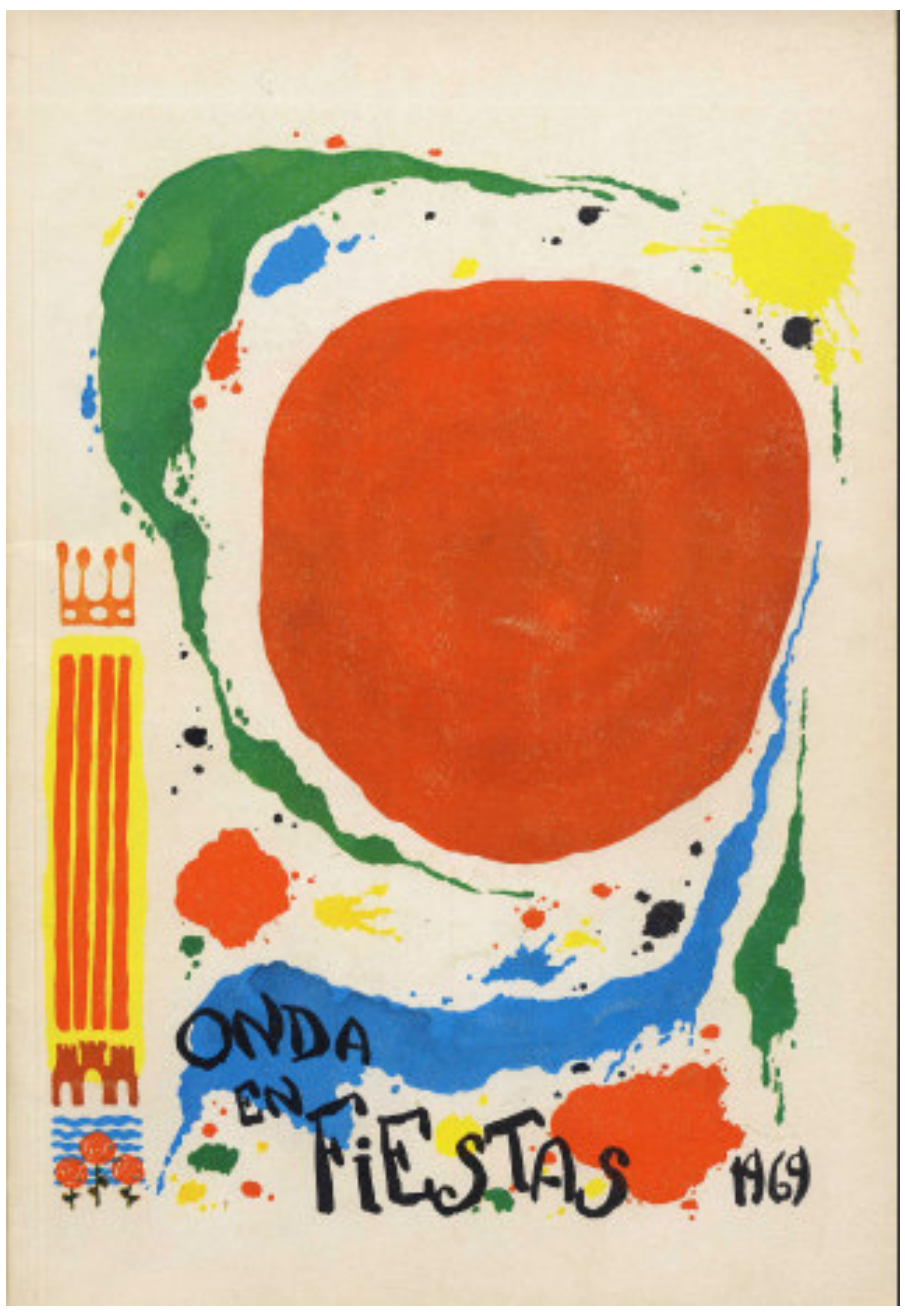




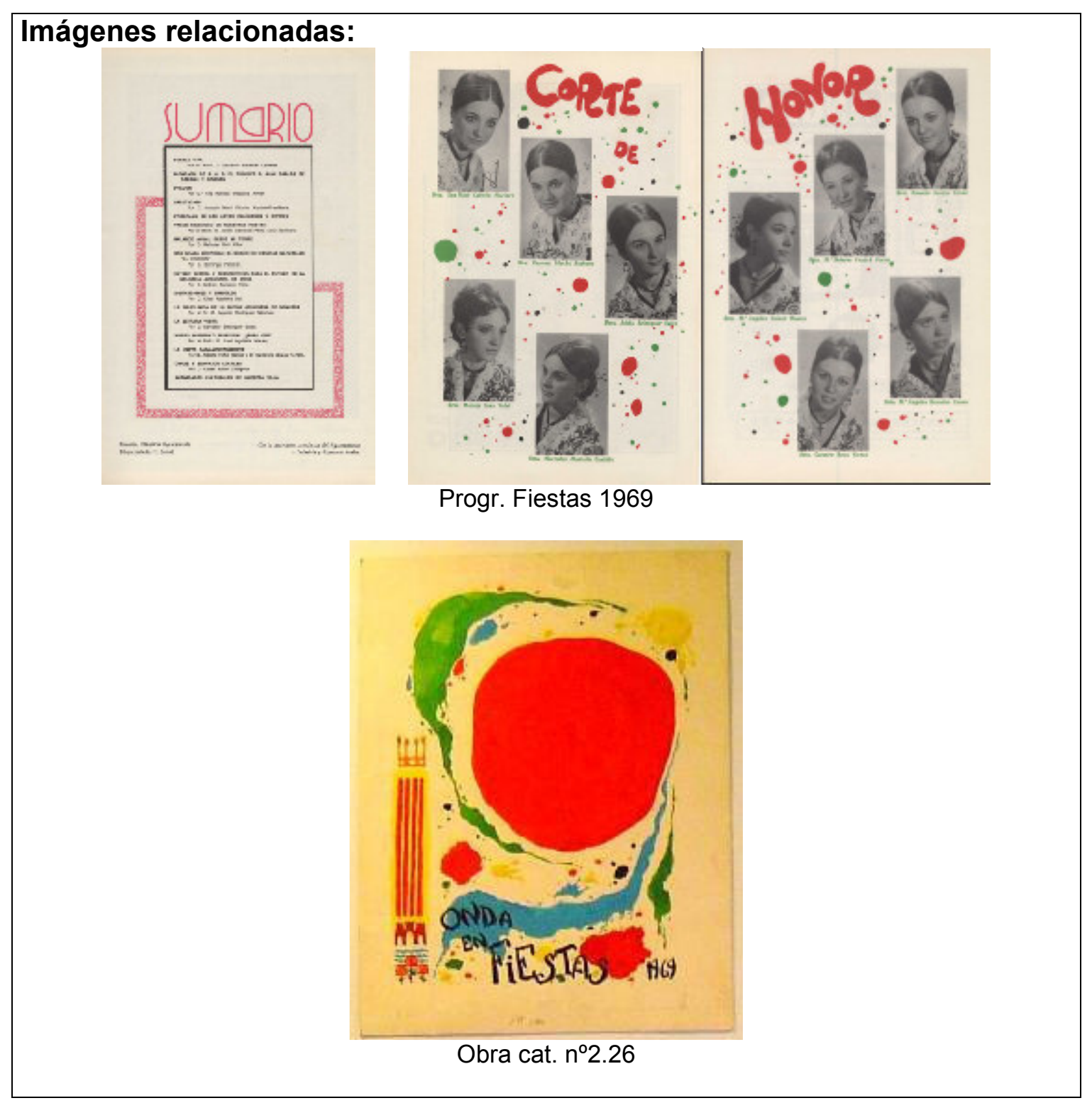


$\mathbf{N}^{0}: 1.15$

Título: La bola de foc símbol de les festes a Onda. Onda en fiestas 1970

Autoría: Manolo Safont

Datación: 1970

Inscripciones: La bola de foc símbol de les festes a Onda. Onda en Fiestas 1970

Técnica: Impresión gráfica

Localización: Biblioteca Municipal de Onda

Descripción: Dibujo para la portada de la Revista programa fiestas patronales de Onda, Fira d'Onda, de 1970, $n^{\circ} 6$, que se celebran durante el mes de Octubre, representa una gran bola circular de color rojo, alrededor de la cual se lee el lema: La bola de foc símbol de les festes a Onda, y el escudo de Onda en el margen inferior izquierdo. En el sumario del programa se indica la autoría de Safont del dibujo de portada y de los dibujos interiores. Un dibujo similar se utilizó como ilustración interior en el programa de fiestas de 1977. Presenta semejanza con la obra catalogada $\mathrm{n}^{\circ} 2.27$, un gran círculo rojo con líneas interiores que denotan movimiento. Paleta cromática: blancos, amarillos, rojos, azules y negros.

Bibliografía:

- Revista Programa Fiestas Patronales de Onda. Ayuntamiento de Onda, Onda, 1970

- Revista Programa Fiestas Patronales de Onda. Ayuntamiento de Onda, Onda, 1977

- Fira d'Onda. Programes de Festes. Biblioteques d'Onda. Ajuntament d'Onda. Onda, 2006

\section{Imagen:}

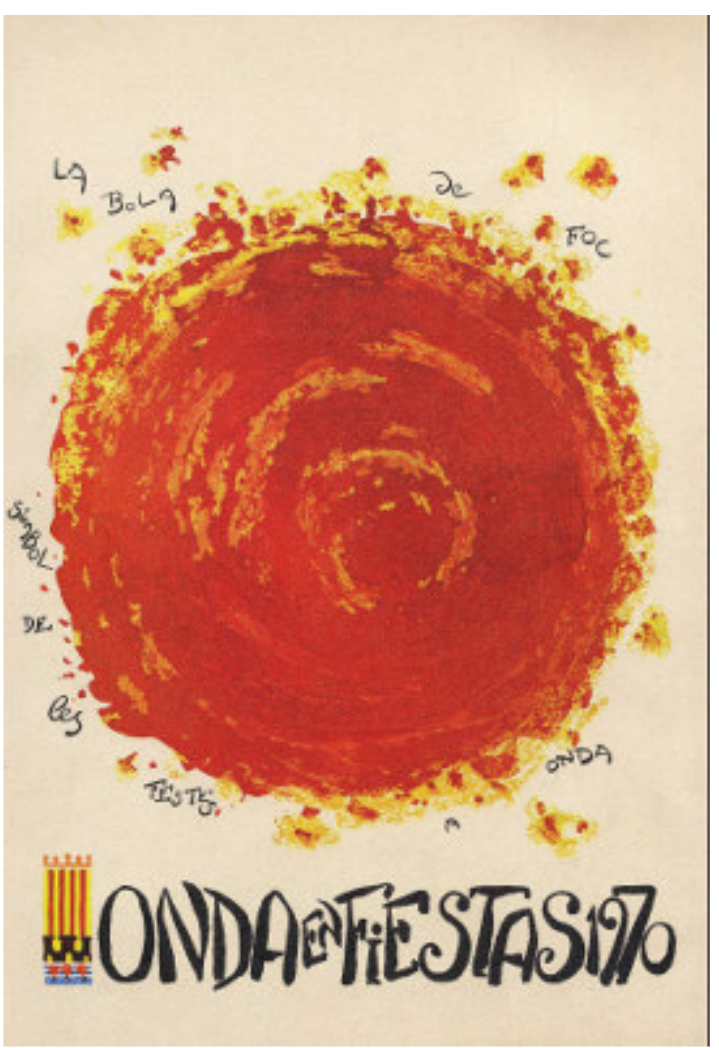




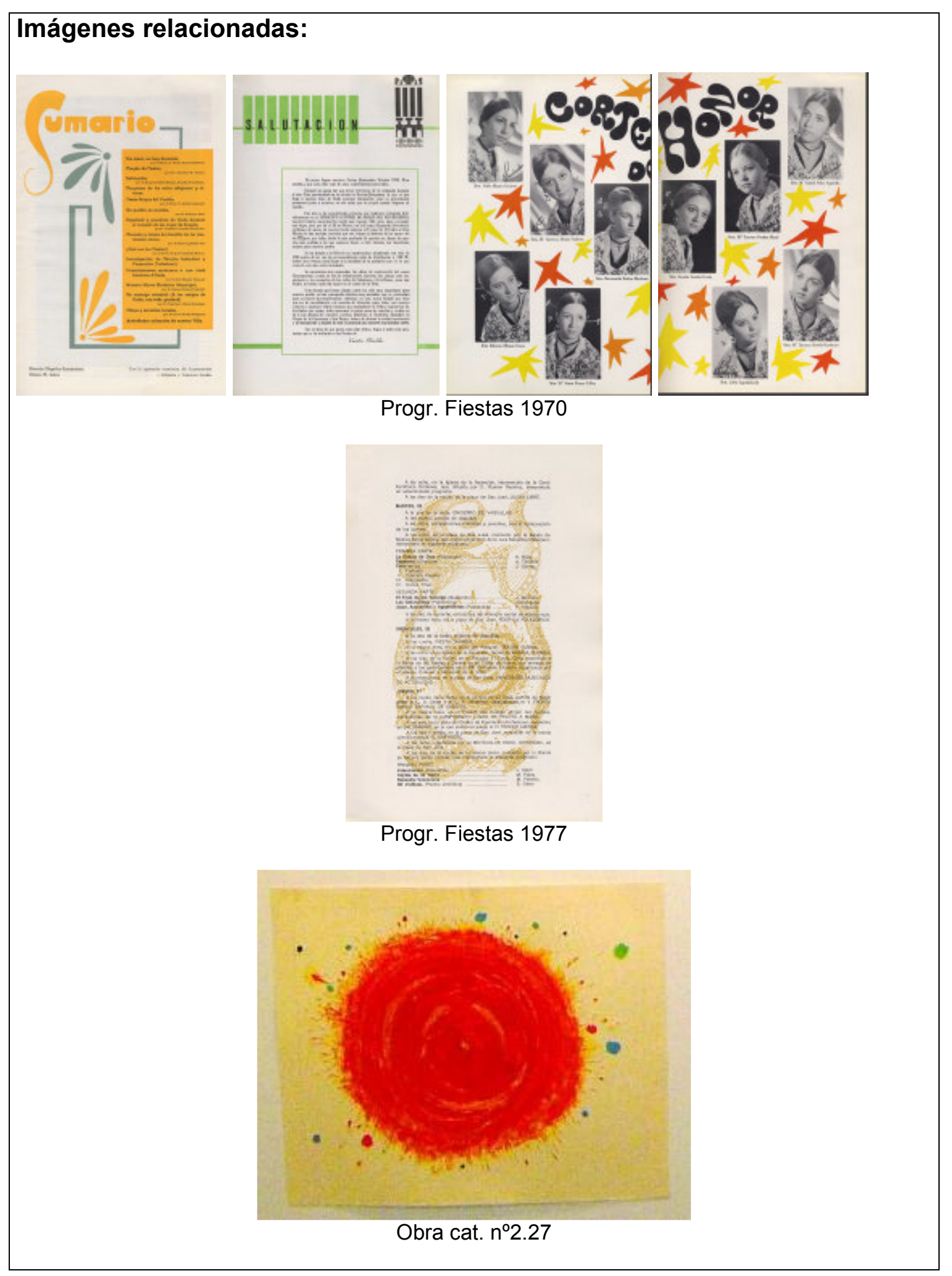


$\mathbf{N}^{0}: 1.16$

Título: Pregón de Fiestas

Autoría: Manolo Safont

Datación: 1970

Inscripciones: Pregón de Fiestas

Técnica: Impresión gráfica

Localización: Biblioteca Municipal de Onda

Descripción: Safont realizó los dibujos para ilustrar el programa de fiestas de 1970. La autoría se indica en el sumario del propio programa. Las imágenes representan unas figuras de pregoneros y sirven como ilustración del pregón de fiestas. Este mismo dibujo vuelve a servir como ilustración en el programa de fiestas de 1971. Paleta cromática: blancos y negros.

Bibliografía:

- Revista Programa Fiestas Patronales de Onda. Ayuntamiento de Onda, Onda, 1970

- Revista Programa Fiestas Patronales de Onda. Ayuntamiento de Onda, Onda, 1971

- Fira d'Onda. Programes de Festes. Biblioteques d'Onda. Ajuntament d'Onda. Onda, 2006

\section{Imagen:}

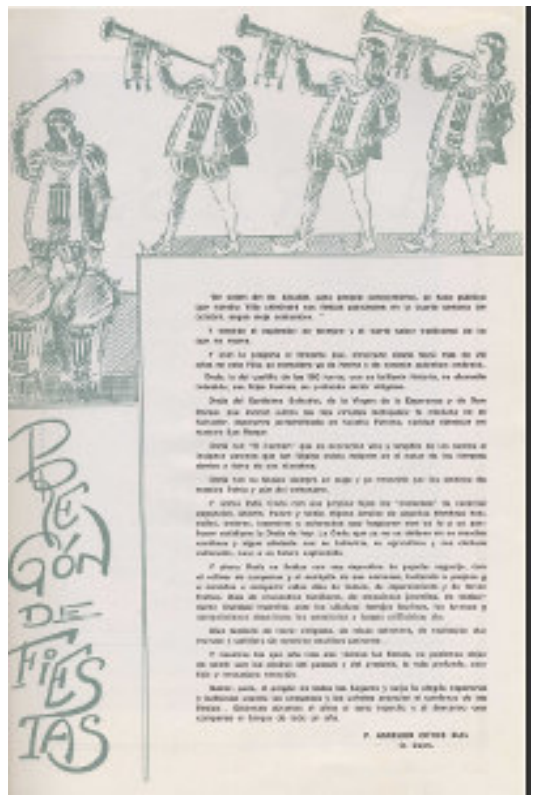

Imágenes relacionadas:

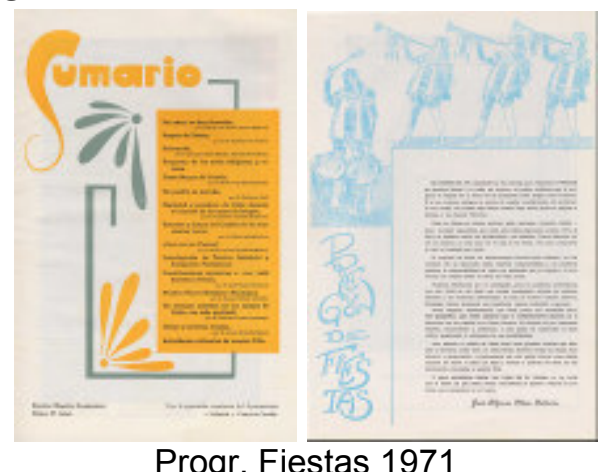

Progr. Fiestas 1971 
$\mathbf{N}^{0}: 1.17$

Título: Sin Título

Autoría: Manolo Safont

Datación: 1970

Técnica: Impresión gráfica

Localización: Biblioteca Municipal de Onda

Descripción: Safont realizó los dibujos para ilustrar el programa de Fiestas de 1970. La autoría se indica en el sumario del propio programa de fiestas. Esta imagen representa la fachada exterior de la capilla de San José, ubicada en el Raval de San José de Onda. Paleta cromática: blancos y naranjas.

Bibliografía:

- Revista Programa Fiestas Patronales de Onda. Ayuntamiento de Onda, Onda, 1970

- Fira d'Onda. Programes de Festes. Biblioteques d'Onda. Ajuntament d'Onda. Onda, 2006

\section{Imagen:}

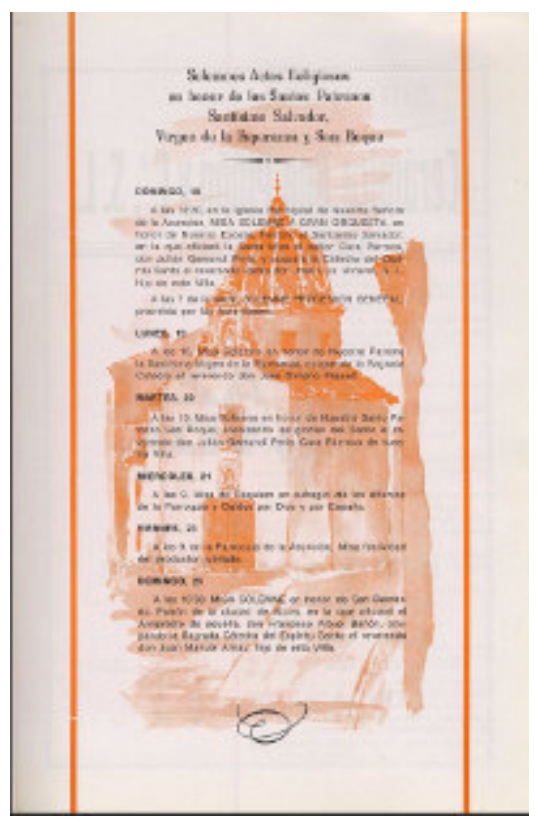

Imágenes relacionadas:

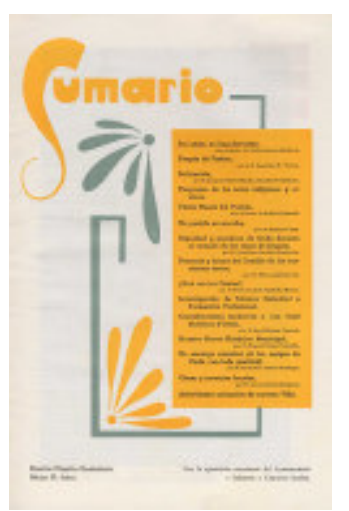

Progr. Fiestas 1970 
$\mathbf{N}^{0}: 1.18$

Título: Sin Título

Autoría: Manolo Safont

Datación: 1970

Técnica: Impresión gráfica

Localización: Biblioteca Municipal de Onda

Descripción: Safont realizó los dibujos para ilustrar el programa de Fiestas de 1970, la autoría se indica en el sumario del propio programa de fiestas. Esta imagen representa a dos chicos tocando el tabal y la dolçaina, instrumentos propios de la música tradicional valenciana. Paleta cromática: blancos y naranjas.

Bibliografía:

- Revista Programa Fiestas Patronales de Onda. Ayuntamiento de Onda, Onda, 1970

- Fira d'Onda. Programes de Festes. Biblioteques d'Onda. Ajuntament d'Onda. Onda, 2006

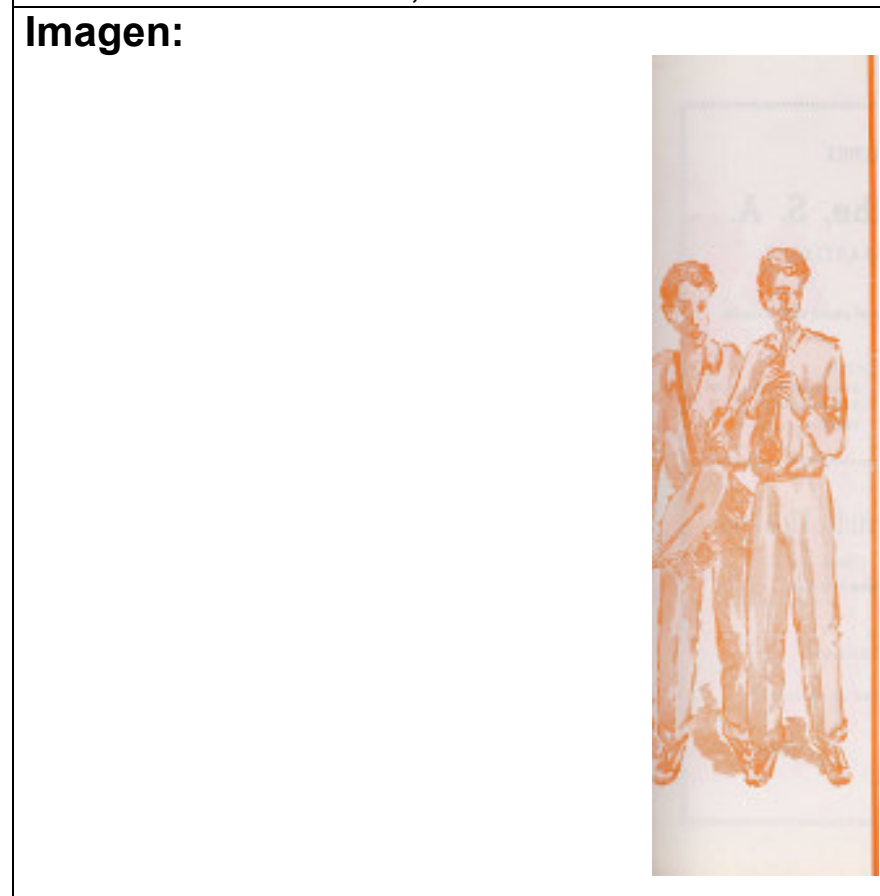

Imágenes relacionadas:

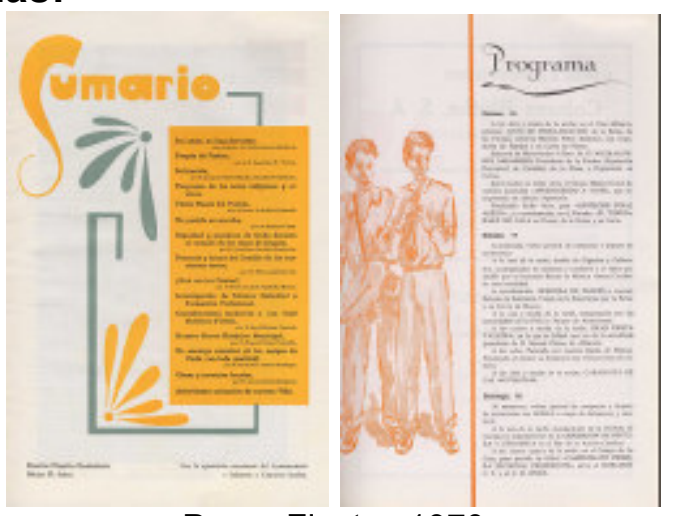

Progr. Fiestas 1970 
No: 1.19

Título: Sin Título

Autoría: Manolo Safont

Datación: 1970

Técnica: Impresión gráfica

Localización: Biblioteca Municipal de Onda

Descripción: Safont realizó los dibujos para ilustrar el programa de Fiestas de 1970. La autoría se indica en el sumario del propio programa de fiestas. La imagen, relacionada con los festejos populares y tradicionales, representa unos gigantes y unos cabezudos. Paleta cromática: blancos y naranjas.

Bibliografía:

- Revista Programa Fiestas Patronales de Onda. Ayuntamiento de Onda, Onda, 1970

- Fira d'Onda. Programes de Festes. Biblioteques d'Onda. Ajuntament d'Onda. Onda, 2006

Imagen:

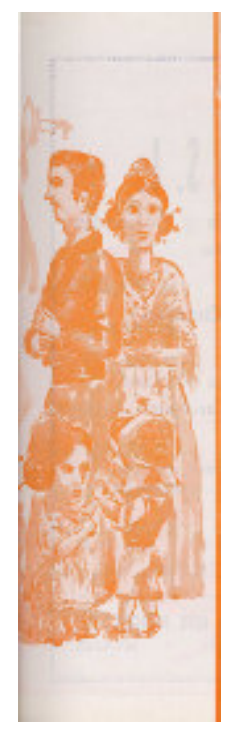

Imágenes relacionadas:

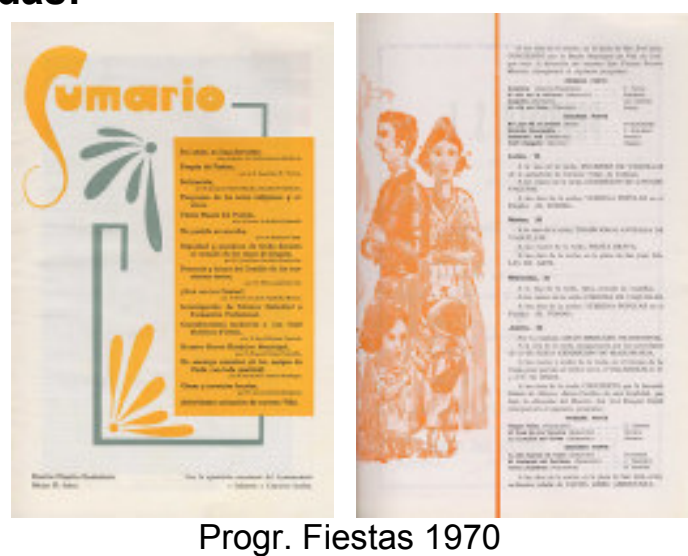

Progr. Fiestas 1970 
$\mathbf{N}^{\circ}: 1.20$

Título: Sin Título

Autoría: Manolo Safont

Datación: 1970

Técnica: Impresión gráfica

Localización: Biblioteca Municipal de Onda

Descripción: Safont realizó los dibujos para ilustrar el programa de Fiestas de 1970. La autoría se indica en el sumario del propio programa de fiestas. La imagen representa una escena taurina, con una figura de un toro embistiendo en primer plano. Esta misma imagen se utilizó en el programa de fiestas de 1967. Paleta cromática: blancos y naranjas

Bibliografía:

- Revista Programa Fiestas Patronales de Onda. Ayuntamiento de Onda, Onda, 1967

- Revista Programa Fiestas Patronales de Onda. Ayuntamiento de Onda, Onda, 1970

- Fira d'Onda. Programes de Festes. Biblioteques d'Onda. Ajuntament d'Onda. Onda, 2006

Imagen:

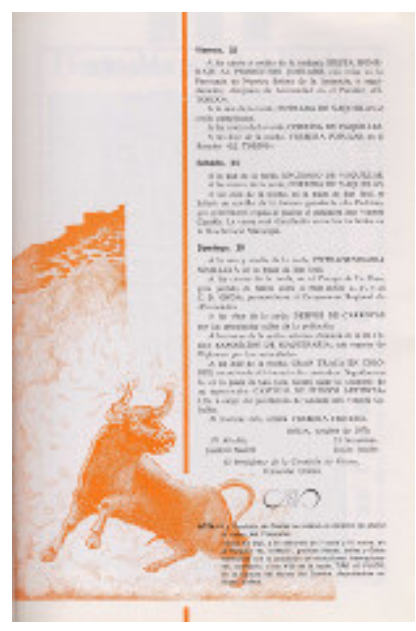

Imágenes relacionadas:

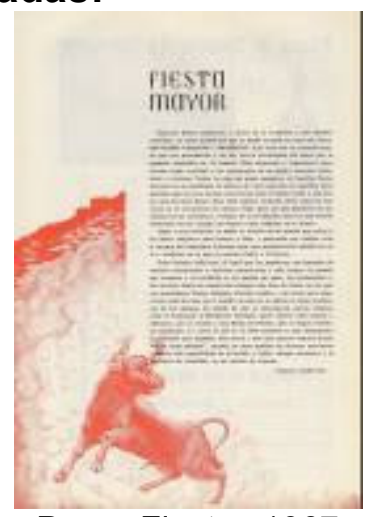

Progr. Fiestas 1967

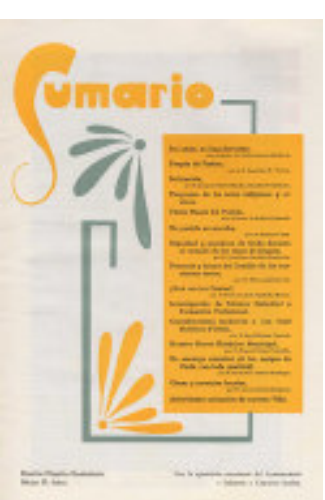

Progr. Fiestas 1970 
$\mathbf{N}^{0}: 1.21$

Título: Sin Título

Autoría: Manolo Safont

Datación: 1971

Técnica: Impresión gráfica

Localización: Biblioteca Municipal de Onda

Descripción: Safont realizó los dibujos para ilustrar el programa de Fiestas de 1971, la autoría se indica en el sumario del propio programa de fiestas. Esta misma imagen se utilizó también para ilustrar los programas de fiestas de 1967, 1974 y 1980. La imagen representa una escena de un encierro taurino, tema relacionado con las fiestas ondenses. Paleta cromática: blancos y rojos.

Bibliografía:

- Revista Programa Fiestas Patronales de Onda. Ayuntamiento de Onda, Onda, 1967

- Revista Programa Fiestas Patronales de Onda. Ayuntamiento de Onda, Onda, 1971

- Revista Programa Fiestas Patronales de Onda. Ayuntamiento de Onda, Onda, 1974

- Revista Programa Fiestas Patronales de Onda. Ayuntamiento de Onda, Onda, 1980

- Fira d'Onda. Programes de Festes. Biblioteques d'Onda. Ajuntament d'Onda. Onda, 2006

Imagen:

Imágenes relacionadas:

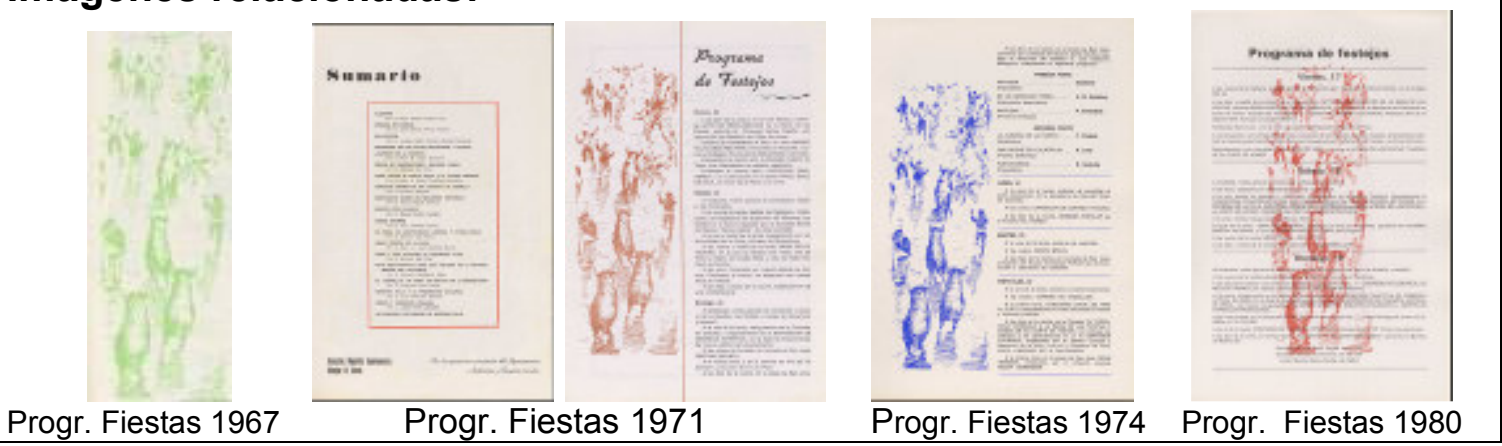


$\mathbf{N}^{0}: 1.22$

Título: Sin Título

Autoría: Manolo Safont

Datación: 1971

Inscripciones: Pregón de Fiestas

Técnica: Impresión gráfica

Localización: Biblioteca Municipal de Onda

Descripción: Safont realizó los dibujos para ilustrar el programa de Fiestas de 1971, la autoría se indica en el sumario del propio programa de fiestas. Las imágenes representan unas figuras de pregoneros y se utilizan para ilustrar el pregón de fiestas. Este mismo dibujo sirvió como ilustración en el programa de fiestas de 1970. Paleta cromática: blancos y azules.

Bibliografía:

- Revista Programa Fiestas Patronales de Onda. Ayuntamiento de Onda, Onda, 1970

- Revista Programa Fiestas Patronales de Onda. Ayuntamiento de Onda, Onda, 1971

- Fira d'Onda. Programes de Festes. Biblioteques d'Onda. Ajuntament d'Onda. Onda, 2006

Imagen:

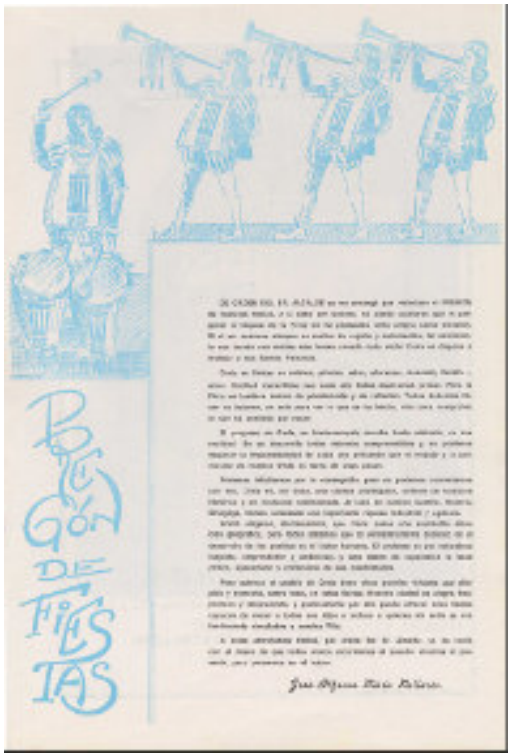

Imágenes relacionadas:

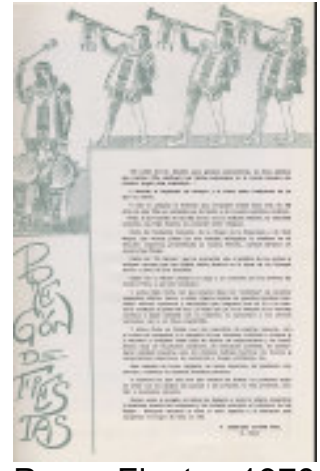

Progr. Fiestas 1970 
No: 1.23

Título: Sin Título

Autoría: Manolo Safont

Datación: 1971

Técnica: Impresión gráfica

Localización: Biblioteca Municipal de Onda

Descripción: Safont realizó los dibujos para ilustrar el programa de Fiestas de 1971, la autoría se indica en el sumario del propio programa de fiestas. Esta imagen es un dibujo de la iglesia Nuestra Señora de la Asunción de Onda, y se utiliza también para ilustrar el programa de fiestas de 1967, 1968, 1974 y 1980. Paleta cromática: blancos y rojos.

Bibliografía:

- Revista Programa Fiestas Patronales de Onda. Ayuntamiento de Onda, Onda, 1967

- Revista Programa Fiestas Patronales de Onda. Ayuntamiento de Onda, Onda, 1968

- Revista Programa Fiestas Patronales de Onda. Ayuntamiento de Onda, Onda, 1971

- Revista Programa Fiestas Patronales de Onda. Ayuntamiento de Onda, Onda, 1974

- Revista Programa Fiestas Patronales de Onda. Ayuntamiento de Onda, Onda, 1980

- Fira d'Onda. Programes de Festes. Biblioteques d'Onda. Ajuntament d'Onda. Onda, 2006

\section{Imagen:}

Imágenes relacionadas:
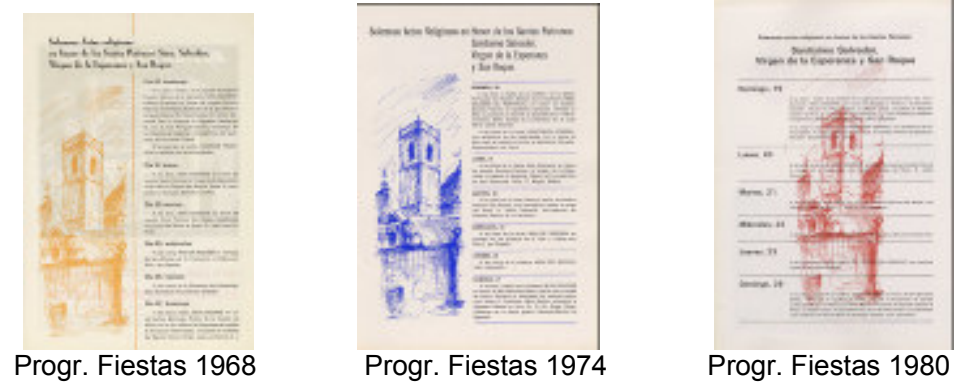
$\mathbf{N}^{0}: 1.24$

Título: Sin Título

Autoría: Manolo Safont

Datación: 1971

Técnica: Impresión gráfica

Localización: Biblioteca Municipal de Onda

Descripción: Safont realizó los dibujos para ilustrar el programa de Fiestas de 1971, la autoría se indica en el sumario del propio programa de fiestas. La imagen representa una mujer y un hombre, ataviados con ropajes tradicionales realizando un baile tradicional. Este dibujo fue utilizado en el programa de fiestas de 1968. Paleta cromática: blancos y rojos.

Bibliografía:

- Revista Programa Fiestas Patronales de Onda. Ayuntamiento de Onda, Onda, 1968

- Revista Programa Fiestas Patronales de Onda. Ayuntamiento de Onda, Onda, 1971

- Fira d'Onda. Programes de Festes. Biblioteques d'Onda. Ajuntament d'Onda. Onda, 2006

\section{Imagen:}

Imágenes relacionadas:

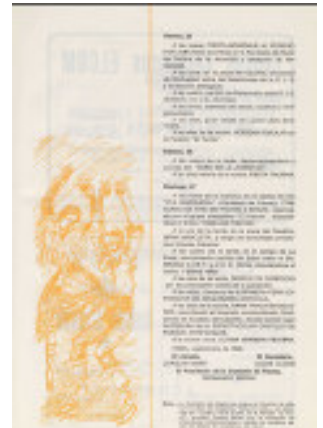

Progr. Fiestas 1968

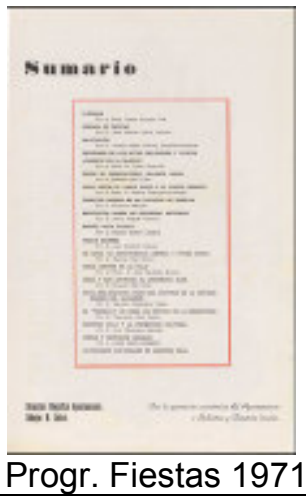


$\mathbf{N}^{0}: 1.25$

Título: Sin Título

Autoría: Manolo Safont

Datación: 1971

Técnica: Impresión gráfica

Localización: Biblioteca Municipal de Onda

Descripción: Safont realizó los dibujos para ilustrar el programa de Fiestas de 1971. La autoría se indica en el sumario del propio programa de fiestas. Esta ilustración de una actuación musical, realizada con formas sencillas, marcando únicamente las siluetas, fue utilizada también en el Programa de fiestas de 1974. Paleta cromática: blancos y rojos

Bibliografía:

- Revista Programa Fiestas Patronales de Onda. Ayuntamiento de Onda, Onda, 1971

- Revista Programa Fiestas Patronales de Onda. Ayuntamiento de Onda, Onda, 1974

- Fira d'Onda. Programes de Festes. Biblioteques d'Onda. Ajuntament d'Onda. Onda, 2006

\section{Imagen:}

Imágenes relacionadas:
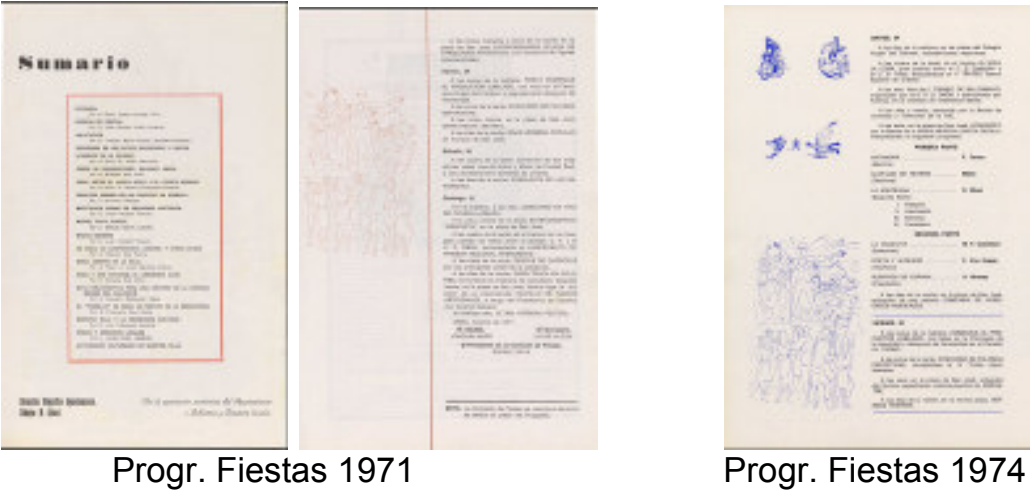
$\mathbf{N}^{\circ}: 1.26$

Título: Onda en fiestas 1974

Autoría: Manolo Safont

Datación: 1974

Inscripciones: Onda en fiestas 1974

Técnica: Impresión gráfica

Localización: Biblioteca Municipal de Onda

Descripción: Portada de la Revista programa fiestas patronales de Onda, Fira d'Onda, de 1974, que se celebran durante el mes de Octubre. También realiza el diseño de la doble página de la corte de honor y los dibujos interiores. La imagen está compuesta por una representación del escudo de Onda y diferentes manchas de colores enmarcando una fotografía de una vista panorámica de Onda, realizada por José Aguilella. Paleta cromática: amarillos, rojos, verdes, azules y negros.

\section{Bibliografía:}

- Revista Programa Fiestas Patronales de Onda. Ayuntamiento de Onda, Onda, 1974

- Fira d'Onda. Programes de Festes. Biblioteques d'Onda. Ajuntament d'Onda. Onda, 2006

\section{Imagen:}

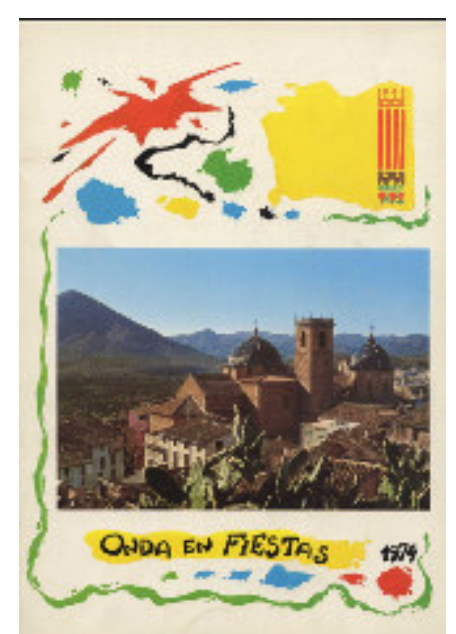

Imágenes relacionadas.

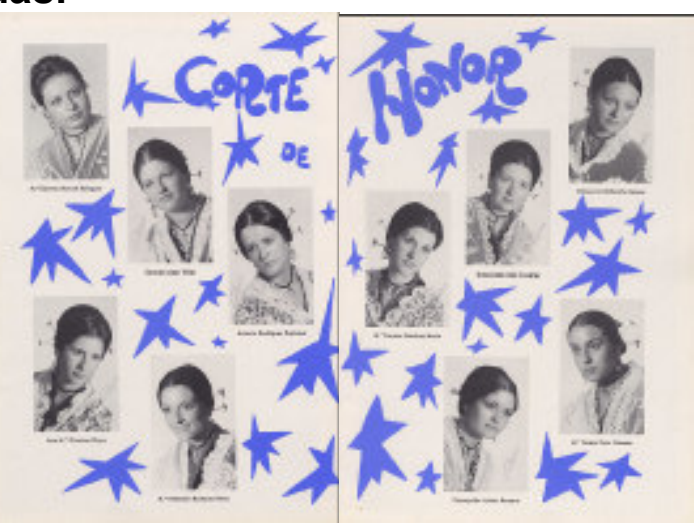

Progr. Fiestas 1974 
$\mathbf{N}^{0}: 1.27$

Título: Sin Título

Autoría: Manolo Safont

Datación: 1974

Técnica: Impresión gráfica

Localización: Biblioteca Municipal de Onda

Descripción: Safont realizó los dibujos para ilustrar el programa de Fiestas de 1971. Esta imagen es un dibujo de la fachada de la iglesia Nuestra Señora de la Asunción de Onda, con la torre campanario, y se utiliza también para ilustrar el programa de fiestas de 1967, 1968, 1971 y 1980. Paleta cromática: blancos y azules.

Bibliografía:

- Revista Programa Fiestas Patronales de Onda. Ayuntamiento de Onda, Onda, 1967

- Revista Programa Fiestas Patronales de Onda. Ayuntamiento de Onda, Onda, 1968

- Revista Programa Fiestas Patronales de Onda. Ayuntamiento de Onda, Onda, 1971

- Revista Programa Fiestas Patronales de Onda. Ayuntamiento de Onda, Onda, 1974

- Revista Programa Fiestas Patronales de Onda. Ayuntamiento de Onda, Onda, 1980

- Fira d'Onda. Programes de Festes. Biblioteques d'Onda. Ajuntament d'Onda. Onda, 2006

Imagen:

Imágenes relacionadas: 
$\mathbf{N}^{0}: 1.28$

Título: Sin Título

Autoría: Manolo Safont

Datación: 1974

Técnica: Impresión gráfica

Localización: Biblioteca Municipal de Onda

Descripción: Safont realizó los dibujos para ilustrar el programa de Fiestas de 1971. Esta misma imagen se utilizó también para ilustrar los programas de fiestas de 1967, 1971 y 1980. La imagen representa una escena de un encierro taurino, tema relacionado con las fiestas ondenses. Paleta cromática: blancos y azules.

\section{Bibliografía:}

- Revista Programa Fiestas Patronales de Onda. Ayuntamiento de Onda, Onda, 1967

- Revista Programa Fiestas Patronales de Onda. Ayuntamiento de Onda, Onda, 1971

- Revista Programa Fiestas Patronales de Onda. Ayuntamiento de Onda, Onda, 1974

- Revista Programa Fiestas Patronales de Onda. Ayuntamiento de Onda, Onda, 1980

- Fira d'Onda. Programes de Festes. Biblioteques d'Onda. Ajuntament d'Onda. Onda, 2006

\section{Imagen:}

Imágenes relacionadas:
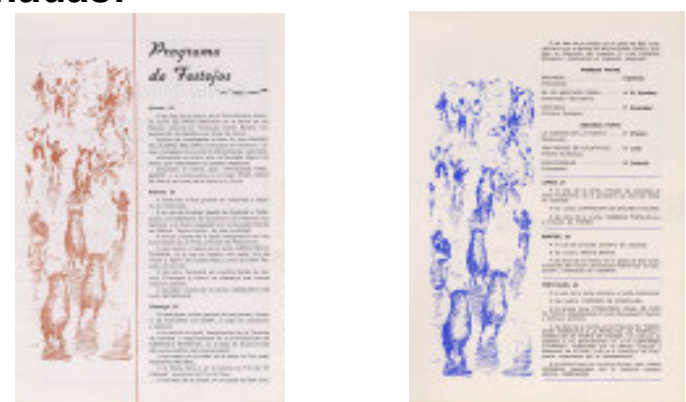

Progr. Fiestas 1967 Progr. Fiestas 1971 
$\mathbf{N}^{\circ}: 1.29$

Título: Sin Título

Autoría: Manolo Safont

Datación: 1974

Técnica: Impresión gráfica

Localización: Biblioteca Municipal de Onda

Descripción: Safont realizó los dibujos para ilustrar el programa de Fiestas de 1974 , en esta imagen se combina un dibujo de gigantes y cabezudos y una imagen de una escena de un partido de fútbol. Paleta cromática: blancos y azules.

Bibliografía:

- Revista Programa Fiestas Patronales de Onda. Ayuntamiento de Onda, Onda, 1974

- Fira d'Onda. Programes de Festes. Biblioteques d'Onda. Ajuntament d'Onda. Onda, 2006

Imagen:

Imágenes relacionadas:

marme th toxign

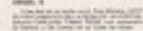

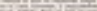

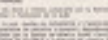

Alemengen

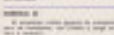

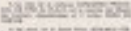

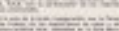

Progr. Fiestas 1974 
$\mathbf{N}^{0}: 1.30$

Título: Sin Título

Autoría: Manolo Safont

Datación: 1974

Técnica: Impresión gráfica

Localización: Biblioteca Municipal de Onda

Descripción: Safont realizó los dibujos para ilustrar el programa de Fiestas de 1974. La escena de la actuación musical ya sirvió de ilustración en el Programa de fiestas de 1971. En esta imagen además de la escena correspondiente a la actuación musical, se combina con otros dibujos que representan una escena de una carrera, una carrera ciclista y un partido de fútbol. Paleta cromática: blancos y azules.

Bibliografía:

- Revista Programa Fiestas Patronales de Onda. Ayuntamiento de Onda, Onda, 1971

- Revista Programa Fiestas Patronales de Onda. Ayuntamiento de Onda, Onda, 1974

- Fira d'Onda. Programes de Festes. Biblioteques d'Onda. Ajuntament d'Onda. Onda, 2006

\section{Imagen:}

Imágenes relacionadas:
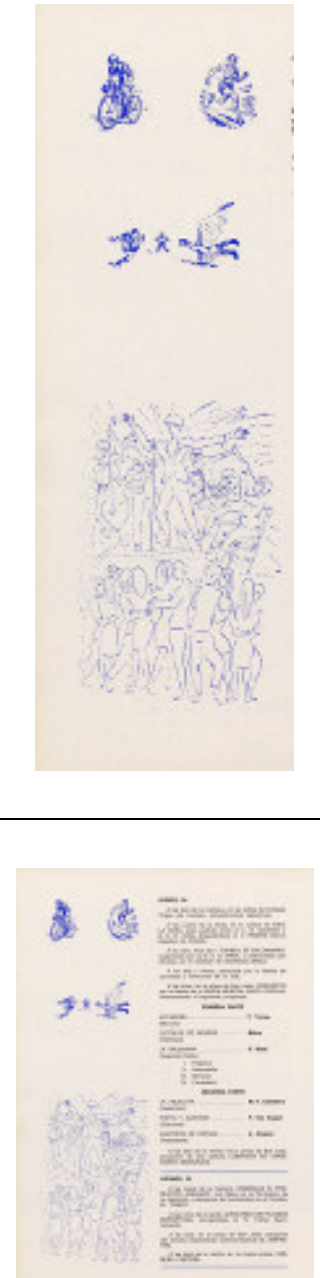

Progr. Fiestas 1974 
$\mathbf{N}^{\circ}: 1.31$

Título: Sin Título

Autoría: Manolo Safont

Datación: 1974

Técnica: Impresión gráfica

Localización: Biblioteca Municipal de Onda

Descripción: Safont realizó los dibujos para ilustrar el programa de Fiestas de 1974. En esta imagen se representan tres escenas relacionadas con las fiestas de Onda: una escena de tauromaquia, una escena de folclore tradicional y una escena de una traca de fuegos artificiales. Paleta cromática: blancos y azules.

Bibliografía:

- Fira d'Onda. Programes de Festes. Biblioteques d'Onda. Ajuntament d'Onda. Onda, 2006

- Revista Programa Fiestas Patronales de Onda. Ayuntamiento de Onda, Onda, 1974

Imagen:

Imágenes relacionadas:

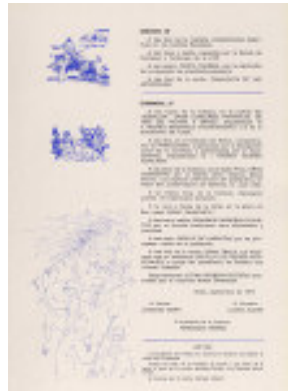

Progr. Fiestas 1974 
$\mathbf{N}^{0}: 1.32$

Título: Sin Título

Autoría: Manolo Safont

Datación: 1975

Técnica: Impresión gráfica

Localización: Biblioteca Municipal de Onda

Descripción: Safont realizó los dibujos para ilustrar el programa de Fiestas de 1975 y también el diseño del programa de fiestas. La autoría se indica en el sumario del propio programa de fiestas. Paleta cromática: blancos y naranjas.

Bibliografía:

- Revista Programa Fiestas Patronales de Onda. Ayuntamiento de Onda, Onda, 1975

- Fira d'Onda. Programes de Festes. Biblioteques d'Onda. Ajuntament d'Onda. Onda, 2006

\section{Imagen:}

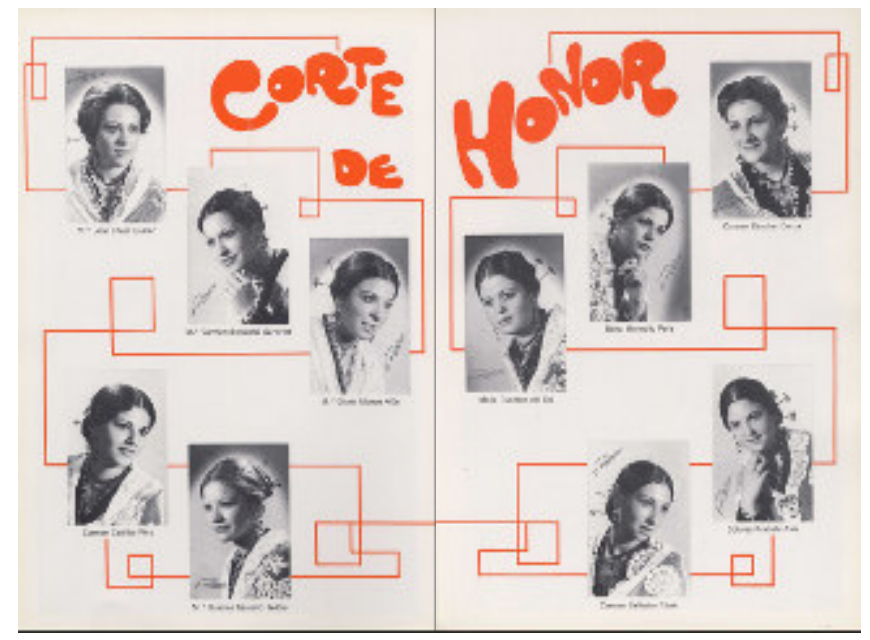

Imágenes relacionadas:

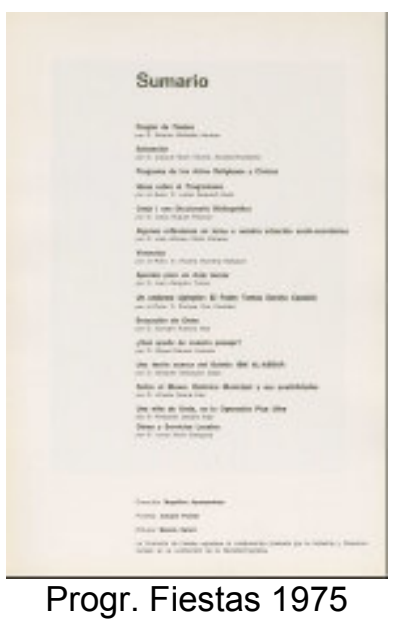


$\mathbf{N}^{\circ}: 1.33$

Título: Sin Título

Autoría: Manolo Safont

Datación: 1975

Técnica: Impresión gráfica

Localización: Biblioteca Municipal de Onda

Descripción: Safont realizó los dibujos para ilustrar el programa de Fiestas de 1975. La autoría se indica en el sumario del propio programa de fiestas. Esta misma ilustración se utiliza en los programas de fiestas de 1976 y 1980 . En esta escena se observa un grupo de personas llegando a la explanada del ermitorio del Santísimo Salvador de Onda. Paleta cromática: blancos y rojos.

Bibliografía:

- Revista Programa Fiestas Patronales de Onda. Ayuntamiento de Onda, Onda, 1975

- Revista Programa Fiestas Patronales de Onda. Ayuntamiento de Onda, Onda, 1976

- Revista Programa Fiestas Patronales de Onda. Ayuntamiento de Onda, Onda, 1980

- Fira d'Onda. Programes de Festes. Biblioteques d'Onda. Ajuntament d'Onda. Onda, 2006

\section{Imagen:}

\section{Imágenes relacionadas:}

Nemarie

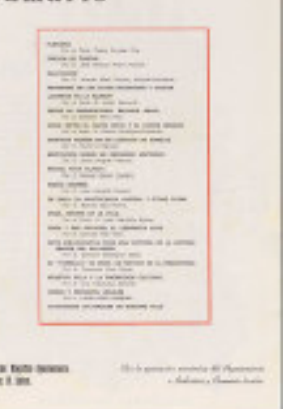

Progr. Fiestas 1975

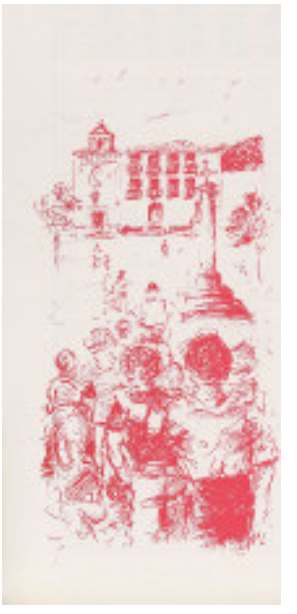

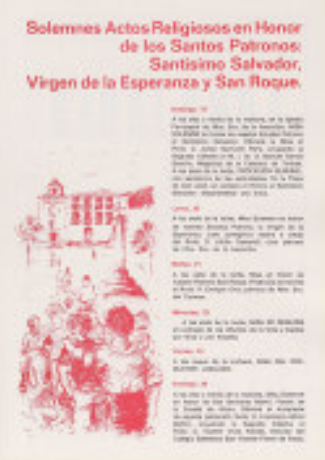

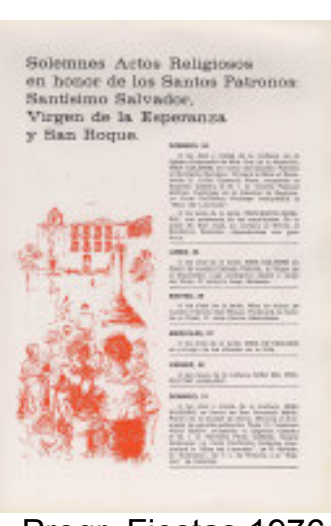

Progr. Fiestas 1976

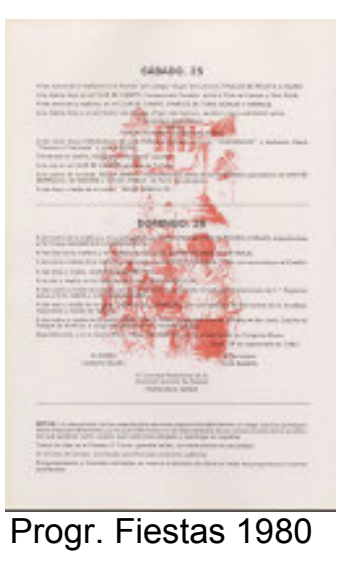


$\mathbf{N}^{\circ}: 1.34$

Título: Sin Título

Autoría: Manolo Safont

Datación: 1975

Técnica: Impresión gráfica

Localización: Bbiblioteca Municipal de Onda

Descripción: Safont realizó los dibujos para ilustrar el programa de Fiestas de 1975. La autoría se indica en el sumario del propio programa de fiestas. Representa una escena de las fiestas patronales de Onda, los gigantes y cabezudos, acompañados por un dolçainer y un tabaleter. Paleta cromática: blancos y rojos.

Bibliografía:

- Revista Programa Fiestas Patronales de Onda. Ayuntamiento de Onda, Onda, 1975

- Fira d'Onda. Programes de Festes. Biblioteques d'Onda. Ajuntament d'Onda. Onda, 2006

\section{Imagen:}

Imágenes relacionadas:

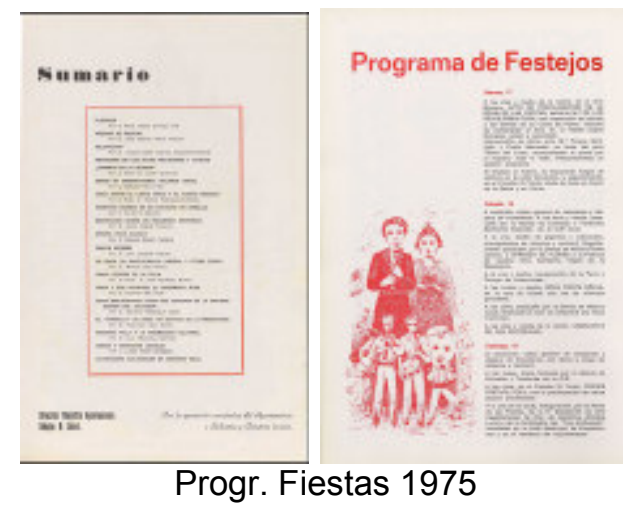


$\mathbf{N}^{0}: 1.35$

Título: Sin Título

Autoría: Manolo Safont

Datación: 1975

Técnica: Impresión gráfica

Localización: Biblioteca Municipal de Onda

Descripción: Safont realizó los dibujos para ilustrar el programa de Fiestas de 1975. La autoría se indica en el sumario del propio programa de fiestas. Esta escena taurina se utiliza también para ilustrar el programa de fiestas de 1980. Paleta cromática: blancos y rojos.

\section{Bibliografía:}

- Revista Programa Fiestas Patronales de Onda. Ayuntamiento de Onda, Onda, 1975

- Revista Programa Fiestas Patronales de Onda. Ayuntamiento de Onda, Onda, 1980

- Fira d'Onda. Programes de Festes. Biblioteques d'Onda. Ajuntament d'Onda. Onda, 2006

\section{Imagen:}

Imágenes relacionadas:
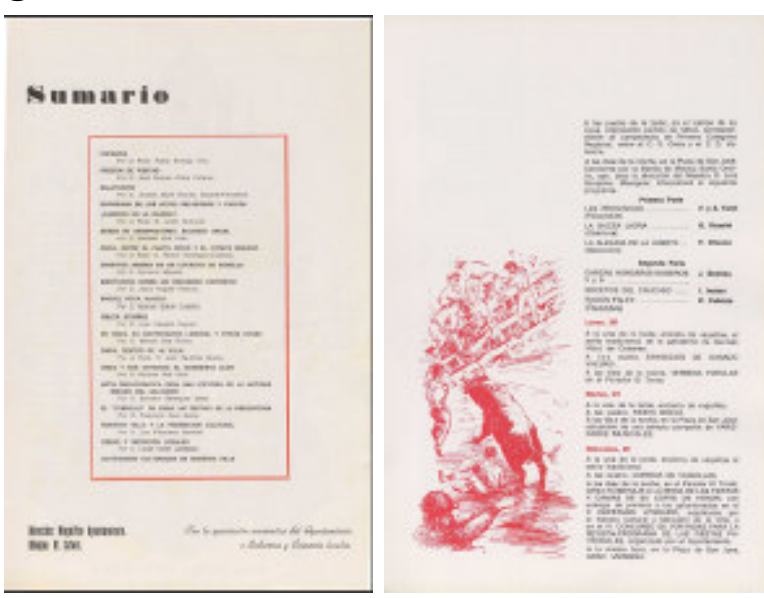

Progr. Fiestas 1975

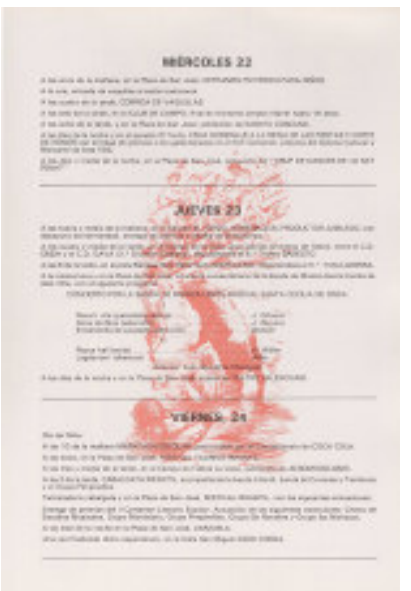

Progr. Fiestas 1980 
$\mathbf{N}^{0}: 1.36$

Título: Sin Título

Autoría: Manolo Safont

Datación: 1975

Técnica: Impresión gráfica

Localización: Biblioteca Municipal de Onda

Descripción: Safont realizó los dibujos para ilustrar el programa de Fiestas de 1975. La autoría se indica en el sumario del propio programa de fiestas. Esta imagen se utilizó también para ilustrar el programa de fiestas de 1976. La imagen representa una escena de un parque de atracciones, con un carrusel y una noria. Paleta cromática: blancos y rojos.

Bibliografía:

- Revista Programa Fiestas Patronales de Onda. Ayuntamiento de Onda, Onda, 1975

- Revista Programa Fiestas Patronales de Onda. Ayuntamiento de Onda, Onda, 1976

- Fira d'Onda. Programes de Festes. Biblioteques d'Onda. Ajuntament d'Onda. Onda, 2006

Imagen:

Imágenes relacionadas:
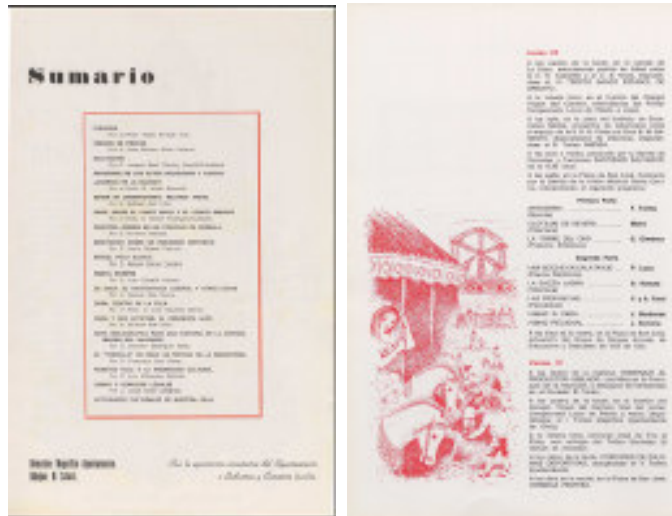

Progr. Fiestas 1975

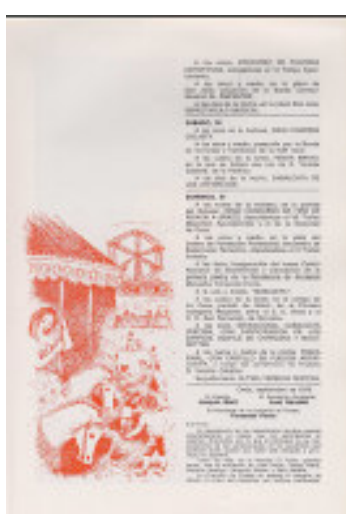

Progr. Fiestas 1976 
No: 1.37

Título: Sin Título

Autoría: Manolo Safont

Datación: 1975

Técnica: Impresión gráfica

Localización: Biblioteca Municipal de Onda

Descripción: Safont realizó los dibujos para ilustrar el programa de Fiestas de 1975. La autoría se indica en el sumario del propio programa de fiestas. Esta misma escena de fuegos artificiales se utilizó para ilustrar el programa de fiestas de 1980. Paleta cromática: blancos y rojos.

Bibliografía:

- Revista Programa Fiestas Patronales de Onda. Ayuntamiento de Onda, Onda, 1975

- Revista Programa Fiestas Patronales de Onda. Ayuntamiento de Onda, Onda, 1980

- Fira d'Onda. Programes de Festes. Biblioteques d'Onda. Ajuntament d'Onda. Onda, 2006

\section{Imagen:}

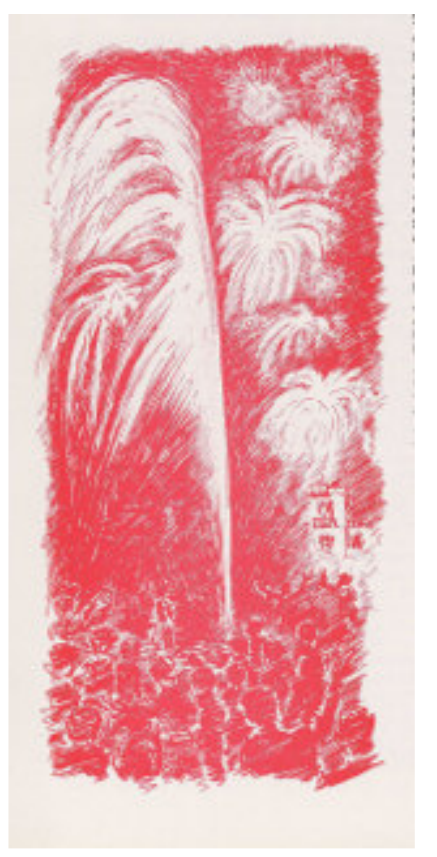

Imágenes relacionadas:
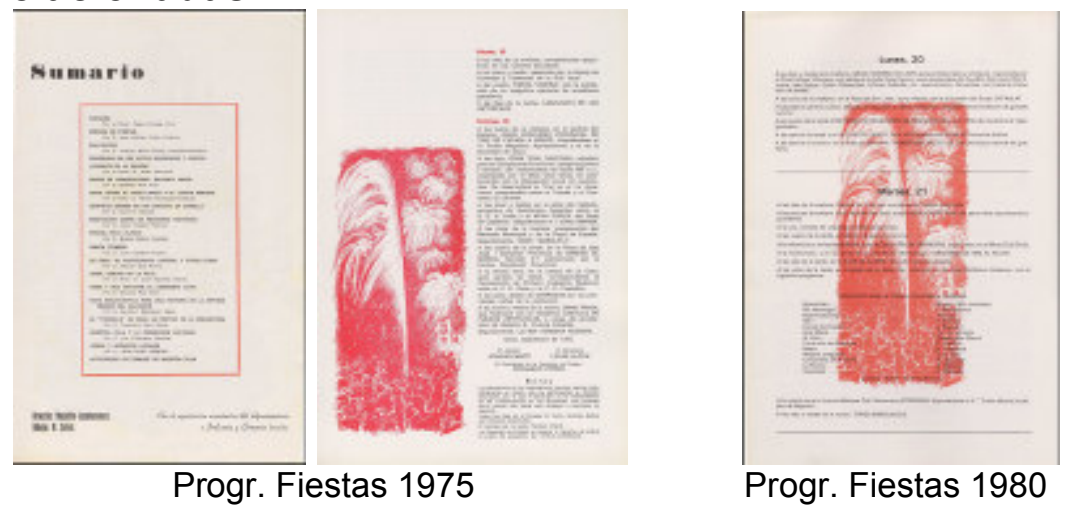

Progr. Fiestas 1980 
$\mathbf{N}^{\circ}: 1.38$

Título: Sin Título

Autoría: Manolo Safont

Datación: 1976

Técnica: Impresión gráfica

Localización: Biblioteca Municipal de Onda

Descripción: Safont realizó los dibujos para ilustrar el programa de Fiestas de 1976, la autoría se indica en el sumario del propio programa de fiestas. Esta misma ilustración se utiliza en los programas de fiestas de 1975 y 1980 . En esta escena se observa un grupo de personas llegando a la explanada del ermitorio del Santísimo Salvador de Onda. Paleta cromática: blancos y rojos.

Bibliografía:

- Revista Programa Fiestas Patronales de Onda. Ayuntamiento de Onda, Onda, 1975

- Revista Programa Fiestas Patronales de Onda. Ayuntamiento de Onda, Onda, 1976

- Revista Programa Fiestas Patronales de Onda. Ayuntamiento de Onda, Onda, 1980

- Fira d'Onda. Programes de Festes. Biblioteques d'Onda. Ajuntament d'Onda. Onda, 2006

\section{Imagen:}

Imágenes relacionadas:

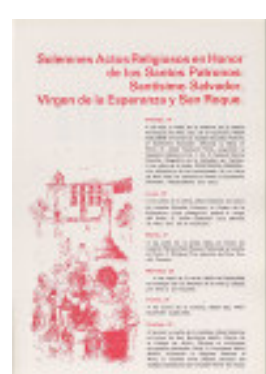

Progr. Fiestas 1975 Progr. Fiestas 1976 Progr. Fiestas 1980 
$\mathbf{N}^{\circ}: 1.39$

Título: Sin Título

Autoría: Manolo Safont

Datación: 1976

Técnica: Impresión gráfica

Localización: Biblioteca Municipal de Onda

Descripción: Safont realizó los dibujos para ilustrar el programa de Fiestas de 1976, la autoría se indica en el sumario del propio programa de fiestas. Esta imagen se utilizó también para ilustrar el programa de fiestas de 1975. La imagen representa una escena de un parque de atracciones, con un carrusel y una noria. Paleta cromática: blancos y rojos.

Bibliografía:

- Revista Programa Fiestas Patronales de Onda. Ayuntamiento de Onda, Onda, 1975

- Revista Programa Fiestas Patronales de Onda. Ayuntamiento de Onda, Onda, 1976

- Fira d'Onda. Programes de Festes. Biblioteques d'Onda. Ajuntament d'Onda. Onda, 2006

Imagen:

Imágenes relacionadas:

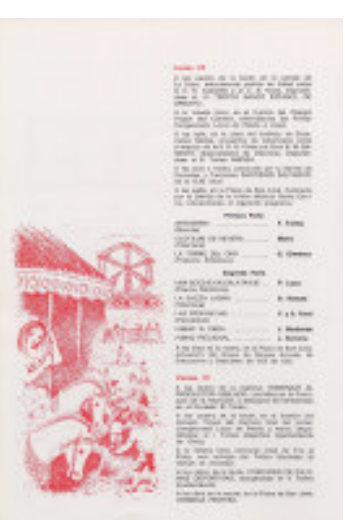

Progr. Fiestas 1975
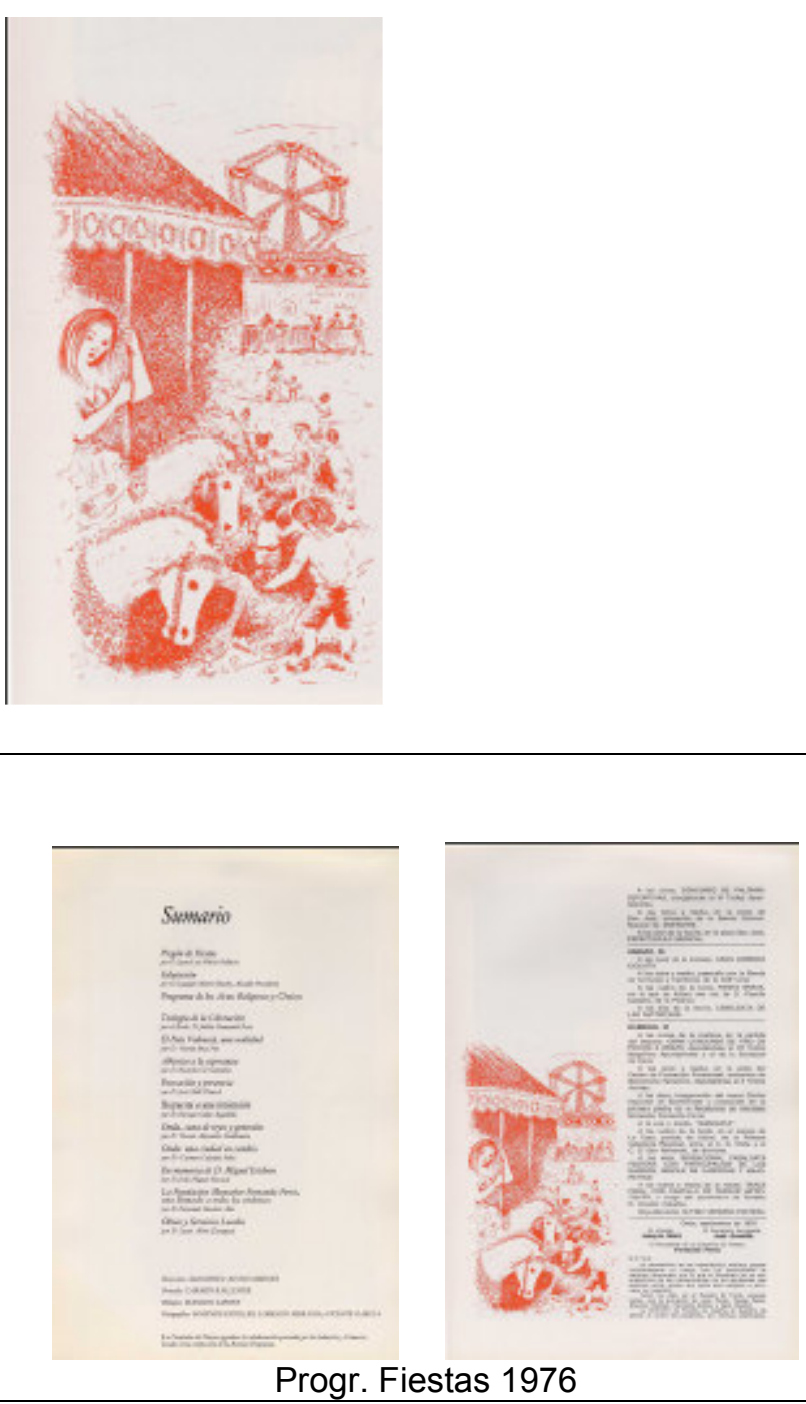

Progr. Fiestas 1976 
$\mathbf{N}^{0}: 1.40$

Título: Sin Título

Autoría: Manolo Safont

Datación: 1976

Técnica: Impresión gráfica

Tema: Imagen femenina

Localización: Biblioteca Municipal de Onda

Descripción: Safont realizó los dibujos para ilustrar el programa de Fiestas de 1976. La autoría se indica en el sumario del propio programa de fiestas, Representa el busto de una figura femenina, de perfil, rodeada de volutas y formas geométricas. Paleta cromática: blancos y rojos.

Bibliografía:

- Revista Programa Fiestas Patronales de Onda. Ayuntamiento de Onda, Onda, 1976

- Fira d'Onda. Programes de Festes. Biblioteques d'Onda. Ajuntament d'Onda. Onda, 2006

Imagen:

Imágenes relacionadas:

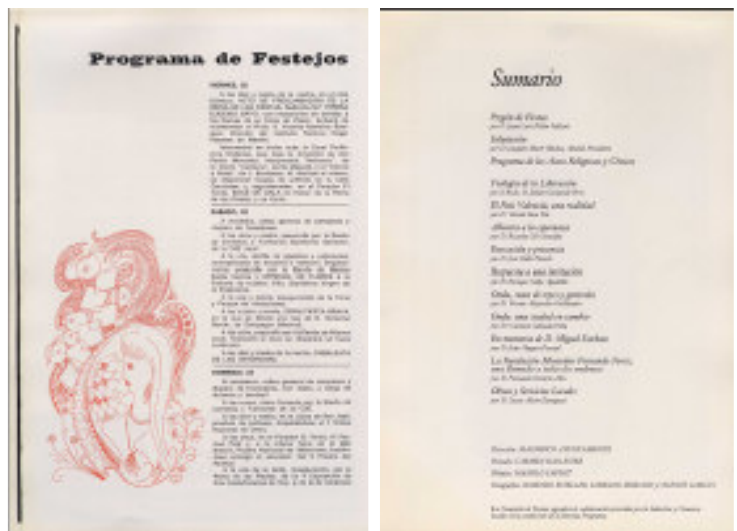

Progr. Fiestas 1976 
$\mathbf{N}^{\circ}: 1.41$

Título: Sin Título

Autoría: Manolo Safont

Datación: 1976

Técnica: Impresión gráfica

Localización: Biblioteca Municipal de Onda

Descripción: Safont realizó los dibujos para ilustrar el programa de Fiestas de 1976. La autoría se indica en el sumario del propio programa de fiestas. La escena representa unas casetas con decoración de guirnaldas y un gran sol sobre ellas. Paleta cromática: blancos y rojos.

Bibliografía:

- Revista Programa Fiestas Patronales de Onda. Ayuntamiento de Onda, Onda, 1976

- Fira d'Onda. Programes de Festes. Biblioteques d'Onda. Ajuntament d'Onda. Onda, 2006

\section{Imagen:}

Imágenes relacionadas:

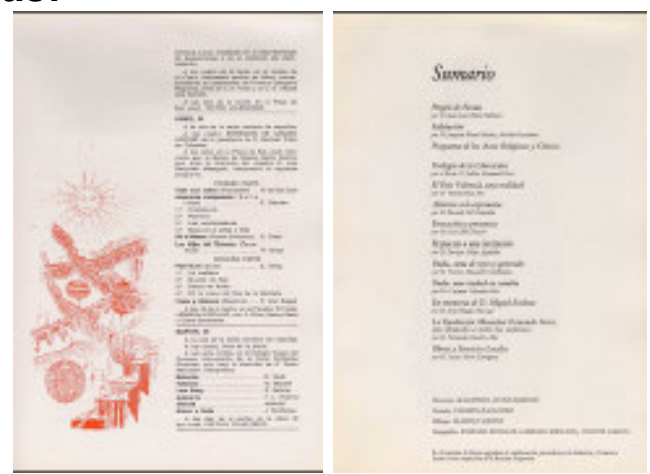

Progr. Fiestas 1976 
No: 1.42

Título: Sin Título

Autoría: Manolo Safont

Datación: 1976

Técnica: Impresión gráfica

Localización: Biblioteca Municipal de Onda

Descripción: Safont realizó los dibujos para ilustrar el programa de Fiestas de 1976. La autoría se indica en el sumario del propio programa de fiestas. La imagen representa una escena de la feria de atracciones. Paleta cromática: blancos y rojos

Bibliografía:

- Revista Programa Fiestas Patronales de Onda. Ayuntamiento de Onda, Onda, 1976

- Fira d'Onda. Programes de Festes. Biblioteques d'Onda. Ajuntament d'Onda. Onda, 2006

\section{Imagen:}

Imágenes relacionadas:

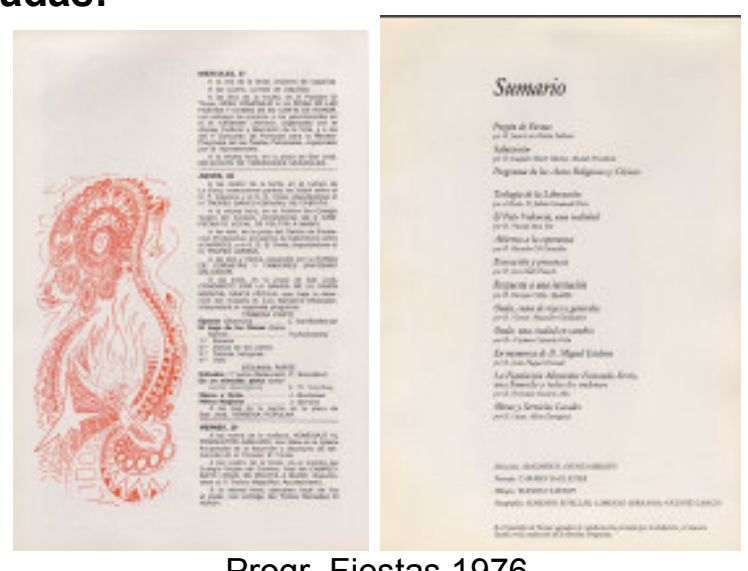

Progr. Fiestas 1976 
No: 1.43

Título: Sin Título

Autoría: Manolo Safont

Datación: 1977

Técnica: Impresión gráfica

Localización: Biblioteca Municipal de Onda

Descripción: Safont realizó los dibujos para ilustrar el programa de Fiestas de 1977. La autoría se indica en el sumario del propio programa de fiestas. La imagen es una representación de una imagen de una Virgen. Paleta cromática: blancos y marrones

Bibliografía:

- Revista Programa Fiestas Patronales de Onda. Ayuntamiento de Onda, Onda, 1977

- Fira d'Onda. Programes de Festes. Biblioteques d'Onda. Ajuntament d'Onda. Onda, 2006

\section{Imagen:}

Imágenes relacionadas:
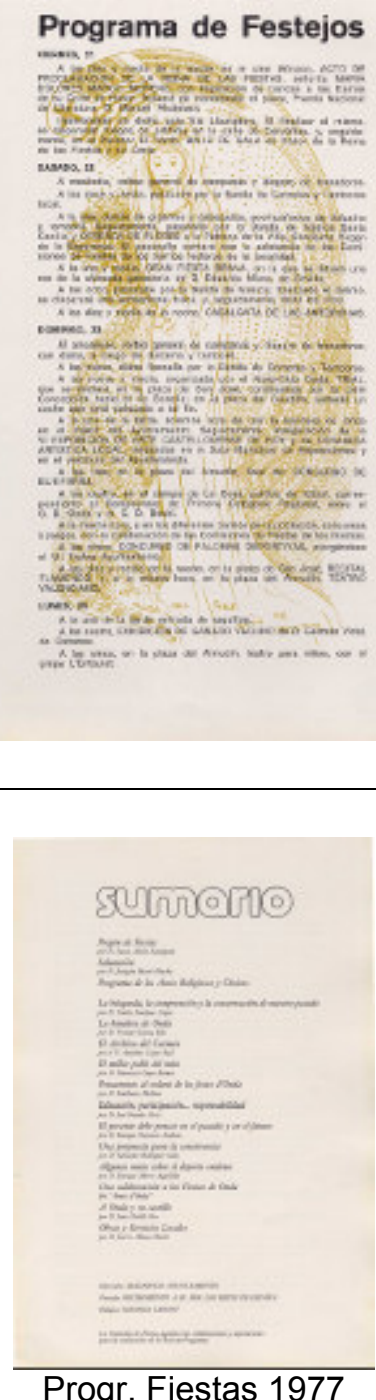

Progr. Fiestas 1977 
$\mathbf{N}^{\circ}: 1.44$

Título: Sin Título

Autoría: Manolo Safont

Datación: 1977

Técnica: Impresión gráfica

Localización: Biblioteca Municipal de Onda

Descripción: Safont realizó los dibujos para ilustrar el programa de Fiestas de 1977. La autoría se documenta en el sumario del propio programa de fiestas. La parte central del dibujo presenta relación con la obra catalogada $n^{0} 1.15$, portada del Programa de Fiestas de 1970, con el lema "La bola de foc símbol de les festes a Onda". La imagen representa una bola de fuego rodeada de formas curvas geométricas. Paleta cromática: blancos y marrones

Bibliografía:

- Revista Programa Fiestas Patronales de Onda. Ayuntamiento de Onda, Onda, 1970

- Revista Programa Fiestas Patronales de Onda. Ayuntamiento de Onda, Onda, 1977

- Fira d'Onda. Programes de Festes. Biblioteques d'Onda. Ajuntament d'Onda. Onda, 2006

\section{Imagen:}

Imágenes relacionadas:

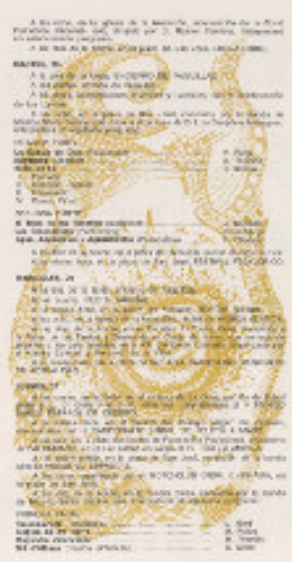

\section{Suñก)}

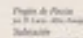

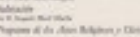

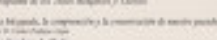

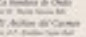

tente

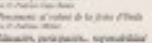

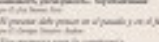

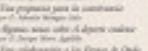

isis

$+2 t=i=4$

Exminominem

$=0$

Progr. Fiestas 1977 
$\mathbf{N}^{0}: 1.45$

Título: Sin Título

Autoría: Manolo Safont

Datación: 1977

Técnica: Impresión gráfica

Localización: Biblioteca Municipal de Onda

Descripción: Safont realizó los dibujos para ilustrar el programa de Fiestas de 1977. La autoría se documenta en el sumario del propio programa de fiestas. La ilustración representa un grupo de personas, en un ambiente festivo decorado con farolillos de papel, presenciando un espectáculo de fuegos artificiales. Paleta cromática: blancos y marrones

Bibliografía:

- Revista Programa Fiestas Patronales de Onda. Ayuntamiento de Onda, Onda, 1977

- Fira d'Onda. Programes de Festes. Biblioteques d'Onda. Ajuntament d'Onda. Onda, 2006

Imagen:

Imágenes relacionadas:

surromerno

mettin-

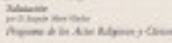

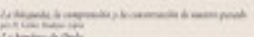

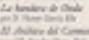

sitett

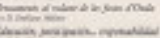

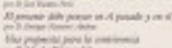

$2 x+1+1$

$7=0$

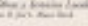

-

का

Progr. Fiestas 1977 
$\mathbf{N}^{0}: 1.46$

Título: Sin Título

Autoría: Manolo Safont

Datación: 1980

Técnica: Impresión gráfica

Localización: Biblioteca Municipal de Onda

Descripción: Safont realizó los dibujos interiores para ilustrar el programa de Fiestas de 1980. La imagen es un dibujo de la fachada de la Iglesia de Nuestra Sra. de la Asunción de Onda, con la torre campanario. Esta misma imagen fue utilizada en los programas de fiestas de 1967, 1968, 1971 y 1974. Paleta cromática: blancos y rojos.

Bibliografía:

- Revista Programa Fiestas Patronales de Onda. Ayuntamiento de Onda, Onda, 1967

- Revista Programa Fiestas Patronales de Onda. Ayuntamiento de Onda, Onda, 1968

- Revista Programa Fiestas Patronales de Onda. Ayuntamiento de Onda, Onda, 1971

- Revista Programa Fiestas Patronales de Onda. Ayuntamiento de Onda, Onda, 1974

- Revista Programa Fiestas Patronales de Onda. Ayuntamiento de Onda, Onda, 1980

- Fira d'Onda. Programes de Festes. Biblioteques d'Onda. Ajuntament d'Onda. Onda, 2006

Imagen:

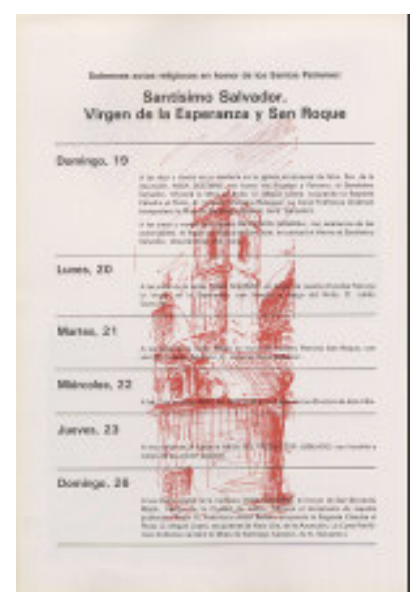

Imágenes relacionadas:

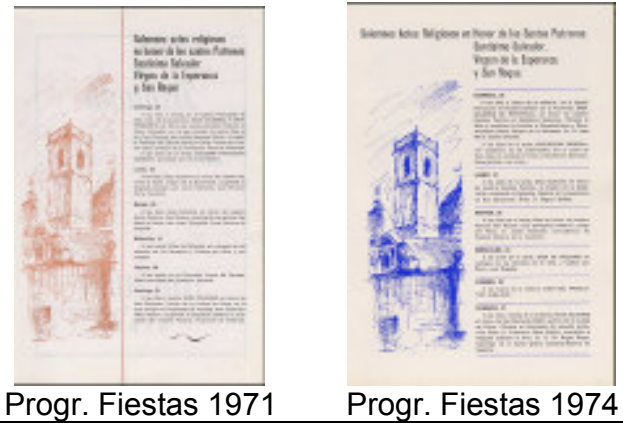


No: 1.47

Título: Sin Título

Autoría: Manolo Safont

Datación: 1980

Técnica: Impresión gráfica

Localización: Biblioteca Municipal de Onda

Descripción: Safont realizó los dibujos interiores para ilustrar el programa de Fiestas de 1980. Esta misma imagen se utilizó también para ilustrar los programas de fiestas de 1967, 1971 y 1974. La imagen representa una escena de un encierro taurino, tema relacionado con las fiestas ondenses. Paleta cromática: blancos y rojos.

Bibliografía:

- Revista Programa Fiestas Patronales de Onda. Ayuntamiento de Onda, Onda, 1967

- Revista Programa Fiestas Patronales de Onda. Ayuntamiento de Onda, Onda, 1971

- Revista Programa Fiestas Patronales de Onda. Ayuntamiento de Onda, Onda, 1974

- Revista Programa Fiestas Patronales de Onda. Ayuntamiento de Onda, Onda, 1980

- Fira d'Onda. Programes de Festes. Biblioteques d'Onda. Ajuntament d'Onda. Onda, 2006

\section{Imagen:}

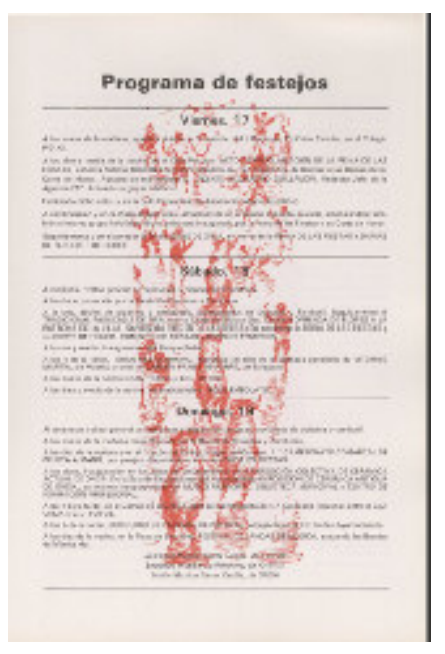

Imágenes relacionadas:

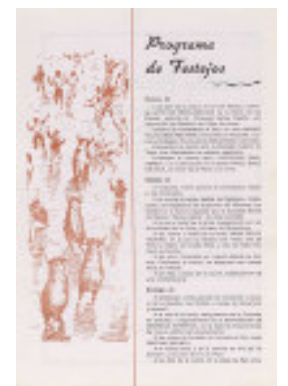

Progr. Fiestas 1971

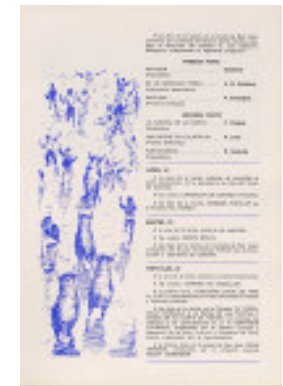

Progr. Fiestas 1974 
No: 1.48

Título: Sin Título

Autoría: Manolo Safont

Datación: 1980

Técnica: Impresión gráfica

Localización: Biblioteca Municipal de Onda

Descripción: Safont realizó los dibujos interiores para ilustrar el programa de Fiestas de 1980. Esta misma escena de fuegos artificiales se utilizó para ilustrar el programa de fiestas de 1975. Paleta cromática: blancos y rojos.

\section{Bibliografía:}

- Revista Programa Fiestas Patronales de Onda. Ayuntamiento de Onda, Onda, 1975

- Revista Programa Fiestas Patronales de Onda. Ayuntamiento de Onda, Onda, 1980

- Fira d'Onda. Programes de Festes. Biblioteques d'Onda. Ajuntament d'Onda. Onda, 2006

\section{Imagen:}

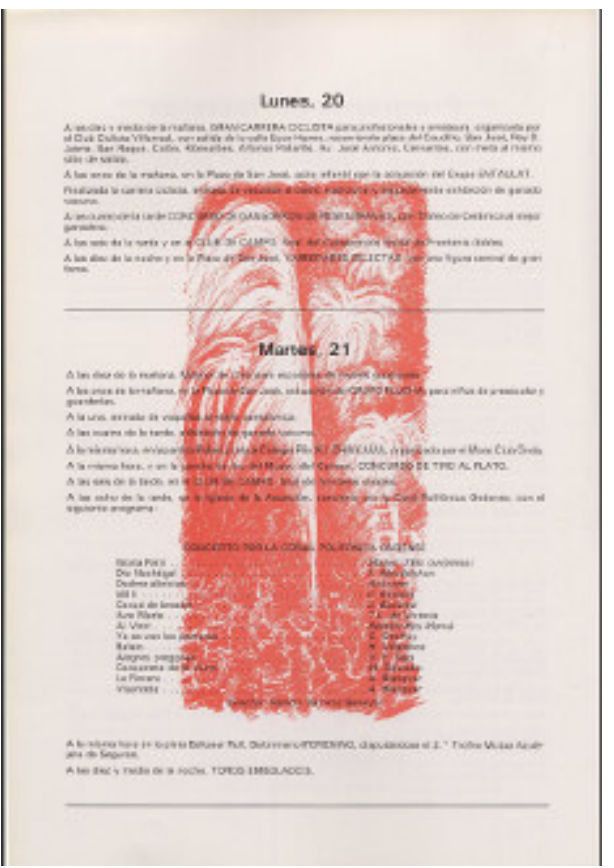

Imágenes relacionadas:

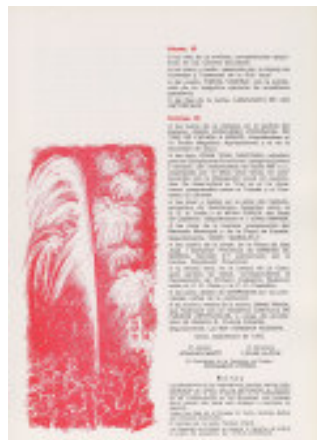

Progr. Fiestas 1975 
No: 1.49

Título: Sin Título

Autoría: Manolo Safont

Datación: 1980

Técnica: Impresión gráfica

Localización: Biblioteca Municipal de Onda

Descripción: Safont realizó los dibujos interiores para ilustrar el programa de Fiestas de 1980. Esta escena taurina se utiliza también para ilustrar el programa de fiestas de 1975. Paleta cromática: blancos y rojos.

\section{Bibliografía:}

- Revista Programa Fiestas Patronales de Onda. Ayuntamiento de Onda, Onda, 1975

- Revista Programa Fiestas Patronales de Onda. Ayuntamiento de Onda, Onda, 1980

- Fira d'Onda. Programes de Festes. Biblioteques d'Onda. Ajuntament d'Onda. Onda, 2006Revista Programa Fiestas Patronales de Onda. Ayuntamiento de Onda, Onda, 1980

Imagen:

Imágenes relacionadas:

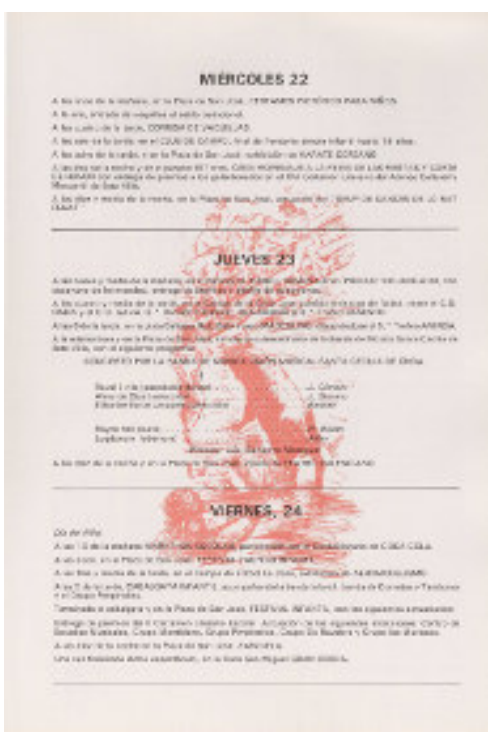

Imágenes relacionadas:

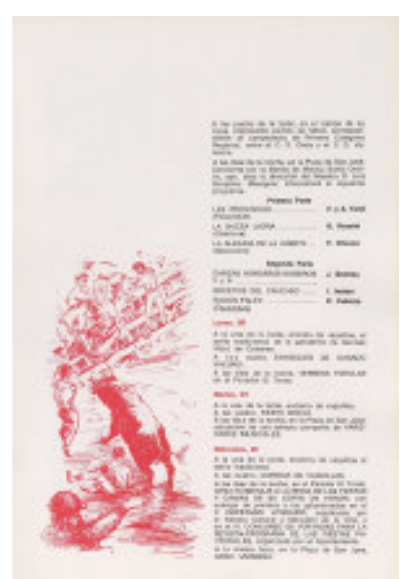

Progr. Fiestas 1975 
$\mathbf{N}^{0}: 1.50$

Título: Sin Título

Autoría: Manolo Safont

Datación: 1980

Técnica: Impresión gráfica

Localización: Biblioteca Municipal de Onda

Descripción: Safont realizó los dibujos interiores para ilustrar el programa de Fiestas de 1980. Esta misma ilustración se utiliza en los programas de fiestas de 1975 y 1976 . En esta escena se observa un grupo de personas llegando a la explanada del ermitorio del Santísimo Salvador de Onda. Paleta cromática: blancos y rojos.

Bibliografía:

- Revista Programa Fiestas Patronales de Onda. Ayuntamiento de Onda, Onda, 1975

- Revista Programa Fiestas Patronales de Onda. Ayuntamiento de Onda, Onda, 1976

- Revista Programa Fiestas Patronales de Onda. Ayuntamiento de Onda, Onda, 1980

- Fira d'Onda. Programes de Festes. Biblioteques d'Onda. Ajuntament d'Onda. Onda, 2006

\section{Imagen:}

Imágenes relacionadas:

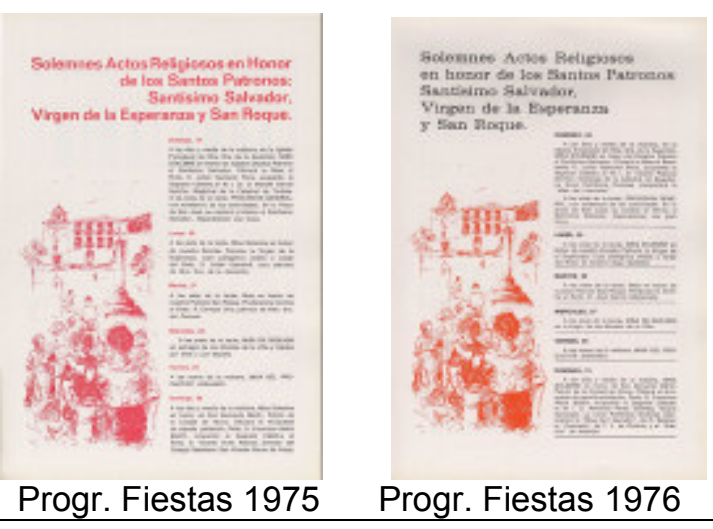


$\mathbf{N}^{0}: 1.51$

Título: Fira d'Onda Octubre 1983

Autoría: Manolo Safont

Datación: 1983

Inscripciones: Fira d'Onda Octubre 1983

Técnica: Impresión gráfica

Localización: Biblioteca Municipal de Onda

Descripción: Este dibujo se utilizó como portada del Programa de Fiestas de Onda de 1983. Se conserva el boceto para la realización de este dibujo, obra catalogada $n^{\circ} 2.64$, y se observan similitudes con las obras catalogadas $n^{0} 1.1$, $\mathrm{n}^{0} 2.19$ y $\mathrm{n}^{0} 2.20$, en el trazado de los arcos y composición de formas. Representa elementos arquitectónicos característicos de Onda, como el castillo, los arcos de la plaza porticada Font de Dins, las chimeneas de las fábricas de azulejos y el escudo de Onda en el margen superior derecho. Paleta cromática: blancos, amarillos, naranjas, rojos, verdes, marrones y negros.

\section{Bibliografía:}

- Revista Programa Fiestas Patronales de Onda. Ayuntamiento de Onda, Onda, 1983

- Fira d'Onda. Programes de Festes. Biblioteques d'Onda. Ajuntament d'Onda. Onda, 2006

\section{Imagen:}

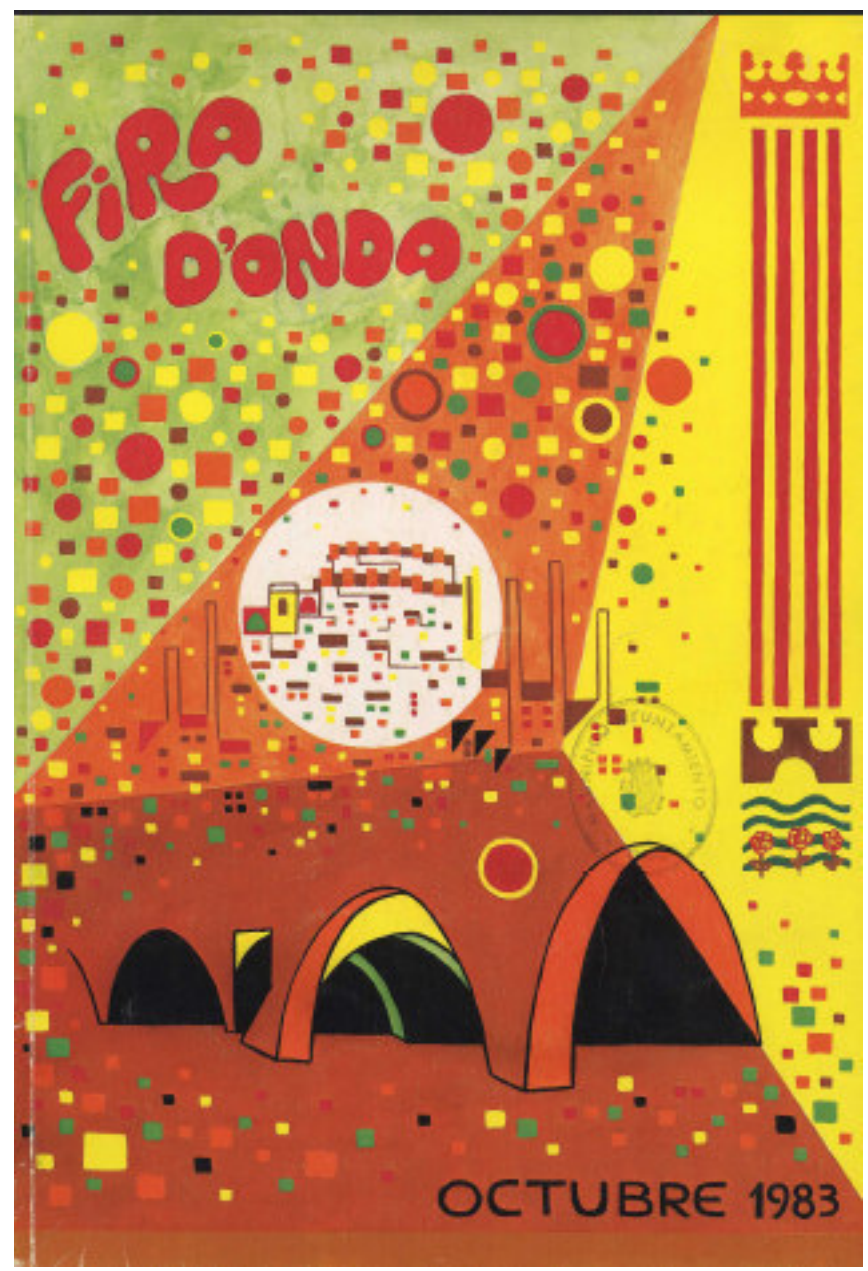




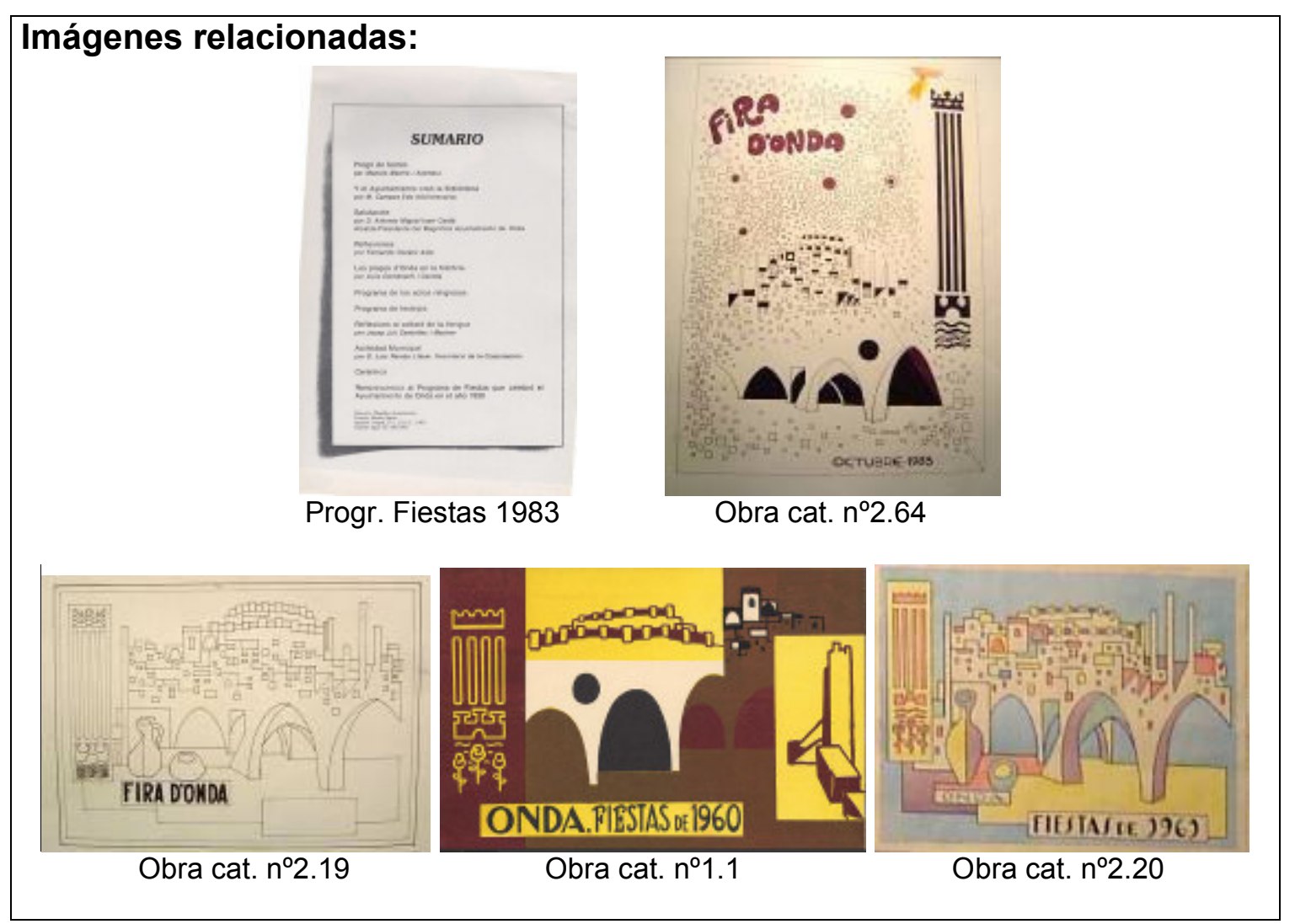




\section{2.- FICHAS CATALOGRÁFICAS: BOCETOS, DIBUJOS Y CARTELES}

En este segundo capítulo del catálogo general de obras, se analizan 73 obras, catalogadas desde el $n^{\circ} 2.1$ al $n^{\circ} 2.73$ : los diferentes bocetos, dibujos y carteles que realizó Safont.

Algunos de estos dibujos o bocetos, son estudios preliminares para la realización de los dibujos de las portadas de alguno de los Programas de Fiestas editados por el Ayuntamiento de Onda, en los que colaboró Safont.

Es interesante destacar la importancia de las obras que corresponden al bloc de apuntes de dibujo de Safont, que contiene 18 dibujos y que se corresponden con las obras catalogadas $n^{\circ} 2.32$ al $n^{\circ} 2.49$, por su fuerza, rapidez de trazo y frescura.

Safont, mantuvo siempre una estrecha vinculación con la entidad bancaria ondense Caja Rural Nuestra Señora de la Esperanza de Onda. Entre las obras catalogadas destacan varios bocetos para diferentes diseños de azulejos, algunos de los cuales hemos podido relacionar con la obra de aplicación arquitectónica para la cual fueron creados, como es el caso de los diseños para los azulejos de la sede de la Caja Rural Nuestra Señora de la Esperanza, situada en la calle San Miguel de Onda, catalogados con el n².9.

Además de estos azulejos, también realizó para Caja Rural de Onda, alrededor de 1980, dos series de dibujos. La primera serie consta de tres obras, con la temática común de tareas agrícolas y fueron creadas para decorar los sobres que utilizaba la entidad bancaria. La segunda serie, consta de cinco dibujos, de las fachadas de las diferentes sedes que ha tenido la Caja Rural de Onda desde su fundación hasta 1980, y le fueron encargados a Safont para ilustrar una publicación que hizo la propia Caja Rural con motivo del 75 aniversario de la fundación de la entidad bancaria. Los dibujos originales de ambas series se encuentran enmarcados y expuestos en las oficinas de la sede principal de Caja Rural de Onda, situada en la plaza El Plà de Onda. 
$\mathbf{N}^{0}: 2.1$

Título: Sin Título

Autoría: Manolo Safont

Datación: 1951

Inscripciones: Safont 1951 en zona central inferior

Técnica: Dibujo sobre papel

Descripción: Este dibujo inacabado, realizado a plumilla, representa la portada principal de la Iglesia Parroquial de Nuestra Señora de la Asunción de Onda. En el dibujo no se representan ni la imagen escultórica de la titular del templo ni los pináculos, esto se debe a que tanto los pináculos como la escultura de la Virgen de la Asunción que se encontraba en la hornacina de la portada fueron destruidas, junto a otras obras de arte y de culto, en el saqueo del 10 de agosto de 1936 y el incendio provocado por milicias de una facción del Frente Popular el 8 o 9 de octubre de 1936 y no se reconstruyó hasta fechas posteriores a la realización del dibujo, tal y como se indica en manolosafont.blogspot.com.es, Paleta cromática: blancos y negros.

\section{Bibliografía:}

- http://www.onda.es/patrimonio/centro-historico/iglesia-de-la-asuncion

- http://www.turismodecastellon.com/700905_es/Iglesia-de-laAsunci\%C3\%B3n-o-Iglesia-Mayor-

- http://manolosafont.blogspot.com.es

\section{Imagen:}

Imágenes relacionadas:

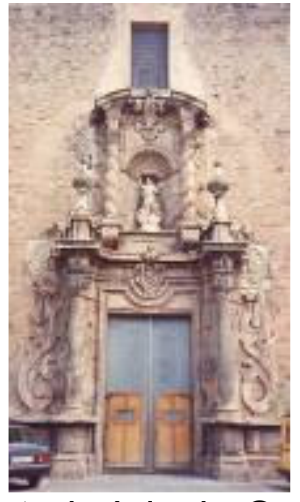

Portada Iglesia Onda 
No: 2.2

Título: Sin Título

Autoría: Manolo Safont

Datación: 1956

Inscripción: Safont 56 en ángulo inferior derecho

Técnica: Dibujo sobre papel

Localización: MAMS

Descripción: Boceto para un diseño de panel cerámico, obra catalogada con el $n^{\circ}$ 3. . Paleta cromática: blancos, amarillos, naranjas, rojos, verdes, azules, marrones y negros.

\section{Exposiciones:}

- "Manolo Safont. Un museu, un llegat i un compromís". MAMS. Del 27 de noviembre de 2004 al 8 de enero de 2005 . Onda.

\section{Imagen:}

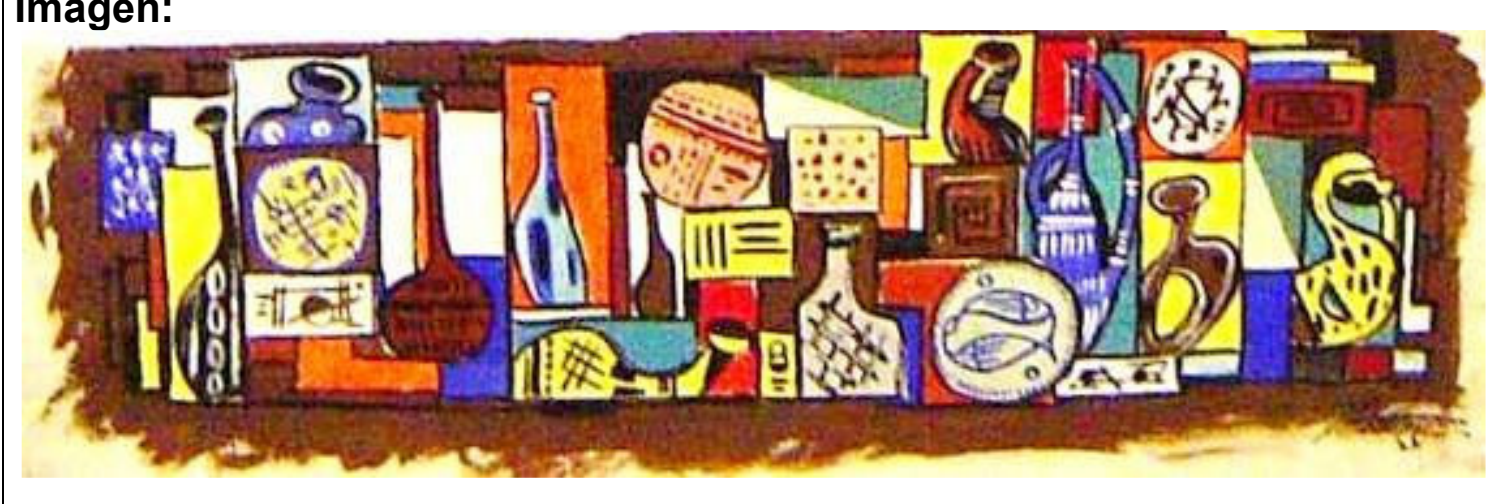

Imágenes relacionadas:

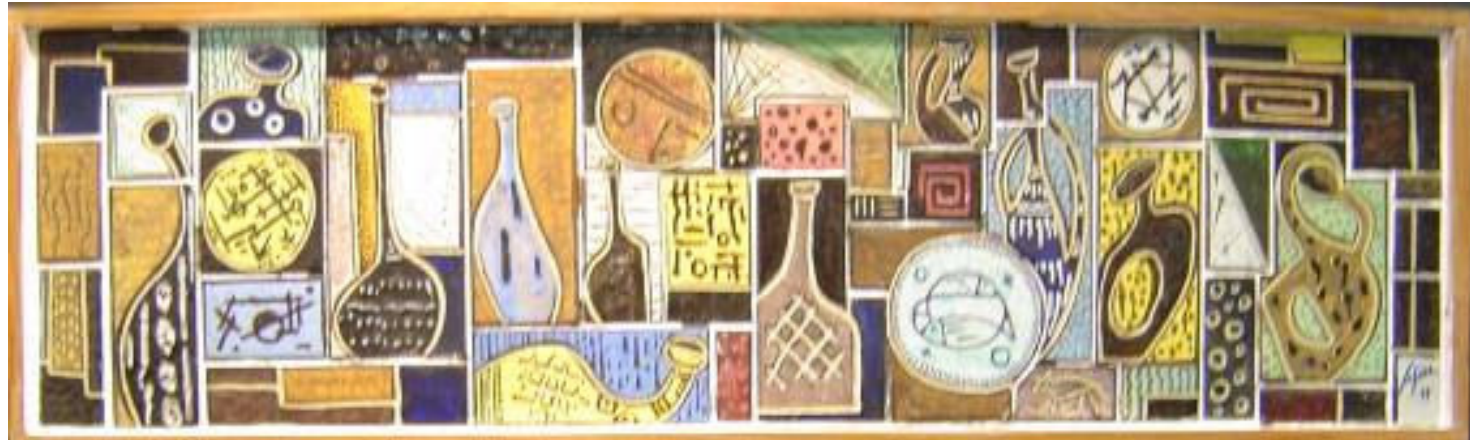

Obra cat. $n^{\circ} 4.2$ 


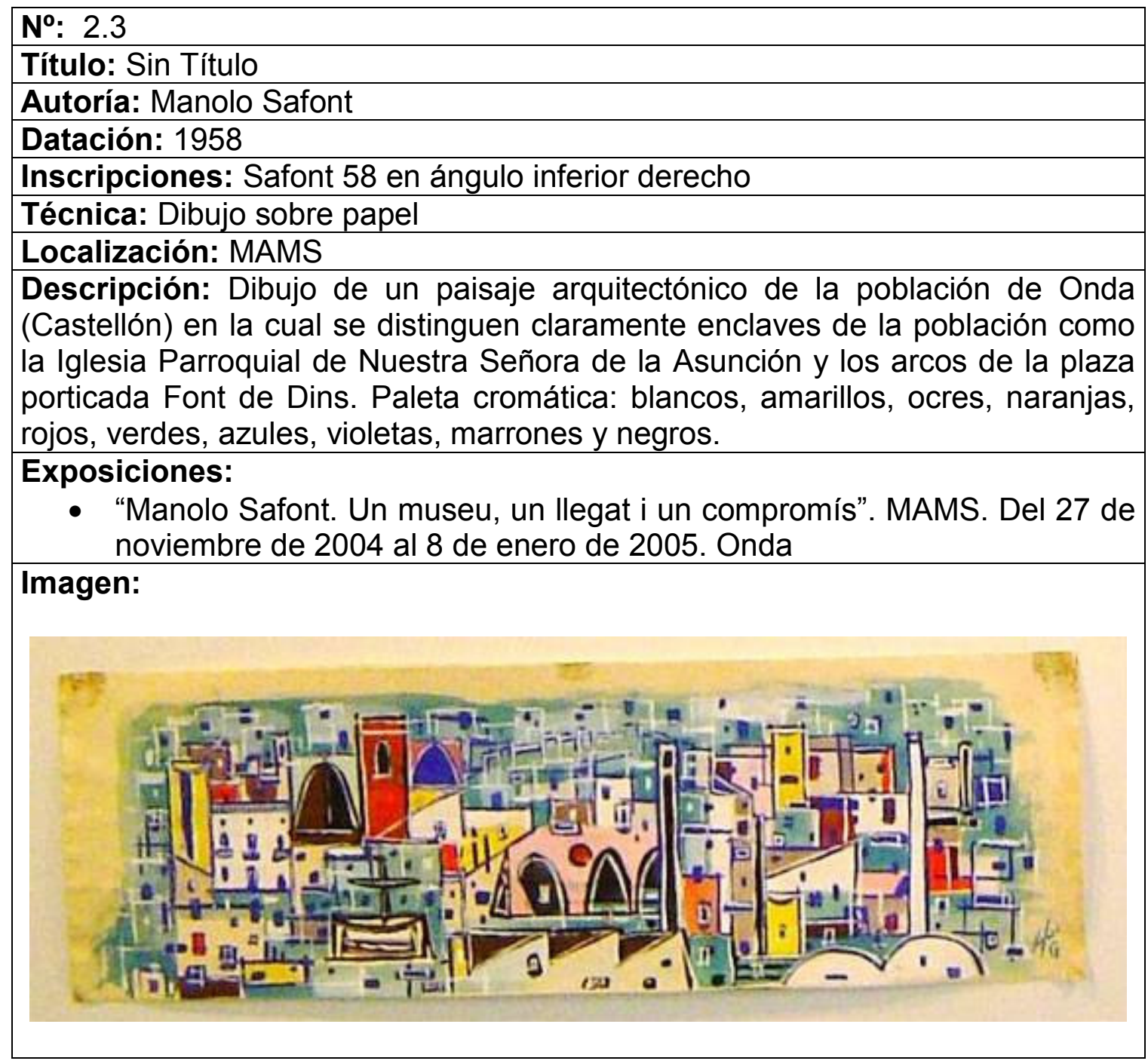


$\mathbf{N}^{0}: 2.4$

Título: Sin Título

Autoría: Manolo Safont

Datación: 1958

Inscripciones: Safont en ángulo superior izquierdo

Técnica: Dibujo sobre papel

Localización: MAMS

Descripción: Posible primer boceto para un panel, realizado en blanco y negro. Representación de trabajadores de la industria cerámica, en la que se observan las diferentes fases para la elaboración de un azulejo. Presenta relación con la obra catalogada $n^{\circ} 2.5$, en la que podemos observar este boceto coloreado. Paleta cromática: blancos y negros.

Exposiciones:

- "Manolo Safont. Un museu, un llegat i un compromís". MAMS. Del 27 de noviembre de 2004 al 8 de enero de 2005. Onda.

\section{Imagen:}

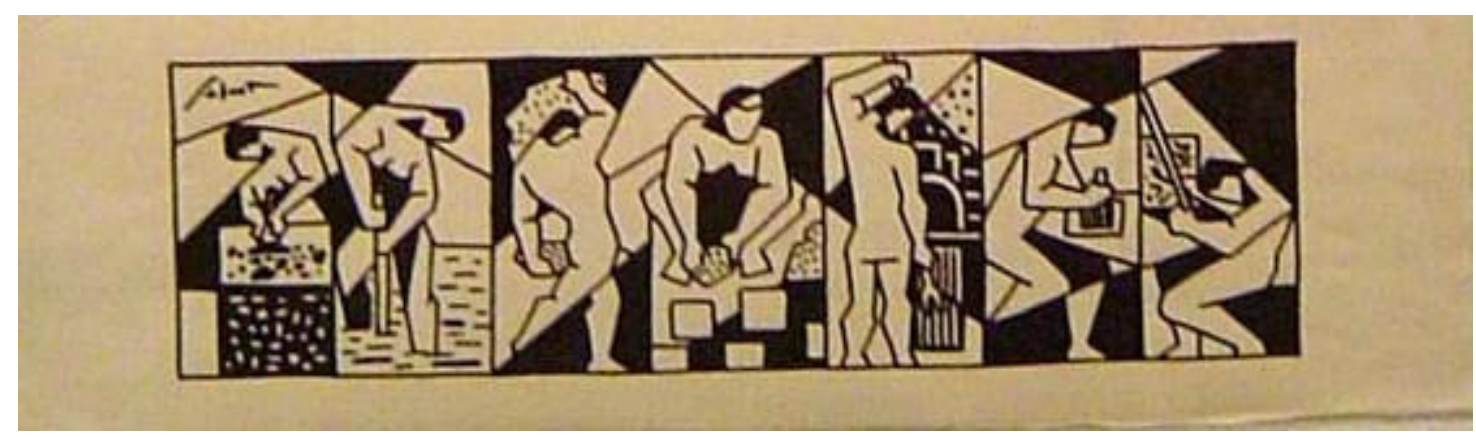

\section{Imágenes relacionadas:}

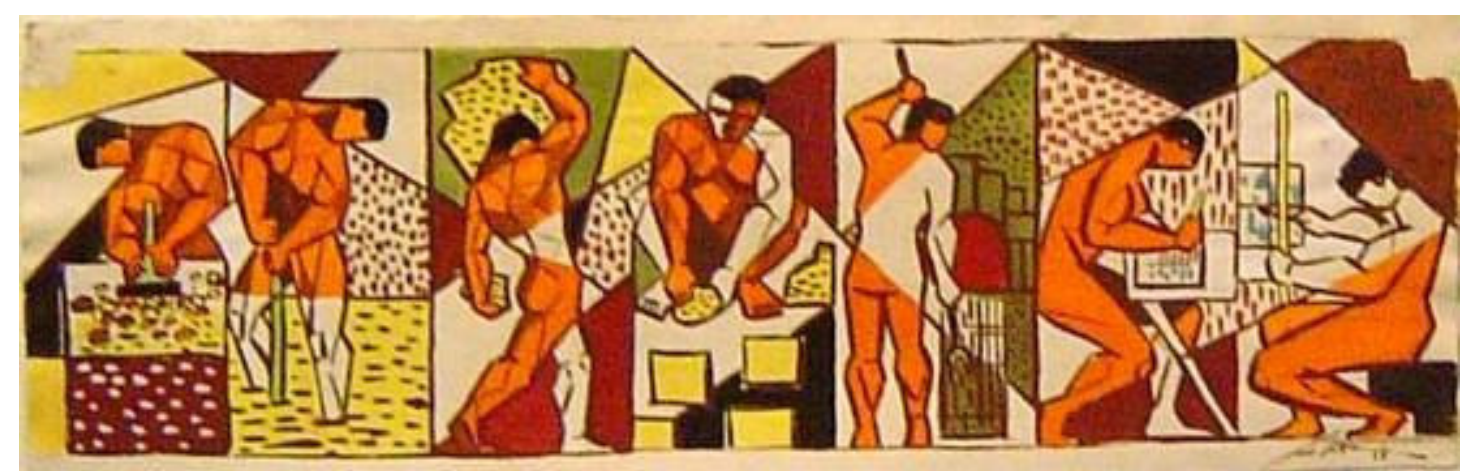

Obra cat. $n^{0} 2.5$ 
No: 2.5

Título: Sin Título

Autoría: Manolo Safont

Datación: 1958

Inscripciones: Safont 58 en ángulo inferior derecho

Técnica: Dibujo sobre papel

Localización: MAMS

Descripción: Posible segundo boceto para un panel. Representación de trabajadores de la industria cerámica, en la que se observan las diferentes fases para la elaboración de un azulejo. Presenta relación con la obra catalogada $n^{\circ} 2.4$, en la que podemos observar este boceto en blanco y negro. Paleta cromática: blancos, amarillos, naranjas, verdes, marrones y negros.

Exposiciones:

- "Manolo Safont. Un museu, un llegat i un compromís". MAMS. Del 27 de noviembre de 2004 al 8 de enero de 2005. Onda.

\section{Imagen:}

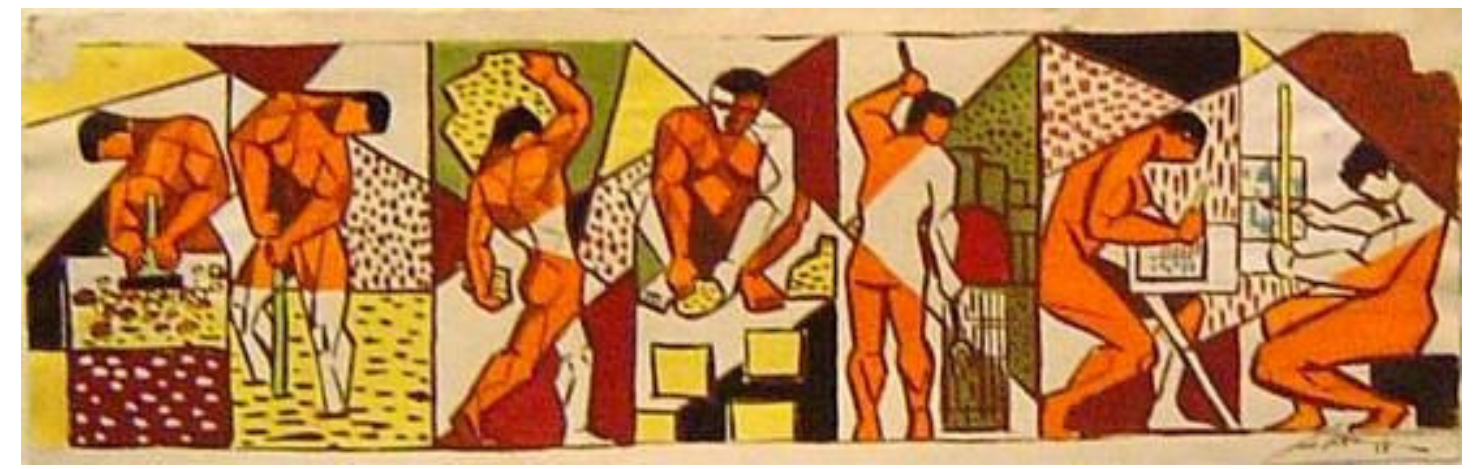

Imágenes relacionadas:

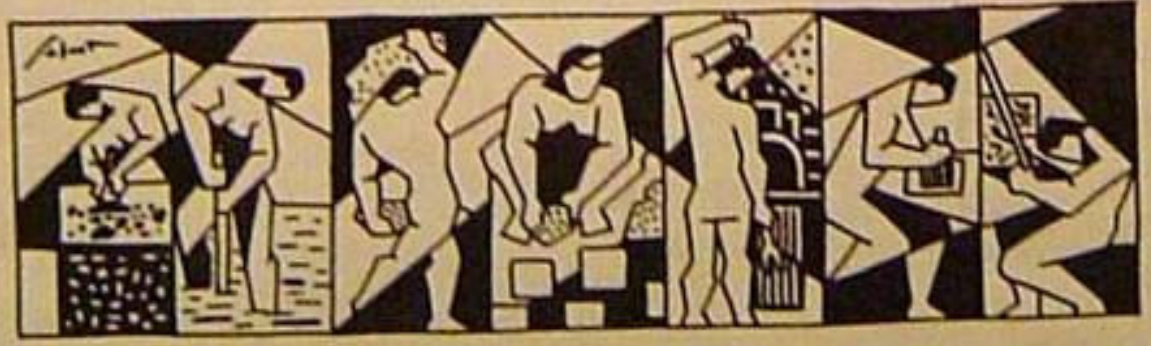

Obra cat. $n^{0} 2.4$ 
No: 2.6

Título: Sin Título

Autoría: Manolo Safont

Datación: 1958

Inscripciones: Safont en ángulo inferior derecho

Técnica: Dibujo sobre papel

Localización: MAMS

Descripción: Posible boceto para la realización de un panel. Representación de trabajadores de la industria cerámica, en la que se observan las diferentes fases para la elaboración de un azulejo. Paleta cromática: blancos, amarillos, azules y marrones.

Exposiciones:

- "Manolo Safont. Un museu, un llegat i un compromís". MAMS. Del 27 de noviembre de 2004 al 8 de enero de 2005. Onda.

\section{Imagen:}

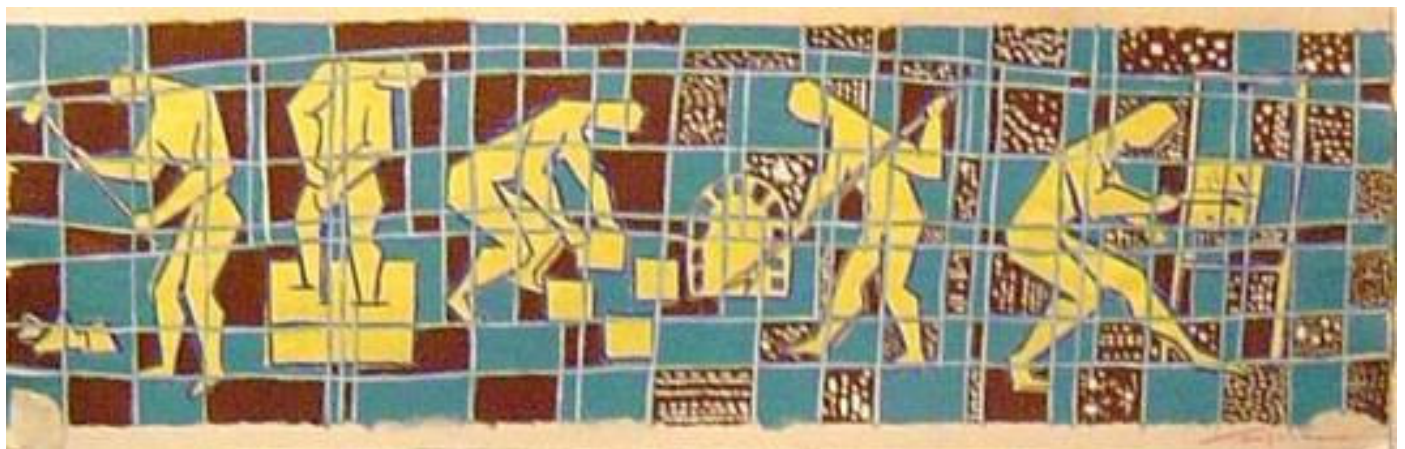


No: 2.7

Título: Sin Título

Autoría: Manolo Safont

Datación: 1958

Inscripciones: Safont 58 en ángulo inferior derecho

Técnica: Dibujo sobre papel

Descripción: Dibujo de figuras humanas geométricas y esquemáticas sobre el dibujo de una paleta de pintor y decoración de tubos de pintura. Realizado con la técnica de plumilla, se observa la influencia de las corrientes artísticas de la vanguardia de la época, intuyéndose la evolución pictórica de Safont hacia el esquematismo y la posterior abstracción. Paleta cromática: blancos, marrones y negros.

Bibliografía:

- http://manolosafont.blogspot.com.es

Imagen:

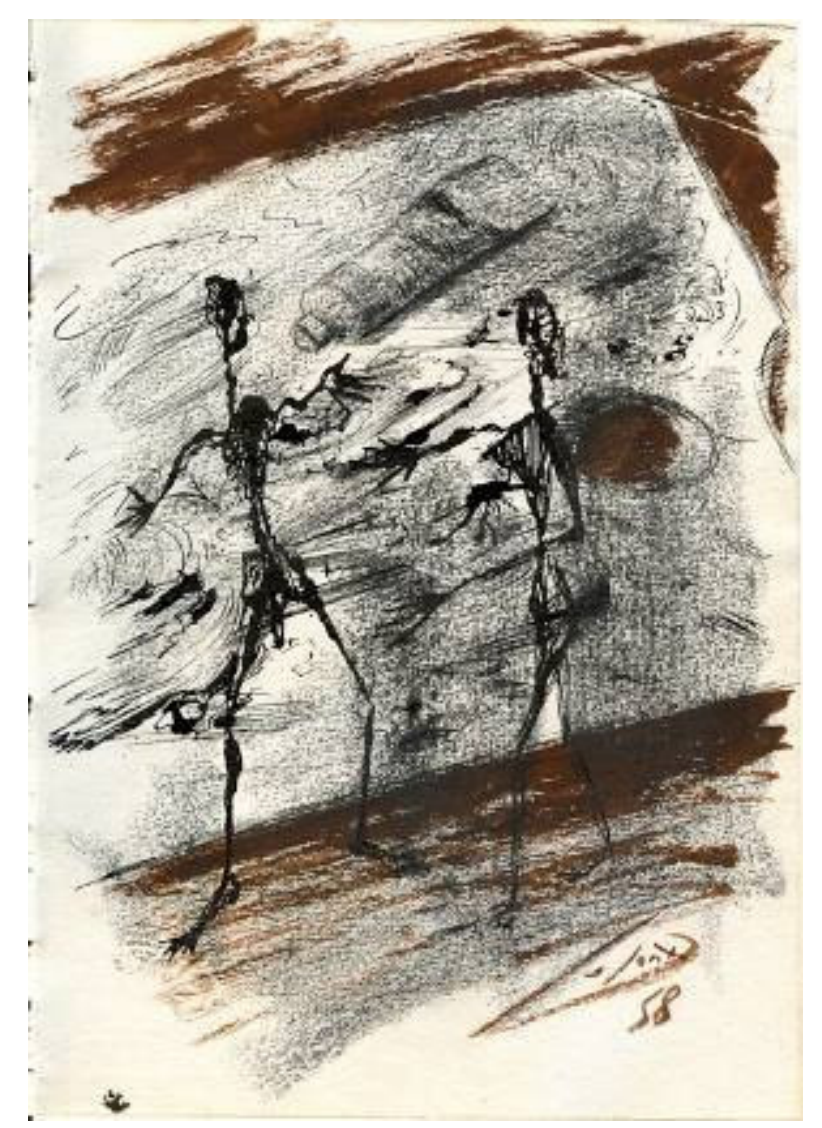


No: 2.8

Título: Sin Título

Autoría: Manolo Safont

Datación: 1958

Inscripciones: Safont en zona inferior lateral izquierda

Técnica: Dibujo sobre papel

Descripción: Dibujo realizado a plumilla de una figura femenina que sostiene en brazos a un niño, podría representar tanto una maternidad como una imagen religiosa de la Virgen con el Niño. Podemos observar influencias de artistas de la vanguardia, en la esquematización y simplificación de las formas, con diseños más geométricos, o el alargamiento del cuello. Paleta cromática: blancos y negros.

Bibliografía:

- http://manolosafont.blogspot.com.es

Imagen:

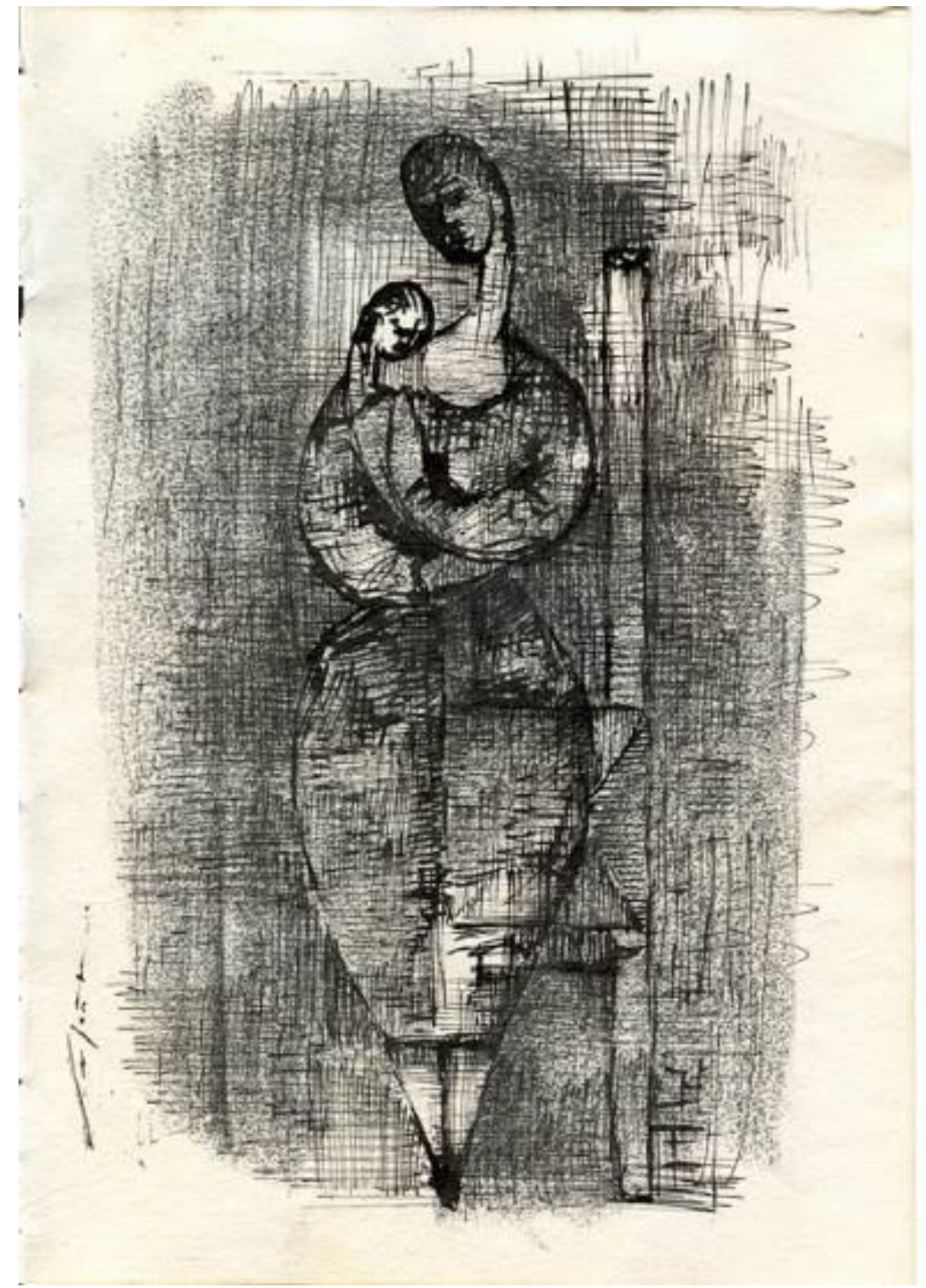


No: 2.9

Título: Sin Título

Autoría: Manolo Safont

Datación: Anterior a 1960

Inscripciones: Safont en ángulo inferior derecho

Técnica: Dibujo sobre papel

Localización: MAMS

Descripción: Diseños preparatorios para los azulejos de la fachada del edificio de la Caja Rural Nuestra Señora de la Esperanza de Onda, en la calle San Miguel de Onda. Obra catalogada con el n6.2. Composición geométrica de formas onduladas, con motivos que se repiten sin fin para adaptarse a los diferentes espacios. Para la datación cronológica de estos bocetos, nos basamos en la fecha de inauguración del edificio, 1960. Paleta cromática: blancos, azules, grises y negros.

\section{Exposiciones:}

- "Manolo Safont. Un museu, un llegat i un compromís". MAMS. Del 27 de noviembre de 2004 al 8 de enero de 2005. Onda.

\section{Bibliografía:}

- http://manolosafont.blogspot.com.es

\section{Imagen:}
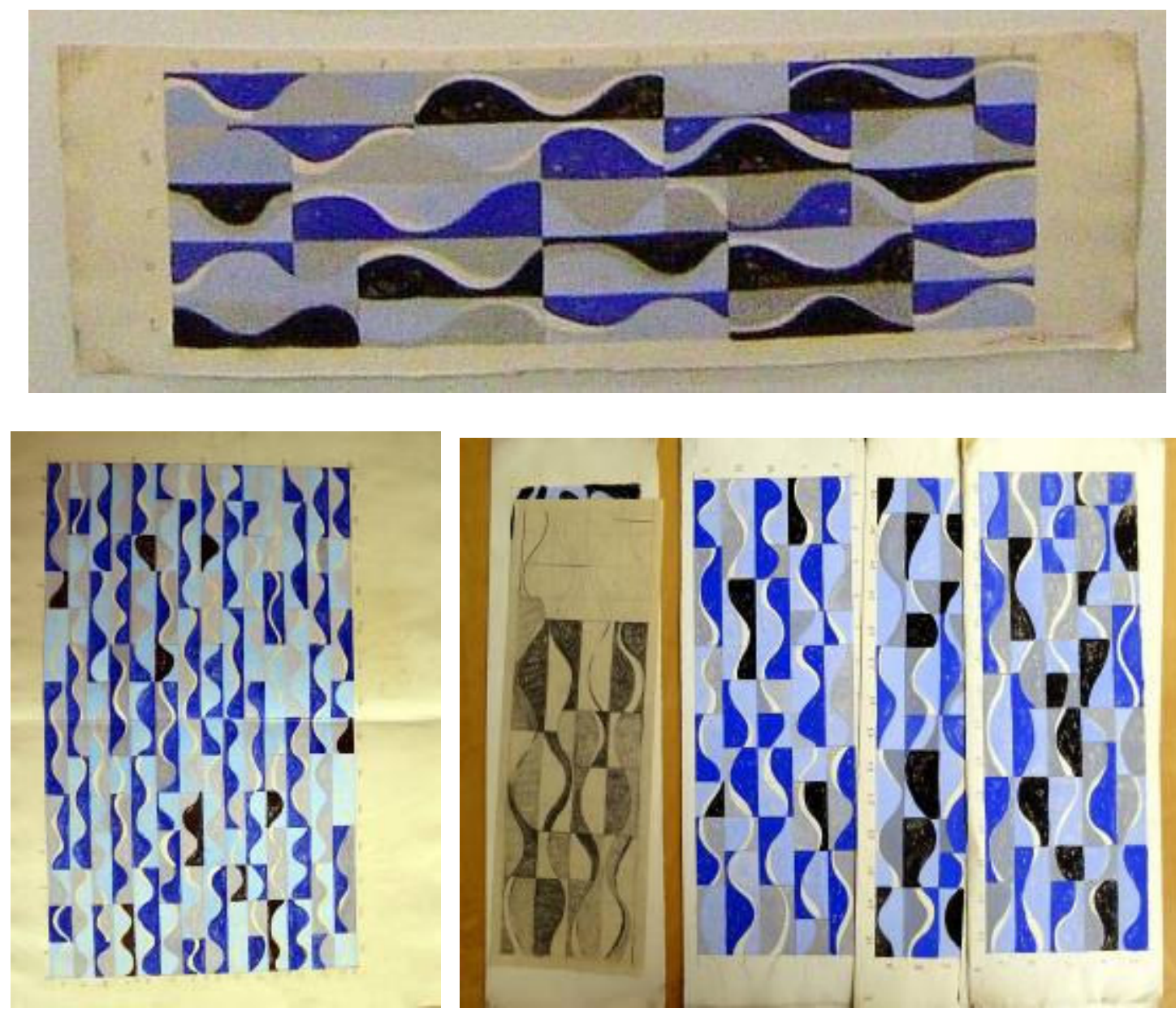


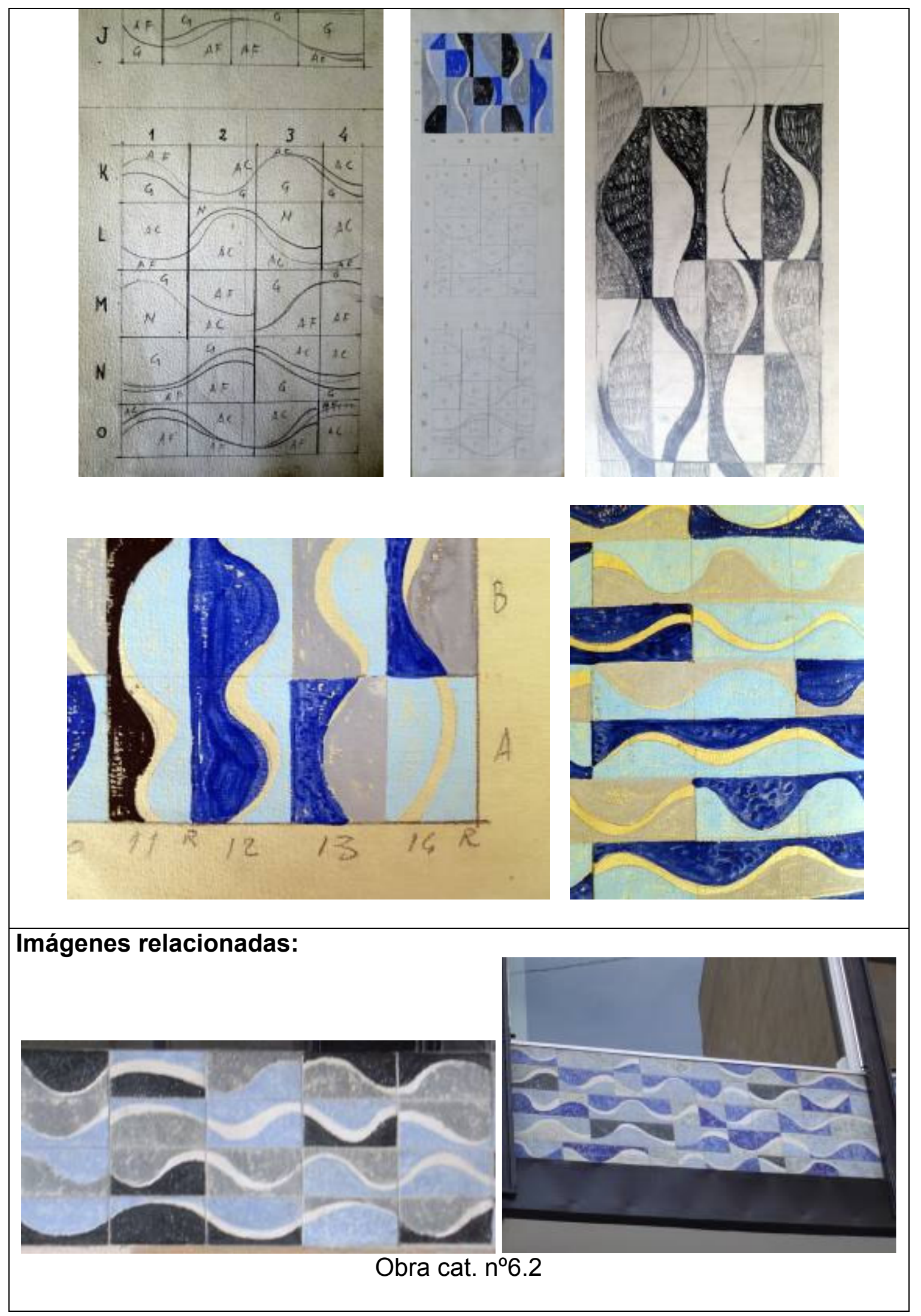


No: 2.10

Título: Sin Título

Autoría: Manolo Safont

Datación: Final década 1950- Inicios década 1960

Técnica: Dibujo sobre papel

Localización: MAMS

Descripción: Boceto para un diseño de azulejo o panel de azulejos. Estilo similar al utilizado para la realización de la obra catalogada con el $n^{\circ} 2.9$ que se utilizó en el diseño de la cerámica de aplicación arquitectónica utilizada en la construcción del edificio de Caja Rural Nuestra Sra. de la Esperanza, en la calle San Miguel de Onda. Paleta cromática: blancos, azules, grises y negros.

Exposiciones:

- "Manolo Safont. Un museu, un llegat i un compromís". MAMS. Del 27 de noviembre de 2004 al 8 de enero de 2005. Onda.

\section{Imagen:}

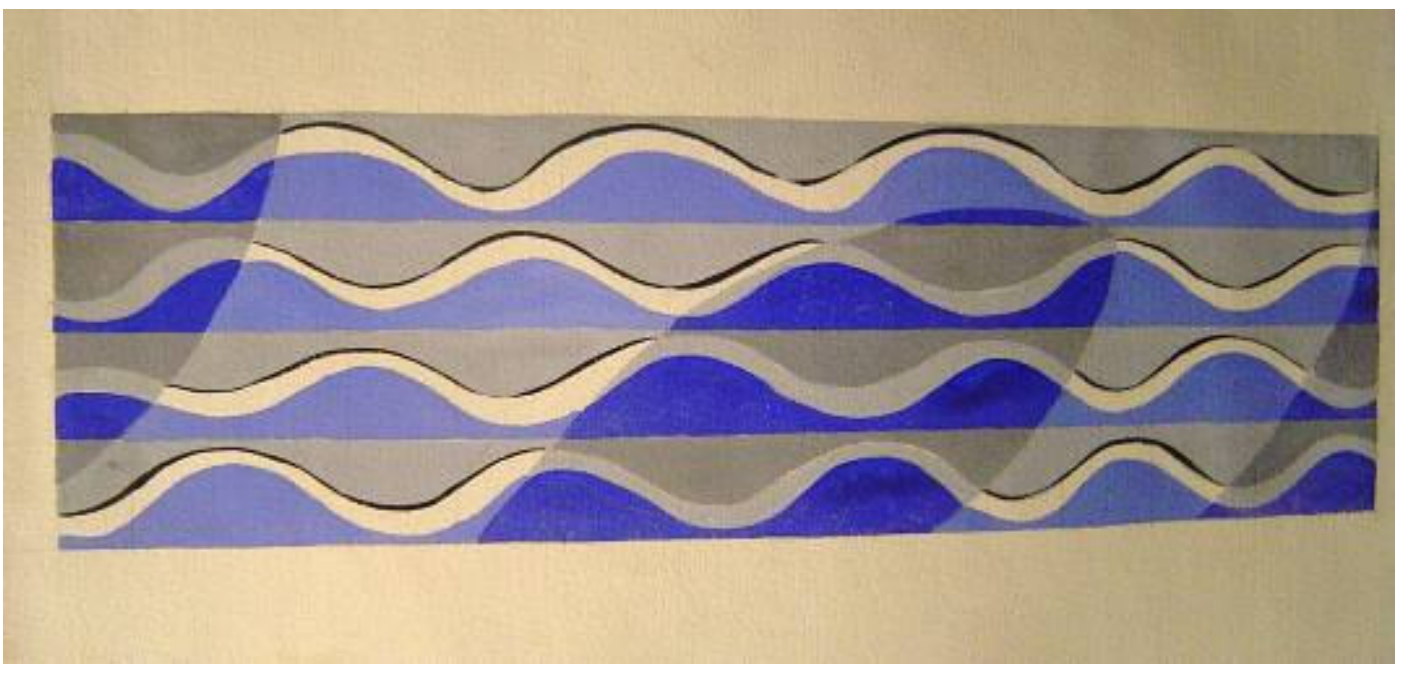

Imágenes relacionadas:

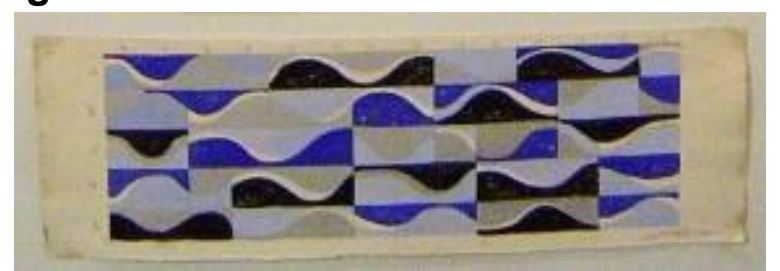

Obra cat. $n^{0} 2.9$

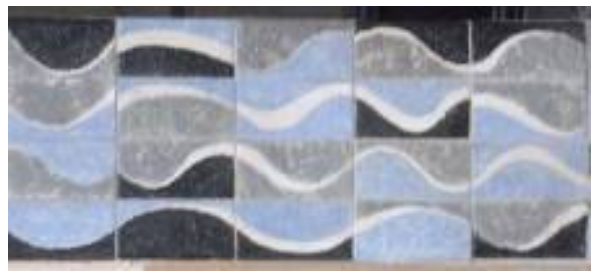

Obra cat. $n^{\circ} 6.2$ 
$\mathbf{N}^{0}: 2.11$

Título: Sin Título

Autoría: Manolo Safont

Datación: Final década 1950- Inicios década 1960

Técnica: Dibujo sobre papel

Localización: MAMS

Descripción: Posible boceto para un diseño de azulejo. Paleta cromática: blancos, amarillos, rojos, azules y grises.

\section{Exposiciones:}

- "Manolo Safont. Un museu, un llegat i un compromís". MAMS. Del 27 de noviembre de 2004 al 8 de enero de 2005. Onda.

\section{Imagen:}

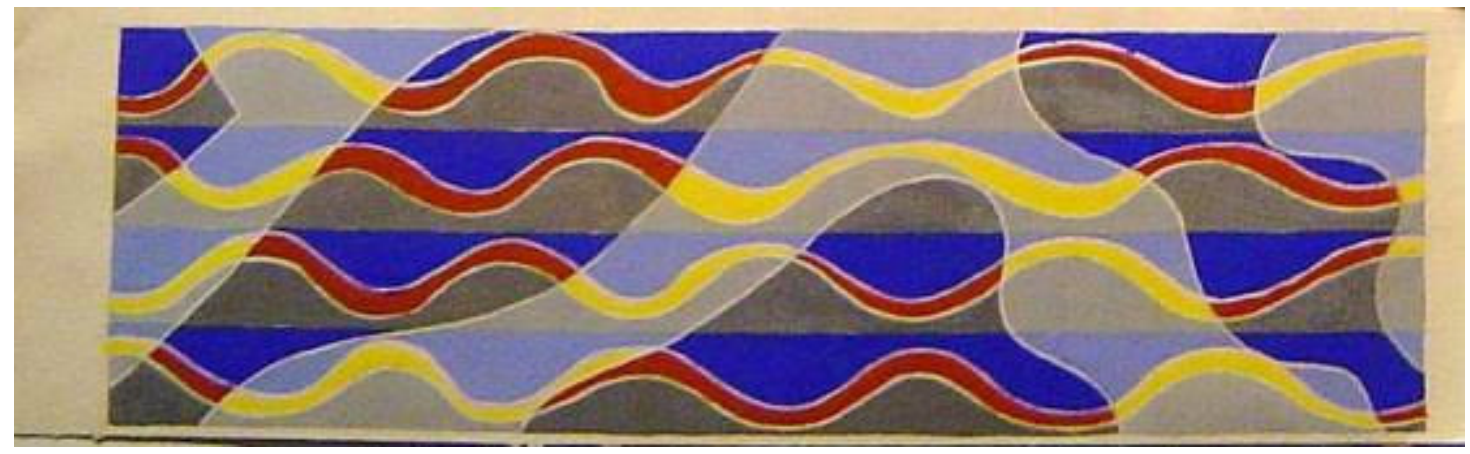


$N^{\circ}: 2.12$

Título: Sin Título

Autoría: Manolo Safont

Datación: Final década 1950- Inicios década 1960

Técnica: Dibujo

Localización: MAMS

Descripción: Posible boceto para un diseño de azulejo. Paleta cromática: blancos, amarillos, naranjas, rojos, marrones y negros.

\section{Exposiciones:}

- "Manolo Safont. Un museu, un llegat i un compromís". MAMS. Del 27 de noviembre de 2004 al 8 de enero de 2005. Onda.

\section{Imagen:}

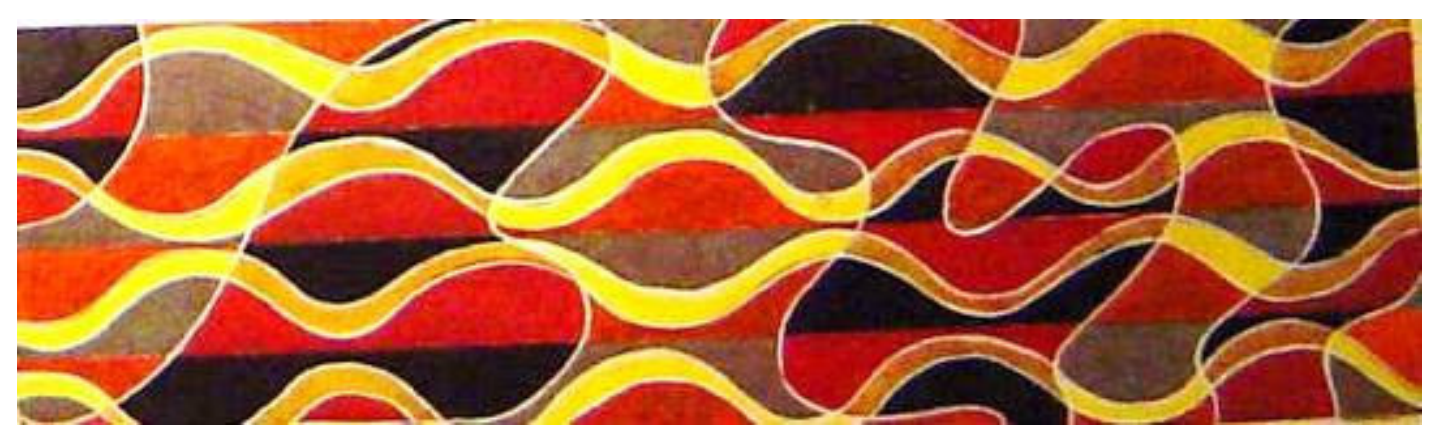


$\mathbf{N}^{0}: 2.13$

Título: Sin Título

Autoría: Manolo Safont

Datación: Final década 1950- Inicios década 1960

Inscripciones: Safont en ángulo inferior derecho

Técnica: Dibujo sobre papel

Localización: MAMS

Descripción: Posible boceto para un diseño de azulejo. Diseño similar al boceto catalogado $n^{0} 2.14$. Paleta cromática: amarillos, azules y negros.

Exposiciones:

- "Manolo Safont. Un museu, un llegat i un compromís". MAMS. Del 27 de noviembre de 2004 al 8 de enero de 2005. Onda.

Imagen:

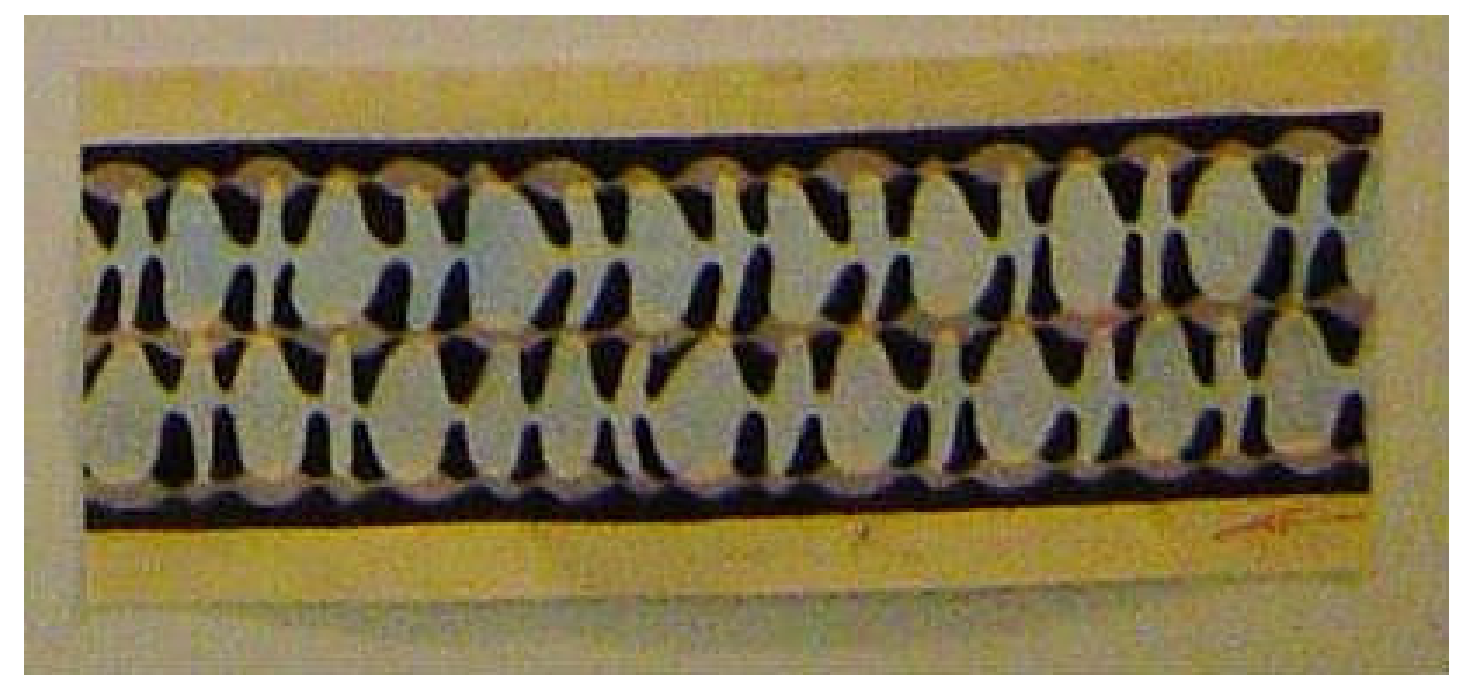


No: 2.14

Título: Sin Título

Autoría: Manolo Safont

Datación: Final década 1950 - Inicios década 1960

Inscripciones: Safont en ángulo inferior derecho

Técnica: Dibujo sobre papel

Localización: MAMS

Descripción: Posible boceto para un diseño de azulejo. Diseño similar al boceto catalogado $n^{\circ} 2.13$. Paleta cromática: blancos, azules, grises y negros.

Exposiciones:

- "Manolo Safont. Un museu, un llegat i un compromís". MAMS. Del 27 de noviembre de 2004 al 8 de enero de 2005 . Onda.

Imagen:

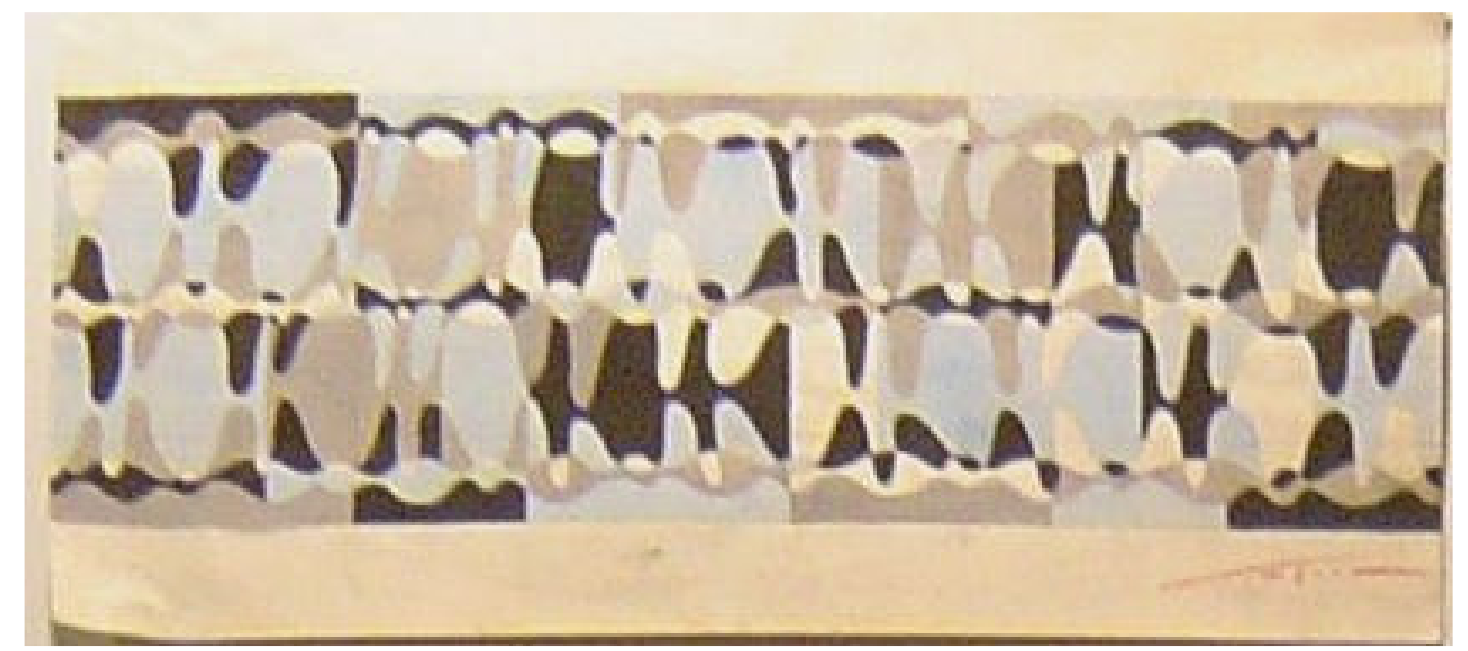


No: 2.15

Título: Sin Título

Autoría: Manolo Safont

Datación: Final década 1950- Inicios década 1960

Técnica: Dibujo sobre papel

Tema: Abstracto

Localización: MAMS

Descripción: Posible boceto para diseño de azulejo con motivos abstractos y geométricos. Paleta cromática: blancos y azules.

Exposiciones:

- "Manolo Safont. Un museu, un llegat i un compromís". MAMS. Del 27 de noviembre de 2004 al 8 de enero de 2005. Onda.

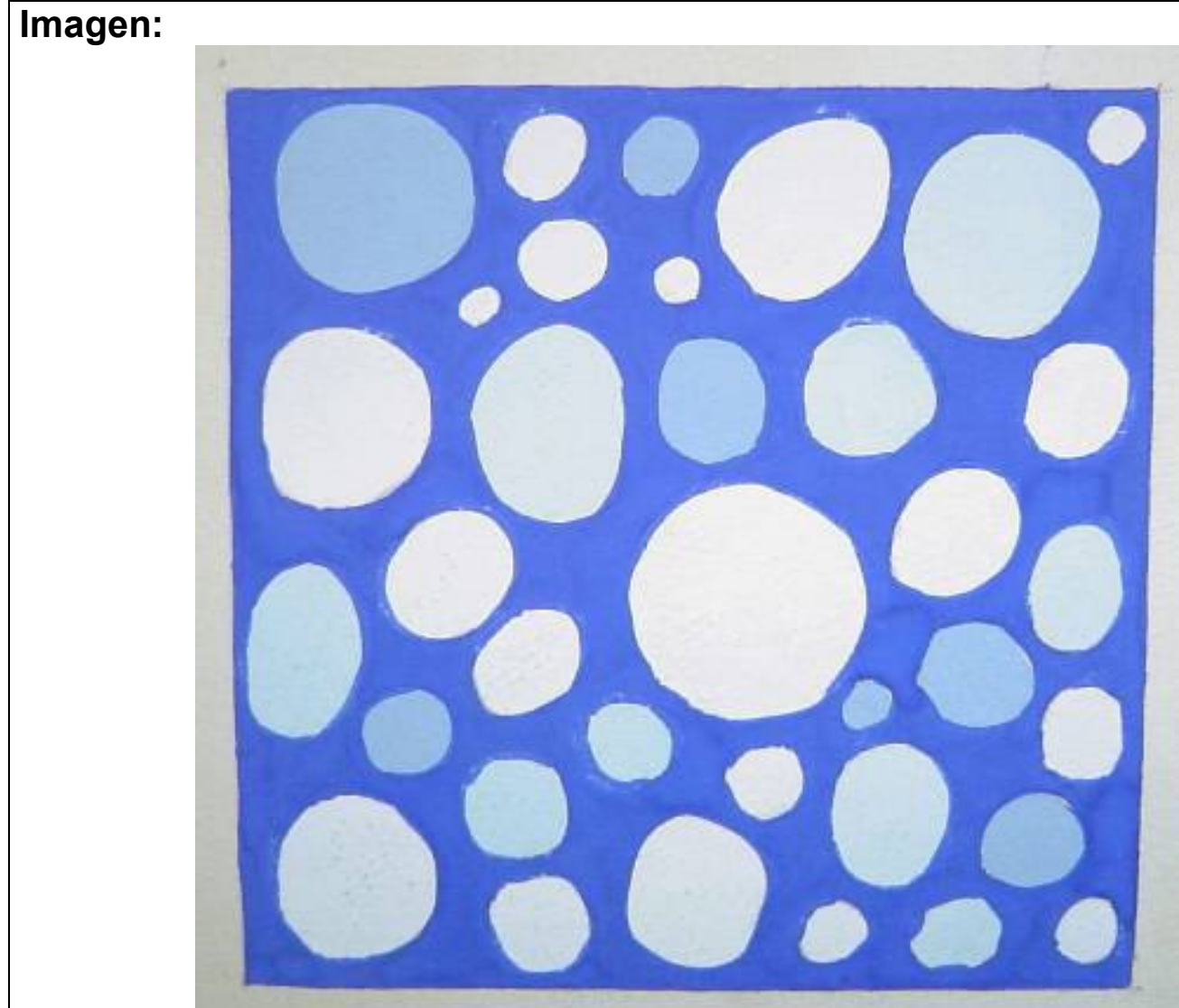


No: 2.16

Título: Sin Título

Autoría: Manolo Safont

Datación: Final década 1950- Inicios década 1960

Técnica: Dibujo sobre papel

Localización: MAMS

Descripción: Posible boceto para diseño de panel de 15 azulejos, en disposición 5x3. Paleta cromática: blancos, amarillos, azules, marrones y negros.

Exposiciones:

- "Manolo Safont. Un museu, un llegat i un compromís". MAMS. Del 27 de noviembre de 2004 al 8 de enero de 2005. Onda.

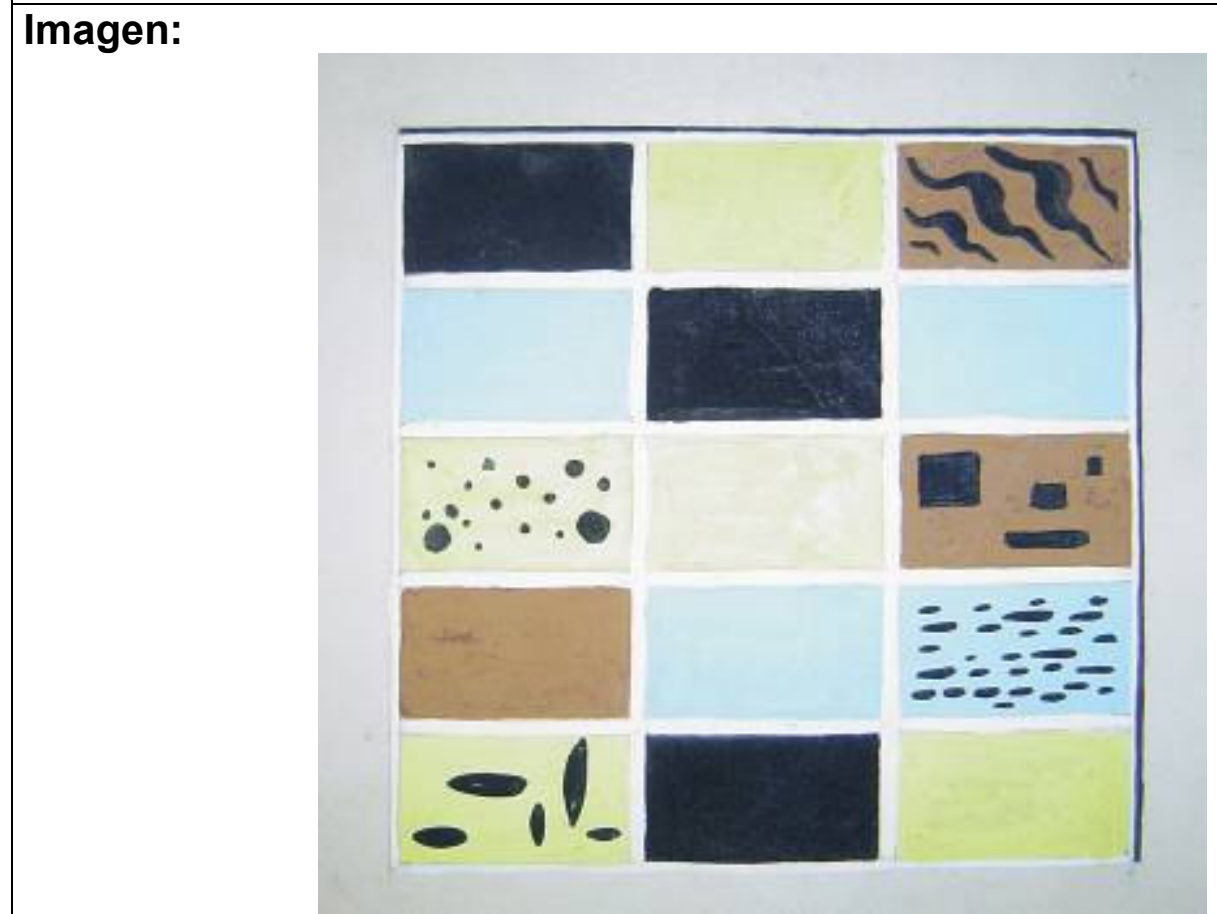




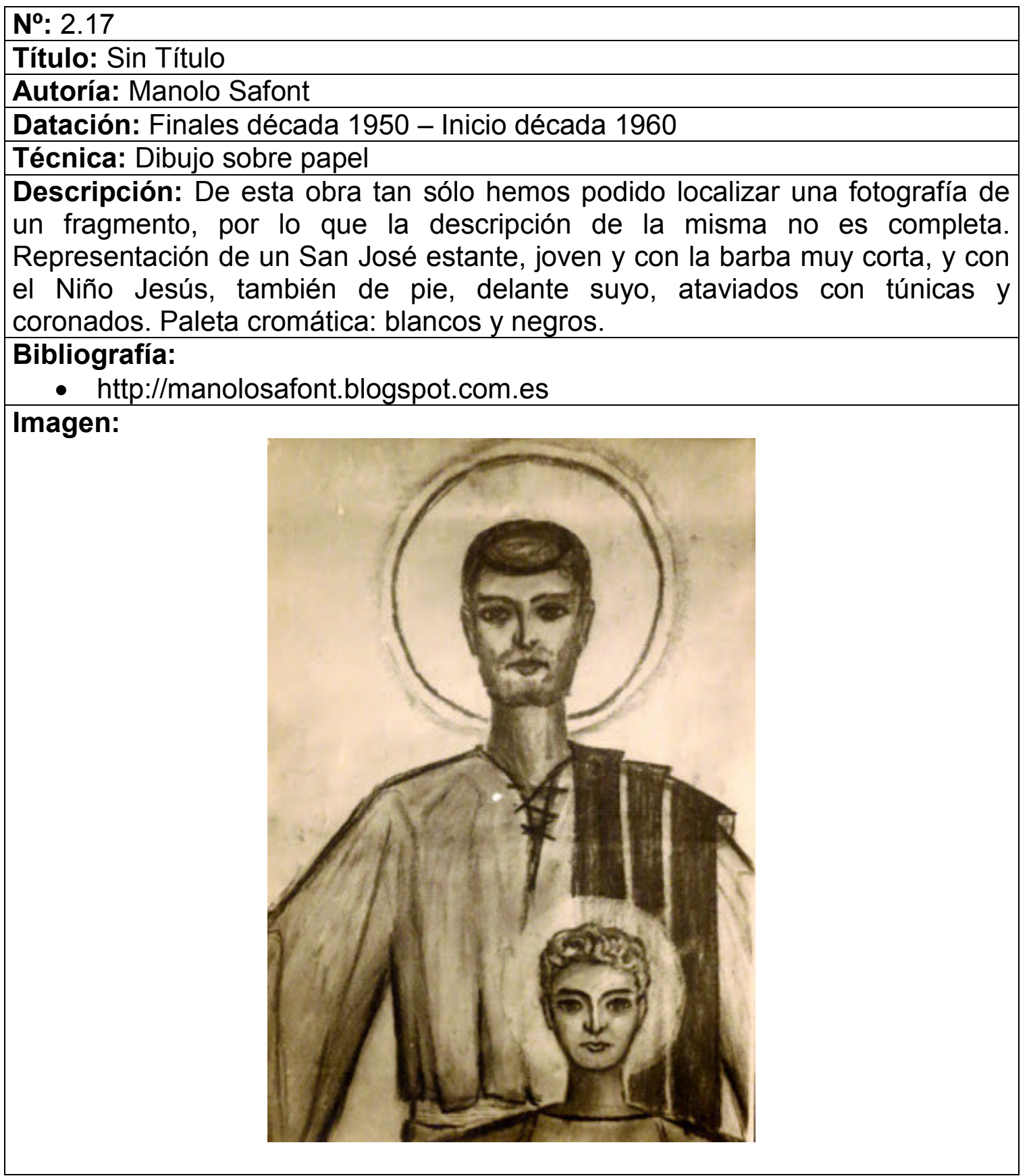


$\mathbf{N}^{\circ}: 2.18$

Título: Sin Título

Autoría: Manolo Safont

Datación: 1960

Inscripciones: Onda, Fiestas de 1960

Técnica: Dibujo sobre papel

Localización: MAMS

Descripción: Dibujo utilizado para realizar la portada del programa de fiestas de Onda de 1960, obra cat. $\mathrm{n}^{\circ 1.1}$. Paleta cromática: blancos, marrones y negros.

\section{Exposiciones:}

- "Manolo Safont. Un museu, un llegat i un compromís". MAMS. Del 27 de noviembre de 2004 al 8 de enero de 2005. Onda.

\section{Bibliografía:}

- Fira d'Onda. Programes de Festes. Biblioteques d'Onda. Ajuntament d'Onda. Onda, 2006

\section{Imagen:}

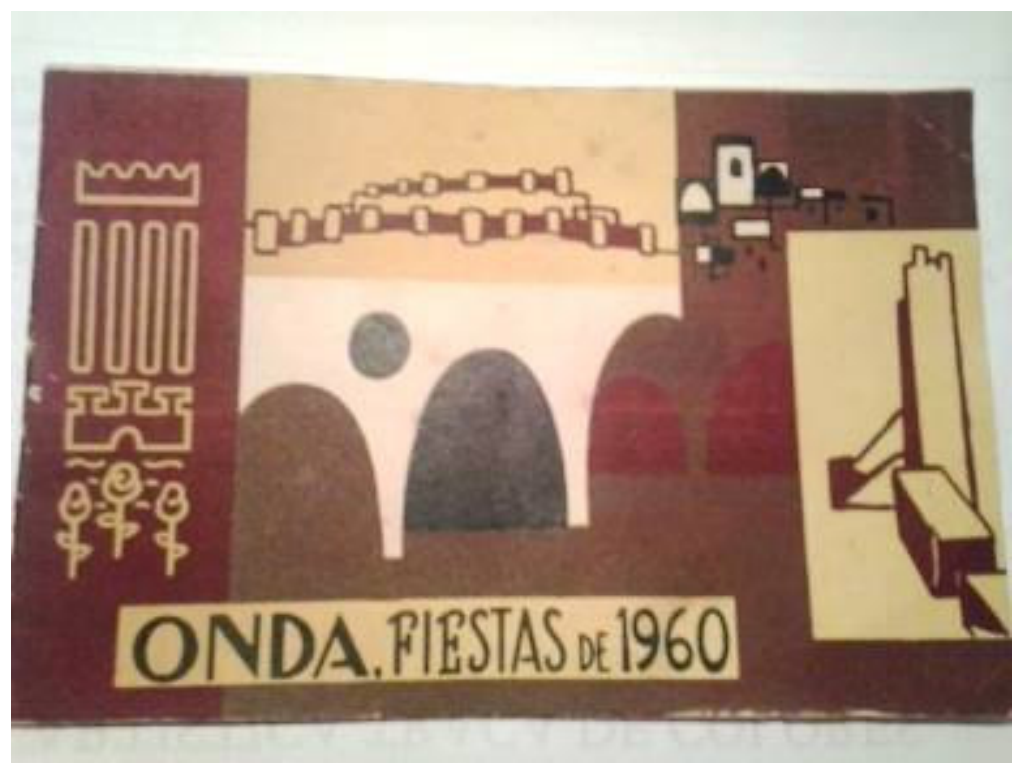

\section{Imágenes relacionadas:}

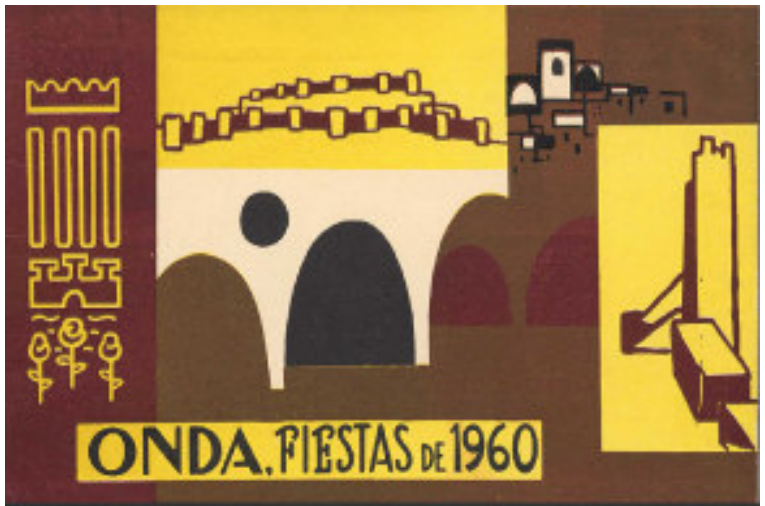

Obra cat. $\mathrm{n}^{0} 1.1$ 
$\mathbf{N}^{0}: 2.19$

Título: Sin Título

Autoría: Manolo Safont

Datación: 1961

Inscripciones: "FIRA D'ONDA"

Técnica: Dibujo sobre papel

Localización: MAMS

Descripción: Dibujo para la realización del cartel anunciador de las fiestas patronales de Onda de 1961, obra catalogada $n^{\circ} 2.20$. Utilizado por el Ayuntamiento de Onda para la realización de una placa conmemorativa que se entregó en octubre de 1983 por la participación de los centros escolares de Onda en los Juegos Escolares que se organizaron en la población, catalogada con el $n^{0} 3.23$. Representa el escudo y elementos arquitectónicos de Onda: castillo, chimeneas de las fábricas de azulejos, iglesia de la asunción, arcos de la Font de Dins y elementos de alfarería tradicional. Paleta cromática: blancos y negros.

Exposiciones:

- "Manolo Safont. Un museu, un llegat i un compromís". MAMS. Del 27 de noviembre de 2004 al 8 de enero de 2005. Onda

\section{Imagen:}

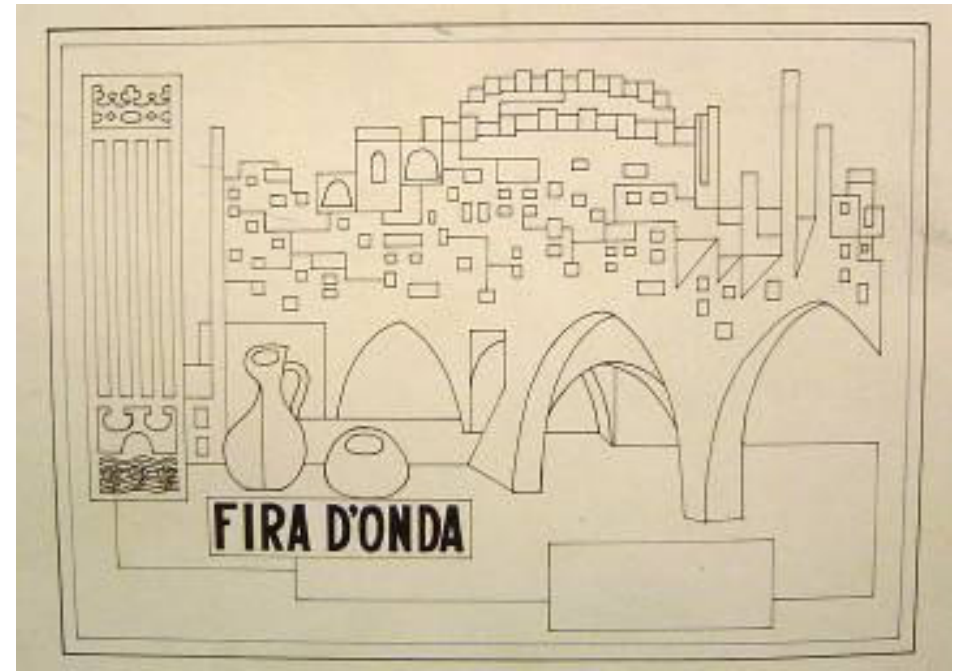

\section{Imágenes relacionadas:}

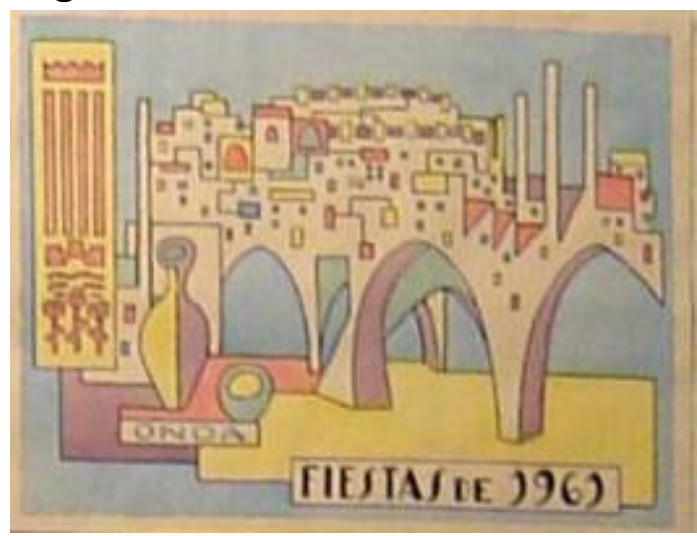

Obra cat. $\mathrm{n}^{\circ} 2.20$

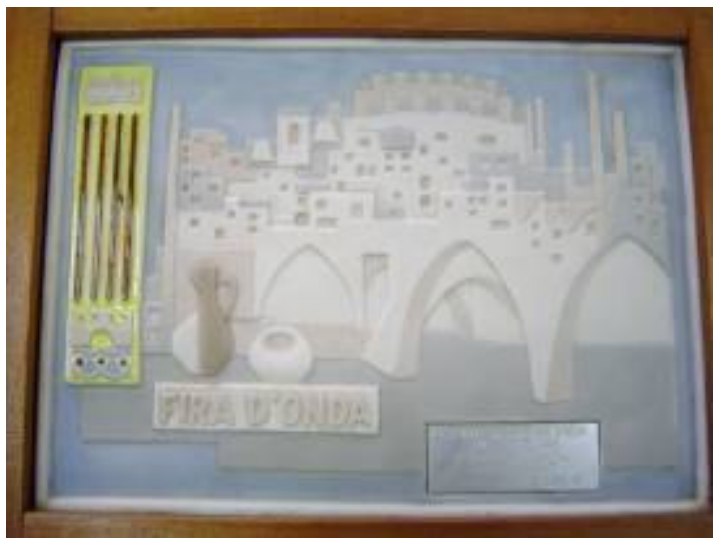

Obra cat. $\mathrm{n}^{0} 3.23$ 
No: 2.20

Título: Sin Título

Autoría: Manolo Safont

Datación: 1961

Inscripciones: "ONDA" "FIESTAS DE 1961"

Técnica: Dibujo sobre papel

Localización: MAMS

Descripción: Dibujo con un paisaje arquitectónico de Onda, incluyendo el escudo local y piezas de cerámica artística. Paleta cromática: blancos, amarillos, naranjas, rojos, verdes, azules, violetas y negros.

Exposiciones:

- "Manolo Safont. Un museu, un llegat i un compromís". MAMS. Del 27 de noviembre de 2004 al 8 de enero de 2005. Onda

Imagen:

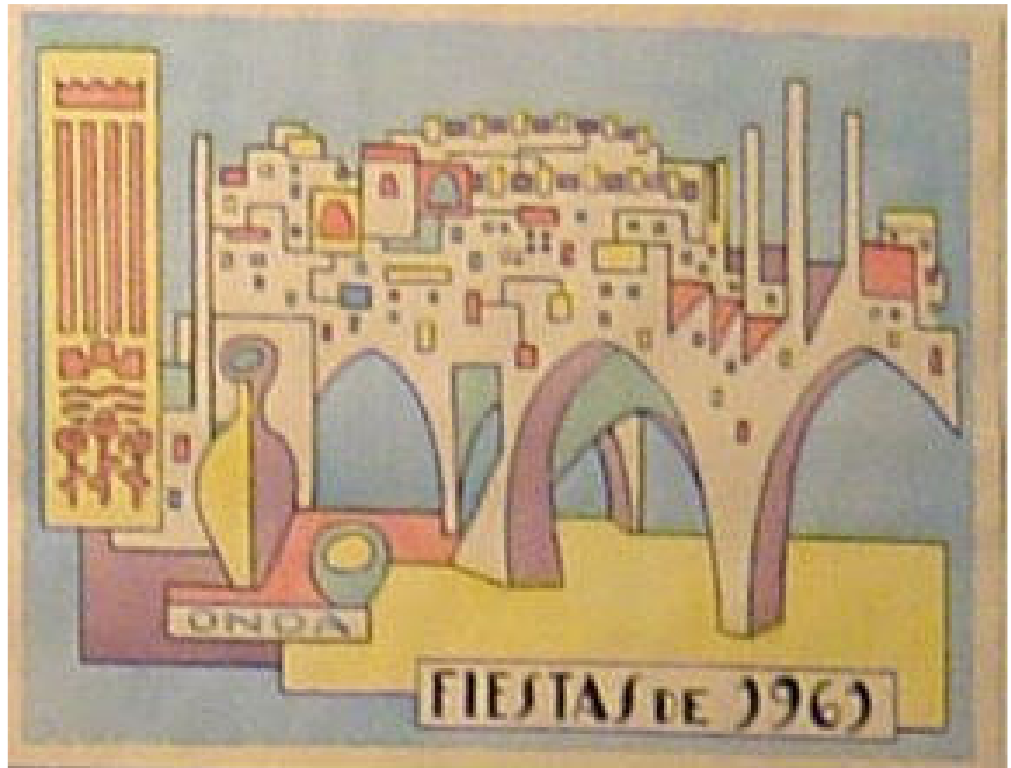

Imágenes relacionadas:

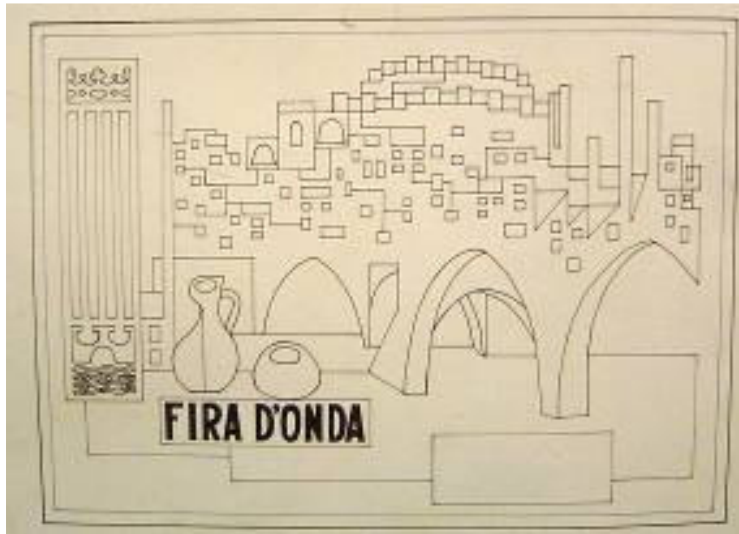

Obra cat. $\mathrm{n}^{\circ} 2.19$

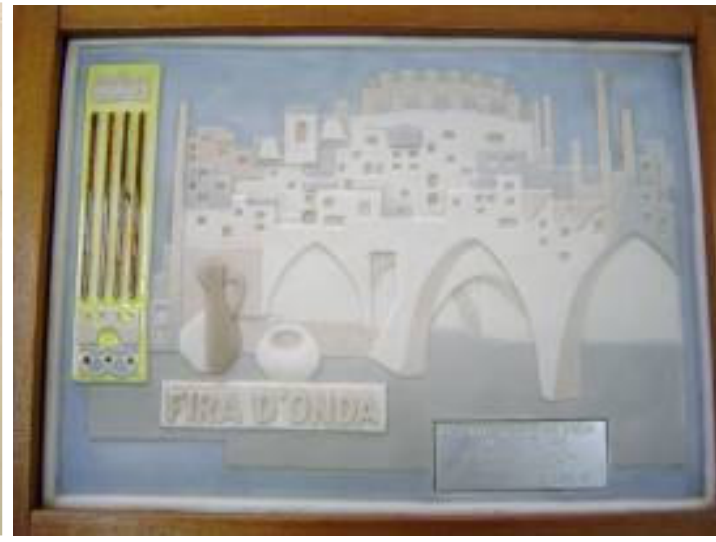

Obra cat. $\mathrm{n}^{\circ} 3.23$ 
$\mathbf{N}^{0}: 2.21$

Título: Sin Título

Autoría: Manolo Safont

Datación: 1961

Inscripciones: "Va ASAMBLEA REVESTIMENTOS Y PAVIMENTOS

CERAMICOS" "MADRID- 9 Y 10- NOVIEMBRE 1961"

Técnica: Dibujo sobre papel

Localización: MAMS

Descripción: Cartel para la $5^{\mathrm{a}}$ Asamblea de Revestimientos y Pavimentos

Cerámicos celebrada en Madrid. El cartel se imprimió también en Madrid.

Paleta cromática: blancos y negros.

Exposiciones:

- "Manolo Safont. Un museu, un llegat i un compromís". MAMS. Del 27 de noviembre de 2004 al 8 de enero de 2005. Onda

\section{Imagen:}

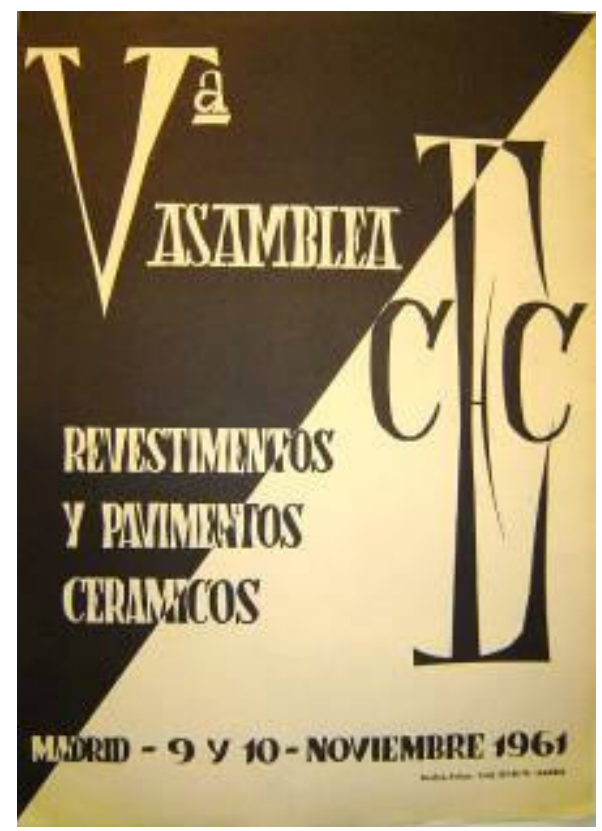


$\mathbf{N}^{0}: 2.22$

Título: Sin Título

Autoría: Manolo Safont

Datación: Inicios década 1960

Dimensiones: 8x25 cms

Técnica: Dibujo sobre papel

Descripción: Dibujo-esbozo de líneas esquemáticas y geométricas, que representa la imagen del Santísimo Salvador, patrón de la localidad de Onda. Se representa tal y como se muestra en la imagen que se venera en Onda, Cristo en posición estante, sosteniendo el orbe sobre su mano izquierda, mientras alza la mano derecha en posición de impartir la bendición. Paleta cromática: blancos y negros.

Bibliografía:

- http://manolosafont.blogspot.com.es

Imagen:

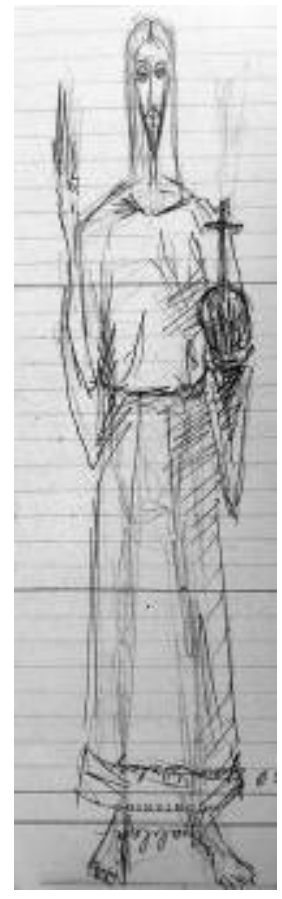

Imágenes relacionadas:

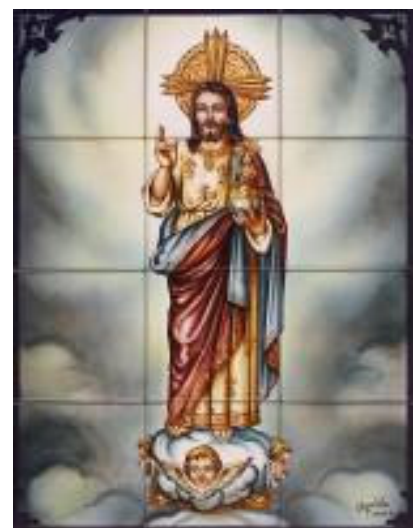

Imagen Santísimo Salvador de Onda 
No: 2.23

Título: Sin Título

Autoría: Manolo Safont

Datación: 1964

Inscripciones: Safont 64 en ángulo inferior derecho

Técnica: Dibujo sobre papel

Localización: MAMS

Descripción: Dibujo sobre papel con representación floral. Paleta cromática: verdes, azules y negros.

Exposiciones:

- "Manolo Safont. Un museu, un llegat i un compromís". MAMS. Del 27 de noviembre de 2004 al 8 de enero de 2005 . Onda.

Imagen: 
$\mathbf{N}^{0}: 2.24$

Título: Sin Título

Autoría: Manolo Safont

Datación: 1968

Inscripciones: Safont en ángulo inferior izquierdo. Lema "ONDA EN FIESTAS"

Técnica: Dibujo sobre papel

Localización: MAMS

Descripción: Dibujo creado para la portada del programa de las fiestas patronales de Onda de 1968, obra catalogada n¹.9. Paleta cromática: blancos, amarillos, naranjas, rojos, azules y negros.

Exposiciones:

- "Manolo Safont. Un museu, un llegat i un compromís". MAMS. Del 27 de noviembre de 2004 al 8 de enero de 2005 . Onda.

\section{Bibliografía:}

- Revista Programa Fiestas Patronales de Onda. Ayuntamiento de Onda, Onda, 1968

- Fira d'Onda. Programes de Festes. Biblioteques d'Onda. Ajuntament d'Onda. Onda, 2006

Imagen:

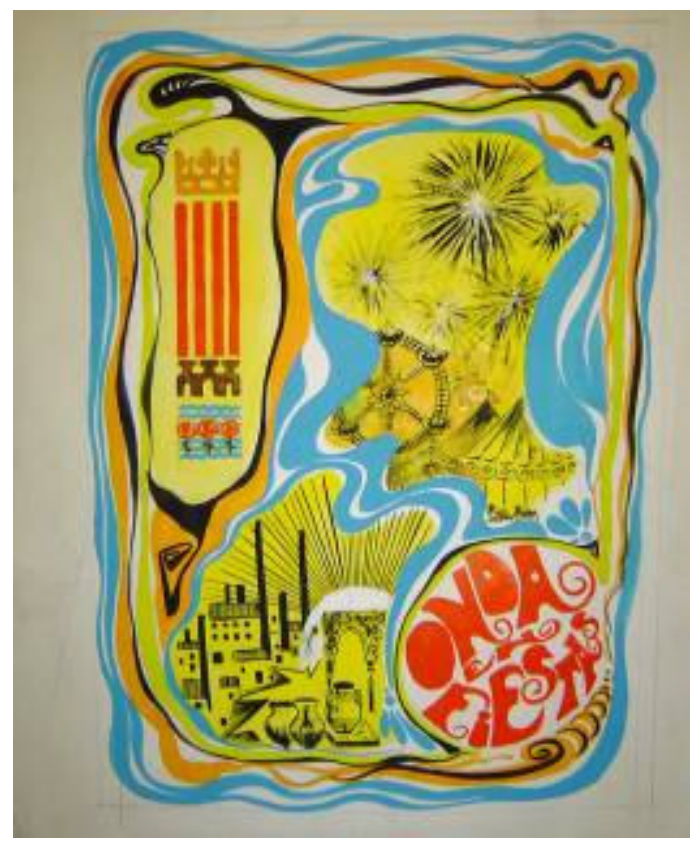

Imágenes relacionadas:

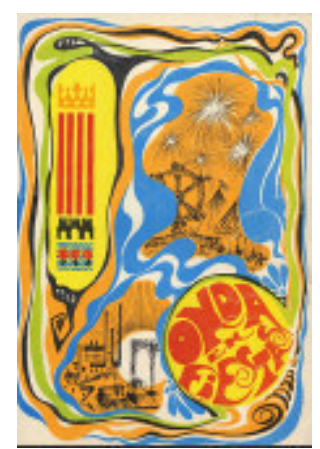

Obra cat. $\mathrm{n}^{01.9}$ 
No: 2.25

Título: Sin Título

Autoría: Manolo Safont

Datación: 1969

Inscripciones: "ONDA EN FIESTAS" "1969"

Técnica: Dibujo sobre papel

Localización: MAMS

Descripción: Dibujo preliminar para la portada del programa de fiestas de Fira d'Onda del año 1969. Presenta el mismo tema y diseño que la obra catalogada con el $n^{\circ} 2.26$, aunque esta pieza es más esquemática, con figuras menos definidas, manteniendo la misma estructura, pero difieren también alguno de los colores utilizados, como el tono verde con el que marca la inscripción de la fecha. Paleta cromática: blancos, amarillos, rojos, verdes, azules y negros.

Exposiciones:

- "Manolo Safont. Un museu, un llegat i un compromís". MAMS. Del 27 de noviembre de 2004 al 8 de enero de 2005 . Onda

Imagen:

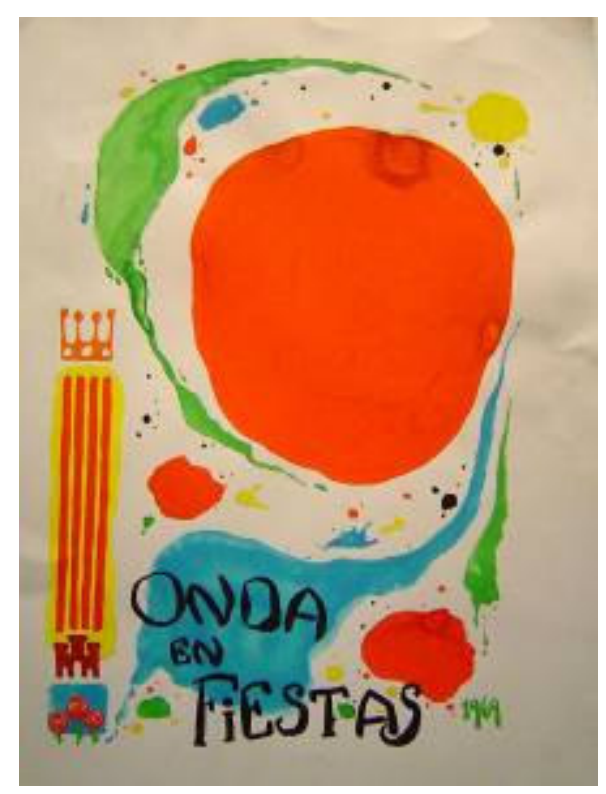

Imágenes relacionadas:

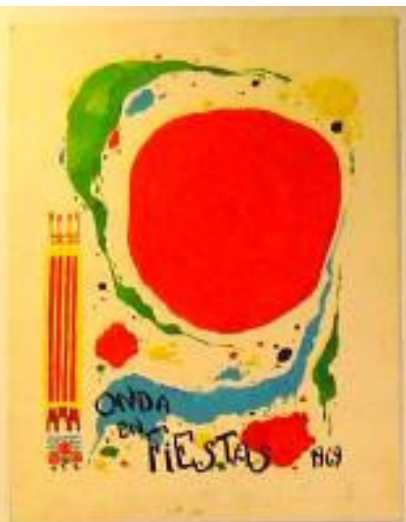

Obra cat. $n^{\circ} 2.26$

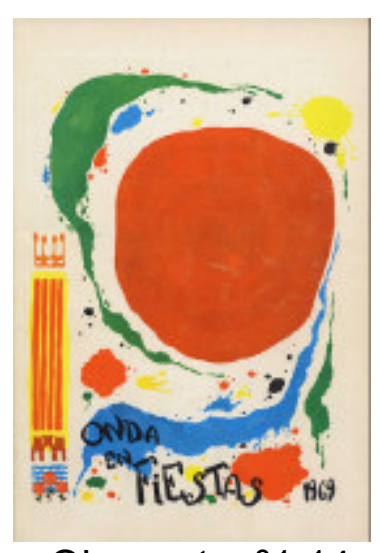

Obra cat. $\mathrm{n}^{01.14}$ 
No: 2.26

Título: Sin Título

Autoría: Manolo Safont

Datación: 1969

Inscripciones: "ONDA EN FIESTAS" "1969"

Técnica: Dibujo sobre papel

Localización: MAMS

Descripción: Este dibujo, con un gran círculo rojo central, rodeado manchas de colores y con el escudo de Onda en el margen izquierdo, fue utilizado como portada del programa de Fiestas de Onda del año 1969, obra cat. n¹.14. Paleta cromática: blancos, amarillos, naranjas, rojos, verdes, azules y negros.

\section{Exposiciones:}

- "Manolo Safont. Un museu, un llegat i un compromís". MAMS. Del 27 de noviembre de 2004 al 8 de enero de 2005 . Onda

\section{Imagen:}

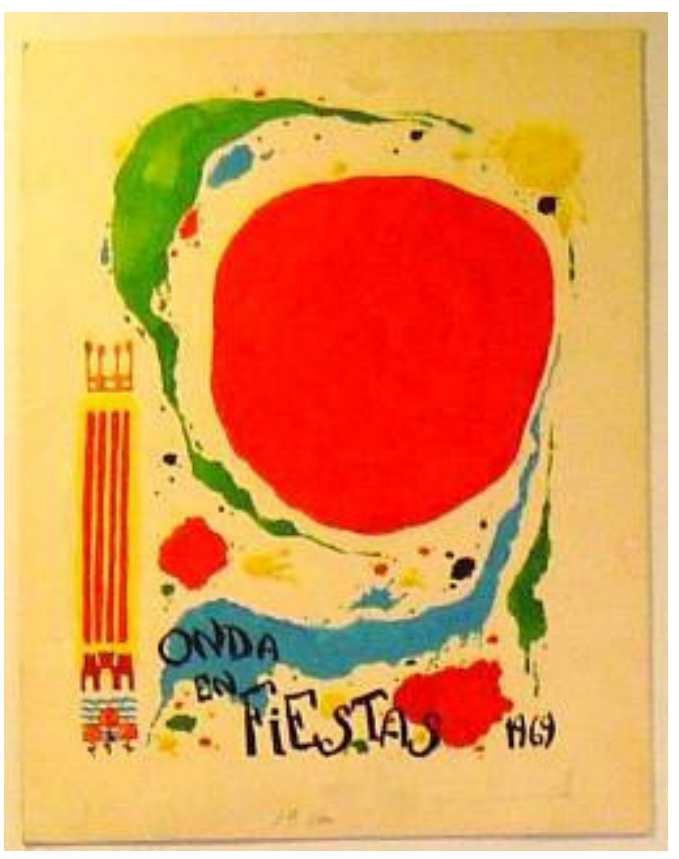

\section{Imágenes relacionadas:}

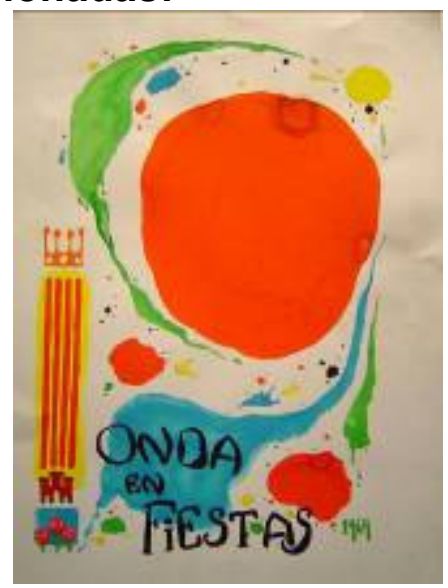

Obra cat. $n^{\circ} 2.25$

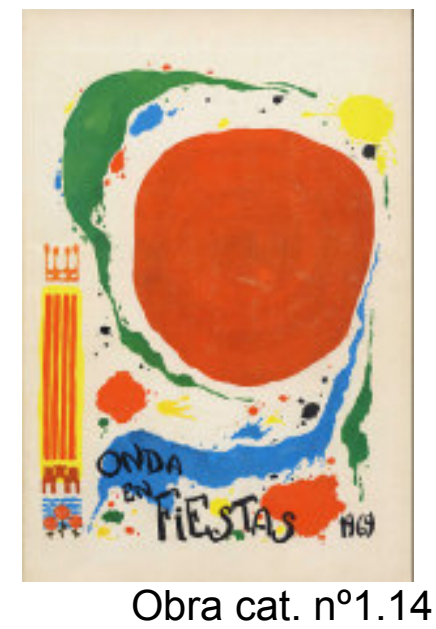

Obra cat. $n^{01.14}$ 
$N^{0}: 2.27$

Título: Sin Título

Autoría: Manolo Safont

Datación: Final década 1960 - Inicio década 1970

Técnica: Dibujo sobre papel

Localización: MAMS

Descripción: Este dibujo recuerda las grandes formas circulares rojas que utiliza en algunas obras, como la utilizada como portada del Programa de Fiestas de Onda de 1970, obra catalogada n¹.15. Paleta cromática: amarillos, naranjas, rojos, verdes y azules.

Exposiciones:

- "Manolo Safont. Un museu, un llegat i un compromís". MAMS. Del 27 de noviembre de 2004 al 8 de enero de 2005. Onda.

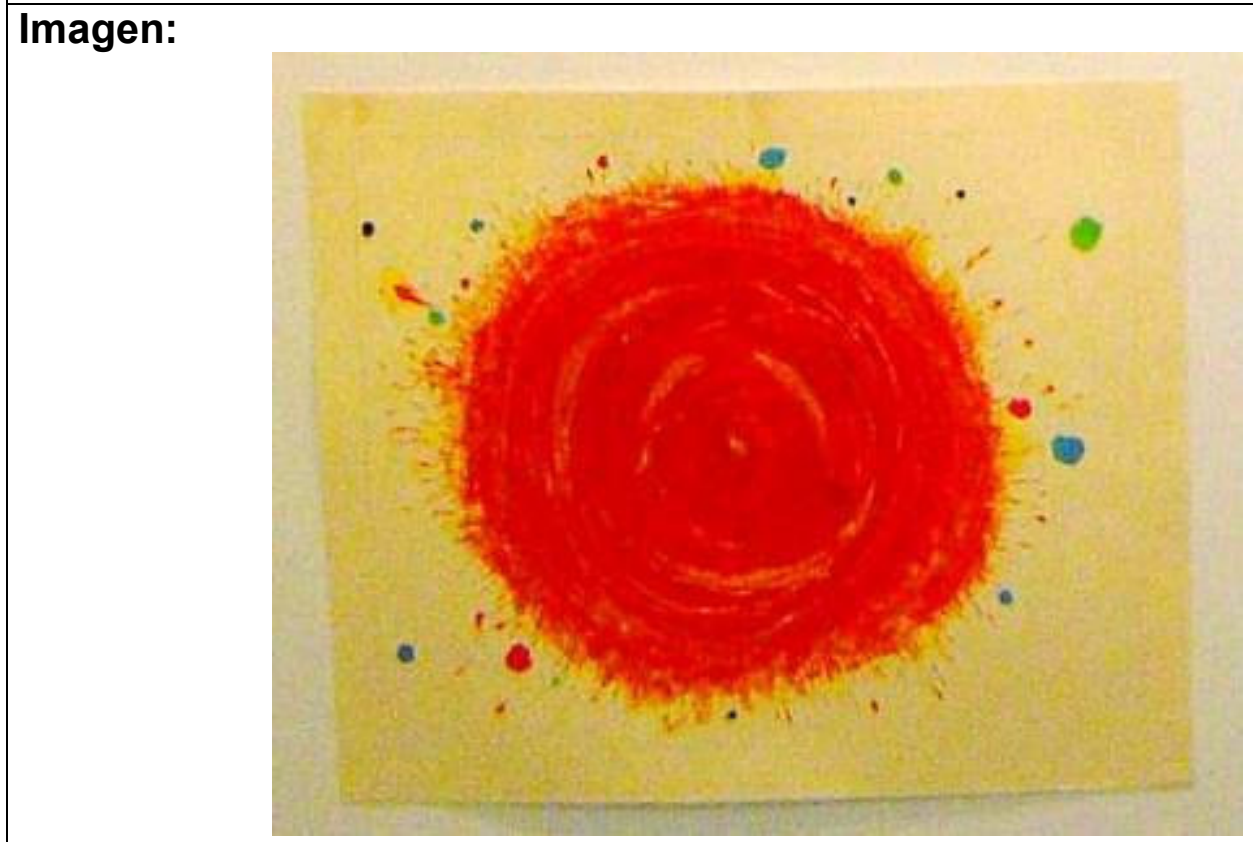

Imágenes relacionadas:

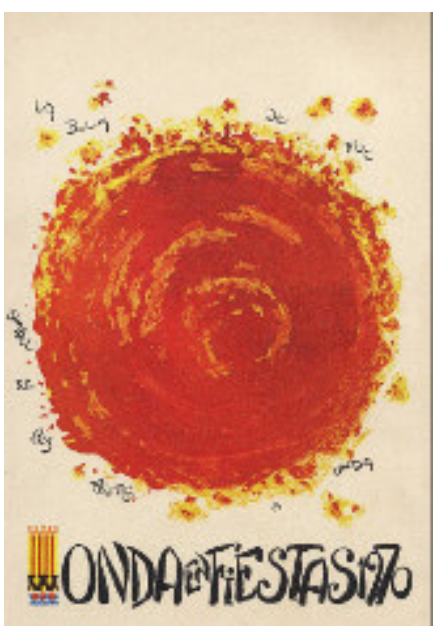

Obra cat. $n^{01.15}$ 
No: 2.28

Título: Sin Título

Autoría: Manolo Safont

Datación: Final década 1960 - Inicio década 1970

Técnica: Dibujo sobre papel

Localización: MAMS

Descripción: Forma elíptica roja central, composición similar a la utilizada en los carteles de fiestas de Onda y en el del centenario de la Banda de Música de Onda, obras catalogadas con los $n^{\circ} 2.25, n^{\circ} 2.26, n^{\circ} 2.50$ y $n^{\circ} 2.54$. Paleta cromática: blancos, amarillos, rojos, verdes y azules.

\section{Exposiciones:}

- "Manolo Safont. Un museu, un llegat i un compromís". MAMS. Del 27 de noviembre de 2004 al 8 de enero de 2005. Onda.

\section{Imagen:}

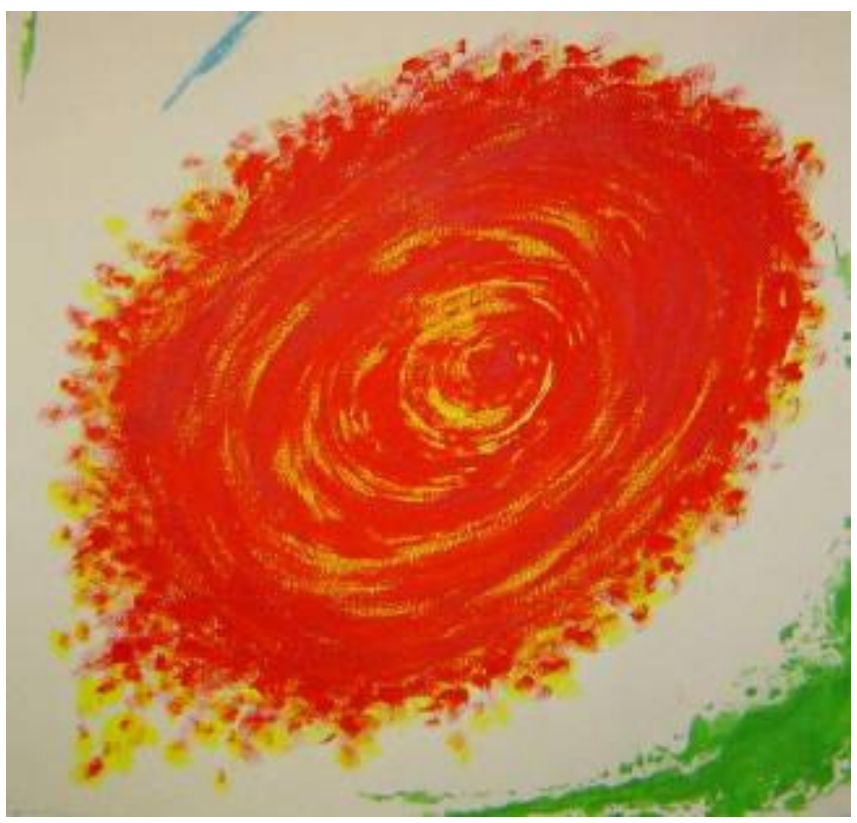

\section{Imágenes relacionadas:}

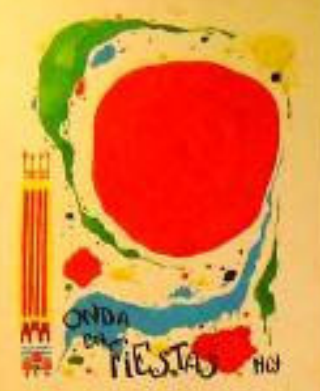

Obra cat. $n^{\circ} 2.25$

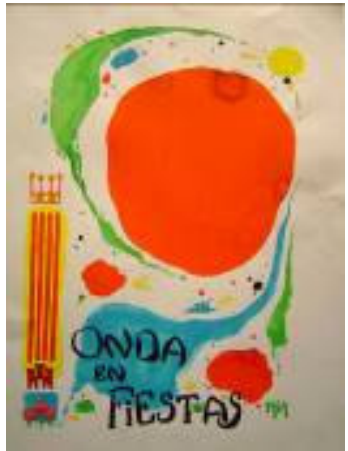

Obra cat. $n^{0} 2.26$

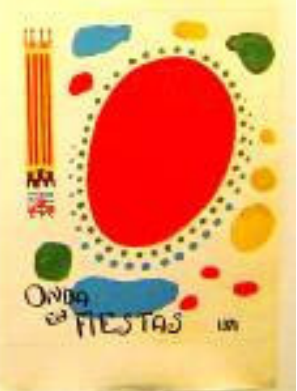

Obra cat. $n^{\circ} 2.50$

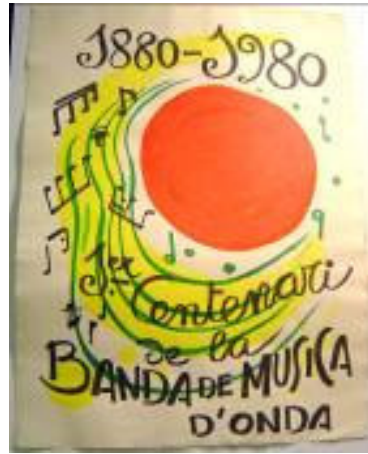

Obra cat. $n^{\circ} 2.54$ 


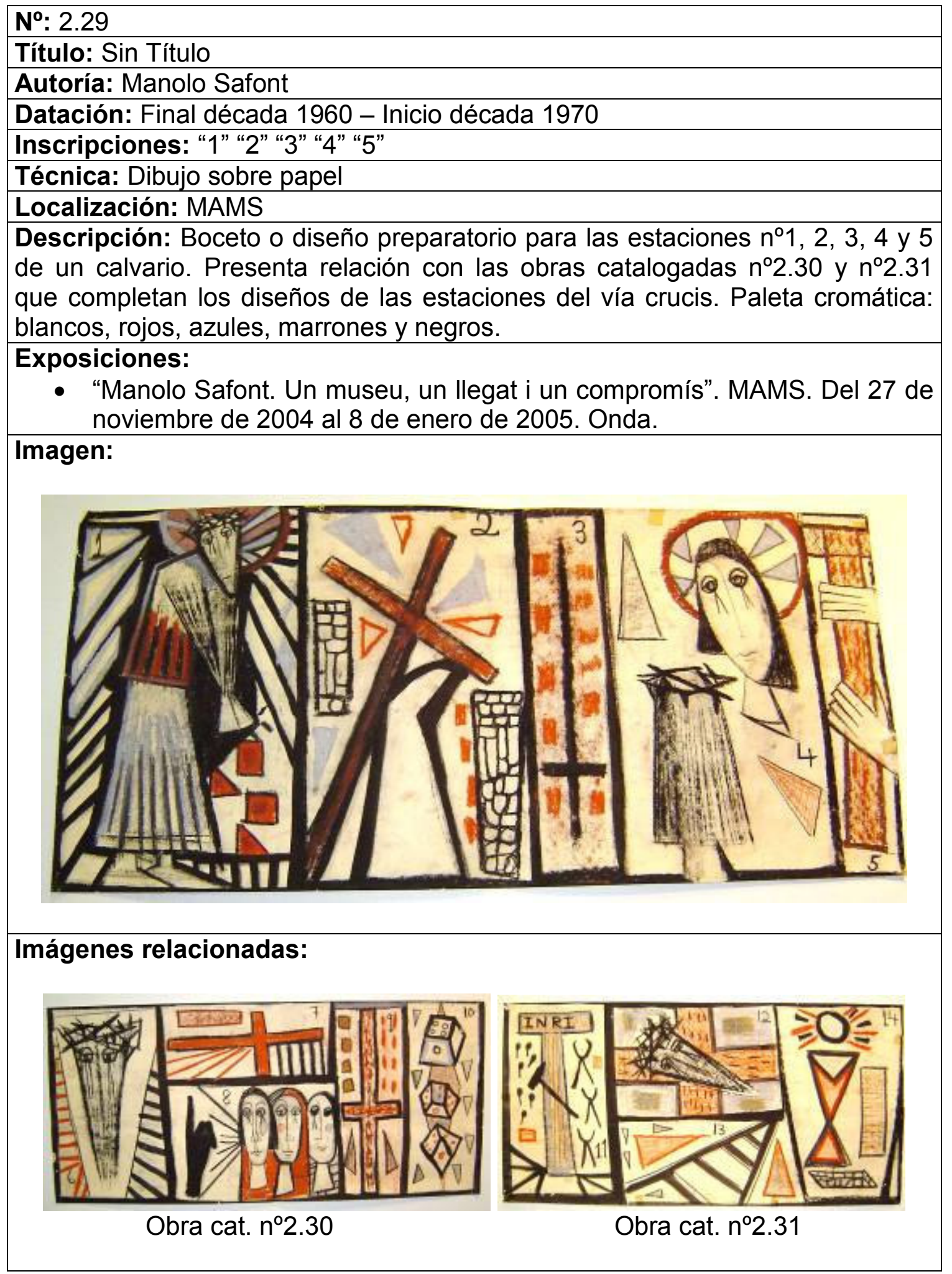


No: 2.30

Título: Sin Título

Autoría: Manolo Safont

Datación: Final década 1960 - Inicio década 1970

Inscripciones: "6" "7" "8" "9" "10"

Técnica: Dibujo sobre papel

Localización: MAMS

Observaciones: Boceto o diseño preparatorio para las estaciones $n^{\circ} 6,7,8,9$ y 10 de un calvario. Presenta relación con las obras catalogadas $n^{\circ} 2.29$ y $n^{\circ} 2.31$, que completan los diseños de las estaciones del vía crucis. Paleta cromática: blancos, rojos, azules, marrones y negros.

\section{Exposiciones:}

- "Manolo Safont. Un museu, un llegat i un compromís". MAMS. Del 27 de noviembre de 2004 al 8 de enero de 2005. Onda.

\section{Imagen:}

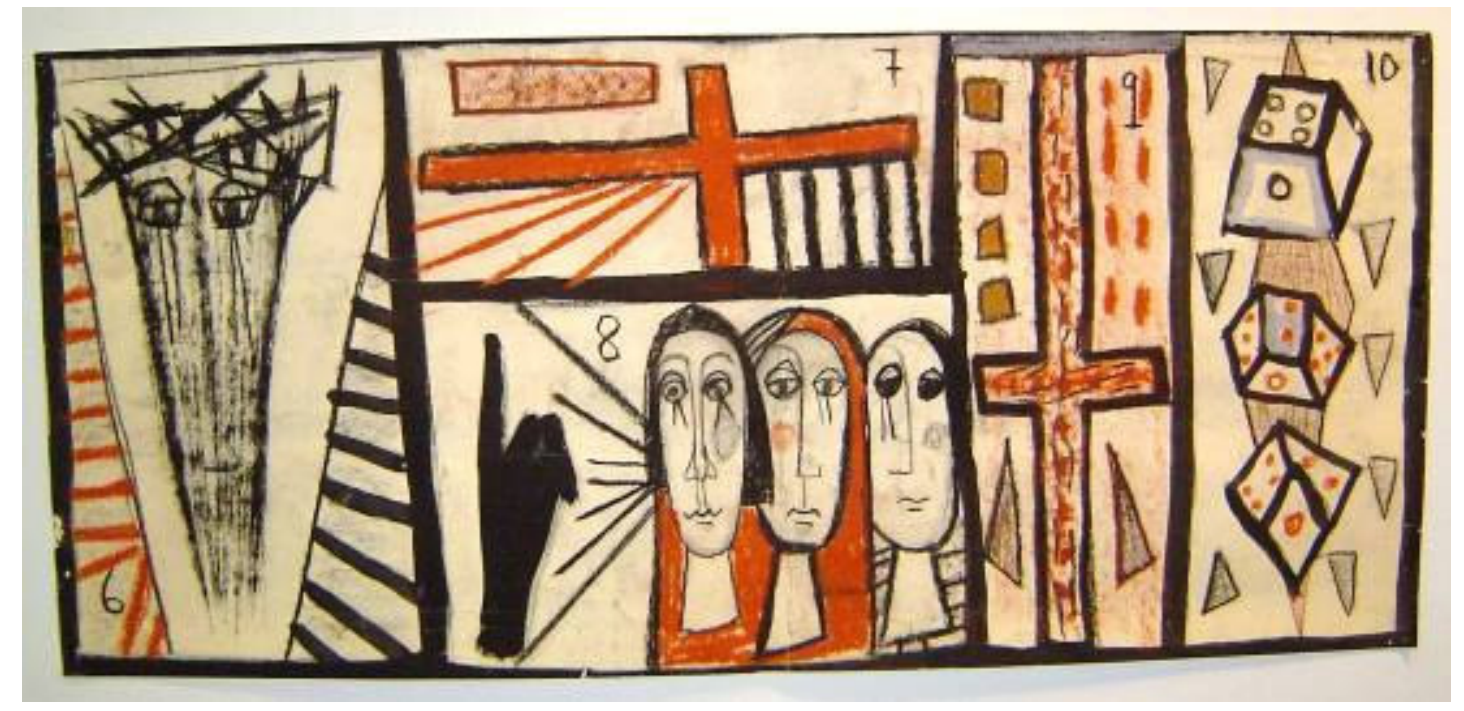

Imágenes relacionadas:

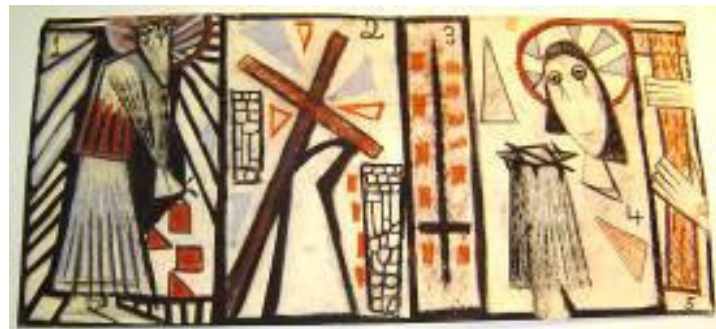

Obra cat. $n^{\circ} 2.29$

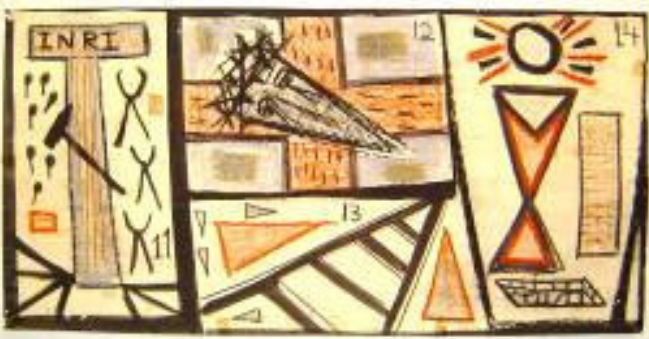

Obra cat. $n^{\circ} 2.31$ 
$\mathbf{N}^{0}: 2.31$

Título: Sin Título

Autoría: Manolo Safont

Datación: Final década 1960 - Inicio década 1970

Inscripciones: "11" "12" "13" "14"

Técnica: Dibujo sobre papel

Localización: MAMS

Descripción: Boceto o diseño preparatorio para las estaciones $n^{011}$, 12, 13 y 14 de un calvario. El diseño de la XI estación presenta similitudes técnicas y

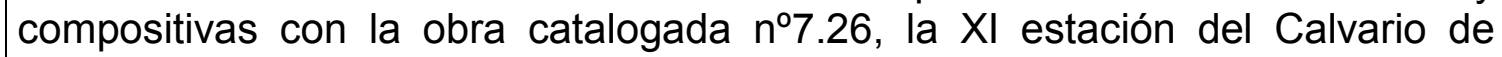
Onda (Castellón). Presenta relación con las obras catalogadas $n^{\circ} 2.29$ y $n^{\circ} 2.30$, que completan los diseños de las estaciones del vía crucis. Paleta cromática: blancos, rojos, azules, marrones y negros.

\section{Exposiciones:}

- "Manolo Safont. Un museu, un llegat i un compromís". MAMS. Del 27 de noviembre de 2004 al 8 de enero de 2005. Onda.

Imagen:

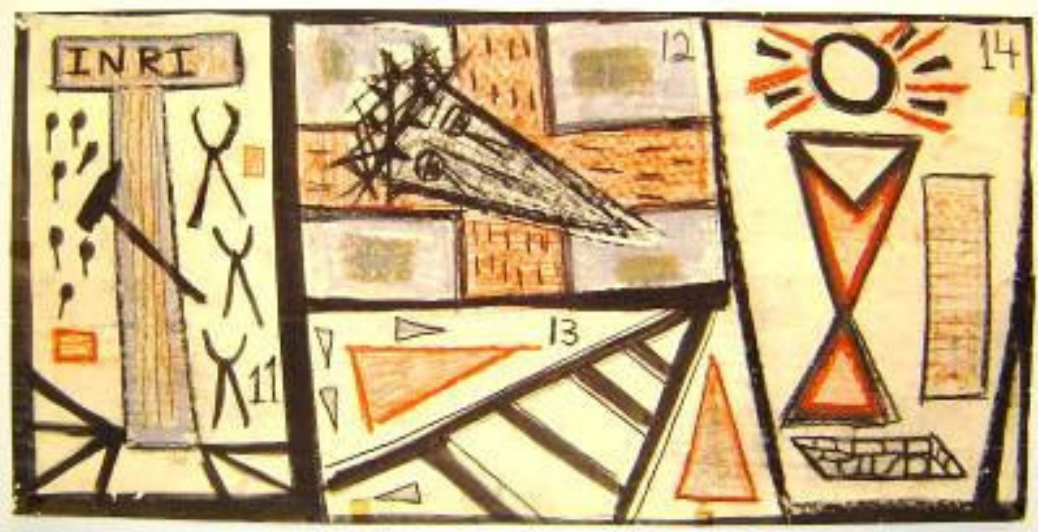

Imágenes relacionadas:

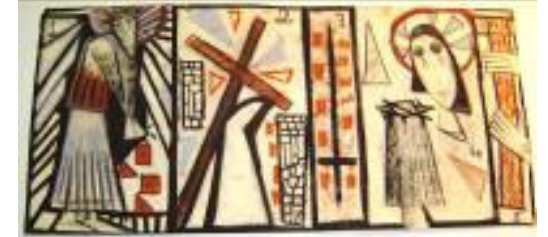

Obra cat. $n^{\circ} 2.29$

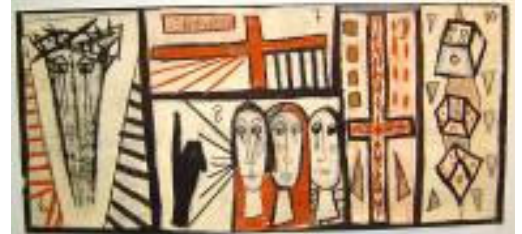

Obra cat. $n^{\circ} 2.30$

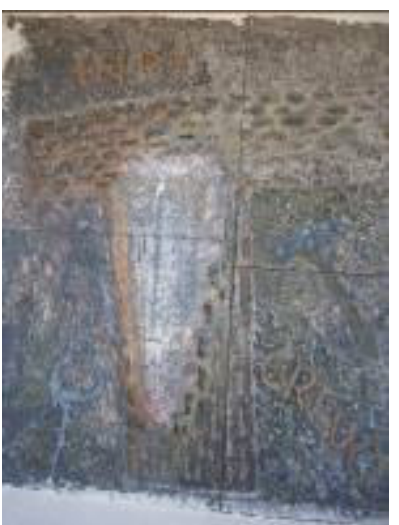

Obra cat. $n^{07.26}$ 
No: 2.32

Título: Sin Título

Autoría: Manolo Safont

Datación: Inicios década 1970

Técnica: Dibujo sobre papel

Descripción: Dibujo realizado a lápiz de un rostro, apenas dibujado, en el que cobra especial interés la boca, abierta, resaltado con un tono más oscuro, convirtiéndose así en el punto focal de la obra. Esta obra forma parte de un cuaderno de dibujo que contiene 18 dibujos, que comprende desde la obra catalogada $\mathrm{n}^{0} 2.32$ a la obra catalogada 2.49. Paleta cromática: blancos y negros.

Bibliografía:

- http://manolosafont.blogspot.com.es

Imagen:

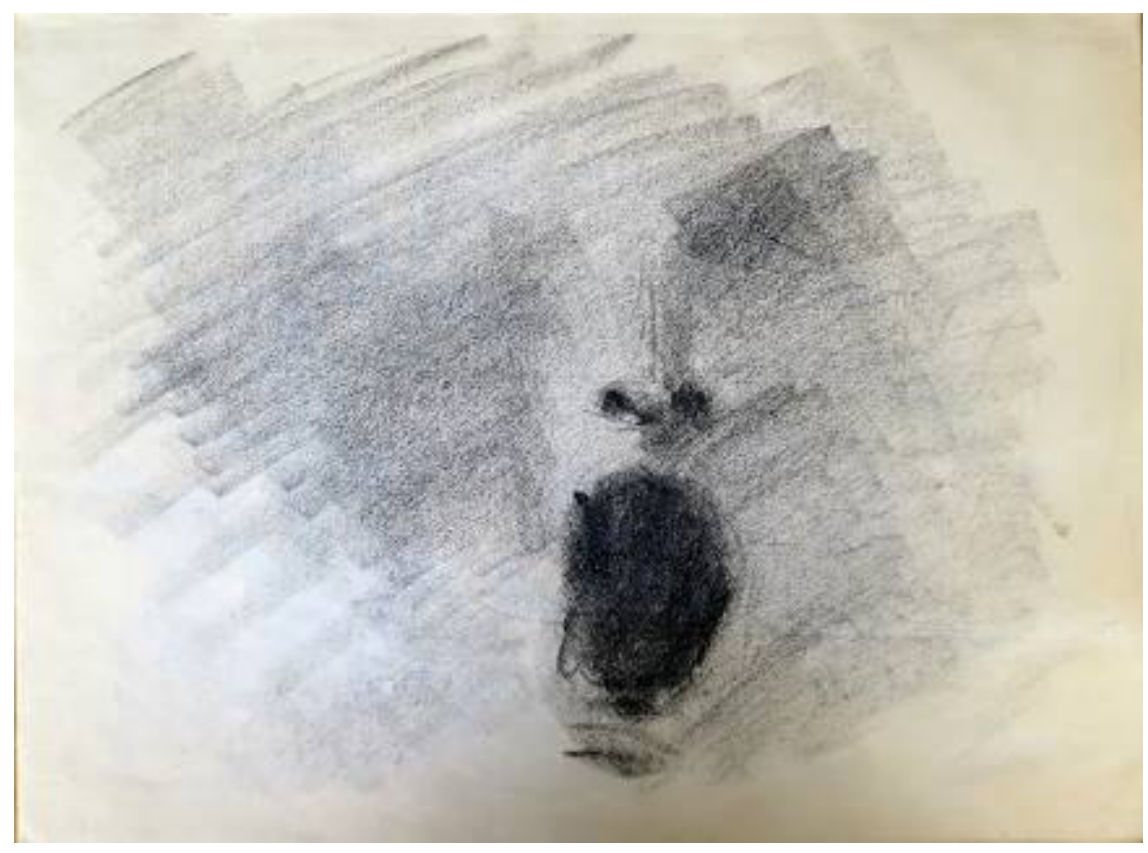


No: 2.33

Título: Sin Título

Autoría: Manolo Safont

Datación: Inicios década 1970

Técnica: Dibujo sobre papel

Descripción: Dibujo abstracto realizado a lápiz, con volutas geométricas entre las cuales Safont entrelaza algunas grafías, como: "por" y "fam". Esta obra forma parte de un cuaderno de dibujo que contiene 18 dibujos, que comprende desde la obra catalogada $n^{0} 2.32$ hasta la obra catalogada 2.49. Mantiene relación con otros dibujos del mismo cuaderno, las obras catalogadas $n^{0} 2.34 \mathrm{y}$ $\mathrm{n}^{\circ} 2.37$. Paleta cromática: blancos y negros.

\section{Bibliografía:}

- http://manolosafont.blogspot.com.es

\section{Imagen:}

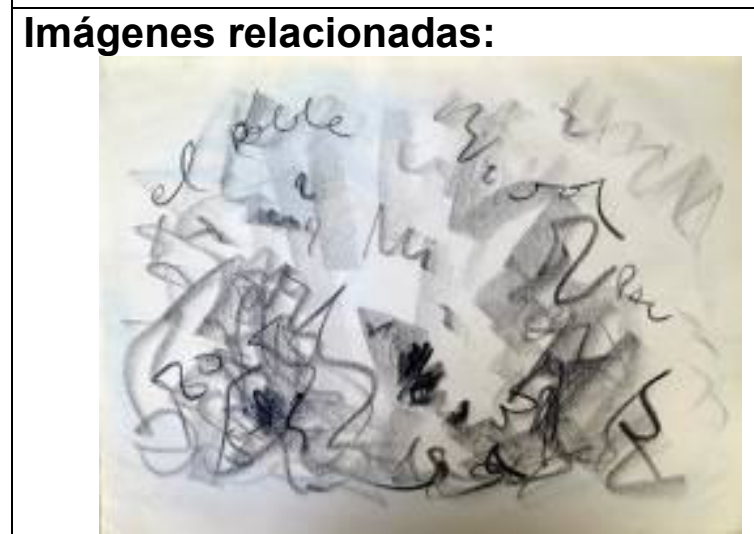

Obra cat. $n^{0} 2.34$

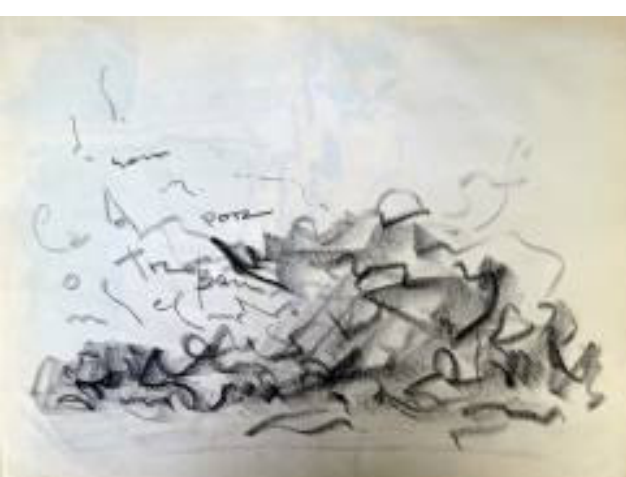

Obra cat. $n^{0} 2.37$ 
No: 2.34

Título: Sin Título

Autoría: Manolo Safont

Datación: Inicios década 1970

Técnica: Dibujo sobre papel

Descripción: Dibujo abstracto realizado a lápiz, con volutas geométricas entre las cuales Safont entrelaza algunas grafías, con la frase: "el poble vol pau". Esta obra forma parte de un cuaderno de dibujo que contiene 18 dibujos, que comprende desde la obra catalogada $n^{\circ} 2.32$ hasta la obra catalogada 2.49. Mantiene relación con otros dibujos pertenecientes al mismo cuaderno de dibujo, las obras catalogadas $\mathrm{n}^{\circ} 2.33$ y $\mathrm{n}^{\circ} 2.37$. Paleta cromática: blancos y negros.

\section{Bibliografía:}

- http://manolosafont.blogspot.com.es

Imagen:

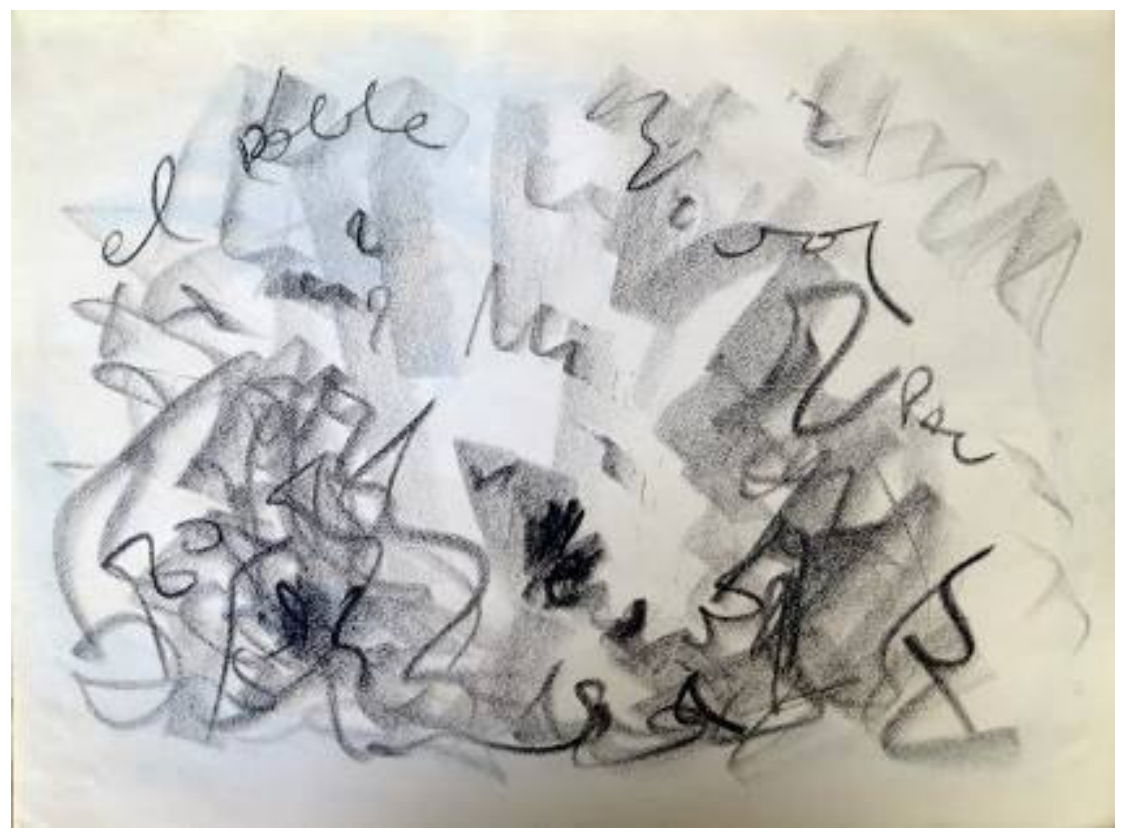

Imágenes relacionadas:

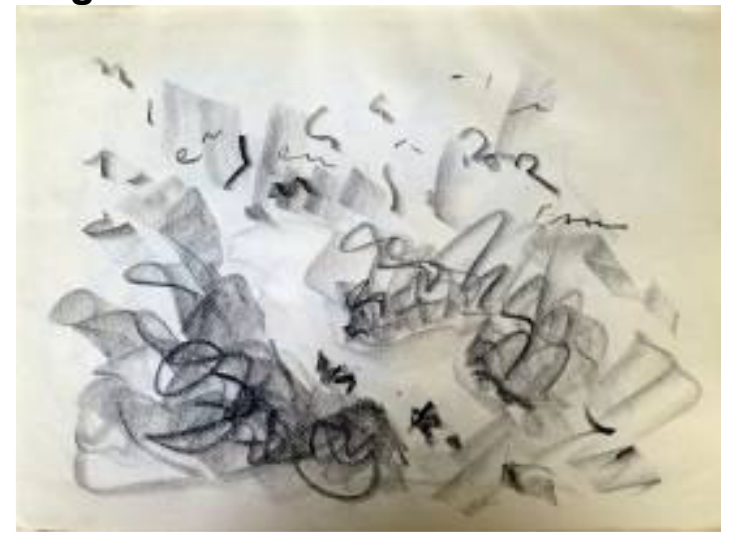

Obra cat. $n^{\circ} 2.33$

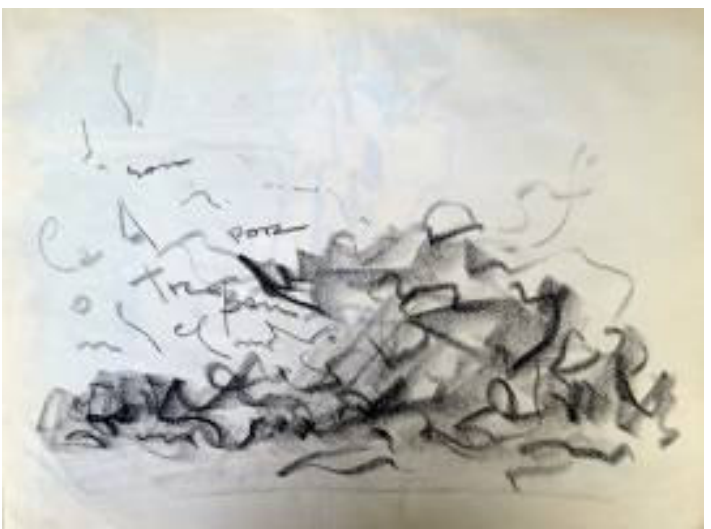

Obra cat. $n^{\circ} 2.37$ 
No: 2.35

Título: Sin Título

Autoría: Manolo Safont

Datación: Inicios década 1970

Técnica: Dibujo sobre papel

Descripción: Dibujo realizado a lápiz, con una representación de unos fuegos artificiales, entre las cuales Safont entrelaza el dibujo de una estrella y algunas grafías, como: "len" y "ciutat". Esta obra forma parte de un cuaderno de dibujo que contiene 18 dibujos, que comprende desde la obra catalogada $n^{\circ} 2.32$ hasta la obra catalogada 2.49. Paleta cromática: blancos y negros.

Bibliografía:

- http://manolosafont.blogspot.com.es

Imagen:

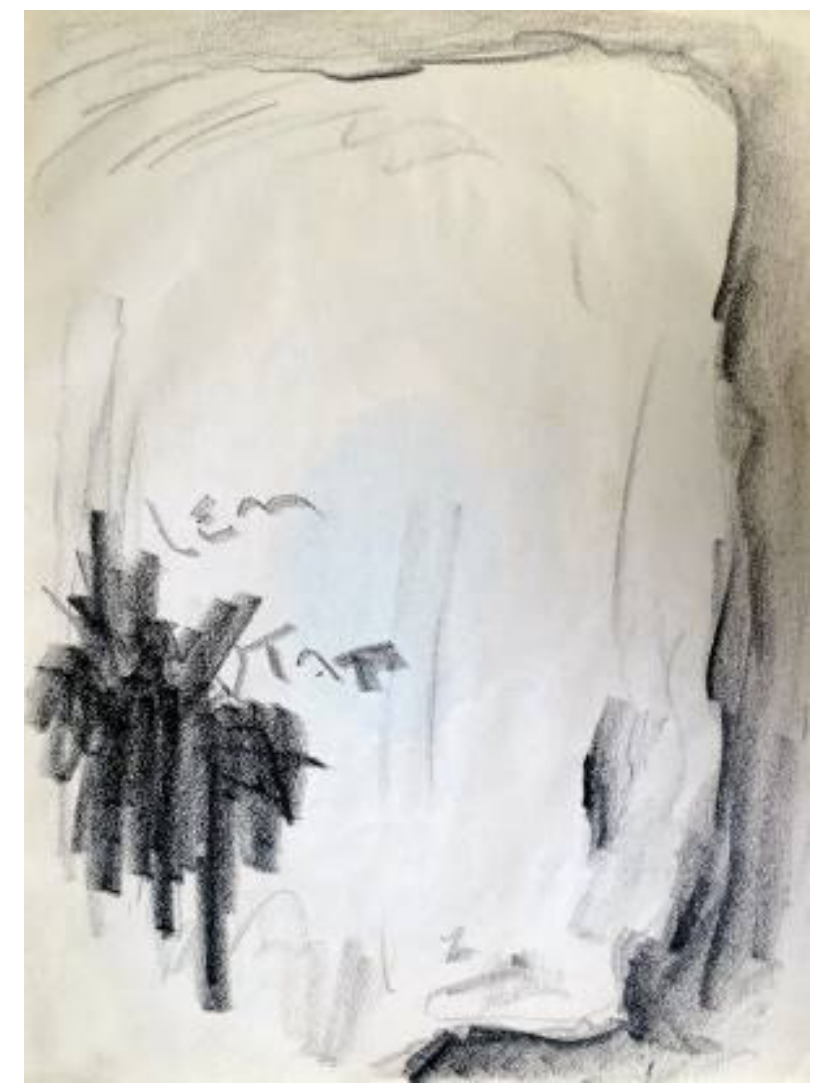


No: 2.36

Título: Sin Título

Autoría: Manolo Safont

Datación: Inicios década 1970

Técnica: Dibujo sobre papel

Descripción: Dibujo abstracto realizado a lápiz, esta obra forma parte de un cuaderno de dibujo que contiene 18 dibujos, que comprende desde la obra catalogada $n^{0} 2.32$ hasta la obra catalogada 2.49. Paleta cromática: blancos y negros

Bibliografía:

- http://manolosafont.blogspot.com.es

Imagen: 
$N^{0}: 2.37$

Título: Sin Título

Autoría: Manolo Safont

Datación: Inicios década 1970

Técnica: Dibujo sobre papel

Descripción: Dibujo abstracto realizado a lápiz, con una representación de volutas geométricas, entre las cuales Safont entrelaza algunas grafías, como: "Ja som" treball", "el", "me" y "por", aunque resulta muy difícil poder deducir una frase completa. Esta obra forma parte de un cuaderno de dibujo que contiene 18 dibujos, que comprende desde la obra catalogada $n^{\circ} 2.32$ hasta la obra catalogada 2.49. Mantiene relación con otros dibujos realizados en el mismo cuaderno, obra catalogada $n^{\circ} 2.33$ y obra catalogada $n^{\circ} 2.34$. Paleta cromática: blancos y negros.

\section{Bibliografía:}

- http://manolosafont.blogspot.com.es

Imagen:

Imágenes relacionadas:

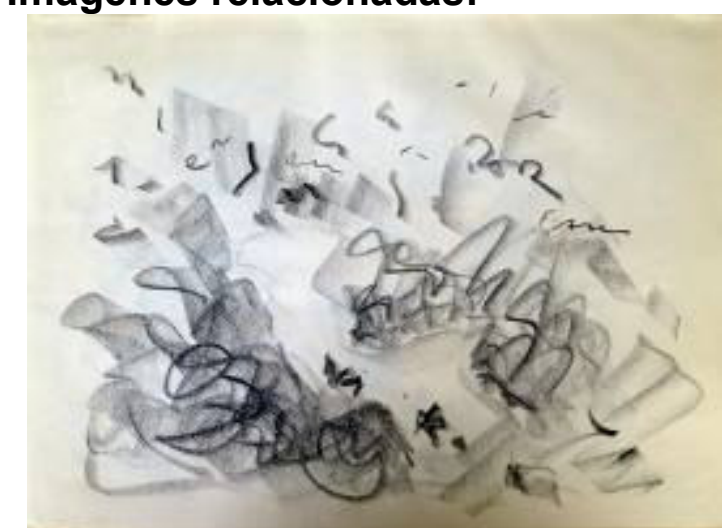

Obra cat. $n^{0} 2.33$

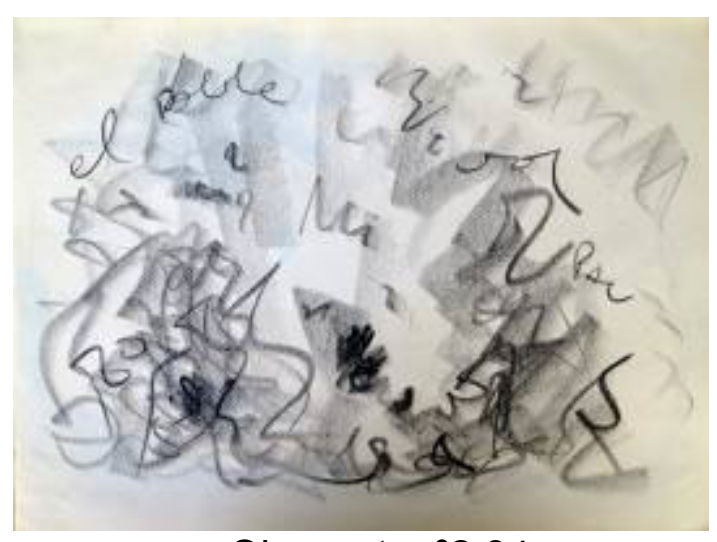

Obra cat. $n^{0} 2.34$ 
$N^{0}: 2.38$

Título: Sin Título

Autoría: Manolo Safont

Datación: Inicios década 1970

Técnica: Dibujo sobre papel

Descripción: Dibujo a lápiz, posible boceto o inspiración para la realización de la obra catalogada $n^{\circ}$. Esta obra forma parte de un cuaderno de dibujo que contiene 18 dibujos, que comprende desde la obra catalogada $n^{\circ} 2.32$ hasta la obra catalogada 2.49. Paleta cromática: blancos y negros.

Bibliografía:

- http://manolosafont.blogspot.com.es

\section{Imagen:}

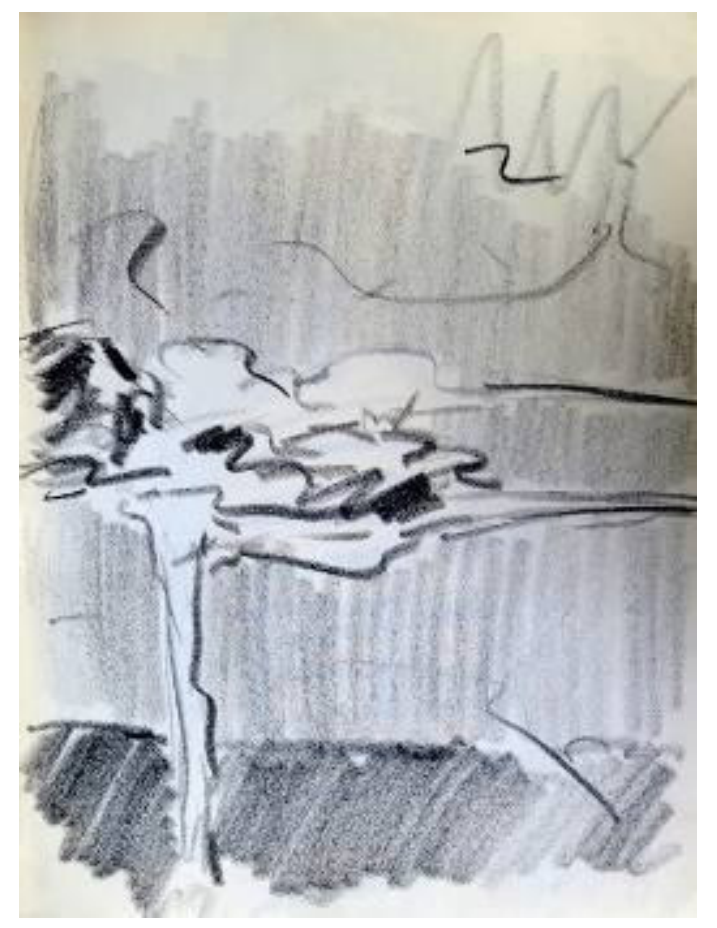

Imágenes relacionadas:

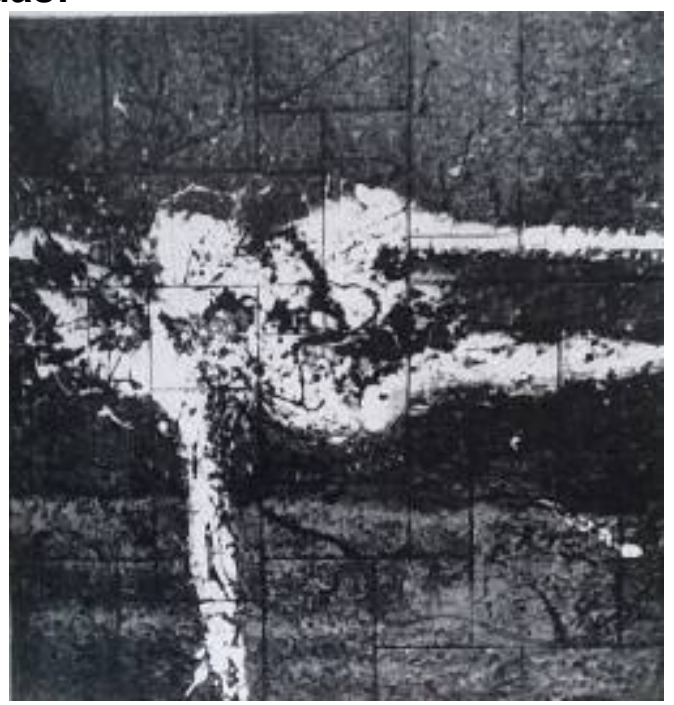

Obra cat. $n^{\circ} 4.20$ 
No: 2.39

Título: Sin Título

Autoría: Manolo Safont

Datación: Inicios década 1970

Técnica: Dibujo sobre papel

Descripción: Dibujo realizado a lápiz, esta obra forma parte de un cuaderno de dibujo que contiene 18 dibujos, que comprende desde la obra catalogada $n^{\circ} 2.32$ hasta la obra catalogada 2.49. Esta obra mantiene relación con otro dibujo del mismo cuaderno, la obra catalogada $\mathrm{n}^{0} 2.40$. Paleta cromática: blancos y negros.

Bibliografía:

- http://manolosafont.blogspot.com.es

Imagen:

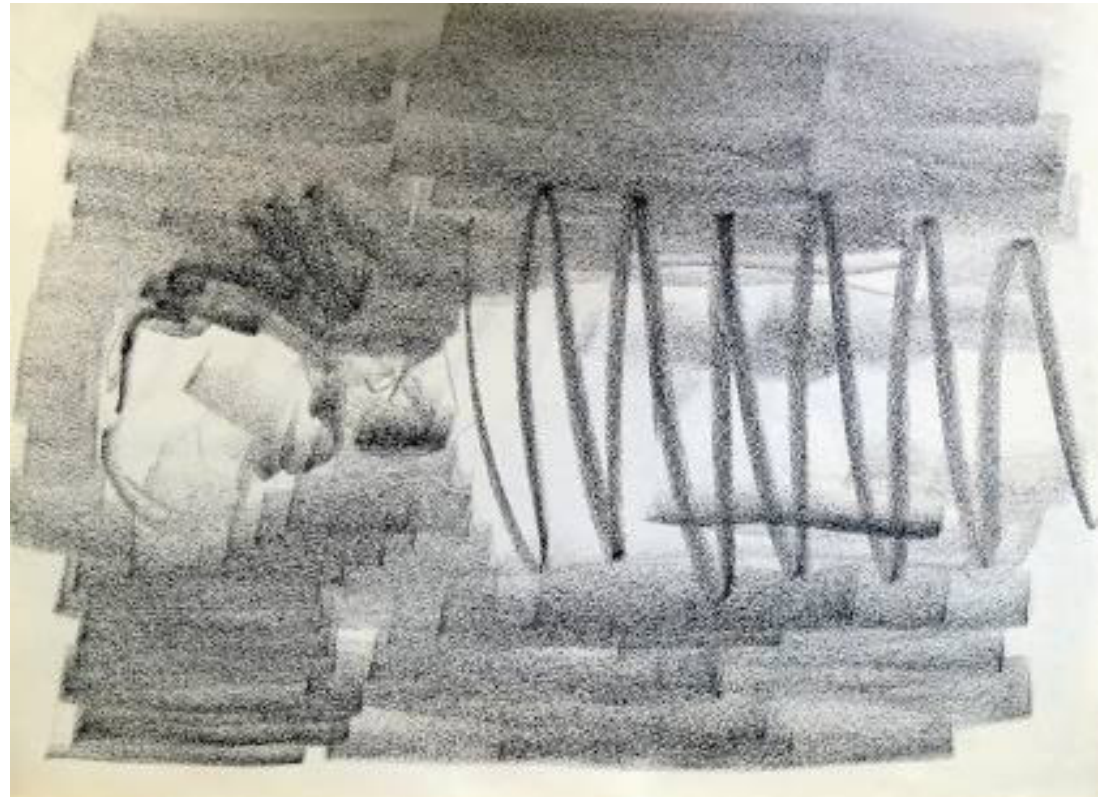

Imágenes relacionadas:

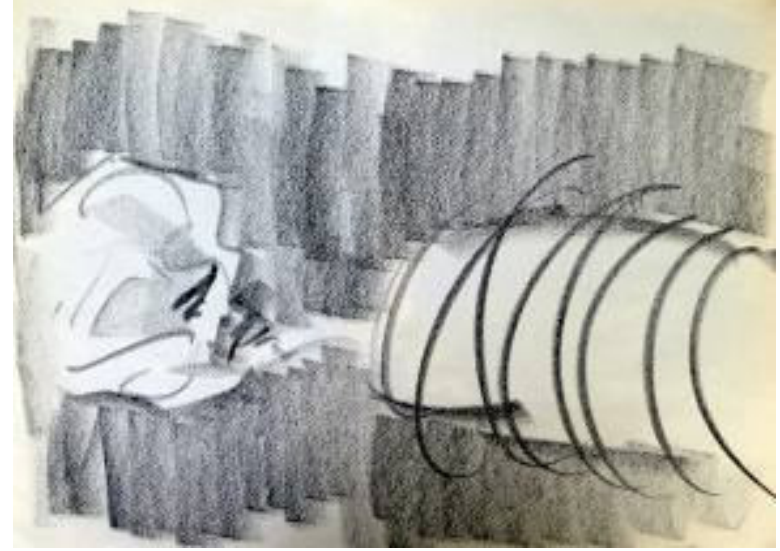

Obra cat. $n^{0} 2.40$ 
No: 2.40

Título: Sin Título

Autoría: Manolo Safont

Datación: Inicios década 1970

Técnica: Dibujo sobre papel

Descripción: Dibujo realizado a lápiz, esta obra forma parte de un cuaderno de dibujo que contiene 18 dibujos, que comprende desde la obra catalogada $n^{\circ} 2.32$ hasta la obra catalogada 2.49. Esta obra mantiene relación con otro dibujo del mismo cuaderno, la obra catalogada $\mathrm{n}^{0} 2.39$. Paleta cromática: blancos y negros.

Bibliografía:

- http://manolosafont.blogspot.com.es

Imagen:

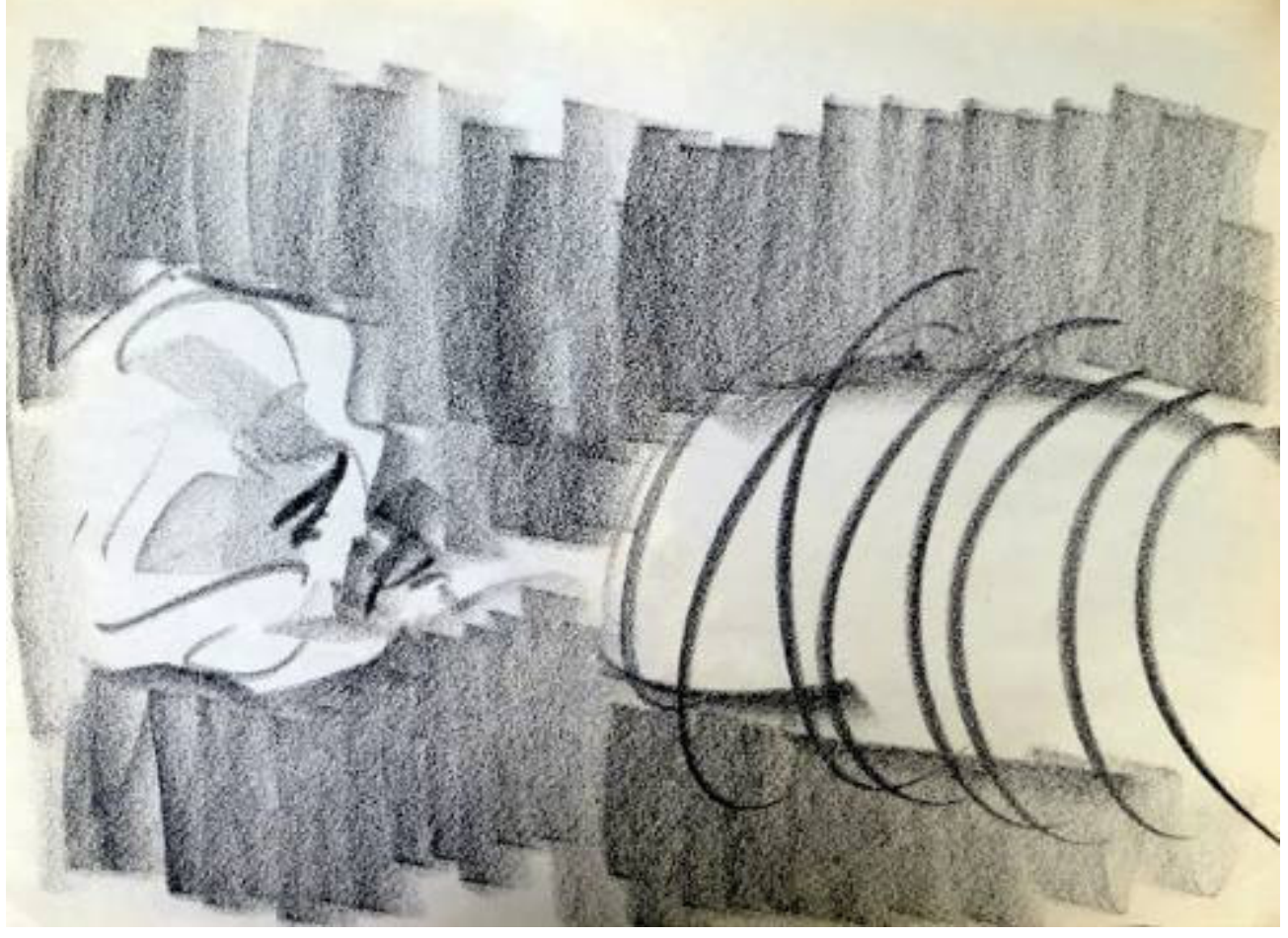

Imágenes relacionadas:

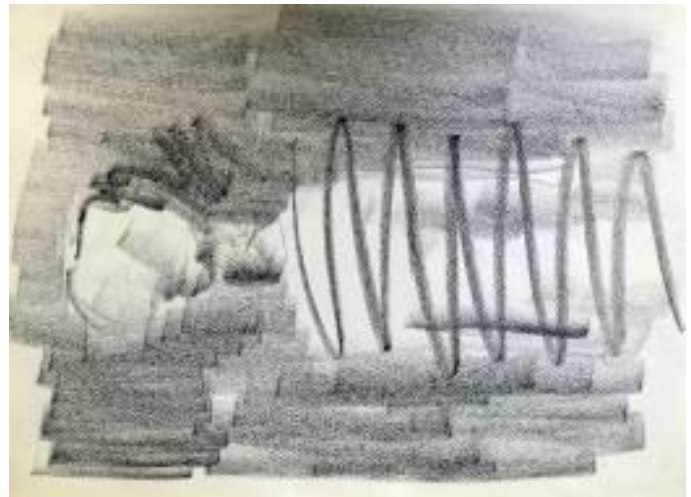

Obra cat. $n^{0} 2.39$ 
No: 2.41

Título: Sin Título

Autoría: Manolo Safont

Datación: Inicios década 1970

Técnica: Dibujo sobre papel

Descripción: Dibujo realizado a lápiz, esta obra forma parte de un cuaderno de dibujo que contiene 18 dibujos, que comprende desde la obra catalogada $\mathrm{n}^{\circ} 2.32$ hasta la obra catalogada 2.49. Paleta cromática: blancos y negros.

Bibliografía:

- http://manolosafont.blogspot.com.es

Imagen:

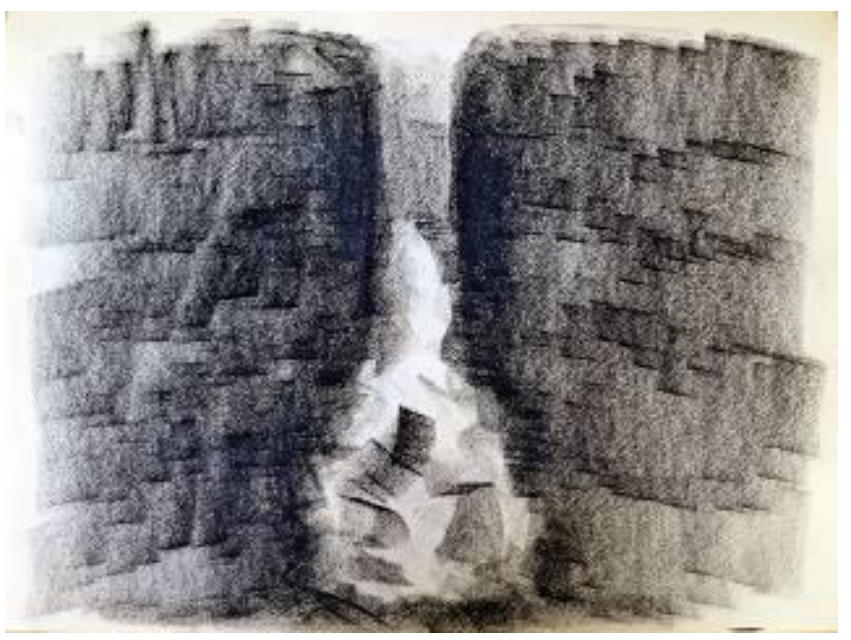


No: 2.42

Título: Sin Título

Autoría: Manolo Safont

Datación: Inicios década 1970

Técnica: Dibujo sobre papel

Descripción: Dibujo realizado a lápiz, esta obra forma parte de un cuaderno de dibujo que contiene 18 dibujos, que comprende desde la obra catalogada $\mathrm{n}^{\circ} 2.32$ hasta la obra catalogada 2.49. Paleta cromática: blancos y negros.

Bibliografía:

- http://manolosafont.blogspot.com.es

Imagen:

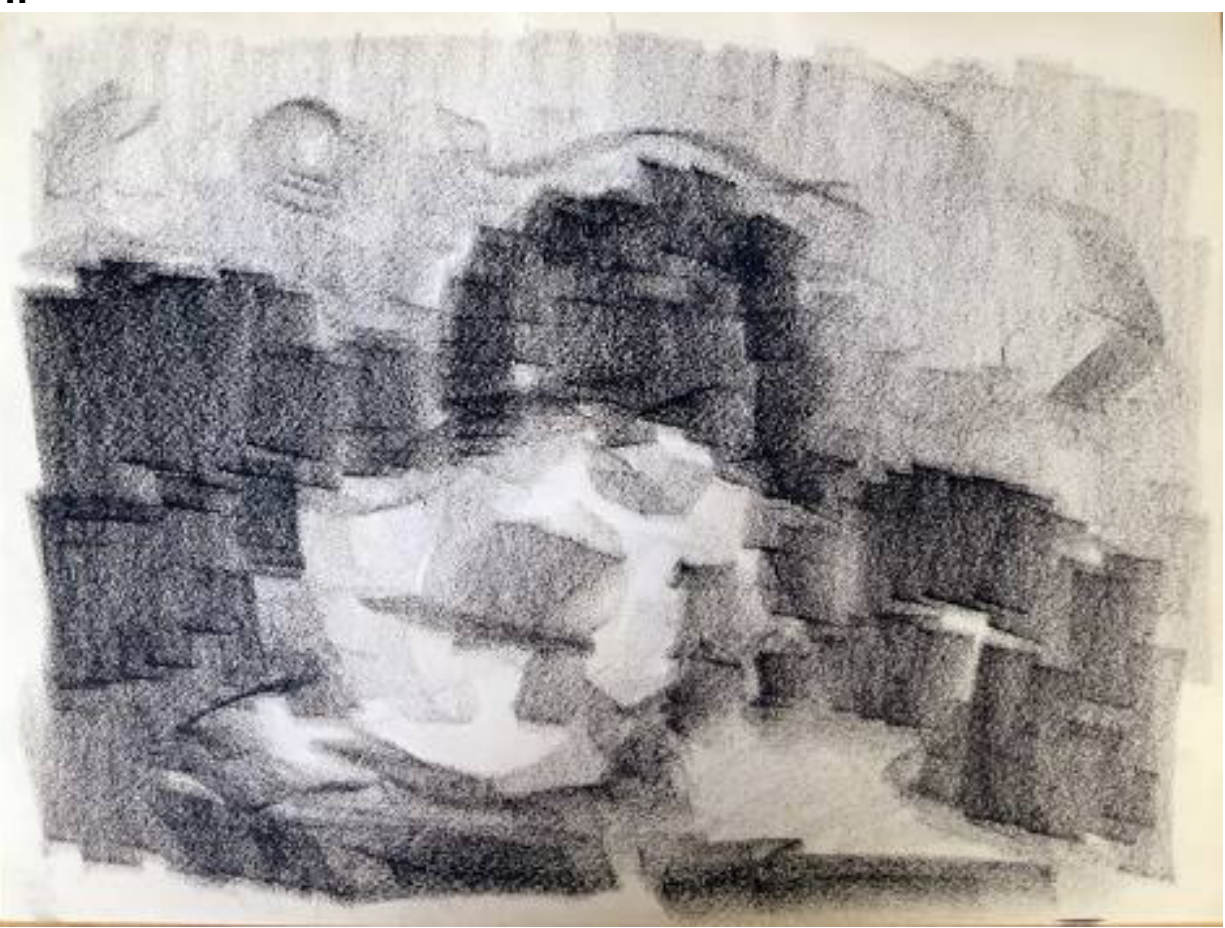


No: 2.43

Título: Sin Título

Autoría: Manolo Safont

Datación: Inicios década 1970

Técnica: Dibujo sobre papel

Descripción: Dibujo realizado a lápiz, esta obra forma parte de un cuaderno de dibujo que contiene 18 dibujos, que comprende desde la obra catalogada $\mathrm{n}^{\circ} 2.32$ hasta la obra catalogada 2.49. Paleta cromática: blancos y negros.

Bibliografía:

- http://manolosafont.blogspot.com.es

Imagen: 
$\mathbf{N}^{\circ}: 2.44$

Título: Sin Título

Autoría: Manolo Safont

Datación: Inicios década 1970

Técnica: Dibujo sobre papel

Descripción: Dibujo realizado a lápiz, representa la forma de una coma o apóstrofo invertido, como si estuviera reflejado en un espejo. Este símbolo es utilizado en otras obras de Safont, como la obra catalogada $n^{\circ} 5.105$. En esta ocasión se muestran dos formas, complementarias entre sí, a semejanza del yin yang taoísta, símbolo de la dualidad de todo lo que existe en el universo. Esta obra forma parte de un cuaderno de dibujo que contiene 18 dibujos, que comprende desde la obra catalogada $n^{\circ} 2.32$ hasta la obra catalogada 2.49. Paleta cromática: blancos y negros.

Bibliografía:

- http://manolosafont.blogspot.com.es

Imagen:

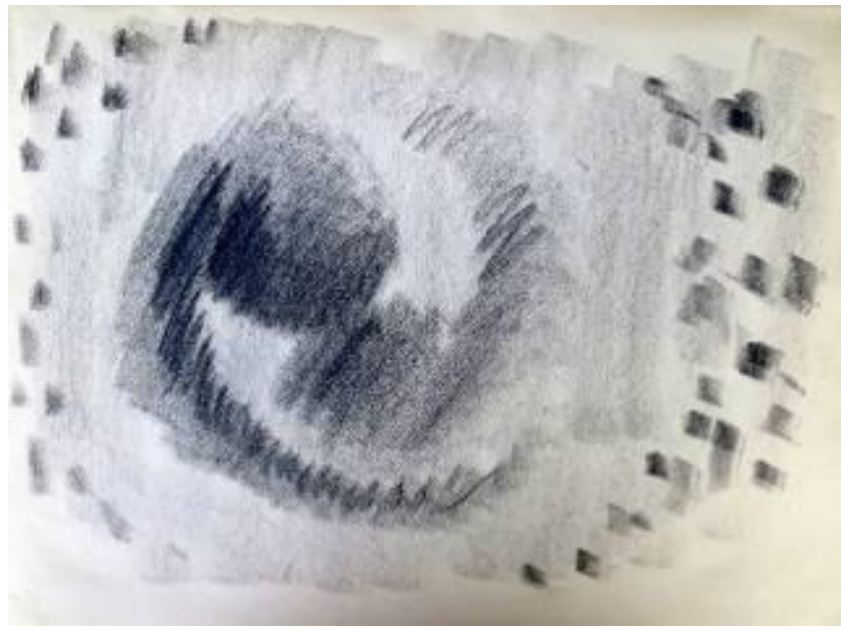

Imágenes relacionadas:

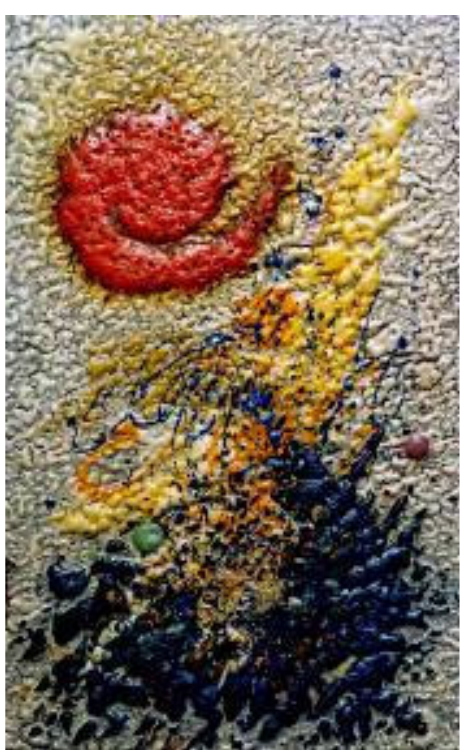

Obra cat. $n^{\circ} 5.105$ 
No: 2.45

Título: Sin Título

Autoría: Manolo Safont

Datación: Inicios década 1970

Técnica: Dibujo sobre papel

Tema: Abstracción

Descripción: Dibujo realizado a lápiz, esta obra forma parte de un cuaderno de dibujo que contiene 18 dibujos, que comprende desde la obra catalogada $\mathrm{n}^{\circ} 2.32$ hasta la obra catalogada 2.49. Paleta cromática: blancos y negros.

Bibliografía:

- http://manolosafont.blogspot.com.es

Imagen: 
No: 2.46

Título: Sin Título

Autoría: Manolo Safont

Datación: Inicios década 1970

Técnica: Dibujo sobre papel

Descripción: Dibujo realizado a lápiz, esta obra forma parte de un cuaderno de dibujo que contiene 18 dibujos, que comprende desde la obra catalogada $\mathrm{n}^{0} 2.32$ hasta la obra catalogada 2.49. Paleta cromática: blancos y negros.

Bibliografía:

- http://manolosafont.blogspot.com.es Imagen:

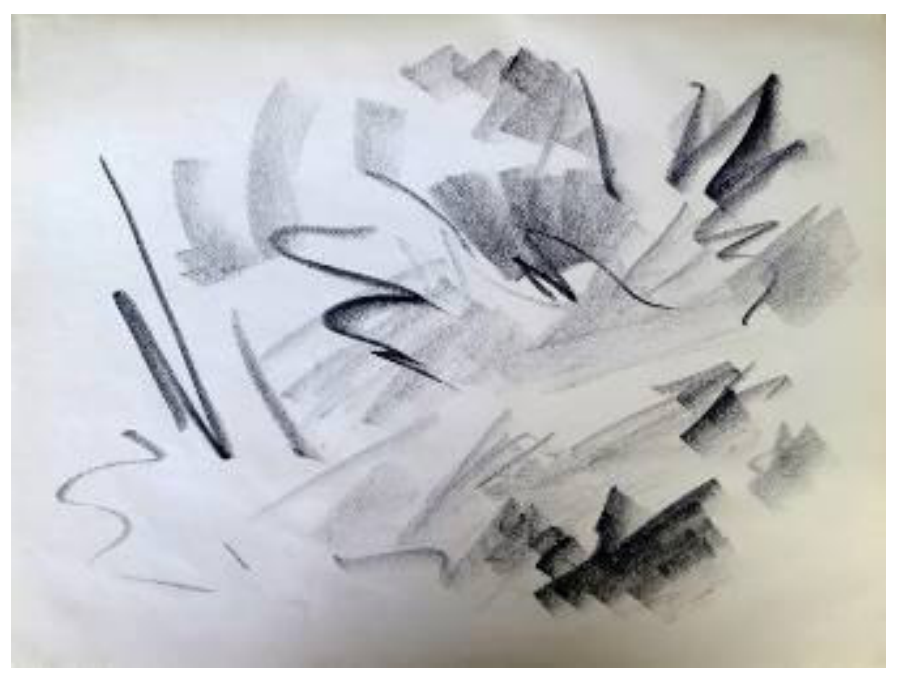


No: 2.47

Título: Sin Título

Autoría: Manolo Safont

Datación: Inicios década 1970

Técnica: Dibujo sobre papel

Descripción: Dibujo realizado a lápiz, esta obra forma parte de un cuaderno de dibujo que contiene 18 dibujos, que comprende desde la obra catalogada $\mathrm{n}^{\circ} 2.32$ hasta la obra catalogada 2.49. Paleta cromática: blancos y negros.

Bibliografía:

- http://manolosafont.blogspot.com.es

Imagen:

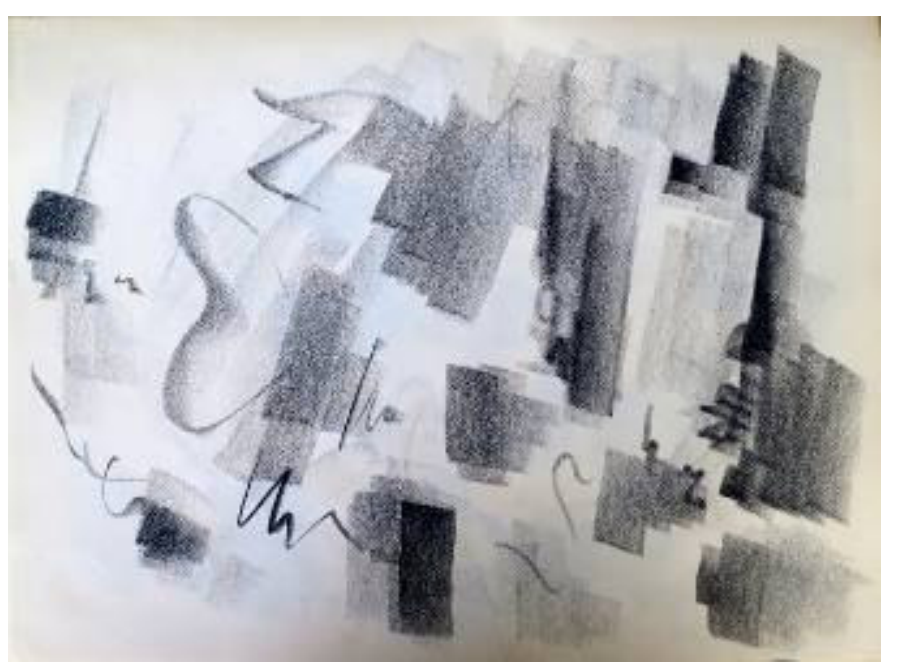


No: 2.48

Título: Sin Título

Autoría: Manolo Safont

Datación: Inicios década 1970

Técnica: Dibujo sobre papel

Descripción: Dibujo realizado a lápiz, esta obra forma parte de un cuaderno de dibujo que contiene 18 dibujos, que comprende desde la obra catalogada $\mathrm{n}^{\circ} 2.32$ hasta la obra catalogada 2.49. Paleta cromática: blancos y negros.

Bibliografía:

- http://manolosafont.blogspot.com.es

Imagen:

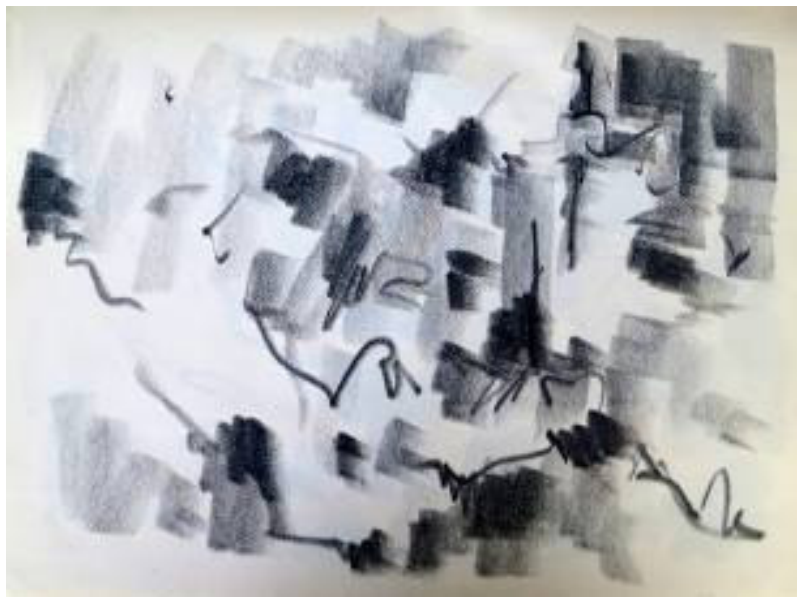


No: 2.49

Título: Sin Título

Autoría: Manolo Safont

Datación: Inicios década 1970

Técnica: Dibujo sobre papel

Descripción: Dibujo realizado a lápiz, esta obra forma parte de un cuaderno de dibujo que contiene 18 dibujos, que comprende desde la obra catalogada $\mathrm{n}^{\circ} 2.32$ hasta la obra catalogada 2.49. Paleta cromática: blancos y negros.

Bibliografía:

- http://manolosafont.blogspot.com.es

Imagen:

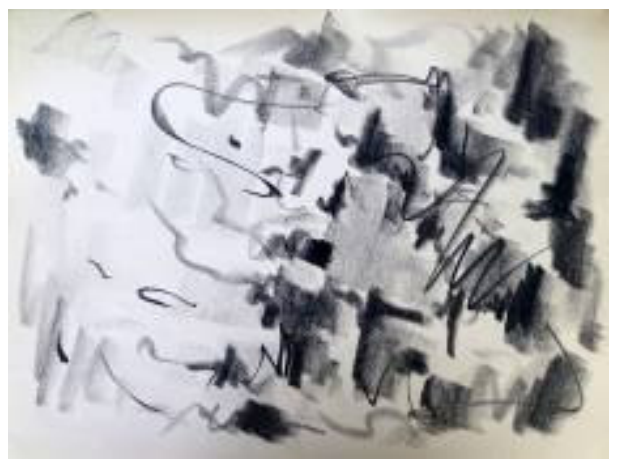


No: 2.50

Título: Sin Título

Autoría: Manolo Safont

Datación: 1971

Inscripciones: "ONDA EN FIESTAS" "1971"

Técnica: Dibujo sobre papel

Localización: MAMS

Descripción: Dibujo realizado para las fiestas patronales de Onda, un óvalo rojo rodeado de pequeños círculos verdes y manchas ovaladas de colores variados. En el margen izquierdo está la representación del escudo de Onda. Paleta cromática: blancos, amarillos, rojos, verdes, azules y negros.

\section{Exposiciones:}

- "Manolo Safont. Un museu, un llegat i un compromís". MAMS. Del 27 de noviembre de 2004 al 8 de enero de 2005. Onda

\section{Imagen:}

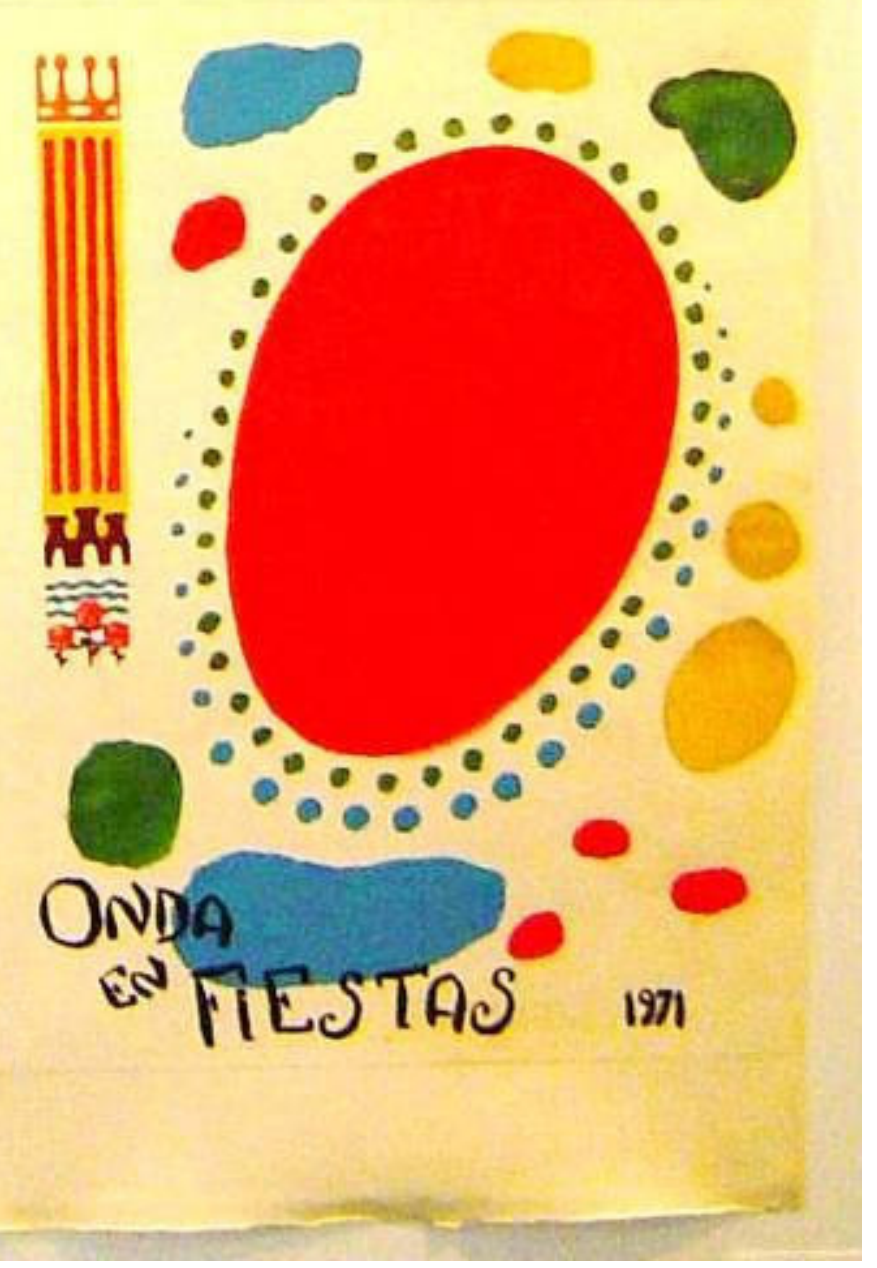


No: 2.51

Título: Farmacia y Laboratorio Dr. Miguel Manuel Arrando

Autoría: Manolo Safont

Datación: 1973-1974

Inscripciones: "Farmacia y Laboratorio Dr, Miguel Manuel Arrando. Avda. Jose Antonio 53. TIf. 601123. Onda" "Para mi buen amigo Miguel. Safont" en margen inferior izquierdo. También se aprecian en lápiz las medidas del diseño.

Dimensiones: $50 \times 61 \mathrm{cms}$

Técnica: Dibujo sobre papel

Localización: Colección privada $\mathrm{n}^{\circ}$ 9. Onda

Descripción: Diseño de Safont para el papel y las bolsas para envolver medicamentos de la Farmacia de Miguel Manuel, de Onda. En este trabajo, se aprecian añadidos de papel para hacer rectificaciones sobre el diseño. Actualmente, esta farmacia sigue utilizando este mismo diseño en el papel y bolsas, aunque ha modificado del diseño original, el nombre de la calle, que pasó de ser Avenida José Antonio a Avinguda País Valencià Paleta cromática: blancos, rojos y negros.

Imagen:

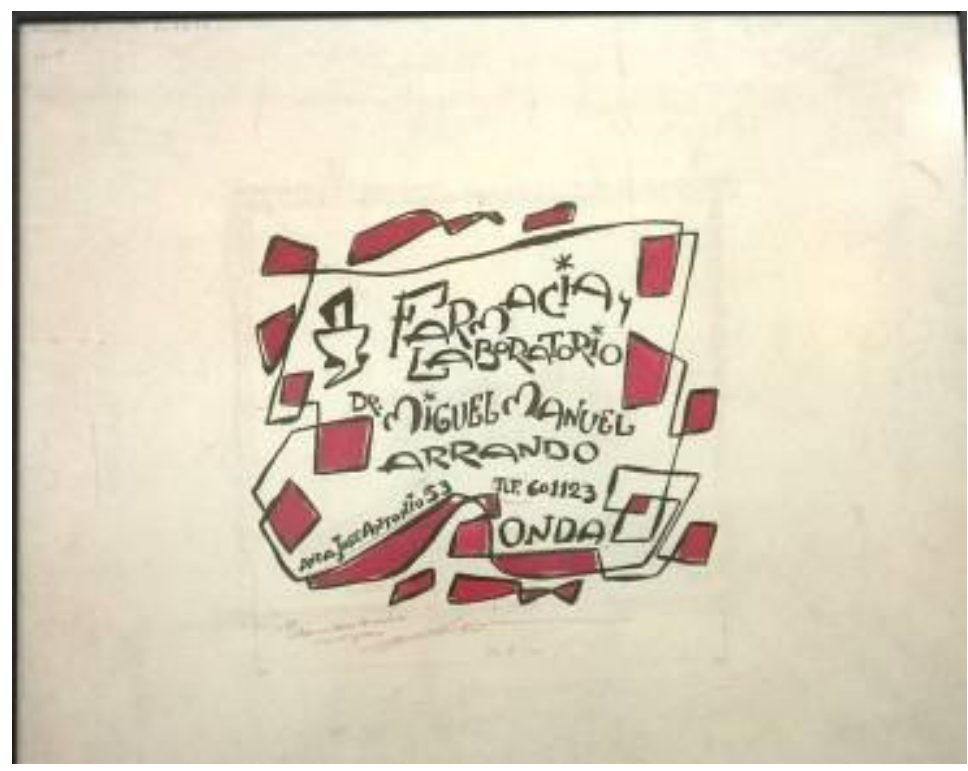

\section{Imágenes relacionadas:}

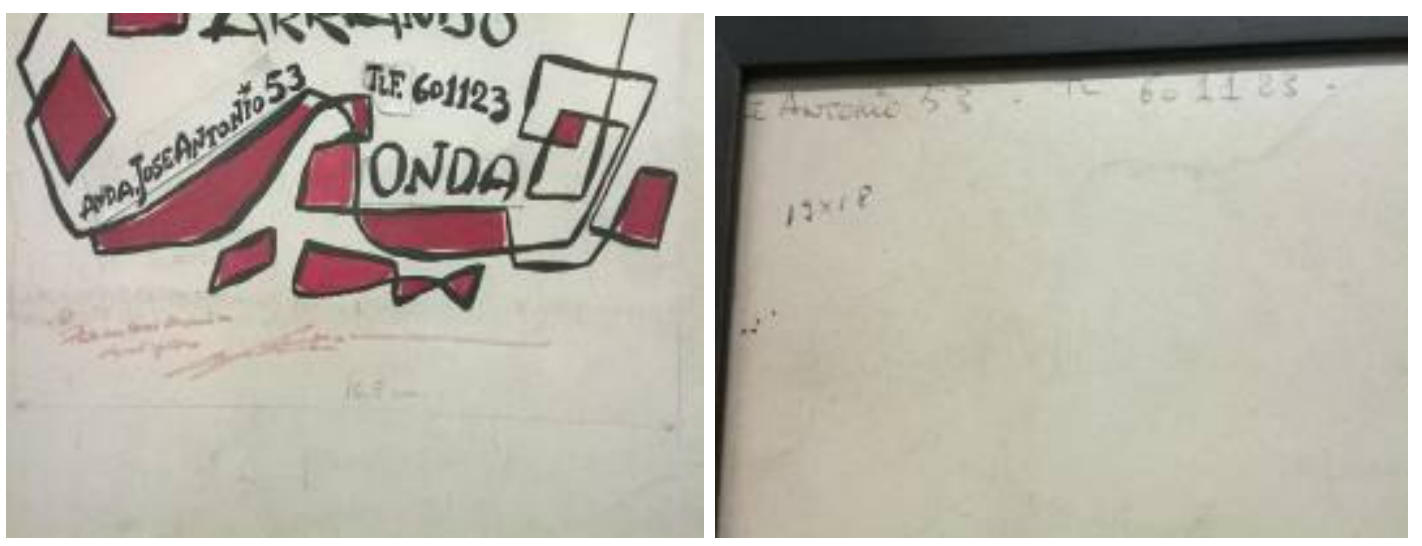

Detalles obra 


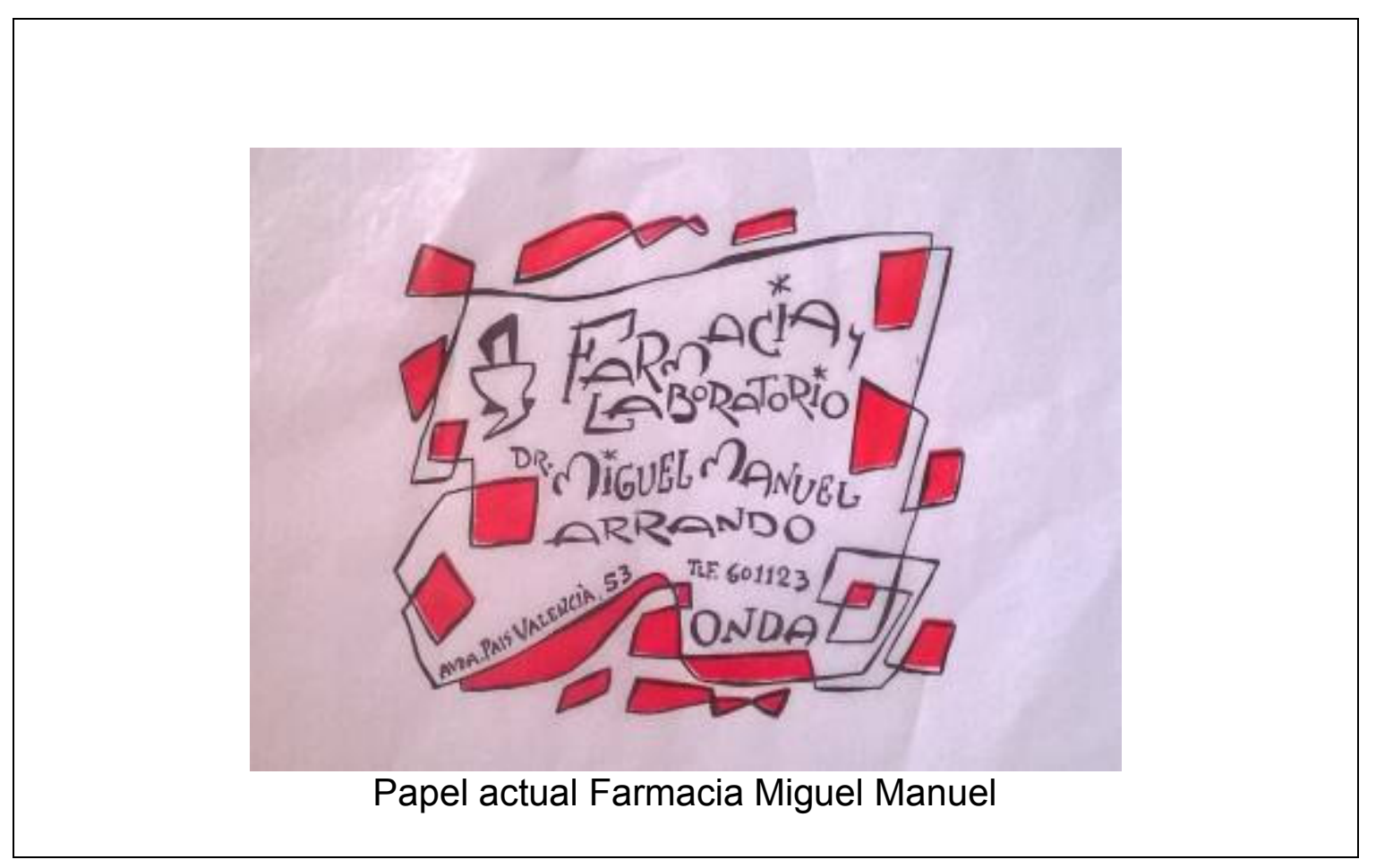


No: 2.52

Título: Sin Título

Autoría: Manolo Safont

Datación: Anterior a 1975

Inscripciones: "CENTRO DE LA JUVENTUD” “LUNES 23 10'30 NOCHE”

"CINE FORUM" "EL ACORAZADO POTIOMKIN"

Técnica: Dibujo sobre papel

Localización: MAMS

Descripción: Cartel anunciador del cine-forum sobre la película "El acorazado Potemkin", película de 1925 dirigida por Serguéi M. Eisenstein, que se realizó en el Centro de la Juventud de Onda. Para la realización de esta obra, Safont se basó en el cartel promocional de la película, obra de Alexandr Ródchenko (URSS, 1891-1956). Datamos esta obra basándonos en que el local que ocupaba el Centro de la Juventud de Onda, perteneciente a Acción Católica, se demolió en 1975. Paleta cromática: blancos y negros.

Exposiciones:

- "Manolo Safont. Un museu, un llegat i un compromís". MAMS. Del 27 de noviembre de 2004 al 8 de enero de 2005. Onda.

\section{Bibliografía:}

- www.filmin.es

- http://ecodiario.eleconomista.es/blogs/la-naranja-metalica

Imagen:

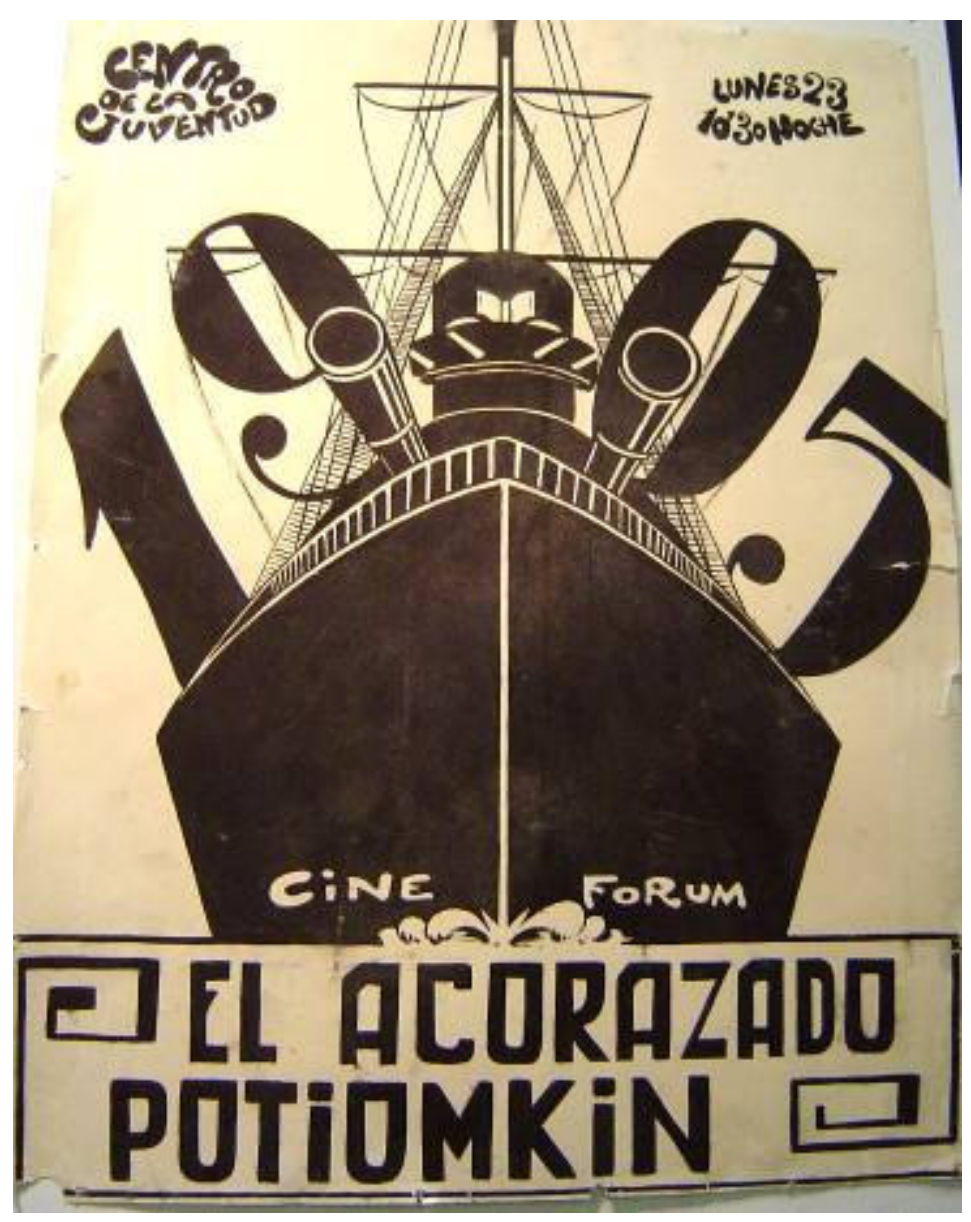




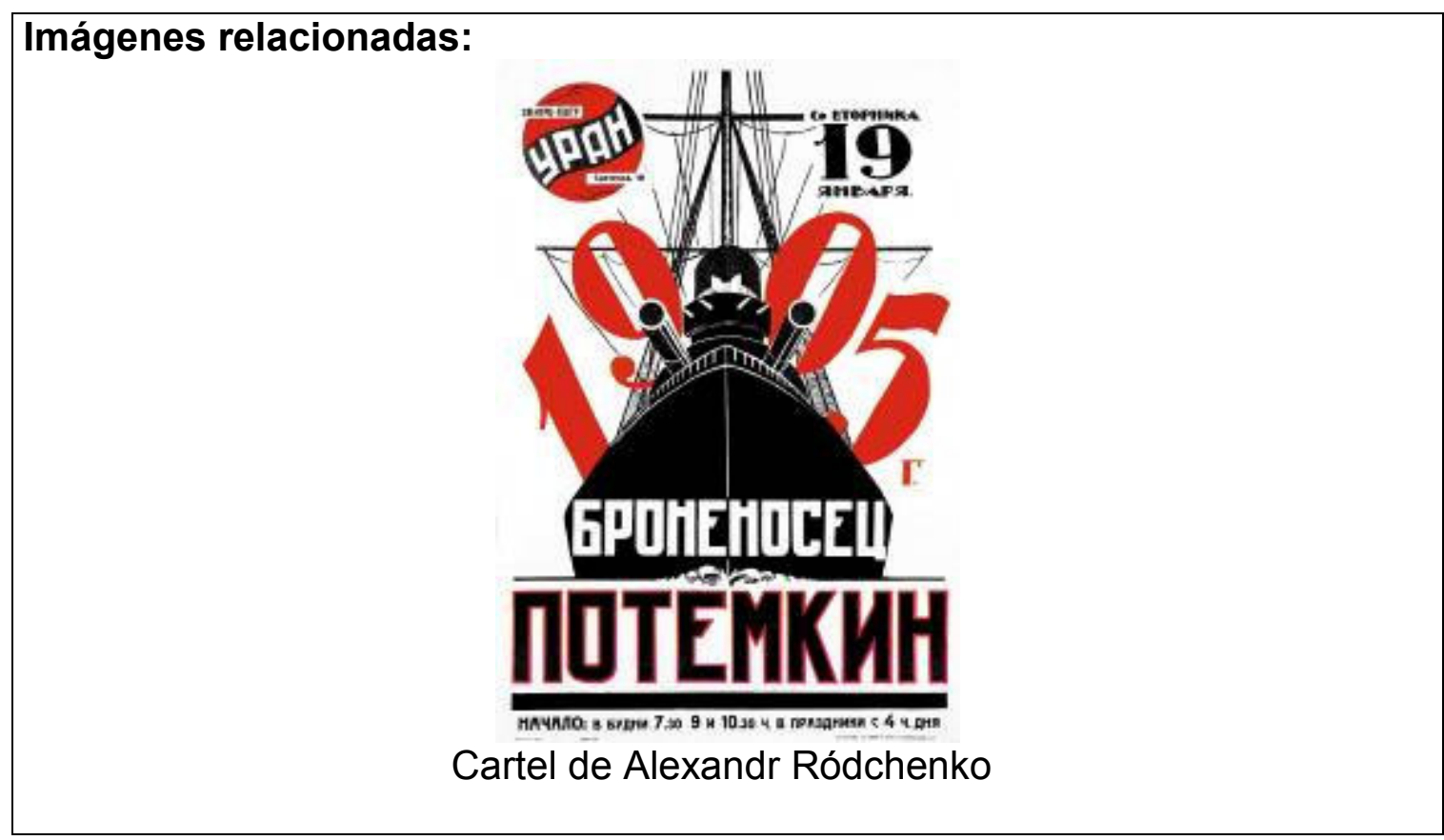


No: 2.53

Título: Sin Título

Autoría: Manolo Safont

Datación: 1976

Técnica: Dibujo sobre papel

Localización: MAMS

Descripción: Boceto para una obra mural de gran formato, con trazado de cuadrícula de 35 piezas realizado en blanco y negro, presentado al concurso organizado por la Fundación General Mediterránea, para la realización de un mural cerámico en una estación de servicio de la autopista del Ebro, obra cat. $n^{0} 7.27$, de la cual sólo hemos podido obtener una fotografía en blanco y negro, por lo que no podemos constatar la paleta cromática de la obra

Exposiciones:

- "Manolo Safont. Un museu, un llegat i un compromís". MAMS. Del 27 de noviembre de 2004 al 8 de enero de 2005 . Onda.

\section{Bibliografía:}

- Concurso de cerámica mural Autopista del Ebro, abril-dic. 1976. Ed. Fundación General Mediteránea, 1976.

\section{Imagen:}

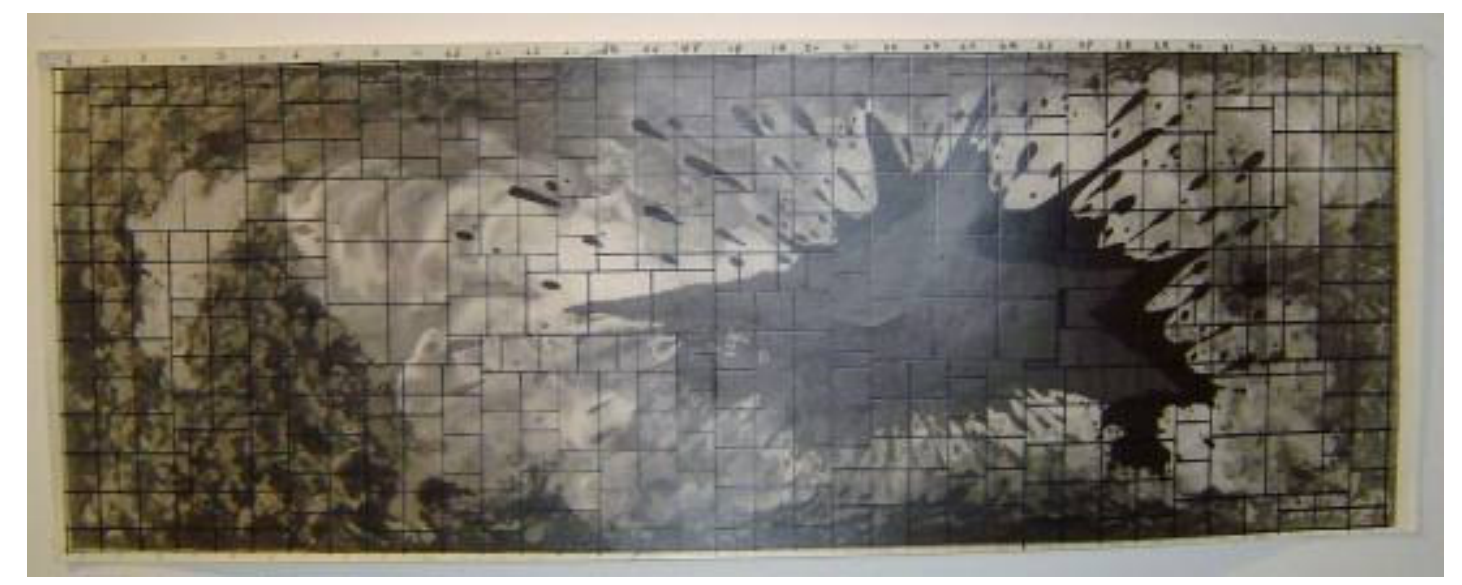

\section{Imágenes relacionadas:}

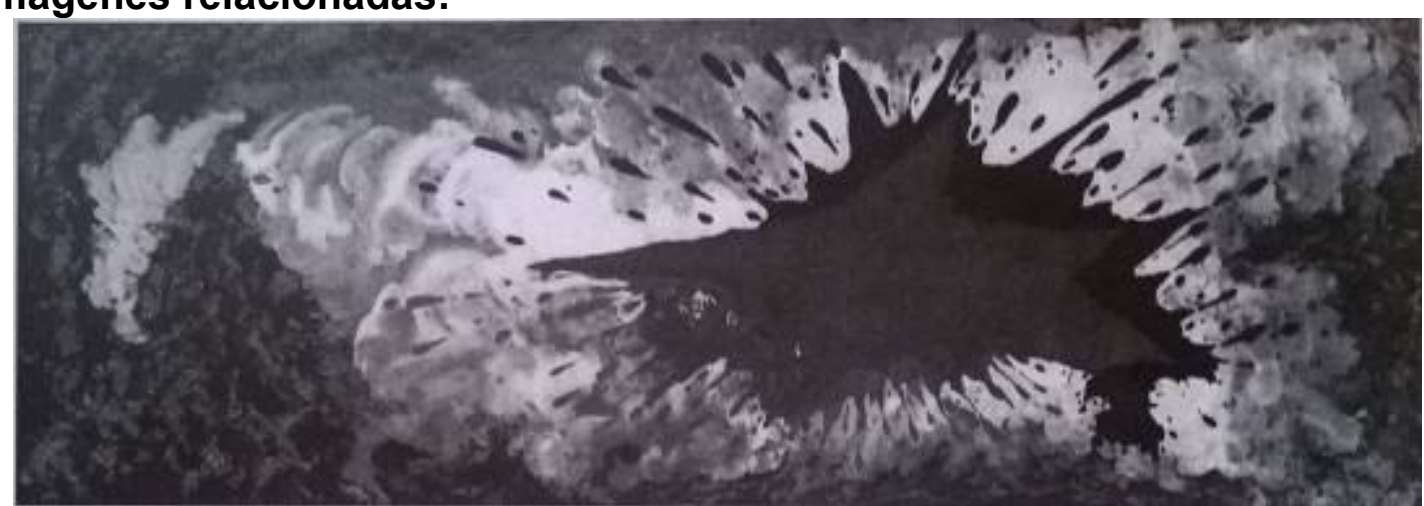

Obra cat. $\mathrm{n}^{0} 7.27$ 


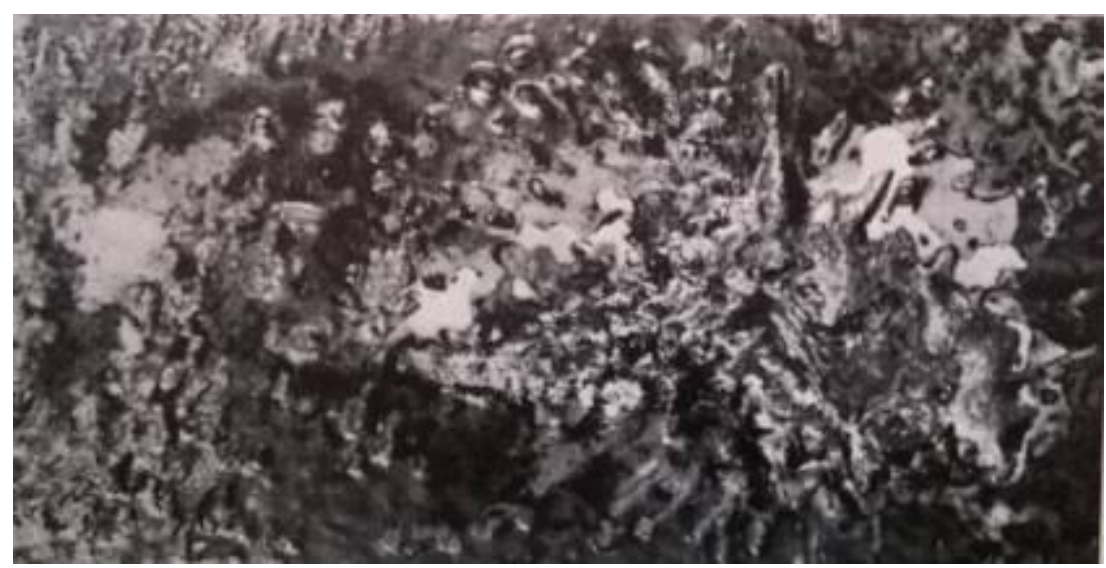

Fragmento obra cat. $\mathrm{n}^{07.27}$ 
No: 2.54

Título: Sin Título

Autoría: Manolo Safont

Datación: 1980

Inscripciones: "1880-1980" "1er Centenari de la BANDA DE MUSICA

D'ONDA"

Técnica: Dibujo sobre papel

Localización: MAMS

Descripción: Cartel conmemorativo del centenario de la banda de música de Onda, perteneciente a la Unión Musical Santa Cecilia. Safont vuelve a recurrir a la composición formada por una gran mancha roja central, aunque en esta obra, al ser para la banda de música, las formas curvas envolventes simulan un pentagrama e incorpora en el diseño unas notas musicales. Paleta cromática: blancos, amarillos, rojos, verdes y negros.

\section{Exposiciones:}

- "Manolo Safont. Un museu, un llegat i un compromís". MAMS. Del 27 de noviembre de 2004 al 8 de enero de 2005 . Onda

\section{Imagen:}

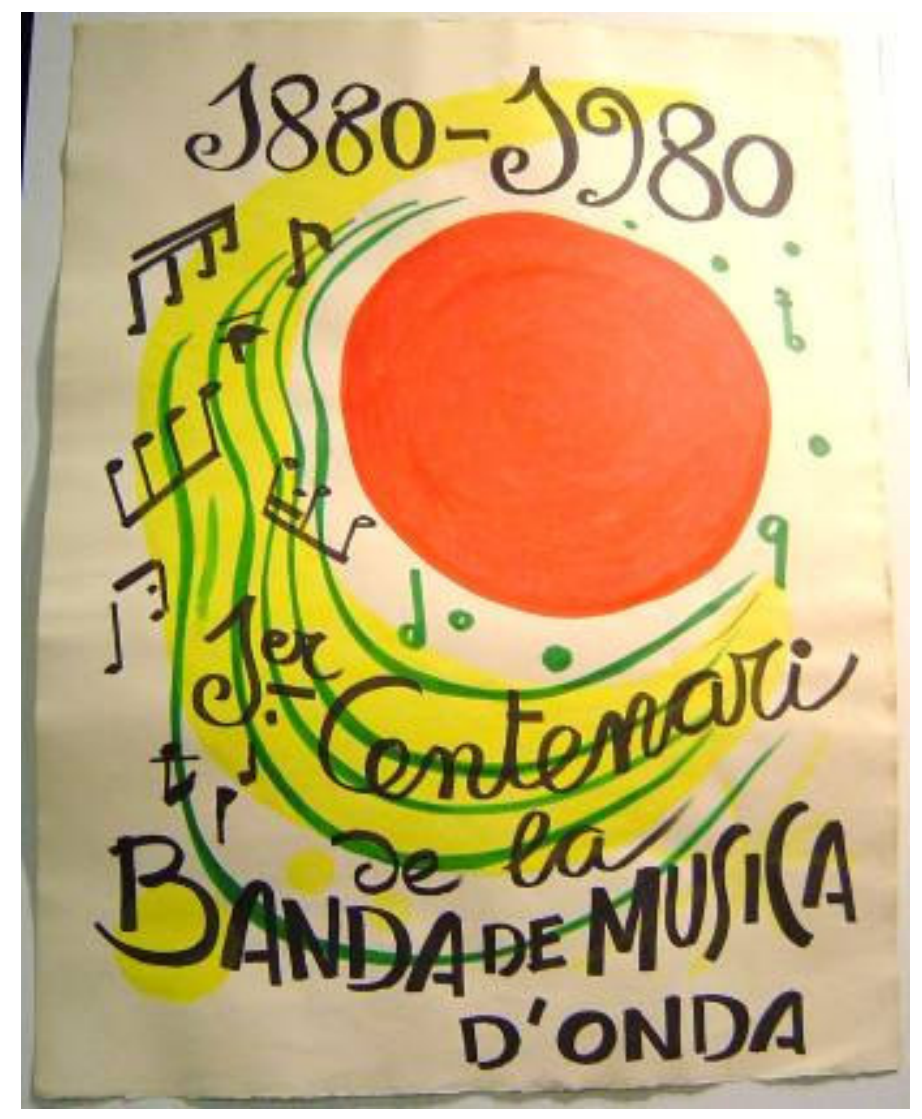


No: 2.55

Título: Recogida de la naranja

Autoría: Manolo Safont

Datación: 1980

Inscripciones: Safont en ángulo inferior derecho

Dimensiones: $31 \times 23 \mathrm{cms}$.

Técnica: Dibujo sobre papel

Localización: Colección privada n¹7 Caja Rural Nuestra Señora de la

Esperanza de Onda, Onda.

Descripción: Dibujo de una escena de recolección de naranjas, en un huerto, con tres mujeres que las depositan en el interior de grandes cestos. Este dibujo pertenece a una serie sobre tareas agrícolas, formada por tres dibujos, junto con las obras catalogadas $n^{\circ} 2.56$ y $n^{\circ} 2.57$, encargadas por la Caja Rural de Onda en 1980, para decorar los sobres de la entidad bancaria. Paleta cromática: blancos y negros.

Bibliografía:

- PRADES ALBALAT, Vicente. "El nacimiento de nuestra Caja Rural. Un largo camino (1884-1930)", La Càmara. Butlletí Informatiu de la Caixa Rural d'Onda, n²9, mayo 2015.

Imagen:

Imágenes relacionadas:

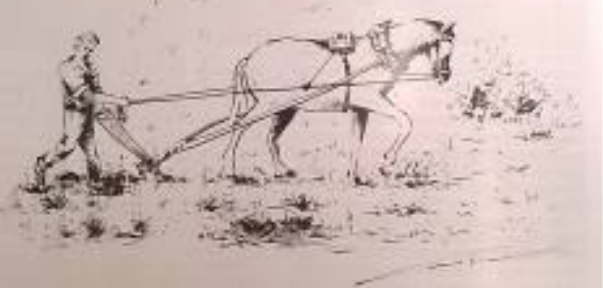

Obra cat. $\mathrm{n}^{0} 2.56$

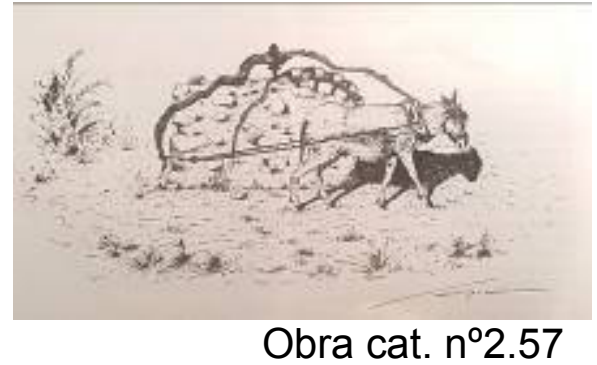

Obra cat. $n^{0} 2.57$ 
$N^{0}: 2.56$

Título: Arando con caballería

Autoría: Manolo Safont

Datación: 1980

Inscripciones: Safont en ángulo inferior derecho

Dimensiones: $23 \times 31 \mathrm{cms}$.

Técnica: Dibujo sobre papel

Localización: Colección privada n¹7 Caja Rural Nuestra Señora de la

Esperanza de Onda, Onda.

Descripción: Dibujo de una escena que representa a un hombre arando con un caballo. Este dibujo pertenece a la serie sobre tareas agrícolas, formada por tres dibujos, junto con las obras catalogadas $n^{\circ} 2.55$ y $n^{\circ} 2.57$, encargadas por la Caja Rural de Onda en 1980, para decorar los sobres de la entidad bancaria. La obra presenta un inadecuado estado de conservación producido por manchas de humedad. Paleta cromática: blancos y negros.

\section{Bibliografía:}

- PRADES ALBALAT, Vicente. "El nacimiento de nuestra Caja Rural. Un largo camino (1884-1930)", La Càmara. Butlletí Informatiu de la Caixa Rural d'Onda, $\mathrm{n}^{\circ} 29$, mayo 2015.

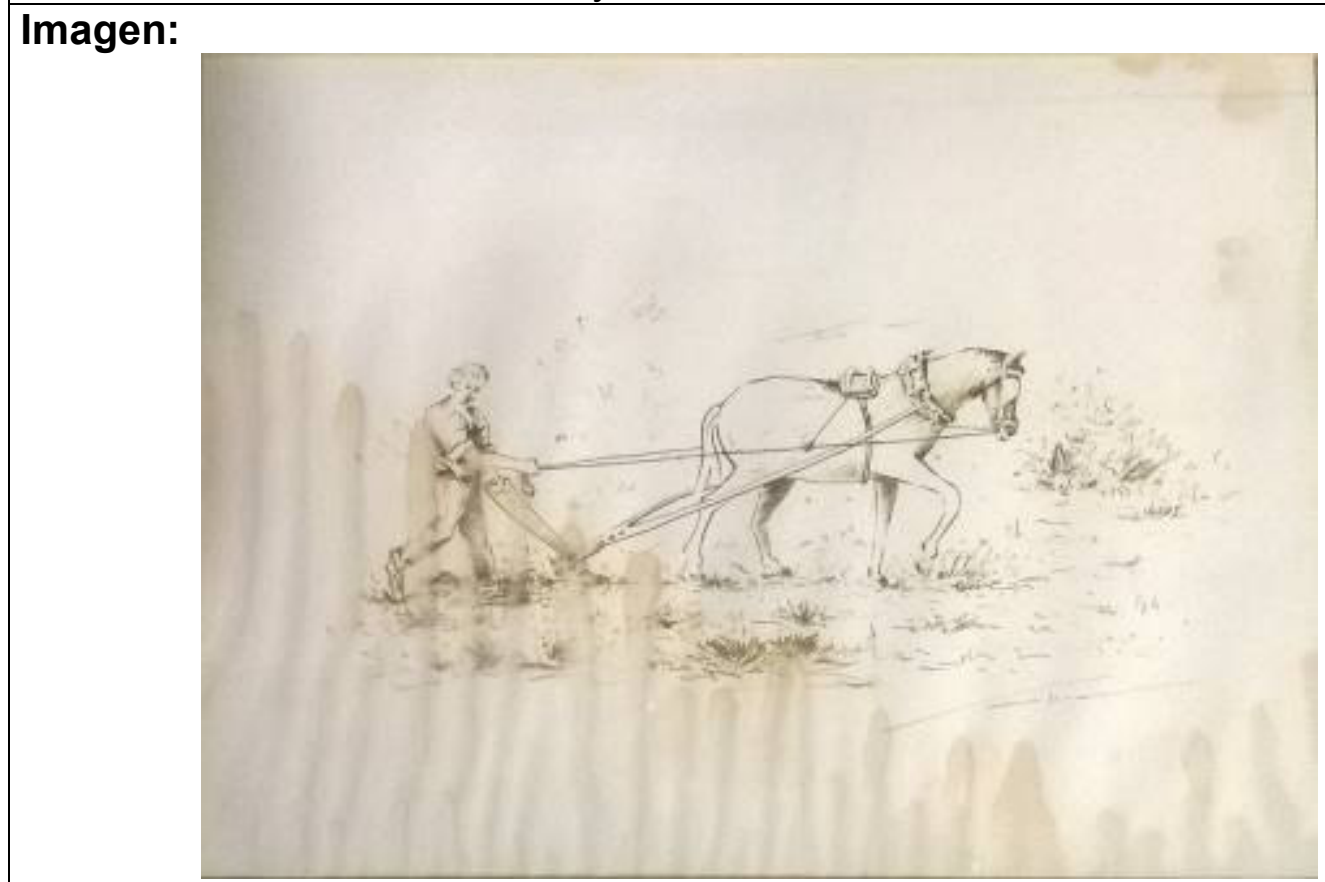

Imágenes relacionadas:
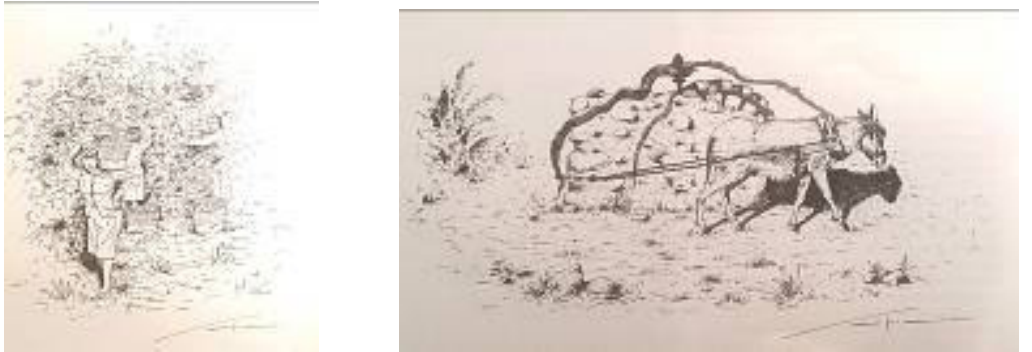

Obra cat. $n^{\circ} 2.55$

Obra cat. $n^{0} 2.57$ 
No: 2.57

Título: Extrayendo agua mediante una noria

Autoría: Manolo Safont

Datación: 1980

Inscripciones: Safont en ángulo inferior derecho

Dimensiones: $23 \times 31 \mathrm{cms}$.

Técnica: Dibujo sobre papel

Localización: Colección privada n¹7 Caja Rural Nuestra Señora de la

Esperanza de Onda, Onda.

Descripción: Dibujo de una escena que representa a un burro girando alrededor de una noria, para extraer agua. Este dibujo pertenece a la serie sobre tareas agrícolas, formada por tres dibujos, junto con las obras catalogadas $n^{\circ} 2.55$ y $n^{\circ} 2.56$, encargadas por la Caja Rural de Onda en 1980, para decorar los sobres de la entidad bancaria. Paleta cromática: blancos y negros.

\section{Bibliografía:}

- PRADES ALBALAT, Vicente. "El nacimiento de nuestra Caja Rural. Un largo camino (1884-1930)", La Càmara. Butlletí Informatiu de la Caixa Rural d'Onda, $\mathrm{n}^{\circ} 29$, mayo 2015.

Imagen:

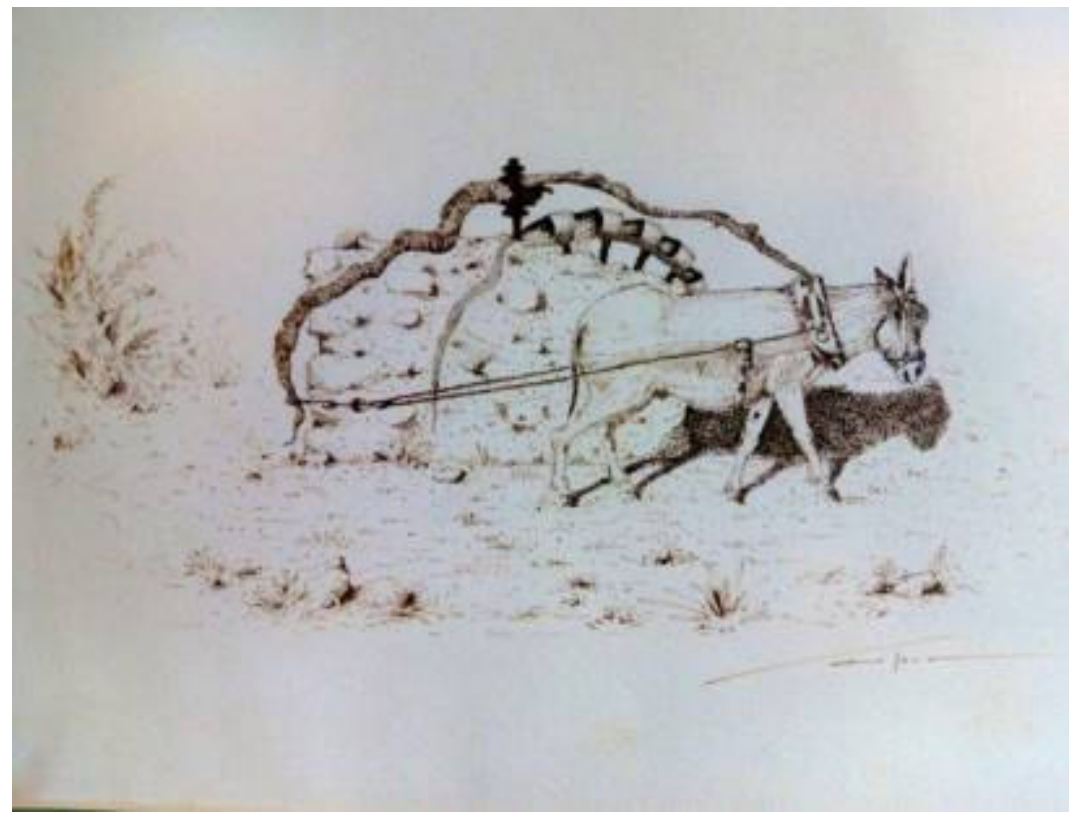

Imágenes relacionadas:

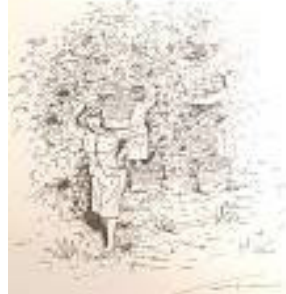

Obra cat. $n^{\circ} 2.55$

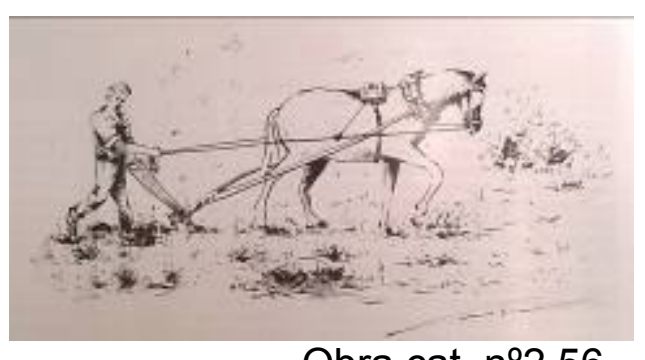

Obra cat. $n^{\circ} 2.56$ 
$\mathbf{N}^{0}: 2.58$

Título: Primera Sede Social Caja Rural Nuestra Sra. de la Esperanza Onda

Autoría: Manolo Safont

Datación: 1980

Inscripciones: "Plaça san Josep Casa Marita" en margen superior derecho y

Safont en ángulo inferior derecho.

Dimensiones: $31 \times 23 \mathrm{cms}$.

Técnica: Dibujo sobre papel

Localización: Colección privada n¹7 Caja Rural Nuestra Señora de la

Esperanza de Onda, Onda.

Descripción: Dibujo arquitectónico que representa la fachada del edificio situado en la Plaza de San José, n¹1 (actualmente demolido) en el cual tuvo su primera sede la Caja Rural Nuestra Señora de la Esperanza de Onda. El inmueble pertenecía a María Lourdes Canelles "Marita". Este dibujo pertenece a la serie sobre las diferentes sedes de la entidad financiera, formado por cinco dibujos, junto con las obras catalogadas $n^{\circ} 2.59, n^{0} 2.60, n^{\circ} 2.61$ y $n^{\circ} 2.62$, encargadas a Safont por la Caja Rural de Onda en 1980. Paleta cromática: blancos y negros.

\section{Bibliografía:}

- "Breve reseña histórica de la Entidad" La Càmara. Butlletí Informatiu de la Caixa Rural d'Onda, abril, 1980

Imagen:

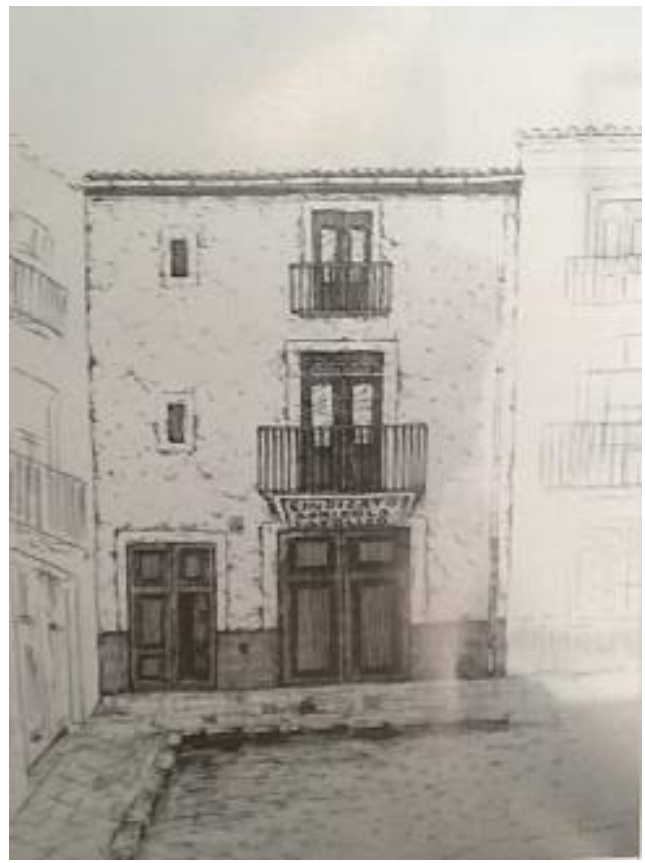

Imágenes relacionadas:

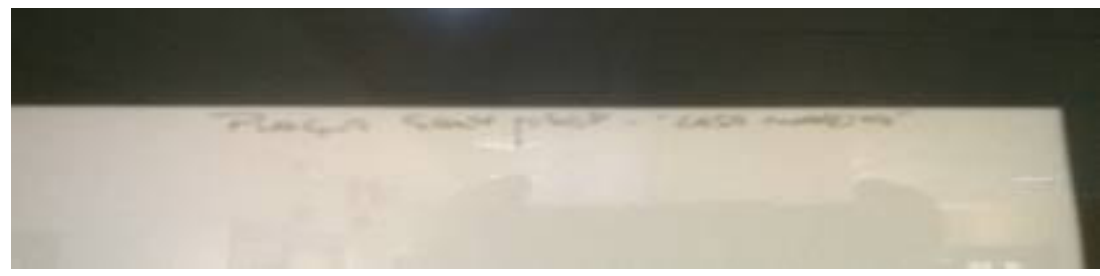

Detalle obra, inscripción margen superior derecho 
No: 2.59

Título: Segunda Sede Social Caja Rural Nuestra Sra. de la Esperanza Onda

Autoría: Manolo Safont

Datación: 1980

Inscripciones: "El Raval - Casa Oscariz" y Safont en ángulo inferior derecho.

Dimensiones: $31 \times 23 \mathrm{cms}$

Técnica: Dibujo sobre papel

Localización: Colección privada n¹7 Caja Rural Nuestra Señora de la

Esperanza de Onda, Onda.

Descripción: Dibujo arquitectónico que representa la fachada del edificio situado en la Plaza de San José, $n^{07}$ en el cual tuvo su segunda sede la Caja Rural Nuestra Señora de la Esperanza de Onda. El inmueble pertenecía a la familia Oscariz. Este dibujo pertenece a la serie sobre las diferentes sedes de la entidad financiera, formado por cinco dibujos, junto con las obras catalogadas $n^{0} 2.58, n^{0} 2.60, n^{0} 2.61$ y $n^{0} 2.62$, encargadas a Safont por la Caja Rural de Onda en 1980. Paleta cromática: blancos y negros.

\section{Bibliografía:}

- "Breve reseña histórica de la Entidad" La Càmara. Butlletí Informatiu de la Caixa Rural d'Onda, abril, 1980

\section{Imagen:}

Imágenes relacionadas:
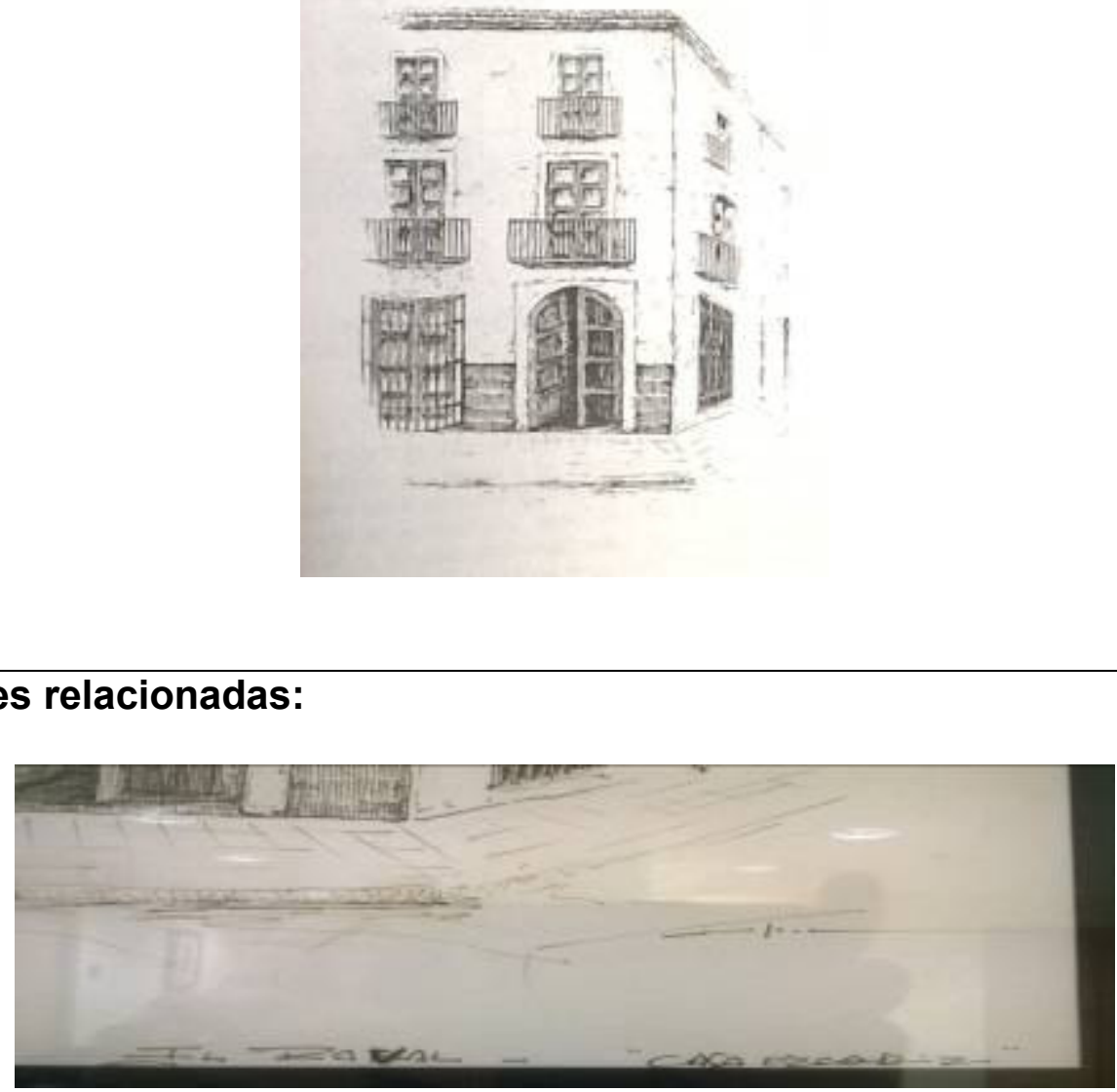

Detalle obra, inscripción margen inferior derecho 
$\mathbf{N}^{\circ}: 2.60$

Título: Tercera Sede Social Caja Rural Nuestra Sra. de la Esperanza Onda

Autoría: Manolo Safont

Datación: 1980

Inscripciones: "Plaça el Plà. Convent les Monjes" en ángulo inferior izquierdo y Safont en ángulo inferior derecho.

Dimensiones: $31 \times 23 \mathrm{cms}$

Técnica: Dibujo sobre papel

Localización: Colección privada n¹7 Caja Rural Nuestra Señora de la

Esperanza de Onda, Onda.

Descripción: Dibujo arquitectónico que representa la fachada del edificio situado en la Plaza de San José, $\mathrm{n}^{0} 7$ en el cual tuvo su tercera sede la Caja Rural Nuestra Señora de la Esperanza de Onda. En este inmueble estuvo ubicado un antiguo convento de las monjas, posteriormente el colegio de la Consolación y actualmente alberga la oficina principal de esta entidad bancaria. Este dibujo pertenece a la serie sobre las diferentes sedes de la entidad financiera, formada por cinco dibujos, junto con las obras catalogadas $n^{\circ} 2.58$, $n^{0} 2.59, n^{0} 2.61$ y $n^{\circ} 2.62$, encargadas a Safont por la Caja Rural de Onda en 1980. Paleta cromática: blancos y negros.

\section{Bibliografía:}

- "Breve reseña histórica de la Entidad" La Càmara. Butlletí Informatiu de la Caixa Rural d'Onda, abril, 1980

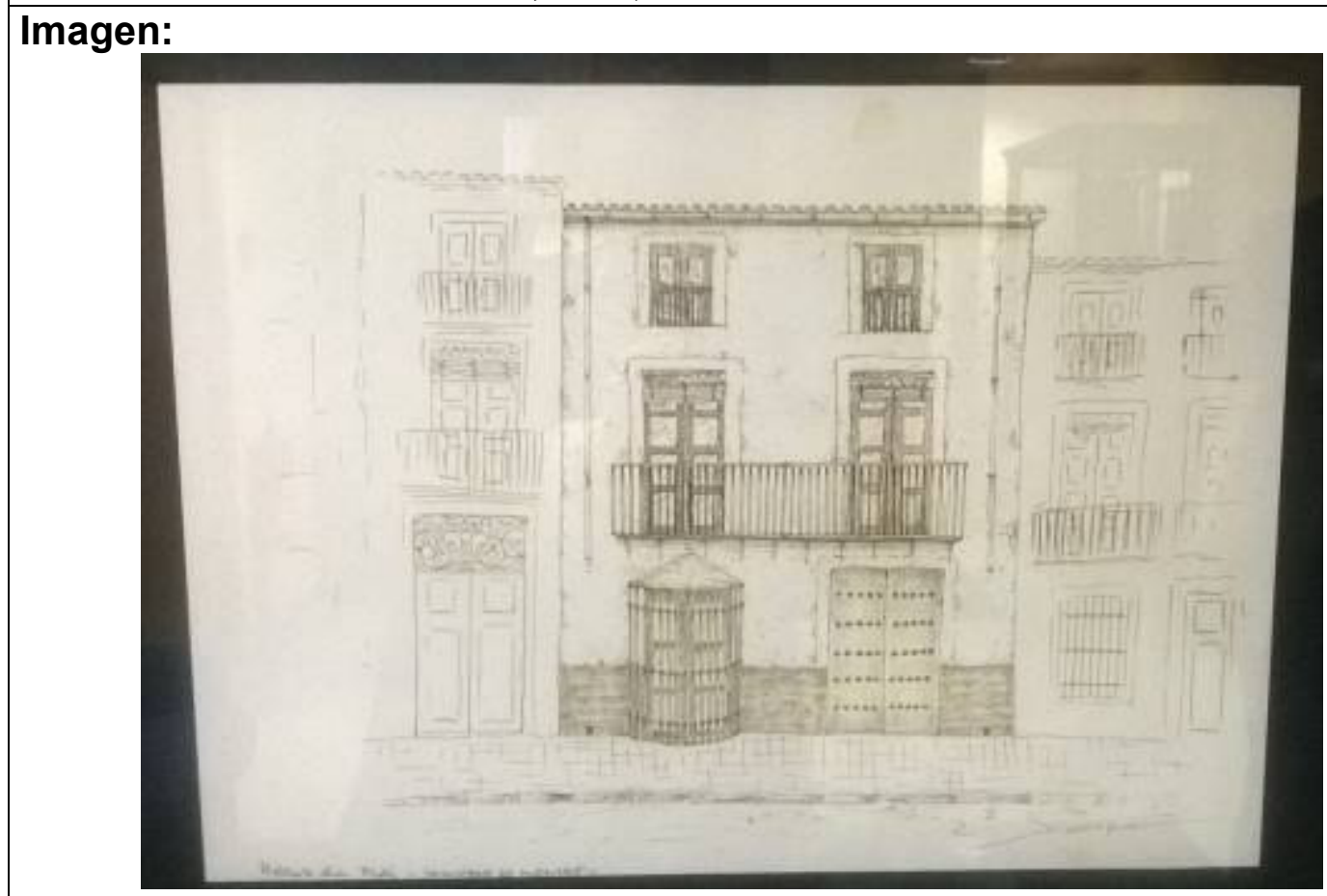

Imágenes relacionadas:

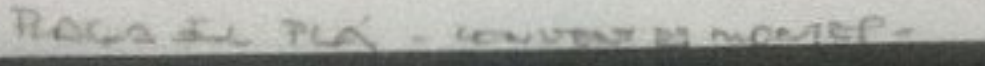

Detalle obra, inscripción margen inferior izquierdo 
$\mathbf{N}^{0}: 2.61$

Título: Cuarta Sede Social Caja Rural Nuestra Sra. de la Esperanza Onda

Autoría: Manolo Safont

Datación: 1980

Inscripciones: "Carrer sant Roc" en margen superior derecho y Safont en ángulo inferior derecho

Dimensiones: $31 \times 23 \mathrm{cms}$

Técnica: Dibujo sobre papel

Localización: Colección privada n¹7 Caja Rural Nuestra Señora de la

Esperanza de Onda, Onda.

Descripción: Dibujo arquitectónico que representa la fachada del edificio situado en la antigua plaza Fermín Galán, actual plaza San Roque, en el cual tuvo su cuarta sede la Caja Rural Nuestra Señora de la Esperanza de Onda. El inmueble pertenecía a la familia Piquer. Este dibujo pertenece a la serie sobre las diferentes sedes de la entidad financiera, formada por cinco dibujos, junto con las obras catalogadas $n^{\circ} 2.58, n^{\circ} 2.59, n^{\circ} 2.60$ y $n^{\circ} 2.62$, encargadas a Safont por la Caja Rural de Onda en 1980. Paleta cromática: blancos y negros

\section{Bibliografía:}

- "Breve reseña histórica de la Entidad" La Càmara. Butlletí Informatiu de la Caixa Rural d'Onda, abril, 1980

\section{Imagen:}

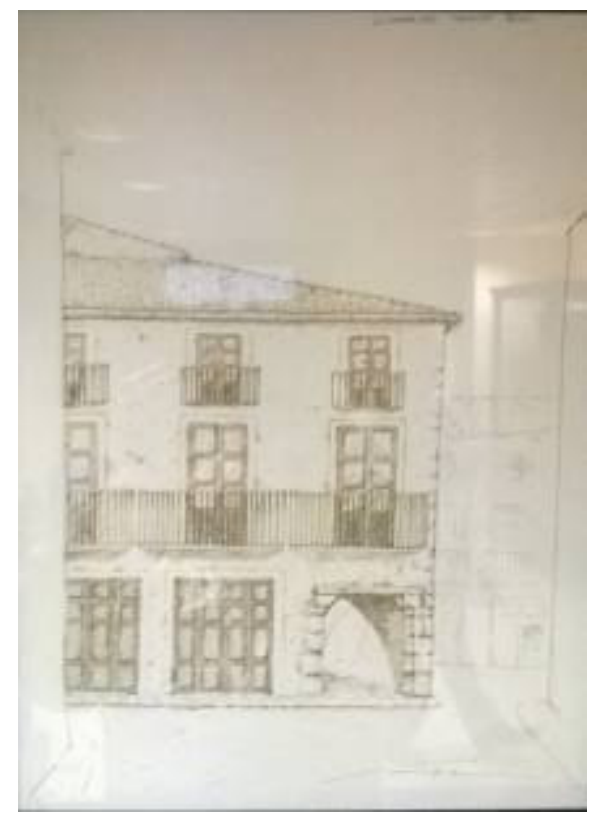

Imágenes relacionadas:

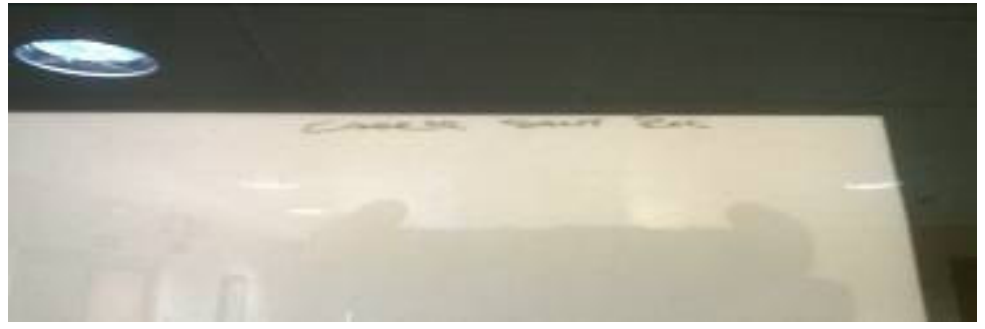

Detalle obra, inscripción margen superior derecho 
$N^{0}: 2.62$

Título: Quinta Sede Social Caja Rural Nuestra Sra. de la Esperanza Onda

Autoría: Manolo Safont

Datación: 1980

Inscripciones: "Carrer del Carme" y Safont en ángulo inferior derecho

Dimensiones: $31 \times 23 \mathrm{cms}$

Técnica: Dibujo sobre papel

Localización: Colección privada n¹7 Caja Rural Nuestra Señora de la

Esperanza de Onda, Onda.

Descripción: Dibujo arquitectónico que representa la fachada del edificio situado en el antiguo Casino de Dalt, ubicado en la calle Virgen del Carmen, $n^{\circ} 10$, en el cual tuvo su quinta sede la Caja Rural Nuestra Señora de la Esperanza de Onda. Este dibujo pertenece a la serie sobre las diferentes sedes de la entidad financiera, formada por cinco dibujos, junto con las obras catalogadas $n^{\circ} 2.58, n^{\circ} 2.59, n^{\circ} 2.60$ y $n^{\circ} 2.61$, encargadas a Safont por la Caja Rural de Onda en 1980. Paleta cromática: blancos y negros.

\section{Bibliografía:}

- "Breve reseña histórica de la Entidad" La Càmara. Butlletí Informatiu de la Caixa Rural d'Onda, abril, 1980

\section{Imagen:}

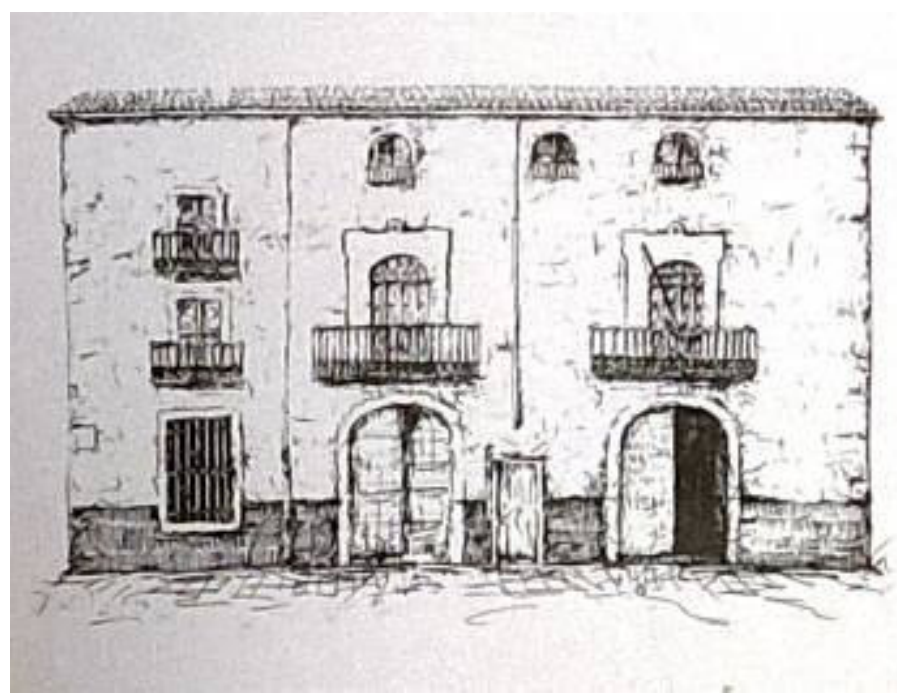

Imágenes relacionadas:

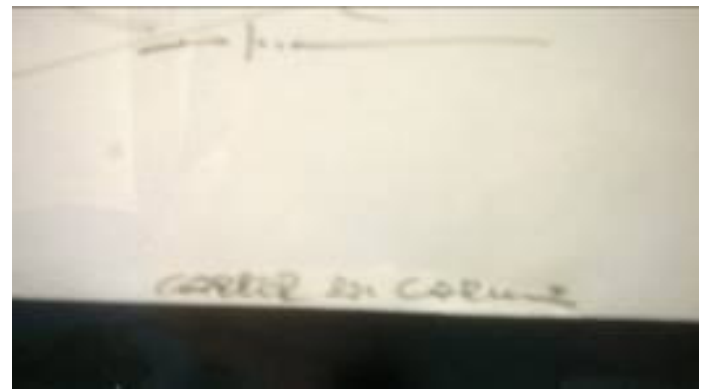

Detalle obra, inscripción ángulo inferior derecho 
No: 2.63

Título: Sin Título

Autoría: Manolo Safont

Datación: 1982

Inscripciones: "associació arqueològica de castelló Llansol de Romaní"

Técnica: Impresión gráfica

Localización: MAMS

Descripción: Safont realizó el dibujo que se utilizó para ilustrar la portada del Butlletí $\mathrm{n}^{\circ} 3$ de l'associació arqueológica de Castelló Llansol de Romaní, con dibujos inspirados en las pinturas rupestres. Paleta cromática: blancos, amarillos, rojos y negros.

\section{Exposiciones:}

- "Manolo Safont. Un museu, un llegat i un compromís". MAMS. Del 27 de noviembre de 2004 al 8 de enero de 2005. Onda.

\section{Bibliografía:}

- Butlletí de l'associació arqueológica de Castelló Llansol de Romaní. Nº 3. Castellón, 1982?

\section{Imagen:}

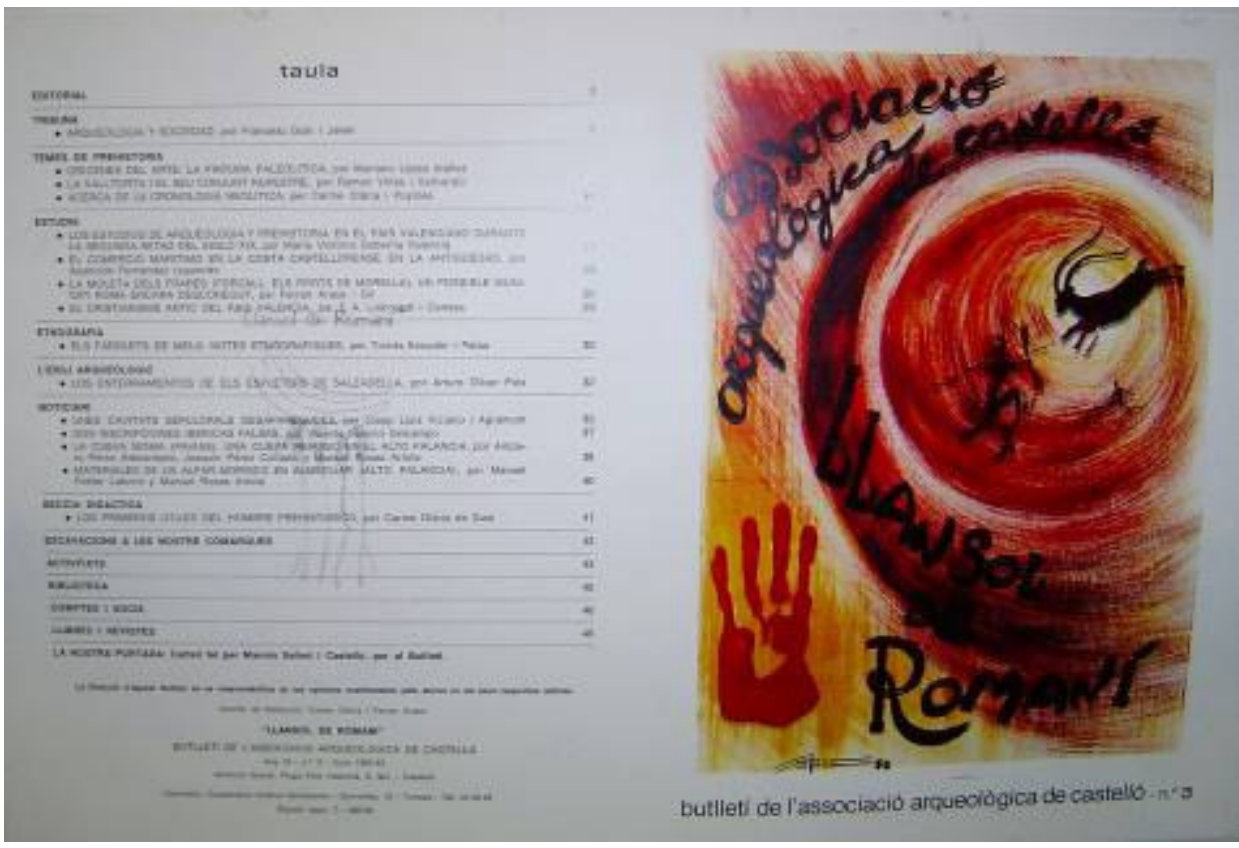


No: 2.64

Título: Sin Título

Autoría: Manolo Safont

Datación: 1983

Inscripciones: "FIRA D'ONDA" "OCTUBRE-1983"

Técnica: Dibujo sobre papel

Localización: MAMS

Descripción: Boceto para realizar el dibujo que sirvió como portada del

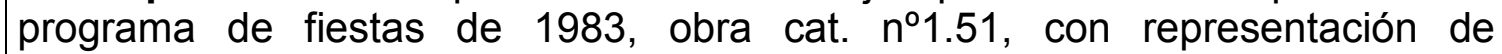
elementos arquitectónicos de la población de Onda: castillo, chimeneas de las fábricas de azulejos, arcos de la Font de Dins y escudo de la población en el margen derecho. Paleta cromática: blancos, amarillos, rojos y negros.

Exposiciones:

- "Manolo Safont. Un museu, un llegat i un compromís". MAMS. Del 27 de noviembre de 2004 al 8 de enero de 2005. Onda

\section{Imagen:}

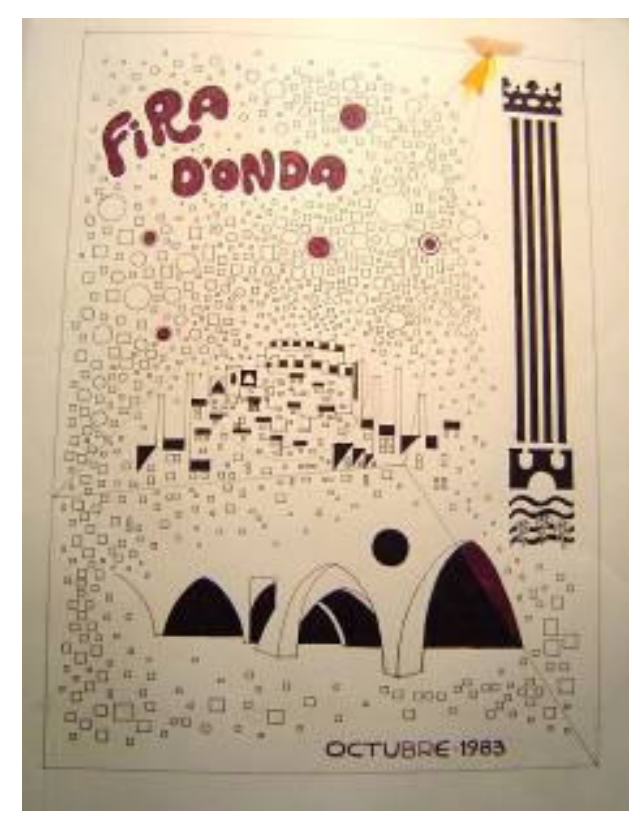

Imágenes relacionadas:

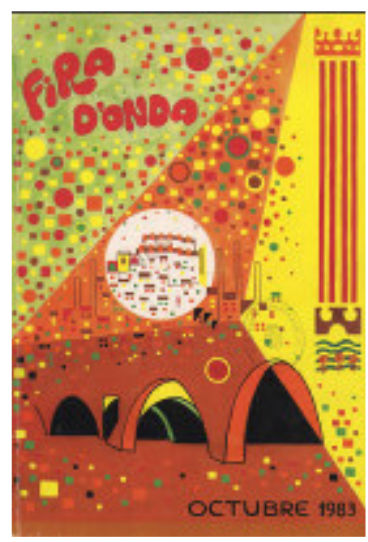

Obra cat. $n^{0} 1.51$ 
No: 2.65

Título: Sin Título

Autoría: Manolo Safont

Datación: 1984

Inscripciones: Safont 84 en ángulo inferior derecho

Dimensiones: $50 \times 32 \mathrm{cms}$

Técnica: Dibujo sobre papel

Localización: Colección privada $\mathrm{n}^{\circ} 1$, Onda

Descripción: Dibujo geométrico abstracto realizado a lápiz Un dibujo muy similar a este se utilizó para ilustrar el cartel anunciador del Primer Curso Nacional Especialización en diagnóstico y tratamiento del autismo infantil, obra catalogada $n^{\circ} 2.66$, que se realizó entre el 28 y 30 de septiembre de 1984 en Castellón de la Plana, organizado por la asociación española de terapeutas de autismo y psicosis infantiles, en colaboración con el centro de rehabilitación de autismo "El Cau" de Castellón. Paleta cromática: blancos y negros.

\section{Imagen:}

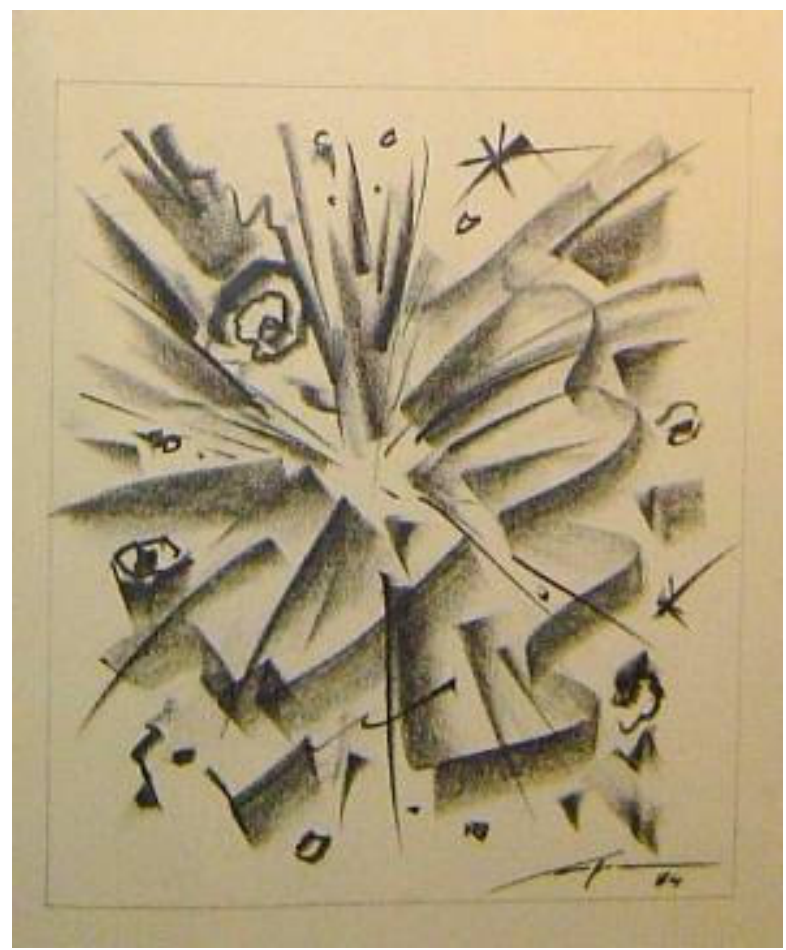

Imágenes relacionadas:

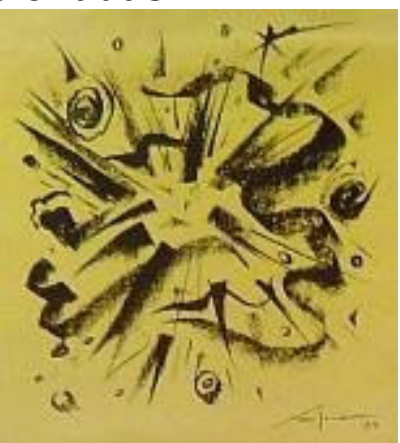

Detalle obra cat. $\mathrm{n}^{0} 2.66$

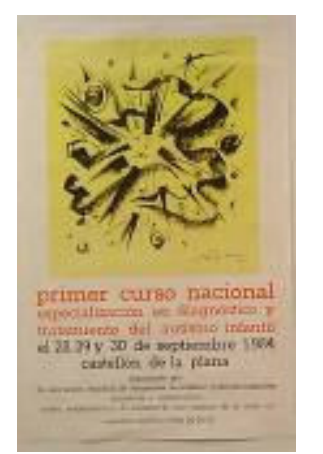

Obra cat. $\mathrm{n}^{\circ} 2.66$ 
$\mathbf{N}^{0}: 2.66$

Título: Sin Título

Autoría: Manolo Safont

Datación: 1984

Inscripciones: Safont 84 en ángulo inferior derecho

Técnica: Impresión gráfica

Localización: MAMS

Descripción: Cartel del Primer Curso Nacional Especialización en diagnóstico y tratamiento del autismo infantil, que se realizó entre el 28 y 30 de septiembre de 1984 en Castellón de la Plana, organizado por la asociación española de terapeutas de autismo y psicosis infantiles, en colaboración con el centro de rehabilitación de autismo "El Cau" de Castellón. Para la realización de este cartel se utiliza un diseño similar al del dibujo original obra catalogada $n^{02} 2.65$. Paleta cromática: amarillos y negros.

Exposiciones:

- "Manolo Safont. Un museu, un llegat i un compromís". MAMS. Del 27 de noviembre de 2004 al 8 de enero de 2005. Onda.

\section{Imagen:}
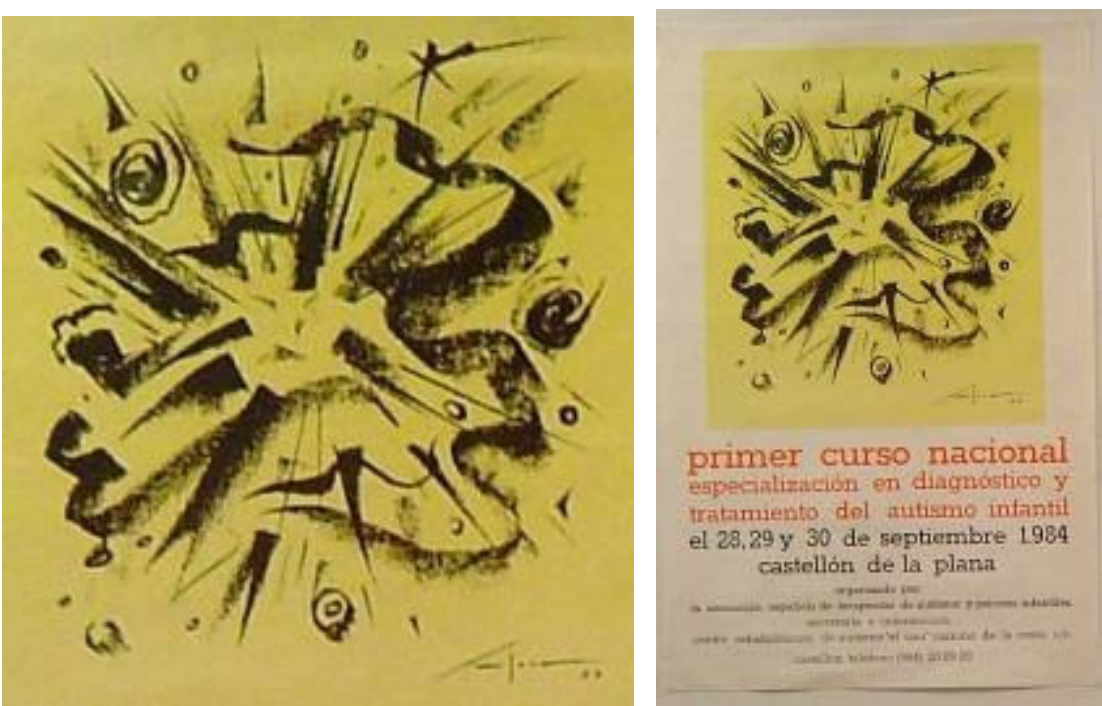

Imágenes relacionadas:

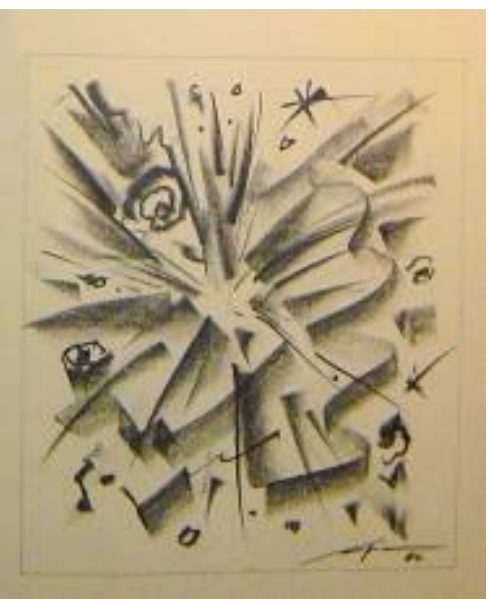

Obra cat. $n^{\circ} 2.65$ 
No: 2.67

Título: Sin Título

Autoría: Manolo Safont

Datación: 1991

Técnica: Dibujo sobre papel

Localización: MAMS

Descripción: Boceto a color con cuadrícula para el mural cerámico instalado en la Escuela de Artes y Oficios de Castellón, obra catalogada $n^{0} 7.31$, realizado en 1991. Paleta cromática: blancos, amarillos, naranjas, rojos, verdes, azules, violetas y marrones.

\section{Exposiciones:}

- "Manolo Safont. Un museu, un llegat i un compromís". MAMS. Del 27 de noviembre de 2004 al 8 de enero de 2005. Onda.

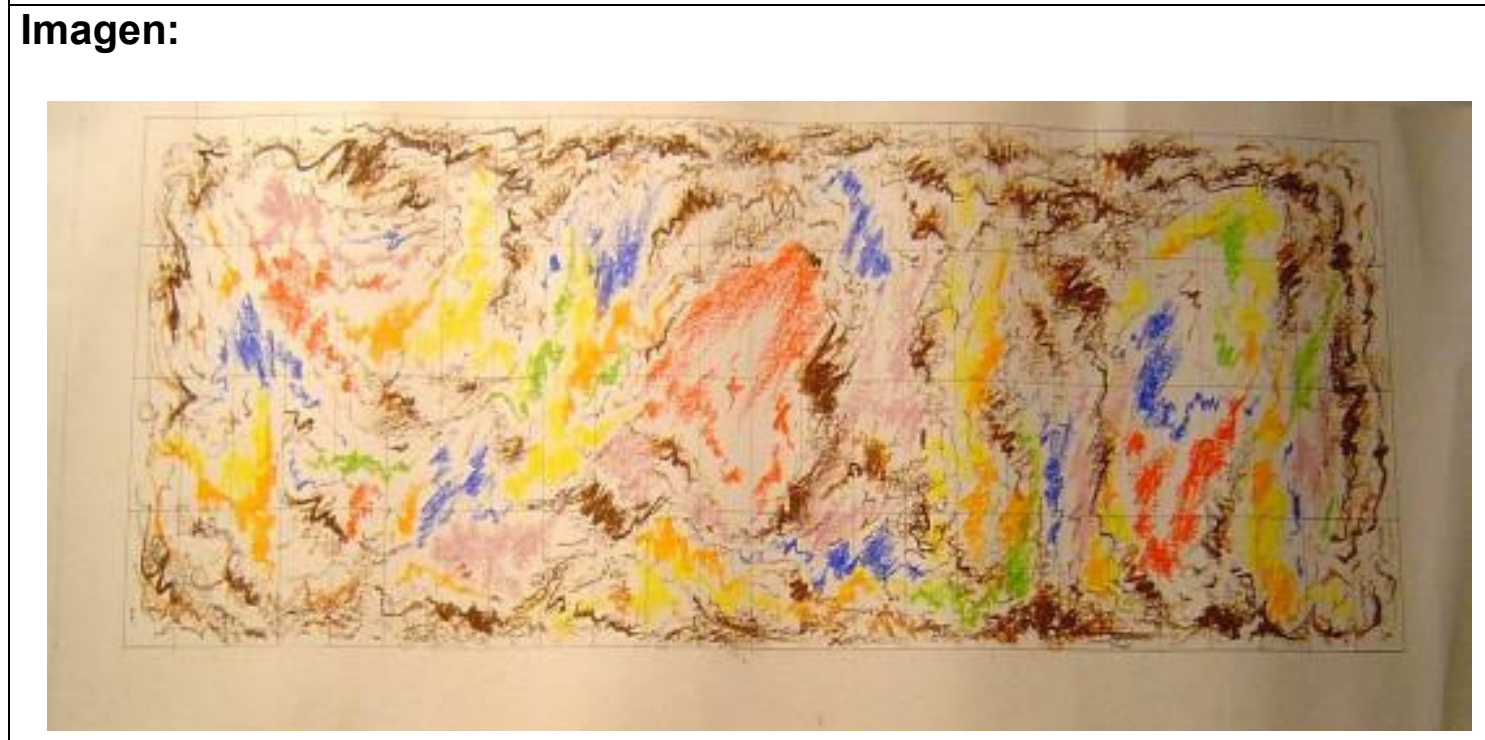

Imágenes relacionadas:

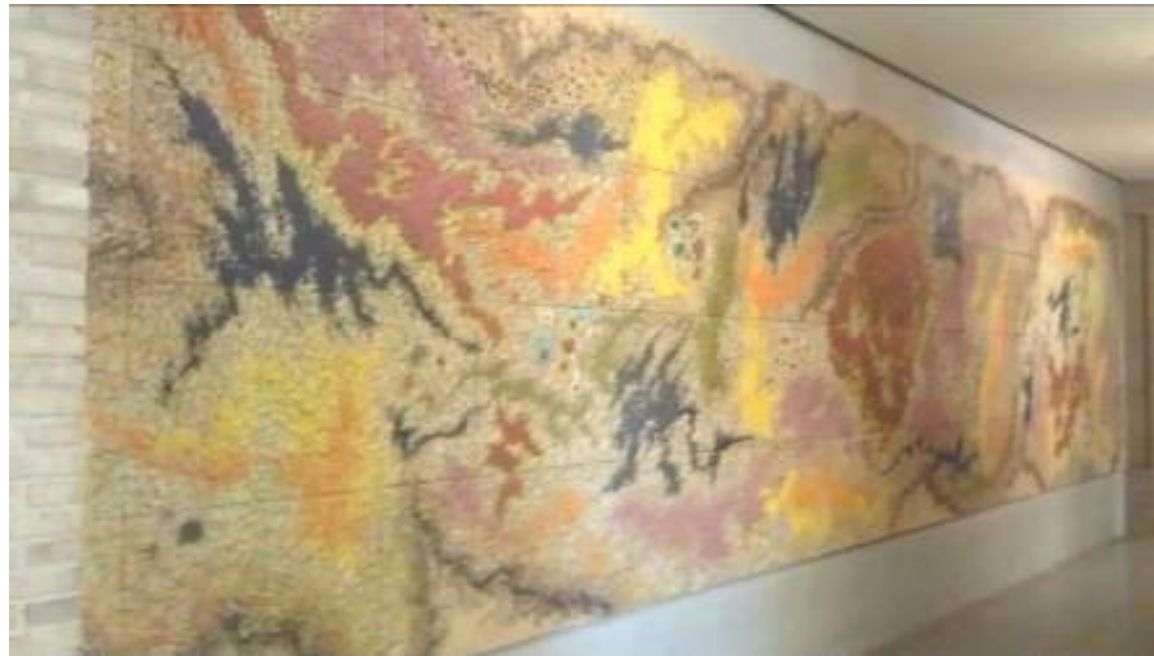

Obra cat. $n^{0} 7.31$ 
No: 2.68

Título: Sin Título

Autoría: Manolo Safont

Datación: 1993

Técnica: Dibujo sobre papel

Localización: MAMS

Descripción: Boceto para la realización del mural cerámico ubicado en el Centro Ocupacional de Vila-Real (Castellón) obra catalogada $n^{07.32}$. Paleta cromática: blancos, amarillos, naranjas, rojos, verdes, azules, violetas, marrones y negros.

Exposiciones:

- "Manolo Safont. Un museu, un llegat i un compromís". MAMS. Del 27 de noviembre de 2004 al 8 de enero de 2005. Onda.

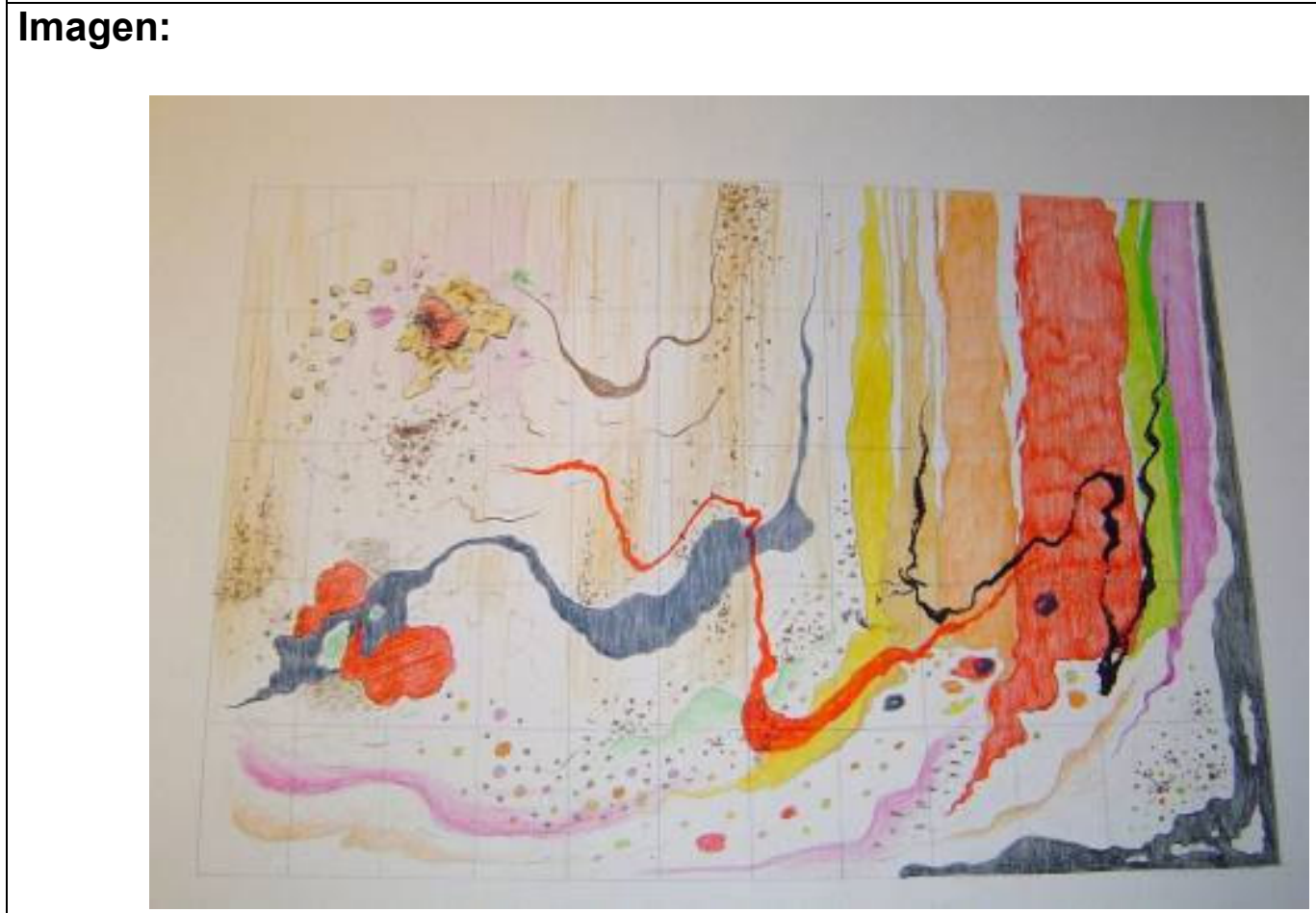

Imágenes relacionadas:

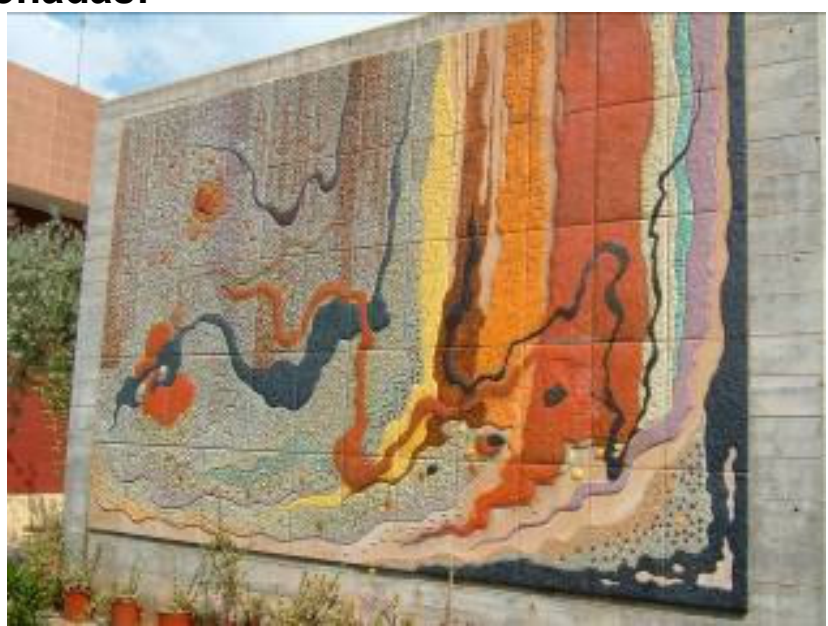

Obra cat. $n^{07.32}$ 
No: 2.69

Título: Sin Título

Autoría: Manolo Safont

Datación: 1994

Técnica: Dibujo sobre papel

Localización: MAMS

Descripción: Boceto en color para un panel cerámico, realizado en 1994, para la prefectura de Mies (Japón), obra catalogada $n^{07.33}$. Paleta cromática: blancos, amarillos, naranjas, verdes, azules, violetas, marrones y negros.

Exposiciones:

- "Manolo Safont. Un museu, un llegat i un compromís". MAMS. Del 27 de noviembre de 2004 al 8 de enero de 2005. Onda.

\section{Imagen:}

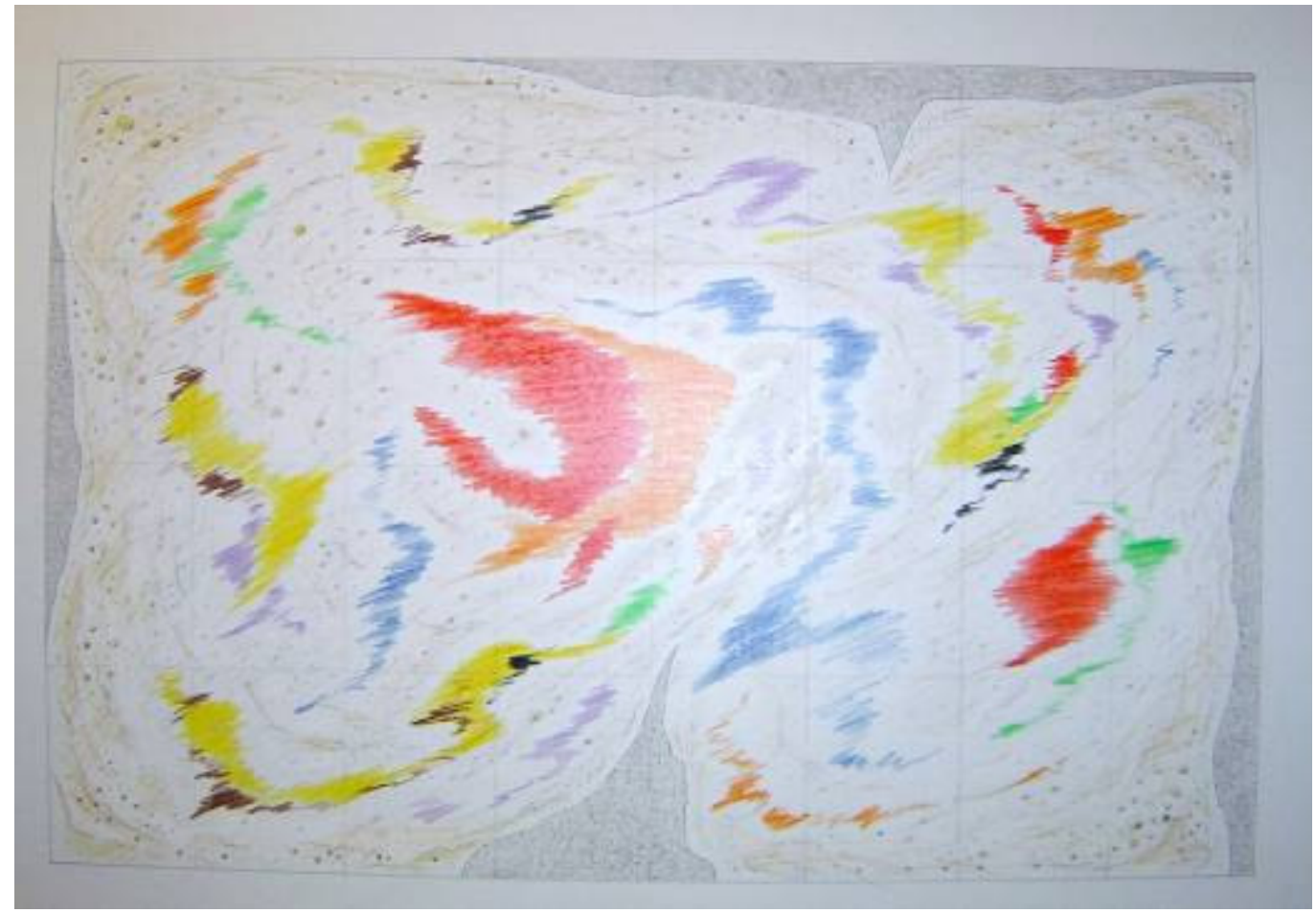

Imágenes relacionadas:

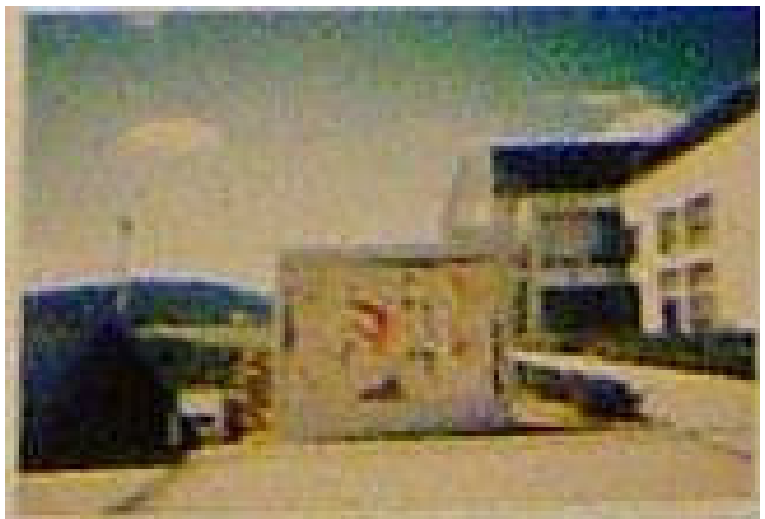

Obra cat. $n^{07.33}$ 

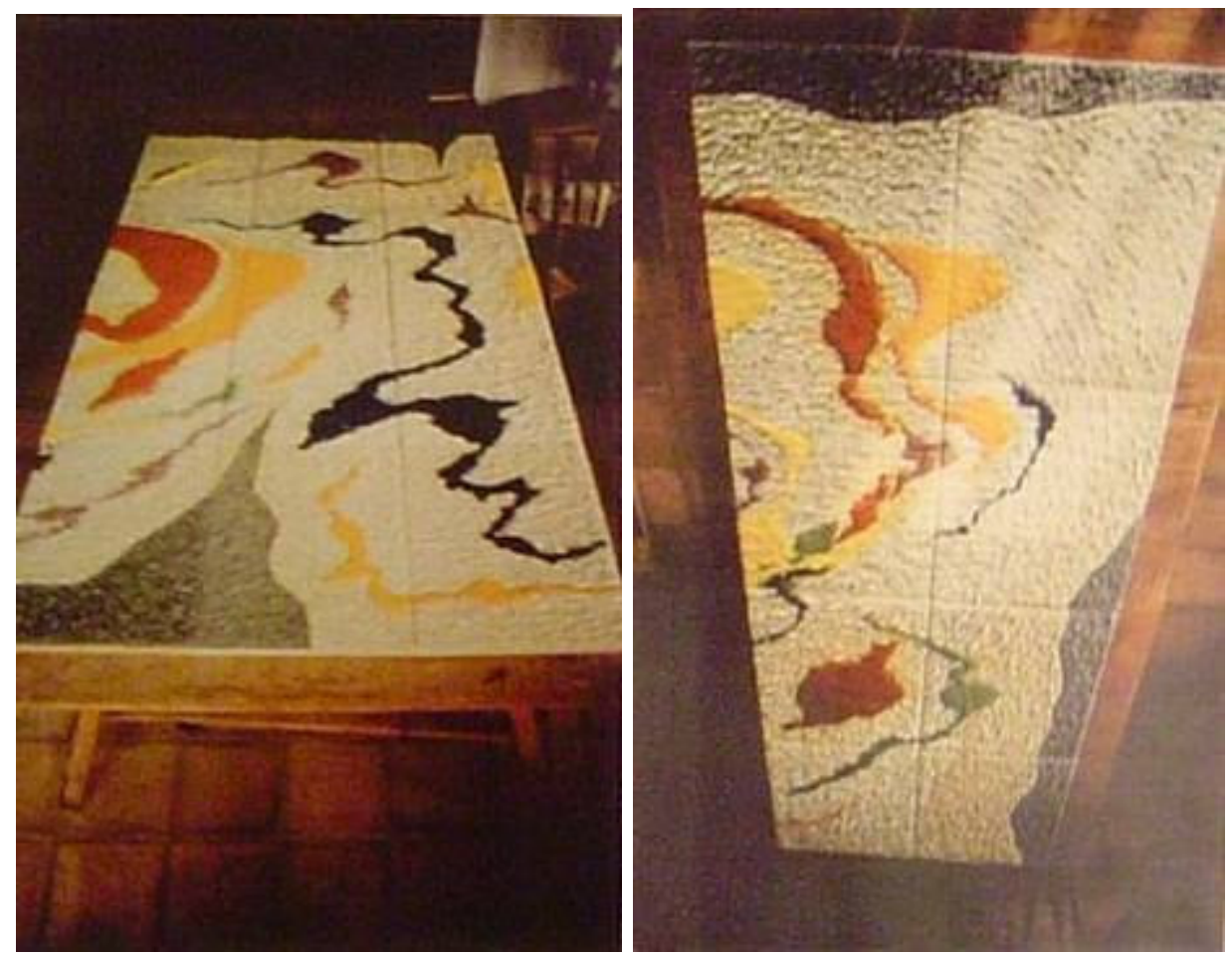

Fragmentos obra cat. $\mathrm{n}^{0} 7.33$ 
No: 2.70

Título: Sin Título

Autoría: Manolo Safont

Datación: 1997

Técnica: Impresión gráfica

Localización: MAMS

Descripción: Cartel del Symposium Internacional Estrés Profesional en Servicios Clínicos, Sociales y Educativos: Prevención y Tratamiento, Cursos Monográficos. Realizado entre el 13 y el 15 de noviembre de 1997 en Castellón y Benicasim. Para la realización de este cartel se utiliza como ilustración la obra de Safont catalogada con el $n^{0} 5.55$. Paleta cromática: blancos, amarillos, naranjas, rojos, azules, marrones y negros.

Exposiciones:

- "Manolo Safont. Un museu, un llegat i un compromís". MAMS. Del 27 de noviembre de 2004 al 8 de enero de 2005. Onda.

\section{Imagen:}

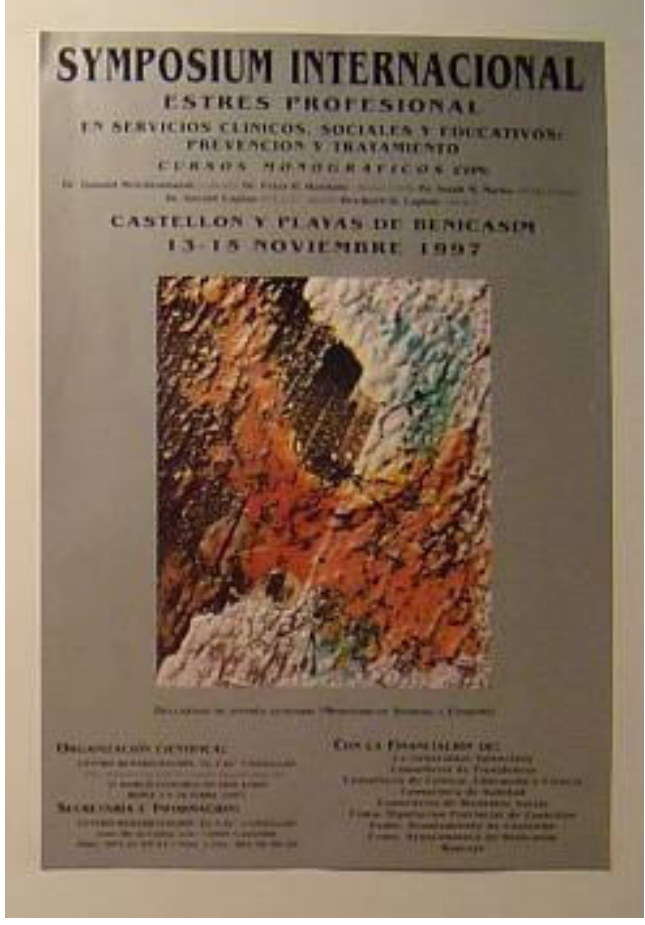

Imágenes relacionadas:

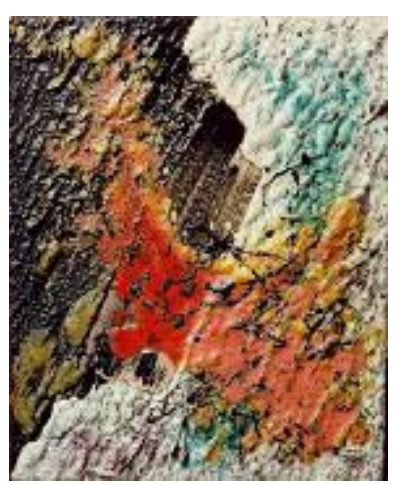

Obra cat. $n^{\circ} 5.55$ 
No: 2.71

Título: Sin Título

Autoría: Manolo Safont

Datación: Anterior a 2004

Técnica: Dibujo sobre papel

Localización: MAMS

Descripción: Dibujos geométricos y orlas de enmarque sobre una reproducción de la imagen del castillo de Onda realizada por Martin de Viciana en el año 1565. Paleta cromática: blancos y negros.

Exposiciones:

- "Manolo Safont. Un museu, un llegat i un compromís". MAMS. Del 27 de noviembre de 2004 al 8 de enero de 2005. Onda.

\section{Bibliografía:}

- Un recorrido por la historia de Onda y su castillo. Ed. Regiduria de Cultura. Mag. Ajuntament d'Onda, 1993

\section{Imagen:}

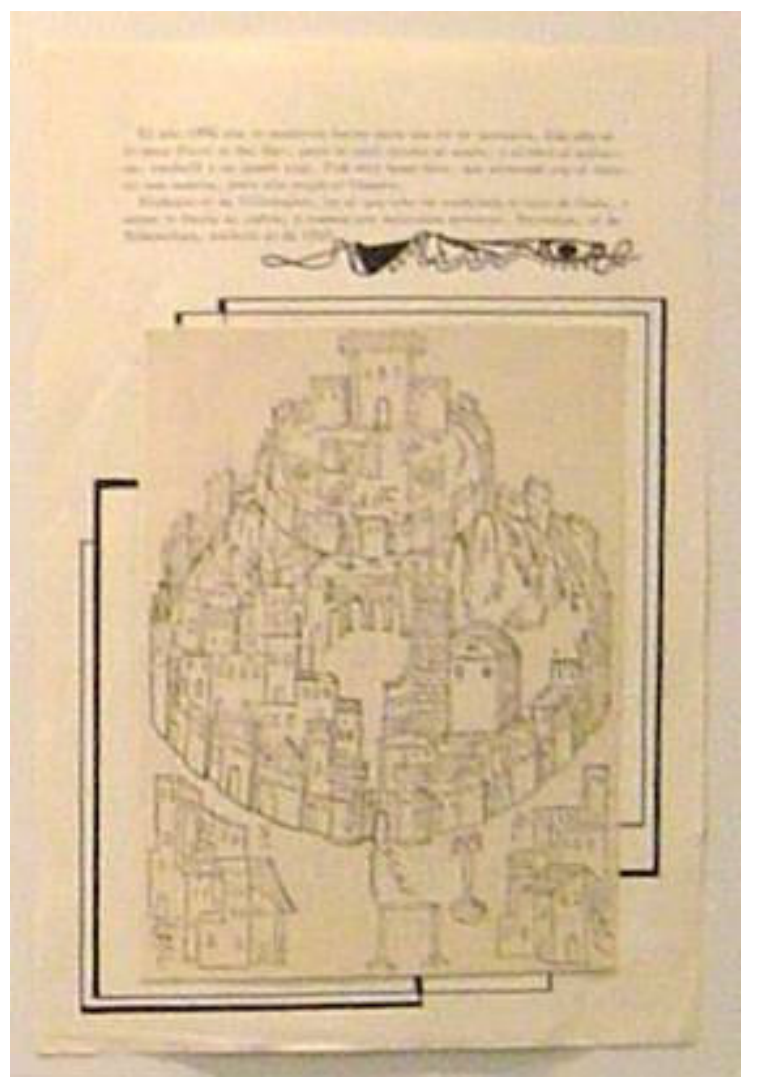


$\mathbf{N}^{0}: 2.72$

Título: Sin Título

Autoría: Manolo Safont

Datación: Anterior a 2004

Inscripciones: Safont en zona inferior central

Técnica: Dibujo sobre papel

Descripción: No hemos podido localizar la obra original, tan sólo una fotografía de la obra que se expuso en el MAMS, por lo que se utiliza la fecha de la exposición para datar la obra. Paleta cromática: blancos, amarillos, rojos y negros.

Exposiciones:

- "Manolo Safont. Un museu, un llegat i un compromís". MAMS. Del 27 de noviembre de 2004 al 8 de enero de 2005. Onda.

\section{Imagen:}

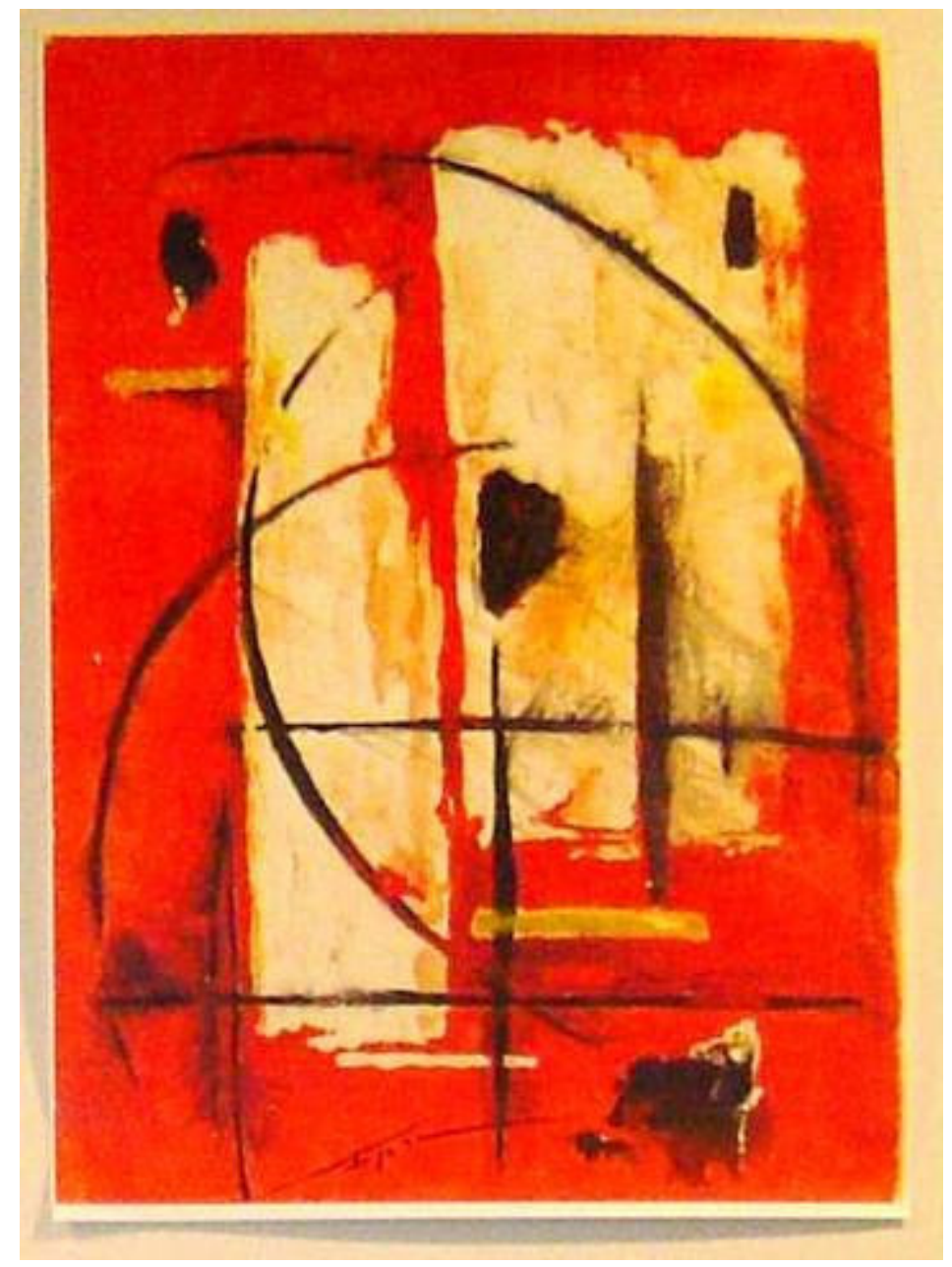


$\mathbf{N}^{0}: 2.73$

Título: Sin Título

Autoría: Manolo Safont

Datación: Anterior a 2004

Técnica: Dibujo sobre papel

Localización: MAMS

Descripción: Dibujo de un gran círculo rojo sobre fondo oscuro. Al carecer de documentación de esta obra, se utiliza para datarla la fecha de su exposición en el MAMS. Paleta cromática: rojos, azules, marrones y negros.

\section{Exposiciones:}

- "Manolo Safont. Un museu, un llegat i un compromís". MAMS. Del 27 de noviembre de 2004 al 8 de enero de 2005. Onda.

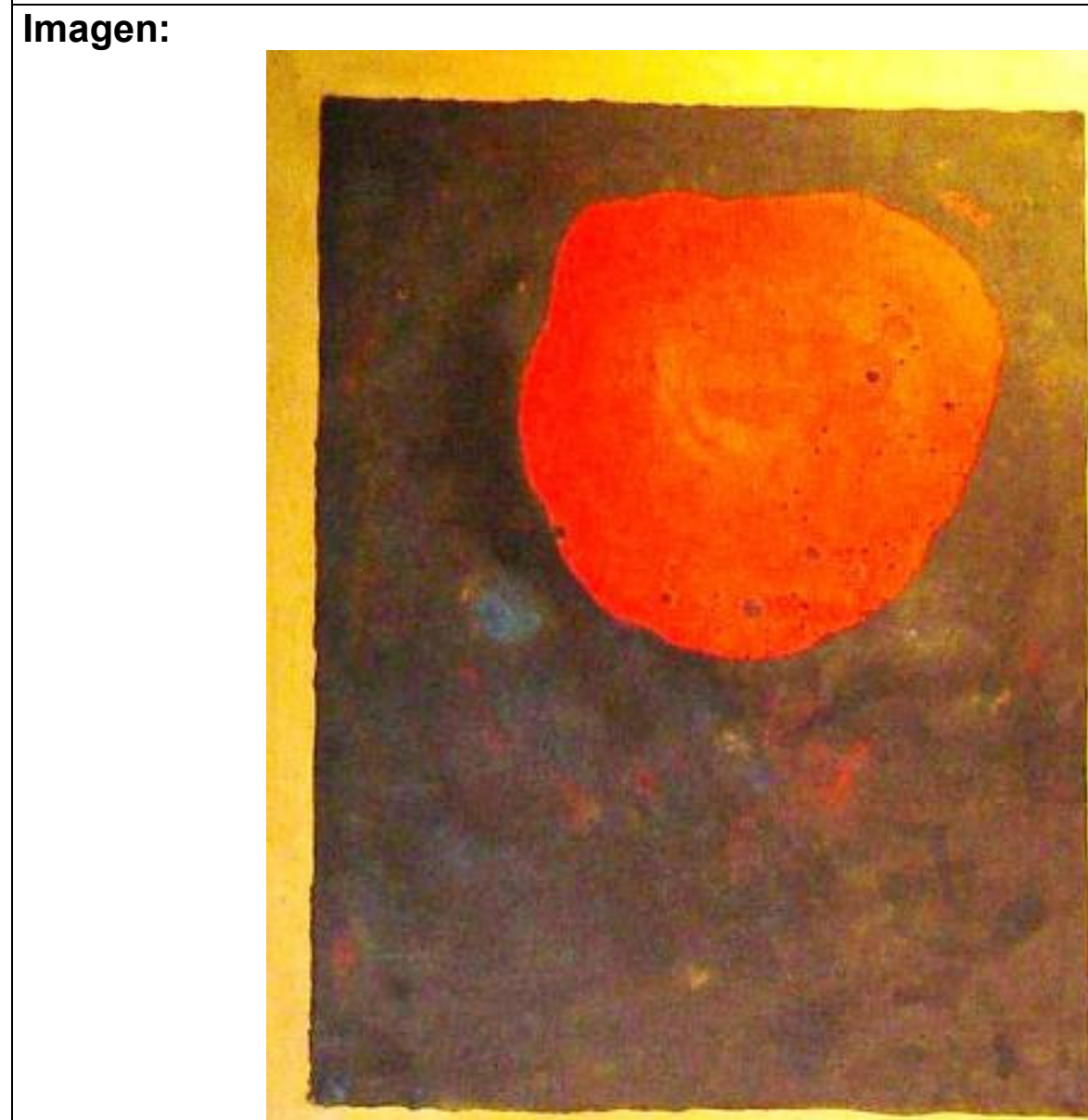




\section{3.- FICHAS CATALOGRÁFICAS: OBRAS DE LA ETAPA DE FIGURACIÓN}

En este tercer capítulo del catálogo general de obras, se analizan un total de 24 obras, catalogadas desde el n³.1 al n³.24, las obras que Safont creó en su etapa figurativa.

Las obras n $\mathrm{n}^{0} 3.1$ y n $\mathrm{n}^{0} 3.2$ son las únicas que se conservan sobre soporte de plato cerámico, el resto de las piezas catalogadas, están realizadas ya sobre soporte de placa cerámica plana.

Se observa la utilización de la técnica tradicional de pintura cerámica, que intenta lograr sobre soporte cerámico y a través de esmaltes, colores y barnices, el mismo tipo de acabados que logra la pintura al óleo sobre lienzo o tabla.

Entre las obras realizadas con la técnica tradicional de pintura cerámica, destacan los dibujos realizados con la técnica denominada "a plumilla" como el dibujo femenino de la obra catalogada $\mathrm{n}^{0} 3.9$, el dibujo de un paisaje del Calvario de Onda obra catalogada $n^{\circ} 3.14$, o la escena costumbrista de género obra catalogada n³.16.

En esta etapa figurativa, es interesante destacar que hemos logrado localizar dos obras iguales realizadas por Safont, la obra $n^{0} 3.8$ que se encuentra en el MAMS y la obra $n^{\circ} 3.15$, que pertenece a la colección privada n¹6, Onda. Estas obras, así como la n³.16 y n³.17 pertenecen a las piezas de serie que Safont realizaba para vender a las tiendas de artesanía cerámica, de hecho la primera está fechada en 1954 mientras que la segunda está fechada en 1958 y también presentan firmas diferentes.

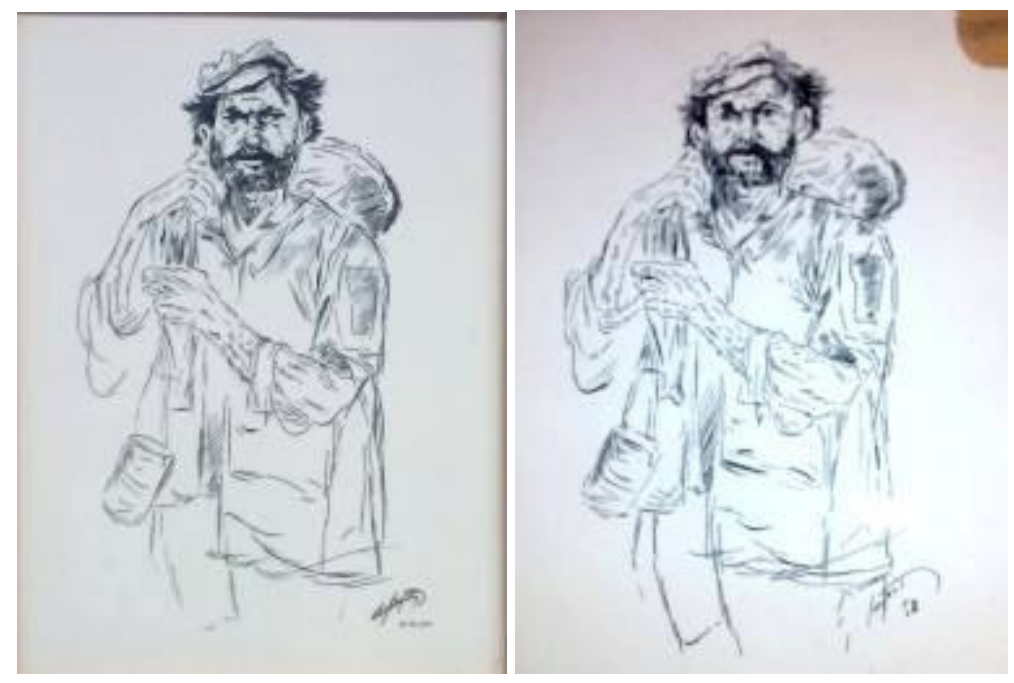

Figura 154: Obra cat. $n^{\circ} 3.8$ y obra cat $n^{\circ} 3.15$ 


\begin{tabular}{|l|}
\hline No: 3.1 \\
\hline Título: Sin Título \\
\hline Autoría: Manolo Safont \\
\hline Datación: 1948 \\
\hline Inscripciones: M. Safont 29.1.48 \\
\hline Dimensiones: 36 cms. diámetro \\
\hline Técnica: Pintura cerámica \\
\hline Localización: Colección privada $n^{\circ} 4$. Onda \\
\hline Descripción: Escena de caza con dos jinetes uniformados sobre un paisaje \\
nevado y acompañados por una manada de perros. Mantiene unidad de forma, \\
estilística, cromática y temática con la obra catalogada con el n².2. Esta obra y \\
la catalogada con el n⿳3.2 fueron regalo personal de Safont para la familia \\
propietaria, y cobran especial relevancia ya que son escasas las piezas de \\
cerámica artística de forma que se conservan de Safont. Paleta cromática: \\
blancos, ocres, azules, marrones y negros. \\
\hline Bibliografía: \\
http://manolosafont.blogspot.com.es \\
\hline Imagen:
\end{tabular}




\begin{tabular}{|l|}
\hline No: 3.2 \\
\hline Título: Sin Título \\
\hline Autoría: Manolo Safont \\
\hline Datación: 1948 \\
\hline Inscripciones: M. Safont 30.3.48 \\
\hline Dimensiones: 36 cms. diámetro \\
\hline Técnica: Pintura cerámica Pintura cerámica \\
\hline Localización: Colección privada n4. Onda \\
\hline Descripción: Escena de caza con un jinete sobre caballo blanco, atravesando \\
una zona de aguas y acompañado por una manada de perros. Mantiene unidad \\
de forma, estilística, cromática y temática con la obra catalogada con el $n^{\circ} 3.1$. \\
Esta obra y la catalogada con el no3.1 fueron regalo personal de Safont para la \\
familia propietaria y cobran especial relevancia ya que son escasas las piezas \\
de cerámica artística de forma que se conservan de Safont. Paleta cromática: \\
blancos, ocres, verdes, azules, violetas y negros. \\
\hline Bibliografía: \\
http://manolosafont.blogspot.com.es/ \\
\hline Imagen: \\
\hline Imágenes relacionadas: \\
\hline
\end{tabular}




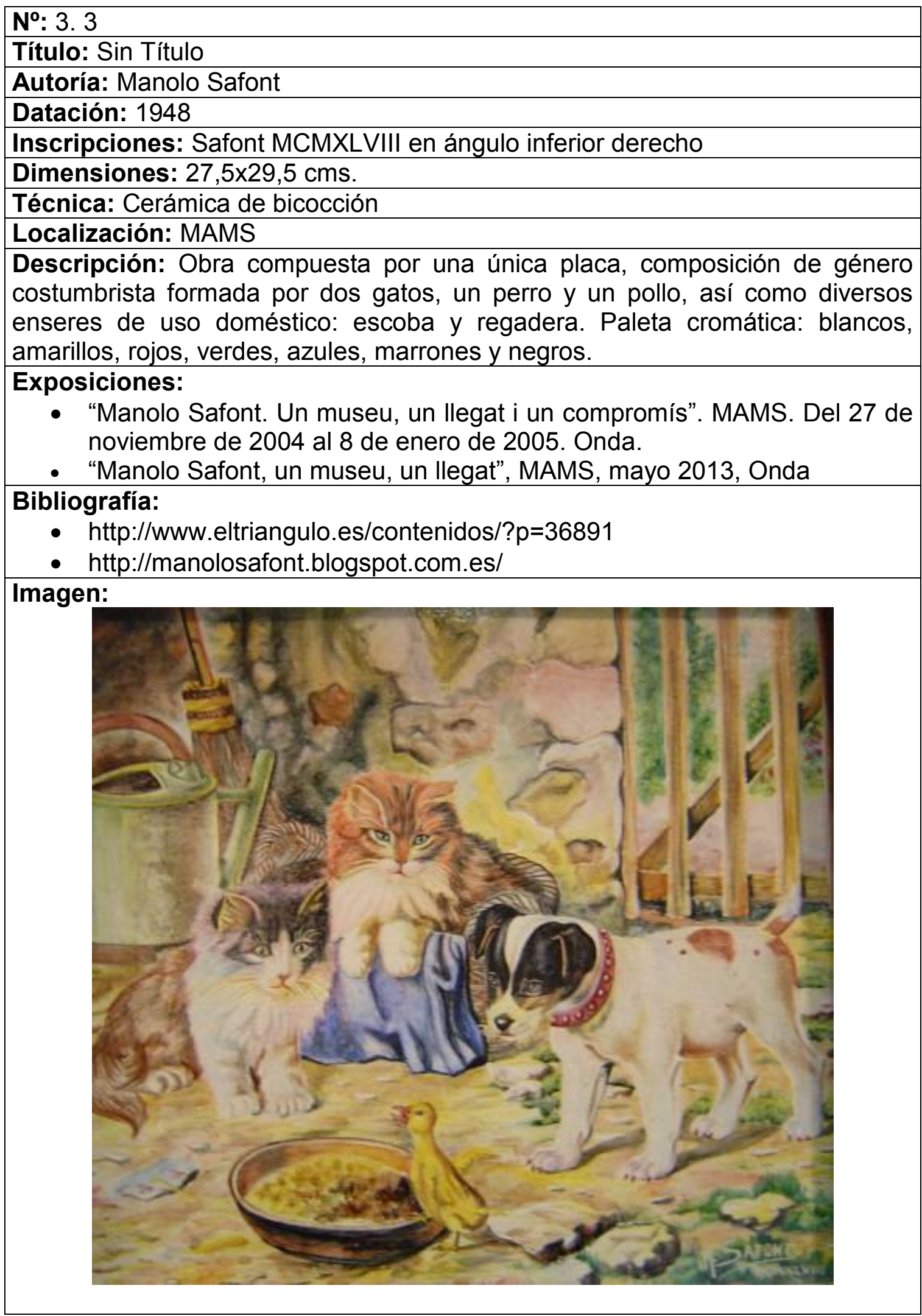




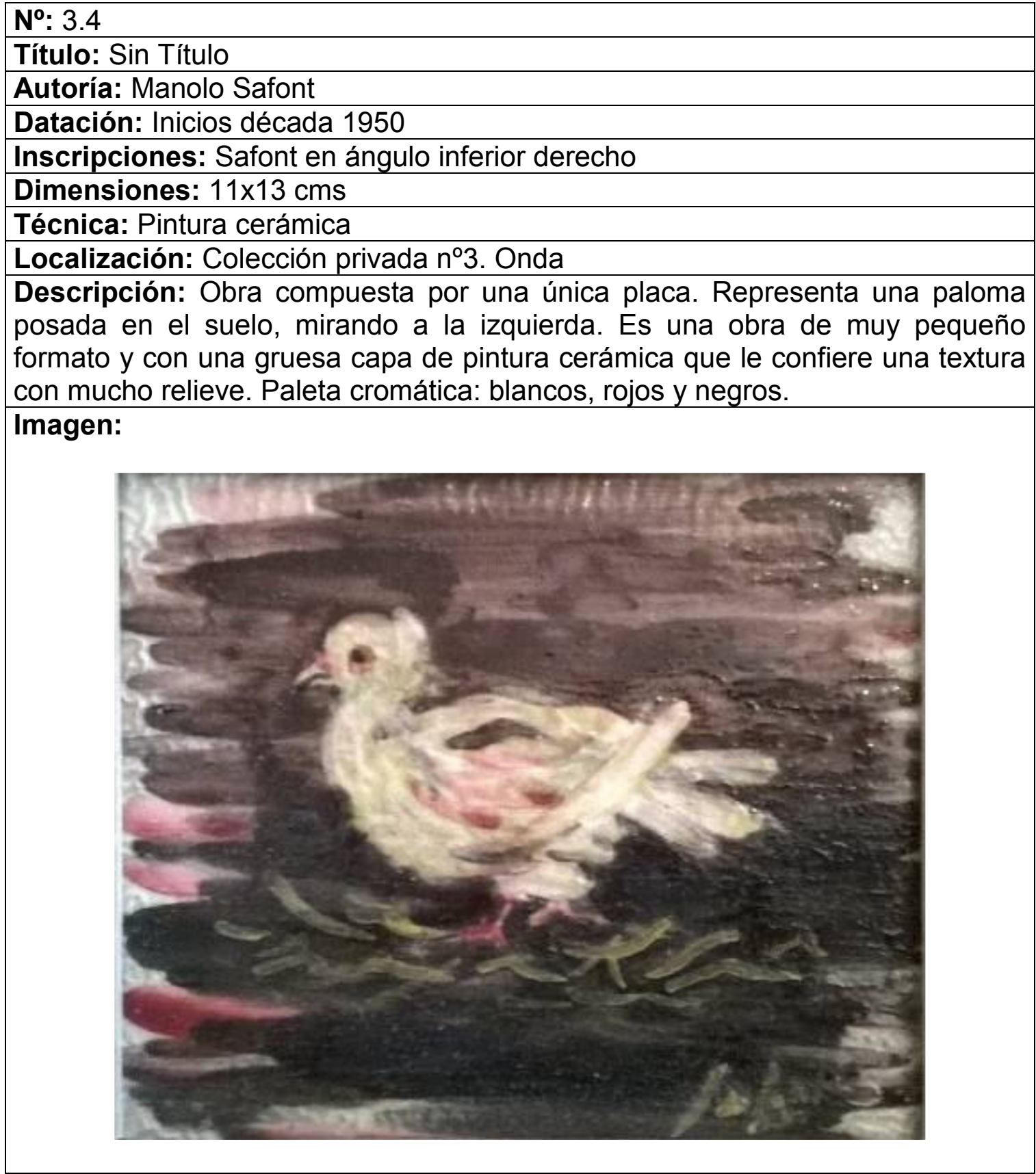




\begin{tabular}{|l|}
\hline No: 3.5 \\
\hline Título: Sin Título \\
\hline Autoría: Manolo Safont \\
\hline Datación: Inicios década 1950 \\
\hline Inscripciones: Safont en ángulo inferior derecho \\
\hline Dimensiones: 10x10 cms \\
\hline Técnica: Pintura cerámica \\
\hline Localización: Colección privada n³. Onda \\
\hline Descripción: Obra compuesta por una única placa. Representa un paisaje en \\
primer plano y al fondo la silueta de un castillo recortada sobre el cielo. La obra \\
presenta defectos de cocción, con cuarteado del esmalte. Paleta cromática: \\
amarillos, ocres, verdes, azules, violetas y negros. \\
\hline Imagen: \\
$\qquad$ \\
\end{tabular}


$\mathbf{N}^{0}: 3.6$

Título: Sin Título

Autoría: Manolo Safont

Datación: 1952

Inscripciones: Safont en zona inferior central

Dimensiones: $19 \mathrm{cms}$. de diámetro

Técnica: Pintura cerámica

Localización: MAMS

Descripción: Obra compuesta por una única placa. Esta pieza, de forma circular, es la única obra de Safont que no se corresponde con un formato cuadrado o rectangular. Representa un grupo de pájaros y nido con tres polluelos sobre la rama de un árbol. Paleta cromática: blancos, amarillos, ocres, rojos, verdes, azules, violetas y negros.

Exposiciones:

- "Manolo Safont. Un museu, un llegat i un compromís". MAMS. Del 27 de noviembre de 2004 al 8 de enero de 2005. Onda.

- "Manolo Safont. Un museu, un llegat", MAMS, mayo 2013, Onda

Bibliografía:

- http://www.eltriangulo.es/contenidos/?p=36891

- http://manolosafont.blogspot.com.es/

\section{Imagen:}

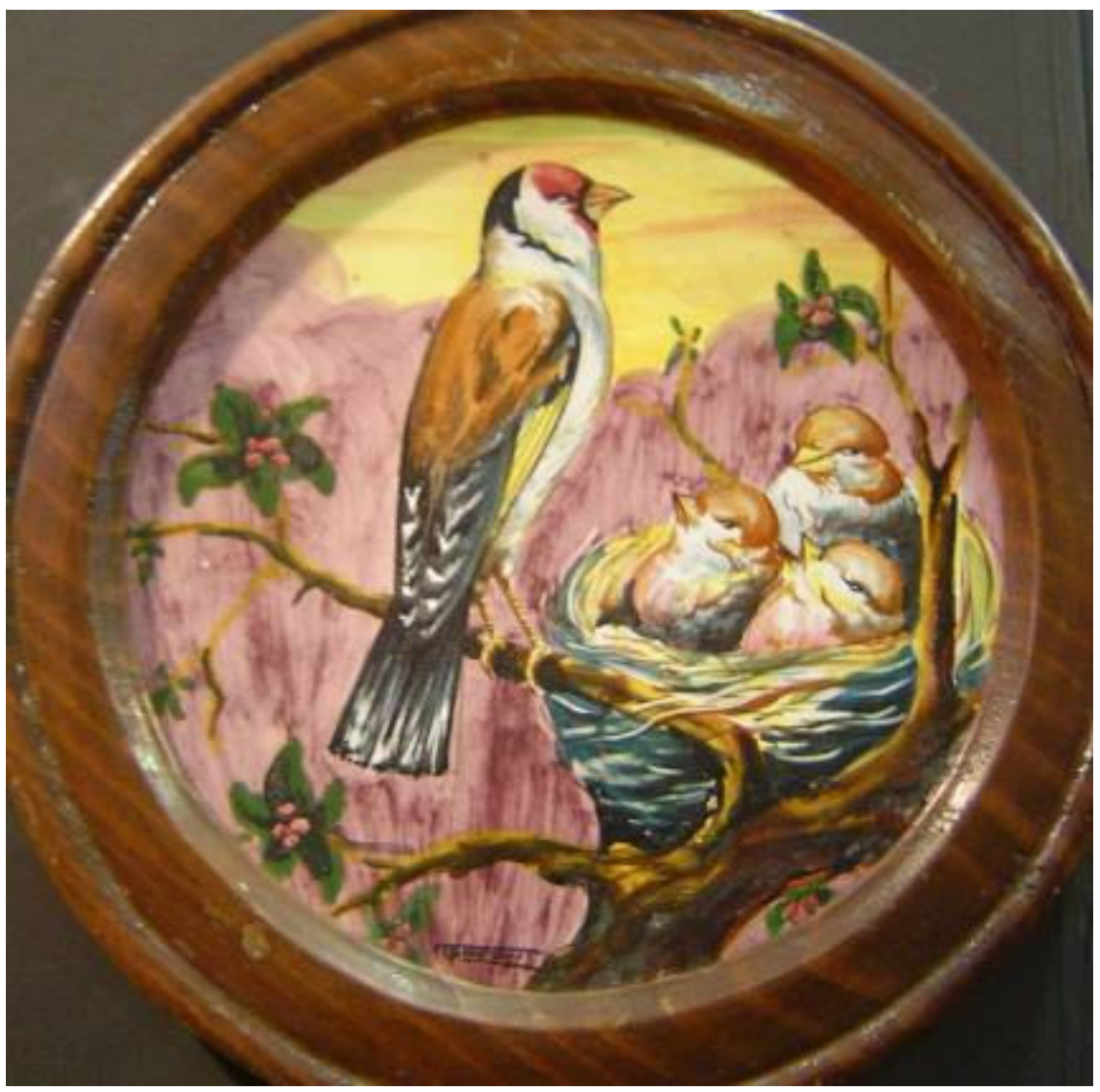


No: 3.7

Título: Nuestra Señora de la Esperanza

Autoría: Manolo Safont

Datación: 1953

Inscripciones: ESTUDIO DE ARTESANIA. Safont. ONDA

Dimensiones: $80 \times 60 \mathrm{cms}$

Técnica: Pintura cerámica

Localización: Colección privada $n^{\circ} 6$. Onda

Descripción: Panel devocional cerámico, realizado con 12 azulejos de 20x20 cms, en disposición 4x3. Representación de Nuestra Señora de la Esperanza, co-patrona de la población de Onda (Castellón). Iconográficamente presenta los atributos propios de la Esperanza, con el cetro en la mano derecha, hábito en color blanco con decoraciones en tonos dorados, representación del sol en la zona abdominal y manto de color verde. Esta imagen fue utilizada como portada del calendario que en 2003 regaló la Caixa Rural d'Onda a sus clientes. Paleta cromática: blancos, ocres, verdes, azules y marrones.

Bibliografía:

- Calendario Caixa Rural d'Onda 2003. Caixa Rural d'Onda. 2003 Imagen:

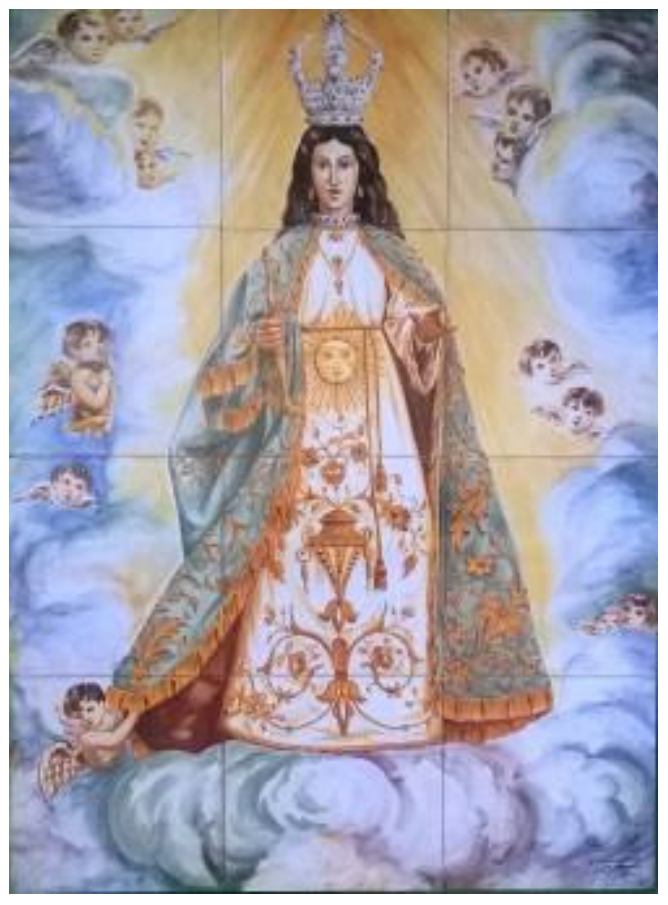

Imágenes relacionadas:

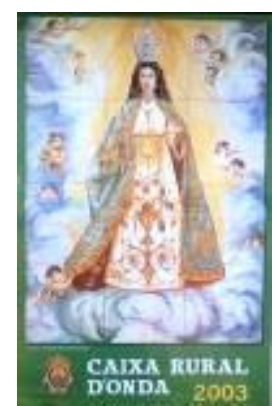

Calendario Caixa Rural Onda 
$\mathbf{N}^{0}: 3.8$

Título: Sin Título

Autoría: Manolo Safont

Datación: 1954

Inscripciones: Safont $\mathrm{X}^{*} \mathrm{VI}$ LIV en ángulo inferior derecho

Dimensiones: $19 \times 13 \mathrm{~cm}$

Técnica: Cerámica de bicocción

Localización: MAMS

Descripción: Obra compuesta por una única placa. Representación de una figura masculina, con un saco sobre el hombro derecho. Esta obra junto con la obra catalogada $n^{0} 3.15$, realizada cuatro años más tarde, formaría parte de las series que Safont vendía a las tiendas de cerámica artística. Cerámica a plumilla. Paleta cromática: blancos y negros.

\section{Exposiciones:}

- "Manolo Safont. Un museu, un llegat i un compromís". MAMS. Del 27 de noviembre de 2004 al 8 de enero de 2005. Onda

- "Manolo Safont, un museu, un llegat", MAMS, mayo 2013, Onda

\section{Bibliografía:}

- http://www.eltriangulo.es/contenidos/?p=36891

- http://manolosafont.blogspot.com.es/

\section{Imagen:}

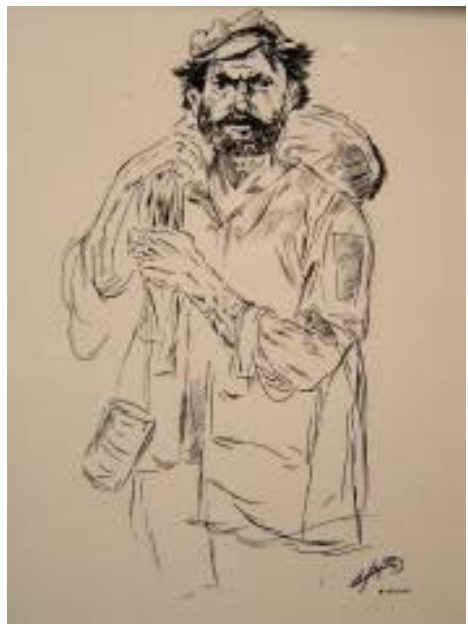

Imágenes relacionadas:

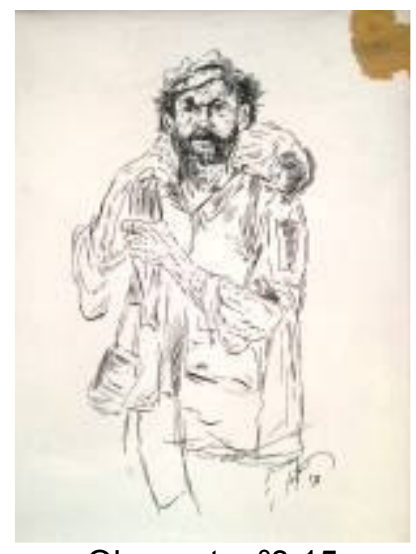

Obra cat. $n^{0} 3.15$ 


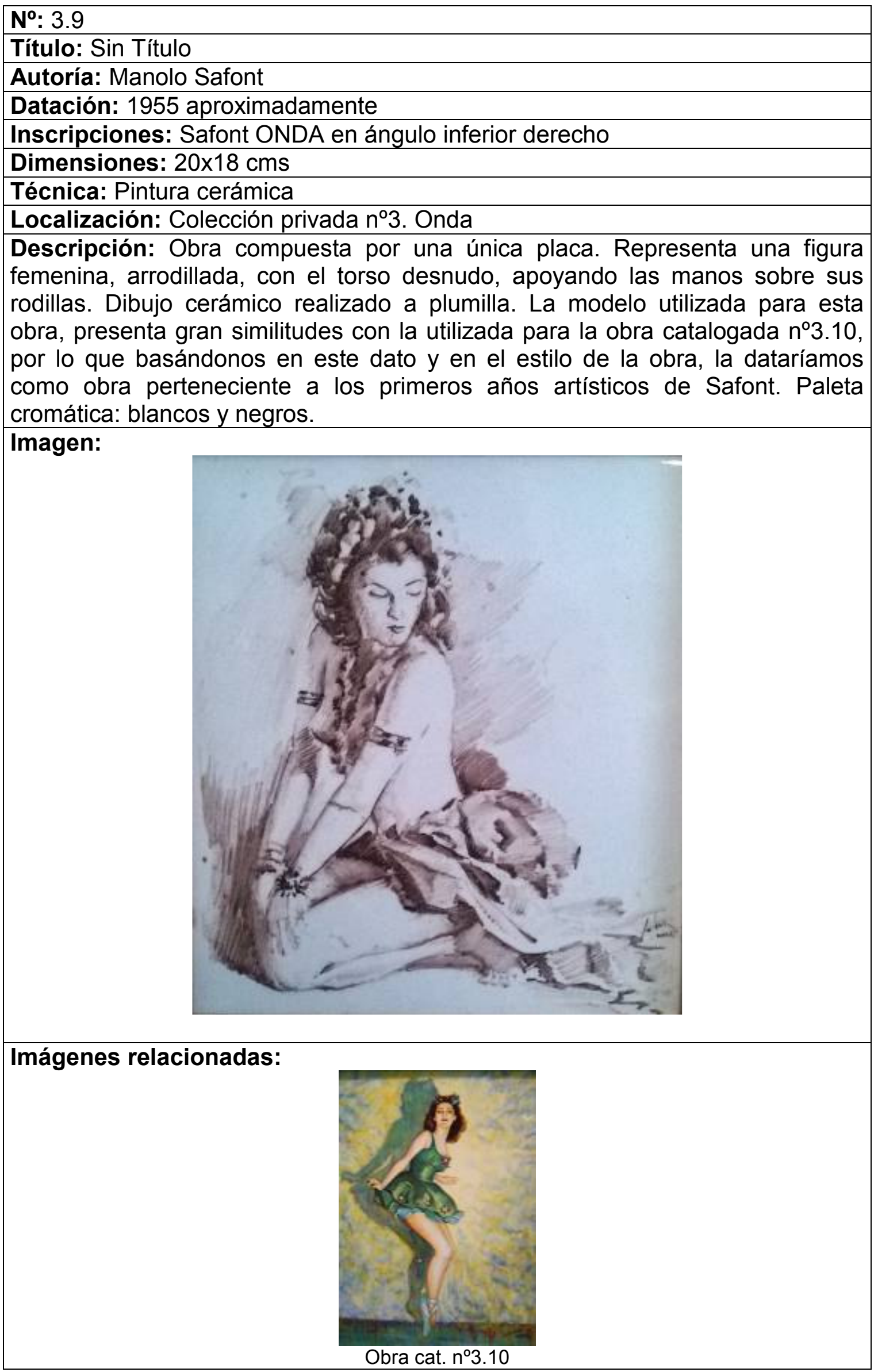




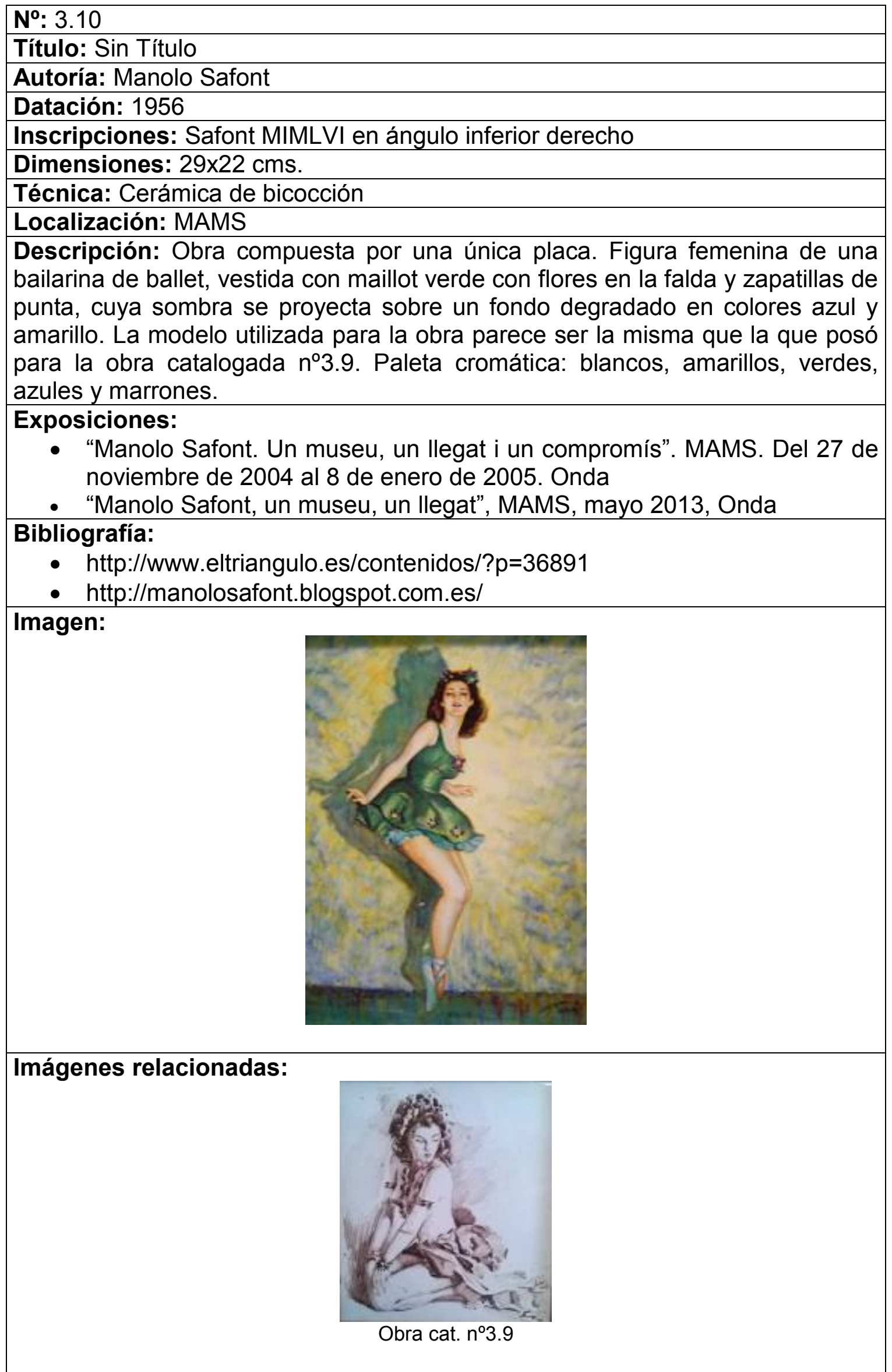




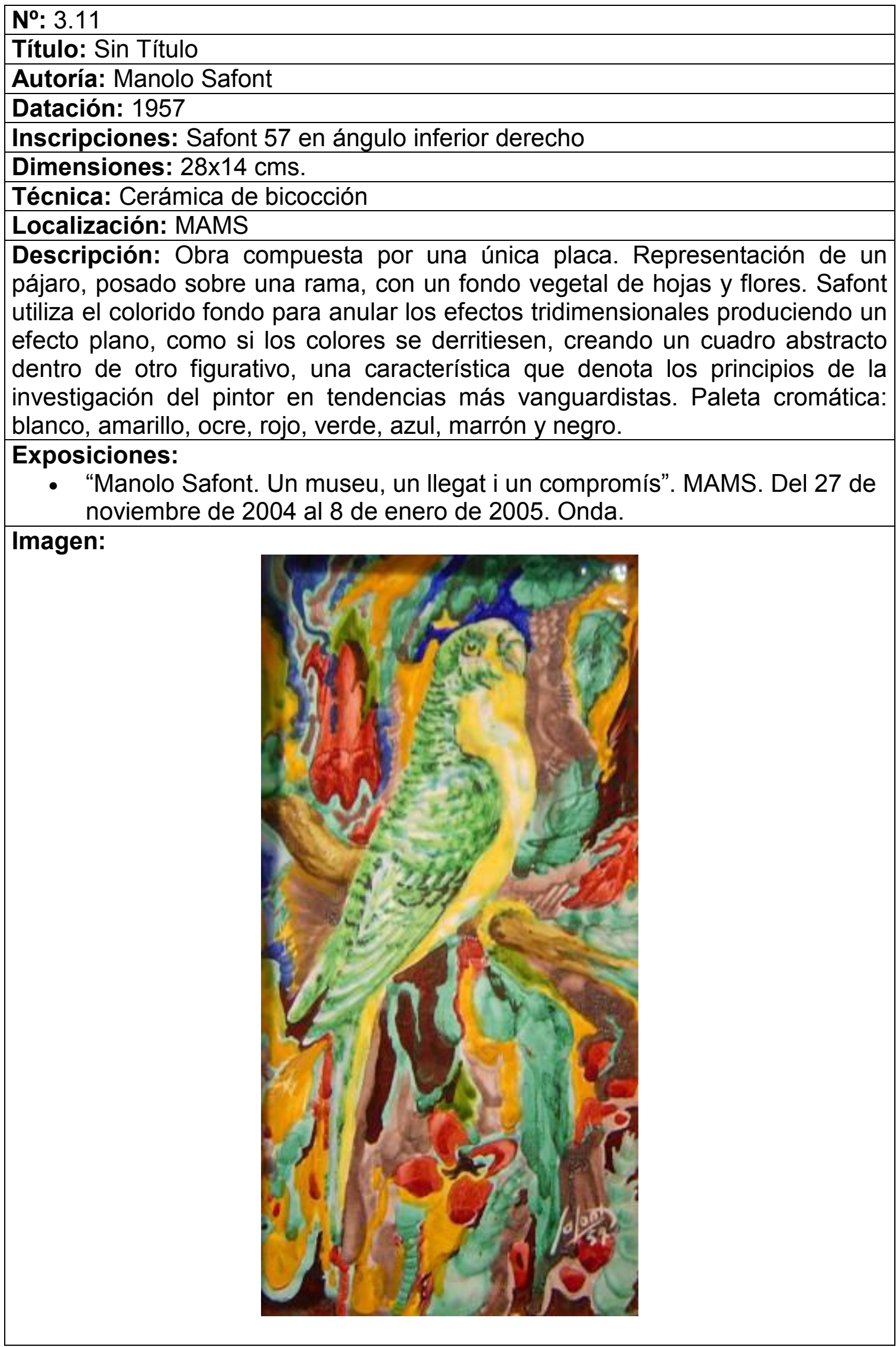




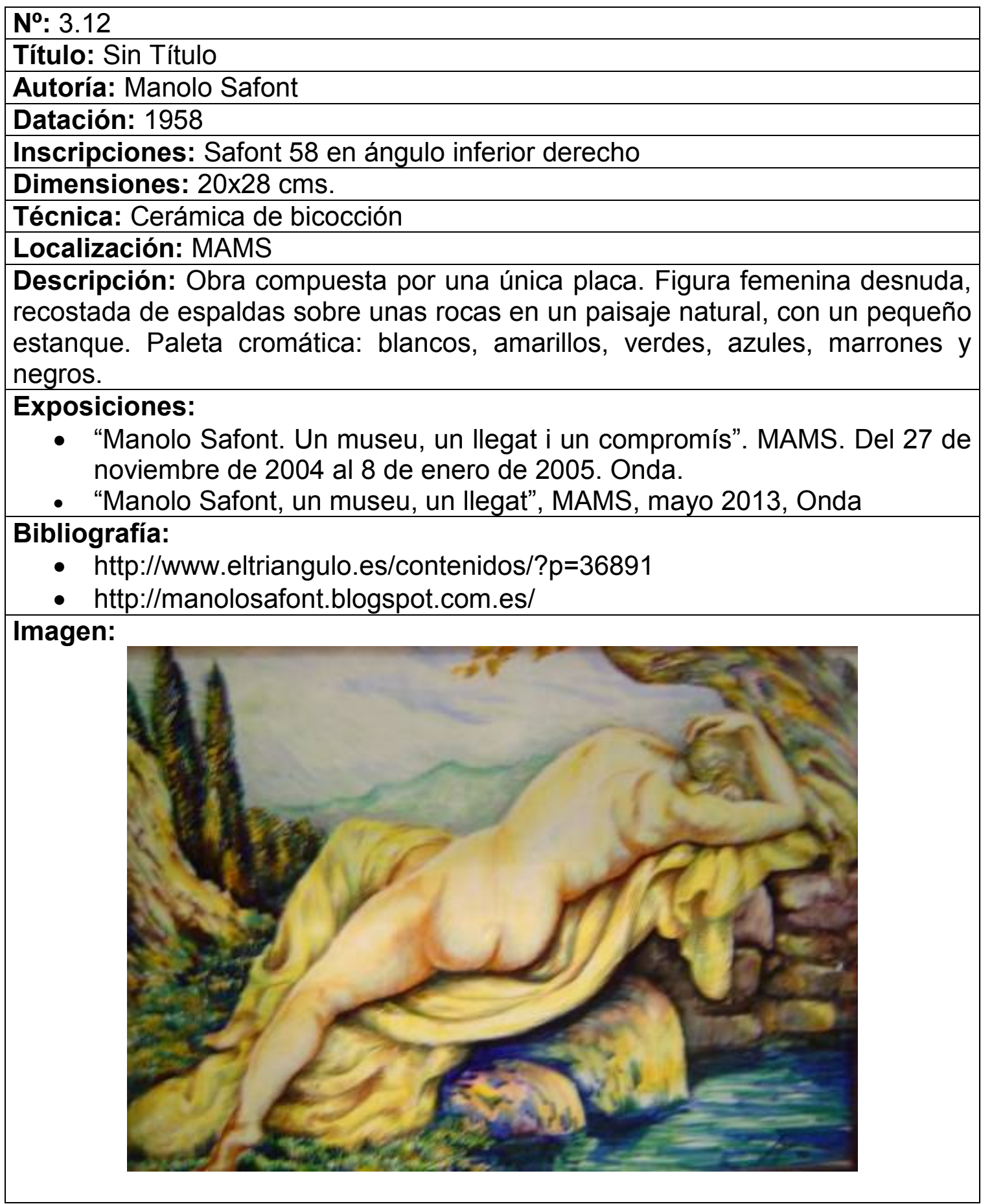


$\mathbf{N}^{0}: 3.13$

Título: Sin Título

Autoría: Manolo Safont

Datación: 1958

Inscripciones: Safont ONDA en zona inferior derecha

Dimensiones: $14 \times 14 \mathrm{cms}$.

Localización: MAMS

Descripción: Obra compuesta por una única placa. Representación de perfil de la cabeza de un perro pastor alemán sobre fondo rojo. Paleta cromática: blancos, rojos, marrones y negros.

Exposiciones:

- "Manolo Safont. Un museu, un llegat i un compromís". MAMS. Del 27 de noviembre de 2004 al 8 de enero de 2005. Onda.

- "Manolo Safont, un museu, un llegat", MAMS, mayo 2013, Onda

\section{Bibliografía:}

- http://www.eltriangulo.es/contenidos/?p=36891

- http://manolosafont.blogspot.com.es/

\section{Imagen:}

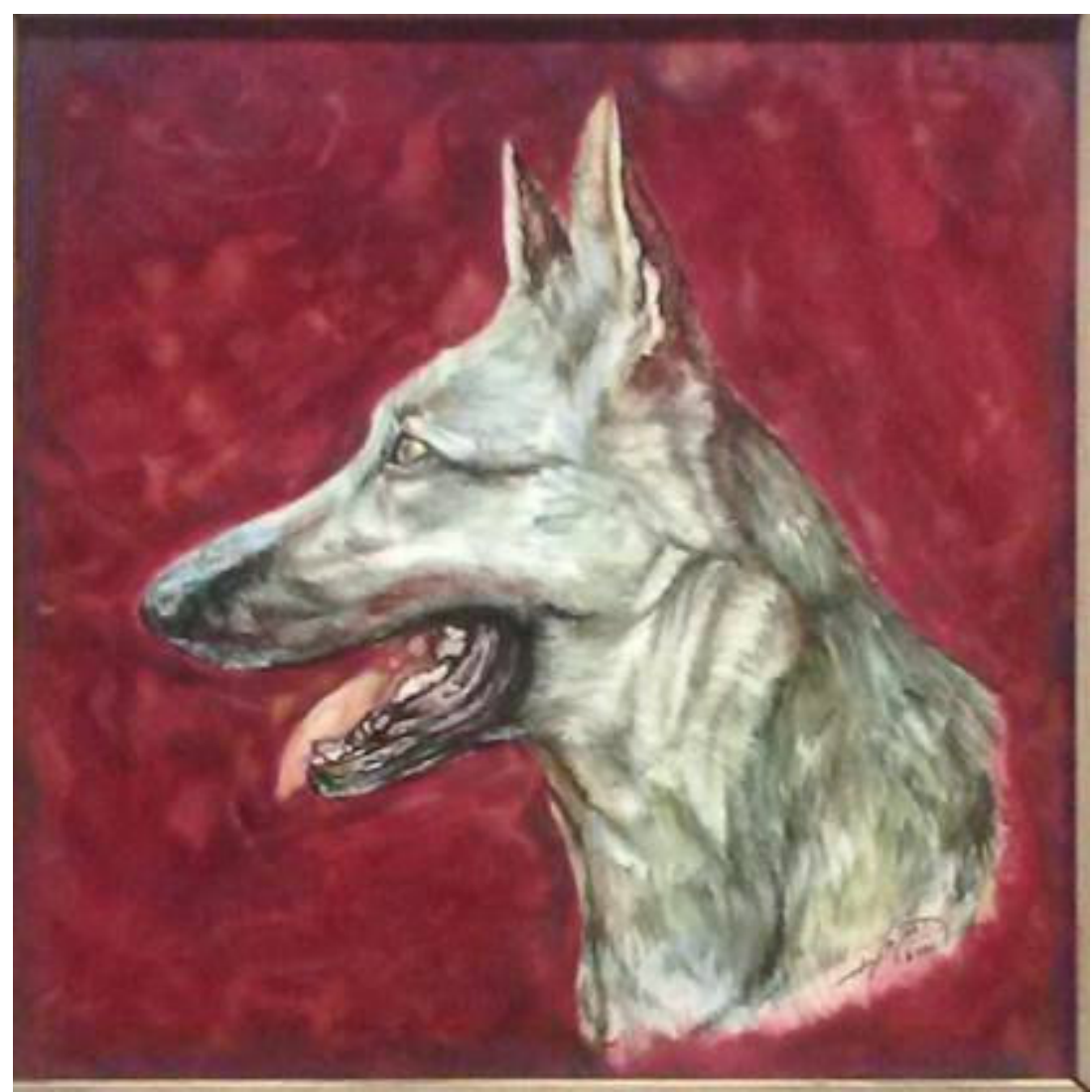


$\mathbf{N}^{0}: 3.14$

Título: Sin Título

Autoría: Manolo Safont

Datación: 1958

Inscripciones: Safont 58 en ángulo inferior derecho

Dimensiones: $20 \times 30 \mathrm{cms}$.

Técnica: Cerámica de bicocción

Tema: Paisaje

Localización: MAMS

Descripción: Pintura cerámica realizada con la técnica de dibujo a plumilla que representa una vista parcial del calvario de Onda (Castellón). Paleta cromática: blancos y negros.

\section{Exposiciones:}

- "Manolo Safont. Un museu, un llegat i un compromís". MAMS. Del 27 de noviembre de 2004 al 8 de enero de 2005. Onda.

- "Manolo Safont, un museu, un llegat", MAMS, mayo 2013, Onda

\section{Bibliografía:}

- OLUCHA, Ferrán. "Manolo Safont. Un museu, un llegat i un compromís". MAMS. Del 27 de noviembre de 2004 al 8 de enero de 2005. Onda.

- http://www.eltriangulo.es/contenidos/?p=36891

- http://manolosafont.blogspot.com.es/

\section{Imagen:}

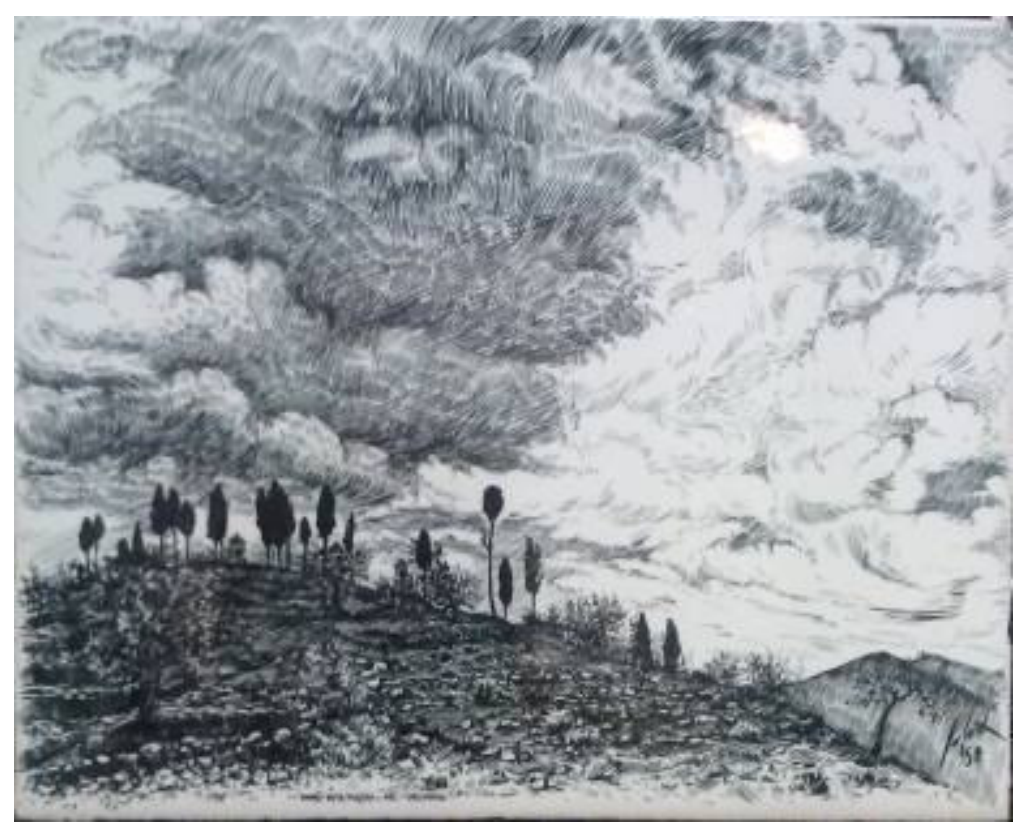


$\mathbf{N}^{0}: 3.15$

Título: Sin Título

Autoría: Manolo Safont

Datación: 1958

Inscripciones: Safont 58 en ángulo inferior derecho

Dimensiones: $20 \times 15 \mathrm{~cm}$

Técnica: Cerámica de bicocción

Localización: Colección privada $n^{0} 16$. Onda

Descripción: Obra compuesta por una única placa. Representación de una figura masculina, con un saco sobre el hombro derecho. Esta obra junto con la obra catalogada $n^{\circ} 3.8$, realizada cuatro años antes, y las obras catalogadas $n^{\circ} 3.16$ y $n^{\circ} 3.17$, formaría parte de las series que Safont vendía a las tiendas de cerámica artística. Presenta un defecto de cocción en el ángulo superior derecho, con una lasca de bizcochado adherido a la pieza. Cerámica a plumilla. Paleta cromática: blancos y negros.

Bibliografía:

- http://www.eltriangulo.es/contenidos/?p=36891

- http://manolosafont.blogspot.com.es/

Imagen:

Imágenes relacionadas:

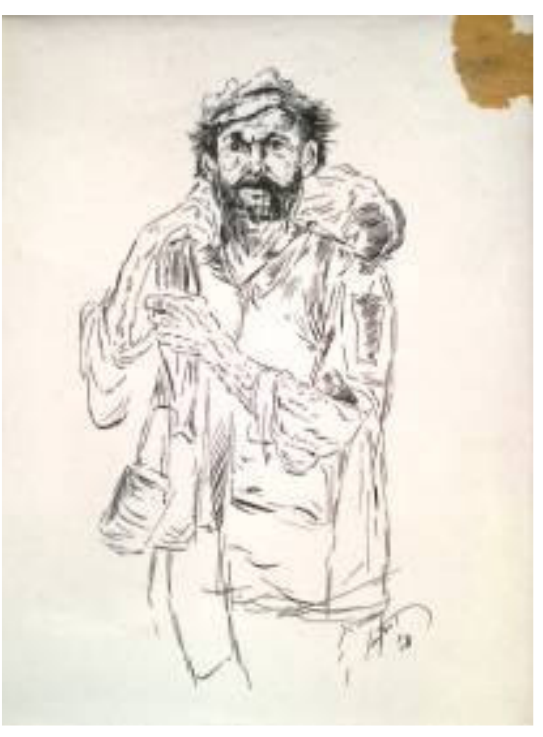

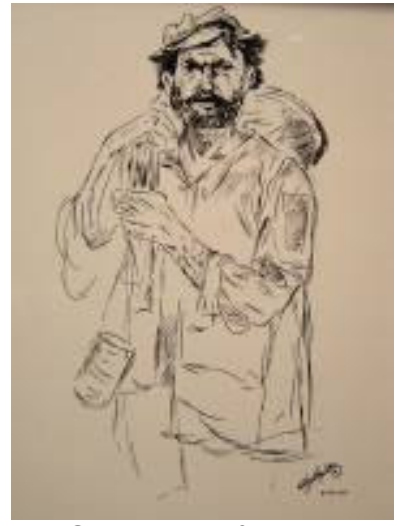

Obra cat. $n^{0} 3.8$

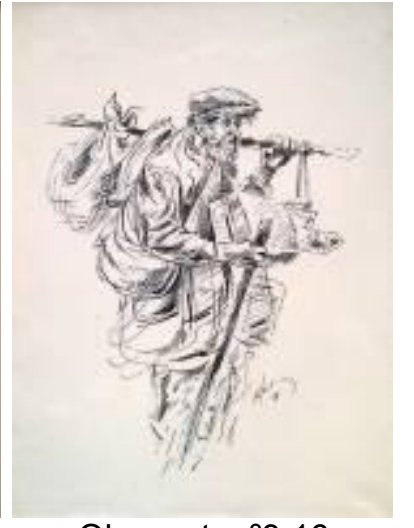

Obra cat. $n^{\circ} 3.16$ 


\begin{tabular}{|l|}
\hline No: 3.16 \\
\hline Título: Sin Título \\
\hline Autoría: Manolo Safont \\
\hline Datación: 1958 \\
\hline Inscripciones: Safont 58 en zona inferior derecha \\
\hline Dimensiones: 20x15 cm \\
\hline Técnica: Cerámica de bicocción \\
\hline Localización: Colección privada n'16. Onda \\
\hline Descripción: Obra compuesta por una única placa. Representación de una \\
figura masculina, un mendigo, con un hatillo sobre el hombro izquierdo. Esta \\
obra junto con las obras catalogadas n⿳3.8, n⿳3.15 y n⿳3.17, formaría parte de \\
las series que Safont vendía a las tiendas de cerámica artística. Cerámica a \\
plumilla. Paleta cromática: blancos y negros. \\
\hline Imagen: \\
\hline
\end{tabular}


$\mathbf{N}^{0}: 3.17$

Título: Sin Título

Autoría: Manolo Safont

Datación: 1958 aproximadamente

Inscripciones: Safont en ángulo inferior izquierdo

Dimensiones: $23 \times 15,5 \mathrm{cms}$.

Técnica: Cerámica de bicocción

Localización: Colección privada $n^{0} 16$. Onda

Descripción: Obra compuesta por una única placa. Representación de una escena costumbrista, en la que un grupo de mujeres y hombres llenan cántaros del agua de una fuente. Cerámica a plumilla. Carece de año de datación pero al pertenecer a la misma colección privada que las obras $n^{\circ} 3.15$ y n³.16, correspondiéndose con ésta en estilo y forma, y según datos proporcionados por la propietaria de que fueron adquiridas a la vez, utilizamos este dato para datarla alrededor de 1958. Paleta cromática: blancos y negros.

Imagen:

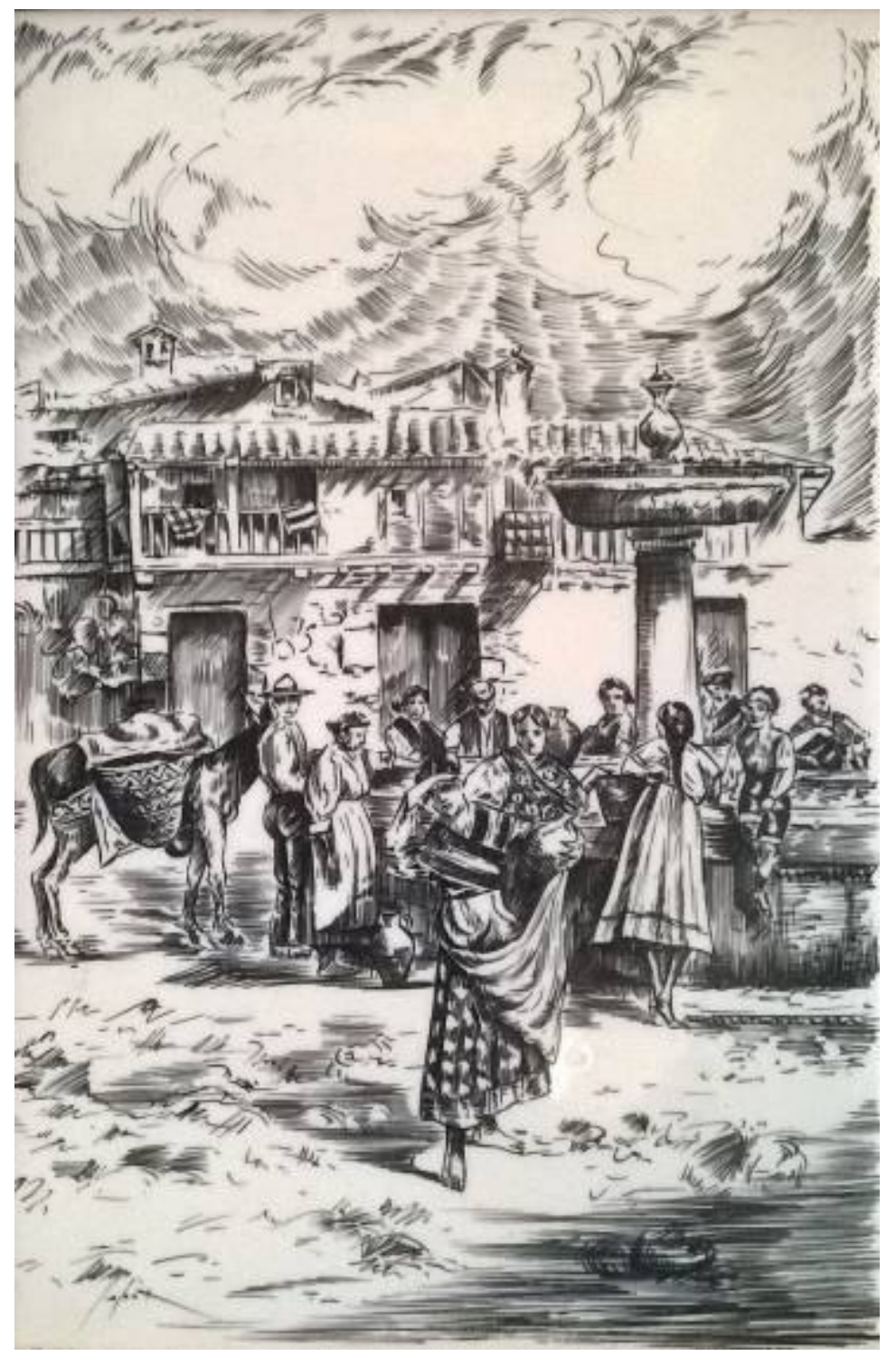


$\mathbf{N}^{0}: 3.18$

Título: Ángel portador de custodia

Autoría: Manolo Safont

Datación: 1959 aproximadamente

Técnica: Cerámica polícroma

Localización: Colección privada $n^{07}$, Vila-Real.

Descripción: Obra compuesta por una única placa. Representación de un ángel que lleva entre sus manos una custodia con la Sagrada Forma. Paleta cromática: blancos, rojos y marrones.

Exposiciones:

- Magnificat, nuevas metáforas de lo sagrado. Sala San Miguel, Fundación Caja Castellón. 15 abril - 30 mayo 2014, Castellón de la Plana Imagen:

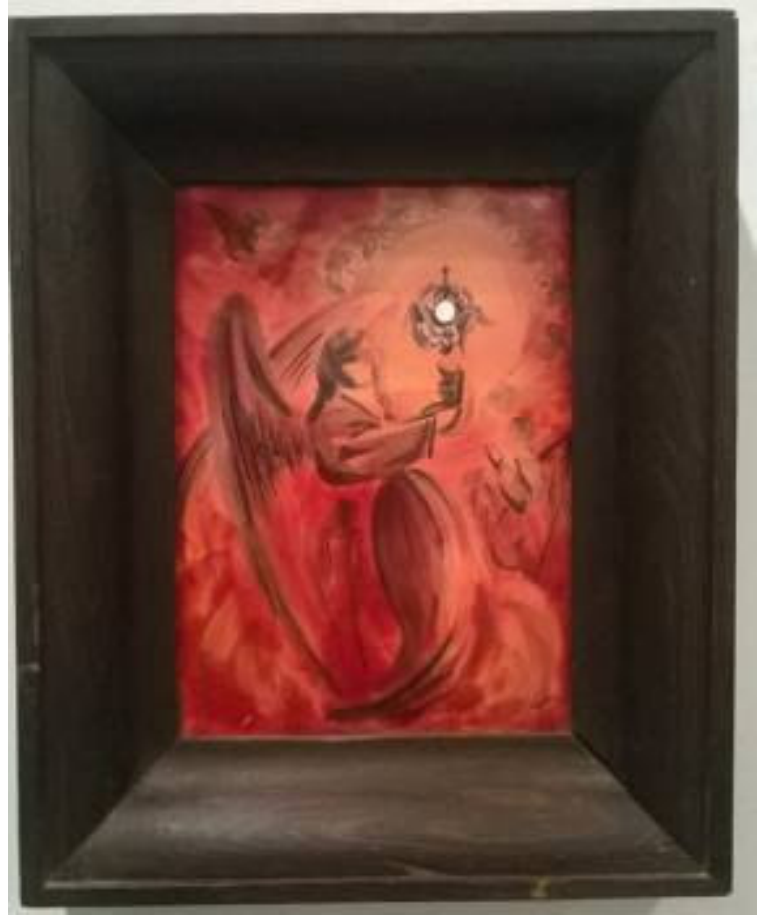

Imágenes relacionadas:

Manolo Safont

(Onda, 1928-2005)

ANGEL PORTADOR DE CUSTODIA

Cenimica policroma, ca.1959

Colección Vicent Llorens Gil

Cartela obra en exposición Magnificat 
$\mathbf{N}^{\circ}: 3.19$

Título: Sin Título

Autoría: Manolo Safont

Datación: Finales década 1950 - Inicio década 1960

Técnica: Pintura cerámica

Descripción: Obra compuesta por 12 placas del mismo tamaño, en disposición 4x3. Representación de San José y el niño Jesús en el taller de la carpintería. Composición figurativa de temática religiosa en la que se observa esquematización de las formas. Tan sólo hemos podido conseguir una imagen en blanco y negro de la obra, por lo que resulta imposible establecer la paleta cromática.

\section{Bibliografía:}

- http://manolosafont.blogspot.com.es

\section{Imagen:}

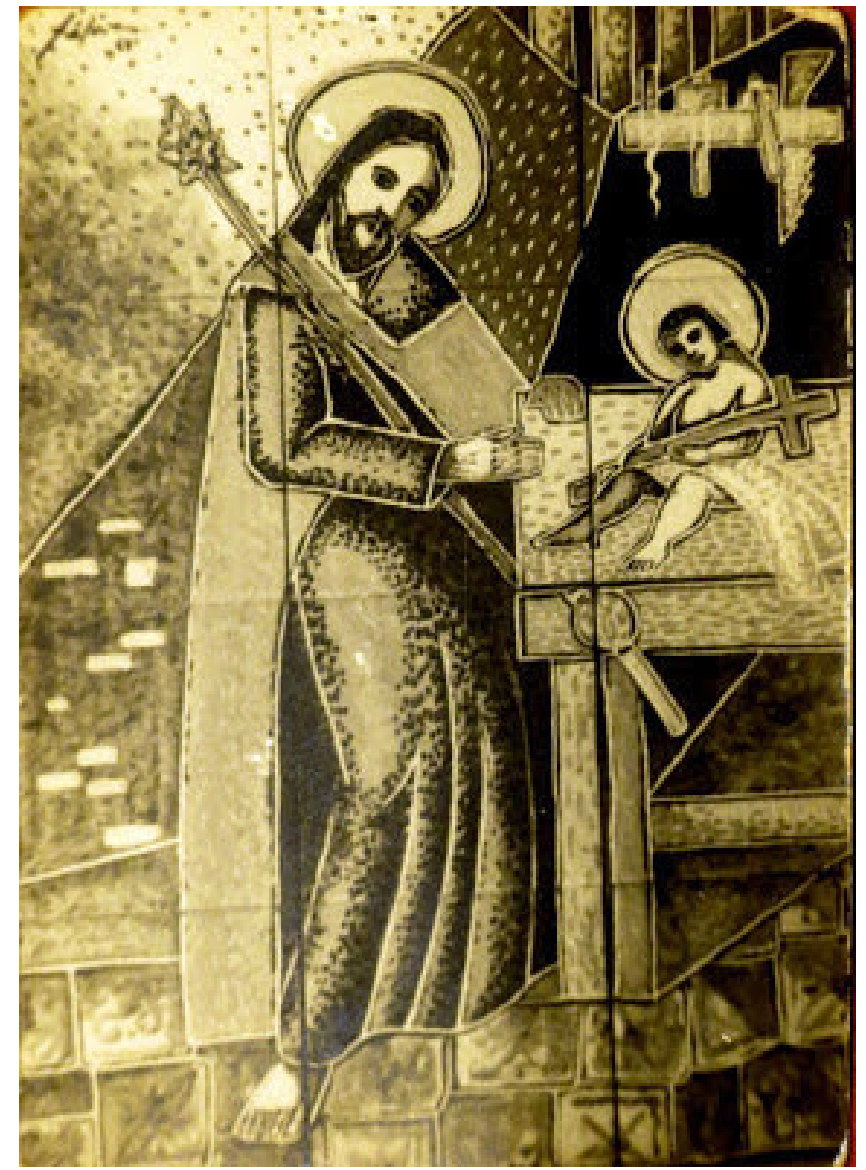


No: 3.20

Título: Sin Título

Autoría: Manolo Safont

Datación: Final década 1950

Técnica: Pintura cerámica

Localización: Colección privada $n^{\circ} 5$. Castellón de la Plana

Descripción: Rostro de egipcia de perfil, mirando a la derecha, sobre fondo rugoso. Forma pareja con la obra catalogada $n^{\circ}$ 3.21. Paleta cromática: blancos, ocres, azules, marrones y negros.

Bibliografía:

- http://manolosafont.blogspot.com.es

Imagen:

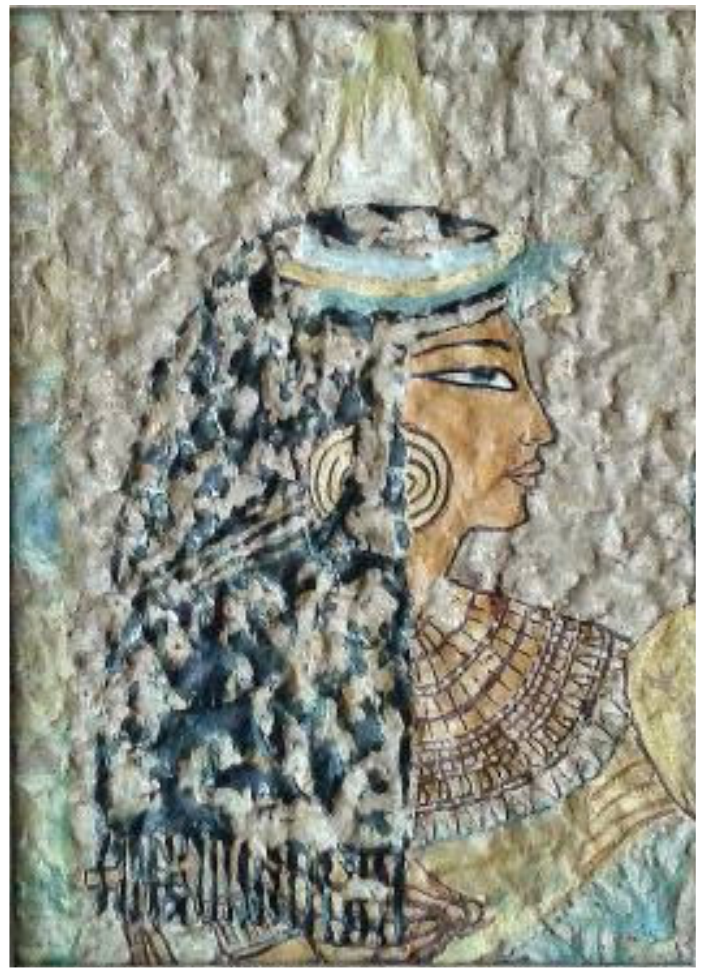

Imágenes relacionadas:

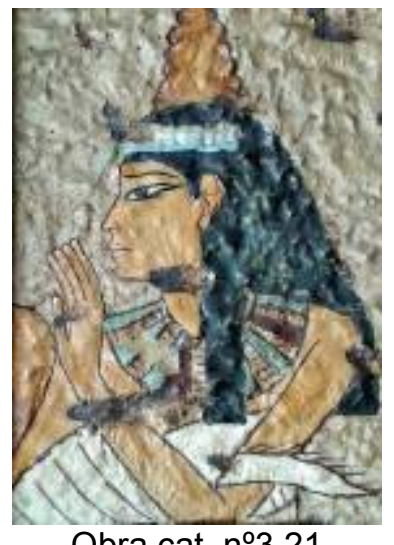

Obra cat. n³.21 
$\mathbf{N}^{0}: 3.21$

Título: Sin Título

Autoría: Manolo Safont

Datación: Final década 1950

Técnica: Pintura cerámica

Localización: Colección Particular 5, Castellón de la Plana

Descripción: Rostro de egipcia, de perfil, mirando a la izquierda, sobre fondo

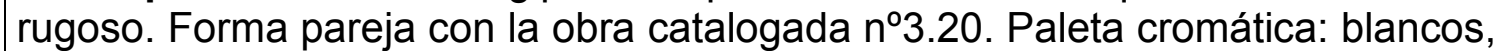
ocres, azules, marrones y negros.

Bibliografía:

- http://manolosafont.blogspot.com.es/

Imagen:

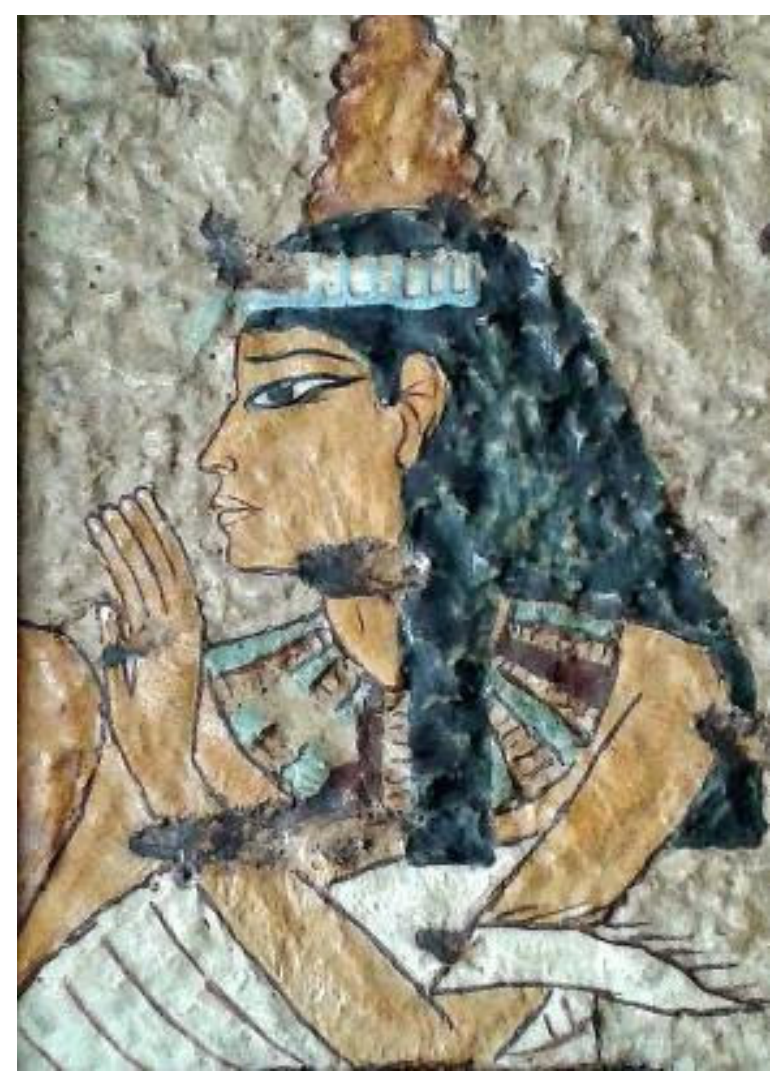

Imágenes relacionadas:

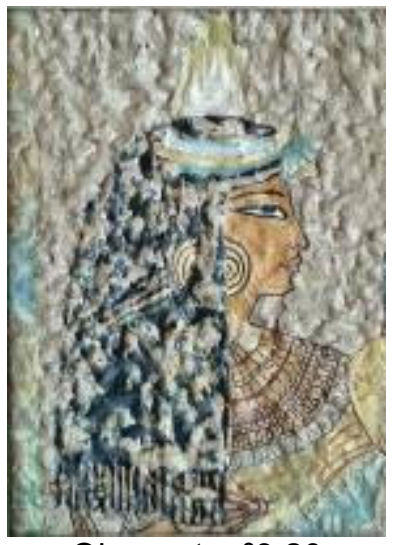

Obra cat. $n^{\circ} 3.20$ 
$\mathbf{N}^{0}: 3.22$

Título: Sin Título

Autoría: Manolo Safont

Datación: 1961

Inscripciones: Safont 61 en zona inferior derecha

Técnica: Pintura cerámica

Localización: Colección privada $\mathrm{n}^{\circ} 5$. Castellón de la Plana

Descripción: Obra compuesta por varias placas, realizada imitando el estilo de las pinturas rupestres, sobre un fondo de color terroso y rugoso que recuerda las paredes de las cuevas prehistóricas, con representación de figuras humanas y animales realizadas en color rojizo. En esta composición observamos piezas fragmentadas $y$ tal como se indica en http://manolosafont.blogspot.com.es, algunas de estas piezas parecen no corresponderse con el conjunto, si seguimos el dibujo de toda la composición, por lo que podría tratarse de los restos de una obra de mayor tamaño, que debió tener algún problema de cocción, lo cual pudo haber supuesto la pérdida de un número indeterminado de piezas y su reutilización formando una composición de un formato menor, aunque consiguiendo mantener un conjunto armónico y agradable a la vista. Esto podría explicar también la extraña ubicación de la firma, aparentemente impropia. El cuadro, a pesar de todo, es una pieza de enorme calidad y buen ejemplo de sus pinturas rupestres. Paleta cromática: rojos, verdes, marrones y negros.

\section{Bibliografía:}

- http://manolosafont.blogspot.com.es

\section{Imagen:}

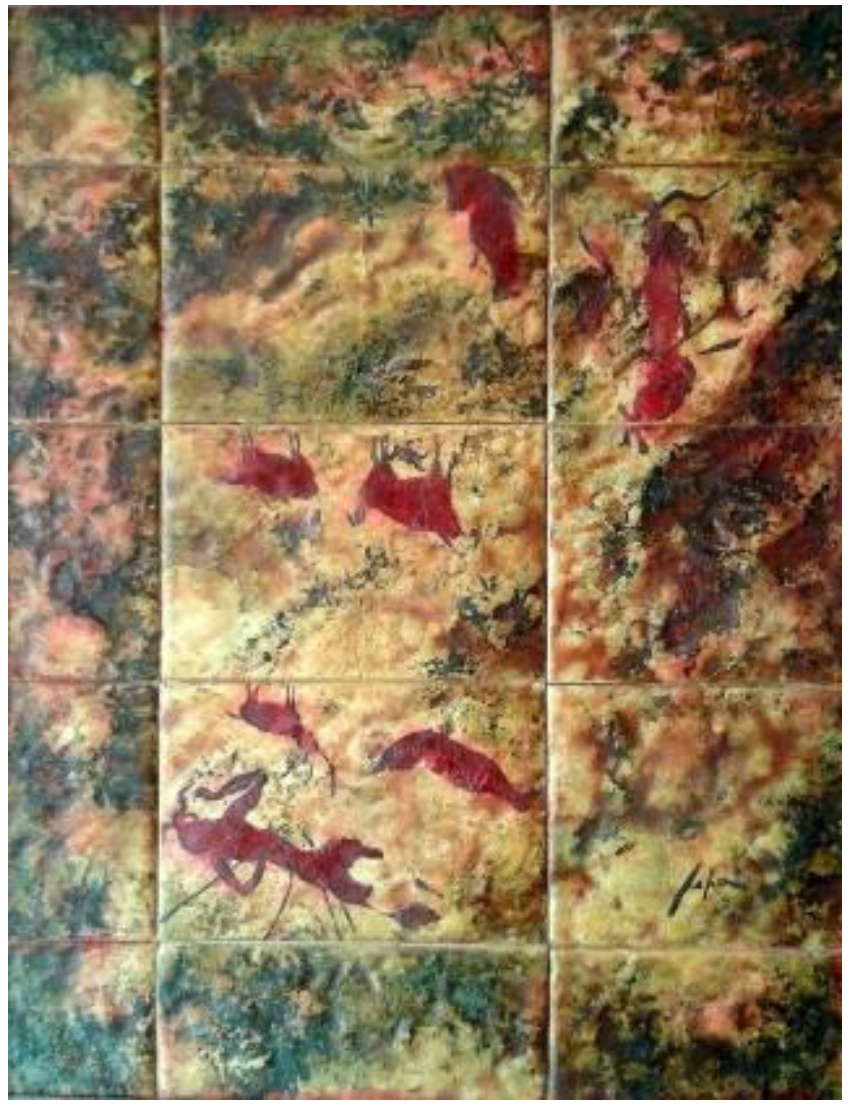




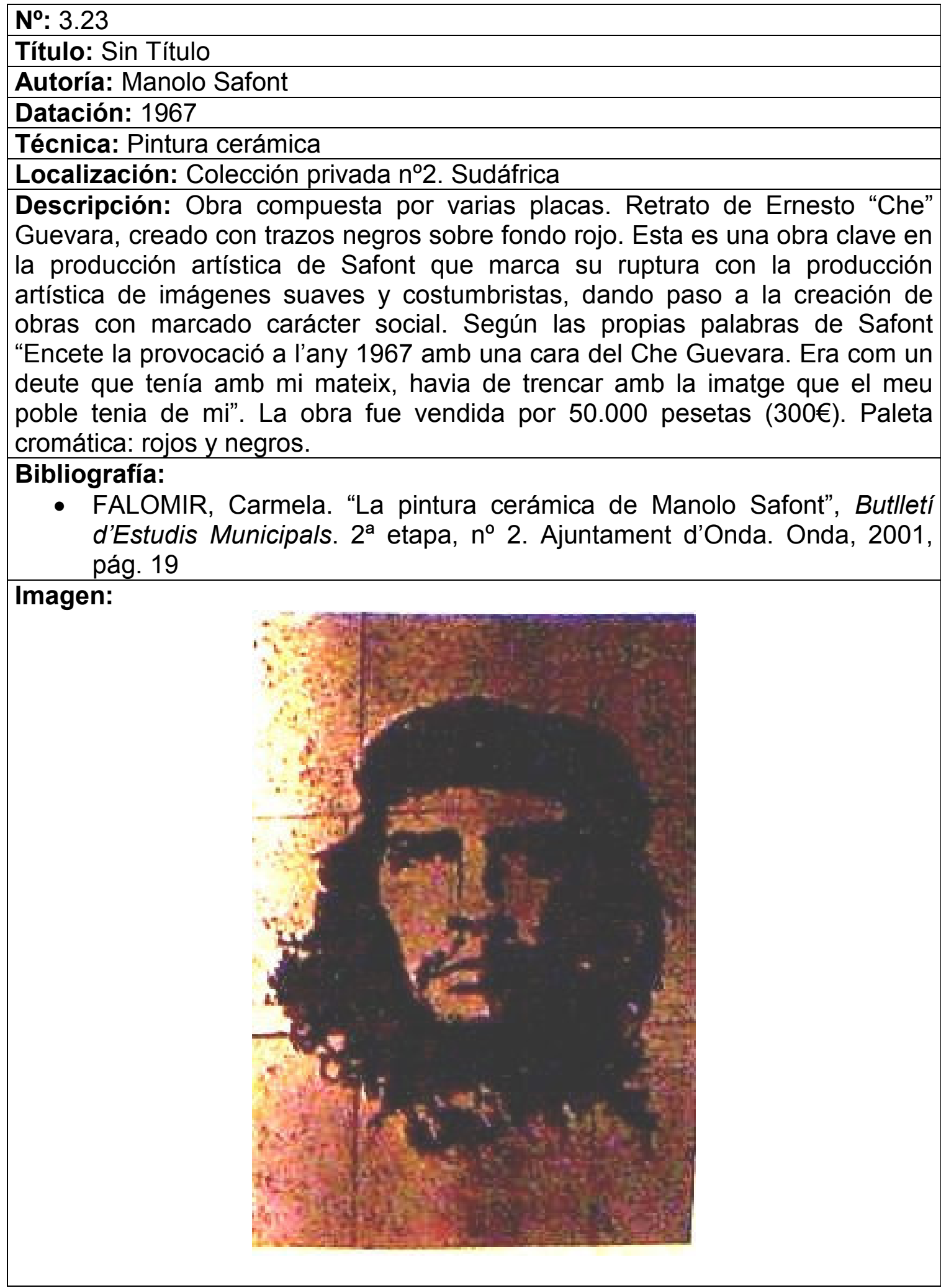




\begin{tabular}{|l|}
\hline No: 3.24 \\
\hline Título: Sin Título \\
\hline Autoría: Manolo Safont \\
\hline Datación: Anterior a 1983 \\
\hline Inscripciones: FIRA D'ONDA y en placa metálica: AYUNTAMIENTO DE \\
ONDA. JOCS ESCOLARS. PARTICIPANT. OCTUBRE 1983" \\
\hline Dimensiones: 18x25 cms \\
\hline Técnica: Pintura cerámica \\
\hline Localización: CEIP PíO XII, Onda, Castellón \\
\hline Descripción: Obra compuesta por una única placa. Placa conmemorativa del \\
Ayuntamiento de Onda, entregada a los centros escolares de la población por \\
su participación en los Juegos Escolares realizados en Octubre de 1983. Se \\
entregó una placa por cada una de las diferentes disciplinas deportivas en las \\
que participó cada centro, y en el caso del CEIP PíO XII, se enmarcaron \\
conjuntas las tres placas recibidas, conformando una única obra de 62,5x29 \\
cms. Para la realización de esta placa conmemorativa se utilizó un diseño que \\
realizó Safont en 1961, obra catalogada con el no2.19 y muy similar a la obra \\
catalogada no2.20, para la celebración de la Fira d'Onda. Representa un pasaje \\
urbano de Onda, en el que se distinguen el castillo, las chimeneas de las \\
fábricas cerámicas, los arcos de la plaza porticada de la Font de Dins, la iglesia \\
de Ntra. Sra de la Asunción, piezas cerámicas de alfarería así como el escudo \\
de Onda. Paleta cromática: blancos, amarillos, rojos, azules y marrones. \\
\hline Imagen: \\
\hline \\
\hline
\end{tabular}


Imágenes relacionadas:

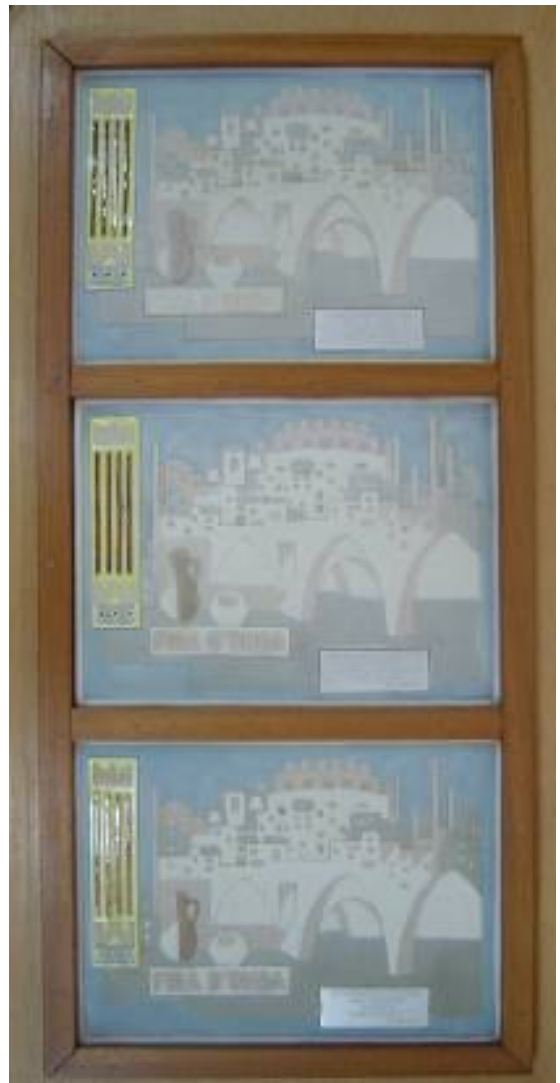

Pieza enmarcada compuesta por tres placas

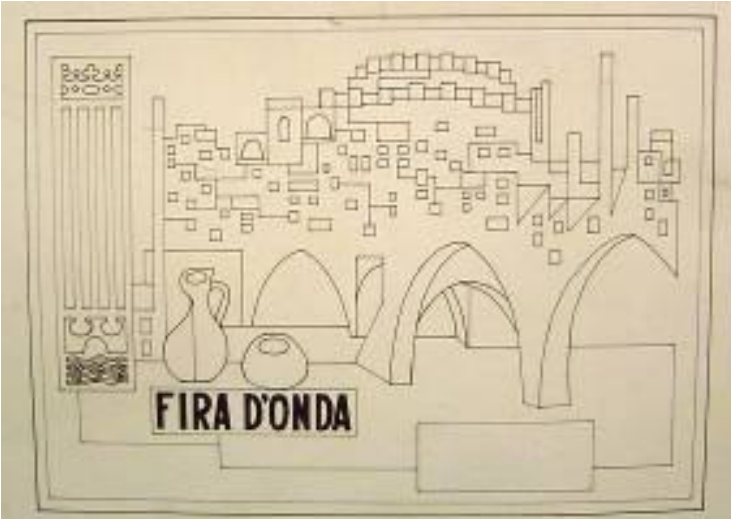

Obra cat. $n^{\circ} 2.19$

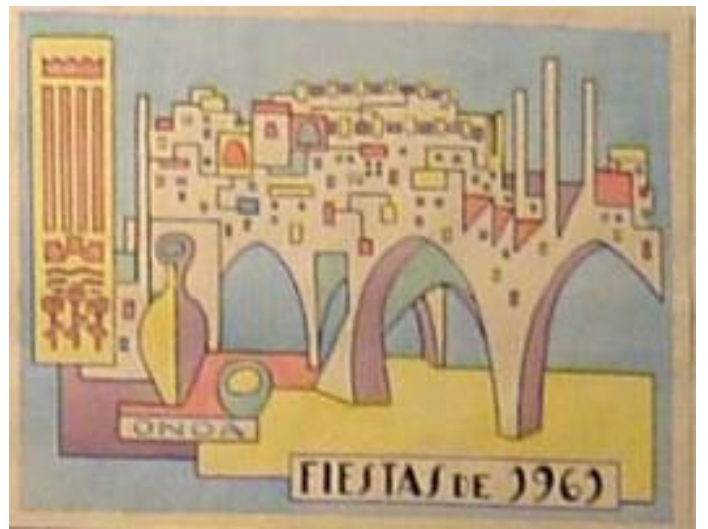

Obra cat. $n^{0} 2.20$ 


\section{4.- FICHAS CATALOGRÁFICAS: OBRAS DE LA ETAPA DE TRANSICIÓN DE LA FIGURACIÓN A LA ABSTRACCIÓN}

Desde 1952, Safont abandona progresivamente el estilo realista tradicional de la pintura cerámica y su obra se ve influenciada por diferentes corrientes y estilos artísticos con los que experimenta, y gracias a los cuales evoluciona.

En sus obras podemos apreciar desde la influencia de Modigliani, con sus retratos femeninos de caras alargadas, cuellos estilizados, ojos almendrados y bocas pequeñas, como en la obra catalogada $n^{\circ} 4.7$; o la influencia de la cerámica picasiana, como se observa en el plato de cerámico de la obra catalogada $n^{\circ} 4.2$; la influencia de Matisse, en la obra catalogada $n^{\circ} 4.3$ y la influencia de Braque en las obras catalogadas $n^{\circ} 4.8, n^{\circ} 4.10$ y $n^{\circ} 4.13$.

La evolución de Safont trascurre por la adaptación de estos estilos artísticos a sus propias obras cerámicas para llegar a desarrollar un estilo propio, en su transición hacia su etapa abstracta, en el que destacan las figuras mutiladas, fusiladas, de grandes ojos y miradas perdidas, enrolladas entre alambradas de espino u ocultas tras gruesos muros, que denuncian la opresión social, cultural y política de la España de las décadas de 1960 y 1970.

Con la llegada de la democracia a España, Safont abandonará esta pintura de denuncia social para sumergirse por completo en su periodo de abstracción.

En este cuarto capítulo del catálogo general, analizamos 39 obras de Safont, catalogadas desde el $n^{\circ} 4.1$ al $n^{\circ} 4.39$.

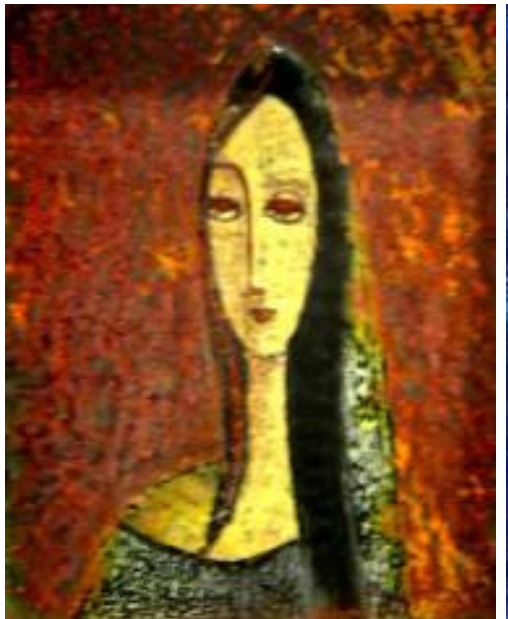

Figura 155

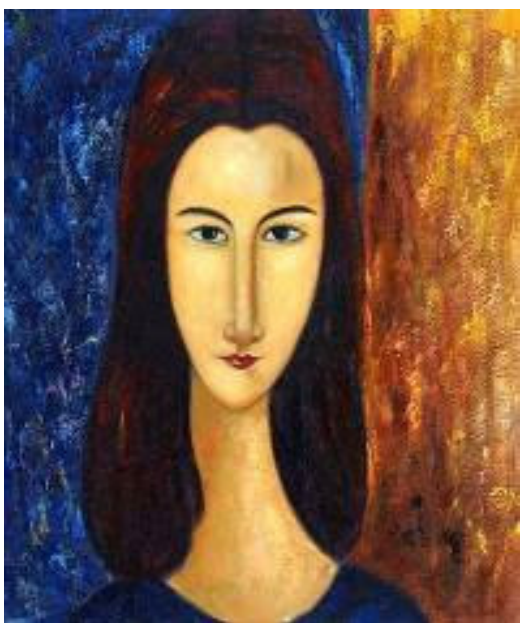

Figura 156

Figura 155: Sin Título. Safont. Obra cat. $n^{\circ} 4.7$

Figura 156: Retrato de Jeanne Hebuterne. Modigliani 


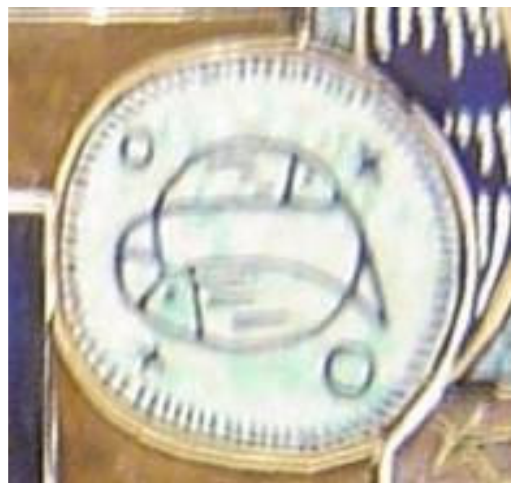

Figura 157

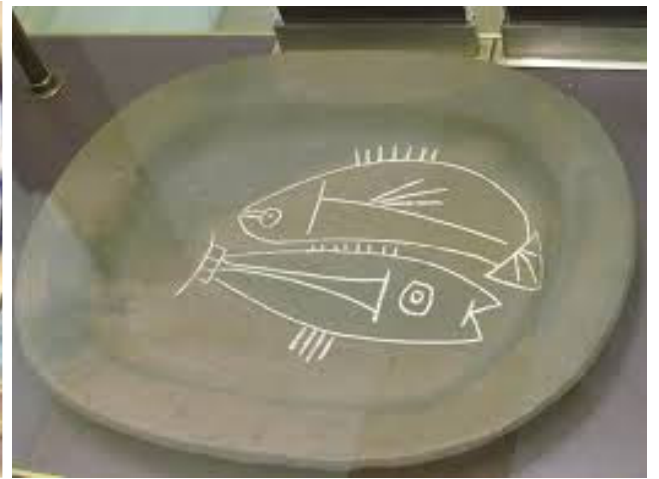

Figura 158

Figura 157: Fragmento obra cat. $n^{\circ} 4.2$. Safont, Figura 158: Plato cerámico. Picasso.

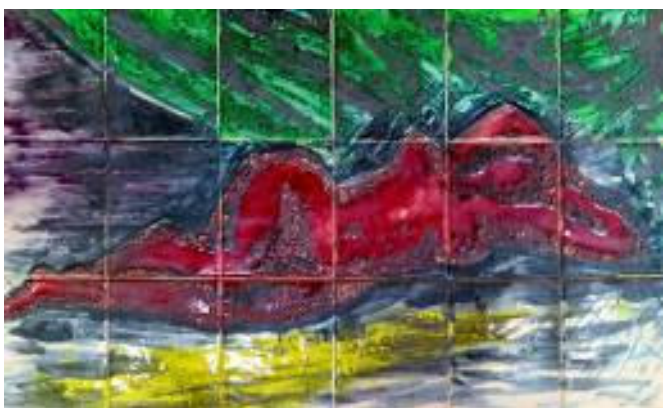

Figura 159

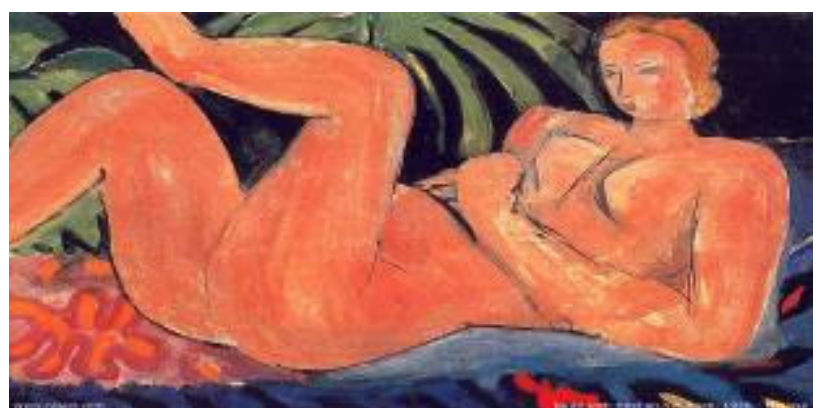

Figura 160

Figura 159: Obra cat. $n^{\circ} 4.3$. Safont.

Figura 160: Desnudo yaciente. Henry Matisse.

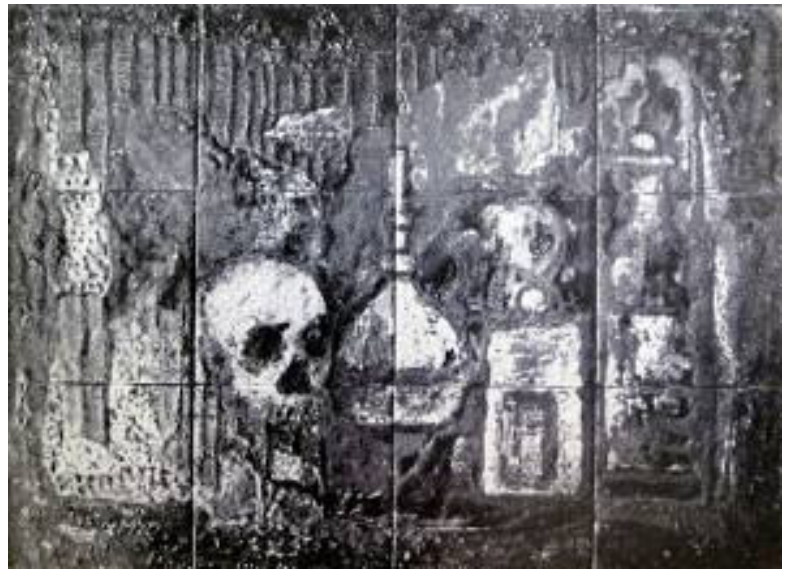

Figura 161

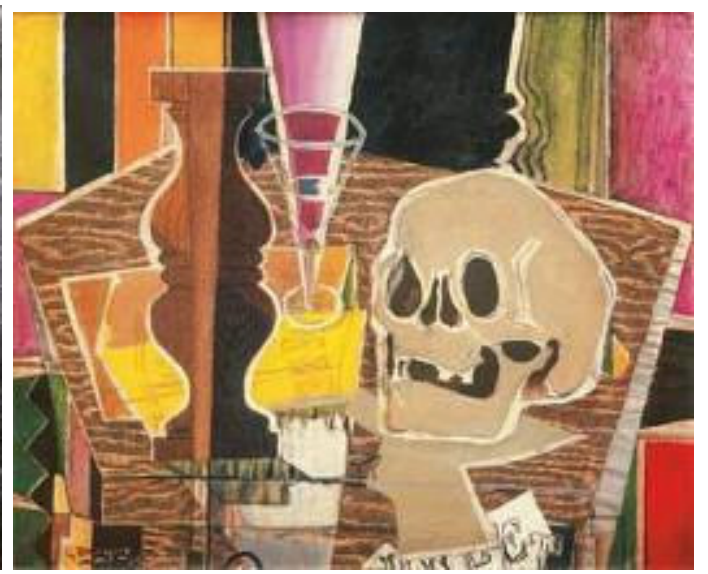

Figura 162

Figura 161: Obra cat. n4.8. Safont

Figura 162: Balaustres y cráneo, Georges Braque. 


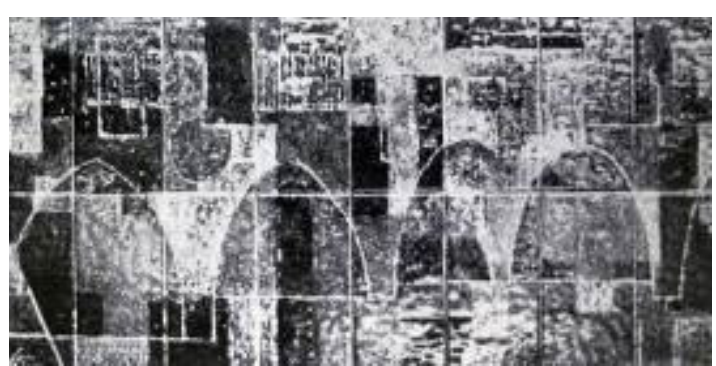

Figura 163

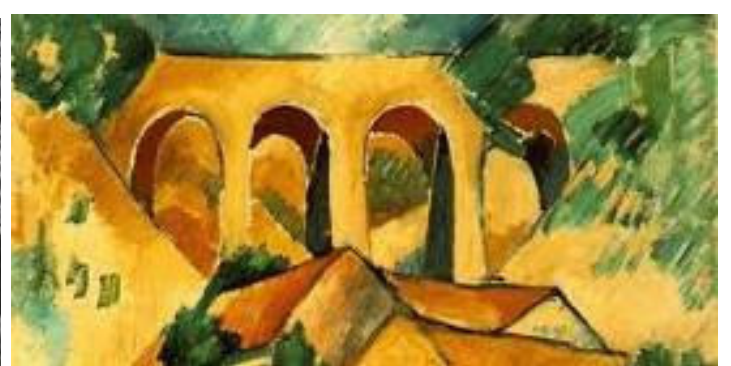

Figura 164

Figura 163: Obra cat. $\mathrm{n}^{\circ} 4.10$. Safont

Figura 164: Viaducto en L'Estaque, Georges Braque.

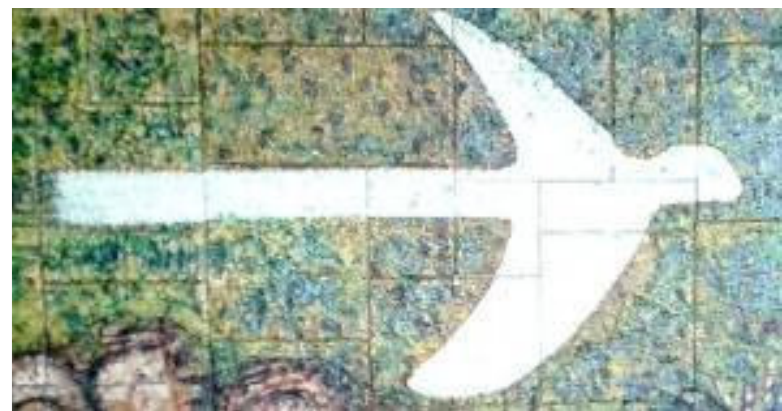

Figura 165

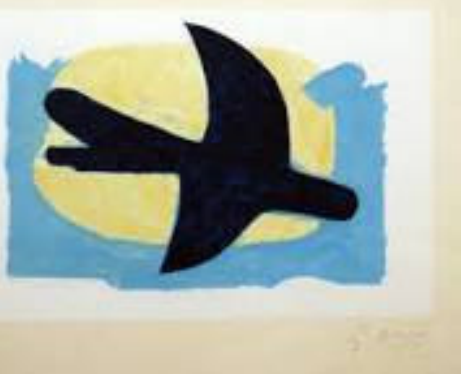

Figura 166

Figura 165: Fragmento obra cat. $n^{\circ} 4.13$. Safont

Figura 166: Pájaro azul y amarillo. Braque 
No: 4.1

Título: Sin Título

Autoría: Manolo Safont

Datación: 1952

Inscripciones: Safont 52 en ángulo inferior derecho

Dimensiones: 80x60 cms.

Técnica: Cerámica de bicocción

Localización: MAMS

Descripción: Obra compuesta por 12 azulejos en disposición 4x3, representación del torso de una figura, realizada con líneas y trazos sintéticos geométricos, con clara inspiración cubista. Paleta cromática: blancos, amarillos, rojos, verdes, marrones y negros.

Exposiciones:

- "Manolo Safont. Un museu, un llegat i un compromís". MAMS. Del 27 de noviembre de 2004 al 8 de enero de 2005. Onda

\section{Imagen:}

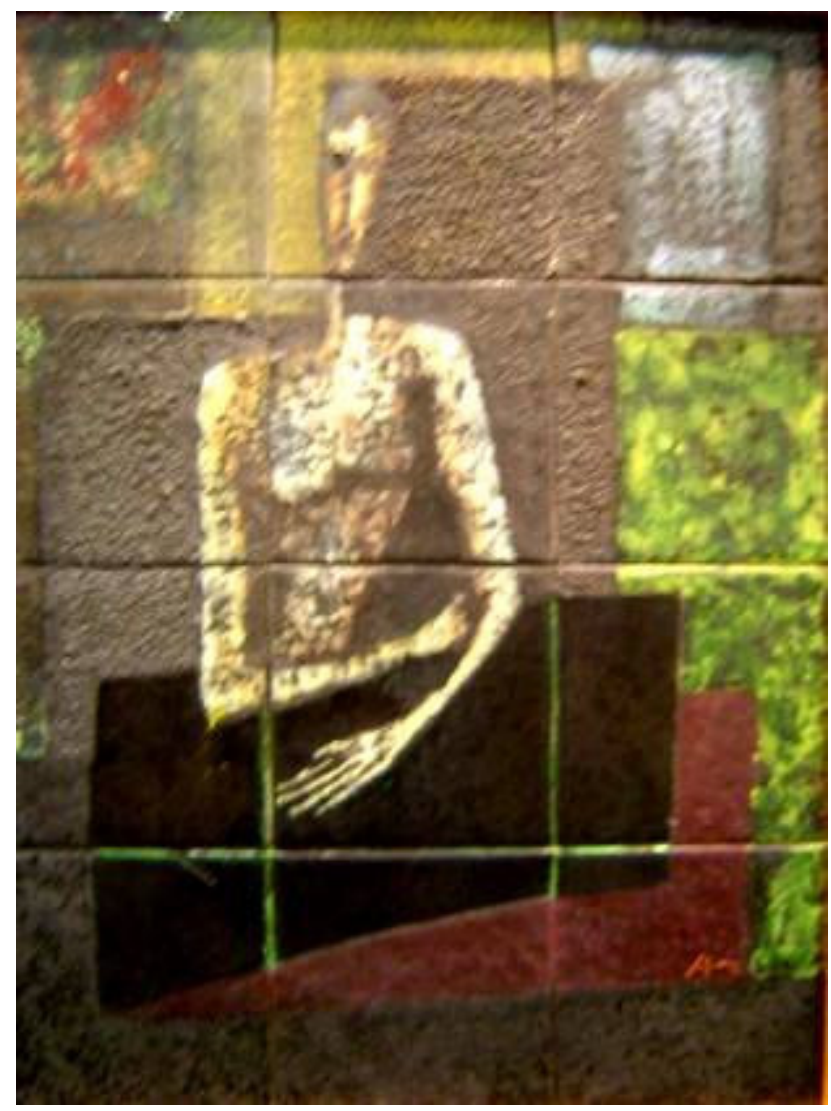


$\mathbf{N}^{0}: 4.2$

Título: Sin Título

Autoría: Manolo Safont

Datación: 1959

Inscripciones: Safont 59 en ángulo inferior derecho

Dimensiones: $41 \times 144 \mathrm{cms}$.

Técnica: Cerámica

Localización: MAMS

Descripción: Obra compuesta por numerosas placas de diferentes tamaños. Bodegón de estilo cubista que representa diferentes modelos de jarrones y platos cerámicos. Se conserva el boceto de la misma, realizado en 1956, obra catalogada $\mathrm{n}^{\circ} 2.2$. El estilo cubista de las piezas cerámicas representadas recuerda el empleado por Picasso en el diseño de sus piezas cerámicas, como el plato con dibujo de dos peces que se conserva en el Museo Nacional de Cerámica González Martí de Valencia. Paleta cromática: blancos, amarillos, ocres, rojos, verdes, marrones y negros.

Exposiciones:

- "Manolo Safont. Un museu, un llegat i un compromís". MAMS. Del 27 de noviembre de 2004 al 8 de enero de 2005. Onda.

\section{Bibliografía:}

- OLUCHA, Ferran. "Manolo Safont. Un museu, un llegat i un compromís". MAMS. Del 27 de noviembre de 2004 al 8 de enero de 2005. Onda.

Imagen:

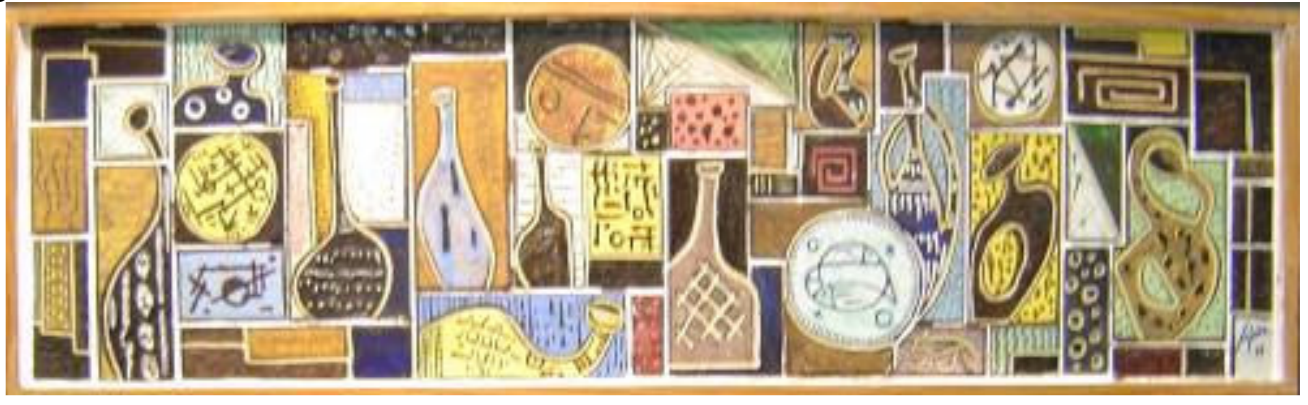

Imágenes relacionadas:

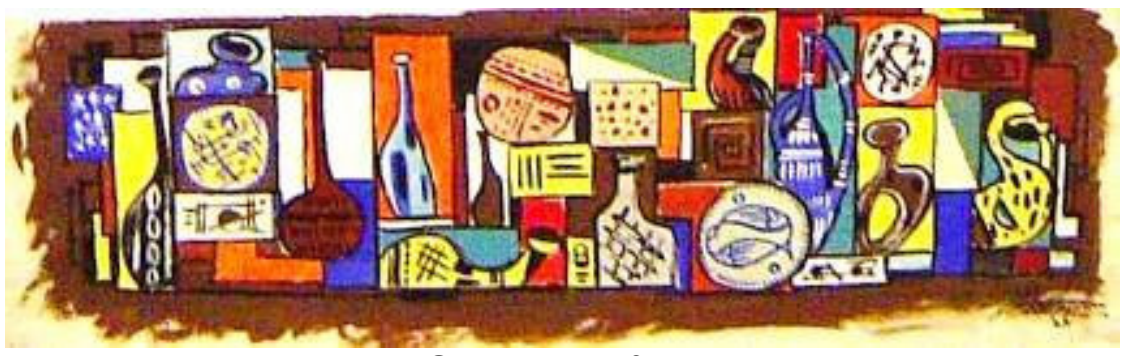

Obra cat. $n^{\circ} 2.2$

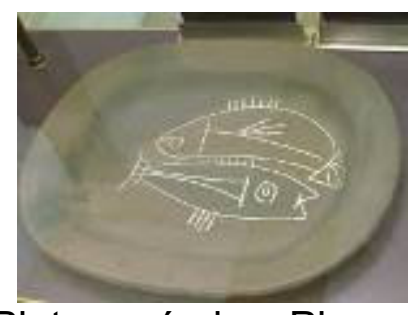

Plato cerámico. Picasso 


\begin{tabular}{l}
\hline No: 4.3 \\
\hline Título: Sin Título \\
\hline Autoría: Manolo Safont \\
Datación: 1959 \\
\hline Inscripciones: Safont 59 en ángulo inferior derecho \\
\hline Dimensiones: $30 \times 60 \mathrm{cms}$ \\
\hline Técnica: Pintura cerámica \\
Descripción: Obra compuesta por 18 placas de azulejos de $10 \times 10 \mathrm{cms}$. en \\
disposición 3x6. Figura femenina, desnuda, tumbada sobre su costado \\
izquierdo, en color rojo, con los brazos flexionados bajo la cabeza. Paleta \\
cromática: blancos, amarillos, rojos, verdes, azules, violetas y negros. \\
\hline Bibliografía: \\
http://manolosafont.blogspot.com.es/ \\
\hline Imagen: \\
\hline \\
\hline \\
\hline
\end{tabular}




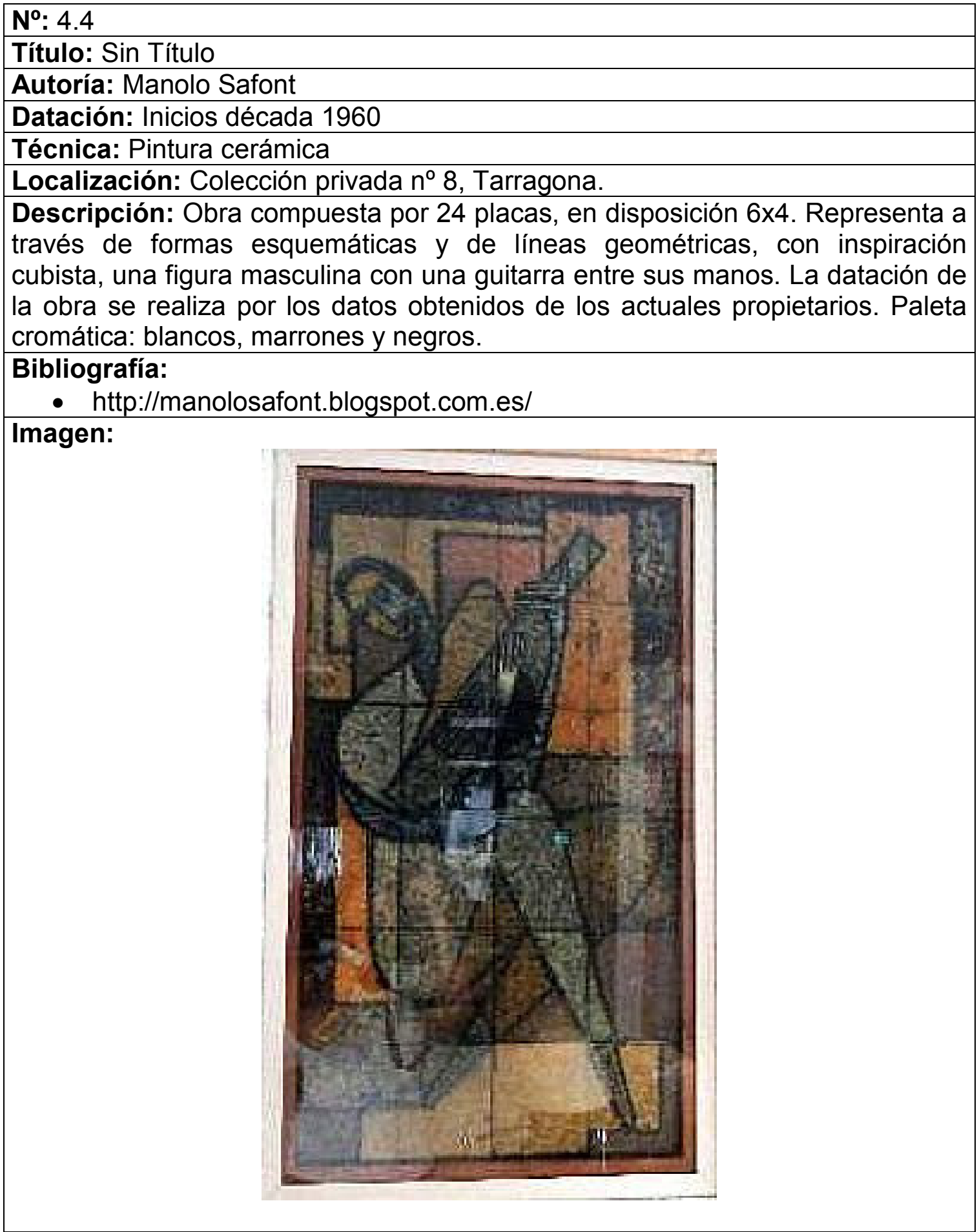




\begin{tabular}{|l|l|}
\hline No: 4.5 \\
\hline Título: Sin Título \\
\hline Autoría: Manolo Safont \\
\hline Datación: Inicios década 1960 \\
\hline Técnica: Pintura cerámica \\
\hline Descripción: Obra compuesta por 8 placas, en disposición 2x4. Tan sólo \\
hemos podido obtener una fotografía en blanco y negro por lo que resulta difícil \\
hacer una descripción completa de la pieza sin poder observar la paleta \\
cromática de la misma. Según consta en http://manolosafont.blogspot.com.es, \\
este bodegón pudo formar parte de la exposición que realizó Safont en la \\
galería Subex de Barcelona en 1974. Representación de siluetas entrelazadas \\
de diferentes tipos de botellas y perfiles de formas rectangulares, de inspiración \\
cubista. \\
\hline Bibliografía: \\
http://manolosafont.blogspot.com.es/
\end{tabular}


$\mathbf{N}^{0}: 4.6$

Título: Sin Título

Autoría: Manolo Safont

Datación: Inicios década 1960

Inscripciones: Safont en ángulo inferior izquierdo

Dimensiones: $45 \times 61 \mathrm{cms}$

Técnica: Pintura cerámica

Localización: MAMS

Descripción: Obra compuesta por 8 placas de azulejos, en la cual observamos la representación de un bodegón de líneas geométricas y estilo cubista, con dos botellas blancas y decoración con formas geométricas. Paleta cromática: blancos, ocres y marrones.

\section{Exposiciones:}

- "Manolo Safont. Un museu, un llegat i un compromís". MAMS. Del 27 de noviembre de 2004 al 8 de enero de 2005. Onda.

- "Manolo safont, un museu, un llegat", MAMS, mayo 2013, Onda

\section{Bibliografía:}

- http://www.eltriangulo.es/contenidos/?p=36891

- http://manolosafont.blogspot.com.es/

\section{Imagen:}

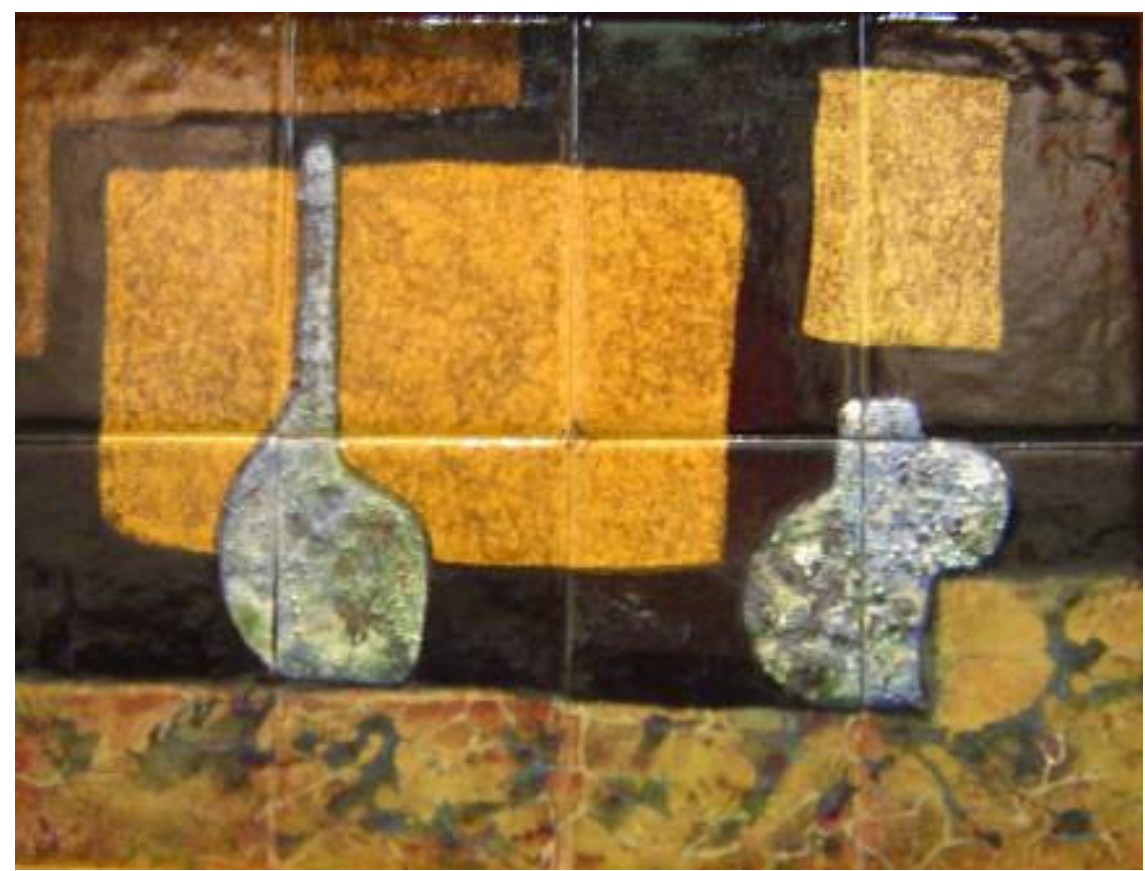




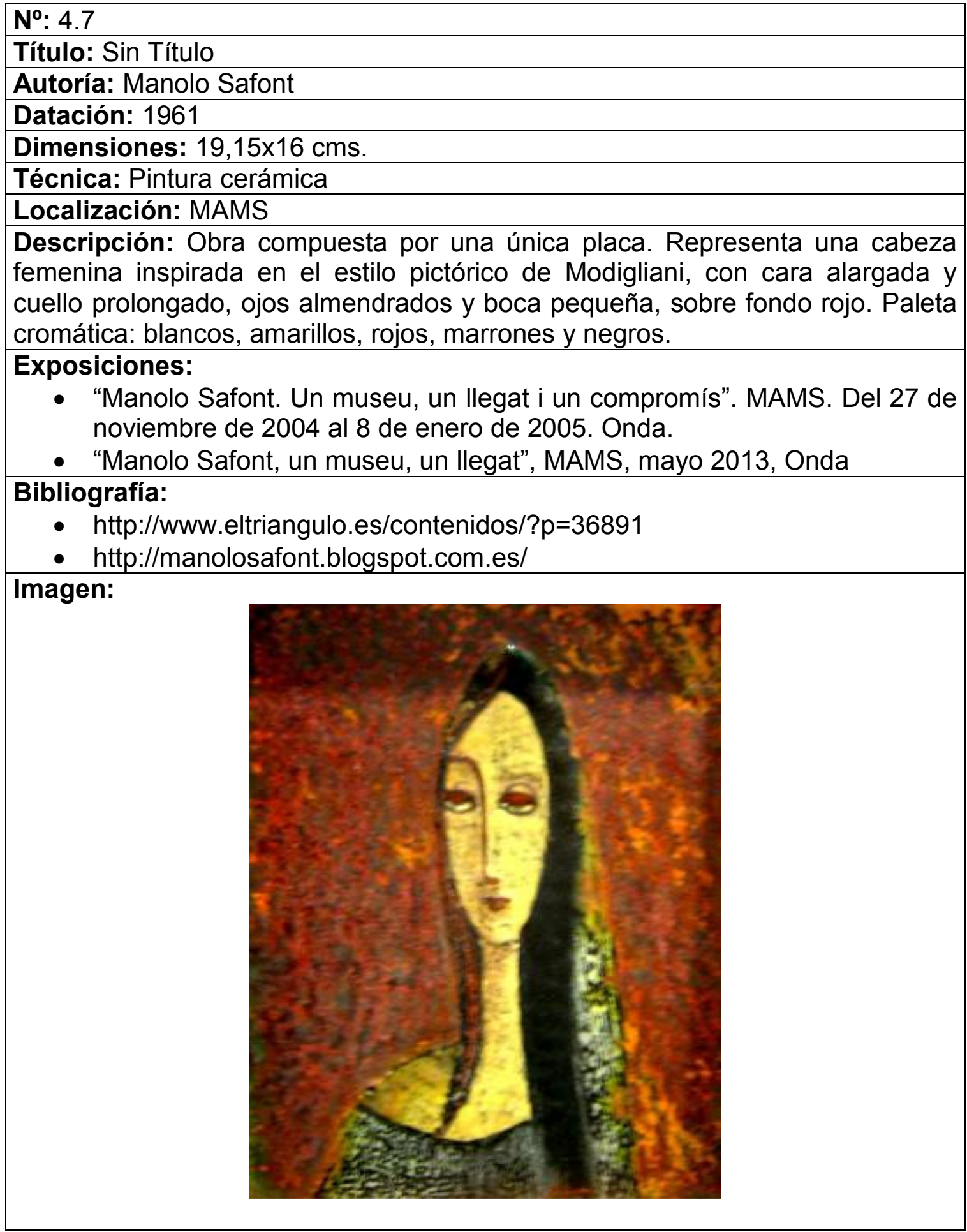


$\mathbf{N}^{0}: 4.8$

Título: Sin Título

Autoría: Manolo Safont

Datación: Anterior a 1962

Técnica: Pintura cerámica

Descripción: Obra compuesta por 12 placas del mismo tamaño, en disposición $3 \times 4$. Tan sólo hemos podido localizar una fotografía en blanco y negro de esta obra. Esta imagen de un bodegón, en la cual vemos diferentes tipos de botellas y un cráneo, podría enmarcarse en la tipología de la "vanitas": "Vanitas vanitatum omnia vanitas" (Vanidad de vanidades, todo es vanidad), Entre los diferentes objetos simbólicos que se utilizan en este tipo de bodegones, el cráneo humano, es uno de los más frecuentes, utilizado como símbolo de la muerte, "memento mori" (recuerda que vas a morir) entre los símbolos de las actividades humanas: saber, ciencia, riqueza, placeres, belleza, etc. Las vanidades denuncian la relatividad del conocimiento, transmitiendo un mensaje sobre la inutilidad de los placeres mundanos frente a la certeza de la muerte y la vanidad del género humano sujeto al paso del tiempo, a la muerte. La imagen de esta obra, en blanco y negro, pertenece al catálogo de la exposición que en 1962 realizó Safont en Madrid, invitado por la Dirección General de Bellas Artes, fecha que se utiliza para datar la obra. No puede establecerse la paleta cromática.

\section{Exposiciones:}

- Safont. Sala de Exposiciones. Dirección General de Bellas Artes. Madrid, 1962

\section{Bibliografía:}

- Safont. Sala de Exposiciones. Dirección General de Bellas Artes. Madrid, 1962

- http://manolosafont.blogspot.com.es/

Imagen:

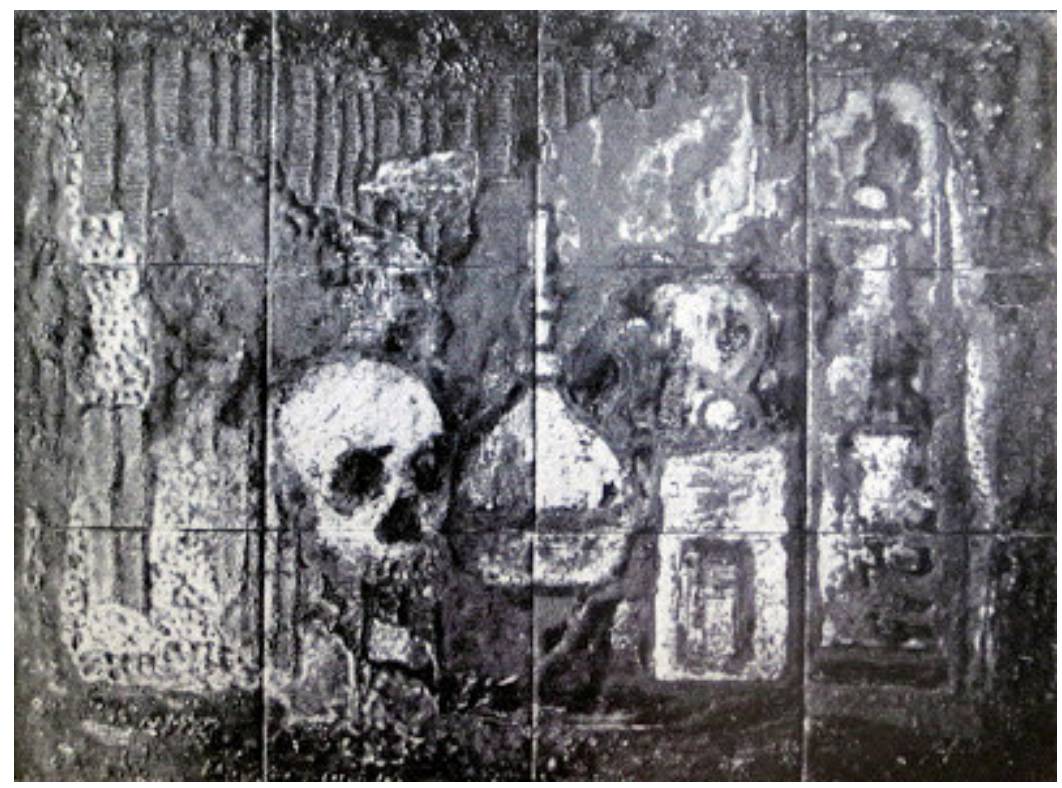


No: 4.9

Título: Sin Título

Autoría: Manolo Safont

Datación: Anterior a 1962

Técnica: Pintura cerámica

Descripción: Obra compuesta por 20 placas del mismo tamaño, en disposición $5 \times 4$. Tan sólo hemos podido localizar una fotografía en blanco y negro de esta obra. Dibujo de líneas esquematizantes y geométricas de estilo cubista, que representa el torso de una figura femenina, con el brazo derecho extendido hacia el cuello de una gran botella. La imagen de esta obra, en blanco y negro, pertenece al catálogo de la exposición que en 1962 realizó Safont en Madrid, invitado por la Dirección General de Bellas Artes, fecha que se utiliza para datar la obra. No puede establecerse paleta cromática.

\section{Exposiciones:}

- Safont. Sala de Exposiciones. Dirección General de Bellas Artes. Madrid, 1962

\section{Bibliografía:}

- Safont. Sala de Exposiciones. Dirección General de Bellas Artes. Madrid, 1962

- http://manolosafont.blogspot.com.es/

Imagen:

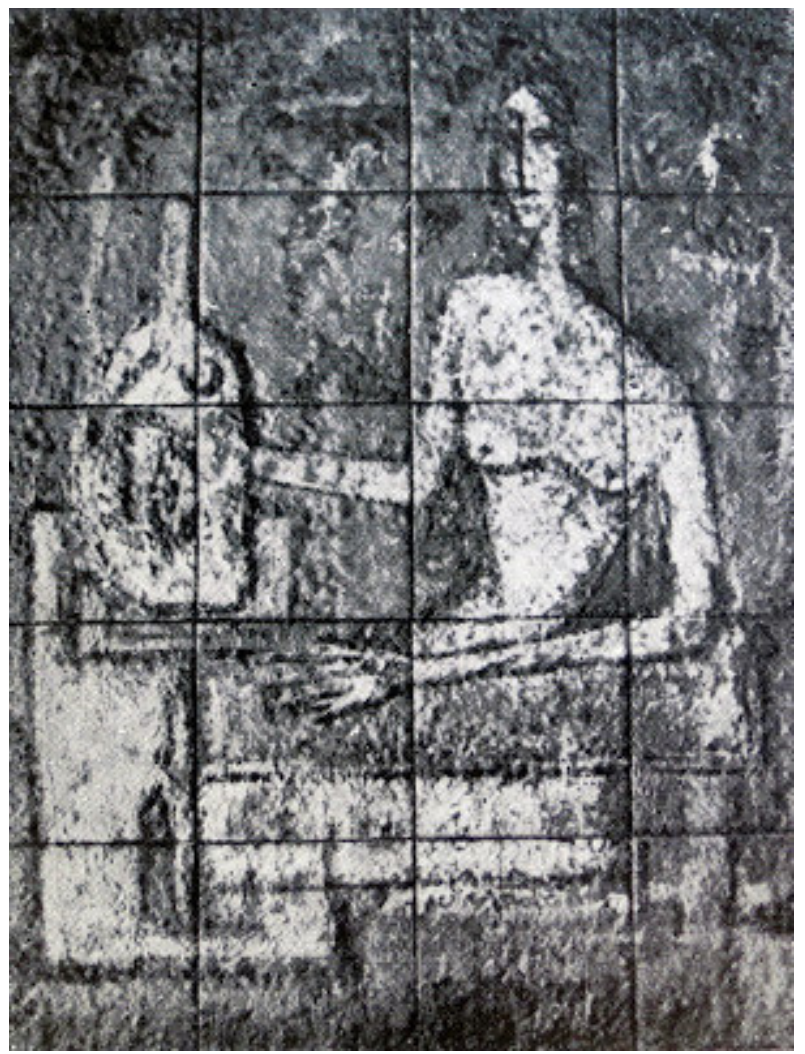


$\mathbf{N}^{0}: 4.10$

Título: Sin Título

Autoría: Manolo Safont

Datación: Anterior a 1962

Técnica: Pintura cerámica

Descripción: Obra compuesta por 16 placas del mismo tamaño, en disposición 2x8. Tan sólo hemos podido localizar una fotografía en blanco y negro de esta obra. Representa una imagen de Onda, en la que distinguen los elementos arquitectónicos que conforman los arcos de la plaza porticada de la Font de Dins. La imagen de esta obra, en blanco y negro, pertenece al catálogo de la exposición que en 1962 realizó Safont en Madrid, invitado por la Dirección General de Bellas Artes, fecha que se utiliza para datar la obra. No puede establecerse paleta cromática.

\section{Exposiciones:}

- Safont. Sala de Exposiciones. Dirección General de Bellas Artes. Madrid, 1962

\section{Bibliografía:}

- Safont. Sala de Exposiciones. Dirección General de Bellas Artes. Madrid, 1962

- http://manolosafont.blogspot.com.es/

\section{Imagen:}

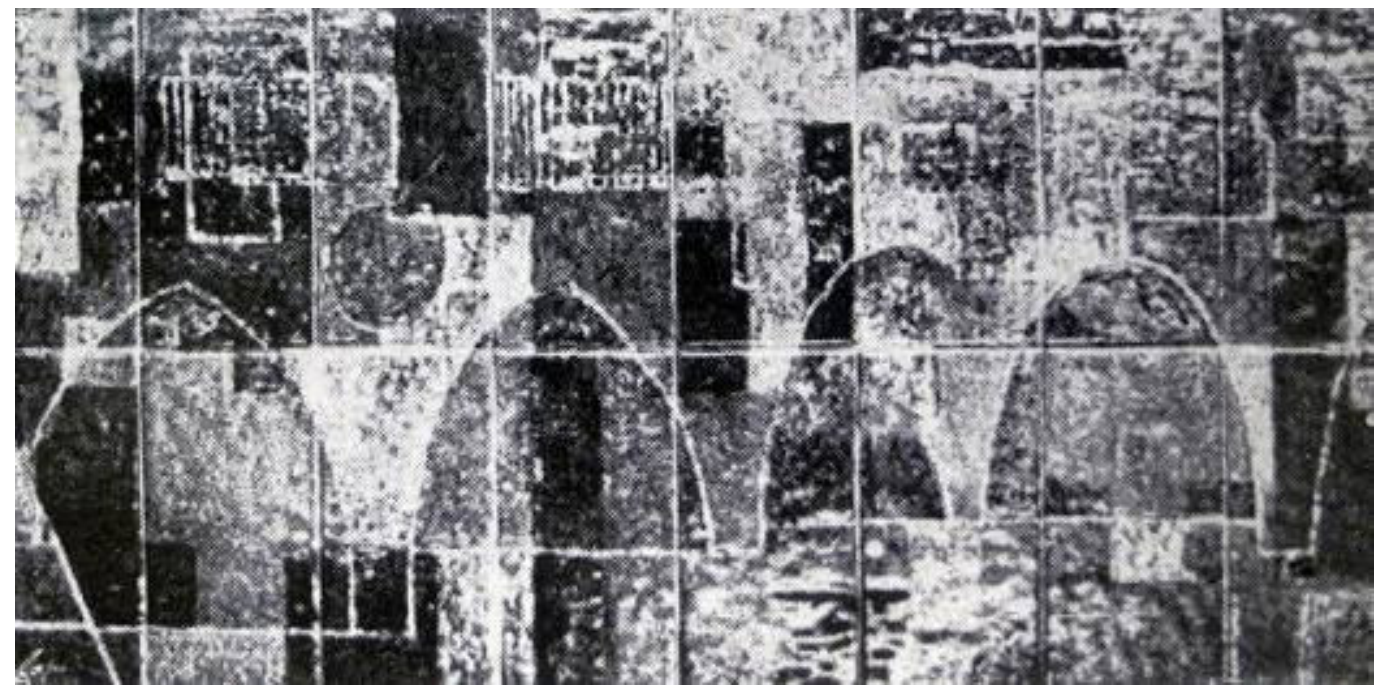


No: 4.11

Título: Sin Título

Autoría: Manolo Safont

Datación: Final década 1960

Dimensiones: $14 \times 28 \mathrm{cms}$

Técnica: Pintura cerámica

Localización: MAMS

Descripción: Imagen de la palma de una mano izquierda, realizada en color rojo, sobre fondo oscuro con vetas de color blanco. Safont utilizó su propia mano como huella y modelo para esta obra. Paleta cromática: blancos, rojos y negros.

Exposiciones:

- "Manolo Safont. Un museu, un llegat i un compromís". MAMS. Del 27 de noviembre de 2004 al 8 de enero de 2005. Onda

\section{Bibliografía:}

- ESTALL "Museo del azulejo Manolo Safont" 2004

\section{Imagen:}

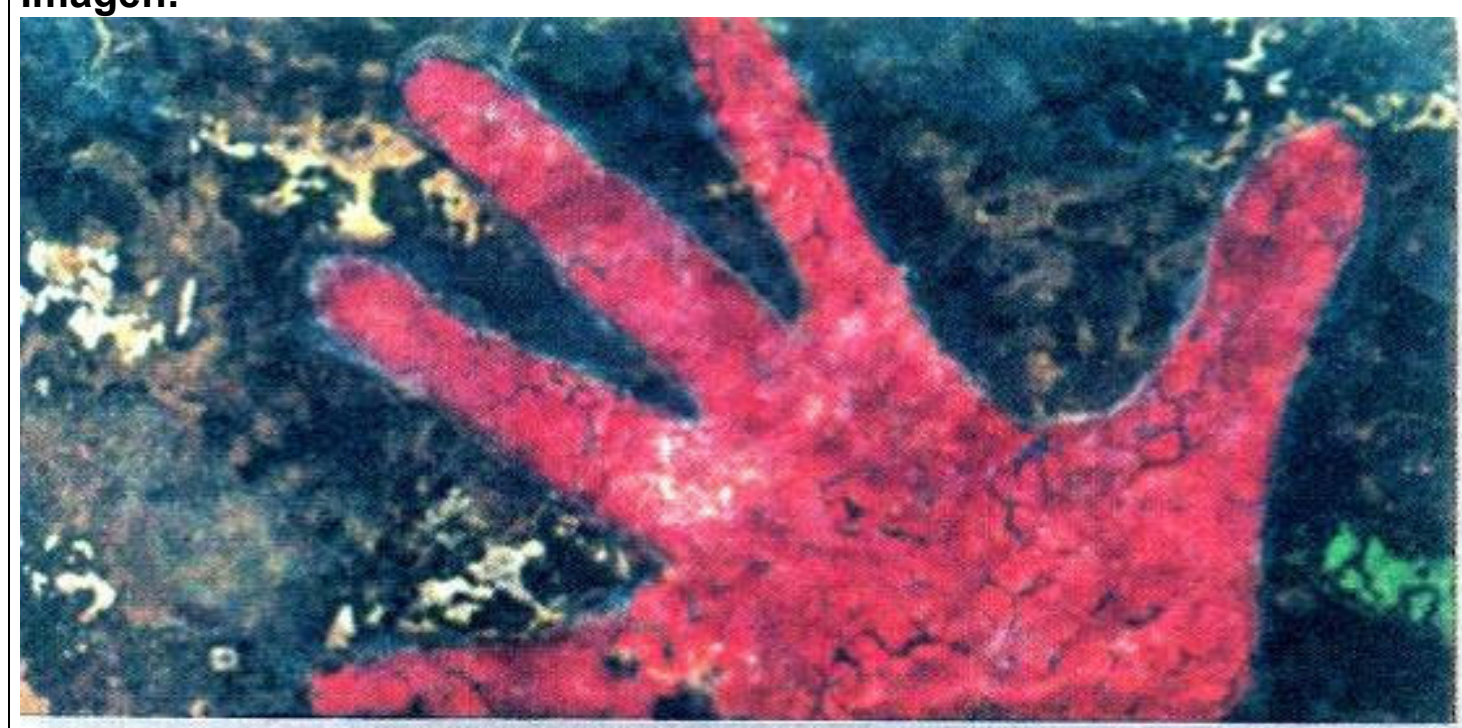


$\mathbf{N}^{0}: 4.12$

Título: Sin Título

Autoría: Manolo Safont

Datación: 1967

Inscripciones: Safont en zona central derecha

Dimensiones: $46,6 \times 88 \mathrm{cms}$ o $35 \times 75 \mathrm{cms}$ o $35 \times 71 \mathrm{cms}$

Técnica: Pintura cerámica

Localización: Casa Joan Fuster, calle San José, n¹0, Sueca, Valencia

Descripción: Obra compuesta por un gran número de placas de diferentes formas y tamaños. Esta obra forma parte del Legado Joan Fuster, catalogada en el legado con el número CF089. Sobre un fondo de color blanco, se representan cinco figuras humanas, en color oscuro, en las cuales destacan los grandes ojos. En esta obra, de forma bastante inusual, Safont firma en la parte central, sobre el margen inferior de la gran placa del margen derecho. Paleta cromática: blancos, marrones y negros.

\section{Exposiciones:}

- Colección permanente Legado Joan Fuster. Casa Joan Fuster. Sueca, Valencia

\section{Bibliografía:}

- http://www.espaijoanfuster.org/content/col-leccio-dart

- http:// www.gva.es/museo/safon11.htm, 1995-1996

\section{Imagen:}

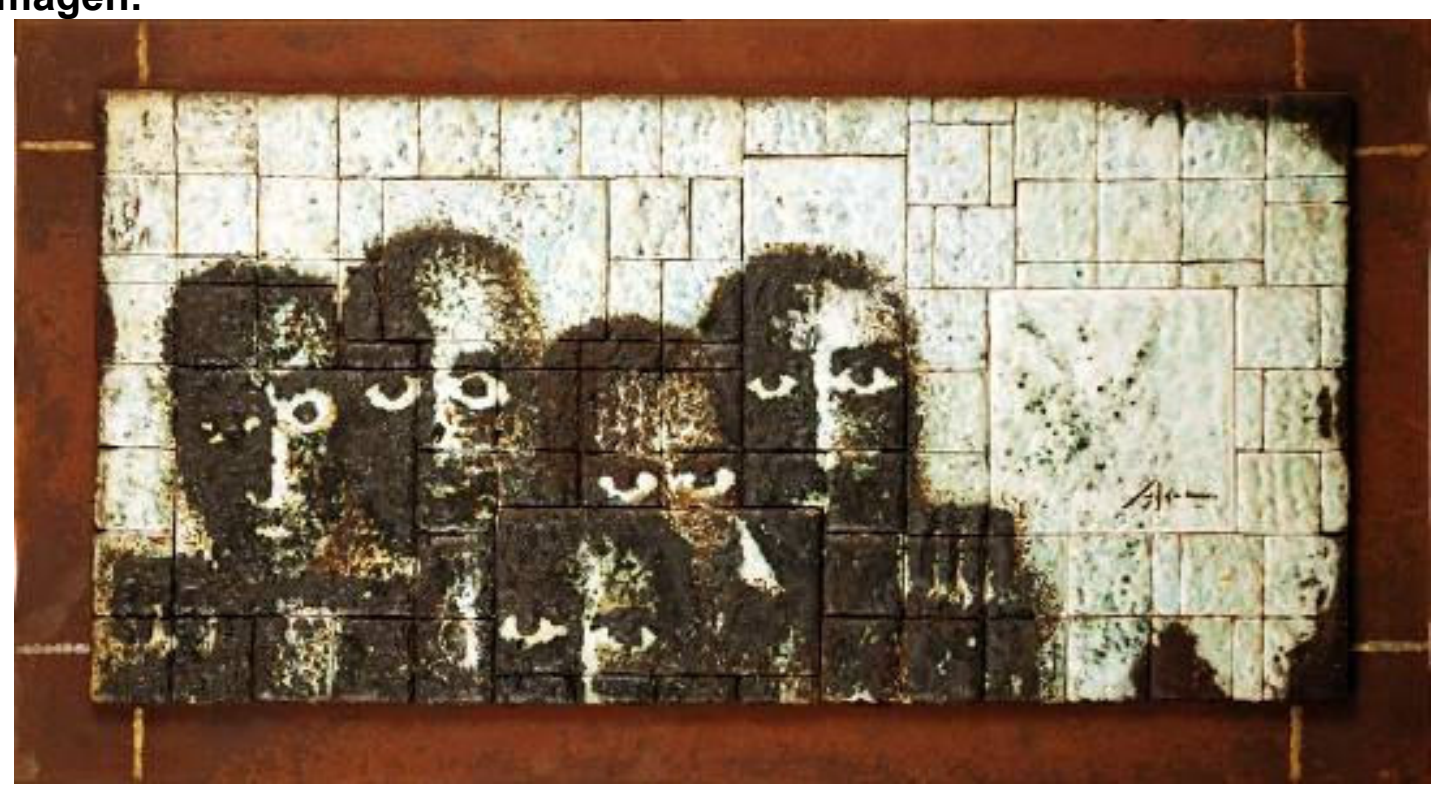


$\mathbf{N}^{\circ}: 4.13$

Título: Sin Título

Autoría: Manolo Safont

Datación: 1970

Técnica: Pintura cerámica

Localización: Colección privada $\mathrm{n}^{\circ} 5$, Castellón de la Plana

Descripción: Obra compuesta por placas de diferentes tamaños. Tal y como se indica en http://manolosafont.blogspot.com.es, existe documentación conservada en el archivo personal de Safont, que nos indica que fue realizada en el año 1970. Representa una estilizada paloma de la paz sobrevolando un campo de batalla con alambradas, elemento que se repite en sus obras de finales de la década de 1960 e inicios de la década de 1970, en las que incluía símbolos de denuncia ante la violencia, la opresión, la dictadura del momento y, por supuesto, también la guerra. Este símbolo de la paloma es un recurso común en el arte y estilísticamente presenta relación con la realizada por Georges Braque para su obra Pájaro azul y amarillo. Paleta cromática: blancos, amarillos, verdes, marrones y negros.

Bibliografía:

- http://manolosafont.blogspot.com.es/

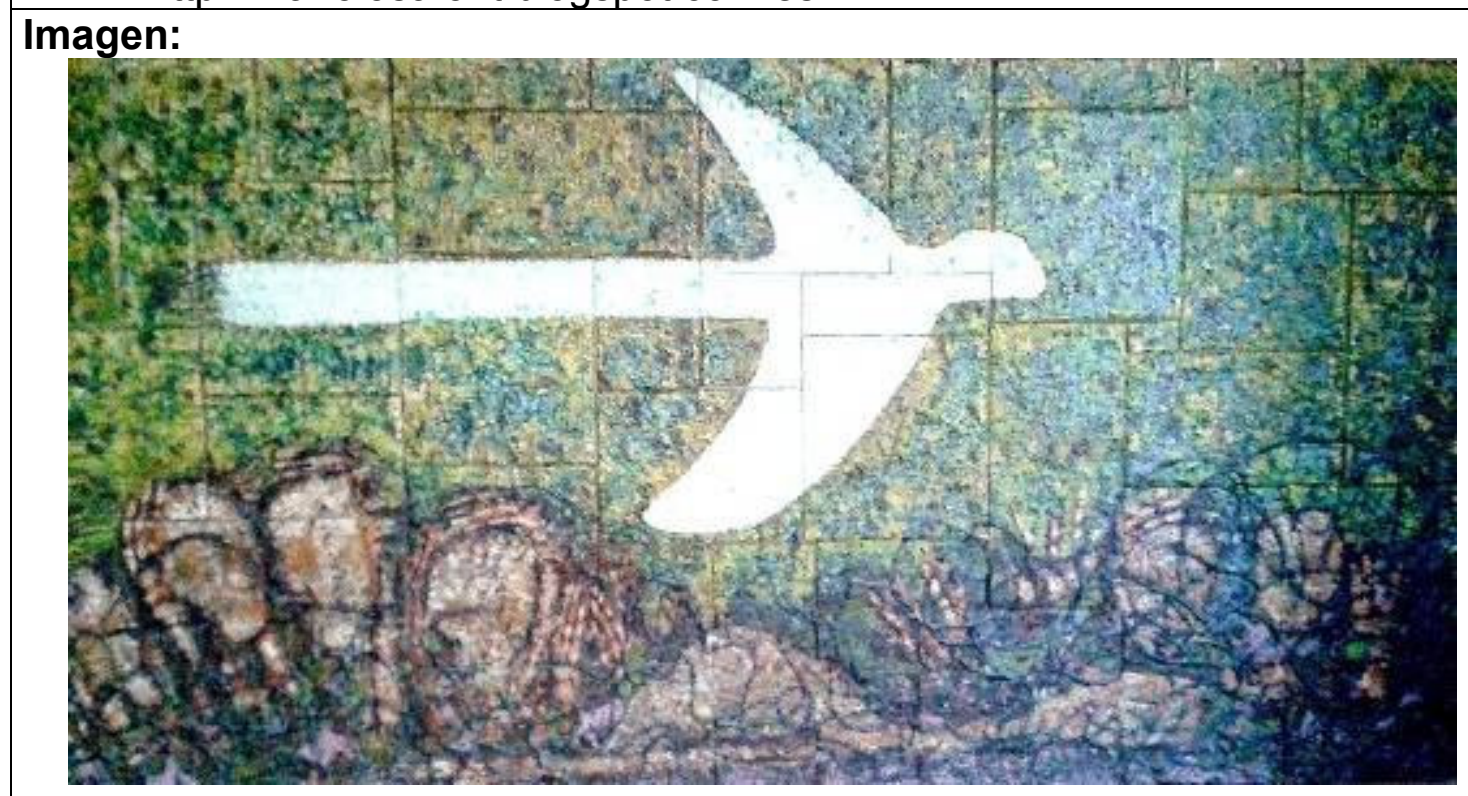

Imágenes relacionadas:

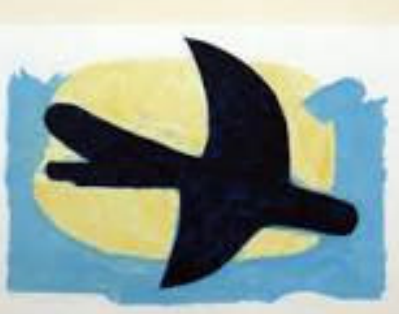

Pájaro azul y amarillo. Braque 
$\mathbf{N}^{\circ}: 4.14$

Título: Autorretrato/ Contra Violencia

Autoría: Manolo Safont

Datación: 1970

Inscripciones: Safont en ángulo inferior derecho

Dimensiones: $60 \times 75 \mathrm{cms}$ o $62 \times 100 \mathrm{cms}$

Técnica: Pintura cerámica

Descripción: Obra compuesta por 24 placas de diferentes tamaños. La imagen de esta obra aparece reproducida en el catálogo de la exposición de la Casa de España en París de 1978 y en el de la exposición en el Museo de Cerámica González Martí de 1980. Su datación es incorrecta (1980) en http://www.gva.es/museo/safon12.htm. Esta obra permaneció, al menos, desde 1985 a 1991, en el Museu d'Art Contemporani dels Països Catalans de Banyoles. La datación la establece la ficha catalográfica de la obra del Museu de Banyoles. En 1991 la obra le fue devuelta a Safont tras solicitarlo el autor. Esta obra aparece como Sin Título en el catálogo de la exposición de París, con el título Autorretrato en http://www.gva.es/museo/safon12.htm, 1995-1996, y con el título Contra Violencia en la ficha catalográfica del Museo de Banyoles. Paleta cromática: blancos, rojos, marrones y negros.

\section{Exposiciones:}

- Safont. Pintura cerámica. Sala Goya. Casa de España en París, del 5 al 15 de octubre de 1978

- Exposición de cerámicas de Safont. Sala de Exposiciones del Museo Nacional de Cerámica "González Martí" Palacio de Dos Aguas, del 3 al 30 marzo 1980, Valencia

\section{Bibliografía:}

- Safont. Pintura cerámica. Sala Goya. Casa de España en París, del 5 al 15 de octubre de 1978

- Exposición de cerámicas de Safont. Sala de Exposiciones del Museo Nacional de Cerámica "González Martí" Palacio de Dos Aguas, del 3 al 30 marzo 1980, Valencia

- http://www.gva.es/museo/safon12.htm, 1995-1996

Imagen:

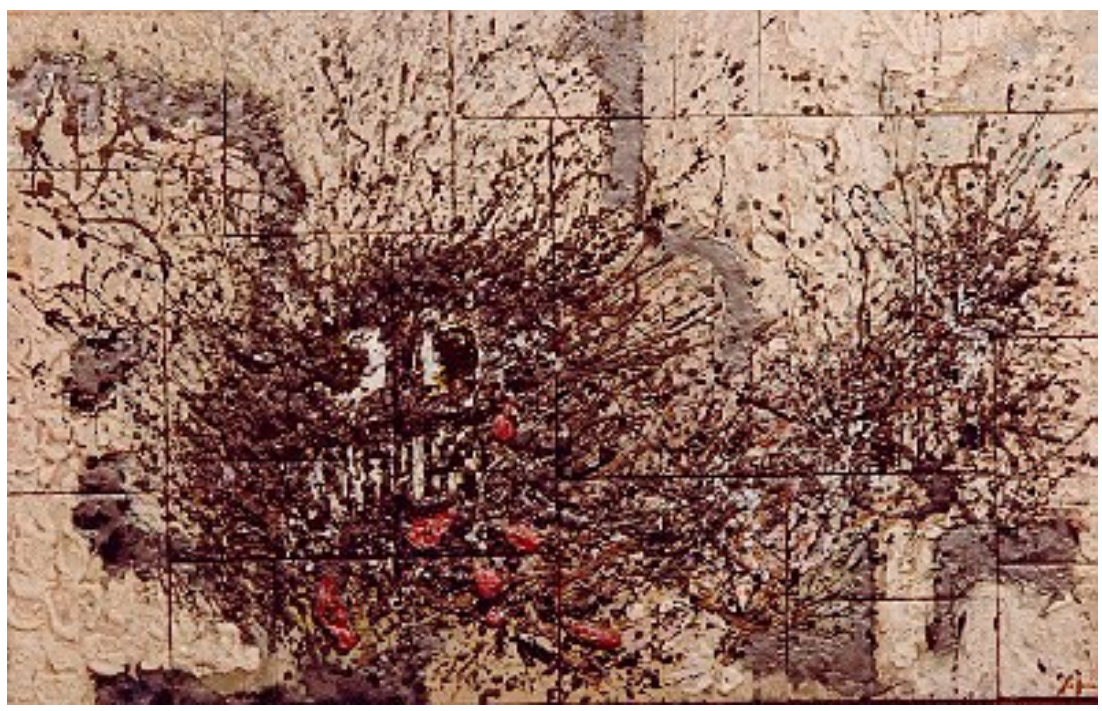


Imágenes relacionadas:

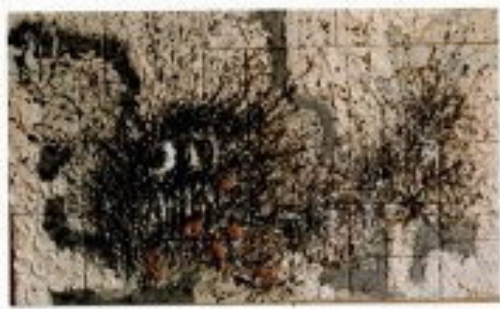

\section{SAFONT \\ ceràmica}

TITOL: •CONTRA VIOLENCIA'.

DATA EXECIOCIO: 1970 .

$62 \times 100 \mathrm{eat}$.

TEMA. - Con indioa el teas, aquesta obra, dóns la impregsió de tractar la tenà t1 ca de la vialèncis actual.

TENDENCIA. - Expresa1on1sne abstracte.

PhLETh DONINANT, - Colora feeds (blaus, grisos, negre 1 verds).

composicio.- Vint-1-dues peces de foraes rectangulars 1 quadrades coaposen 1'ober. B1 treactanent de rugositat de cada una de les parts de cersinica g juda a donar un caire d'agresalvitat.

Con el trtol indica senbla spareixer on el centre un permonatge totalnent infornal aclanant lo no-violèncla. hótaden al tena unea taques veraelloses que s'observen a la part inferior. Venen contra reatadea per un conjunt de taquea dispars que es veuen en tota l'ober.

PROCEDIMENT, - Cerànía.

TECKICA.- Bs tracts a'un tipus de cerantes af́s avıat d'avantguarda ja que pel seu tractanent formal 1 tècnle difereix totalnent del concepte de oeràntaa tradicional. Cal destgear el degoteig 1 la rugositat que doatna en tota la oonpasicis.

\#MMARCAMENT.- Ve anmarcada anb una fusta reotangular de 87'5 × 125 cn. De grulx $2 \mathrm{~cm}$.

ESTMT DB CONSERVRCIO, - NoTng1.

ANOPACIONS DEL DARPERA.- Manolo Safont: Caste116, Bant Josep 12, Onda. Caste116 de la Plana.

Ficha catalográfica de la obra realizada en 1985 por el Museu Museu d'Art Contemporani dels Països Catalans de Banyoles. 
$N^{0}: 4.15$

Título: Sin Título

Autoría: Manolo Safont

Datación: 1970

Inscripciones: Safont en zona inferior izquierda

Dimensiones: $60 \times 40 \mathrm{cms}$

Técnica: Pintura cerámica

Localización: Casa Joan Fuster, calle San José, n¹0, Sueca, Valencia

Descripción: Obra compuesta por 2 placas, con la imagen de un puño cerrado y alzado junto a una representación de la senyera, esta obra pertenece actualmente al Legado Joan Fuster, catalogada en dicho legado con el número CF010. En la exposición que realizó en 1980 en el Museo Nacional de Cerámica "González Marti", Safont tuvo que retirar esta obra de la exposición por ser una representación de la senyera y tener claras connotaciones nacionalistas, en desacuerdo con la política del momento. Paleta cromática: blancos, amarillos, rojos y negros.

\section{Exposiciones:}

- Safont. Pintura cerámica. Sala Goya. Casa de España en París, del 5 al 15 de octubre de 1978

- Safont ceràmiques. Biblioteca Pública Municipal Vila-Real, del 17 al 31 de mayo de 1980

- Colección permanente Legado Joan Fuster. Casa Joan Fuster. Sueca, Valencia

\section{Bibliografía:}

- Safont. Pintura cerámica. Sala Goya. Casa de España en París, del 5 al 15 de octubre de 1978

- Safont ceràmiques. Biblioteca Pública Municipal Vila-Real, del 17 al 31 de mayo de 1980

- FALOMIR VENTURA, Carmela. "La pintura cerámica de Manolo Safont", Butlletí d’Estudis Municipals, Regiduria de Cultura, $2^{a}$ etapa, $n^{\circ} 2$, Onda, 2001 , pág. 22

- http://www.espaijoanfuster.org/content/col-leccio-dart

Imagen:

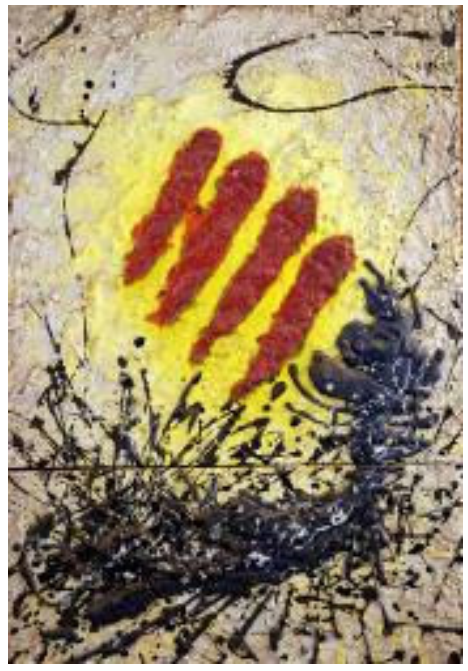


$\mathbf{N}^{0}: 4.16$

Título: Sin Título

Autoría: Manolo Safont

Datación: 1971

Dimensiones: $65 \times 55 \mathrm{cms}$

Técnica: Pintura cerámica

Descripción: Obra compuesta por 17 placas de diferentes tamaños. Tan sólo hemos podido localizar una fotografía en blanco y negro de esta obra, por lo que no puede establecerse la paleta cromática. En el margen inferior se observa una masa oscura que ocupa $1 / 4$ de la composición, mientras que los otros $3 / 4$ de la obra son de un color claro y apenas presentan masa matérica.

Exposiciones:

- Manolo Safont. Pintor ceramista. Círculo Mercantíl e Industrial, Castellón de la Plana, 13-27 marzo, 1971

\section{Bibliografía:}

- Manolo Safont. Pintor ceramista. Círculo Mercantíl e Industrial, Castellón de la Plana, 13-27 marzo, 1971

- FALOMIR, Carmela. "La pintura cerámica de Manolo Safont" en Butlletí d'Estudis Municipals. $2^{\mathrm{a}}$ etapa, n². Ajuntament d'Onda. Onda, 2001, pág. 14

Imagen:

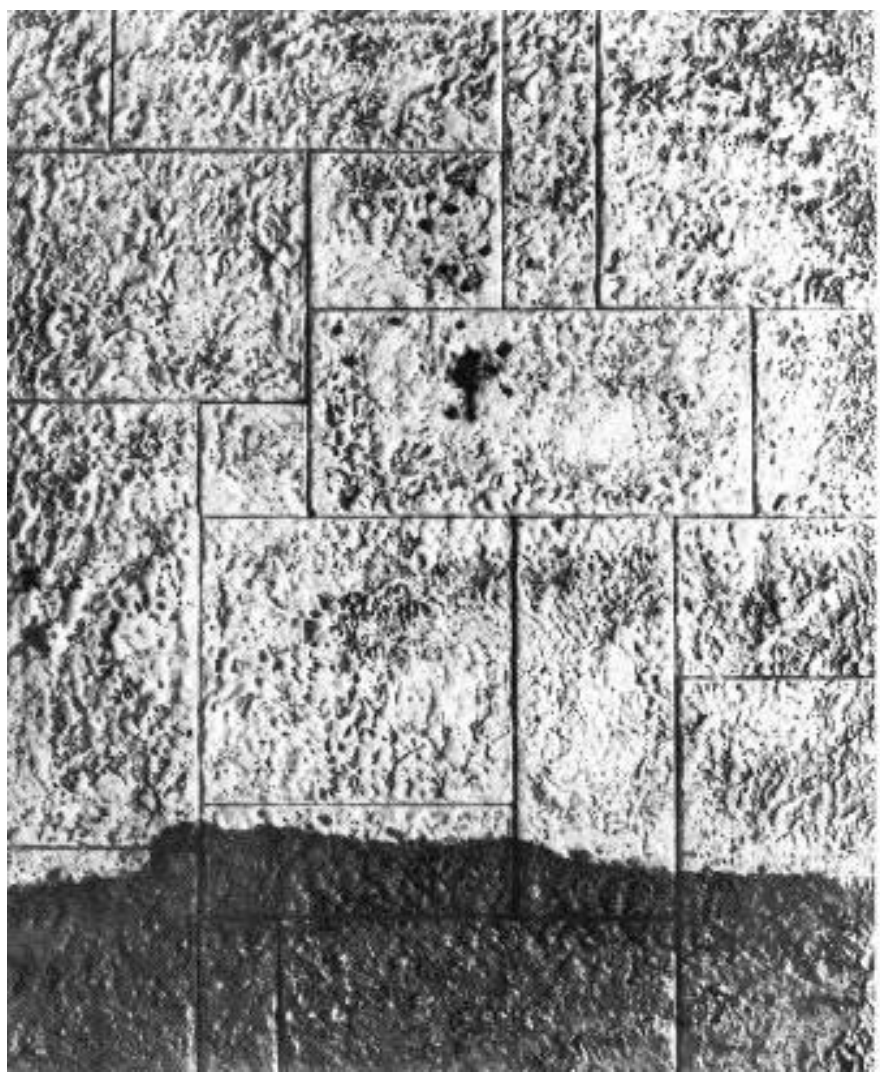


$\mathbf{N}^{0}: 4.17$

Título: Sin Título

Autoría: Manolo Safont

Datación: Anterior a 1972

Tema: Pintura cerámica

Descripción: Obra compuesta por placas de diferentes tamaños. Tan sólo hemos podido localizar una imagen en blanco y negro de esta obra, por lo que nos resulta imposible establecer ni una completa descripción de la obra ni la paleta cromática utilizada. Representa dos manos, que parten del margen inferior de la obra, la mano derecha hasta la muñeca y la mano izquierda hasta el codo.

Bibliografía:

- repositori.uji.es

Imagen:

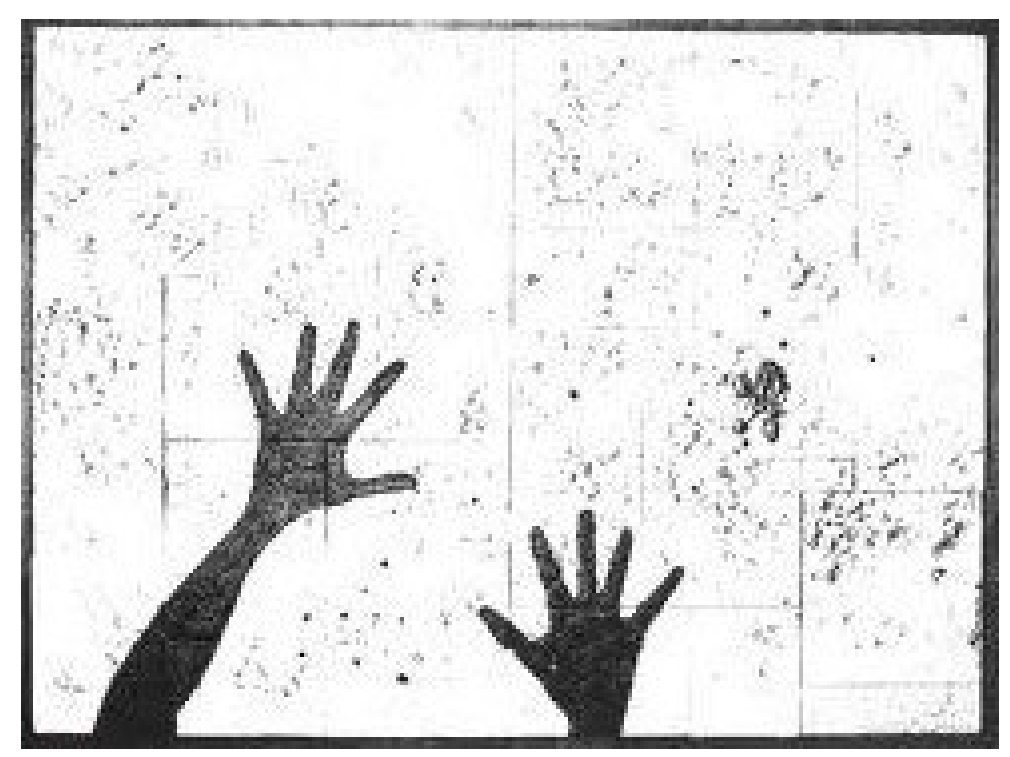


No: 4.18

Título: Sin Título

Autoría: Manolo Safont

Datación: Anterior a 1972

Técnica: Pintura cerámica

Descripción: Obra compuesta por varias placas de diferentes tamaños. Tan sólo hemos podido localizar una fotografía en blanco y negro de esta obra, por lo que no se establece la paleta cromática. Representa las siluetas de los torsos de un grupo de personas, con los brazos extendidos hacia arriba, con las palmas de las manos abiertas. Se utiliza la referencia bibliográfica para datar la obra.

\section{Bibliografía:}

- ALONSO DUQUE, J.F. Informaciones/Monografía. Vidrio y cerámica. 25 abril 1972, pág. 11

Imagen:

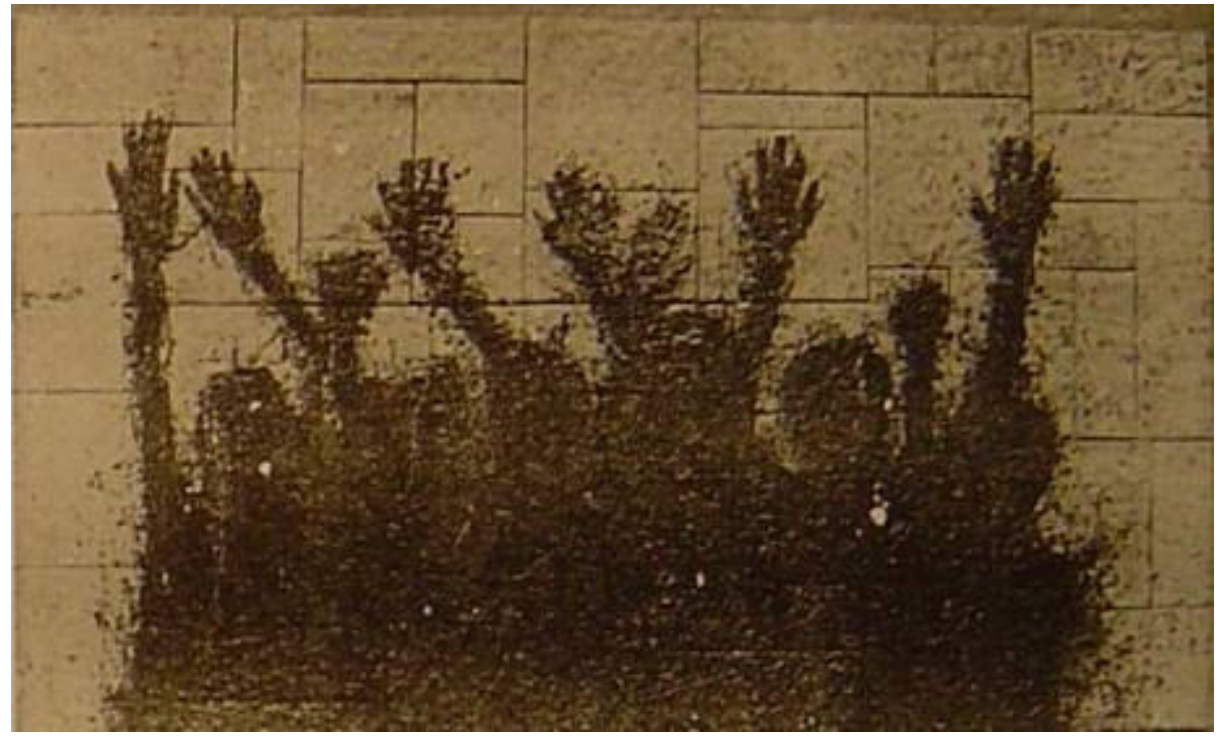


No: 4.19

Título: Sin Título

Autoría: Manolo Safont

Datación: Anterior a 1972

Técnica: Pintura cerámica

Descripción: Obra compuesta por placas de diferentes tamaños. Tan sólo hemos podido localizar una fotografía en blanco y negro de esta obra, por lo que sólo podemos describir las formas de la misma. En el margen inferior izquierdo se observa una esfera circular y en la zona superior derecha, una estrella de cinco puntas. Utilizamos la referencia bibliográfica para datar la obra.

Bibliografía:

- ALONSO DUQUE, J.F. Informaciones/Monografía. Vidrio y cerámica. 25 abril 1972, pág. 11

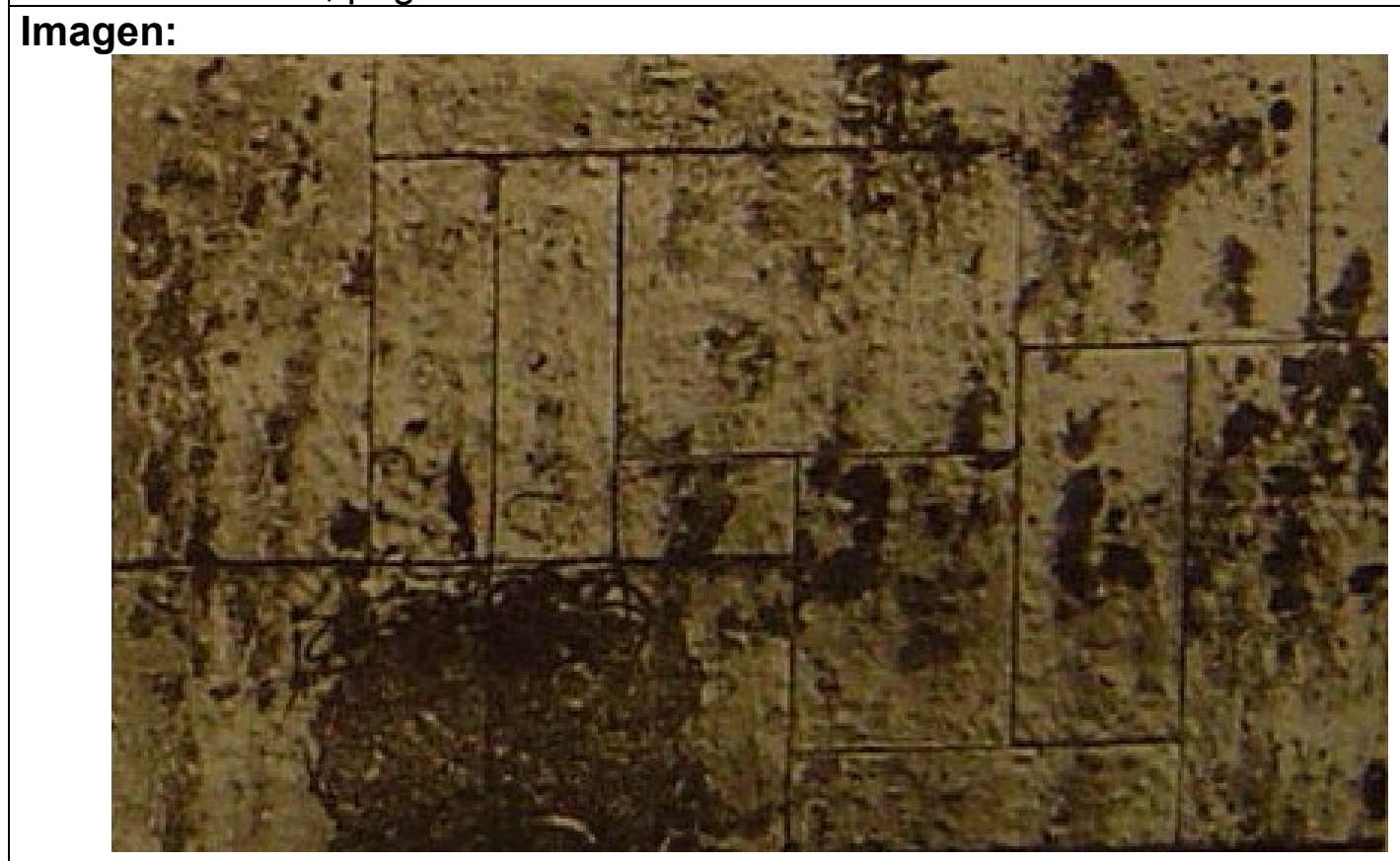


$\mathbf{N}^{0}: 4.20$

Título: Sin Título

Autoría: Manolo Safont

Datación: 1972

Dimensiones: 100x95 cms

Técnica: Pintura cerámica

Descripción: Obra compuesta por varias placas de diferentes tamaños. Tan sólo hemos podido localizar una fotografía en blanco y negro de esta obra, por lo que no se establece la paleta cromática. Representa una figura humana, centrada, tumbada, que extiende el brazo derecho hacia el margen inferior de la obra. De esta obra se conserva en un bloc de dibujo, el boceto preparatorio, obra catalogada $\mathrm{n}^{\circ} 2.38$.

Bibliografía:

- Il Art Castellonenc d'Avui. Sala Municipal d'Onda, diciembre 1973 enero 1974, Onda

- FALOMIR VENTURA, Carmela. "La pintura cerámica de Manolo Safont", Butlletí d’Estudis Municipals, Regiduria de Cultura, $2^{a}$ etapa, $n^{\circ} 2$, Onda, 2001 , pág. 11

\section{Imagen:}

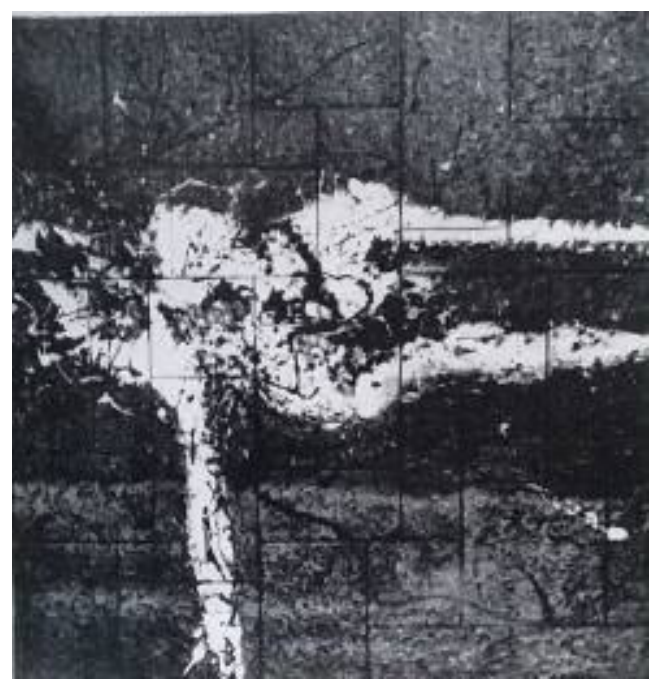

Imágenes relacionadas:

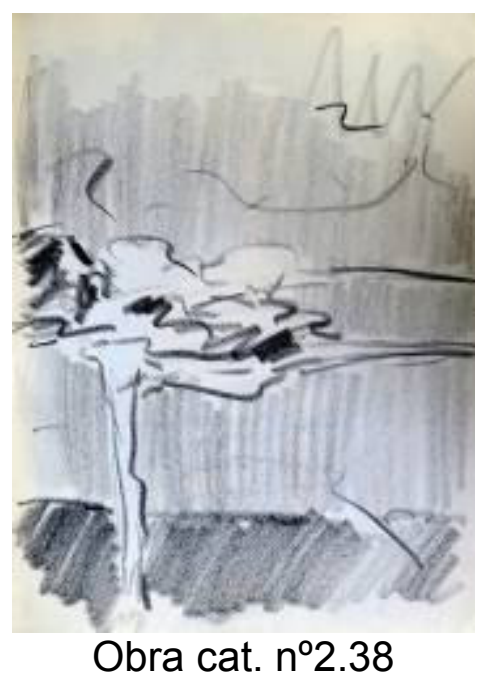


$\mathbf{N}^{0}: 4.21$

Título: Reixat/Alambrada

Autoría: Manolo Safont

Datación: 1972

Dimensiones: $60 \times 115 \mathrm{cms}$

Técnica: Pintura cerámica

Localización: Museo de Bellas Artes de Castellón, Castellón de la Plana

Descripción: Rosalía Torrent se refiere a esta tipología de obras en el catálogo de la exposición realizada en 1998 en Morella: "És en aquest període quan assistim a algunes de les obres més emotives de Safont: els seus coneguts rostres esglaiats, obrint els ulls a la llum a través d'excletxes de murs de presons, el sets i els uts de les xarxes de filferro....". Representación de dos zonas con cromatismo muy diferenciado, la zona superior en un color claro y luminoso, con salpicaduras de color, mientras que la zona inferior utiliza un cromatismo mucho más oscuro y con la figura de una reja de alambre de espino. Esta obra fue adquirida por la Diputación de Castellón, y se expone actualmente en el Museo de Bellas Artes de Castellón. Paleta cromática: blancos, marrones y negros.

\section{Exposiciones:}

- Il Art Castellonenc d'Avui. Sala Municipal d'Onda, diciembre 1973 enero 1974, Onda

- Colección permanente. Museo Bellas Artes, Castellón de la Plana

\section{Bibliografía:}

- ALONSO DUQUE, J.F. Informaciones/Monografía. Vidrio y cerámica. 25 abril 1972, pág. 11

- TORRENT, Rosalía "Manolo Safont: Creador d'intensitat", Safont , 9 octubre - 9 noviembre 1998, Morella (Castellón), pág. 9

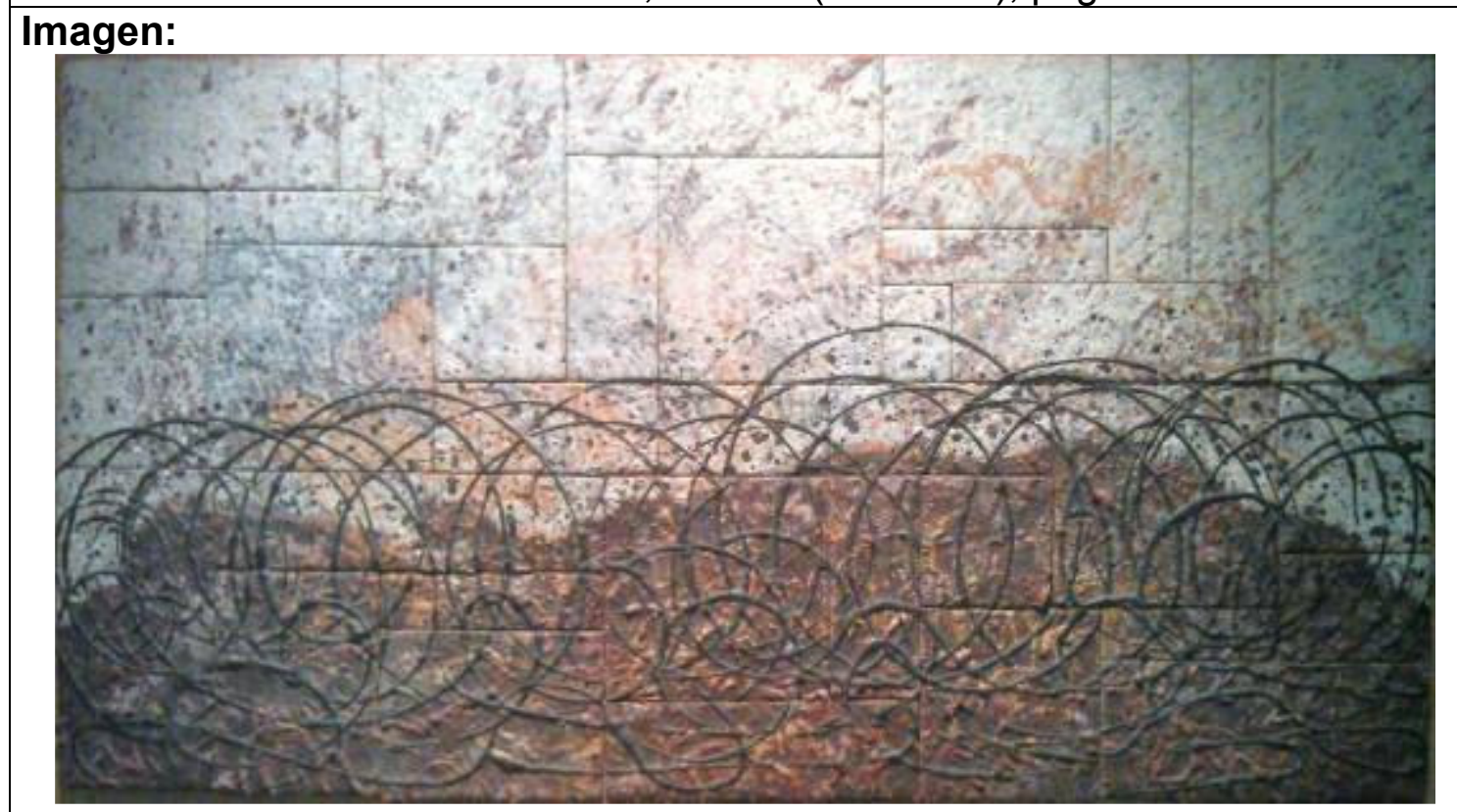


$\mathbf{N}^{0}: 4.22$

Título: Sin Título

Autoría: Manolo Safont

Datación: 1973

Dimensiones: $75 \times 55 \mathrm{cms}$,

Técnica: Pintura cerámica

Descripción: Obra compuesta por 17 placas de diferentes tamaños. Tan sólo hemos podido localizar una fotografía en blanco y negro de esta obra, por lo que no se establece la paleta cromática. En las $3 / 4$ partes inferiores de la obra, vemos una masa de color claro, con una mancha de color oscuro, centrada, creada por eliminación de masa.

Bibliografía:

- FALOMIR, Carmela. "La pintura cerámica de Manolo Safont" en Butlletí d'Estudis Municipals. 2a etapa, $\mathrm{n}^{\circ}$ 2. Ajuntament d'Onda. Onda, 2001, pág. 20

\section{Imagen:}

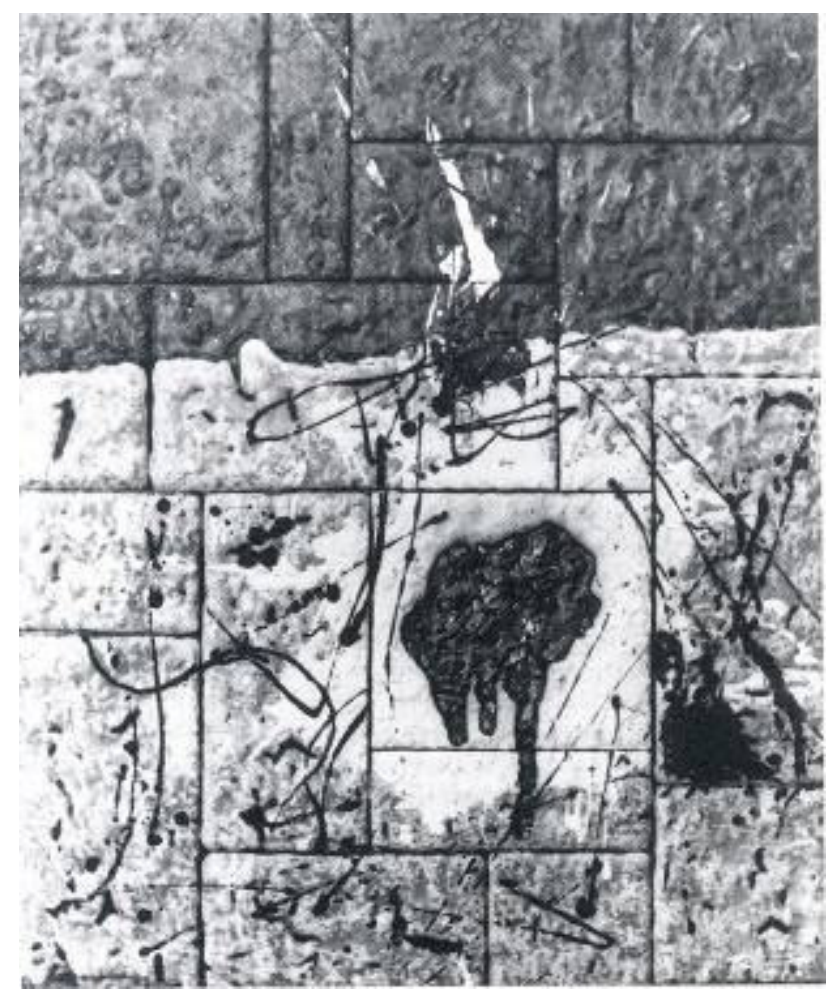


No: 4.23

Título: Sin Título

Autoría: Manolo Safont

Datación: 1973

Inscripciones: Safont 73 en margen inferior izquierdo

Dimensiones: $50 \times 95 \mathrm{cms}$

Técnica: Pintura cerámica

Localización: Museo de Arte Contemporáneo de Vilafamés "Aguilera Cerní", Vilafamés, Castellón

Descripción: Obra compuesta por 27 placas de diferentes tamaños Tal y como se indica en manolosafont.blogspot.com.es, representa a una víctima de la represión franquista, acribillada a balazos, pero se trata de una figura diluida en un intenso juego de colores y materia especialmente bien trabajada, que orienta la mirada del espectador en primer lugar hacia el lado meramente estético de la obra, pero el mensaje que transmite va llegándole poco a poco con posterioridad. Tan sólo cuando conoces la verdadera historia de la obra, eres capaz de ver tanto la figura humana, como los círculos rojos, que representan la sangre de los balazos recibidos. Safont depositó la obra en el museo de Vilafamés entre 1973 y 1974. Paleta cromática: blancos, rojos, marrones y negros.

\section{Exposiciones:}

- Colección permanente Museo de Arte Contemporáneo de Vilafamés "Aguilera Cerní", Vilafamés, Castellón

\section{Bibliografía:}

- FALOMIR, Carmela. "La pintura cerámica de Manolo Safont" en Butlletí d'Estudis Municipals. $2^{\mathrm{a}}$ etapa, $\mathrm{n}^{\circ}$ 2. Ajuntament d'Onda. Onda, 2001, pág. 23

- http://manolosafont.blogspot.com.es/

\section{Imagen:}

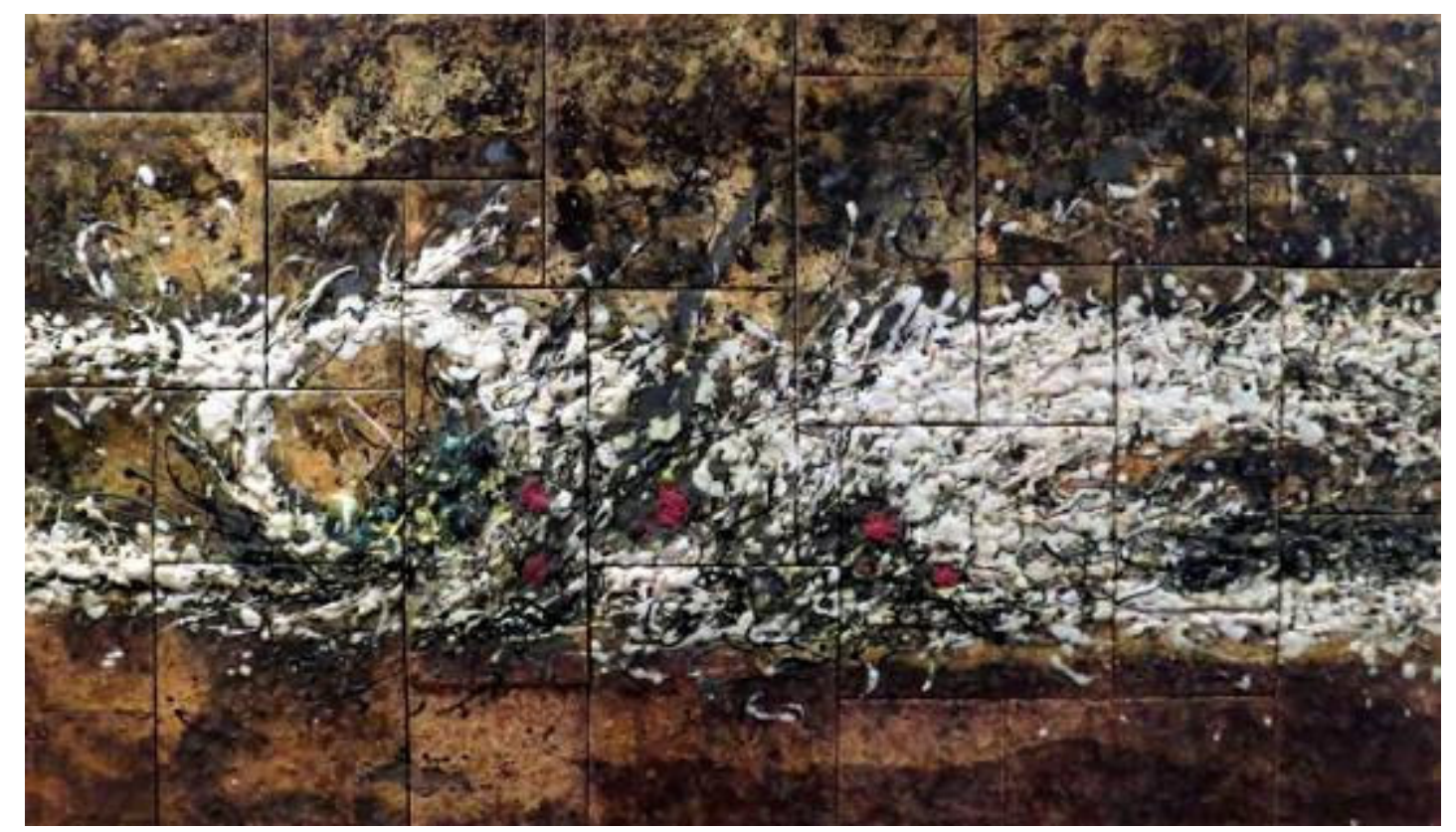


No: 4.24

Título: Sin Título

Autoría: Manolo Safont

Datación: 1973

Técnica: Pintura cerámica

Tema: Transición a la abstracción

Descripción: Obra compuesta por 15 placas de diferentes tamaños. Tan sólo hemos podido localizar una fotografía en blanco y negro de esta obra, por lo que no se establece la paleta cromática. Sobre base oscura, una forma centrada y de color claro, de la cual parten tres brazos en dirección superior derecho, superior izquierdo e inferior derecho.

\section{Exposiciones:}

- Il Art Castellonenc d’Avui. Sala Municipal d'Onda, diciembre 1973 enero 1974, Onda

\section{Imagen:}

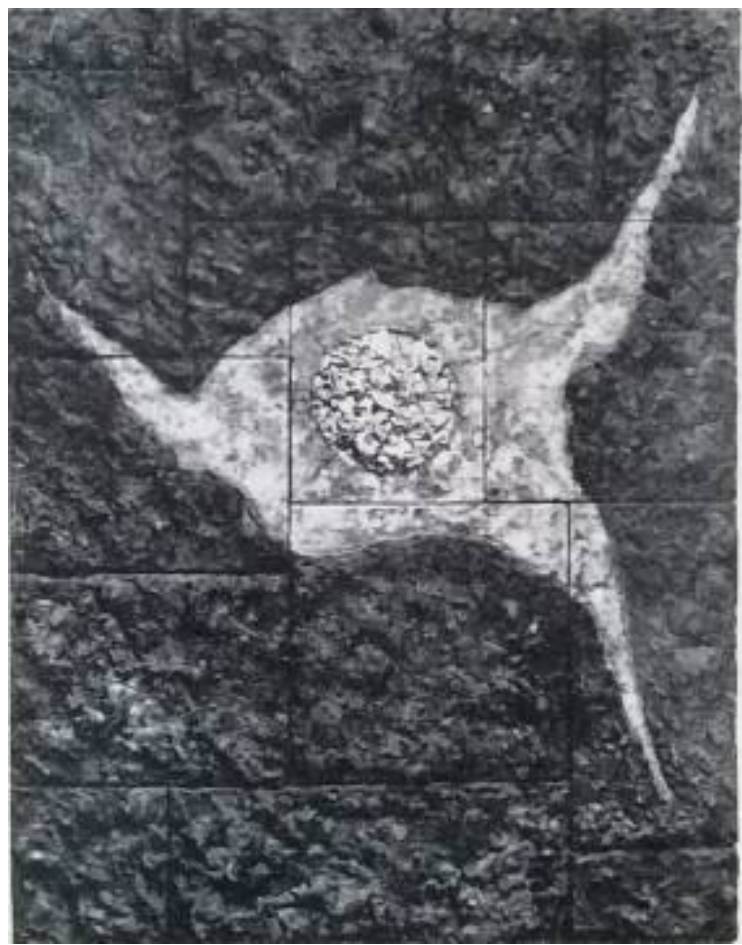


No: 4.25

Título: Sin Título

Autoría: Manolo Safont

Datación: 1973

Técnica: Pintura cerámica

Descripción: Obra compuesta por placas de diferentes tamaños. Fue utilizada en el cartel de la exposición "Safont Pintures ceràmiques" 28 Febrer-26 Març 1975. Galeria Cànem. Castelló. Una gran aspa roja, destaca en la parte inferior, sobre un fondo blanco, en contraste con los colores oscuros utilizados en la zona superior de la obra. Paleta cromática: blancos, rojos, marrones y negros.

Exposiciones:

- Safont Pintures ceràmiques, 28 Febrer-26 Març 1975. Galeria Cànem. Castelló.

\section{Imagen:}

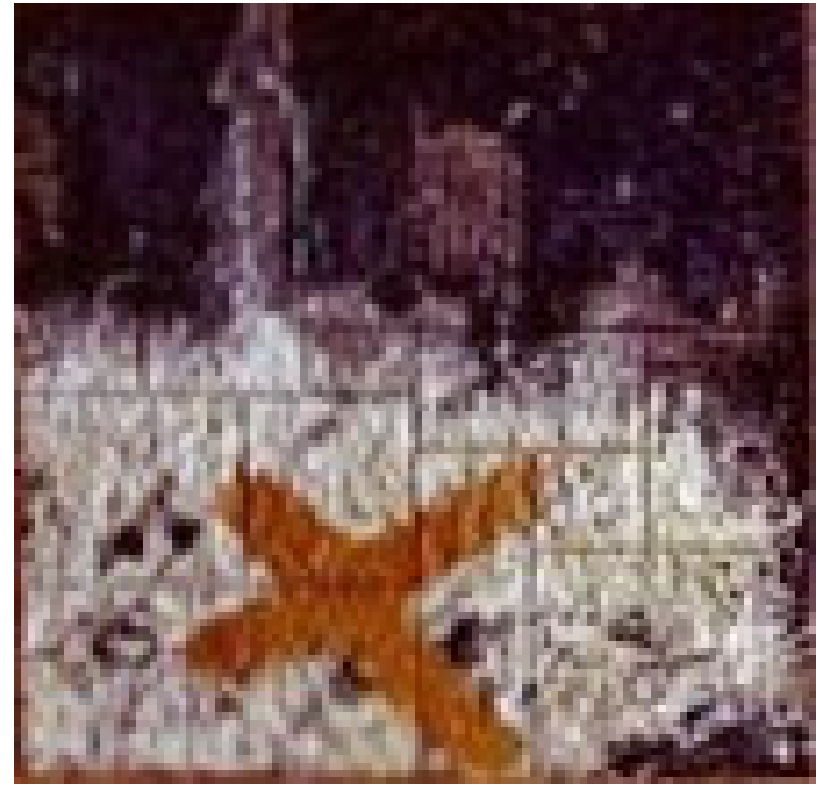

Imágenes relacionadas:

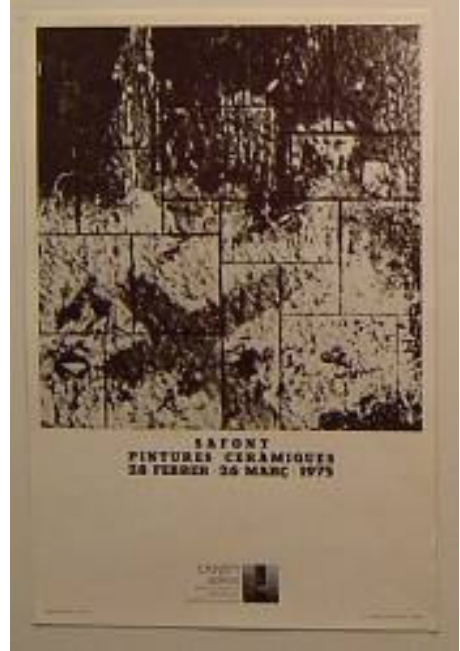

Cartel exposición Galería Cànem 
No: 4.26

Título: Sin Título

Autoría: Manolo Safont

Datación: 1973

Dimensiones: $77 \times 55 \mathrm{cms}$,

Técnica: Pintura cerámica

Descripción: Obra compuesta por siete placas de diferentes tamaños. Tan sólo hemos podido observar una fotografía en blanco y negro de la obra, por lo que la descripción está incompleta. Representa un gran círculo en color claro central y la silueta de la letra "A" mayúscula en bajo relieve en la zona inferior izquierda de la obra.

Bibliografía:

- FALOMIR, Carmela. "La pintura cerámica de Manolo Safont" en Butlletí d'Estudis Municipals. 2a etapa, $\mathrm{n}^{\circ}$ 2. Ajuntament d'Onda. Onda, 2001, pág. 17

\section{Imagen:}

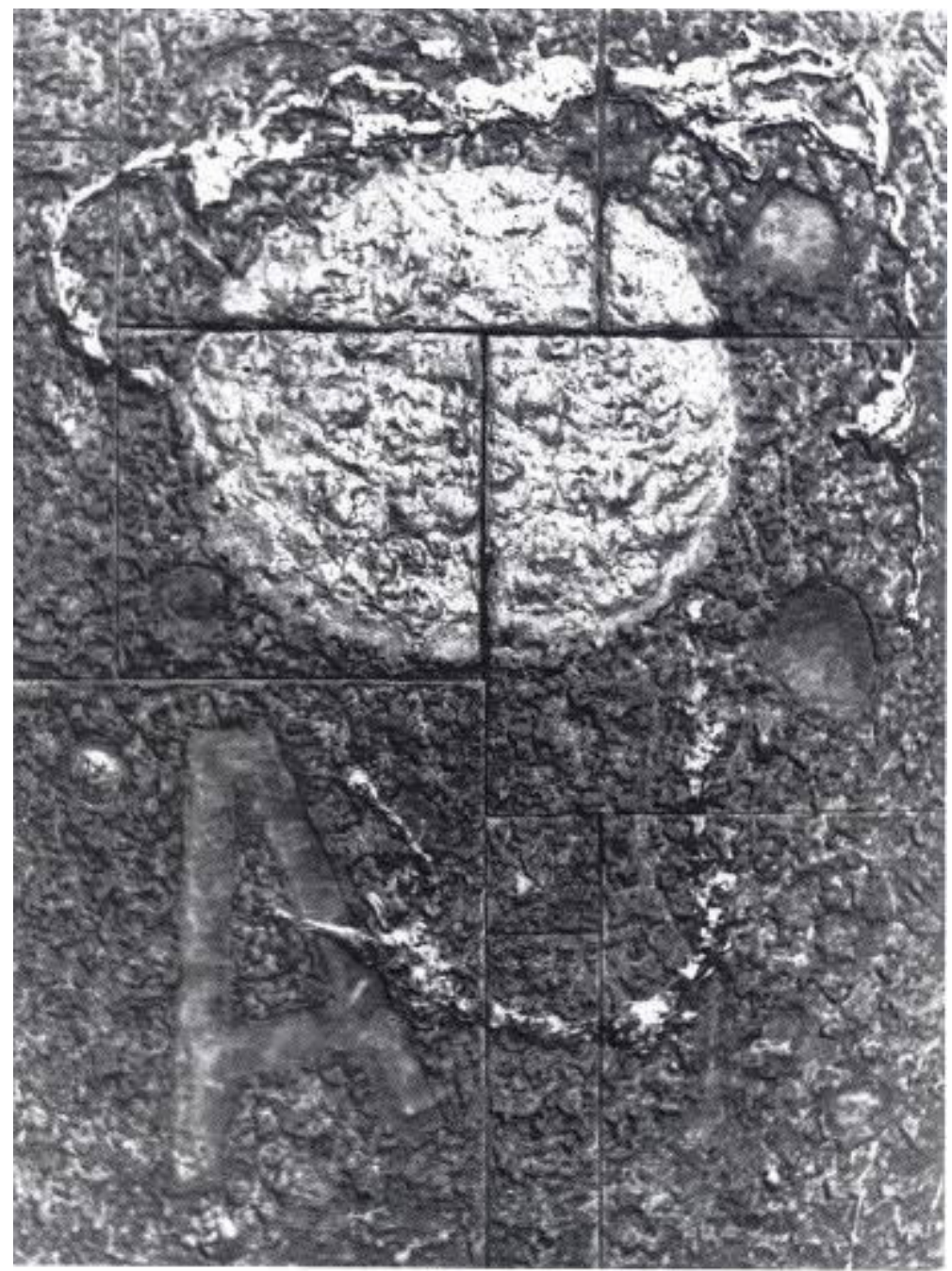


No: 4.27

Título: Sin Título

Autoría: Manolo Safont

Dimensiones: $55 \times 115 \mathrm{cms}$

Datación: 1973

Técnica: Pintura cerámica

Descripción: Obra compuesta por placas de diferentes tamaños. Un muro roto realizado con colores oscuros, a través del cual asoma una desdibujada forma humana, realizada en color blanco. Paleta cromática: blancos, amarillos, rojos, marrones y negros.

Exposiciones:

- Il Art Castellonenc d'Avui. Sala Municipal d'Onda, diciembre 1973 enero 1974, Onda

\section{Bibliografía:}

- FALOMIR, Carmela. "La pintura cerámica de Manolo Safont" en Butlletí d'Estudis Municipals. $2^{\mathrm{a}}$ etapa, $\mathrm{n}^{\circ}$ 2. Ajuntament d'Onda. Onda, 2001, pág. 34

- http://manolosafont.blogspot.com.es/

Imagen:

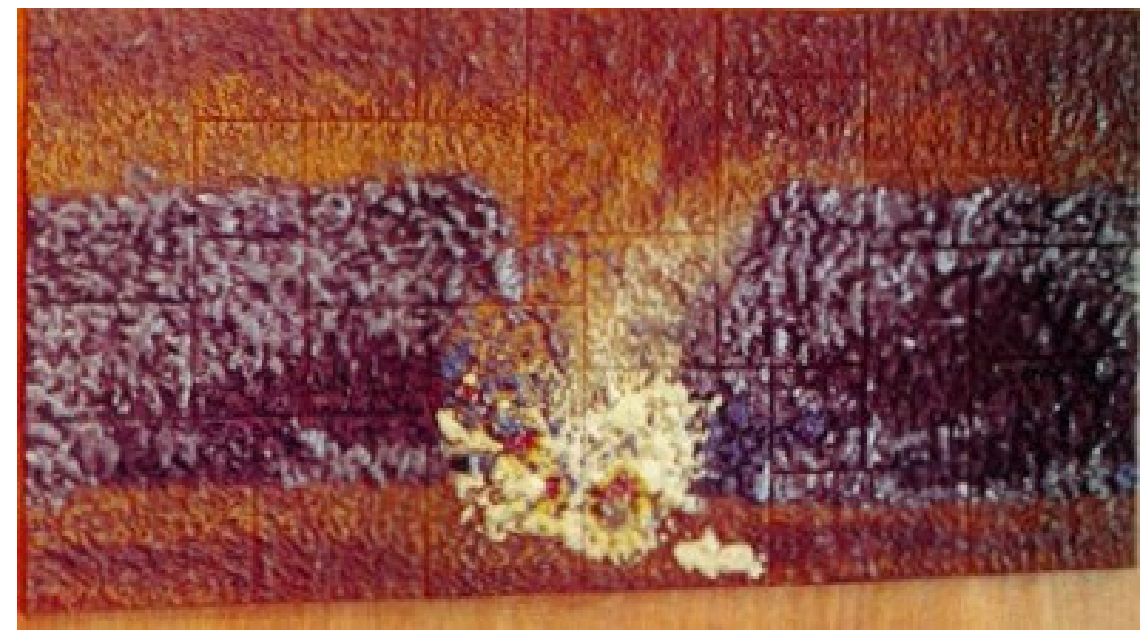


$\mathbf{N}^{0}: 4.28$

Título: Sin Título

Autoría: Manolo Safont

Datación: 1973

Técnica: Pintura cerámica

Descripción: Obra compuesta por placas de diferentes tamaños. Masa oscura en la parte inferior de la obra, sobre la cual destaca una forma abstracta realizada en color blanco y rojo. Paleta cromática: blancos, amarillos, rojos, marrones y negros.

Exposiciones:

- Il Art Castellonenc d'Avui. Sala Municipal d'Onda, diciembre 1973 enero 1974, Onda

\section{Bibliografía:}

- http://manolosafont.blogspot.com.es/

Imagen:

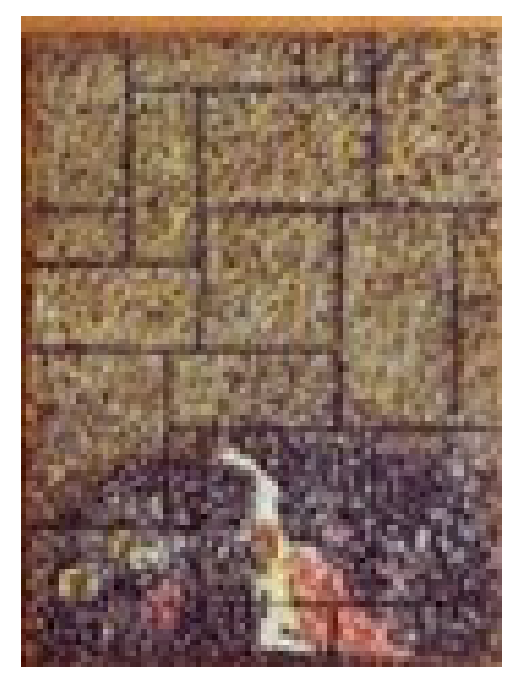


No: 4.29

Título: Sin Título

Autoría: Manolo Safont

Datación: 1973

Técnica: Pintura cerámica

Descripción: Obra compuesta por placas de diferentes tamaños. Forma central oscura realizada sobre un fondo en colores claros. Paleta cromática: blancos, rojos, marrones y negros.

Exposiciones:

- Il Art Castellonenc d'Avui. Sala Municipal d'Onda, diciembre 1973 enero 1974, Onda

Bibliografía:

- http://manolosafont.blogspot.com.es/

Imagen:

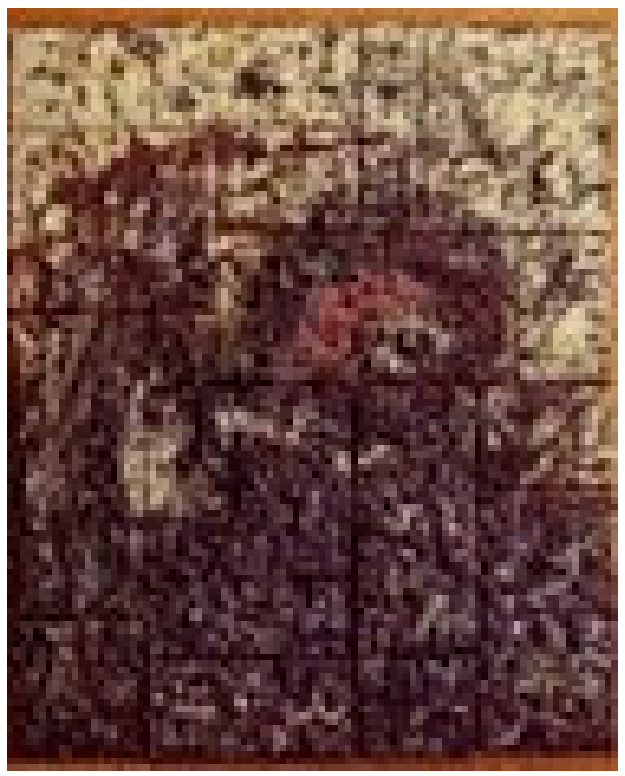


$\mathbf{N}^{0}: 4.30$

Título: Sin Título

Autoría: Manolo Safont

Datación: 1976

Dimensiones: $90,5 \times 86 \mathrm{cms}$

Técnica: Pintura cerámica

Localización: Museo de Arte Contemporáneo, Elche, Alicante

Descripción: Obra compuesta por varias placas de diferentes tamaños de gres. Sobre el margen inferior, se observa el busto de una figura, que alza su brazo derecho hasta el margen superior de la obra, con un rostro que parece una calavera. Paleta cromática: blancos, ocres, rojos, marrones y negros.

Exposiciones:

- Colección permanente Museo de Arte Contemporáneo de Elche, Elche, Alicante

Imagen:

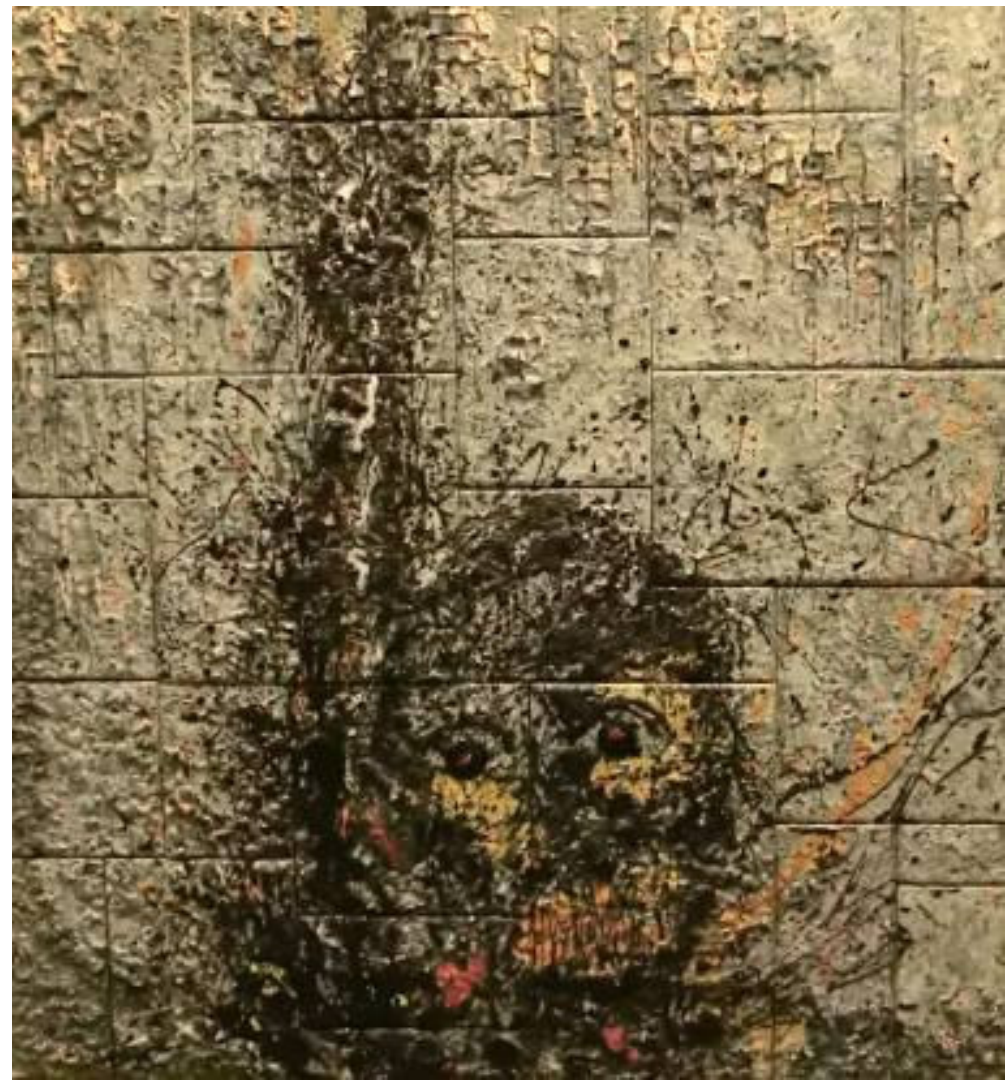


No: 4.31

Título: Sin Título

Autoría: Manolo Safont

Datación: Anterior a 1978

Técnica: Pintura cerámica

Descripción: Obra compuesta por varias placas de diferentes tamaños. Tan sólo hemos podido observar una fotografía en blanco y negro de esta obra, por lo que no se establece la paleta cromática. Sobre un fondo claro, se representa una carga matérica en el margen derecho y zona central, con una mancha central de formas redondeadas.

Exposiciones:

- Safont. Pintura cerámica. Sala Goya. Casa de España en París, del 5 al 15 de octubre de 1978

\section{Bibliografía:}

- Safont. Pintura cerámica. Sala Goya. Casa de España en París, del 5 al 15 de octubre de 1978

Imagen:

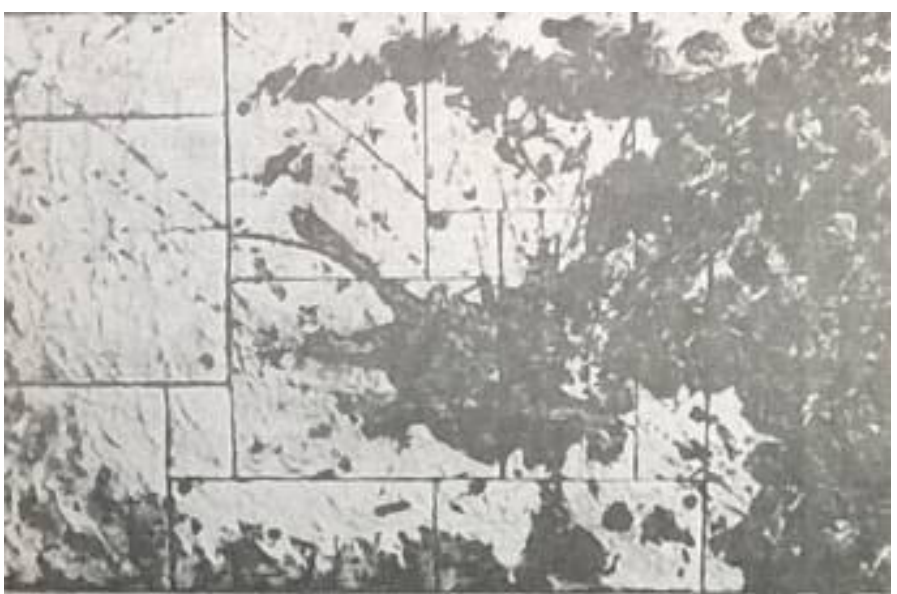


No: 4.32

Título: Sin Título

Autoría: Manolo Safont

Datación: Anterior a 1978

Técnica: Pintura cerámica

Descripción: Obra compuesta por una única placa. Tan sólo hemos podido localizar una fotografía en blanco y negro de esta obra, por lo que no se establece la paleta cromática. Sobre un fondo claro, se observa una masa en la zona inferior, con extensiones de goteo hacia el margen superior.

\section{Exposiciones:}

- Safont. Pintura cerámica. Sala Goya. Casa de España en París, del 5 al 15 de octubre de 1978

- Safont. Palau Oliver de Boteller, del 9 al 16 maig 1983, Generalitat de Catalunya, Tortosa

\section{Bibliografía:}

- Safont. Pintura cerámica. Sala Goya. Casa de España en París, del 5 al 15 de octubre de 1978

- Safont. Palau Oliver de Boteller, del 9 al 16 maig 1983, Generalitat de Catalunya, Tortosa

Imagen:

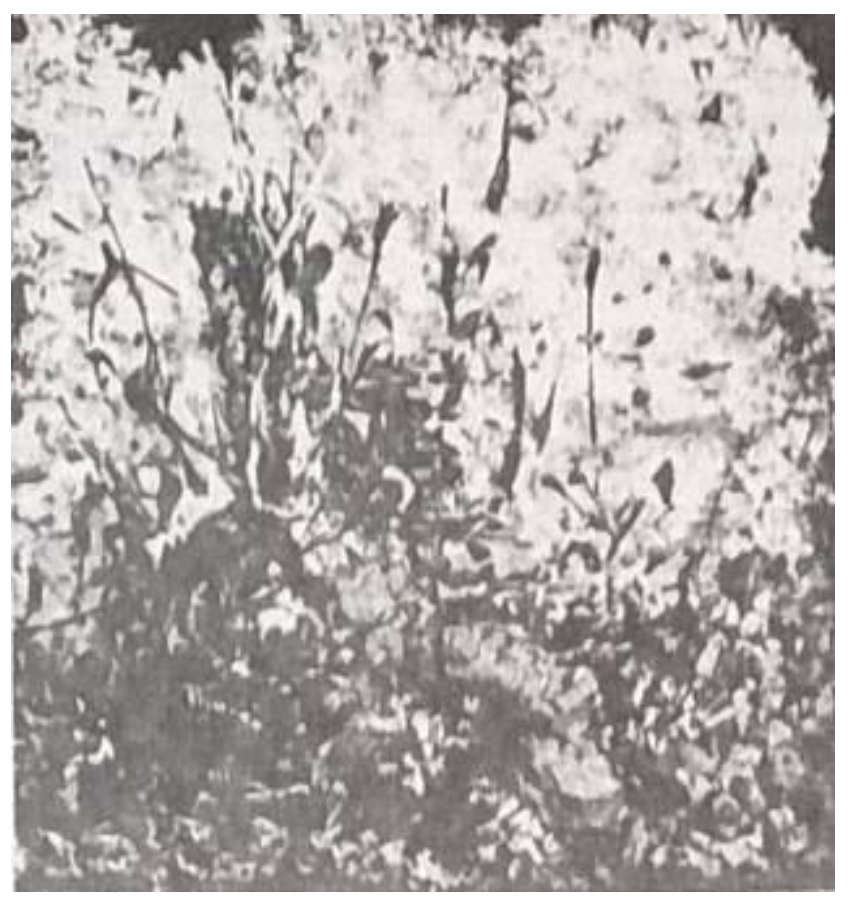


No: 4.33

Título: Sin Título

Autoría: Manolo Safont

Datación: Anterior a 1978

Técnica: Pintura cerámica

Descripción: Obra compuesta por 2 placas. Tan sólo hemos podido localizar una fotografía en blanco y negro de esta obra, por lo que no se establece la paleta cromática. Una masa oscura en dirección oblicua descendiente que va desde la izquierda a la derecha del margen inferior de la obra, mientras que en la zona superior se observan salpicaduras.

Exposiciones:

- Safont. Pintura cerámica. Sala Goya. Casa de España en París, del 5 al 15 de octubre de 1978

\section{Bibliografía:}

- Safont. Pintura cerámica. Sala Goya. Casa de España en París, del 5 al 15 de octubre de 1978

\section{Imagen:}

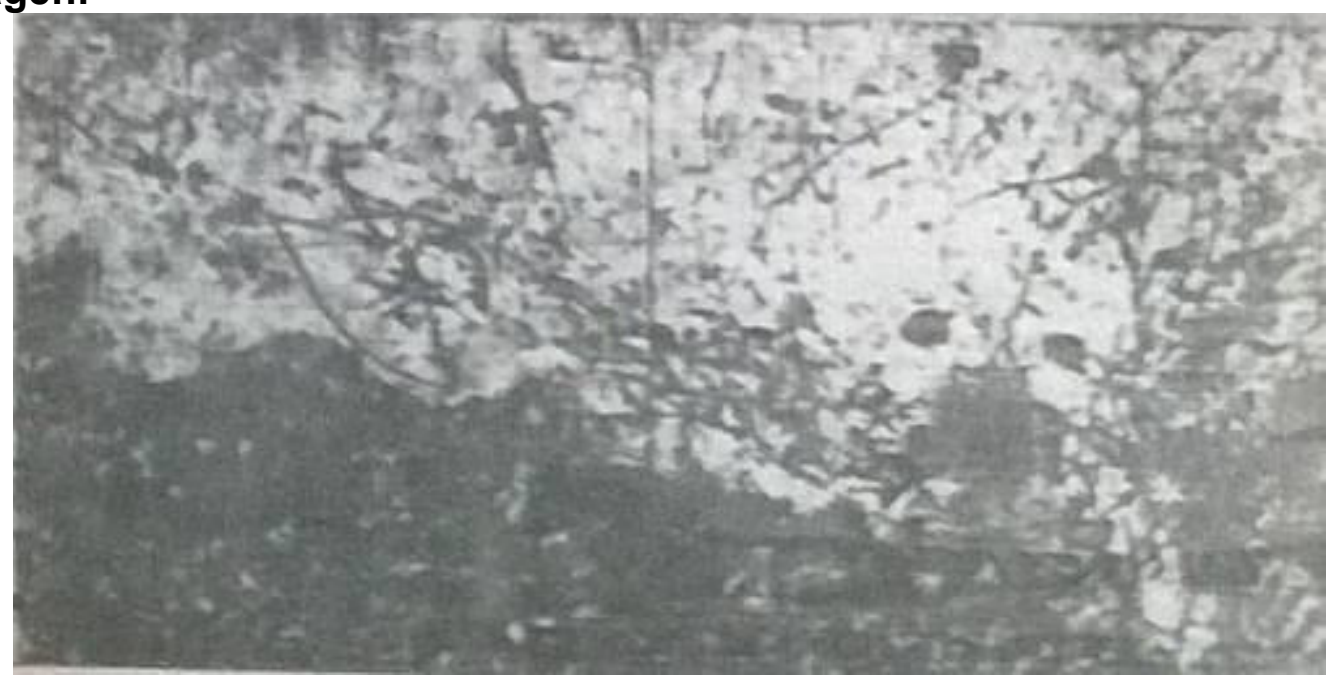


$N^{0}: 4.34$

Título: Sin Título

Autoría: Manolo Safont

Datación: 1978

Inscripciones: Safont 78 en lateral superior izquierdo. Llibertat

Dimensiones: $30 \times 40 \mathrm{cms}$.

Técnica: Pintura cerámica

Descripción: Obra compuesta por una única placa, fue utilizada como portada de los catálogos de las exposiciones de Safont en la Casa de España en París en 1978, en la del Museo González Martí en 1980 y en la de Torrent en 1980. Sobre una base inferior con mucha textura, se observa una forma de color blanco, parecida a un cráneo humano, con los ojos muy marcados, y sobre éste, un fondo rojizo sobre el que se lee "Llibertat". Paleta cromática: blancos, amarillos, rojos, azules, violetas y negros.

\section{Exposiciones:}

- Safont. Pintura cerámica. Sala Goya. Casa de España en París, del 5 al 15 de octubre de 1978

- Exposición de cerámicas de Safont. Sala de Exposiciones del Museo Nacional de Cerámica "González Martí" Palacio de Dos Aguas, del 3 al 30 marzo 1980, Valencia

- Safont. Torre I, Sala Municipal d'Exposicions de l'Ajuntament de Torrent, del 2 al 21 de novembre, 1980, Torrent (Valencia)

\section{Bibliografía:}

- Safont. Pintura cerámica. Sala Goya. Casa de España en París, del 5 al 15 de octubre de 1978

- Exposición de cerámicas de Safont. Sala de Exposiciones del Museo Nacional de Cerámica "González Martí" Palacio de Dos Aguas, del 3 al 30 marzo 1980, Valencia

- Safont. Torre I, Sala Municipal d'Exposicions de l'Ajuntament de Torrent, del 2 al 21 de novembre, 1980, Torrent (Valencia)

- http://www.gva.es/museo/safon14.htm, 1995-1996

- FALOMIR, Carmela. "La pintura cerámica de Manolo Safont" en Butlletí d'Estudis Municipals. $2^{\mathrm{a}}$ etapa, $\mathrm{n}^{\circ}$ 2. Ajuntament d'Onda. Onda, 2001, pág. 25.

Imagen:

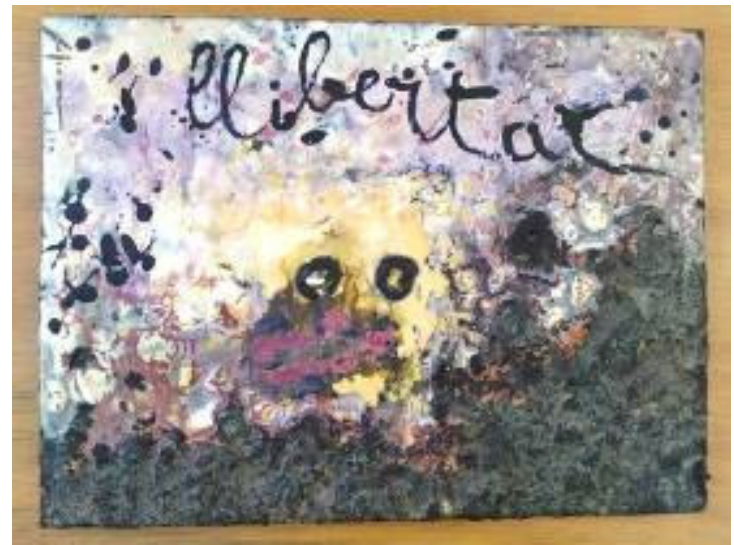


No: 4.35

Título: Sant Vicent

Autoría: Manolo Safont

Datación: Inicio década 1960 - Final década 1970

Inscripciones: Safont en ángulo inferior izquierdo.

Dimensiones: $103 \times 70 \mathrm{cms}$

Técnica: Pintura cerámica

Localización: Colección privada $\mathrm{n}^{\circ} 15$, Onda

Descripción: Obra compuesta por una 12 placas, en disposición 4×3, en la que se representa "el miracle del mocadoret" (el milagro del pañuelito) realizado por San Vicente Ferrer, fraile dominico patrón principal de Valencia. Cuenta la leyenda que en 1385 estaba predicando San Vicente Ferrer a las puertas de la Iglesia de Santos Juanes de Valencia, cuando en un momento determinado de su sermón, hizo ver a los presentes que a su alrededor había personas que sufrían y morían por pobreza y que era necesaria la caridad. Así, el dominico sacó su pañuelo lanzándolo al aire y dijo a la multitud que siguieran el vuelo del pañuelo, y que allí donde se detuviese encontrarían personas necesitadas. De esta manera, el pañuelo sobrevoló las calles hasta entrar por una ventana en una casa de una plaza, actualmente plaza del Miracle del mocadoret, donde encontraron una familia a punto de fallecer en la miseria, que fue socorrida por las personas que vieron el milagro. En la obra se representa a San Vicente, con tonsura, y hábito dominico, de color blanco, con capa negra, de pie, con el brazo derecho en alto y el pañuelo, volando, en el ángulo superior izquierdo. Alrededor de San Vicente un grupo de seis personas están escuchando su sermón. Realizada con predominio de formas geométricas y base texturizada, con una gama de colores suaves. Paleta cromática: blancos, amarillos, rojos, azules, marrones y negros.

Bibliografía:

- http://www.jdiezarnal.com/valenciajosemarti.html Imagen:

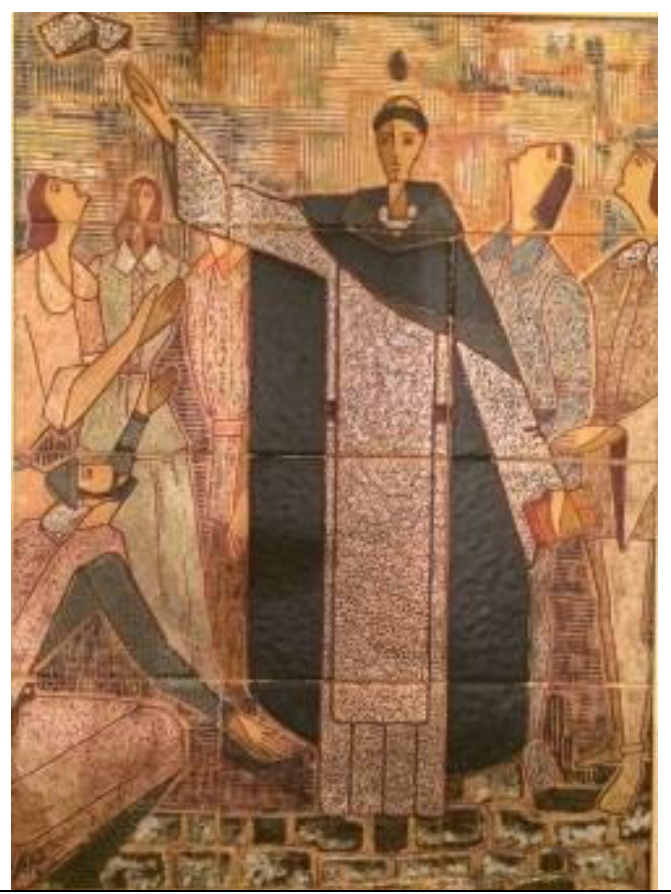


No: 4.36

Título: Sin Título

Autoría: Manolo Safont

Datación: Anterior a 1980

Dimensiones: $45 \times 75 \mathrm{cms}$

Técnica: Pintura cerámica

Descripción: Obra compuesta por 6 placas de diferentes tamaños. En la parte inferior de la obra se observan tres rostros-cráneos humanos, muy desdibujados. Paleta cromática: blancos, amarillos, rojos, marrones y negros.

Bibliografía:

- http://www.gva.es/museo/safon15.htm, 1995-1996

Imagen:

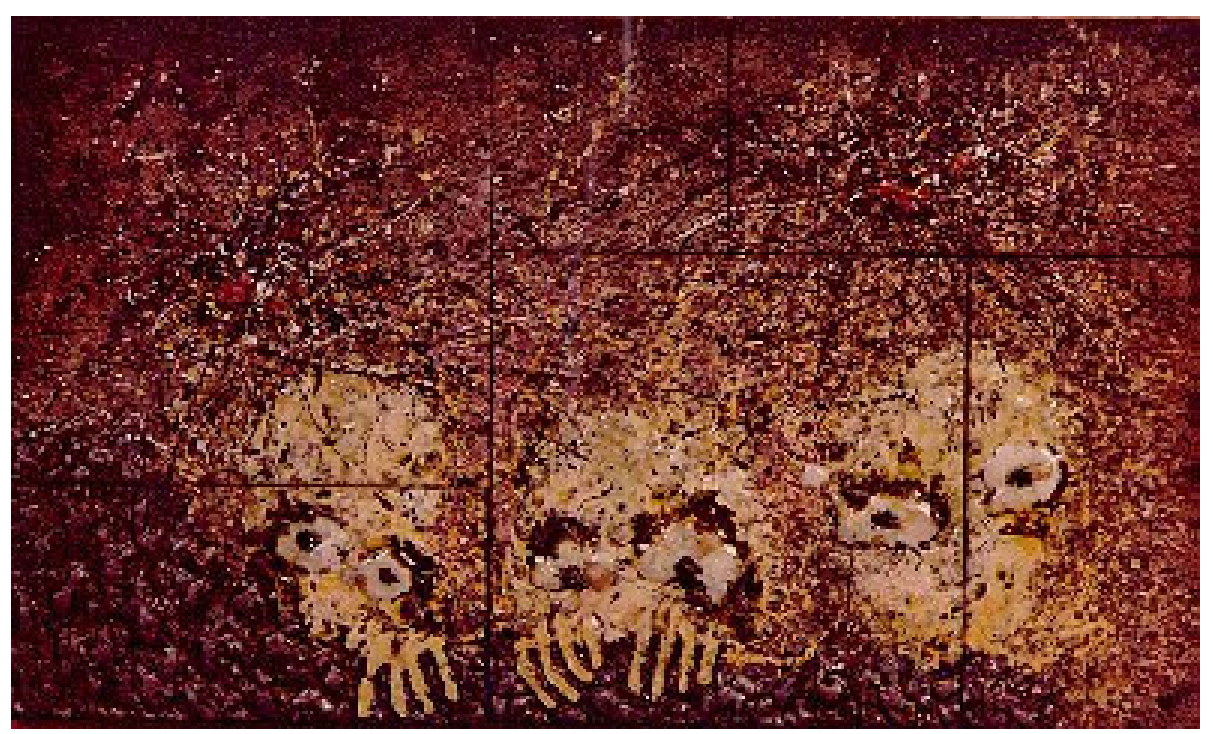


No: 4.37

Título: Sin Título

Autoría: Manolo Safont

Datación: Anterior a 1980

Técnica: Pintura cerámica

Descripción: Obra compuesta por placas de diferentes tamaños. En la parte superior izquierda se observa una forma que parece una paloma, realizada en color claro. Paleta cromática: blancos, rojos, marrones y negros.

Exposiciones:

- Exposición de cerámicas de Safont. Sala de Exposiciones del Museo Nacional de Cerámica "González Martí" Palacio de Dos Aguas, del 3 al 30 marzo 1980, Valencia

\section{Bibliografía:}

- Exposición de cerámicas de Safont. Sala de Exposiciones del Museo Nacional de Cerámica "González Martí" Palacio de Dos Aguas, del 3 al 30 marzo 1980, Valencia

\section{Imagen:}

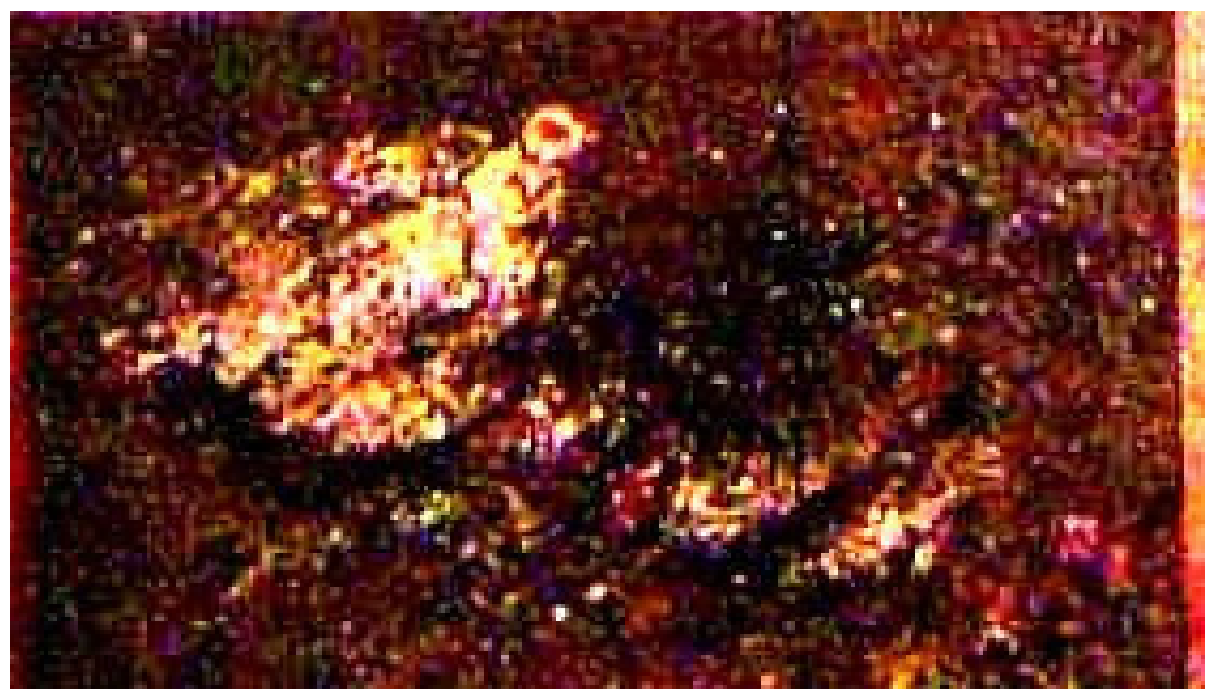


$N^{0}: 4.38$

Título: Sin Título

Autoría: Manolo Safont

Datación: Anterior a 1980

Dimensiones: $60 \times 90 \mathrm{cms}$

Técnica: Pintura cerámica

Descripción: Obra compuesta por varias placas de diferentes tamaños. Tan sólo hemos podido localizar una fotografía en blanco y negro de esta obra, por lo que la descripción no está completa. Rosalía Torrent se refiere a esta tipología de obras en el catálogo de la exposición realizada en 1998 en Morella: "És en aquest període quan assistim a algunes de les obres més emotives de Safont: els seus coneguts rostres esglaiats, obrint els ulls a la llum a través d'excletxes de murs de presons ». En un vano centrado abierto en un muro, se observan ocho figuras humanas, de las cuales tan sólo observamos parte del rostro y los enormes ojos.

Bibliografía:

- TORRENT, Rosalía "Manolo Safont: Creador d'intensitat" Safont 9 octubre-9 noviembre 1998, Morella (Castellón), pág. 9

- FALOMIR, Carmela. "La pintura cerámica de Manolo Safont" en Butlletí d'Estudis Municipals. $2^{\mathrm{a}}$ etapa, $\mathrm{n}^{\circ}$ 2. Ajuntament d'Onda. Onda, 2001, pág. 31

Imagen:

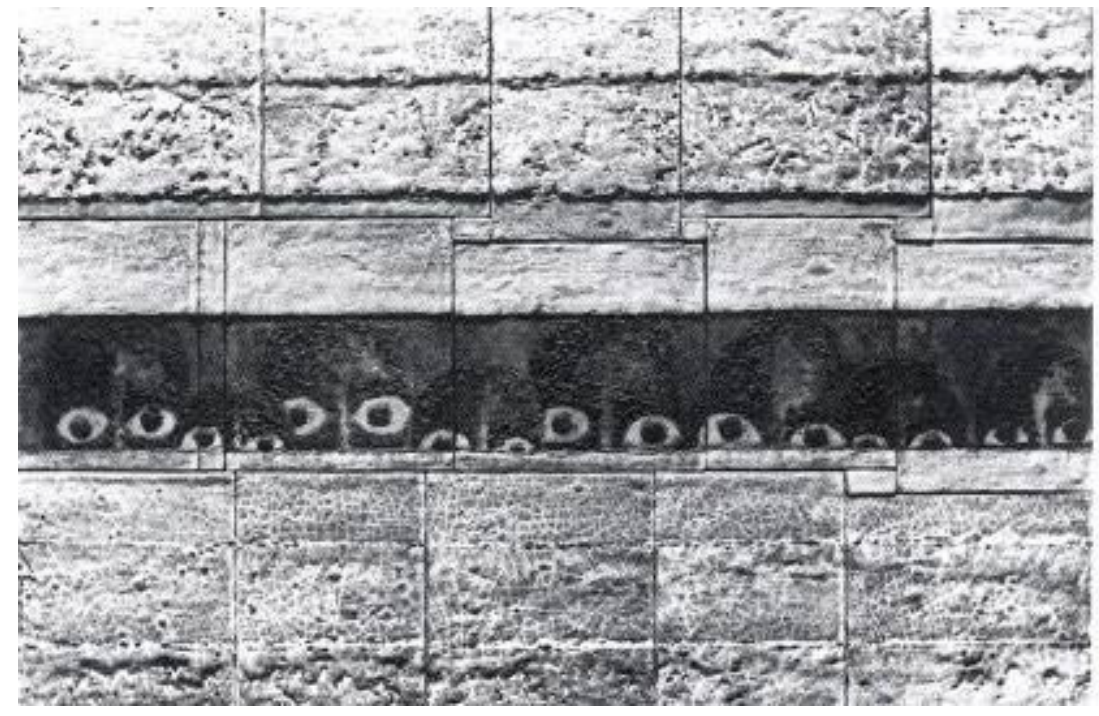


No: 4.39

Título: Sin Título

Autoría: Manolo Safont

Datación: Anterior a 1998

Técnica: Pintura cerámica

Descripción: Obra compuesta por varias placas de diferentes tamaños. Rosalía Torrent se refiere a esta tipología de obras en el catálogo de la exposición realizada en 1998 en Morella: "És en aquest període quan assistim a algunes de les obres més emotives de Safont: els seus coneguts rostres esglaiats, obrint els ulls a la llum a través d'excletxes de murs de presons". Tan sólo hemos podido localizar una fotografía en blanco y negro de la obra, por lo que no se establece la paleta cromática. Representa un muro, formado por placas cerámicas de diferentes tamaños, y a través de una abertura en este muro, vemos asomado un rostro con grandes ojos, mirando hacia el exterior.

\section{Bibliografía:}

- Safont. 9 octubre-9 noviembre 1998, Morella, Castellón, pág. 9

- http://repositori.uji.es/

\section{Imagen:}

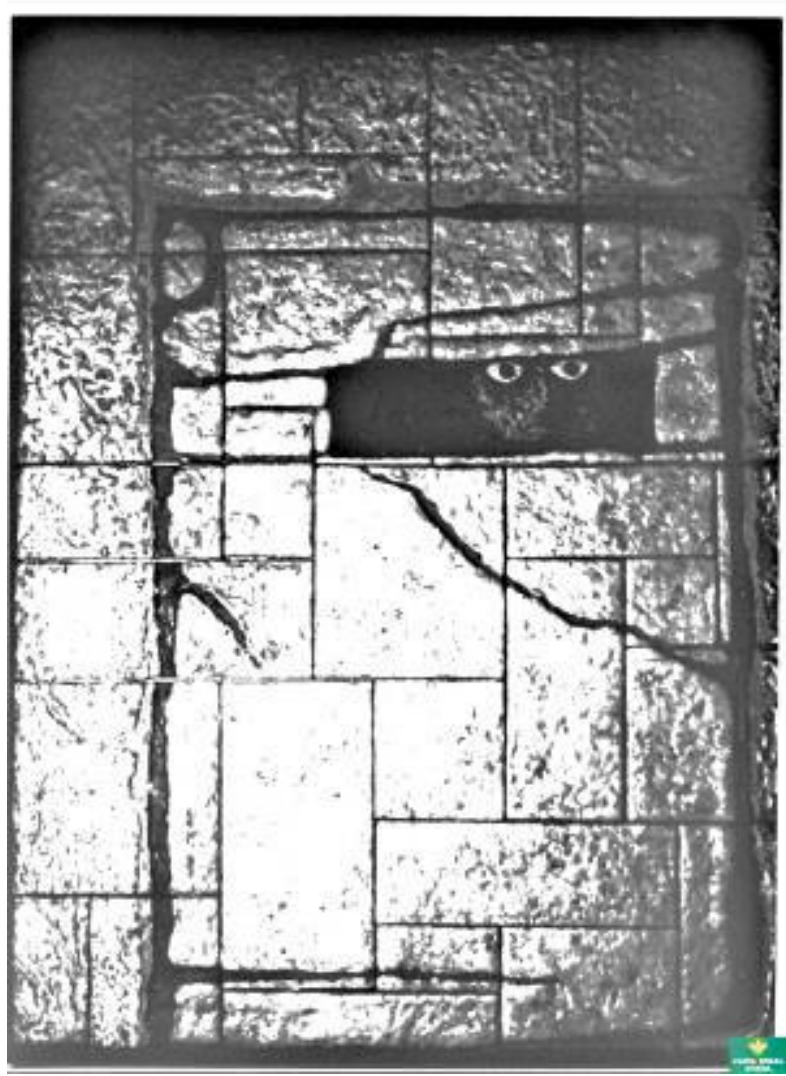




\section{5.- FICHAS CATALOGRÁFICAS: OBRAS DE LA ETAPA DE ABSTRACCIÓN}

Abandonada definitivamente su etapa de figuración, y tras una etapa de transición en la cual Safont recurre a la figuración como medio de denuncia social, su obra evoluciona definitivamente hacia la abstracción.

Será este estilo artístico con el que cree todas sus obras que realizará hasta su fallecimiento.

En esta etapa, Safont desarrolla un dominio completo de la materia y el color que traslada a sus obras con composiciones en las que progresivamente va utilizando más cantidad de masa cerámica, creando texturas y relieves más gruesos. Crea con completa libertad, sin condicionamientos impuestos por la figura.

Combina diferentes tipos de soportes, realizando obras tanto sobre una placa única, o dos, o tres, como obras sobre bases compuestas por diez o veinte placas de pequeñas dimensiones, que encaja con gran maestría.

Las primeras obras de esta etapa presentan una paleta sobria, de pocos colores y predominio de tonos neutros: gris, negro, blanco y marrón, aunque mantiene la utilización del rojo como color recurrente, y progresivamente incorpora otros tonos, ampliando la paleta con nuevos colores: verdes, violetas, amarillos, una amplia gama de azules, etc.

Debido a la gran textura de las obras y al fundiente de los colores cerámicos, en muchas de ellas resulta muy difícil la correcta lectura de las fechas con las que Safont data sus obras junto con su firma.

En este capítulo se analizan 114 obras, catalogadas desde la obra $n^{\circ} 5.1$ a la $n^{\circ} 5.114$. 
$\mathbf{N}^{0}: 5.1$

Título: Sin Título

Autoría: Manolo Safont

Datación: Anterior a 1966

Inscripciones: Safont en ángulo inferior izquierdo

Dimensiones: $50 \times 100 \mathrm{cms}$.

Técnica: Pintura cerámica

Localización: Colegio de Arquitectos de Castellón de la Plana (Castellón)

Descripción: Obra compuesta por 10 placas, en disposición 2 × 5. Sobre base de color claro, dos grandes masas azules situadas a izquierda y derecha de la composición con finos puentes de unión entre ellas. Se utiliza una imagen de esta obra para ilustrar el artículo de Luis Prades Perona, Presidente del Ateneo de Castellón, "Safont. Ceramista de Onda" publicado en el Programa de Fiestas de Onda de 1966. La obra fue adquirida por el Colegio de Arquitectos de Castellón. Paleta cromática: blancos, azules, marrones y negros.

Bibliografía:

- PRADES PERONA, Luis. "Safont. Ceramista de Onda" Programa de Fiestas 1966. Ayuntamiento de Onda, Onda, 1966

Imagen:

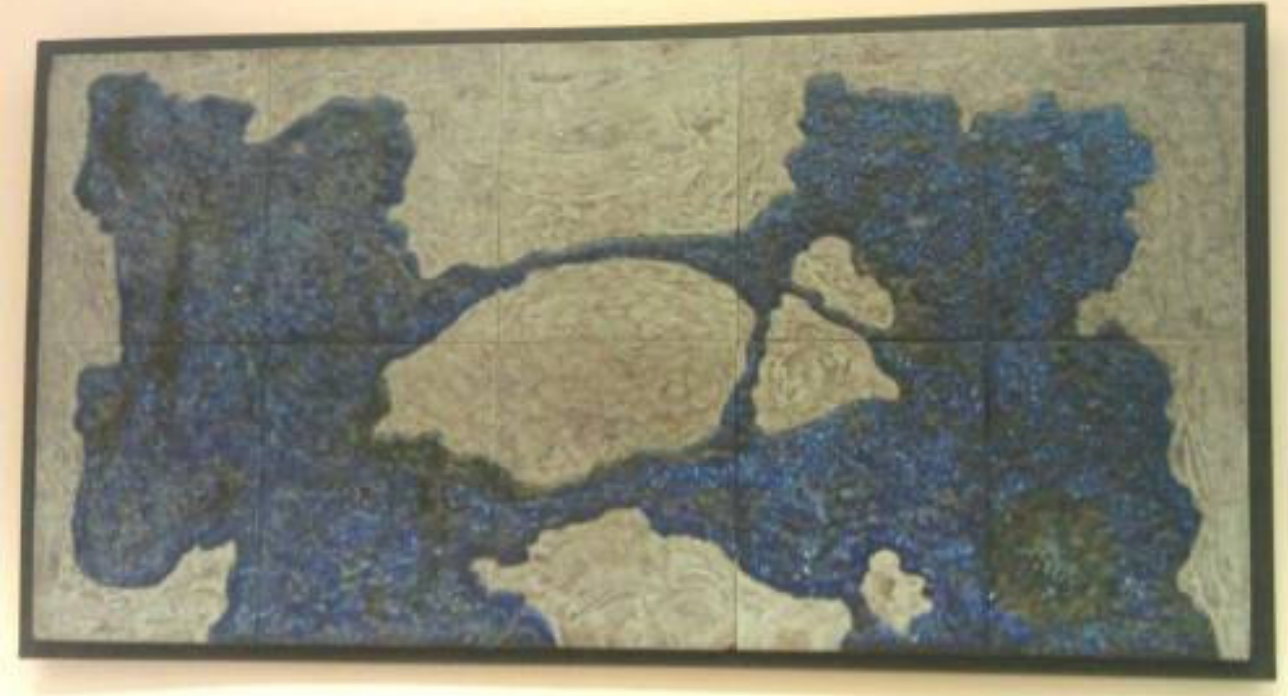

Imágenes relacionadas:

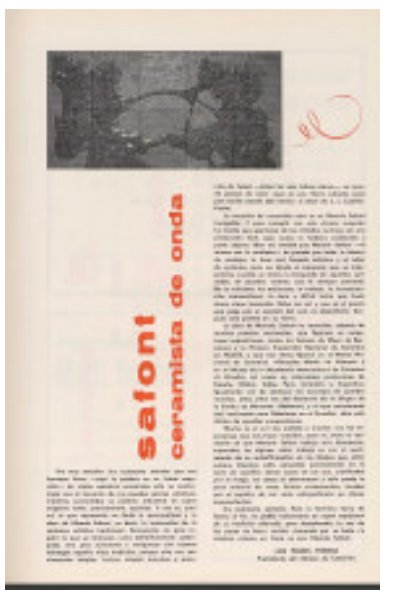


$\mathbf{N}^{0}: 5.2$

Título: Sin Título

Autoría: Manolo Safont

Datación: Década 1960

Dimensiones: $15 \times 15 \mathrm{cms}$

Técnica: Pintura cerámica

Localización: MAMS

Descripción: Obra compuesta por una única placa, con aguadas de color rojo.

Paleta cromática: amarillos, rojos y negros.

Exposiciones:

- Manolo Safont. Un museu, un llegat i un compromís. MAMS. Del 27 de noviembre de 2004 al 8 de enero de 2005. Onda

- Manolo Safont, un museu, un llegat, MAMS, mayo 2013, Onda

Bibliografía:

- http://www.eltriangulo.es/contenidos/?p=36891

- http://manolosafont.blogspot.com.es/

Imagen:

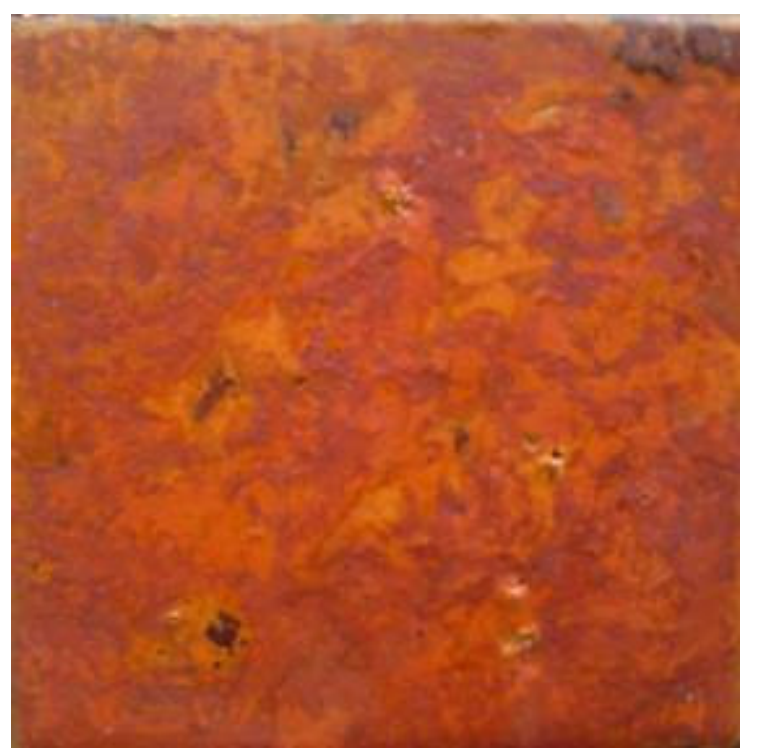


$\mathbf{N}^{0}: 5.3$

Título: Sin Título

Autoría: Manolo Safont

Datación: Década 1960

Inscripciones: Safont en ángulo inferior derecho

Dimensiones: $50 \times 100 \mathrm{cms}$

Técnica: Pintura cerámica

Localización: MAMS

Descripción: Obra compuesta por 20 placas de diferentes tamaños. Gran masa blanca y ocre rodeada en el margen superior, izquierdo e inferior de una masa oscura. Paleta cromática: blancos, ocres y negros.

Exposiciones:

- Manolo Safont. Un museu, un llegat i un compromís. MAMS. Del 27 de noviembre de 2004 al 8 de enero de 2005. Onda

- Manolo Safont, un museu, un llegat, MAMS, mayo 2013, Onda

\section{Bibliografía:}

- http://www.eltriangulo.es/contenidos/?p=36891

- http://manolosafont.blogspot.com.es/

Imagen:

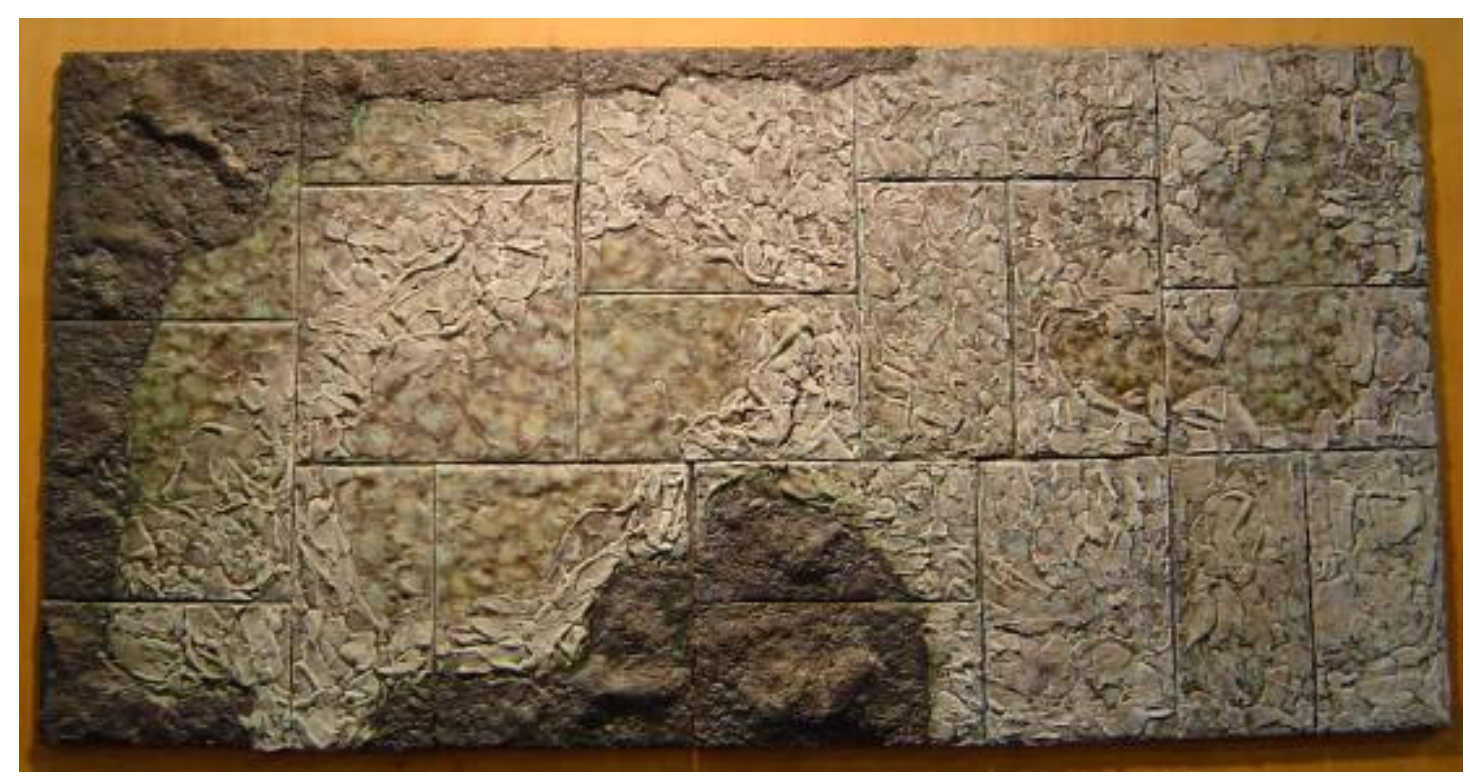


$\mathbf{N}^{\circ}: 5.4$

Título: Sin Título

Autoría: Manolo Safont

Datación: Década 1960

Dimensiones: $28 \times 52 \mathrm{cms}$

Técnica: Pintura cerámica

Localización: MAMS

Descripción: Obra compuesta por cuatro placas de 28x13 cms. Masa oscura con relieve sobre fondo rojo. Paleta cromática: amarillos, rojos, azules y negros.

Exposiciones:

- Manolo Safont. Un museu, un llegat i un compromís. MAMS. Del 27 de noviembre de 2004 al 8 de enero de 2005. Onda

- Manolo Safont, un museu, un llegat, MAMS, mayo 2013, Onda

Bibliografía:

- http://www.eltriangulo.es/contenidos/?p=36891

- http://manolosafont.blogspot.com.es/

\section{Imagen:}

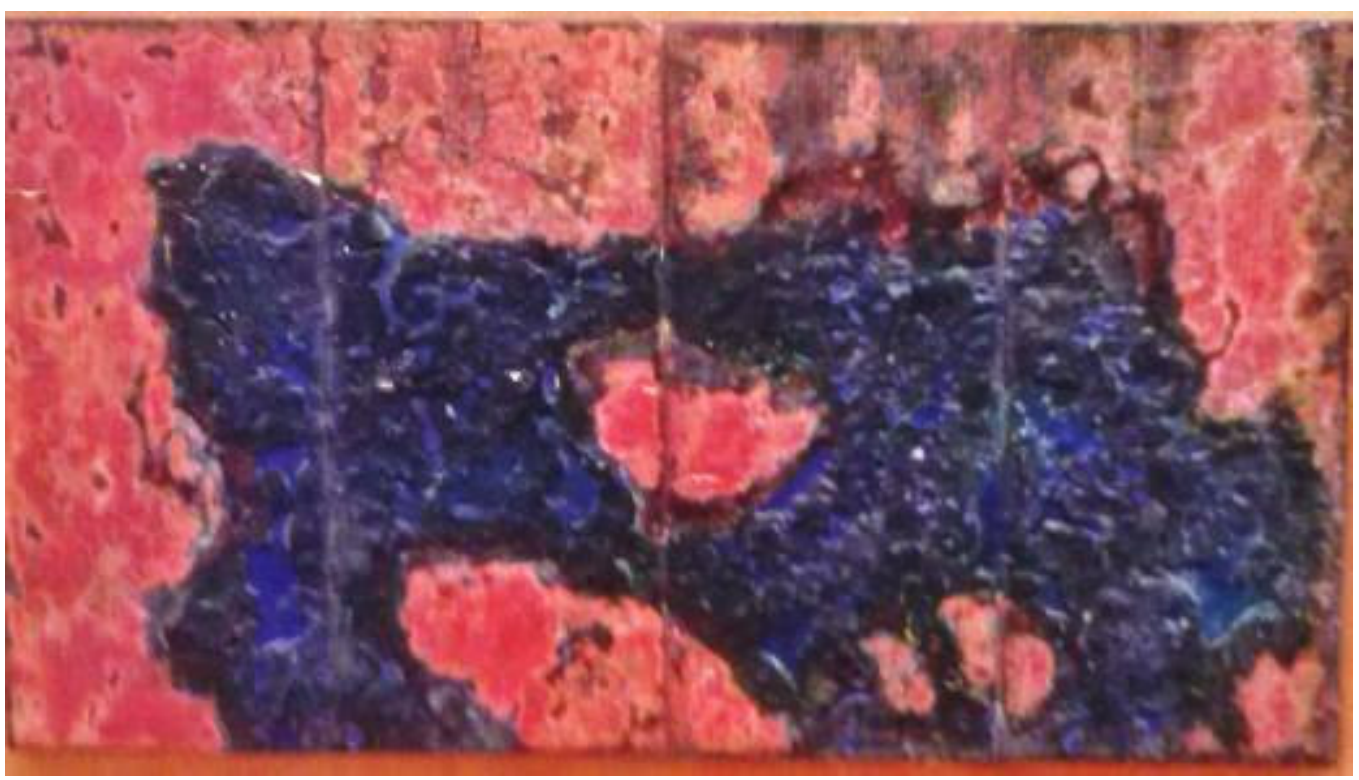


$\mathbf{N}^{0}: 5.5$

Título: Sin Título

Autoría: Manolo Safont

Datación: Década 1960

Inscripciones: Safont en ángulo inferior izquierdo

Dimensiones: $63 \times 110 \mathrm{cms}$

Técnica: Pintura cerámica

Localización: Colección privada $\mathrm{n}^{\circ} 15$, Onda.

Descripción: Obra compuesta por 26 placas de diferentes tamaños. Cuatro grandes masas rojas con pequeñas salpicaduras sobre fondo negro texturizado. Paleta cromática: rojos y negros.

Imagen:

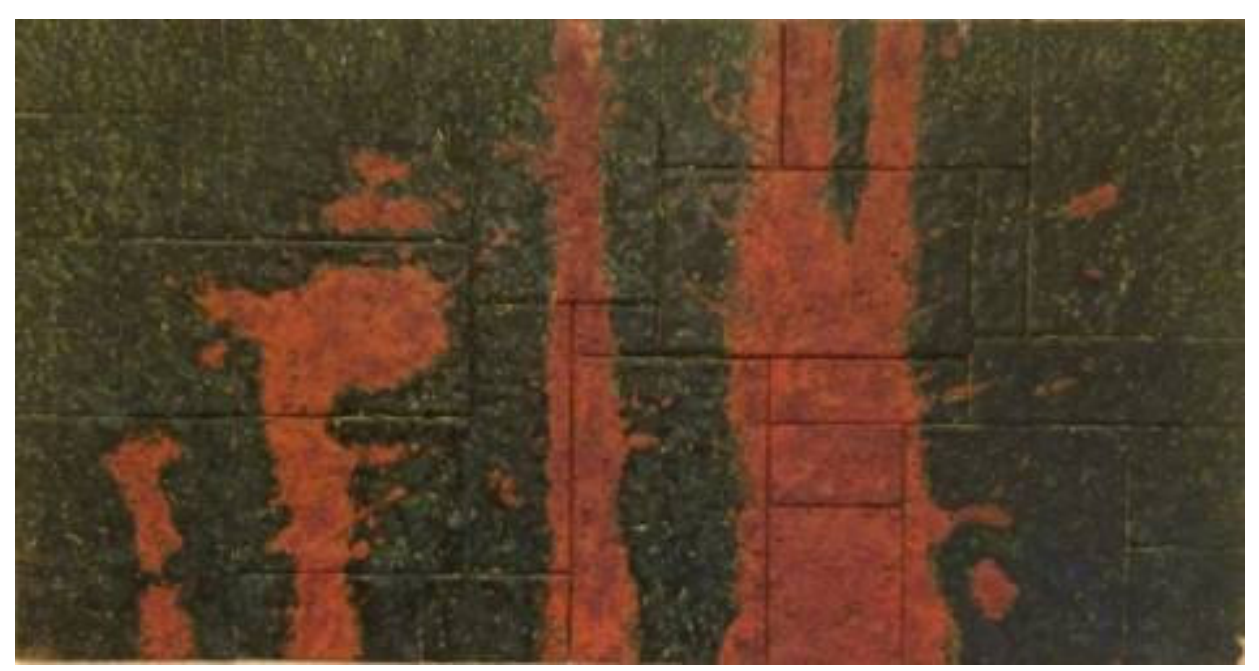




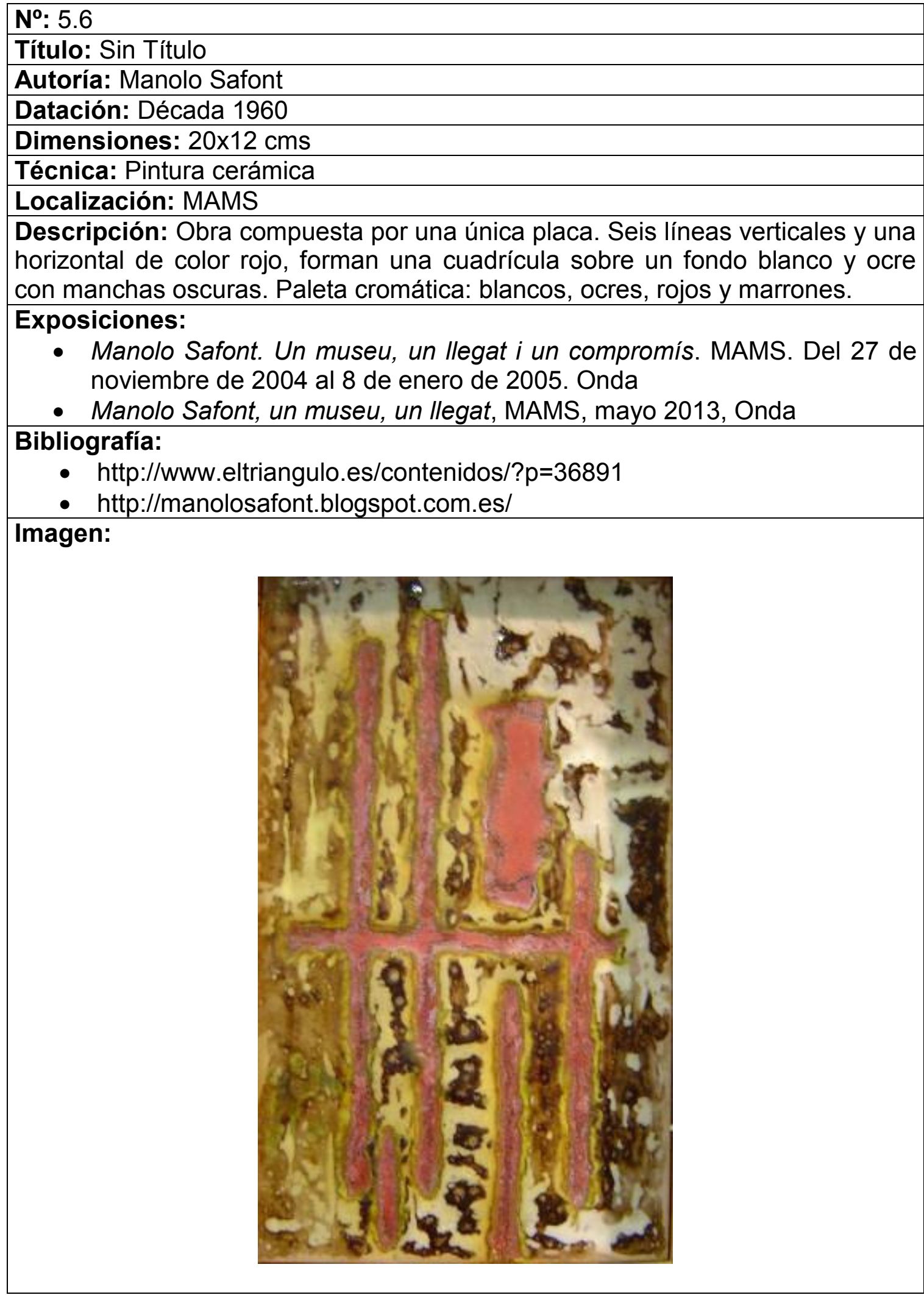


No: 5.7

Título: Sin Título

Autoría: Manolo Safont

Datación: Década 1960

Dimensiones: $30 \times 58 \mathrm{cms}$

Técnica: Pintura cerámica

Localización: MAMS

Descripción: Obra compuesta por 4 placas del mismo tamaño. Pieza con relieve y textura uniforme con trazado vertical. Paleta cromática: blancos, amarillos, rojos, verdes y negros.

Exposiciones:

- Manolo Safont. Un museu, un llegat i un compromís. MAMS. Del 27 de noviembre de 2004 al 8 de enero de 2005. Onda.

- Manolo Safont, un museu, un llegat, MAMS, mayo 2013, Onda

Bibliografía:

- http://www.eltriangulo.es/contenidos/?p=36891

- http://manolosafont.blogspot.com.es/

Imagen:

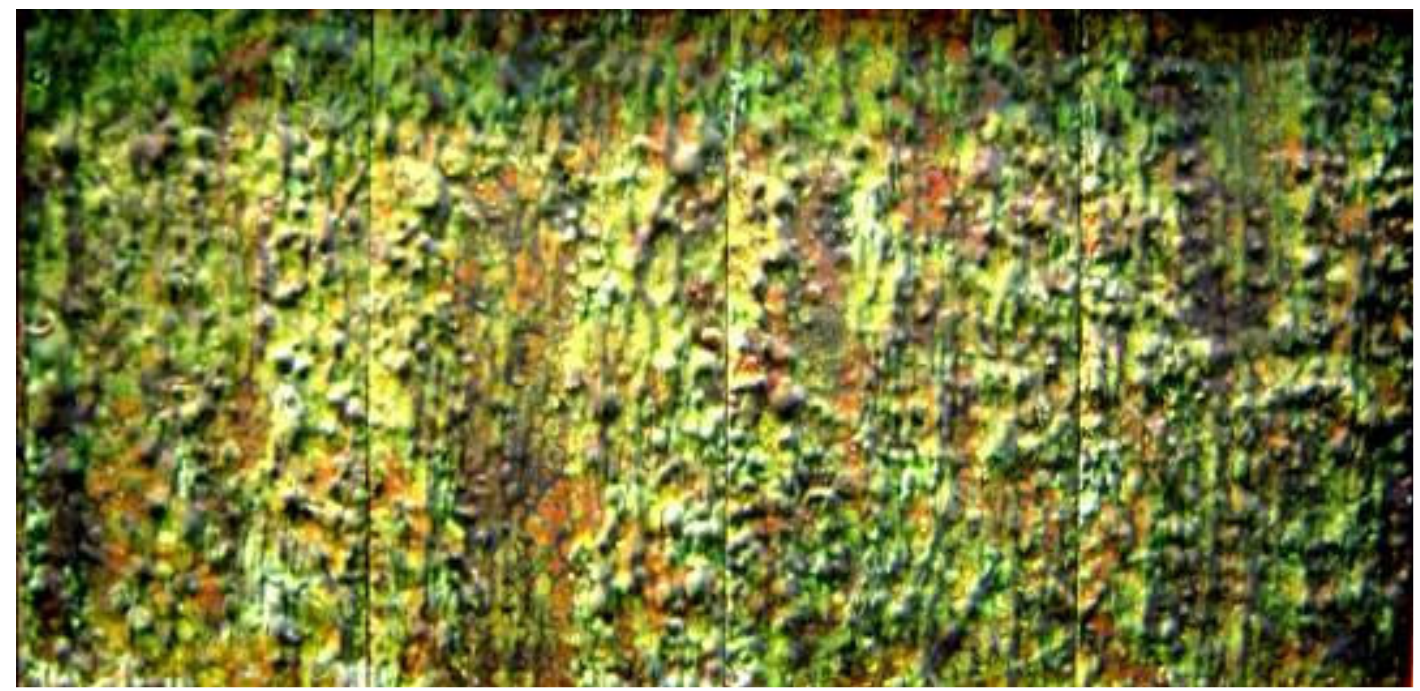


$\mathbf{N}^{0}: 5.8$

Título: Sin Título

Autoría: Manolo Safont

Datación: Final década 1960

Inscripciones: Safont en ángulo inferior derecho

Dimensiones: $85 \times 70 \mathrm{cms}$

Técnica: Pintura cerámica

Localización: MAMS

Descripción: Obra compuesta por 19 placas de diferentes tamaños. Una gran masa multicolor en disposición vertical, sobre un fondo liso rojo. Paleta cromática: blancos, amarillos, rojos, verdes y negros.

Exposiciones:

- Manolo Safont. Un museu, un llegat i un compromís. MAMS. Del 27 de noviembre de 2004 al 8 de enero de 2005. Onda

- Manolo Safont, un museu, un llegat, MAMS, mayo 2013, Onda

Bibliografía:

- http://www.eltriangulo.es/contenidos/?p=36891

- http://manolosafont.blogspot.com.es/

\section{Imagen:}

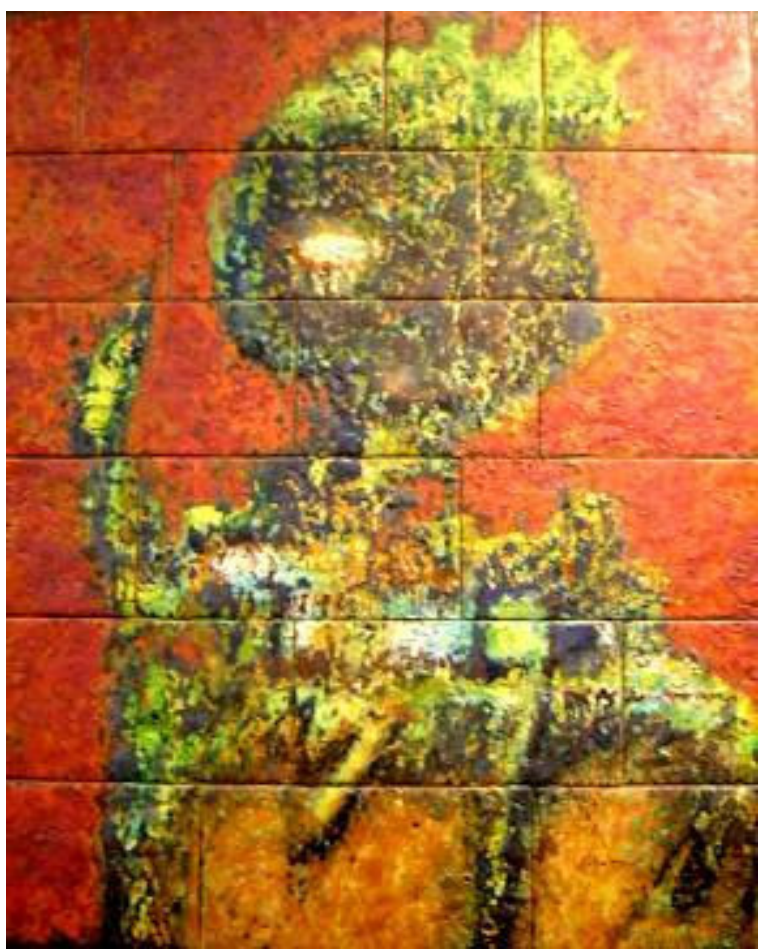


$\mathbf{N}^{0}: 5.9$

Título: Sin Título

Autoría: Manolo Safont

Datación: 1972

Inscripciones: Safont 72 en ángulo inferior izquierdo

Dimensiones: $70 \times 88 \mathrm{cms}$

Técnica: Pintura cerámica

Localización: Colección privada $\mathrm{n}^{\circ} 13$, Onda.

Descripción: Obra compuesta por gran número de placas, de diversos tamaños. Sobre superficie texturizada de color marrón, se extiende una gran masa blanca de forma semicircular desde el margen izquierdo, y sobre ella semicírculo de color azul y naranja, con un pequeño círculo rojo en la zona del margen inferior. Paleta cromática: blancos, amarillos, naranjas, rojos, azules, marrones y negros.

\section{Imagen:}

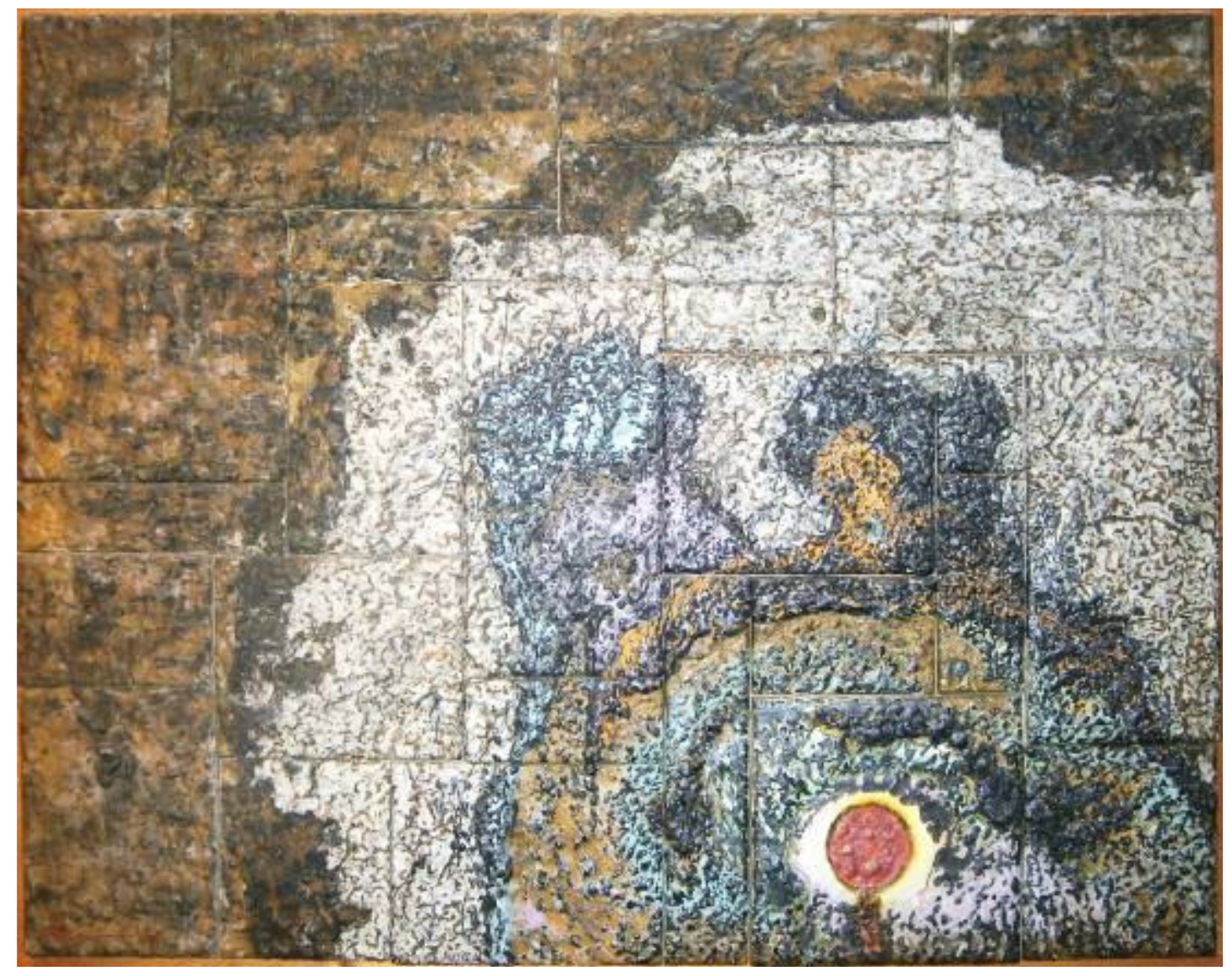




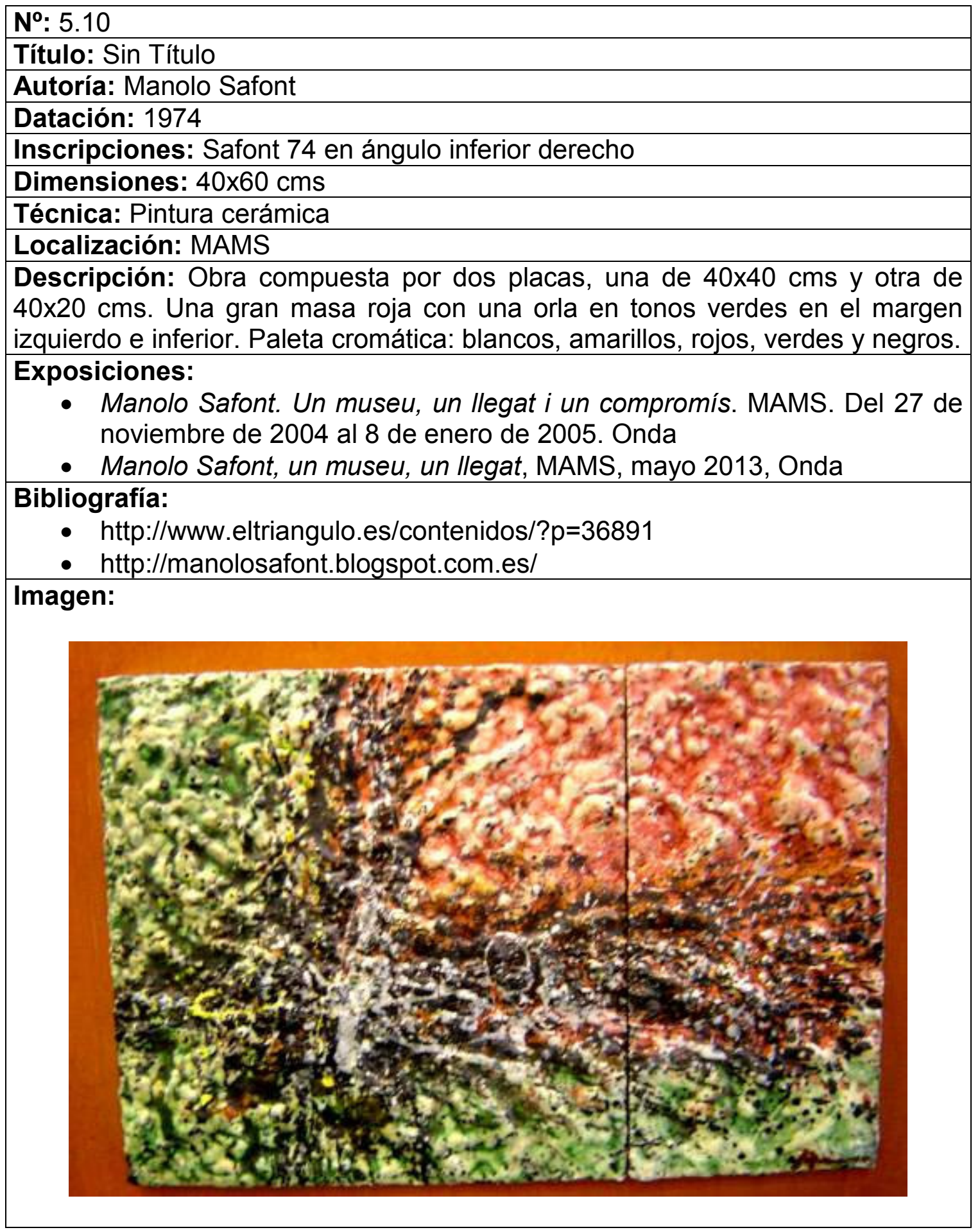


$\mathbf{N}^{\circ}: 5.11$

Título: Sin Título

Autoría: Manolo Safont

Datación: 1974

Inscripciones: Safont 74 en ángulo inferior derecho

Dimensiones: $100 \times 100 \mathrm{cms}$

Técnica: Pintura cerámica

Localización: Colección privada $\mathrm{n}^{\circ} 13$, Onda.

Descripción: Obra de gran tamaño compuesta por múltiples placas de diversos tamaños. Grandes masas oscuras, sobre una superficie texturizada de color marrón, convergen en el centro de la obra, con una masa de color blanco con salpicaduras de color negro. Safont creó una obra muy similar a esta, formaban pareja, que vendió a la entidad bancaria Caja de Ahorros de Valencia. Paleta cromática: blancos, amarillos, rojos, marrones y negros.

Imagen:

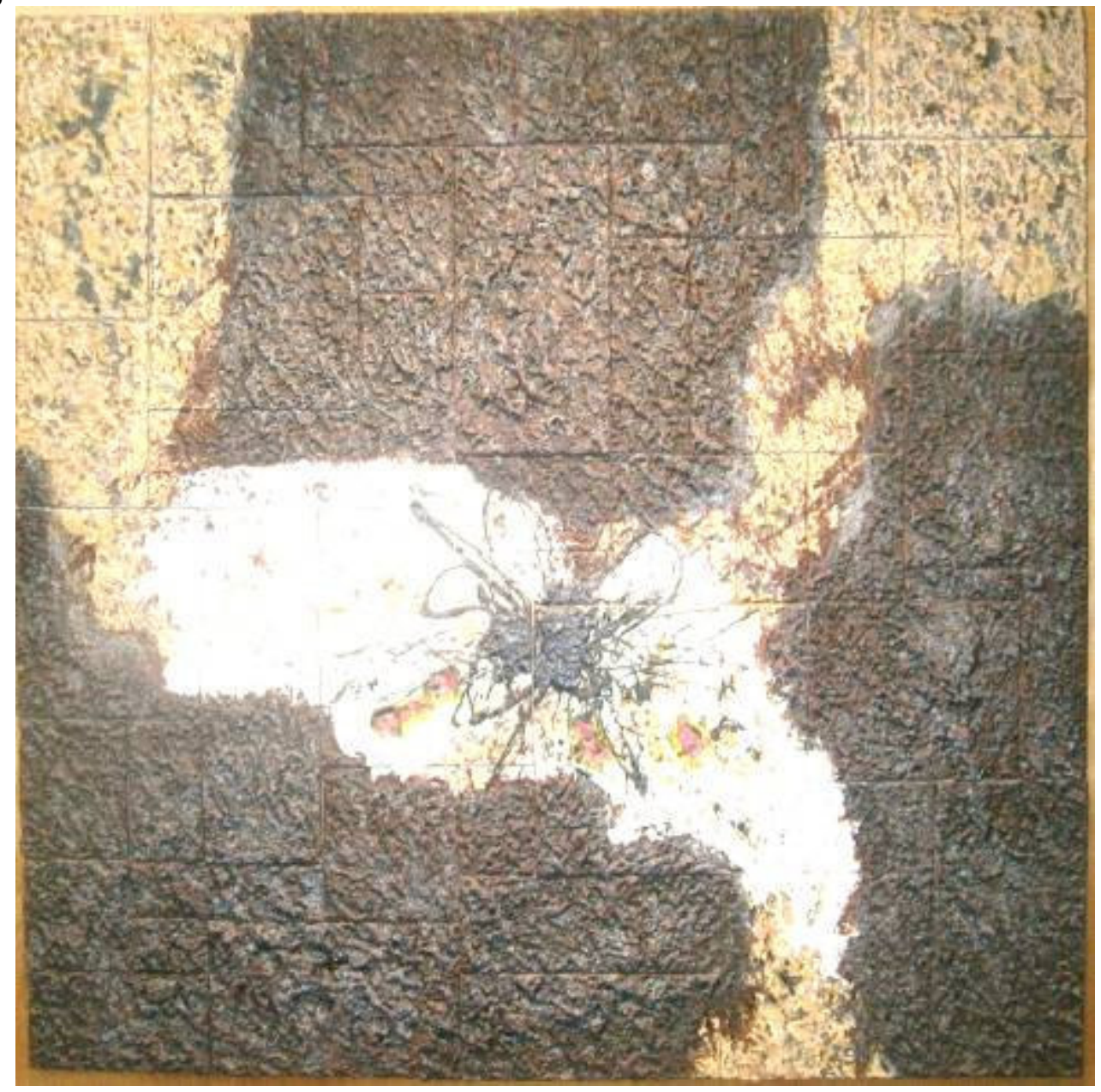


$\mathbf{N}^{0}: 5.12$

Título: Sin Título

Autoría: Manolo Safont

Datación: 1978

Inscripciones: Safont 78 en ángulo superior derecho

Dimensiones: $32 \times 45 \mathrm{cms}$.

Técnica: Pintura cerámica

Localización: Colección privada $\mathrm{n}^{\circ} 20$, Onda.

Descripción: Obra compuesta por 2 placas y utilizada para ilustrar el cartel y el catálogo de la exposición Manolo Safont realizada en la Caja de Ahorros de Alicante y Murcia de Elche del 24 de noviembre al 6 de diciembre de 1980. De temática abstracta, la placa situada a la izquierda de la composición, presenta un margen izquierdo irregular recortado. Paleta cromática: blancos, amarillos, rojos, azules y negros.

Exposiciones:

- Manolo Safont. Cerámica. Sala de exposiciones Caja de Ahorros de Alicante y Murcia, del 24 de noviembre al 6 de diciembre de 1980, Elche

- Manolo Safont. Un museu, un llegat i un compromís. MAMS. Del 27 de noviembre de 2004 al 8 de enero de 2005. Onda.

\section{Bibliografía:}

- Manolo Safont. Cerámica. Sala de exposiciones Caja de Ahorros de Alicante y Murcia, del 24 de noviembre al 6 de diciembre de 1980, Elche Imagen:

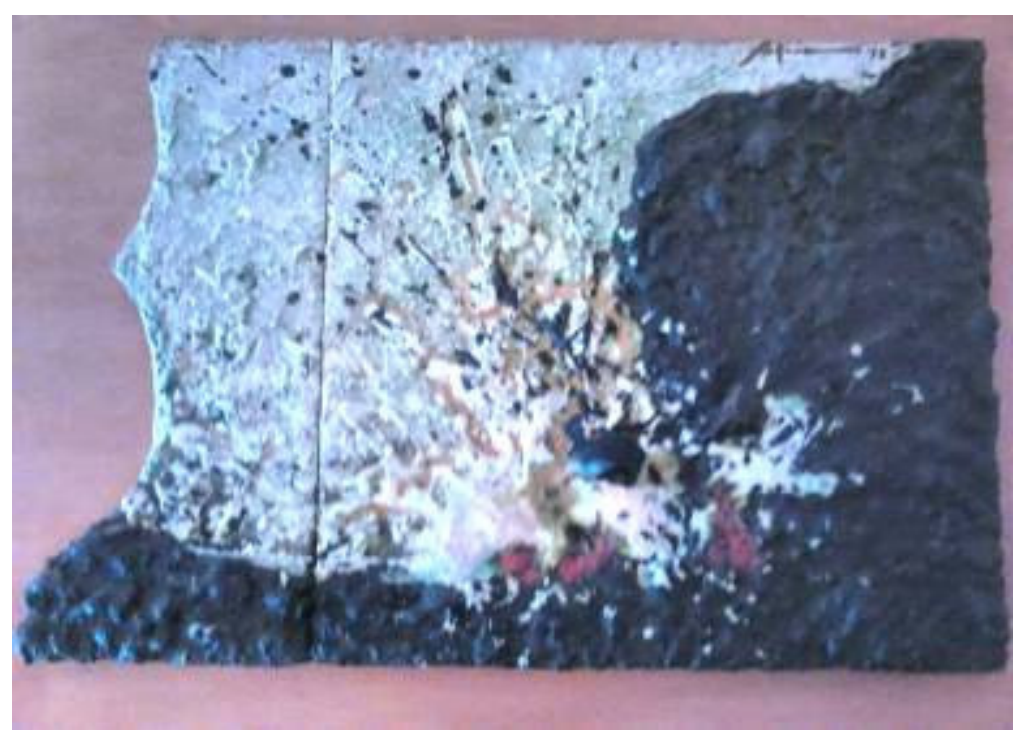

Imágenes relacionadas:

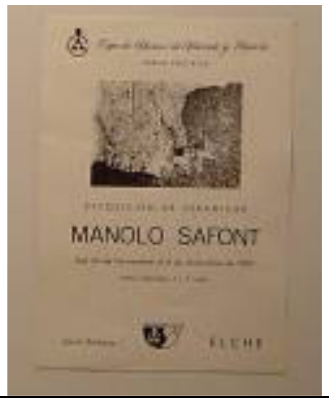


№: 5.13

Título: Sin Título

Autoría: Manolo Safont

Datación: 1978

Inscripciones: Safont margen inferior centrado

Técnica: Pintura cerámica

Localización: MAMS

Descripción: Obra compuesta por una única placa. Esta pieza fue donada en 2011 al MAMS por Pilar Gregorio, procedente de su colección privada. Masa blanca central creada con finos trazos en relieve, sobre una base de color claro, rodeada de masa oscura texturizada en las zonas laterales. Paleta cromática: blancos, amarillos, rojos, azules y negros.

Exposiciones:

- Manolo Safont, un museu, un llegat, MAMS, mayo 2013, Onda

\section{Bibliografía:}

- http://www.elperiodic.com/onda/noticias/108184_pilar-gregorio-donacuadro-manolo-safont-museu-taulell.html

- $\quad$ http://www.eltriangulo.es/contenidos/?p=12304

- $\quad h t t p: / / w w w . e l t r i a n g u l o . e s / c o n t e n i d o s / ? p=36891$

- http://manolosafont.blogspot.com.es/

Imagen:

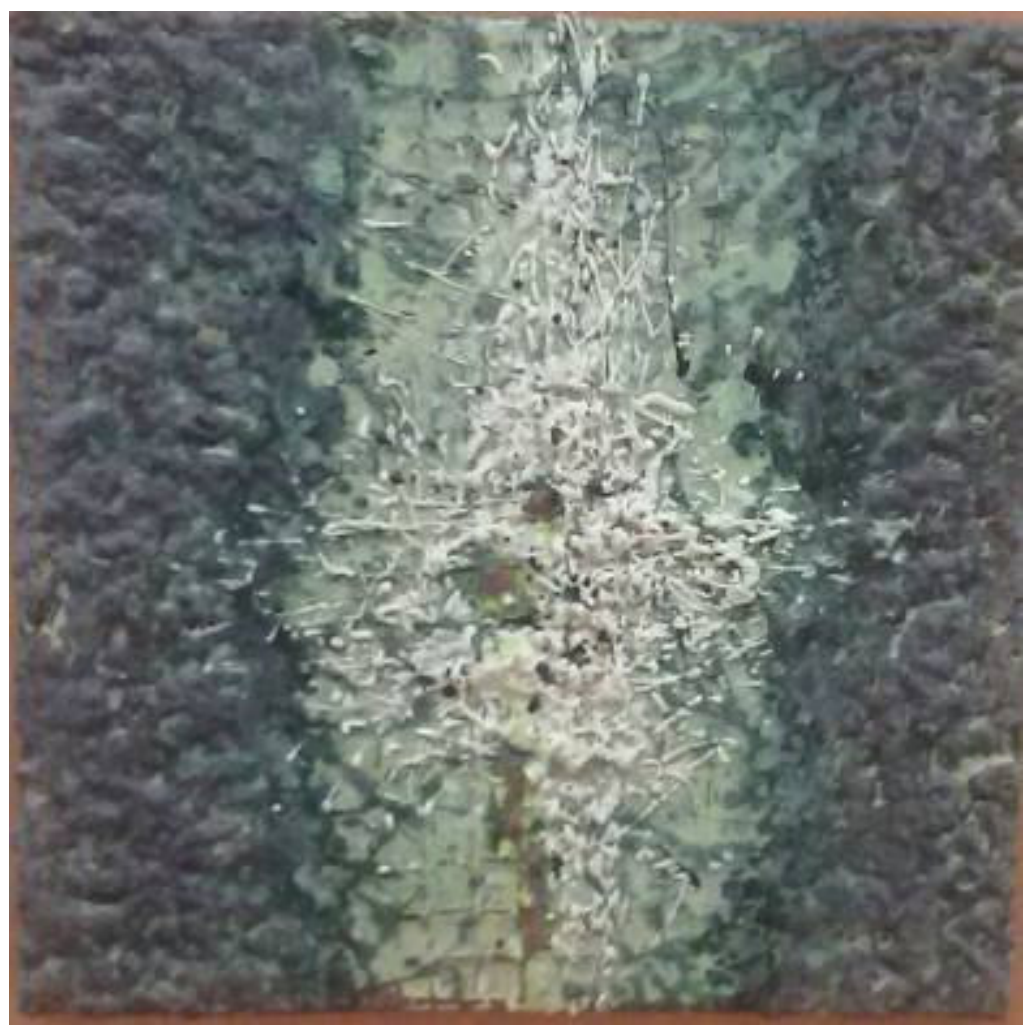


No: 5.14

Título: Sin Título

Autoría: Manolo Safont

Datación: 1978

Inscripciones: Safont en margen inferior

Dimensiones: $61 \times 120 \mathrm{cms}$

Técnica: Pintura cerámica

Localización: Colección Privada $\mathrm{n}^{\circ 1}$, Onda.

Descripción: Obra compuesta por 6 placas de diferentes tamaños, 3 placas de $40 \times 40 \mathrm{cms}$ y 3 placas de $21 \times 40 \mathrm{cms}$. En la imagen obtenida del catálogo de la exposición de Caja Rural de Onda en 2002, esta obra aparece fotografiada de forma invertida y con una saturación de color que distorsiona la paleta cromática utilizada en el original. Sobre grandes masas de color claro, destacan en relieve pequeños círculos de color rojo y verde, completando la obra gran número de salpicaduras realizadas en color negro. Paleta cromática: blancos, amarillos, ocres, rojos, verdes, marrones y negros.

\section{Exposiciones:}

- Manolo Safont. Exposición conmemorativa de la inauguración del nuevo edificio social. Caja Rural Nuestra Señora de la Esperanza. 23 diciembre 2001- 6 enero 2002. Onda

\section{Bibliografía:}

- GASCÓ, A. "La cerámica de Safont, un grito de pasión y libertad cuajado en color", Castellón Diario, 9 enero 1989, pág. 11

- Manolo Safont. Exposición conmemorativa de la inauguración del nuevo edificio social. Caja Rural Nuestra Señora de la Esperanza. 23 diciembre 2001- 6 enero 2002. Onda

Imagen:

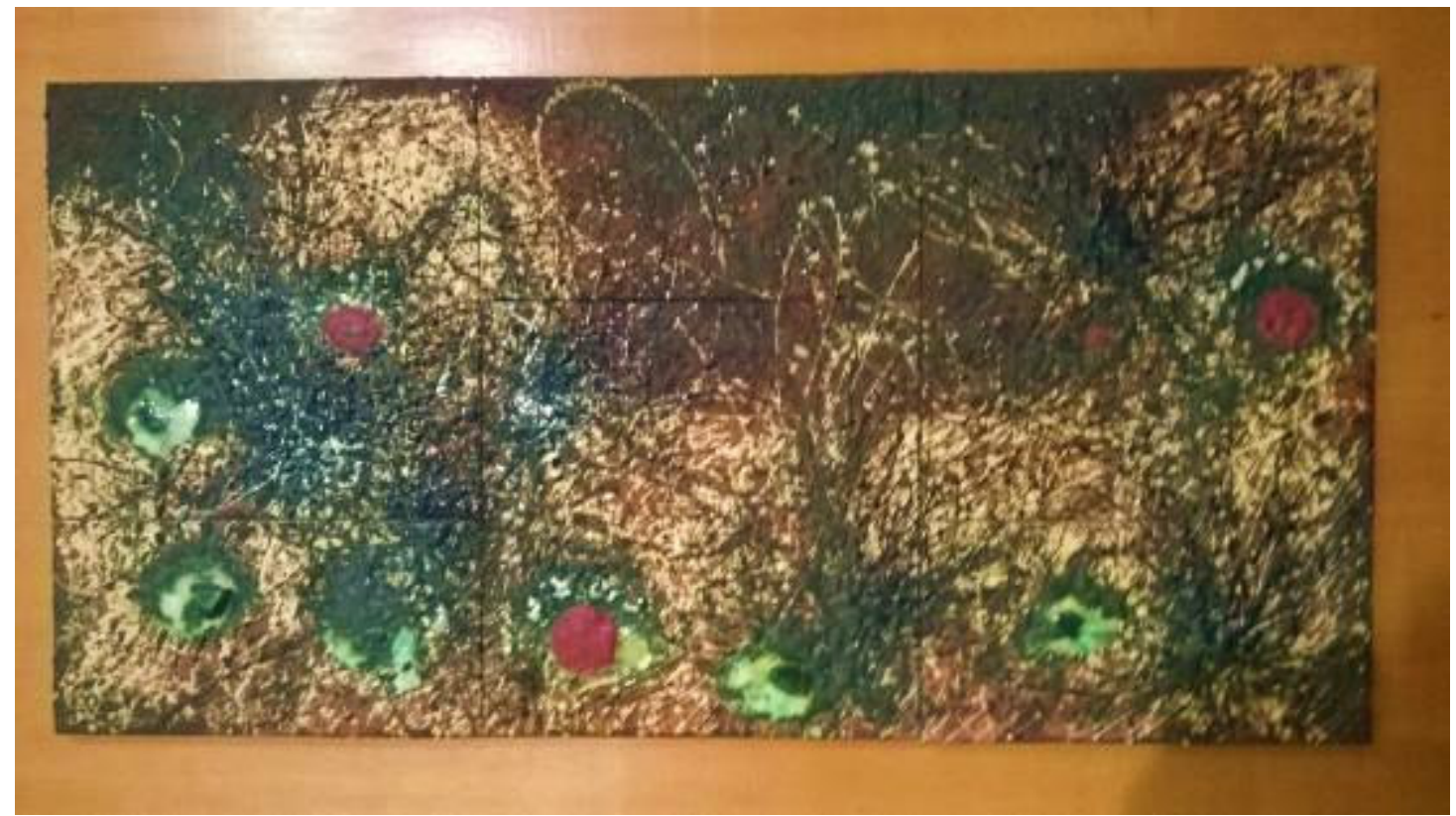


Imágenes relacionadas:

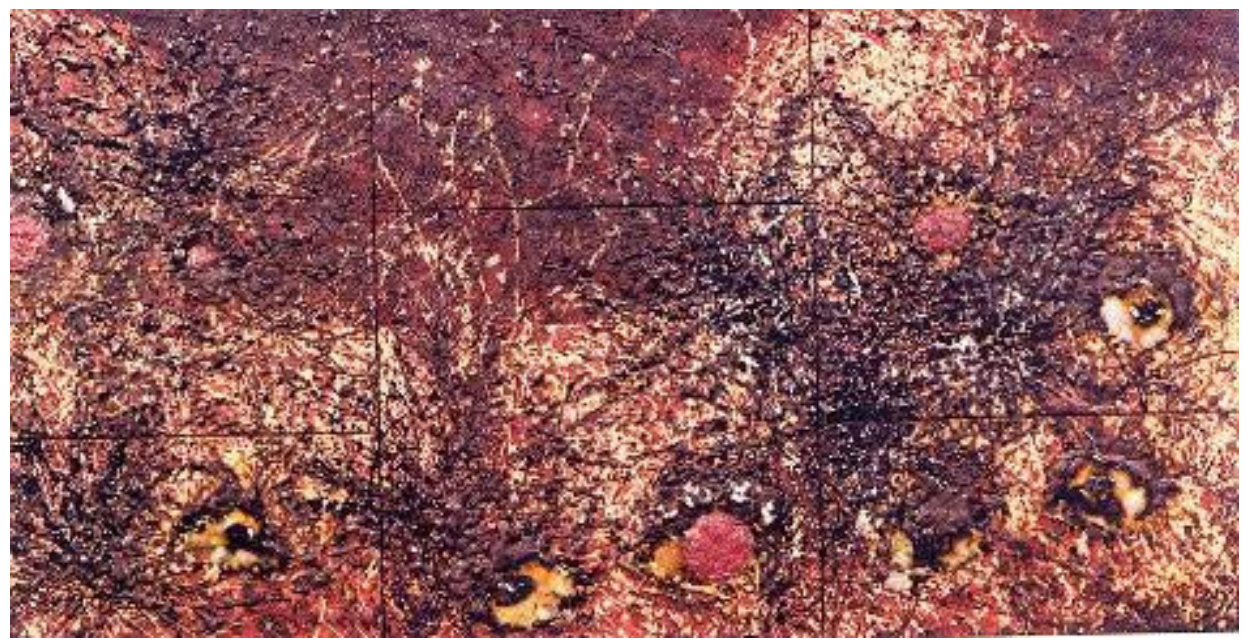

Imagen catálogo exposición 2002 Onda (invertida)

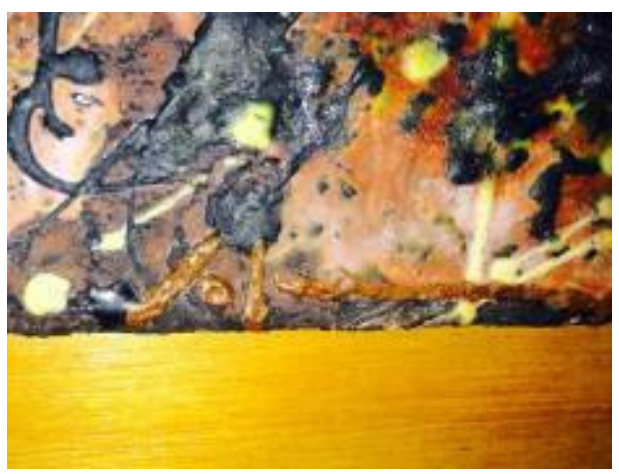

Detalle autoría 
$\mathbf{N}^{\circ}: 5.15$

Título: Nebulosa

Autoría: Manolo Safont

Datación: 1979

Dimensiones: 40x90cms o 40x40cms

Técnica: Pintura cerámica

Localización: MAMS

Descripción: Obra compuesta por una única placa. De temática abstracta, presenta un diseño de nebulosa, con forma espiral en color blanco sobre fondo de tonos rojizos. Obra compuesta por una única placa. Paleta cromática: blancos, rojos y negros.

Exposiciones:

- Manolo Safont. Un museu, un llegat i un compromís. MAMS. Del 27 de noviembre de 2004 al 8 de enero de 2005. Onda.

\section{Bibliografía:}

- $\quad$ http://www.gva.es/museo/safon9.htm, 1995

- FALOMIR, Carmela. "La pintura cerámica de Manolo Safont" en Butlletí d'Estudis Municipals. $2^{a}$ etapa, $\mathrm{n}^{\circ}$ 2. Ajuntament d'Onda. Onda, 2001, pág. 28

Imagen:

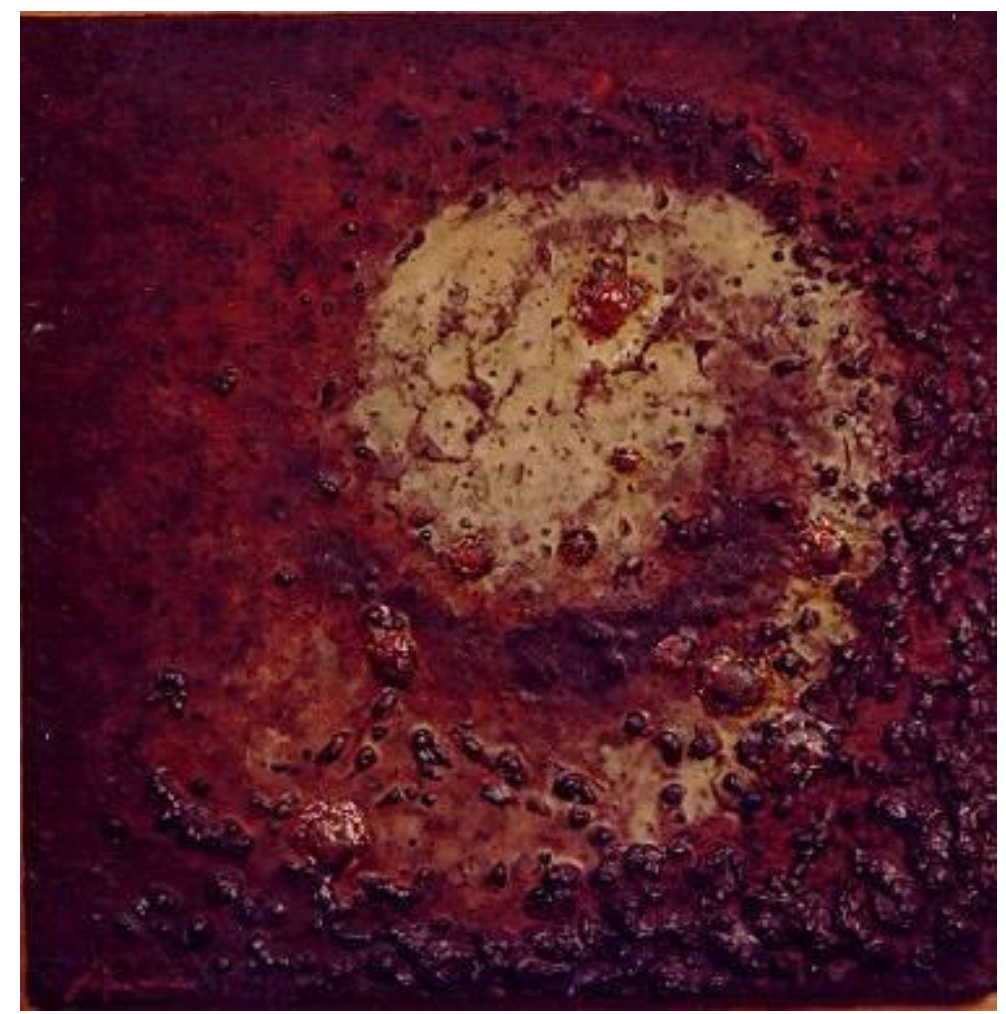


$\mathbf{N}^{0}: 5.16$

Título: Roig i negre

Autoría: Manolo Safont

Datación: 1979

Dimensiones: $80 \times 80 \mathrm{cms}$.

Técnica: Pintura cerámica

Localización: Museo de Bellas Artes de Castellón

Descripción: Obra compuesta por 3 placas de $40 \times 40 \mathrm{cms}$ y 1 placa fragmentada en 4. Sobre un fondo oscuro, una masa roja central que ocupa casi la mitad de cada una de las placas. Datada en 1979 por Pérez Camps, se muestra con otra dirección en el libro Historia de la cerámica valenciana, 1992. Paleta cromática: rojos y negros.

Exposiciones:

- Safont, 9 octubre-9 noviembre 1998, Morella (Castellón)

Bibliografía:

- PÉREZ CAMPS, Josep; SOler FERRER, María Paz. Historia de la cerámica valenciana Tomo IV, Vicent García Editores, Valencia, 1992, pág. 275

- Safont, 9 octubre-9 noviembre 1998, Morella (Castellón), pág. 22

Imagen:

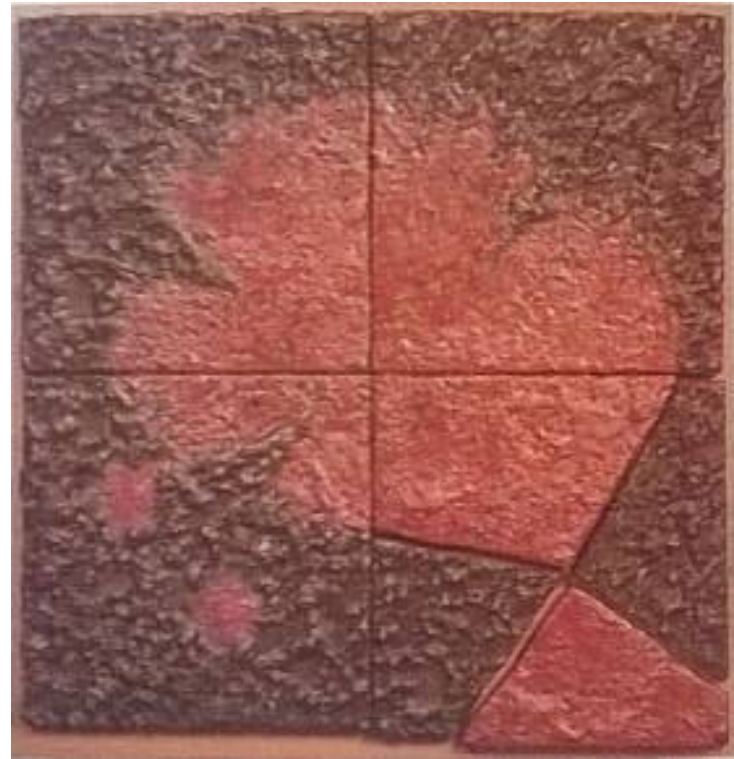

Imágenes relacionadas:

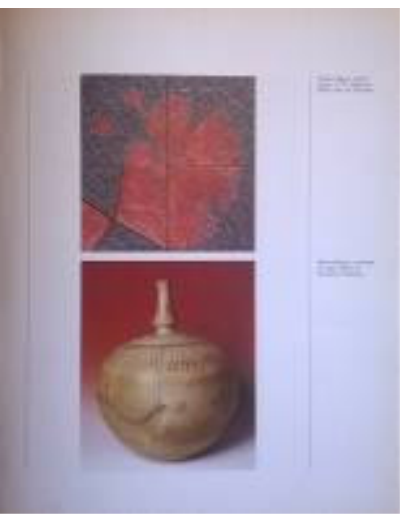


$\mathbf{N}^{\circ}: 5.17$

Título: Sin Título

Autoría: Manolo Safont

Datación: 1979

Inscripciones: Safont 79 en ángulo inferior derecho

Dimensiones: $56 \times 88 \mathrm{cms}$.

Técnica: Pintura cerámica

Localización: Colección privada $n^{\circ} 18$. Castellón.

Descripción: Obra compuesta por 2 placas del mismo tamaño, fragmentadas cada una de ellas en cuatro partes, como un puzzle. Esta obra ilustra los catálogos de las exposiciones realizadas en 1980 en el Museo Nacional de Cerámica "González Martí" y la de la sala Torre I en Torrent. Paleta cromática: rojos y negros.

\section{Exposiciones:}

- Exposición de cerámicas de Safont. Sala de Exposiciones del Museo Nacional de Cerámica "González Martí" Palacio de Dos Aguas, del 3 al 30 marzo 1980, Valencia

- Safont. Torre I, Sala Municipal d'Exposicions de l'Ajuntament de Torrent, del 2 al 21 de novembre, 1980, Torrent (Valencia)

\section{Bibliografía:}

- Exposición de cerámicas de Safont. Sala de Exposiciones del Museo Nacional de Cerámica "González Martí" Palacio de Dos Aguas, del 3 al 30 marzo 1980, Valencia

- Safont. Torre I, Sala Municipal d'Exposicions de l'Ajuntament de Torrent, del 2 al 21 de novembre, 1980, Torrent (Valencia)

\section{Imagen:}

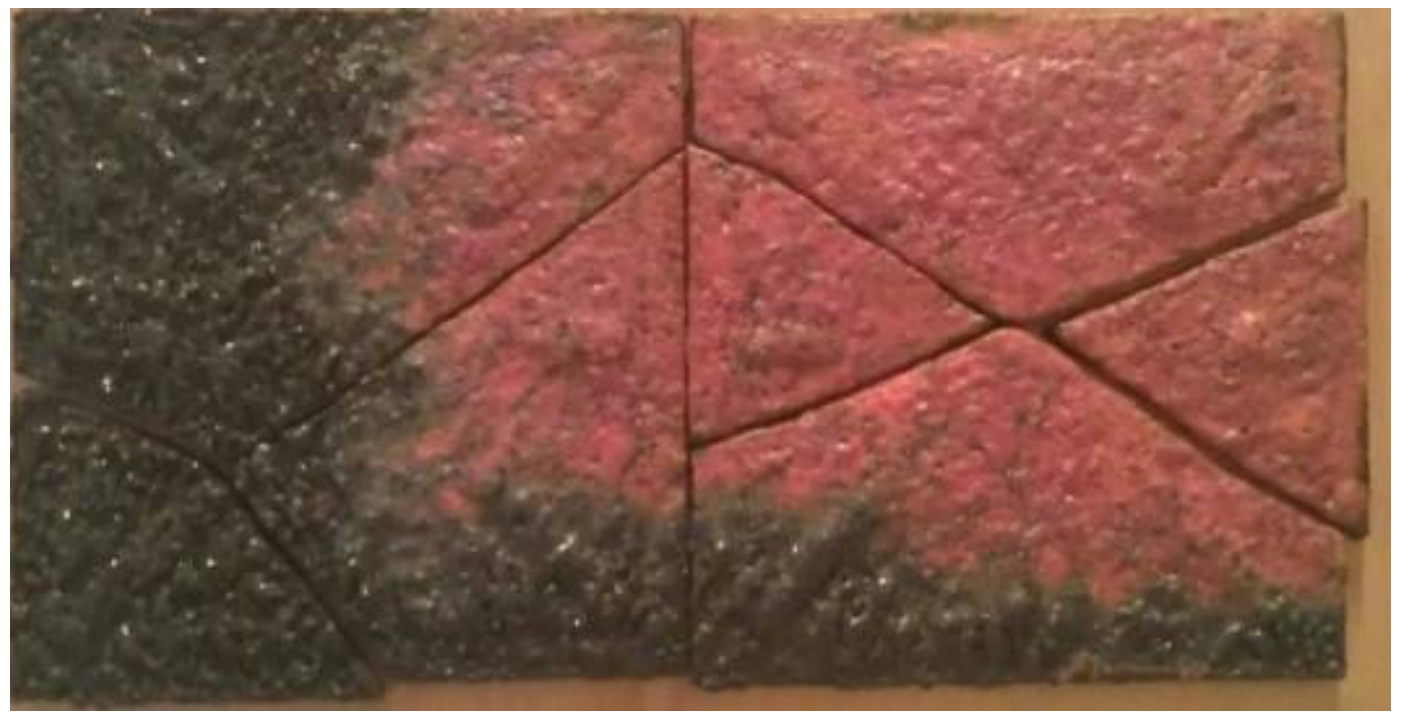


$N^{0}: 5.18$

Título: Sin Título

Autoría: Manolo Safont

Datación: Inicios década 1970

Dimensiones: $40 \times 60 \mathrm{cms}$

Técnica: Pintura cerámica

Localización: MAMS

Descripción: Obra compuesta por diez placas de diferentes tamaños, en disposición $2 \times 3$, con formas geométricas y silueteadas en relieve. Paleta cromática: blancos, amarillos, rojos, azules, marrones y negros.

Exposiciones:

- Manolo Safont. Un museu, un llegat i un compromís. MAMS. Del 27 de noviembre de 2004 al 8 de enero de 2005. Onda.

\section{Imagen:}

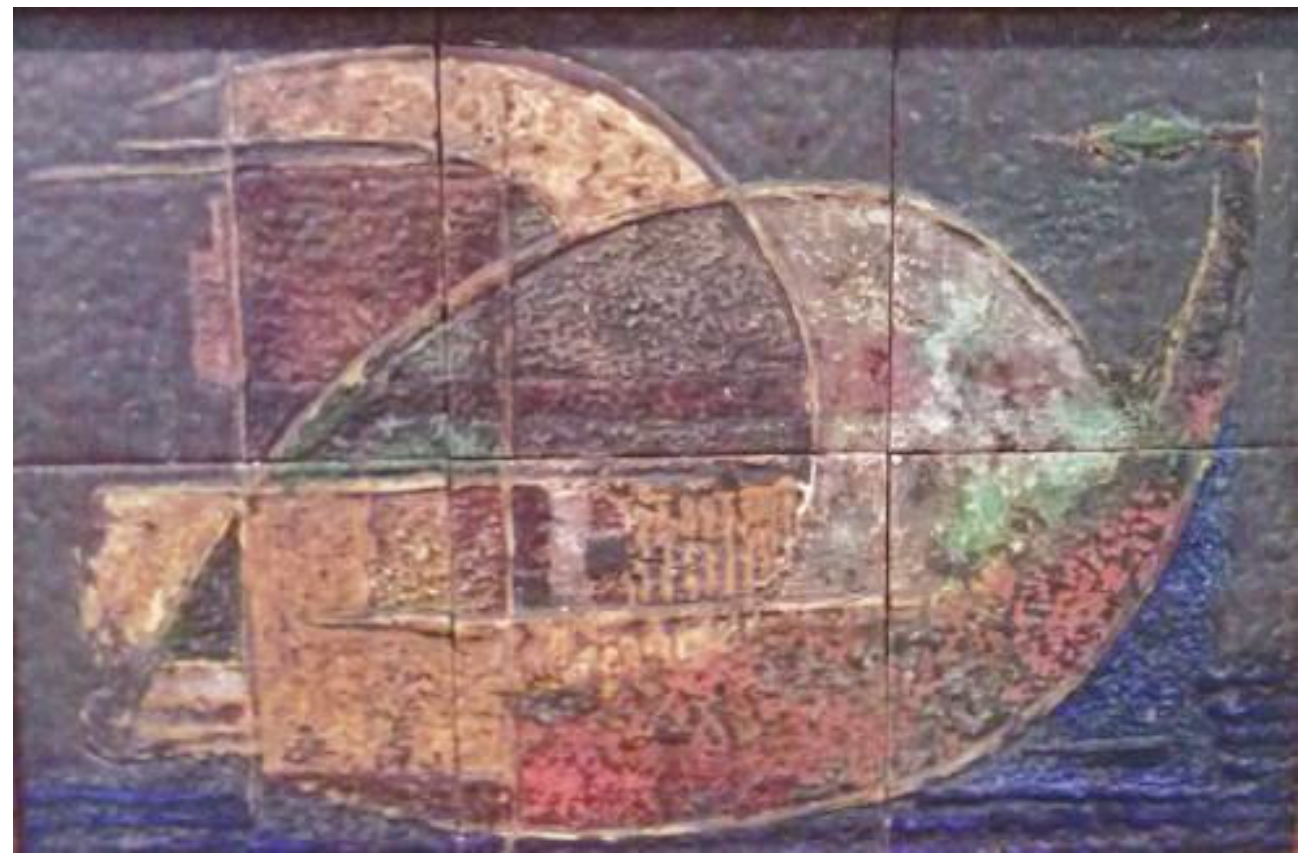


No: 5.19

Título: Sin Título

Autoría: Manolo Safont

Datación: Final década 1970

Inscripciones: Safont en ángulo inferior derecho

Dimensiones: 40x80 cms

Técnica: Pintura cerámica

Localización: MAMS

Descripción: Obra compuesta por 2 placas de 40x40 cms. Sobre una masa clara, con salpicaduras negras, crea un relieve en la zona inferior en color oscuro, en el que destacan una macha roja y amarilla. Paleta cromática: blancos, amarillos, rojos, marrones y negros.

\section{Exposiciones:}

- Manolo Safont. Un museu, un llegat i un compromís. MAMS. Del 27 de noviembre de 2004 al 8 de enero de 2005. Onda

- Manolo Safont, un museu, un llegat, MAMS, mayo 2013, Onda

\section{Bibliografía:}

- http://www.eltriangulo.es/contenidos/?p=36891

- http://manolosafont.blogspot.com.es/

\section{Imagen:}

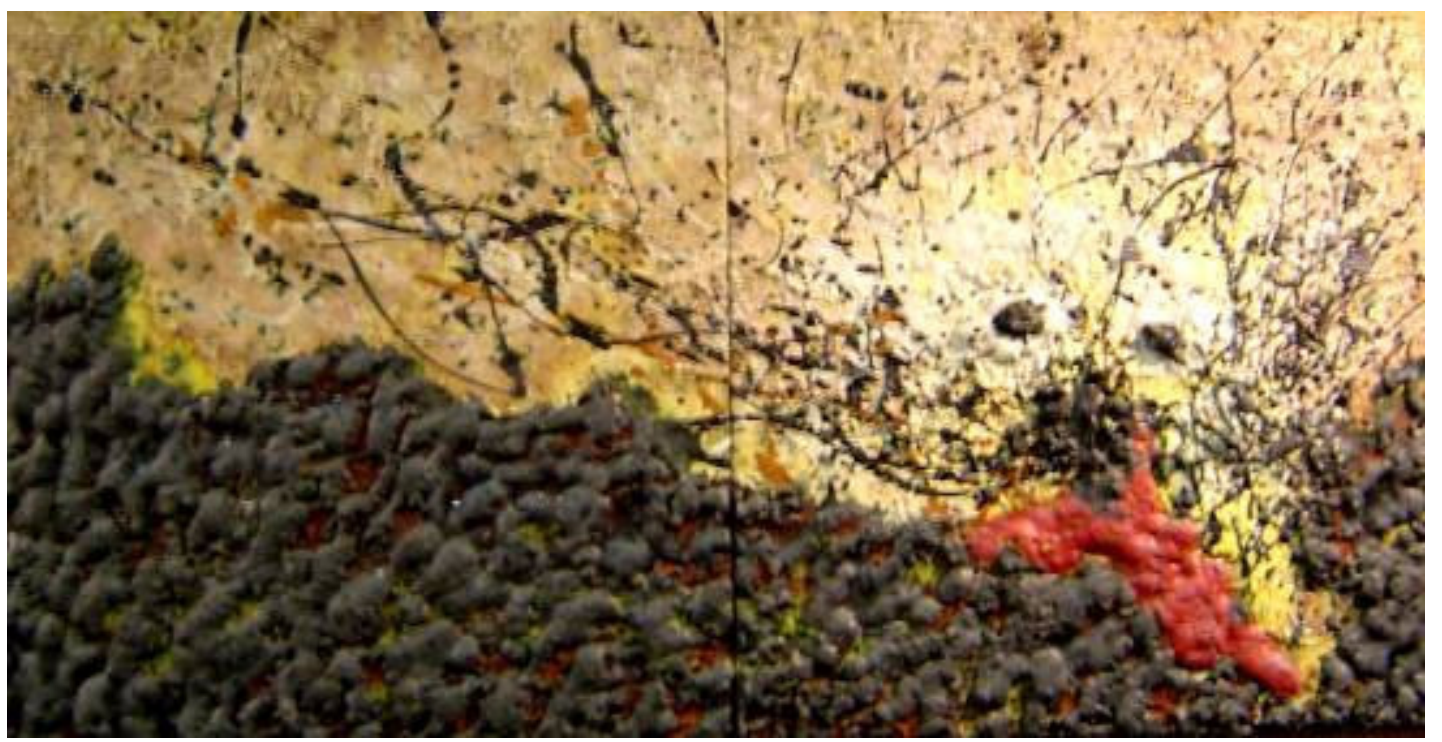


No: 5.20

Título: Sin Título

Autoría: Manolo Safont

Datación: Anterior a 1980

Inscripciones: Safont en ángulo inferior derecho

Dimensiones: 40x80 cms

Técnica: Pintura cerámica

Localización: MAMS

Descripción: Obra compuesta por dos placas de 40x40 cms. La placa de la derecha presenta una grieta-rotura de factura irregular, posiblemente producida por un problema en la temperatura de cocción de la pieza. Esta obra fue utilizada para ilustrar el catálogo de la exposición celebrada en Elche en 1980. Paleta cromática: blancos, amarillos, rojos y negros.

Exposiciones:

- Manolo Safont. Cerámica. Sala de exposiciones Caja de Ahorros de Alicante y Murcia, del 24 de noviembre al 6 de diciembre de 1980, Elche

- Manolo Safont. Un museu, un llegat i un compromís. MAMS. Del 27 de noviembre de 2004 al 8 de enero de 2005. Onda

- Manolo Safont, un museu, un llegat, MAMS, mayo 2013, Onda

Bibliografía:

- Manolo Safont. Cerámica. Sala de exposiciones Caja de Ahorros de Alicante y Murcia, del 24 de noviembre al 6 de diciembre de 1980, Elche

- http://www.eltriangulo.es/contenidos/?p=36891

- http://manolosafont.blogspot.com.es/

Imagen:

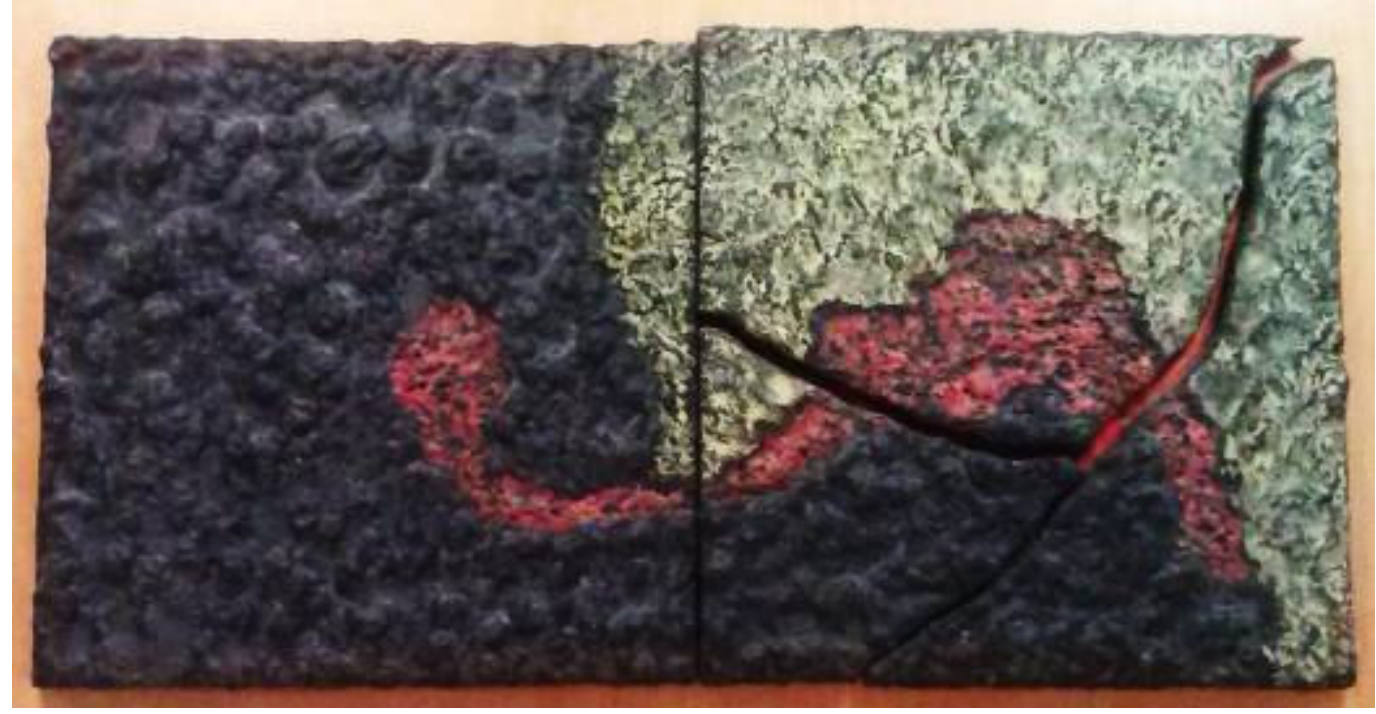




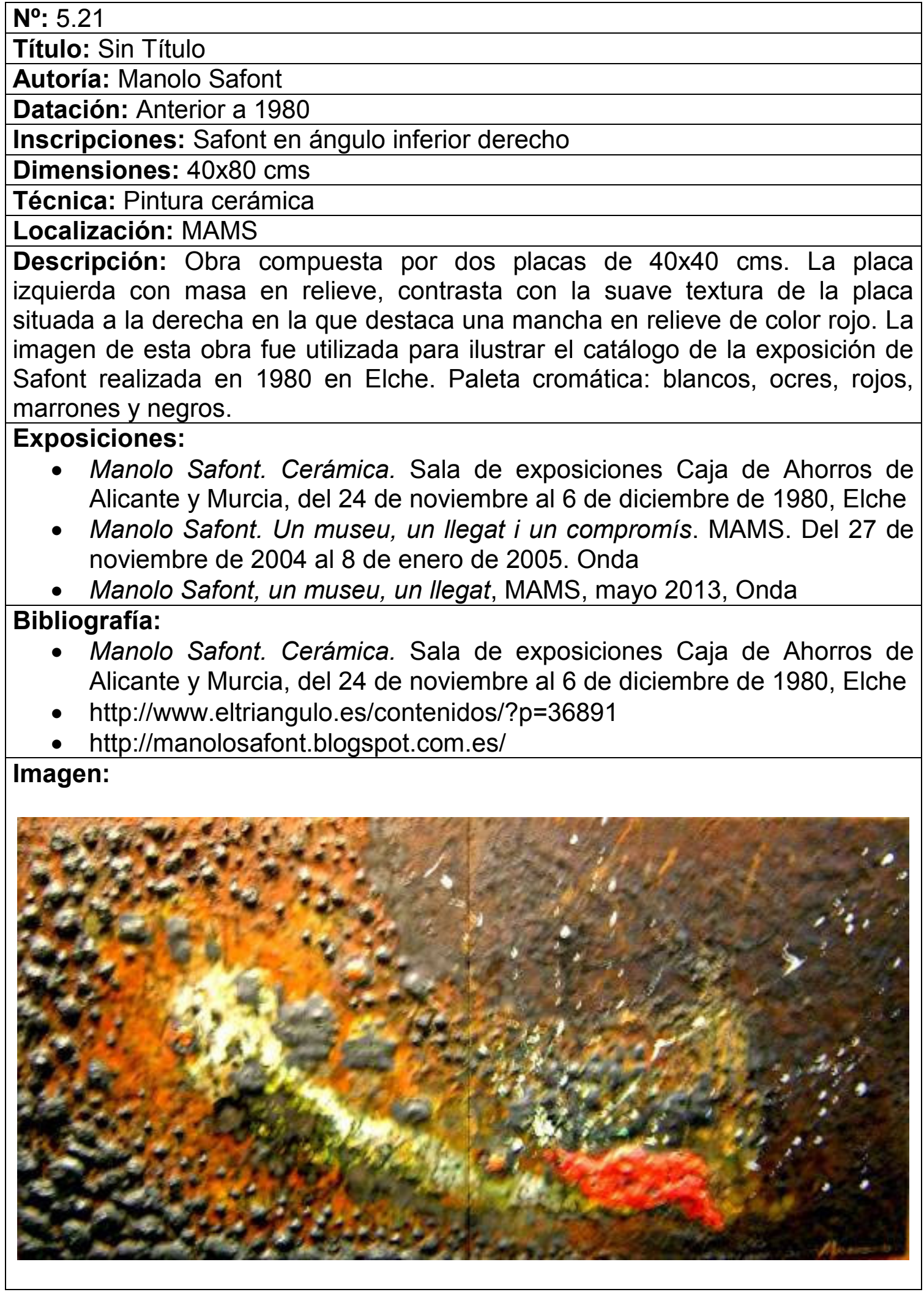


No: 5.22

Título: Sin Título

Autoría: Manolo Safont

Datación: Anterior a 1980

Técnica: Pintura cerámica

Descripción: Obra compuesta por 2 placas del mismo tamaño. Sobre una base de color claro, crea finos bajorrelieves de líneas verticales, cubiertos por una masa matérica oscura que se extiende hacia el margen derecho y superior de la placa. La imagen de esta obra se utiliza para ilustrar los catálogos de las exposiciones de Safont realizadas en 1980 en el Museo Nacional de Cerámica "González Martí" y la de Elche. Paleta cromática: blancos, marrones y negros.

\section{Exposiciones:}

- Exposición de cerámicas de Safont. Sala de Exposiciones del Museo Nacional de Cerámica "González Martí" Palacio de Dos Aguas, del 3 al 30 marzo 1980, Valencia

- Manolo Safont. Cerámica. Sala de exposiciones Caja de Ahorros de Alicante y Murcia, del 24 de noviembre al 6 de diciembre de 1980, Elche

\section{Bibliografía:}

- Exposición de cerámicas de Safont. Sala de Exposiciones del Museo Nacional de Cerámica "González Martí" Palacio de Dos Aguas, del 3 al 30 marzo 1980, Valencia

- Manolo Safont. Cerámica. Sala de exposiciones Caja de Ahorros de Alicante y Murcia, del 24 de noviembre al 6 de diciembre de 1980, Elche Imagen:

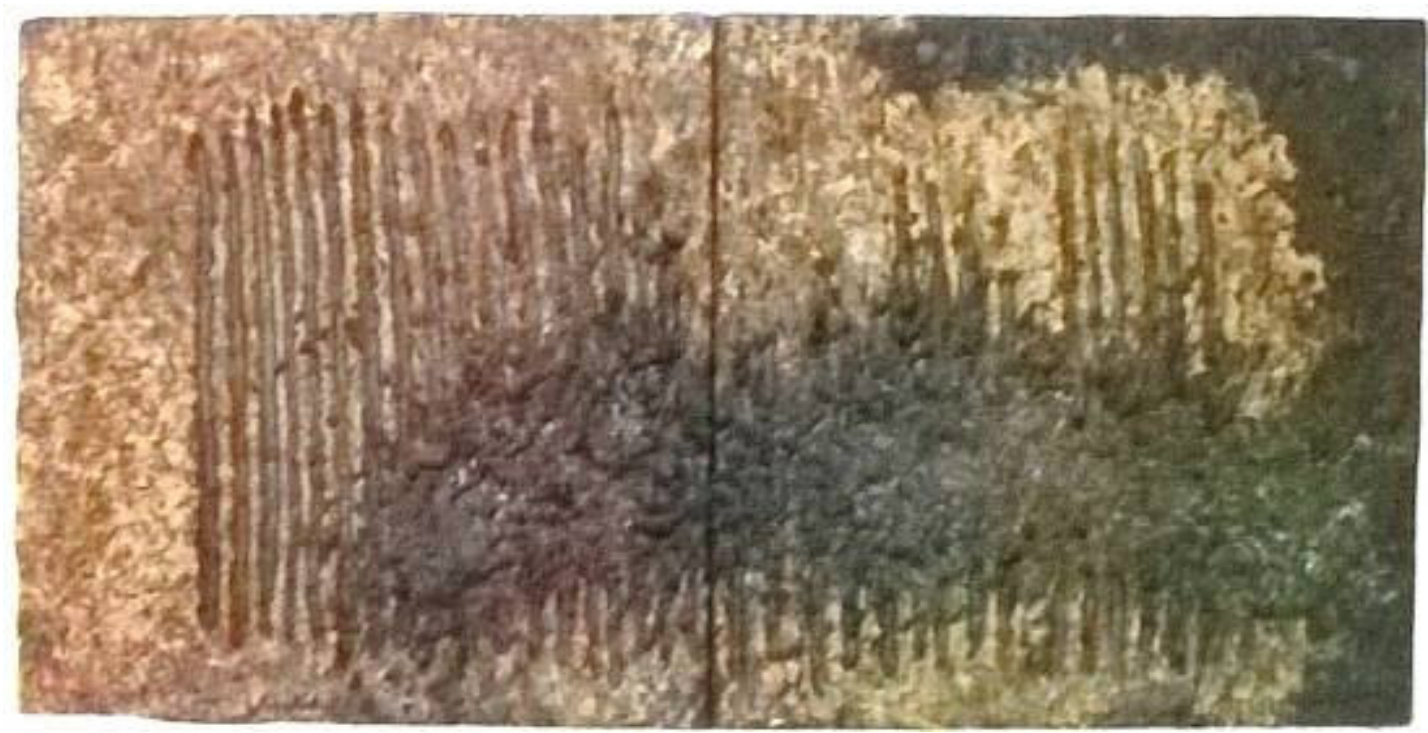


$\mathbf{N}^{0}: 5.23$

Título: Sin Título

Autoría: Manolo Safont

Datación: 1980

Dimensiones: $11 \times 11 \mathrm{cms}$

Técnica: Pintura cerámica

Localización: MAMS

Descripción: Obra compuesta por una única placa, con texturas y relieves en color rojo. Paleta cromática: amarillos, rojos y negros.

Exposiciones:

- Manolo Safont. Un museu, un llegat i un compromís. MAMS. Del 27 de noviembre de 2004 al 8 de enero de 2005. Onda

- Manolo Safont, un museu, un llegat, MAMS, mayo 2013, Onda

Bibliografía:

- http://www.eltriangulo.es/contenidos/?p=36891

- http://manolosafont.blogspot.com.es/

\section{Imagen:}

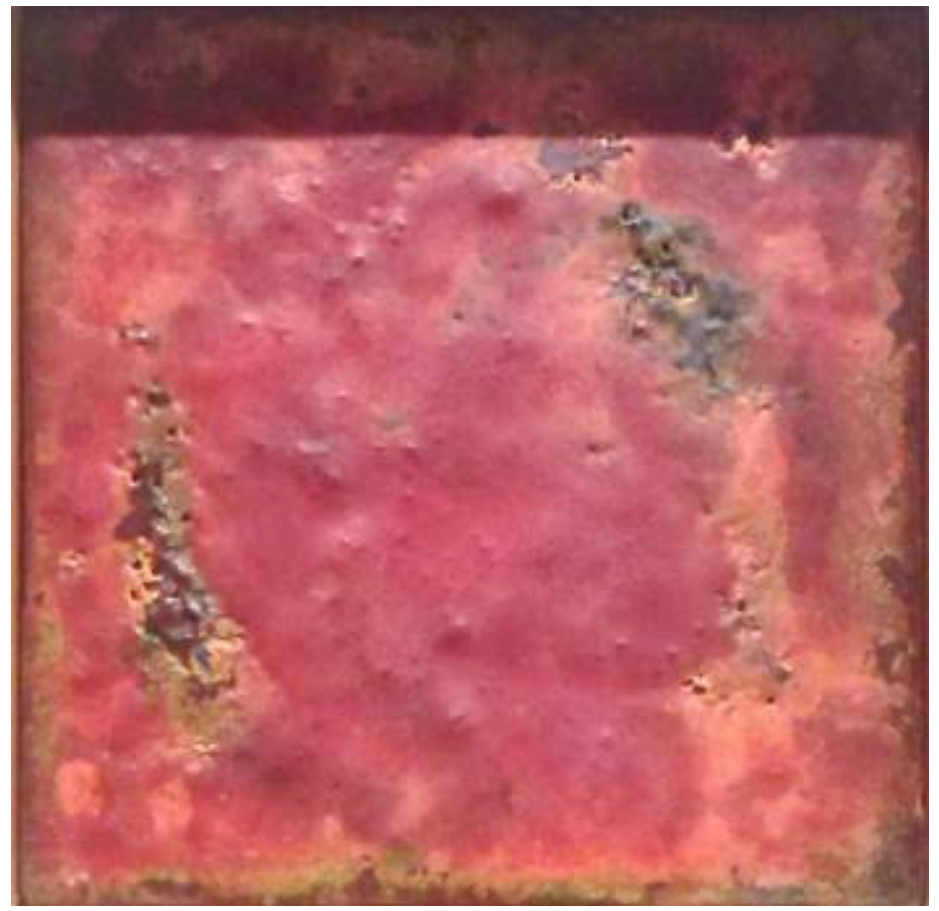




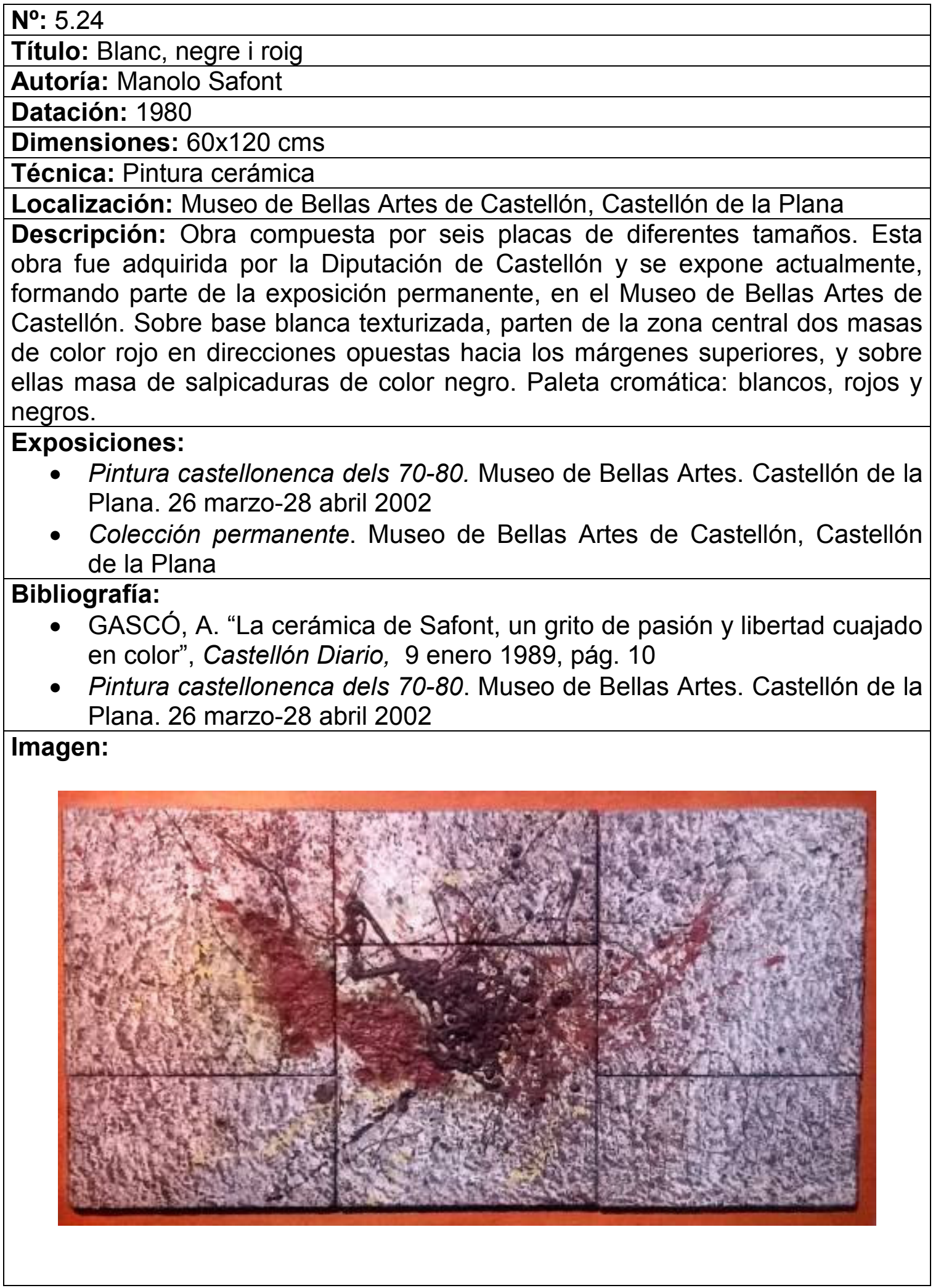




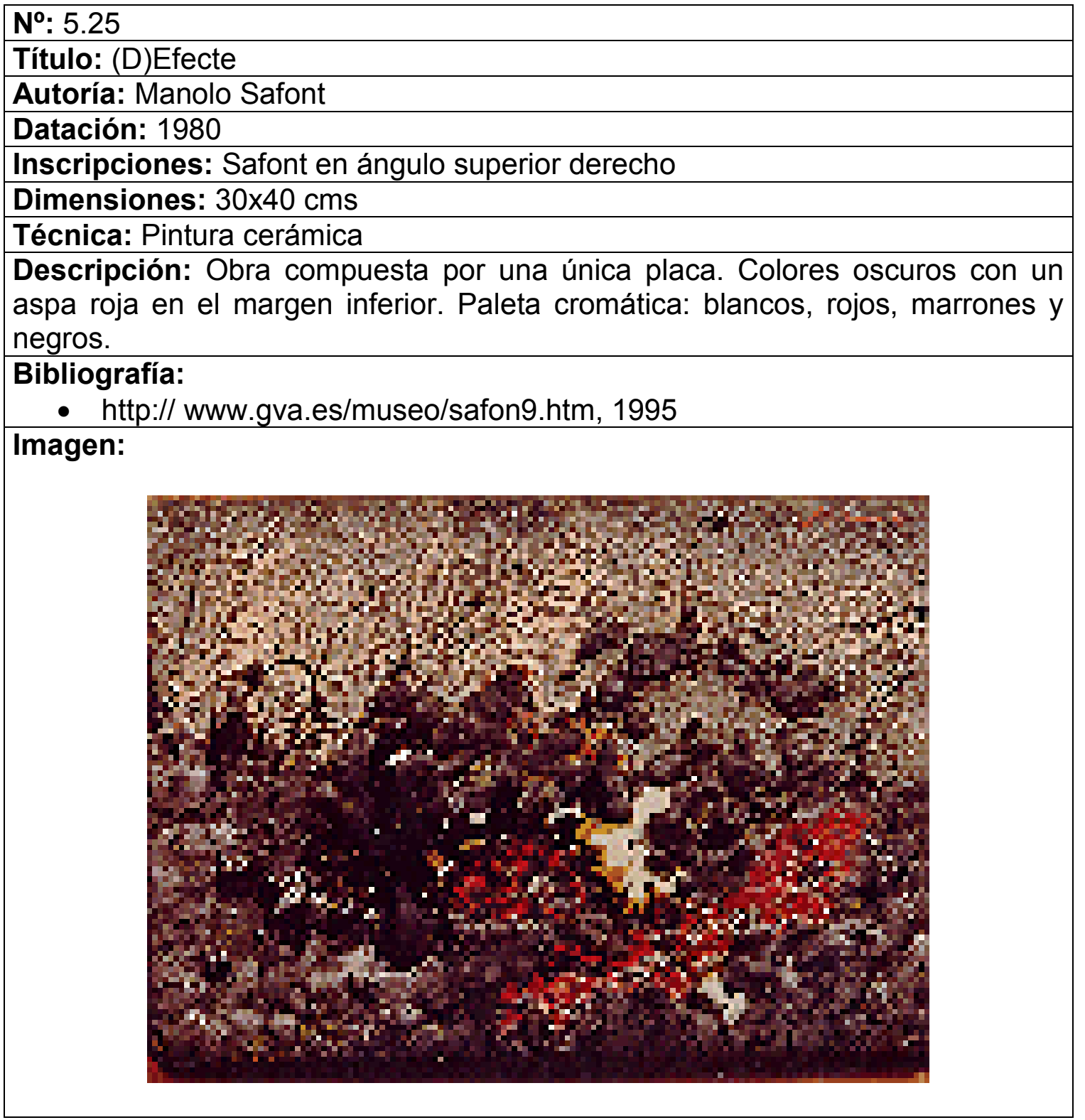


$N^{0}: 5.26$

Título: Sin Título

Autoría: Manolo Safont

Datación: Anterior a 1982

Técnica: Pintura cerámica

Localización: Colección privada n¹4, Castellón de la Plana

Descripción: Obra compuesta por 5 placas del mismo tamaño, y la sexta, situada a la derecha en la composición, fragmentada en dos. Mancha amarilla en la zona inferior con pequeñas gotas rojas sobre fondo matérico negro muy texturizado. Esta obra se utilizó para ilustrar el catálogo de la exposición realizada por Safont en 1982 en Barcelona. Paleta cromática: amarillos, rojos y negros.

Exposiciones:

- Safont, 20 octubre.20 novembre, Museu de Ceràmica, Palau Nacional, Montjuic, Ajuntament de Barcelona, Barcelona 1982

\section{Bibliografía:}

- Safont, 20 octubre-20 novembre, Museu de Ceràmica, Palau Nacional, Montjuic, Ajuntament de Barcelona, Barcelona 1982

\section{Imagen:}

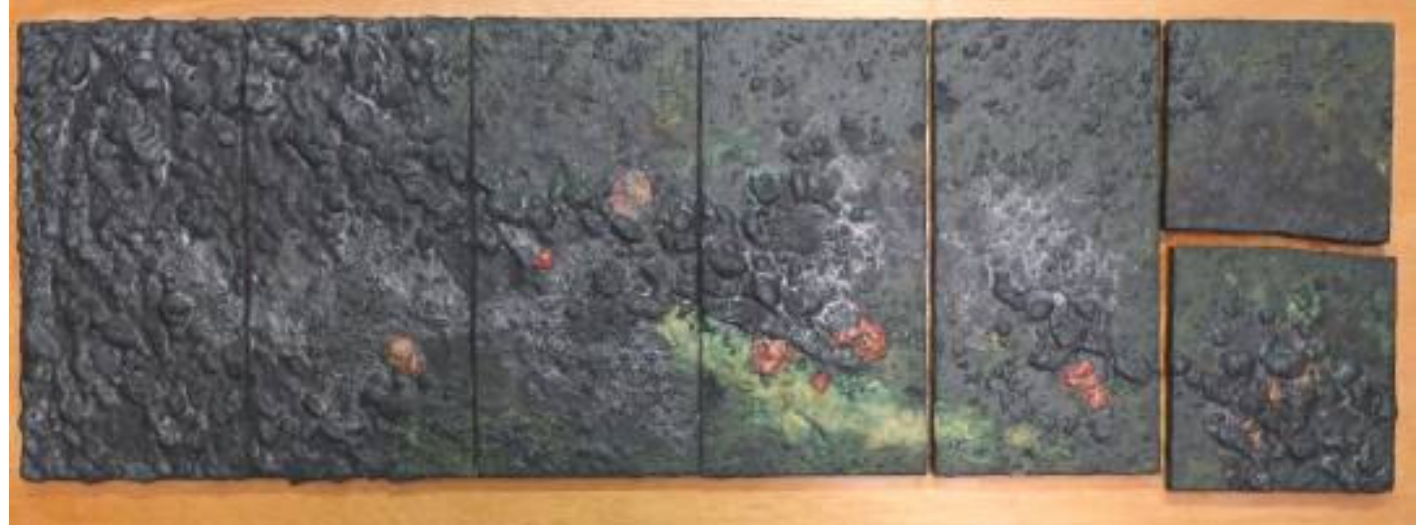

Imágenes relacionadas:

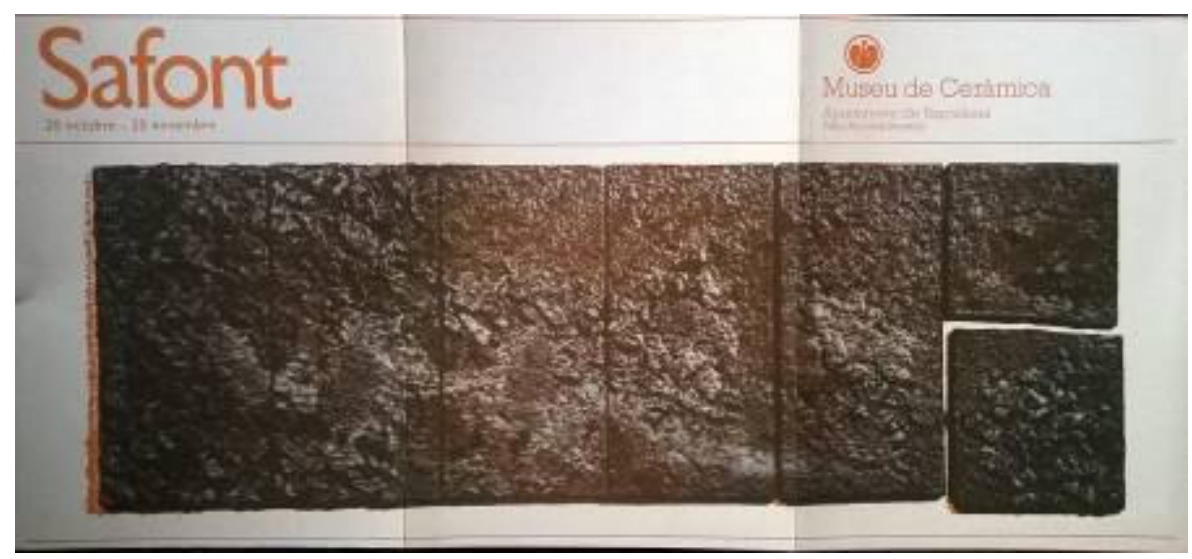




\begin{tabular}{|l|}
\hline No: 5.27 \\
\hline Título: Sin Título \\
\hline Autoría: Manolo Safont \\
\hline Datación: Anterior a 1982 \\
\hline Técnica: Pintura cerámica \\
\hline Descripción: Obra compuesta por dos placas de diferente tamaño y utilizada \\
para ilustrar el catálogo de la exposición realizada por Safont en 1982 en \\
Barcelona. Obra compuesta por dos masas diferenciadas de color y texturas \\
contrapuestas, situada la de color claro en el margen izquierdo e inferior, y \\
sobre ella la huella de la palma de la mano izquierda surgiendo del margen \\
inferior. Sólo hemos podido obtener una imagen en blanco y negro de la obra, \\
por lo que resulta imposible establecer la paleta cromática.
\end{tabular}




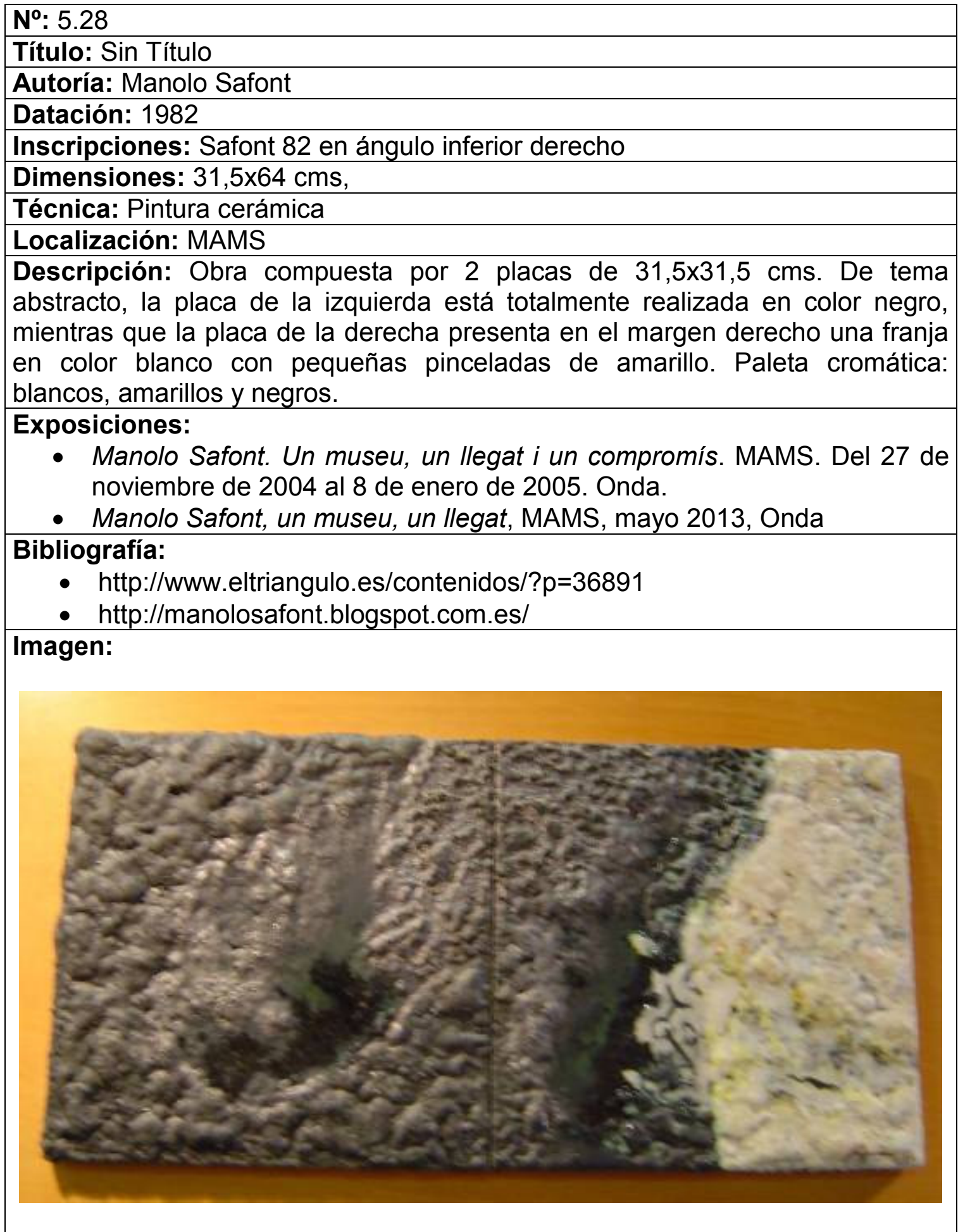


$\mathbf{N}^{\circ}: 5.29$

Título: Sin Título

Autoría: Manolo Safont

Datación: 1982

Inscripciones: Safont 82 en ángulo inferior derecho

Dimensiones: $40 \times 50 \mathrm{cms}$

Técnica: Pintura cerámica

Localización: MAMS

Descripción: Obra compuesta por una única placa, de tema abstracto, presenta recortes en los márgenes de la obra y reservas que permiten ver la placa base en su color original. Paleta cromática: ocres, rojos y negros.

Exposiciones:

- Safont. 9 octubre-9 noviembre, 1998. Morella (Castellón)

\section{Bibliografía:}

- Safont. 9 octubre-9 noviembre 1998, Morella (Castellón) pág, 21

- FALOMIR, Carmela. "La pintura cerámica de Manolo Safont" en Butlletí d'Estudis Municipals. $2^{a}$ etapa, $n^{\circ}$ 2. Ajuntament d'Onda. Onda, 2001, pág. 37

\section{Imagen:}

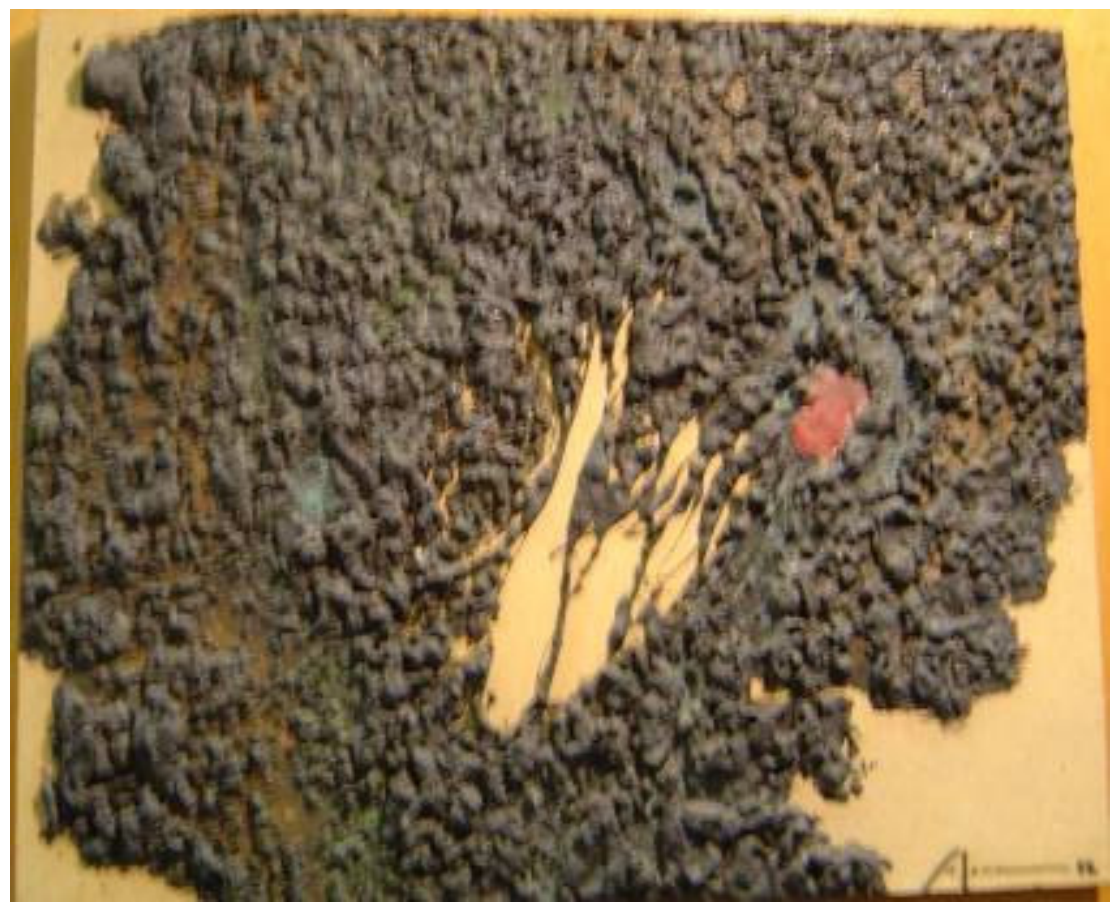


No: 5.30

Título: Sin Título

Autoría: Manolo Safont

Datación: 1982

Dimensiones: $43 \times 52 \mathrm{cms}$

Técnica: Pintura cerámica

Localización: MAMS

Descripción: Obra compuesta por una única placa. Forma abstracta circular de color blanco con pinceladas de amarillo, sobre fondo color negro. Paleta cromática: blancos, amarillos y negros

Bibliografía:

- http://www.gva.es/museo/safon8.htm, 1995

Imagen:

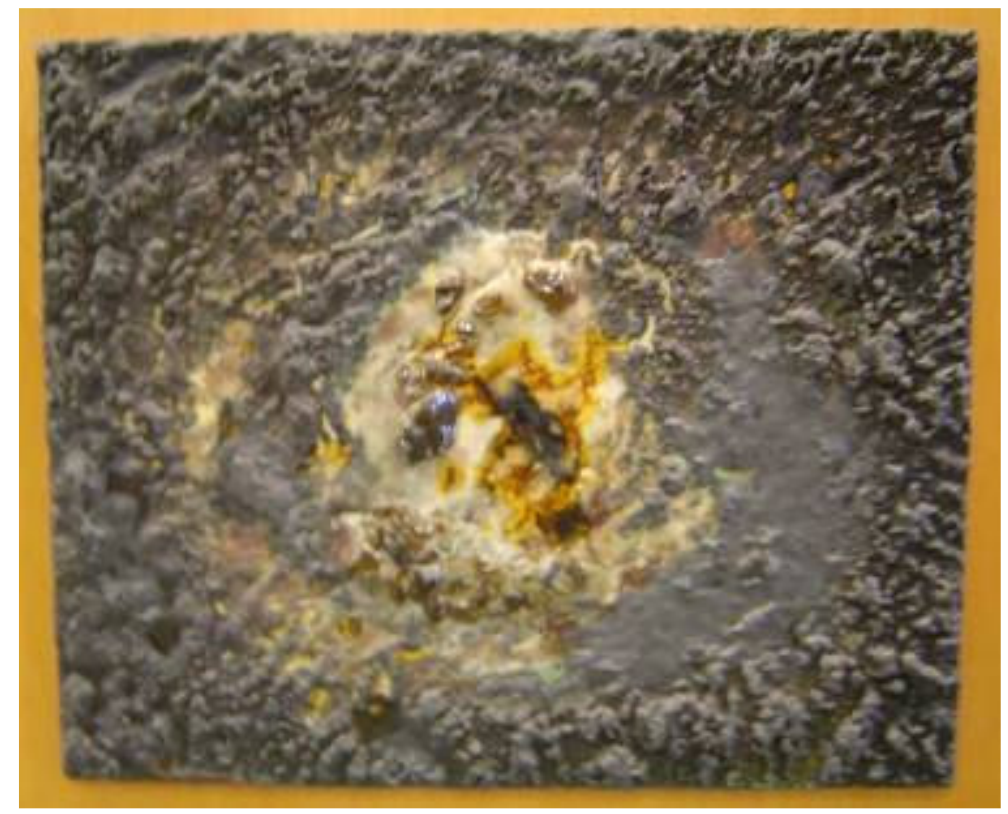


$\mathbf{N}^{\circ}: 5.31$

Título: Sin Título

Autoría: Manolo Safont

Datación: 1982

Inscripciones: Safont en ángulo inferior derecho

Dimensiones: $20 \times 40 \mathrm{cms}$

Técnica: Pintura cerámica

Localización: MAMS

Descripción: Obra compuesta por una única placa. Sobre base texturizada negra, se crean salpicaduras en color blanco que parten del margen inferior con pequeñas masas circulares de color rojo. Paleta cromática: blancos, amarillos, rojos y negros.

\section{Exposiciones:}

- Manolo Safont. Un museu, un llegat i un compromís. MAMS. Del 27 de noviembre de 2004 al 8 de enero de 2005. Onda

- Manolo Safont, un museu, un llegat, MAMS, mayo 2013, Onda

\section{Bibliografía:}

- http://www.eltriangulo.es/contenidos/?p=36891

- http://manolosafont.blogspot.com.es/

\section{Imagen:}

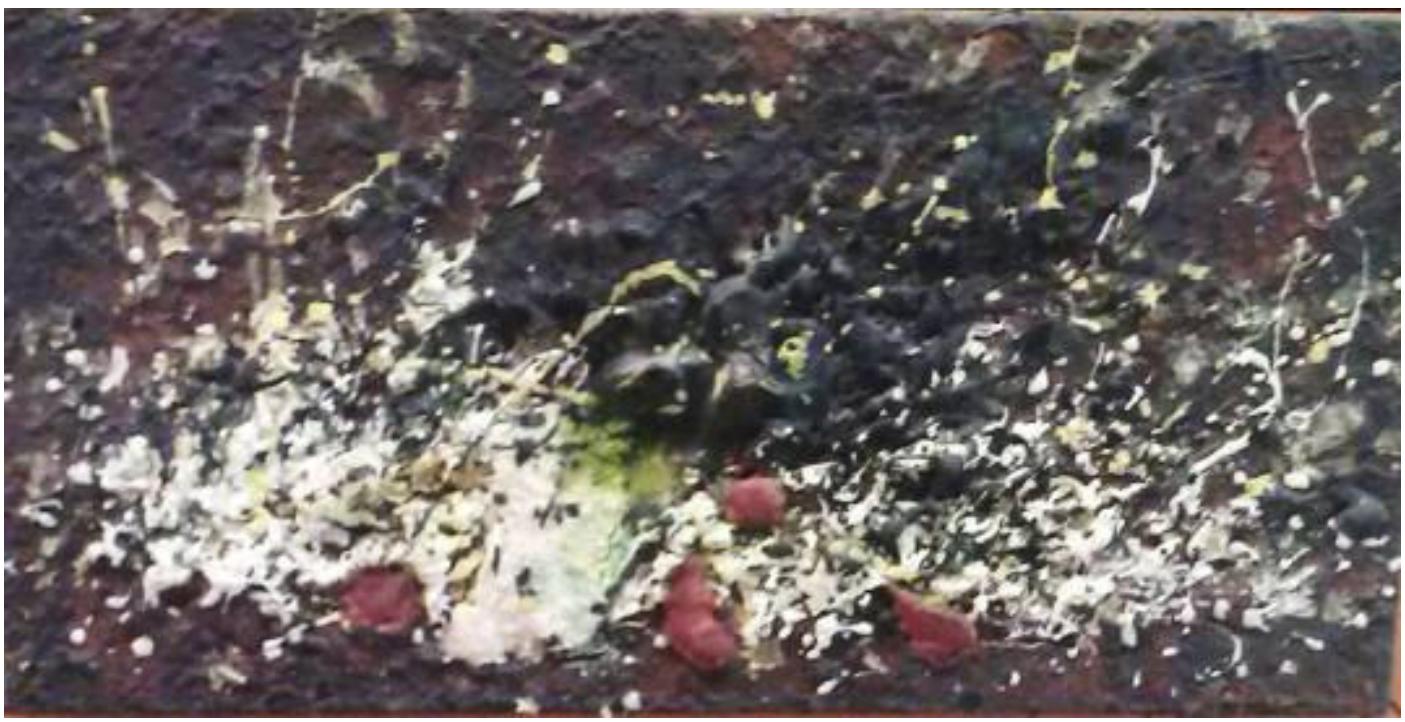




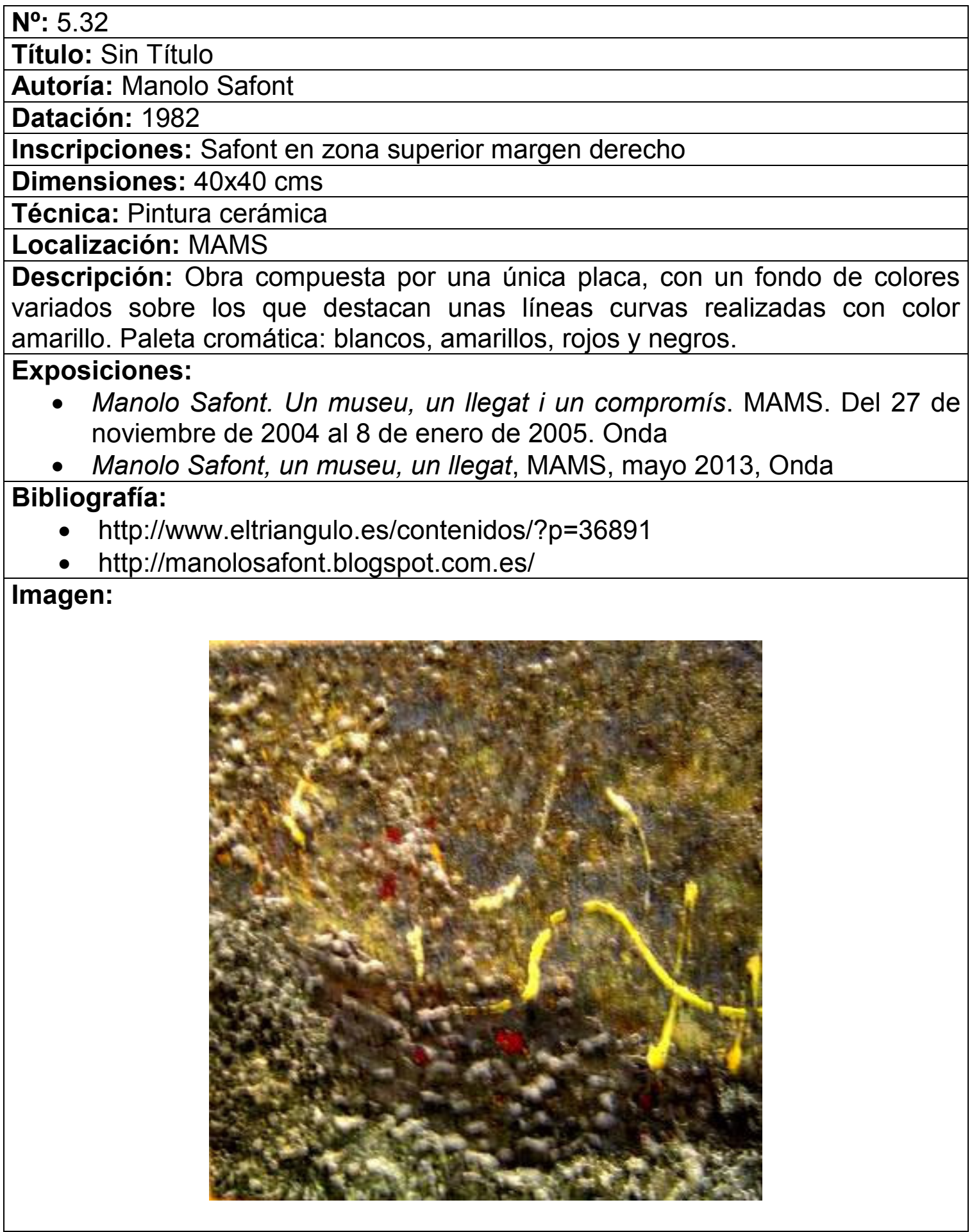


$\mathbf{N}^{\circ}: 5.33$

Título: Sin Título

Autoría: Manolo Safont

Datación: 1982

Dimensiones: $30 \times 43 \mathrm{cms}$

Técnica: Pintura cerámica

Localización: MAMS

Descripción: Obra realizada sobre una única placa. Masa oscura de gran relieve con mancha blanca y roja en el margen inferior, dejando al descubierto una zona lisa ocre en la zona superior e izquierda. Presenta una grieta rotura que parte del ángulo superior izquierdo, en dirección oblicua, con una repigmentación inadecuada, precisando una adecuada restauración. Paleta cromática: blancos, ocres, rojos y negros.

\section{Exposiciones:}

- Manolo Safont. Un museu, un llegat i un compromís. MAMS. Del 27 de noviembre de 2004 al 8 de enero de 2005. Onda

- Manolo Safont, un museu, un llegat, MAMS, mayo 2013, Onda

\section{Bibliografía:}

- http://www.eltriangulo.es/contenidos/?p=36891

- http://manolosafont.blogspot.com.es/

Imagen:

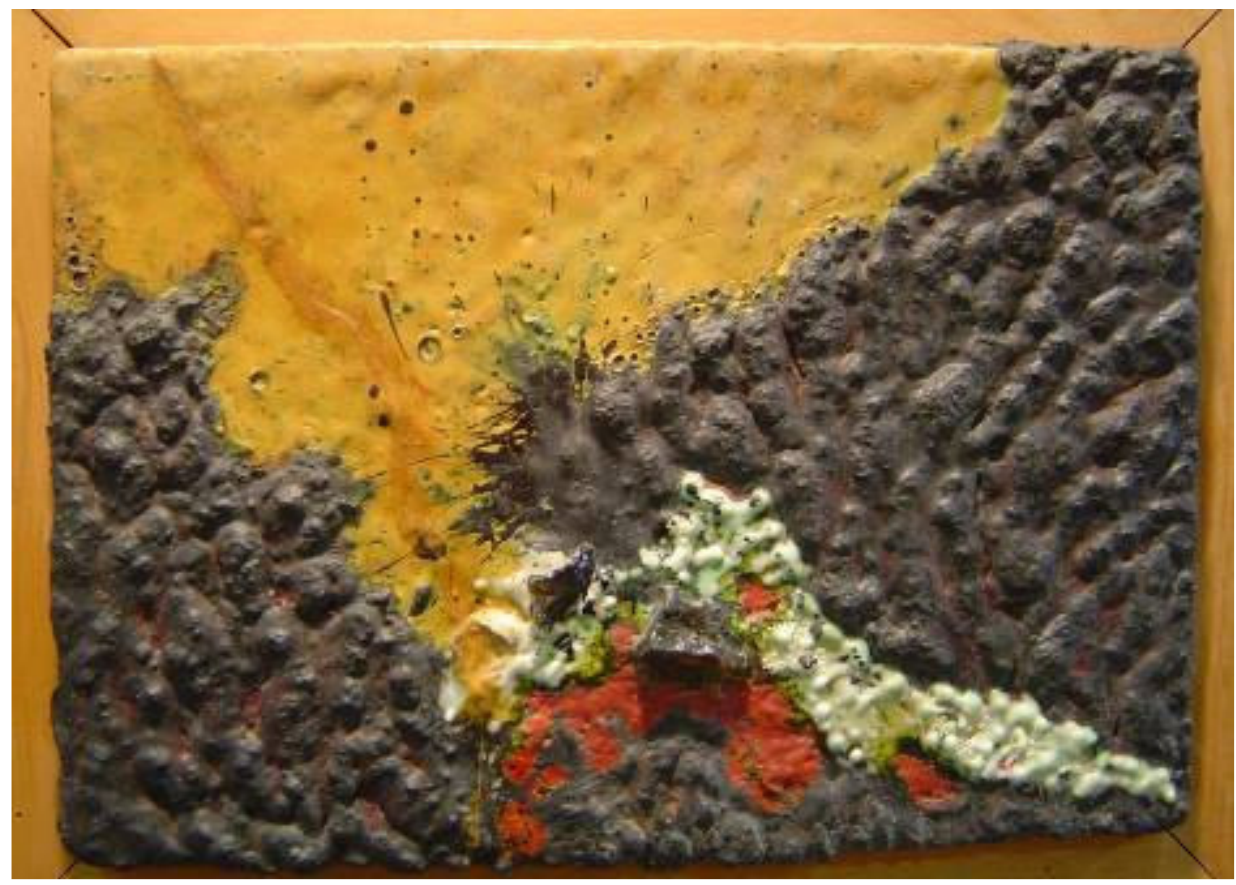


$N^{0}: 5.34$

Título: Sin Título

Autoría: Manolo Safont

Datación: Anterior a 1983

Dimensiones: $60 \times 60 \mathrm{cms}$

Técnica: Pintura cerámica

Descripción: Obra compuesta por 4 placas del mismo tamaño, en disposición $2 \times 2$. Sobre fondo oscuro rugoso se sitúa en el tercio inferior una masa blanca, con manchas circulares rojas con borde amarillo, y salpicaduras negras y blancas que se extienden sobre el fondo rugoso. La imagen de esta obra fue utilizada para ilustrar los catálogos de las exposiciones de Safont en la galería Fontana d'Or de Gerona en 1983 y la de 1984 en el Castillo de Peñíscola (Castellón). Paleta cromática: blancos, amarillos, rojos y negros.

Exposiciones:

- Manolo Safont. Fontana d'Or, del 28 de marzo al 16 de abril de 1983, Gerona

- Manolo Safont. Ceràmica. Expossició Castell de Peníscola, del 28 de juliol al 19 d'agost de 1984. Diputació de Castelló

\section{Bibliografía:}

- Manolo Safont. Fontana d'Or, del 28 de marzo al 16 de abril de 1983, Gerona

- Manolo Safont. Ceràmica. Expossició Castell de Peníscola, del 28 de juliol al 19 d'agost de 1984. Diputació de Castelló

- GASCÓ, A. "La cerámica de Safont, un grito de pasión y livertad cuajado en color", Castellón Diario, 9 enero 1989, pág. 10

- http://www.gva.es/museo/safon7.htm, 1995-1996

Imagen:

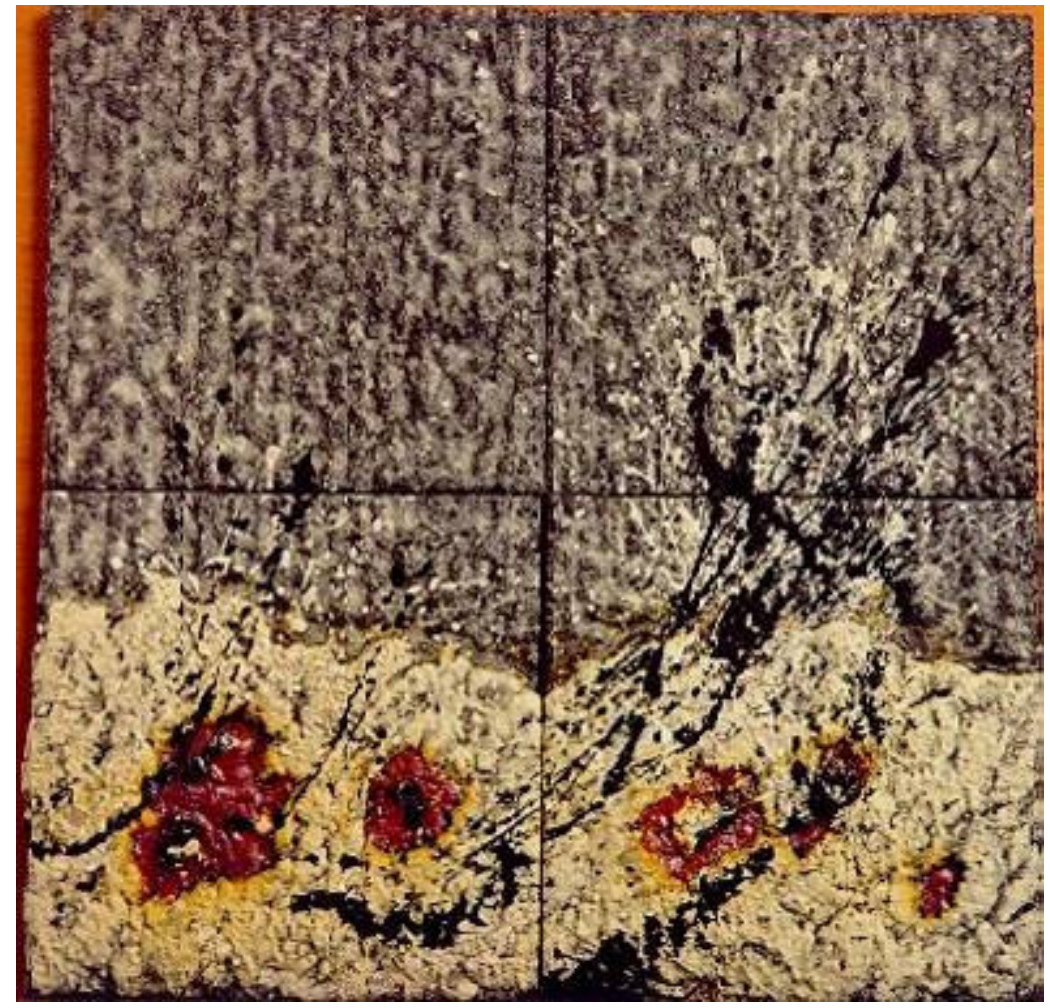


Imágenes relacionadas:

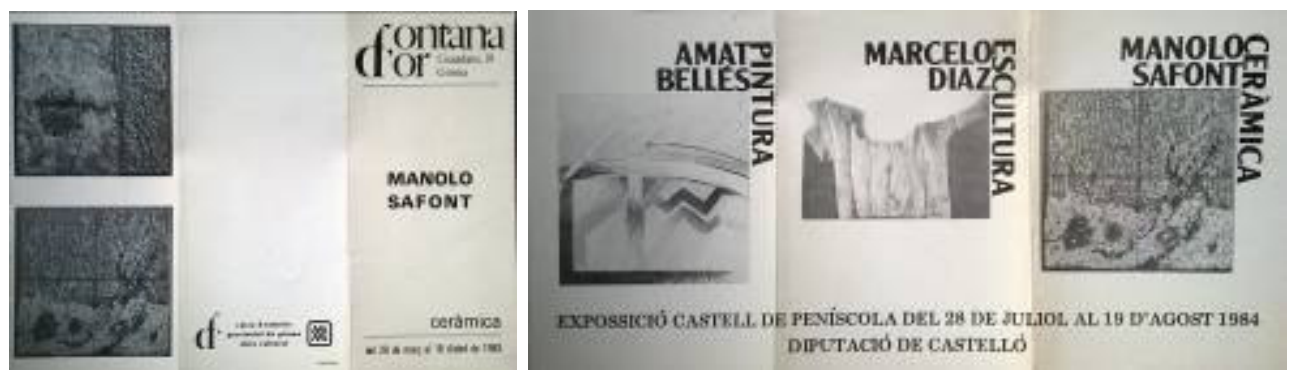


$\mathbf{N}^{0}: 5.35$

Título: Sin Título

Autoría: Manolo Safont

Datación: Anterior a 1983

Técnica: Pintura cerámica

Descripción: Obra compuesta por una única placa. La imagen de esta obra fue utilizada para ilustrar el catálogo de la exposición de Safont en la galería Fontana d'Or de Gerona en 1983. Sólo hemos podido localizar una imagen en blanco y negro de la obra por lo que la descripción no es completa y no puede establecerse la paleta cromática.

Exposiciones:

- Manolo Safont. Fontana d'Or, del 28 de marzo al 16 de abril de 1983, Gerona

\section{Bibliografía:}

- Manolo Safont. Fontana d'Or, del 28 de marzo al 16 de abril de 1983, Gerona

Imagen:

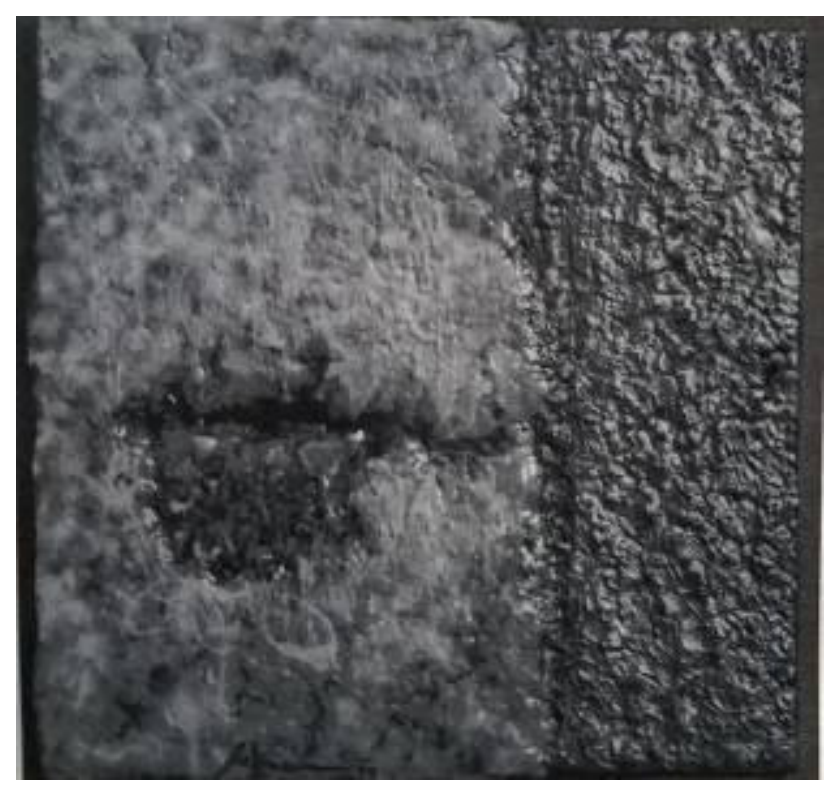

Imágenes relacionadas:

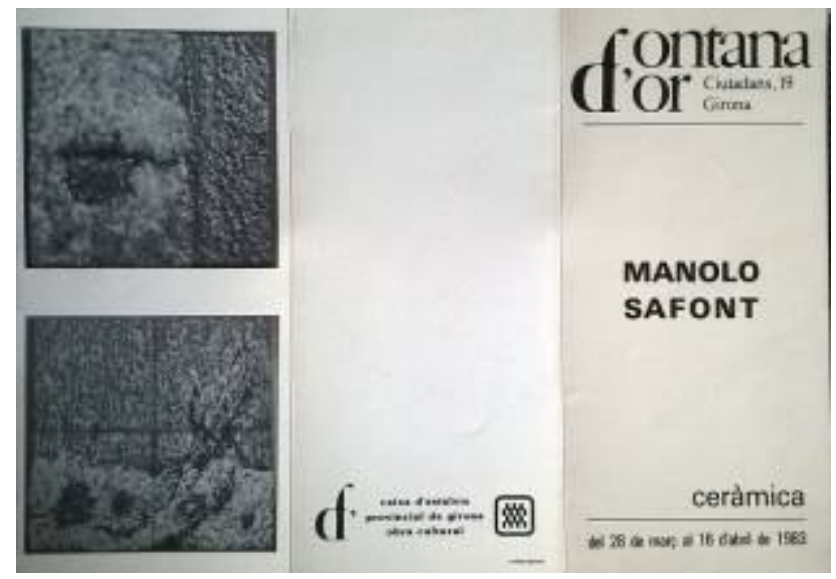


$\mathbf{N}^{0}: 5.36$

Título: Sin Título

Autoría: Manolo Safont

Datación: Anterior a 1983

Técnica: Pintura cerámica

Descripción: Obra compuesta por 3 placas del mismo tamaño. La imagen de esta obra fue utilizada para ilustrar el catálogo de la exposición de Safont en la galería Fontana d'Or de Gerona en 1983. Solo hemos obtenido una imagen en blanco y negro de esta obra, por lo que no puede completarse la descripción de la obra, ni establecer la paleta cromática.

Exposiciones:

- Manolo Safont. Fontana d'Or, del 28 de marzo al 16 de abril de 1983, Gerona

Bibliografía:

- Manolo Safont. Fontana d'Or, del 28 de marzo al 16 de abril de 1983, Gerona

Imagen:

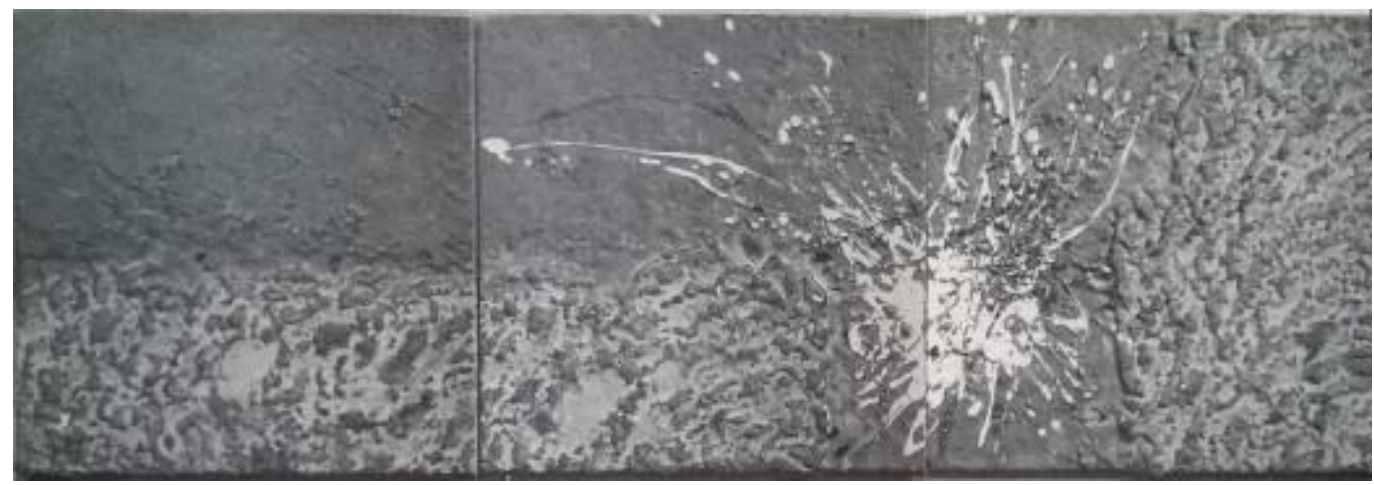

Imágenes relacionadas:

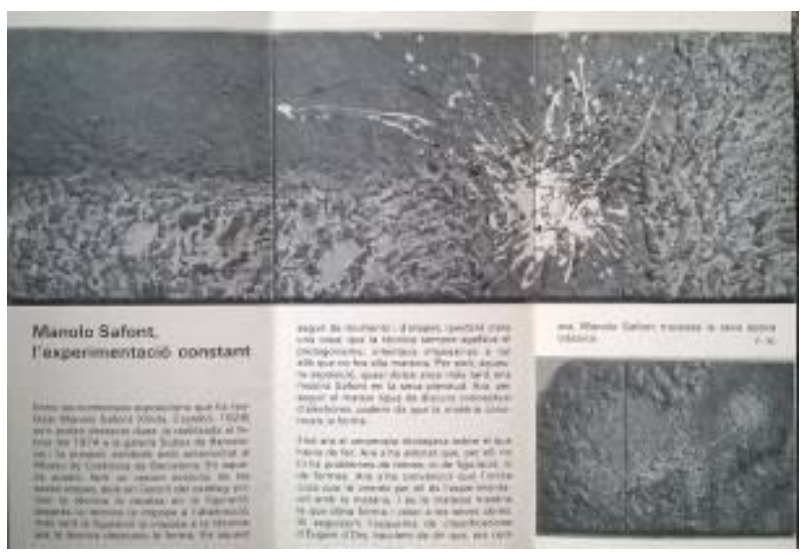


$\mathbf{N}^{0}: 5.37$

Título: Sin Título

Autoría: Manolo Safont

Datación: Anterior a 1983

Técnica: Pintura cerámica

Descripción: Obra compuesta por 3 placas del mismo tamaño, la placa situada a la izquierda tiene el borde superior redondeado. La imagen de esta obra fue utilizada para ilustrar el catálogo de la exposición de Safont en la galería Fontana d'Or de Gerona en 1983. Solo hemos obtenido una imagen en blanco y negro de esta obra, por lo que no puede completarse la descripción de la obra, ni establecer la paleta cromática.

Exposiciones:

- Manolo Safont. Fontana d'Or, del 28 de marzo al 16 de abril de 1983, Gerona

\section{Bibliografía:}

- Manolo Safont. Fontana d'Or, del 28 de marzo al 16 de abril de 1983, Gerona

Imagen:

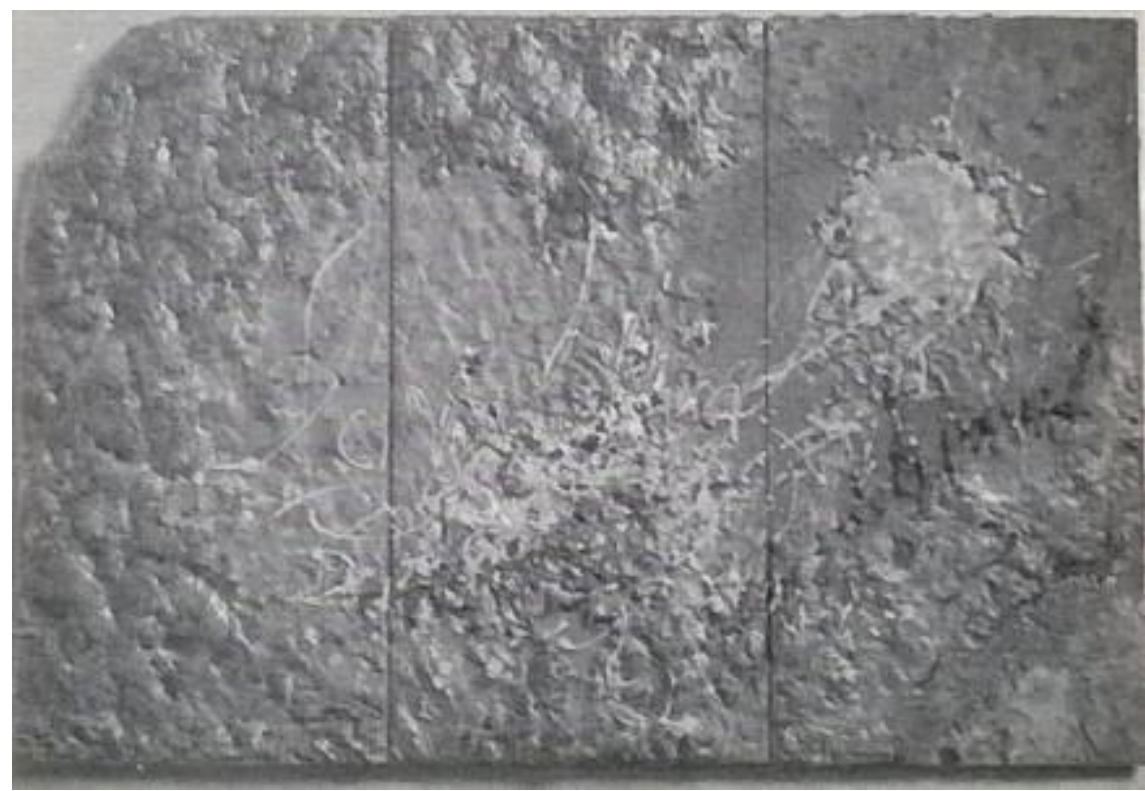

Imágenes relacionadas:

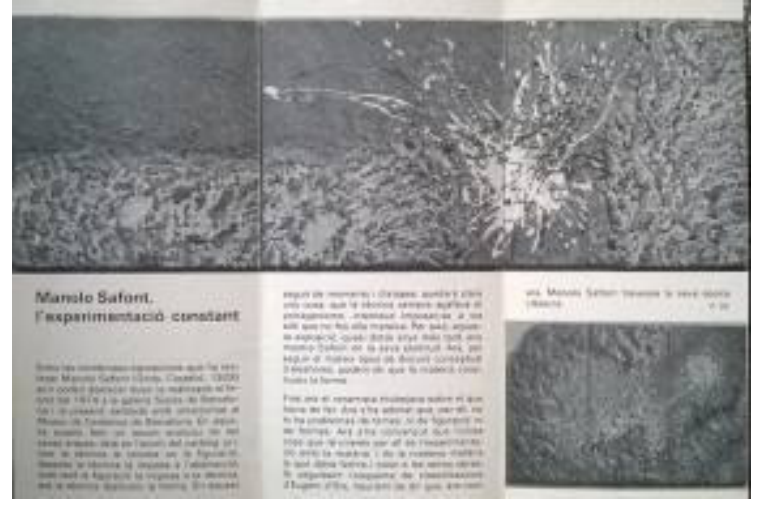


$\mathbf{N}^{0}: 5.38$

Título: Sin Título

Autoría: Manolo Safont

Datación: Anterior a 1983

Técnica: Pintura cerámica

Descripción: Obra compuesta por dos placas del mismo tamaño, presentando una fragmentación en forma triangular en el ángulo inferior izquierdo de la pieza situada a la derecha en la obra. Solo hemos obtenido una imagen en blanco y negro de esta obra, por lo que no puede completarse la descripción de la obra, ni establecer la paleta cromática.

\section{Exposiciones:}

- Safont. Palau Oliver de Boteller, del 9 al 16 maig 1983, Generalitat de Catalunya, Tortosa

\section{Bibliografía:}

- Safont. Palau Oliver de Boteller, del 9 al 16 maig 1983, Generalitat de Catalunya, Tortosa

Imagen:

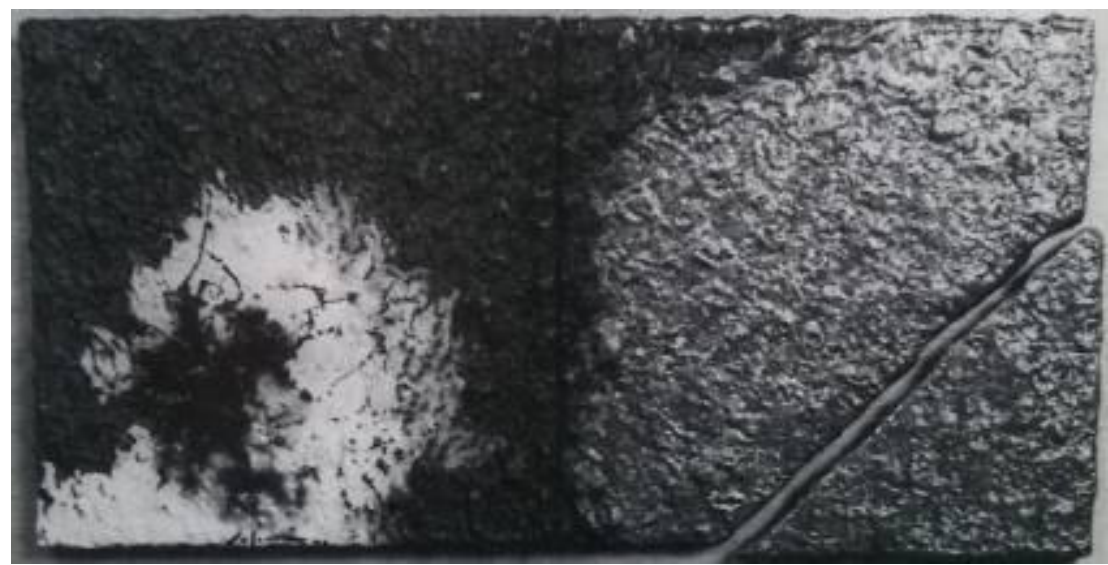

Imágenes relacionadas:

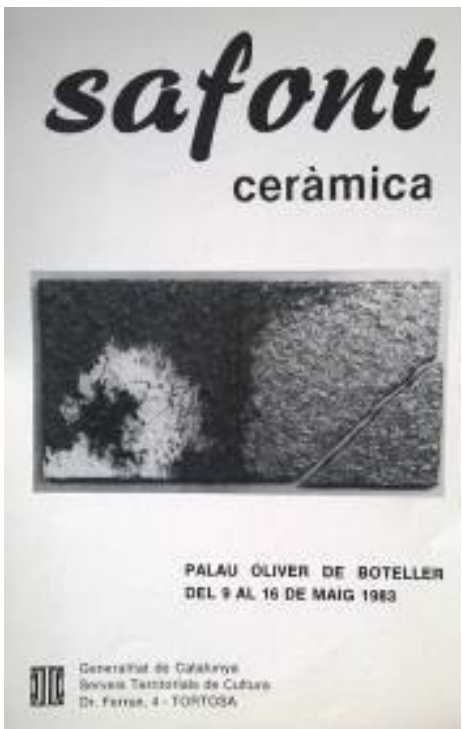


$\mathbf{N}^{0}: 5.39$

Título: Sin Título

Autoría: Manolo Safont

Datación: 1984

Inscripciones: Safont en zona inferior lateral derecha

Dimensiones: $16 \times 21 \mathrm{cms}$

Técnica: Pintura cerámica

Localización: MAMS

Descripción: Obra compuesta por una única placa. Sobre fondo oscuro, mancha amarilla y sobre ella mancha roja, con relieve de salpicaduras en color oscuro. Paleta cromática: blancos, amarillos, rojos, verdes y negros.

Exposiciones:

- Manolo Safont. Un museu, un llegat i un compromís. MAMS. Del 27 de noviembre de 2004 al 8 de enero de 2005. Onda

Imagen:

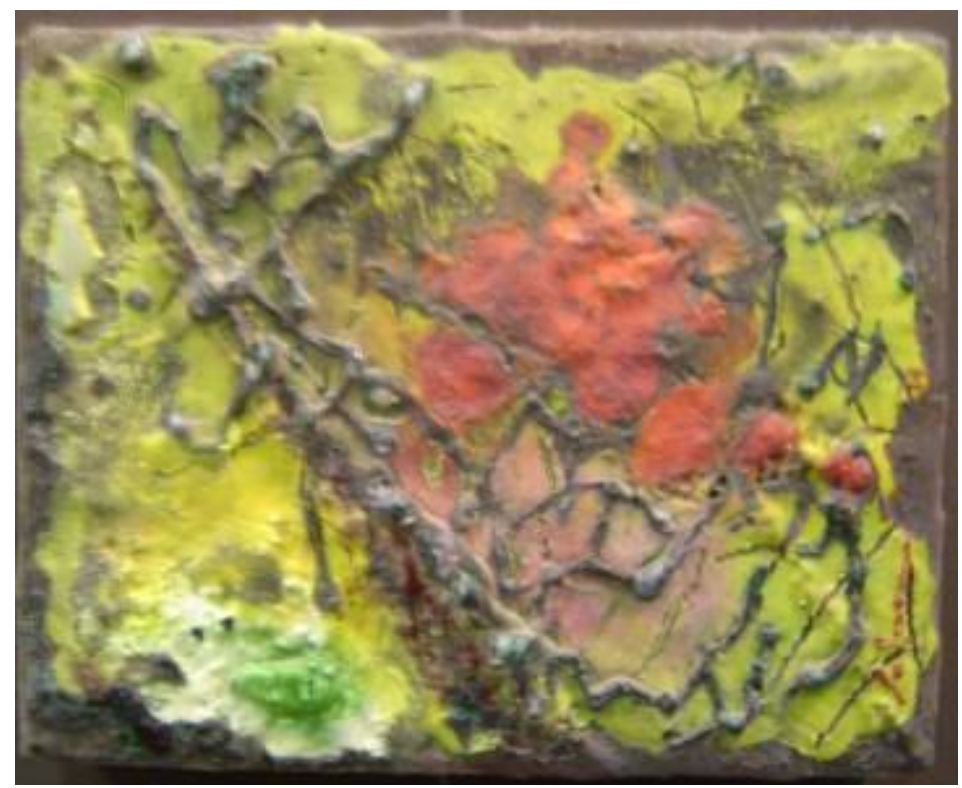


$\mathbf{N}^{\circ}: 5.40$

Título: Sin Título

Autoría: Manolo Safont

Datación: 1984

Dimensiones: $40 \times 40 \mathrm{cms}$

Técnica: Pintura cerámica

Localización: MAMS

Descripción: Obra compuesta por una única placa. Mancha roja sobre salpicaduras blancas y amarillas en la zona inferior que resalta sobre la zona negra texturizada del resto de la obra. Muy similar a la obra catalogada n5.41. Paleta cromática: blancos, amarillos, rojos, marrones y negros.

Exposiciones:

- Manolo Safont. Un museu, un llegat i un compromís. MAMS. Del 27 de noviembre de 2004 al 8 de enero de 2005. Onda.

\section{Imagen:}

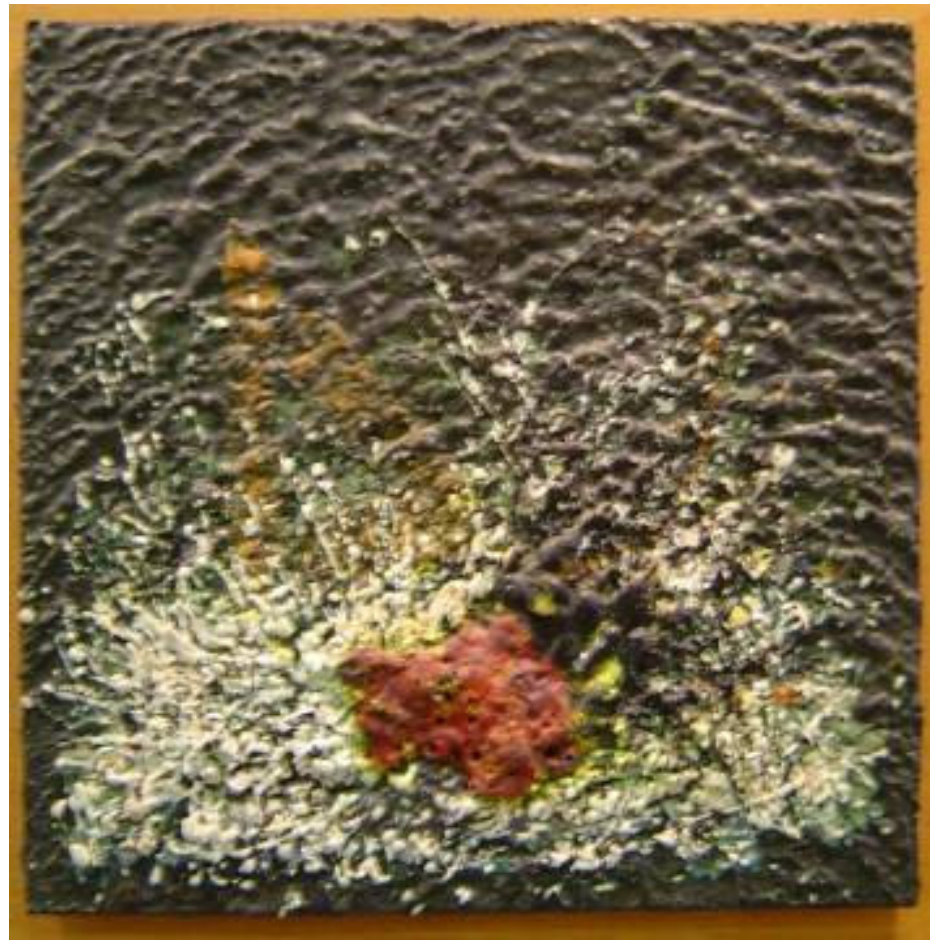


$\mathbf{N}^{0}: 5.41$

Título: Sin Título

Autoría: Manolo Safont

Datación: 1984

Dimensiones: $40 \times 40 \mathrm{cms}$

Técnica: Pintura cerámica

Localización: MAMS

Descripción: Obra compuesta por una única placa. Mancha roja sobre salpicaduras blancas y amarillas en la zona inferior que resalta sobre la zona negra texturizada del resto de la obra. Muy similar a la obra catalogada $n^{\circ} 5.40$. Paleta cromática: blancos, amarillos, rojos, marrones y negros.

\section{Exposiciones:}

- Manolo Safont. Un museu, un llegat i un compromís. MAMS. Del 27 de noviembre de 2004 al 8 de enero de 2005. Onda.

\section{Imagen:}

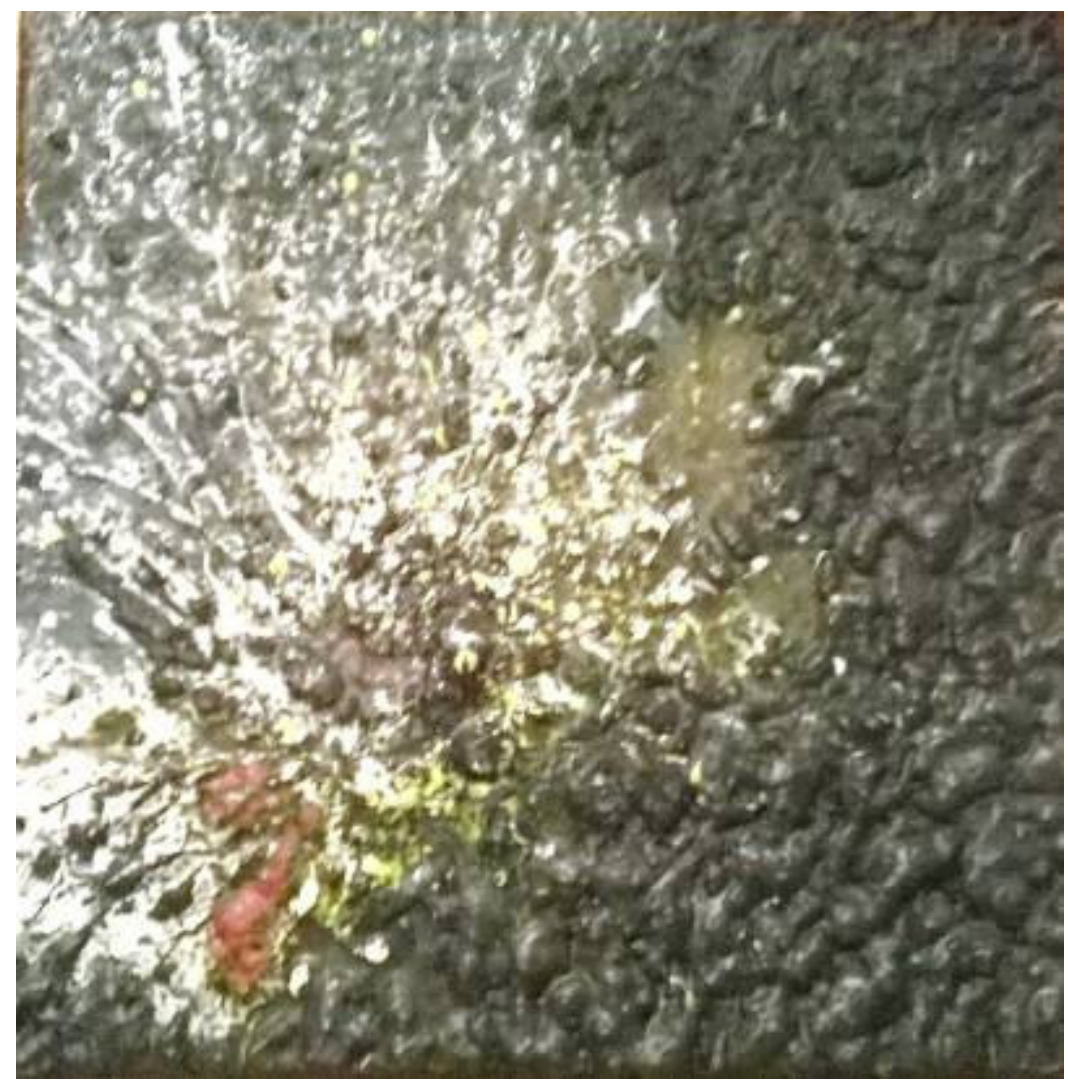


$\mathbf{N}^{0}: 5.42$

Título: Sin Título

Autoría: Manolo Safont

Datación: 1984

Inscripciones: Safont en ángulo inferior izquierdo

Dimensiones: 20x20 cms

Técnica: Pintura cerámica

Localización: MAMS

Descripción: Obra compuesta por una única placa. Siguiendo el patrón de las obras catalogadas $n^{0} 5.40$ y $n^{0} 5.41$, una mancha roja sobre salpicaduras blancas y amarillas en la zona inferior que se funde sobre la zona negra texturizada del resto de la obra, con salpicaduras del resto de la paleta cromática. Paleta cromática: blancos, amarillos, rojos y negros.

\section{Exposiciones:}

- Manolo Safont. Un museu, un llegat i un compromís. MAMS. Del 27 de noviembre de 2004 al 8 de enero de 2005. Onda

\section{Imagen:}

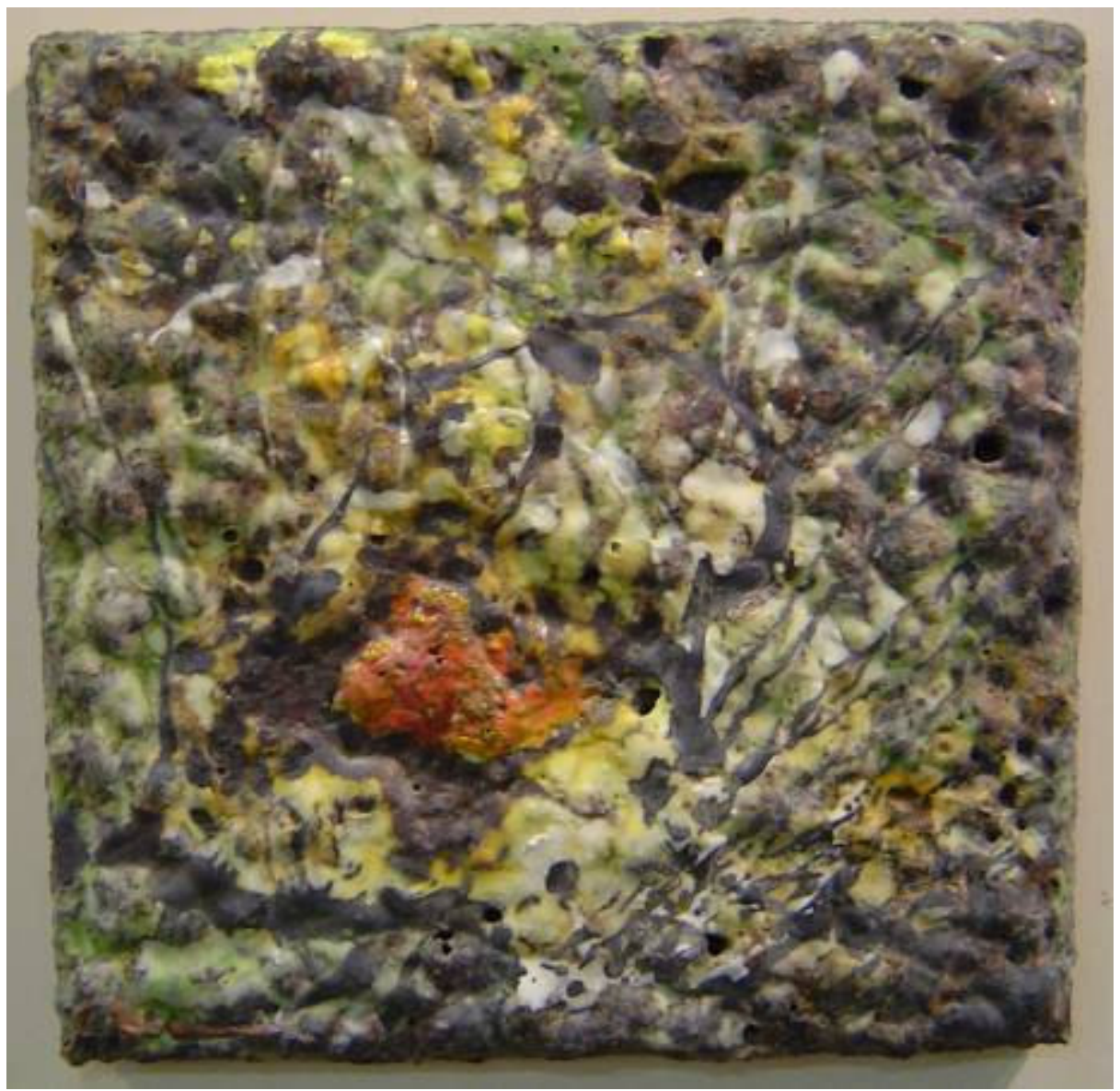


$\mathbf{N}^{0}: 5.43$

Título: Sin Título

Autoría: Manolo Safont

Datación: Anterior a 1986

Inscripciones: Safont en ángulo inferior derecho

Dimensiones: $20 \times 40 \mathrm{cms}$

Técnica: Pintura cerámica

Localización: Colección privada $\mathrm{n}^{\circ} 13$, Onda.

Descripción: Obra compuesta por una única placa. Sobre base de color blanco y ocre, una masa negra muy texturizada en la zona central inferior en contraste con una masa blanca a al izquierda creada por salpicaduras con textura fina. Paleta cromática: blancos, amarillos, marrones y negros.

Imagen:

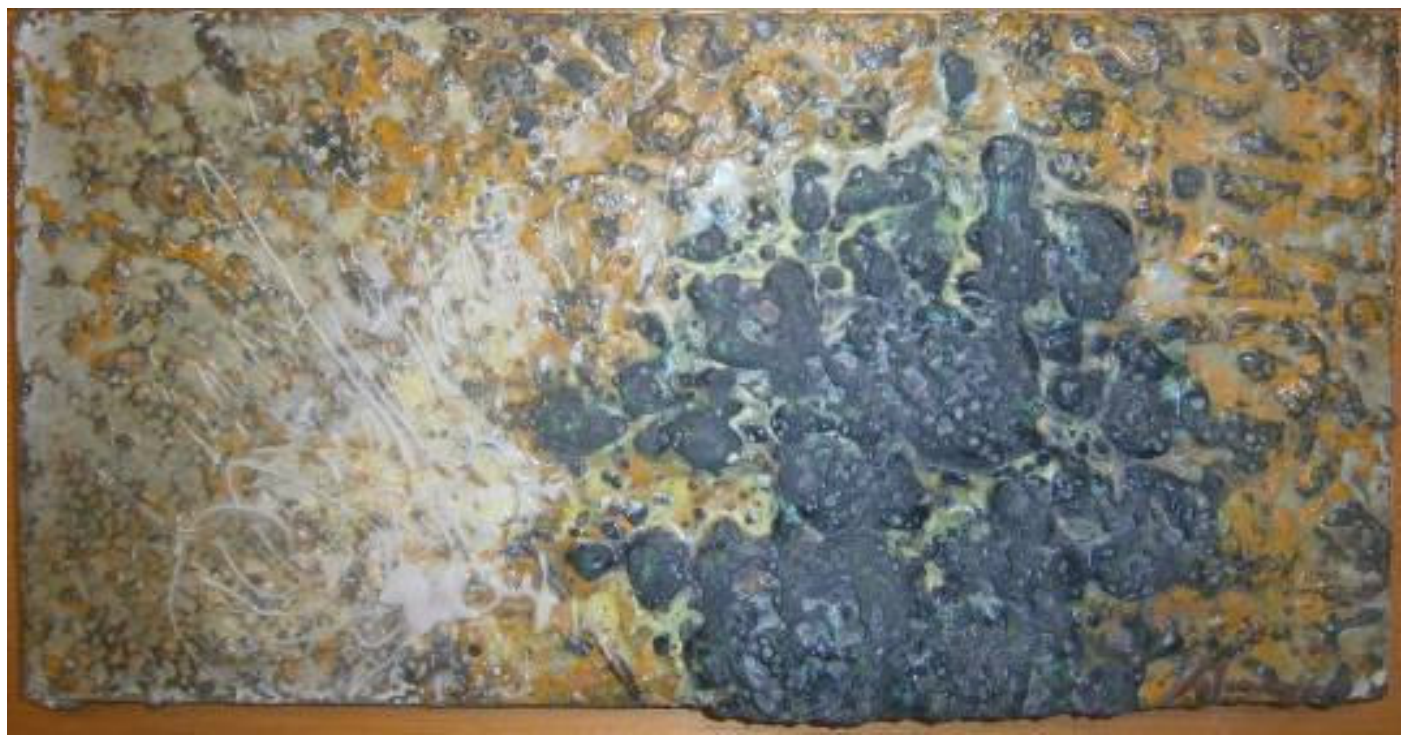

Imágenes relacionadas:

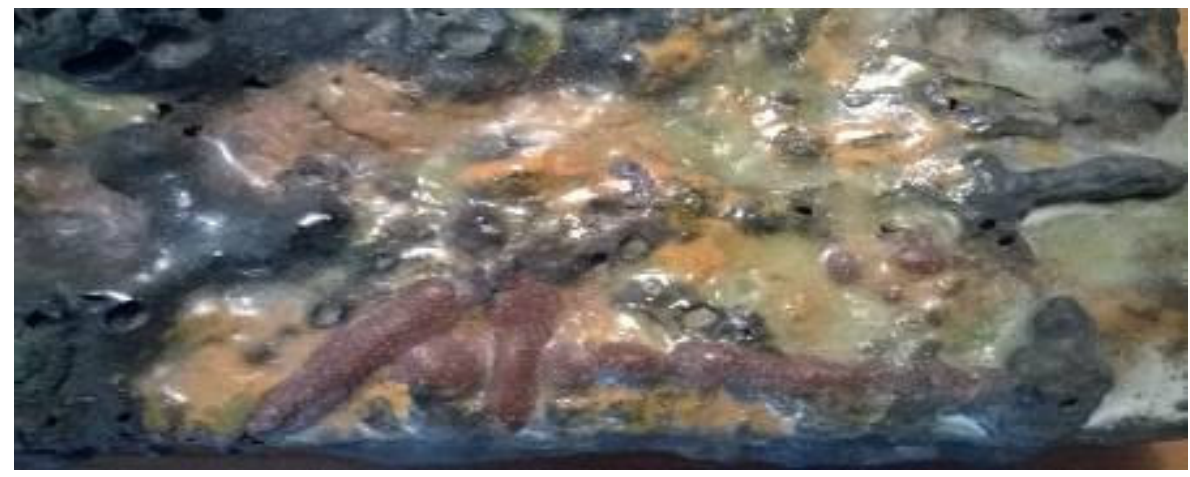

Detalle autoría 
$\mathbf{N}^{0}: 5.44$

Título: Sin Título

Autoría: Manolo Safont

Datación: 1986

Inscripciones: Safont 86 en ángulo inferior izquierdo

Dimensiones: $60 \times 152 \mathrm{cms}$

Técnica: Pintura cerámica

Localización: Colección privada $n^{\circ}$ 9, Onda

Descripción: Obra compuesta por 4 placas de $60 \times 38 \mathrm{cms}$. La imagen de esta obra fue utilizada para ilustrar el catálogo de la exposición de Safont en La Pobla Tornesa en 1987. La composición, con amplia utilización de la paleta cromática, se concentra en la zona central de la pieza, quedando libres los márgenes en los que podemos observar la base blanca texturizada. Paleta cromática: blancos, amarillos, ocres, rojos y negros.

Exposiciones:

- Safont a la Pobla Tornesa, estiu 1987, Consellería de Cultura, Educación y Ciencia. Valencia

- Manolo Safont. Exposición conmemorativa de la inauguración del nuevo edificio social. Caja Rural Nuestra Señora de la Esperanza. 23 diciembre 2001- 6 enero 2002. Onda

\section{Bibliografía:}

- Safont a la Pobla Tornesa, estiu 1987, Consellería de Cultura, Educación y Ciencia. Valencia

- GIRALT-MIRACLE, Daniel /OLUCHA MONTINS, Ferran. Wences Rambla/ Manolo Safont, Centre Cultural d'Alcoi. Marzo, 1995, pág. 17

- Manolo Safont. Exposición conmemorativa de la inauguración del nuevo edificio social. Caja Rural Nuestra Señora de la Esperanza. 23 diciembre 2001- 6 enero 2002. Onda

\section{Imagen:}

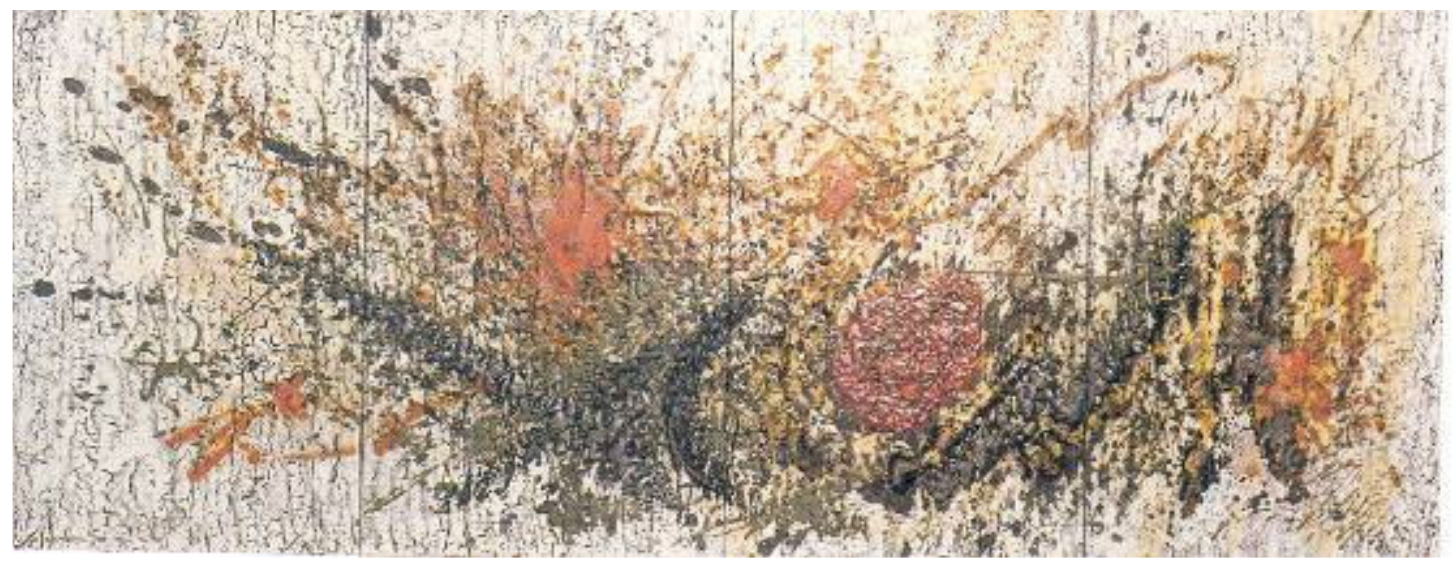


$\mathbf{N}^{0}: 5.45$

Título: Sin Título

Autoría: Manolo Safont

Datación: 1986

Inscripciones: Safont en zona inferior izquierda

Dimensiones: $60 \times 76 \mathrm{cms}$

Técnica: Pintura cerámica

Localización:

Descripción: Obra compuesta por 2 placas de 30x38 cms. La imagen de esta obra fue utilizada para ilustrar el catálogo de la exposición de Safont en La Pobla Tornesa en 1987 y el calendario de Caixa Rural d'Onda de 2003. Grandes masas de color, con bordes redondeados, que parten del margen superior de la obra. Paleta cromática: blancos, amarillos, rojos, azules, violetas, marrones y negros.

Exposiciones:

- Safont a la Pobla Tornesa, estiu 1987, Consellería de Cultura, Educación y Ciencia. Valencia

- Safont in Brussel. Hotel Charlemagne. 9 marzo-23 abril, 1989

\section{Bibliografía:}

- Safont a la Pobla Tornesa, estiu 1987, Consellería de Cultura, Educación y Ciencia. Valencia

- Safont in Brussel. Hotel Charlemagne. 9 marzo-23 abril, 1989

- http://www.gva.es/esmuseo/safon2.htm, 1995-1996

- Calendario Caixa Rural d'Onda 2003. Caixa Rural d'Onda 2003

\section{Imagen:}

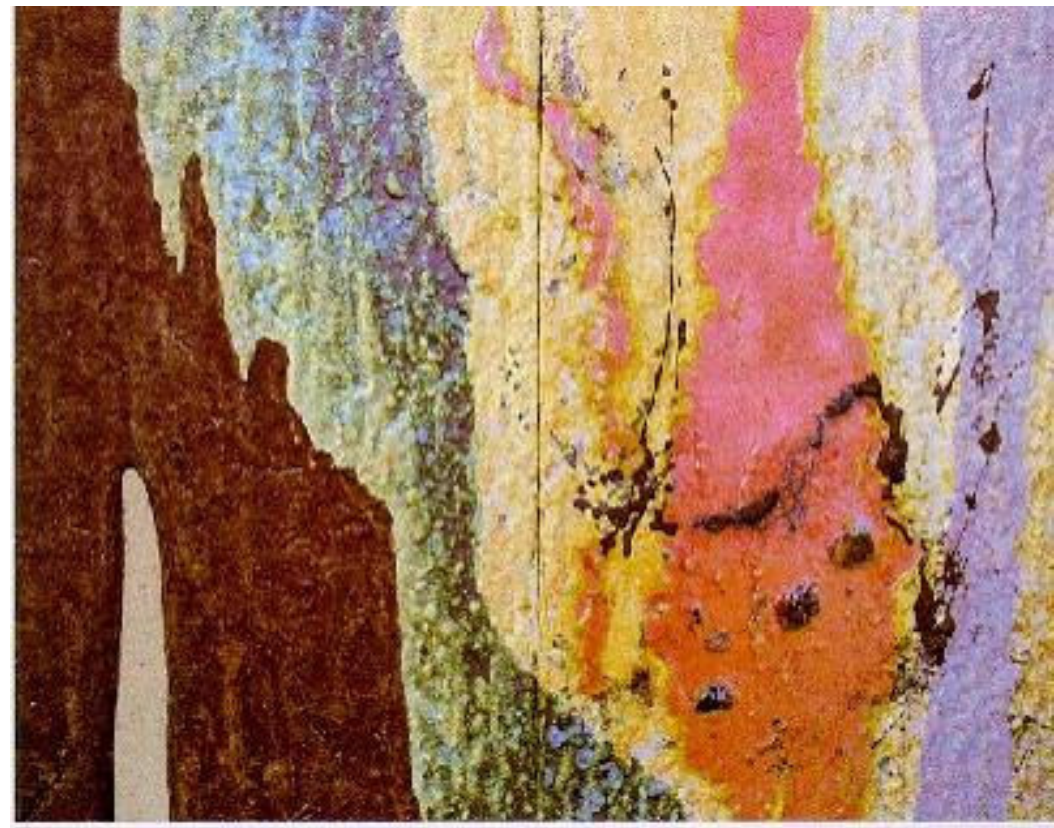


$\mathbf{N}^{0}: 5.46$

Título: Sin Título

Autoría: Manolo Safont

Datación: Anterior a 1987

Inscripciones: Safont en zona superior izquierda

Dimensiones: $76 \times 100 \mathrm{cms}$

Técnica: Pintura cerámica

Localización: Negociado de Cultura. Ayuntamiento de Castellón, calle Gaibiel. Castellón de la Plana

Descripción: Obra compuesta por 4 placas de 38x50 cms de refractario. Se utilizó para ilustrar el calendario de Caixa Rural d'Onda de 2003. Esta obra fue adquirida por el Excelentísimo Ayuntamiento de Castellón. En el margen derecho de la obra, una superficie negra texturizada contrasta con la superficie lisa del margen izquierdo sobre la cual se crean pequeñas masas de color azul y amarillo, y una gran masa de color rojo. Paleta cromática: blancos, ocres, rojos, azules y negros.

Exposiciones:

- Safont a la Pobla Tornesa, estiu 1987, Consellería de Cultura, Educación y Ciencia. Valencia

- Safont. Ajuntament de Castelló, 22 diciembre 1988 - 12 enero 1989, Castellón

- GIRALT-MIRACLE, Daniel / OLUCHA MONTINS, Ferran. Wences Rambla/ Manolo Safont, Centre Cultural d'Alcoi, Marzo 1995,

- Cerámica fin de siglo. Atarazanas Valencia, 25 noviembre - 2 enero 2000

- Manolo Safont. Exposición conmemorativa de la inauguración del nuevo edificio social. Caja Rural Nuestra Señora de la Esperanza. 23 diciembre 2001- 6 enero 2002. Onda

\section{Bibliografía:}

- Safont a la Pobla Tornesa, estiu 1987, Consellería de Cultura, Educación y Ciencia. Valencia

- Safont. Ajuntament de Castelló, 22 diciembre 1988 - 12 enero 1989, Castellón

- GIRALT-MIRACLE, Daniel/OLUCHA MONTINS, Ferran. Wences Rambla/ Manolo Safont, Centre Cultural d'Alcoi, Marzo 1995, pág.19

- DE LA CALLE, Román; PÉREZ CAMPS, Josep. Cerámica fin de siglo. Generalitat Valenciana, Valencia, 1999, pág. 290-291

- Manolo Safont. Exposición conmemorativa de la inauguración del nuevo edificio social. Caja Rural Nuestra Señora de la Esperanza. 23 diciembre 2001- 6 enero 2002. Onda

- Calendario Caixa Rural d'Onda 2003. Caixa Rural d'Onda 2003 


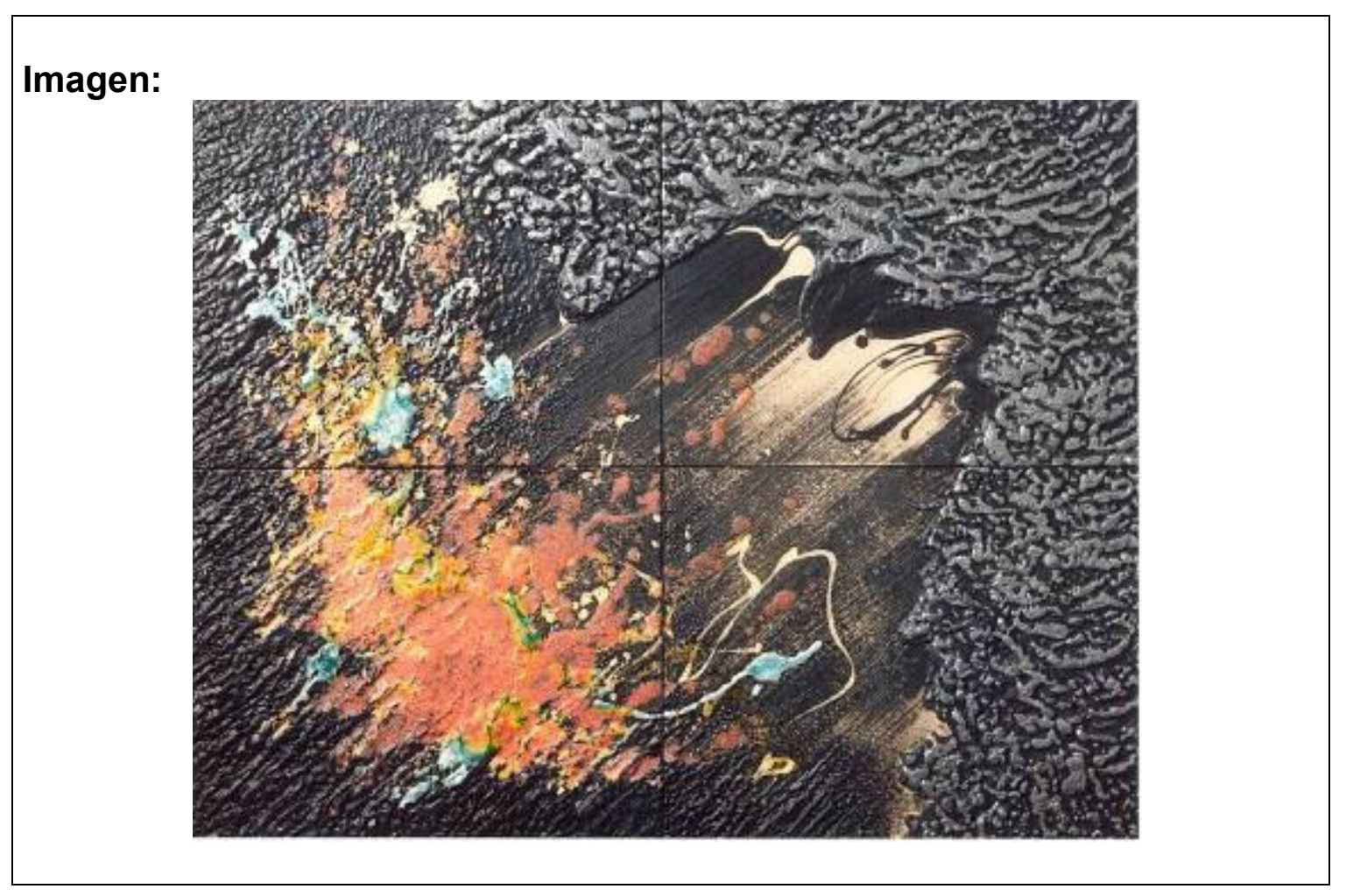


$\mathbf{N}^{\circ}: 5.47$

Título: Sin Título

Autoría: Manolo Safont

Datación: Anterior a 1987

Inscripciones: Safont en ángulo inferior izquierdo

Dimensiones: $34 \times 55 \mathrm{cms}$ o $34 \times 75 \mathrm{cms}$

Técnica: Pintura cerámica

Descripción: Obra compuesta por una única placa. Sobre base rugosa de color ocre, crea un gran relieve central de masa de colores rojo, azul y violeta, expandiéndose el color violeta sobre una superficie lisa hacia el ángulo superior derecho de la obra. Paleta cromática: blancos, amarillos, rojos y violetas.

Exposiciones:

- Safont a la Pobla Tornesa, estiu 1987, Consellería de Cultura, Educación y Ciencia. Valencia

\section{Bibliografía:}

- Safont a la Pobla Tornesa, estiu 1987, Consellería de Cultura, Educación y Ciencia. Valencia

- http://www.gva.es/museo/safon3.htm, 1995-1996

Imagen:

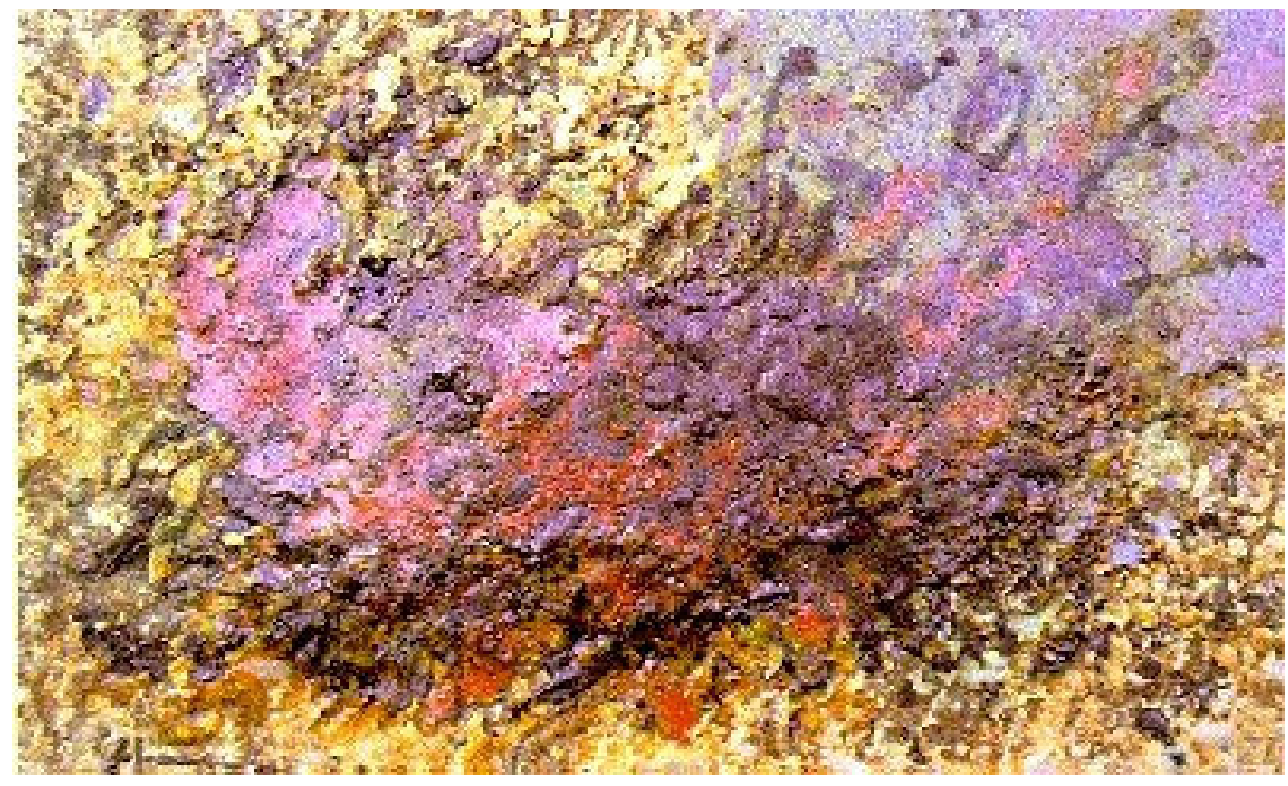


$\mathbf{N}^{0}: 5.48$

Título: Sin Título

Autoría: Manolo Safont

Datación: Anterior a 1987

Dimensiones: $51 \times 41 \mathrm{cms}$

Técnica: Pintura cerámica

Descripción: Obra compuesta por una única placa. La imagen de esta obra fue utilizada para ilustrar el catálogo de la exposición realizada en La Pobla Tornesa en 1987. Base de color violeta con suave textura sobre la que crea una gran masa de textura gruesa negra sobre un rectángulo de color ocre liso. Paleta cromática: blancos, violetas y negros.

Exposiciones:

- Safont a la Pobla Tornesa, estiu 1987, Consellería de Cultura, Educación y Ciencia. Valencia

\section{Bibliografía:}

- Safont a la Pobla Tornesa, estiu 1987, Consellería de Cultura, Educación y Ciencia. Valencia

- http://www.gva.es/museo/safon1.htm, 1995-1996

Imagen:

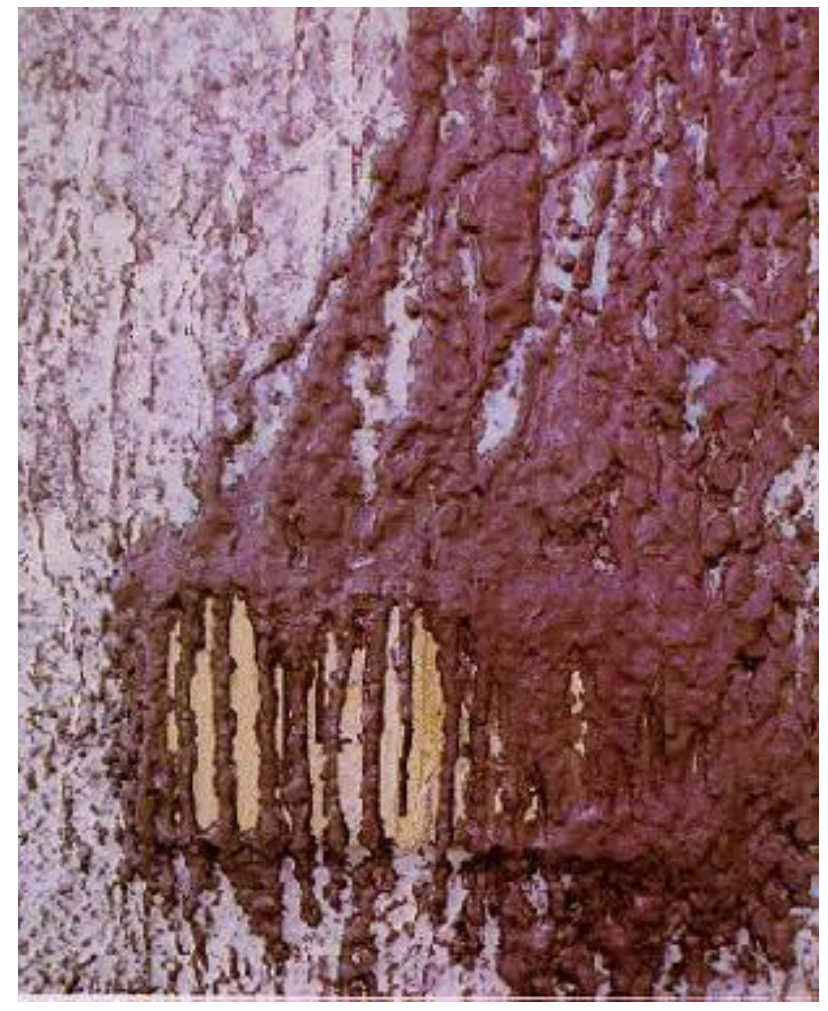




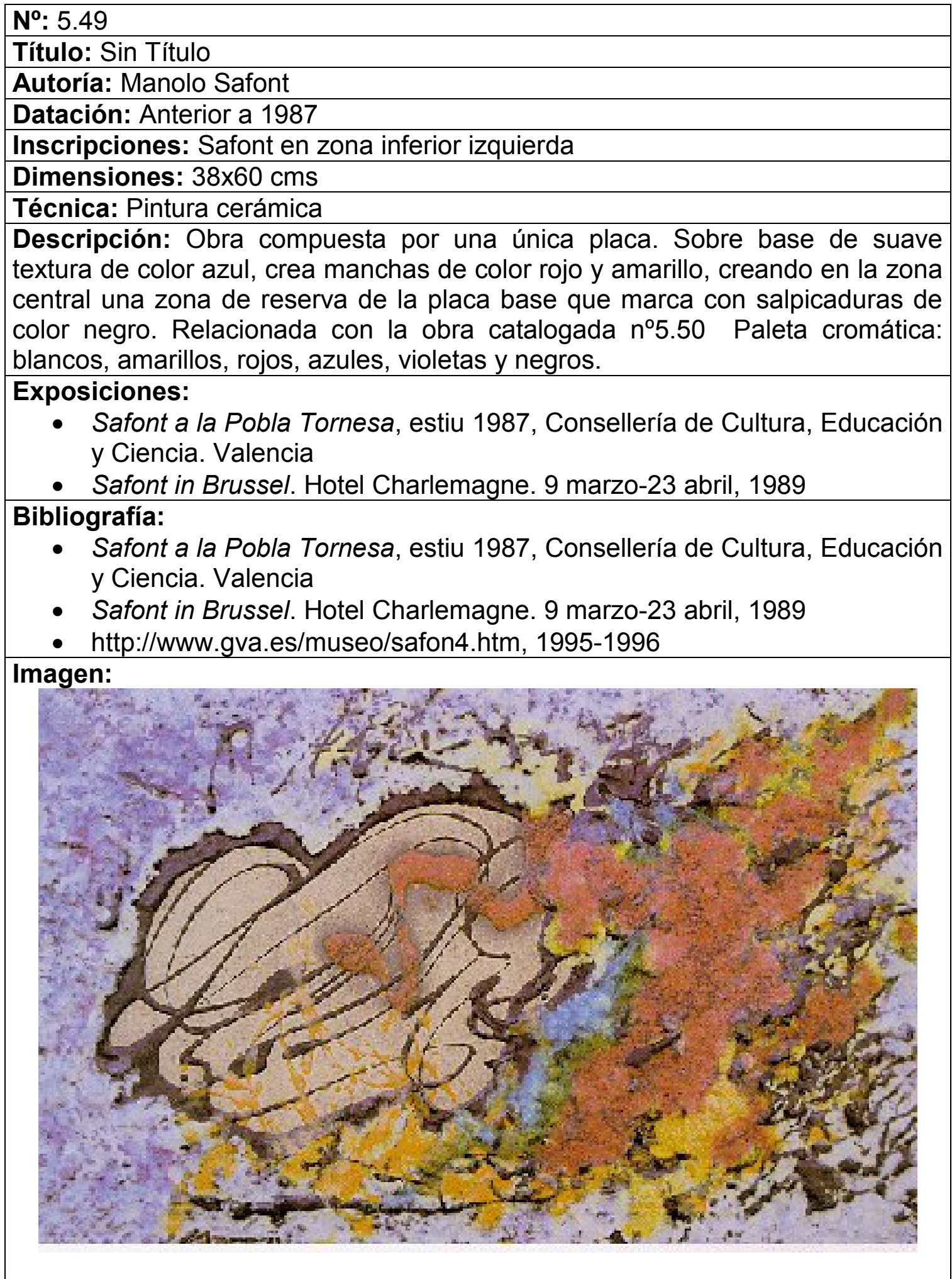


$\mathbf{N}^{\circ}: 5.50$

Título: Sin Título

Autoría: Manolo Safont

Datación: Anterior a 1987

Dimensiones: $38 \times 60 \mathrm{cms}$

Técnica: Pintura cerámica

Descripción: Obra compuesta por una única placa. Gruesa línea curva de color marrón, en la parte central de la obra, sobre base texturizada de color azul, con manchas rojas y amarillas y salpicaduras de color negro. Relacionada con la obra $\mathrm{n}^{05.49}$. Paleta cromática: amarillos, ocres, rojos azules, violetas y negros.

Exposiciones:

- Safont a la Pobla Tornesa, estiu 1987, Consellería de Cultura, Educación y Ciencia. Valencia

\section{Bibliografía:}

- Safont a la Pobla Tornesa, estiu 1987, Consellería de Cultura, Educación y Ciencia. Valencia

\section{Imagen:}

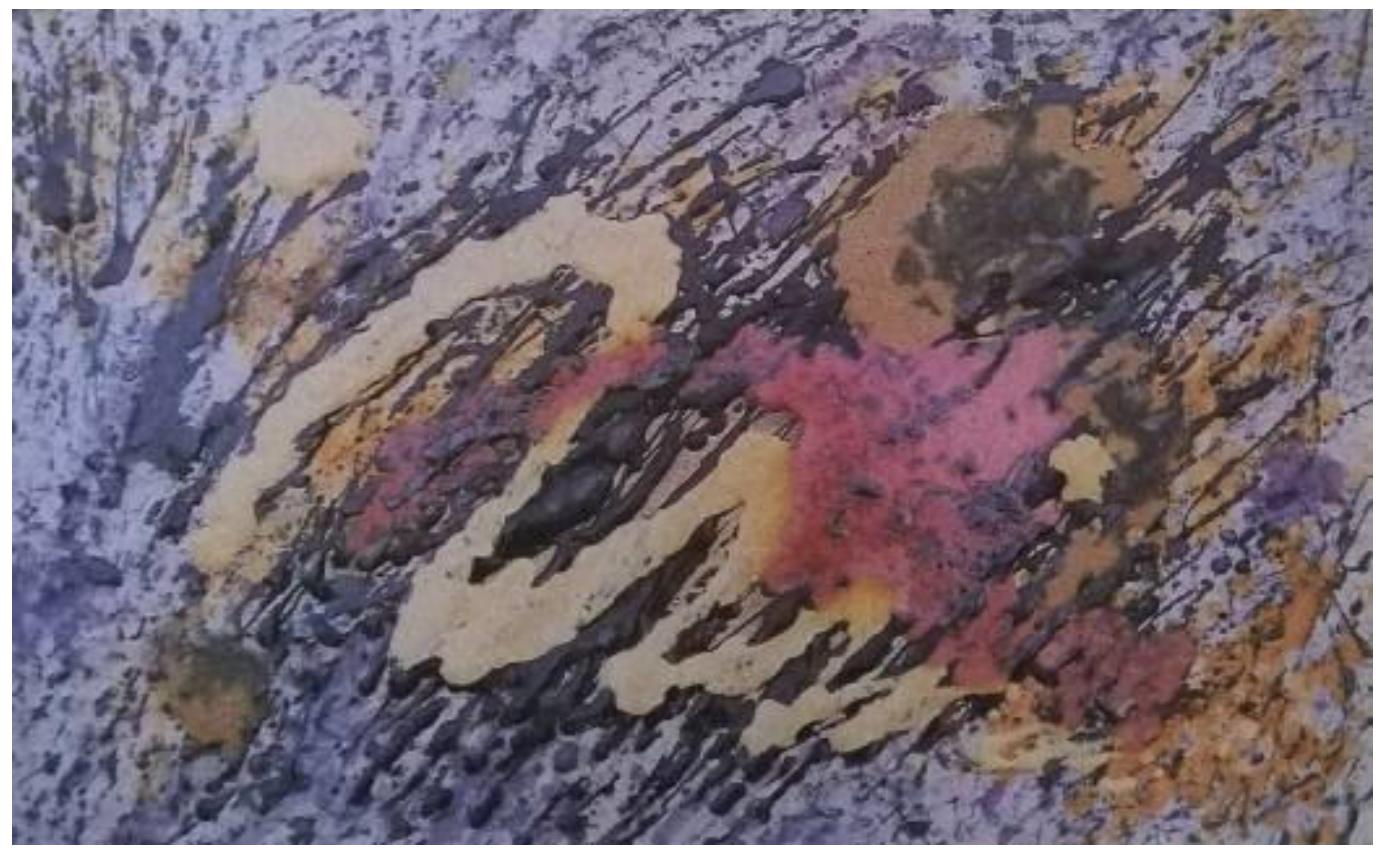


$\mathbf{N}^{\circ}: 5.51$

Título: Sin Título

Autoría: Manolo Safont

Datación: Anterior a 1987

Dimensiones: $40 \times 112 \mathrm{cms}$

Técnica: Pintura cerámica

Descripción: Obra compuesta por 3 placas. En la placa izquierda y derecha hay grandes manchas rojas y amarillas, y en la placa central una línea de color marrón cruza la placa de arriba a abajo. Paleta cromática: blancos, amarillos, rojos, azules, marrones y negros.

Exposiciones:

- Safont a la Pobla Tornesa, estiu 1987, Consellería de Cultura, Educación y Ciencia. Valencia

- Safont in Brussel. Hotel Charlemagne. 9 marzo-23 abril, 1989

- GIRALT- MIRACLE, Daniel/OlUCHA MONTINS, Ferran. Wences Rambla/ Manolo Safont, Alcoi, marzo 1995

\section{Bibliografía:}

- Safont a la Pobla Tornesa, estiu 1987, Consellería de Cultura, Educación y Ciencia. Valencia

- Safont in Brussel. Hotel Charlemagne. 9 marzo-23 abril, 1989

- GIRALT- MIRAClE, Daniel/OLUCHA MONTINS, Ferran. Wences Rambla/ Manolo Safont, Alcoi, marzo 1995, pág. 24

\section{Imagen:}

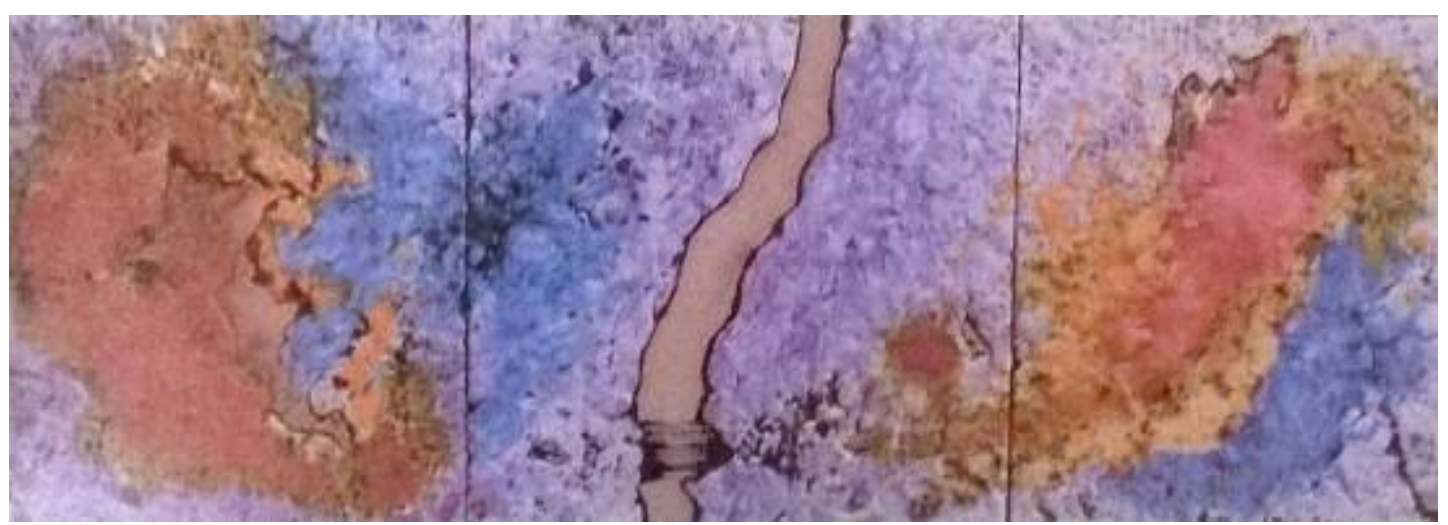


$\mathbf{N}^{0}: 5.52$

Título: Sin Título

Autoría: Manolo Safont

Datación: Anterior a 1987

Dimensiones: $55 \times 33 \mathrm{cms}$

Técnica: Pintura cerámica

Observaciones: Obra compuesta por una única placa. Masas grandes de color claro, silueteadas de negro, en el margen inferior, se superponen sobre un fondo rojo. Paleta cromática: blancos, ocres, rojos, marrones y negros.

Exposiciones:

- Safont a la Pobla Tornesa, estiu 1987, Consellería de Cultura, Educación y Ciencia. Valencia

- Safont in Brussel. Hotel Charlemagne. 9 marzo-23 abril, 1989

\section{Bibliografía:}

- Safont a la Pobla Tornesa, estiu 1987, Consellería de Cultura, Educación y Ciencia. Valencia

- Safont in Brussel. Hotel Charlemagne. 9 marzo-23 abril, 1989 Imagen:

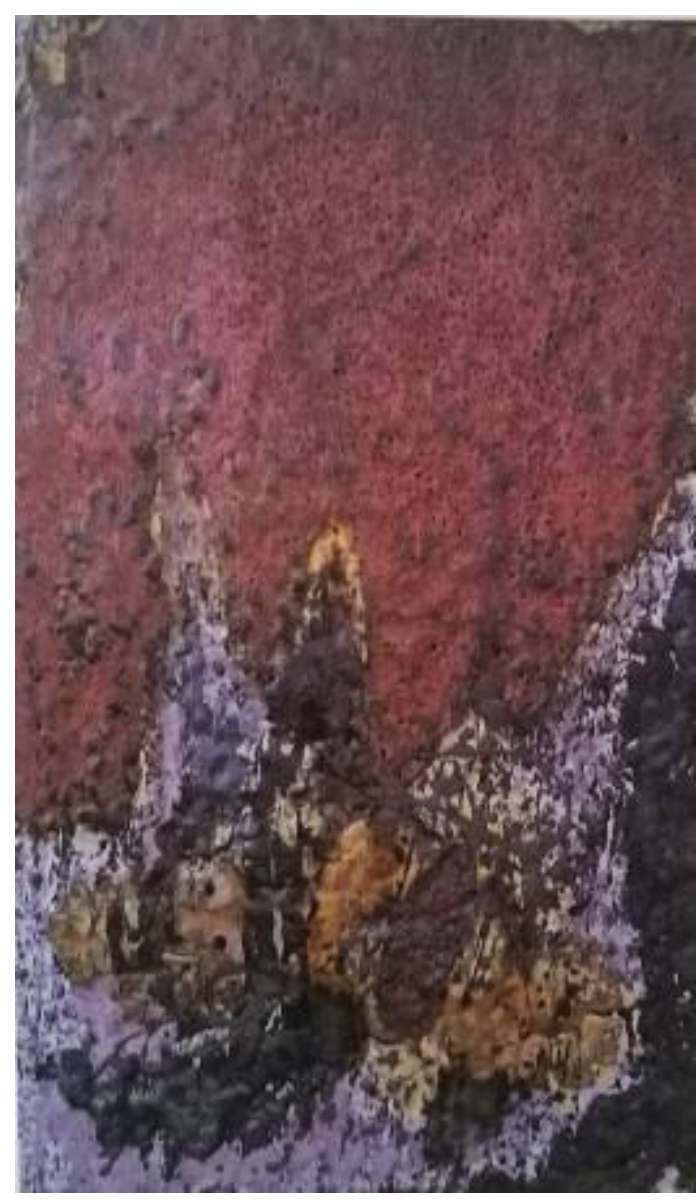


$\mathbf{N}^{\circ}: 5.53$

Título: Sin Título

Autoría: Manolo Safont

Datación: Anterior a 1987

Inscripciones: Safont en ángulo inferior izquierdo

Dimensiones: $50 \times 80 \mathrm{cms}$

Técnica: Pintura cerámica

Descripción: Obra compuesta por dos placas de $50 \times 40 \mathrm{cms}$. En la placa izquierda un estrecho bajorrelieve parte del margen superior hacia el margen inferior, y en la placa derecha, una mezcla de colores como una gran explosión centrada. Paleta cromática: blancos, rojos, azules y marrones.

Exposiciones:

- Safont a la Pobla Tornesa, estiu 1987, Consellería de Cultura, Educación y Ciencia. Valencia

\section{Bibliografía:}

- Safont a la Pobla Tornesa, estiu 1987, Consellería de Cultura, Educación y Ciencia. Valencia

Imagen:

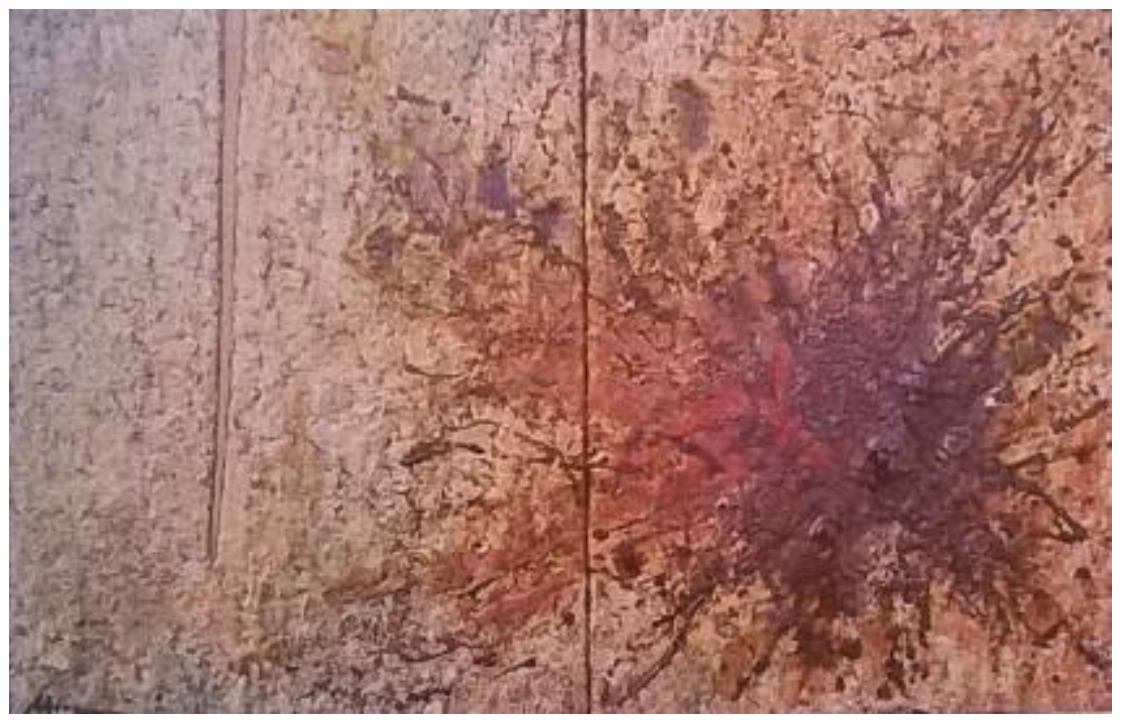


$\mathbf{N}^{0}: 5.54$

Título: Sin Título

Autoría: Manolo Safont

Datación: 1987

Inscripciones: Safont 87 en ángulo inferior izquierdo

Dimensiones: $80 \times 100 \mathrm{cms}$ o $76 \times 90 \mathrm{cms}$

Técnica: Pintura cerámica

Descripción: Obra compuesta por 4 placas de 40x50 cms. Representación de la palma de una mano derecha, en color rojo y dirección oblicua, con manchas de colores amarillos y azules y salpicaduras de color negro. Paleta cromática: blancos, ocres, naranjas, rojos, azules y negros.

Exposiciones:

- Safont a la Pobla Tornesa, estiu 1987, Consellería de Cultura, Educación y Ciencia. Valencia

- Manolo Safont. Exposición conmemorativa de la inauguración del nuevo edificio social. Caja Rural Nuestra Señora de la Esperanza. 23 diciembre 2001- 6 enero 2002. Onda

\section{Bibliografía:}

- Safont a la Pobla Tornesa, estiu 1987, Consellería de Cultura, Educación y Ciencia. Valencia

- Safont in Brussel. Hotel Charlemagne. 9 marzo-23 abril, 1989

- Manolo Safont. Exposición conmemorativa de la inauguración del nuevo edificio social. Caja Rural Nuestra Señora de la Esperanza. 23 diciembre 2001- 6 enero 2002. Onda

Imagen:

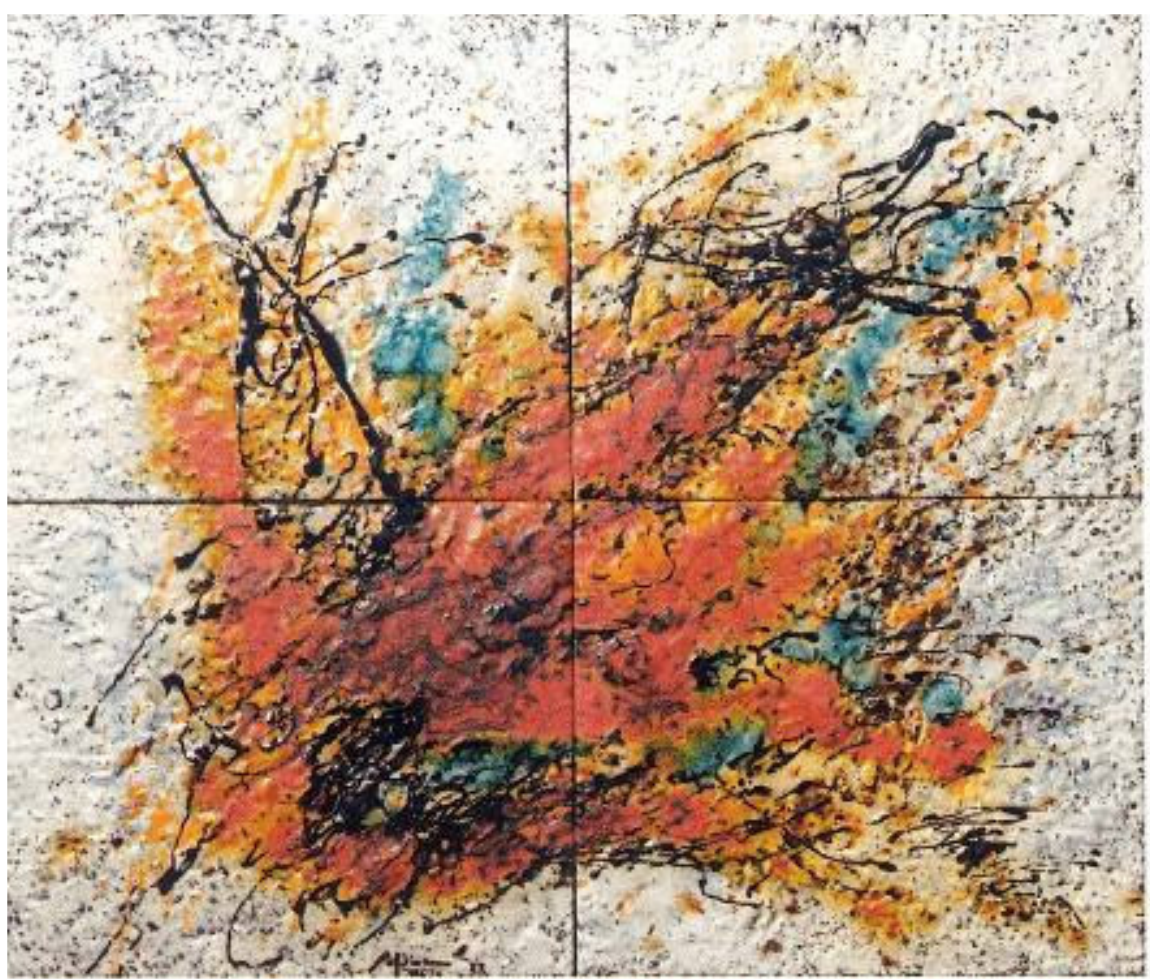


$\mathbf{N}^{0}: 5.55$

Título: Sin Título

Autoría: Manolo Safont

Datación: 1987

Inscripciones: Safont en zona inferior izquierda

Dimensiones: $50 \times 40 \mathrm{cms}$

Técnica: Pintura cerámica

Descripción: Obra compuesta por una única placa. Utilizada para ilustrar el cartel del Symposium Internacional de Estrés Profesional en Servicios Clínicos, Sociales y Educativos: Prevención y Tratamiento, realizado en Castellón y playas de Benicasim del 13 al 15 de noviembre de 1997, obra catalogada con el $n^{\circ} 2.70$. Contrastan dos grandes masas de color negro y blanco situadas en los márgenes derecho e izquierdo de la obra, con una gran masa roja que cruza ambas en disposición oblicua. También se utilizó para ilustrar el calendario de Caixa Rural d'Onda de 2003. Paleta cromática: blancos, ocres, rojos, azules y negros.

Exposiciones:

- Safont a la Pobla Tornesa, estiu 1987, Consellería de Cultura, Educación y Ciencia. Valencia

\section{Bibliografía:}

- Safont a la Pobla Tornesa, estiu 1987, Consellería de Cultura, Educación y Ciencia. Valencia

- http://www.gva.es/museo/safon5.htm, 1995-1996

- Calendario Caixa Rural d'Onda 2003. Caixa Rural d'Onda 2003 Imagen:

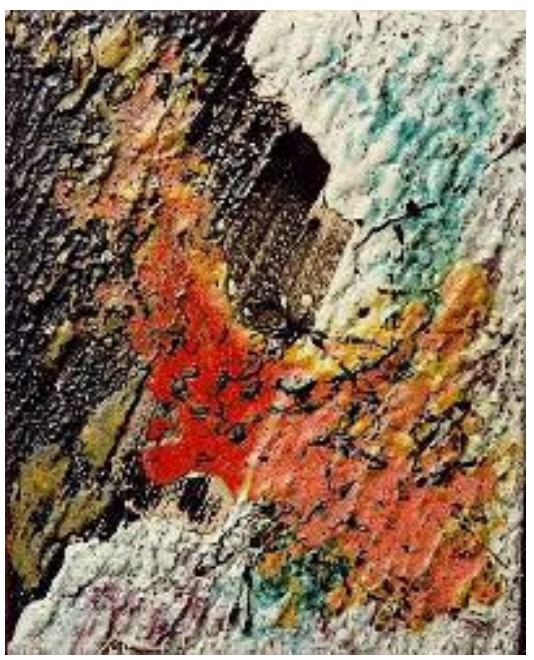

Imágenes relacionadas:

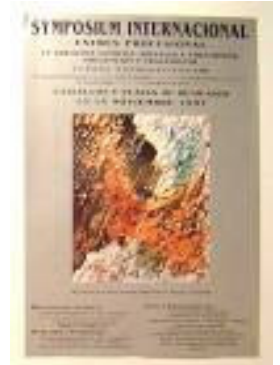

Obra cat. $n^{\circ} 2.70$ 
$\mathbf{N}^{0}: 5.56$

Título: Sin Título

Autoría: Manolo Safont

Datación: 1987

Dimensiones: $50 \times 40 \mathrm{cms}$

Técnica: Pintura cerámica

Descripción: Obra compuesta por una única placa. Paleta cromática: blancos, amarillos, ocres, rojos, azules y negros.

\section{Exposiciones:}

- Safont a la Pobla Tornesa, estiu 1987, Consellería de Cultura, Educación y Ciencia. Valencia

\section{Bibliografía:}

- Safont a la Pobla Tornesa, estiu 1987, Consellería de Cultura, Educación y Ciencia. Valencia

- http://www.gva.es/museo/safon6.htm, 1995

\section{Imagen:}

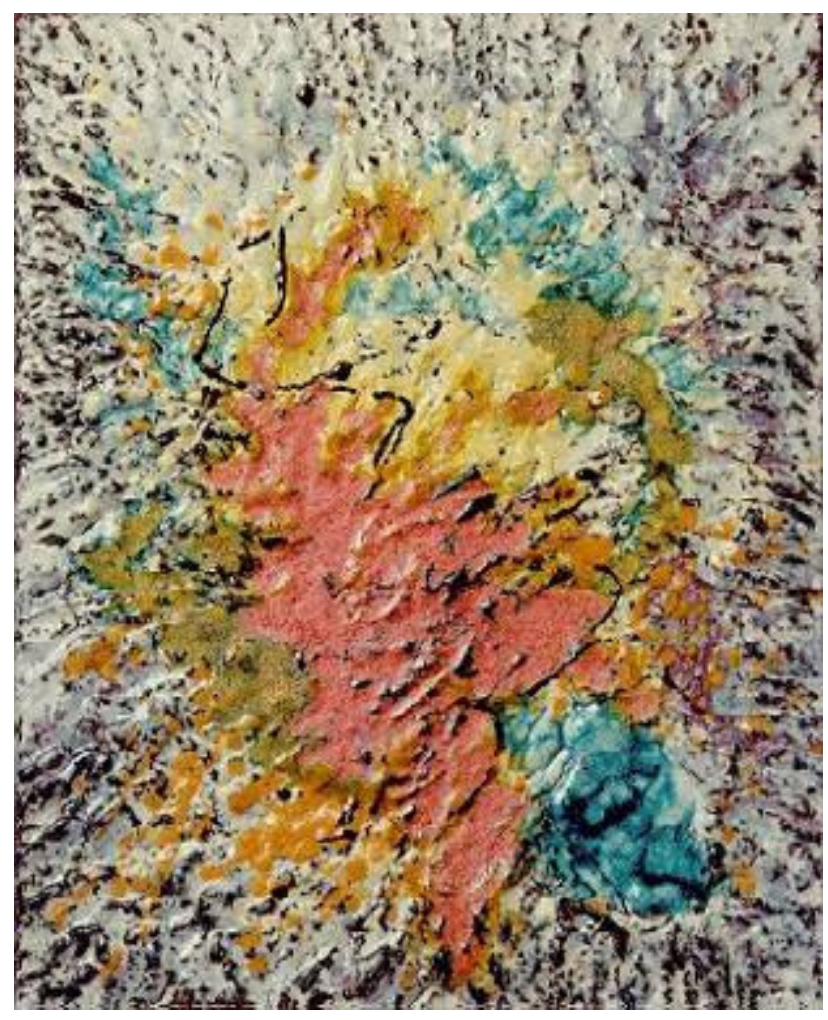




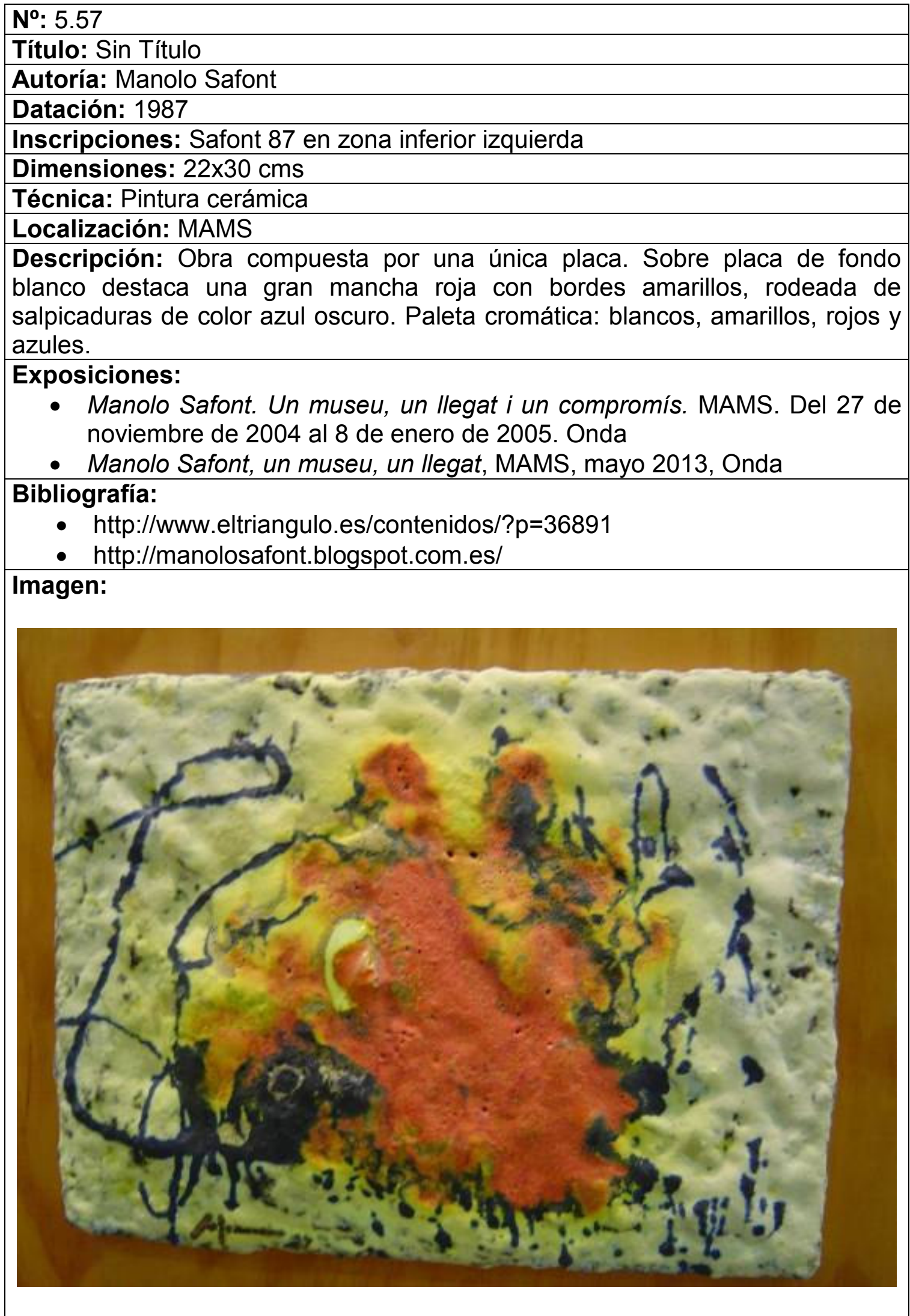


$\mathbf{N}^{0}: 5.58$

Título: Sin Título

Autoría: Manolo Safont

Datación: 1987

Inscripciones: Safont en zona inferior izquierda

Dimensiones: $50 \times 125 \mathrm{cms}$

Técnica: Pintura cerámica

Descripción: Obra compuesta por 3 placas de refractario. Masa de color azul claro en el margen izquierdo de la obra contrapuesto a la masa negra que hay en las otras dos placas, sobre ambas masas destacan gruesas pinceladas de color rojo. Paleta cromática: blancos, amarillos, rojos, azules y negros.

Exposiciones:

- Safont a la Pobla Tornesa, estiu 1987, Consellería de Cultura, Educación y Ciencia. Valencia

- Safont in Brussel. Hotel Charlemagne. 9 marzo-23 abril, 1989

- GIRALT- MIRAClE, Daniel/OlUCHA MONTINS, Ferran. Wences Rambla/ Manolo Safont, Alcoi, marzo 1995

- Safont, 9 octubre-9 noviembre 1998, Morella, Castellón

- Cerámica fin de siglo. Atarazanas Valencia, 25 noviembre - 2 enero 2000

\section{Bibliografía:}

- Safont in Brussel. Hotel Charlemagne. 9 marzo-23 abril, 1989

- GIRALT- MIRACLE, Daniel/OLUCHA MONTINS, Ferran. Wences Rambla/ Manolo Safont, Alcoi, marzo 1995, pág. 18

- Safont, 9 octubre-9 noviembre 1998, Morella, Castellón, pág. 36

- DE LA CALLE, Román; PÉREZ CAMPS, Josep. Cerámica fin de siglo. Generalitat Valenciana, Valencia, 1999, pág. 289

\section{Imagen:}

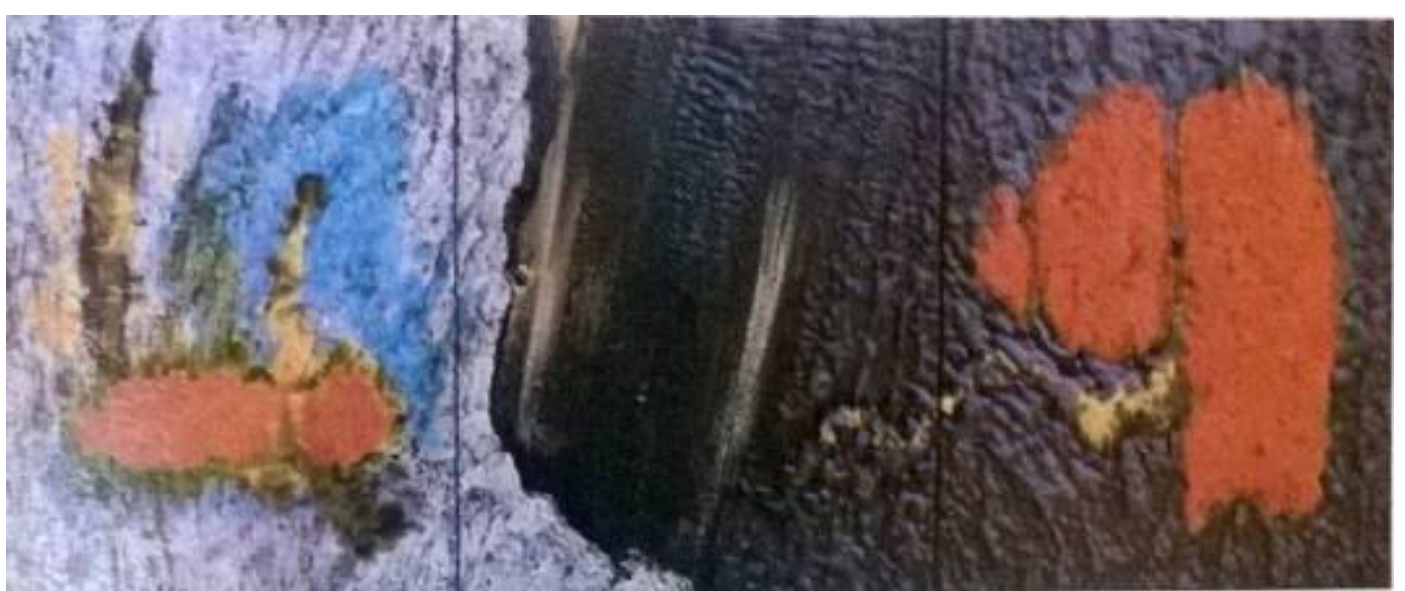


$\mathbf{N}^{0}: 5.59$

Título: Sin Título

Autoría: Manolo Safont

Datación: 1987

Dimensiones: $100 \times 144 \mathrm{cms}$

Técnica: Pintura cerámica

Localización: Colección Ayuntamiento de Onda. MAMS.

Descripción: Obra compuesta por cuatro placas. Sobre una base clara, con salpicaduras, una línea diagonal marca una zona oscura a la derecha sobre la que vemos una gran mancha roja. Paleta cromática: blancos, amarillos, rojos y negros.

Exposiciones:

- Safont a la Pobla Tornesa, estiu 1987, Consellería de Cultura, Educación y Ciencia. Valencia

- Safont in Brussel. Hotel Charlemagne. 9 marzo-23 abril, 1989

- Manolo Safont, un museu, un llegat, MAMS, mayo 2013, Onda

\section{Bibliografía:}

- Safont a la Pobla Tornesa, estiu 1987, Consellería de Cultura, Educación y Ciencia. Valencia

- Safont in Brussel. Hotel Charlemagne. 9 marzo-23 abril, 1989

- Catàleg d'obres d'art de l'Ajuntament d'Onda. Ajuntament d'Onda, Onda 2014, págs. 18-21, ref. A123

- http://www.eltriangulo.es/contenidos/?p=36891

- http://manolosafont.blogspot.com.es/

Imagen:

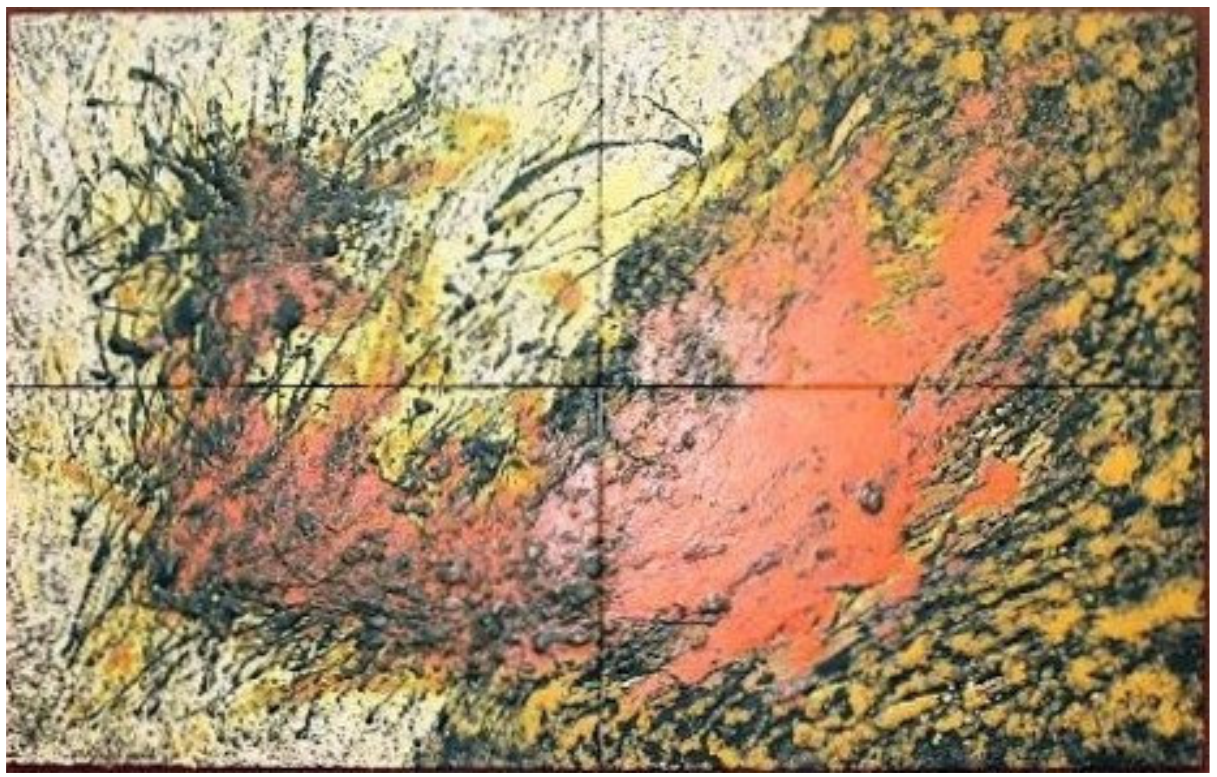


$\mathbf{N}^{0}: 5.60$

Título: Sin Título

Autoría: Manolo Safont

Datación: 1988

Dimensiones: $50 \times 80 \mathrm{cms}$

Técnica: Pintura cerámica

Localización: MAMS

Descripción: Obra compuesta por 2 placas de 50x40 cms de refractario. Obra de colores oscuros, con salpicaduras negras y amarillas en forma curva que parten del ángulo inferior izquierdo al ángulo superior derecho, y masas de color rojo en el margen inferior. Paleta cromática: amarillos, rojos, marrones y negros.

Exposiciones:

- Safont. 22 diciembre 1988 - 12 enero 1989. Ayuntamiento de Castellón

- Safont in Brussel. Hotel Charlemagne. 9 marzo-23 abril, 1989

- Manolo Safont. Un museu, un llegat i un compromís. MAMS. Del 27 de noviembre de 2004 al 8 de enero de 2005. Onda.

- GIRALT- MIRACLE, Daniel/OLUCHA MONTINS, Ferran. Wences Rambla/ Manolo Safont, Alcoi, marzo 1995

- Cerámica fin de siglo. Atarazanas Valencia, 25 noviembre - 2 enero 2000

Bibliografía:

- Safont. 22 diciembre 1988 - 12 enero 1989. Ayuntamiento de Castellón

- Safont in Brussel. Hotel Charlemagne. 9 marzo-23 abril, 1989

- GIRALT- MIRACLE, Daniel/OLUCHA MONTINS, Ferran. Wences Rambla/ Manolo Safont, Alcoi, marzo 1995, pág. 22

- DE LA CALLE, Román; PÉREZ CAMPS, Josep. Cerámica fin de siglo. Generalitat Valenciana, Valencia, 1999, pág. 286

Imagen:

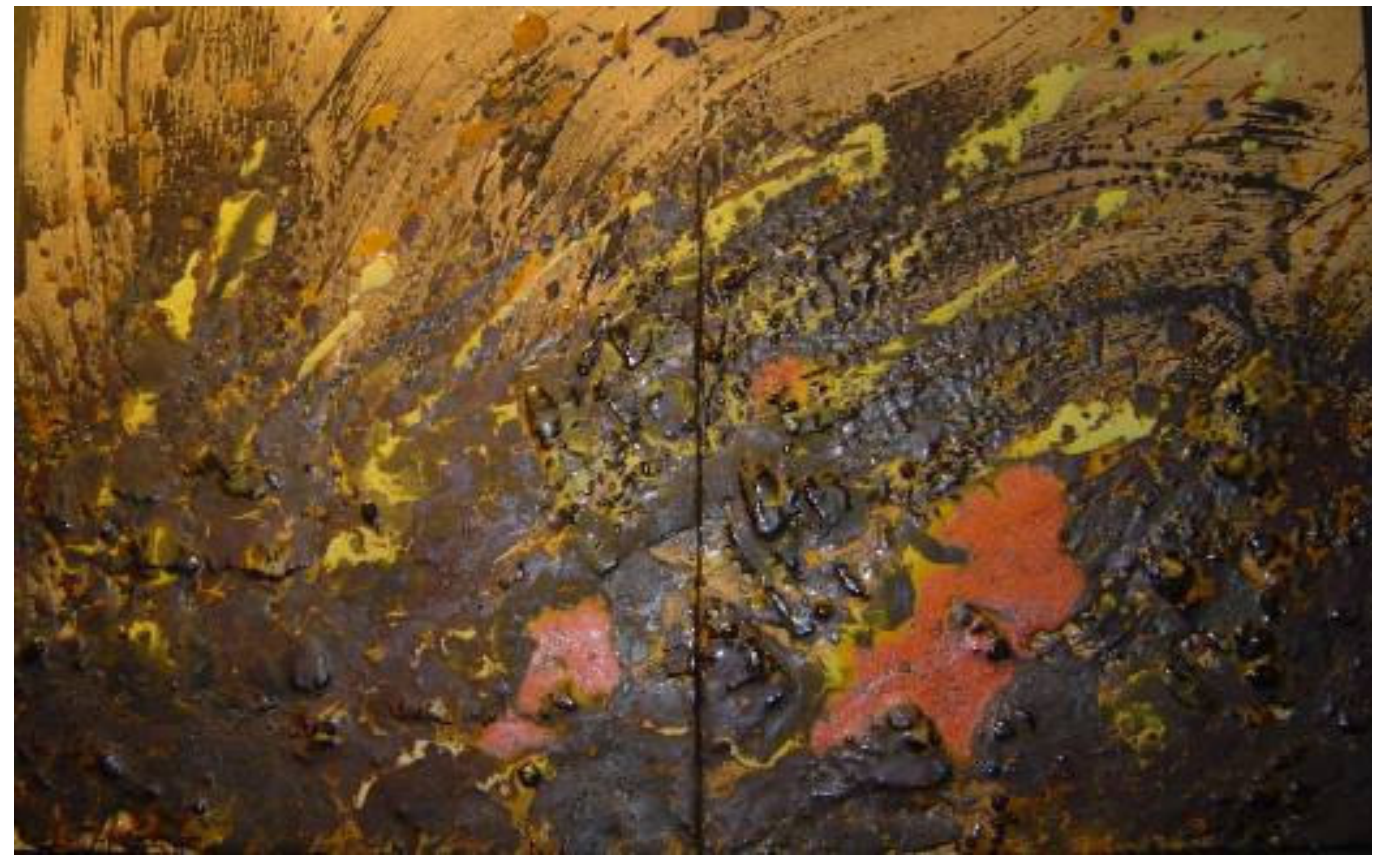


$\mathbf{N}^{0}: 5.61$

Título: Sin Título

Autoría: Manolo Safont

Datación: 1988

Inscripciones: Safont 88 en zona inferior izquierda

Dimensiones: $50 \times 80 \mathrm{cms}$

Técnica: Pintura cerámica

Localización: MAMS

Descripción: Obra compuesta por 2 placas de 50x40 cms de refractario. Sobre el color original de la placa base, crea masas de color similar a la base con salpicaduras de color blanco y manchas de color azul claro y rojo. Paleta cromática: blancos, ocres, rojos, azules y negros.

Exposiciones:

- Safont. 22 diciembre 1988 - 12 enero 1989. Ayuntamiento de Castellón

- Cerámica fin de siglo. Atarazanas Valencia, 25 noviembre - 2 enero 2000

- Manolo Safont. Un museu, un llegat i un compromís. MAMS. Del 27 de noviembre de 2004 al 8 de enero de 2005. Onda.

- Homenatge a la Saleta. Sala Municipal d'Exposicions d'Onda. Ajuntament d'Onda, Octubre, 2005, Onda

- Manolo Safont, un museu, un llegat, MAMS, mayo 2013, Onda

\section{Bibliografía:}

- Safont. 22 diciembre 1988 - 12 enero 1989. Ayuntamiento de Castellón

- http://www.gva.es/museo/safon13.htm, 1995

- DE LA CALLE, Román; PÉREZ CAMPS, Josep. Cerámica fin de siglo. Generalitat Valenciana, Valencia, 1999, pág. 287

- Homenatge a la Saleta. Sala Municipal d'Exposicions d'Onda. Ajuntament d'Onda, Octubre, 2005, Onda, pág. 40

- http://www.eltriangulo.es/contenidos/?p=36891

- http://manolosafont.blogspot.com.es/

Imagen:

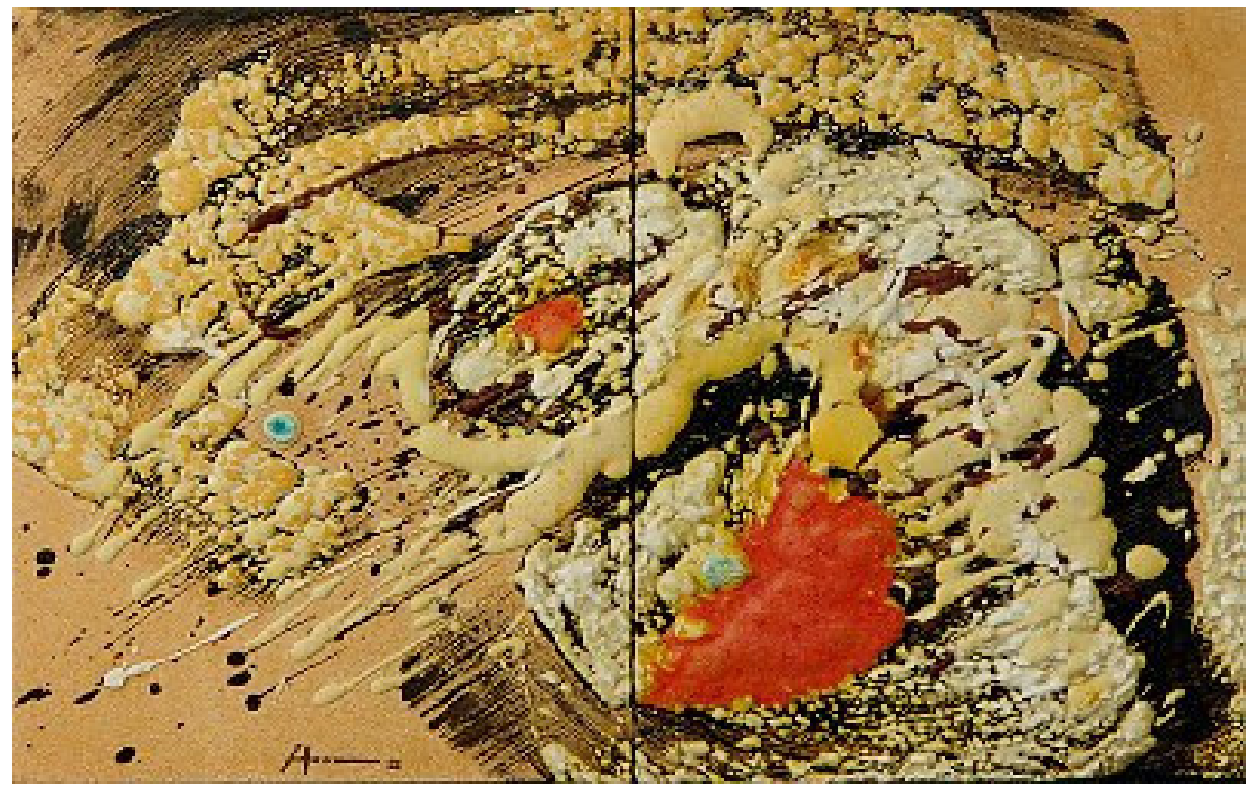


$\mathbf{N}^{0}: 5.62$

Título: Sin Título

Autoría: Manolo Safont

Datación: 1988

Inscripciones: Safont 88 en ángulo inferior derecho

Dimensiones: $76 \times 120 \mathrm{cms}$

Técnica: Pintura cerámica

Descripción: Obra compuesta por cuatro placas de $38 \times 60 \mathrm{cms}$, en disposición $2 \times 2$. Sobre base blanca, con una mancha roja en el ángulo inferior derecho, forma un relieve en el margen izquierdo, creando la sensación de haber quitado la base, quedando enrollada y dejando al descubierto una zona central de color negro. Esta imagen fue utilizada para ilustrar el calendario de Caixa Rural d'Onda de 2003. Paleta cromática: blancos, ocres, rojos y negros.

\section{Exposiciones:}

- Safont in Brussel. Hotel Charlemagne. 9 marzo-23 abril, 1989

- Manolo Safont. Exposición conmemorativa de la inauguración del nuevo edificio social. Caja Rural Nuestra Señora de la Esperanza. 23 diciembre 2001- 6 enero 2002. Onda

\section{Bibliografía:}

- Safont in Brussel. Hotel Charlemagne. 9 marzo-23 abril, 1989

- Manolo Safont. Exposición conmemorativa de la inauguración del nuevo edificio social. Caja Rural Nuestra Señora de la Esperanza. 23 diciembre 2001- 6 enero 2002. Onda

- Calendario Caixa Rural d'Onda 2003. Caixa Rural d'Onda 2003 Imagen:

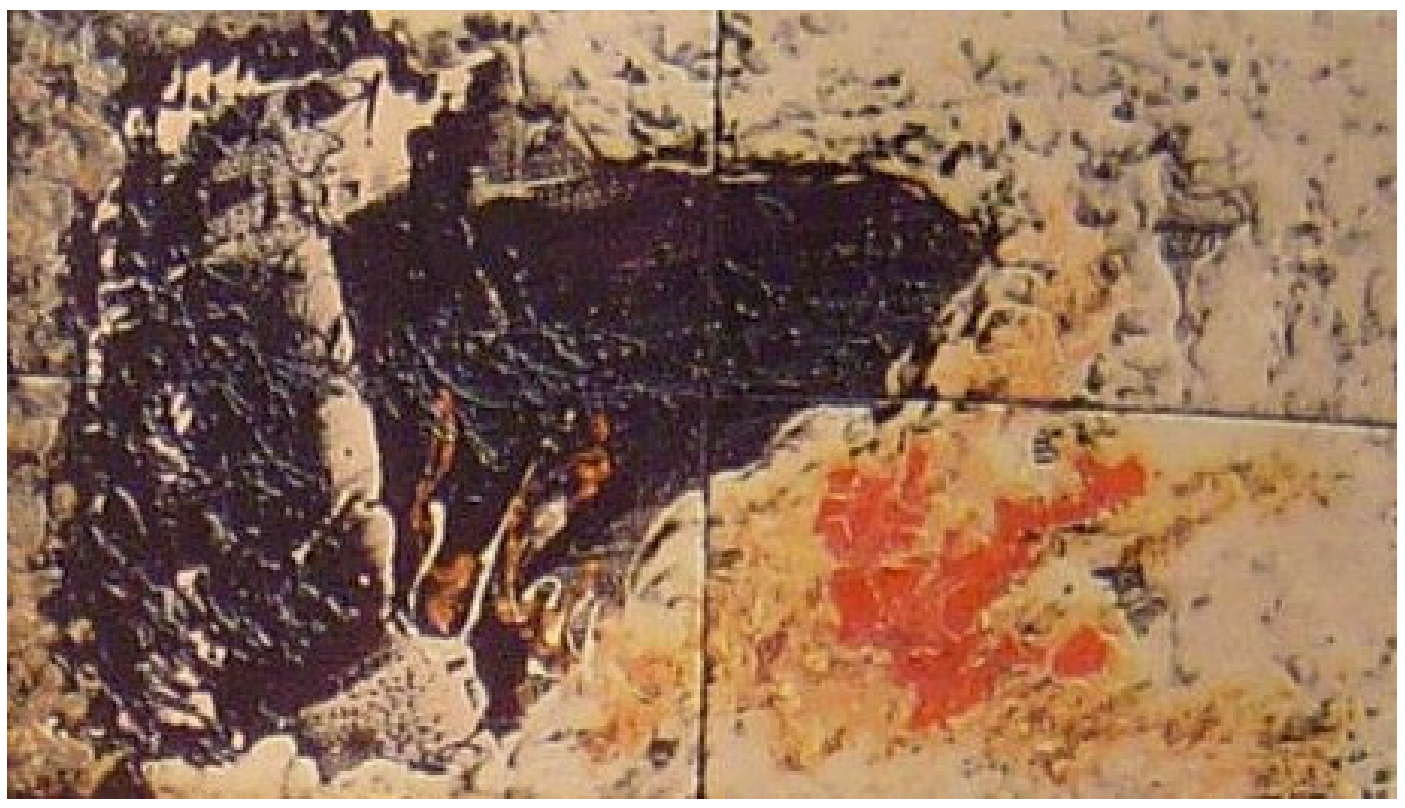


$\mathbf{N}^{0}: 5.63$

Título: Sin Título

Autoría: Manolo Safont

Datación: Anterior a 1988

Dimensiones: 60x76 cms

Técnica: Pintura cerámica

Descripción: Obra compuesta por dos placas. Esta obra se utilizó para ilustrar la portada del catálogo de la exposición de Safont en Bruselas de 1989, el catálogo de la exposición del Ayuntamiento de Castellón de 1988, el catálogo de Alcoi de 1995 y la exposición en la Galería Canem de 1995. Al carecer de firma visible y ser una obra abstracta resulta difícil establecer la direccionalidad correcta de la obra, en el catálogo de Bruselas aparece en una dirección, mientras que en el resto de imágenes encontradas de esta obra se muestra en la dirección opuesta. En esta ficha catalográfica la mostramos con la direccionalidad que se utiliza en todas las publicaciones de la misma, excepto en el catálogo de la exposición de Bruselas, que se muestra invertida. Paleta cromática: blancos, ocres, rojos, marrones y negros.

\section{Exposiciones:}

- Safont. 22 diciembre 1988- 12 enero 1989, Ayuntamiento de Castellón

- Safont in Brussel. Hotel Charlemagne. 9 marzo-23 abril, 1989

- GIRALT- MIRACLE, Daniel/OlUCHA MONTINS, Ferran. Wences Rambla/ Manolo Safont, Alcoi, marzo 1995

- Manolo Safont. Cànem Galería, 11 mayo- 16 junio 1995

\section{Bibliografía :}

- Safont. 22 diciembre 1988- 12 enero 1989, Ayuntamiento de Castellón

- Safont in Brussel. Hotel Charlemagne. 9 marzo-23 abril, 1989

- GIRALT- MIRACLE, Daniel/OLUCHA MONTINS, Ferran. Wences Rambla/ Manolo Safont, Alcoi, marzo 1995, pág. 23

- Manolo Safont. Canem Galería, 11 mayo- 16 junio 1995

Imagen:

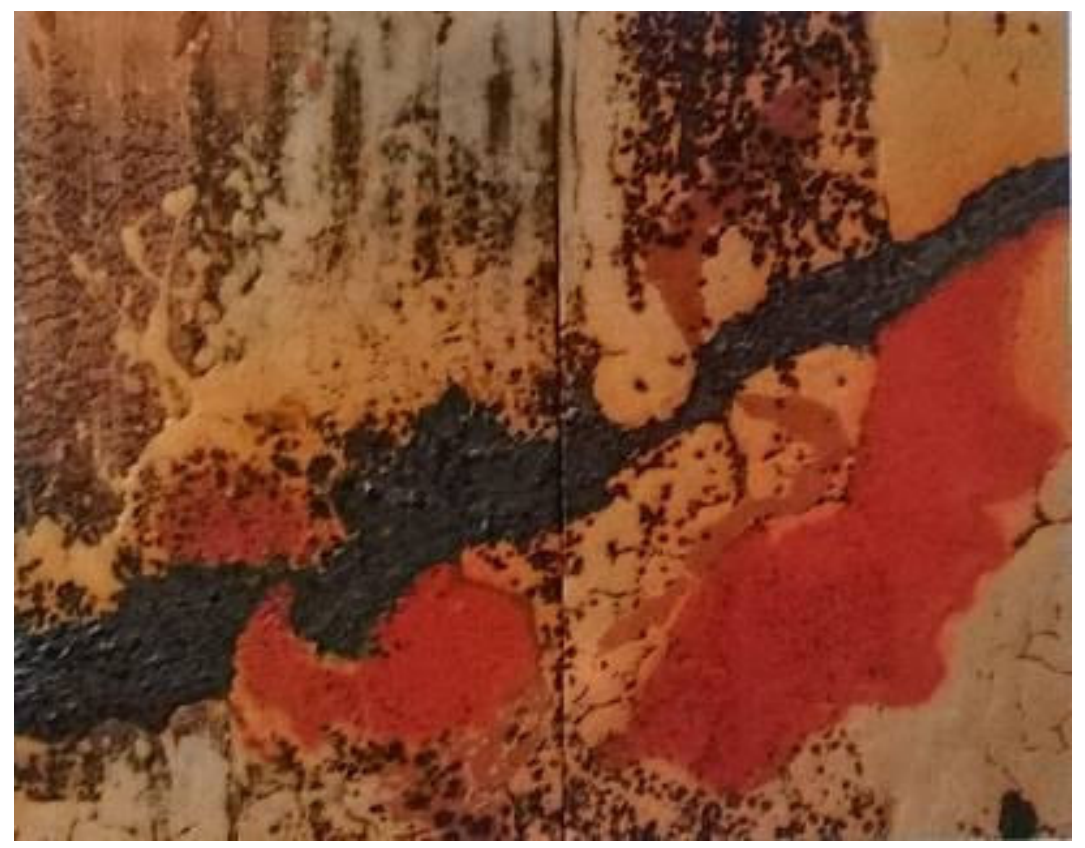




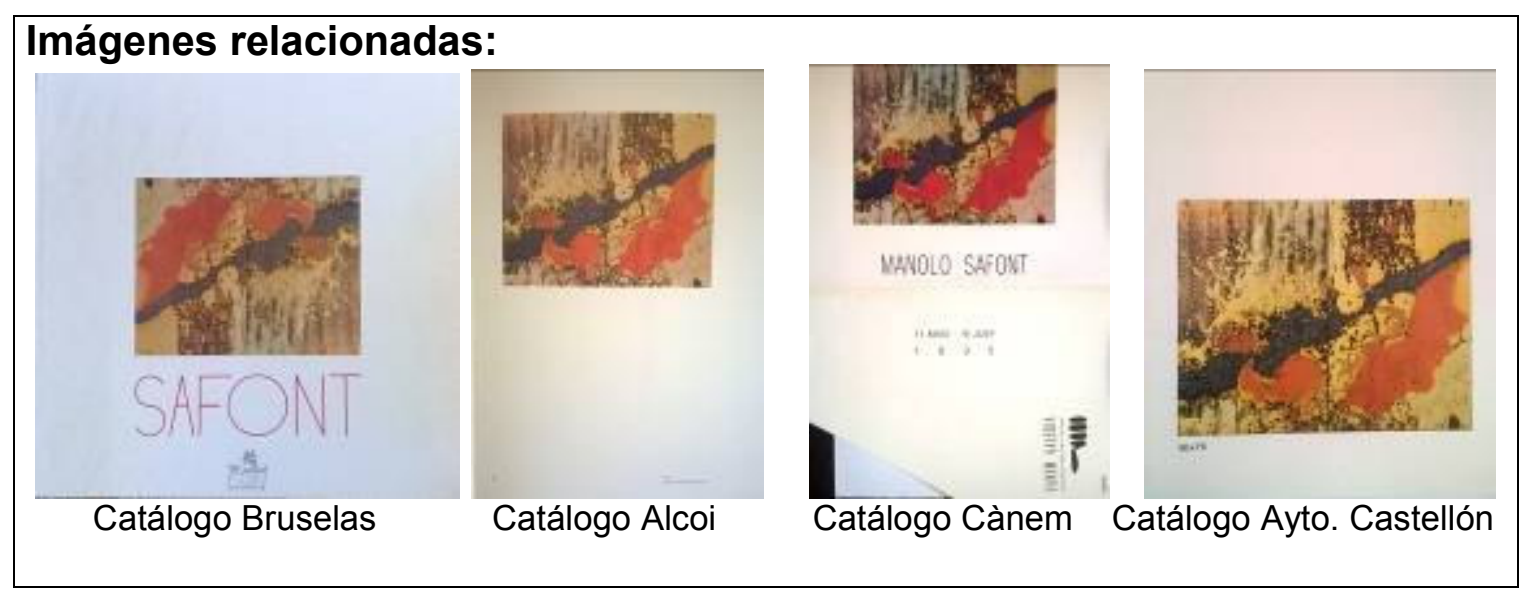


$\mathbf{N}^{0}: 5.64$

Título: Sin Título

Autoría: Manolo Safont

Datación: Anterior a 1989

Inscripciones: Safont en zona inferior izquierda

Dimensiones: $40 \times 60 \mathrm{cms}$

Técnica: Pintura cerámica

Localización: MAMS

Descripción: Obra compuesta por una única placa. Sobre la placa base con zonas de reserva, se extiende una capa de masa oscura, y sobre ella una masa blanca con manchas rojas y amarillas que caen como goterones desde el margen superior. Paleta cromática: blancos, amarillos, ocres, rojos y negros.

Exposiciones:

- Safont in Brussel. Hotel Charlemagne. 9 marzo-23 abril, 1989

- Manolo Safont. Un museu, un llegat i un compromís. MAMS. Del 27 de noviembre de 2004 al 8 de enero de 2005. Onda

- Manolo Safont, un museu, un llegat, MAMS, mayo 2013, Onda

Bibliografía:

- Safont in Brussel. Hotel Charlemagne. 9 marzo-23 abril, 1989

- http://www.eltriangulo.es/contenidos/?p=36891

- http://manolosafont.blogspot.com.es/

Imagen:

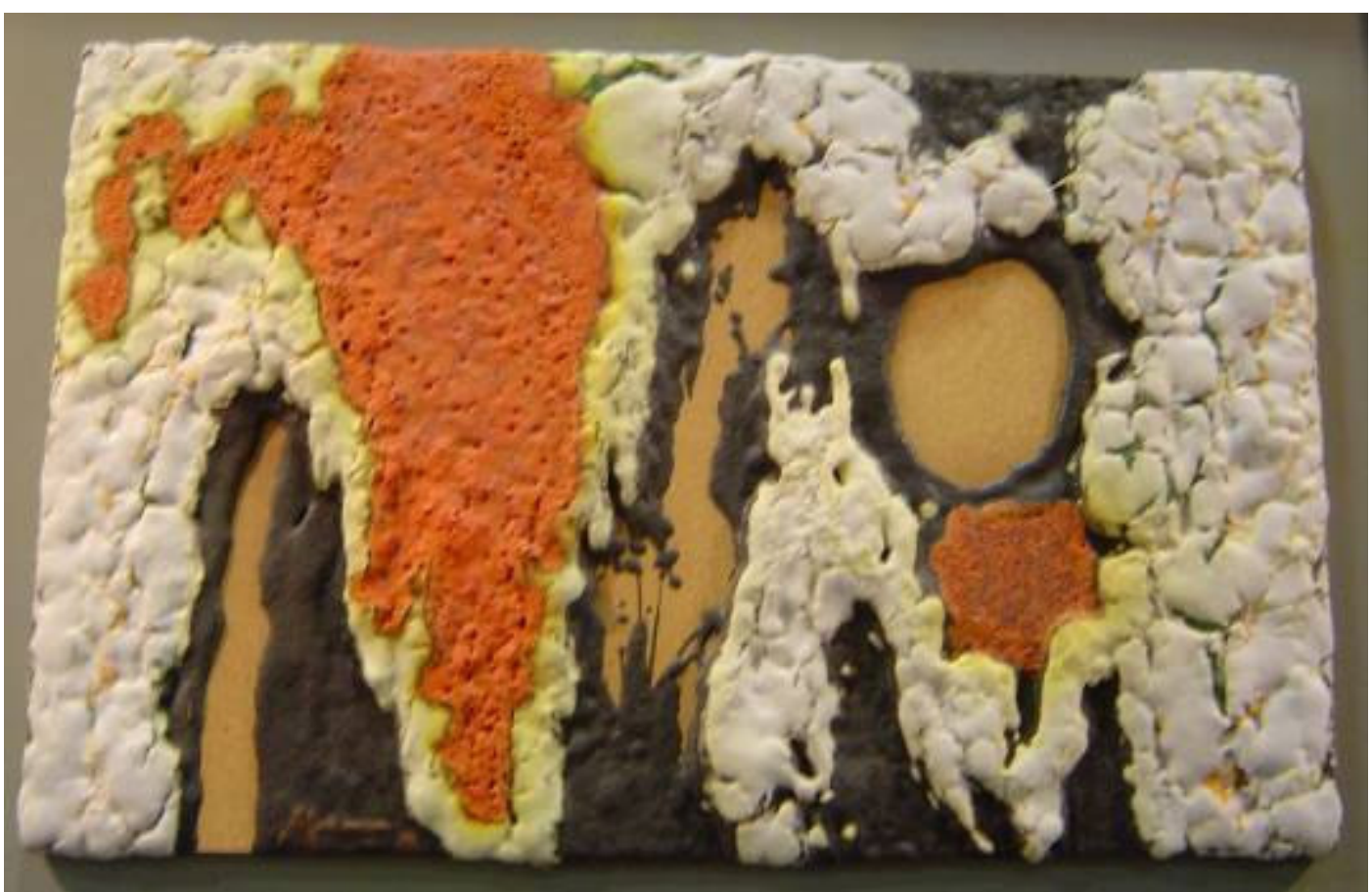




\begin{tabular}{|l|}
\hline No: 5.65 \\
\hline Título: Sin Título \\
\hline Autoría: Manolo Safont \\
\hline Datación: Anterior a 1989 \\
\hline Inscripciones: Safont en zona inferior izquierda \\
\hline Dimensiones: 30 x 60 \\
\hline Décnica: Pintura cerámica \\
crea una zona de reserva en el margen izquierdo con salpicaduras de color \\
negro, en la zona derecha de la composición vemos una mancha roja y amarilla \\
sobre masa blanca. Paleta cromática: blancos, amarillos, rojos y negros. \\
\hline Exposiciones: \\
Bibliografía: \\
Imagen:
\end{tabular}


No: 5.66

Título: Sin Título

Autoría: Manolo Safont

Datación: Anterior a 1989

Inscripciones: Safont en zona inferior izquierda

Dimensiones: $60 \times 48 \mathrm{cms}$

Técnica: Pintura cerámica

Descripción: Obra compuesta por una única placa, se utiliza para ilustrar el artículo de Gascó sobre la exposición de Safont de 1989 en Onda. Combinación geométrica de masas creadas con líneas verticales y manchas circulares. Paleta cromática: blancos, ocres, rojos y negros.

Exposiciones:

- Safont, Ayuntamiento de Castellón, 22 diciembre 1988 - 6 enero 1989, Castellón

- Safont in Brussel. Hotel Charlemagne. 9 marzo-23 abril, 1989

- GIRALT- MIRACLE, Daniel/OlUCHA MONTINS, Ferran. Wences Rambla/ Manolo Safont, Alcoi, marzo 1995

\section{Bibliografía:}

- Safont in Brussel. Hotel Charlemagne. 9 marzo-23 abril, 1989

- GASCÓ, A. "Importante muestra de Manolo Safont de pintura cerámica" Castellón Diario, 31 diciembre 1989

- GIRALT- MIRACLE, Daniel/OlUCHA MONTINS, Ferran. Wences Rambla/ Manolo Safont, Alcoi, marzo 1995, pág. 21

Imagen:

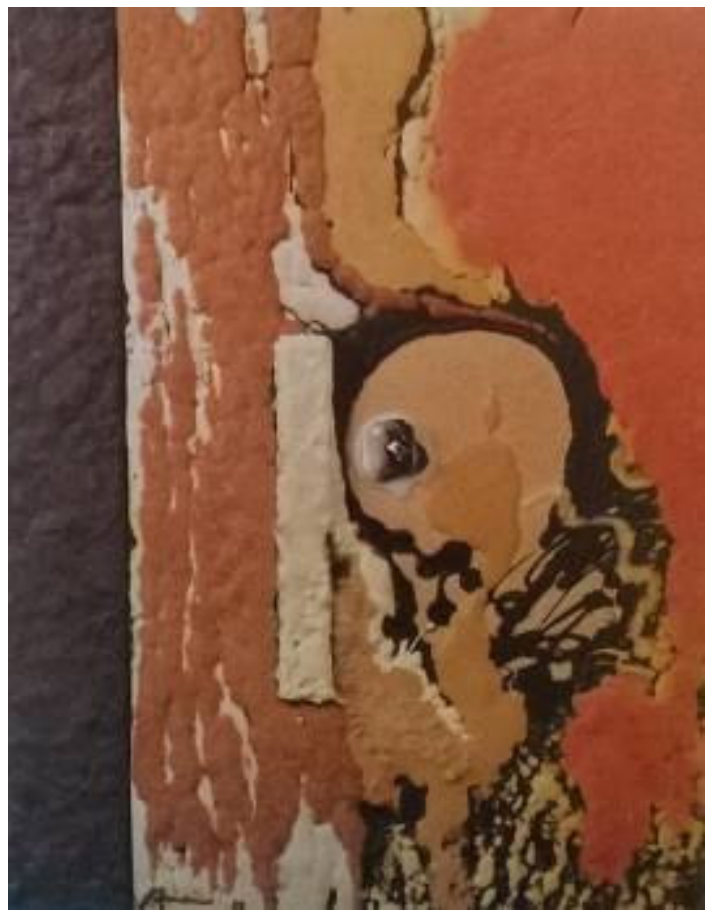


$\mathbf{N}^{\circ}: 5.67$

Título: Sin Título

Autoría: Manolo Safont

Datación: Anterior a 1989

Inscripciones: Safont en ángulo inferior izquierdo

Dimensiones: $50 \times 80 \mathrm{cms}$

Técnica: Pintura cerámica

Descripción: Obra compuesta por 2 placas de $50 \times 40 \mathrm{cms}$. Sobre base clara salpicaduras blancas y negras, con una mancha curva roja en la placa derecha. Paleta cromática: blancos, ocres, rojos y negros.

Exposiciones:

- Safont in Brussel.. Hotel Charlemagne. 9 marzo-23 abril, 1989

\section{Bibliografía:}

- Safont in Brussel. Hotel Charlemagne. 9 marzo-23 abril, 1989 Imagen:

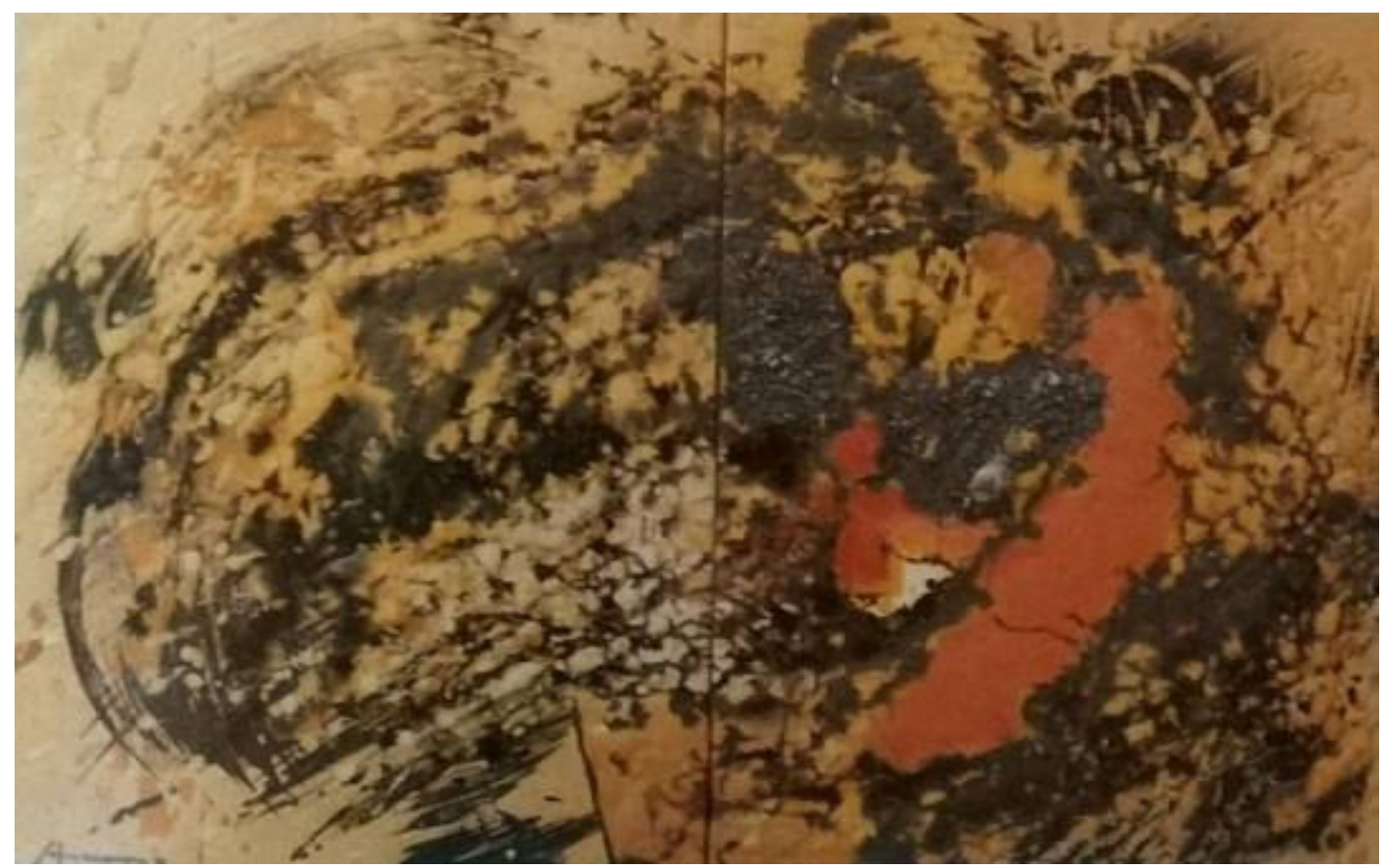


$\mathbf{N}^{0}: 5.68$

Título: Sin Título

Autoría: Manolo Safont

Datación: 1989

Dimensiones: $50 \times 80 \mathrm{cms}$,

Técnica: Pintura cerámica

Localización: MAMS

Descripción: Obra compuesta por 2 placas de 50x40 cms de refractario. La imagen fue utilizada para ilustrar el calendario de Caixa Rural d'Onda de 2003. Paleta cromática: blancos, amarillos, rojos, azules y negros.

Exposiciones:

- M. Safont, 13 marzo - 12 abril 1991, Galería d'art Octubre, Universitat Jaume I, Castellón

- Cerámica fin de siglo. Atarazanas Valencia, 25 noviembre - 2 enero 2000

- "Manolo Safont. Un museu, un llegat i un compromís". MAMS. Del 27 de noviembre de 2004 al 8 de enero de 2005. Onda.

\section{Bibliografía:}

- M. Safont, 13 marzo - 12 abril 1991, Galería d'art Octubre, Universitat Jaume I, Castellón

- DE LA CALLE, Román; PÉREZ CAMPS, Josep. Cerámica fin de siglo. Generalitat Valenciana, Valencia, 1999, pág. 288

- FALOMIR, Carmela. "La pintura cerámica de Manolo Safont" en Butlletí d'Estudis Municipals. $2^{\mathrm{a}}$ etapa, $\mathrm{n}^{\circ}$ 2. Ajuntament d'Onda. Onda, 2001, pág. 41

- Calendario Caixa Rural d'Onda 2003. Caixa Rural d'Onda 2003

- OLUCHA, Ferrán. "Manolo Safont. Un museu, un llegat i un compromís". MAMS. Del 27 de noviembre de 2004 al 8 de enero de 2005. Onda

\section{Imagen:}

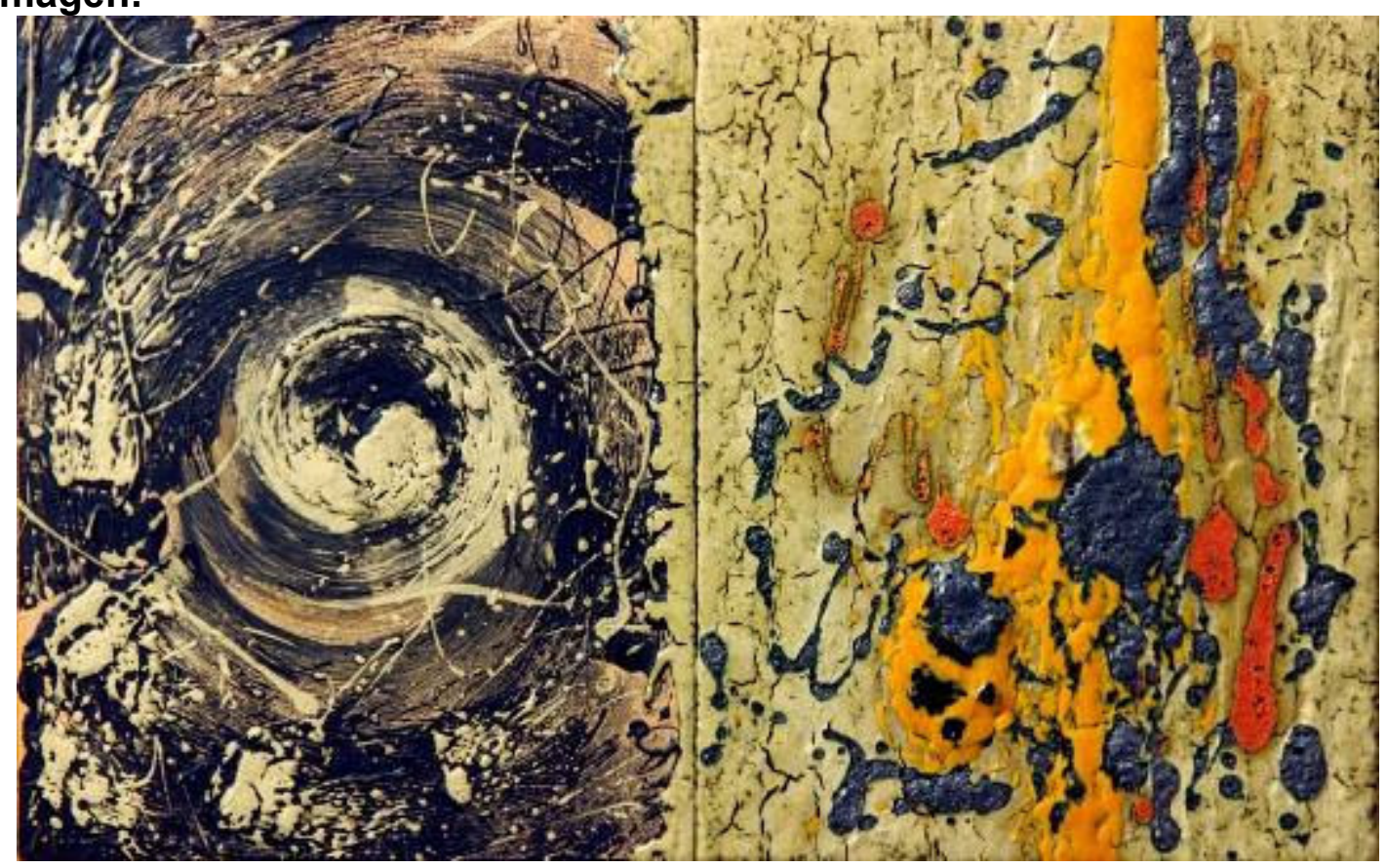


$\mathbf{N}^{0}: 5.69$

Título: Sin Título

Autoría: Manolo Safont

Datación: 1989

Inscripciones: Safont 89 en ángulo superior izquierdo

Dimensiones: $76 \times 60 \mathrm{cms}$

Técnica: Pintura cerámica

Descripción: Obra compuesta por 2 placas de 38x28 cms. En la placa inferior una gran mancha roja sobre salpicaduras de toda la paleta cromática que se extienden sobre la placa superior. Paleta cromática: blancos, ocres, rojos, marrones y negros.

Bibliografía:

- FALOMIR, Carmela. "La pintura cerámica de Manolo Safont" en Butlletí d'Estudis Municipals. $2^{a}$ etapa, $\mathrm{n}^{\circ}$ 2. Ajuntament d'Onda. Onda, 2001, pág. 40

Imagen:

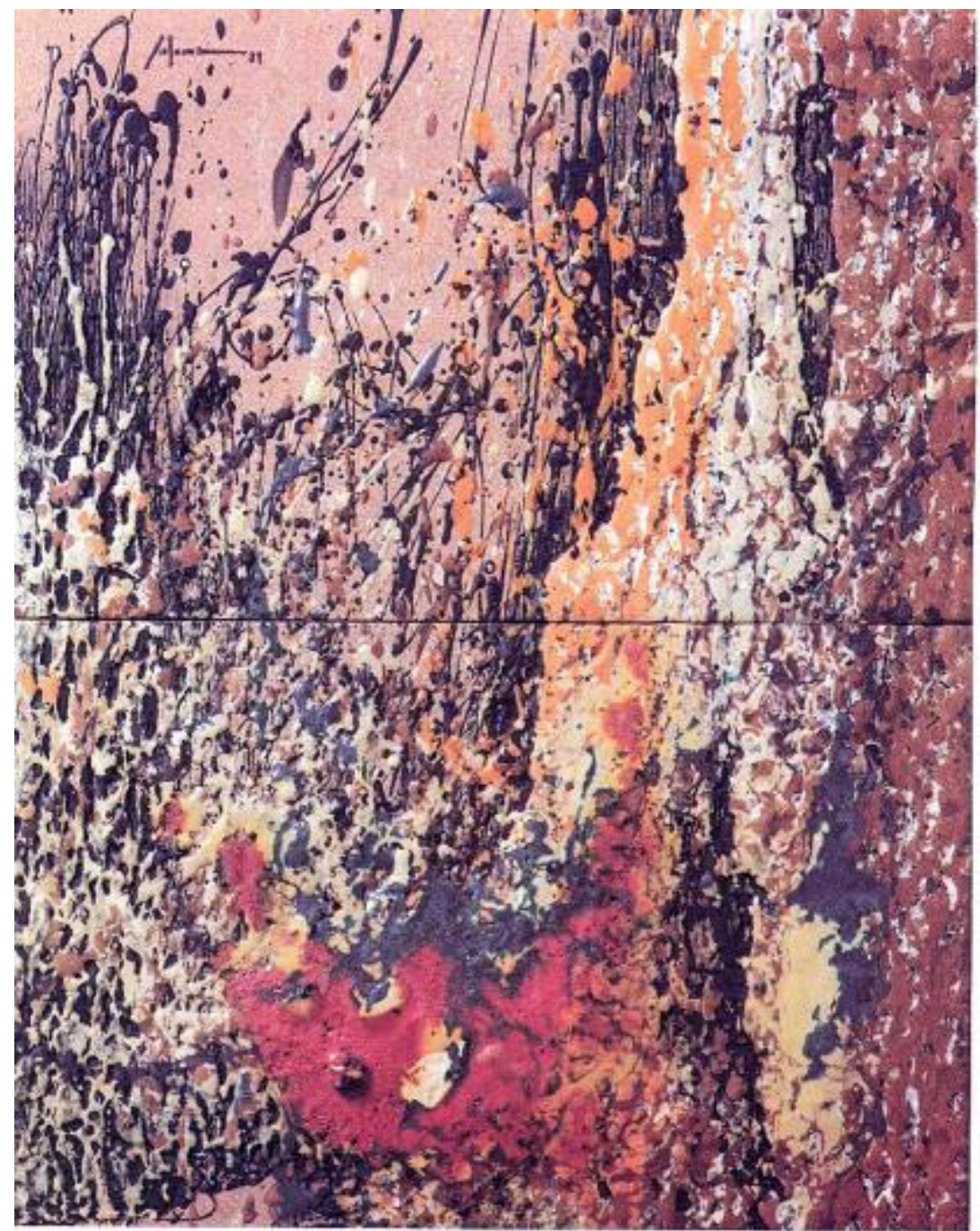


$\mathbf{N}^{0}: 5.70$

Título: Sin Título

Autoría: Manolo Safont

Datación: 1989

Inscripciones: Safont 89 en ángulo superior izquierdo

Dimensiones: $50 \times 80 \mathrm{cms}$

Técnica: Pintura cerámica

Descripción: Obra compuesta por 2 placas de 50x40 cms. Grandes manchas centrales de color rojo y negro, sobre fondo texturizado creado por salpicaduras de toda la paleta cromática de la obra, dejando una zona de reserva en el ángulo superior izquierdo sobre el que firma. Paleta cromática: blancos, amarillos, rojos, marrones y negros.

Exposiciones:

- Safont, 9 octubre-9 noviembre 1998, Morella (Castellón)

\section{Bibliografía:}

- Safont, 9 octubre-9 noviembre 1998, Morella (Castellón), pág. 27 Imagen:

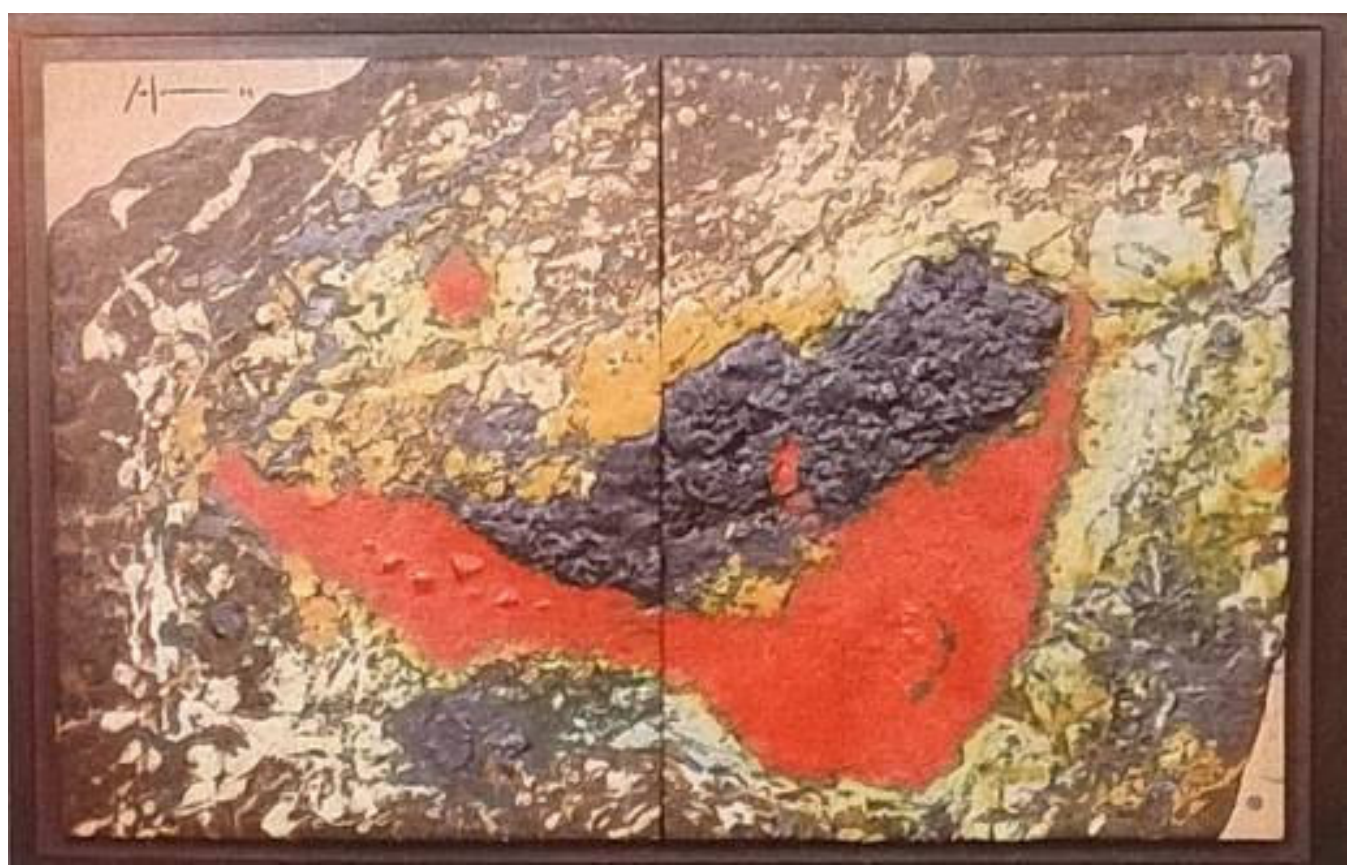




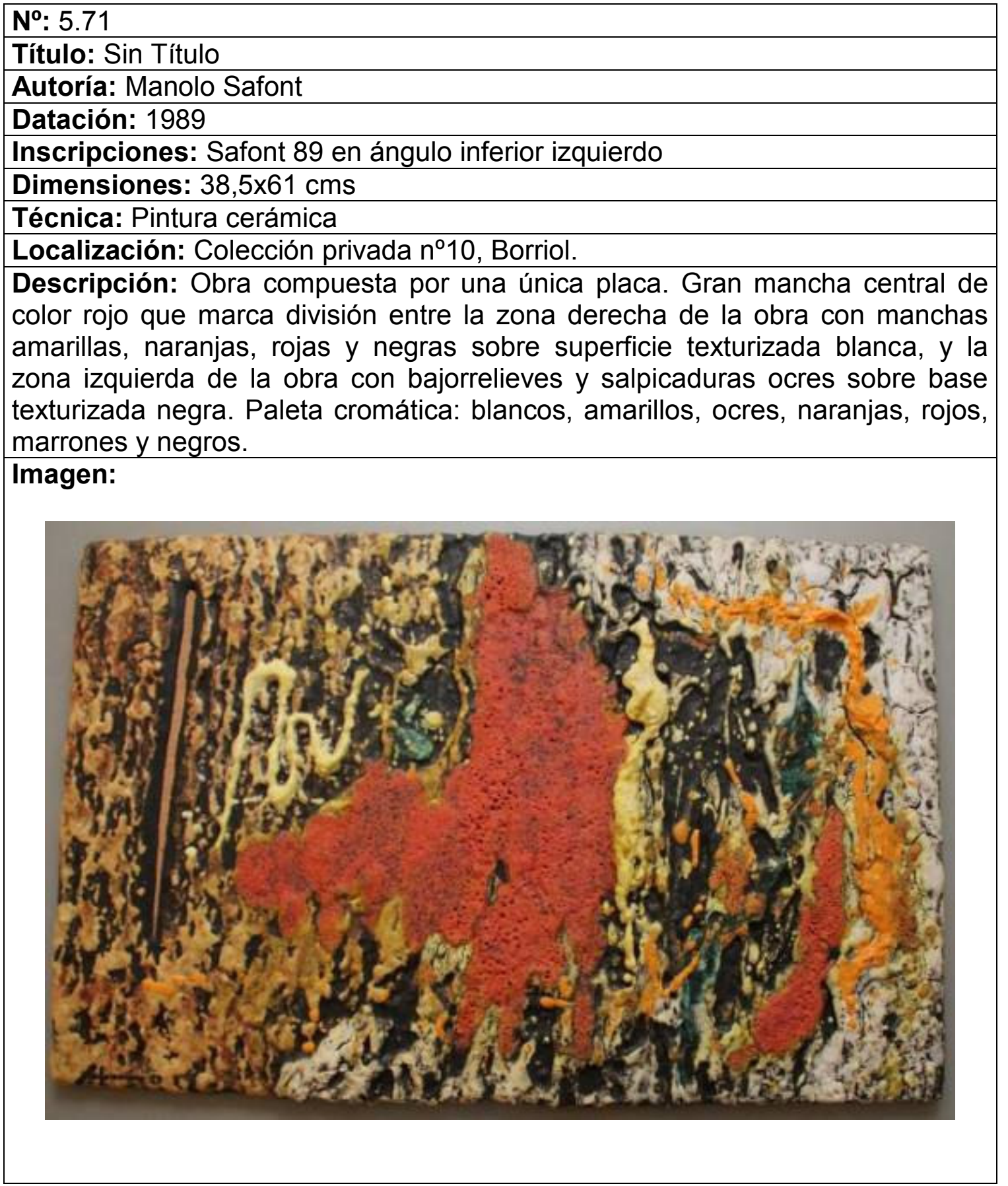




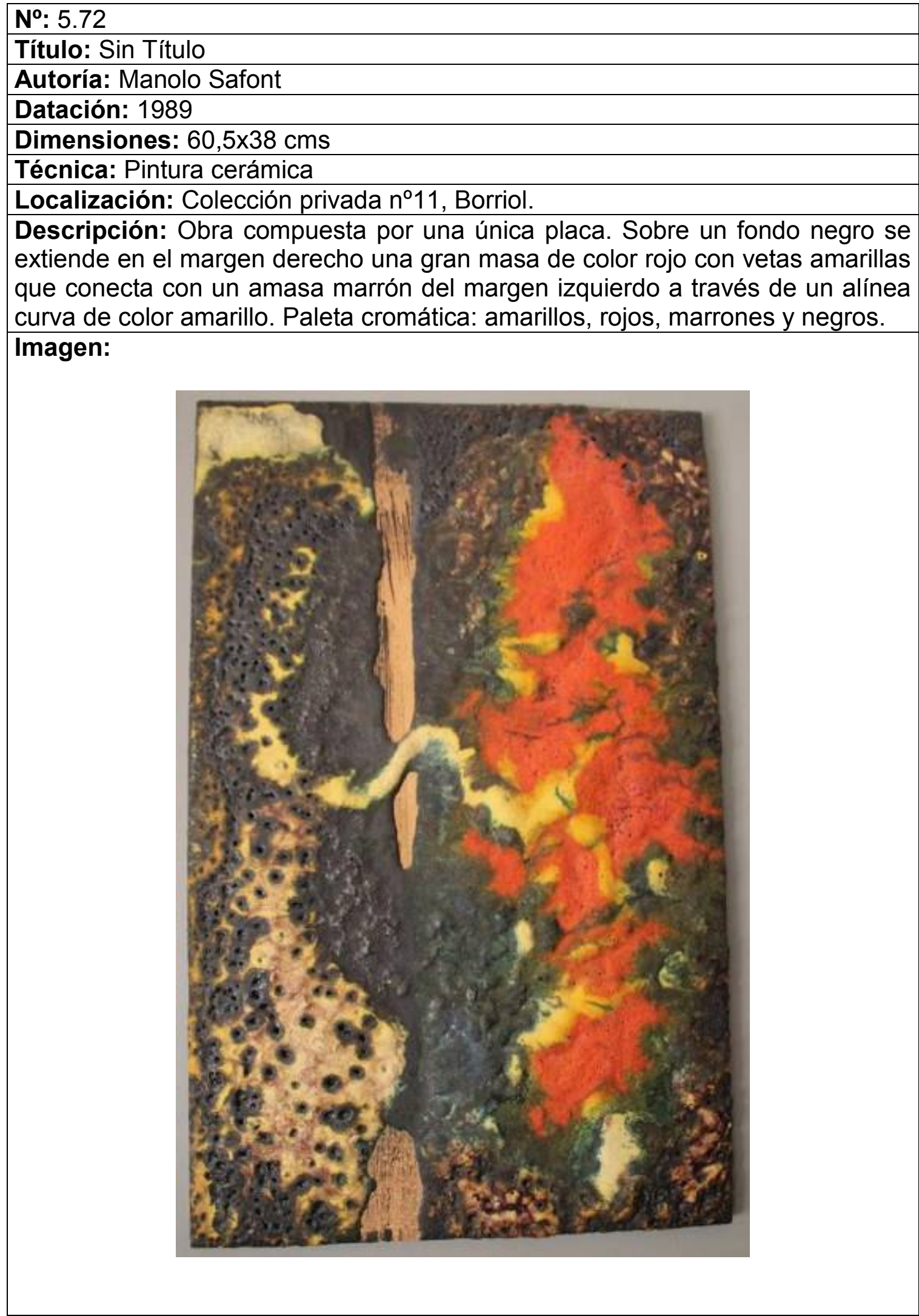


No: 5.73

Título: Sin Título

Autoría: Manolo Safont

Datación: Inicios década 1980

Inscripciones: Safont en zona central inferior

Dimensiones: $40 \times 40 \mathrm{cms}$

Técnica: Pintura cerámica

Localización: MAMS

Descripción: Obra compuesta por una única placa, con una zona central en disposición vertical con suave relieve que contrasta con las grandes masas de relieve de los márgenes derecho e izquierdo. Paleta cromática: blancos, ocres, marrones y negros.

Exposiciones:

- Manolo Safont. Un museu, un llegat i un compromís. MAMS. Del 27 de noviembre de 2004 al 8 de enero de 2005. Onda.

- Manolo Safont, un museu, un llegat, MAMS, mayo 2013, Onda

\section{Bibliografía:}

- http://www.eltriangulo.es/contenidos/?p=36891

- http://manolosafont.blogspot.com.es/

Imagen:

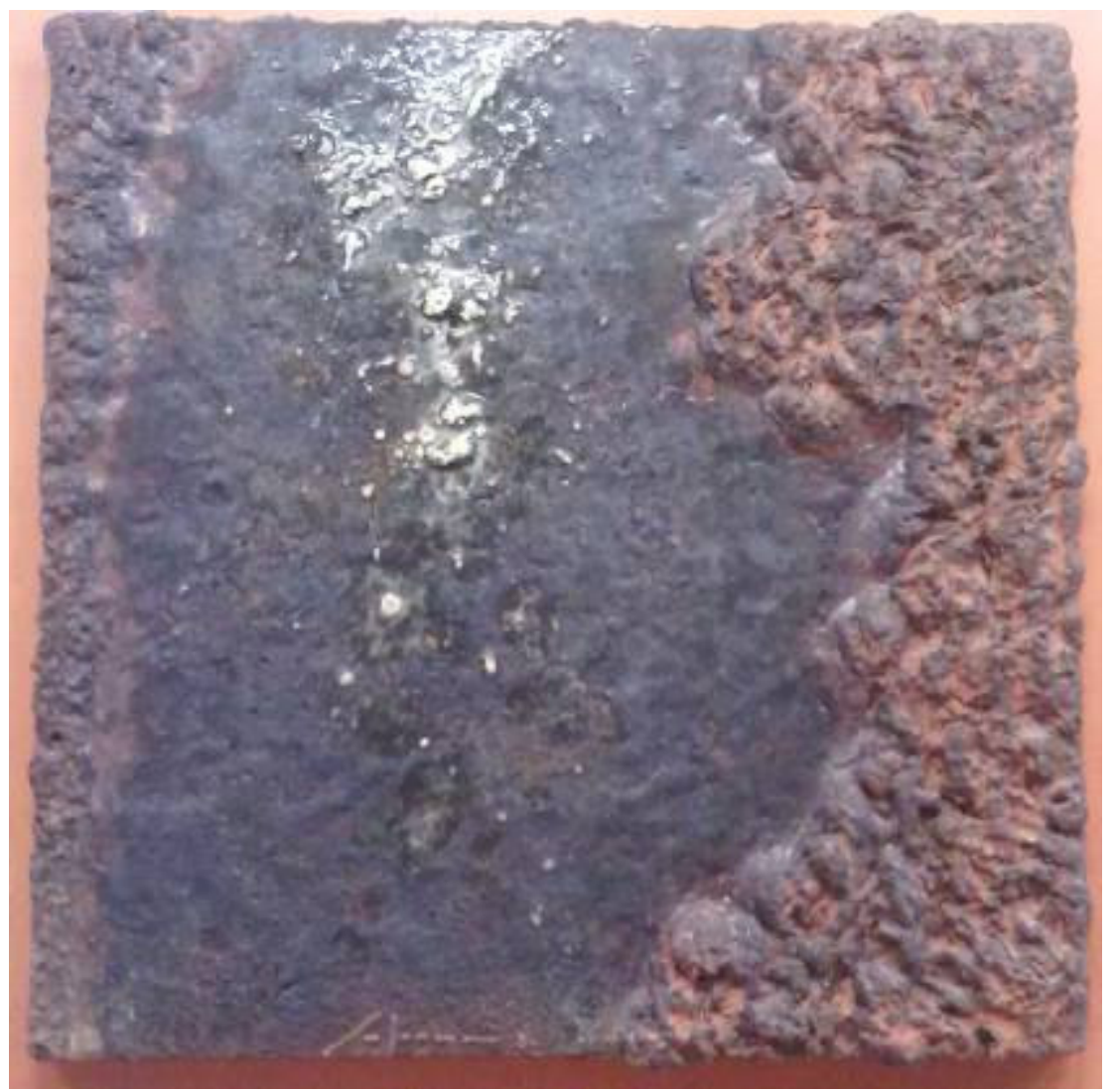


No: 5.74

Título: Sin Título

Autoría: Manolo Safont

Datación: Década 1980

Dimensiones: $30 \times 38 \mathrm{cms}$

Técnica: Pintura cerámica

Localización: MAMS

Descripción: Obra compuesta por una única placa, con una masa multicolor en el centro de la pieza, de la cual parten salpicaduras hacia la zona superior en colores blanco y negro. Paleta cromática: blancos, amarillos, ocres, rojos, marrones y negros.

\section{Exposiciones:}

- Manolo Safont. Un museu, un llegat i un compromís. MAMS. Del 27 de noviembre de 2004 al 8 de enero de 2005. Onda

- Manolo Safont, un museu, un llegat, MAMS, mayo 2013, Onda

\section{Bibliografía:}

- http://www.eltriangulo.es/contenidos/?p=36891

- http://manolosafont.blogspot.com.es/

\section{Imagen:}

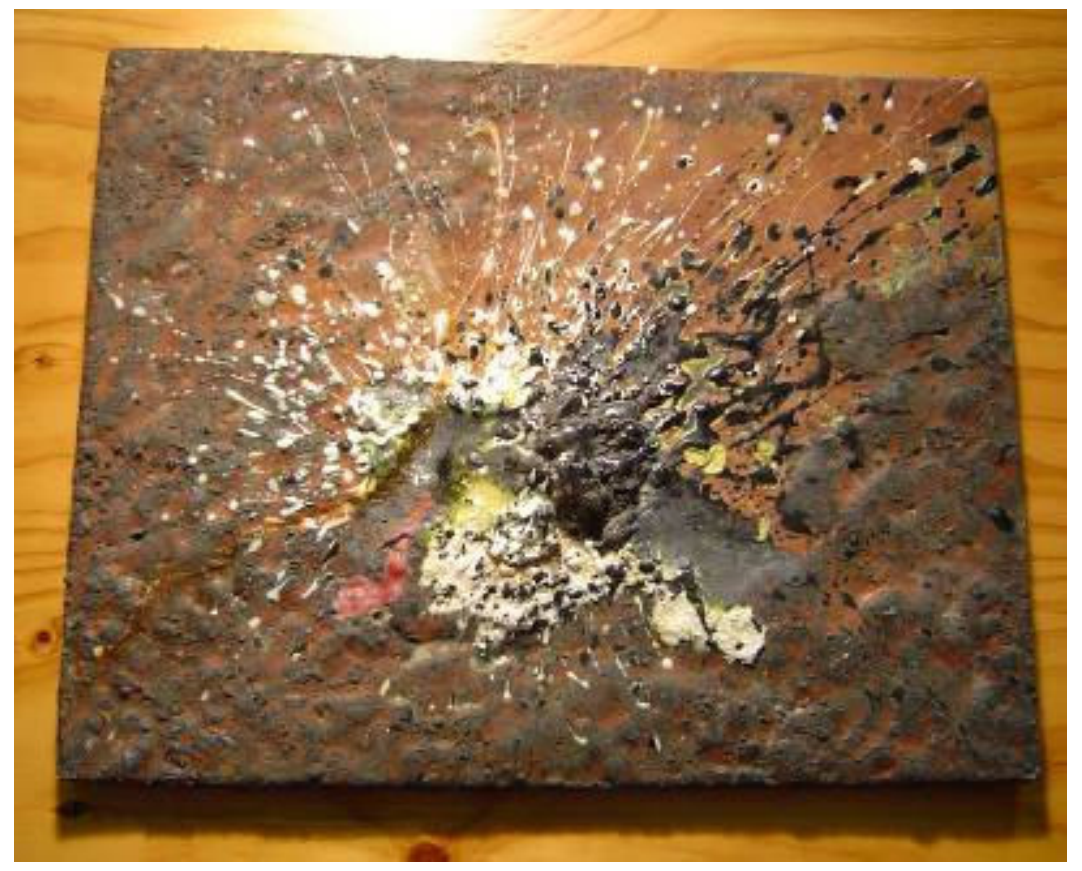


No: 5.75

Título: Sin Título

Autoría: Manolo Safont

Datación: 1990

Inscripciones: Safont en zona inferior

Dimensiones: $49 \times 40 \mathrm{cms}$ o $50 \times 40 \mathrm{cms}$

Técnica: Pintura cerámica

Localización: MAMS

Descripción: Obra compuesta por una única placa. Dos manchas rojas y blancas centradas sobre un fondo blanco, con relieves de salpicaduras negras. La imagen fue utilizada para ilustrar el calendario de Caixa Rural d'Onda de 2003. Paleta cromática: blancos, ocres, rojos y negros.

\section{Exposiciones:}

- Manolo Safont. Exposición conmemorativa de la inauguración del nuevo edificio social. Caja Rural Nuestra Señora de la Esperanza. 23 diciembre 2001- 6 enero 2002. Onda

- Manolo Safont, un museu, un llegat, MAMS, mayo 2013, Onda

\section{Bibliografía:}

- Manolo Safont. Exposición conmemorativa de la inauguración del nuevo edificio social. Caja Rural Nuestra Señora de la Esperanza. 23 diciembre 2001- 6 enero 2002. Onda

- Calendario Caixa Rural d'Onda 2003. Caixa Rural d'Onda 2003

- http://www.eltriangulo.es/contenidos/?p=36891

- http://manolosafont.blogspot.com.es/

\section{Imagen:}

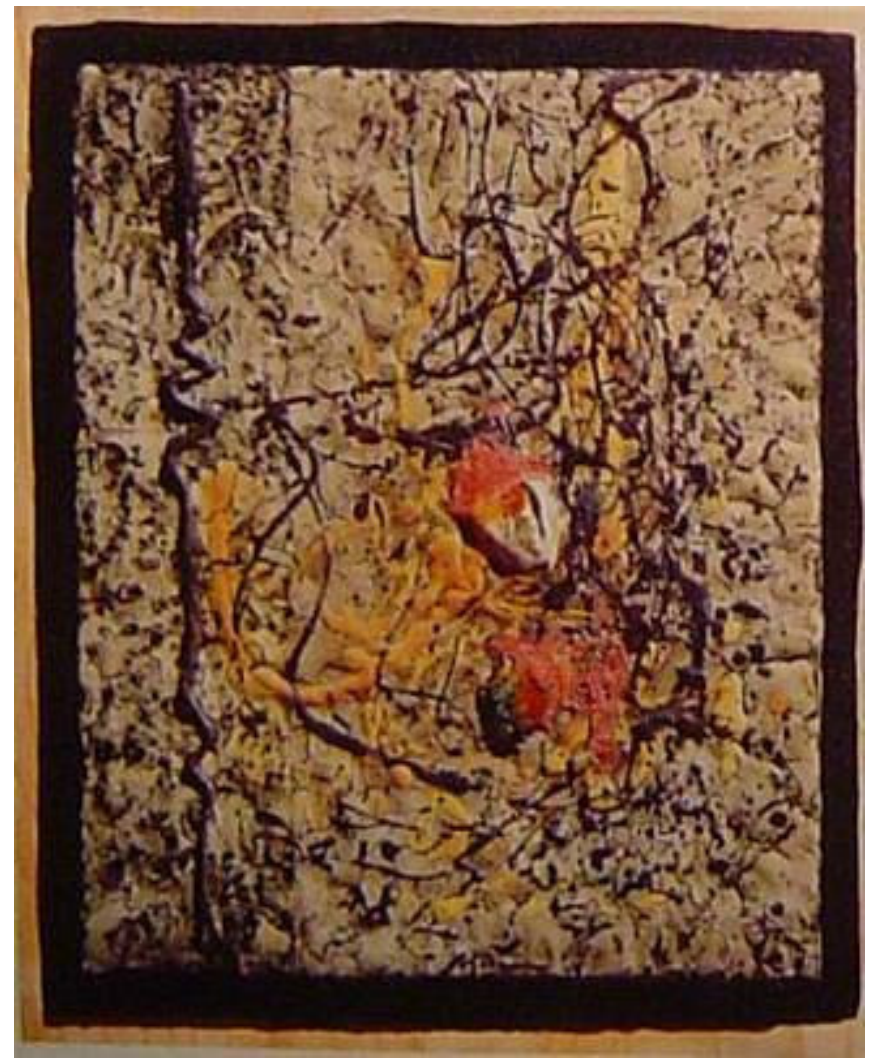


No: 5.76

Título: Sin Título

Autoría: Manolo Safont

Datación: 1990

Inscripciones: Safont 90 en ángulo inferior izquierdo

Dimensiones: 40x20 cms

Técnica: Pintura cerámica

Localización: MAMS

Descripción: Obra compuesta por una única placa. Sobre fondo blanco con salpicaduras negras, destacan dos masas rojas rodeadas de masa negra en la zona inferior de la obra. Paleta cromática: blancos, amarillos, rojos y negros.

Exposiciones:

- Manolo Safont. Un museu, un llegat i un compromís. MAMS. Del 27 de noviembre de 2004 al 8 de enero de 2005. Onda

- Manolo Safont, un museu, un llegat. MAMS, mayo 2013, Onda

Bibliografía:

- http://www.eltriangulo.es/contenidos/?p=36891

- http://manolosafont.blogspot.com.es/

Imagen:

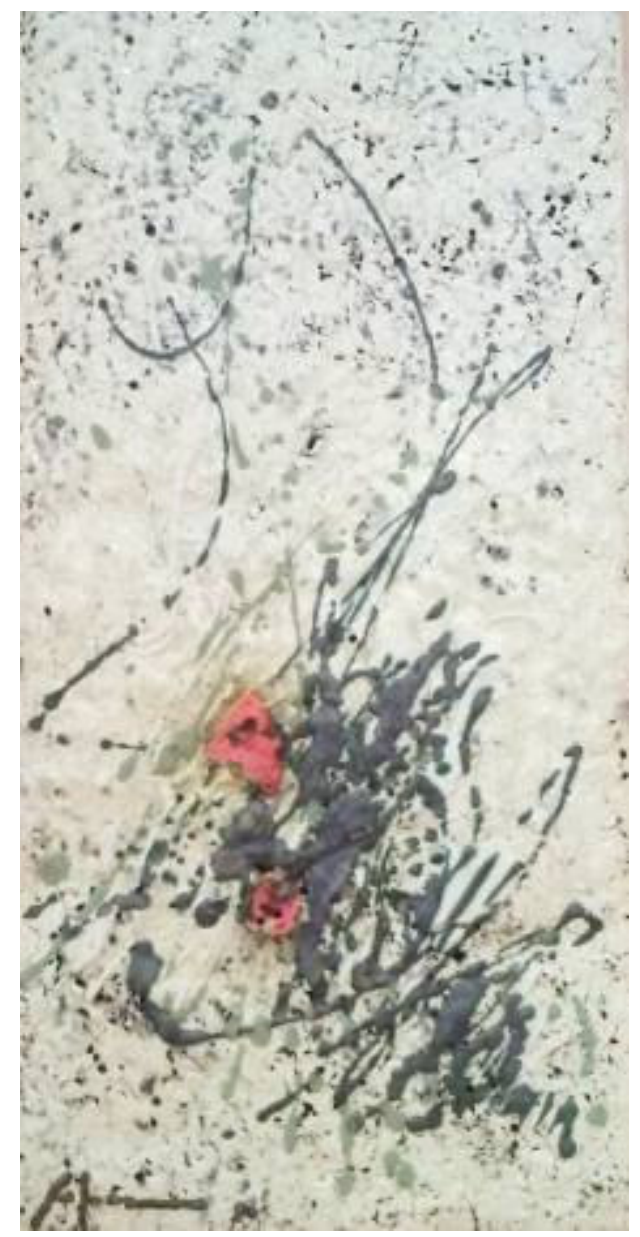




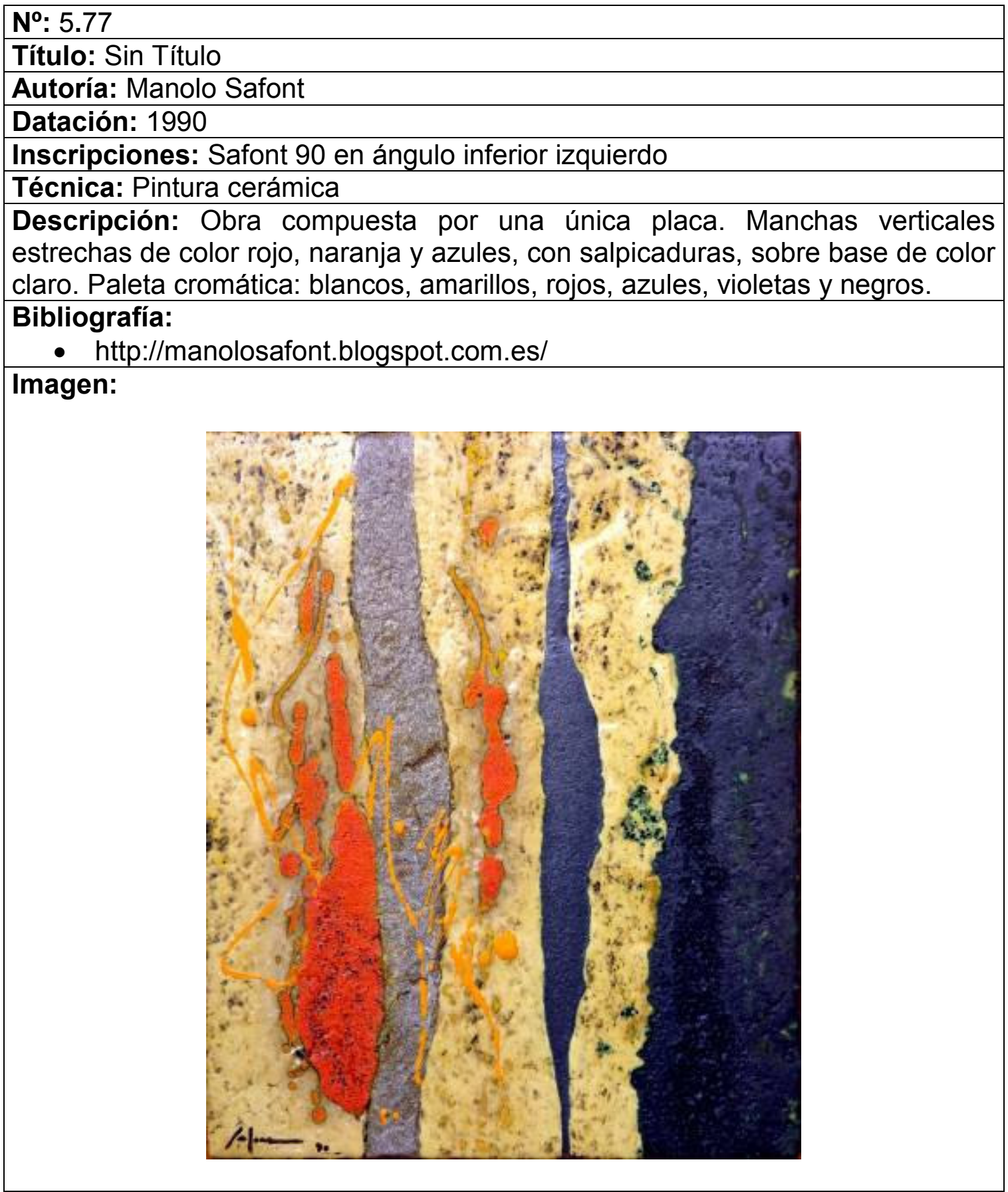


$N^{\circ}: 5.78$

Título: Sin Título

Autoría: Manolo Safont

Datación: 1990

Inscripciones: Safont 90 ángulo inferior izquierdo

Técnica: Pintura cerámica

Descripción: Obra compuesta por una única placa. Manchas planas amarillas, violetas y rojos, sobre fondo texturizado azul claro con salpicaduras negras.

Paleta cromática: blancos, amarillos, ocres, rojos, azules, violetas y negros.

Bibliografía:

- http://manolosafont.blogspot.com.es/

Imagen:

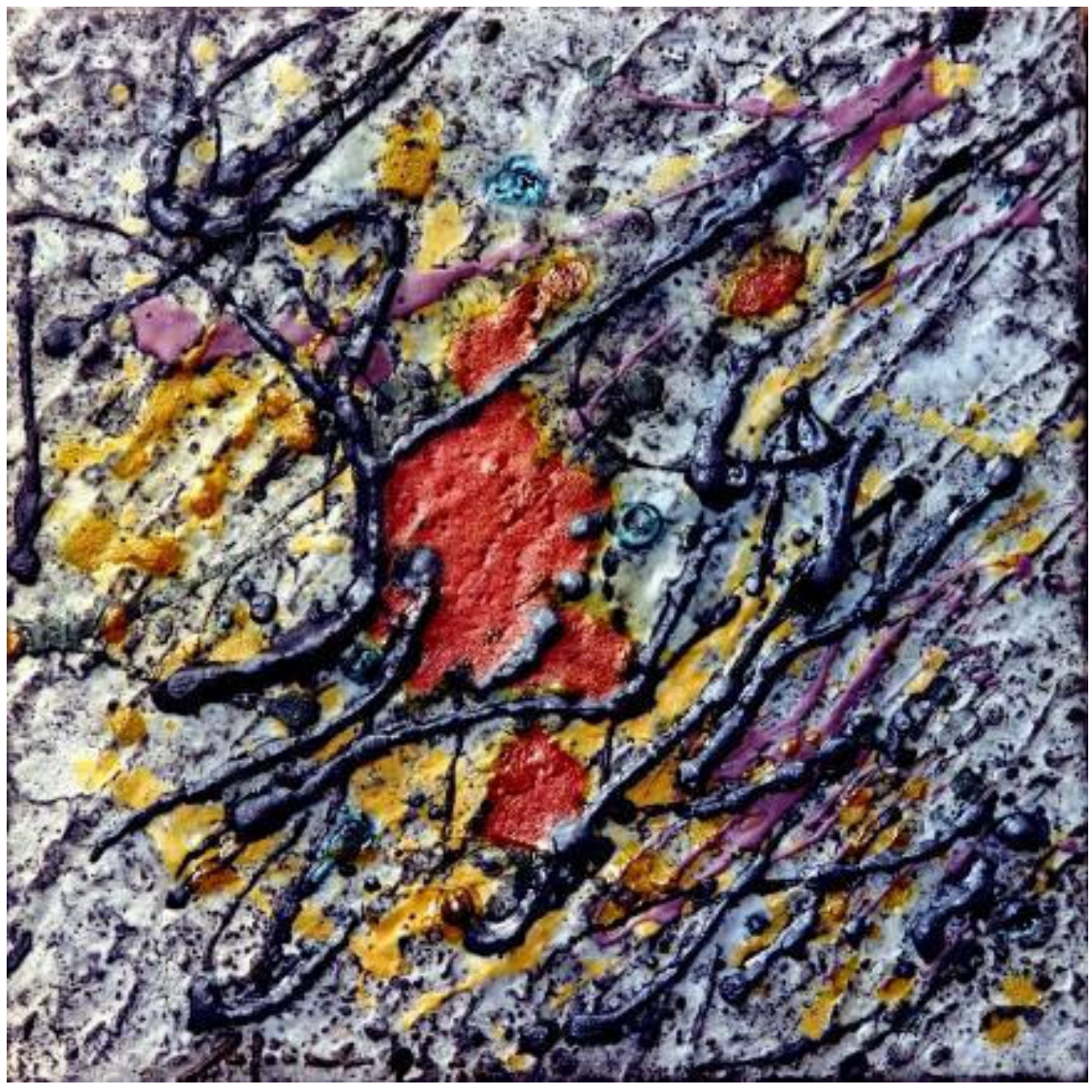


$\mathbf{N}^{0}: 5.79$

Título: Sin Título

Autoría: Manolo Safont

Datación: 1990

Inscripciones: Safont 90 en ángulo inferior izquierdo

Técnica: Pintura cerámica

Descripción: Obra compuesta por una única placa. Una gran mancha roja envuelta con salpicaduras negras en relieve. Paleta cromática: blancos, amarillos, rojos y negros.

Bibliografía:

- http://manolosafont.blogspot.com.es/

Imagen:

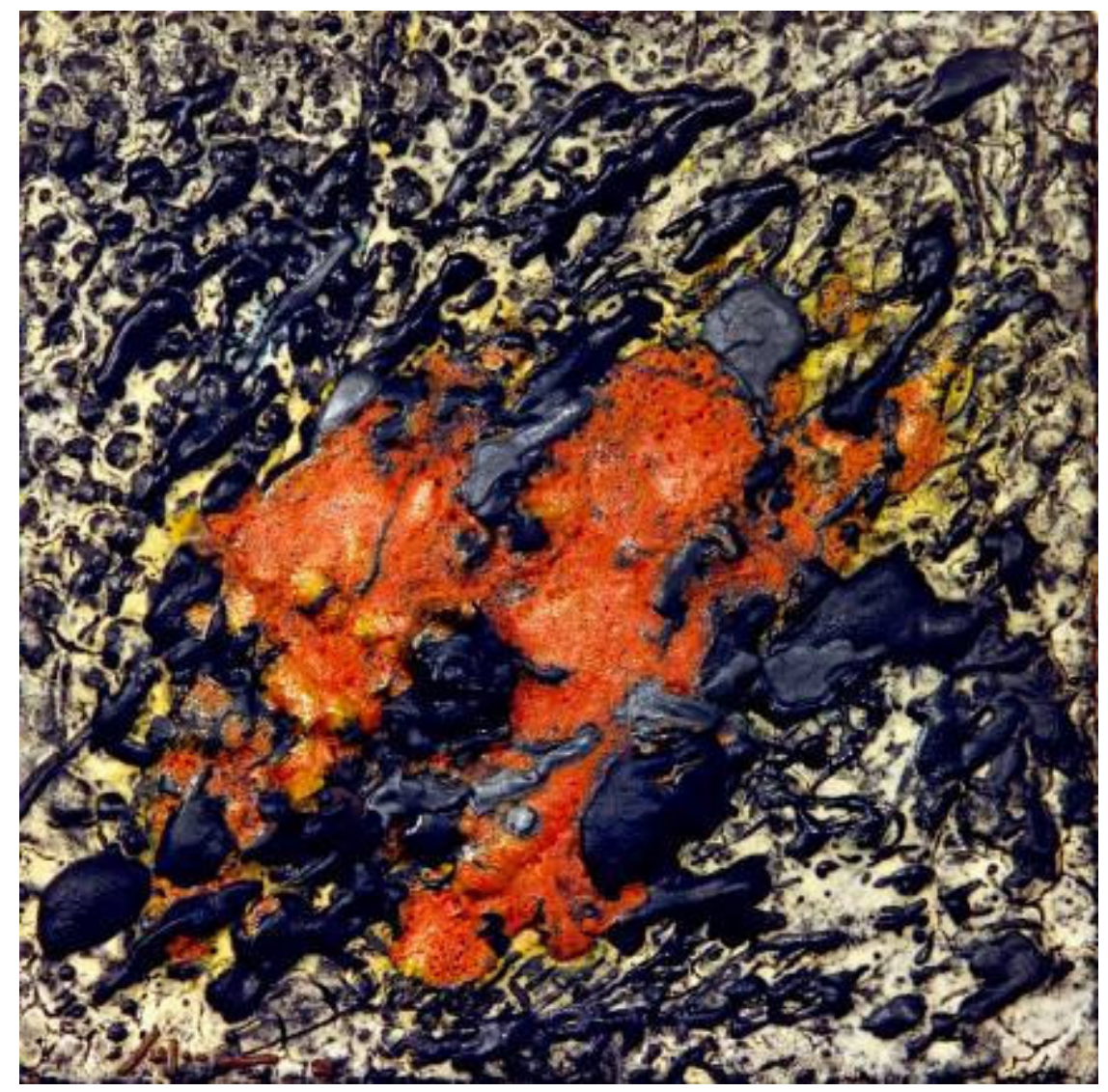




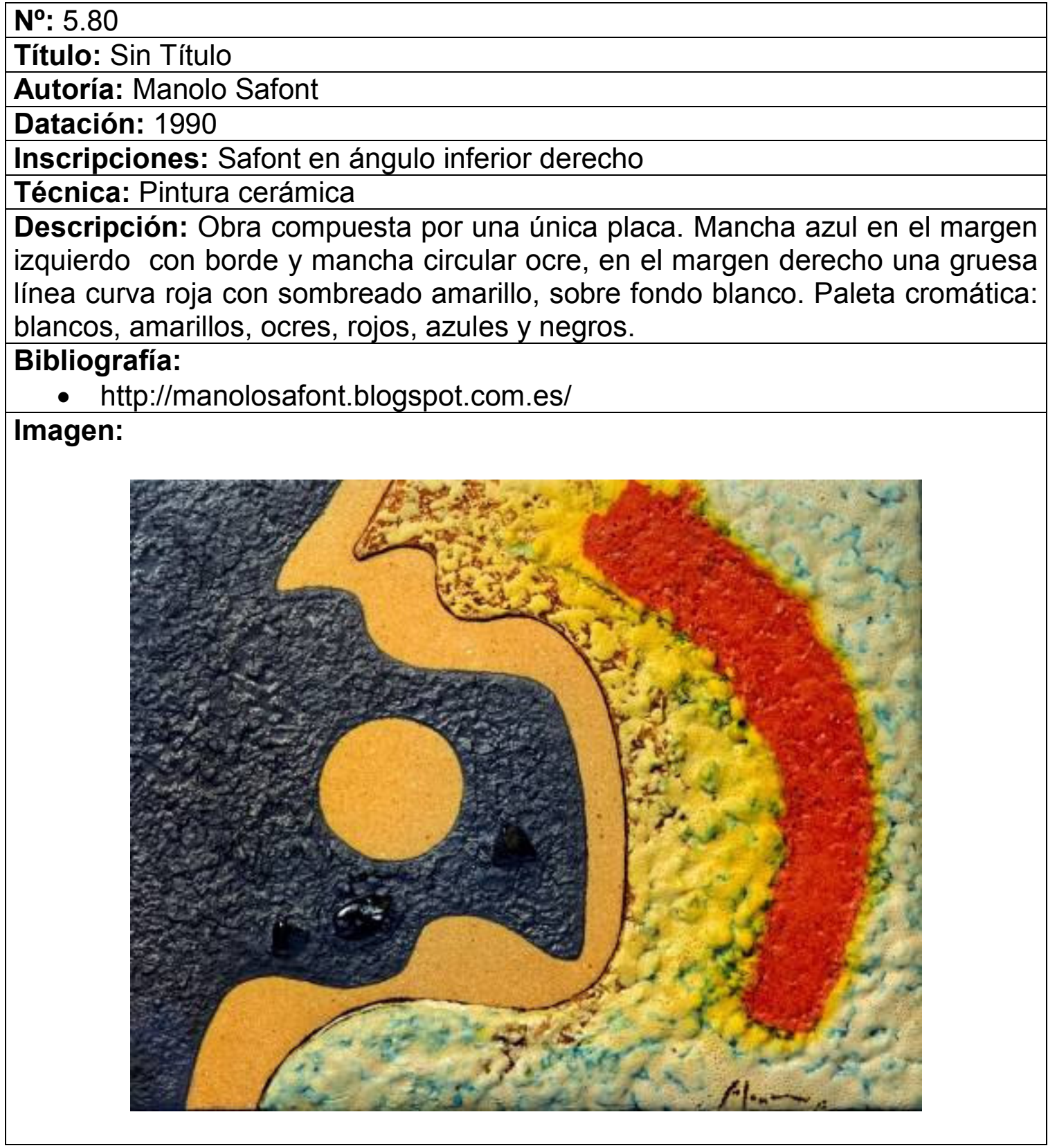


$\mathbf{N}^{\circ}: 5.81$

Título: Sin Título

Autoría: Manolo Safont

Datación: 1990

Inscripciones: Safont 90 en margen inferior

Dimensiones: 40x20 cms

Técnica: Pintura cerámica

Descripción: Obra compuesta por una única placa. Sobre fondo blanco manchas centrales de color rojo, verde, amarillo y azul, con salpicaduras de color negro. Paleta cromática: blancos, amarillos, rojos, verdes, azules y negros.

Exposiciones:

- Safont, 9 octubre-9 noviembre 1998, Morella (Castellón)

Bibliografía:

- Safont. 9 octubre-9 noviembre 1998, Morella (Castellón), pág. 28 Imagen:

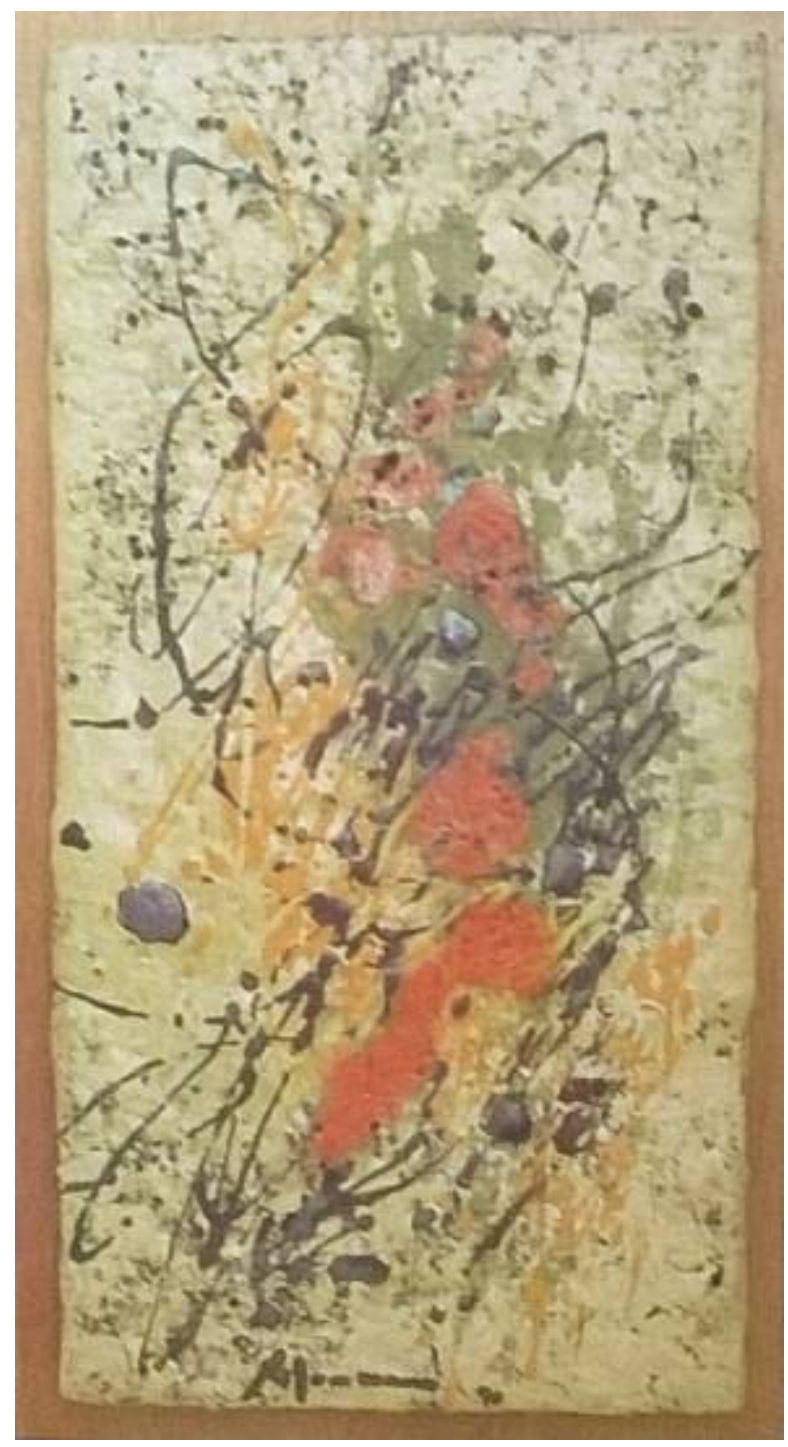


No: 5.82

Título: Sin Título

Autoría: Manolo Safont

Datación: 1991

Inscripciones: Safont 91 en ángulo inferior izquierdo

Dimensiones: $60 \times 38 \mathrm{cms}$

Técnica: Pintura cerámica

Descripción: Obra compuesta por una única placa. Sobre fondo blanco, cuatro pequeñas manchas de colores azul, verde y rojo, con finas salpicaduras negras que llegan al margen superior de la obra, donde hay pequeñísimas manchas con la misma paleta de color. Paleta cromática: blancos, rojos, verdes, azules y negros.

Exposiciones:

- Safont, 9 octubre-9 noviembre 1998, Morella (Castellón)

- Manolo Safont, un museu, un llegat, MAMS, mayo 2013, Onda

\section{Bibliografía:}

- Safont, 9 octubre-9 noviembre 1998, Morella (Castellón), pág. 23

- http://www.eltriangulo.es/contenidos/?p=36891

- http://manolosafont.blogspot.com.es/

Imagen:

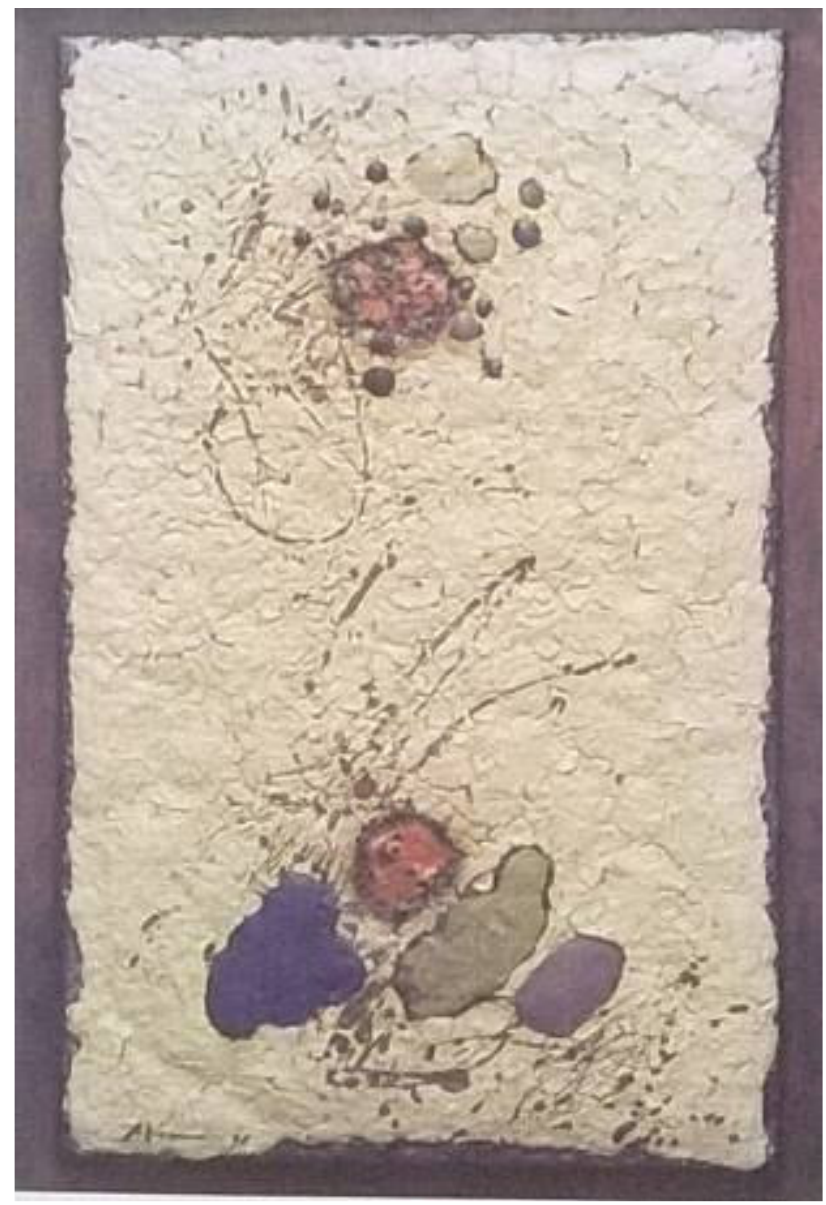


$\mathbf{N}^{\circ}: 5.83$

Título: Sin Título

Autoría: Manolo Safont

Datación: 1991

Inscripciones: Safont 91 en ángulo inferior izquierdo

Dimensiones: $60 \times 38 \mathrm{cms}$

Técnica: Pintura cerámica

Descripción: Obra compuesta por una única placa, dividida en dos zonas verticales con diferentes colores, ocre la izquierda y azul derecha, situando sobre la zona izquierda ocre un círculo rojo y tres líneas verticales oscuras y tres pequeños círculos blancos sobre la masa azul del margen derecho. Paleta cromática: blancos, ocres, rojos, azules y negros.

Exposiciones:

- Safont, 9 octubre-9 noviembre 1998, Morella (Castellón)

Bibliografía:

- Safont, 9 octubre-9 noviembre 1998, Morella (Castellón), pág. 24 Imagen:

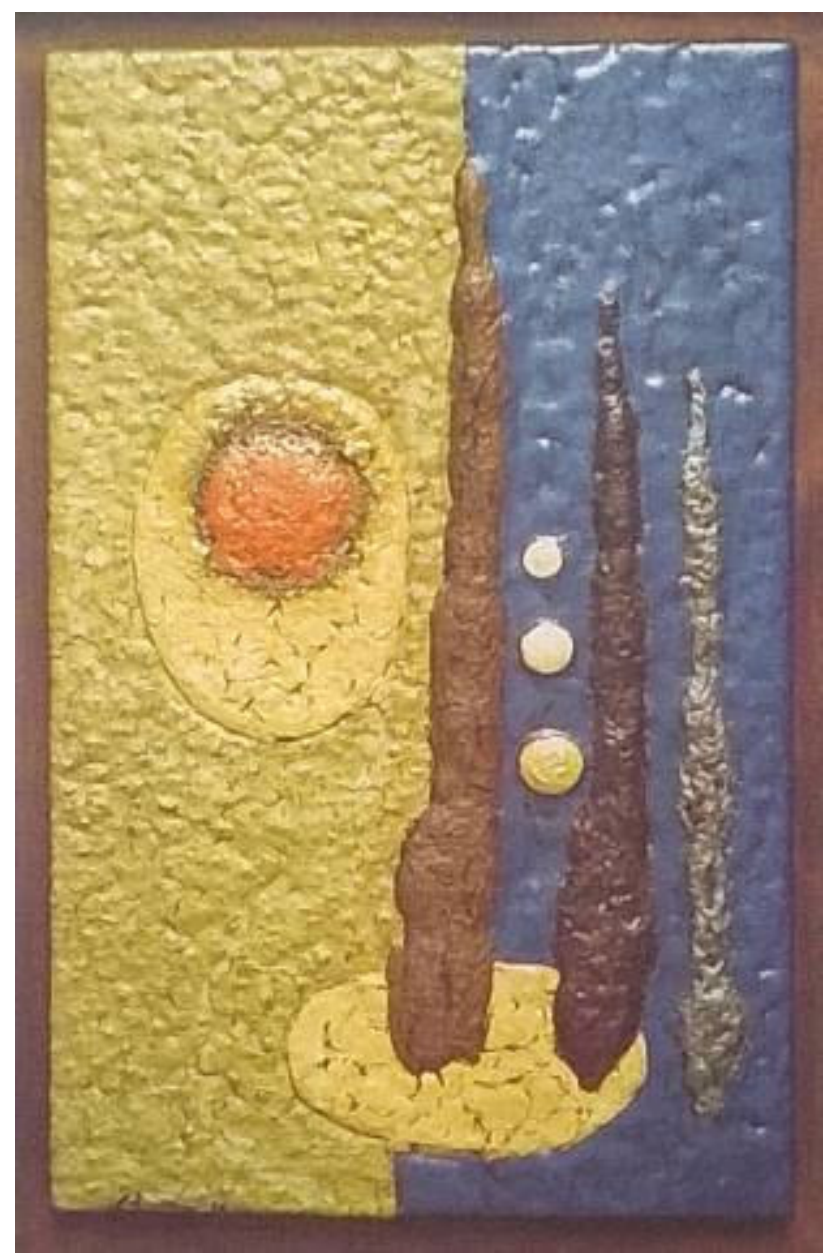


No: 5.84

Título: Sin Título

Autoría: Manolo Safont

Datación: Anterior a 1994

Inscripciones: Safont en ángulo inferior derecho

Dimensiones: $60 \times 48 \mathrm{cms}$

Técnica: Pintura cerámica

Descripción: Obra compuesta por una única placa. Sobre manchas verticales en colores grises y marrones, manchas amarillas y gotas rojas, con salpicaduras de color negro. Paleta cromática: blancos, amarillos, rojos y negros.

Exposiciones:

- Safont. Multi-Art 94. Escola-Llar, Morella, agosto 1994

- GIRALT- MIRACLE, Daniel/OLUCHA MONTINS, Ferran. Wences Rambla/ Manolo Safont, Alcoi, marzo 1995

\section{Bibliografía:}

- Safont. Multi-Art 94. Escola-Llar, Morella, agosto 1994

- GIRALT- MIRACLE, Daniel/OLUCHA MONTINS, Ferran. Wences Rambla/ Manolo Safont, Alcoi, marzo 1995, pág. 20

- VVAA, Butlletí d'Estudis Municipals, $2^{\mathrm{a}}$ etapa, $\mathrm{n}^{\circ} 2$, Onda, 2001 Imagen:

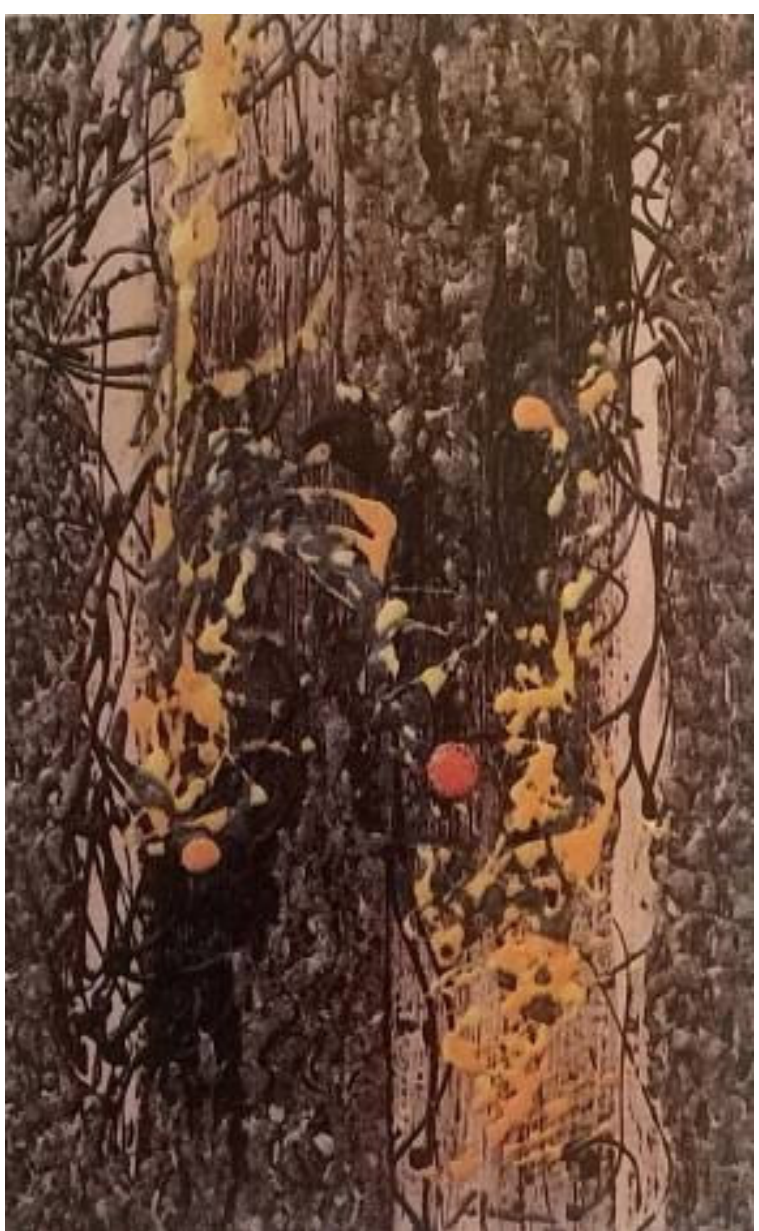




\begin{tabular}{|l|l|}
\hline No: 5.85 \\
\hline Título: Sin Título \\
\hline Autoría: Manolo Safont \\
\hline Datación: Anterior a 1995 \\
\hline Dimensiones: $25,2 \times 71,5 \mathrm{cms}$ \\
\hline Técnica: Pintura cerámica \\
\hline Localización: Casa Joan Fuster, calle San José, $\mathrm{n}^{\circ} 10$, Sueca, Valencia \\
\hline $\begin{array}{l}\text { Descripción: Obra compuesta por } 14 \text { placas de diferentes tamaños, pertenece } \\
\text { al Legado Joan Fuster, catalogada con el número CF011. Sobre fondo liso de } \\
\text { color oscuro se adhiere materia cerámica con textura confiriendo volumen a la } \\
\text { zona inferior de la obra. Paleta cromática: blanco, marrón y negro. }\end{array}$ \\
\hline $\begin{array}{l}\text { Exposiciones: } \\
\text { Colección permanente Casa Joan Fuster, Sueca, Valencia }\end{array}$ \\
\hline $\begin{array}{l}\text { Bibliografía: } \\
\text { http://www.espaijoanfuster.org/content/col-leccio-dart }\end{array}$ \\
\hline \begin{tabular}{l} 
Imagen: \\
\hline
\end{tabular} \\
\hline
\end{tabular}


$\mathbf{N}^{0}: 5.86$

Título: Sin Título

Autoría: Manolo Safont

Datación: 1995

Inscripciones: Safont 95 en ángulo inferior derecho

Dimensiones: $64 \times 40 \mathrm{cms}$.

Técnica: Pintura cerámica

Localización: Colección privada n¹9, Castellón

Descripción: Obra compuesta por una única placa. Predominio de trazos verticales con una masa en tonos oscuros en la zona izquierda, tonos claros en la zona central y tonos azules en la zona derecha, sobre la que destacan salpicaduras amarillas y una pequeña masa de color rojo. Paleta cromática: blancos, ocres, rojos, azules, marrones y negros.

Exposiciones:

- Safont, Saleta Municipal d'Onda, Regiduria de Cultura, del 24 al 31 octubre de 1999, Onda

\section{Bibliografía:}

- Safont, Saleta Municipal d'Onda, Regiduria de Cultura, del 24 al 31 octubre de 1999, Onda

Imagen:

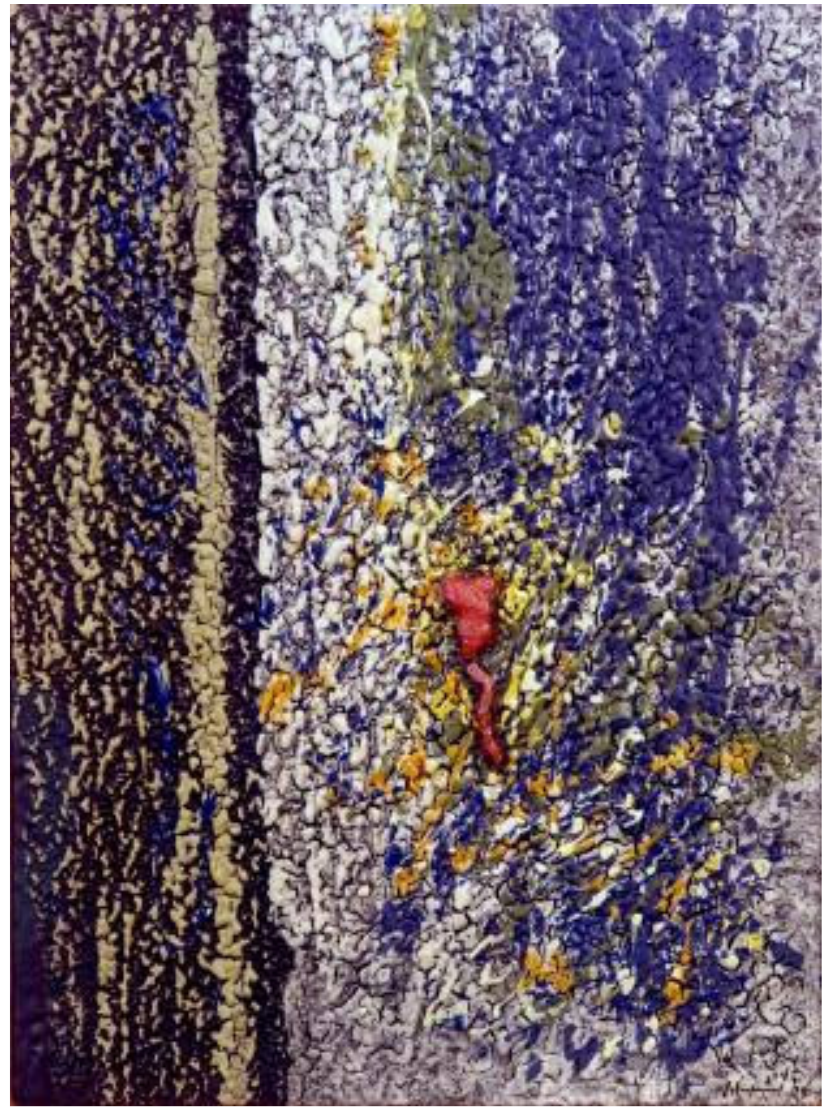


$\mathbf{N}^{0}: 5.87$

Título: Sin Título

Autoría: Manolo Safont

Datación: Anterior a 1998

Dimensiones: $80 \times 70 \mathrm{cms}$

Técnica: Pintura cerámica

Descripción: Obra compuesta por 18 placas de diferentes tamaños. Sobre superficie roja, dos grandes masas negras, en la zona central y margen izquierdo de la obra, con salpicaduras de color amarillo. Paleta cromática: blancos, amarillos, rojos y negros.

Exposiciones:

- Safont, 9 octubre-9 noviembre, 1998, Morella (Castellón)

\section{Bibliografía:}

- Safont, 9 octubre-9 noviembre, 1998, Morella (Castellón), pág.20 Imagen:

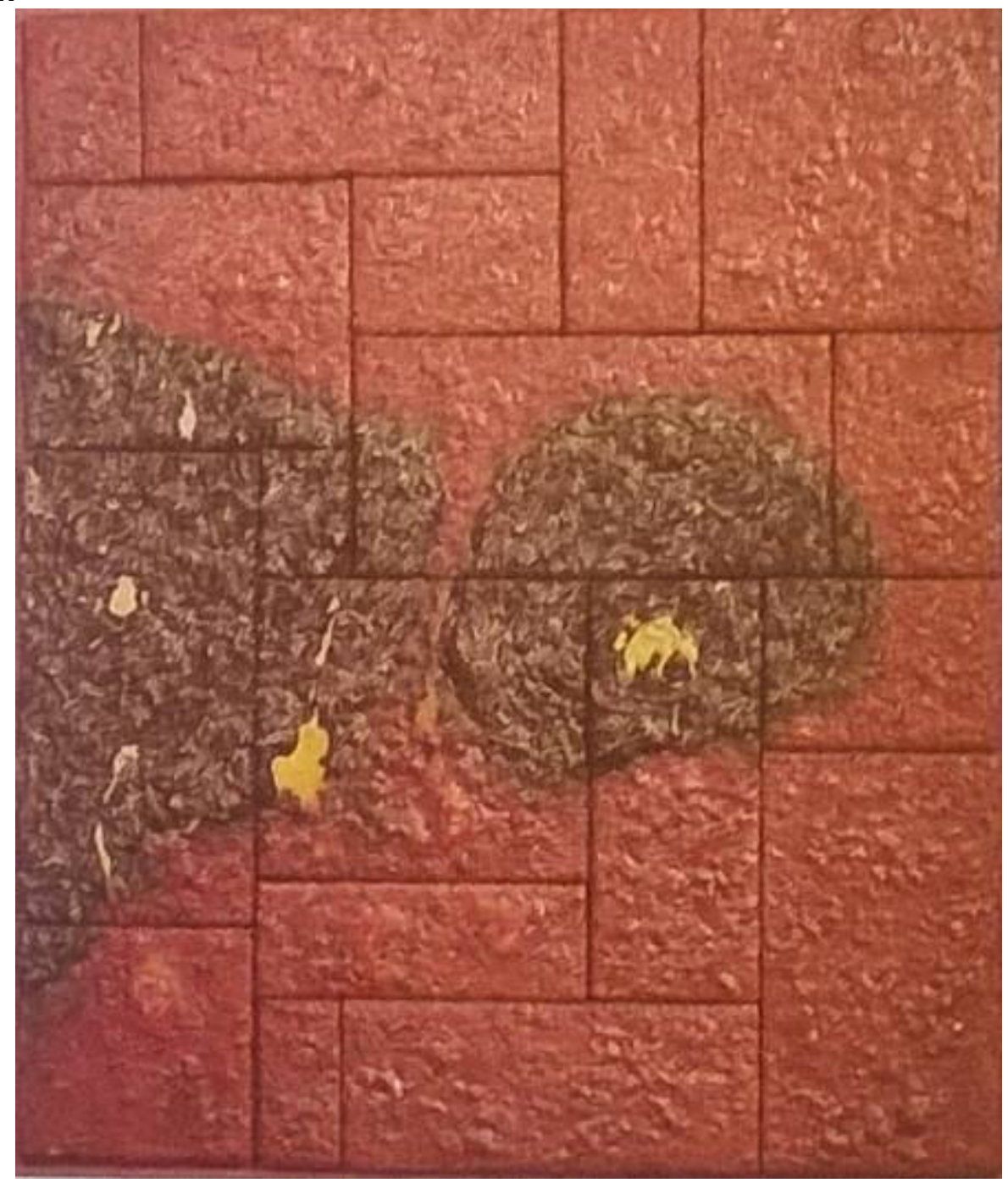


$\mathbf{N}^{0}: 5.88$

Título: Sin Título

Autoría: Manolo Safont

Datación: Anterior a 1998

Inscripciones: Safont en ángulo inferior derecho

Dimensiones: $60 \times 38 \mathrm{cms}$

Técnica: Pintura cerámica

Descripción: Obra compuesta por una única placa. La zona superior de color ocre, con un círculo blanco, un pequeño círculo rojo y una masa negra, contrasta con una zona inferior de color azul sin apenas superposición de masas. Paleta cromática: blancos, amarillos, rojos, azules y negros.

Exposiciones:

- Safont, 9 octubre-9 noviembre 1998, Morella, Castellón

Bibliografía:

- Safont, 9 octubre-9 noviembre 1998, Morella, Castellón, pág 32 Imagen:

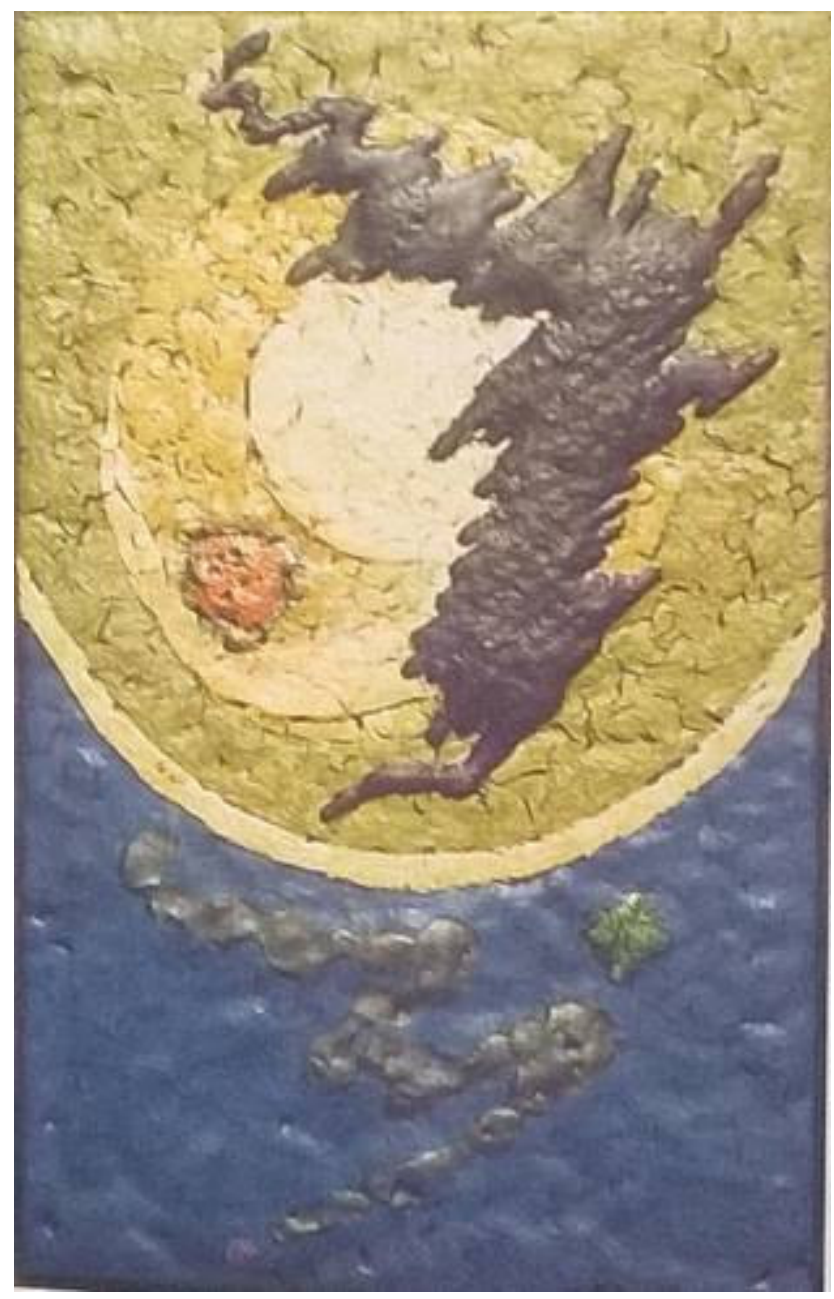


$\mathbf{N}^{0}: 5.89$

Título: Sin Título

Autoría: Manolo Safont

Datación: Anterior a 1998

Dimensiones: $40 \times 54 \mathrm{cms}$

Técnica: Pintura cerámica

Descripción: Obra compuesta por una única placa. Separados por una línea curva de color marrón, a la izquierda de la obra destaca una masa vertical de color blanco y a la derecha una mancha circular roja, rodeada por una orla amarilla, y con una gran mancha azul claro a su izquierda. Paleta cromática: blancos, amarillos, rojos, azules y marrones.

Exposiciones:

- Safont, 9 octubre-9 noviembre 1998, Morella, Castellón

Bibliografía:

- Safont, 9 octubre-9 noviembre 1998, Morella, Castellón, pág 33 Imagen:

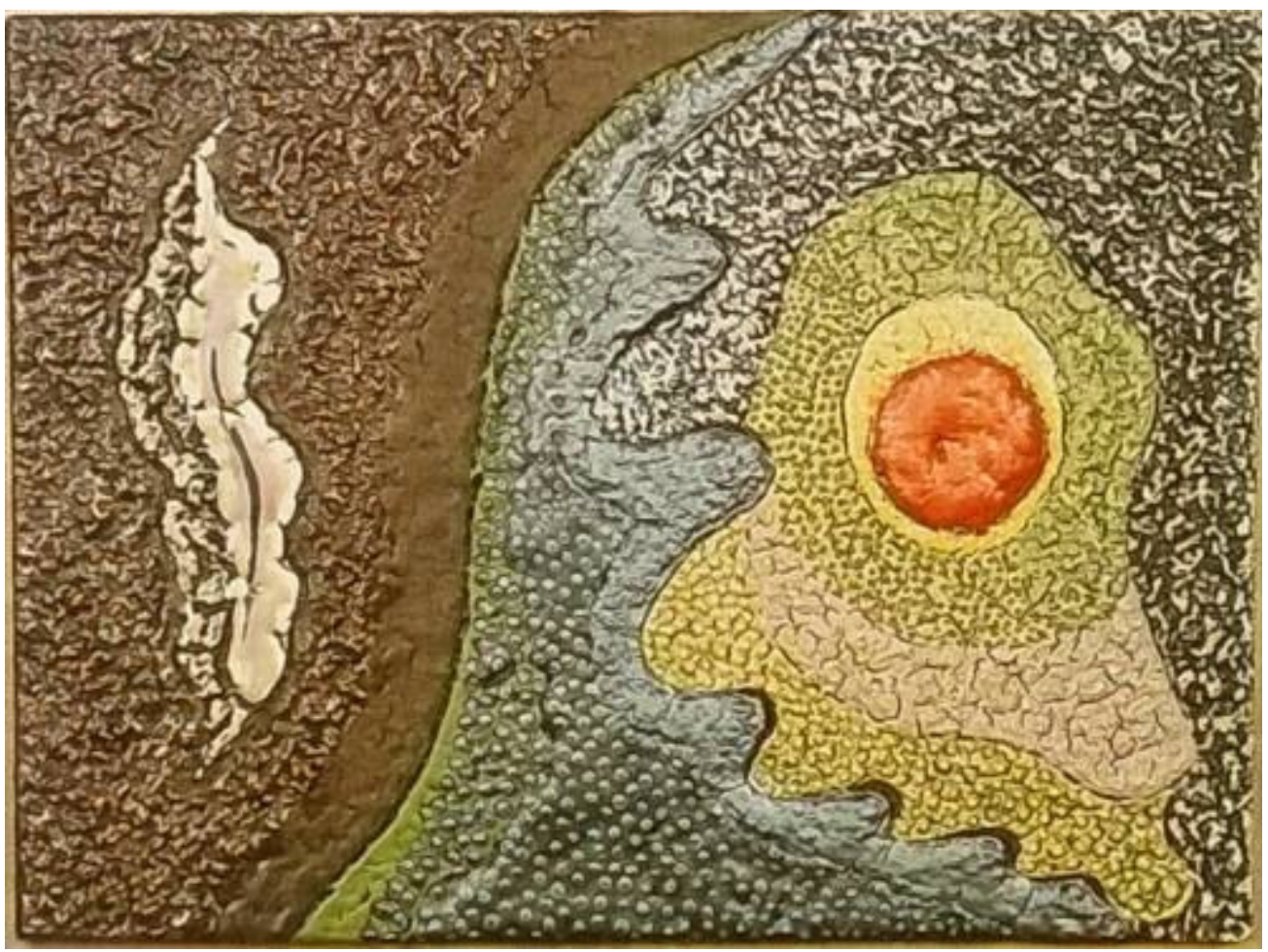


$\mathbf{N}^{\circ}: 5.90$

Título: Sin Título

Autoría: Manolo Safont

Datación: Anterior a 1998

Técnica: Pintura cerámica

Descripción: Obra compuesta por 3 placas del mismo tamaño. Pieza creada con suaves transiciones de la gama cromática del color rojo, con colores más oscuros en el margen izquierdo de la pieza y colores más suaves en el margen derecho de la obra. La imagen de esta obra fue utilizada por el Ayuntamiento de Morella para realizar las invitaciones que se enviaron para la inauguración de la exposición de Safont en las Salas Góticas del Ayuntamiento de Morella el 9 de octubre de 1998. Paleta cromática: blancos, rojos y negros. Imagen:

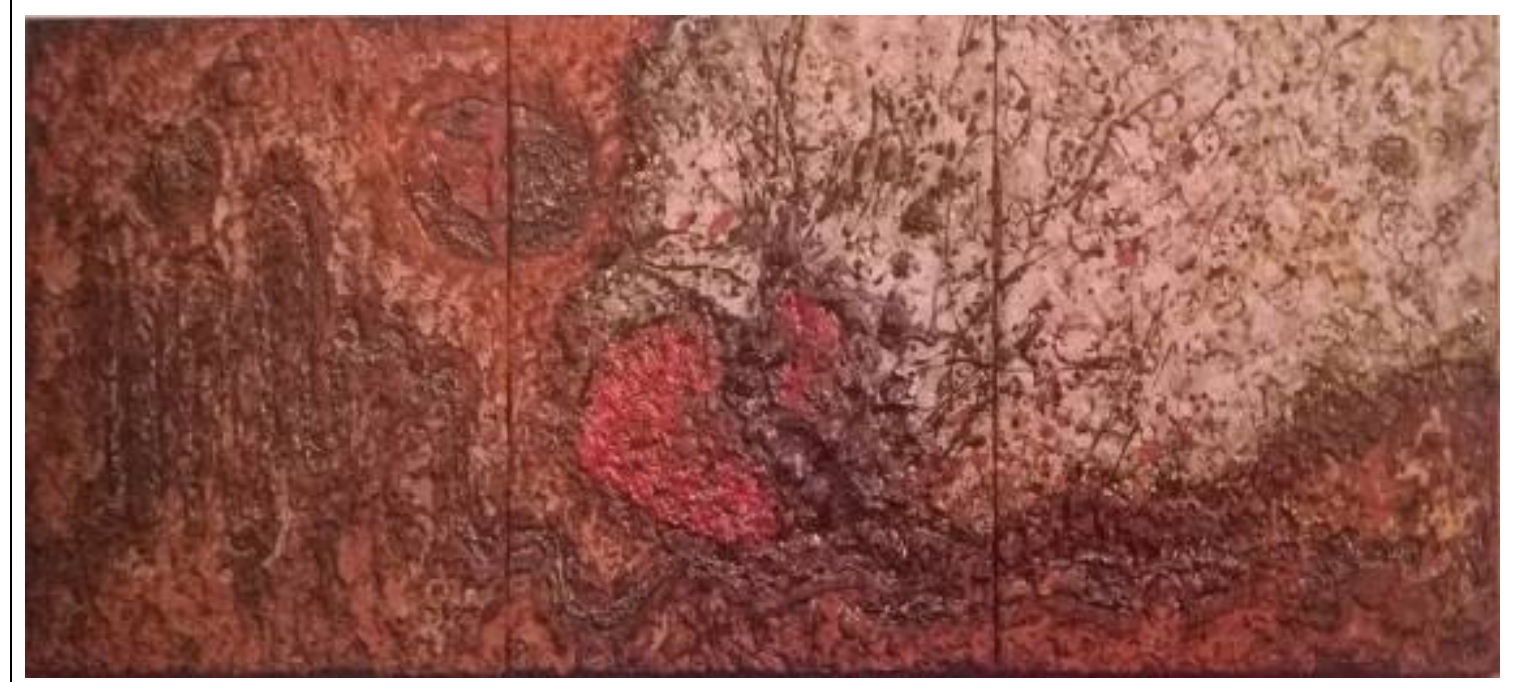

Imágenes relacionadas:

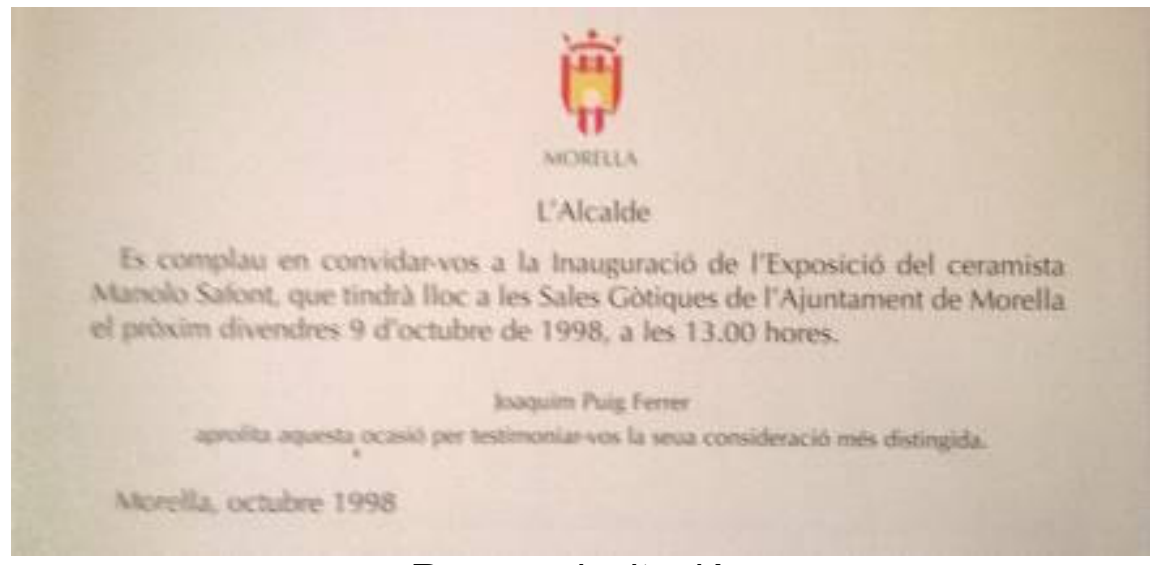

Reverso invitación 
$\mathbf{N}^{0}: 5.91$

Título: Sin Título

Autoría: Manolo Safont

Datación: 1998

Dimensiones: $40 \times 54 \mathrm{cms}$

Técnica: Pintura cerámica

Localización: MAMS

Descripción: Obra compuesta por una única placa. Zonas curvas en disposición diagonal con texturas en gradación de color de tonos claros a oscuros, marcando la línea divisoria una zona de reserva del color original de la placa base. Paleta cromática: blancos, azules, marrones y negros.

Exposiciones:

- Safont, 9 octubre-9 noviembre 1998, Morella, Castellón

- Manolo Safont. Un museu, un llegat i un compromís. MAMS. Del 27 de noviembre de 2004 al 8 de enero de 2005. Onda.

- Manolo Safont, un museu, un llegat. MAMS, mayo 2013, Onda

Bibliografía:

- Safont, 9 octubre-9 noviembre 1998, Morella, (Castellón), pág. 35

- FALOMIR, Carmela. "La pintura cerámica de Manolo Safont" en Butlletí d'Estudis Municipals. $2^{\mathrm{a}}$ etapa, $\mathrm{n}^{\circ}$ 2. Ajuntament d'Onda. Onda, 2001, pág. 44

- http://www.eltriangulo.es/contenidos/?p=36891

- http://manolosafont.blogspot.com.es/

Imagen:

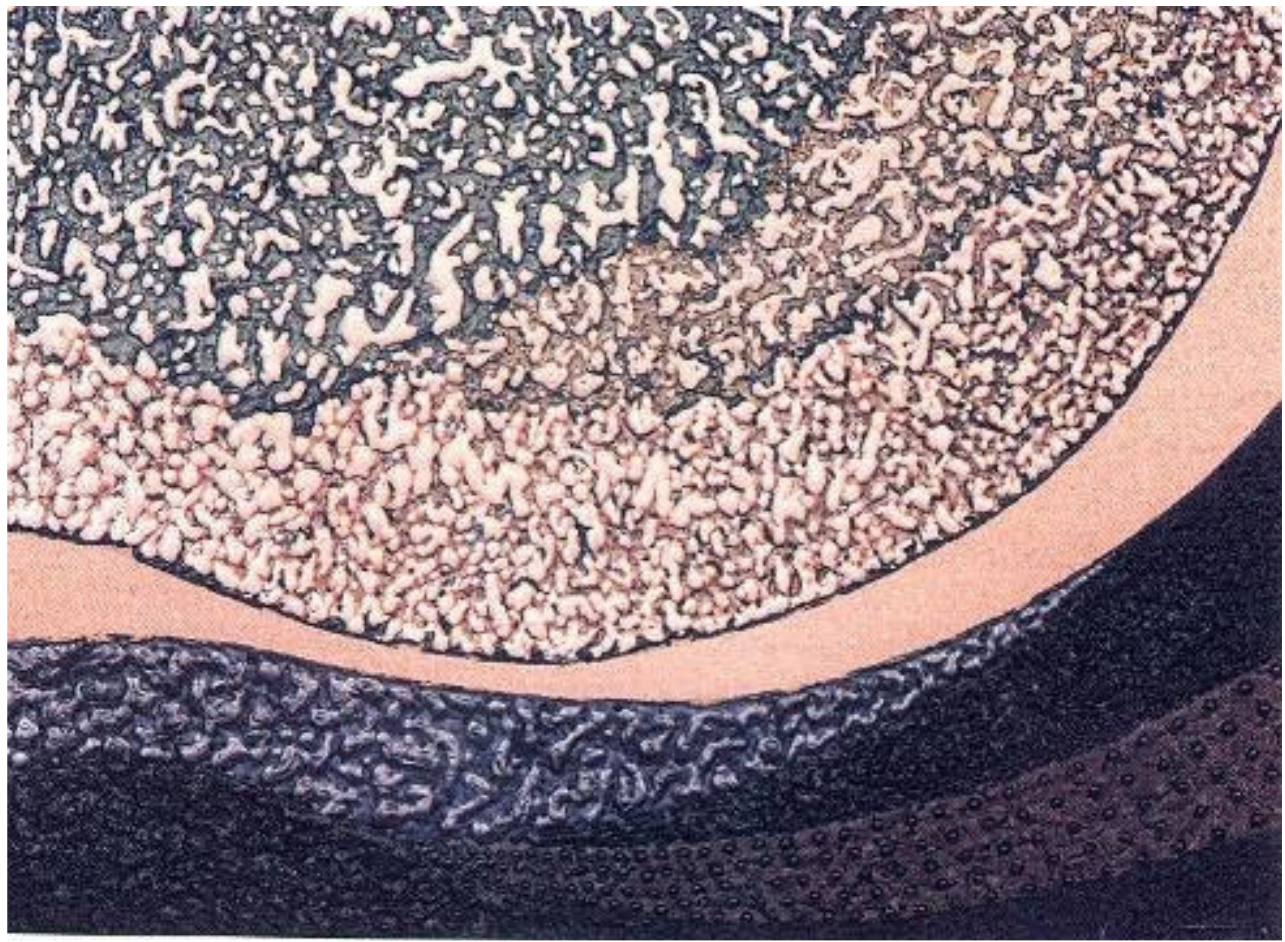


No: 5.92

Título: Sin Título

Autoría: Manolo Safont

Datación: 1998

Inscripciones: Safont 98 en ángulo inferior izquierdo

Dimensiones: $61 \times 76 \mathrm{cms}$

Técnica: Pintura cerámica

Localización: Colección privada $\mathrm{n}^{0} 12$, Onda.

Descripción: Obra compuesta por 2 placas de $61 \times 38 \mathrm{cms}$. Sobre un fondo rugoso con mucha textura, trazado de una línea vertical y otra horizontal, totalmente lisa, formando una cuadrícula en la que destaca un pequeño círculo rojo y un gran círculo liso blanco. Paleta cromática: blancos, amarillos, rojos, marrones y negros.

Exposiciones:

- Safont. 9 octubre-9 noviembre 1998, Morella (Castellón)

- Manolo Safont. Exposición conmemorativa de la inauguración del nuevo edificio social. Caja Rural Nuestra Señora de la Esperanza. 23 diciembre 2001- 6 enero 2002. Onda

\section{Bibliografía:}

- Safont. 9 octubre-9 noviembre 1998, Morella, Castellón, pág. 34

- Manolo Safont. Exposición conmemorativa de la inauguración del nuevo edificio social. Caja Rural Nuestra Señora de la Esperanza. 23 diciembre 2001- 6 enero 2002. Onda

Imagen:

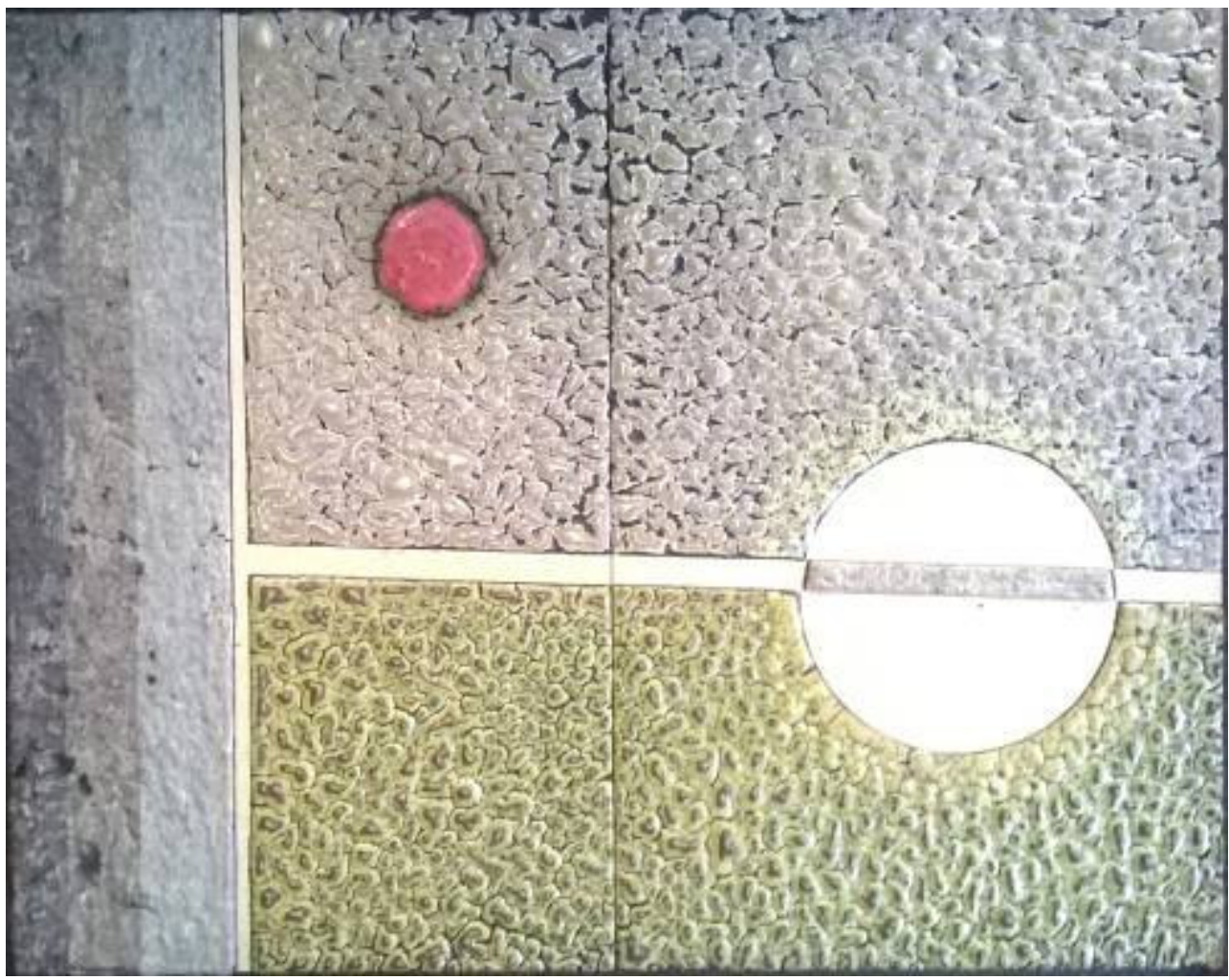


No: 5.93

Título: Sin Título

Autoría: Manolo Safont

Datación: 1998

Inscripciones: Safont 98 en ángulo inferior derecho

Dimensiones: $54 \times 40 \mathrm{cms}$

Técnica: Pintura cerámica

Localización: MAMS

Descripción: Obra compuesta por una única placa. Esta obra forma una serie junto con otras tres, catalogadas con el $n^{\circ} 94$, $n^{\circ} 95$ y $n^{\circ} 96$, con las que comparte tamaño, formato y estilo. Paleta cromática: blancos, amarillos, rojos, verdes, marrones y negros.

\section{Exposiciones:}

- Safont, Saleta Municipal d'Onda, Regiduria de Cultura, del 24 al 31 octubre de 1999, Onda

- Manolo Safont. Un museu, un llegat i un compromís. MAMS. Del 27 de noviembre de 2004 al 8 de enero de 2005. Onda.

\section{Bibliografía:}

- Safont, Saleta Municipal d'Onda, Regiduria de Cultura, del 24 al 31 octubre de 1999, Onda

- http://www.eltriangulo.es/contenidos/?p=36891

- http://manolosafont.blogspot.com.es/

Imagen:

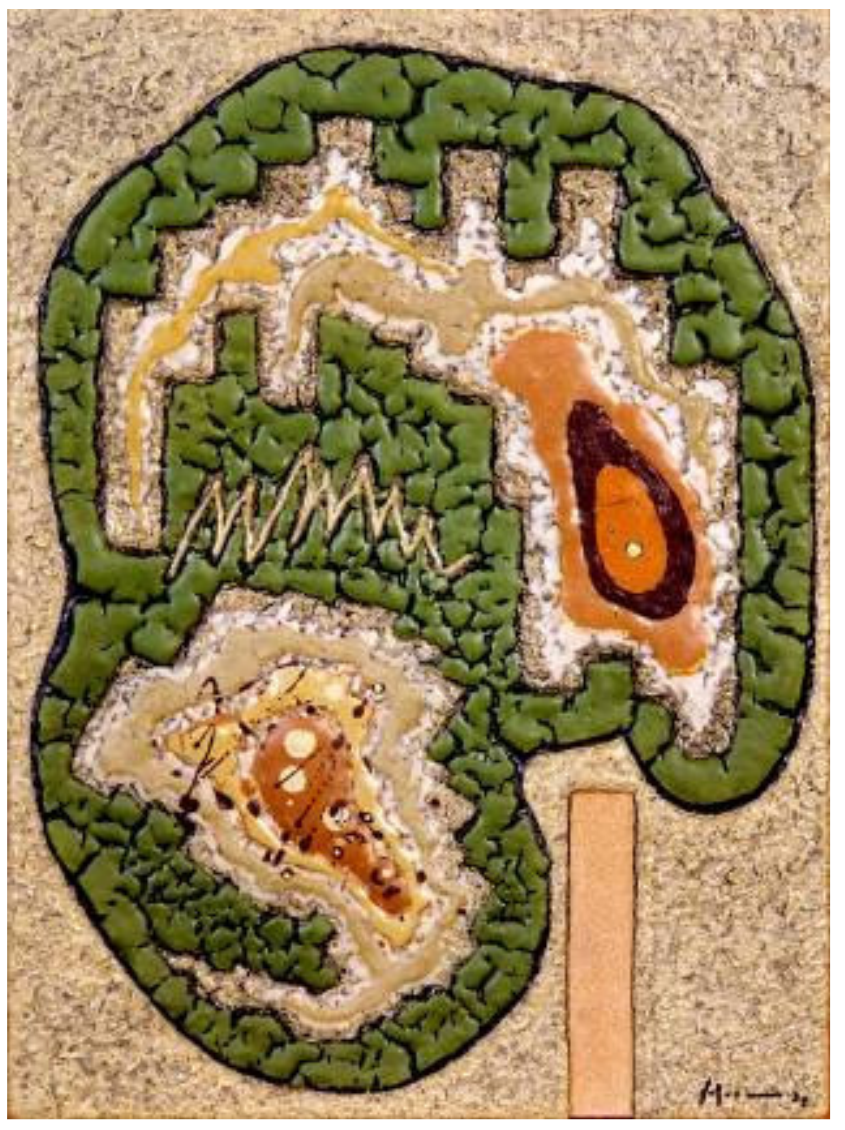


Imágenes relacionadas:

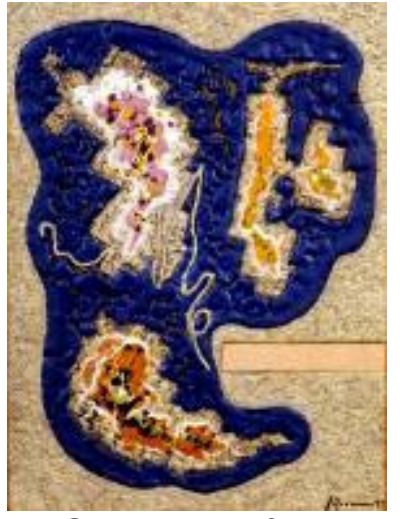

Obra cat. n॰94

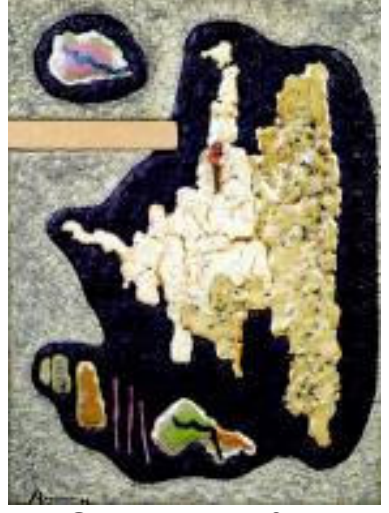

Obra cat. n95

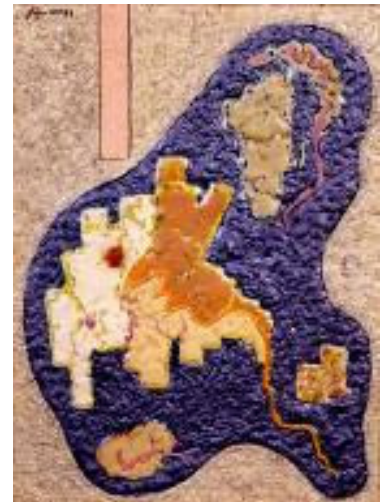

Obra cat. n96 
$\mathbf{N}^{0}: 5.94$

Título: Sin Título

Autoría: Manolo Safont

Datación: 1998

Inscripciones: Safont 98 en ángulo inferior derecho

Dimensiones: $54 \times 40 \mathrm{cms}$

Técnica: Pintura cerámica

Localización: MAMS

Descripción: Obra compuesta por una única placa. Esta obra forma una serie junto con otras tres, catalogadas con el $n^{\circ} 93, n^{\circ} 95$ y $n^{\circ} 96$, con las que comparte tamaño, formato y estilo. Paleta cromática: blancos, amarillos, azules, violetas, marrones y negros.

\section{Exposiciones:}

- Safont, Saleta Municipal d'Onda, Regiduria de Cultura, del 24 al 31 octubre de 1999, Onda

- Manolo Safont. Un museu, un llegat i un compromís. MAMS. Del 27 de noviembre de 2004 al 8 de enero de 2005. Onda.

- Manolo Safont, un museu, un llegat. MAMS, mayo 2013, Onda

\section{Bibliografía:}

- Safont, Saleta Municipal d'Onda, Regiduria de Cultura, del 24 al 31 octubre de 1999, Onda

- http://www.eltriangulo.es/contenidos/?p=36891

- http://manolosafont.blogspot.com.es/

Imagen:

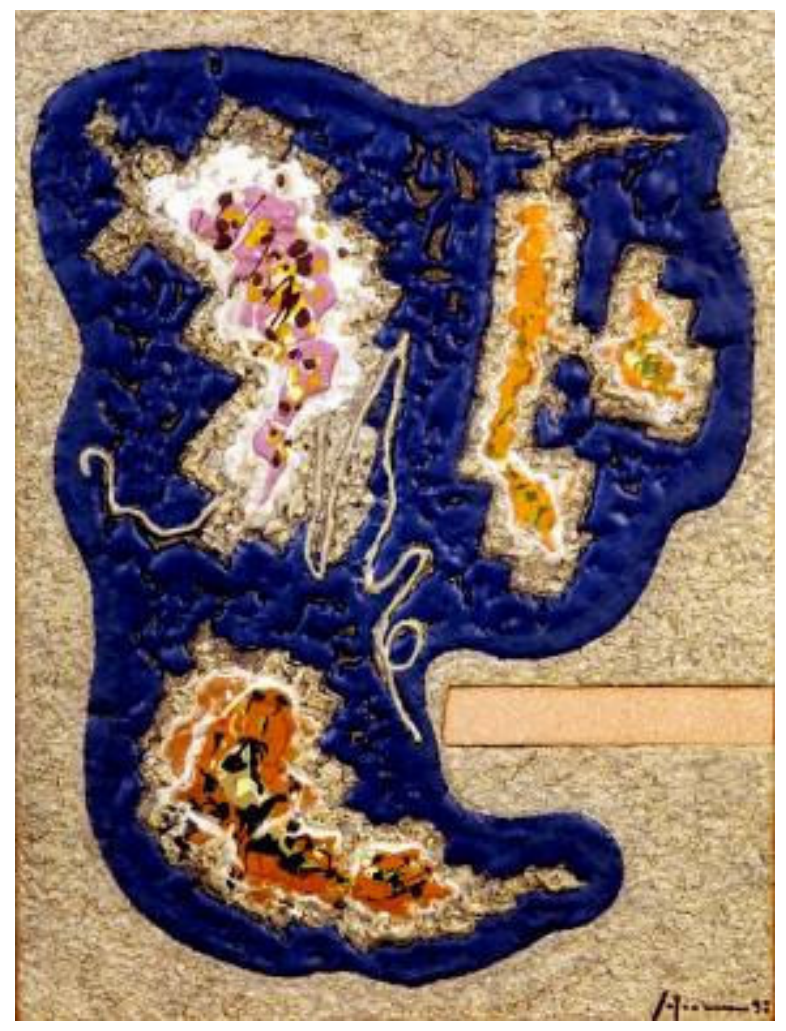


Imágenes relacionadas:

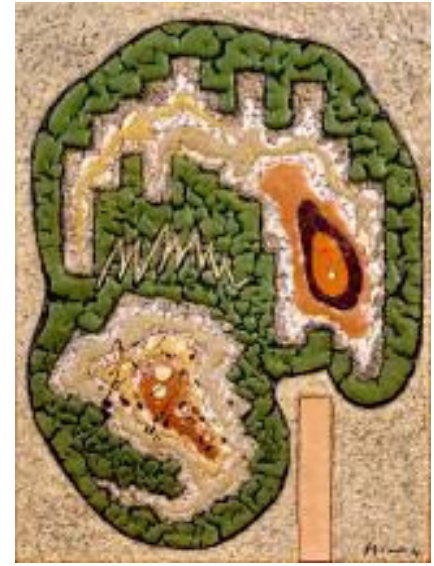

Obra cat. $n^{\circ} 93$

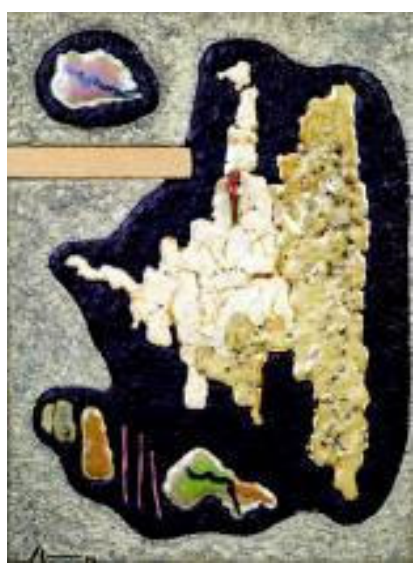

Obra cat. n95

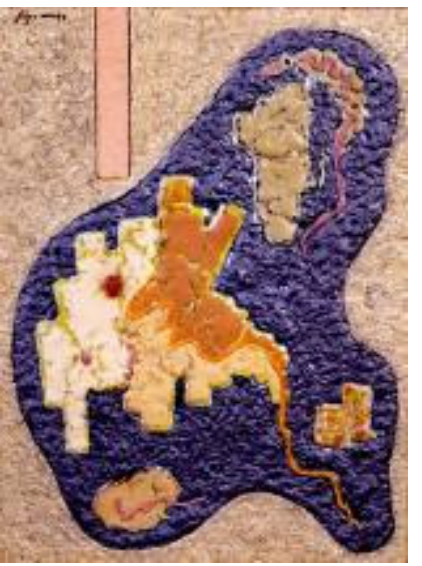

Obra cat. $n^{\circ} 96$ 
$\mathbf{N}^{0}: 5.95$

Título: Sin Título

Autoría: Manolo Safont

Datación: 1998

Inscripciones: Safont 98 en ángulo inferior izquierdo

Dimensiones: $54 \times 40 \mathrm{cms}$

Técnica: Pintura cerámica

Descripción: Obra compuesta por una única placa. Esta obra forma una serie junto con otras tres, catalogadas con el $n^{\circ} 93, n^{\circ} 94$ y $n^{\circ} 96$, con las que comparte tamaño, formato y estilo. Paleta cromática: blancos, amarillos, rojos, verdes, azules, violetas y negros.

Exposiciones:

- Safont, 9 octubre-9 noviembre 1998, Morella (Castellón)

\section{Bibliografía:}

- Safont, 9 octubre-9 noviembre 1998, Morella, Castellón, pág 30

\section{Imagen:}

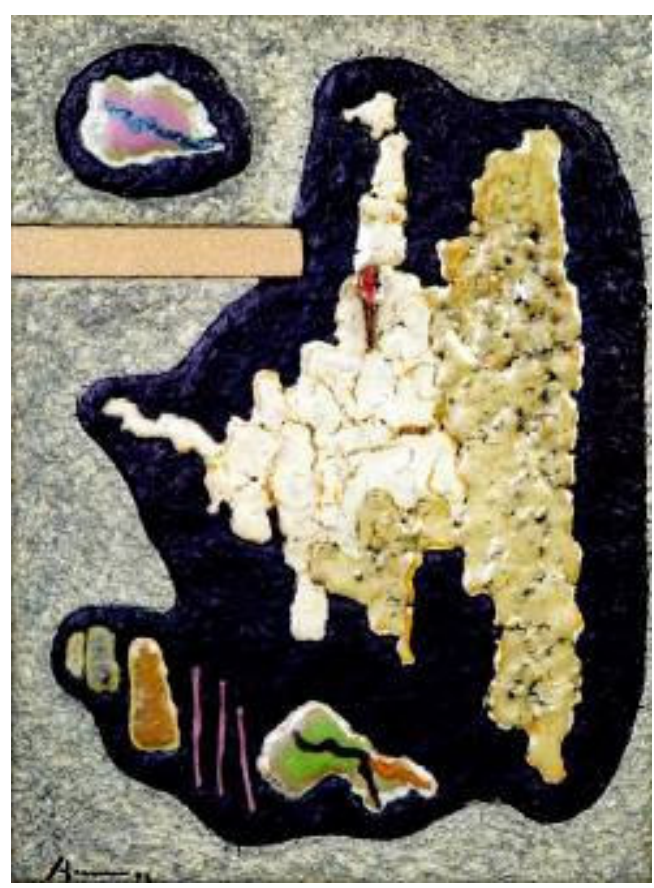

\section{Imágenes relacionadas:}

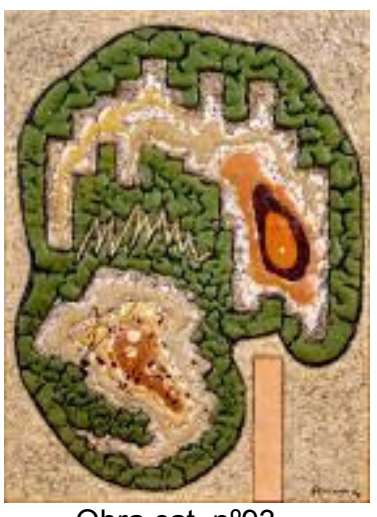

Obra cat. n॰93

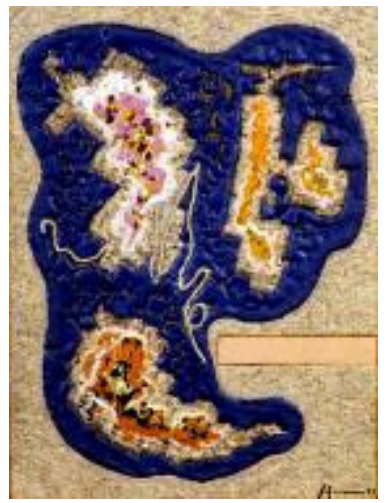

Obra cat. n॰94

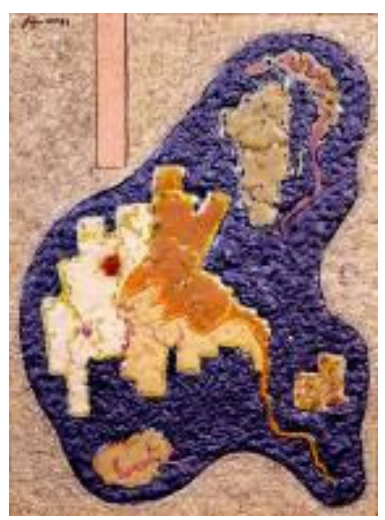

Obra cat. n96 
$N^{0}: 5.96$

Título: Sin Título

Autoría: Manolo Safont

Datación: 1998

Inscripciones: Safont 1998 en ángulo superior izquierdo

Dimensiones: $54 \times 50 \mathrm{cms}$

Técnica: Pintura cerámica

Observaciones: Obra compuesta por una única placa. Esta obra forma una serie junto con otras tres, catalogadas con el $n^{\circ} 93, n^{\circ} 94$ y $n^{\circ} 95$, con las que comparte tamaño, formato y estilo. Paleta cromática: blancos, ocres, rojos, azules y marrones.

\section{Imagen:}

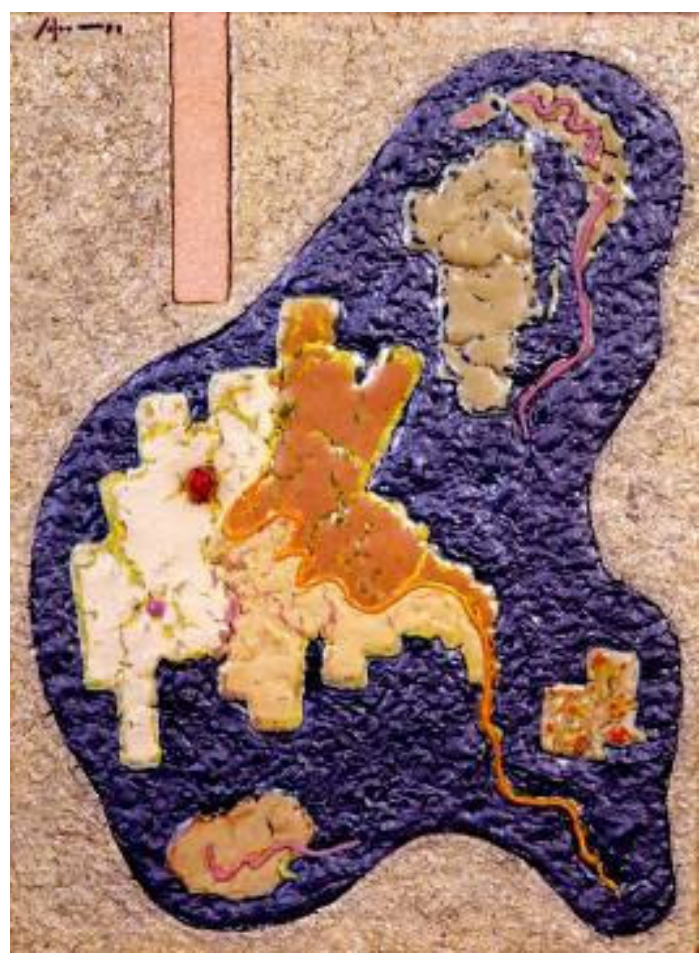

\section{Imágenes relacionadas:}

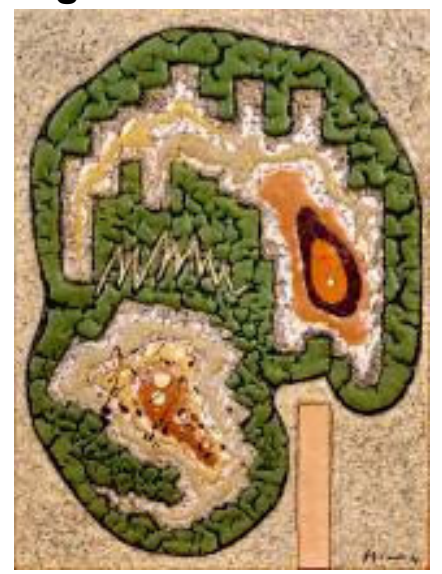

Obra cat. n93

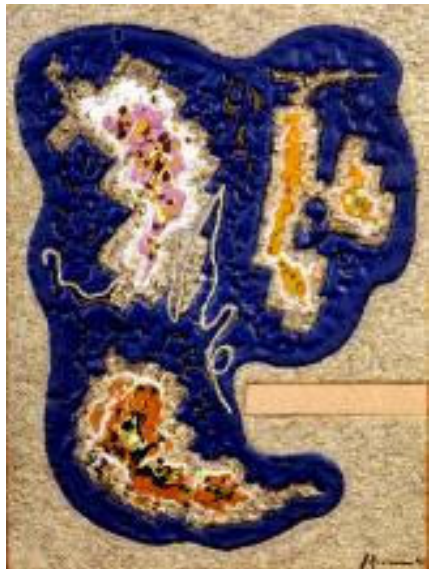

Obra cat. n॰94

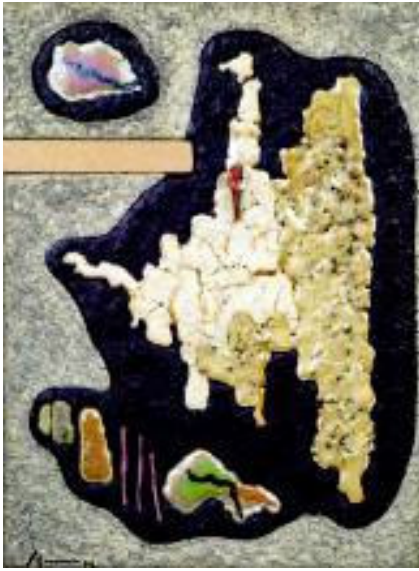

Obra cat. n95 
$\mathbf{N}^{0}: 5.97$

Título: Sin Título

Autoría: Manolo Safont

Datación: Inicio década 1980 - Final década 1990

Inscripciones: Safont en ángulo inferior izquierdo

Dimensiones: $80 \times 40 \mathrm{cms}$

Técnica: Pintura cerámica

Localización: MAMS

Descripción: Obra compuesta por 2 placas de diferentes tamaños. La pieza queda dividida por la mitad vertical con un gran desnivel provocado con relieve matérico de color oscuro, sobre el que destaca una pequeña mancha roja. Paleta cromática: blancos, amarillos, rojos y negros.

\section{Exposiciones:}

- Manolo Safont. Un museu, un llegat i un compromís. MAMS. Del 27 de noviembre de 2004 al 8 de enero de 2005. Onda

- Manolo Safont, un museu, un llegat, MAMS, mayo 2013, Onda

\section{Bibliografía:}

- http://www.eltriangulo.es/contenidos/?p=36891

- http://manolosafont.blogspot.com.es/

\section{Imagen:}

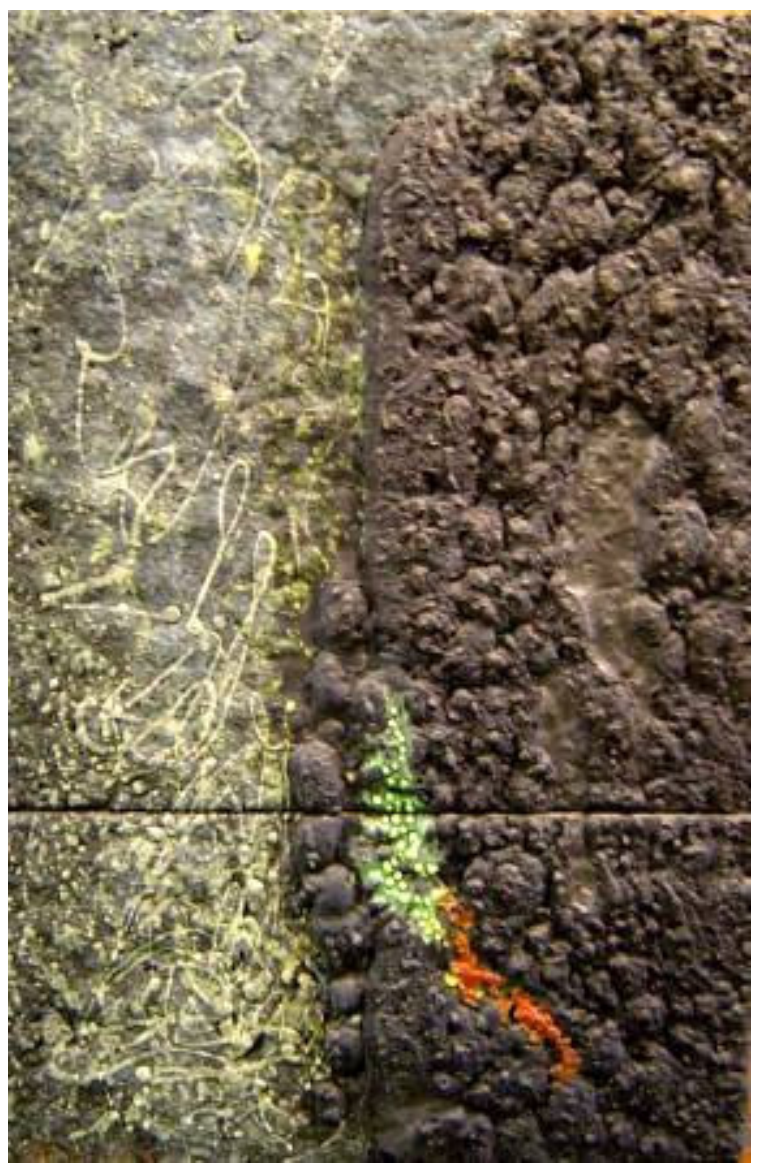


$\mathbf{N}^{0}: 5.98$

Título: Sin Título

Autoría: Manolo Safont

Datación: Inicio década 1980 - Final década 1990

Dimensiones: $40 \times 40 \mathrm{cms}$

Técnica: Pintura cerámica

Localización: MAMS

Descripción: Obra compuesta por una única pieza. Sobre fondo blanco destaca una mancha roja de forma alargada. Paleta cromática: blanco, amarillo, rojo y negro.

Exposiciones:

- Manolo Safont. Un museu, un llegat i un compromís. MAMS. Del 27 de noviembre de 2004 al 8 de enero de 2005. Onda

- Manolo Safont, un museu, un llegat, MAMS, mayo 2013, Onda

Bibliografía:

- http://www.eltriangulo.es/contenidos/?p=36891

- http://manolosafont.blogspot.com.es/

\section{Imagen:}

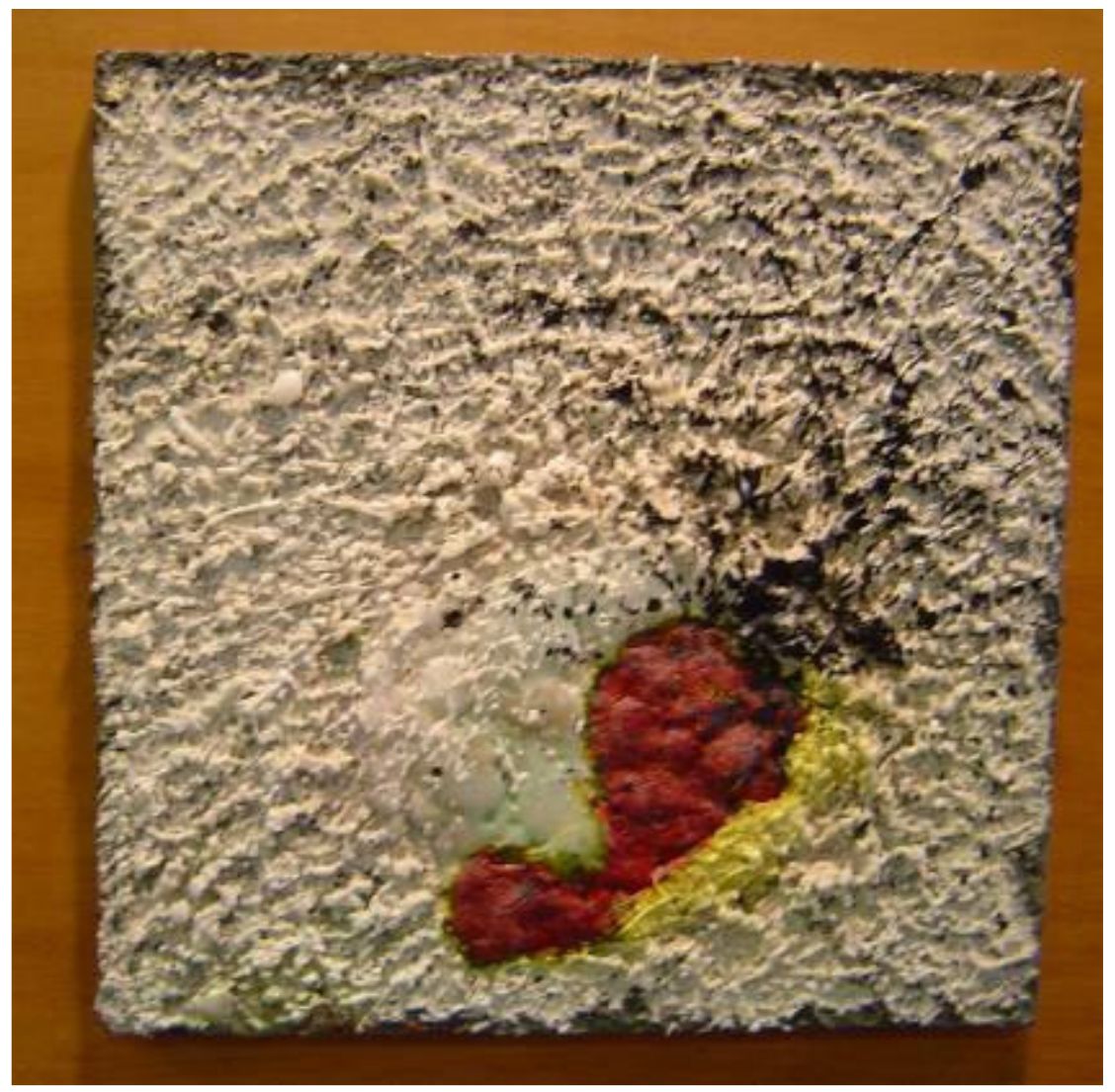


$\mathbf{N}^{0}: 5.99$

Título: Sin Título

Autoría: Manolo Safont

Datación: Inicio década 1980 - Final década 1990

Dimensiones: $40 \times 40 \mathrm{cms}$

Técnica: Pintura cerámica

Localización: MAMS

Descripción: Obra compuesta por una única placa, con recorte en el margen superior e inferior y un gran relieve en la zona central. Paleta cromática: blancos, amarillos, rojos, marrones y negros.

Exposiciones:

- Manolo Safont. Un museu, un llegat i un compromís. MAMS. Del 27 de noviembre de 2004 al 8 de enero de 2005. Onda

- Manolo Safont, un museu, un llegat, MAMS, mayo 2013, Onda

Bibliografía:

- http://www.eltriangulo.es/contenidos/?p=36891

- http://manolosafont.blogspot.com.es/

Imagen:

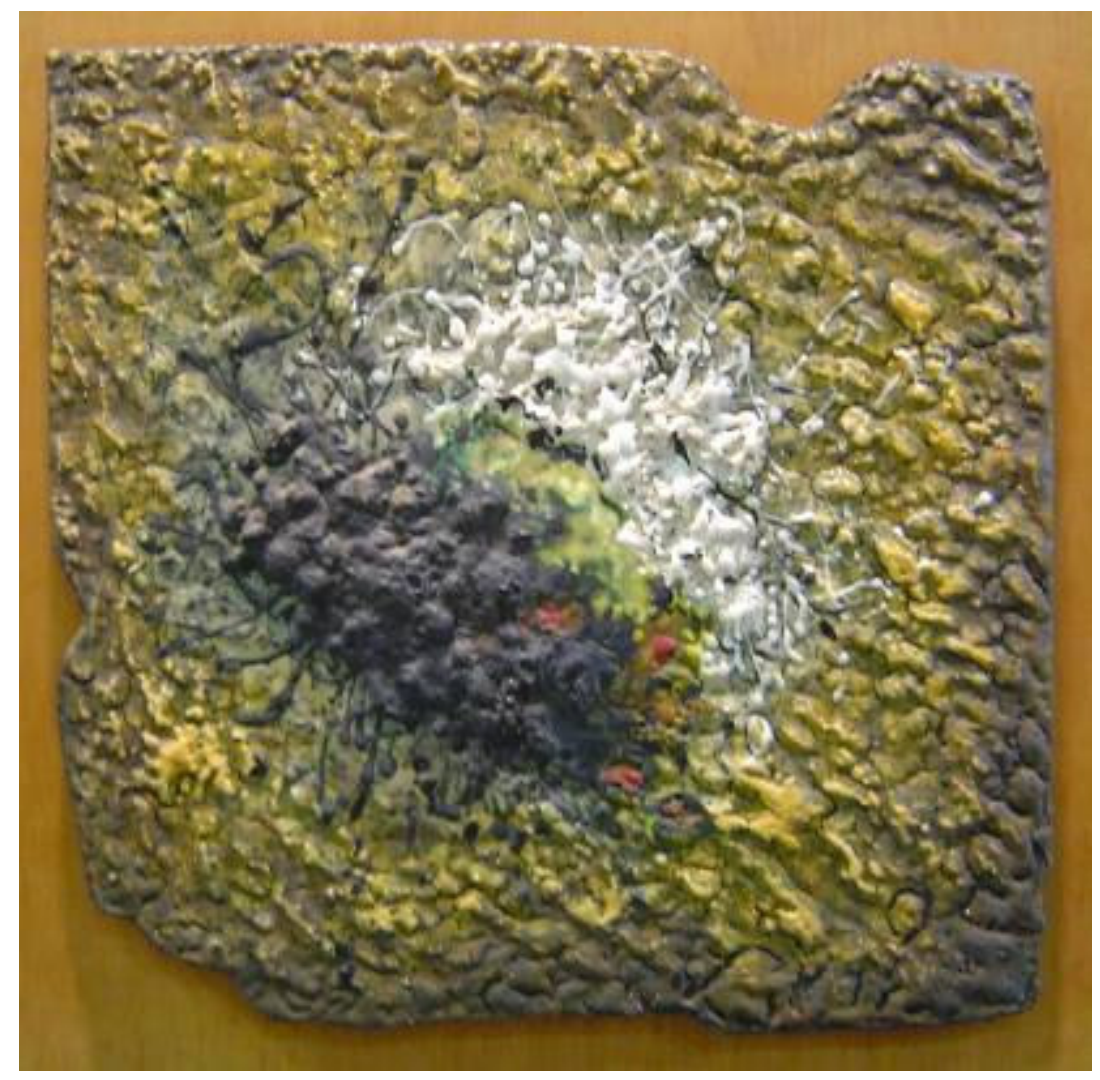




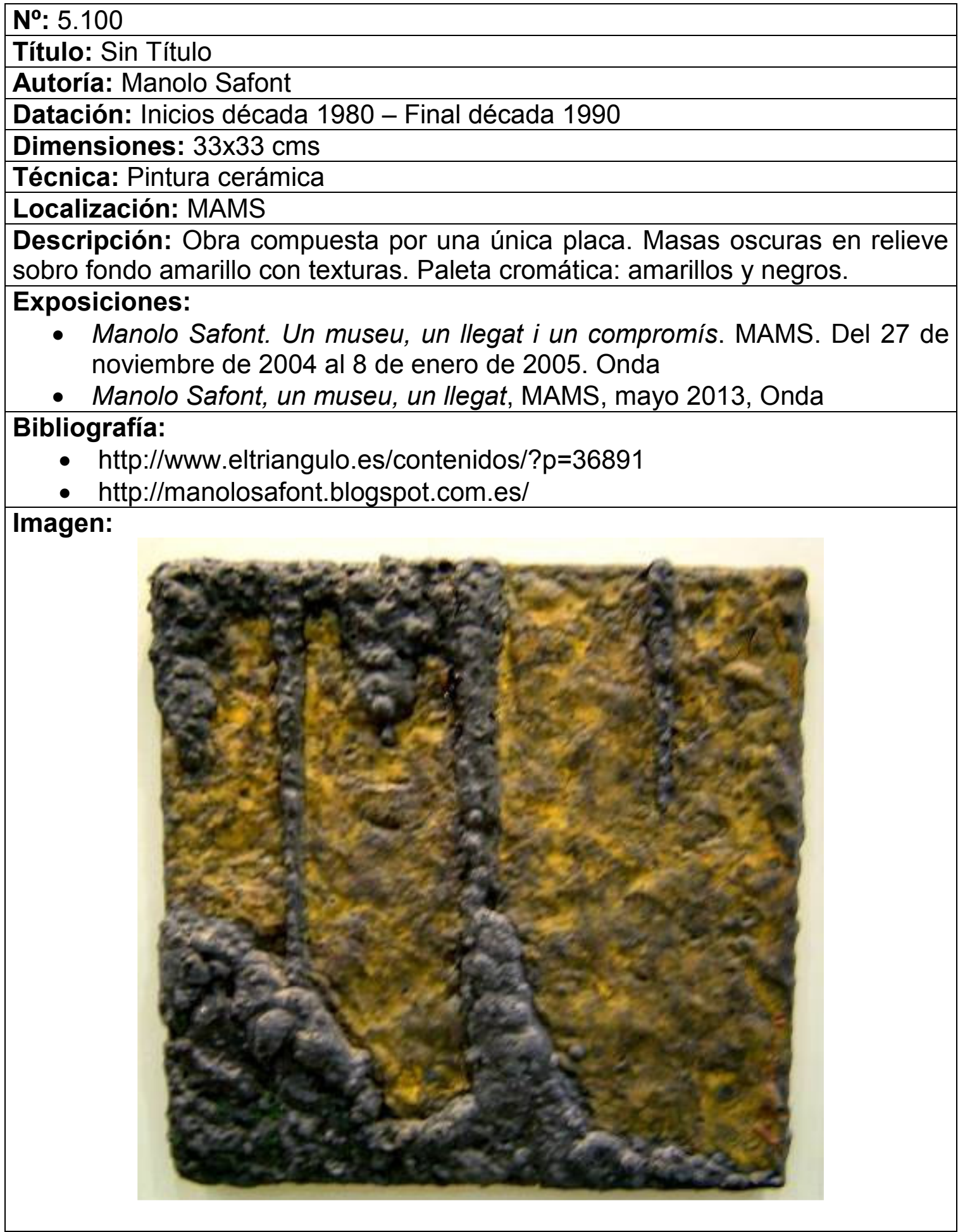


$\mathbf{N}^{0}: 5.101$

Título: Sin Título

Autoría: Manolo Safont

Datación: Inicio década 1980 - Final década 1990

Inscripciones: Safont en ángulo superior izquierdo

Dimensiones: $44 \times 51,50 \mathrm{cms}$

Técnica: Pintura cerámica

Localización: MAMS

Descripción: Obra compuesta por una única placa. Sobre un fondo verde, en los márgenes inferior y derecho crea una masa de gran volumen y textura de color negro, y entre ambas una pequeña masa blanca. Paleta cromática: blancos, verdes, marrones y negros.

Exposiciones:

- Manolo Safont. Un museu, un llegat i un compromís. MAMS. Del 27 de noviembre de 2004 al 8 de enero de 2005. Onda

- Manolo Safont, un museu, un llegat, MAMS, mayo 2013, Onda

Bibliografía:

- http://www.eltriangulo.es/contenidos/?p=36891

- http://manolosafont.blogspot.com.es/

Imagen:

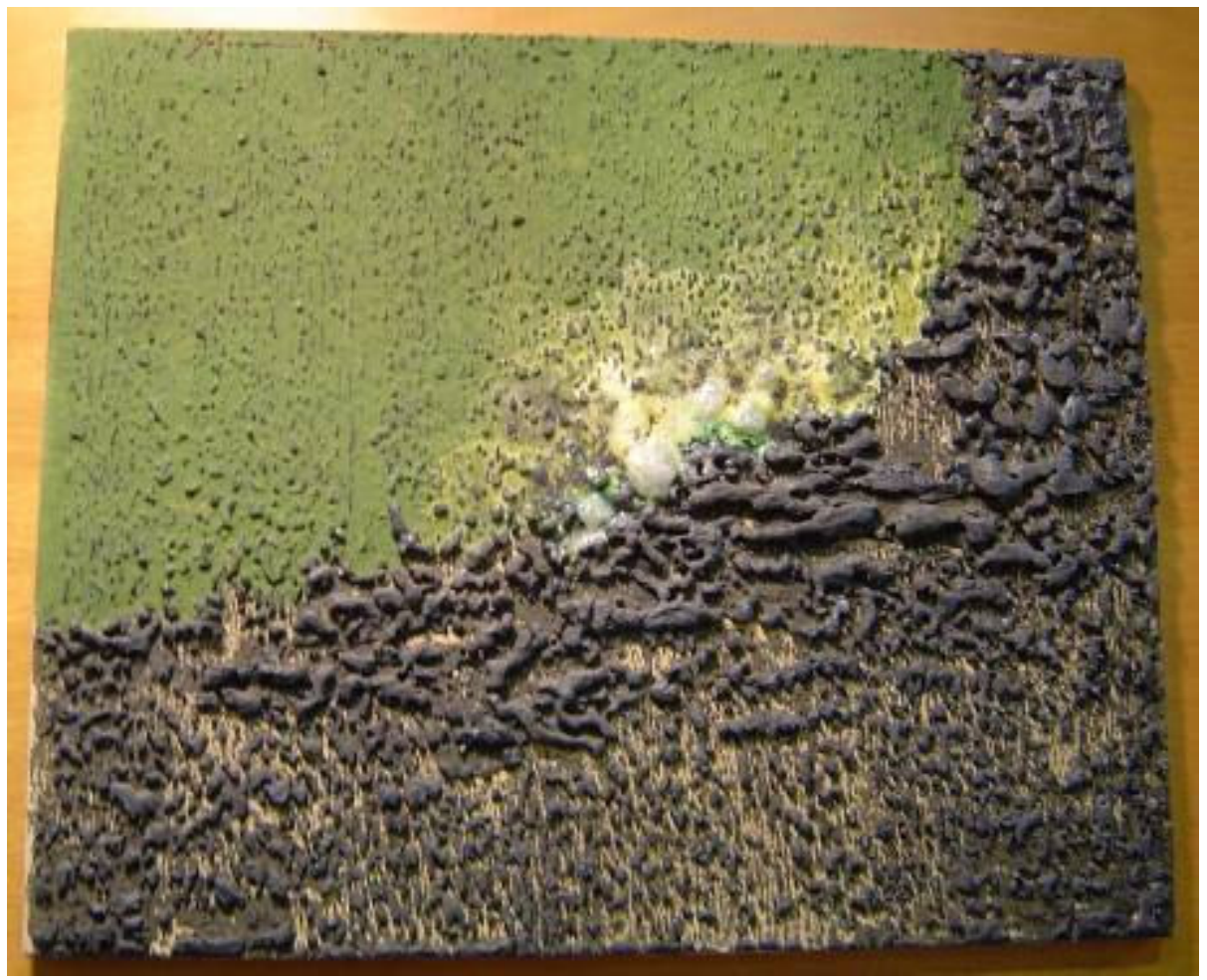


$N^{\circ}: 5.102$

Título: Sin Título

Autoría: Manolo Safont

Datación: Finales década 1980 - Inicios década 1990

Inscripciones: Safont en ángulo inferior izquierdo

Dimensiones: $40 \times 60 \mathrm{cms}$

Técnica: Pintura cerámica

Localización: MAMS

Descripción: Obra compuesta por 3 placas del mismo tamaño, en disposición vertical. La placa de la derecha presenta un recorte en el ángulo inferior derecho. Paleta cromática: amarillos, rojos y negros.

Exposiciones:

- Manolo Safont. Un museu, un llegat i un compromís. MAMS. Del 27 de noviembre de 2004 al 8 de enero de 2005. Onda

- Manolo Safont, un museu, un llegat, MAMS, mayo 2013, Onda

Bibliografía:

- http://www.eltriangulo.es/contenidos/?p=36891

- http://manolosafont.blogspot.com.es/

Imagen:

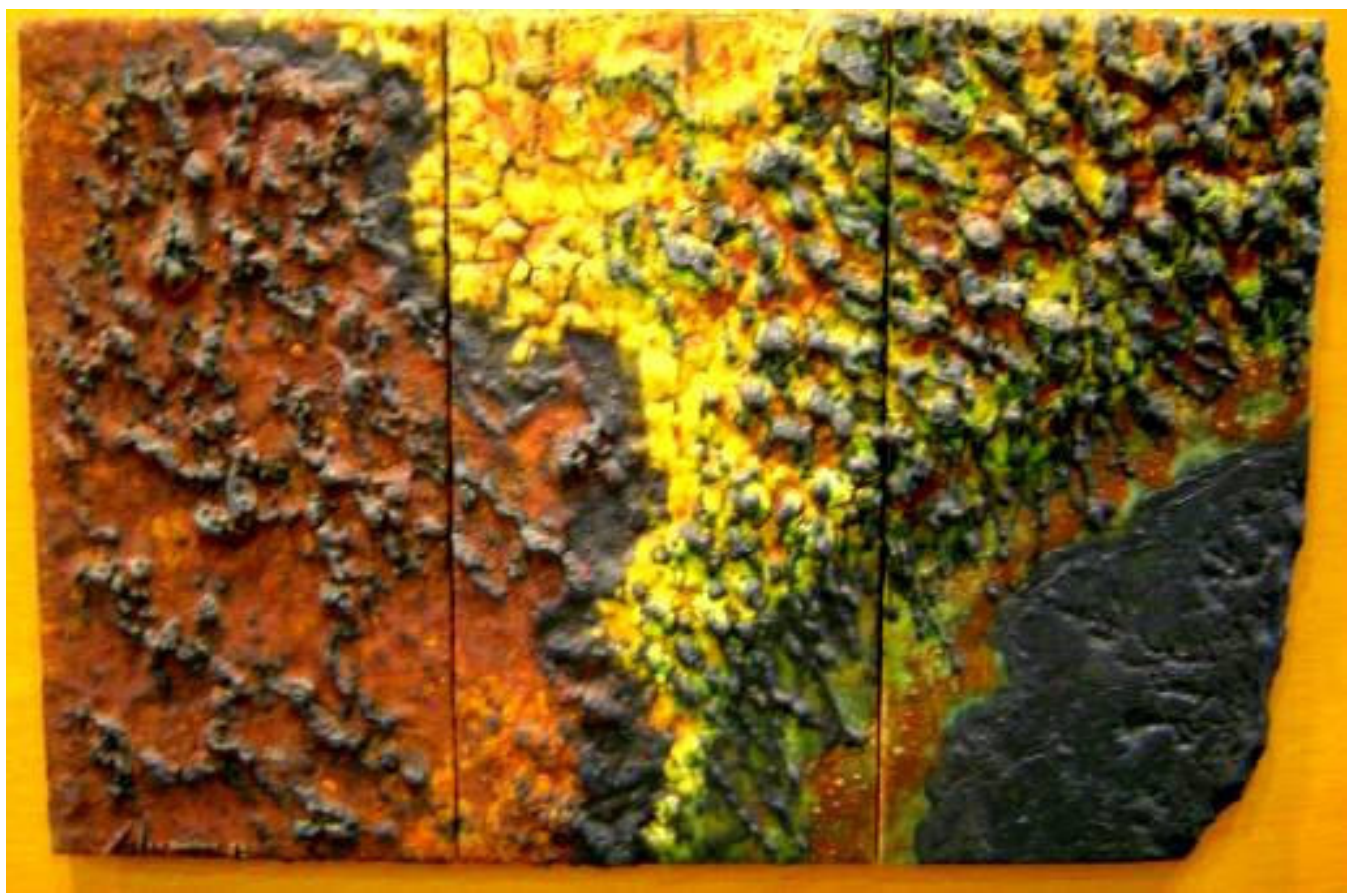


No: 5.103

Título: Sin Título

Autoría: Manolo Safont

Datación: Década 1990

Técnica: Pintura cerámica

Descripción: Obra compuesta por una única placa. Dos masas claramente diferenciadas, con color marrón a la izquierda y negro a la derecha, sobre la masa marrón y en la zona inferior destaca un círculo rojo en relieve. Paleta cromática: rojos, marrones y negros.

Bibliografía:

- http://manolosafont.blogspot.com.es/

\section{Imagen:}

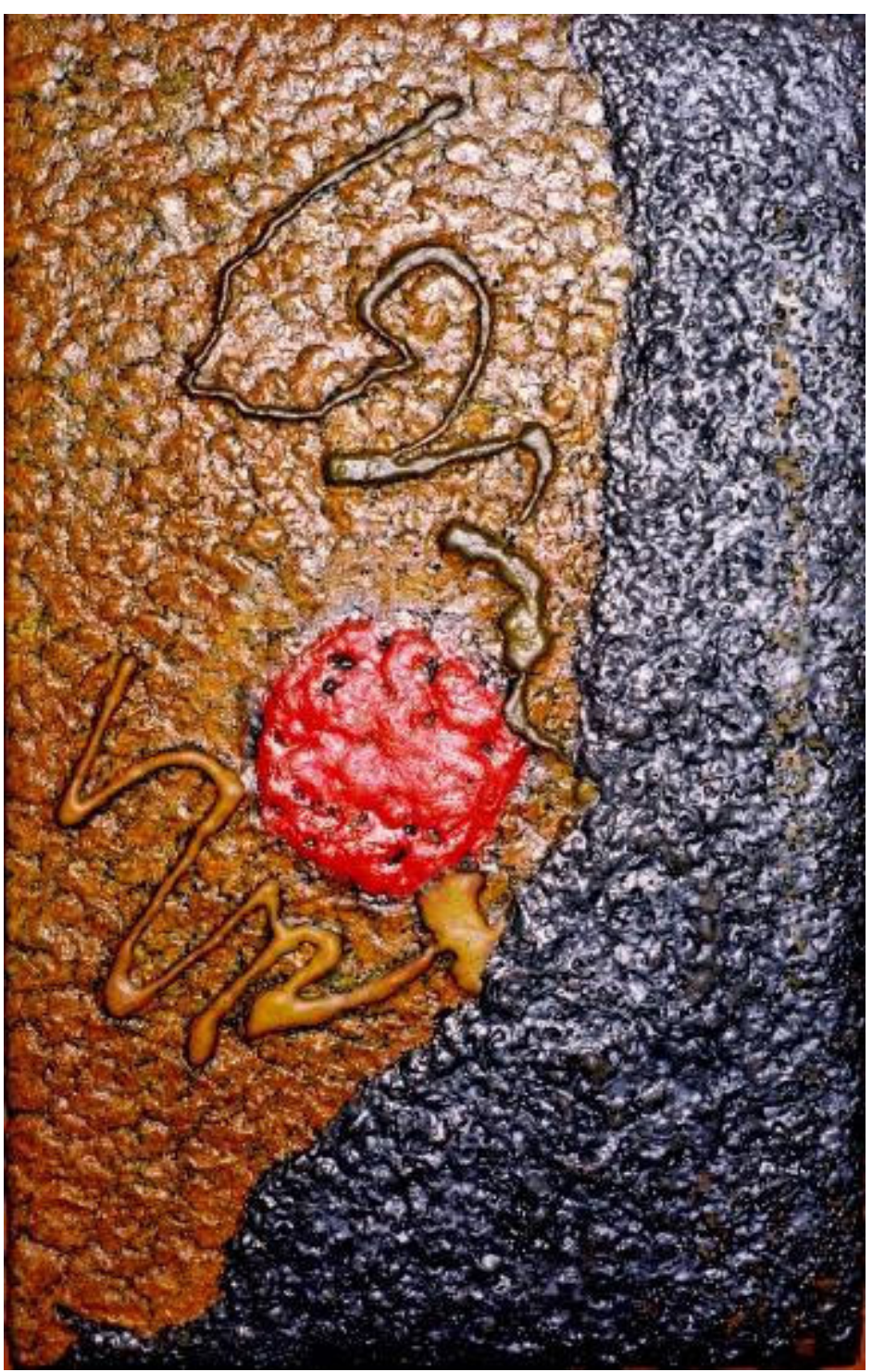


$N^{0}: 5.104$

Título: Sin Título

Autoría: Manolo Safont

Datación: Década 1990

Inscripciones: Safont en ángulo inferior derecho

Dimensiones: $40 \times 54 \mathrm{cms}$

Técnica: Pintura cerámica

Localización: MAMS

Descripción: Obra compuesta por una única placa. Sobre fondo azul, destaca en el margen izquierdo una gran masa en colores claros, separada con unas líneas trazadas en relieve y ligeramente onduladas que separan la zona derecha de la composición, en la que hay cuatro formas geométricas rectangulares de color blanco, ocre y violeta. Paleta cromática: blancos, amarillos, ocres, rojos, verdes, azules y violetas.

\section{Exposiciones:}

- Safont, 9 octubre-9 noviembre 1998, Morella (Castellón)

\section{Bibliografía:}

- Safont, 9 octubre-9 noviembre 1998, Morella (Castellón), pág. 29 Imagen:

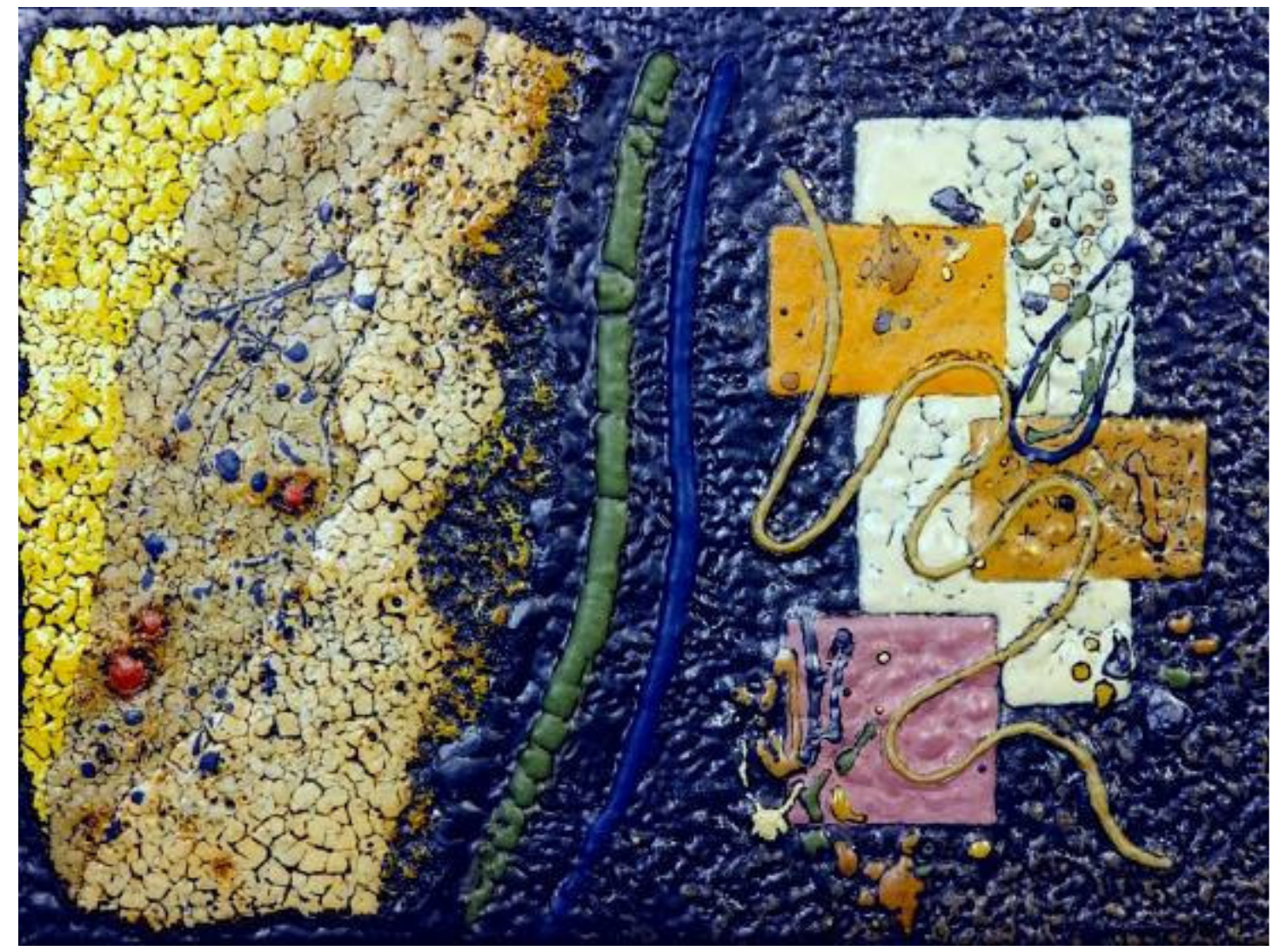


$N^{0}: 5.105$

Título: Sin Título

Autoría: Manolo Safont

Datación: Década 1990

Técnica: Pintura cerámica

Descripción: Obra compuesta por una única placa. Una gran masa roja en la zona superior sobre un fondo blanco que presenta en el margen inferior una masa de color negro del que parte en diagonal hacia el ángulo superior derecho una masa amarilla. El motivo de la coma o apóstrofo invertido, como reflejado en un espejo, es utilizado por Safont en otras obras, como la obra catalogada $\mathrm{n}^{0}$ 2.44. Paleta cromática: blancos, amarillos, rojos, verdes, azules y violetas.

\section{Bibliografía:}

- http://manolosafont.blogspot.com.es/

Imagen:

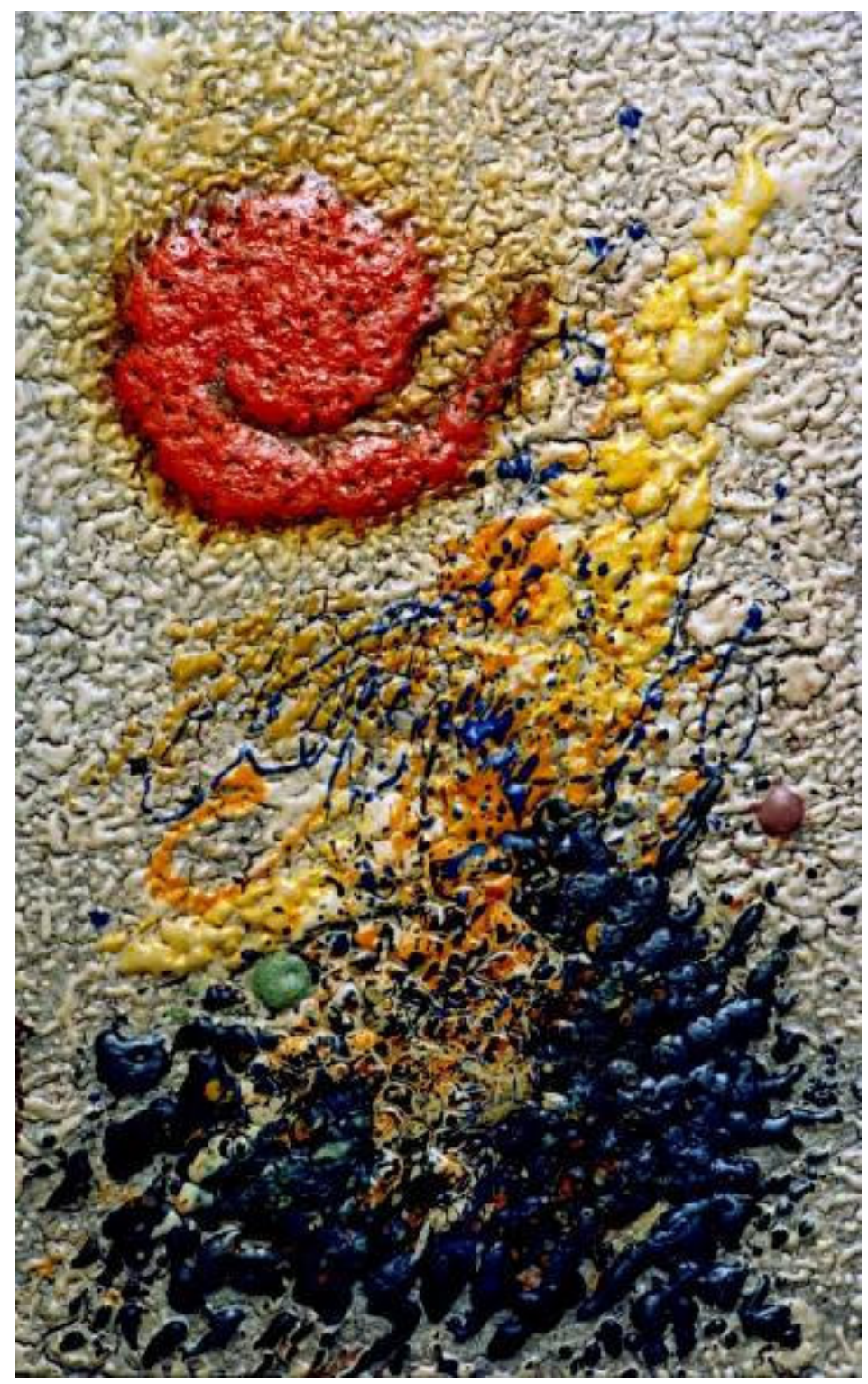


Imágenes relacionadas:

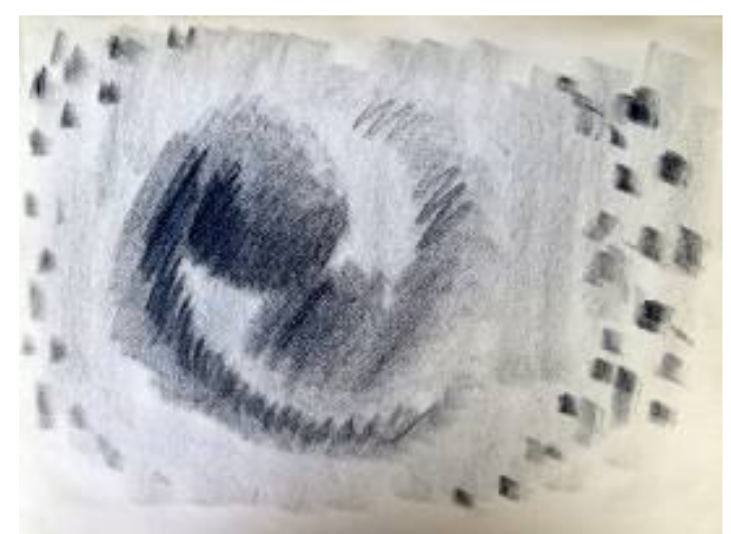

Obra cat. $n^{\circ} 2.44$ 
No: 5.106

Título: Sin Título

Autoría: Manolo Safont

Datación: Década 1990

Técnica: Pintura cerámica

Descripción: Obra compuesta por una única placa. Salpicaduras blancas y negras, con pequeñas manchas rojas sobre fondo ocre texturizado. Paleta cromática: blancos, ocres, rojos y negros.

\section{Bibliografía:}

- http://manolosafont.blogspot.com.es/ Imagen:

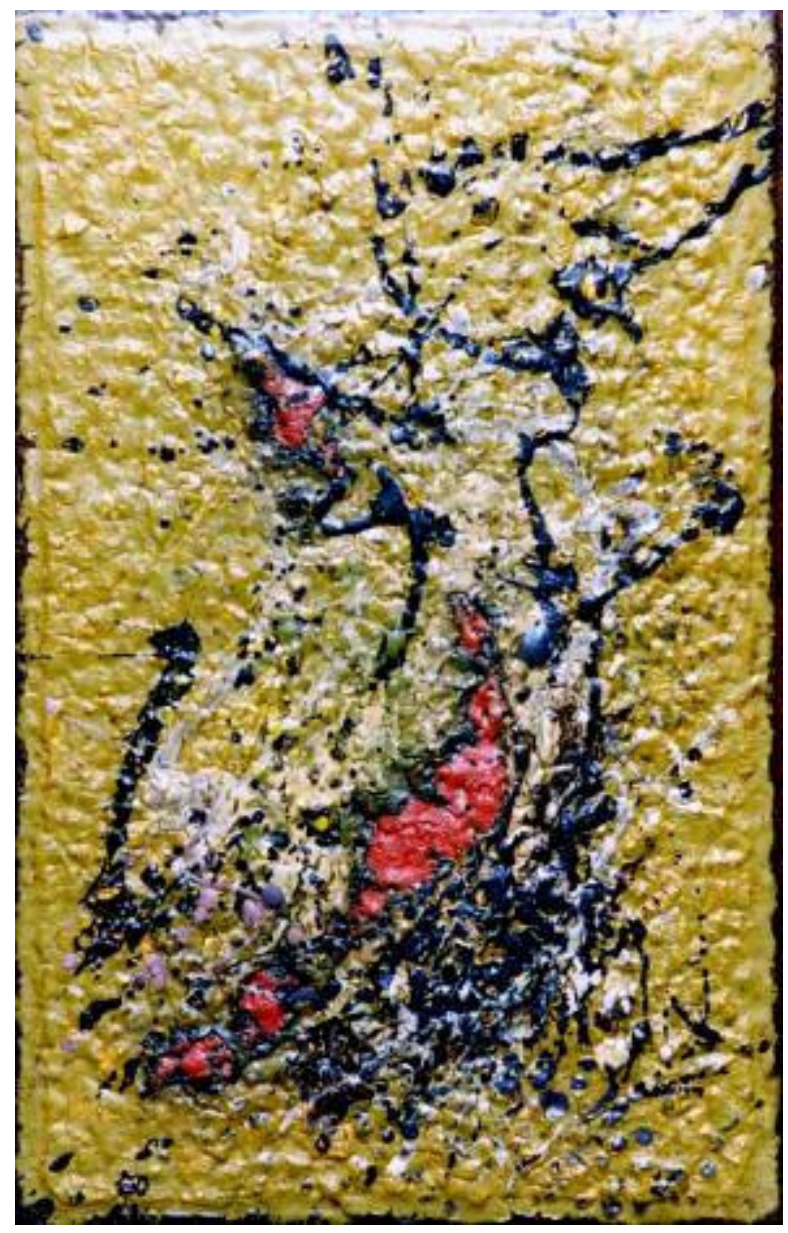


$\mathbf{N}^{0}: 5.107$

Título: Sin Título

Autoría: Manolo Safont

Datación: Década 1990

Inscripciones: Safont en ángulo superior izquierdo

Dimensiones: $60 \times 38 \mathrm{cms}$

Técnica: Pintura cerámica

Descripción: Obra compuesta por una única placa. Predominio de masas verticales rectangulares de diferentes colores sobre los que se marca una línea de color claro silueteando la masa de color gris situada en el margen izquierdo de la composición. Paleta cromática: blancos, amarillos, rojos, verdes, azules y negros.

Exposiciones:

- Safont, 9 octubre - 9 noviembre 1998, Morella, Castellón

\section{Bibliografía:}

- Safont, 9 octubre - 9 noviembre 1998, Morella, Castellón

- http://manolosafont.blogspot.com.es/

\section{Imagen:}

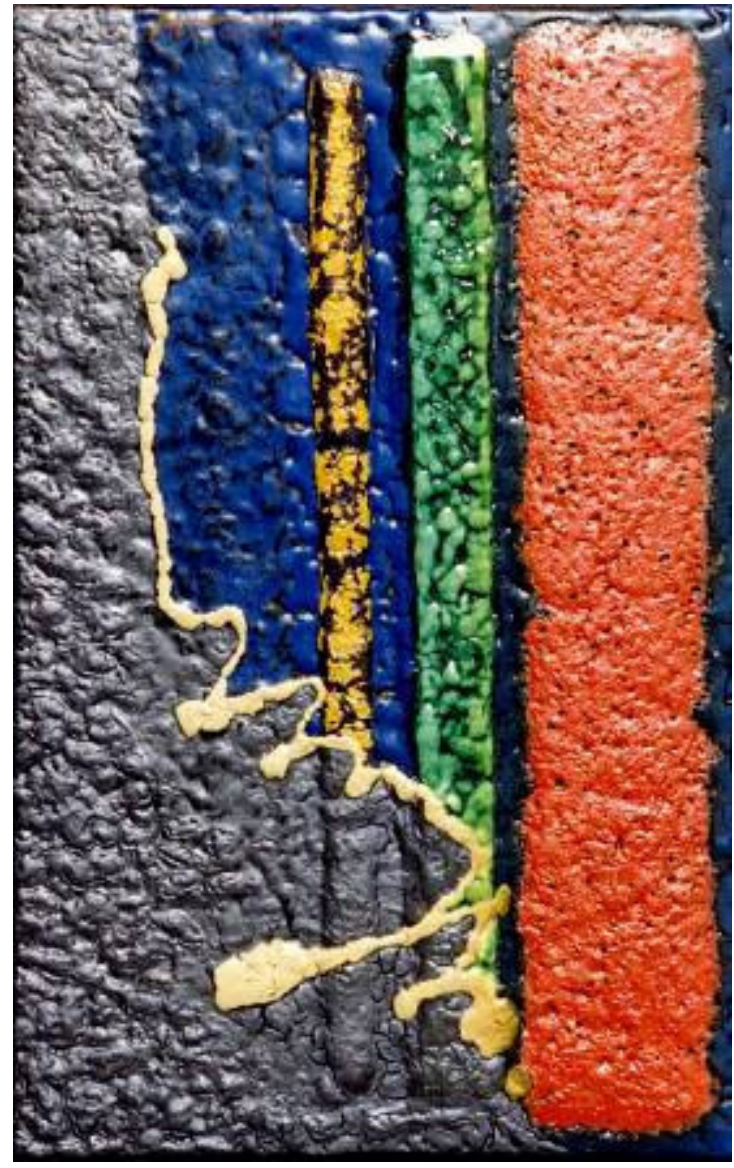


No: 5.108

Título: Sin Título

Autoría: Manolo Safont

Datación: Década 1990

Inscripciones: Safont en ángulo inferior izquierdo

Dimensiones: $54 \times 40 \mathrm{cms}$

Técnica: Pintura cerámica

Localización: Colección privada $\mathrm{n}^{\circ} 22$, Onda.

Descripción: Obra compuesta por una única placa. Base muy rugosa de color claro, coloreada en algunas zonas con esmalte sobrepuesto de colores ocre, violeta, naranja y rojo, con salpicaduras y líneas curvas en color blanco y azul. Esta obra forma pareja con la obra catalogada n5.109 .Paleta cromática: blancos, amarillos, ocres, rojos, azules y violetas.

\section{Bibliografía:}

- http://manolosafont.blogspot.com.es/ Imagen:

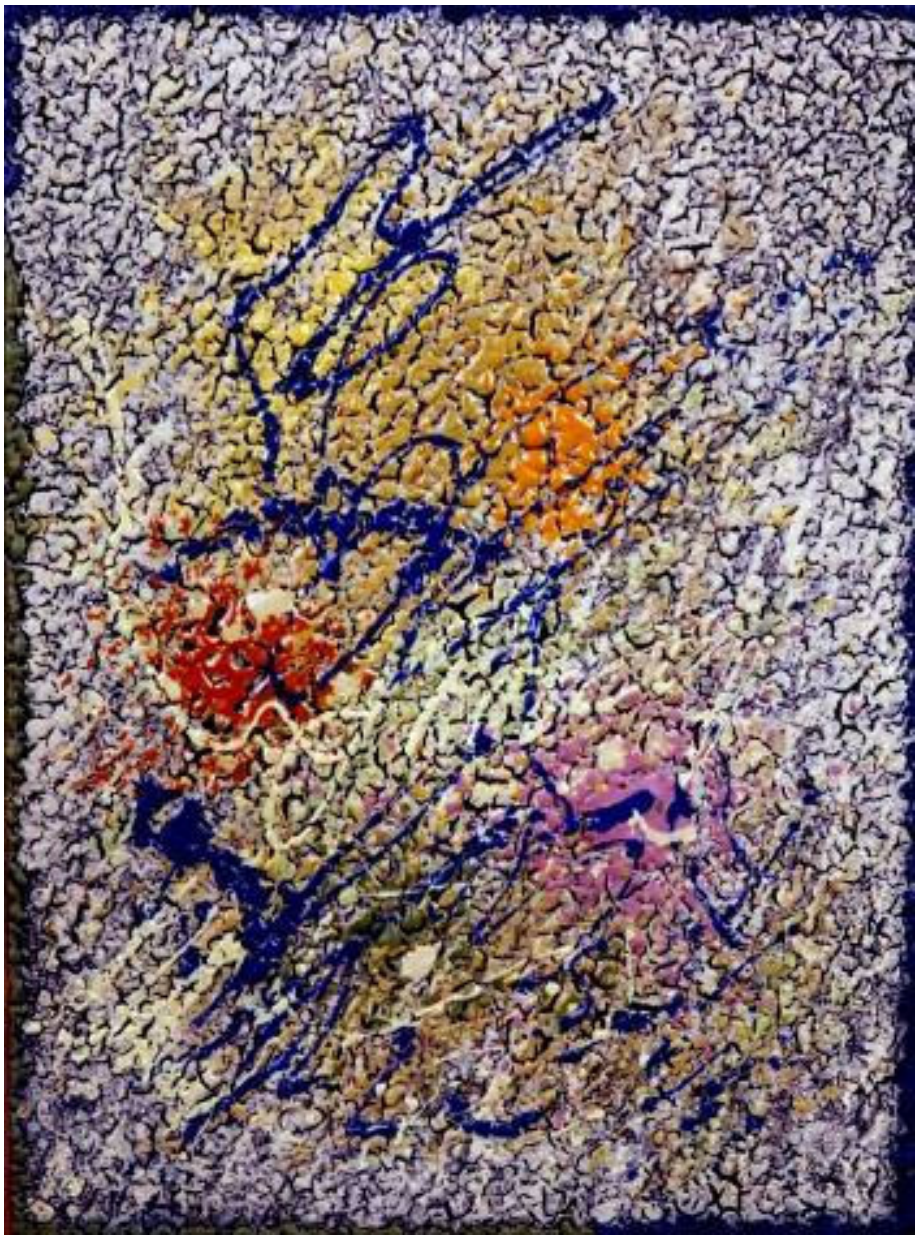


No: 5.109

Título: Sin Título

Autoría: Manolo Safont

Datación: Década 1990

Dimensiones: $54 \times 40 \mathrm{cms}$

Técnica: Pintura cerámica

Localización: Colección privada $n^{\circ} 21$, Onda.

Descripción: Obra compuesta por una única placa. Base muy rugosa de color claro, coloreada en algunas zonas con esmalte sobrepuesto de colores ocre, naranja y una pequeña masa alargada de color rojo, con salpicaduras y líneas curvas en color azul. Esta obra forma pareja con la obra catalogada $n^{0} 5.108$. Paleta cromática: blancos, amarillos, ocres, rojos, azules y violetas. Imagen:

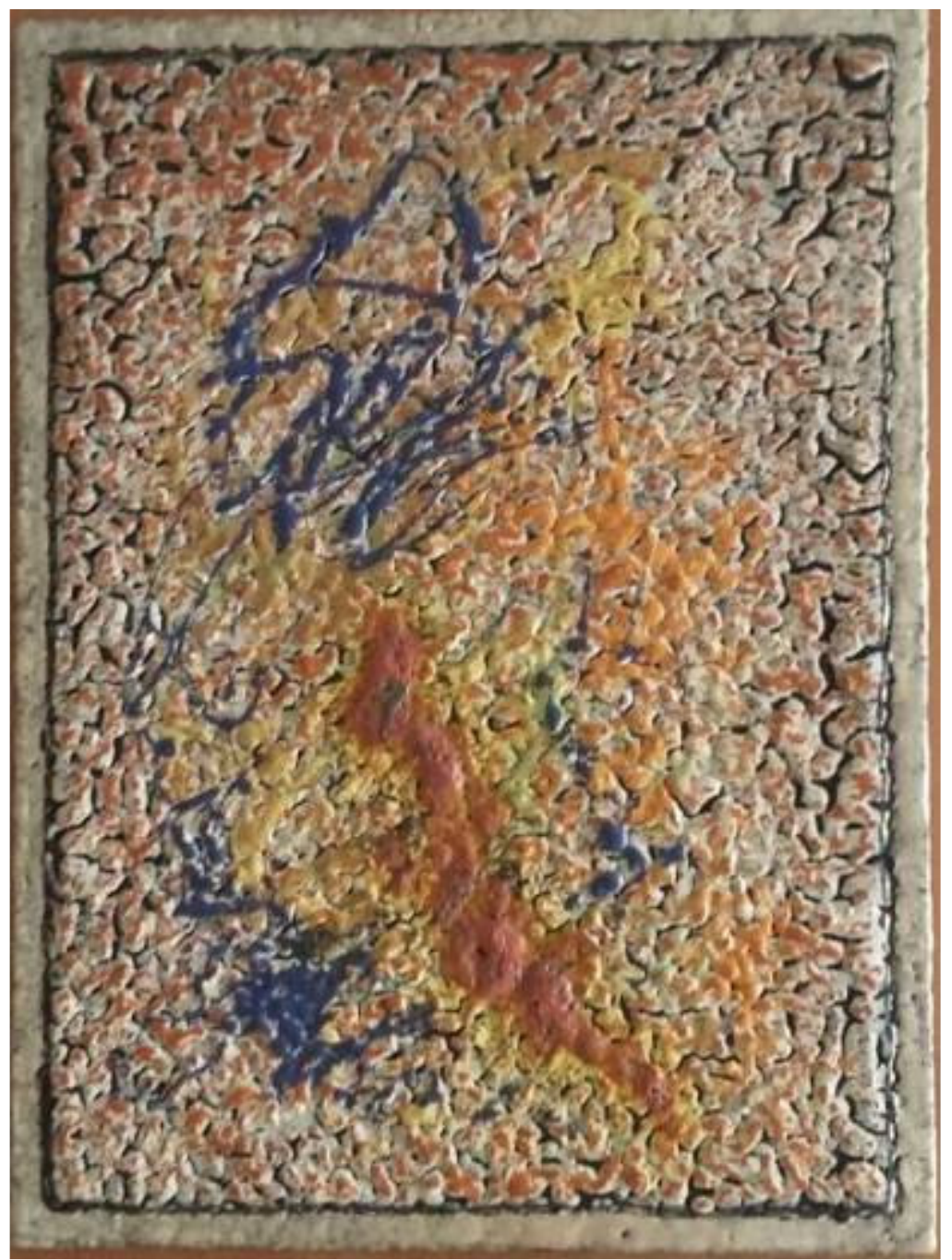


$N^{0}: 5.110$

Título: Sin Título

Autoría: Manolo Safont

Datación: Década 1990

Inscripciones: Safont en ángulo inferior derecho

Dimensiones: $40 \times 56 \mathrm{cms}$

Técnica: Pintura cerámica

Localización: Colección privada $n^{013}$, Onda

Descripción: Obra compuesta por una única placa. Masas en disposición curva en dirección diagonal de diversos colores, con masa roja circular en el margen superior izquierdo y masa azul circular en el margen inferior derecho. Paleta cromática: blancos, amarillos, rojos, azules, marrones y negros.

Exposiciones:

- Safont, 9 octubre-9 noviembre 1998, Morella, Castellón

Bibliografía:

- Safont, 9 octubre-9 noviembre 1998, Morella, Castellón, pág 31

- http://manolosafont.blogspot.com.es/

Imagen:

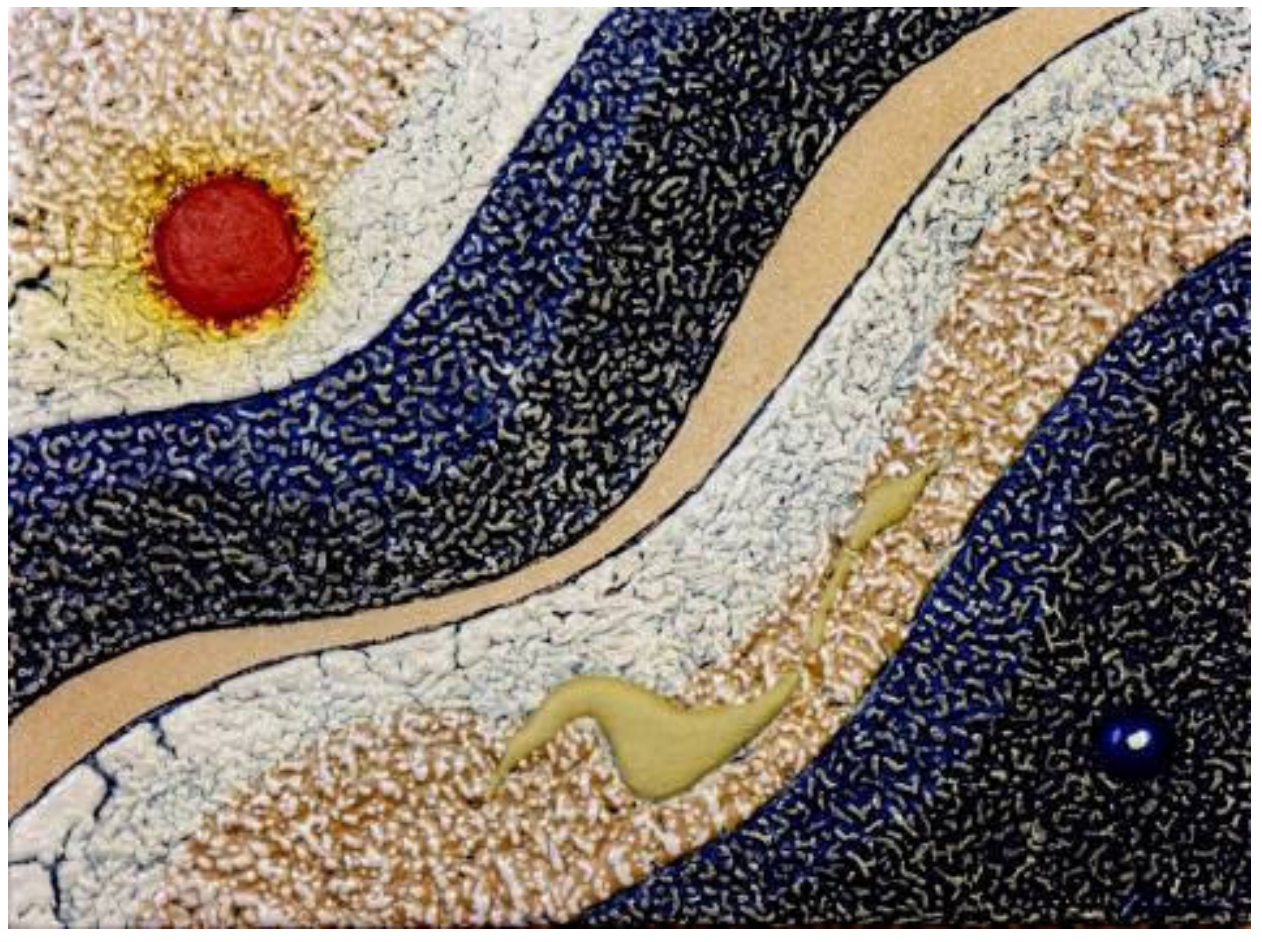


$\mathbf{N}^{0}: 5.111$

Título: Sin Título

Autoría: Manolo Safont

Datación: Década 1990

Inscripciones: Safont en ángulo inferior derecho

Dimensiones: $38 \times 120 \mathrm{cms}$

Técnica: Pintura cerámica

Descripción: Obra compuesta por 2 placas de igual tamaño. Sobre fondo gris cruza un estrecho rectángulo de color blanco que divide las dos piezas en cuatro espacios, quedando casi limpio la placa situada a la izquierda de la composición, mientras que en el margen derecho de la segunda placa se aprecia una masa de color verde con borde negro y pequeña masa circular roja, con salpicaduras blancas y negras. Paleta cromática: blancos, rojos, verdes, azules y negros.

Exposiciones:

- Safont, 9 octubre-9 noviembre 1998, Morella, Castellón

\section{Bibliografía:}

- Safont, 9 octubre-9 noviembre 1998, Morella, Castellón, pág. 26

- http://manolosafont.blogspot.com.es/

\section{Imagen:}

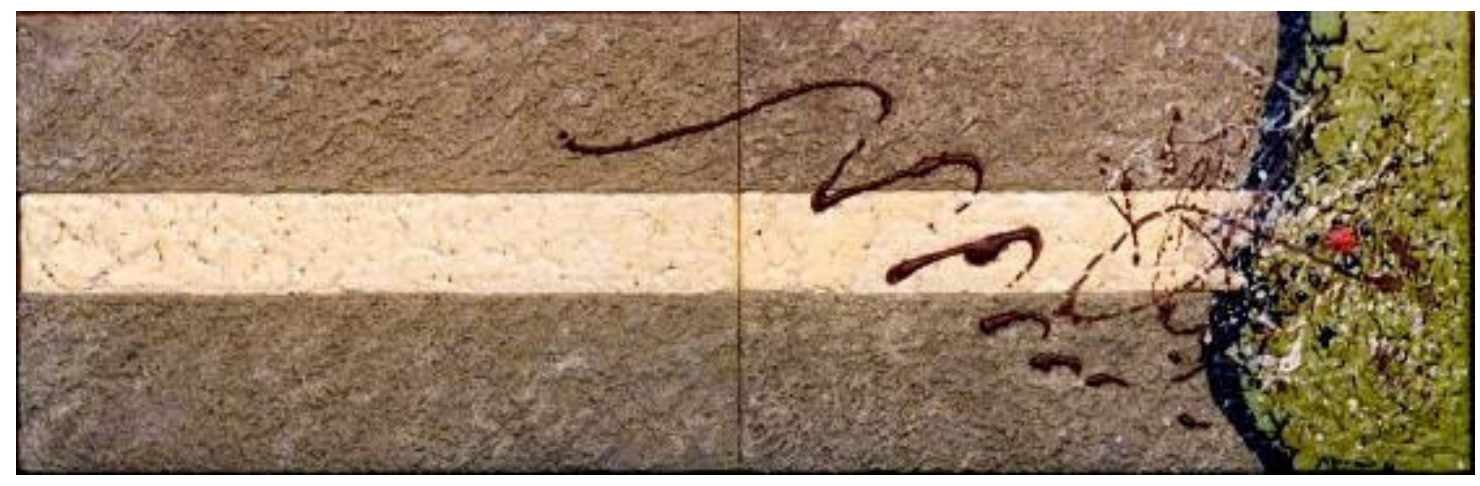


$\mathbf{N}^{0}: 5.112$

Título: Sin Título

Autoría: Manolo Safont

Datación: Década 1990

Inscripciones: Safont en ángulo inferior derecho

Técnica: Pintura cerámica

Descripción: Obra compuesta por 2 placas del mismo tamaño. La placa situada a la izquierda completamente llena de salpicaduras blancas, violetas, amarillas y roja, contrasta con la austeridad de la placa situada a la derecha, con una estrecha masa vertical ahusada de color negro sobre un texturizado fondo gris. Paleta cromática: blancos, amarillos, rojos, azules, violetas y negros. Bibliografía:

- http://manolosafont.blogspot.com.es/

Imagen:

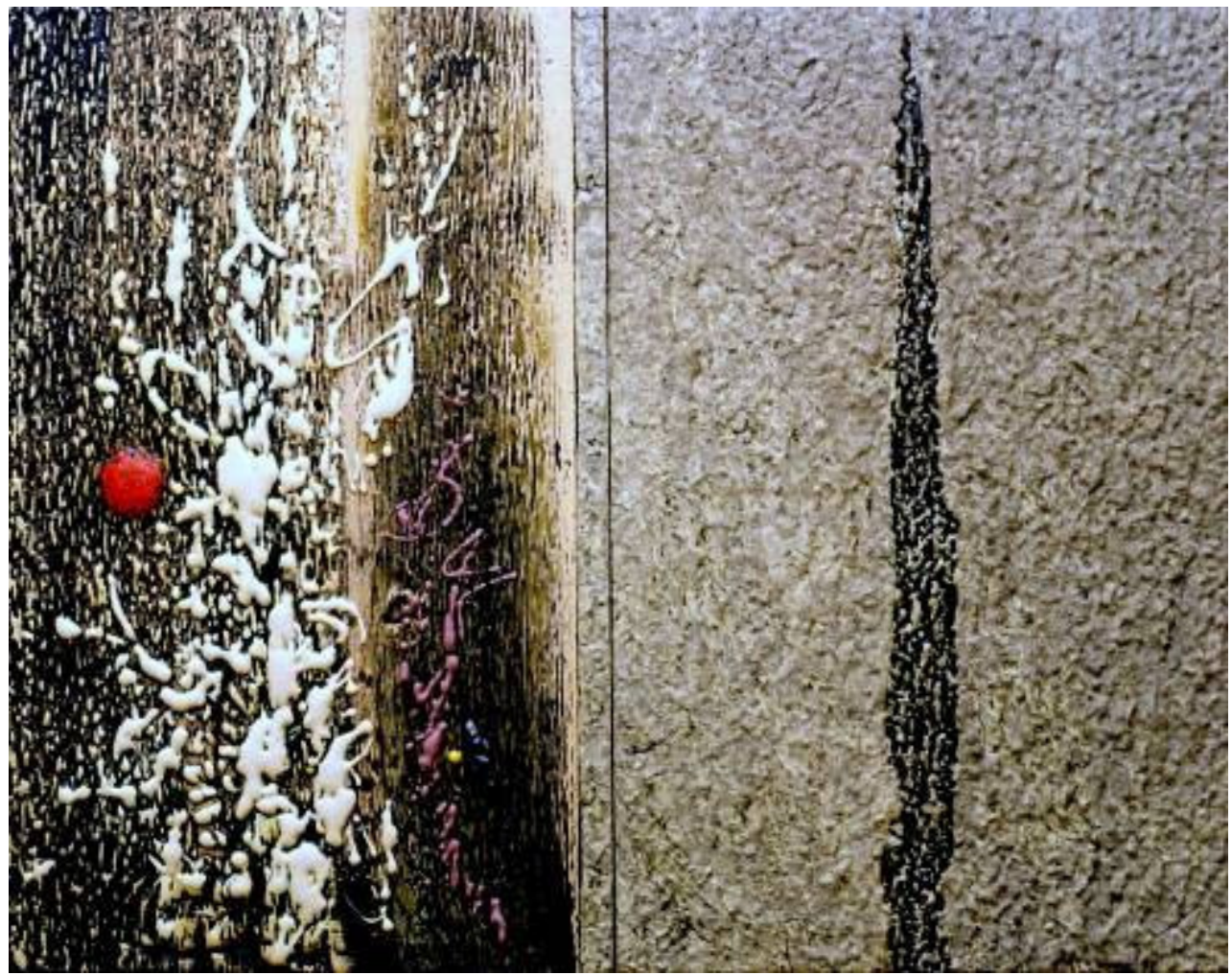


$N^{0}: 5.113$

Título: Sin Título

Autoría: Manolo Safont

Datación: Década 1990

Dimensiones: $12 \times 18,5 \mathrm{cms}$

Técnica: Pintura cerámica

Localización: MAMS

Descripción: Obra compuesta por una única placa. Mancha roja de forma ahusada, rodeada de pequeñas manchas circulares amarillas sobre superficie rugosa de color negro. Paleta cromática: blancos, amarillos, rojos y negros.

Exposiciones:

- Manolo Safont. Un museu, un llegat i un compromís. MAMS. Del 27 de noviembre de 2004 al 8 de enero de 2005. Onda.

\section{Imagen:}

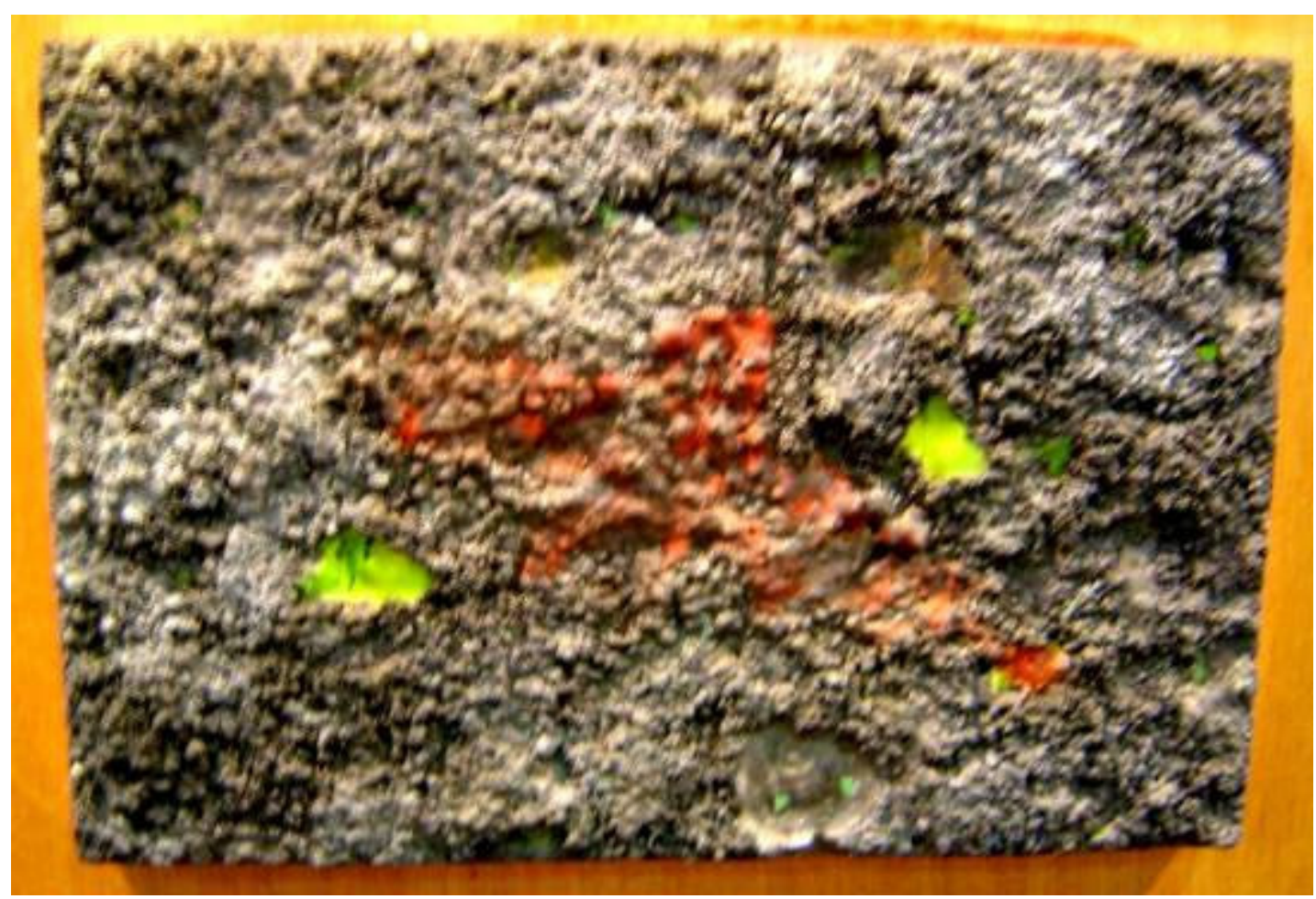


No: 5.114

Título: Sin Título

Autoría: Manolo Safont

Datación: Anterior a 2004

Dimensiones: $63 \times 63 \mathrm{cms}$

Técnica: Pintura cerámica

Localización: Colección privada $\mathrm{n}^{\circ} 15$, Onda.

Descripción: Obra compuesta por 10 placas de diferentes tamaños. Dos grandes manchas negras, que parecen dos notas musicales, sobre una base levemente texturizada de color marrón, sobre la que también se crea una mancha naranja y verde, y un círculo rojo. Paleta cromática: naranja, rojos, verdes, marrones y negros.

Exposiciones:

- Manolo Safont. Un museu, un llegat i un compromís. MAMS. Del 27 de noviembre de 2004 al 8 de enero de 2005. Onda.

\section{Imagen:}

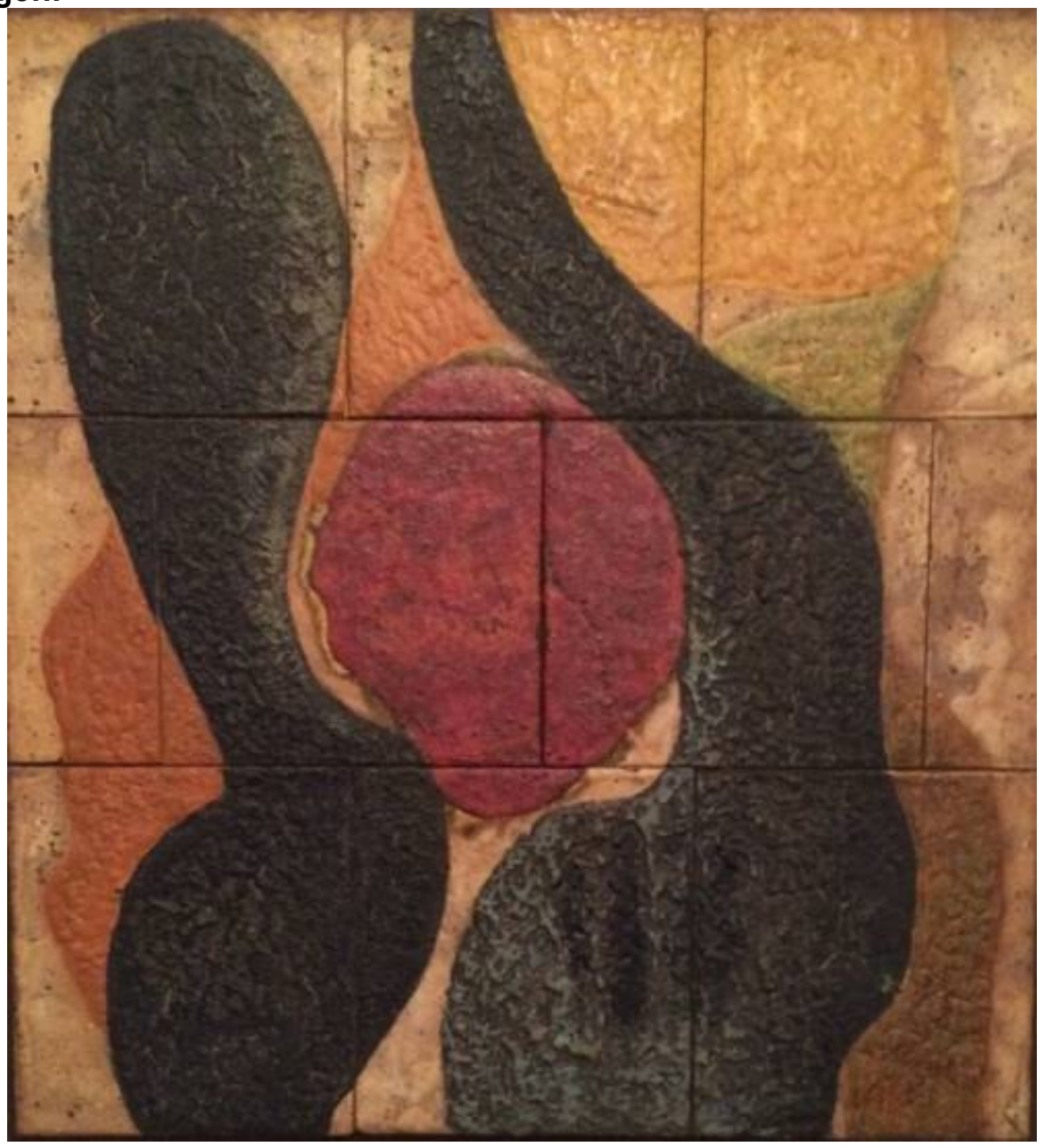




\section{6.- FICHAS CATALOGRÁFICAS: OBRAS DE APLICACIÓN ARQUITECTÓNICA}

En los primeros años de la década de 1950, Safont realizó los azulejos para recubrir los cuatro pilares y la barra del bar del local que la Asociación de Acción Católica tenía en Onda.

En 1968, Safont comenzó su colaboración con diferentes arquitectos para crear diseños de azulejos de aplicación arquitectónica que estos utilizaban en sus nuevas construcciones.

Colaboró con arquitectos como Luis Gay Ramos, entre cuyas obras arquitectónicas destacan la construcción del edificio de Caja Rural y el Cine Mónaco en Onda; el hotel Excelsior, hotel Astoria y el restaurante del Jardín de Viveros en Valencia; la restauración de la Catedral de Valencia y la reconstrucción del Templo de Santa Catalina, así como con Ramón Monfort Salvador, presidente del Colegio Territorial de Arquitectos de Castellón de 2005 a 2011 y Decano del Colegio Oficial de Arquitectos de la Comunidad Valenciana, de 2009 a 2012.

En 1958, el arquitecto Luis Gay Ramos, había solicitado a Safont la realización de un diseño cerámico para un zócalo de azulejos que se instaló en el vestíbulo del edificio que estaba construyendo en Onda, el Cine Mónaco. Al encargarle a este mismo arquitecto la construcción del edificio de la Caja Rural de Onda, Luis Gay Ramos, contrata de nuevo a Safont para la realización de los azulejos que se ubicarán en la fachada exterior, terraza, vestíbulo y en la propia oficina bancaria de la entidad.

Aunque algunas de estas obras de Safont ya no se conservan hoy en día, como los azulejos del bar de Acción Católica de Onda, o los del vestíbulo del Cine Mónaco, aún es posible disfrutar de algunas de sus obras de aplicación arquitectónica en Onda, como la fachada del edificio social de la Caja Rural de Onda, o el quiosco de prensa ubicado en la calle Colón, conocida en Onda con el sobrenombre de La Safona.

En este sexto capítulo del catálogo general se analizan tres obras de Safont de aplicación arquitectónica catalogadas con los n6.1 a nº.3. 
$\mathbf{N}^{0}: 6.1$

Título: Sin Título

Autoría: Manolo Safont

Datación: Final década 1950 - Inicios década 1960

Técnica: Pintura cerámica de aplicación arquitectónica

Localización: Desaparecidos

Descripción: Entre finales de la década de 1950 y comienzos de la década de 1960, Safont realiza los azulejos para decorar la barra del bar de la asociación Acción Católica, situada en la actual calle Historiador Bernardo Mundina, que ya no existe actualmente. Tan sólo hay una fotografía de esta obra, en blanco y negro, y ninguna referencia bibliográfica, por lo que la ficha catalográfica no está completa. Sobre un fondo oscuro, vemos unas líneas claras que delimitan unas siluetas con formas geométricas.

Imagen:

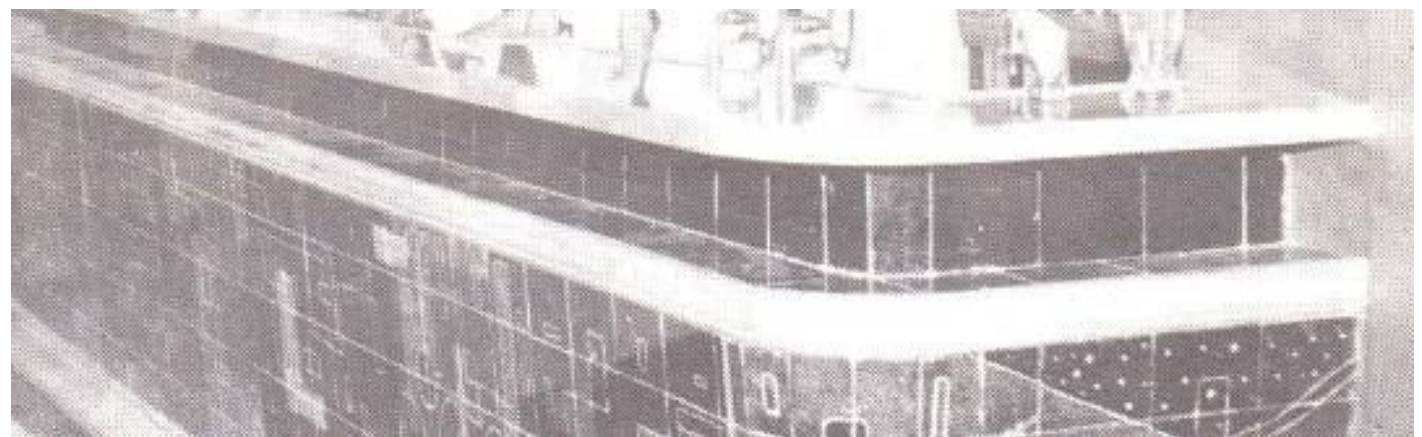


$\mathbf{N}^{\circ}: 6.2$

Título: Sin Título

Autoría: Manolo Safont

Datación: 1960

Técnica: Pintura cerámica de aplicación arquitectónica

Localización: Fachada exterior, hall, piso principal y terraza del edificio social Caja Rural Nuestra Señora de la Esperanza, c/ San Miguel, n¹, Onda (Castellón)

Descripción: Obra de cerámica de aplicación arquitectónica, abstracta, compuesta por diferentes paneles, tanto en la fachada como en el hall y terraza del edificio. Las composiciones están formadas por azulejos con diseño de ondas, que al combinarlos provoca la ilusión de movimiento, confiriendo ligereza visual a estas piezas. Se conservan los bocetos de las diferentes composiciones utilizadas en el edificio, obra catalogada con el $n^{0} 2.2$. En septiembre de 2004 se realizó una exhaustiva limpieza de su fachada que incluyó la restauración de los azulejos deteriorados por el paso del tiempo. Actualmente esta antigua oficina bancaria se utiliza como local social de la Caja Rural de Onda. Paleta cromática: blancos, azules, grises y negros.

\section{Bibliografía:}

- La Càmara. Butlletí Informatiu de la Caixa Rural d'Onda, n8, septiembre 2005, Onda

- La Càmara. Butlletí Informatiu de la Caixa Rural d’Onda, n²0, mayo 2010, Onda

- http://repositori.uji.es

\section{Imagen:}

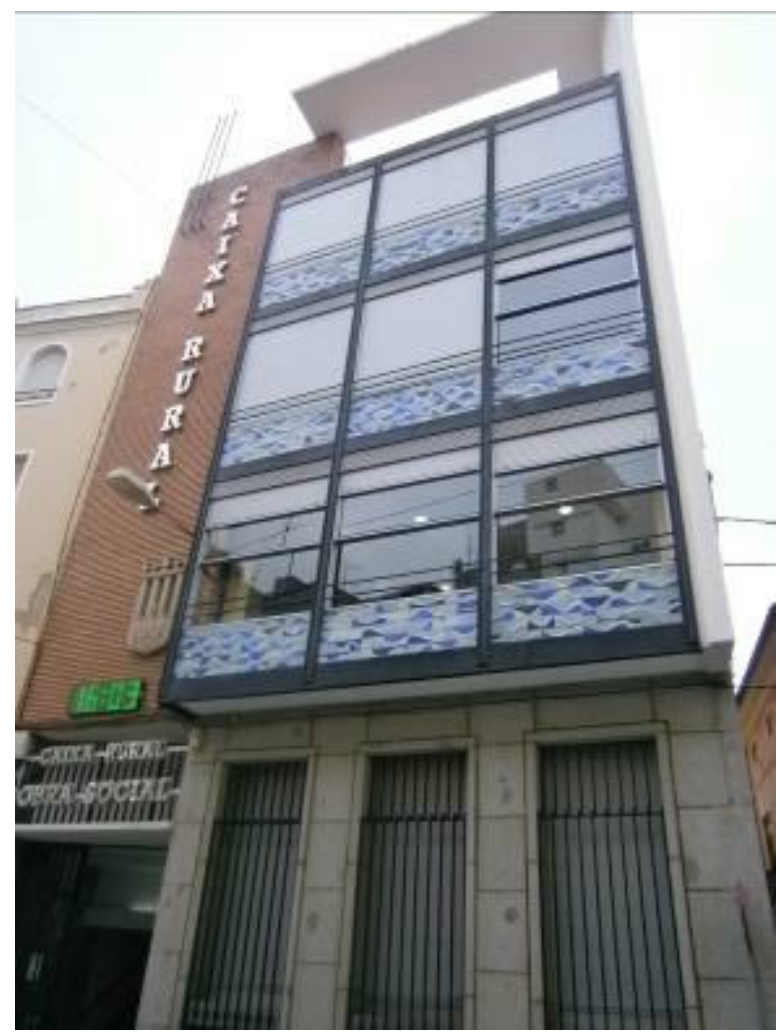

Fachada principal 


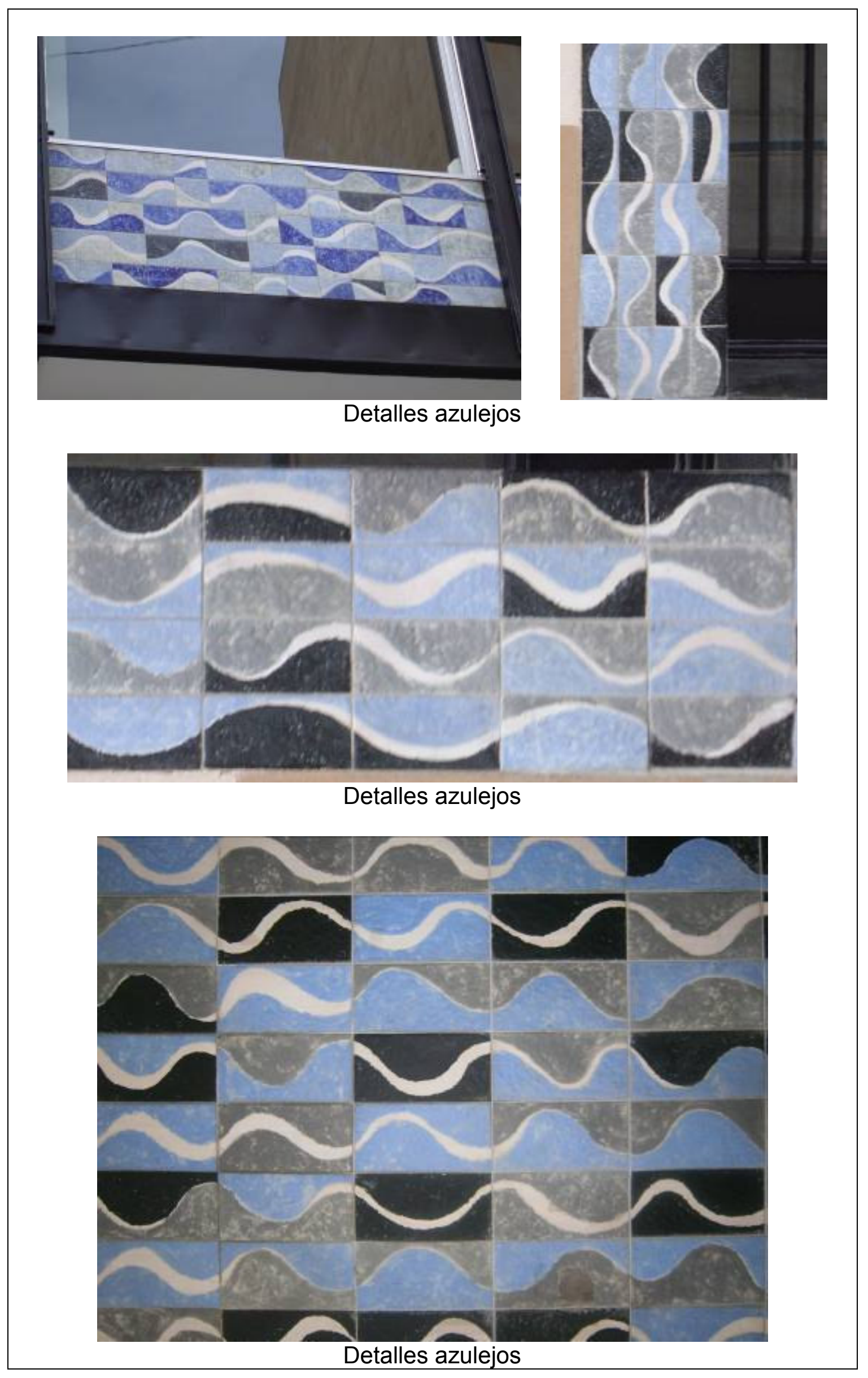


Imágenes relacionadas:

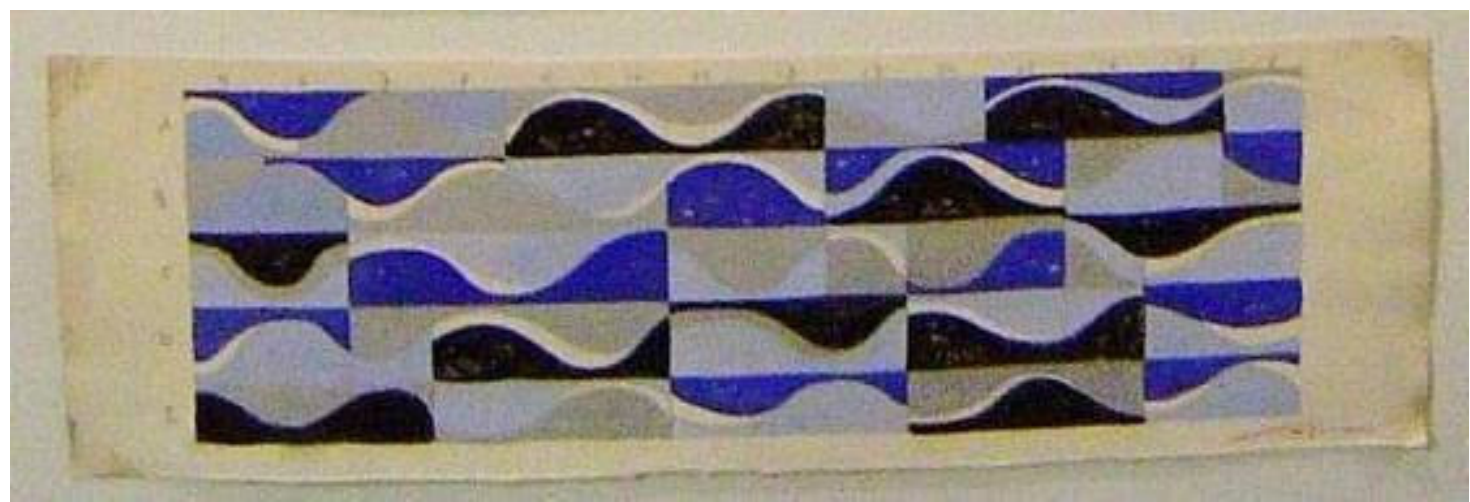

Obra cat. $n^{0} 2.2$

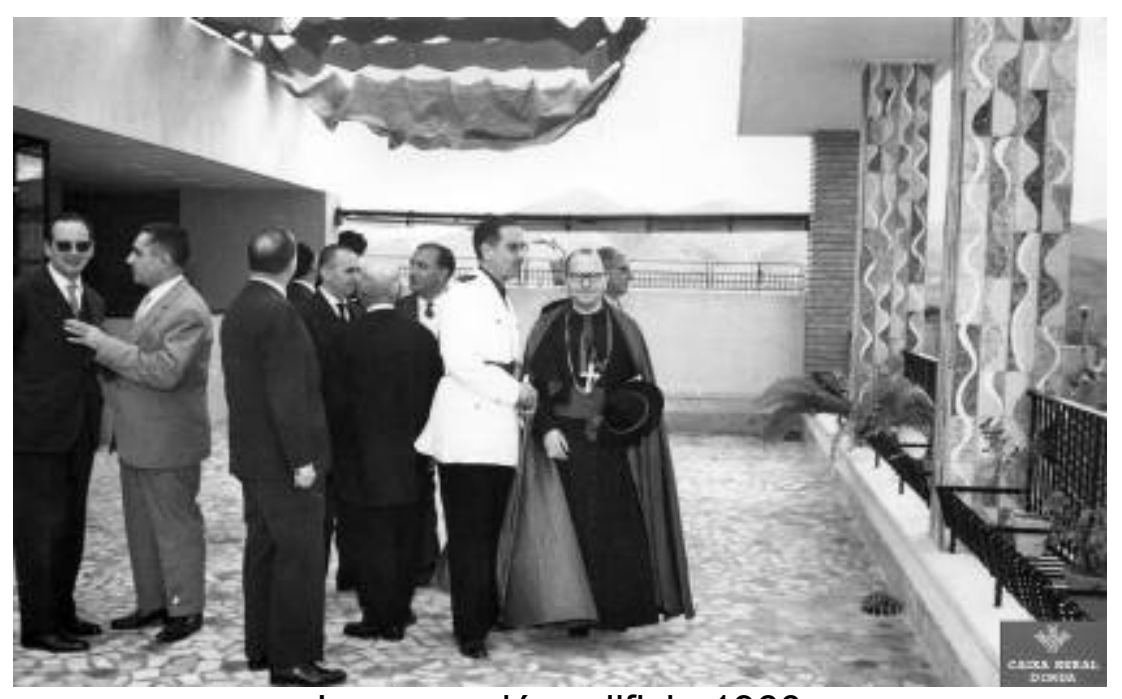

Inauguración edificio 1960

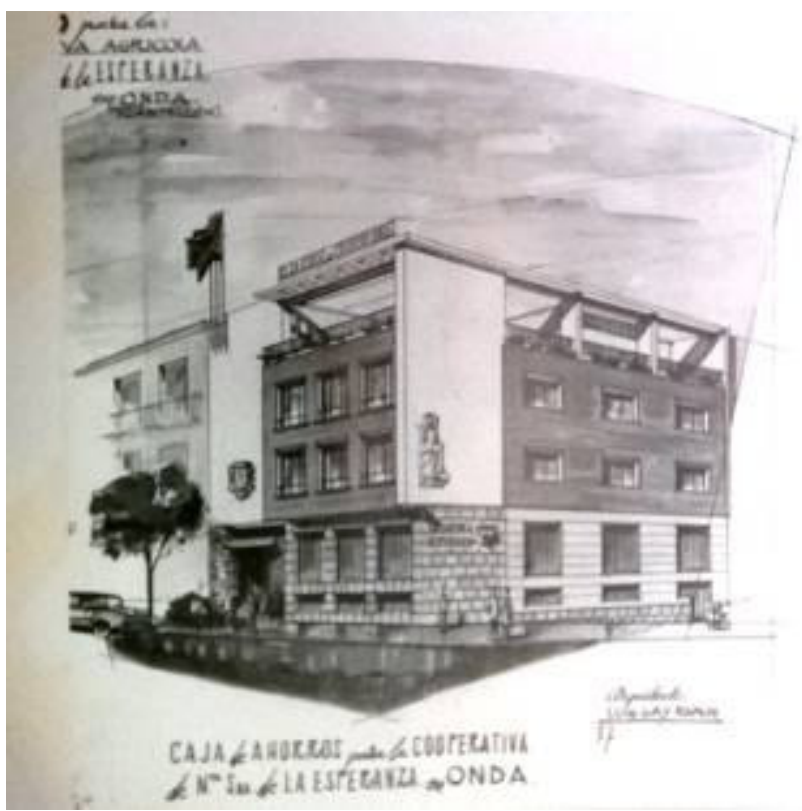

Anteproyecto del edificio. Arquitecto Luis Gay Ramos 
No: 6.3

Título: Sin Título

Autoría: Manolo Safont

Datación: 1961-1962

Técnica: Pintura cerámica de aplicación arquitectónica

Localización: Calle Colón (La Safona), Onda (Castellón)

Descripción: Obra de cerámica de aplicación arquitectónica, abstracta, realizada con azulejos polícromos. Como consecuencia de las obras de remodelación de la calle Colón (La Safona) de Onda se derribó el antiguo quiosco de prensa. Una vez finalizadas las obras para la ampliación de la calzada, Safont realizó tanto el diseño de la estructura como los azulejos del nuevo quiosco, que actualmente se encuentra en desuso. Este quiosco pertenecía a la asociación Acción Católica de Onda. Paleta cromática: blancos, amarillos, ocres, rojos, verdes, azules, violetas, marrones y negros.

\section{Imagen:}
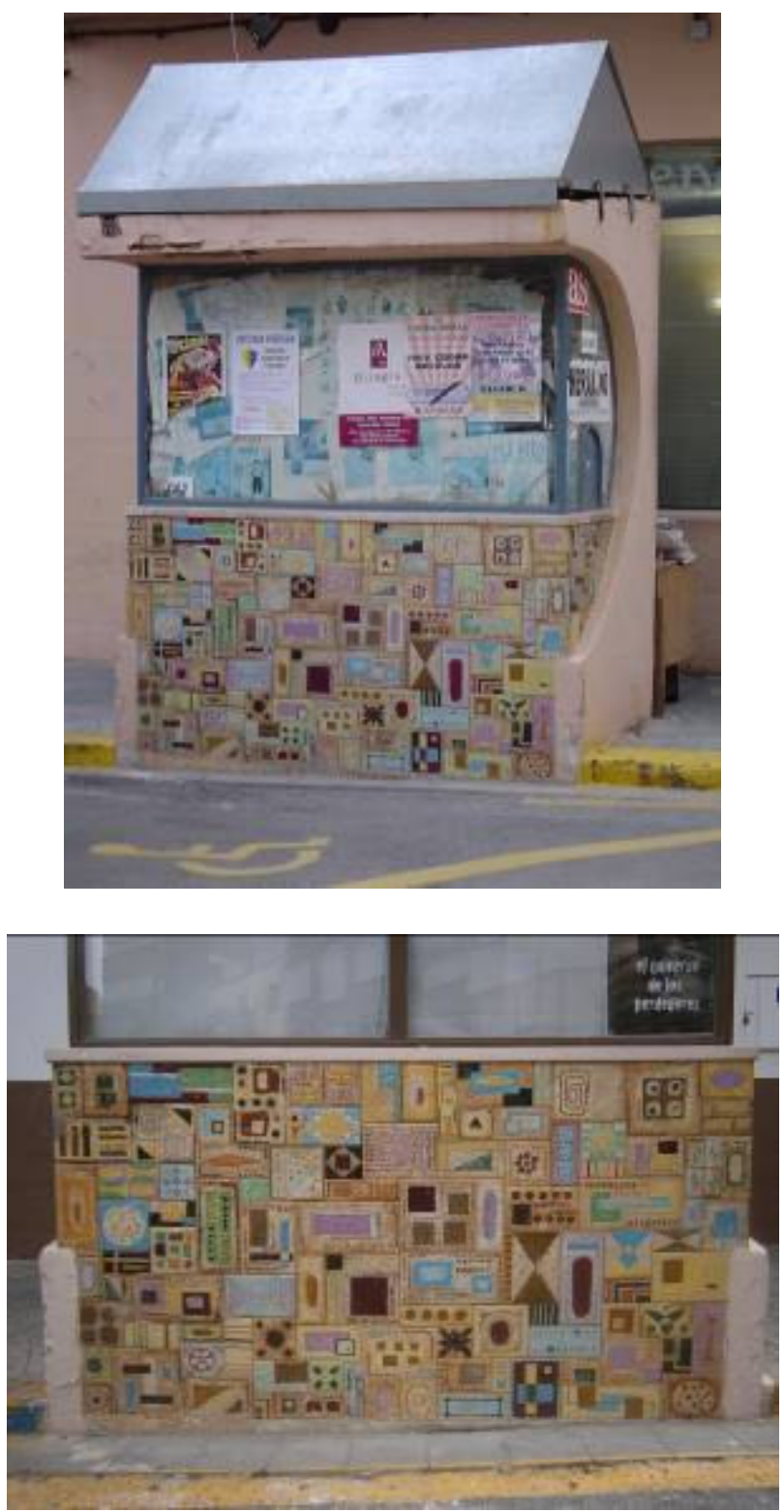


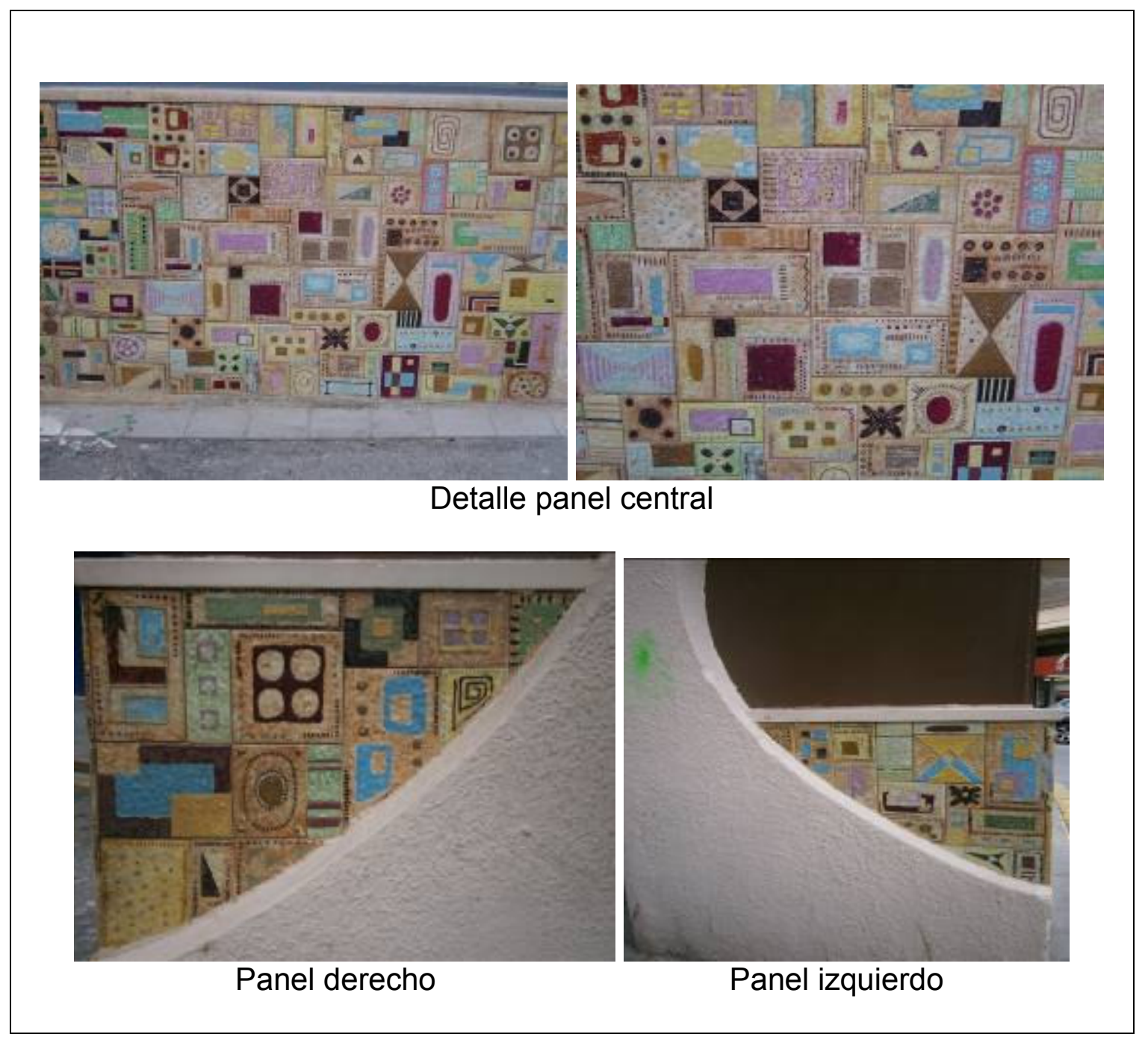




\section{7.- FICHAS CATALOGRÁFICAS: OBRAS MURALES}

Este séptimo capítulo del catálogo general, analiza las obras murales realizadas por Safont. Las 33 obras están catalogadas en fichas individuales que comprenden desde el $n^{0} 7.1$ al $n^{0} 7.33$.

Consideramos obra mural, aquella que fue creada para ser adherida sobre un soporte arquitectónico, un muro, sea interior o exterior. Por sus dimensiones y su ubicación en el espacio arquitectónico, el arte mural es también un medio de transmisión sociocultural, que necesita para mostrarse, insertarse en un ámbito de exposición pública, por ello aborda temas religiosos, históricos alegóricos o patrióticos de significación popular.

En el caso particular del mural cerámico, la obra pictórica está realizada sobre una base cerámica, que es horneada para fijar los colores, esmaltes y barnices, para ser luego adheridos al muro por medio de un mortero o mezcla adhesiva.

De las 33 obras murales de Safont, destaca en sus inicios la intervención en la Capilla de la Comunión de la Iglesia de Nuestra Señora de la Asunción de Onda, con la creación de cinco paneles murales independientes, obras catalogadas $n^{0} 7.1, n^{0} 7.2, n^{0} 7.3, n^{0} 7.4$ y $n^{0} 7.5$, y posteriormente, por su monumentalidad, el mural La Sagrada Familia, obra catalogada $n^{0} 7.23$, aunque actualmente ya no es un mural, ya que tras su restauración por los Servicios de Conservación y Restauración de la Diputación de Castellón, los azulejos se han adherido sobre diferentes paneles, facilitando de este modo su movilidad y exposición en diversos lugares.

Mención aparte merecen las 14 estaciones que realizó Safont para el Calvario de la población de Espadilla (Castellón). La Iglesia valenciana del último cuarto del siglo XVIII propició una eclosión del Vía Crucis, la Vía dolorosa de Cristo hacia la cruz. La liturgia proponía para ello catorce hitos o estaciones separados por un número determinado y variable de pasos. Los hubo interiores, en claustros, en las naves de los templos, en jardines y huertos conventuales, urbanos, etc. De forma habitual se colocan en las paredes interiores de los muros de las naves de las iglesias y en los calvarios.

Los calvarios suelen ubicarse en pequeñas montañas o colinas próximas a las localidades urbanas, rodeados de cipreses en los que se construyen 
casilicios de base cuadrada con tejado de cuatro vertientes, cubiertos en ocasiones por tejas vidriadas. El recorrido por los casalicios se iniciaba con la escena de la flagelación de Cristo y finalizaba con la escena del entierro. Lo que unificaba en la Comunidad Valenciana toda esta tipología, era el soporte, azulejos cerámicos, casi siempre con un formato de 2x2 azulejos. Son Vía Crucis alejados del dramatismo, que mueven a la reflexión y a la participación. La expresión latina Vía Crucis significa "Camino a la Cruz", y hace referencia directa al camino que recorrió Cristo durante su Pasión, desde el Pretorio de Pilatos hasta el Calvario. Al margen de esta vía física, la expresión Vía Crucis se utiliza en la terminología cristiana, para designar una forma de oración, acompañada de meditación sobre los diferentes acontecimientos que le ocurrieron a Jesús en este camino, a la que se añaden su muerte, descendimiento y sepultura. Junto con diferentes oraciones, mayoritariamente de penitencia y arrepentimiento, se intercalan catorce meditaciones, llamadas estaciones, ya que las personas que hacen este ejercicio de piedad, se detienen durante unos momentos, para poder meditar, en cada una de las diferentes escenas.

En 1962, D. Juan Tortajada Andreu, cura párroco de Espadilla, le encargó a Safont la realización de los paneles de azulejos, en formato 2x2 de las estaciones del Vía Crucis, con imágenes de la Pasión de Jesús, para colocarlos en los casalicios del calvario de Espadilla. Cada una de estas 14 estaciones fue sufragada por entidades o particulares de la población, pagando el sacerdote la III $^{a}$ estación, incluso el propio Safont y su esposa Ana, colaboraron también en el proyecto, donando la estación XIVa. Ninguna de las obras presenta firme visible en el anverso. Destaca la maestría con que Safont resolvió el problema de las juntas para no romper la armonía del dibujo, con los surcos horizontales y verticales divisorios de las aristas de los azulejos.

El Viernes Santo de 1991, bajo el papado de Juan Pablo II, se creó un nuevo Vía Crucis con 15 estaciones, basadas todas ellas en momentos del Nuevo Testamento, ya que el anterior recogía muchos pasajes de los Evangelios apócrifos y escenas tradicionales, entre los que se encontraban el encuentro de Jesús con María, su madre y el acto en el que la Verónica le enjuga el rostro a Jesús. Fue un intento de acercar ecuménicamente a todas las confesiones cristianas, y aunque se usa alternativamente al tradicional, en 
ningún caso lo ha sustituido. Al aumentar el número de estaciones, en 1998, se añadió una nueva estación en Espadilla, la $X V^{a}$ estación "La resurrección de Jesús", que con un estilo pictórico similar a las realizadas por Safont, pintó el ceramista ondense Vicente Aguilella.

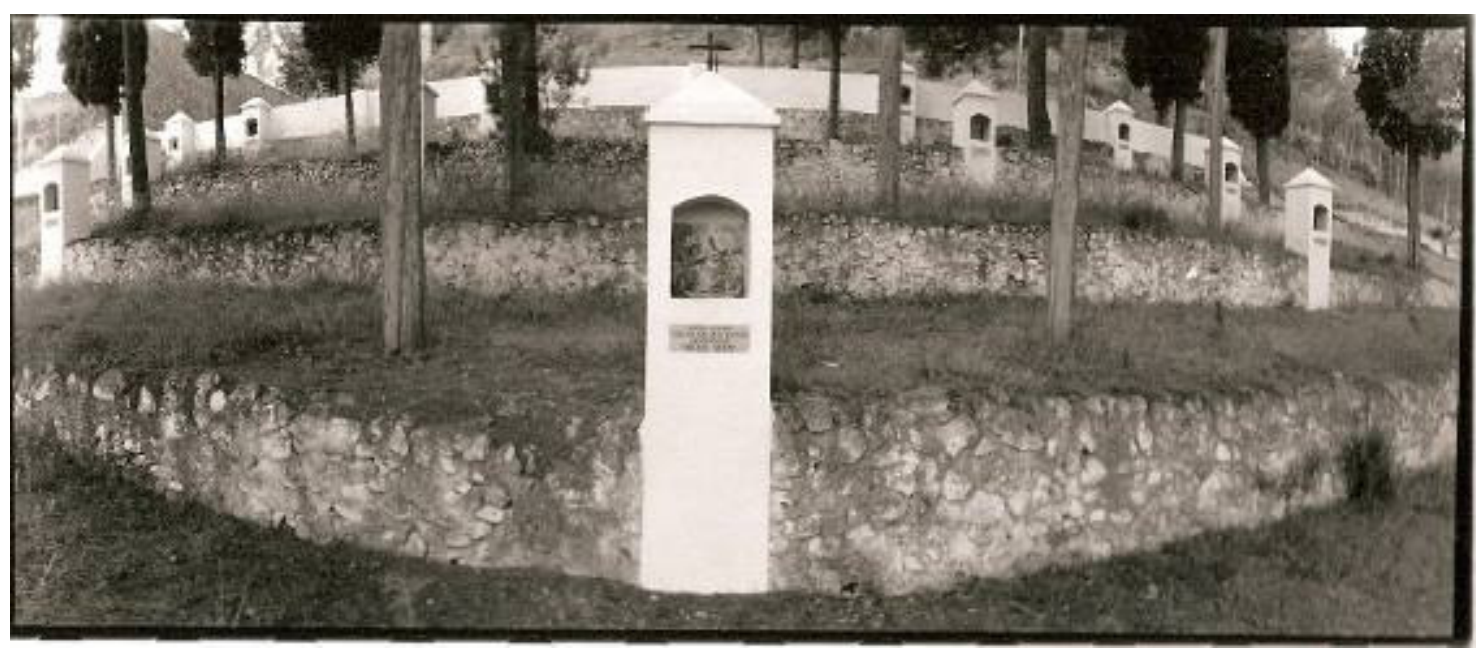

Figura 167: Calvario de Espadilla (Castellón)

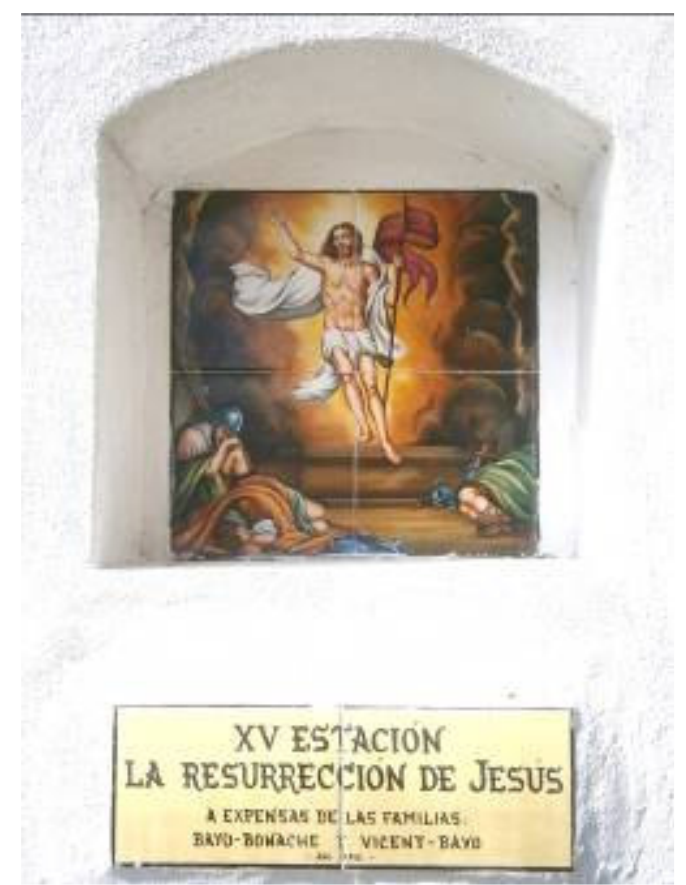

Figura 168: XVª Estación Calvario de Espadilla. Vicente Aguilella 


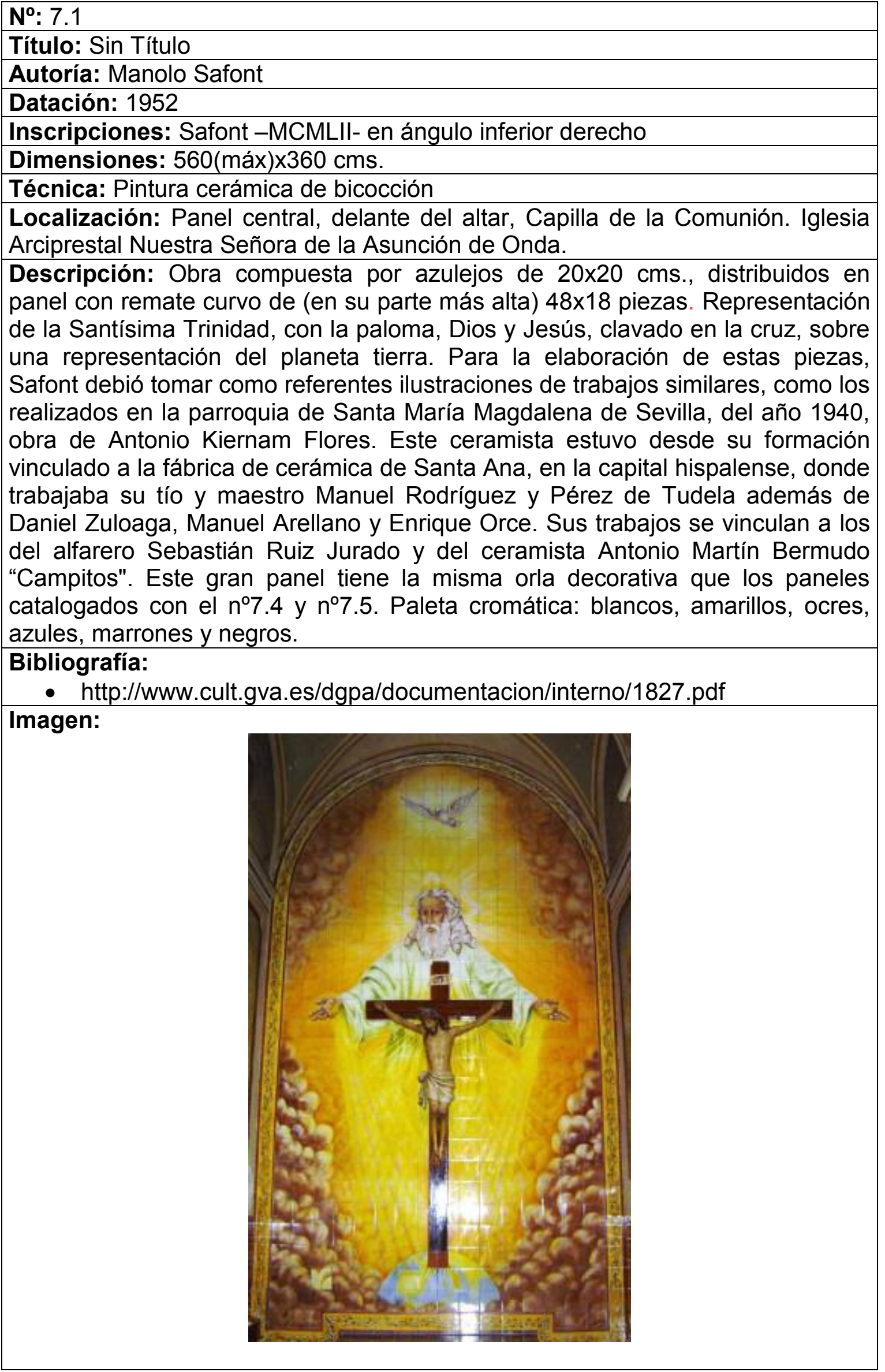




\section{Imágenes relacionadas:}

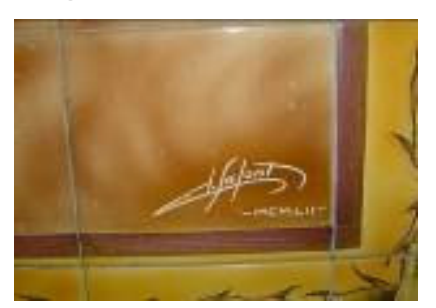

Detalle autoría

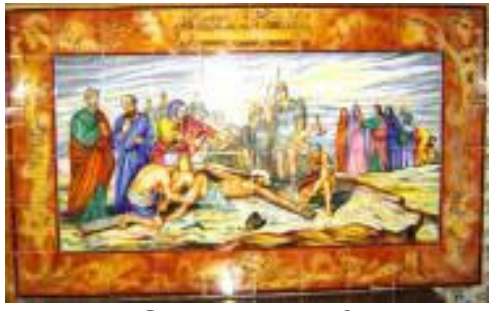

Obra cat. $\mathrm{n}^{07.4}$

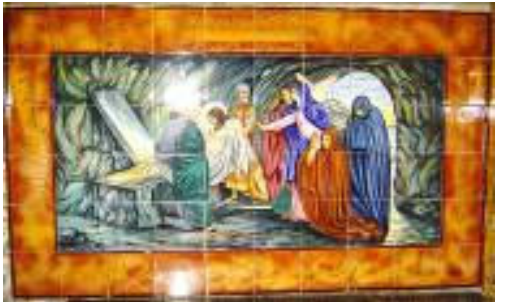

Obra cat. $\mathrm{n}^{07.5}$

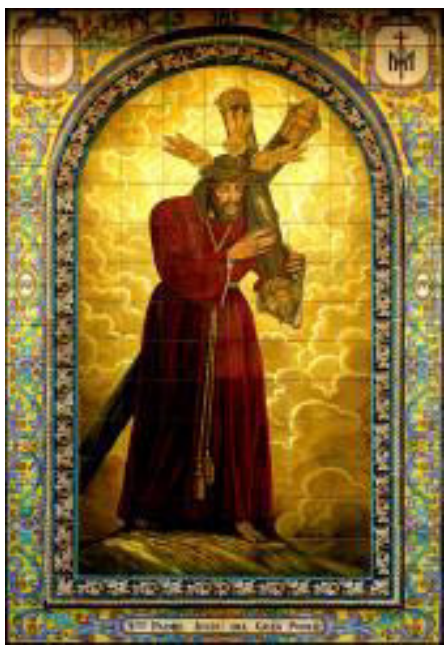

Jesús del Gran Poder de la iglesia de Santa María Magdalena de Sevilla, 1940, de Antonio Kiernam Flores (Fábrica de Santa Ana), con el mismo tratamiento de nubes al fondo y uso de colores 
No: 7.2

Título: Sin Título

Autoría: Manolo Safont

Datación: 1952

Inscripciones: Safont en ángulo inferior derecho

Dimensiones: $140 \times 140 \mathrm{cms}$.

Técnica: Pintura cerámica de bicocción

Localización: Panel lateral Capilla de la Comunión. Iglesia Arciprestal Nuestra Señora de la Asunción de Onda, Castellón

Descripción: Obra compuesta por 49 azulejos de 20x20 cms., distribuidos en panel de $7 \times 7$ piezas La representación de la figura del pelícano picando su propio pecho para alimentar a sus crías con su propia sangre es una de las imágenes de más utilizadas en relación con el sacramento de la comunión. La relación existente entre la figura de Jesucristo y la del Pelícano se basa en la capacidad de sacrificio del animal que cuando se siente herido no duda en picarse el pecho para alimentar a sus crías y evitar así que estas mueran. Esta ave, que vive en las orillas de lagos y ríos en las regiones cálidas, da de comer a sus polluelos con el alimento que extrae con el pico de la bolsa de piel del pecho. Tomando esto como punto de partida, antiguas leyendas imaginaron que el pelícano, en caso de necesidad, nutre a sus pequeños con su propia carne. La tradición cristiana, precisamente por esto, a partir del medioevo, comenzó a utilizar el pelícano como símbolo eucarístico, viendo en su sangre vivificadora la figura de la sangre redentora de Cristo. Enfrentada con otro panel con las mismas dimensiones, estilo y gama cromática con la representación del cordero pascual, obra catalogada con el n07.3. Paleta cromática: blancos, amarillos, ocres, verdes, azules, violetas y marrones.

\section{Bibliografía:}

- http://www.cult.gva.es/dgpa/documentacion/interno/1827.pdf

\section{Imagen:}

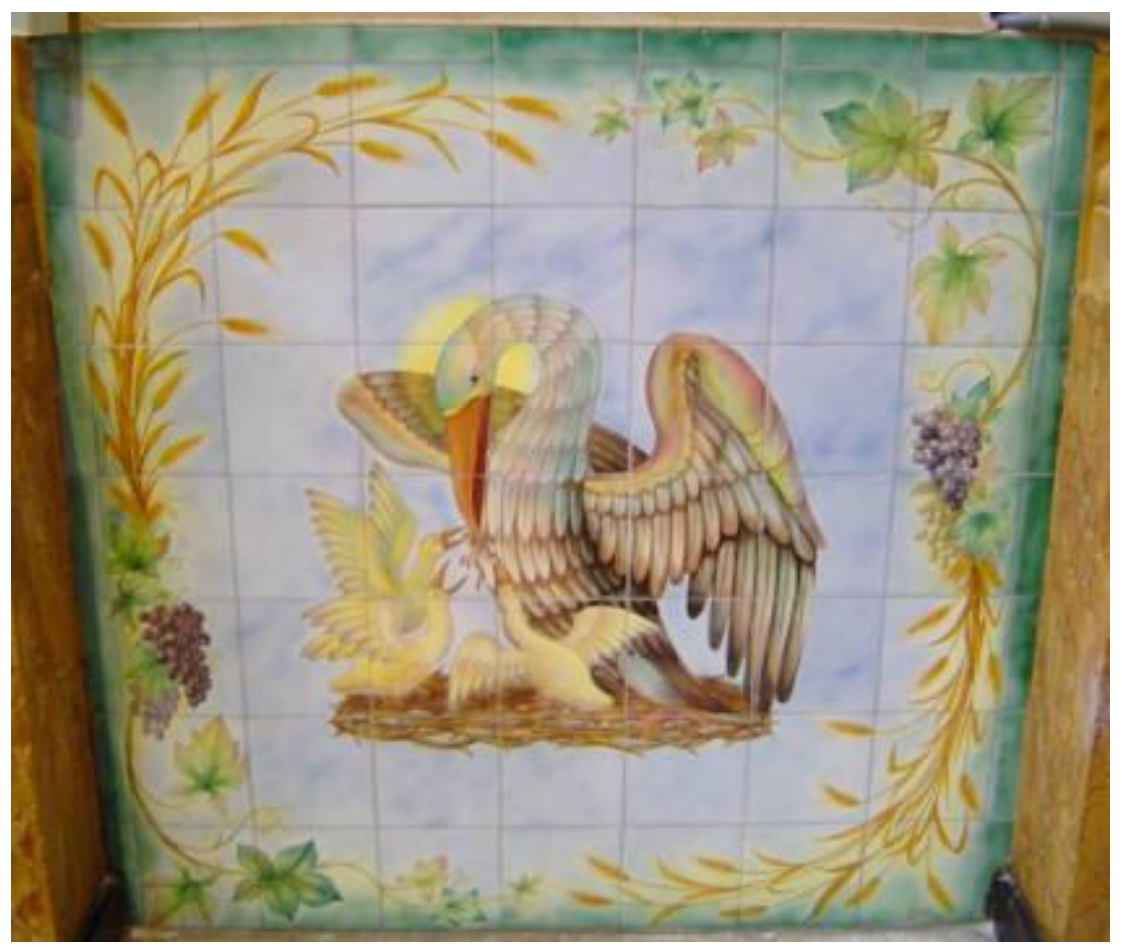


Imágenes relacionadas:

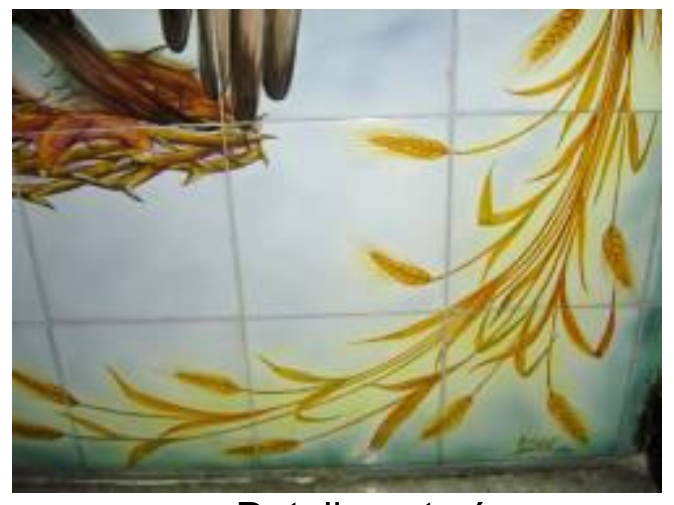

Detalle autoría

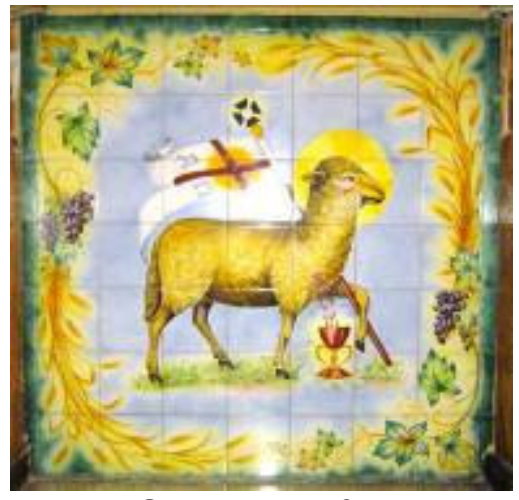

Obra cat. $n^{07.3}$ 
$\mathbf{N}^{0}: 7.3$

Título: Sin Título

Autoría: Manolo Safont

Datación: 1952

Inscripciones: "Safont" en ángulo inferior derecho

Dimensiones: $140 \times 140 \mathrm{cms}$.

Técnica: Pintura cerámica de bicocción

Localización: Panel lateral Capilla de la Comunión. Iglesia Arciprestal Nuestra Señora de la Asunción de Onda

Descripción: Obra compuesta por 49 azulejos de 20x20 cms, distribuidos en panel de $7 \times 7$ piezas, Representación del cordero pascual, con el báculo y estandarte, vertiendo su sangre en un cáliz, alusión al sacramento de la comunión. Simboliza el sacrificio sin mancha de Cristo para la salvación de los creyentes. La cena Pascual consistía en el sacrificio de un cordero, por lo tanto el paralelismo entre Jesús y el cordero Pascual nos hace ver que la Eucaristía es la actualización del autentico sacrificio en el que Jesús se entrega a los demás. Enfrentada con otro panel con las mismas dimensiones, estilo y gama cromática con la representación de un pelícano, obra catalogada con el n²7.2. Paleta cromática: blancos, amarillos, ocres, verdes, azules, violetas y marrones.

\section{Bibliografía:}

- http://www.cult.gva.es/dgpa/documentacion/interno/1827.pdf Imagen:

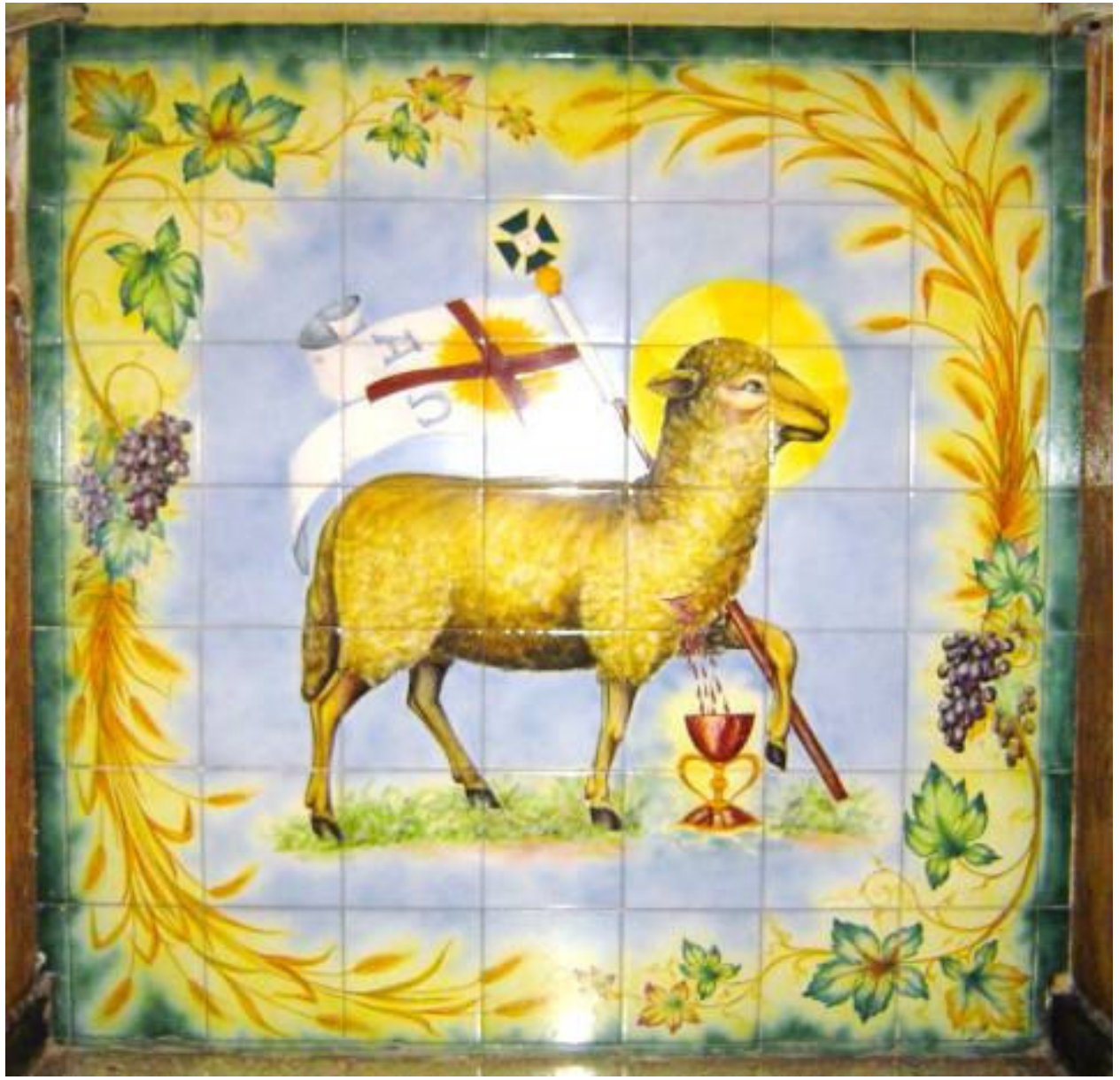




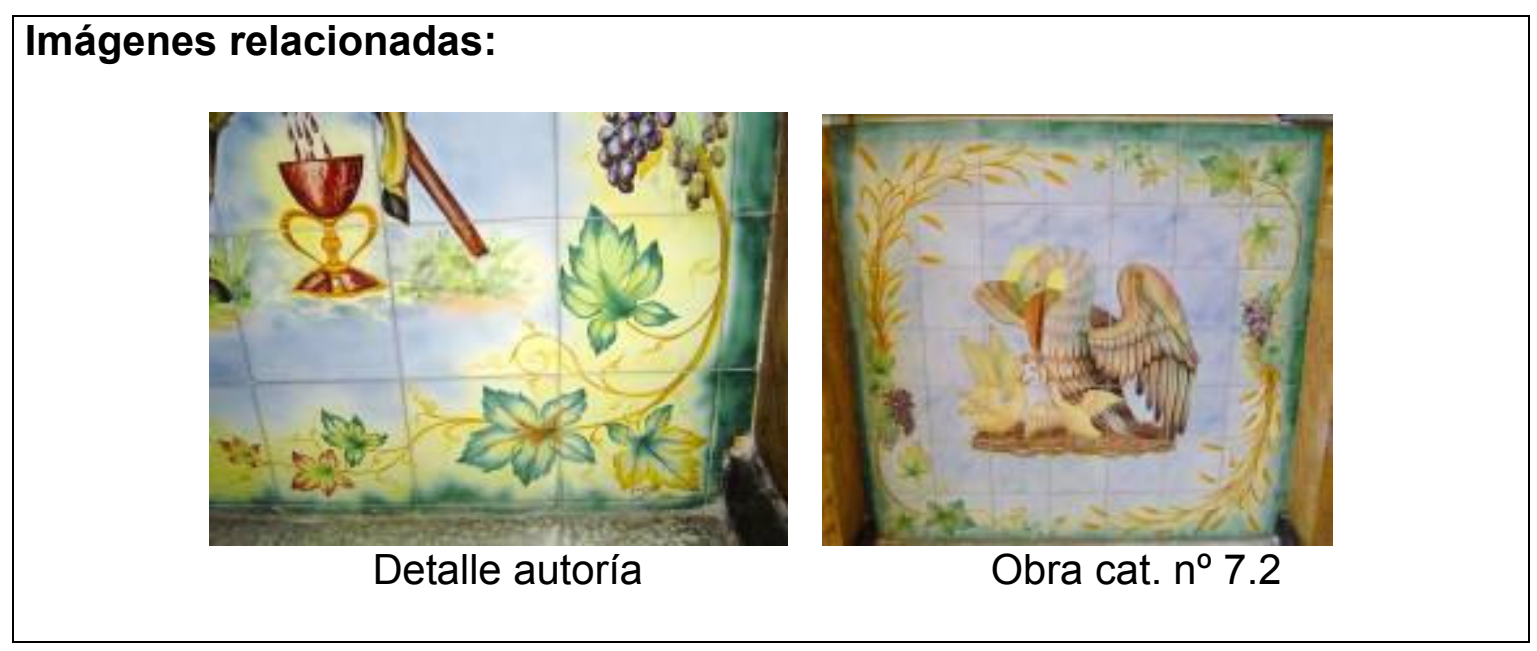


$\mathbf{N}^{0}: 7.4$

Título: Sin Título

Autoría: Manolo Safont

Datación: 1952

Inscripciones: Safont en ángulo inferior derecho

Dimensiones: $120 \times 200 \mathrm{cms}$. en azulejos de $20 \times 20$ distribuidos en $6 \times 10$

Técnica: Pintura cerámica de bicocción

Localización: Capilla de la Comunión. Iglesia Arciprestal Nuestra Señora de la Asunción de Onda.

Descripción: Obra compuesta por una escena central, polícroma, formada por 32 azulejos de 20x20, en disposición de panel 4×8, rodeado de un marco-orla, realizado en tonos ocres y tierras, con decoración relativa a la Última Cena, formado por 28 azulejos de $20 \times 20$. Forma pareja con la obra catalogada con el $\mathrm{n}^{\circ} 7.5$, con la cual mantiene una unidad estilística y temática, al referirse a escenas de la Semana Santa; esta obra es una representación de la escena evangélica de la crucifixión de Cristo. La escena se corresponde con la XI estación del Calvario (curiosamente la autoría de esta estación en el calvario de Onda también es de Safont). Estos paneles tienen la misma orla decorativa que el gran panel central con el tema de la Santísima Trinidad del altar mayor. Presenta similitudes compositivas con la estación $\mathrm{XI}$ realizada para el Vía Crucis del Calvario de Espadilla, obra catalogada $\mathrm{n}^{07.19}$. Paleta cromática: blancos, amarillos, ocres, rojos, verdes, azules, violetas, marrones y negros.

Bibliografía:

- http://www.cult.gva.es/dgpa/documentacion/interno/1827.pdf Imagen:

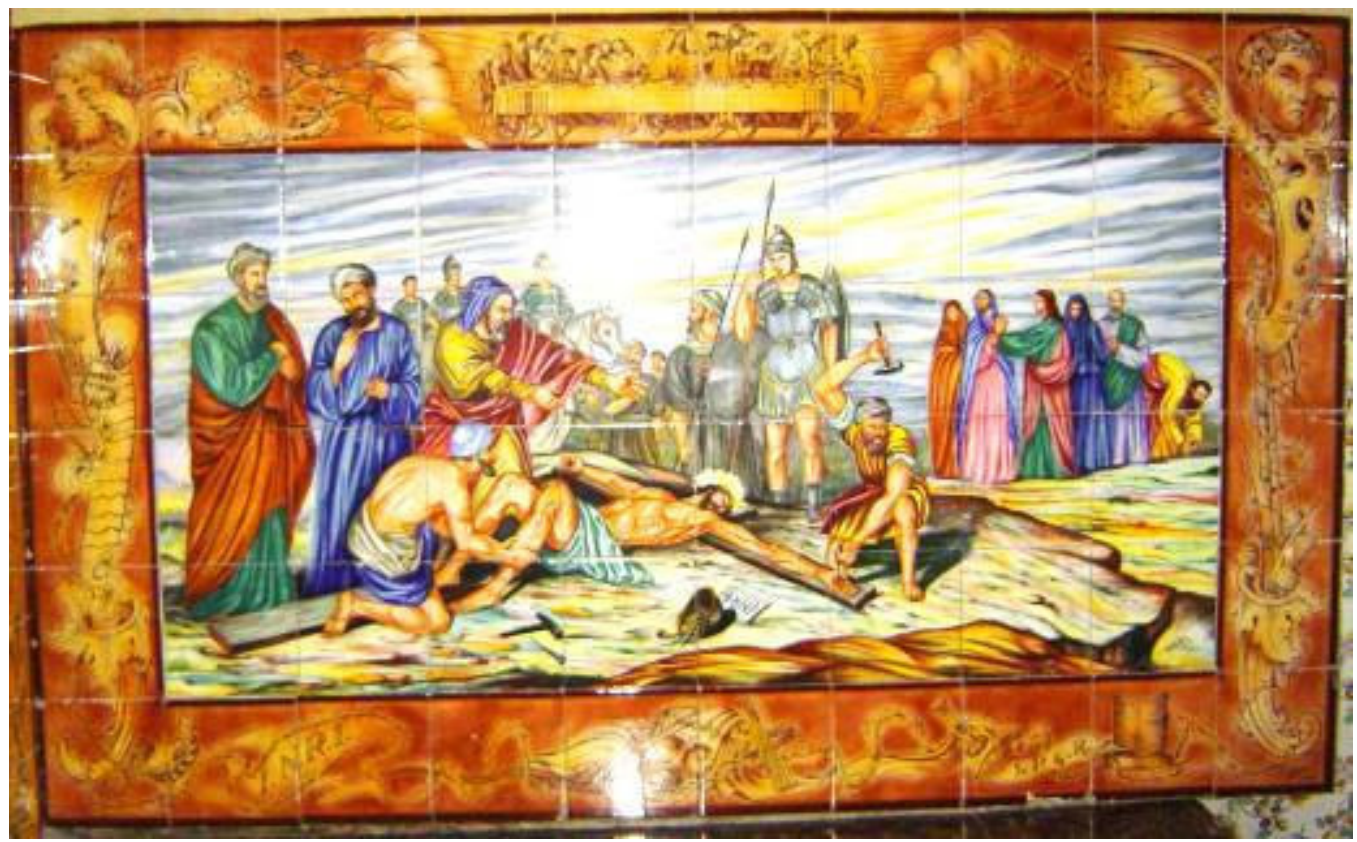


Imágenes relacionadas:

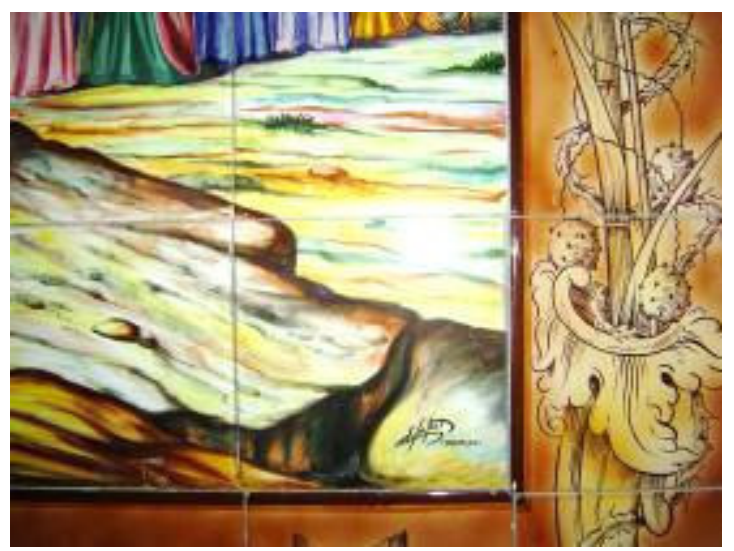

Detalle autoría

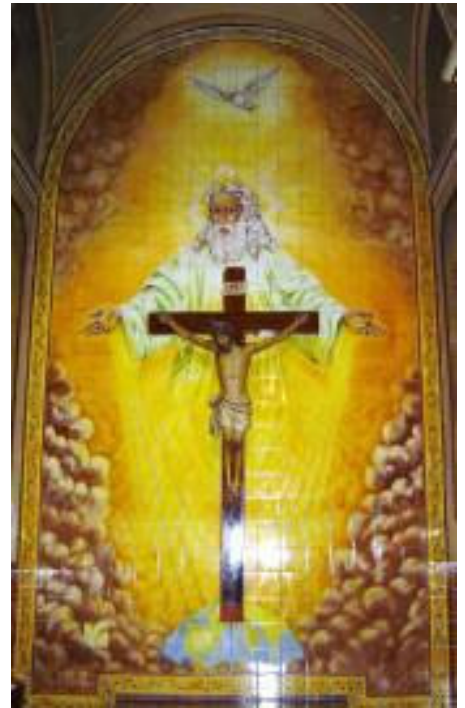

Obra cat. $\mathrm{n}^{07.1}$

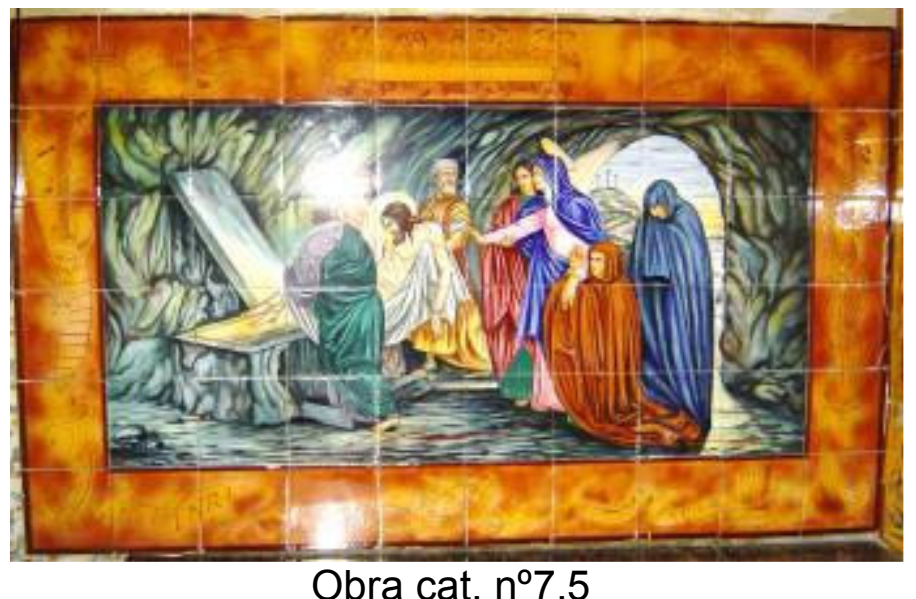

Obra cat. $n^{07.5}$

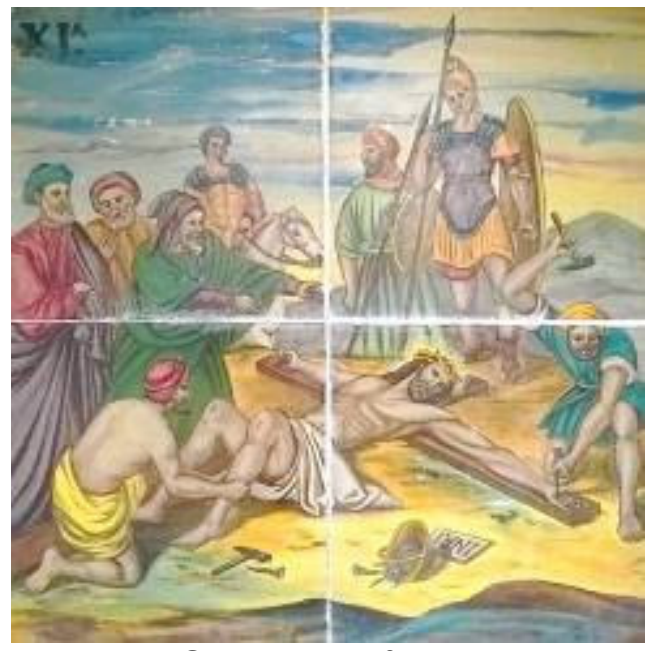

Obra cat. $n^{07} 7.19$ 
No: 7.5

Título: Sin Título

Autoría: Manolo Safont

Datación: 1952

Inscripciones: Safont en ángulo inferior derecho

Dimensiones: $120 \times 200 \mathrm{cms}$. en azulejos de $20 \times 20$ distribuidos en $6 \times 10$

Técnica: Pintura cerámica de bicocción

Localización: Capilla de la Comunión. Iglesia Arciprestal Nuestra Señora de la Asunción de Onda.

Descripción: Pieza formada por una escena central, polícroma, de 32 azulejos de $20 \times 20$, en disposición de panel $4 \times 8$, rodeado de un marco-orla, realizado en tonos ocres y tierras, con decoración relativa a la Última Cena, formado por 28 azulejos de $20 \times 20$. Forma pareja con la obra catalogada con el $n^{07.4}$, con la cual mantiene una unidad estilística y temática, al referirse a escenas de la Semana Santa, esta obra representa la escena evangélica del Santo Entierro, tomada de la estación XIV del Calvario. Estos paneles tienen la misma orla decorativa que el gran panel central con el tema de la Santísima Trinidad del altar mayor. Presenta similitudes compositivas con la obra catalogada $n^{07.22}$, la estación XIV del Calvario de Espadilla. Paleta cromática: blancos, amarillos, ocres, rojos, verdes, azules, violetas, marrones y negros.

\section{Bibliografía:}

- http://www.cult.gva.es/dgpa/documentacion/interno/1827.pdf

Imagen:

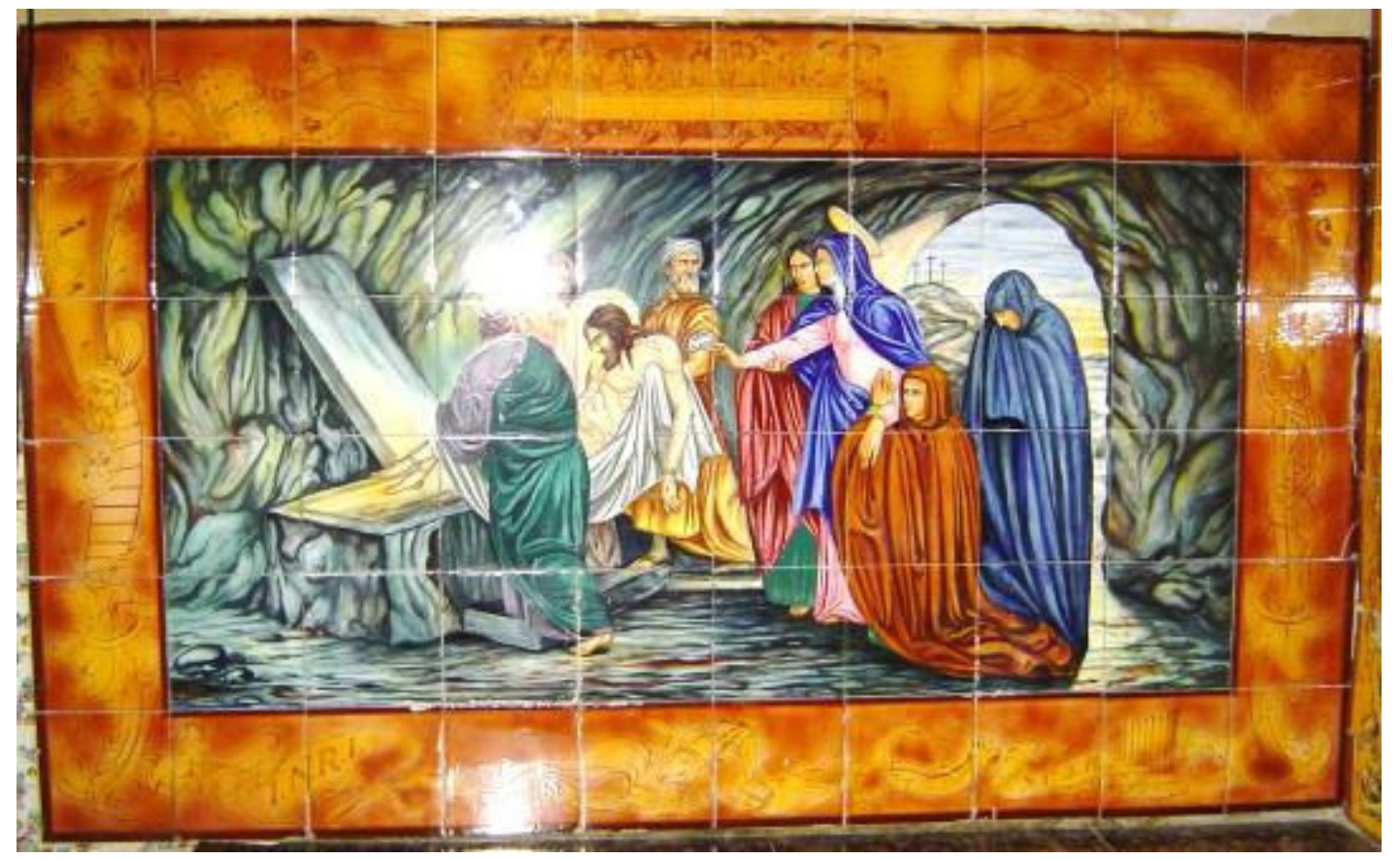


Imágenes relacionadas:

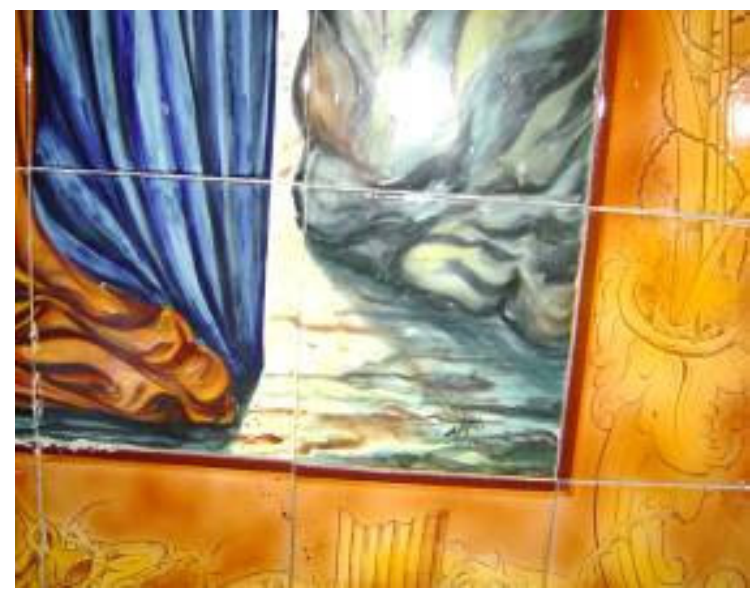

Detalle autoria

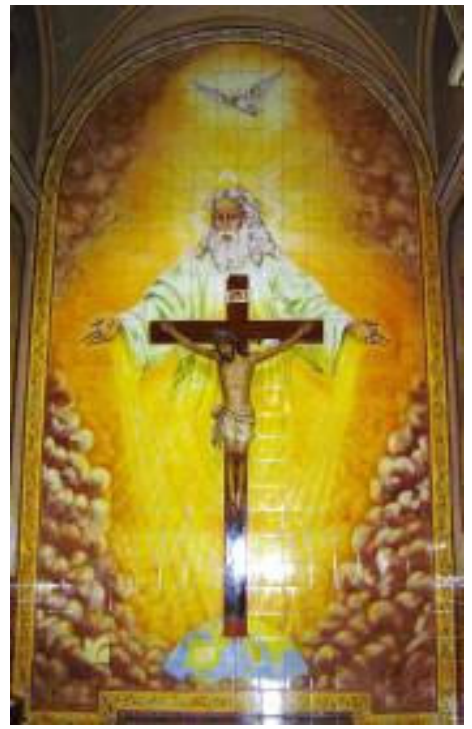

Obra cat. $n^{\circ} 7.1$

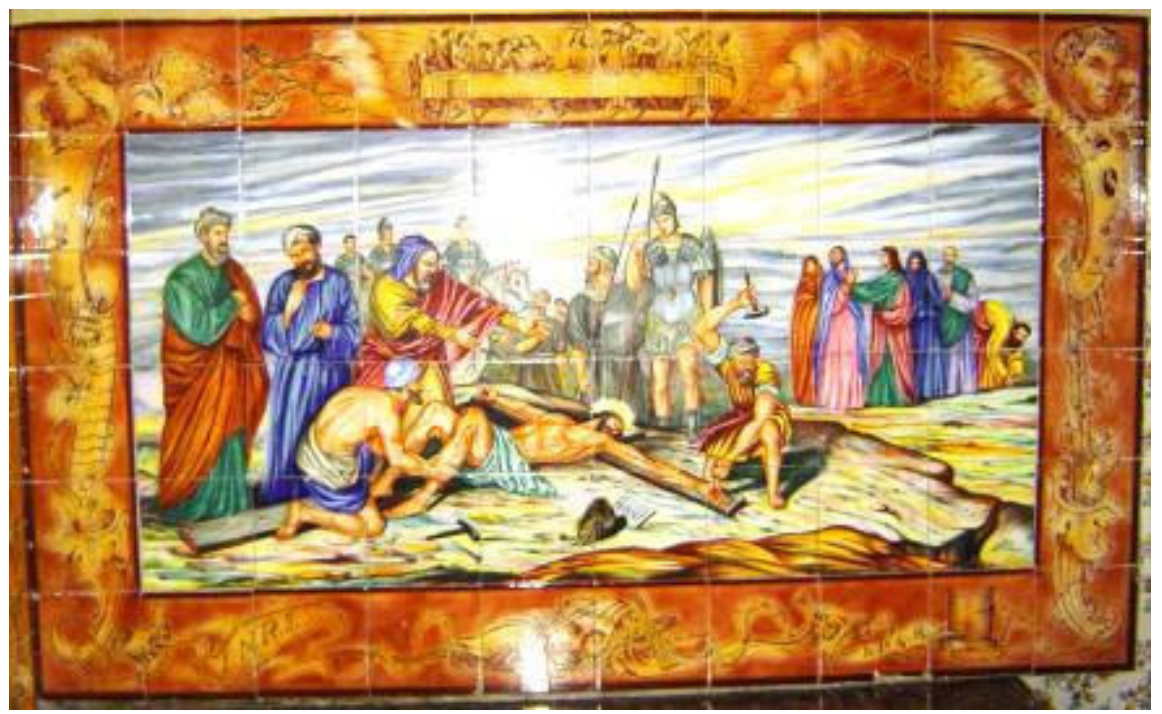

Obra cat. $n^{07.4}$

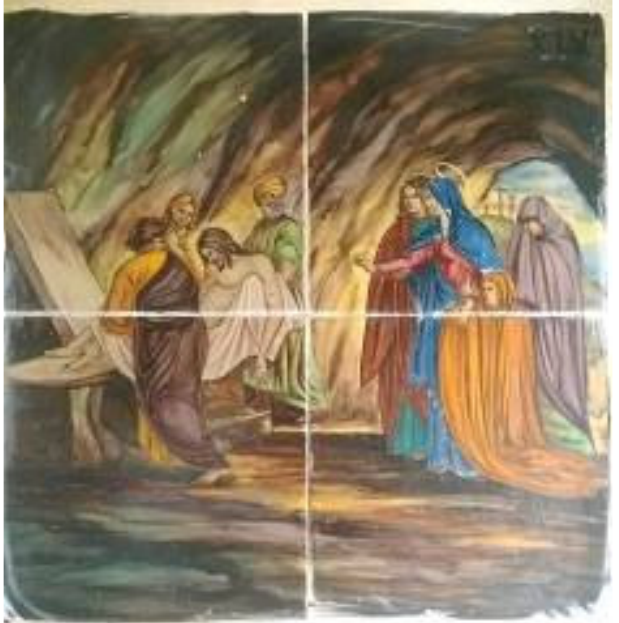

Obra cat. $n^{07.22}$ 
No: 7.6

Título: La Última Cena

Autoría: Manolo Safont

Datación: 1953

Técnica: Pintura cerámica de bicocción

Localización: Comedor Seminario Diocesano de Tortosa

Descripción: Obra mural cerámica figurativa, realizada para el comedor del Seminario de Tortosa. Esta sala tiene un zócalo cerámico realizado con azulejos en diferentes tonalidades de color azul, quizás fue por eso, por lo que a Safont le encargaron que el panel de la Última Cena estuviera realizado predominando este color. Para realizar esta obra, tal y como puede observarse en la imagen fotográfica de Safont realizando el panel, se baso en la obra de La Última Cena de Leonardo da Vinci. Paleta cromática: blancos, azules y negros.

\section{Bibliografía:}

- http://www.csagrada.com

- http://manolosafont.blogspot.com.es

\section{Imagen:}

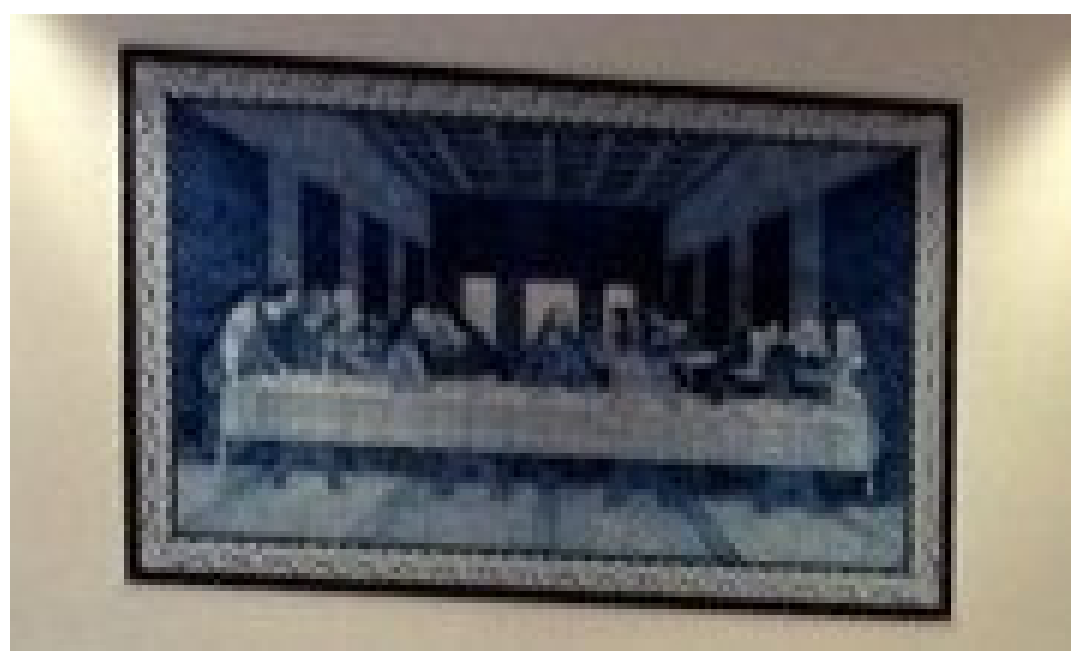

Imágenes relacionadas:

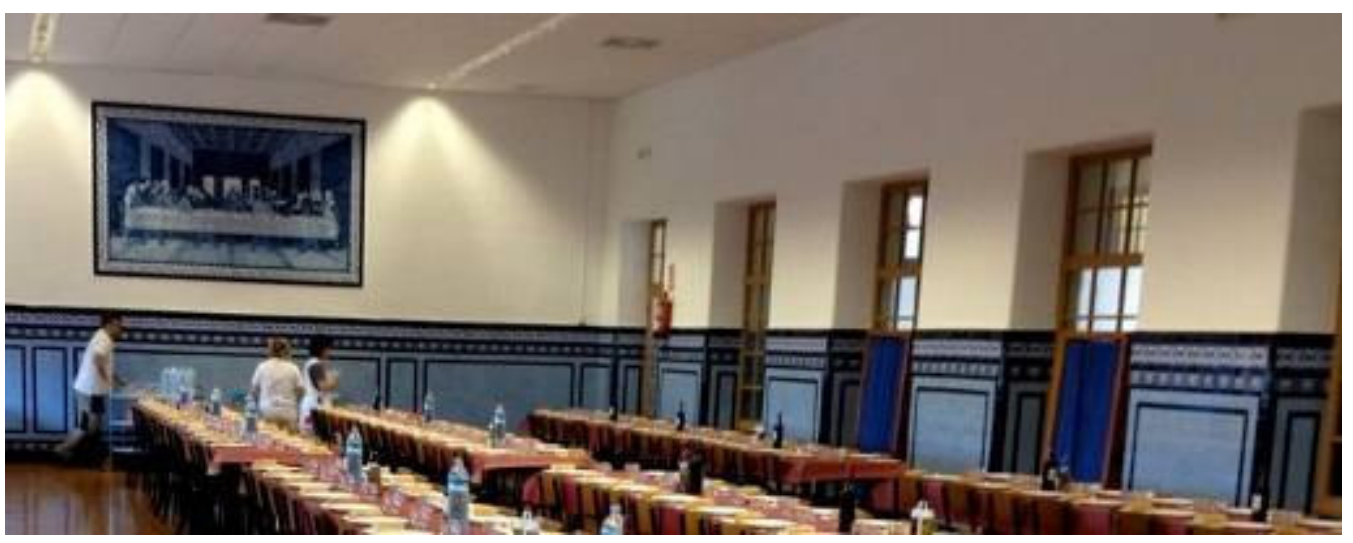

Comedor Seminario Tortosa 


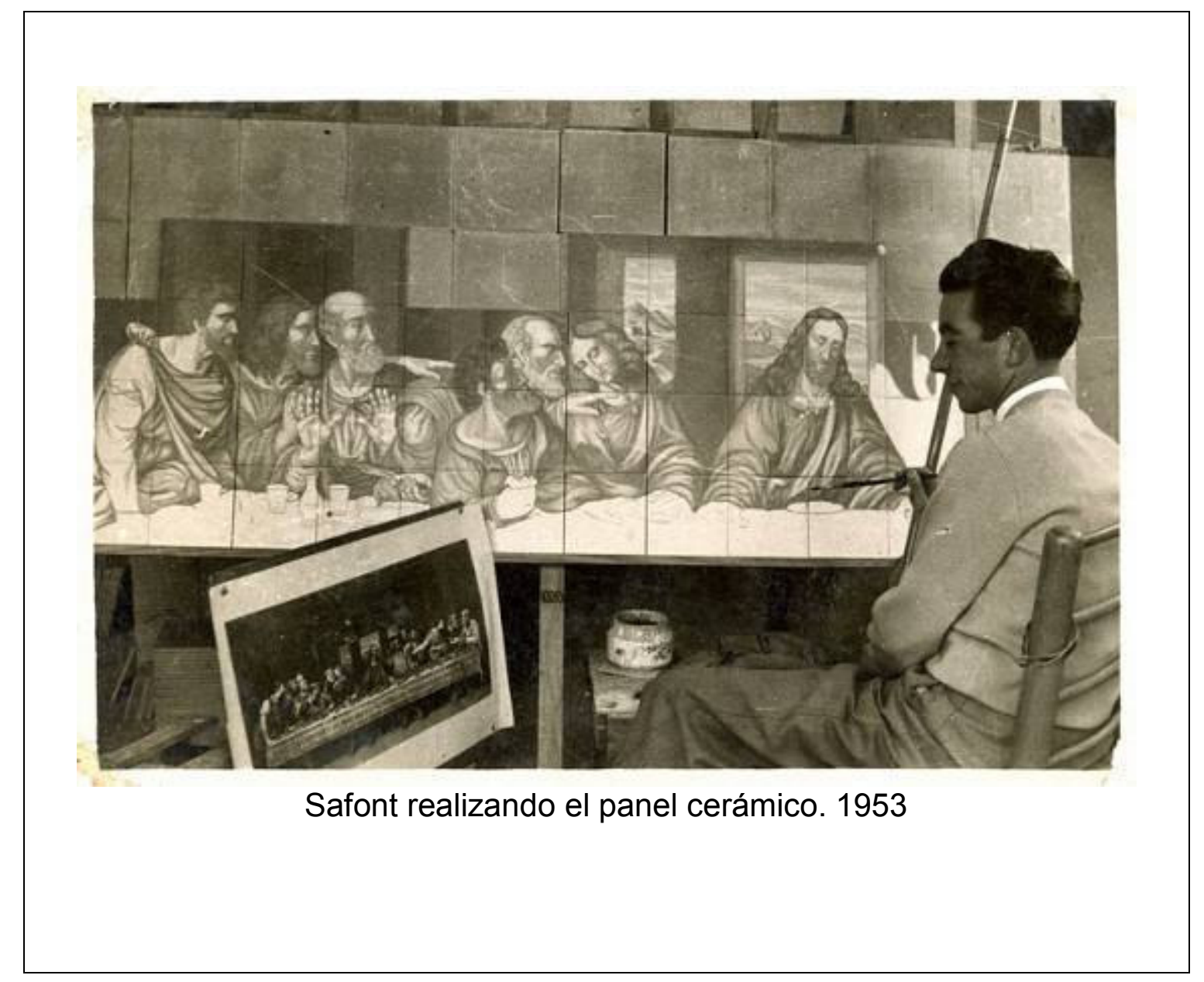


No: 7.7

Título: Sin Título

Autoría: Manolo Safont

Datación: 1954

Inscripciones: Año Santo Mariano 1954 en ángulo inferior izquierdo; Parroquia de la Asunción de Ntra. Sra. en filacteria en zona central inferior; M. Safont Onda en ángulo inferior derecho

Dimensiones: Semicircular 620x460cm aprox.

Técnica: Azulejo plano esmaltado, dibujo estarcido pintado a mano.

Localización: Fachada de la Iglesia Parroquial de la Asunción de Nuestra Señora. Plaza de la Iglesia s/n. Sueras. Castellón

Descripción: Obra compuesta por 594 azulejos de 20x20 cms. Iconografía: "Bula Munificentissimus Deus" (Dios, que es sumamente magnánimo) CONSTITUCIÓN APOSTÓLICA DE NUESTRO SANTÍSIMO SEÑOR PÍO POR LA DIVINA PROVIDENCIA PAPA PÍO XII EN LA QUE SE DEFINE COMO DOGMA DE FE QUE LA VIRGEN MARÍA, FUE ASUNTA EN CUERPO $Y$ ALMA A LA GLORIA CELESTE. 1 noviembre 1950.

Safont, en el retablo de la iglesia parroquial de Sueras, nos muestra su versión del relato asuncionista. En la parte superior la Santísima Trinidad, misterio central de la fe y de la vida cristiana, representados en el retablo en el centro, por el Espíritu Santo en forma de paloma, que irradia una gran luz que ilumina toda la escena con su resplandor, al mismo tiempo que abren las nubes de la Gloria Celestial de las que se asoman querubines a ambos lados; a la derecha Jesucristo, de medio cuerpo, con rostro adulto, barbado, con el torso desnudo que cubre con una túnica gris-azulada, porta en su mano derecha una Cruz de madera como símbolo de su sacrificio redentor, al mismo tiempo que extiende su mano izquierda hacia su Madre, a la que dirige su mirada.

A la izquierda, también en la parte superior Dios Padre, de medio cuerpo, representado como un anciano, sobre su cabeza de cabellos y barba canosa el triángulo trinitario, cubre su cuerpo con un gran manto; su mano izquierda aparece posaba sobre un orbe, mientras la derecha la extiende también hacia la Virgen.

En la parte central del retablo, emergiendo de una gran nube gris, está la Virgen María en posición estante. Para realizar esta imagen, Safont, se inspiró en la obra pictórica de Murillo, "la Asunción de la Virgen" (1670-1680), que se encuentra en el museo Hermitage de San Petersburgo.

Sobre una nube; se muestra La Virgen María en actitud triunfante, viste amplia túnica blanca de pureza que ciñe a la cintura con un cíngulo de tela gris azulada, y envuelve su cuerpo con un gran manto azul, sobre su cuello y hombros un pañolón blanco azulado. Tiene el rostro joven y los cabellos largos de color oscuro. En su ascenso los ropajes dan muestras de ese movimiento, en sintonía también con su cabeza que la dirige hacia arriba como buscando a su Hijo que la llama. Tiende su brazo derecho hacia arriba y mientras tiene ambas manos extendidas, parece que acuda presurosa hacia quien la llama.

Alrededor de la nube nueve ángeles infantes en actitudes diversas, sin mostrar esfuerzo parecen que la empujan hacia arriba. El rostro de la Virgen que mira hacia lo alto, queda totalmente iluminado por la luz que irradia el Espíritu Santo. Safont añade un elemento que no está en la obra de Murillo; uno de los ángeles infantes que vuela en la nube, a los pies de la Virgen, muestra en su mano 
derecha un ramo de azucenas, quizá recordando la declaración dogmática de la Inmaculada Concepción, que cumplía cien años entonces.

En la parte inferior a la izquierda del espectador, el retablo nos muestra una vista aérea de la Basílica de San Pedro de Roma, escrito con letras negras sobre el pavimento de la plaza se lee: AÑO SANTO MARIANO. 1954. En la parte posterior de la cúpula de la Basílica, emerge una gran cruz que irradia luz, como símbolo de toda la cristiandad; en la parte superior a ésta cruz, un ángel porta entre sus manos un puñado de rosas que deja caer a modo de homenaje celestial sobre la Basílica.

En la parte inferior a la derecha del espectador, aparece sentado sobre su cátedra el Papa Pío XII, como recuerdo al Pontífice que definió y proclamó el dogma de la Asunción, desde el atrio exterior de la Basílica de San Pedro, rodeado de gran número de dignatarios eclesiásticos y de una muchedumbre que llenaba la plaza.

Safont nos presenta al Papa como queriendo recordar quizá ese momento de la proclamación; aparece vestido de pontifical, alba blanca que deja ver en las bocamangas, y una gran capa pluvial que se adorna en el pecho con un gran escudo redondo; sobre su cabeza la Tiara papal; su cuerpo está levemente girado hacia su derecha. Con su mano derecha, en la que se observa el anillo del pescador, imparte la bendición "urbi et orbi". En la parte superior del Pontífice, un ángel lo sobrevuela y mientras le dirige su mirada, lleva entre sus manos unas espigas y un racimo de uva como simbología de la Eucaristía.

En la parte inferior del retablo, centrado en el mismo, aparece una gran filacteria blanca con la inscripción: PARROQUIA DE LA ASUNCIÓN DE NTRA. SRA.

Estado de Conservación y restauración: Bueno. No presenta lagunas ni grietas. El gran retablo está situado en el imafronte de la iglesia parroquial, y es el segundo de mayor tamaño de la provincia de Castellón.

El 9 octubre de 1950, el párroco de Sueras, Mn. Joaquín Amorós, pide por escrito al prelado diocesano el cambio de titularidad de la parroquia, de la Natividad de Ntra. Sra., por el de La Asunción de Nuestra Señora. Con fecha 9 de noviembre, justo un mes después, el prelado diocesano Dr. D. Manuel Moll i Salord, firmaba el decreto del cambio de titularidad, justo ocho días después de la proclamación del dogma de la Asunción, por el Papa Pío XII.

El año 1954 es declarado por el Papa, Año Mariano Universal, para conmemorar el primer centenario de la definición dogmática de la Inmaculada Concepción de María en la "Bula Ineffabilis Deus". Así pues, el nuevo rector, Mn. Vichares, y la propia feligresía parroquial, para celebrar dicha efeméride, y el cambio de titularidad parroquial, le encargan al ceramista ondense Manolo Safont Castelló la realización de un gran retablo para el imafronte de la iglesia. En el encargo le comentan que en el retablo se haga referencia a la Asunción de Nuestra Señora y al año mariano proclamado por el Papa. Safont aceptó el encargo de la parroquia y se puso a trabajar de inmediato en el mismo.

El importe del retablo fue costeado por lo propios parroquianos, quienes al precio de 5 pesetas cada azulejo lo fueron pagando poco a poco. Tan poco a poco, que cuando tenían recaudado alguna importante cantidad, avisaban al ceramista para que cobrara. Safont, se desplazaba en bicicleta hasta Sueras recorriendo los $7 \mathrm{~km}$. que la separan Onda, para cobrar. A principios de octubre de 1954 se terminó su colocación.

Según fuentes orales de Mn. Vicent Gimeno, rector de Sueras desde 1981 a 


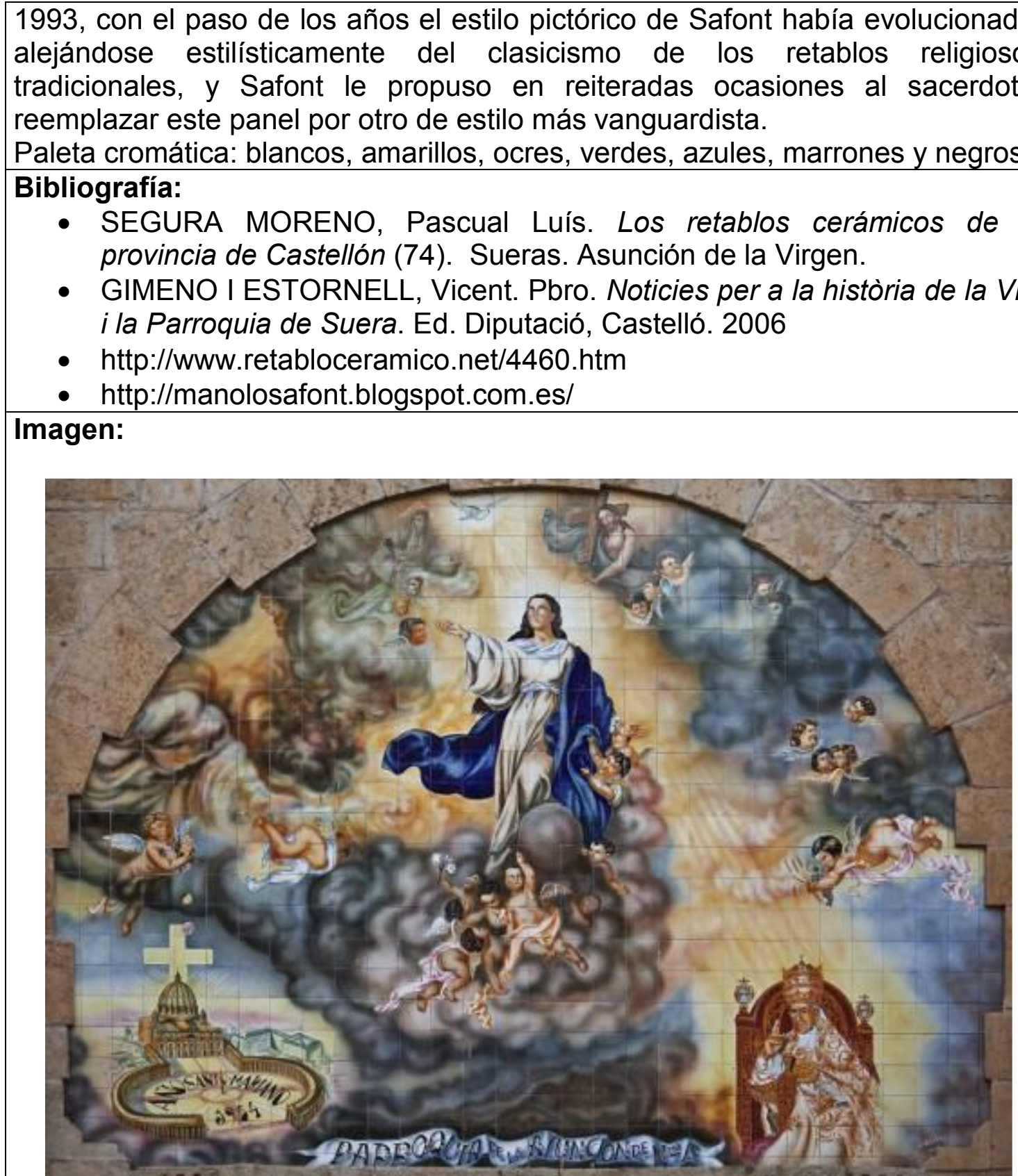

Imágenes relacionadas:

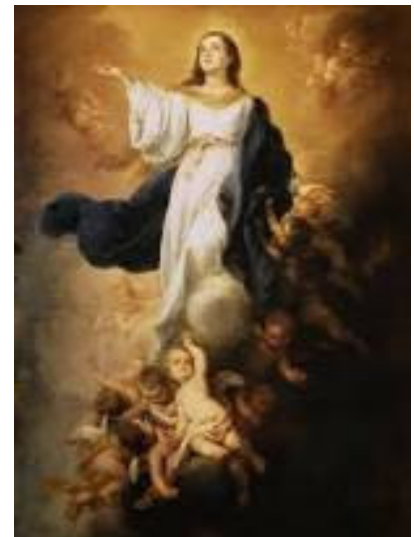

La Asunción de la Virgen. Murillo 


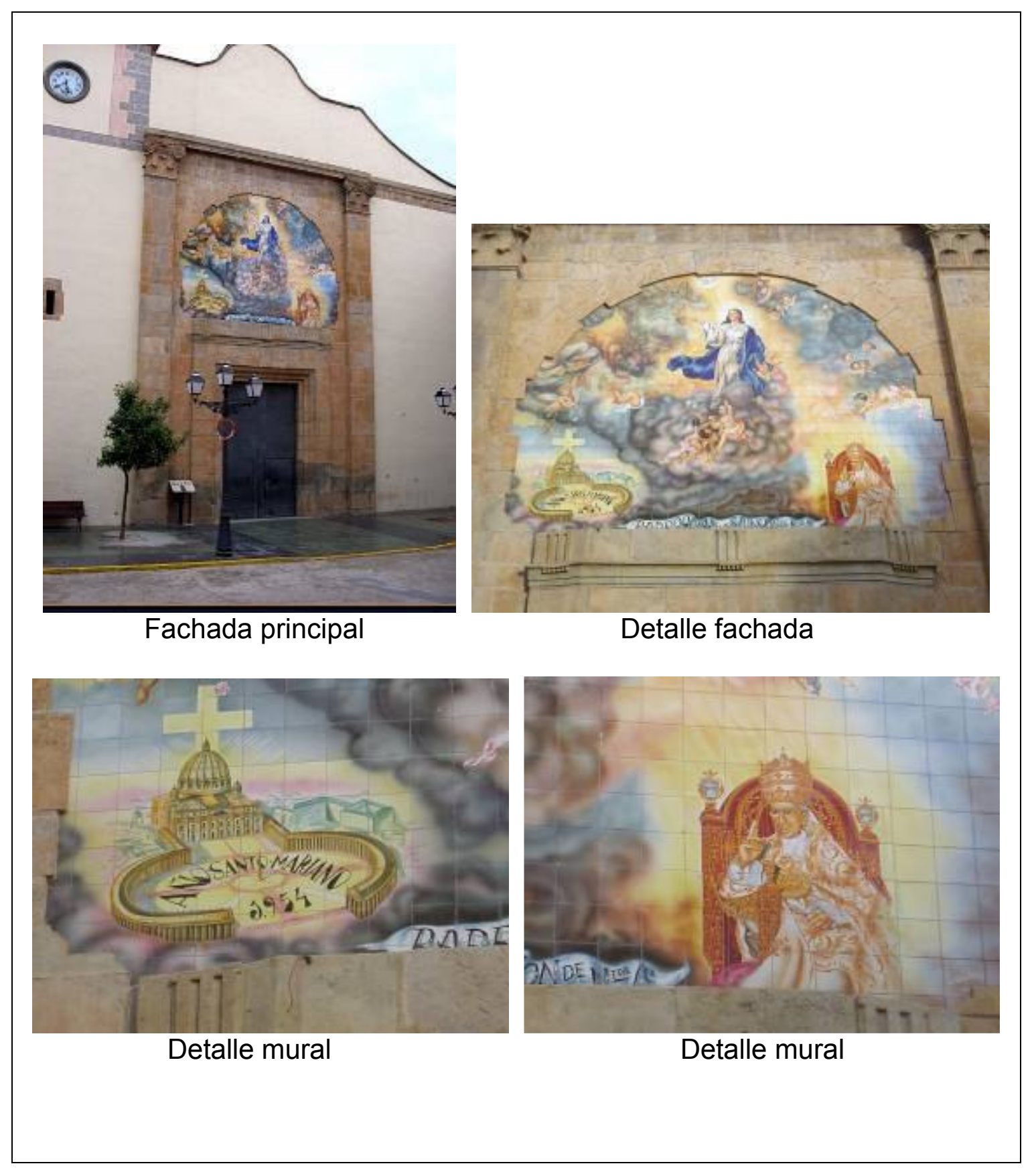


No: 7.8

Título: San Jorge

Autoría: Manolo Safont

Datación: 1958

Inscripciones: Safont 58 en ángulo inferior derecho

Dimensiones: $80 \times 60 \mathrm{cms}$

Técnica: Pintura cerámica de bicocción

Localización: Calle San Jorge, $n^{\circ} 5$, Onda, Castellón

Descripción: Panel devocional ubicado en la calle de Onda con el nombre del santo, con la representación iconográfica habitual de San Jorge, sobre un caballo encabritado, con ropa militar, casco y amplio manto, en el momento de clavar la lanza a un dragón-demonio postrado a los pies del caballo. Obra compuesta por 12 azulejos de 20x20 cms en disposición 4×3, con filete amarillo y cubrecanto marrón. Paleta cromática: blancos, amarillos, rojos, verdes, azules, marrones y negros.

Bibliografía:

- ESTALL I POLES, Vicent. La devoció en Taulell. Les capelles devocionals de taulells d'Onda. Ajuntament d'Onda, 1997, pág. 36

- FELIU FRANCH, Joan. Historia del retablo cerámico en la Plana de Castelló. Análisis de un recurso patrimonial. Fundación Dávalos-Fletcher, Castellón, 2007, pág. 190

\section{Imagen:}

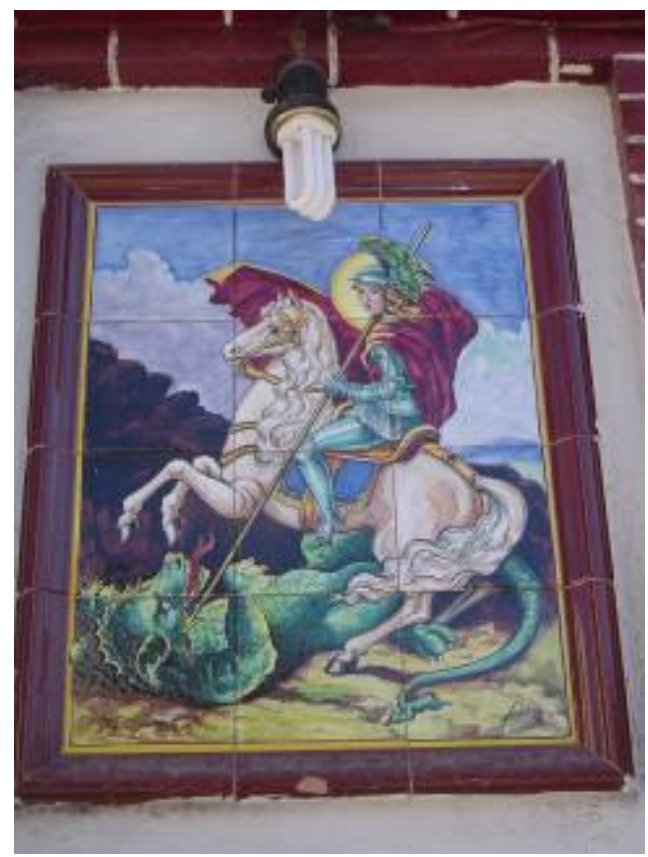

Imágenes relacionadas:

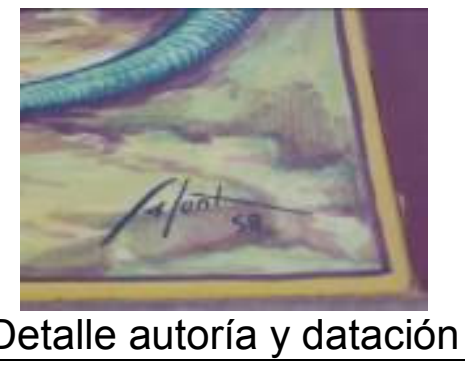


No: 7.9

Título: I Estación

Autoría: Manolo Safont

Datación: 1962

Inscripciones: $1^{\text {a }}$ en ángulo superior derecho. En placa cerámica independiente a la obra catalogada, pero adosada al mismo casilicio de la estación del calvario figura la siguiente leyenda, que alude tanto a la reflexión moral de esta primera estación, como a la persona que la ha sufragado:

PRIMERA ESTACIÓN

JESÚS CONDENADO A MUERTE

A EXPENSAS

DEL RVDO. D. FRANCISCO BLANQUER

Dimensiones: $40 \times 40 \mathrm{cms}$

Técnica: Pintura cerámica de bicocción

Localización: Calvario de Espadilla, Castellón.

Descripción: Obra compuesta por 4 azulejos de 20x20 cms, en disposición $2 \times 2$. La pieza no está firmada ni fechada, la autoría y datación se adjudican por fuentes orales parroquiales. La escena de esta primera estación corresponde al momento bíblico en que Jesús condenado a muerte: "Reo es de muerte", dijeron de Jesús los miembros del Sanedrín, y como no podían ejecutar a nadie, lo llevaron de la casa de Caifás al Pretorio. Pilato no encontraba razones para condenar a Jesús, e incluso trató de liberarlo, pero, ante la presión amenazante del pueblo instigado por sus jefes: “¡Crucifícalo, crucifícalo!”, "Si sueltas a ése, no eres amigo del César", pronunció la sentencia que le reclamaban y les entregó a Jesús, después de azotarlo, para que fuera crucificado. Paleta cromática: blancos, amarillos, rojos, verdes, azules, violetas, marrones y negros.

Bibliografía:

- http://www.franciscanos.org/oracion/viacruz00.htm Imagen:

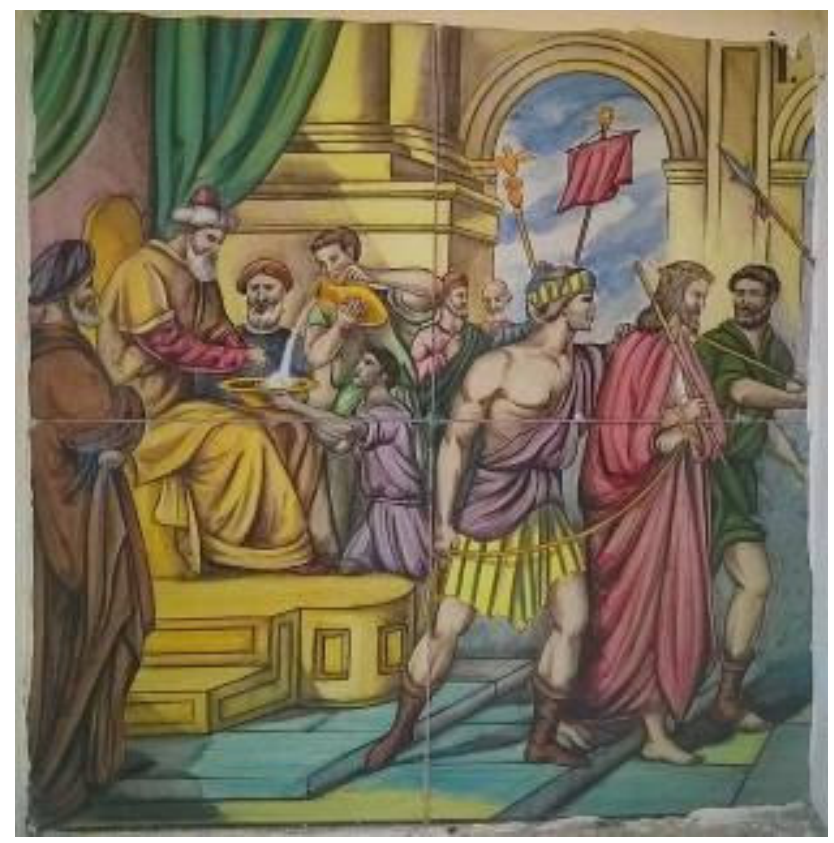


Imágenes relacionadas:

THIULDA ESTACION JESLS CONIENAE A HUERT a EPENSAS

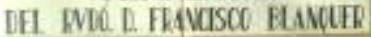

Casilicio

PRIUERA ESTACION

JESUS CONDENADO A MUERTE A EXPENSAS

DEL RVDÓ. D. FRANCISCO BLANQUER

Placa cerámica 
No: 7.10

Título: II Estación

Autoría: Manolo Safont

Datación: 1962

Inscripciones: $\|^{a}$ en ángulo superior derecho. En placa cerámica independiente a la obra catalogada, pero adosada al mismo casilicio de la estación del calvario figura la siguiente leyenda, que alude tanto a la reflexión moral de esta segunda estación, como a la persona que la ha sufragado:

\section{SEGUNDA ESTACIÓN}

JESÚS SALE CON LA CRUZ A CUESTAS

A EXPENSAS

VICENTE NEBOT

Dimensiones: 40 x $40 \mathrm{cms}$

Técnica: Pintura cerámica de bicocción

Localización: Calvario de Espadilla, Castellón.

Descripción: Obra compuesta por 4 azulejos de 20x20 cms, en disposición $2 \times 2$. La pieza no está firmada ni fechada, la autoría y datación se adjudican por fuentes orales parroquiales. La escena de esta segunda estación corresponde al momento bíblico en que Jesús, condenado a muerte, es entregado a los soldados del procurador, que lo llevaron consigo al pretorio y, reunida la tropa, hicieron mofa de él. Llegada la hora, le quitaron el manto de púrpura con que lo habían vestido para la burla, le pusieron de nuevo sus ropas, le cargaron la cruz en que había de morir y salieron camino del Calvario para allí crucificarlo. Paleta cromática: blancos, amarillos, rojos, verdes, azules, violetas, marrones y negros.

\section{Bibliografía:}

- http://www.franciscanos.org/oracion/viacruz00.htm

Imagen:

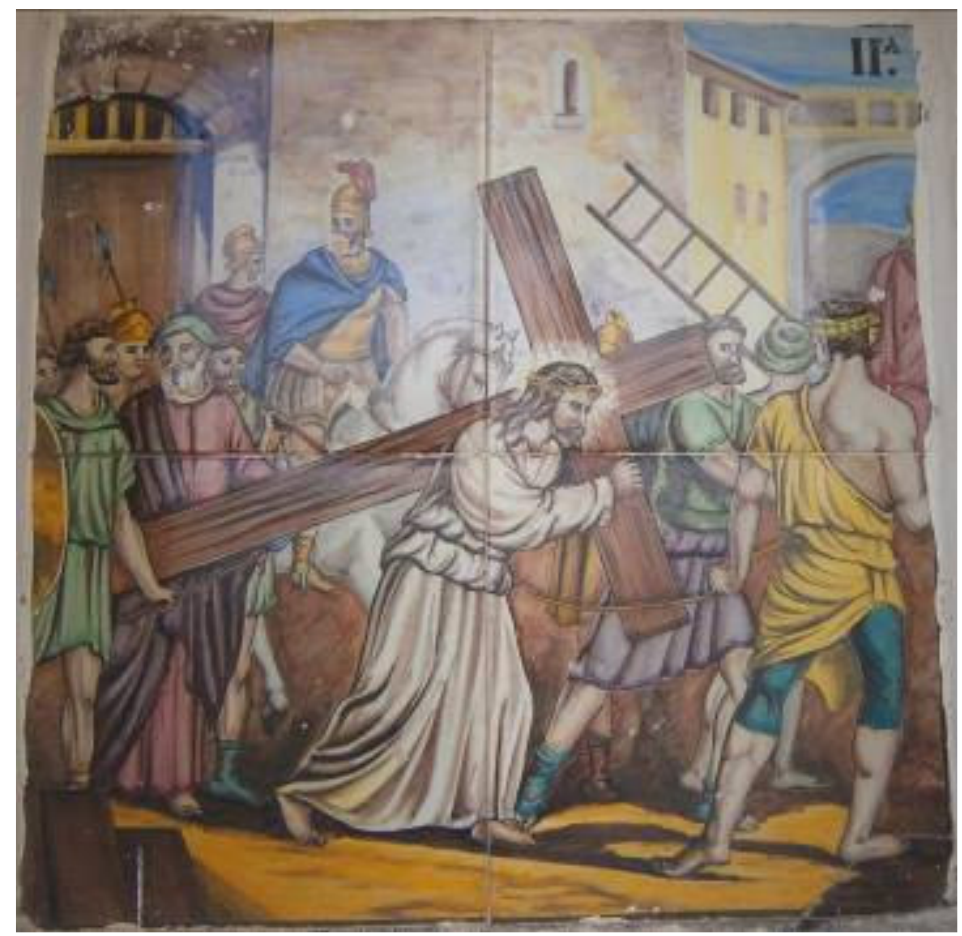


Imágenes relacionadas:

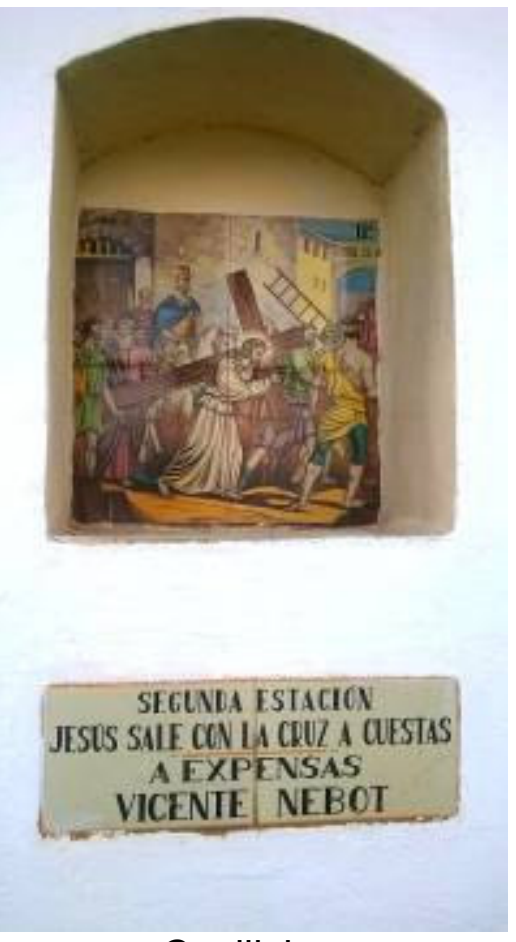

Casilicio

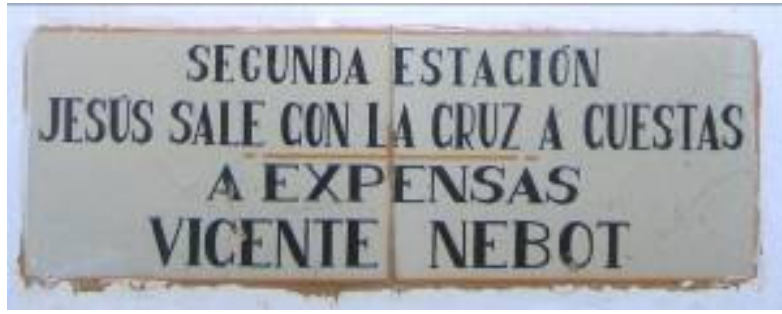

Placa cerámica 
No: 7.11

Título: III Estación.

Autoría: Manolo Safont

Datación: 1962

Inscripciones: III a en ángulo superior derecho. En placa cerámica independiente a la obra catalogada, pero adosada al mismo casilicio de la estación del calvario figura la siguiente leyenda, que alude tanto a la reflexión moral de esta tercera estación, como a la persona que la ha sufragado:

TERCERA ESTACIÓN

JESÚS CAE POR PRIMERA VEZ

A EXPENSAS

RVDO. D. JUAN TORTAJADA ANDREU

Dimensiones: 40 × $40 \mathrm{cms}$

Técnica: Pintura cerámica de bicocción

Localización: Calvario de Espadilla, Castellón.

Descripción: Obra compuesta por 4 azulejos de 20x20 cms, en disposición $2 \times 2$. La pieza no está firmada ni fechada, la autoría y datación se adjudican por fuentes orales parroquiales. La escena de esta tercera estación corresponde al momento bíblico en que Jesús cae por primera vez, agotadas las fuerzas por la sangre perdida en la flagelación, debilitado por los sufrimientos que le infligieron, en ayunas y sin haber dormido, apenas pudo dar algunos pasos y pronto cayó bajo el peso de la cruz. Se sucedieron los golpes e imprecaciones de los soldados, las risas y expectación del público. Jesús, logró levantarse para seguir su camino. Paleta cromática: blancos, amarillos, rojos, verdes, azules, violetas, marrones y negros.

Bibliografía:

- http://www.franciscanos.org/oracion/viacruz00.htm Imagen:

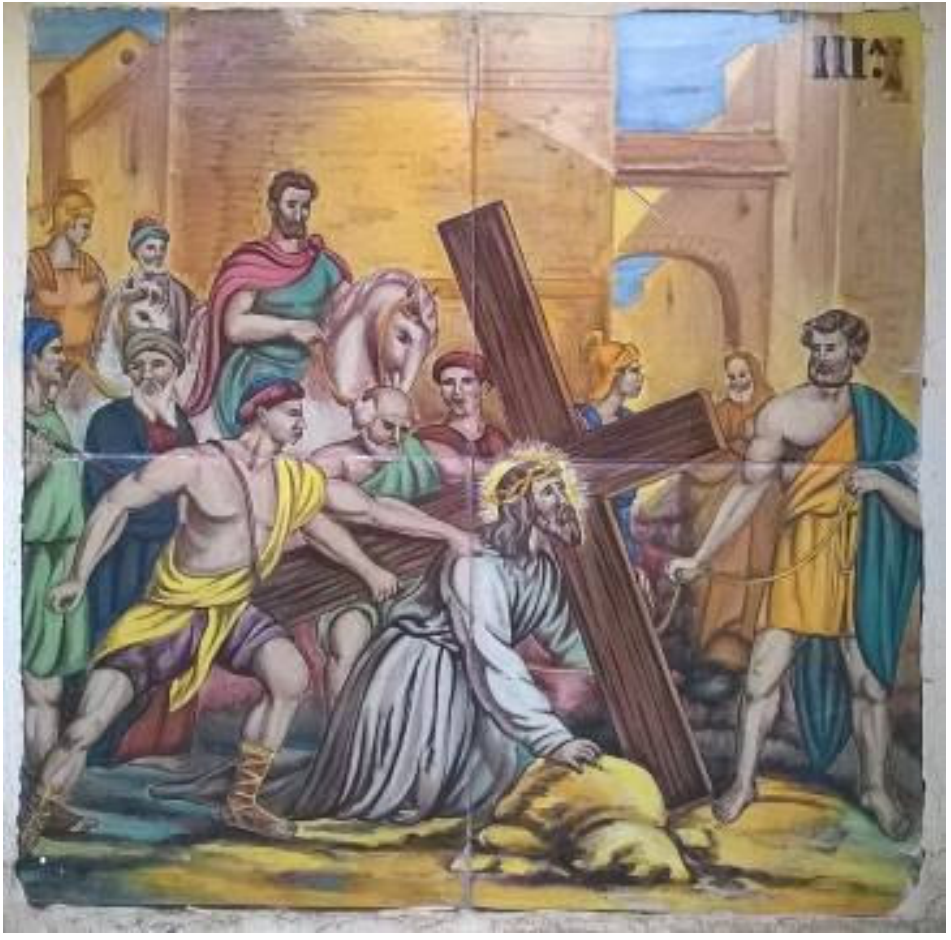


Imágenes relacionadas:

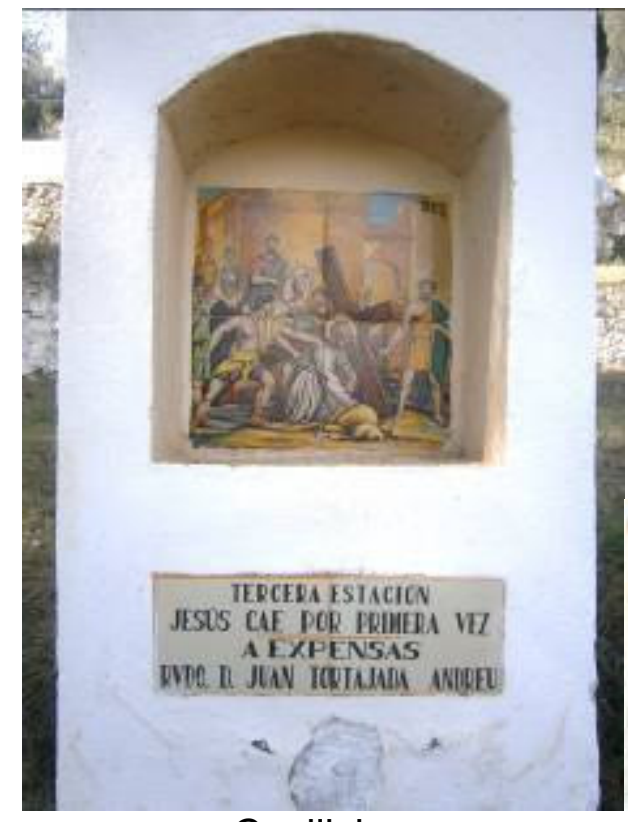

Casilicio

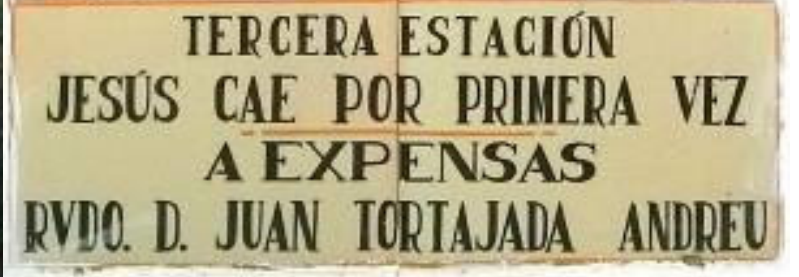

Placa cerámica 
$\mathbf{N}^{0}: 7.12$

Título: IV Estación.

Autoría: Manolo Safont

Datación: 1962

Inscripciones: IV a en ángulo superior derecho. En placa cerámica independiente a la obra catalogada, pero adosada al mismo casilicio de la estación del calvario figura la siguiente leyenda, que alude tanto a la reflexión moral de esta cuarta estación, como a la familia que la ha sufragado:

\section{CUARTA ESTACIÓN \\ JESÚS ENCUENTRA A SU \\ MADRE SANTÍSIMA \\ A EXPENSAS \\ $D^{a}$. MERCEDES CAMPOS Y FAMILIA}

Dimensiones: $40 \times 40 \mathrm{cms}$.

Técnica: Pintura cerámica de bicocción

Localización: Calvario de Espadilla, Castellón.

Descripción: Obra compuesta por 4 azulejos de 20x20 cms, en disposición $2 \times 2$. La pieza no está firmada ni fechada, la autoría y datación se adjudican por fuentes orales parroquiales. La escena de esta cuarta estación corresponde al momento bíblico en que Jesús se encuentra con su madre. En su camino hacia el Calvario, Jesús va rodeado por una multitud de soldados, jefes judíos, pueblo, etc. También se encuentra allí María, su madre, que no aparta la vista de su Hijo. Paleta cromática: blancos, amarillos, rojos, verdes, azules, violetas, marrones y negros.

\section{Bibliografía:}

- http://www.franciscanos.org/oracion/viacruz00.htm Imagen:

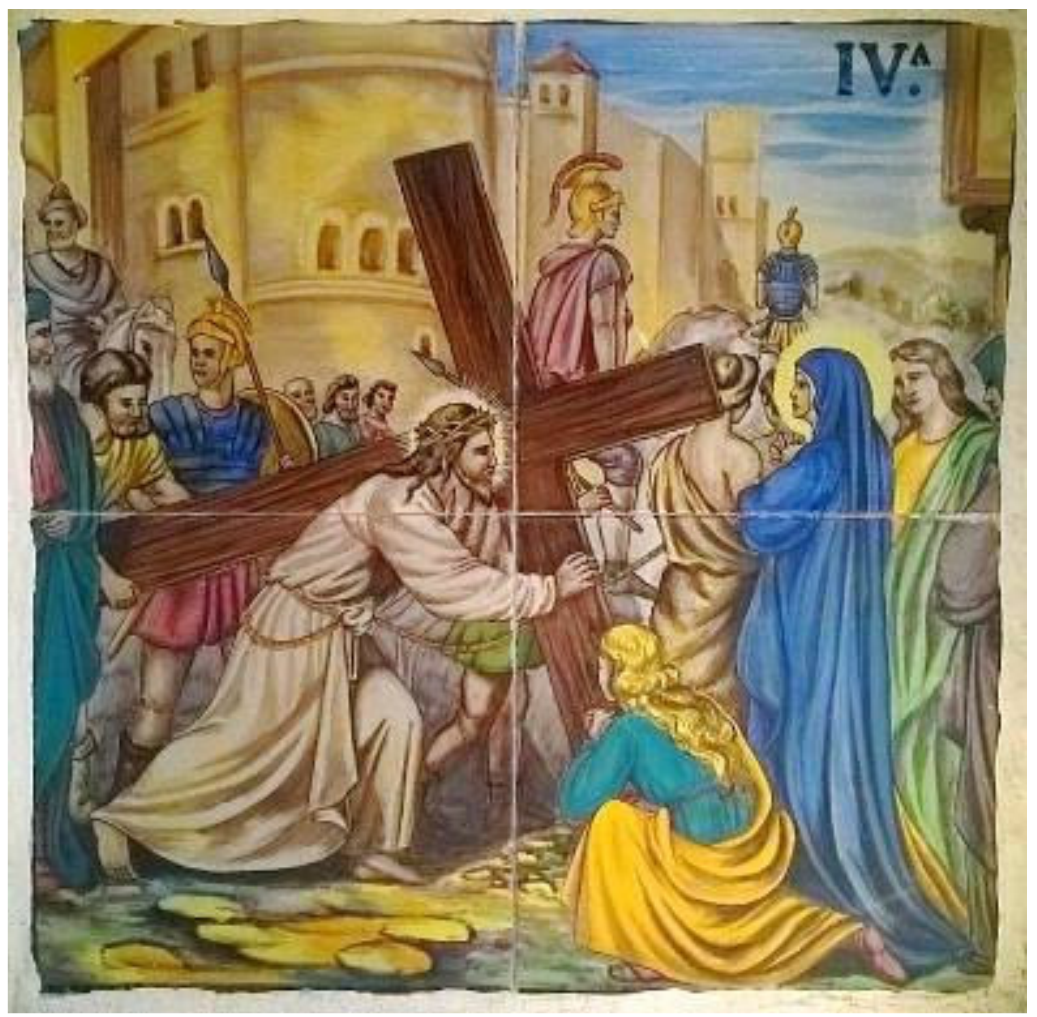


Imágenes relacionadas:

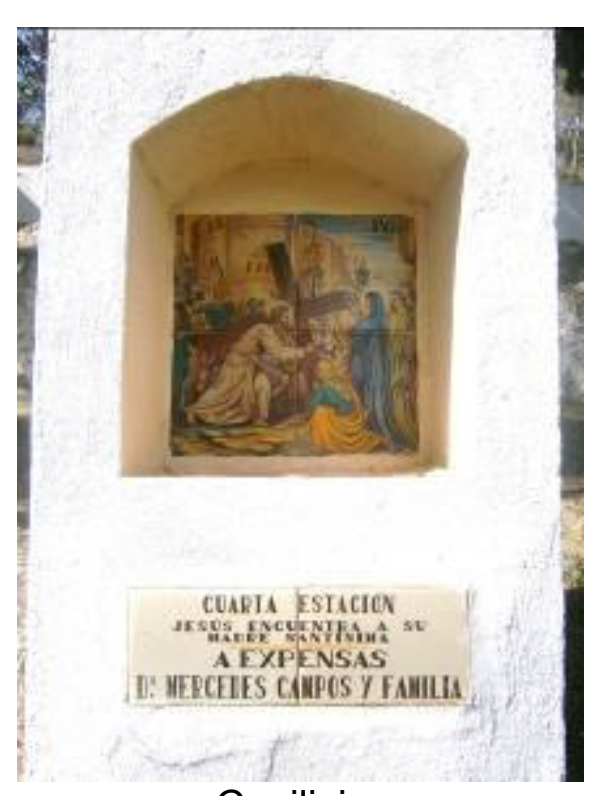

Casilicio
CUARTA ESTACIÓN JESUS ENCUENTRA A SU A EXPENSAS D: MERCEDES CAMPOS Y FAMIILIA

Placa cerámica 
No: 7.13

Título: $V^{a}$ Estación.

Autoría: Manolo Safont.

Datación: 1962.

Inscripciones: $V^{a}$ en ángulo superior izquierdo. En placa cerámica independiente a la obra catalogada, pero adosada al mismo casilicio de la estación del calvario figura la siguiente leyenda, que alude tanto a la reflexión moral de esta quinta estación, como a la persona que la ha sufragado:

QUINTA ESTACIÓN

SIMÓN CIRINEO LE AYUDA

A LLEVAR LA CRUZ

A EXPENSAS

RVDO. D. ANTONIO ROMERO

Dimensiones: $40 \times 40 \mathrm{cms}$.

Técnica: Pintura cerámica de bicocción

Localización: Calvario de Espadilla, Castellón

Descripción: Obra compuesta por 4 azulejos de 20x20 cms, en disposición $2 \times 2$. La pieza no está firmada ni fechada, la autoría y datación se adjudican por fuentes orales parroquiales. La escena de esta quinta estación corresponde al momento bíblico en que Jesús salió del pretorio llevando a cuestas su cruz, camino del Calvario, pero su primera caída puso de manifiesto el agotamiento del reo. Temerosos los soldados de que la víctima sucumbiese antes de hora, pensaron en buscarle un sustituto. Entonces el centurión obligó a un tal Simón de Cirene, que venía del campo y pasaba por allí, a que tomara la cruz sobre sus hombros y la llevara detrás de Jesús. Paleta cromática: blancos, amarillos, rojos, verdes, azules, violetas, marrones y negros.

Bibliografía:

- http://www.franciscanos.org/oracion/viacruz00.htm Imagen:

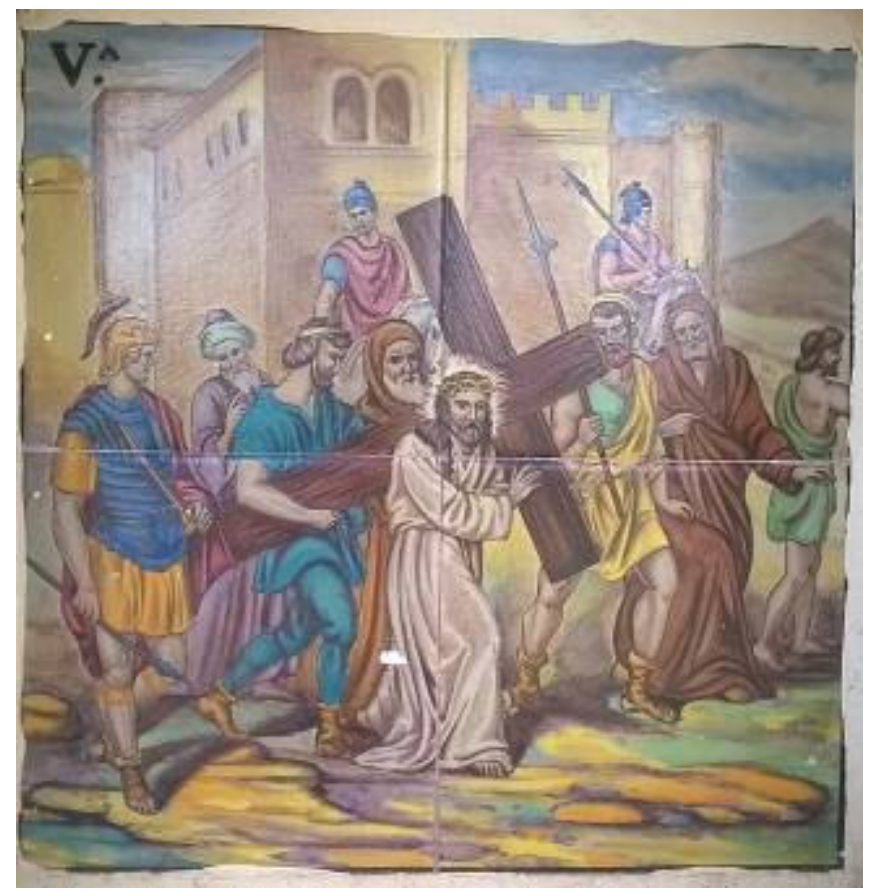


Imágenes relacionadas:

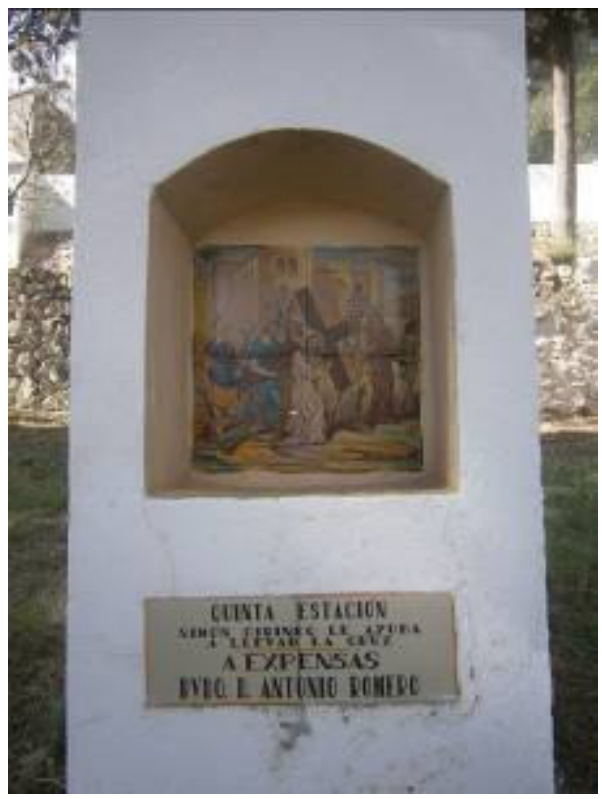

Casilicio

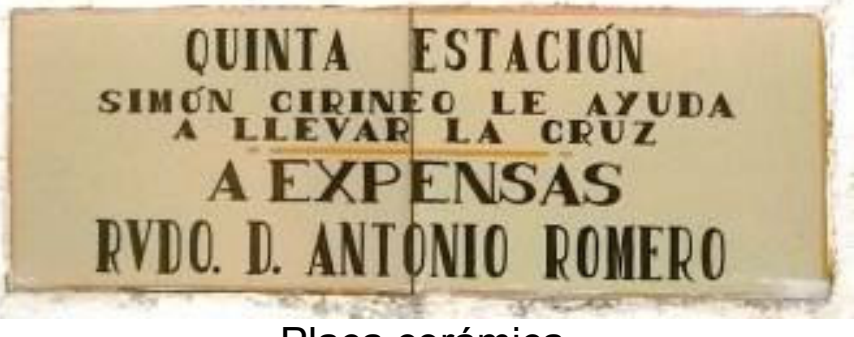

Placa cerámica 
No: 7.14

Título: $\mathrm{VI}^{\mathrm{a}}$ Estación.

Autoría: Manolo Safont

Datación: 1962

Inscripciones: $\mathrm{VI}^{\mathrm{a}}$ en ángulo superior derecho. En placa cerámica independiente a la obra catalogada, pero adosada al mismo casilicio de la estación del calvario figura la siguiente leyenda, que alude tanto a la reflexión moral de esta sexta estación, como a la familia que la ha sufragado:

SEXTA ESTACIÓN

LA VERÓNICA ENJUGA

EL ROSTRO DE JESÚS

A EXPENSAS

FAMILIA LECHA ORTELLS

Dimensiones: $40 \times 40 \mathrm{cms}$.

Técnica: Pintura cerámica de bicocción

Localización: Calvario de Espadilla, Castellón.

Descripción: Obra compuesta por 4 azulejos de 20x20 cms, en disposición $2 \times 2$. La pieza no está firmada ni fechada, la autoría y datación se adjudican por fuentes orales parroquiales. La escena de esta sexta estación corresponde al momento bíblico en que la Verónica enjuga el rostro de Jesús. Camino del Calvario, con el rostro desfigurado por el sufrimiento, la sangre, los salivazos, el polvo, el sudor... Entonces, una mujer del pueblo, Verónica de nombre, se abrió paso entre la muchedumbre llevando un lienzo con el que limpió piadosamente el rostro de Jesús, y en respuesta de gratitud, le dejó grabada en él su Santa Faz. Paleta cromática: blancos, amarillos, rojos, verdes, azules, violetas, marrones y negros.

\section{Bibliografía:}

- http://www.franciscanos.org/oracion/viacruz00.htm Imagen:

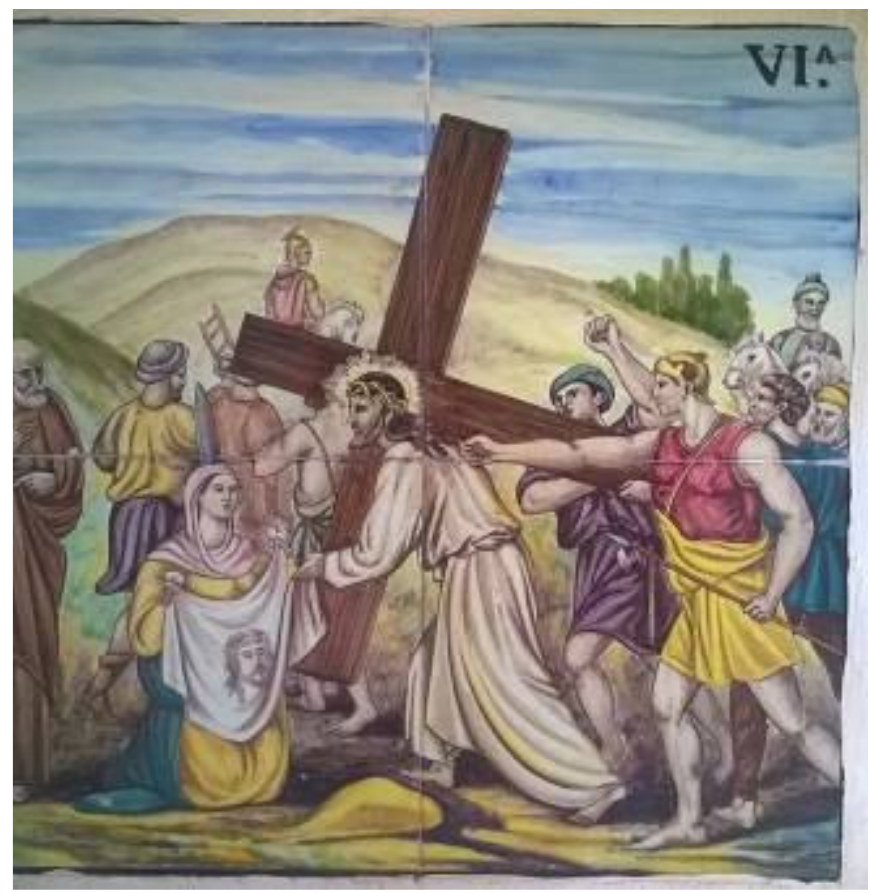


Imágenes relacionadas:

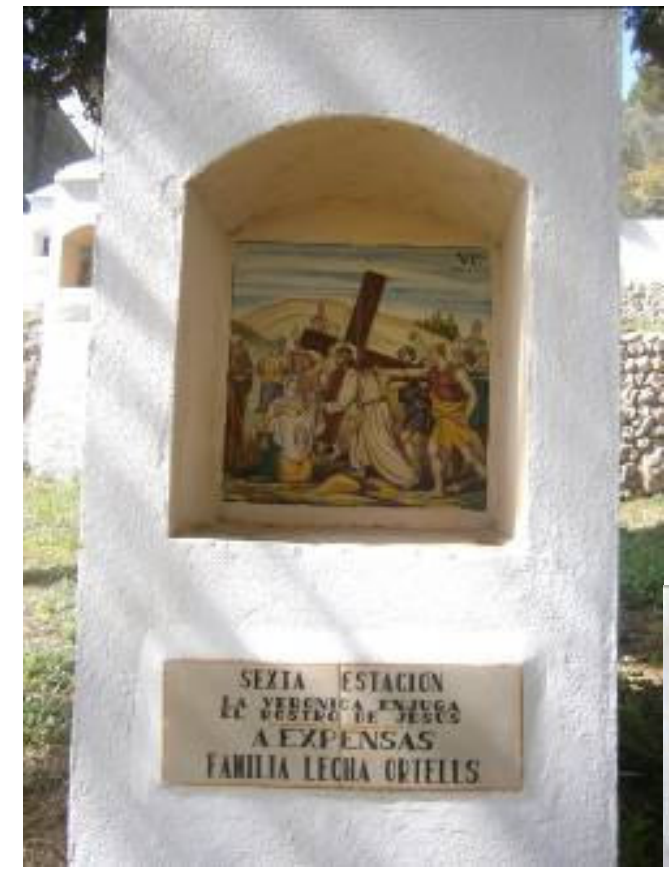

Casilicio

\section{SEXTA ESTACION} LA YERTNICA ENJUGA A EXPENSAS FAIIIIIA LECHA ORIELLS

Placa cerámica 
No: 7.15

Título: VII ${ }^{\mathrm{a}}$ Estación.

Autoría: Manolo Safont

Datación: 1962

Inscripciones: $\mathrm{VII}^{\mathrm{a}}$ en ángulo superior derecho. En placa cerámica independiente a la obra catalogada, pero adosada al mismo casilicio de la estación del calvario figura la siguiente leyenda, que alude tanto a la reflexión moral de esta séptima estación, como a la persona que la ha sufragado:

SEPTIMA ESTACIÓN

JESÚS CAE POR SEGUNDA VEZ

A EXPENSAS

D. JOSÉ OLMEDO

Dimensiones: $40 \times 40 \mathrm{cms}$.

Técnica: Pintura cerámica de bicocción

Localización: Calvario de Espadilla, Castellón.

Descripción: Obra compuesta por 4 azulejos de 20x20 cms, en disposición $2 \times 2$. La pieza no está firmada ni fechada, la autoría y datación se adjudican por fuentes orales parroquiales. La escena de esta séptima estación corresponde al momento bíblico en que Jesús había tomado de nuevo la cruz y con ella a cuestas llegó a la cima de la empinada calle que daba a una de las puertas de la ciudad. Allí, extenuado, sin fuerzas, cayó por segunda vez bajo el peso de la cruz. Faltaba poco para llegar al sitio en que tenía que ser crucificado, y Jesús, aún logró reunir fuerzas, levantarse y proseguir su camino. Paleta cromática: blancos, amarillos, rojos, verdes, azules, violetas, marrones y negros.

\section{Bibliografía:}

- http://www.franciscanos.org/oracion/viacruz00.htm Imagen:

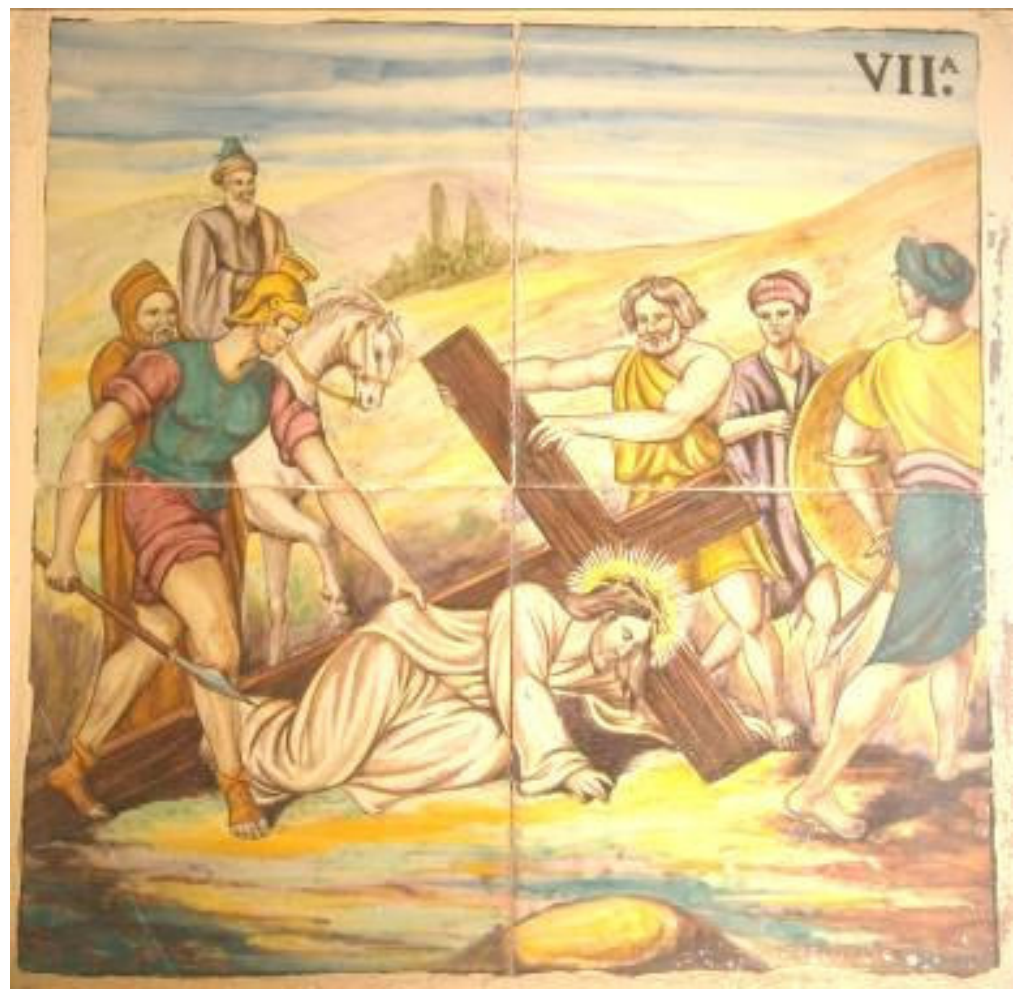


Imágenes relacionadas:
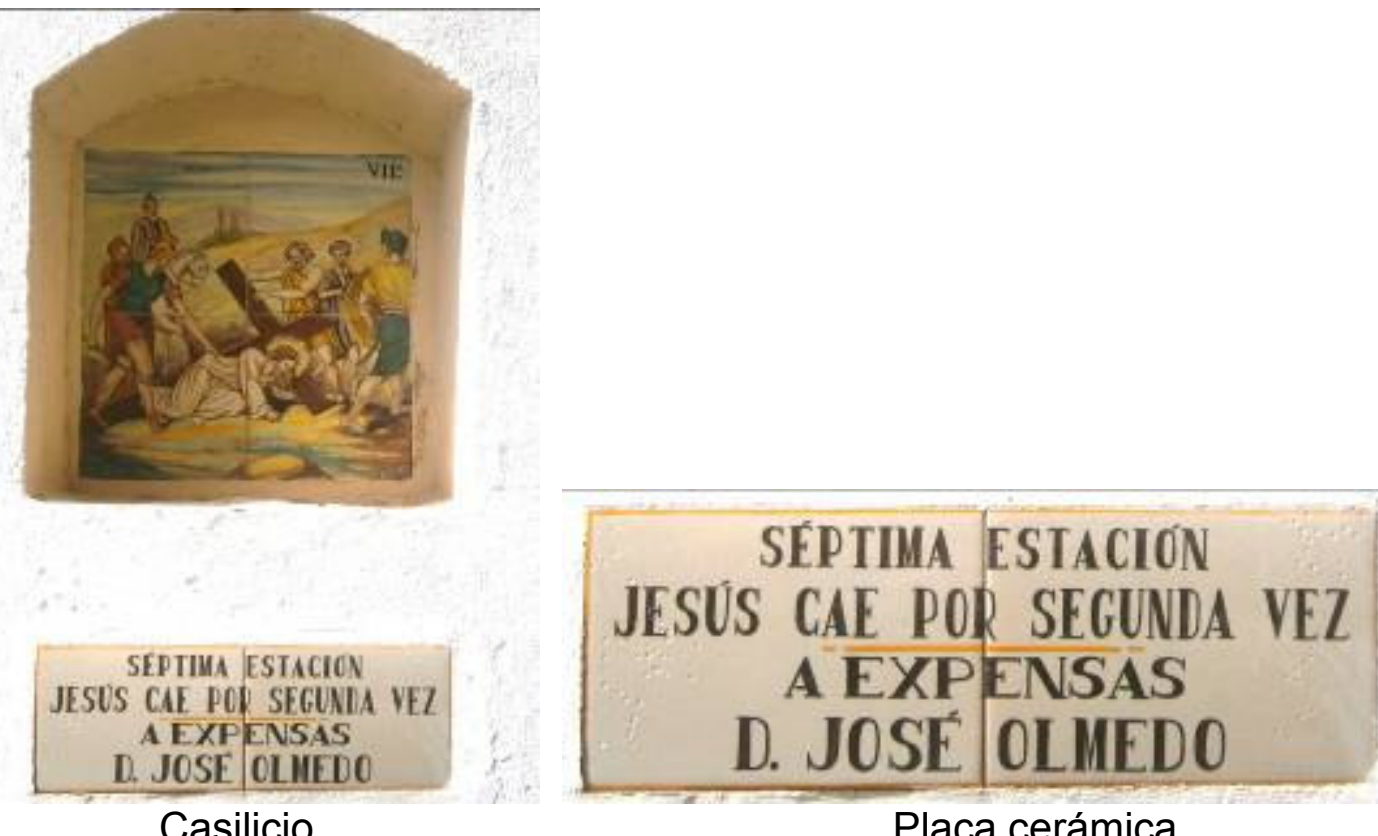

Placa cerámica 
No: 7.16

Título: VIII ${ }^{a}$ Estación.

Autoría: Manolo Safont

Datación: 1962

Inscripciones: VIII ${ }^{a}$ en ángulo superior derecho. En placa cerámica independiente a la obra catalogada, pero adosada al mismo casilicio de la estación del calvario figura la siguiente leyenda, que alude tanto a la reflexión moral de esta octava estación, como al colectivo que la ha sufragado:

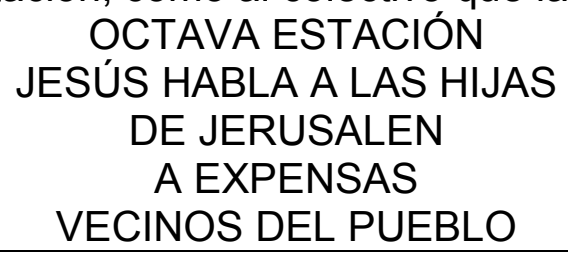

Dimensiones: $40 \times 40 \mathrm{cms}$

Técnica: Pintura cerámica de bicocción

Localización: Calvario de Espadilla, Castellón.

Descripción: Obra compuesta por 4 azulejos de $20 \times 20 \mathrm{cms}$, en disposición 2x2. La pieza no está firmada ni fechada, la autoría y datación se adjudican por fuentes orales parroquiales. La escena de esta octava estación corresponde al momento bíblico en que a Jesús, habla y consuela a las mujeres de Jerusalén. Camino del Calvario, lo seguía una gran multitud del pueblo, y unas mujeres se lamentaban por él. Jesús, volviéndose a ellas les dijo: "Hijas de Jerusalén, no lloréis por mí; llorad más bien por vosotras y por vuestros hijos". Paleta cromática: blancos, amarillos, rojos, verdes, azules, violetas, marrones y negros.

\section{Bibliografía:}

- http://www.franciscanos.org/oracion/viacruz00.htm Imagen:

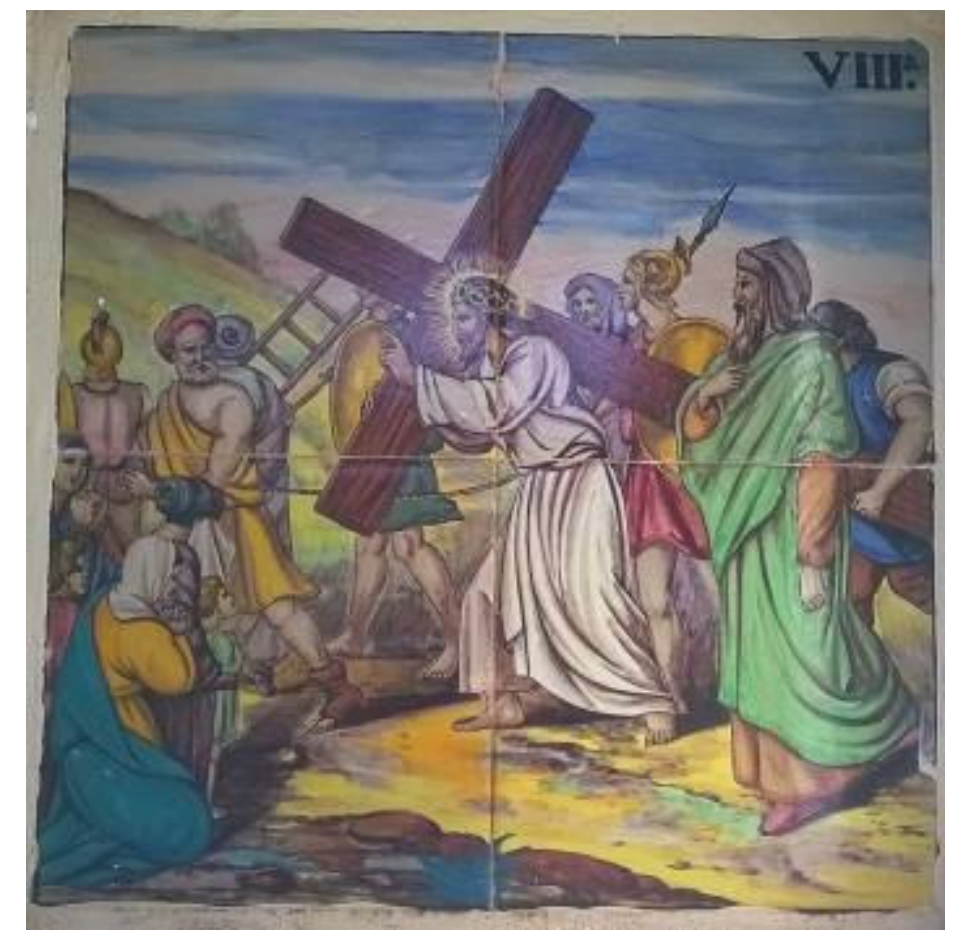


Imágenes relacionadas:

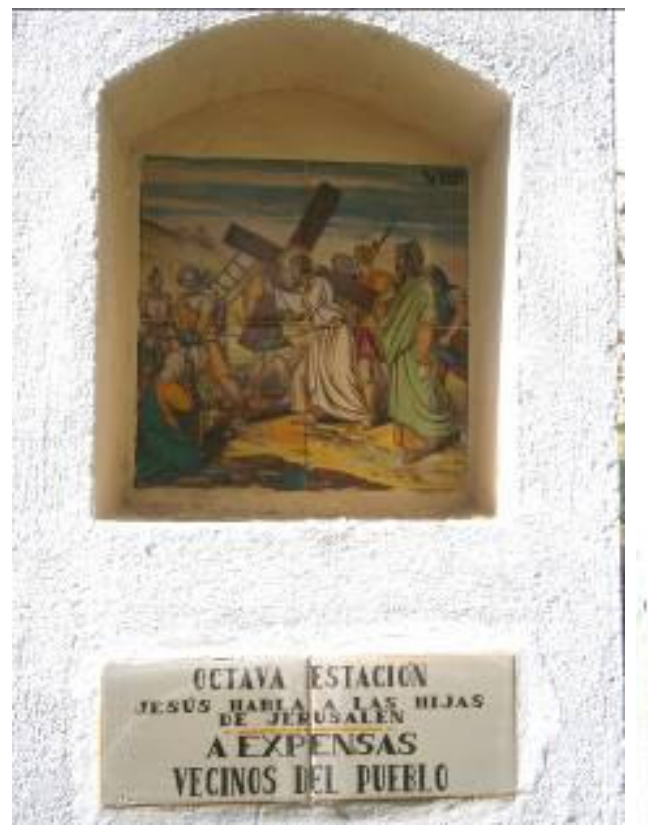

Casilicio

OCTAVA IESTACION

JESÚS HABLA UA LAS HIJAS

A EXPENSAS

VECINOS DEL PUEBLO

Placa cerámica 
No: 7.17

Título: IX Estación.

Autoría: Manolo Safont

Datación: 1962

Inscripciones: IX en ángulo superior izquierdo. En placa cerámica independiente a la obra catalogada, pero adosada al mismo casilicio de la estación del calvario figura la siguiente leyenda, que alude tanto a la reflexión moral de esta novena estación, como a la persona que la ha sufragado:

NOVENA ESTACIÓN

JESÚS CAE EN TIERRA

POR TERCERA VEZ

A EXPENSAS

RVDO. D. LUIS ALCÓN

Dimensiones: $40 \times 40 \mathrm{cms}$.

Técnica: Pintura cerámica de bicocción

Localización: Calvario de Espadilla, Castellón.

Descripción: Obra compuesta por 4 azulejos de 20x20 cms, en disposición $2 \times 2$. La pieza no está firmada ni fechada, la autoría y datación se adjudican por fuentes orales parroquiales. La escena de esta novena estación corresponde al momento bíblico en que Jesús, una vez llegado al Calvario, en la cercanía inmediata al punto en que iba a ser crucificado, cayó por tercera vez, exhausto y sin fuerzas ya para levantarse. Paleta cromática: blancos, amarillos, rojos, verdes, azules, violetas, marrones y negros.

\section{Bibliografía:}

- http://www.franciscanos.org/oracion/viacruz00.htm

Imagen:

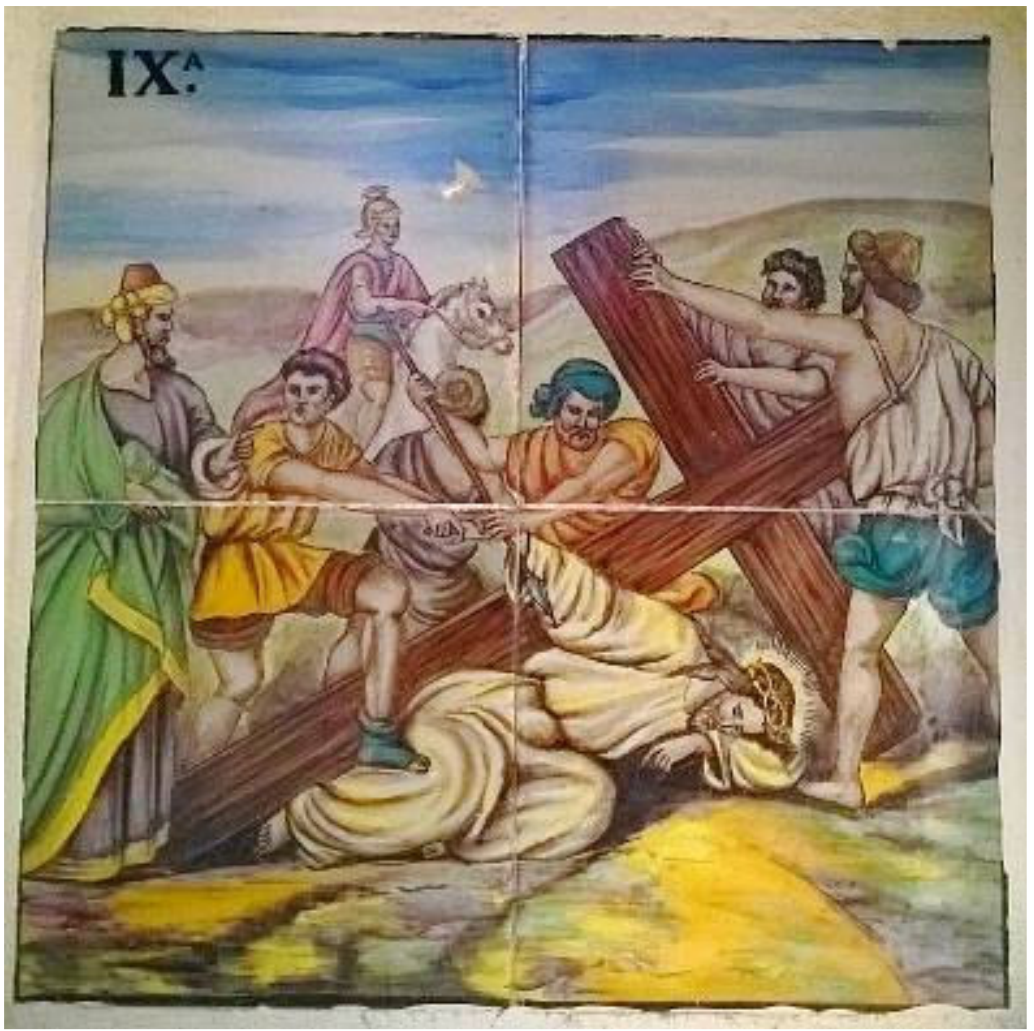


Imágenes relacionadas:

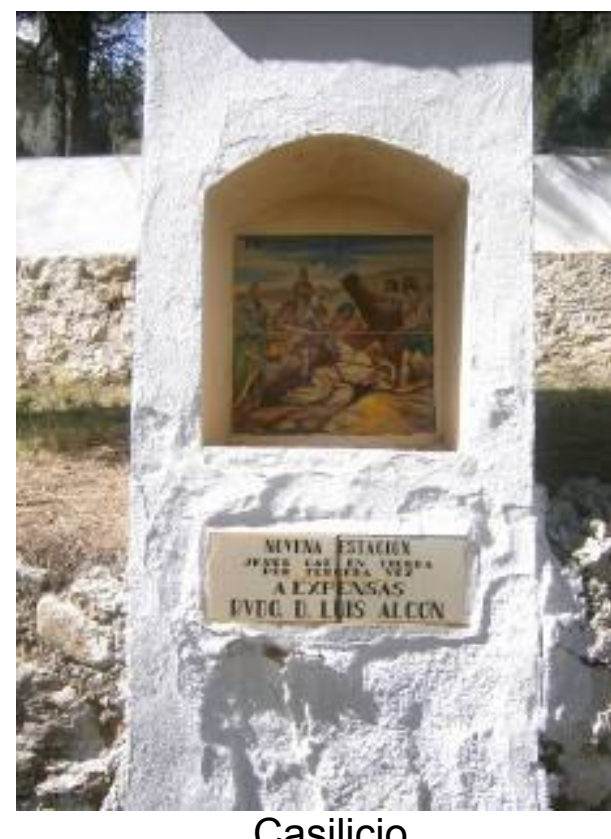

Casilicio

NOVENA ESTACION JESUS CAE EN TIERRA A EXPENSAS RVDO. D. LUIS ALCÓN

Placa cerámica 
No: 7.18

Título: $X^{a}$ Estación.

Autoría: Manolo Safont

Datación: 1962

Inscripciones: $X^{a}$ en ángulo superior derecho. En placa cerámica independiente a la obra catalogada, pero adosada al mismo casilicio de la estación del calvario figura la siguiente leyenda, que alude tanto a la reflexión moral de esta décima estación, como a la familia que la ha sufragado:

DÉCIMA ESTACIÓN
JESÚS ES DESPOJADO DE
SUS VESTIDURAS
A EXPENSAS
HERMANOS JOSÉ-TRINI
Y ENRIQUE PRADAS PÉREZ

Dimensiones: $40 \times 40 \mathrm{cms}$.

Técnica: Pintura cerámica de bicocción

Localización: Calvario de Espadilla, Castellón

Descripción: Obra compuesta por 4 azulejos de 20x20 cms, en disposición $2 \times 2$. La pieza no está firmada ni fechada, la autoría y datación se adjudican por fuentes orales parroquiales. La escena de esta décima estación corresponde al momento bíblico en que ya en el Calvario y antes de crucificar a Jesús, le dieron a beber vino mezclado con mirra; era una piadosa costumbre de los judíos para amortiguar la sensibilidad del que iba a ser ajusticiado. Jesús lo probo, como gesto de cortesía, pero no quiso beberlo, prefería mantener la plena lucidez y conciencia. Por otra parte, los soldados despojaron a Jesús, sin cuidado ni delicadeza alguna, de sus ropas, incluidas las que estaban pegadas en la carne viva, y, después de la crucifixión, se las repartieron. Paleta cromática: blancos, amarillos, rojos, verdes, azules, violetas, marrones y negros.

\section{Bibliografía:}

- http://www.franciscanos.org/oracion/viacruz00.htm Imagen:

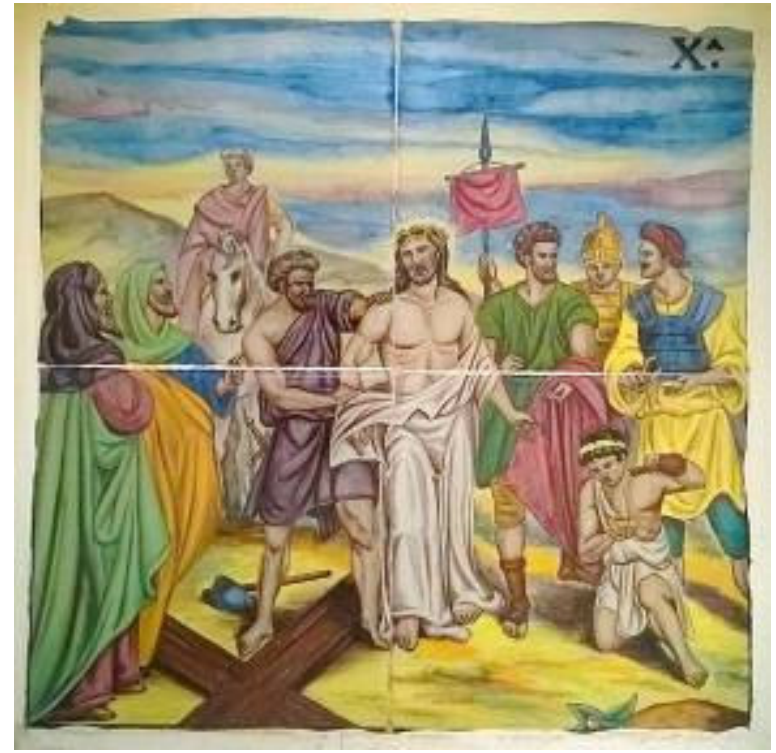


Imágenes relacionadas:

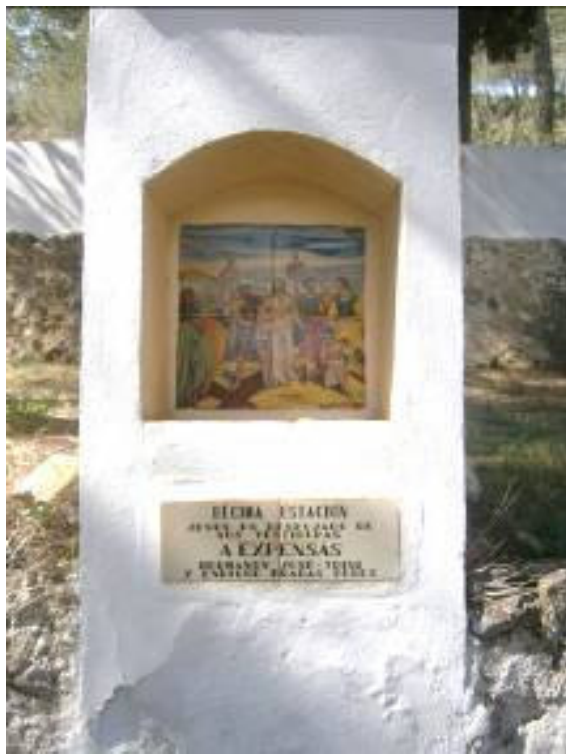

Casilicio
DECIHA ESTACIÓN JESUS ES DESPOJADO DE US VESTIORAS A EXPENSAS HERMANOS JOSE-TRINE ENRIOUE PRADAS PEDEZ

Placa cerámica 
$\mathbf{N}^{0}: 7.19$

Título: $\mathrm{XI}^{\mathrm{a}}$ Estación

Autoría: Manolo Safont

Datación: 1962

Inscripciones: $\mathrm{XI}^{\mathrm{a}}$ en ángulo superior izquierdo. En placa cerámica independiente a la obra catalogada, pero adosada al mismo casilicio de la estación del calvario figura la siguiente leyenda, que alude tanto a la reflexión moral de esta undécima estación, como al colectivo que la ha sufragado:

\section{UNDÉCIMA ESTACIÓN \\ JESÚS ES CLAVADO \\ EN LA CRUZ \\ A EXPENSAS \\ NIÑOS ESCUELAS -1962-}

Dimensiones: $40 \times 40 \mathrm{cms}$.

Técnica: Pintura cerámica de bicocción

Localización: Calvario de Espadilla, Castellón.

Descripción: Obra compuesta por 4 azulejos de 20x20 cms, en disposición $2 \times 2$. La pieza no está firmada ni fechada, la autoría y datación se adjudican por fuentes orales parroquiales. La escena de esta undécima estación corresponde al momento bíblico de la crucifixión, en que Jesús fue fijado en la cruz con cuatro clavos de hierro que le taladraban las manos y los pies. Levantaron la cruz en alto y el cuerpo de Cristo quedó entre cielo y tierra, pendiente de los clavos y apoyado en un saliente que había a mitad del palo vertical. En la parte superior de este palo, encima de la cabeza de Jesús, pusieron el título o causa de la condenación: "INRI. Jesús el Nazareno, el Rey de los judíos". También crucificaron con él a dos ladrones, uno a su derecha y el otro a su izquierda. Presenta similitudes compositivas y estilísticas con el panel cerámico obra catalogada $n^{07.4}$, ubicado en la Capilla de la Comunión de la Iglesia de Nuestra Sra. de la Asunción de Onda. Paleta cromática: blancos, amarillos, rojos, verdes, azules, violetas, marrones y negros.

Bibliografía:

- http://www.franciscanos.org/oracion/viacruz00.htm Imagen:

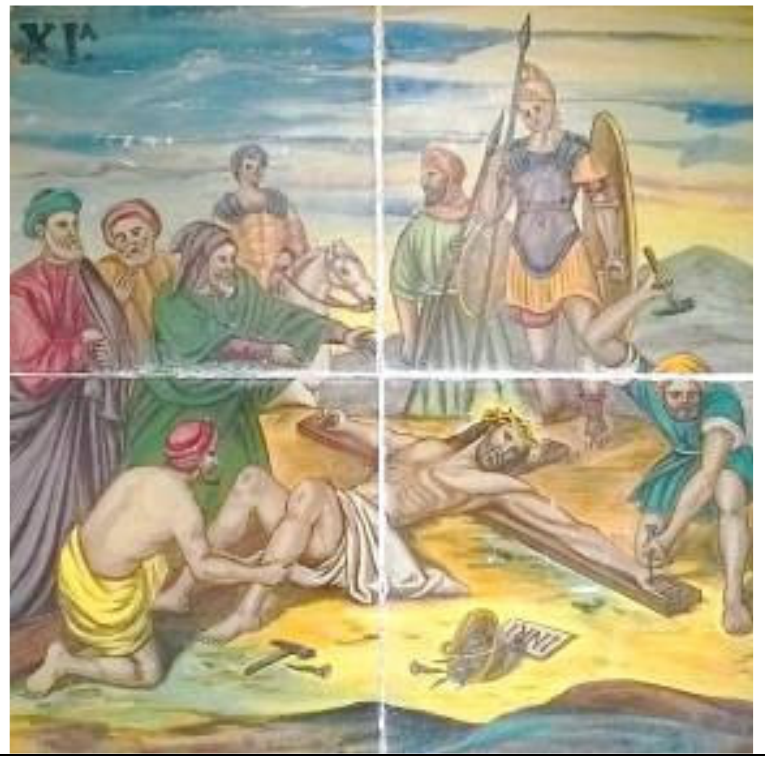


Imágenes relacionadas:

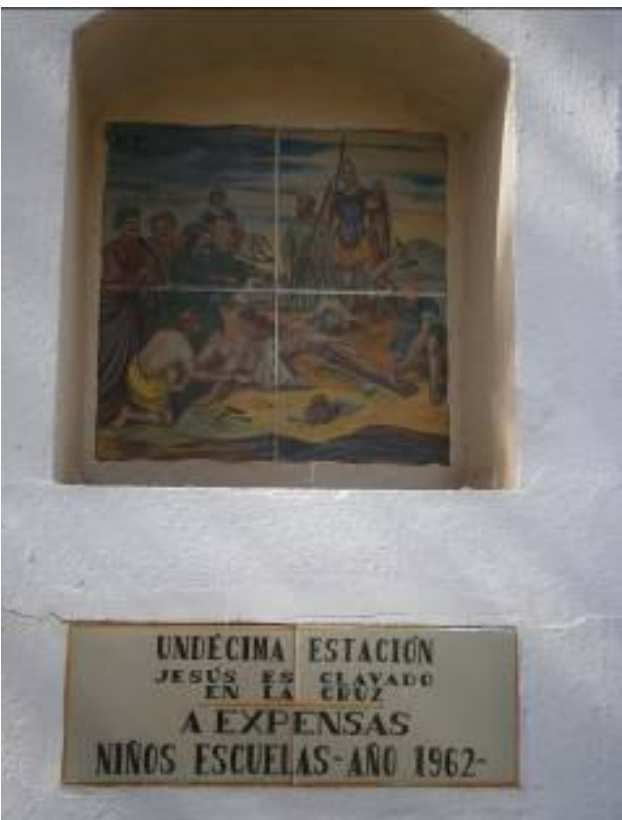

Casilicio

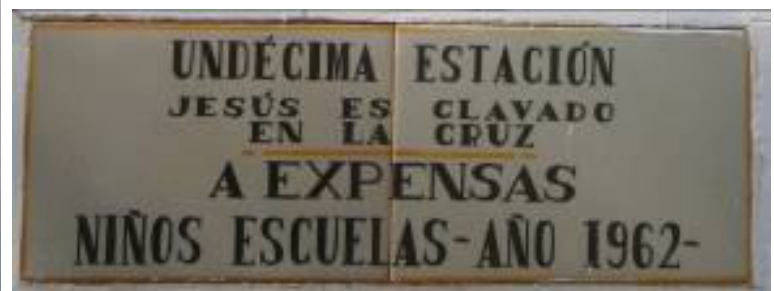

Placa cerámica

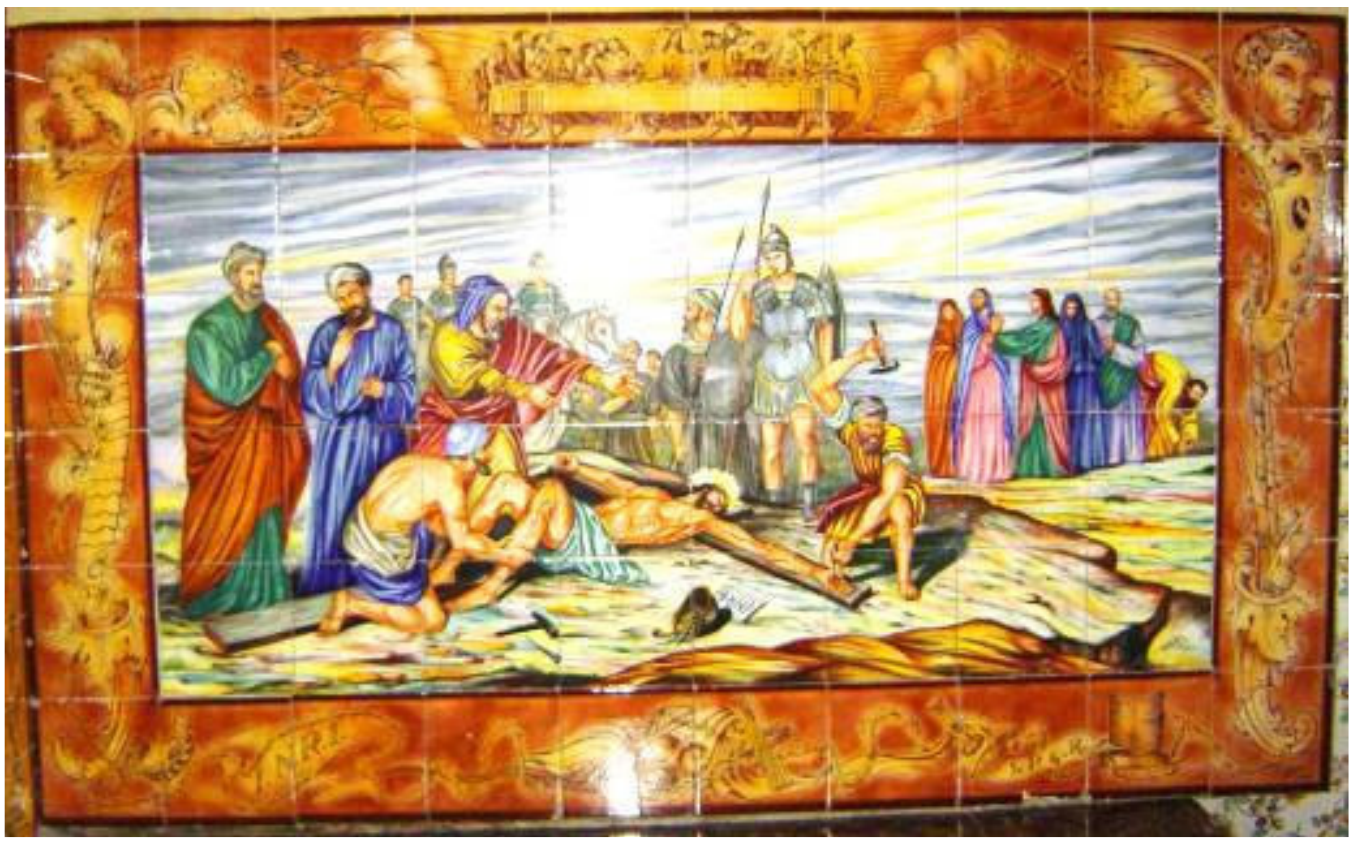

Obra cat. $n^{07.4}$ 
$\mathbf{N}^{0}: 7.20$

Título: XII ${ }^{\mathrm{a}}$ Estación

Autoría: Manolo Safont

Datación: 1962

Inscripciones: XII a en ángulo superior izquierdo. En placa cerámica independiente a la obra catalogada, pero adosada al mismo casilicio de la estación del calvario figura la siguiente leyenda, que alude tanto a la reflexión moral de esta duodécima estación, como al colectivo que la ha sufragado:

\section{DUODÉCIMA ESTACIÓN \\ JESÚS AGONIZA EN LA CRUZ \\ A EXPENSAS \\ LAS HIJAS DE MARÍA \\ AÑO -1962-}

Dimensiones: 40 x $40 \mathrm{cms}$.

Técnica: Pintura cerámica de bicocción

Localización: Calvario de Espadilla, Castellón.

Descripción: Obra compuesta por 4 azulejos de 20x20 cms, en disposición $2 \times 2$. La pieza no está firmada ni fechada, la autoría y datación se adjudican por fuentes orales parroquiales. La escena de esta duodécima estación corresponde al momento bíblico que trascurre desde la crucifixión hasta la muerte de Jesús. Desde el principio, muchos de los presentes, incluidas las autoridades religiosas, se desataron en ultrajes y escarnios contra el Crucificado. Poco después ocurrió el episodio del buen ladrón, a quien dijo Jesús: "Hoy estarás conmigo en el paraíso". San Juan nos refiere otro episodio: Viendo Jesús a su Madre junto a la cruz y con ella a Juan, dice a su Madre: "Mujer, ahí tienes a tu hijo", luego dice al discípulo: "Ahí tienes a tu madre", y desde aquella hora el discípulo la acogió en su casa. Después de esto, nos dice el mismo evangelista, sabiendo Jesús que ya todo estaba cumplido, dijo: "Tengo sed". Tomó el vinagre que le acercaron, y añadió: "Todo está cumplido", e inclinando la cabeza murió. Paleta cromática: blancos, amarillos, rojos, verdes, azules, violetas, marrones y negros.

\section{Bibliografía:}

- http://www.franciscanos.org/oracion/viacruz00.htm

Imagen:

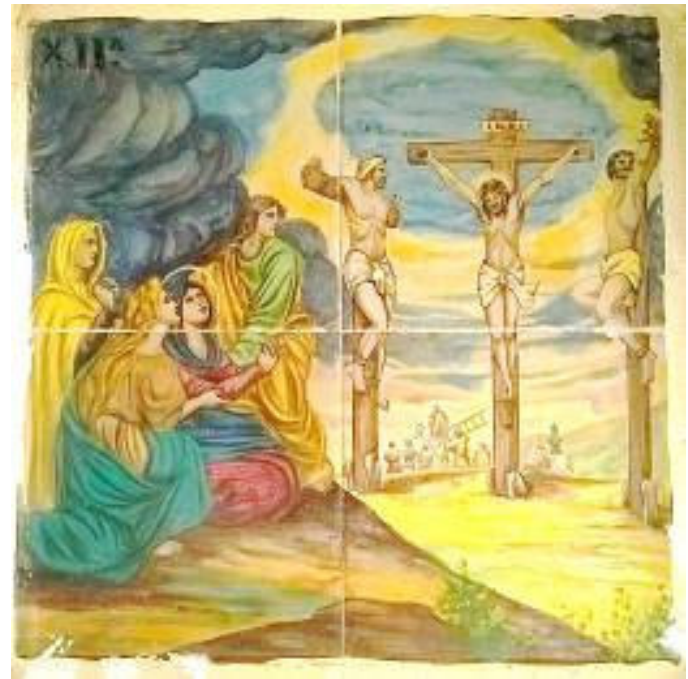


Imágenes relacionadas:

DUODECIIIA ESTACION JESUS AGONIZI EN LA CDU7 A EXPENSAS LAS HKAS DE MADH Casilicio
DUODÉCIUA ESTACIÓN JESUS AGONIZA EN LA CRUZ A EXPENSAS LAS HIJAS DE MARIA Placa cerámica 
No: 7.21

Título: XIII ${ }^{\mathrm{a}}$ Estación

Autoría: Manolo Safont

Datación: 1962

Inscripciones: XIII en ángulo superior derecho. En placa cerámica independiente a la obra catalogada, pero adosada al mismo casilicio de la estación del calvario figura la siguiente leyenda, que alude tanto a la reflexión moral de esta décima tercia estación, como a la persona que la ha sufragado:

DÉCIMA TERCIA ESTACIÓN

JESÚS MUERTO EN LOS

BRAZOS DE SU MADRE

A EXPENSAS

RVDO. D. JOSÉ CASTELLS

Dimensiones: $40 \times 40 \mathrm{cms}$.

Técnica: Pintura cerámica de bicocción

Localización: Calvario de Espadilla, Castellón.

Descripción: Obra compuesta por 4 azulejos de 20x20 cms, en disposición $2 \times 2$. La pieza no está firmada ni fechada, la autoría y datación se adjudican por fuentes orales parroquiales. La escena de esta décima tercia estación corresponde al momento bíblico en que para que los cadáveres no quedaran en la cruz al día siguiente, que era un sábado muy solemne para los judíos, éstos rogaron a Pilato que les quebraran las piernas y los retiraran; los soldados sólo quebraron las piernas de los otros dos, y a Jesús, que ya había muerto, uno de los soldados le atravesó el costado con una lanza. Después, José de Arimatea y Nicodemo, discípulos de Jesús, obtenido el permiso de Pilato y ayudados por sus criados y otros discípulos de Jesús, se acercaron a la cruz, desclavaron cuidadosa y reverentemente los clavos de las manos y los pies y con todo miramiento lo descolgaron. Al pie de la cruz estaba la Madre, que recibió en sus brazos y puso en su regazo maternal el cuerpo sin vida de su Hijo. Paleta cromática: blancos, amarillos, rojos, verdes, azules, violetas, marrones y negros.

\section{Bibliografía:}

- http://www.franciscanos.org/oracion/viacruz00.htm

\section{Imagen:}

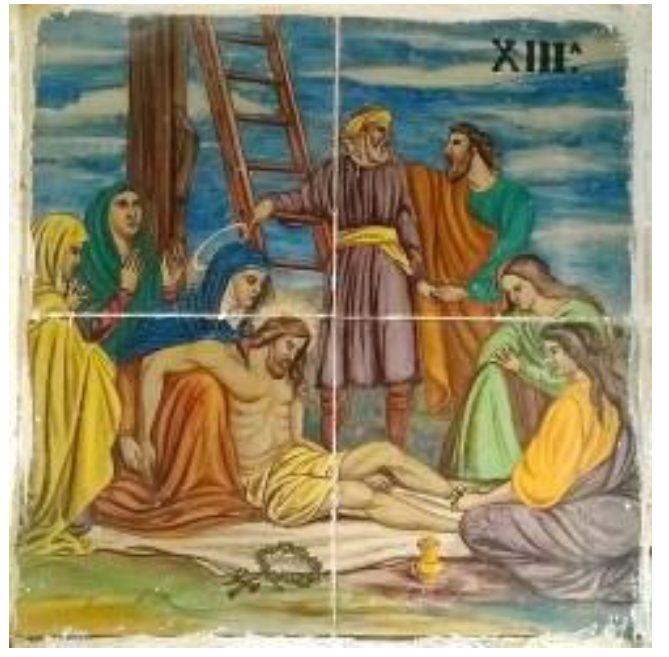


Imágenes relacionadas:

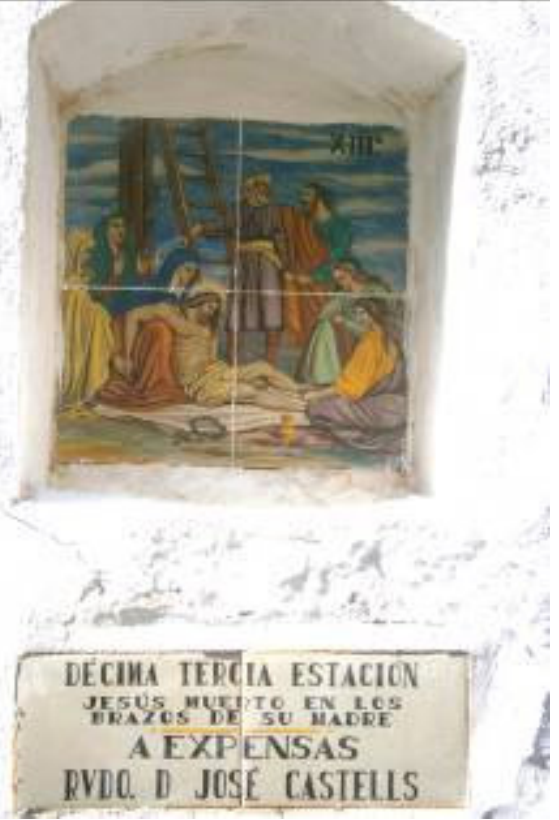

Casilicio

DECIHA IERCIA ESTACIÓN JESUS MUEDTO EN LOS

A EXPENSAS

RVDO. D JOSÉ CASTELIS

Placa cerámica 
No: 7.22

Título: XIVª Estación

Autoría: Manolo Safont

Datación: 1962

Inscripciones: XIV ${ }^{a}$ en ángulo superior derecho. En placa cerámica independiente a la obra catalogada, pero adosada al mismo casilicio de la estación del calvario figura la siguiente leyenda, que alude tanto a la reflexión moral de esta décima cuarta estación, como al matrimonio que la ha sufragado: DÉCIMA CUARTA ESTACIÓN JESÚS ES SEPULTADO

A EXPENSAS

MATRIMONIO SAFONT DEL MORAL

Dimensiones: $40 \times 40 \mathrm{cms}$.

Técnica: Pintura cerámica de bicocción

Localización: Calvario de Espadilla, Castellón.

Descripción: Obra compuesta por 4 azulejos de 20x20 cms, en disposición $2 \times 2$. La pieza no está firmada ni fechada, la autoría y datación se adjudican por fuentes orales parroquiales. La escena de esta décima cuarta estación corresponde al momento bíblico en que José de Arimatea y Nicodemo tomaron el cuerpo de Jesús de los brazos de María y lo envolvieron en una sábana limpia que José había comprado. Cerca de allí tenía José un sepulcro nuevo que había cavado para sí mismo, y en él enterraron a Jesús. Mientras los varones procedían a la sepultura de Cristo, las santas mujeres que solían acompañarlo y su Madre, frente al sepulcro, observaban dónde y cómo quedaba colocado el cuerpo. Después, hicieron rodar una gran piedra hasta la entrada del sepulcro, y regresaron todos a Jerusalén. Presenta similitudes compositivas y estilísticas con la obra catalogada $\mathrm{n}^{07.5}$, panel cerámico ubicado en la Capilla de la Comunión de la Iglesia de Nuestra Sra. de la Asunción de Onda. Paleta cromática: blancos, amarillos, rojos, verdes, azules, violetas, marrones y negros.

\section{Bibliografía:}

- http://www.franciscanos.org/oracion/viacruz00.htm

\section{Imagen:}

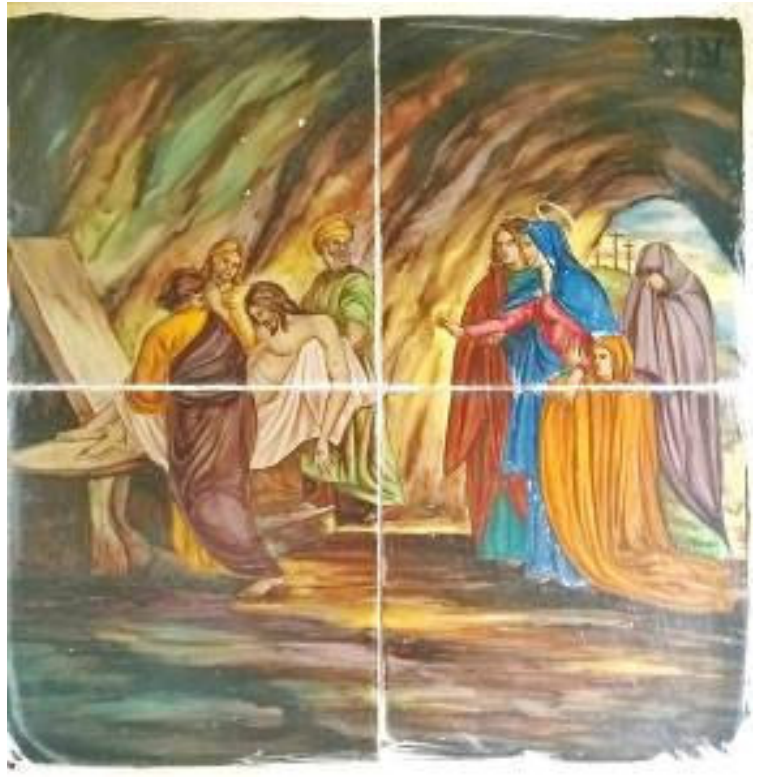




\section{Imágenes relacionadas:}
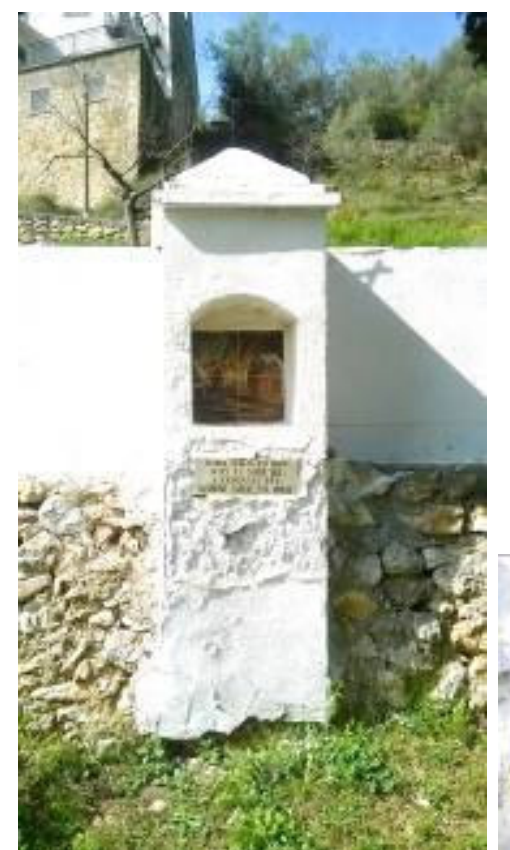

Casilicio
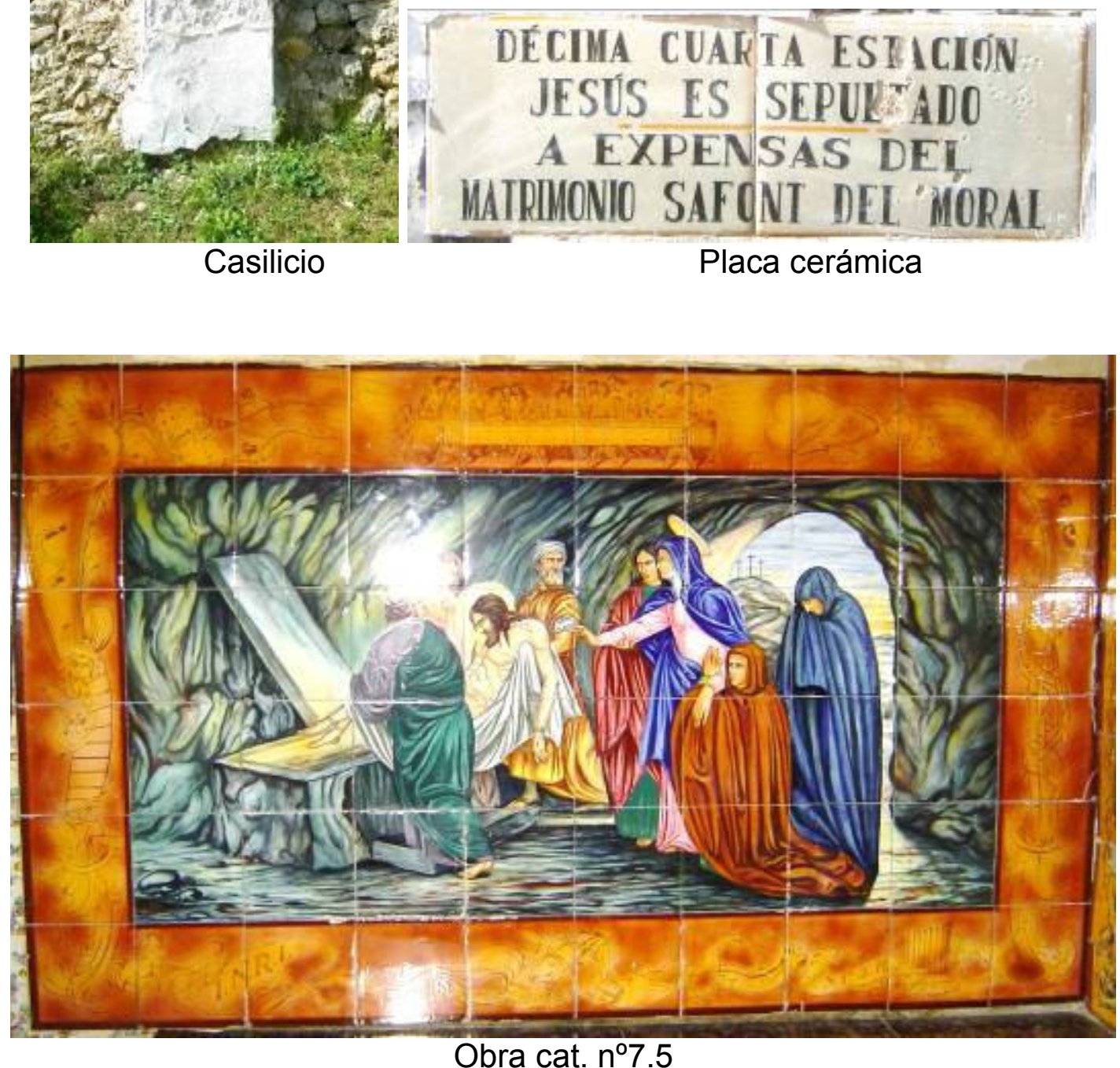
$\mathbf{N}^{0}: 7.23$

Título: Sagrada Familia

Autoría: Manolo Safont

Datación: 1963-1964

Dimensiones: $3 \times 2,5 \mathrm{~m}^{2}$

Técnica: Pintura cerámica

Localización: MAMS

Descripción: Mural realizado para decorar el hall interior del la oficina principal de la entidad bancaria Caja de Ahorros y Monte de Piedad, situada en la calle San Miguel de Onda. Al realizar las obras de remodelación de las oficinas, el mural se desmontó y se depositó en cajas, donándose posteriormente al Museo Histórico Municipal de Onda. La retirada de este mural fue un trabajo muy costoso, ya que se compone de piezas de $7 \times 7 \mathrm{cms}$ y durante el proceso muchas de ellas se fracturaron o lascaron. Con la creación en 2004 del Museo del Azulejo Manolo Safont en Onda, este mural pasó a formar parte de los fondos del nuevo museo. En 2013, con motivo de la realización de la exposición Magnificat, la Fundación Caja Castellón, heredera de la Caja de Ahorros y Monte de Piedad se interesa por este mural cerámico para poderlo exponer. Dado el estado de conservación en que se encontraba, la Diputación, previa solicitud del Ayuntamiento de Onda, costeó, a través del Servicio de Conservación y Restauración de la Diputación de Castellón, la restauración del mismo, con el fin de poder exponerlo. Una vez finalizada la exposición, la obra, perfectamente restaurada y adherida sobre seis paneles que permiten facilitar su transporte y manejo, se devolvió al Museo del Azulejo Manolo Safont de Onda. El objetivo de la restauración ha sido la eliminación de los deterioros que afectaban a la obra y la reintegración de las pérdidas de soporte que padecía el conjunto. En primer lugar, se eliminó el antiguo mortero que tenían adherido los azulejos por su reverso y se realizaron tratamientos de limpieza y neutralización de las piezas. En segundo lugar, se adhirieron los azulejos fragmentados y se realizaron las piezas faltantes mediante moldes extraídos de los azulejos originales. Posteriormente, se llevó a cabo una reintegración tanto del soporte cerámico como del estucado de las zonas esmaltadas. Finalmente, se realizó el montaje sobre un soporte inerte, se llevó a cabo la reintegración cromática y se aplicó una capa de protección final. Paleta cromática: blancos, ocres, rojos, verdes, marrones y negros.

Exposiciones:

- Magnificat, nuevas metáforas de lo sagrado. Sala San Miguel, Fundación Caja Castellón. 15 abril - 30 mayo 2014, Castellón de la Plana

\section{Bibliografía:}

- LLOPICO MUÑOZ, Alfredo. “A Manolo Safont”, Castelló al mes, mayo 2014, Castellón, pág. 6

- http://manolosafont.blogspot.com.es/

- http://www.20minutos.es/noticia/2114075/0/

- http://www.elperiodicomediterraneo.com/

- http://informaciona.com

- http://www.eltriangulo.es/

- http://www.noodls.com/

- http://arrelsonline.es/ 


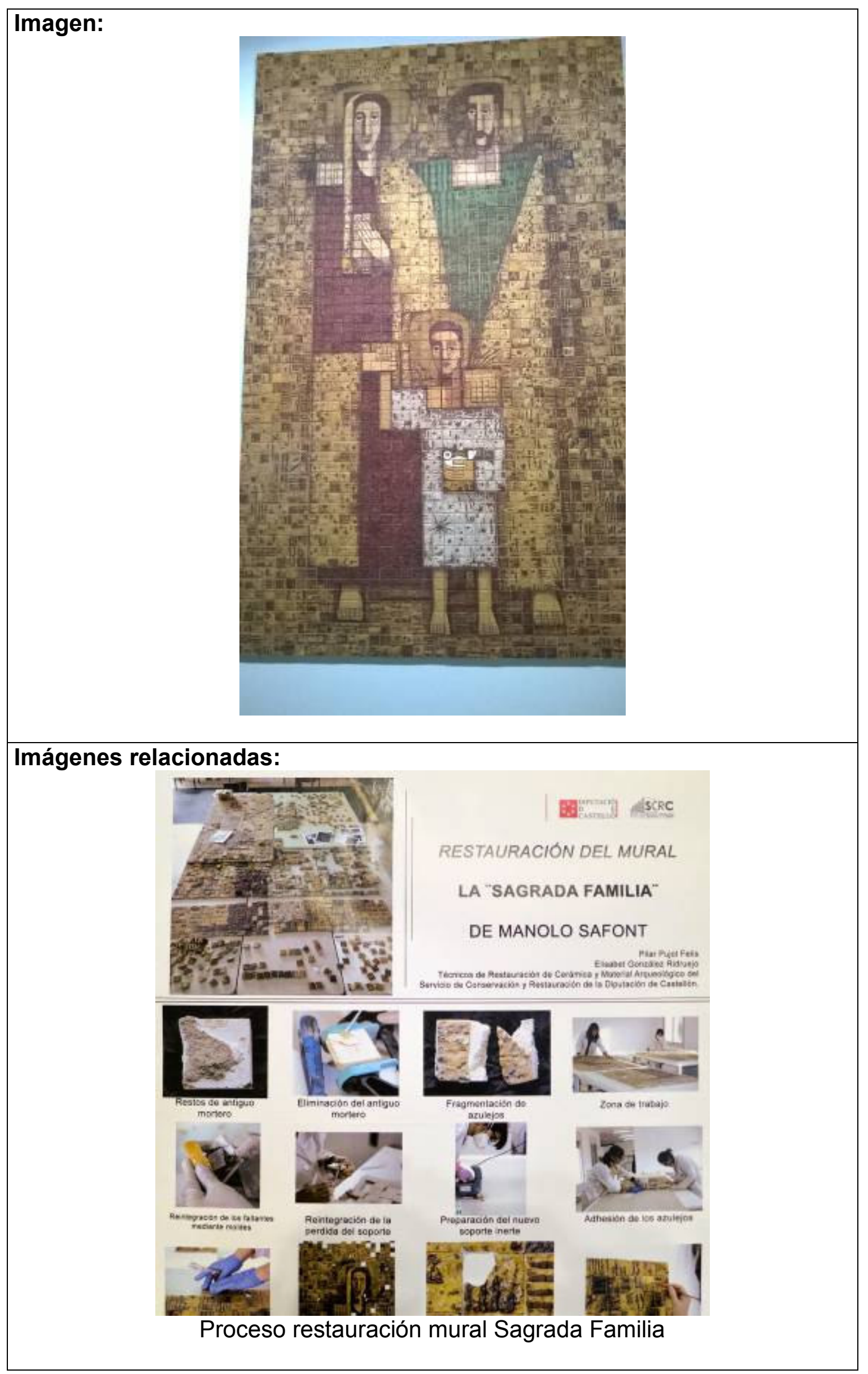




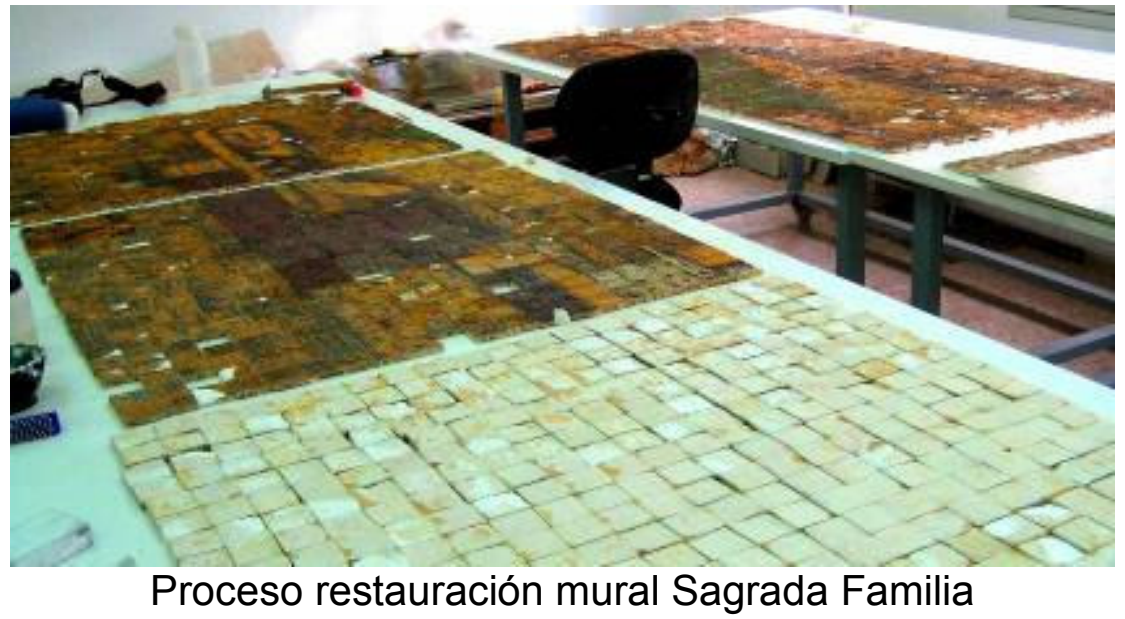

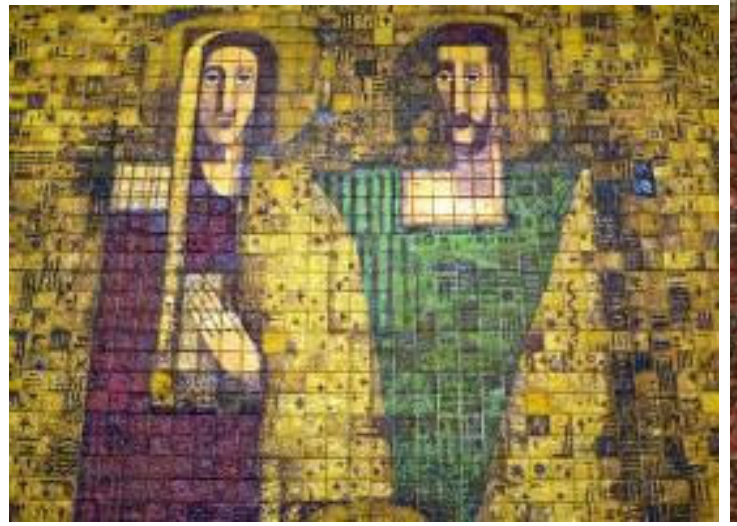

Detalle mural Sagrada Familia

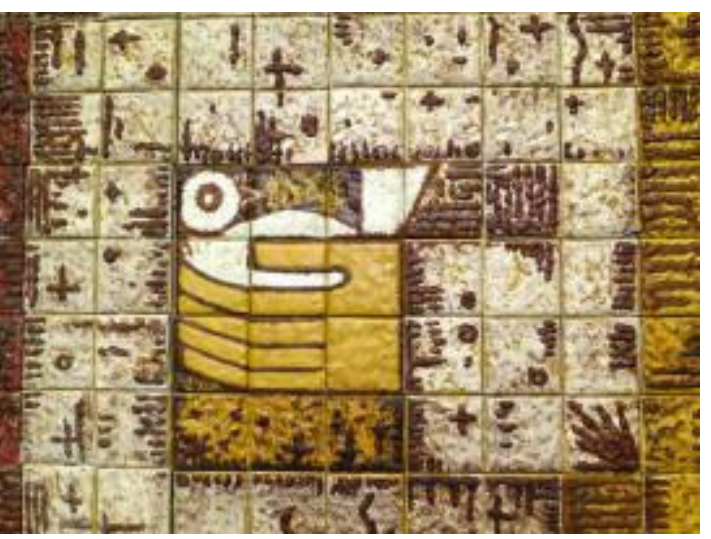

Detalle mural Sagrada Familia

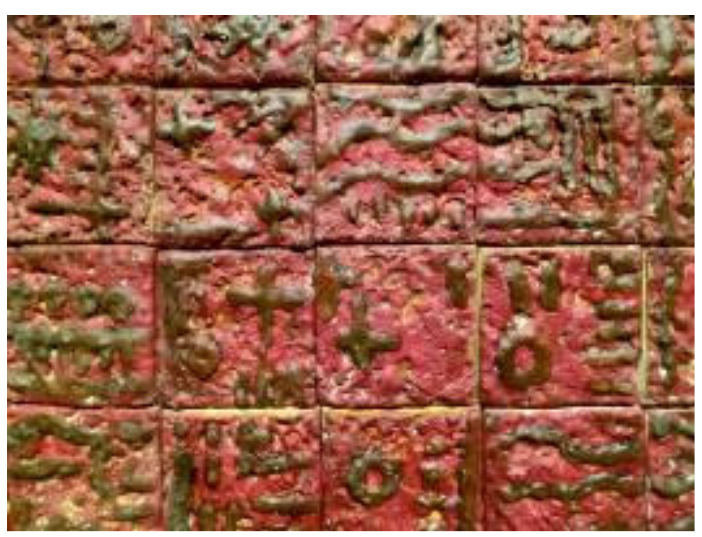

Detalle mural Sagrada Familia

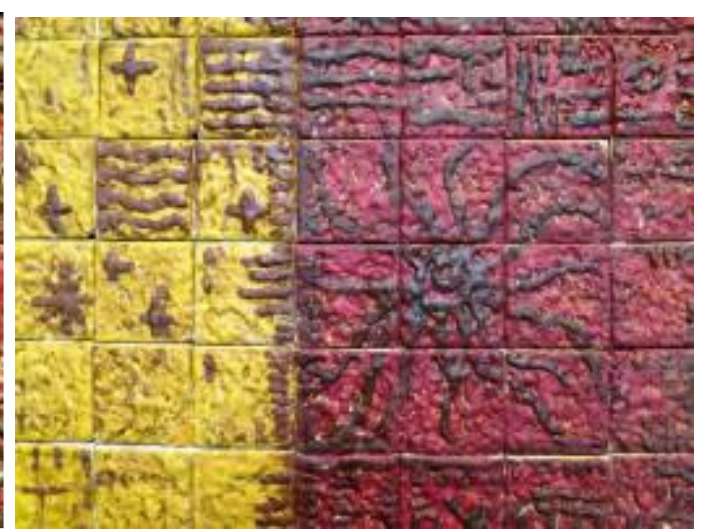

Detalle mural Sagrada Familia 


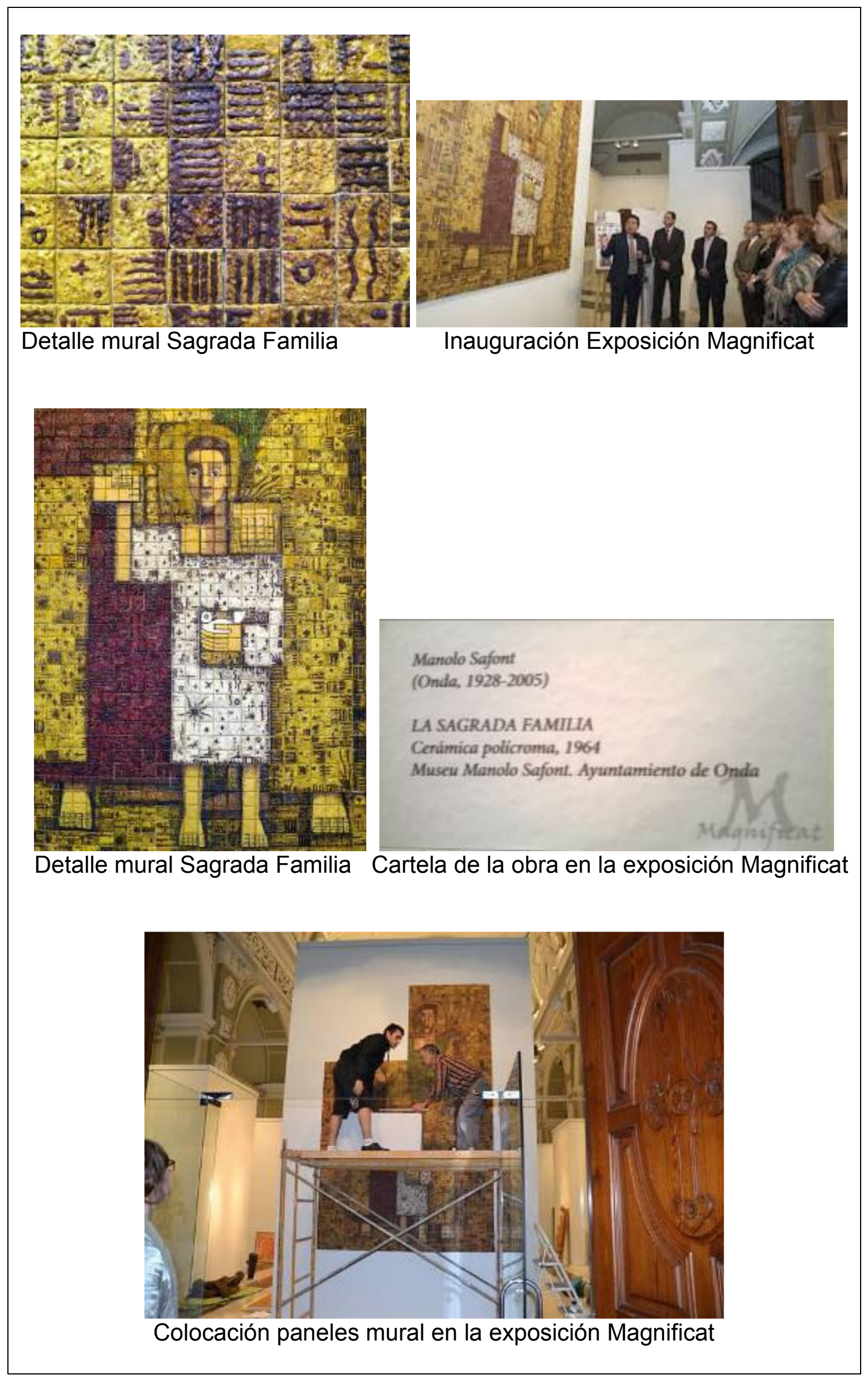




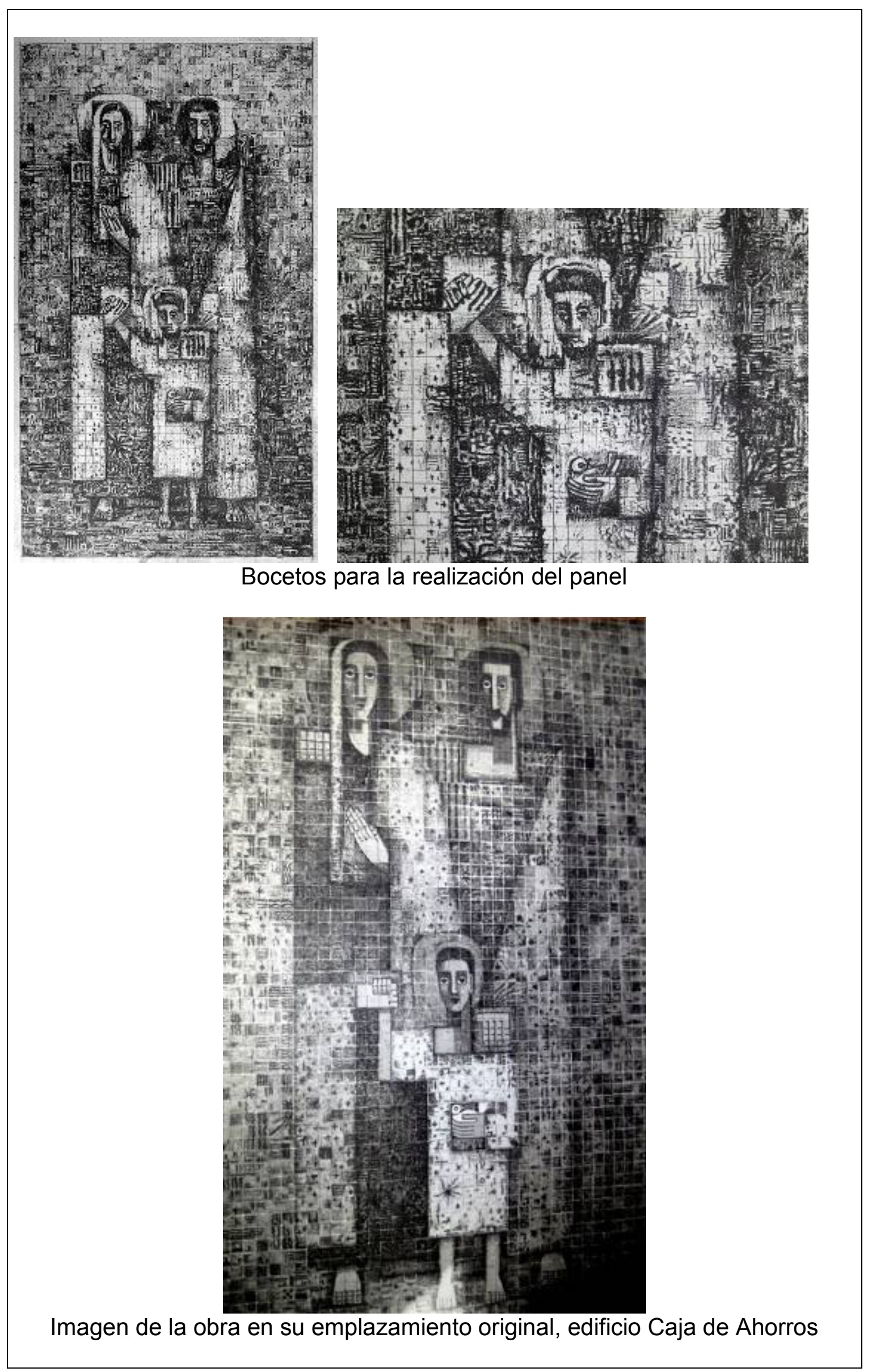




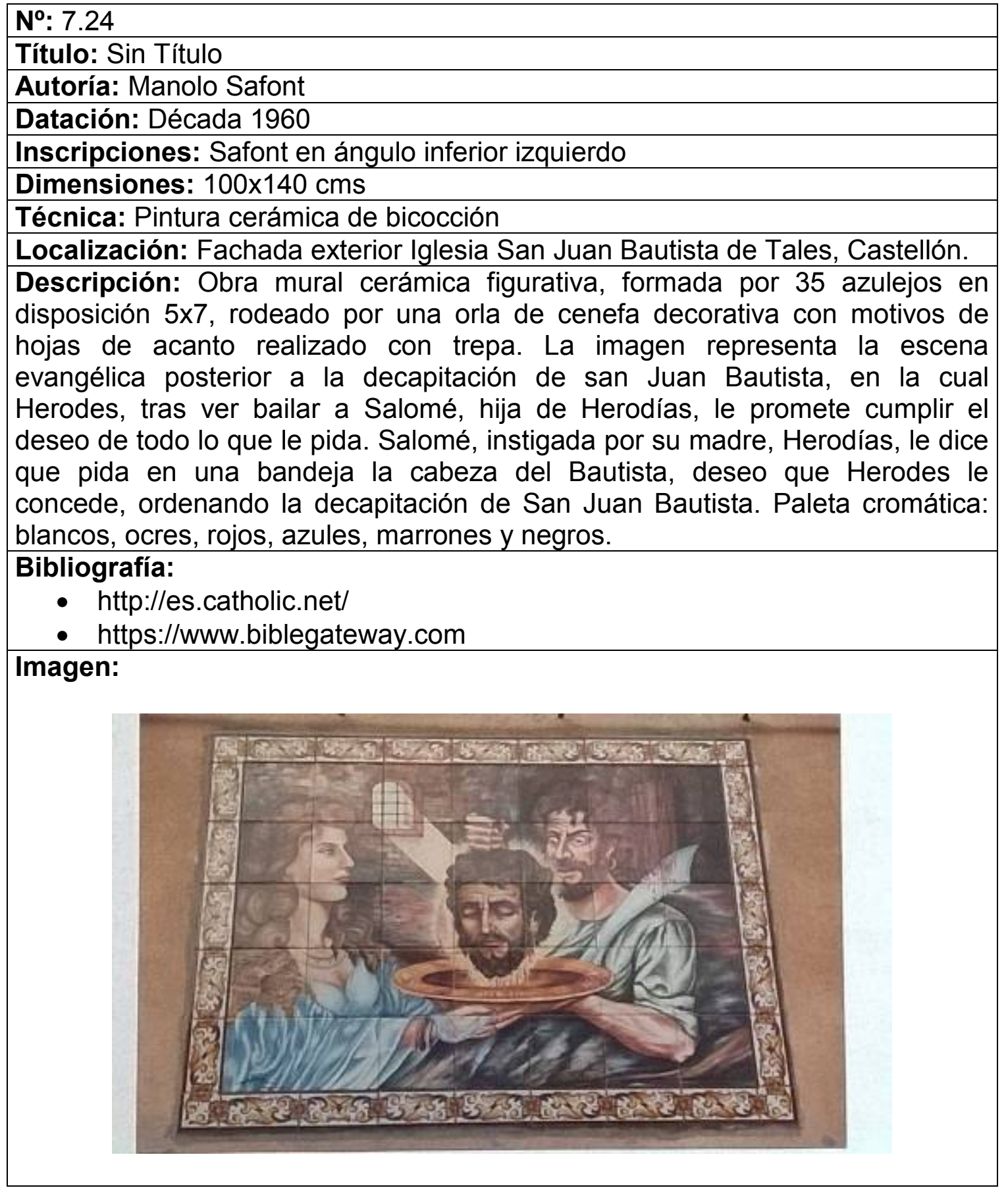


$\mathbf{N}^{0}: 7.25$

Título: Virgen de la Merced

Autoría: Manolo Safont

Datación: 1968

Técnica: Pintura cerámica

Dimensiones: $110 \mathrm{~m}^{2}$

Localización: Iglesia Catedral de Babahoyo (Ecuador)

Descripción: Gran panel cerámico de estilo cubista, con la representación de la imagen de la Virgen de la Merced, ataviada con túnica roja y manto azul, y con el Niño Jesús en brazos, sentado sobre su rodilla izquierda, con un fondo de colores claros y formas geométricas.

El gran mural se encuentra ubicado en el frontón de la fachada principal de la Iglesia Catedral de Babahoyo, fue realizado en la escuela de pintura Alberto Durero, en España y la obra física estuvo a cargo de la constructora española Safont.

El panel está formado por placas cerámicas del mismo tamaño.

La construcción de la iglesia se inició en 1957, terminándose la obra en 1963. En 1969 se realizó la bendición del mural de la Virgen de las Mercedes.

Cada pieza se envió numerada desde España para facilitar su colocación. Safont fue realizando las piezas, que iba enviando poco a poco. El propio Safont relata este proceso en una entrevista en Levante en 1979 "Fue horrible porque ya sabía lo que iba a hacer...jTenía que rellenarlo!".

En agosto de 2012 se realizó la restauración de este gran mural; el trabajo estuvo a cargo del artista plástico José Muñoz, pintor local de Babahoyo, que había realizado exposiciones en ésta y otras ciudades del país, así como en Alemania y que está ligado a la Curia local. Muñoz explicó que la restauración contemplaba la limpieza del mural y el reemplazo de las baldosas que se encontraban dañadas por otras del mismo material y color, con el propósito de mantener sin cambios el diseño original. "Como último paso se colocará un producto impermeabilizante que hará que la obra esté protegida de los efectos del sol y de la lluvia, lo que permitirá preservarla por muchos años". "Desde que nosotros pegamos el mural nadie lo ha limpiado ni le han hecho arreglos", señala Manuel Benítez Villacrés, una de las personas que trabajaron en la construcción de la iglesia y que además colaboró en la colocación del mural de la Virgen.

Paleta cromática: blancos, amarillos, rojos, verdes, azules y negros.

\section{Bibliografía:}

- MUÑOZ PEIRATS, Ma José. "El mundo creativo de Manolo Safont", Levante, Valencia 1979

- FALOMIR, Carmela. "La pintura cerámica de Manolo Safont" en Butlletí d'Estudis Municipals. $2^{a}$ etapa, $n^{\circ}$ 2. Ajuntament d'Onda. Onda, 2001, pág. 18

- http://www.eluniverso.com/2002/08/25

- repositori.uji.es/ arxiu d'imatges de la Caixa Rural d'Onda 


\section{Imagen:}

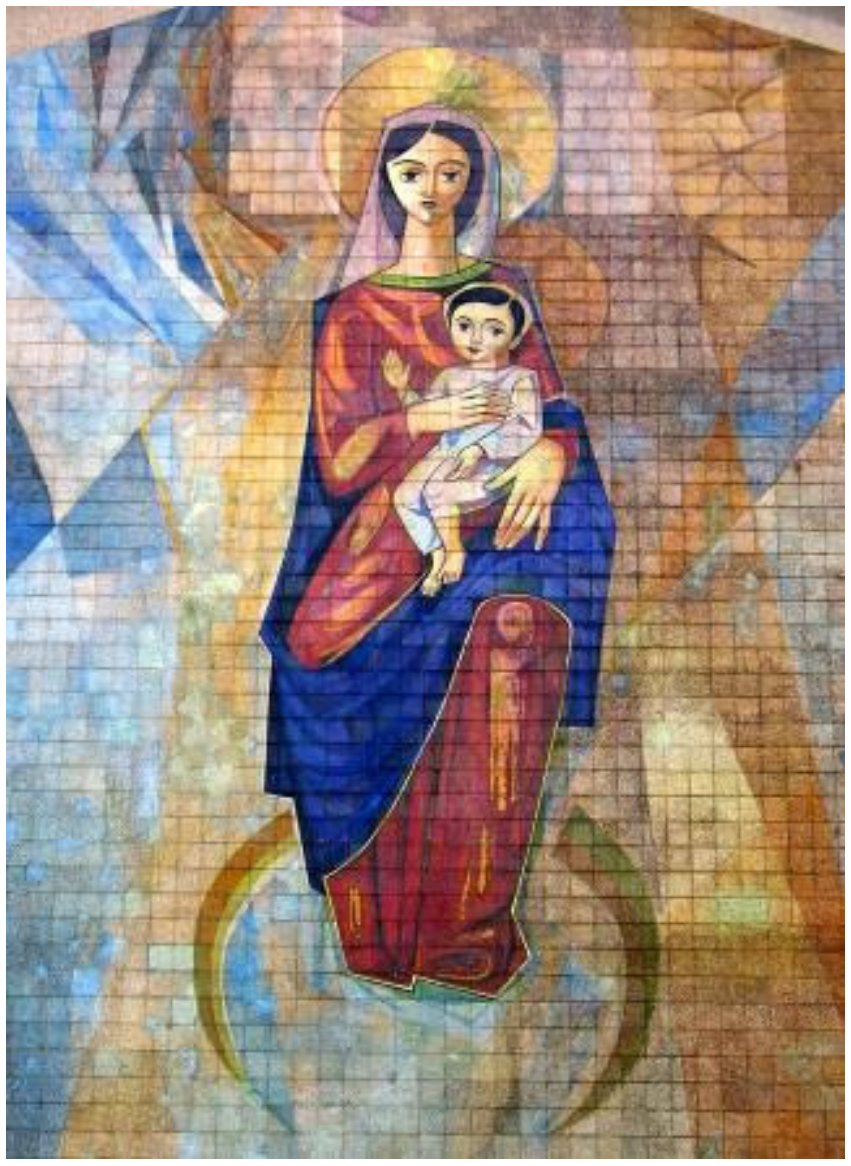

\section{Imágenes relacionadas:}

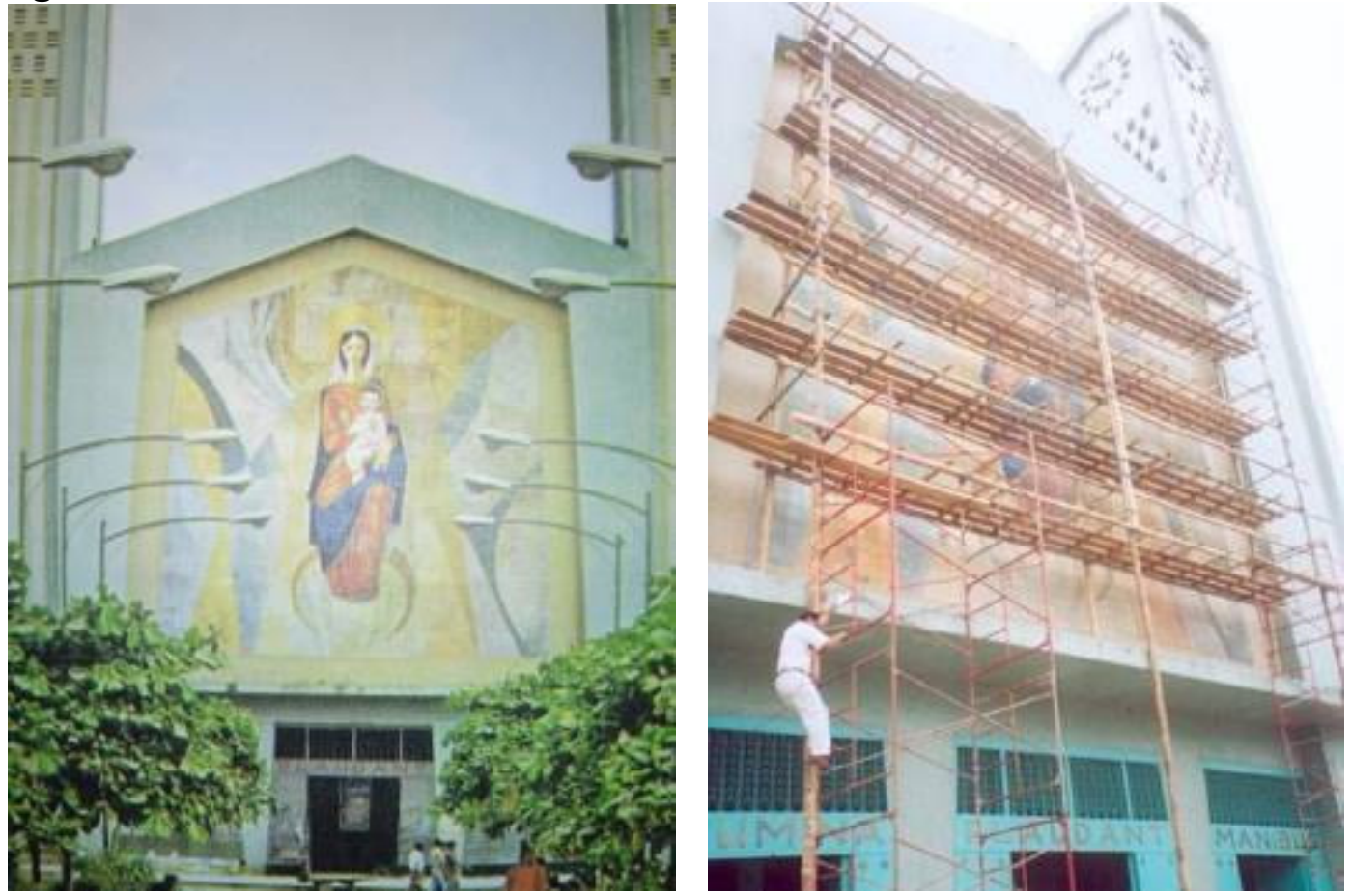

Trabajos restauración mural cerámico 

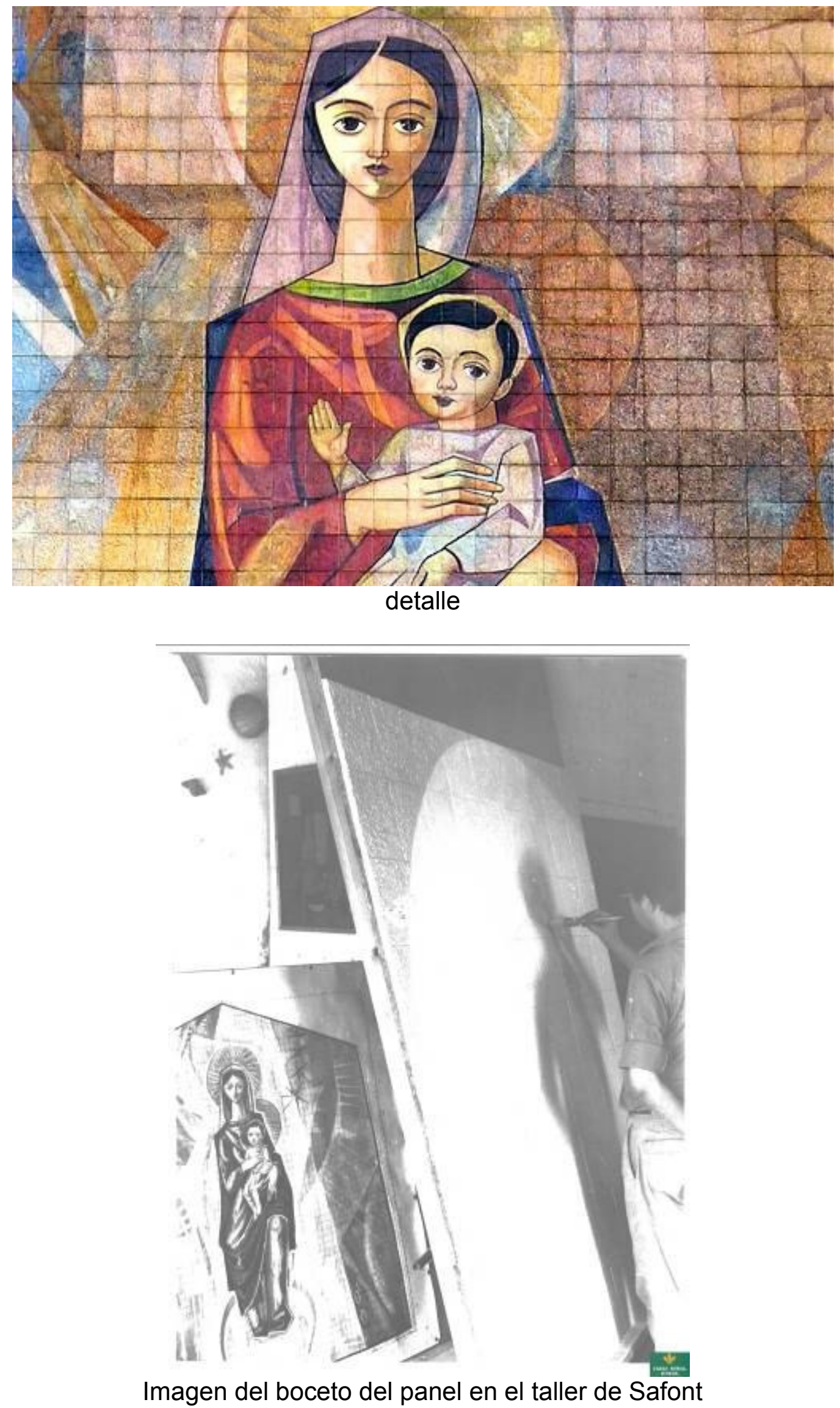
No: 7.26

Título: Sin Título

Autoría: Manolo Safont

Datación: Final década 1960 - Inicios década 1970.

Inscripciones: INRI y CREU CLAVAT. Safont en ángulo inferior derecho.

Técnica: Pintura cerámica

Localización: XI Estación, Calvario de Onda (Castellón)

Observaciones: Obra compuesta por cuatro placas de diferente tamaño. En la parte superior izquierda se observa la inscripción INRI y en la parte inferior derecha, la inscripción CREU CLAVAT, y la representación de la cruz y de un martillo y unas tenazas, herramientas para clavar en la cruz. En la parte inferior de la estación, se observa una placa cerámica con la inscripción "XI ESTACIÓN. Jesús es crucificado. Llegados al lugar llamado Calvario, le crucificaron a él y a los malhechores, uno a la derecha y otro a la izquierda. Lc. 23,33 ¡Señor! Has apurado por nosotros hasta el extremo de tu vida, el cáliz del sufrimiento. Siendo Divinidad tu inocencia, te has hecho reo entre malhechores. Estos, representando a la humanidad y a mi mismo te hemos llevado hasta la Cruz. Tus brazos abiertos, sienten el deseo de abrazar al hombre hasta su ultimo momento, como lo hiciste con el buen ladrón". Las estaciones del calvario de Onda están decoradas con paneles cerámicos de diferentes artistas cerámicos ondenses, realizados entre 1940 y 1960. "Y lo crucificaron", dicen escuetamente los evangelistas. Había llegado el momento terrible de la crucifixión, y Jesús fue fijado en la cruz con cuatro clavos de hierro que le taladraban las manos y los pies. Levantaron la cruz en alto y el cuerpo de Cristo quedó entre cielo y tierra, pendiente de los clavos y apoyado en un saliente que había a mitad del palo vertical. En la parte superior de este palo, encima de la cabeza de Jesús, pusieron el título o causa de la condenación: INRI: Jesús el Nazareno, el Rey de los Judíos. También crucificaron con él a dos ladrones, uno a su derecha y el otro a su izquierda. Aunque es tan sólo una de las estaciones, esta obra presenta muchas similitudes con el dibujo de un boceto de las estaciones de un calvario realizado por Safont, obra catalogada $\mathrm{n}^{\circ} 2.31$. Paleta cromática: blancos, azules, marrones y negros.

\section{Bibliografía:}

- http://www.franciscanos.org/oracion/viacruz00.htm

- http://www.onda.es/otros-enclaves/calvario-y-sta-catalina

Imagen:

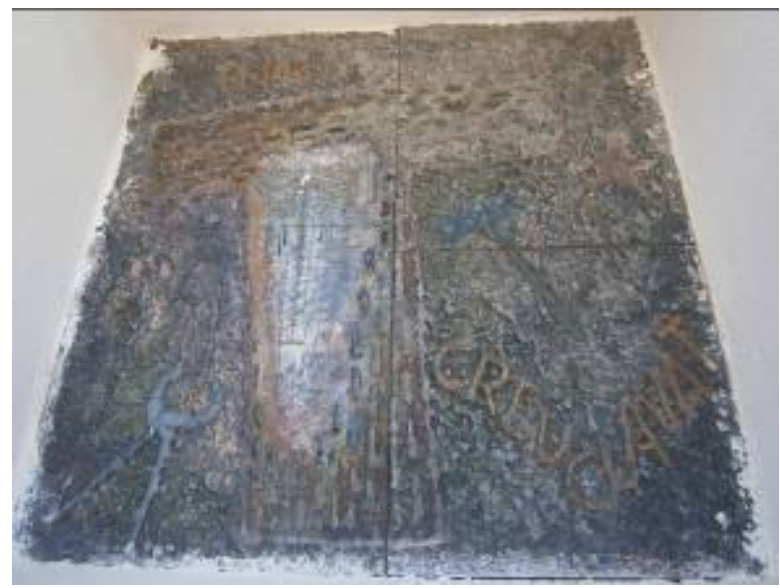




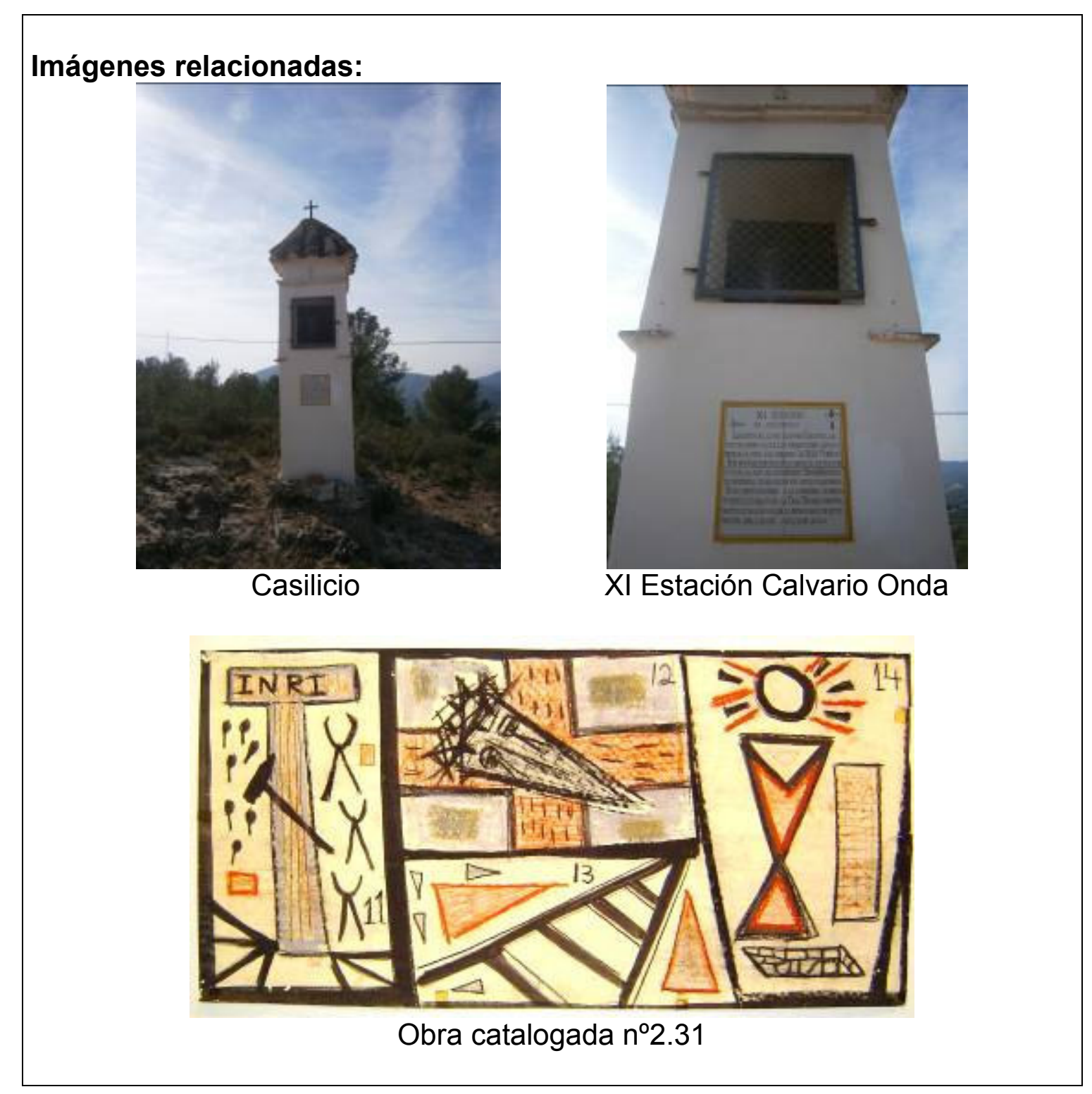




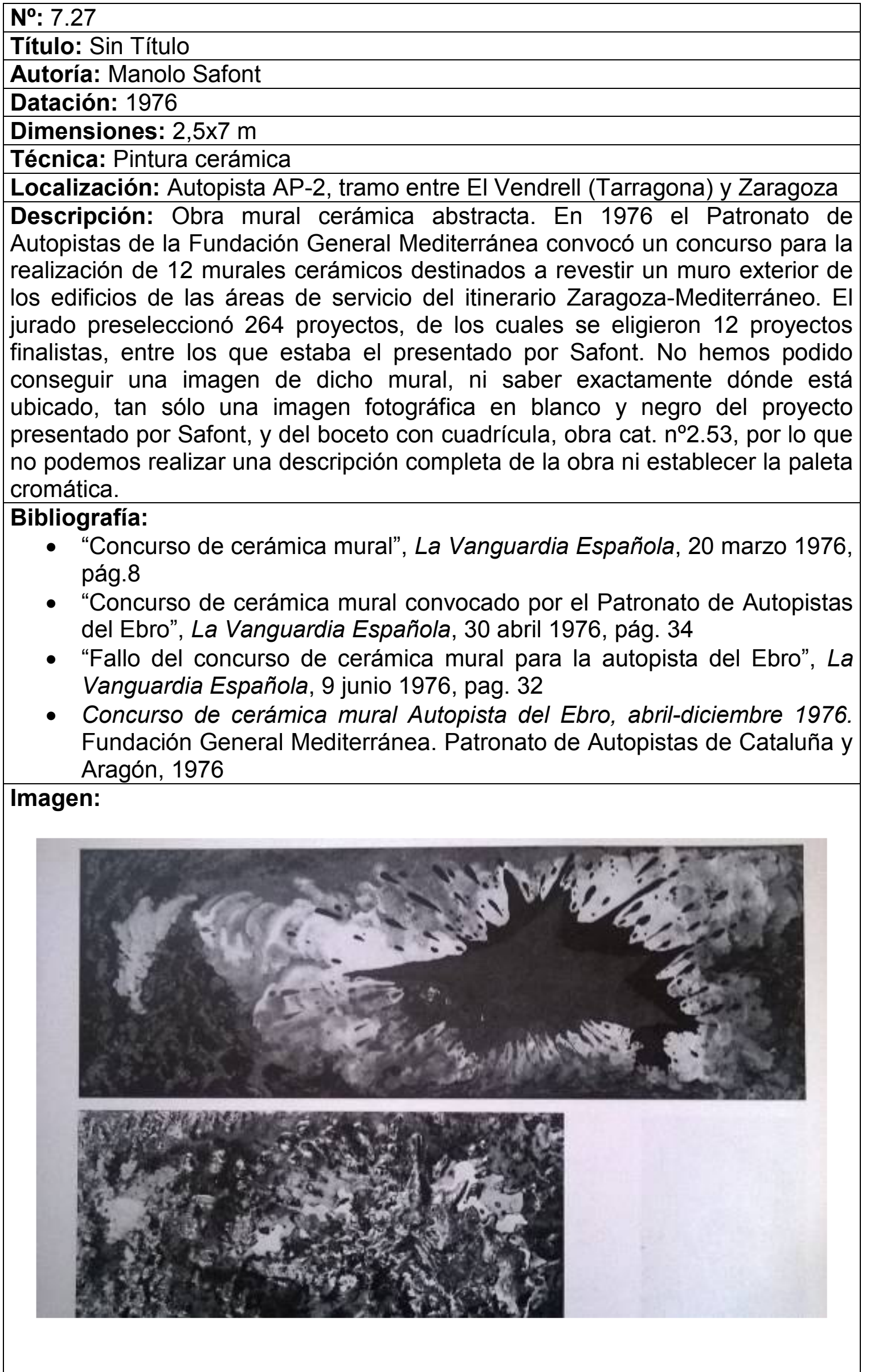


Imágenes relacionadas:

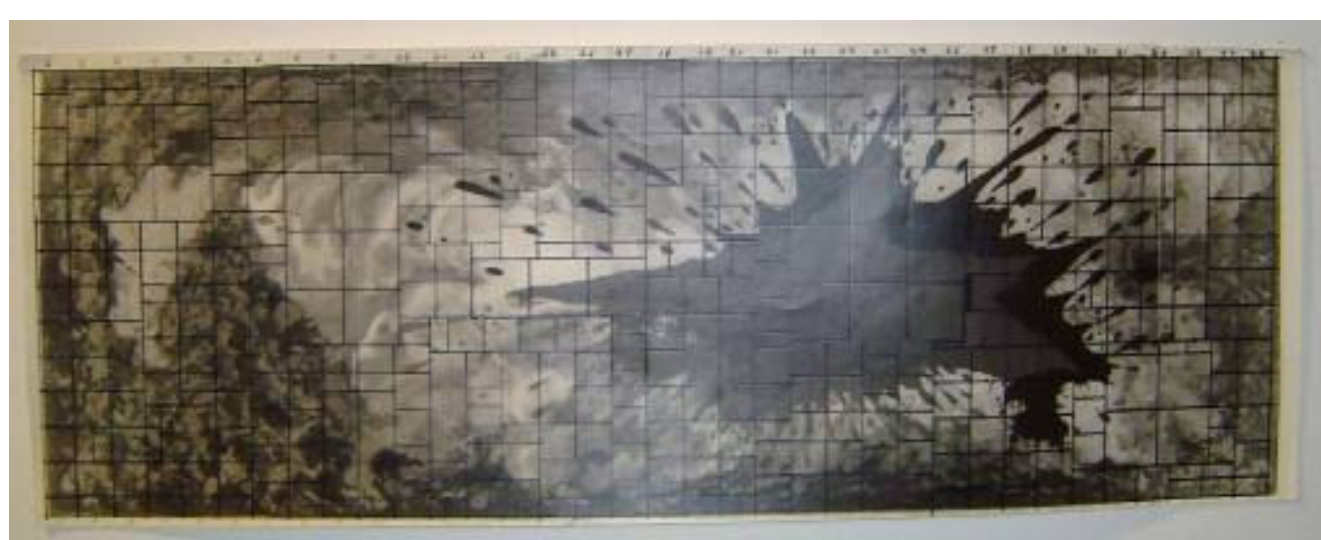

Boceto para panel cerámico obra cat. $n^{0} 2.53$ 
$\mathbf{N}^{0}: 7.28$

Título: Sin Título

Autoría: Manolo Safont

Datación: 1985

Técnica: Pintura cerámica

Localización: IES Vicent Castell i Domenech, calle Illa Baleato, n¹8, Castellón de la Plana

Descripción: Obra mural cerámica abstracta. Creado para el antiguo Instituto Mixto $n^{\circ} 5$ de Castellón de la Plana, actual IES Castell i Domenech. Este mural cerámico es un homenaje a Paco Esteve (arqueólogo castellonense), en el que Safont introduce un elemento figurativo pero descompuesto, en el que predomina la abstracción, rememorando el mundo de la arqueología, como la silueta de una mano roja al estilo de las pinturas rupestres, o los fragmentos con diseños geométricos esquemáticos en color negro, que recuerdan los fragmentos cerámicos que se encuentran en las excavaciones arqueológicas. Paleta cromática: blancos, amarillos, rojos, verdes, violetas, marrones y negros. Bibliografía:

- FALOMIR VENTURA, Carmela. "La pintura cerámica de Manolo Safont", Butlletí d'Estudis Municipals, Regiduria de Cultura, $2^{\mathrm{a}}$ etapa, n², Onda, 2001 , pág. 27

Imagen:

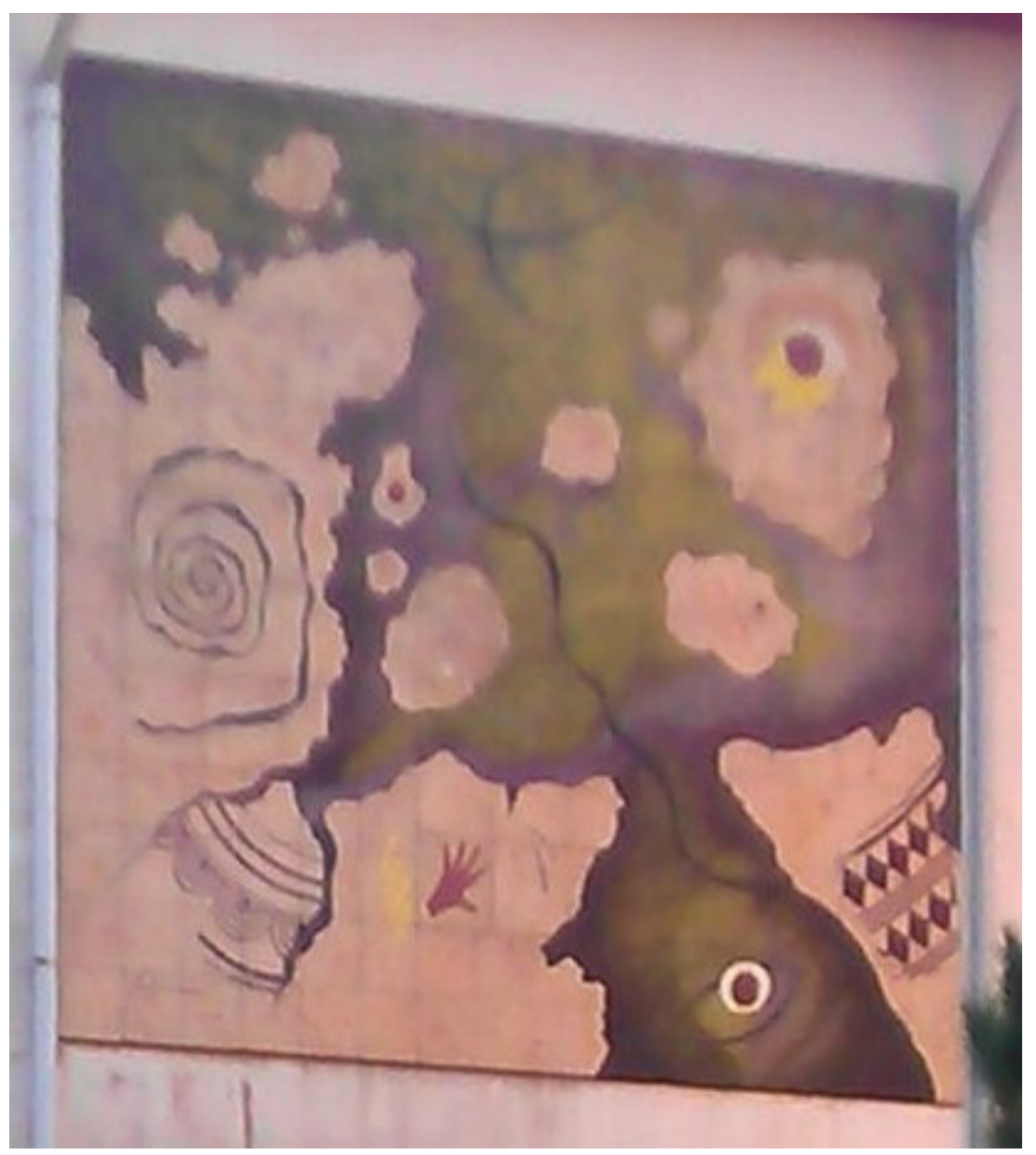


Imágenes relacionadas:

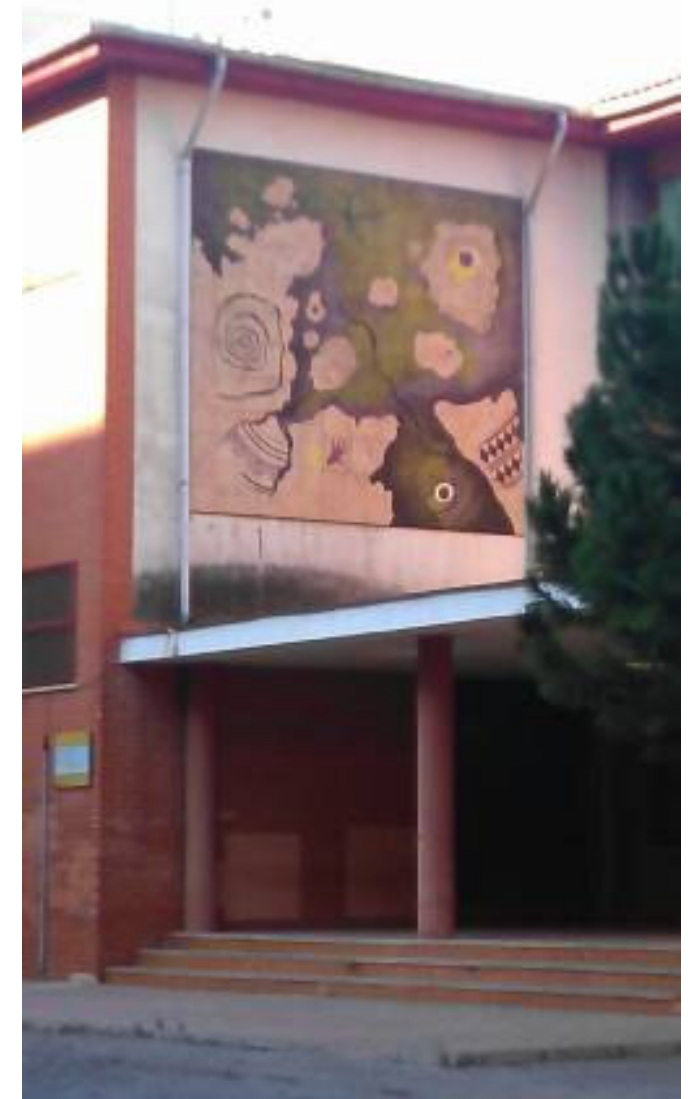

IES Vicent Castell i Domènech 


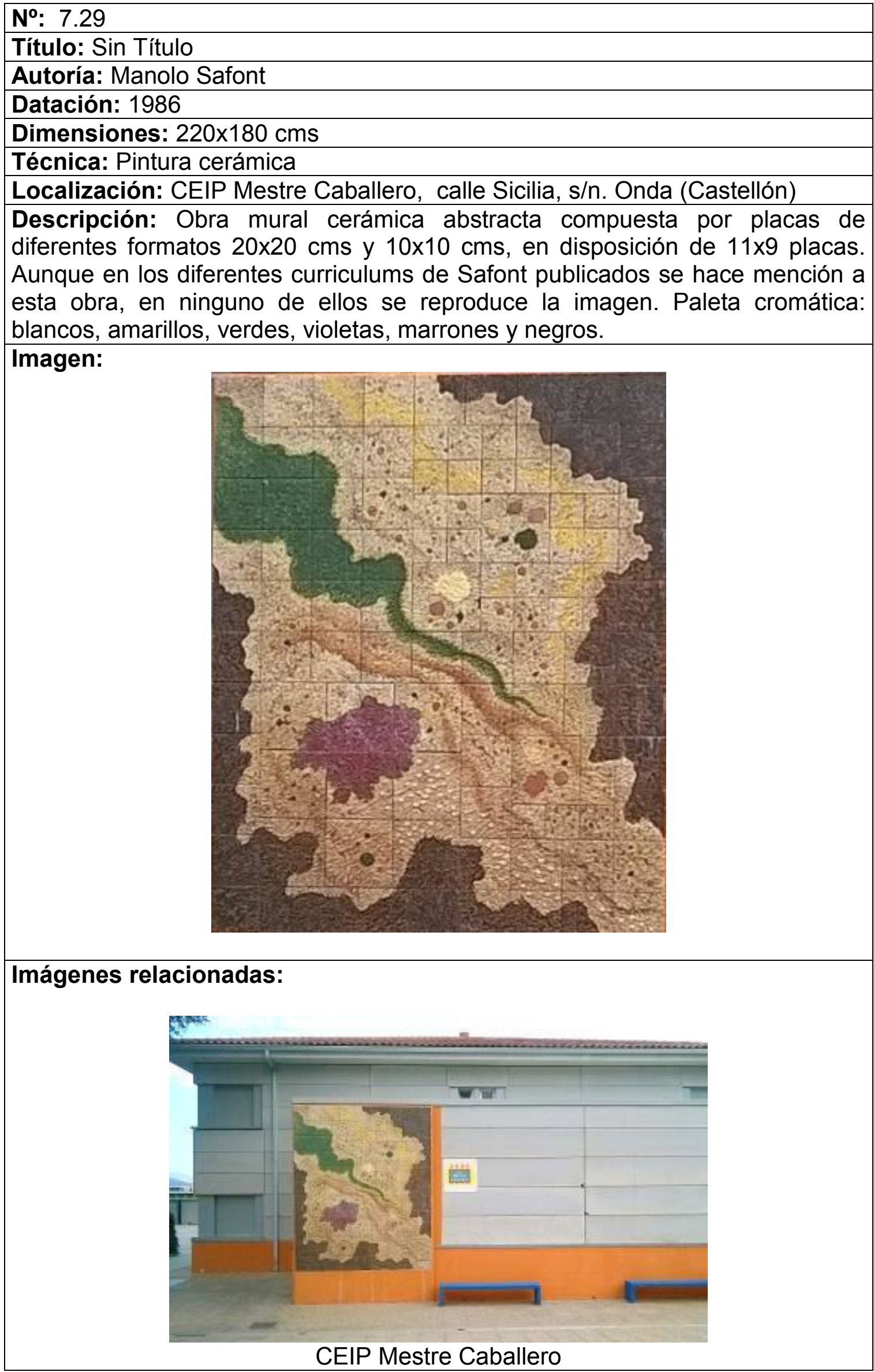


$\mathbf{N}^{0}: 7.30$

Título: Sin Título

Autoría: Manolo Safont

Datación: 1987

Inscripciones: Safont en ángulo inferior izquierdo

Dimensiones: 224x450 cms

Técnica: Pintura cerámica

Localización: Gobierno Civil Castellón

Descripción: Obra mural cerámica abstracta, compuesta por 65 placas, en disposición 5x13. En 1955, Ramón Catalán pintó una alegoría de la Guerra Civil para decorar la planta noble del edificio de Gobierno Civil en Castellón, ubicado en la plaza María Agustina. El mural de R. Catalán plasmaba la entrada de las tropas nacionales en Castellón en junio de 1938, con exaltación del ejército vencedor de la contienda, una obra considerada de gran valor artístico, pero con claras connotaciones franquistas. Con la llegada de la democracia, se procedió a eliminar los símbolos y referencias al franquismo de los edificios oficiales. A finales de la década de 1980, la gobernadora civil de Castellón, Pilar Bravo, decidió eliminar el mural de Ramón Catalán y encargo para sustituirlo un mural cerámico a Manolo Safont, que realizó una composición cerámica abstracta de gran fuerza creativa. Paleta cromática: blancos, amarillos, naranjas, rojos, azules, marrones y negros.

Bibliografía:

- FALOMIR VENTURA, Carmela. "La pintura cerámica de Manolo Safont", Butlletí d'Estudis Municipals, Regiduria de Cultura, $2^{\mathrm{a}}$ etapa, n², Onda, 2001 , pág. 27

- "Un mural contra otro mural" 25/11/12 www.elperiodicomediterraneo.com

- "El mural destruido fue pintado en 1955 por R. Catalán" 25/11/2012 www.elperiodicomediterraneo.com/

Imagen:

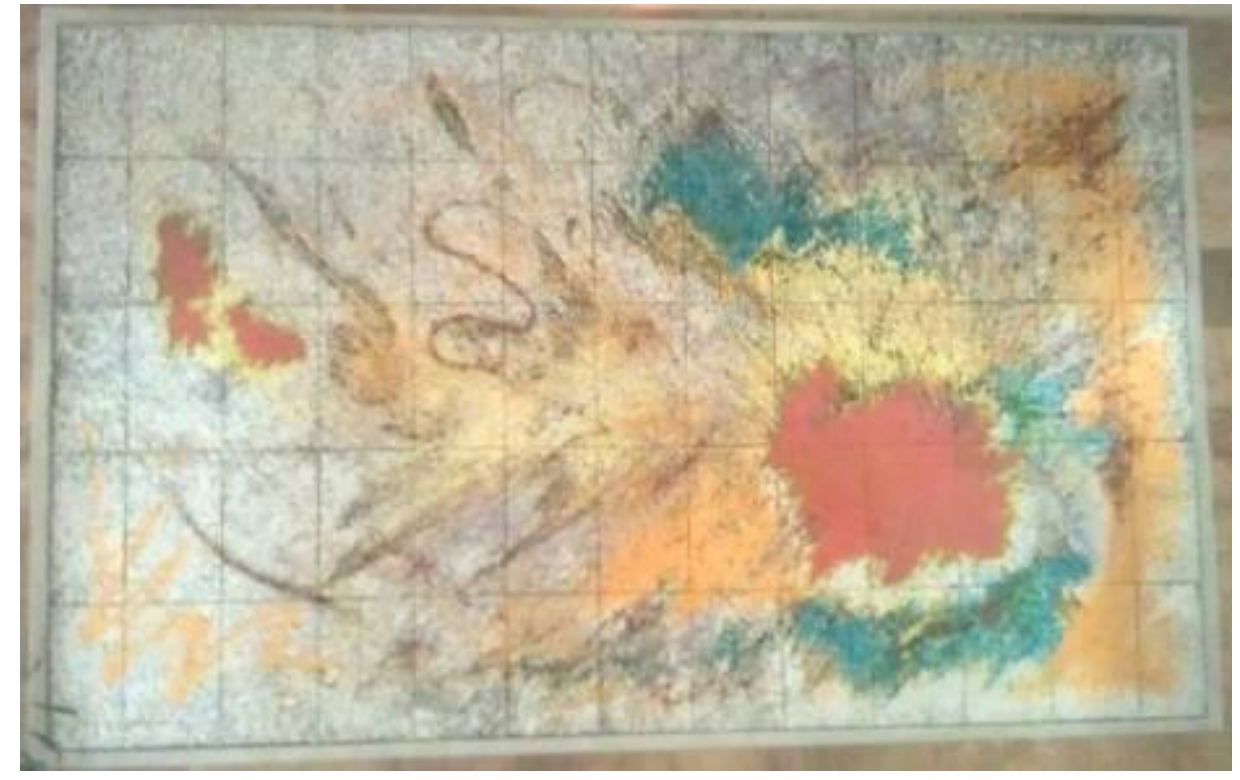


No: 7.31

Título: Sin Título

Autoría: Manolo Safont

Datación: 1991

Inscripciones: Safont ONDA 90 en ángulo inferior derecho

Dimensiones: $30 \mathrm{~m}^{2}$

Técnica: Pintura cerámica

Localización: Escola d'Arts i Oficis (Castellón)

Descripción: Obra mural cerámica abstracta de grandes dimensiones, situada en un muro del sótano de la Escuela de Artes y Oficios de Castellón, antiguo edificio de la Beneficencia. Dado su gran tamaño y la escalera que tiene delante, resulta imposible conseguir una imagen frontal completa de la obra. En el margen inferior derecho, aparece la fecha "90", que se corresponde al año en que Safont terminó de realizar el panel, aunque tras la cocción de las placas, el proceso de preparación del muro y su colocación, no terminó hasta 1991. Se conserva el boceto original de la pieza, obra catalogada $n^{\circ} 2.67$, con el cual podemos establecer una completa concordancia con la obra final, tanto en distribución de masas y formas como en la utilización de colores. Paleta cromática: blancos, amarillos, naranjas, azules, verdes, violetas, marrones y negros.

Bibliografía:

- FALOMIR VENTURA, Carmela. "La pintura cerámica de Manolo Safont", Butlletí d'Estudis Municipals, Regiduria de Cultura, $2^{a}$ etapa, $n^{\circ} 2$, Onda, 2001 , pág. 29

\section{Imagen:}

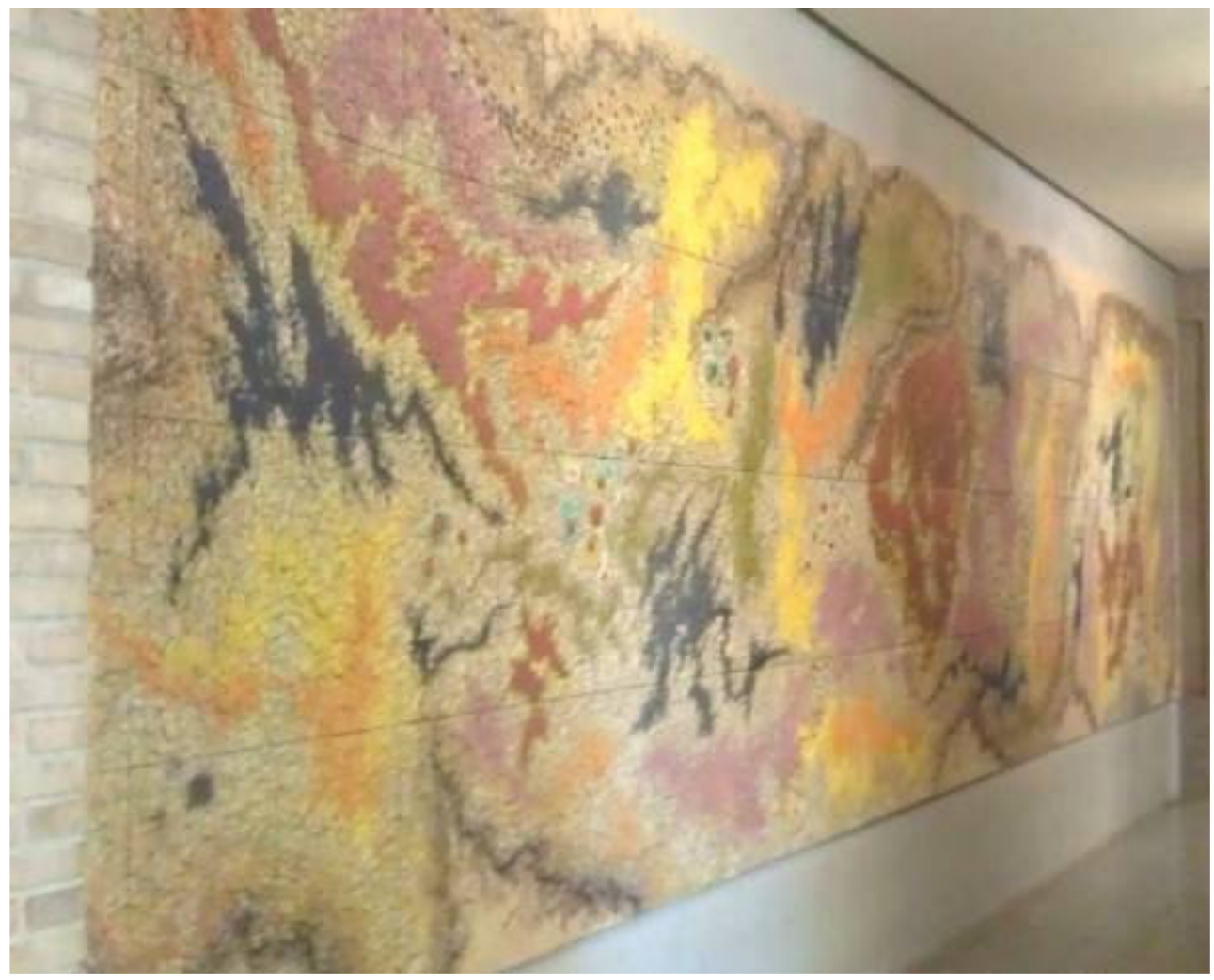


Imágenes relacionadas:

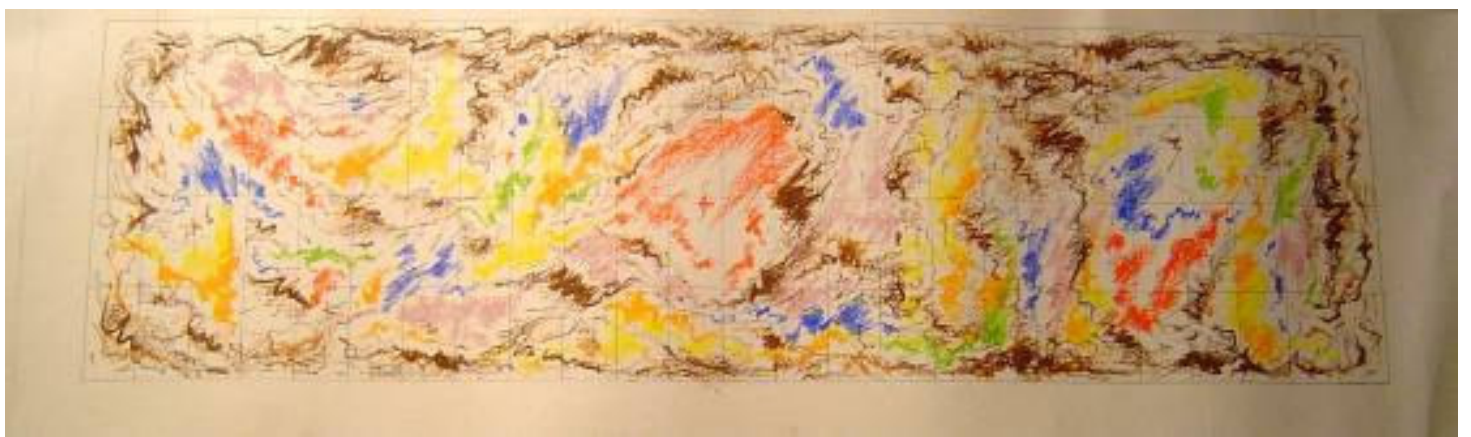

Obra cat. $n^{0} 2.67$

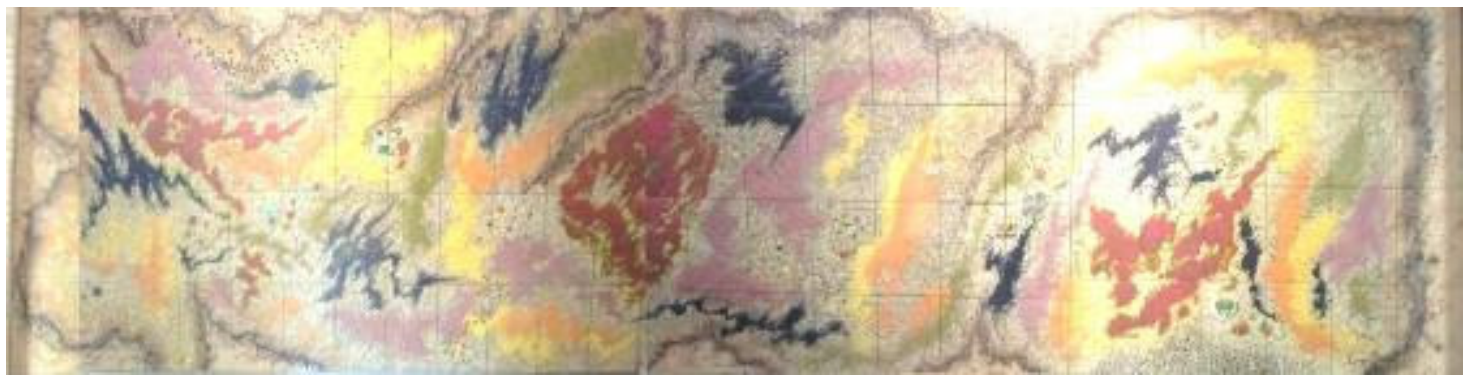

Fotomontaje de la obra

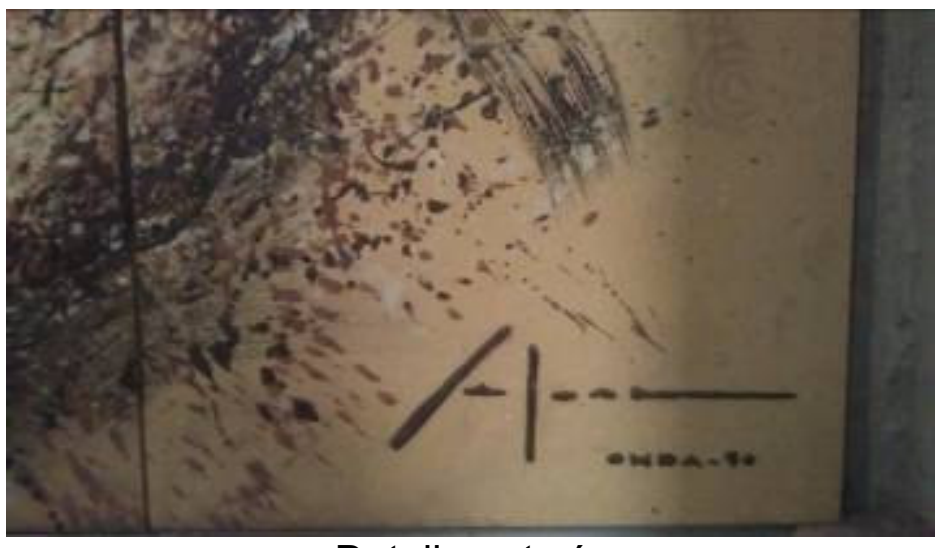

Detalle autoría 


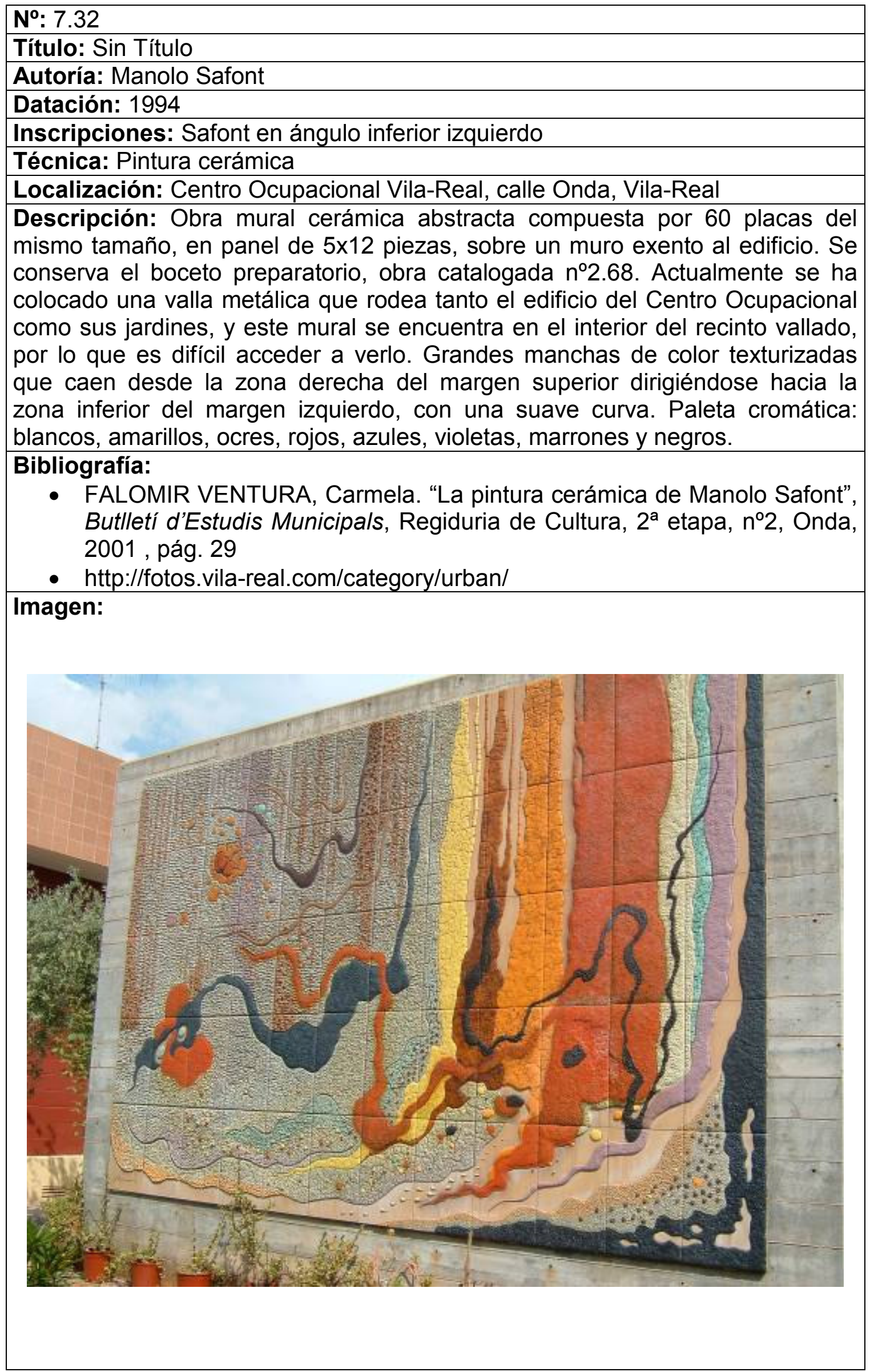


Imágenes relacionadas:

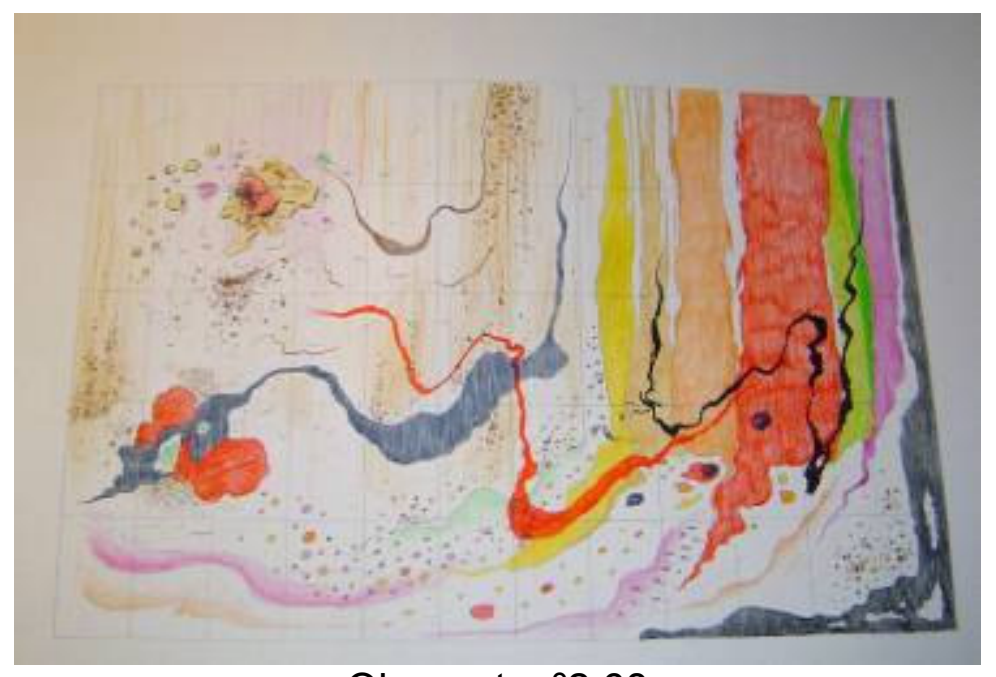

Obra cat. $n^{0} 2.68$ 
$\mathbf{N}^{0}: 7.33$

Título: Sin Título

Autoría: Manolo Safont

Datación: 1994

Técnica: Pintura cerámica

Localización: Parlamento Prefectura de Mie, Japón

Descripción: Obra mural cerámica abstracta. Este mural se realiza en 1994 para conmemorar el hermanamiento entre la Prefectura de Mie (Japón) y la Comunidad Valenciana. Grandes manchas de color destacan sobre un fondo blanco. Se conserva el boceto del panel, obra catalogada $n^{\circ} 2.69$. Paleta cromática: blancos, amarillos, rojos, verdes, azules, marrones y negros.

Bibliografía:

- FALOMIR VENTURA, Carmela. "La pintura cerámica de Manolo Safont", Butlletí d'Estudis Municipals, Regiduria de Cultura, $2^{\mathrm{a}}$ etapa, $\mathrm{n}^{\circ} 2$, Onda, 2001 , pág. 29

\section{Imagen:}

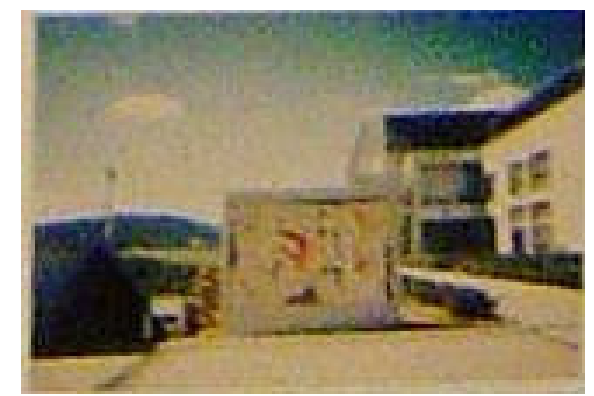

Imágenes relacionadas:
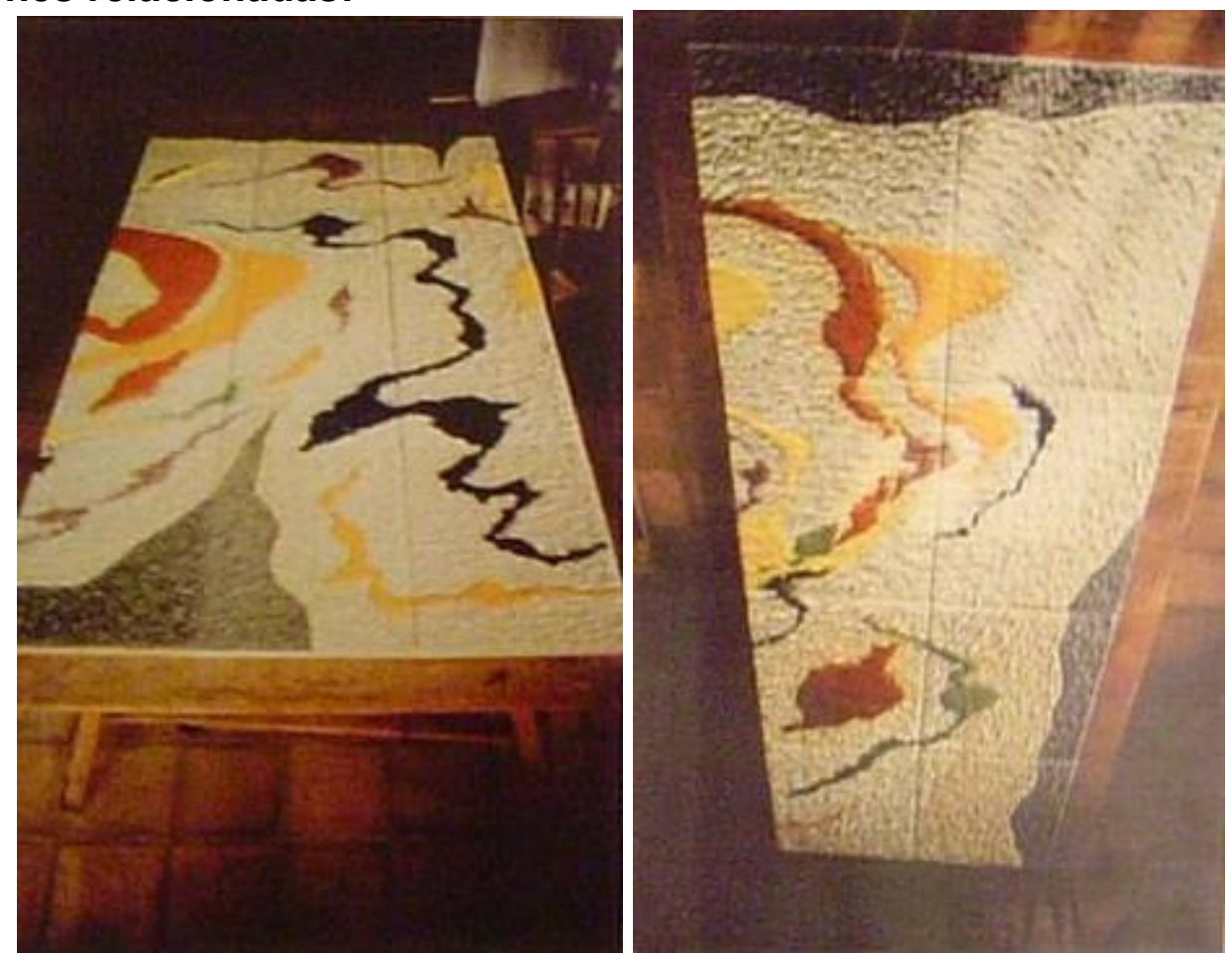

Fragmentos del mural 


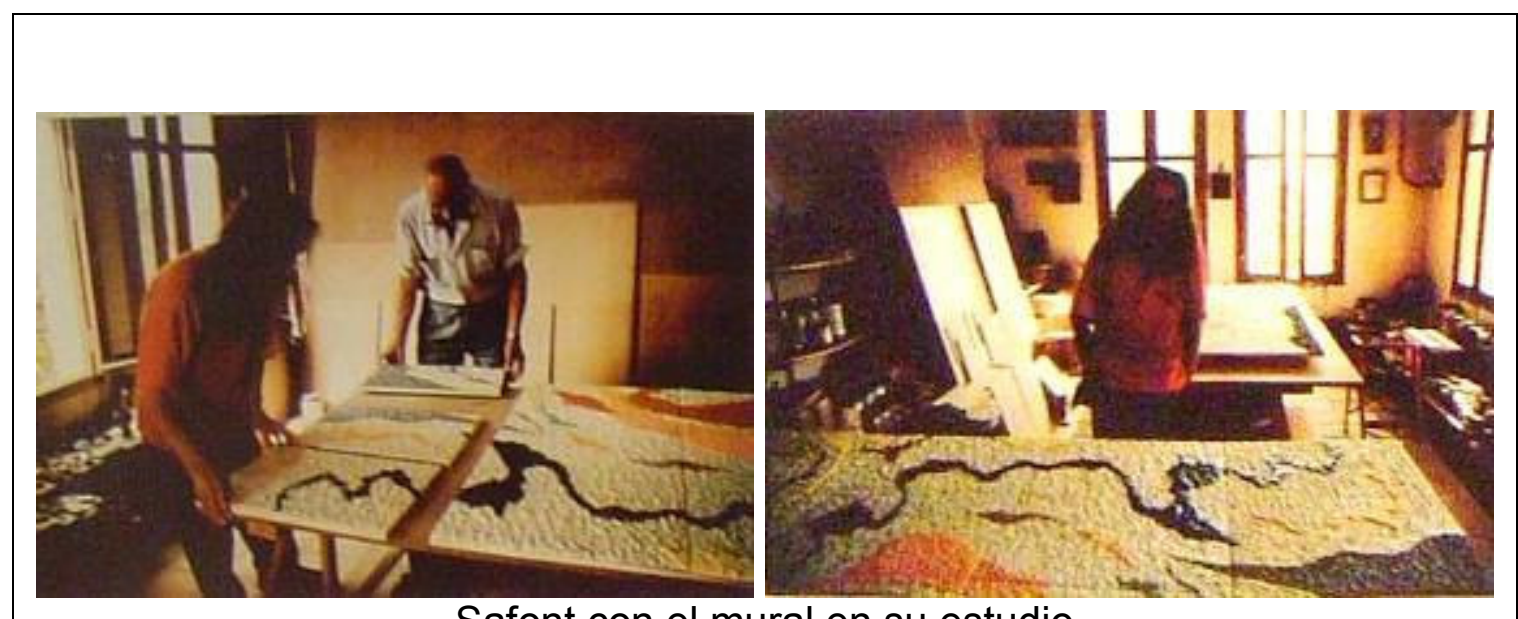

Safont con el mural en su estudio

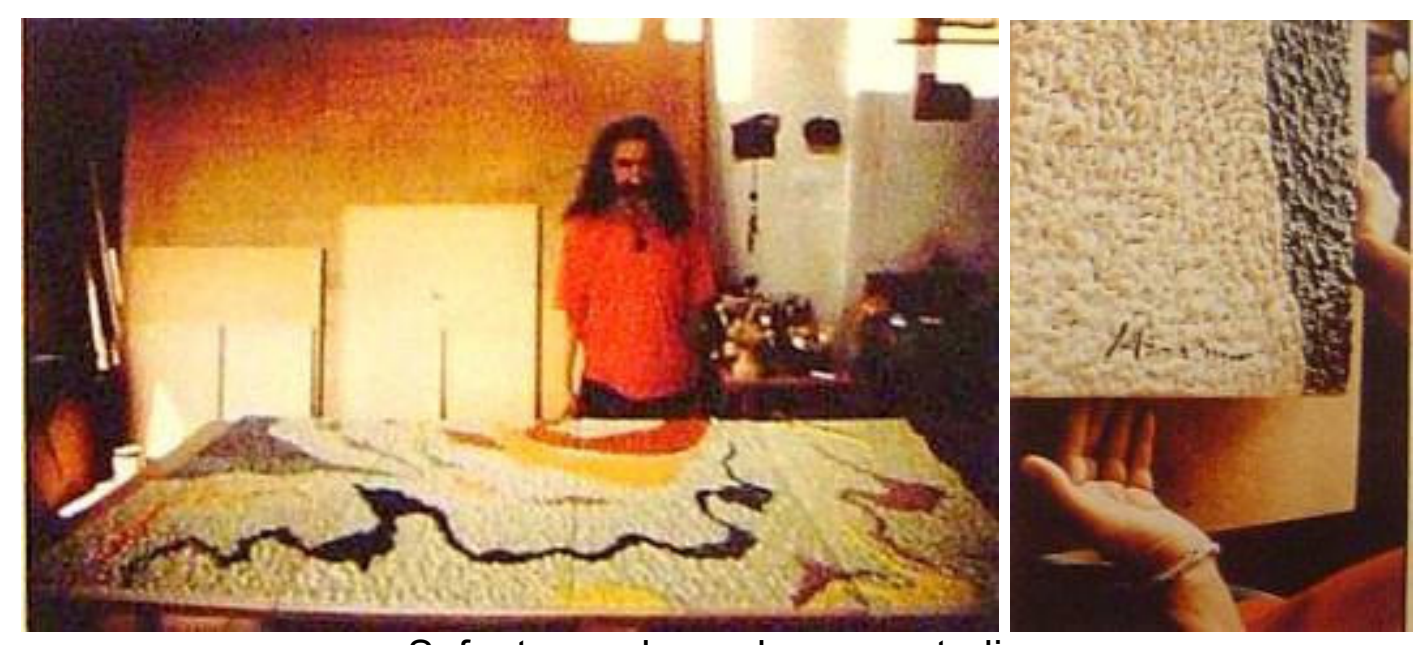

Safont con el mural en su estudio
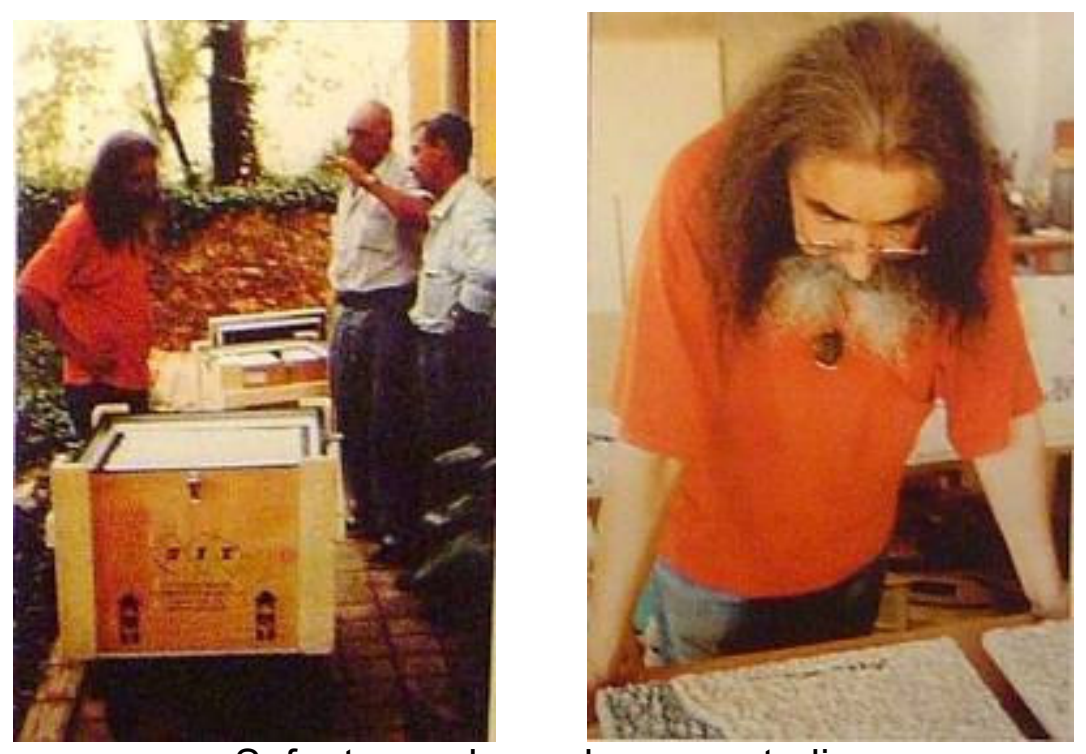

Safont con el mural en su estudio 


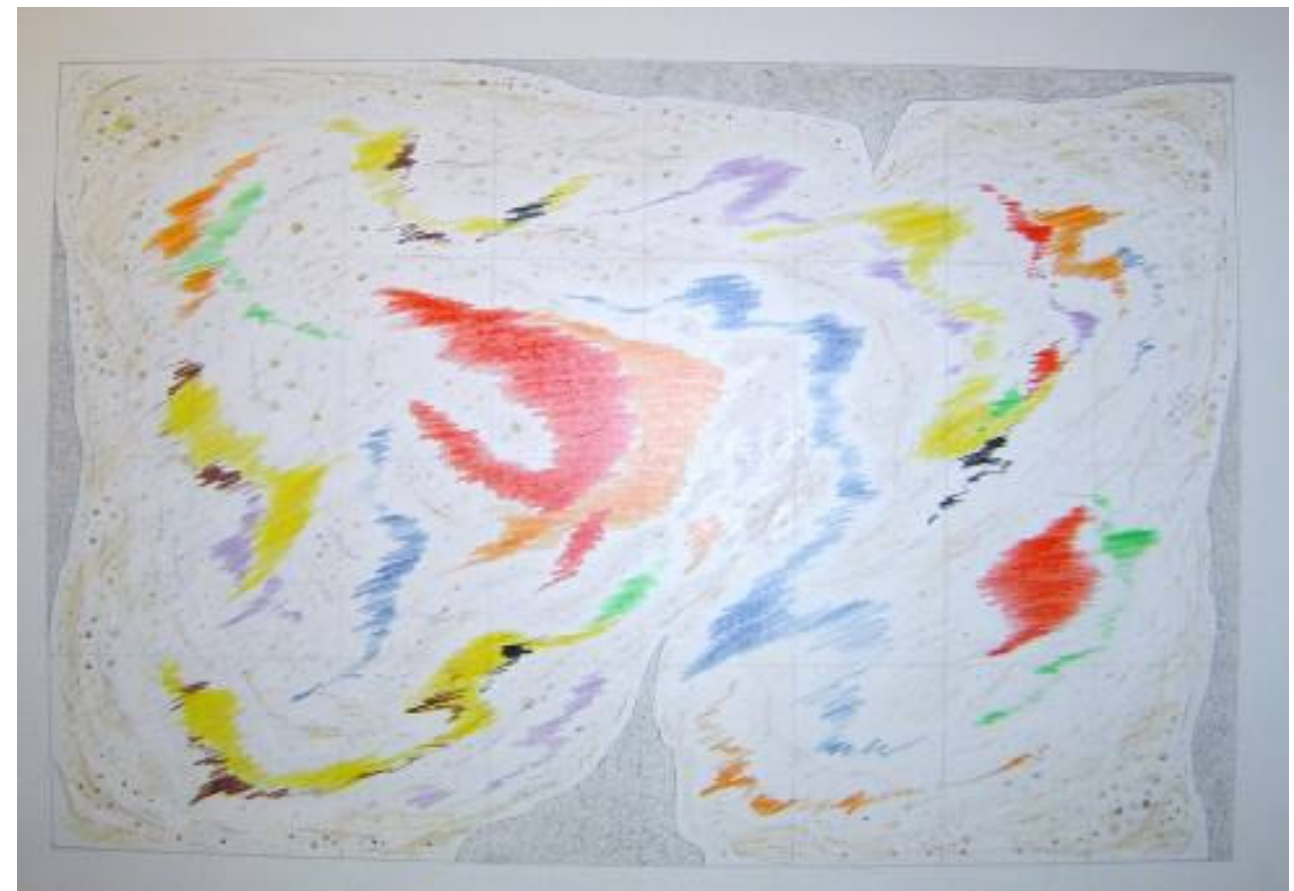

Boceto del panel. Obra cat. $n^{0} 2.69$ 


\section{CAPITULO 7 \\ CONCLUSIONES SOBRE LA FIGURA Y OBRA DE MANOLO SAFONT}

Una vez realizado el estudio y catalogación de la producción artística de Safont y de investigar sobre su biografía, es imposible desligar la una de la otra. Safont estuvo vinculado al mundo del arte desde su juventud, en primer lugar en su vertiente más industrial, a través de su trabajo en las fábricas de azulejos y de cerámica artística, y posteriormente a la pintura cerámica, una vez emprende su camino en solitario con el objetivo de investigar y crear obras artísticas elaboradas con esta técnica, siendo la materia el componente esencial de sus obras. De formación autodidacta, no acudió a escuelas artísticas ni tuvo profesores que le enseñaran.

La trayectoria artística de Safont atravesó diferentes etapas y ámbitos artísticos, desde sus obras de dibujos y trabajos de obra gráfica impresa, a su producción cerámica, en la cual avanzó desde una etapa inicial de estilo realista, dominada por la figuración en la cual comenzó pintando imágenes religiosas y escenas domésticas y réplicas de pinturas egipcias y prehistóricas con el estilo y técnicas tradicionales de la pintura cerámica.

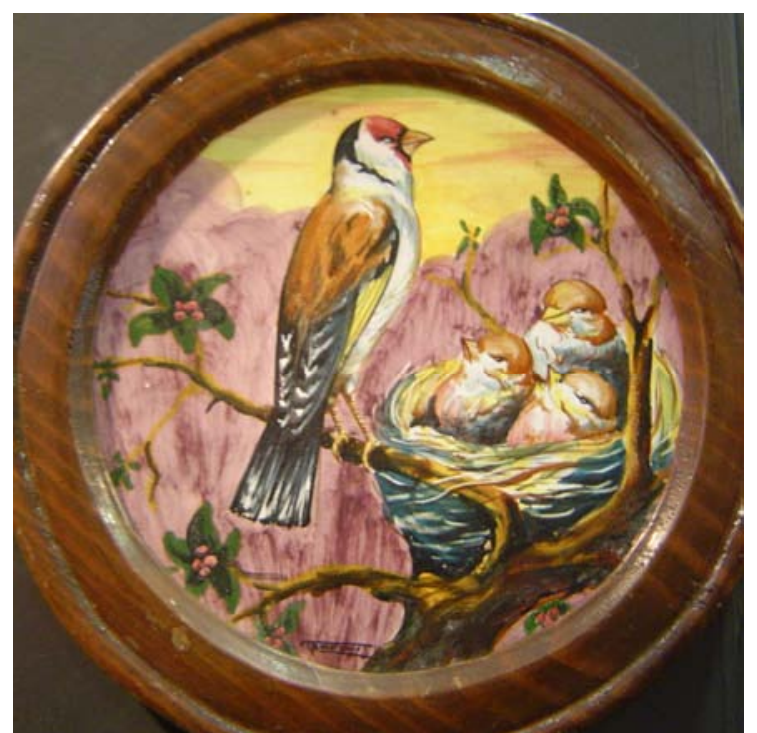

Figura 169: Sin Título. Safont. Obra cat. n³.6

Tras la etapa realista, comienza una etapa de transición en la cual se aprecian las influencias de movimientos artísticos internacionales ya consolidados, como el cubismo, que imprime a las obras de Safont rasgos 
característicos como la utilización de líneas para trazar figuras geométricas de corte esquematizante

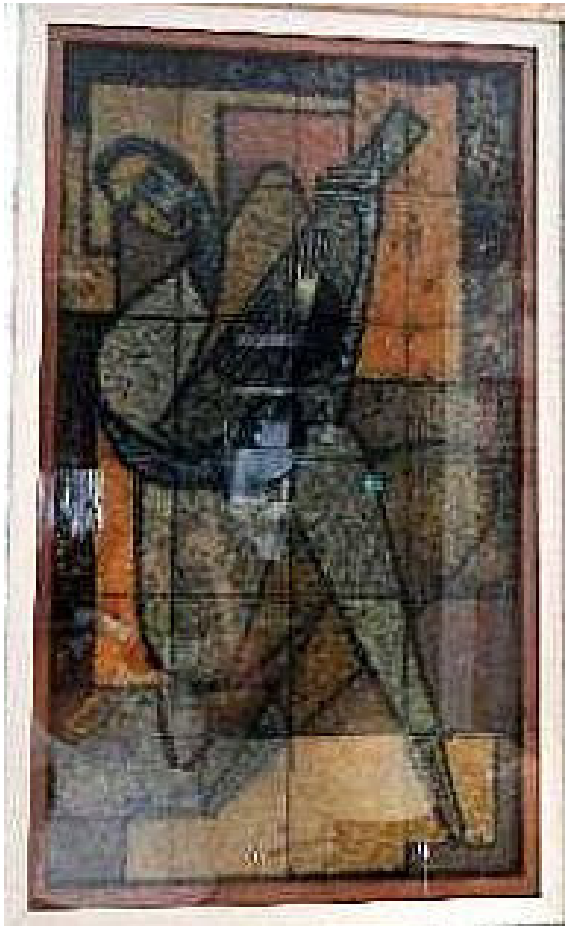

Figura 170: Sin Titulo. Safont. Obra cat. $\mathrm{n}^{\circ} 4.4$

En esta etapa de transición artística Safont utiliza la figuración como un recurso para hacer más comprensible su obra. Safont fue una persona con grandes convicciones sociales y políticas, y su obra era el medio de expresión que utilizó para denunciar la situación social, cultural y política que la dictadura franquista había provocado en España. Serán habituales los cuerpos mutilados, muertos, como figuras fantasmagóricas de las que impresionan sus grandes ojos.

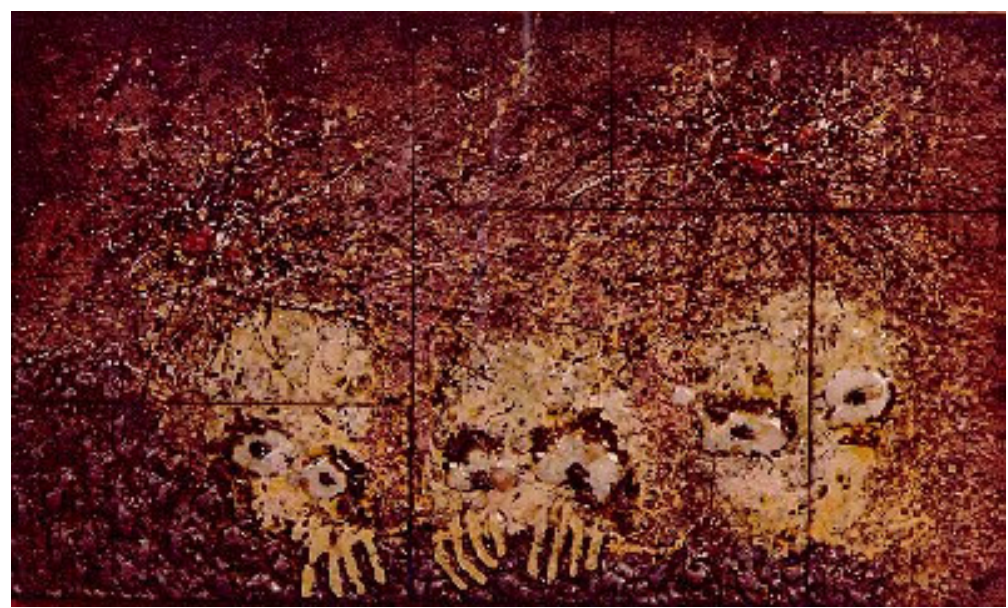

Figura 171: Sin Título. Safont. Obra cat. $\mathrm{n}^{\circ} 4.36$ 
Finalizada la dictadura, y con la instauración de la democracia, al desaparecer la situación ante la que manifestaba su protesta, Safont ya no necesita utilizar su arte como medio de denuncia. La figuración deja de ser un elemento necesario y su estilo artístico evoluciona hacia la abstracción matérica, encontrando en ella un estilo artístico que le permite expresarse y crear libremente, sin ataduras, experimentando con formas, colores y materias, creando composiciones en las que la utilización de los propios elementos cerámicos será lo esencial de las obras.

Las obras de esta etapa muestran una composición equilibrada, que se configura poco a poco, cada elemento, cada mancha de color, es analizada y estudiada para lograr el equilibrio en medio de un caos organizado, en el que cada color, cada línea y trazo, encuentran su lugar para contribuir a mostrar un conjunto armónico.

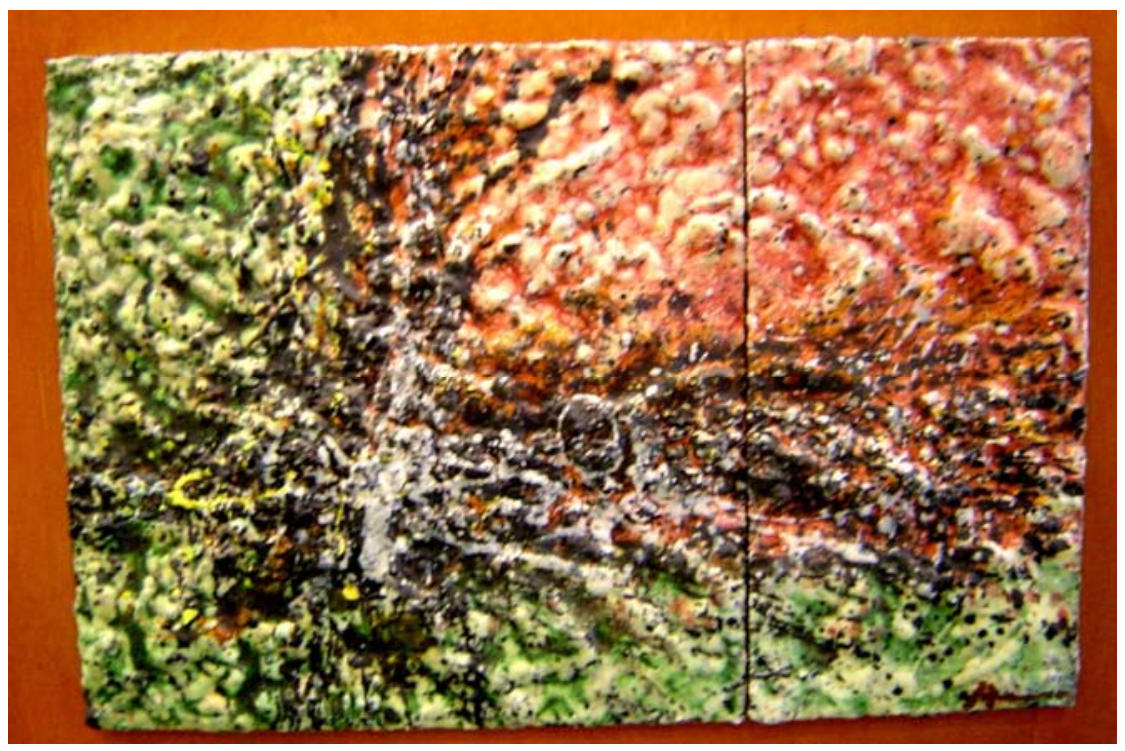

Figura 172: Sin Título. Safont. Obra cat. n5.10

Prescinde de la forma sin prescindir del mensaje, abandona la figuración porque le oprime, le coarta, no le deja expresar todo lo que siente, piensa y necesita trasmitir. En sus obras domina el gesto, hasta el punto que podemos establecer cierta relación entre las obras cerámicas de Safont y las obras gestuales del action painting de Jackson Pollock

Safont no intentó trabajar la cerámica imitando o copiando los acabados de otras artes pictóricas como el óleo, no pretendió copiar ni imitar en cerámica lo que otros artistas creaban sobre lienzos o tablas, no le interesó crear obras 
que reprodujeran fielmente la realidad. Safont fue capaz de crear un lenguaje propio a partir de los materiales y técnicas ancestrales de la cerámica, un lenguaje que hace reconocibles e identificables sus obras a simple vista, con un estilo propio y característico.

Como personaje social, Safont mostró siempre una fuerte vinculación con su entorno y más concretamente con la población de Onda, en la que nació, vivió y murió. La casa de Onda de Safont, era la casa de todos, un lugar que siempre tuvo sus puertas abiertas para todos aquellos que sentían interés por la cultura y el arte, convirtiéndose en un importante foco cultural en el cual se reunían diferentes personas que con el paso de los años han llegado a ser referentes artísticos, sociales o políticos del panorama cultural valenciano: Alberto García Esteve, Antoni Seva, Antonio Miró, Jesús Huguet, Amat Bellés, Wences Rambla, Ximo Puig, etc.

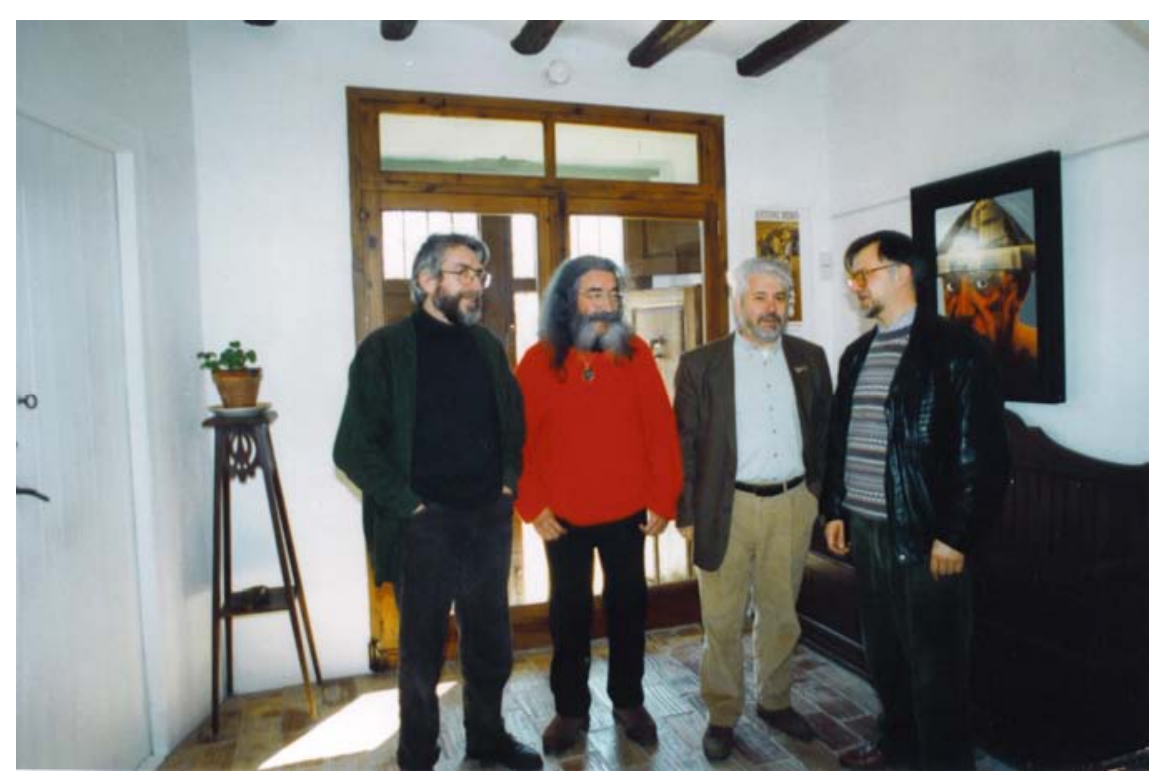

Figura 173: Antoni Miró, Manolo Safont, Jesús Huguet y Wences Rambla

Safont se implicaba en todas las facetas del arte y la cultura, fue promotor del Museo histórico Municipal y de la Sala Municipal de Exposiciones de Onda La Saleta, así como de diversas asociaciones y publicaciones culturales, llegando incluso a publicar unos breves artículos en los Programas de Fiestas de Onda que editaba el Ayuntamiento de Onda con motivo de las fiestas patronales, en su etapa como director del Museo Histórico Municipal. Gracias a sus amistades y sus relaciones personales, conformó un elenco de 
artistas que exponían periódicamente en La Saleta, a través de las diferentes ediciones de la muestra de Art Castellonenc d'Avui, haciendo de Onda un foco irradiador de la cultura artística en este periodo.

Pese a ser una persona muy tímida y sencilla, vencía estos impedimentos para volcarse apasionadamente en todos los proyectos que organizaba o en los cuales participaba. La Saleta fue un centro expositivo que proporcionó a muchos artistas jóvenes las oportunidades que las galerías de arte o los circuitos más comerciales o tradicionales les negaban. Safont no sólo creaba arte, lo promovía y lo promocionaba. Manolo Sales, ceramista ondense, recuerda cómo tras realizar su primera exposición en l'Alcora (Castellón) le informaron que había vendido una obra. Safont, del cual era amigo personal, compró esta obra para ayudar a este joven artista, pero no quiso hacerlo directamente para que Sales no se viera en la situación de regalársela.

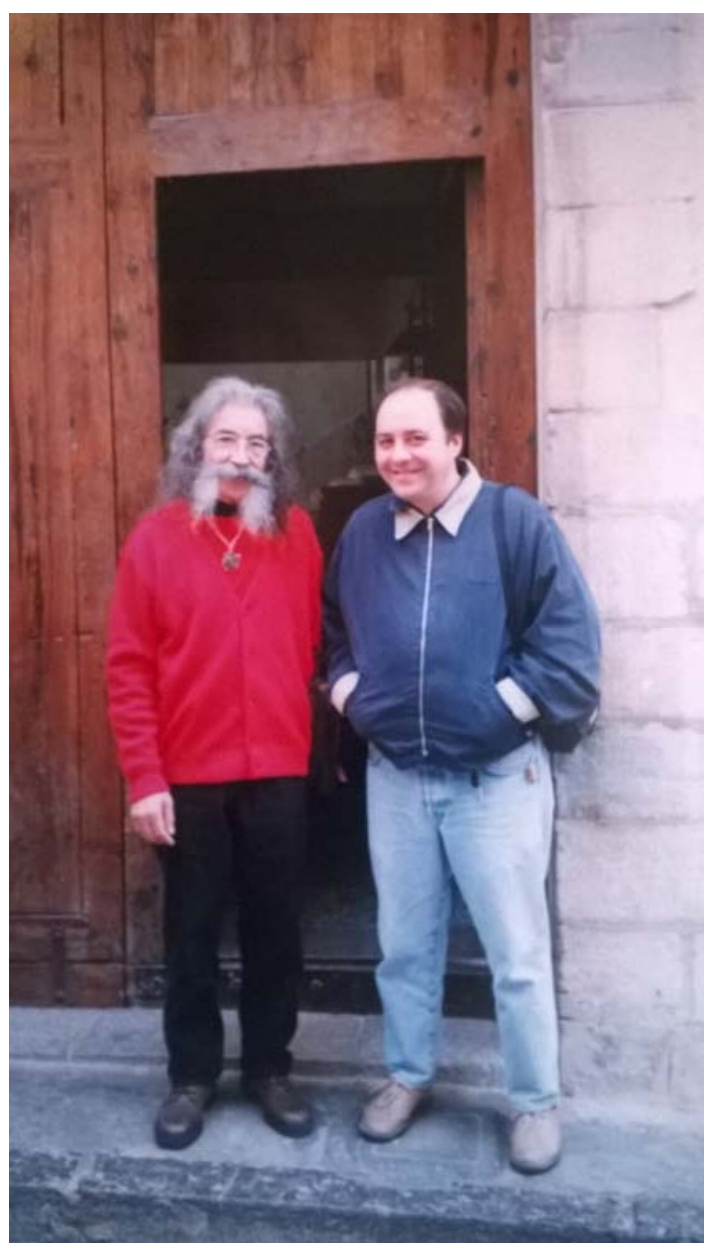

Figura 174: Manolo Safont y Manolo Sales 
Pese a ser un artista reconocido a nivel nacional e internacional, nunca perdió el arraigo con su tierra, y quiso vivir y trabajar siempre en su pueblo natal, llegando a donar todas sus propiedades y producción artística a Onda. Justo era que Onda reconociera a través de homenajes y premios el esfuerzo y dedicación de Safont. Aunque su vinculación con el Museo parte del momento de su nombramiento como director en 1968 y con La Saleta desde 1971, momento de su creación, no fue hasta 1998, cuando con motivo de un homenaje para celebrar los 70 años de su nacimiento, se suceden los actos de reconocimiento a su trayectoria artística y labor social, culminando con la denominación del Museo de Onda como Museo del Azulejo Manolo Safont.

Quizás sea el titulo de la exposición que se realizó en 2004 para la inauguración de este museo, la que pueda definirnos más concisa y claramente su trabajo, su vida y su obra:

"Manolo Safont: un Museu, un llegat, un compromís"

"Safont es en sus superficies o placas, fuerte, solidamente agresivo, con un sentido de expresividad que hace pensar en que de no estar inventada la cerámica habría que hacerlo ahora para que tuviera el vehículo de comunicación adecuado. Fuerza y fuego, técnica controlada por la inteligencia" (Felipe Vicente Garin Llombart) ${ }^{1}$

"No crec que ningú puga negar que Manolo Safont és un dels creadors plàstics més suggestius, més autèntics, més rigorosos del Pais Valencià actual. I, pot ser, encara, el més insòlit" (Joan Fuster) ${ }^{2}$

"Manolo Safont es uno de los más interesantes ceramistas del arte español actual" (Vicent García Edo) $)^{3}$

\footnotetext{
${ }^{1}$ Garín Llombart, Felipe Vicente. Catálogo exposición Safont. Museo Nacional de Cerámica González Martí, del 3 al 30 de marzo de 1980, Valencia.

${ }^{2}$ Fuster, Joan. Safont ceràmica. Palau Oliver de Boteller, del 9 al 16 de mayo de 1983, Tortosa. "No creo que nadie pueda negar que Manolo Safont es uno de los creadores plásticos más sugestivos, más auténticos, más rigurosos del País Valenciano actual. Y puede ser, aún, el más insólito"

${ }^{3}$ GARCía Edo, Vicent. Safont. Catálogo exposición Sala Goya, Casa de España en Paris, del 5 al 18 de octubre de 1978.
} 
"Podem ben bé dir que l'obra de ceràmica de Manolo Safont- una de les més suggestives, és riques, més rigoroses- és una obra fullosa que té diverses lectures" (Vicent Andrés Estellés) ${ }^{4}$

"En el ámbito de su generación es un rompedor y un innovador. Incomprendido en sus primeros años como ceramista, llega más tarde a valorarse su obra en círculos restringidos, para finalmente ser considerado como uno de los grandes ceramistas valencianos contemporáneos" (Ramón Monfort Salvador) ${ }^{5}$

"Sería ben difícil trobar al rol d'artistes plàstics valencians actuals un de més lligat al seu origen, en funció de la propia materia usada per tal de expressarse, que Manolo Safont" (Jesús Huguet) ${ }^{6}$

${ }^{4}$ ANDRES ESTELLES, Vicent. Fragment sobre Manolo Safont, Catálogo exposición Safont. Sala Municipal de l'Ajuntament de Torrent, del 2 al 21 de novembre de 1980.

${ }^{5}$ MONFORT, Ramón. Safont. Catálogo exposición La Pobla Tornesa (Castellón), 1987.

${ }^{6}$ Huguet, Jesús. Safont. Catálogo exposición La Pobla Tornesa (Castellón), 1987. 


\section{CAPÍTULO 8 \\ APÉNDICE DOCUMENTAL}

\section{1.- ÍNDICE DE FIGURAS}

- Figura 1: Manolo Safont y Cristina Benaches

- Figura 2: Manuel Safont Castelló

- Figura 3: Manuel Safont (el menor)

- Figura 4: Manolo Safont, situado el cuarto por la derecha de la fila superior, posando con sus compañeros de escuela en la puerta de la Iglesia de Nuestra Señora de la Asunción de Onda

- Figura 5: Manolo Safont durante el servicio militar

- Figura 6: La barra del bar de Acción Católica con los azulejos realizados por Safont

- Figura 7: Tarjeta de visita profesional de Safont

- Figura 8: Safont realizando el panel para el Seminario de Tortosa

- Figura 9: Iglesia Parroquial Nuestra Señora de la Asunción, Sueras

- Figura 10: Diploma Exposición Nacional de Artesania de Granada

- Figura 11: Cine Teatro Mónaco de Onda

- Figura 12: Inauguración edificio Caja Rural Nuestra Señora de la Esperanza de Onda

- Figura 13: Portada programa fiestas Onda 1960

- Figura 14: Diploma Sociedad Coral El Micalet

- Figura 15: Quiosco de prensa de La Safona

- Figura 16: Catálogo exposición Sala Exposiciones Dirección General de Bellas Artes de Madrid, 1961

- Figura 17: Mural Sagrada Familia MAMS

- Figura 18: Artículo de Luís Padres Perona

- Figura 19: "Ernesto Che Guevara" de Manolo Safont

- Figura 20: Mural Catedral de Babahoyo, Ecuador.

- Figura 21: Portada programa de fiestas de Onda de 1968

- Figura 22: Safont en los inicios de su etapa como director del Museo de Onda

- Figura 23: Portada programa fiestas 1969

- Figura 24: Cartel anunciador de la exposición del Círculo Mercantil e Industrial de Castellón, realizado por el propio Safont

- Figura 25: Portada programa fiestas de Onda 1970

- Figura 26: Safont 1971

- Figura 27: Catálogo exposición Círculo mercantil e Industrial de Castellón, 1971

- Figura 28: Dibujo de la Iglesia de la Asunción de Onda

- Figura 29: Manolo y Ana, 1973

- Figura 30: Safont en la Saleta Municipal d'Onda, 1973

- Figura 31: Manolo Safont, Onda, 1974

- Figura 32: Portada programa de fiestas de Onda de 1974 
- Figura 33: Cartel exposición Galería Cànem

- Figura 34: Dibujo de Safont para el programa de fiestas de 1975

- Figura 35: Dibujo de Safont para el programa de fiestas de Onda de 1976

- Figura 36: Casa-alquería de Manolo Safont

- Figura 37: Manolo Safont

- Figura 38: Catálogo exposición Safont en Sala Municipal de Onda, 1978

- Figura 39: Catálogo exposición Sala Goya, Casa de España en París, 1978.

- Figura 40: Catálogo exposición Museo Nacional de Cerámica González Martí, 1980.

- Figura 41: Catálogo exposición Biblioteca Municipal Vila-Real

- Figura 42: Catálogo exposición Ayuntamiento de Torrent.

- Figura 43: Catálogo exposición Caja de Ahorros de Alicante y Murcia, Elche.

- Figura 44: Catálogo exposición Museu Historic Municipal d'Onda.

- Figura 45: Catálogo exposición Museu de Ceràmica, Barcelona.

- Figura 46: Catálogo exposición Fontana d'Or, Girona.

- Figura 47: Catálogo exposición Palau Oliver de Boteller, Tortosa

- Figura 48: Portada programa fiestas de Onda, 1983

- Figura 49: Catálogo exposición Castell de Papa Luna, Peñíscola

- Figura 50: Catálogo exposición colectiva Segorbe

- Figura 51: Mural IES Vicent Castell i Doménech.

- Figura 52: Jornades de ceràmica, Colegio Oficial de Arquitectos de la Comunidad Valenciana

- Figura 53: Mural cerámico del CEIP Mestre Caballero de Onda

- Figura 54: Catálogo exposición La Pobla Tornesa.

- Figura 55: Mural Gobierno Civil Castellón

- Figura 56: Catálogo exposición Ayuntamiento de Castellón

- Figura 57: Catálogo exposición Safont in Brussel.

- Figura 58: Mural Escuela de artes y Oficios, Castellón

- Figura 59: Catálogo exposición Galería Octubre, Universitat Jaume I

- Figura 60: Mural Centro Ocupacional Vila-Real

- Figura 61: Catálogo exposición Morella

- Figura 62: Catálogo exposición Galería Cànem

- Figura 63: Cartel Symposium Internacional de Estrés Profesional

- Figura 64: Catálogo exposición Morella 1998

- Figura 65: Acta del Pleno del Ayuntamiento de Onda

- Figura 66: Acta de aceptación de los bienes de Manolo Safont donados al pueblo de Onda

- Figura 67: Calendario 2003 Caja Rural Nuestra Señora de la Esperanza. Onda

- Figura 68: Manolo y Anita recibiendo el galardón del Seny Onder 2002

- Figura 69: Premio Protagonistas de Castellón, Artes Plásticas 2003

- Figura 70: Matasellos conmemorativo inauguración Museo Azulejo Manolo Safont 
- Figura 71: Manolo Safont y Ana del Moral. Inauguración Museo del Azulejo Manolo Safont

- Figura 72: Capilla ardiente en el Museo del Azulejo de Onda

- Figura 73: Tarjeta invitación Día Internacional de los Museos, MAMS

- Figura 74: Inauguración exposición Magnificat.

- Figura 75: Grayson Perry

- Figura 76 Rebecca Warren

- Figura 77: Richard Deacon

- Figura 78: Kosho Ito

- Figura 79: Detalle mural cerámico de Joan Miró. Palacio de Congresos de Madrid.

- Figura 80: Xavier Montsalvatje

- Figura 81: Sin palabras de Antonio González

- Figura 82: Bambú 25 de Xohan Viqueira

- Figura 83: Mar de Gel de María Bofill

- Figura 84: Manuscrita, $123 \mathrm{~cm}$ diámetro de May Criado

- Figura 85: Obra de Agustín Ruíz de Almodóvar

- Figura 86: Orígens de Jordi Marcet y Rosa Vila-Abadal

- Figura 87: Exposición Triálogos

- Figura 88: Exposición Allà, on el món s’acaba

- Figura 89: V Bienal de Cerámica. El Vendrell

- Figura 90: Cerámica en la Red

- Figura 91: Mà com a eina, Madola

- Figura 92: Estrella de Elena Canencia

- Figura 93: Detalle de En esencia de Fanny Galera

- Figura 94: Obra de Samuel Bayarri

- Figura 95: Escultura mural de Enric Mestre

- Figura 96: Obra de Juana Fernández

- Figura 97: I Muestra Internacional de Cine Cerámico

- Figura 98: Obra de Camil.la Pérez Salvà

- Figura 99: El Carmen de Carmen, instalación de Carmen Ballester

- Figura 100: Obra de Manolo Sales

- Figura 101: Sin Título. Safont. Obra cat. n³.1

- Figura 102: Sin Título. Safont. Obra cat. n³3.9

- Figura 103: Sin Título. Safont. Obra cat. n०3.3

- Figura 104: Sin Título. Safont. Obra cat. n².5

- Figura 105: Balaustres y cráneo, Georges Braque, 1938.

- Figura 106: Sin Título, Manolo Safont, anterior a 1962. Obra cat. $n^{\circ} 4.8$

- Figura 107: Viaducto en L'Estaque, Georges Braque, 1908.

- Figura 108: Sin Título, Manolo Safont, anterior a 1962. Obra cat. n4.10

- Figura 109: Desnudo yaciente, Henry Matisse, 1936.

- Figura 110: Sin Título, Manolo Safont 1959. Obra cat. nº.3

- Figura 111: Sin Título. Safont. Obra cat. nº4.23

- Figura 112: Sin Título. Safont. Obra cat. $n^{\circ} 4.21$

- Figura 113: Sin Título, Gérard Zlotykamion, década de 1960.

- Figura 114: Sin Título, Safont, anterior a 1972. Obra cat. nº.18 
- Figura 115: Sin Título, Gérard Zlotykamion, 1965-1970.

- Figura 116: Sin Título, Safont, 1976. Obra cat. nº4.30

- Figura 117: Llibertat, Safont, 1978. Obra cat. $n^{\circ} 4.34$

- Figura 118: Sin Título, 1982. Safont. Obra cat. n5.29

- Figura 119: Sin Título, Safont. Obra cat. n०5.20

- Figura 120: Sin Título, Safont. Obra cat. n5.57

- Figura 121: Número 1 A, Jackson Pollock, 1948.

- Figura 122: Sin Título, Safont. Obra cat. n०5.61

- Figura 123: Número 5, Jackson Pollock.

- Figura 124: Sin Título, Safont. Obra cat. $n^{0} 5.78$

- Figura 125: Sin Título, Safont. Obra cat. n $n^{\circ} 5.14$

- Figura 126: Mural CEIP Mestre Caballero, Safont. Obra cat. n7.29

- Figura127: Piso-estudio de Safont en el Raval de San José de Onda, situado en el último piso de la casa situada a la izquierda en la imagen

- Figura 128: Casa-estudio de Safont en la calle Escultor Folià

- Figura 129: Carta de la Dirección de Museos y Exposiciones del Ministerio de Educación y Ciencia, con el nombramiento de Safont como director del Museo Histórico Municipal

- Figura 130: Museo Histórico Municipal de Onda

- Figura 131: Museo del Azulejo Manolo Safont

- Figura 132: La Saleta de Onda

- Figura 133: Safont exponiendo en La Saleta diciembre 1973 - enero 1974

- Figura 134: Viñeta de Quique

- Figura 135: Manolo Safont y Enrique Navarro, alcalde de Onda

- Figura 136: Calendario Caixa Rural d'Onda 2003

- Figura 137: Viñeta de Quique

- Figura 138: Manuel Galver, presidente del Ateneo Cultural y Mercantil de Onda, con Ana del Moral y Manolo Safont

- Figura 139: Diploma Premio Protagonistas 2003

- Figura 140: Matasellos conmemorativo Museo del Azulejo Manolo Safont

- Figura 141: Matasellos conmemorativo Museo del Azulejo Manolo Safont

- Figura 142: Cena homenaje a Manolo Safont

- Figura 143: Capilla ardiente en el Museo del Azulejo Manolo Safont

- Figura 144: Trabajos del alumnado del CEIP PÍO XII

- Figura 145: Pieza romboidal Parque de la cerámica de Onda

- Figura 146: Safont con su esposa Ana, el artista Ripollés, y Eloisa Tarazona y Jesús Broch, gestores del Cau de l'Art. Verano 2005

- Figura 147: Manolo Safont

- Figura 148: Manolo Safont, obra de Rosendo Esteller

- Figura 149: Manolo Safont

- Figura 150: Carta manuscrita de Manolo Safont

- Figura 151: Manolo Safont

- Figura 152: Manolo Safont y Ana del Moral

- Figura 153: Manolo Safont

- Figura 154: Obra cat. $n^{0} 3.8$ y obra cat n³.15 
- Figura 155: Sin Título. Safont. Obra cat. $n^{\circ} 4.7$

- Figura 156: Retrato de Jeanne Hebuterne. Modigliani

- Figura 157: Fragmento obra cat. n4.2. Safont,

- Figura 158: Plato cerámico. Picasso.

- Figura 159: Obra cat. $n^{\circ} 4.3$. Safont.

- Figura 160: Desnudo yaciente. Henry Matisse.

- Figura 161: Obra cat. $n^{\circ} 4.8$. Safont

- Figura 162: Balaustres y cráneo, Georges Braque.

- Figura 163: Obra cat. $n^{\circ} 4.10$. Safont

- Figura 164: Viaducto en L'Estaque, Georges Braque

- Figura 165: Fragmento obra cat. $n^{\circ}$ 4.13. Safont

- Figura 166: Pájaro azul y amarillo. Braque

- Figura 167: Calvario de Espadilla (Castellón)

- Figura 168: XVa Estación Calvario de Espadilla. Vicente Aguilella

- Figura 169: Sin Título. Safont. Obra cat. n³.6

- Figura 170: Sin Título. Safont. Obra cat. nº4.4

- Figura 171: Sin Título. Safont. Obra cat. n4.36

- Figura 172: Sin Título. Safont. Obra cat. n5.10

- Figura 173: Antoni Miró, Manolo Safont, Jesús Huguet y Wences Rambla

- Figura 174: Manolo Safont y Manolo Sales 


\section{2.- BIBLIOGRAFÍA}

\subsection{1.- Bibliografía general}

- AA.VV. "Cronica-87", en Historia Gráfica de la C. Valenciana. Valencia, 1988.

- AA.VV. Catálogo Nacional de Arte Contemporáneo. Edit. Ibérico 2000. Madrid-Barcelona, 1989.

- AA.VV. Diccionario Ràfols de Artistas Contemporáneos de Cataluña y Baleares. Edicions Catalanes, S.A. Barcelona, 1989.

- AA.VV. El arte valenciano en la década de los ochenta. AVCA y Generalitat Valenciana, Valencia, 1993.

- AA.VV. Gran Enciclopedia Catalana. T. XIII, 1968.

- AA.VV. La Provincia de Castellón de la Plana. Tierras y Gentes. Castellón, CAMP, 1985.

- AA.VV. Pintura Contemporánea al País Valenciano, 1900-1979. 1977.

- AA.VV. Plástica valenciana contemporánea. Valencia, 1986.

- AdAmson, Glenn. The invention of arts. Ed. Bloomsbury, 2013.

- ANDRÉS, J. (Dirección). Quién es quién en la Comunidad Valenciana. Vicent García Editores, S.A. Valencia, 1988.

- ARLANDIS, Eduard. "La cultura en comarcas: Onda", en Turia $n^{\circ}$ 791, Valencia, 2-8 abril de 1979.

- Berenguer Palau, L. Artistas valencianos contemporáneos. Valencia, 1995.

- Blasco, Ricard. Arte y Cultura al País Valenciano. 1979.

- Bonet Correa, A. (Coordinador). Historia de las Artes Aplicadas e Industriales en España. Cátedra, Madrid, 1992.

- Calderón Gómez, J. Pasado, presente y futuro del saturnismo en la industria de la cerámica de Castellón. Castellón de la Plana, s.d.

- Campos, A. Antología de artistas castellonenses. Castellón, 1984.

- Ciricl Pellicer, Alexandre. Ceràmica actual dels Paisos Catalans. Conferencia, 1979.

- CIRICI, Alexandre / MANENT, Ramón. Ceràmica catalana. Ed. Destino, Barcelona, 1977. 
- Coll Conesa, Jaume/ Pérez CAmps, Josep. "Bibliografía Histórica de la cerámica española (1988-1983)" en Fórum Cerámico, n6, Novembre 1996, Asociación de Ceramología, Agost, 1996.

- Estall i Poles, Vicent Joan. La industria cerámica en Onda. Las fábricas, 1778-1997. Monografías del Museo del Azulejo de Onda, I. Ajuntament d'Onda, 1997.

- Estrada, D. Estética. Herder, Barcelona, 1985.

- Feliu Franch, Joan. La Arquitectura esmaltada. Cerámica arquitectónica de Onda en el S.XIX. Ajuntament d'Onda, Onda, 2001.

- Feliu franch, Joan/ Palomo Ferrer, Xavier. Finestres del Cel. Ajuntament de Vinaroç, Vinaroç, 2002.

- GAscó SIDRO, Antonio. "Pintores de Castellón. Del Neoclasicismo al Arte Contemporáneo" en Levante de Castellón, Castellón, 1996.

- Guttmann Goldberger, Beatriz. El Museo de Vilafamés: un hecho insólito", Colección Universitaria, Diputación de Castelló, Castelló, 1995.

- HierRo, J. "Un viejísimo arte joven", en Tauta n¹5, 1973.

- Layuno Rosas, María Ángeles. Richard Serra. Editorial Nerea, San Sebastián, 2001.

- Lozano Bartolozzi, Ma del M. Las claves del Arte Abstracto. Barcelona, Planeta, 1990.

- LUBAR, Robert S. La Mediterrània de Miró: concepción d'una identitat cultural. Fundació Joan Miró. Leonardo Arte, 1993.

- Mestre, Enric. "Ceràmica actual a la Comunitat Valenciana", en Exposición del Congreso Internacional de la cerámica. Museo de Cerámica González Martí, Generalitat Valenciana, Ministeri de Cultura, Valencia, 1986.

- Monrós, Guillermo/ BADENES, J. Antonio/ GARCíA, Araceli/ TENA, Ma Angeles. El color de la cerámica: Nuevos mecanismos en pigmentos para los nuevos procesados de la industria cerámica. Publicaciones de la Universitat Jaume I, Castelló, 2003.

- Monteagudo García, Encarna. Cerámica de los ochenta. 1993.

- MuÑoz, Manuel. La Pintura Contemporánea al País Valenciano 1900-1980. 1981. 
- Olucha Montins, Ferrán. "Història de l'art castellonenc: la producció bibliográfica" en Millars. Espai i Història, $\mathrm{n}^{\circ} \mathrm{XX}$, Departament d'Historia, Geografía i Art. Universitat Jaume I, Castellón, 1997.

- Olucha Montins, Ferrán. Enciclopedia Valenciana. T. VIII. Valencia, 1993.

- Pastor Moreno, Alfonso. "La cocción de los materiales cerámicos" en Tecnología de la cocción cerámica desde la antigüedad a nuestros días. Asociación de Ceramología, Agost, 1992.

- Patuel Chust, Pascual. Wences Rambla. Un itinerario plástico. Valencia, 1993.

- Peiró Coronado, F. Catálogo. Onda, 1972.

- Pellicer, A. I. De la cerámica. F.A.D, Barcelona, 1979.

- Peña, Pedro de la. Cuaderno de cerámica. Escuela Municipal de Cerámica. Onda. Ed. Magnífico Ayuntamiento de Onda. Onda.

- PÉRez CAmps, Josep. "El siglo de la cerámica valenciana: de la industria al arte", en Cerámica fin de siglo (Catálogo exposición), del 7 de marzo al 10 de mayo de 2000, Generalitat Valenciana, Valencia, 1999.

- Pérez CAmps, Josep. Historia de la cerámica española. T. IV, Valencia, 1992.

- PéReZ GuIlLÉn, Inocencio V. La pintura cerámica valenciana del SXVIII. Edicions Alfons el Magnànim. Institució Valenciana d’Estudis i Investigació. Valencia, 1991.

- Pérez Sánchez, E. Valencia. Madrid, Noguer, 1985.

- Peris Segarra, Miguel. Tenebres. 1970.

- PorCAR, Josep Lluís. "Cerámica Hábitat" en AT arquitectura técnica: revista del Consejo de Colegios Oficiales de Aparejadores y Arquitectos de la Comunidad Valenciana, ${ }^{\circ} 15$, Valencia, septiembre 1992, pp. 28-33.

- PORCAR, Josep Lluís. Ceràmica-Hàbitat: ceràmica al equipament urba, 8 ceramistes Espanyols (Catálogo exposición). Centro Eusebio Sempere de Arte y Comunicación Audiovisual, Sala Municipal d'Exposicions Lonja del Pescado d'Alacant en Alicante, del 26 de mayo al 30 de junio de 1992.

- RAdA, Pravoslav. Las técnicas de la cerámica. Editorial Libsa, Madrid, 1990. 
- Rambla ZaragozÁ, Wences. "A la meua obra" en Homenaje de artistas contemporáneos en la Cartuja de Vall de Christ, en el VI Centenario de su Fundación. Ajuntament de Sogorb, 1985.

- Rambla ZaragozÁ, Wences. "La década de los 80 en Castellón, primera revisión sobre las artes plásticas", en Estudis Castellonencs, V, Castellón, 1992-1993.

- Rambla ZaragozÁ, Wences. "Utilitarismo para embellecer: la cerámica arquitectónica" en Millars. Espai i Historia, $\mathrm{n}^{\circ} \mathrm{XXV}$, Departament d'Història, Geografía i Art, Universitat Jaume I, Castellón, 2002.

- Rambla Zaragozá, Wences. La década de los ochenta en Castellón: revisión de las artes plásticas. Instituto Valenciano Arte Moderno, Valencia, 1993.

- Rambla Zaragozá, Wences. Pintura Castellonenca dels 70 i 80 del S.XX (Catálogo exposición), Museu de Belles Arts de Castelló, Coleccions artístiques de la Diputació de Castelló, del 26 de març al 28 d'abril de 2002. Castellón, 2002.

- Rambla ZaragozÁ, Wences. Seis poéticas figurativas en la plástica de Castellón (1955-1985). Diputació de Castelló, 1990.

- Rambla Zaragozá, Wences./ Torrent, Rosalía. "El arte en el siglo XX", en Historia de Castellón. Levante de Castellón, Prensa Valenciana, S.A., Castellón, 1992

- Reglamento de la Escuela de Cerámica de Onda. Diputación Provincial. Castellón, 1926.

- Rodríguez Culebras, R. "Sobre el arte hoy en Castellón", en Anuario 1979. Castellón, Colegio de Arquitectos, Delegación de Castellón, 1979.

- Rodríguez Culebras, R. "El arte hoy en Castellón" en Anuario. Revista del Colegio de Arquitectos. Castellón, 1985.

- Safont Castelló, Manolo. "La cerámica a Onda (I)" en Penyagolosa $\mathrm{n}^{\circ} 3$, juny-juliol 1984.

- Safont Castelló, Manolo. "Presentación" en José Antonio Sorolla. Gran Format. Col.lecció Monografies d'Artistes Onders, n¹, Ajuntament d'Onda, Regidoria de Cultura, Onda, 2002.

- SÁnCHEZ PACHECO, Trinidad. "Cerámica española" en Summa Artis. Historia General del Arte, volumen XLII, Espasa-Calpe, Madrid, 1997.

- SÁnchez PACheCo, Trinidad. Cerámica española. Asociación Cultural Saloni. Barcelona, 1995. 
- Soler ferrer, Ma Paz / Pérez Camps, Josep. Historia de la Cerámica Valenciana. Tomo IV. Vicent García Editores, Valencia, 1992.

- ToRrent Escaplés, Rosalía. Cerámica Artística Actual Vila-real. Ajuntament de Vila-real, Vila-real, 1999.

- Ventura Melia. La lluita contra el foc. Generalitat Valenciana, Valencia, 1980.

- VenturI, L. Historia de la Crítica de Arte. Gustavo Gili, Barcelona, 1979.

\subsection{2.- Bibliografía específica}

- AA.VV. Ceràmica hàbitat: ceràmica a l'equipament urbà=ceramics as part of urban amenities = cerámica en el equipamiento urbano: del 26 de maig al 30 de juny de 1992, Sala Municipal d'Exposicions Lonja del Pescado, Alacant. Cerámica Hábitat. Ayuntamiento de Alicante, 1992

- AA.VV. Safont a la Pobla Tornesa. La Pobla de Tornesa, 1987.

- ANDRÉs Estellés, Vicent. Fragment sobre Manolo Safont, Catálogo exposición Safont. Sala Municipal de l'Ajuntament de Torrent, del 2 al 21 de novembre de 1980.

- ARDIT, Manuel. "Safont", en Gran Enciclopedia Valenciana. T. X, 1972.

- ARDIt, Manuel. "Memoria d'Onda", Programa Fira d'Onda 1998, Octubre 1998, Onda.

- B.W. L 'Exposition des oeuvres du céramiste espagnol Manolo Safont, vers l' avenir. 1979.

- Bellés I RoIg, Amat. "Manolo Safont, cerámicas", en Catálogo de fiestas. Saleta Municipal de Onda, 1990.

- CAstillo Puche, J. L. "La pintura al horno de Safont", en Taula $\mathrm{n}^{\circ} 50,1975$.

- Castillo Puche, J. L. "Safont", en Taula, no 15, 1973.

- Castillo Puche, J. L. Exposición de cerámicas de Safont. Madrid, Dirección General de Bellas Artes, 1962.

- Cerámica Fin de Siglo. Catálogo Exposición. Atarazanas del 25/11 de 1999 al 2/1 del 2000. Arte. Generalitat Valenciana, Valencia 1999.

- "Cerámica fin de siglo" en Actividades, Octubre-NoviembreDiciembre 1999. Generalitat Valenciana, Consellería de Cultura, Educació i Ciència. Dirección General de Promoció Cultural i Patrimoni Artistic. Valencia, 1999. 
- Codina Armengot, Eduardo. Cerámicas Safont. Sala Estilo, Castellón, 1961.

- De la Calle, Romà; Pérez Mondragón, F. Sobre el descrèdit de la modernitat. PUV, Universitat de València, Valencia, 2010.

- "Doble mostra de Wences Rambla i Manuel Safont, en el Centre Cultural Ciutat d' Alcoi, 16 de març", en La Ciutat. 1995.

- Dols Rusinyol, J. "Manolo Safont en Subex", en Destino, $\mathrm{n}^{\circ}$ 1897, Barcelona, 1974.

- Esteban, M. C.I Gallardo, M. A./ Muñoz de la Torre, M. J./ VIUDES DE CASTRO. La pintura en la cerámica, Manolo Safont pintor ceramista. Trabajo de final de curso, Valencia, Facultad de Bellas Artes, 1984.

- Estelles, Vicent Andrés. Safont, cerámicas. Biblioteca Municipal, Vila-real, 1980.

- Estelles, Vicent Andrés/ Fuster, Joan. Safont, ceràmica. Catálogo, Palau Oliver de Boteller, Tortosa, 1983.

- Exposicions Fira d'Onda 2004. Ajuntament d'Onda, Octubre 2004.

- F.D.C. Safont. Hotel Charlemagne, Brussel-Hall, 1989.

- Falomir Ventura, Carmela. "La pintura cerámica de Manolo Safont", en Butlletí d'Estudis Municipal, $2^{\mathrm{a}}$ etapa, ${ }^{\circ} 2$, Onda, 2001.

- Falomir Ventura, Carmela. Estudi de l'obra de Manolo Safont. Trabajo para el curso de doctorado de la Universidad Jaume I de Castellón, 1993.

- Ferre Pérez, Juan Bautista, Lista de fácil acceso a las fotografías de alumnos. Colonia Escolar Virgen del Carmen. S. e, Onda, S.d.

- Fuster, Joan. Manolo Safont, pintor ceramista. Círculo Mercantil e Industrial, Castellón, 1970.

- Fuster, Joan. Safont ceràmica. Palau Oliver de Boteller, del 9 al 16 de mayo de 1983, Tortosa, 1983.

- Fuster, Joan. Safont, ceràmiques. Museo Municipal de Manises, 1981.

- García Edo, Vicent. Safont, Pintura cerámica. Catálogo exposición Sala Goya, Casa de España en París, del 5 al 15 de octubre de 1978.

- García Edo, Vicent. Safont. Catálogo, Saleta Municipal de Onda. 1978. 
- Garín Llombart, Felipe./ Fuster, Joan. Safont. Valencia, Museo Nacional de Cerámica, 1980.

- Giménez de HARO, Jaime. Safont a la Pobla Tornesa: inauguració de la Casa de la Cultura (Catálogo exposición), Consellería de Cultura, Educació i Ciència, Valencia, 1987.

- Gozalbo, Daniel / MiRalles, Francesc. Safont. Catálogo, Ayuntamiento de Castellón, 1989.

- Homenatge a La Saleta. Sala Municipal d'Exposicions d'Onda. Octubre 2005. Onda.

- Huguet, Jesús. "Manolo Safont, pintor d'Onda", en Safont (Catálogo exposición). Saleta Municipal d'Onda, Regidoria de Cultura, del 24 al 31 de octubre de 1998. Onda. 1998.

- Huguet, Jesús. "Arrels d'una obra ceràmica", en Safont (Catálogo exposición). Exposición conmemorativa de la inauguración del nuevo edificio social. Caja Rural Nuestra Señora de la Esperanza de Onda. Del 23 de diciembre de 2001 al 6 de enero de 2002. Onda, 2001.

- Huguet, Jesús. Manolo Safont o l'art ajustat. Morella, 1998.

- Huguet, Jesús. Safont (Catálogo exposición). Generalitat Valenciana, Valencia, 1989.

- Huguet, Jesús. Safont. Catálogo exposición La Pobla Tornesa (Castellón), 1987.

- Jiménez de HARo, Jaime. Catálogo de la obra expuesta en la inauguración de la Casa de Cultura de La Pobla Tornesa, Castellón, 1987.

- Lengua Campillo, M. Victoria. Manolo Safont, ceramista. Trabajo para la Universidad de Valencia, Valencia, 1987.

- M. Safont, Catálogo exposición Galería Octubre, Universitat Jaume I, Castellón.

- M.V. "Manolo Safont. La lluita contra el foc", Generalitat, segona quinzena, desembre 1980.

- Manolo Safont, 11 maig-16 juny. Catálogo, Castellón, Galería Cànem, 1995.

- Menezo, Rafael./ Seva, Antonio. Fang i Pinzells (película), 1968.

- Miralles, F./ Olucha, F./ Huguet, J. Safont. Castellón, 1989.

- Miralles, Francesc. "Manuel Safont, cerámica", en Fontana d'Or. Gerona, 1983.

- Miralles, Francesc."Manuel Safont, Gerona", en Lápiz n 3, febrero, Madrid, 1983. 
- Monfort, Ramón. Safont. Catálogo exposición La Pobla Tornesa (Castellón), 1987.

- NavarRo Andreu, Enrique. Safont (Catálogo exposición). Saleta Municipal d'Onda. Regidoria de Cultura. Del 24 al 31 d'octubre de 1999. Onda, 1999.

- Nieto AlCaide, V. Manolo Safont. Ramón Durán, Madrid, 1973.

- NuRakkesm, F. Manolo Safont, cerámicas. Subex, Barcelona, 1974.

- Oltra, Joaquín. Manolo Safont, ceramista innovador y tradicional. 1970.

- Olucha Montins, Ferran. "Manolo Safont". Catálogo exposición Fontana d'Or, del 28 marzo al 16 abril, Gerona, 1983.

- Olucha Montins, Ferrán. M. Safont (Catálogo de la exposición), en Octubre-Galeria d'Art. Universitat Jaume I, Castellón, 1991.

- Olucha Montins, Ferrán. Manolo Safont. Un museu, un llegat $i$ un compromis (Catálogo exposición), Exposición Inaugural del Museu del Taulell Manolo Safont, del 27 de noviembre de 2004 al 8 de enero de 2005. Onda, 2004.

- Olucha Montins, Ferrán. Manolo Safont. Vila-real, VI Exposición Provincial de Cerámica, 1984.

- Olucha Montins, Ferrán. Manolo Safont: ceramista pintor. Morella, 1998.

- Olucha Montins, Ferrán. Safont (Catálogo exposición). Generalitat, Valencia, 1989.

- Olucha Montins, Ferrán. Safont, cerámica. Peñíscola, Castillo del Papa Luna, 1984.

- Olucha Montins, Ferrán. Safont. Saleta Municipal de Onda, Castellón, 1990.

- Olucha Montins, Ferran / GiRalt-Miracle, Daniel, Wences Rambla: olis i tècniques mixtes; Manuel Safont: Pintura ceràmica. Alcoi, Centre Cultural d'Alcoi, marzo de 1995.

- Palacios, W. "Cerámica de Manuel Safont", en Castellón-66. 1967.

- Patuel Chust, Pascual. "W. Rambla - M. Safont: dos poéticas abstractas", en Tendencias en las artes y el diseño, $\mathrm{n}^{\circ} 16$, abril de 1995, pág. 37.

- Pérez Sánchez, A. Manolo Safont, pintor ceramista. Círculo Mercantil e Industrial, Castellón, 1971. 
- PorCAR, Josep Lluís. Ceràmica-Habitat-Ceràmica a l'equipament urbà. 8 ceramistes holandesos, 8 ceramistes espanyols. Catálogo de la exposición, Castellón, 1992.

- Prades Perona, Luís. "Safont ceramista de Onda" en Programa de Fiestas de Onda, Ayuntamiento de Onda, 1966.

- Prados de la Plaza, F. "Safont", en Bellas Artes, n² 23, 1973.

- Puig, A. "Safont", en Gazeta del Arte, n² 21, 1974.

- Puig, Ximo. L 'hora de l'artista i de l'home. Morella, 1998.

- Rambla ZaragozÁ, Wences. Sobre els valors formals de l'obra de Manolo Safont. Morella, 1998.

- RAmBLA, Wenceslao / TORRENT, Rosalía. "El arte del siglo XX" en Historia de Castellón. Levante de Castellón. Editorial Prensa Valenciana, S.A., Castellón, 1992, pág. 668.

- Rambla, Wenceslao. Pintura castellonenca dels 70-80. S XX. Museu de Belles Arts de Castelló. Coleccions Artístiques de la Diputació de Castelló. Castellón, 2002.

- Romagosa, C. "Manolo Safont "treballador" de una nueva cerámica" en Cerámica Española. nº 3, 1974.

- Safont (In Brussel). Generalitat Valenciana, Valencia, 1989.

- Safont CAstelló, Manolo. Angelina Alós (Catálogo Exposición). Castellón, 1984.

- Safont Castelló, Manolo. Safont (Catálogo exposición). Ajuntament d'Onda, Onda, 1990.

- "Safont, de la tierra y del fuego", en Boletín de Información Municipal de Castellón, n7, diciembre 1989, pág. 21.

- Safont. Exposición conmemorativa de la inauguración del nuevo edificio social, Caja Rural Nuestra Sra. de la Esperanza. Onda, del 23 de diciembre de 2001 al 6 de enero de 2002.

- Safont. Saleta Municipal d'Onda, Regiduria de Cultura, del 24 al 31 de octubre de 1999, Onda.

- Sales, Belenguer. M. Safont. Saleta Municipal de Onda, 1974.

- SÁnchez PACHeCo, Trinidad. Safont. Barcelona, Museo de Cerámica, Palau Nacional Monjuit, Barcelona, 1982.

- Sandoval, A. "Safont", en Arte actual español. Santander, Universidad de Santander, Museo Municipal, 1975.

- Seva I Llinares, Antoni. Fang i pinzells, inédito, 1966.

- Signes, M. Safont, ceràmiques. Ayuntamiento de Riba-roja, 1981.

- Signes, M. Safont. Catálogo, Ramón Durán, Madrid, 1975. 
- ToRrent Escaplés, Rosalía. "Manolo Safont", en Safont (Catálogo exposición). Saleta Municipal d'Onda, Regidoria de Cultura, del 24 al 31 de octubre 1998. Onda, 1998.

- ToRrent Escaplés, Rosalía. Manolo Safont: creador d'intensitat. Morella, 1998.

- TORRent, Rosalía. "Manolo Safont". Catálogo Exposición Saleta Municipal d'Onda, Regiduria de Cultura, Ajuntament d'Onda, del 24 al 31 octubre, 1999.

- Vuegen, Christine. Safont. Hotel Charlemagne, Dezeweek in Brussel, 1989.

\subsection{3.- Artículos de prensa}

- "9 d'octubre a Morella. Raimon i Safont", en Levante Castelló. Castellón, 9 de octubre de 1998.

- Actis DATO, Raquel. "Manuel Safont, vuelve a Castellón", en Mediterráneo. Castellón, 1975.

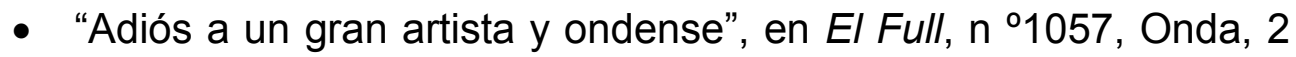
de diciembre de 2005.

- Albalat, Antoni. "Cerámicas de Manolo Safont", en Mediterráneo. Castellón, 1989.

- Albalat, Antoni. "Manolo Safont, ceramista: programe la llibertat a totes hores", en El Temps. Valencia, marzo 1992.

- Albalat, Antoni. "La intifada del fang", en Levante EL MERCANTIL VALENCIANO. 27 de noviembre de 2005, pág. 7.

- Albalat, Antoni. "Manolo Safont. La Intifada de fang" en EI Temps, 1991.

- Albalat, Antonio. "La obra más reciente del ceramista Manolo Safont”, en Mediterráneo. Castellón, 1987.

- Alós, Víctor. "El Ateneo de Onda reconoce a Safont con el Seny Onder 2002". El Mundo/ Castellón al día, 2 de marzo de 2003.

- 'Ana del Moral y Manolo Safont recibieron el 'Seny Onder' en un emotivo acto", El Full, marzo 2003.

- "Ana del Moral y Manolo Safont recibieron el Seny Onder en un emotivo acto". Anuario El Full. Febrero 2003.

- ANDRÉS, Javier. "Nombres propios", en El Periódico Mediterráneo, 30 noviembre 2000.

- “Anuario-882", en Mediterráneo. Castellón, 1988. 
- AsensI, J. "Casi cincuenta años dedicados al arte - Manolo Safont: La cerámica me apasiona por su misterio", en Mediterráneo. Castellón, 1993.

- Bellés, Salvador. "Seres humanos de Castellón. Manolo Safont: Pasión por la cerámica y el arte universal". El periódico Mediterráneo, 24 diciembre 2005.

- BoIx, I. "M. Safont: un innovador en el ámbito pictórico de la cerámica artística", en Castellón Diario, Castellón, 1982.

- Canelles I Roca, Federico. "Pels segles dels segles", el Full, $\mathrm{n}^{\circ}$ 1057, 2 diciembre 2005.

- Canelles I Roca, Federico. "Per molts anys", El Full, marzo 1998.

- CAstillo. "Un artista fuera de serie", en Ya. Madrid, 1973.

- "Cerámica de Manolo Safont en la Sala Octubre del C.U.C", en Mediterráneo. Castellón, 1991.

- "Cerámica de Safont", en Cuéntame Castellón, pág. 198.

- Chavarri AndúJar, E. L. "El nuevo Safont", en Las Provincias. Valencia, 1987.

- Chavarri Andújar, E. L. "Manolo Safont en Cànem", en Las Provincias. Valencia. 1979.

- Chavarri AndúJar, E. L. "Manolo Safont en Onda", en Las Provincias, Valencia, 1974.

- Chavarri AndúJar, E. L. "Manolo Safont, ceramista de Onda", en Las Provincias. Valencia, 1980.

- Chavarri AndúJar, E. L. "Safont", en Las Provincias. Valencia, 1979.

- Chavarri AndúJAR, E. L. "Safont: una nueva pintura en la vieja magia de la cerámica", en Las Provincias. Valencia, 1987.

- D.G./L.S. "In memoriam: Manolo Safont", El Periódico Mediterráneo, 25 de noviembre de 2005, pag 28.

- DíAZ, Marcelo. "El ceramista Manolo Safont", en Mediterráneo. Castellón, 1989.

- DOMÉNECH, Lluís. "Miradas sobre una década: Radio Luxemburgo, desde Onda", en Cuéntame Castellón, pág. 40.

- Duque, Alonso. "Manuel Safont, un artista internacional de la cerámica", en Informaciones. Madrid, 1972.

- DURÁn, Angeles. "Com serà l'edifici on estudiaran els 2.000 alumnes d'Humanes i Socials?", en Vox UJI $\mathrm{n}^{\circ} 18$, desembre 2000, pp.8-9, UJI, Castellón, 2000. 
- E.M.G. "La lonja del pescado muestra desde ayer la obra de ocho ceramistas", en ABC. Alicante, 1992.

- EBro. "Un ceramista", en La Vanguardia. Barcelona, 1980.

- Edo. "Cerámica y Muralla", en La Vanguardia. Barcelona, 1990.

- "El ceramista de Onda Manolo Safont crea un mural para Mie", en Mediterráneo. Castellón, 1994.

- "El ceramista Manolo Safont gana el premio Vicent Ventura", en Levante El Mercantíl Valenciano, 14 de abril de 2005, pág. 63.

- "El ceramista Manolo Safont gana el Premio Vicent Ventura", en Heraldo de Castellón, 14 de abril de 2005.

- "El ceramista Manolo Safont recibió un homenaje", La Rodalía, $\mathrm{n}^{\circ}$ 20, mayo 2005, pág 21.

- "El ceramista Manolo Safont, homenajeado en Onda tras la concesión del VI Premio Vicent Ventura", en El Full, n 1030, 22 de abril de 2005.

- "El ceramista Safont expone a la ciudad belga de Hasselt", en Mediterráneo. Castellón, 1989.

- "El ceramista Safont exposa a la Sala Octubre de la Universidad Jaume I", en Mediterráneo. Castellón, 1991.

- "El Consell Valencià de Cultura visitó la localidad". Crónica d'Onda. Octubre y noviembre de 2004, pág. 7.

- "El Museo del Azulejo de Onda llevará el nombre de Safont", en El Levante de Castelló, 25 de noviembre de 2000.

- "El Museo del Azulejo será inaugurado oficialmente el próximo 27 de noviembre". El Full. 19 de noviembre de 2004, Onda.

- "El Museu Manolo Safont volverá a ocupar un lugar de privilegio en CEVISAMA 2006", El Full, $\mathrm{n}^{\circ}$ 1065, 3 de febrero de 2006, Onda.

- Estall I Poles, Vicent. "Manolo Safont: Un museu, un llegat i un compromís", Crònica d'Onda, Diciembre del 2005 y enero del 2006, pág. 10.

- EUROPA PRESS, "Font de Mora lamenta la pèrdua del ceramista d'Onda Manolo Safont i destaca la seua generositat i qualitat artistica", http://es.news.yahoo,com /051125/4/4fa6k.html, 25 noviembre 2005.

- "Exposició tretze pintors castellonencs a l'Alcora. Obra propiedad del Museo de Bellas Artes de la Diputación de Castellón", en Levante. Castellón, 1994.

- "Exposición de Díaz, Bellés y Safont", Castellón Diario, 27 de julio de 1984, pág. 9. 
- "Exposición de Manolo Safont en Bruselas", en Mediterráneo. Castellón, 1989.

- FABRA, María. "El señor del santuario laico", en El País, 15 abril 2005,

http://elpais.com/diario/2005/04/15/cvalenciana/1113592712_850 215.html

- Fabra, María. "Manolo Safont el alquimista de la cerámica". El País, 25 de noviembre de 2005, pág. 57.

- Ferrer, A. "Entrevista amb Safont, ceramista", en SAO. Valencia, 1983.

- Figueroa Ferretti, L. "Cerámicas Safont", en Arriba. Madrid, 1962.

- Gall, Francesc. "Manolo Safont en Subex", en Mundo, n 1762, 1974.

- García García, M. "Las cerámicas artísticas de M. Safont", en El País.1979.

- García, Cristina "Fallece el ceramista Manolo Safont", Heraldo de Castellón, 25 de noviembre de 2005, pág. 36.

- García, M. "Cuadros cerámicos de Safont", en Estafeta Literaria. Madrid.1962.

- GASCÓ SIDRO, Antonio. "Importante muestra de Manolo Safont de Pintura Cerámica", en Castellón Diario. Castellón, 31 diciembre 1989, pág. 6.

- GASCÓ SIDRO, Antonio. "L 'altre nou d'octubre", en Levante Castelló. Castellón, 10 de octubre de 1998.

- Gascó SidRo, Antonio. "La cerámica de Safont, un grito de pasión y libertad cuajado de color", en Castellón Diario. Castellón, 1989.

- GASCÓ SIDRO, Antonio. "La libertad hecha plástica por el rito del barro y del fuego", en Castellón Diario. Castellón, 1984.

- GAscó SIDRO, Antonio. "Símbol de llibertat", en "Universitat i Cultura", Mediterráneo, Castellón, 23 de mayo de 1995.

- Gascó, Antonio. "Fallece el ceramista Manolo Safont", Levante EL MERCANTIL VALENCIANO, 25 de noviembre de 2005, pág. 71.

- Gascó, Antonio. "Importante muestra de Manolo Safont de pintura cerámica", Castellón Diario, 31 de diciembre de 1989, pág.6. 
- Gascó, Antonio. "Safont y Rambla, las dos caras de la abstracción". Levante EL MERCANTIL VALENCIANO, Posdata, marzo 1995, pág 5.

- Gaspar, M. "Safont expone en la CAAM, Cada obra mía es fruto la investigación", en La Verdad. 1980.

- Godes. "Safont en el Ateneo", en Mediterráneo. Castellón, 1967.

- Godor, M. "Bellés, Díaz y Safont, tres artistas en un gran momento", en Mediterráneo. Castellón, 1984.

- Godoy, M. "Manolo Safont recrea una inconfundible caligrafía geológica en la cerámica", en Mediterráneo. Castellón, 1987.

- Gozalbo, Daniel. "Manolo Safont, in memoriam", en El Temps, 6 decembre 2005, pág. 79.

- Hernández, Merxe. "Morella. Safont, l'elegancia estética en la ceràmica", en Mediterráneo. Castellón, 9 de diciembre de 1998.

- HeRnández, Merxe. "Safont concluye su mosaico cerámico para Vila-real", en Mediterráneo. Castellón, 1994.

- Hierro, J. "Cerámicas de Safont", en El Alcázar. Madrid, 1962.

- Hierro, J. "Safont", en Nuevo Diario. Madrid, 1973.

- "Inauguración mural de 14 m2, en el Centro Ocupacional de Vilareal", en Mediterráneo. Levante, Castellón Diario. Castellón, 1994.

- JOFRE, J. "M. Safont, el ceramista més important al País Valencia, exposició al Palacio Oliver de Boteller", en La Veu del Baix Ebre. Tortosa, 1983.

- La Cámara. Butlletí Informatiu de la Caixa Rural d'Onda. n8, septiembre 2005. Onda.

- Llorens, J. "Manolo Safont", en Castellón Diario. Castellón, 1990.

- LóPez, María José. "El poder del fuego y de la tierra, entremezclados. El ceramista Manolo Safont crea con sus manos universos de color y luz", en Castellón Diario. Castellón, 19 de agosto de 1991.

- Luque, A. "El pintor ceramista Safont", en Las Provincias. Valencia, 1989.

- LUQUe, A. "Safont expone su obra en la Universidad Jaume I", en Las Provincias. Valencia, 1991.

- M.A.C. "Exposición de Manuel Safont en el Museo Nacional de Cerámica", en Levante. Valencia, 1980.

- "Manolo Safont a la Fontana d'Or", en Punt Diari. Girona, 1983. 
- "Manolo Safont rep el premi Vicent Ventura" nota de prensa del Ayuntamiento de Onda, El Full, no 1029, 15 de abril de 2005, Onda.

- "Manolo Safont rep el premi Vicent Ventura", en El Full, n¹029, 15 abril 2005.

- "Manolo Safont y su mujer, Ana del Moral, ceden su patrimonio inmobiliario y artístico al pueblo de Onda", en El Full, Junio 2002.

- Mariner, A. "Homenaje a Safont", Arrels, n40, 25 julio 2007, pág. 29.

- Mariscal, Paco. "Safont", en El País, Quadern no 34, 2 abril 1998, pág. 4.

- Martínez, Ángel. "El Seny Onder es para Ana del Moral y Manolo Safont", en El Periódico Mediterráneo. 7 de febrero de 2003, pág. 21.

- Martínez, Ángel. "70 años de homenaje al artista de la cerámica Manolo Safont", en El Periódico Mediterráneo, 29 de marzo de 1998.

- Martínez, Ángel. "Adiós a un gran artista", en El Periódico Mediterráneo. 25 de noviembre de 2005, pág. 27.

- Martínez, Ángel. "Distinción del 'Seny Onder' de Onda. Tributo para Ana y Manolo", el Periódico Mediterráneo, 2 marzo 2003, pág. 26.

- Martínez, Ángel. "Hasta siempre, maestro", en El Periódico Mediterráneo, 26 de noviembre de 2005, pág. 27.

- Martínez, Ángel. "Tributo para Ana y Manolo", en El Periódico Mediterráneo. 2 de marzo de 2003. pág. 26.

- Matesanz, Victoria. "La exposición "Cerámica-Hàbitat" lleva el arte y la tradición a la Lonja", en Información. Alicante, 1992.

- Monjo, Joan M. "Per la Plana Baixa: Onda", en Las Provincias. Valencia, 1975.

- "Mor Manolo Safont, reconegut artista ceràmic i soci d'ACPV", http:// www. acpv, 30 de noviembre de 2005.

- "Mor Manolo Safont", Acció Cultural del País Valencià, 27 noviembre 2005.

- Morales, Merxe. "Hàbitat reúne la obra de 16 holandeses y españoles en Castellón", en Mediterráneo. Castellón, 1992.

- Muñoz, M. J. "El mundo creativo de Manolo Safont", en Levante. Valencia, 1979.

- NABAS, Ernesto. "Manolo Safont, ceramista internacional", en Las Provincias. Valencia, 1974. 
- NABAS, Ernesto. "Manolo Safont, ceramista", en Las Provincias. Valencia, 1976.

- NABAS, Ernesto. "Onda: Safont expone en su pueblo", en Las Provincias. Valencia, 1974.

- "Naranjada" en El Periódico Mediterráneo, 25 de noviembre de 2000.

- "Naranjada" en El Periódico Mediterráneo, 29 de marzo de 1998.

- Navarro Andreu, Enrique. "Manolo Safont, un projecte, un poble", El Full, nº1057, 2 diciembre 2005.

- "Onda celebra el Día de los Museos con una exposición infantil sobre la obra de Safont", El Full, n 1080, 26 mayo 2006

- "Onda conocerá la obra completa de Manolo Safont en una exposición”. Crónica d'Onda. Octubre y noviembre de 2004, pág. 12.

- "Onda dice adiós a Manolo Safont", en El País, 26 de noviembre de 2005.

- "Onda dio el último adiós al genial Manolo Safont", en Crónica d'Onda, diciembre del 2005 y enero del 2006, pág 9.

- "Onda se rinde al genial arte de Manolo Safont", en Crónica d'Onda, mayo y junio de 2005, pág. 13.

- Ortega, L. "Fallece el célebre artista de Onda Manolo Safont", en Las Provincias, 25 de noviembre de 2005, pág.12.

- Panadero, Amparo. "Manuel Safont, tiempo de libertad donde estalla la forma y el color", en Mediterráneo. Castellón, 1987.

- Panadero, Amparo. "Mural en el Gobern Civil, esta obra es la exposición de libertades, de la forma y del color", en Mediterráneo. Castellón, 1987.

- Panadero, Amparo. "Safont, de la tierra: del fuego", en Boletín de Información Municipal. Castellón, 1989.

- Panadero, Amparo. "Seixanta anys de Safont", en Festa $i$ Cultura. Morella, agosto de 1998.

- PANAdero, Amparo. "Tots els colors del roig", en El País. Madrid, 10 de octubre de 1998.

- Panadero, Amparo. "Arte". El Periódico Mediterráneo, 5 de enero de 2003.

- Panadero, Amparo. "Carta a Niurka", en El Periódico Mediterráneo, 5 de enero de 2003.

- Panadero, Amparo. "Seny Onder", en El Periódico Mediterráneo. 2 de marzo de 2003. 
- Pascual, Francisco. "Ahir i avui, xicotetes notes", en Mediterráneo. Castellón, 11 de octubre de 1998.

- Pascual, Francisco. "Manolo Safont, un artista comprometido con su tiempo", en Mediterráneo. Castellón, 1977.

- PAstor IBÁÑEZ, Vicenta. "La pintura cerámica de Safont", en La Verdad. 1980.

- Pradas, Antonio. "El santuario de Manolo Safont", en Mediterráneo. Castellón, 1994.

- PResentación, Diego. "Nueva exposición de Manolo Safont", en Mediterráneo. Castellón, 1973.

- Puerto, Gonzalo. "Manolo Safont en Vila-real", en Mediterráneo. Castellón, 1980.

- Puig, Lluís. "Morella. Actuació de Raimon i exposició de Safont", en Levante Castelló, 8 de octubre de 1998.

- Puig, Ximo. "Tots els colors del roig. A Manolo Safont, una ànima lliure”, en El Periódico Mediterráneo, 26 noviembre 2005, pág. 27.

- Quique. Viñeta Humor Gráfico. El Periódico Mediterráneo, 1 de marzo de 2003.

- R.C. "Manolo Safont. Onda despide al reconocido artista", en Levante EL MERCANTIL VALENCIANO, 26 noviembre 2005, pág. 57.

- Regalado, Emilio. "Onda gestionará la amplia obra del ceramista Safont tras la cesión del patrimonio del artista", en El Periódico Mediterráneo, 27 de junio de 2002.

- Riubal, Alvaro. "Los pueblos cerámicos, noticias de Onda", en La Vanguardia. 1977.

- Rodríguez, Carlos "Enrique Navarro destaca que Safont Ha sido el mejor artista que hemos tenido", en Levante EL MERCANTIL VALENCIANO, 25 de noviembre de 2005, pág. 72.

- Rodríguez, Carlos "Manolo Safont. Onda despide al reconocido artista", en Levante EL MERCANTIL VALENCIANO, 26 de noviembre de 2005, pág. 57.

- Rodríguez, Carlos. "Fallece Manolo Safont", en Levante EL MERCANTIL VALENCIANO, 25 noviembre 2005, pág. 72.

- Rodríguez, Carlos. "Onda despide emocionada a Safont", en Levante EL MERCANTIL VALENCIANO, 26 noviembre 2005, pág. 55.

- Rodríguez, Carlos. "Safont transforma en un idílico edén su mansión de Onda”, en La Rodalía, juliol 2004, pág. 20. 
- Rodríguez, Conxa. "Las cerámicas de Manuel Safont", en El País, Artes no 158, 20 de noviembre de 1982, pág. 4.

- "Safont concluye su mosaico cerámico en Vila-real" en Mediterráneo, 1 de febrero de 1994, pág. 7.

- Sánchez Camargo, M. "Safont", en Pueblo. Madrid, 1962.

- Silvestre, Jacobo "Onda rinde tributos al ceramista Manolo Safont”, en El Mundo. Castellón al día, 18 de abril de 2005.

- Soler, Joan. "Safont", en Levante Castelló. Castellón, 1998.

- Sopeña IBáÑEz, Federico. "Onda: Arte y Artesanía", en Ya, Madrid.1971.

- "Una exposición de Manolo Safont inaugurada en la "diada" del Mediterrani", Levante Castelló. Castellón, 10 de octubre de 1998.

- "Unieke Keramische kunst van "Manolo Safont" uit spanje te opheylissen". Hier tienen. 1979.

- "Unieke Keramische kunst van "Manolo Safont" uit spanje-publipers-donderdag". 1979.

- "Universitat i Cultura", en Mediterráneo. Castellón, 16 de mayo de 1995.

\subsection{4.- Bibliografía cronológica}

\section{1}

- Codina Armengot, Eduardo. Cerámicas Safont. Sala Estilo, Castellón, 1961.

\section{2}

- Castillo Puche, J. L. Exposición de cerámicas de Safont. Madrid, Dirección General de Bellas Artes, 1962.

- Figueroa Ferretti, L. "Cerámicas Safont", en Arriba. Madrid, 1962.

- García, M. "Cuadros cerámicos de Safont", en Estafeta Literaria. Madrid.1962.

- Hierro, J. "Cerámicas de Safont", en El Alcázar. Madrid, 1962.

- Sánchez Camargo, M. "Safont", en Pueblo. Madrid, 1962.

1966

- Prades Perona, Luís. "Safont ceramista de Onda" en Programa de Fiestas de Onda, Ayuntamiento de Onda, 1966.

- Seva I Llinares, Antoni. Fang i pinzells, inédito, 1966. 
1967

- Godes. "Safont en el Ateneo", en Mediterráneo. Castellón, 1967.

- Palacios, W. "Cerámica de Manuel Safont", en Castellón-66. 1967.

1968

- Menezo, Rafael./ Seva, Antonio. Fang i Pinzells (película), 1968.

1970

- Fuster, Joan. Manolo Safont, pintor ceramista. Círculo Mercantil e Industrial, Castellón, 1970.

- Oltra, Joaquín. Manolo Safont, ceramista innovador y tradicional. 1970

1971

- Pérez SÁnchez, A. Manolo Safont, pintor ceramista. Círculo Mercantil e Industrial, Castellón, 1971.

- Sopeña IBÁÑEZ, Federico. "Onda: Arte y Artesanía", en Ya, Madrid.1971.

1972

- ARDIT, Manuel. "Safont", en Gran Enciclopedia Valenciana. T. X, 1972.

- Duque, Alonso. "Manuel Safont, un artista internacional de la cerámica", en Informaciones. Madrid, 1972.

1973

- CAstillo. "Un artista fuera de serie", en Ya. Madrid, 1973.

- CAstillo Puche, J. L. "Safont", en Taula, nº 15, 1973.

- Hierro, J. "Safont", en Nuevo Diario. Madrid, 1973.

- Nieto Alcaide, V. Manolo Safont. Ramón Durán, Madrid, 1973.

- Prados de la Plaza, F. "Safont", en Bellas Artes, n² 23, 1973.

- Presentación, Diego. "Nueva exposición de Manolo Safont", en Mediterráneo. Castellón, 1973.

1974

- Chavarri Andújar, E. L. "Manolo Safont en Onda", en Las Provincias, Valencia, 1974.

- Dols Rusinyol, J. "Manolo Safont en Subex", en Destino, $\mathrm{n}^{\circ}$ 1897, Barcelona, 1974.

- Galı, Francesc. "Manolo Safont en Subex", en Mundo, n 1762, 1974. 
- NABAS, Ernesto. "Manolo Safont, ceramista internacional", en Las Provincias. Valencia, 1974.

- NABAS, Ernesto. "Onda: Safont expone en su pueblo", en Las Provincias. Valencia, 1974.

- NuRakkesm, F. Manolo Safont, cerámicas. Subex, Barcelona, 1974.

- Puig, A. "Safont", en Gazeta del Arte, nº 21, 1974.

- Romagosa, C. "Manolo Safont "treballador" de una nueva cerámica" en Cerámica Española. nº 3, 1974.

- SAles, Belenguer. M. Safont. Saleta Municipal de Onda, 1974.

1975

- Actis dato, Raquel. "Manuel Safont, vuelve a Castellón", en Mediterráneo. Castellón, 1975.

- CAstillo Puche, J. L. "La pintura al horno de Safont", en Taula $\mathrm{n}^{\circ}$ 50, 1975.

- Monjo, Joan M. "Per la Plana Baixa: Onda", en Las Provincias. Valencia, 1975.

- Sandoval, A. "Safont", en Arte actual español. Santander, Universidad de Santander, Museo Municipal, 1975.

- Signes, M. Safont. Catálogo, Ramón Durán, Madrid, 1975.

1976

- NABAS, Ernesto. "Manolo Safont, ceramista", en Las Provincias. Valencia, 1976.

1977

- Pascual, Francisco. "Manolo Safont, un artista comprometido con su tiempo", en Mediterráneo. Castellón, 1977.

- RiubaL, Alvaro. "Los pueblos cerámicos, noticias de Onda", en La Vanguardia. 1977.

1978

- García Edo, Vicent. Safont, Pintura cerámica. Catálogo exposición Sala Goya, Casa de España en París, del 5 al 15 de octubre de 1978.

- García Edo, Vicent. Safont. Catálogo, Saleta Municipal de Onda. 1978.

1979

- B.W. L 'Exposition des oeuvres du céramiste espagnol Manolo Safont, vers l' avenir. 1979. 
- Chavarri Andújar, E. L. "Manolo Safont en Cànem", en Las Provincias. Valencia. 1979.

- Chavarri AndúJar, E. L. "Safont", en Las Provincias. Valencia, 1979.

- García García, M. "Las cerámicas artísticas de M. Safont", en El País.1979.

- Muñoz, M. J. "El mundo creativo de Manolo Safont", en Levante. Valencia, 1979.

- "Unieke Keramische kunst van "Manolo Safont" uit spanje te opheylissen". Hier tienen. 1979.

\section{0}

- ANDRÉS Estellés, Vicent. Fragment sobre Manolo Safont, Catálogo exposición Safont. Sala Municipal de l'Ajuntament de Torrent, del 2 al 21 de novembre de 1980.

- Chavarri AndúJar, E. L. "Manolo Safont, ceramista de Onda", en Las Provincias. Valencia, 1980.

- EBro. "Un ceramista", en La Vanguardia. Barcelona, 1980.

- Estelles, Vicent Andrés. Safont, cerámicas. Biblioteca Municipal, Vila-real, 1980.

- Garín Llombart, Felipe./ Fuster, Joan. Safont. Valencia, Museo Nacional de Cerámica, 1980.

- Gaspar, M. "Safont expone en la CAAM, Cada obra mía es fruto la investigación", en La Verdad. 1980.

- M.A.C. "Exposición de Manuel Safont en el Museo Nacional de Cerámica", en Levante. Valencia, 1980.

- M.V. "Manolo Safont. La lluita contra el foc", Generalitat, segona quinzena, desembre 1980.

- PAstor IbáÑEz, Vicenta. "La pintura cerámica de Safont", en La Verdad. 1980.

- Puerto, Gonzalo. "Manolo Safont en Vila-real", en Mediterráneo. Castellón, 1980.

\section{1}

- Fuster, Joan. Safont, ceràmiques. Museo Municipal de Manises, 1981.

- Signes, M. Safont, ceràmiques. Ayuntamiento de Riba-roja, 1981.

\section{2}

- BoIX, I. "M. Safont: un innovador en el ámbito pictórico de la cerámica artística", en Castellón Diario, Castellón, 1982. 
- Rodríguez, Conxa. "Las cerámicas de Manuel Safont", en El País, Artes no 158, 20 de noviembre de 1982, pág. 4.

- SÁnchez PACHeCo, Trinidad. Safont. Barcelona, Museo de Cerámica, Palau Nacional Monjuit, Barcelona, 1982.

\section{3}

- AndRes Estelles, Vicent / Fuster, Joan. Safont, ceràmica. Catálogo, Palau Oliver de Boteller, Tortosa, 1983.

- Ferrer, A. "Entrevista amb Safont, ceramista", en SAO. Valencia, 1983.

- Fuster, Joan. Safont ceràmica. Palau Oliver de Boteller, del 9 al 16 de mayo de 1983, Tortosa, 1983.

- Jofre, J. "M. Safont, el ceramista més important al País Valencia, exposició al Palacio Oliver de Boteller", en La Veu del Baix Ebre. Tortosa, 1983.

- "Manolo Safont a la Fontana d'Or", en Punt Diari. Girona, 1983.

- MiRalles, Francesc. "Manuel Safont, cerámica", en Fontana d'Or. Gerona, 1983.

- Miralles, Francesc."Manuel Safont, Gerona", en Lápiz n 3, febrero, Madrid, 1983.

- Olucha Montins, Ferran. "Manolo Safont". Catálogo exposición Fontana d'Or, del 28 marzo al 16 abril, Gerona, 1983.

\section{4}

- Esteban, M. C./ Gallardo, M. A./ Muñoz de la Torre, M. J./ VIUDES DE CASTRO. La pintura en la cerámica, Manolo Safont pintor ceramista. Trabajo de final de curso, Valencia, Facultad de Bellas Artes, 1984.

- "Exposición de Díaz, Bellés y Safont", Castellón Diario, 27 de julio de 1984, pág. 9.

- GASCÓ SIDRO, Antonio. "La libertad hecha plástica por el rito del barro y del fuego", en Castellón Diario. Castellón, 1984.

- Godoy, M. "Bellés, Díaz y Safont, tres artistas en un gran momento", en Mediterráneo. Castellón, 1984.

- Olucha Montins, Ferrán. Manolo Safont. Vila-real, VI Exposición Provincial de Cerámica, 1984.

- Olucha Montins, Ferrán. Safont, cerámica. Peñíscola, Castillo del Papa Luna, 1984.

- Safont CAstelló, Manolo. Angelina Alós (Catálogo Exposición). Castellón, 1984. 
- AA.VV. Safont a la Pobla Tornesa. La Pobla de Tornesa, 1987.

- Albalat, Antonio. "La obra más reciente del ceramista Manolo Safont", en Mediterráneo. Castellón, 1987.

- Chavarri AndúJar, E. L. "El nuevo Safont", en Las Provincias. Valencia, 1987.

- ChavarRi AndúJAR, E. L. "Safont: una nueva pintura en la vieja magia de la cerámica", en Las Provincias. Valencia, 1987.

- Godor, M. "Manolo Safont recrea una inconfundible caligrafía geológica en la cerámica", en Mediterráneo. Castellón, 1987.

- Huguet, Jesús. Safont. Catálogo exposición La Pobla Tornesa (Castellón), 1987.

- Jiménez de HARO, Jaime. Catálogo de la obra expuesta en la inauguración de la Casa de Cultura de La Pobla Tornesa, Castellón, 1987.

- Lengua Campillo, M. Victoria. Manolo Safont, ceramista. Trabajo para la Universidad de Valencia, Valencia, 1987.

- Monfort, Ramón. Safont. Catálogo exposición La Pobla Tornesa (Castellón), 1987.

- Panadero, Amparo. "Manuel Safont, tiempo de libertad donde estalla la forma y el color", en Mediterráneo. Castellón, 1987.

- Panadero, Amparo. "Mural en el Gobern Civil, esta obra es la exposición de libertades, de la forma y del color", en Mediterráneo. Castellón, 1987.

\section{8}

- “Anuario-882”, en Mediterráneo. Castellón, 1988.

\section{9}

- Albalat, Antoni. "Cerámicas de Manolo Safont", en Mediterráneo. Castellón, 1989.

- DíAZ, Marcelo. "El ceramista Manolo Safont", en Mediterráneo. Castellón, 1989.

- "El ceramista Safont expone a la ciudad belga de Hasselt", en Mediterráneo. Castellón, 1989.

- "Exposición de Manolo Safont en Bruselas", en Mediterráneo. Castellón, 1989.

- F.D.C. Safont. Hotel Charlemagne, Brussel-Hall, 1989. 
- Gascó Sidro, Antonio. "La cerámica de Safont, un grito de pasión y libertad cuajado de color", en Castellón Diario. Castellón, 1989.

- GASCÓ SIDRO, Antonio. "Importante muestra de Manolo Safont de Pintura Cerámica", en Castellón Diario. Castellón, 31 diciembre 1989, pág. 6.

- Gascó, Antonio. "Importante muestra de Manolo Safont de pintura cerámica", Castellón Diario, 31 de diciembre de 1989, pág.6.

- Gozalbo, Daniel / MiRalles, Francesc. Safont. Catálogo, Ayuntamiento de Castellón, 1989.

- Huguet, Jesús. Safont (Catálogo exposición). Generalitat Valenciana, Valencia, 1989.

- Luque, A. "El pintor ceramista Safont", en Las Provincias. Valencia, 1989.

- Miralles, F./ Olucha, F./ Huguet, J. Safont. Castellón, 1989.

- Olucha Montins, Ferrán. Safont (Catálogo exposición). Generalitat, Valencia, 1989.

- PanAdero, Amparo. "Safont, de la tierra: del fuego", en Boletín de Información Municipal. Castellón, 1989.

- Safont (In Brussel). Generalitat Valenciana, Valencia, 1989.

- "Safont, de la tierra y del fuego", en Boletín de Información Municipal de Castellón, n7, diciembre 1989, pág. 21.

- Vuegen, Christine. Safont. Hotel Charlemagne, Dezeweek in Brussel, 1989.

1990

- Bellés I RoIg, Amat. "Manolo Safont, cerámicas", en Catálogo de fiestas. Saleta Municipal de Onda, 1990.

- Edo. "Cerámica y Muralla", en La Vanguardia. Barcelona, 1990.

- LlORENS, J. "Manolo Safont", en Castellón Diario. Castellón, 1990.

- Olucha Montins, Ferrán. Safont. Saleta Municipal de Onda, Castellón, 1990.

- Safont Castelló, Manolo. Safont (Catálogo exposición). Ajuntament d'Onda, Onda, 1990.

1991

- Albalat, Antoni. "Manolo Safont. La Intifada de fang" en El Temps, 1991. 
- "Cerámica de Manolo Safont en la Sala Octubre del C.U.C", en Mediterráneo. Castellón, 1991.

- "El ceramista Safont exposa a la Sala Octubre de la Universidad Jaume I", en Mediterráneo. Castellón, 1991.

- LóPEZ, María José. "El poder del fuego y de la tierra, entremezclados. El ceramista Manolo Safont crea con sus manos universos de color y luz", en Castellón Diario. Castellón, 19 de agosto de 1991.

- LUqUe, A. "Safont expone su obra en la Universidad Jaume I", en Las Provincias. Valencia, 1991.

- Olucha Montins, Ferrán. M. Safont (Catálogo de la exposición), en Octubre-Galeria d'Art. Universitat Jaume I, Castellón, 1991.

1992

- AA.VV. Ceràmica hàbitat: ceràmica a l'equipament urbà=ceramics as part of urban amenities = cerámica en el equipamiento urbano: del 26 de maig al 30 de juny de 1992, Sala Municipal d'Exposicions Lonja del Pescado, Alacant. Cerámica Hábitat. Ayuntamiento de Alicante, 1992.

- Albalat, Antoni. "Manolo Safont, ceramista: programe la llibertat a totes hores", en El Temps. Valencia, marzo 1992.

- E.M.G. "La lonja del pescado muestra desde ayer la obra de ocho ceramistas", en ABC. Alicante, 1992.

- MAtesanz, Victoria. "La exposición "Cerámica-Hàbitat" lleva el arte y la tradición a la Lonja", en Información. Alicante, 1992.

- Morales, Merxe. "Hàbitat reúne la obra de 16 holandeses y españoles en Castellón", en Mediterráneo. Castellón, 1992.

- Porcar, Josep Lluís. Ceràmica-Habitat-Ceràmica a l'equipament urbà. 8 ceramistes holandesos, 8 ceramistes espanyols. Catálogo de la exposición, Castellón, 1992.

1993

- AsEnsI, J. "Casi cincuenta años dedicados al arte - Manolo Safont: La cerámica me apasiona por su misterio", en Mediterráneo. Castellón, 1993.

- Falomir Ventura, Carmela. Estudi de l'obra de Manolo Safont. Trabajo para el curso de doctorado de la Universidad Jaume I de Castellón, 1993.

\section{4}

- "El ceramista de Onda Manolo Safont crea un mural para Mie", en Mediterráneo. Castellón, 1994. 
- "Exposició tretze pintors castellonencs a l'Alcora. Obra propiedad del Museo de Bellas Artes de la Diputación de Castellón", en Levante. Castellón, 1994.

- HeRnÁndez, Merxe. "Safont concluye su mosaico cerámico para Vila-real", en Mediterráneo. Castellón, 1994.

- "Inauguración mural de $14 \mathrm{~m} 2$, en el Centro Ocupacional de Vilareal", en Mediterráneo. Levante, Castellón Diario. Castellón, 1994.

- Mariscal, Paco. "Safont", en El País, Quadern no 34, 2 abril 1998, pág. 4.

- Pradas, Antonio. "El santuario de Manolo Safont", en Mediterráneo. Castellón, 1994.

- "Safont concluye su mosaico cerámico en Vila-real" en Mediterráneo, 1 de febrero de 1994, pág. 7.

\section{5}

- "Doble mostra de Wences Rambla i Manuel Safont, en el Centre Cultural Ciutat d' Alcoi, 16 de març", en La Ciutat. 1995.

- Gascó, Antonio. "Safont y Rambla, las dos caras de la abstracción". Levante EL MERCANTIL VALENCIANO, Posdata, marzo 1995, pág 5.

- GAScó SIDRO, Antonio. "Símbol de llibertat", en "Universitat i Cultura", Mediterráneo, Castellón, 23 de mayo de 1995.

- Manolo Safont, 11 maig-16 juny. Catálogo, Castellón, Galería Cànem, 1995.

- Olucha Montins, Ferran / GiRalt-Miracle, Daniel, Wences Rambla: olis i tècniques mixtes; Manuel Safont: Pintura ceràmica. Alcoi, Centre Cultural d'Alcoi, marzo de 1995.

- Patuel Chust, Pascual. "W. Rambla - M. Safont: dos poéticas abstractas", en Tendencias en las artes y el diseño, $\mathrm{n}^{\circ} 16$, abril de 1995, pág. 37.

- "Universitat i Cultura", en Mediterráneo. Castellón, 16 de mayo de 1995.

1998

- ARDIT, Manuel. "Memoria d'Onda", Programa Fira d'Onda 1998, Octubre 1998, Onda.

- Canelles I Roca, Federico. "Per molts anys", El Full, marzo 1998.

- Gascó SidRo, Antonio. "L 'altre nou d'octubre", en Levante Castelló. Castellón, 10 de octubre de 1998. 
- Hernández, Merxe. "Morella. Safont, l'elegancia estética en la ceràmica", en Mediterráneo. Castellón, 9 de diciembre de 1998.

- Huguet, Jesús. "Manolo Safont, pintor d'Onda", en Safont (Catálogo exposición). Saleta Municipal d'Onda, Regidoria de Cultura, del 24 al 31 de octubre de 1998. Onda. 1998.

- Huguet, Jesús. Manolo Safont o l'art ajustat. Morella, 1998.

- Martínez, Ángel. "70 años de homenaje al artista de la cerámica Manolo Safont", en El Periódico Mediterráneo, 29 de marzo de 1998.

- "Naranjada" en El Periódico Mediterráneo, 29 de marzo de 1998.

- Olucha Montins, Ferrán. Manolo Safont: ceramista pintor. Morella, 1998.

- Panadero, Amparo. "Seixanta anys de Safont", en Festa $i$ Cultura. Morella, agosto de 1998.

- PanAdero, Amparo. "Tots els colors del roig", en El País. Madrid, 10 de octubre de 1998.

- Pascual, Francisco. "Ahir i avui, xicotetes notes", en Mediterráneo. Castellón, 11 de octubre de 1998.

- PuIG, Lluís. "Morella. Actuació de Raimon i exposició de Safont", en Levante Castelló, 8 de octubre de 1998.

- Puig, Ximo. L 'hora de l'artista i de l'home. Morella, 1998.

- RAmbla ZaragozÁ, Wences. Sobre els valors formals de l'obra de Manolo Safont. Morella, 1998.

- RAmbLA, Wenceslao / TORRENT, Rosalía. "El arte del siglo XX" en Historia de Castellón. Levante de Castellón. Editorial Prensa Valenciana, S.A., Castellón, 1992, pág. 668.

- Rambla, Wenceslao. Pintura castellonenca dels 70-80. S XX. Museu de Belles Arts de Castelló. Coleccions Artístiques de la Diputació de Castelló. Castellón, 2002.

- Soler, Joan. "Safont", en Levante Castelló. Castellón, 1998.

- ToRrent EscaplÉs, Rosalía. "Manolo Safont", en Safont (Catálogo exposición). Saleta Municipal d'Onda, Regidoria de Cultura, del 24 al 31 de octubre 1998. Onda, 1998.

- ToRrent EscaplÉs, Rosalía. Manolo Safont: creador d'intensitat. Morella, 1998.

- "Una exposición de Manolo Safont inaugurada en la "diada" del Mediterrani", Levante Castelló. Castellón, 10 de octubre de 1998. 
- "9 d'octubre a Morella. Raimon i Safont", en Levante Castelló. Castellón, 9 de octubre de 1998.

\section{9}

- Cerámica Fin de Siglo. Catálogo Exposición. Atarazanas del 25/11 de 1999 al 2/1 del 2000. Arte. Generalitat Valenciana, Valencia 1999.

- Navarro Andreu, Enrique. Safont (Catálogo exposición). Saleta Municipal d'Onda. Regidoria de Cultura. Del 24 al 31 d'octubre de 1999. Onda, 1999.

- Safont. Saleta Municipal d'Onda, Regiduria de Cultura, del 24 al 31 de octubre de 1999, Onda.

- TORRENT, Rosalía. "Manolo Safont". Catálogo Exposición Saleta Municipal d'Onda, Regiduria de Cultura, Ajuntament d'Onda, del 24 al 31 octubre, 1999.

\section{0}

- ANDRÉs, Javier. "Nombres propios", en El Periódico Mediterráneo, 30 noviembre 2000.

- DuRÁN, Angeles. "Com serà l'edifici on estudiaran els 2.000 alumnes d'Humanes i Socials?", en Vox UJI n¹8, desembre 2000, pp.8-9, UJI, Castellón, 2000.

- "El Museo del Azulejo de Onda llevará el nombre de Safont", en El Levante de Castelló, 25 de noviembre de 2000.

- "Naranjada" en El Periódico Mediterráneo, 25 de noviembre de 2000.

2001

- Falomir Ventura, Carmela. "La pintura cerámica de Manolo Safont", en Butlletí d'Estudis Municipal, 2a etapa, n², Onda, 2001.

- Huguet, Jesús. "Arrels d'una obra ceràmica", en Safont (Catálogo exposición). Exposición conmemorativa de la inauguración del nuevo edificio social. Caja Rural Nuestra Señora de la Esperanza de Onda. Del 23 de diciembre de 2001 al 6 de enero de 2002. Onda, 2001.

\section{2}

- "Manolo Safont y su mujer, Ana del Moral, ceden su patrimonio inmobiliario y artístico al pueblo de Onda”, en El Full, Junio 2002.

- Regalado, Emilio. "Onda gestionará la amplia obra del ceramista Safont tras la cesión del patrimonio del artista", en El Periódico Mediterráneo, 27 de junio de 2002. 
- Safont. Exposición conmemorativa de la inauguración del nuevo edificio social, Caja Rural Nuestra Sra. de la Esperanza. Onda, del 23 de diciembre de 2001 al 6 de enero de 2002.

2003

- Alós, Víctor. "El Ateneo de Onda reconoce a Safont con el Seny Onder 2002". El Mundo/ Castellón al día, 2 de marzo de 2003.

- "Ana del Moral y Manolo Safont recibieron el Seny Onder en un emotivo acto". Anuario El Full. Febrero 2003.

- 'Ana del Moral y Manolo Safont recibieron el 'Seny Onder' en un emotivo acto", El Full, marzo 2003.

- Martínez, Ángel. "El Seny Onder es para Ana del Moral y Manolo Safont", en El Periódico Mediterráneo. 7 de febrero de 2003, pág. 21.

- Martínez, Ángel. "Distinción del 'Seny Onder' de Onda. Tributo para Ana y Manolo", el Periódico Mediterráneo, 2 marzo 2003, pág. 26.

- Martínez, Ángel. "Tributo para Ana y Manolo", en El Periódico Mediterráneo. 2 de marzo de 2003. pág. 26.

- Panadero, Amparo. "Arte". El Periódico Mediterráneo, 5 de enero de 2003.

- Panadero, Amparo. "Carta a Niurka", en El Periódico Mediterráneo, 5 de enero de 2003.

- Panadero, Amparo. "Seny Onder", en El Periódico Mediterráneo. 2 de marzo de 2003.

- Quique. Viñeta Humor Gráfico. El Periódico Mediterráneo, 1 de marzo de 2003.

\section{4}

- "El Consell Valencià de Cultura visitó la localidad". Crónica d'Onda. Octubre y noviembre de 2004, pág. 7.

- "El Museo del Azulejo será inaugurado oficialmente el próximo 27 de noviembre". El Full. 19 de noviembre de 2004, Onda.

- Exposicions Fira d'Onda 2004. Ajuntament d'Onda, Octubre 2004.

- Olucha Montins, Ferrán. Manolo Safont. Un museu, un llegat $i$ un compromis (Catálogo exposición), Exposición Inaugural del Museu del Taulell Manolo Safont, del 27 de noviembre de 2004 al 8 de enero de 2005. Onda, 2004.

- "Onda conocerá la obra completa de Manolo Safont en una exposición". Crónica d’Onda. Octubre y noviembre de 2004, pág. 12. 
- Rodríguez, Carlos. "Safont transforma en un idílico edén su mansión de Onda", en La Rodalía, juliol 2004, pág. 20.

\section{5}

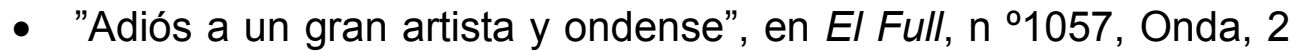
de diciembre de 2005.

- Albalat, Antoni. "La intifada del fang", en Levante EL MERCANTIL VALENCIANO. 27 de noviembre de 2005, pág. 7.

- BELlÉs, Salvador. "Seres humanos de Castellón. Manolo Safont: Pasión por la cerámica y el arte universal". El periódico Mediterráneo, 24 diciembre 2005.

- Canelles I Roca, Federico. "Pels segles dels segles", El Full, n¹057, 2 diciembre 2005.

- D.G./L.S. "In memoriam: Manolo Safont", El Periódico Mediterráneo, 25 de noviembre de 2005, pag 28.

- "El ceramista Manolo Safont gana el premio Vicent Ventura", en Levante El Mercantíl Valenciano, 14 de abril de 2005, pág. 63.

- "El ceramista Manolo Safont gana el Premio Vicent Ventura", en Heraldo de Castellón, 14 de abril de 2005.

- "El ceramista Manolo Safont, homenajeado en Onda tras la concesión del VI Premio Vicent Ventura”, en El Full, nº 1030, 22 de abril de 2005.

- "El ceramista Manolo Safont recibió un homenaje", La Rodalía, nº 20, mayo 2005, pág 21.

- EuRopa PRESS, "Font de Mora lamenta la pèrdua del ceramista d'Onda Manolo Safont i destaca la seua generositat i qualitat artistica", http://es.news.yahoo,com /051125/4/4fa6k.html, 25 noviembre 2005.

- Fabra, María. "El señor del santuario laico", en El País, 15 abril 2005 , http://elpais.com/diario/2005/04/15/cvalenciana/1113592712_850 215.html

- FABra, María. "Manolo Safont el alquimista de la cerámica". El País, 25 de noviembre de 2005, pág. 57.

- García, Cristina "Fallece el ceramista Manolo Safont", Heraldo de Castellón, 25 de noviembre de 2005, pág. 36.

- Gascó, Antonio. "Fallece el ceramista Manolo Safont", Levante EL MERCANTIL VALENCIANO, 25 de noviembre de 2005, pág. 71.

- Gozalbo, Daniel. "Manolo Safont, in memoriam", en El Temps, 6 decembre 2005, pág. 79. 
- La Cámara. Butlletí Informatiu de la Caixa Rural d'Onda. n8, septiembre 2005. Onda.

- "Manolo Safont rep el premi Vicent Ventura" nota de prensa del Ayuntamiento de Onda, El Full, no 1029, 15 de abril de 2005, Onda.

- "Manolo Safont rep el premi Vicent Ventura", en El Full, n¹029, 15 abril 2005.

- Martínez, Ángel. "Adiós a un gran artista", en El Periódico Mediterráneo. 25 de noviembre de 2005, pág. 27.

- Martínez, Ángel. "Hasta siempre, maestro", en El Periódico Mediterráneo, 26 de noviembre de 2005, pág. 27.

- "Mor Manolo Safont, reconegut artista ceràmic i soci d'ACPV", http:// www. acpv, 30 de noviembre de 2005.

- "Mor Manolo Safont", Acció Cultural del País Valencià, 27 noviembre 2005.

- Navarro Andreu, Enrique. "Manolo Safont, un projecte, un poble", El Full, nº1057, 2 diciembre 2005.

- "Onda se rinde al genial arte de Manolo Safont", en Crónica d’Onda, mayo y junio de 2005, pág. 13.

- "Onda dice adiós a Manolo Safont", en El País, 26 de noviembre de 2005.

- Ortega, L. "Fallece el célebre artista de Onda Manolo Safont", en Las Provincias, 25 de noviembre de 2005, pág. 12.

- PUIG, Ximo. "Tots els colors del roig. A Manolo Safont, una ànima lliure", en El Periódico Mediterráneo, 26 noviembre 2005, pág. 27.

- R.C. "Manolo Safont. Onda despide al reconocido artista", en Levante EL MERCANTIL VALENCIANO, 26 noviembre 2005, pág. 57.

- Rodríguez, Carlos "Enrique Navarro destaca que Safont Ha sido el mejor artista que hemos tenido", en Levante EL MERCANTIL VALENCIANO, 25 de noviembre de 2005, pág. 72.

- Rodríguez, Carlos "Manolo Safont. Onda despide al reconocido artista", en Levante EL MERCANTIL VALENCIANO, 26 de noviembre de 2005, pág. 57.

- Rodríguez, Carlos. "Fallece Manolo Safont", en Levante EL MERCANTIL VALENCIANO, 25 noviembre 2005, pág. 72.

- Rodríguez, Carlos. "Onda despide emocionada a Safont", en Levante EL MERCANTIL VALENCIANO, 26 noviembre 2005, pág. 55. 
- Silvestre, Jacobo "Onda rinde tributos al ceramista Manolo Safont”, en El Mundo. Castellón al día, 18 de abril de 2005.

\section{6}

- "El Museu Manolo Safont volverá a ocupar un lugar de privilegio en CEVISAMA 2006", El Full, $\mathrm{n}^{\circ}$ 1065, 3 de febrero de 2006, Onda.

- Estall I Poles, Vicent. "Manolo Safont: Un museu, un llegat i un compromís", Crònica d'Onda, Diciembre del 2005 y enero del 2006, pág. 10.

- Homenatge a La Saleta. Sala Municipal d'Exposicions d'Onda. Octubre 2005. Onda.

- Ferre Pérez, Juan Bautista, Lista de fácil acceso a las fotografías de alumnos. Colonia Escolar Virgen del Carmen. S. e, Onda, S.d.

- M. Safont, Catálogo exposición Galería Octubre, Universitat Jaume I, Castellón.

- "Onda celebra el Día de los Museos con una exposición infantil sobre la obra de Safont", El Full, $\mathrm{n}^{\circ}$ 1080, 26 mayo 2006

- "Onda dio el último adiós al genial Manolo Safont", en Crónica d'Onda, diciembre del 2005 y enero del 2006, pág 9.

\section{7}

- Mariner, A. "Homenaje a Safont", Arrels, n040, 25 julio 2007, pág. 29.

\subsection{5.- URLs}

- http://ajuntament.onda.es/web/guest/home/journal_content/56/10 $124 / 43798$

- http://albertoandres.blogspot.com.es/2010/10/la-pastapontevedra-espana.html

- http://ca.wikipedia.org/wiki/Sala_Municipal_d\%27Exposicions_d\% 27Onda

- http://castello.es/web30/pages/noticias_web10.php?cod=2701

- http://ceramico.blogspot.com

- http://elpais.com/diario/1979/04/19/cultura/293320808_850215.ht $\mathrm{ml}$

- http://madmuseum.org/exhibition/body-soul

- http://mariabofill.com 
- http://masdearte.com/opinion/arte-sin-trabas/grayson-perry-whoare-you-exhibition

- http://recortesdeforolandia.blogspot.com

- http://ujiapps.uji.es/com/noticies/2015/03/1q/exposicio-essencial

- http://www.100kubik.de

- http://www.abc.es/agencias/noticia.asp?noticia=759124

- http://www.capaesculturas.com

- http://www.ceramista.biz/ceramica_artistica.htm

- http://www.cerco.es/cerco_index.asp?id=57

- http://www.clubcece.es/pdf/exfilnuco2.htm.

- http://www.cristinaguzman.com

- http://www.cristinaguzman.com/index.htm

- $h t t p: / / w w w . d o l s c e r a m i s t e s . c o m$

- $h t t p: / / w w w . e a f a c . c o m$

- http://www.elmundo.es/elmundo/2011/06/27/castellon/130917110 4.html

- http://www.elpais.es/articulo/20051126elpval_22/Tes/elpepiautval

- http://www.elperiodicomediterraneo.com/noticias/castellon/sereshumanos-castellon-salvador-belles-pasion-ceramica-arteuniversal_199460.html

- http://www.enfangat.net

- http://www.gva.es/museo/safon.htm. "Manolo Safont. Unas notas"

- http://www.ifacc.es/

- http://www.japantimes.co.jp/culture/2009/08/14/arts/breaking-allthe-rules-in-ceramics/\#.VYMTLPntmkp

- http://www.josepforaster.com

- http://www.lasprovincias.es/v/20100219/culturas/ceramica-enricmestre-20100219.html

- http://www.lissongallery.com/artists/richard-deacon

- http://www.maycriado.com

- http://www.mecd.gob.es/prensa-mecd/dms/mecd/prensamecd/actualidad/2015/03/20150311-ceramica/dossierprensa.pdf

- http://www.micice.es

- http://www.museuceramica.bcn.cat

- http://www.museulalcora.es 
- http://www.pulsceramics.com

- http://www.racba.org/es/mostrarcurriculum.php?id=554

- http://www.saatchigallery.com/artists/rebecca_warren.htm

- http://www.taringa.net/posts/arte/13574520/La-Ceramica-en-elArte-Contemporaneo.html

- https://www.youtube.com/results?search_query=manolo+safont

- https://www.youtube.com/watch?v=jrsG9S1d6FY "La Diputación restaura un emblemático mural cerámico de Manolo Safont que se expondrá de forma permanente en el Museu de Onda" 


\section{3.- FUENTES}

- Acta del acuerdo adoptado en Pleno por el Ayuntamiento de Onda sobre la denominación del Museo del Azulejo, 2 de febrero de 2001, Onda, inédito.

- Acta Seny Onder 2002. Ateneo Cultural y Mercantil de Onda. 29 de enero de 2003.

- Carta enviada por Antoni Miró a Manolo Safont en marzo de 1998, inédita.

- Carta enviada por Antoni Seva a Manolo Safont el 25/03/1998, inédita.

- Carta enviada por Consuelo Císcar a Manolo Safont el 23 /01/2001, inédita.

- Carta enviada por Enric Arenós Cortés a Manolo Safont el 25/02/2003, inédita.

- Carta enviada por Fernando Romero Subirón a Manolo Safont el 12/03/2001, inédita.

- Carta enviada por Ferran Olucha a Manolo Safont el 25/02/ 2003, inédita.

- Carta enviada por Joan F. Mira a Manolo Safont en marzo de 1998, inédita.

- Carta enviada por Joan Romero a Manolo Safont el 277/03/1998, inédita.

- Carta enviada por Manuel Ardit Lucas a Manolo Safont el 22/03/1998, inédita.

- Carta enviada por Matilde Salvador a Manuel Galver, Presidente del Ateneo Cultural y Mercantil de Onda el 27/02/2003, inédita.

- Carta enviada por Nadal Florenci Escrig González a Manolo Safont el 28/03/1998, inédita.

- Carta enviada por Pilar Espona a Manolo Safont el 25/03/1998, inédita.

- Carta escrita por el Director General de Bellas Artes, dirigida al Alcalde del Ayuntamiento de Onda, inédita.

- Carta manuscrita enviada por Manolo Safont a Francisco Lobo Toledo, rector de la Universitat Jaume I de Castellón, en la cual explica el estado del proyecto del mural cerámico encargado por la UJI. Inédita. 
- Certificado de la Secretaría del Ayuntamiento de Onda, con las propuestas de acuerdo sobre la aceptación donación de bienes de Manolo Safont y Ana-Teresa del Moral, 24/06/2002, inédito.

- Diploma: Premios Protagonistas de Castellón 2003. Onda Cero Radio. Patrocinado por Ceracasa Cerámica, el jurado de los Premios Protagonistas de Castellón en su segunda edición decide por mayoría otorgar el galardón Protagonista de las Artes Plásticas 2003 a Manuel Safont. Castellón, 12 de junio de 2003.

- Documento enviado por el Alcalde de Onda, Enrique Navarro a Manolo Safont el 14/02/1998, inédito.

- Documento enviado por el Ministerio de Educación y Ciencia, Sección de Museos y Exposiciones, con fecha del 24 enero de 1969, al Alcalde-Presidente del Magnífico Ayuntamiento de Onda, y con registro de entrada del Ayuntamiento de Onda del 31 de enero de 1969.

- Documentos inéditos facilitados por Manolo Safont pertenecientes a su archivo personal.

- Galver, Manuel. Notas manuscritas tomadas por el presidente del Ateneo Cultural y Mercantil de Onda, en una conversación que mantuvo con Manolo Safont para preparar el discurso que debía pronunciar con motivo del homenaje que se realizó en Onda por la concesión del premio Seny Onder de 2003.

- Huguet, Jesús. "Homenatge a Manolo Safont. Onda, 28 de març de 1998", 1998, inédito.

- Palomero, Josep. "A Manolo Safont, en el seu setanté aniversari, i a Anna, per haver-los propiciat", 1998, inédito.

- PITARCH, Vicent. "Parlament en I'homenatge a Manolo Safont (Onda, 28.03.98)", 1998, inédito.

- PItARCh, Vicent. "Discurso en el homenaje del 70 aniversario de Safont", 28 marzo 1998, inédito. 


\section{4.- ANEXO}

\section{Trascripción del audio del fragmento del cortometraje documental Fang $i$ pinzells de Rafael Menezo:}

"He anat a l'escola primaria i res mès, desprès he treballat a la fàbrica. No he tingut ningú mestre, tot ho he fet per la mateixa afició, tot ho he fet a casa, no he tingut professors ni mitjos per poder anar a l'escola.

Hasta el 37 vaig assistir a l'Escola Provincial de Ceràmica, la primera bomba que va caure en guerra va caure allí damunt.

Jo crec que un no es pot arrepentir de tot el que ha fet, lo que te que fer es millorar la seua obra $i$ al final vaig deixar ja tot tipus d'encarrecs trillats $i$ me vaig dedicar de plè a la creació pràctica. I eixe temps em va servir per coneixer el procès de fabricació del taulell i l'ambient en que s'envolta l'obra.

Vaig començar pels molins de terra i vaig acabar en l'almacen, passant per les prenses de taulells, forn d'escaldat, pintaor $i$ forn de passatge, $i$ vaig començar per lo que fan tots, encarrecs per les tendes de comerç.

Vaig deixar els camins trillats $i$ facilons, vaig buscar relleus $i$ reaccions d'àcids $i$ els meus experiments es van introduir en un nou tipo de cuadre ceràmic i la meua investigación en la nova pintura que realitzaba... sense donarme conte treballaba dos cuadres en un, era tan rico el fondo com la figura.

La meua casa està oberta a tot el mòn, si els que venen de nou son sincers."

"He ido a la escuela primaria y nada más, después he trabajado en la fábrica. No he tenido ningún maestro, todo lo he hecho por la propia afición, todo lo he hecho en casa, no he tenido profesores ni medios para poder ir a una escuela.

Hasta el 37 asistí a la Escuela Provincial de Cerámica, la primera bomba que cayó en guerra, cayó justo allí encima. 
Yo creo que uno no puede arrepentirse de todo lo que ha hecho, lo que tiene que hacer es mejorar su obra y al final tuve que dejar ya todo tipo de encargos trillados y me dediqué de lleno a la creación práctica. $Y$ ese tiempo me sirvió para conocer el proceso de fabricación del azulejo y el ambiente en que se envuelve la obra.

Comencé por los molinos de tierra y acabé en el almacén, pasando por las prensas de azulejos, horno de bizcochado, pintador y horno de pasaje, y comencé por lo que hacen todos, encargos para las tiendas de comercio.

Dejé los caminos trillados y facilotes, busqué relieves y reacciones de ácidos y mis experimentos se introdujeron en un nuevo tipo de cuadro cerámico, y mi investigación en la nueva pintura que realizaba... sin darme cuenta trabajaba dos cuadros en uno, era tan rico el fondo como la figura.

Mi casa está abierta a todo el mundo, si los que vienen de nuevo son sinceros" 


\section{La intifada del fang. Antoni Albalat.}

(Manolo Safont, Onda -el poble de mon pare- 1928-2005). Article publicat a Levante de Castelló el 27 de novembre de 2005. Sempre et durem al cor, amic Manolo. Antoni Albalat.

A Manolo Safont el cabell i la barba li caïen, com una heura facial, grises. No era cap casualitat que un ceramista, que va exercir el seu art des de feia més de cinquanta anys, mimetitzara somàticament el color de les cendres del foc que van materialitzar la seua creació.

Safont no va tindre escola, ni li féu cap falta. A catorze anys entrà d'obrer en una fàbrica de ceràmica del seu poble. La seua afecció envers la pintura, que aplicava meticulosament a la ceràmica, aconseguint taulells amb sabor a gravat o fotografies, el marcà un ofici sense el qual ho hagués sabut viure.

Però com un Prometeu que robà el foc als déus, a Safont li oprimien les cadenes $i$ va haver de trencar-les. Si no hagués estat així, avui l'hauríem recordat com un artesà consagrat i no com un artista universal. Un dia va decidir trencar amb els encàrrecs $i$, en 1952 bastí el seu taller que no tingué forn fins el 1984. "Jo tenia un món a banda", em deia referint-se a l'època en què treballava per encàrrec, "vaig aguantar cinc anys de casat pintant encàrrecs $i$ ensenyant allò que volia fer i no m'ho demanaven. Vaig haver de tallar".

Aleshores es dedicà a aplicar la ceràmica a l'arquitectura, es cansà aviat i sorgiren els seus quadres ceràmics. La seua evolució fou una marxa oscilllant entre la figuració i l'abstracció. Una lluita constant a la recerca de la matèria, el color $i$ el resultat final ha estat condicionat sempre pel foc.

Als anys seixanta es decidí a abandonar qualsevol traç figuratiu, que només reprengué per fer de la seua obra una crítica social a la dictadura franquista. "Disposava", —deia en una entrevista que li vaig fer fa any"d'unes forces naturals i no sabia què fer amb elles, tenia por de lluitar amb la matèria pura, sense cap incrustació figurativa. Era el que més em plaïa". La manca d'escola, de recursos fins i tot, no el va amoïnar i del geni creador brollà la investigació, cremant etapes i definint noves sintaxis en les quals la ceràmica 
tradicional, gràcies a aqueix impuls nou, s'alliberava del volum terrisser, de l'estigma decoratiu i assolí una dignitat immanent. Tot això va exigir una catarsi que polzà les fibres més íntimes d'aquest home díscol se n'ha anat també abillat de vermell.

"Estic programant la llibertat a totes hores", afirmava amb rotunditat, "en les meues creacions hi ha sempre una xicoteta violència; la llibertat no m'arribava i aqueix desencís s'ha traduït en creativitat $i$ en una lluita de domini damunt la matèria. Ara com ara em trobe amb tota la riquesa acumulada, utilitzant-la en una nova forma d'expressió".

Una nova expressió que va aparèixer en 1987 quan realitzà un mural per al Govern Civil de Castelló que sepultà un vestigi iconogràfic de la dictadura. Era la darrera codolada de la intifada ceràmica de Safont, iniciada als anys setanta amb afusellaments i mans destrossades dels obrers, opressions de masses de colors foscos que, el 1987 obriren camí a un esclat de color. A un nou llenguatge obert a l'esperança.

Les ombres s'esvaïren i les masses d'esmalt deixaren la dialèctica per crear harmonies cromàtiques i tàctils que arrodoniren el seu procés evolutiu. Passades aquestes èpoques, Safont va col.locar, en 1991, un mural de més de trenta metres quadrats a l'Escola d'Arts i Oficis, l'antiga Beneficència, de Castelló de la Plana i després també al Japó. Ací, en un tot unitari, Safont plantejava a l'espectador la multiplicitat del seu món. Unitats que podien delimitar-se en articulacions amb entitat pròpia; pergamins ceràmics, ara testament de tota la seua trajectòria. La trajectòria d'un home que, a despit les opinions dels crítics que el definien com a pintor o ceramista, ell es considerava "un ceramista que pinta. Per damunt de tot", assegurava, "em sent ceramista, però he tingut una vocació de pintor, de pintor de secà, perquè no mai he eixit de casa. No he fruit de la vida, he fruit del meu treball i no en tinc prou hores".

Amb tot, aqueix tancament, quasi místic, del ceramista amb els seus quadres i en la seua alquímia, no l'ha empresonat en una torre d'ivori. Lluny de l'elitisme, Manuel Safont es va bolcar sempre amb el seu poble, el seu país $i$ l'amargor que tots tres han patit. "Des d'un principi", deia, "m'he sentit un obrer, 
he estat junt a l'obrer, he comprès la necessitat del feble, que és qui sempre perd. I tot això ho he palesat en la pintura".

És per aquesta raó que l'art comercial no li interessa, perquè: "el poble no pot gaudir d'aqueixes coses $i$ té tot el dret a conèixer-ho $i$ a viure-ho. Preferesc fer exposicions sense guanyar diners perquè les galeries trenquen la llibertat creadora".

I d'aquesta actitud, l'artista pobre, però digne, va fer bandera d'ofici, a despit de les crítiques que li recriminaven no ser un ceramista complet per no tenir forn al seu estudi. "Els pobres sempre ens conformem amb el que tenim. Lluitant $i$ sacrificant-te et mena un món que et naix $i$ que ha entrat a dintre teu. La mancança de mitjans m'ha dut a estar sempre canviant $i$ això m'obliga a entregar-me més $i$ a treballar. No hi ha muses, ni res, el treball es qui t'alliçona $i$ això no ix de cap escola".

Ara que la terra se l'ha emportat, els orfes de foc som tots nosaltres.

A Manolo Safont el cabello y la barba le caían, como una hiedra facial, grises. No era casualidad que un ceramista, que ejerció su arte desde hacía más de cincuenta años, mimetizará somáticamente el color de las cenizas del fuego que materializaron su creación.

Safont no tuvo escuela, ni le hizo ninguna falta. A catorce años entró de obrero en una fábrica de cerámica de su pueblo. Su afección hacia la pintura, que aplicaba meticulosamente a la cerámica, logrando azulejos con sabor a grabado o fotografías, le marcó un oficio sin el cual lo hubiera sabido vivir.

Pero como un Prometeo que robó el fuego a los dioses, a Safont le oprimían las cadenas y tuvo que romperlas. Si no hubiera sido así, hoy deberíamos recordado como un artesano consagrado y no como un artista universal. Un día decidió romper con los encargos y, en 1952 construyó su taller que no tuvo horno hasta el 1984. "Yo tenía un mundo aparte", me decía refiriéndose a la época en que trabajaba por encargo, "aguanté cinco años de casado pintando encargos y enseñando lo que quería hacer y no me lo pedían. Tuve que cortar". 
Entonces se dedicó a aplicar la cerámica en la arquitectura, se cansó pronto y surgieron sus cuadros cerámicos. Su evolución fue una marcha oscilante entre la figuración y la abstracción. Una lucha constante en busca de la materia, el color y el resultado final ha estado condicionado siempre por el fuego.

En los años sesenta se decidió a abandonar cualquier trazo figurativo, que sólo retomó para hacer de su obra una crítica social a la dictadura franquista. "Disponía", decía en una entrevista que le hice hace años- "de unas fuerzas naturales y no sabía qué hacer con ellas, tenía miedo de luchar con la materia pura, sin ninguna incrustación figurativa. Era lo que más me gustaba". La falta de escuela, de recursos incluso, no lo preocupaba y del genio creador brotó la investigación, quemando etapas y definiendo nuevas sintaxis en las que la cerámica tradicional, gracias a ese impulso nuevo, se liberaba del volumen alfarero, del estigma decorativo y alcanzó una dignidad inmanente. Todo ello exigió una catarsis que pulsó las fibras más íntimas de este hombre díscolo que se ha ido también ataviado de rojo.

"Estoy programando la libertad a todas horas", afirmaba con rotundidad, "en mis creaciones hay siempre una pequeña violencia; la libertad no me llegaba y ese desencanto se ha traducido en creatividad y en una lucha de dominio sobre la materia. Por ahora me encuentro con toda la riqueza acumulada, utilizándola en una nueva forma de expresión".

Una nueva expresión que apareció en 1987 cuando realizó un mural para el Gobierno Civil de Castellón que sepultó un vestigio iconográfico de la dictadura. Era el último golpe de la intifada cerámica de Safont, iniciada en los años setenta con fusilamientos y manos destrozadas de los obreros, opresiones de masas de colores oscuros que, en 1987 abrieron camino a un estallido de color. A un nuevo lenguaje abierto a la esperanza.

Las sombras se desvanecieron y las masas de esmalte dejaron la dialéctica para crear armonías cromáticas y táctiles que redondearon su proceso evolutivo.

Pasadas estas épocas, Safont colocó, en 1991, un mural de más de treinta metros cuadrados en la Escuela de Artes y Oficios, la antigua 
Beneficencia, de Castellón de la Plana y después también en Japón. Aquí, en un todo unitario, Safont planteaba al espectador la multiplicidad de su mundo. Unidades que podían delimitarse en articulaciones con entidad propia; pergaminos cerámicos, ahora testamento de toda su trayectoria. La trayectoria de un hombre que, a despecho de las opiniones de los críticos que lo definían como pintor o ceramista, él se consideraba "un ceramista que pinta. Por encima de todo", aseguraba, "me siento ceramista, pero he tenido una vocación de pintor, de pintor de secano, porque no nunca he salido de casa. No he disfrutado de la vida, he fruto de mi trabajo y no tengo bastantes horas".

Con todo, ese encierro, casi místico, del ceramista con sus cuadros y en su alquimia, no lo ha encarcelado en una torre de marfil. Lejos del elitismo, Manuel Safont se volcó siempre con su pueblo, su país y la amargura que los tres han sufrido. "Desde un principio", decía, "me he sentido un obrero, he estado junto al obrero, he comprendido la necesidad del débil, que es quien siempre pierde. $Y$ todo esto lo he manifestado en la pintura". Es por esta razón que el arte comercial no le interesa, porque: "el pueblo no puede disfrutar de esas cosas y tiene todo el derecho a conocerlo ya vivirlo. Prefiero hacer exposiciones sin ganar dinero porque las galerías rompen la libertad creadora".

$Y$ de esta actitud, el artista pobre, pero digno, hizo bandera de oficio, a despecho de las críticas que le recriminaban no ser un ceramista completo por no tener horno en su estudio. "Los pobres siempre nos conformamos con lo que tenemos. Luchando y sacrificándote te conduce a un mundo que te nace y que ha entrado dentro de ti. La falta de medios me ha llevado a estar siempre cambiando y eso me obliga a entregarme más y a trabajar. No hay musas, ni nada, el trabajo es quien te alecciona y eso no sale de ninguna escuela".

Ahora que la tierra se lo ha llevado, los huérfanos de fuego somos todos nosotros. 